
Digitized by the Internet Archive in 2019 with funding from Kahle/Austin Foundation 


Draceer J.A. Neoxis

Alan c. Morrib.

May 10" 1901.

\section{FLOWERS OF THE FIELD}




$$
\therefore \quad x+x^{20}
$$




\title{
FLOWERS OF THE FIELD.
}

\author{
BY THE LATE \\ REV. C. A. "JOHNS, B.A., F.L.S. \\ EwentysnintB Eoition

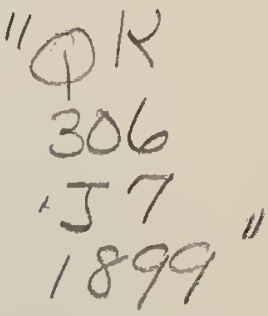 \\ Entirely rewritten and revised
}

$\mathrm{BY}$

G. S. BOULGER, F.L.S., F.G.S., PROFESSOR OF BOTANY IN THE CITY OF LONDON COLLEGE.

Published under the Direction of the General

Literature Comznittee.

Thomas J. Bata Library

TRENT UNIVERSITY

PETERBOROUGH, ONTARIO LONDON :

SOCIETY FOR PROMOTING CHRISTIAN FNOWLEDGE, TORTHUMBERLAND AVENUE, W.C. ; 43, QUEEN VICTORIA STREET, E.C. BRIGHTON : 129 , NORTH STREET.

NEW YORK: E. J. B. YOUNG \& CO.

1899 . 
QK306. Jr 1899

Dedicated,

BY GRACIOUS PERMISSION,

TO

HER ROYAL HIGHNESS PRINCESS ALICE MARY OF ALBA NY. 


\title{
INTRODUCTION.
}

\author{
PART I. \\ EXPLANATION OF TERMS.
}

The object of this volume is to introduce the lover of Nature to an acquaintance with the common British flowering plants, to teach the unscientific how to find out the names of the flower met with in the course of country rambles. Such a knowledge of plants, it may be said, and said with truth, is not Botany; but it is a siep towards Botany; for there can be no dovict that scientific treatises on this subject would often be studied with more pleasure if the reader were familiar with the outward appearance of the examples quoted; just as we take greater interest in accounts of astronomical discoveries if we have seen and handled a telescope than if we had merely had one described to us, no matter with what accuracy and minuteness. The reader, or, inasmuch as even the elementary linowledge of a science can only be attained by study, the student, who wishes to make this volume practically useful is recommended to read with care and attention the following pages, into which the author has introduced nothing but what is essential to the proper understanding of the body of the work.

Before a novice can commence the study of any science, he must make himself acquainted with the terms employed by writers on that science, and he

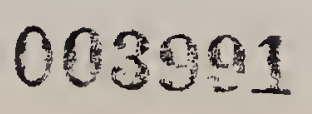


must not be friglitened if things new to him should have strange names. Unmeaning and hard to be remembered they must appear to him at first, but this will be only as long as they remain mere sounds. When he has gained a knowledge of the things for which they stand, they will lose their formidable appearance, and, hard as they may still be to pronounce, they will very soon become familiar to the mind, if not to the tongue. In a scientific treatise on Botany, taken in its widest sense, these terms must of necessity be very numerous; but not so, however, with a popular description of the plants growing wild in a single country of limited extent. The author has, therefore, endenvoured to lieep technical terms as much as possible out of sight, in the hope that the lover of Nature may be beguiled into forming an acquaintance with the outward appearance of the plants of his neiglibourhood, and erentually be induced to study them more in detail. $\mathrm{He}$ las, consequently, avoided the use of Latin words wherever English ones would do as well, and has not dealt with the mternal structure of plints, or with any organs but those with which it is necessary that the student should be familiar before he refer's to the body of the work for a description of any plant which he may have found.

'The organs of a flowering plant may be described under the heads of Root, Stea, Lfaf, Hars, Ixflorescexce, Bracts, Flower, Rèertache, Calix, Corolla, Stamens, Cakiels, Frutt, and Seed.

The Roor may be the direct downward prolongation of the axis of the seedling plant, when it is called a $t(x)-r .00 t$. It is then sometimes enlarged and fleshy, as in the conical root of the Cirrot and the Parsnip; or it may be much branched, as in the Wallfower. Roots given off in no definite order, such as those which spring from tho base of bulbs or from other stem structures, are termed adventitious. 
They are generally fibrous, as in Grasses; but may be swollen, as in the Dropwort, when they are termed nodulose. Such swollen roots, if clustered together, as in the Lesser Celandine ( $\mathrm{p} .17$ ), are called fasciculate. In many Orchids two fibres or two groups of confluent fibres are enlarged into what are termed tubercles, and the root is then called tuberculate.

The slender branches of roots are called rootlets; but the actual absorption of liquid food from the

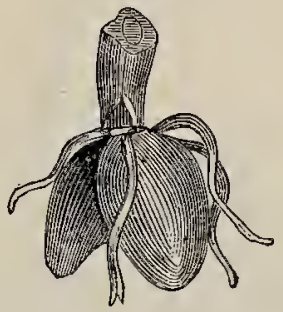

Tuberculate root of an Orchis.

soil is often performed by root-hairs, very delirate hairs, almost microscopic in size, which occur on the surface of young roots. Old roots of trees become corky like stems.

The STen bears buds, which unfold either as elongating shoots, or as flovers. The points on the stem where the leaves are given off are termed nocles. 'They are sometimes swollen, as in the Persicaria (p. 624) and most of the Pirk family. The space between two successive nodes is called an internode. In many herbaceous plants the internodes are short, and the nodes consequently crowded and the leaves in a tuft or rosette, as in the Daisy (p. 372) and the Primrose (p. 470).

The stem may be unbranched; but is more commonly branched, each branch originating in a bud in the angle between a leaf and the stem. This angle is called the axil of the leaf, from a Latin word meaning the arm-pit, and such a bud is, therefore. termed axillary. 
Many quick-growing stems, especially among Grasses and the Umbelliferous family (p. 2-8), have hollow or fistular internodes.

Stems may be undelground or aërial, the chief forms of underground stems being the tuber, the corm, the bulb, the rhizome, and the suckel.

The tuber is a fleshy rounded structure giving oft

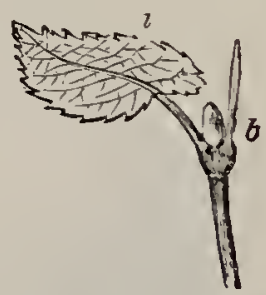

Portion of a branch with leaf $l$ and bud $b$.

few, if any, roots, and bearing s.attered buds, being made up of several internodes, as in the Potato and the Black Bryony.

The corm is a short, thick, solid stem, generally of one internode, giving of' roots below, and bening

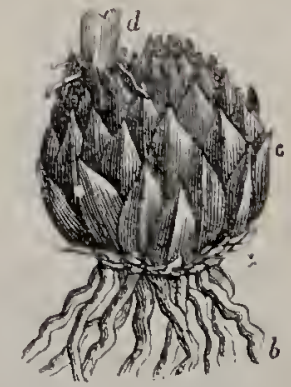

Scaly bulb of the Lily : $a$, shortened stem ; $b$, fivrous roots ; $c$, sc.nles; d, flowering stem.

buds on its "upper surface, as in the Snowdrop, Crucus, Lords-and-ladies, de.

The bull, is a short stem made up of many unelongated internodes and enclosed in numerons tiesly leaf-scales. When these are narrow and overlap like tiles, as in Lilies, the bulb is called scaly; when they 
are sheathing and concentric, as in the Onion, tunicate.

The rhizome, or rootstock, is an elongated stem bearing scale-leaves and adventitious roots at its nodes. It generally grows horizontally and is fleshy, as in Solomon's-seal and Iris; but it may be slender, as in Couch-grass and Sand-sedge. When the older portion dies away it has an abrupt or premorse (bitten.

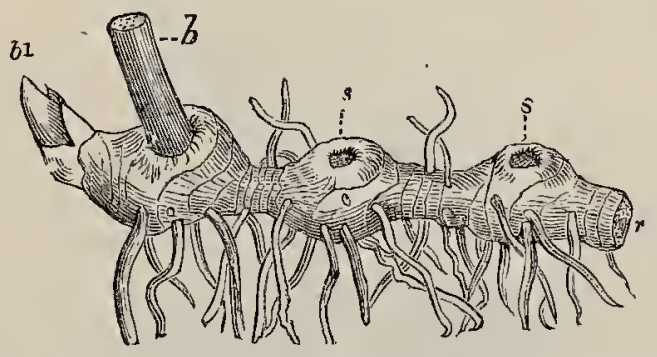

Portion of rhizome, $r$, of the Soiomon's-seal ; $b$, telminal bud; $b$, a branch; $s, s$, scars produced by the decay of old branches.

off) end, as in the Devil's-bit Scabious (p. 361) and the Primrose.

The sucker is a branch, or secondary stem, given off underground and rising to the surface, as in the Common Elm, Mints, and Roses.

Stems may be woody or herbaceous, the former being chiefly characteristic of perennial plants. A woody plant with one main stem at least ten or twelve feet high is called a tree; whilst if it branches freely near the ground it is a shmeb, or if less than three feet high, an undershrub.

A large number of plants, known as herbaceous perennials, have perennial underground stems, but send up branches above ground that are annual, dying down each winter.

Aërial stems may be erect, mostrate, or ascending, horizontal, that is, at first, but bending upwards at their points. They may be twining, as in the Hop, 


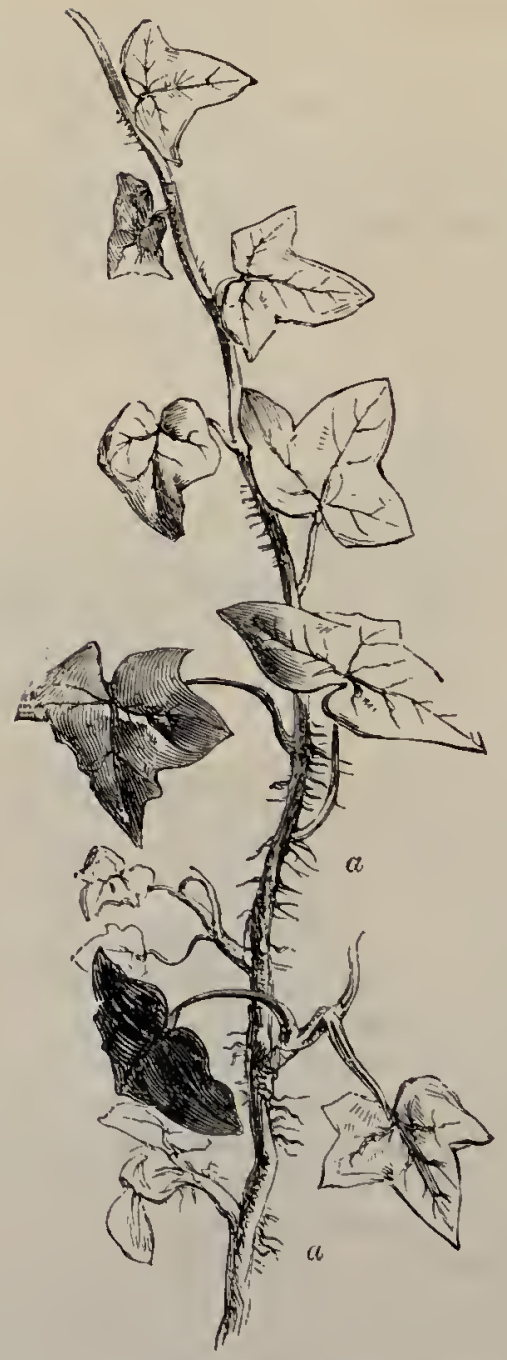

Common Ivy : $a$, $a$, ä̈rial roots.

Honeysuckle, and Convolvulus, or may climb in other ways, such as the roots in the Iry, the prickles in Roses, the tendrils in Tares, and the twisted leaf- 
stalks in Clematis. They may be spinescent, ending in straight spines, as in the Blackthorn, or they may

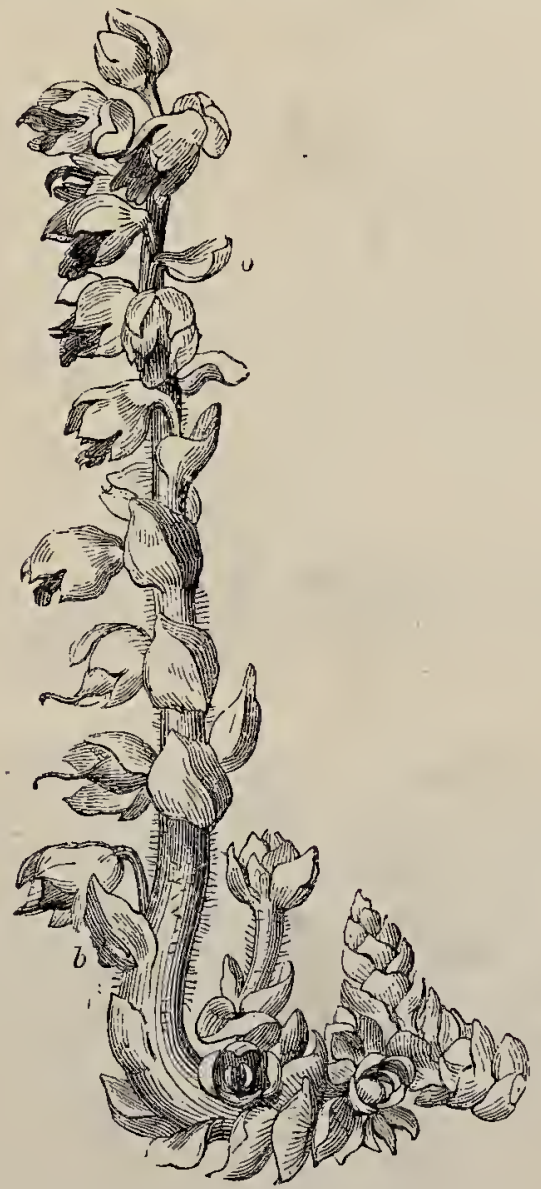

Toothwort with scaly leaves and bracts $(b)$.

exceptionally be flattened and leaf-life, as in Butcher'sbroom (p. 727 ).

The runner is a prostrate axillary branch, rooting at its nodes, and bearing. buds which develop into new 
plants, as in the Strawberry. The off set is similar but • shorter, and bears only a terminal bud, as in the House-leek (p. 255).

The LeAF is most important as a means of distinguishing closely allied plants. Underground stems and the aërial stems of a few plants, such as the parasitic Toothwort, have small scaly or membranoiss leaves; but a typical leaf has a blade, a stalk, and a sheath, or two appendages at its base known as stipules. Leaves which have no stalks are termed sessile (sitting), as in Eryngo (p. 288).

The stipules may be united round the stem, as in

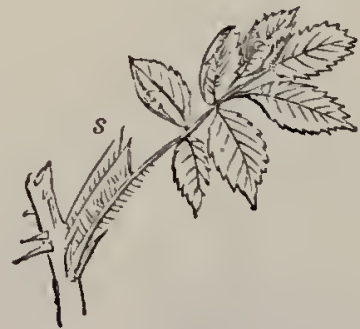

Leaf of Rose with stipules : $s$, aper of tle sheath.

the Knot-grass family, in which, and in the Rose, they occur exceptionally in addition to a sheath.

Other characters of the leaves are their vernation (from the Latin, ver, spring), or folding in the bud, their position and arrangement, veining, form, base, apex, margin, surface, texture, colour, and duration. In vernation leaves may be conduplicate, or folded down the midrib, like the two halves of a sheet of note-paper, as in the Cherry ; plaited, like a fan, as in the Beech; convolute, or rolled up like a scroll, as in the Plum ; involute, with the margins rolled upwards, as in the Water-lily; revolute, with them rolled backward, as in the Dock; valuate, when they touch one another without overlapping; or, imbricate, where they overlap like roofing-tiles. 
In position they are either ralical, springing directly from an underground stem, as in the Primrose; or cautine, produced higher up, on an aërial stem. Both may occur on the same plant, as in Tower Mustard (p. 54).

In arrangement leaves may spring singly or scattered. from the stem, as in Balsam (p. 151); opposite, in pairs, as in the Pink (p. 99); or whorled, with more than two from one node, as in Herb Paris ( $\mathrm{p} .745)$.

The veins of leaves may be parallel, as in grasses; or curved, as in the Lily-of-the-Valley, with much finer cross-veins; or irregularly net-veined, as in the Primrose, of very varying degrees of fineness. They may be palmate, radiating from the base of the leaf, as in the Sycamore; or pinnate, with cross-veins springing from a midrib, like the barbs of a feather, as in the Beech.

The forms of leaves are very variable, and even on one plant leaves may occur which can only be satisfactorily described by uniting two of the following terms.

They may be needle-shaped, as in the Pine; linear, with parallel sides and more than four times as long as they are broad, as in the Grasses; oblong, with parallel sides but not more than four times as long as broad, as in some Pondweeds; oval, with rounded sides, widest across the middle and more than twice as long as broad, as in the Butterwort; elliptical, less than twice as long as they are broad, as in the Apple; round, as in the Water-lilies and Pennyworts; lanceolate, widest near the base and at least four times as long as they are broad; ovate, or egg-shaped, widest near the base but little more than twice as long as broad, as in the Pear; kidney-shaped, broader than they are long, as in the Ground-Ivy (p. x.); ob-lanceolate, or reversedly lance-shaped, as in the Ribwort Plantain (p. 604); obovate, or reversedly egg-shaped, as in the Cowslip; deltoid, or nearly an equal-sided 
triangle, as in the Orache; arou-shaped, as in the Arrow-head (p. 768); haiberd-shaped, with the barbs, or auricles, as they are called, pointing outwards, as in Sheep's Sorrel; or rhomboid, as in the Birch.

The base of the blade of the leaf may be wedge. shaped ; tapering downwards, as in the Daisy (p. 37: $)$; heart-shaped, as in the Violet; oblique, or larger on

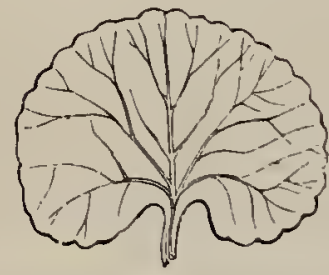

Leaf of Ground Iry.

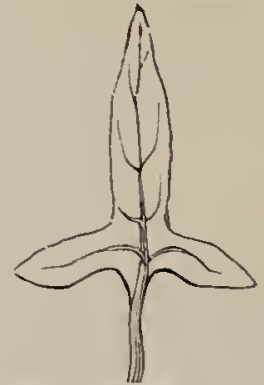

Lenf of Sheep's Sorrel.

one side than on the other, as in the Lime-tree (p. 138); decurent, when it runs down the sides of the stem as a wing, as in Thistles; perfoliate (from the Latin, per, through, and folium, a leaf), when the auricles are so united round the stem that the stem appears to be growing through the leaf, as in Hare's-ear (p. 295); or peltate (from the Latin, pelta, a shield), when they are so united in a stalked leaf that the stalk is attacherl to the leaf near its centre, as in the Pennyworts (pp. 250, 287). When two opposite leaves are unitert by their bases they arecalled connate (from con, together, and natus, born), as in the Yellow-rort (p. 489).

The point or apes of a leaf may be rounded, as in the Oak; pointed; bristly; notched : or reversedly heart-shaped, as in the leaflets of Wood-Sorrel.

The margin of the leaf is either entive, or free from indentations, as in the Lily-of-the-Valley; fringed with hairs, as in young Beech leaves: wavy, as in the Oak; crenate, or scalloped, as in the Violet; toothed: or lobed. If the teeth point outward it is termed 
dentate, the Holly leaf being spinously dentate; if upward, as in the Elm, the leaf is serate or saw-edged.

When a leaf is lobed or divided, its lobes or leaflets are arranged according to its venation, generally palmately or pinnately. The division may extend to various depths from the margin towards the base or midrib, the leaf being termed simple, if it does not extend all the way, and compound, if it divides the leaf into distinct leaflets. A palmate leaf of three leaflets is called ternate, as in Trefoils; one of five, quinate, as in Cinquefoil (p. 215). In pinnate leaves it is important to notice whether there is a terminal (odd) leaflet or not; how many pairs of leaflets there are; and if these are again divided up (bi-pinnate). If there is a terminal lobe or leaflet larger than the

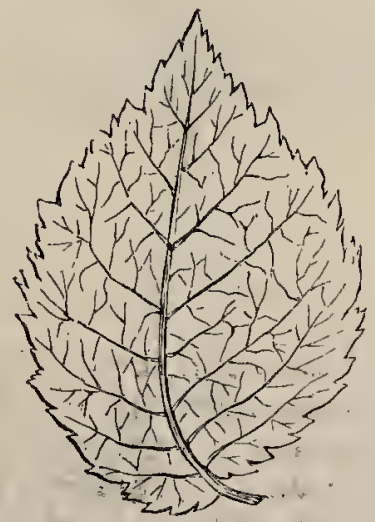

Oblique serrate leaf of the Common Elm.

rest, as in the White Mustard, the leaf is called lyrate. In describing a compound leaf it is generally only necessary to mention the type on which the leaflets are arranged, whether palmate or pinnate, and to describe one leaflet as if it were a simple leaf. If a leaf be divided up into such fine segments that their arrangement cannot well be determined, as in the 
submerged leaves of the Water Crowfoots, it is called decompound.

The same terms are used in describing the surfaces of leaves as for those of herbaceous stems. They may be glabrous, or free from hairs; polished, as in many Evergreens and Monocotyledons; glaucous, with a blue-grey waxy bloom, as in the Sea-kale; downy, as in

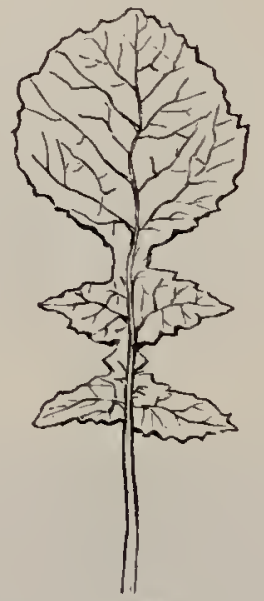

Lyrate leaf of the White Mustard.

Sage; hairy: miclly, as in the Tenzle; or ylandular, dotted over with oil-glands, as in St. John's-wort.

In texture leaves may be leathery, as Holly, or fleshy, as in House-leek; and in duration they are either deciduous, dying and falling in autumn or earlier, or evergreen, lasting until a new crop has formed, as in the Ivy, the Pine, and the Iew.

The Ilares on stems or leares require careful notice, as to whether they are few or many, long or short, stiff or weak, spreading (erect on the surface from which they spring) or adpressed (lying flat). The Nettles are the only British plants with stinging hairs.

The Inflonescence is a branch known as the peduncle (literally "little foot," and therefore some- 
times called foot-stalk), which generally bears modified leaves known as bracts, from the axils of which spring secondary branches, which may branch again or bear a flower, the stalk immediately below a flower being termed a pedicel or flower-stall. A peduncle springing directly from an underground stem and not bearing foliage-leaves, forms the inflorescence known as a seape, which may be one-flowered, as in the Tulip, or many-flowered, as in the Hyacinth, Cowslip, or Primrose, 'The difference between the two last-named examples is that the Cowslip has a long peduncle and short pedicels; whilst the Primrose has

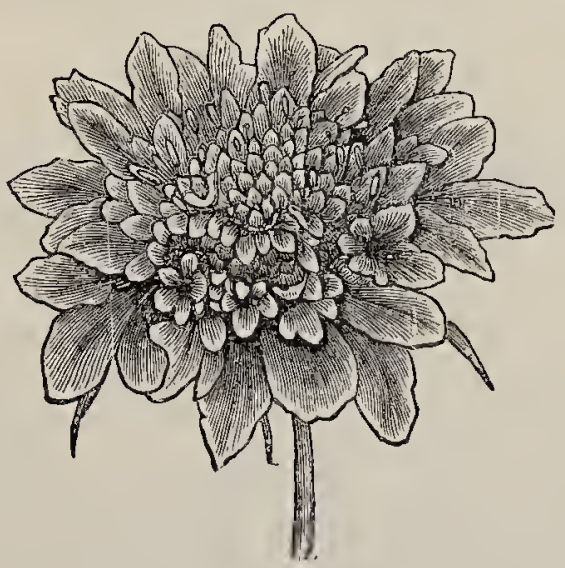

Head of Ecabious.

a very short peduncle buried among its leaves, and long pedicels.

Among other chief varieties of the inflorescence are the following:-The spite, an elongated axis with sessile flowers as in the Plantains (p. 604). The spadix, a spike with a fleshy axis or peduncle, as in Lords-and-ladies (p. 761). The catkin, generally described as a deciduous spike, as in the Hazel and the Willows (p. 676). The raceme, an elongated axis with stalked flowers, as in Mignonette (p.86). 
A corymb, which only differs from a raceme in the lower redicels being longer, so as to bring all the flowers nearly to a level, as in the Walltower. A head, in which many small sessile flowers, or florets, as they are called, are crowded together on the expanded apex of the peduncle, which is then termed the common receptacle. This occurs in the Scabious (p. xiii.) and in all the great order Compositce, the Daisies, Dandelions, Thistles, dc., which Linnæeus called "compound flowers." An umbel, in which many flower-stalks radiate from a common centre, as in the Ivy (p. 330).

If an inflorescence is branched more than once it is termed compound. Thus an ear of Wheat is a compouncl spitie or spike of spikelets, and the Carrot, Parsnip, Hemlocks, and most other members of the order Unbellifere have compouncl umbels.

When the terminal or central flower in a cluster opens first the inflorescence is called a cyme. Among the various forms of cyme are the fascicle, a crowded cluster of nearly sessile flowers, as in the Pinks (p. 99), and the verticillaster or false whorl, where two such cluster's occur in the axils of opposite leaves, as in the Dead-nettles and other members of the order Latratce (pp. 565-602).

Bracts are small leaves which are generally to be found below the flower. The inflorescence of the Creciferc is remarkable for being without any, or ebracteate. Sometimes they are mere membranous scales, as in the Cranesbills; or they may be leaf-like, as in the Anemones; or pretaloid, resembling the petals in colour and texture, as in the Wild Hyacintl. When in one or more whorls below the inflorescence they are called the involucre (from the Latin involuerum, an envelope). In the Dandelion the involucre consists of two whorls of green bracts, those of the outer whorl reflexed (p. 429). In the Knapweeds the numerous bracts of the involucle are membranous, 
dark brown, and arranged imbricately, i.e., overlapping like roof-tiles. All Compositce and most Unuelliferce have involucres. An involucre persisting in the fruit stage, like the leafy husk of a Hazel-nut or the "cup" of an A corn, is termed a cumule. This structure gives its name to the order Cupuliferce.

The Frower is a branch bearing leaves modified so as to assist in the production of seed, and generally crowded together on the expanded apex of the pedicel, or flower-stalk, which is termed the receptacle or thatamus. As much of the classification of plants is based upon the characters of the flower, a know-

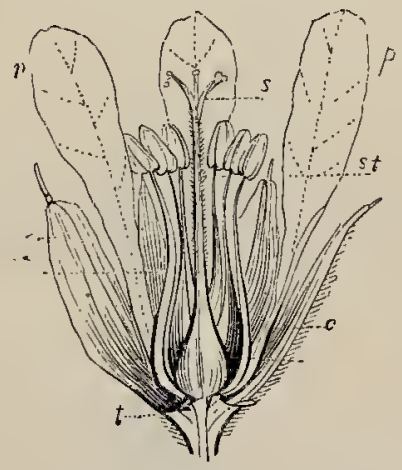

Section of a fiower.

ledge of its structuro is indispensable to the student. A typical flower has four kinds of floral leaves, sepals, petals, stamens, and carpets. The sepals collectively form the calyr (Greek for a cup), and the petals constitute the corolla ("little crown"). The calyx and corolla together are called the pericnth (Greek, peri-, round, anthos, a flower), or floral envelopes; whilst the stamens and carpels are called the essential organs, because seed cannot be formed if they are absent. If both calyx and corolla are present in the same flower, as in the Buttercup, in which flower the five sepals are green and the petals 
golden, the flower is termed complete; but if one of these envelopes is absent, as in the Marsh-marigold, the flower is incomplete. Incomplete flowers are monochlamydeous (Greek, monos, one, chlamys, a cloak) if, as in this case, they have one envelope; achlamydeous if, as in the Ash, they have neither calyx nor corolla. If both stamens and carpels occur in the same flower it is termed perfect; if only one class of essential organs is present the flower is imperfect, and staminate or carpellate as the case may be. Plants with imperfect flowers may be either

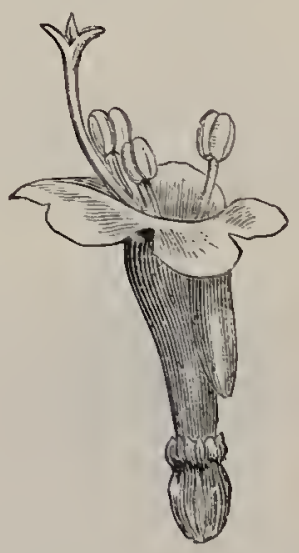

Asymmetric flower of Valerian.

monocious (Greek, monos, one, oilios, a house), where, as in the Hazel, the staminate and carpellate flower's are on the same plant; or dicecious, where, as in Willows and Poplars, they are on different individuals. Where neither stamens nor carpels are present, as in the outer florets of the blue Cornflower, or the outer flowers in the cluster of the Guelder Rose, the flower is neuter.

As a rule the leaves of each whorl are alternate with those of the preceding whorl, the petals being opposite the spaces between the sepals and the outer 
row of stamens opposite the sp.ces between the petals. The Primrose and its allies form a marked exception to this rule in that its stamens are opposite to, or stand in front of, its petals.

Where the floral leaves in each whorl are similar in size and shape the flower can be divided symmetrically in several directions, as in the Buttercup; and it is then called polysymmetric. Where from differences in the form of the leaves it can only be so divided in one direction, as in the Pea, the flower is monosigmmetric. Occasionally it is asymmetric, or not symmetrically divisible by any plane, as in Valerian.

The Receptacle is a very important structure in the classification of flowering plants, as upon it what. is called the insertion of the floral leaves depends. Thus if sepals, petals, stamens, and carpels spring onebeneath the other from a more or less conical receptacle, as in the Buttercup, the calyx is inferior, the corolla and stamens are hypogynous (Greek, hupo, under, gune, a woman), the carpels are superior, and the flower as a whole is called thalamifloral. If, as in the Bramble or the Strawberry, the calyx, corolla, and

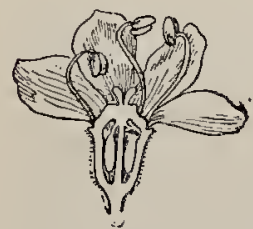

Flower of Cow-parsnip, showing epigynous insertion.

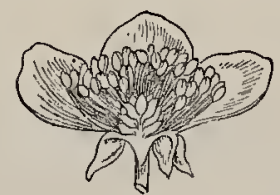

Flower of Bramule, slowing perigy nous insertion.

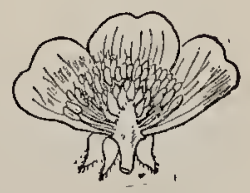

Flower of Buttercup in section, showing hypogynous iusertion.

stamens are carried out from under the carpels by a horizontal disk-like extension of the receptacle, the calyx is still inferior and the carpels superior, but the petals and stamens are termed perigynous. So, too, if, as in the Plum or the Rose, the sepals, petals, and stamens are carried up on a tubo-like expansion of the receptacle which does not adhere to the sides of 
the carpels. If, as in the Apple, the Pear, and the Hawthorn, this receptacular tube does adhere to the sides of the cripels, the calyx becomes superior and the ovary formed by the carpels inferior, the petals and stamens being still perigynous. If, lastly, as in Composite and $t m$ melliferce, this adherent tube carries the sepals, petals, and stamens on to the top of the ovary, the calyx is superior, the ovary inferior, and the petals and stamens eprigynous (Greek, epi, upon). When the petals and stamens are perigynous or epigynous the Hower is sometimes called calyeifloral, as if these parts sprang from the calyx.

The CAlry (from the Greek, Tialux, a cun) is usually green and leaf-like, though it may be petcitoid, as in the Marsh-marigold. Its sepals may be free (polysepalons) or united (ganoscpratous), like a cup. In all hypogynons flowers it will be, as we have seen, inferior, and in all epigynous ones, superior. In direction the sepals may be erect, as in the Cabbages; ascending, as in Mustard; spreading, as in Strawberry; or reflerecl, as in the bulbous Buttercup. At their base they may be pouched, as in the two outer ones of most Cruciferer. or they may be spurred, as is one of those of the Larkspur. Even when made up of five united sepals, the calyx is often bi-labiate or two-lipped, as in the Broom and the Sage. It may be tubular, as in Centaury; tubular and plaitect, as in Primrose, folded so as to be star-shaped, if cut across; bell-shaped, as in Henbane; barrel-shaped, or urceolute, and inflated, or separated by some considerable space from the corolla within it, as in the Bladder-campion; or cylindric, as in the Carnation. In some Compositer. and other flowers the calyx is replaced by a circle of hairs called a papmus, which of ten enlarges in the fruit. stage, as in 'ihistle-down. In duration the calyx may be caducous, falling off as the flower opens, as in Poppies; deciduous, falling with the petals and stamens when the seed is set, as in the Cherry; or persistent, 
remaining in the fruit stage, as in the Strawberry. When persistent it is generally marcescent or withered, as in the Hawthorn, Apple, Medlar, and Gooseberry.

The Conorla ("little crown") is the ring of more delicate, or petaloid, lenves within the calyx, which are usurlly coloured-that is, not green-and often fragrant. They are also msually attached by a narrower base than the sepals, this being sometimes drawn out into a long narrow portion or claw, as in the Pinks, when the broader upper part is dis-

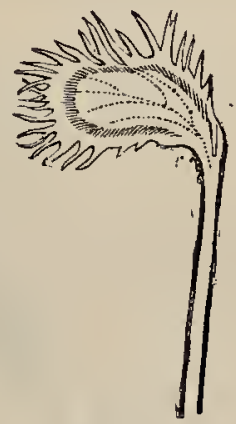

Clawed petal of a Pink.

tinguished as the $7 \mathrm{im} h$. If coherent the petals are gamopetalous and the united part forms the corollatule, the junction of the tube with the free limb being known as the throat. In the Borage tribe the throat of the corolla is generally furnished with little scales or swellings. If not coherent the petals are polypetalous, and this is a discriminating character of great importance in the classification of Dicotyledons, as also is their insertion, whether hypogynous, perigynous, or epirynous, and, to a less extent, their symmetry. Of polypetalous types the most important are the cruciform, consisting of four petals placed crosswise, as in the Cruciferce. (p. $\mathrm{xx}$ ), and the papitionaceous (Latin, papitio, a butterfly) characteristic of the Pea 
and Bean tribe, in which there are five petals, the posterior one-that nearest the stem-called the standard and usually the largest, the two side ones termed wings, and the two lower or anterior ones, often slightly united, known as the lieel (p. 163).

Among gamopetalous corollas the chief polysymmetric forms are :-

Tubular, narrow, as if formed by united erect petals, ns in the florets of Thistles or the disk-florets of a Daisy.

Bell-shapel, wider, as in Campanula (p. 443).

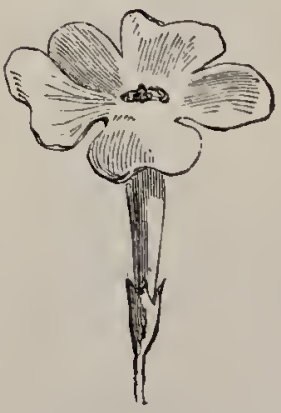

Salver-shaped corolla of Primrose.

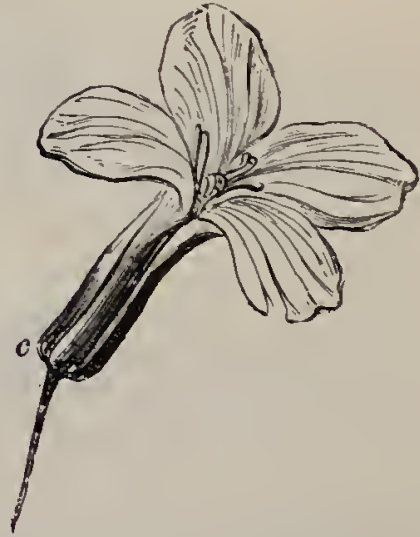

Cruciate carolla : $c$, git bous calrx.

Urceolate, or barrel-shaped, as in Heaths (p. $45 \mathrm{t}$ ). Funnel-shaped, as in the Simall Field Convolvulus. Trumpet-shaped, with reflexed margin, as in the Jarge White Convolvulus.

Salver-shaped, with long tube and limb at right angles to it, as in Primrose.

Rotate, or wheel-shaped, with a short tube, as in Pimpernel, Forget-me-not, and Eider.

The chief monosymmetric gamopetalous types are the bi-labiate, or two-lipped, and the 7igulate, or strap-shaped. The bi-labiate may be either ringent, 
or gaping, as in the Natural Order Labiatce; or personate (from persúna, a mask); as in Toad-flax. The ligulate occurs in all the florets of the sub-order Liguliflorce in the order Compositce, as in the Dandelion and Chicory, and in the outer or ray florets of many other Compositce, such as the Daisy.

In some cases, such as the Flaxes, the corolla is fugacious, falling off directly it is gathered; and in a

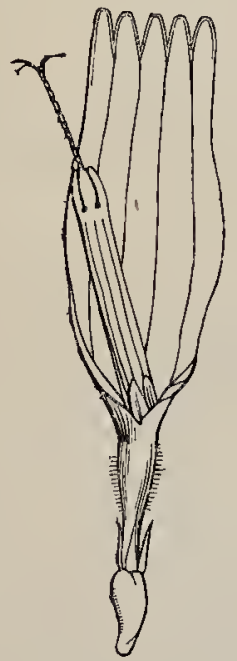

Ray-fioret of Composite showing ligulate corolla and syngenesious anthers.

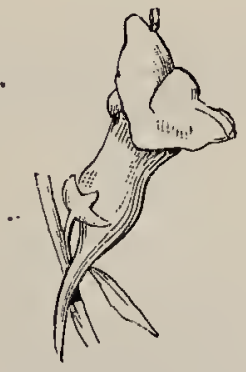

Personate carolla of Toad-flax.

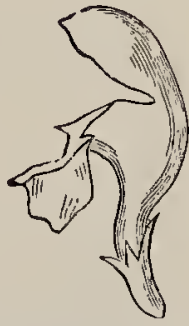

lingent corolla of Dead-nettle.

few others, as in Campanula, it is persistent, remaining in a withered condition round the fruit.

'The astivation (Latin, cestivus, belonging to summer), or folding of the leaves of the flower in the bud, is often characteristic of Natural Order's or other large groups. In Clematis the sepals are valvate, touching at their edges without overlapping; in all other Ranunculacece they are imbricate, overlapping like tiles on a roof. Poppies have their 
petals crumpled. The Maluace have their sepals valvate and their petals convolute, with one edge towards the centre of the flower, and the other rolled round the next petal. In Convolulus the colnerent petals are convolute and twisted upwards, or contorted.

The Stanexs usially consist of one, two, or more whorls of thread-like stalks known as filcuments, each surmounted by an oblong or rounded body, generally two-lobed externally and two-chambered within, which is called the anther, and contains the pollen, a fine dust-like substance. When mature the anther bursts and discharges the pollen, which is the active agent in "setting" or fertilising the seed. The number of stamens varies from one to an indefinite number, but is very commonly either the same as that of the petals or twice as many. They may be equal or unequal in length; but if, as in most Labiatee and Scrophulariacer, there are foup stamens, two long and two short, they are termed didyncmous (Greek, lis, two, dinamis, strength); and if, as in the Cruciferce, there are six stamens, four longer than the other two, they are termed tetradymamous. The stamens may be free or united, and in the latter case they may all be united into a tube below, as in the Malvacer, when they are termed monalél.jphous (Greek, monos, one, adétphos, a brother): or they inay be united in several croups or polyactétphous, as in the St. Joln's-worts (p, 1:8); or they might be united by their anthers only, as in the Compositu, when they are called syncyenésious (Greek, sum, together, genesis, beginning). "In insertion they may be hypogynous, perigynous, epigynous, or, when united to the petals, as in the Primrose, epipetalous. In the Orchidece. (p. 687), the stamens are united with the carpels in i central column, and are then termed !!muandrous. The filament may be fitiform or thread-like; capillary, or so slender as to bend under the weight of the anther, as in Grasses; subulate. or awl-shaped, as. 
in the Tulip; petcloid or broad, as in the Water-lilies; or absent, when the antlier is termed sessite, as in Lilac.

Though generally yellow, the anther is violet in many Grasses and black in Poppies; and among its chief variations in form are the divergent ends of its two lobes in Grasses (p. 826). Its attachment to the filament is often an important character. It may be basifixed, or attached only at its base; dorsifived, or attached along its whole lengtlı; or versatile, sô attached by a point that it can be freely turned round, as in Lilies and Grasses. It generally splits

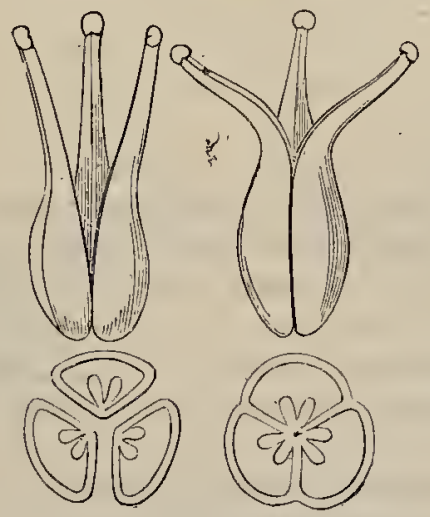

Diagram of apocarpous and syncarpous carpels with cross sections of their ovaries.

longitudinally when mature; but less commonly it does so transversely; in the Heath tribe by terminal pores; and in the Barberry (p. 28) by valves. Whilst in the Compositce and Amaryllidacece it bursts inwards, towards the centre of the blossom, or is, as it is called, introrse; in Iridacece and the Barberry it is extrorse, discharging its pollen outwards.

The Carpers occupy the centre of the flower. There may be only one, as in the Leryminosce and Prunece (p.199), or more than one, and in the latter case they may be free from one another, or apocarpous, 
as in the Ranunculacece, or united (syncarpous), as in Litiacece. In either case the lower part forms one or more chamber's, containing the ovules or unfertilised seeds, which chambers, if distinct, are termed ourvies; if united, a syncarpous ovary, which may be onechambered, as in Violets and Orchids, or have two, three, or more chambers, generally as many as there are carpels. Above the ovary there is generally one or more shaft-like tubes called styles. Each apocarpous carpel will generally have a separate style, as in the Strawbery or the Bramble; but a syncarpous ovary, such as that of the Violet or the Lily, may have only one. Sometimes, as in the Daisy and the Iris, the style may fork at its upper end and it bears the stigma, a variously-shaped, sticky surface to which the grains of pollen adhere when dropped on to it, or carried thither by wind or insects. Besides noting whether the ovary is apocarpous or syncarpous, its external form, and the number of chambers into which it may be divided internally, it is important to determine whether it is superior, free, that is, from the calyx, or inferior, that is, adherent to the calyx-tube, and also how many ovules there are in each chamber, and how they are arranged. This arrangement is termed placentation, because the ovules commonly spring from a spongy cushion-like portion of the inner wall of the ovary called a placenta. As the solitary ovule in the Polygonacee, in the Walnut and in the Gymmospermous ${ }^{1}$ Yew appcars to be a direct prolongation of the branch or axis, it is called terminal. That of the Compositer, though lising from the base of the ovary and, therefore, termed basal, is lateral to the axis ; whilst in the Primulacere and in the Caryophyllacece several ovules springing from a central axis in a one-chambered ovary, they are called free-central. In TVater-lilies, Poppies, and the Flowering-rush (Butomus) the 
placentation is superficial, the ovules being scattered over the inner walls of the ovary. Most onechambered ovaries which contain many ovules, such as that of the Violets, have lines of ovules down their sides, corresponding to the number of carpels. This is called parietal placentation (Latin, paries, a wall). The Cruciferce are exceptional in having parietal placentation in a two-chambered ovary, a partition (known as a replum) growing across between the two placentas (p. 44). Most many-chambered ovaries have central placentation, as, for example, in the Lilies

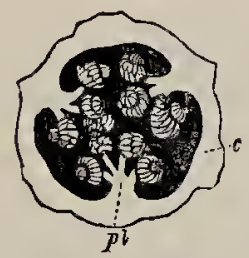

Parietal placentation.

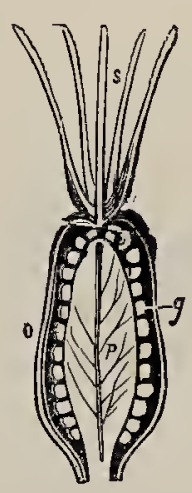

Free-central placentation.

or St. John's-worts, in which the rows of ovules spring from the central axis formed by the inrolled margins of the united carpels.

The Frout is the ovary and other adherent parts that enlarge after the fertilisation of the ovules. It may be succulent or dry. In the latter case, if oneseeded, it will generally be indehiscent, not splitting, that is, when ripe; but if many-seeded it will commonly split, either into pieces known as nutlets, eaeh enclosing one or two seeds, or so as to disclose its seeds. Our ehief types of fruit may be thus classified :- 
Oí one carpei (monocarpellar?!) -

1. Pod, or legume, dry and splitting down both sides, as in the Leguminosc.

2. Drupe, or stone-fruit, with a skin, flesh, and stone, the kernel being the seed, as in the tribe Priviece of the Rosacece.

Of more than one carpel (polycarpellary)-

Apocarpous (carpels distinct).

3. Etcerio (Greek, hĕtcíros, a companion), a collection of carpels (firitlets), ench of which may be div, one-seeded and indehiscent, when it is called an achene (Greek, a, not; chaino, I split), as in the Buttercup, Striwberry, and Rose; or each may be a dry manyseeded pod or follicle, splitting down one side, as in the Marsh-marigold and the Columbine; or ench may be a succulent miniature drupe or clrujél, as in the Blackberry and Raspberry.

Syncarpous (carpels united).

Superior.

4. Coryolsis, dry, indehiscent, and one-seeded, as in Wheat and most Grasses, ench grain being a fruit formed of two carpels with a groove where they join.

5. Sitiqua, the dry, two-chambered dehiscent pod of the Crucitere (p. 44 ).

6. Reyma, dry, splitting into nutlets, as in Mallows, Cranesbills, Spurges, Mint, Borage, de.

7. Samura, dry and winged, as in the Asl, Maple, and Elm.

8. Capsule, dry and deliscent, as in the Violets, Primrose, Pinks, dce, opening by vatres in the Violets, by tecth in the Primrose, by pores in the Poppy, and by splitting all round in the Pinpernels.

\section{Inferior.}

9. Cypséta (Greek, Riépsílo, a chest), dry, one-seeded, and indehiscent, as in the Compositce, and often surmounted by a downy pappus, as in Thistledown. 
10. Nut, very similar, but generally larger and hardel, as in the Beech, Acorn, or Hazel.

11. Cremocarp, dry and splitting into two nutlets, as in the Unbelliferce (p. 279).

12. Berry, succulent, as in the Gooseberry.

13. Pome, succulent, with a tough core, as in the

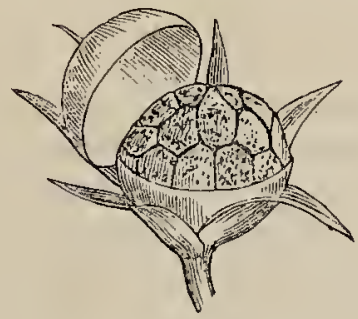

Capsule of Pimpernel.

Apple, Hawthorn, Mountain Ash, and other members of the sub-order Ponacece of the Rosacece.

The SEens are only naked in such plants as the Yew and the Firs, which are, therefore, called Gymnospermia (nakedseeded). In other flowering plants they are enclosed in the fruit, and if the fruit is indehiscent they have commonly a brown bitter outer skin. The seeds of dehiscent fruits are more often conspicuously colouled as in the Spindlc-tree (p. 156); and they are sometimes, as in the Willows, Poplar, Willowherbs, dc., furnished with tufts of hair, which aid in their dispersal by wind. The most important distinction among seeds for purposes of classification is into dicotylédonous, having two opposite lobes or seed-leaves (cotylédons) with the primary bud between them, and mŏnŏcotylectonous, with only one such cotylédon.

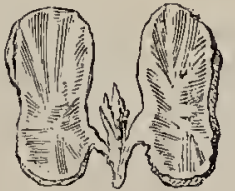

Dicotyledonous seed.

Other terms which are employed in the body of the work will be explained as they occur, or in the glossary at the end of the volume. 


\section{PART II.}

\section{TIIE CLASSIFICATION OF PLANTS.}

So great is the number of different kinds, or species, of plants that no one could possibly bear them all in mind or recollect their distinctive characteristics. Whilst in 1753, when the great Swedish botanist Linnæus published his "Species Plintarum," only 7,300 species were known to him, botanists at the present day have upwards of 100,000 species to denl with, of Flowering Plants alone. It becomes necessary, therefore, to classify them in a succession of larger or more general groups, according as they agree with one another in many or in fewer characters. TVe can then more readily remember the cliaracters of the comparatively few larger groups ; and, knowing them, can on examination refer any plant to its position in the classification.

Plants which agree in all essential points, though differing perhaps in size or in the colour of their flowers, are said to belong to a single species. Naturalists of all schools of thought agree that the individuals of a species have all had a common ancestry. Facl species has a Latin or scientific name, which since the time of Linneus ${ }^{1}$ has consisted of two words, the second of which is peculiar to it and is known' as the specific name, whilst the first is known as the generic name, being shared with other species,

(1) No little merit is due to Linnalu for inventing the specific name of plants. The method in use previously was to attacli to erery plaut rome such title as the following:-Gramen xerampelinum, malacea, pertenui ramosaque sparsi panicula. The name of this grass Limnaus expressed with precision and simplieity by the two words, l'ou bulbosa. 
which, agreeing in certain characters, are said to belong to the same genus. The wild Sweet-scented Violet, for example, is called by botanists Viola odorata, the name Viola indicating that it belongs to the genus so called. Besides the Scented Violet, we have wild in England the Marsh Violet, the Hairy Violet, the Wood Violets, the Dog Violet, the Pansy, and several others, all belonging to the same genus, and, therefore, described under the name Viola. But the Marsli Violet differs from the Sweet-scented in having broader and blunter leaves, in being almost entirely free from hairs, and in having smaller, pale lilac, scentless flowers, with a shorter spur to the corolla, besides growing in much wetter situations. The Marsh Violet is, therefore, a distinct species, Viola palustris.

It is by no means easy to determine what character's are sufficiently constant, true to seed, and important to constitute a species. Among the Wood Violets, for instance, we may find that most have broad-pointed leaves, broad blue petals with numerous branched dark veins at their base, and a thick yellowish-white spur; but that some have the leaves drawn out into a longer point, the petals narrower and more lilac, with few slightly-branched veins, and a compressed dark-bluish spur. Some botanists consider these two forms as distinct species, $V$. Riviniáne and $V$. sitvéstris, whilst others call them both varieties of $V$. silvéstris, the first being then known as $V$. silvéstris, var. Riviniána, and the second as $V$. sitréstris, var. Reichenbachiana, "var." being the abbreviation of the Latin "varietas.".

On the leaf-stalk of a Siveet-scented Violet or of a Wood Violet we shall find two small narrow stipules; but in the Pansy we shall see that these are replaced by a pair that are large, leafy, and pinnately-lobed. This is only one of the characters that make us separate the Pansy as a distinct species, $V$. tricolor. 
Sweet Violets, Wood Violets, Pansies, and in fact all other Violets, though thus differing specifically, agree in having monosymmetric flowers with ear-like lobes (avicles) at the base of each of their five sepals, a spur to the posterior petal, and five united anthers with tail-like appendages from the base of two of them. These then are the generic characters of the genus Tiola. According to the theory of descent, all the species in a genus arc descended from a common ancestry, but from a common ancestry more remote than that commen to the individuals constituting a species. In gromping specics in one genus all the characters of the plants have to be taken into consideration, and we shall commonly find that all the species of any one genus will agree in the number and insertion of their floral leares, the kind of fruit, and the general type of leat : but that the species will differ from one another in the size and form of the various parts. The mere colour of petals or of fruit is generally considered only as a varietal character. So far as a classification does take all the characters of plants into nccount, it is a natural system; whilst onc based only upon a single set of characters is an artificial system.

The best of all artificial systens is that of Linnews, based primarily upon the number and arrangement of the stamens, and secondarily upon the carpels. Like all other artificial systems, this is a mere index, telling nothing about a plant bcyond the one character considered, separating plants obviously allied, and placing together others which have but one character in commoll. Linneus himself recognised the tentative character of his system. "All plants," he says, in his "Philosophia Botanica," "are allied by aftinities, just as territories come in contact with each other on a map. Botanists should uncensingly endearour to arrive at a natural system of classification. Such a natural system is the final aim of botanical science. 
Our insufficient knowledge of plancs is what renders such a system impracticable at present."

Botanists rowadays seldom employ the Linnean System, preferring the more ditficult but more instructive Natural System. In this we may reverently be said to be thinking out for ourselves the thoughts of the Creator, for, according to the theory of descent, which gives us the most rational explanation of the meaning of resemblances, we are reconstructing the pedigree of the Vegetable Kingdom.

One of the most striking assurances that our system is truly natural is afforded us by the discorery that many groups of genera classed together in what we term natural orders, solely on account of structural characters, agree closely also in their properties. This obviously also gives a practical utility to the system. In the present work, for instance, adopting a system based upon those of Antoine Iaurent de Jussieu (1774) and Auguste Pyrame de Candolle (1813), we group the genera into natural orders, the Latin names of which are adjectival, ending in $k$, agreeing with the word plante understood. The name of the first of these orders, Ranunculacea, means "plants allied to Ranunculus," and the order includes, in addition to the Buttercups (Ranunculus), Anemones, Hellebores, Aconites, Larkspurs, Columbines, Pronies, Clematis, and others. These agree in the absence of any union between the parts of their flowers and in having hypogynous and generally numerous stamens; but they also agree in having an acrid, often poisonous, juice. Another large Natural Order, the Ciuciferce, consists almost exclusively of herbaceous plants with simple leaves, flowers without bracts, four sepals, four petals, six stamens, of which four are longer than the other two, and two united carpels forming a siliqua; but they also agree in being wholesome and generally pungent from the presence of oil of mustard. Yet another group, the Labiatce, agree in their square 
stems, opposite and decussate, simple leaves, twolipped (bi-labiate) corollas, four stamens, two long and two short, and two carpels dividing into four nutlets; but they also agree in being aromatic from the presence of volatile essential oils in which are dissolved camphor-like substances. The structure of a newly-discovered plant may thus afford a traveller considerable information as to its probable properties.

The Vegetable Kingdom is now generally divided into four sub-kingdoms : the Thallophyta, including seaweeds and fungi; the Bryophyta, or mosses and liverworts; the Pteridophyta, or ferms, horsetails, and clubmosses; and the Phanerogamia, or Spermaphyta, the flowering, seed-bearing plants. Of these only the last comes within the scope of the present work. It is divided into tro divisions, very unequal in the number of species belonging to them : the Anfiosperms, or fruit-bearing plants, which have thcir ovules enclosed in closed ovaries with a viscid stigma to receive tho pollen; and the Gymnosperms, including the conebearing trees, which have naked seeds and no stigmas, the pollen falling directly upon the orule. The Angiosperms, the larger division, is subdivided into two classes, the Dicotyledons and the Monocotyledons. The characters of these clisses, and of the sub-classes, serics, and orders into which they are divided, are fully given in the body of the work. 


\section{PART III.}

THE IDENTIFICATION OF PLANTS.

A Few words may be of use here as to the way to employ the body of the book when we wish to find out the name of any flowering plant we may have met with in our walks. Suppose we have found on some chalk-down a small wiry undershrub with opposite, entire leaves and conspicuous yellow flowers, in what part of this work must we look for its name and description? Even if we cannot detect the netted veins in the leaves, the five petals make us suspect the plant to be a Dicotyledon. There is a calyx of three larger and two minute sepals below the petals and these last are not united; so that it almost certainly belongs to the sub-class Polypetalæ, as we see by the Tabular View of the Natural Orders on pp. xxxviii-lii. Not only is the ovary distinctly above both calyx and corolla, or "superior," but the numerous stamens elearly spring from beneath it, and are, therefore, "hypogynous." The plant belongs then to the series Thalamifloræ. An examination and dissection of the ovary, or, more easily, of the capsular fruit, shows a number of ovules or seeds springing in three rows from the sides of a one-chambered ovary. It is, therefore, almost certainly "syncarpous," and for that reason does not belong to Orders 1 or 2 . The leaves at once tell us that it can hardly belong to Orders $3,4,5,6$, or 7 in the Tabular View; but all its characters igree with those of Order 8, the Cistinere, or Rock-Rose Family, so we turn to the fuller description of this group at p. 87, to which we are referred in the Tabular View, 
before looking elsewhere. There we find that there is but one British genus in the Order, viz., Heliannthemum, and that, of the four truly British species, only one, $H$. Chamcecistus, is at all common. The prostrate growth, small stipules, and green upper surfaces of its leaves at once show us that it is to this species, the Common Rock-Rose. that our specimen belongs.

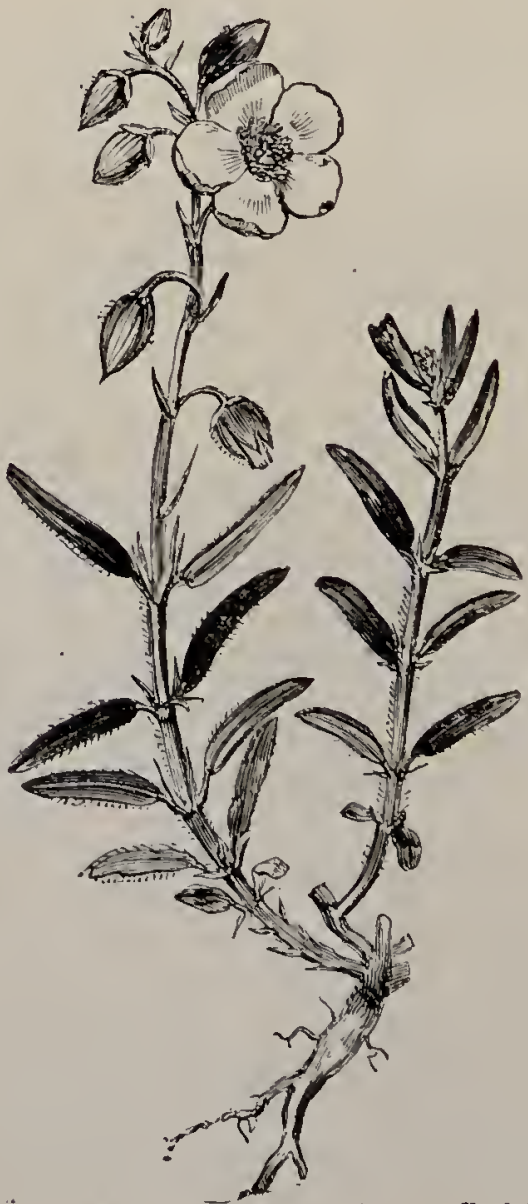


We may find a second example to test at no great distance. It is an erect; herbaceous plant with smooth leaves and long racemes of green flowers. Here again the veins and stipules of the leaves and the four sepals and petals, though the latter are so cut up as to be difficult to count, suggest a Dico-

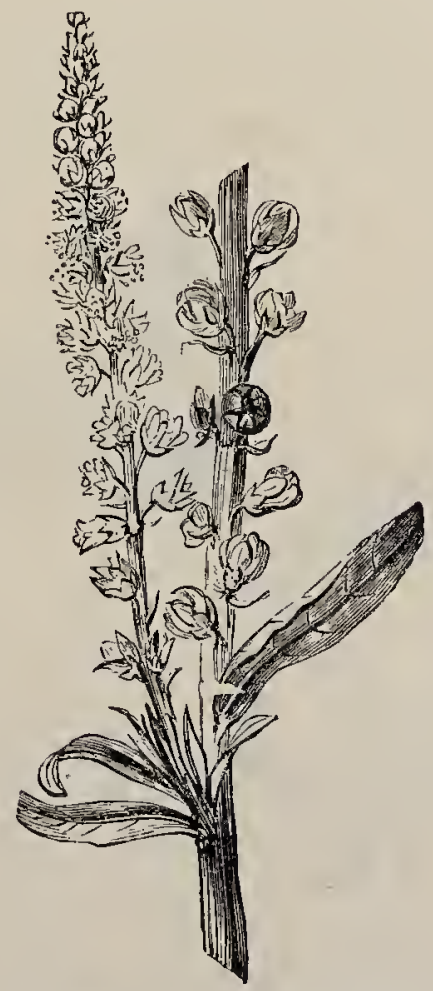

RESÉDA LUTÉoIA (Dyer's Rocket).

tyledon. The numerous stamens spring from a relatively large, fleshy outgrowth or "disk," which is hypogynous, but by its one-sided development renders the flower monosymmetric The ovary is distinctly superior, springing from the top of this disk and is three-sided externally and one-chambered, and con 
tains three lateral rows of ovules. These characters make us again turn to the Polypetale and, among them, to the Thalamiflor:e. We soon see that the ovary does not agree with those described in the Tabular View under Orders 1-4, or, for that matter', 5 or 6 , whilst the numerous stamens at once make us pass over these last two Orders and pause at Order 7, the Resedacece or Mignonette Family. Turning to the fuller description of this group on p. 85, we again find but one British genus, Reséda,

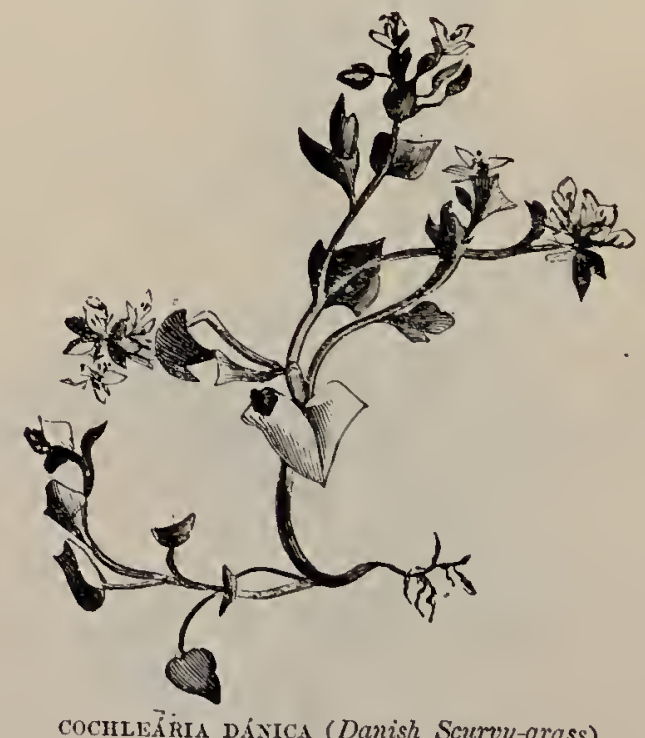

COCHLEAKIA DAXICA (Danish Scurvy-grass).

containing two wild species. The undivided leaves and four sepals of the plant before us enable us to decide between these two. It is $R$. Luteola, the Weld or Dyer's Rocket.

One more example will suffice. The plant to be examined is a small annual herb growing near the sea or in the inarshes bordering some tidal river. Its leaves are rather fleshy and have no stipules, the 
lower ones are heart-shaped, and the upper ones, which have short petioles, are deltoid or angular. The white flowers with four distinct green sepals, four white petals and six stamens, of which four are longer than the other two (tetradynamous), after referring us, as before, in succession to Dicotyledons, to Polypetalæ, and to Thalamifloræ, cause us, in running through the characters of the orders, to pause at Order 6, the Cruciferce or Cabbage Family. This is a large order" containing more than twenty-five genera, so we have to turn to the table of these genera on pp. $44-47$. We may have some little difficulty here; but, if we find any fruit on our specimen, the short pod which is not flattened but inflated, and contains a number of seeds, and the unnotched petals suggest the genus Cochlearia, the Scurvy-grass. On turning to the description of this genus on p. 69 we find that it includes three or four British species; but that, among these, the stalked deltoid leaves and egg-shaped pod show our specimen to be C. dánica, the Danish Scurvy-grass.

By puzzling out every plant he meets with in this manner the student fixes their distinctive structural characters in his mind, and acquires a far more valuable knowledge of plants than he would get by being told their names, by identifying them from pictures, or by any artificial key. 


\section{TABULAR VIEW OF THE NATURAL ORDERS.}

Sub-kingoos. Spérmaphytes or Phánerogams.Plants producing flowers and seed.

Division I. Angiosperms.--Plants having their ovules in closed ovaries.

Crass I. Dicotylédons.--Plants having two cotyledons, ${ }^{1}$ net-veined leaves and floral leaves in whorls of 5,4 , or 2 . (pp. 1-682.)

Sub-Class 1. Polypétalce.--Having both calyx and corolla, and the petals of the latter free. ${ }^{2}$ (pe. 2-333.)

Series 1. Thalamifóre.-Petals and stamens hypogynous ; ovary superior. ${ }^{3}$ (pp. 2-154.)

\section{$\S$ Ovary apocarpous.}

- Order 1. Ranunculáceu (The Buttercup Family). -Except Clematis, herbs with watery, generally acrid juice; scattered leaves; sepals 3 or more; petals usually 5 ; stamens usually indefinite; fruit of achenes or follicles; with no colnesions in the flower. (p. 2.)

Orver 2. Berberidece (The Barberry Family).-Shrubs with scattered leaves; polysymmetric flowers; sepals $6-9$; petals 6 ; stamens 6 ; opening by valves; fruit berry-like. (p. 28.)

(l) Almost overy chatacter is in naturc subject to exceptions; thus the Oak las of ten threo cotyledons, the Dodder liardly a vestige of any.

(2) Flowers without corolla occur in Raumenlácex, Cruciferx, Violíeer, Caryophyllícex, Rosácex, Saxifrígex, Halorágea, Lythrácex, Onagrúcea. Petals moro or less coherent occur in Fumariácer, Polsgaláceæ, Portuláceæ, Tamaricíneæ, Malvícee, Ilicíneæ, Crassulíceæ, and Cucurbitácex.

(3) Stamens apparently springing from a perigynous disk in Castalir (Nymphæáceæ). 
$\S \S$ Ovary syncarpous; carpels many ; ovules many.

Order 3. Nymphceácew (The Water-lily Family). -Water-plants with floating leaves; solitary, large polysymmetric flowers; petals many, gradually passing into stamens; stamens indefinite; carpels enclosed in cup-like disk; ovules superficial. (p. 30.)

Order 4. Papaverácece (The Poppy Family).Herbs with milky juice; scattered leaves; conspicuous polysymmetric flowers; sepals 2, caducous; petals 4 ; stamens indefinite; ovules superficial or parietal; fruit capsular. (p. 33.)

$\S \S \S$ Ovary syncarpous, $1-2$ chambered ; carpels $2-5$; ovules parietal.

- Order 5. Fumariácece ('The Fumitory Family).Herbs with watery juice; divided leaves; flowers in bracteate racemes, monosymmetric; sepals 2 ; petals 4 , the inner pair coherent; stamens 4, diadelphous; carpels 2 ; ovary one-chambered. (p. 40.)

- Order 6. Cruciferce (The Cabbage Family).Herbs, often pungent, with scattered, exstipulate, simple leaves; flowers in ebracteate racemes, polysymmetric; sepals 4 ; petals 4 ; stamens 6 , tetradynamous; carpels 2 ; ovary two-chambered; fruit a siliqua. (p. 43.)

Order 7. Resedacece (The Mignonette Family).Herbs, with scattered, exstipulate leaves; flowers greenish, in bracteate racemes, monosymmetric ; sepals $4-7$, persistent; petals 4-7; stamens indefinite; carpels 3 ; ovary one-chamkered. (p. 85.)

Order 8. Cistinece (The Rock-Rose Family).-Undershrubs with entire, opposite leaves; conspieuous polysymmetric flowers; sepals $3-5$; petals 5 ; stamens indefinite; carpels 3 ; ovary one-chambered: (p. 87.)

Order 9. Violacece (The Violet Family.)--Herbs with scattered, stipulate, simple leaves; flowers monosymmetric; sepals 5; petals 5, 1-spurred; sta 
mens 5 ; carpels 3 ; ovary one-chambered; ovules many. (p. 89.)

Order 10. Polygalácece (The Milkwort Family).Herbs with scattered, exstipulate, simple leaves; flowers in racemes, monosymmetric; sepals 5 , the inner ones petaloid; petals $3-5$; stamens 8 , diadelphous; carpels 2 ; ovary two-chambered; ovules 2. (p. 93.)

Order 11. Franteniácece (The Ser-heath).-A her.b with opposite, exstipulate leaves; small, axillary, polysymmetric Howers; sepals, petals, and stamens 4 - 6 each; carpels $2-5$; orary one-chambered. (p. 96.)

$\S \S \S \S$ Ovaly syncarpous, one-chambered; carpels 2 -5; placenta free-central or basal.

- Order 12. Campoptryllácer (The Pink Family).Herbs, mostly with swollen nodes; opposite, simple leaves; Howers polysymmetric, white or red; sepals $4-5$; petals $4-5$; stamiens $8-10$; styles $2-5$; ovules many; placentation free-centr'al ; fruit a capsule, opening by teeth or pores. (p. 96.)

Order 13. Portulácece (The Purslane Family).Smooth, succulent herbs with exstipulate, simple, entire lenves, opposite or alternate; small flowers; sepals 2 ; petals 5 ; stamens $3-5$; ovules few, basal. (p. 123.)

Ormer 14. Tamariscinea (The Tamarisk).-A slumb with minute leaves and lateral spikes of small flower's; sepals and petals $4-5$ each ; stamens $4-10$, on a disk; styles 3 ; ovules many, basal. (p. 125.)

$\$ \$ \$ \S$ Ovary syncal pous, two- or mole-chambered; placentas axile.

Ordar 15. Elatineer. (The Waterwort Family).Small aquatic herbs with opposite, stipulate, spathulate leaves and minute axillary flowers; sepals, petals, stnmens, and carpels 2-5 each ; ovules many. (p. 127.) 
Order 16. Hypericínece (The St. John's-wort Family).-Herbs or shrubs with opposite, simple leaves, often dotted with glands, and conspicuous yellow polysymmetric flower's, generally in cymes; sepals 5 ; petals 5 ; stamens polyadelphous; carpels $3-5$; ovules many. (p. 128.)

Order 17. Maluácece (The Mallow Family).Herbs or shrubs with mucilaginous juice, scattered, stipulate leaves, and conspicuous polysymmetric flowers; sepals 5, valvate; petals 5, convolute; stamens monadelphous; carpels many, each 1-ovuled. (p. 132.)

Orderr 18. Tiliacese (The Linden Fanily).--Trees with scattered, stipulate, oblique, serrate leaves, a large bract adherent to the flower-stalk, and clusters of greenish polysymmetrie flowers; sepals 5; petals 5 ; stamens many; carpels 5, each 2-ovuled. (p. 137.)

Order 19. Linece (The Flax Family).-Herbs with slender stems; narrow, simple, entire, exstipulate leaves and polysymmetric flower's ; sepals, petals, stamens, and carpels $4-5$ each; petals fugacious; carpels 2-ovuled. (p. 139.)

- Order 20. Geraniácerp (The Crane's-bill Family).-. Herbs, often succulent, with leaves generally stipulate; and conspicuous polysymmetric or monosymmetric flowers; sepals $3-5$; petals $3-5$; stamens $5-10$; carpels $3-5$; ovules 1 or more in each chamber. (p. 142.)

OrDER 21. Ilicinece (The Holly).-A tree with evergreen spinous leaves and small white flowers; sepals, petals, stamens, and carpels $4-5$ each; fruit berry-like, with 4 one-seeded stones. (p. 152.)

Senies 2. Calyciflorece-Petals and stamens perigynous or epigynous; ovary superior or inferior. ${ }^{1}$ (pp. 154-333.)

(1) The stamens are sometimes indistinctly perigynous in Leguminósæ, Saxifrágeæ, Crassuláceæ, and Droserúcex. 
§ Stamens perigynous; ovary generally superior. ${ }^{1}$

Order 22. Celastrinece (The Spindle-tree). - A shrub or tree, glabrous; with opposite leaves; small greenish flowers; pink, fleshy capsules; and orange seeds; sepals, petals, stamens, carpels, and seeds usually 4 each. (p. 155.)

Order 23. Rhámnea (The Buckthorn Family).Shrubs with simple leaves, small, gieenish flowers, and berry-like fruit; sepals, petals, and stamens $4-5$ each; stamens opposite petals ; ovary 3 -chambered; chambers 1-ovuled. (p. 157.)

Order 24. Acerinece (The Maple Family).-Trees with opposite, palmately-lobed leaves and sinall, green, polysymmetric flowers; sepals and petals 4-9 each ; stamens 8 , on a disk; carpels 2; fruit a double samara. (p. 159.)

' Order 25. Leguminósa (The Pea Family).Shrubs or herbs with scattered, stipulate, usually compound leaves and papilionaceous flower's; sepals and petals 5 each; stamens 10 , monadelphous or diadelphous; carpel 1 ; fruit a pod. (p. 16.)

- Orber 26. Rosácece (The Rose Family).-Trees, shrubs, or herbs with scattered, stipulate, simple or compound leaves and polysymmetric flowers; sepals $4-5$; petals $4-5$; stamens many; carpels, 1, 2, 5, or many, free or united f fruit various. (p. 199.)

Onder 27. Saxifragew (The Saxifrage Family).Shrubs and herbs with polysymmetric llowers; sepals $4-5$; petals $4-5$; stamens $4-10$; carpels $2-4$, united. (p. 239.)

Order 28. Crassulácce (The Stonecrop Family).Succulcnt herbs with simple leaves and polysymmetric flowers; sepals, petals, and carpcls $3-20$ each, usually 5 ; stamens usually twice as many as the petals ; carpels free, forming follicles. (p. 248.)

Orber 29. Droserácece (IThe Sundew Family).Small viscid marsh plants with radical leaves, sinall

(1) It is inferior in some Rosícex and Sasifrágex. 
white polysymmetric flowers, and capsular fruits; sepals, petals, and stamens 5 each; carpels $3-5$; ovules many. (p. 255.)

Order 30. Lythráriece (The Loosestrife Family).Herbs with entire, generally opposite leaves and polysymmetric flowers; sopals and petals $3-6$ each; stamens generally twice as many as the petals; carpols 2-6; fruit a many-seeded capsule. (p. 258.)

$\S \S$ Stamens epigynous; ovary syncarpous, inferior.

Order 31. IIalorágece (The Mare's-tail Family).Aquatic herbs with opposite or whorled leaves and very inconspicuous flowers; sepals 2-4, or absent; petals $2-4$, valvate or absent; stamens $1-8$; carpels $1-4$; styles distinct; ovules 1 in each chamber. (p. 261.)

Order 32. Onagráriece (The Willow-herb Family). - Herbs with simple exstipulate leaves and generally conspicuous polysymmetric flowers; sepals 2-4, valvate; petals 2-4, contorted, or absent; stamens $2-8$; carpels $1-6$, usually 4. (p. 267.)

Order 33. Cucurbitácece (The White Bryony).-A hispid climbing herb with tendrils, palmately-lobed leaves, greenish dicecious flowers, and scarlet berries; sepals 5, united; petals 5, united; stamens 3 ; carpels 3. (p. 275.)

- Order 34 . Umbelliferce (The Parsley Family).Herbs, mostly with pinnate leaves, sheathing at the base, and compound umbels of small white flowers; sepals, petals, and stamens 5 each ; carpels 2, 1-ovuled; fruit a cremocarp. (p. 278.)

Order 35. Araliácece (The Ivy).--A climbing shrub with adhesive rootlets, evergreen leaves, simple umbels of yellowish flowers, and black berries; sepals, petals, stamens, carpels, and seeds 5 each. (p. 329.)

Order 36. Comácece (The Dogwood Family).-Shrubs and herbs with opposite leaves, small flowers, and berry-like fruits; sepals, petals, and stamens 4 each; carpels 2, 1-ovuled. (p. 331.) 
Sub-Class 2. Gamopétale.--Having both calyx and corolla and the petals of the latter united.' (pp. 333-610.) 448.)

Series 1. Epúgynce.-Ovary inferior. ${ }^{2}$ (pp. $333-$ \$ Stamens epipetalous. ${ }^{3}$

- Orner 37. Caprifoliácece (The Honeysuckle Family).--Trees, shrubs, and herbs with opposite leaves and generally conspicuous flowers, sometimes monosymmetric; sepals $3-5$; petals $3-5$; stamens $4-10$; carpels $3-5$; ovules 1 or many in each chamber. (p. 333.)

- Order 38. Rubiácece (The Bedstraw Family).Herbs with whorled lenves and small polysymmetric Howers; sepals, petals, and stamens $4-6$ each ; carpels 2, 1-ovuled.

(p. 342.)

Order 39. Valeriánece (The Valerian Family).Herbs with opposite leaves and small asymmetric flowers; sepals $3-5$, often pappose; petals $3-5$; stamens 1 or 3 ; carpels 3 ; ovary 1 -ovuled. (p. 350.)

Order 40. Dipsácece (The Teazle Family). - Herbs with opposite leaves and heads of small Howers, each with 4 or 5 petals and 4 free stamens; ovary 1-cliam. bered and 1-ovuled. (p. 356.)

- Ordwr 41. Compósite (The Composite Family). Herbs with heads of small flowers with tubular or ligulate corollas and $4-5$ stamens with syngenesious anthers; style 2-fid; ovary 1-cliambered, 1-ovuled. (p. 361.)

$\S \S$ Stamens on the ovary (epigynous).

Order 42. Campranulácece (The Bellfower Fimily). -Herbs with milky juice, scattercd leaves, and usually conspicuous bluish flowers; sepals, petals, and

(1) Caunopetalous forms occur cxccptionally among Polypétalx. (See p. xxxviii, notc.) Frec petals occur in some Ericícer, Plumbagínes, and Geutiínce. Petals aro absont in some Primulácere and Oleácer.

(2) The ovary is also inferior in some Primulicere.

(3) The stamens aro also epipetalnus in scmo Cimpanulícer. 
stamens 5 each ; carpels $2-5$; ovules many ; placentation axile. (p. 435.)

Oruer 43. Vacciniácece (The Cranberry Family).Undershrubs with scattered, simple leaves; small, drooping, reddish or pink flowers, and edible berries; sepals, petals, and carpels $4-5$ each; stamens $8-10$. (p. 445.) 610.)

Series 2. Hypógynce.-Ovary superior. (pp. 448$\S$ Stamens free (hypogynous).

Order 44. Enicácece (The Heath Family).-Trees, undershrubs, or herbs with opposite or whorled, evergreen leaves, and small, often conspicuous, polysymmetric flowers ; sepals, petals, and carpels $4-5$ each ; stamens 5-10. (p. 448).

Order 45. Monotrópece. (The Bird's-nest).-A fleshy yellowish saprophyte with scattered brown scale-leaves and bell-shaped polysymmetric flowers; sepals, petals, and carpels $4-5$ each; petals scarcely cohering; stamens $8-10$; fruit a capsule; seeds many. (p. 461.)

$\$$ Stamens epipetalous. ${ }^{1}$

- Order 46. Plumbagínece (The Thrift Family).Herbs, mostly maritime, with radical leaves and small flowers; sepals, petals, and stamens 5 each ; stamens opposite the petals; carpels $3-5$; ovary 1 chambered, 1-ovuled. (р. 463.)

Order 47. Primulácece (The Primrose Family).Herbs, mostly with radical leaves, conspicuous polysymmetric flowers, and capsular fruits ; sepals, petals, and stamens $4-9$ each ; stamens opposite the petals; ovary 1-chambered; placentation free-central ; ovules many. (p. 466.)

Order 48. Oleácece (The Olive Family). - Trees or shrubs with opposite leaves and small polysymmetric.

(1) Except in some Plantagineæ and Illecebráceæ, 
flowers ; sepals and petals 4 each, or absent; stamens 2 ; fruit a samara or berry-like. (p. 480.)

Order 49. Apocynácece (The Periwinkle Family).Perennial, slender, prostrate underslirubs with milky juice; opposite, evergreen, entire leaves, and large polysymmetric flowcrs; sepals, petals, and stamens 5 each ; corolla salver-shape, contorted in bud. (p. 484.)

Order 50. Gentiánece (The Gentian Family).Bitter glabrous herbs, mostly with opposite, simple, entire leaves and conspicuous polysymmetric flowers; sepals, petals, and stamens 4-10 each; carpels 2; fruit a capsule; seeds many. (p. 486.)

Order 51. Polemonicicu (The Jacob's Lathler).An erect herb with pinnate leaves and conspicuous polysymmetric llowers; sepals, petals, and stamens 5 each ; carpels 3 ; fruit a 3-chambererl, many-seeded capsule. (p. 496.)

- Order 52. Boragínece (The Borage Family).Herbs, mostly rough, with scattered, simple leaves, and conspicuous polysymmetric flowers; sepals, petals, and stamens 5 each; carpels 2, 2-ovuled; fruit a regma of 4 1-seeded nutlets. (p. 498.).

Orner 53. Convolvulácea (I'he Bindweed Family). -Herbs, generally twining, with scattered, simple leaves, or leafless, and polysymmetric flowers ; sepals, petals, and stamens 4-5 each; carpels 2, 2-ovuled; fruit a 4-seeded capsule. (p. 514.)

- Order 54. Solanácece (The Nightshade Family). Herbs or shrubs with scattered leaves and polysymmetric flowers; sepals, petals, and stamens 5 each; carpels 2 ; fruit a capsule, or berry-like, manysecded. (p. 519.)

- Ordir 55. Scrophularinea (The Figwort Family). -Herbs having mostly conspicuous monosymmetric flowers; sepals, petals, and stamens $4-5$ each ; corolla often bi-labiate; stamens generally didynamous ; carpels 2 ; fruit a 2 -chambered, many-seeded capsule. (p. 526.)

Order 56. Orobanchacece (The Broom-rape Family). 
-Fleshy, brownish parasites, with scattered scaleleaves and monosymmetric flowers; sepals 4-5; petals 5, bi-labiate ; stamens didynamous ; carpels 2 ; fruit a 1-chambered, many-seeded capsule. (p. 553.)

Order 57. Lentibuláriece (The Butterwort Family). -Insectivorous marsh herbs with monosymmetric, conspicuous flowers; sepals and petals 5 each, usually bi-labiate; stamens 2 ; carpels 2 ; fruit a 1 -chambered, many-seeded capsule. (p. 558.)

Order 58. Verbenacece (The Vervain).-An erect, branched herb with opposite leaves and a compound spike of small monosymmetric flowers; sepals and petals 5 each; corolla bi-labiate; stamens didynamous; fruit a regma of 41 -seeded nutlets. (p. 563.)

- Order 59. Labiáte (The Labiate Family).-Aromatic herbs with square stems; opposite leaves and verticillasters of bi-labiate flowers; sepals and petals 5 each, usually bi-labiate; stamens didynamous; carpels 2 ; fruit a regma of 41 -seeded nutlets. (p. 565.)

Order 60. Plantaginece (The Plantain Family).Herbs with simple, radical leaves and small greenisls flowers; sepals, petals, and stamens 4 each, with slender filaments and exserted anthers; carpels 2-4 ; fruit a 1-4-chambered capsule. (p. 602.)

ORDER 61. Illecebrácece (The Knot-grass Family).Small herbs with simple, sessile leaves and small flowers ; sepals and petals $4-5$ each, or petals absent ; stamens $1-10$; carpels $2-3$; ovary 1 -chambered, 1-ovuled. (p. 606.)

Sub-Cuass 3. Incomplétce.-Corolla, and sometimes calyx also, absent. (pp.610-682.)

- Serres 1. Monochlamýdece.-Corolla alone absent. (pp. 611-649.)

$\S$ Ovary superior and usually 1-chambered and 1-ovuled. ${ }^{1}$

- Order 62. Amaranthácece (The Amaranth).-An

(1) It is 2-chambered in the Elms (Urticácex). 
annual, glabrous, prostrate herb, with scattered, petiolate, simple leaves, and small, axillary, green, monocious flowers; sepals and stamens $3-5$ each. (p. 611.)

Order 63. Chenopodiácere (The Goose-foot Family). - Herbs with simple leaves, or leafless jointed stems and inconspicuous green flowers; sepals $3-5$, persis. tent; stamens $1-5$. (p. 612.)

Order 64. Polygonácece (The Persicaria Family).Herbs with scattered simple leaves with sheathing stipules and small flowers; sepals $3-6$, green or coloured, usually' persistent; stamens 5-8. (p. 623.)

Order 65. Thymeleácea (The Daphne Family).Shrubs with tough inner bark; simple, entire leaves; and sweet-scented, perfect flowers; sepals 4 ; stamens 8 ; fruit berry-like. (p. 63t.)

Order 66. Elcagnácece (Tlie Sea-Buckthorn).-A shrub with silvery scales; scattercd, simple, entire leaves, and inconspicuous dicecious flowers; sepals 2-4, persistent; stamens 4; fruit berry-like. (p. 636.)

Order 67. Uiricice (The Nettle Fimily). -Trees, shrubs, or herbs with tough inner bark; simple, usually stipulate and serrate leares; and small flowers; sepals $1-8$; stamens $4-8$; carpels $1-2$; ovary sometimes 2-chambered. (p. 637.)

\section{$\$ \S$ Ovary inferior.}

Order 68. Aristolochicicen (The Birthwort Family). - Herbs and climbing shrubs with scattered simple leaves and perfect flowers, sometimes monosymmetric; sepals $2-3$, sometimes coloured; stamens 6-12; ovary 4-6-chambered; ovules many. (p. 614.)

Order 69. Loranthacere (The Mistletoe). - A green, parasitic, much-branched shrub with opposite, simple, entire lcaves; inconspicuous diccious flowers and white viscid bcrries; sepals and stamens 4 each; ovary 1-chambered, 1-oruled. (p. 646.)

Order 70. Santalacee" (The Bastard Toad-flax).- 
A slender, perenvial, herbaceous, prostrate lootparasite, with scattered, linear leaves and inconspicuous perfect flowers; sepals and stamens $4-5$ each; ovary 1-chambered; ovules 3; fruit dry, 1-seeded. (p. 648.)

Series 2. Achlamýlece.-Calyx and corolla both absent; ${ }^{2}$ flowers imperfect. (pp. 649-682.)

\section{$\S$ Flowers not in catkins.}

Order 71. Empetrácece (The Crowberry).-An evergreen mountain shrub, resinous, with scattered narrow leaves ; inconspicuous, diœcious flowers; and a drupaceous fruit; perianth of 6 scales; stamens 3 ; ovary 6-9-chambered; ovules 1 in each chamber. (p. 649.)

- Order 72. Euphorbiácea (The Spurge Tribe).Trees, shrubs, or herbs, generally with milky juice; leaves scattered, simple ; flowers inconspicuous, sometimos in cup-like involucre; stamens 1,4 , or 8 20 ; carpels $2-3$; ovules $1-2$ in each carpel. (p. 651.)

Order 73. Ceratophýllee ('I'he Hornwort Family). -Submerged herbs with whorled dichotomous leaves and minute moncecious flowers; stamens 12-20; ovary 1-chambered, 1-ovuled. (p. 661.)

\section{$\S \S$ Flowers in catkins.}

Order 74. Myricácece (The Bog-Myrtle).-An aromatic marsh shrub with scattered simple leaves, inconspicuous flowers and a small drupe; stamens 4-8; ovary 1-chambered, 1-ovuled. (p. 664.)

Order 75. Cupulifera (The Mast-bearing Family).

Trees or shrubs with scattered, simple, stipulate leaves and small flowers; stamens 2-20; carpels $2-3,1-2$-ovuled; fruit a 1-2-chambered nut with 1 seed in each chamber. (p. 664.)

Order 76. Saticinece (The Willow Family).--Trees,

(1) Except in the Box and the Mercury (Enphorbiáceæ). 
shrubs, or herbs, with scattered, simple, stipulate leaves, and conspicuous catkins which generally precede the leaves; stamens $2-30$; carpels 2 ; ovary 1-chambered; seeds many, with silky hairs. (p.675.)

Cuass II. Monocotylédons.-Plants having one cotyledon, parallel-veined leaves and floral leares generally in whorls of $3 .^{1}$ (pp. 682-896.)

Sub-Class 1. Petaloideco.--Having the perianth usually petaloid and coloured, not as a rule green or glumaceous. $^{2}$ (pp. 683-784.) 723.)

Series 1. Ejufypna.-Perianth superior. (pp.683-

Order 77. Mydrocharidece (The Frog-bit Family). -Aquatic herbs with conspicuous flowers, polysymmetric and dicecious; sepals and petals 3 each; stamens 3-12 carpels $3-6$; fruit a berry. (p. 683.) - Order 78. Orchídea (The Orchid Family).-Herbs mostly with tuberculate roots and conspicuous mono symmetric flowers; sepals, petals, and carpels 3 each : stamens 1-2, gynandrous; ovaly l-chambered; fruit a many seeded capsule. (p. 687.)

- Order 79. Iridere (The Iris Family). - Herbs with fleshy underground stems, narrow leaves and handsome flowers; sepals, petals, stamens, and carpels 3 each; ovary 3-chambered; fruit a many-seeded capsule. (p. T09.)

- Order 80. Amaryllidece (The Amaryllis Family).Herbs with bulbs, narrow leaves and handsome polysymmetric flower's; sepals, petals and carpels 3 each; stamens 6 ; ovary 3-chambered; fruit a capsule; seeds 3 or more. (p. 715.)

Order 81. Dioscúrece (The Black Bryony).-A

(1) Leares are net-reined in the Blaek Bryony (Dioseoreáeer), Herb Paris (Liliácees), and Arum (Aroidere); and the Horal leaves are in whorls
of four in Naiadicees.

(2) The perianth is membranous or green in Juneácen, Naiadáece, and
(2) The Erioránlex, aud abseut in Typháeer, Aroíder, and Lemníeer. 
climbing herbaceous perennial with broad, glossy netveined leaves and small monœcious flowers; sepals, petals, and carpels 3 each ; stamens 6 ; ovary 3 -chambered; fruit a berry; seeds 6 . (p. 721.)

Series 2. Hypógynce. - Perianth inferior or absent. (pp. 723-784.)

- Order 82. Liliácece (The Lily Family)._Mostly herbs with conspicuous, polysymmetric flowers ; sepals, petals, and carpels 3 each ; stamens 6 ; ovary 3 -chambered; seeds 3 or more. (p. 723.)

- Order 83. Juncácece (The Rush Family).-Herbs with cylindric or narrow leaves and small brown flowers; perianth membranous; sepals, petals, and carpels 3 each; stamens 6 ; ovary 1 -3-chambered ; fruit capsular; seeds 3 or more. (p. 716.)

ORDER 84. Typhácece (The Reed-mace Family).Erect aquatic plants with long linear leaves and small monœcious flowers in conspicuous spikes or heads; perianth absent; stamens many; fruit l-chambered, 1 seeded. (p. 755.)

ORDEe 85. Aroidece (The Cuckoo-pint Family).Herbaceous perennials with radical leaves, sometimes net-veined and small flowers on a fleshy spadix enclosed in a leafy spathe; perianth of 6 leaves or absent; stamens 1-6; ovary 1_-3-chambered; fruit berry-like; seeds few. (p. 759.$)$

Order 86. Lemnácece (The Duckweed Family).Minute floating plants with green thalloid fronds, rarely flowering; flowers very minute, in a spathe; stamen 1 ; ovary 1-chambered; ovules $1-7$. (p. 764.)

Order 87. Alismácece (The Water-Plantain Family). -Water-plants with radical, regularly net-veined leaves and conspicuous perfect flowers; sepals and petals 3 each ; stamens 6, 9, or more; carpels numerous and distinct, or nearly so, 1-2-ovuled. (p. 765.)

Order 88. Naiadácece. (The Pond-weed Family).- 
Aquatic plants, mostly with floating or submerged leaves and inconspicuous flowers; sepals $4-6$ or absent ; stamens and carpels $1-6$ each ; ovules $1-3$ in each carpel. (p. 770).

Order 89. Eriocáulece (The Pipe-wort).-An aquatic plant with subulate leaves and minute monnecious flowers; sepals, petals, and carpels 2 each; stamens 4 ; ovary 2-chambered ; chambers 1-ovuled. (p. 784.)

Sub-Class 2. Glumiferce.-Having no true perianth, but the flowers in the axils of chaff-like scales (glumes) forming spikelets. (pp. 784-896.)

Order 90. Cyperácece (The Sedge Family).-Herbs with stems usually solid and triangular in section; leaves tristichous, linear, with tubular sheaths; statmens $1-3$; anthers basifixed; carpels and stigmas 2-3; ovary 1-chambered, 1-ovuled. (p. 785.)

Order 91. Graminece (The Grass Family).-Herbs with stems usually hollow; leaves distichous, linear, with split sheaths; stamens $2-3$; anthers versatile; carpels and stigmas 1-2; ovary 1-chambered, 1ovuled. (p. 825.)

Division II. Gymmosperms.-Plants having no ovary, the ovules being naked. (pp. 896-903)

Class I. Conífere. - Trees and shrubs with rigid, evergreen, necdle-sliaped or linear leaves; and imperfect flowers, the staminate ones deciduous and catkinlike, the sced-baring ones either a solitary ovule or a cone of the hy or woody scales. (pp. $897-903$.)

Order 92. Araucariácece (The Monkey-Puzzle Family).-Cones perfect; seeds with woody or leathery testa and no aril. (p. S98.)

Oruer 93. Turricere (The Yew Family).--Seeds projecting beyond carpels or without carpels, with fleshy testa or aril. (p. 901.) 


\section{FLOWERS OF THE FIELD.}

\section{Division I. ANGIOSPERMS.}

\section{Class I. DICOTYLEDONS.}

Tris is the more extensive of the two classes into which ordinary flowering-plants, or angiosperms, are divided, and derives its name from the two cotyledons or leaves of the embryo which are almost invariably present in the seed of this class. These cotyledons enclose the plumule or bud of the future shoot, which, when the seed begins to sprout or germinate, lengthens into the leafy stem. At the same time the embryo in this class puts forth in a downward direction a main root, called in its early stage a radicle. In the perennial woody members of the class the stem increases in diameter by annual concentric layers of wood formed near the outer surface of the stem, but beneath the bark, this type of stem being called exogenous (growing externally). The leaves have irregularly netted veins of various degrees of fineness. The flowers have their sepals and petals, and (less 
regularly) their stamens and carpels, in whorls of 5 each or sometimes of 2 or 4 .

\section{Sub Class: I. POLTPÉTALA.}

Flowers generally furnished with both calyx and corolla; petals generally distinct.

SERIES I. THALAMIFLÓRA.-Ord. I.-XXI,

Petals and stamens springing from the floral receptacle or thatamus, below the ovary (hyporynous) : orary superior.

Natural Order I. Ranunculáceed,-T'he Buttercup Family.

Herbs with a watery, acrid, and often poisonous juice and scattered leaves (except Clématis, which is a shrub with opposite leaves). The leaves are generally much divided, and the flowers conspicuous and either polysymmetric or monosymmetric. The sepals and petals sometimes graduate into one another, and are often spurred, the sepals being 3,5 , or more, and the petals often absent, or 5, rarely 2, 4, or more. The stamens are indefinite in number and hypogynous; the carpels rarely 1 or 2 , generally 3 - 5 or more numerous, distinct, and forming either an etrerio of one-seeded indehiscent achenes or a ring of many-seeded follicles. In Actec there is exceptionally a berry-like fruit. The Order is a numerous one, chiefly characteristic of temperate regions. Many of them are garden favourites. Species of Aconitum yield valuable drugs.

\section{+ Carpels 1-seeded.}

1. Clématis. - $\Lambda$ shrub with opposite pinnate leaves, climbing by twisting its leaf-stalks; sepals 4- 
6 , petaloid, valvate; petats 0 ; carpels ending in a long feathery tail.

2. Timalíctrum.-Sepals $4-5$, petaloid, imbricate; petals 0 ; carpels without tails.

3. Anemóne. - Involucre of three leafy bracts some distance below the flower ; sepals 4-20, petaloid, imbricate; petals 0 .

*4. Adónis.-Sepals 5, petaloid, imbricate ; petals 5 - 10, scarlet; carpels without tails.

5. Mrosúrus.-A small plant; sepals 5, imbricate, spurred; petals 5, tubular ; carpels along an elongated axis.

6. Ranúnculus.--Sepals 3-5, imbricate; petals 5 or more, with a nectary at the base; carpets in an oblong or globular head.

\section{† Carpels many-seeded.}

7. CÁ тtнa.--Sepals 5, petaloid, imbricate, yellow; petals 0 ; fruit of numerous follicles.

8. Tróllius.-Sepals 5-15, petaloid, imbricate, yellow ; petals $5-15$, small, linear, flat; fruit of 5 or more follicles.

9. Helúborus.-Sepals 5, persistent; petals 510 , small, tubular, bi-labiate; fruit of 3 to 10 sessile follicles.

*10. Erárintis.--Sepals 5, deciduous; petals 5, small, tubular, bi-labiate, clawed; fruit of 5 or 6 stalked follicles.

11. Aquilígra.-Sepals 5, petaloid, deciduous; petals 5, large, spurred; fruit of 5 follicles.

*12. Detraínium. - Flover monosymmetric ; sepals 5 , petaloid, deciduous, the posterior one spurred; petals $2-4,2$ enclosed in spur; fruit of $1-5$ follicles.

* Genera the numbers of which are preceded by on asterisk, and species the numbers of which are followed by one, are probably not wild. 
13. Aconf́rum.-Flower monosymmetric; sepa7s 5 , petaloid, deciduous, the posterior one hooded; petals 2-5, 2 tubular, with long claws, enclosed in hood; fruit of $3-5$ follicles.

14. Acræa.—Sepals 3-5, petaloid, caducous; petals 4, minute, or absent; fruit berry-like, black, many-seeded.

15. Pж́́nis,—Sepa7s 5, persistent; petals 5-10; fruit of $2-5$ follicles.

1. Cuématis (Traveller's Joy).-A shrub with woody stem; leares opposite, compound, exstipulate, some of them climbing by twisting their petioles; sepals 4, valvate, petaloid ; petals 0 ; stamens many; carpels many, l-ovuled; fruit an etrrio of achenes with long, feathery awns. (Name from the Greek lilému, a vine-shoot.)

1. C. Vitalha (Traveller's Joy).-The only British species. A hedge-shrub, especially common on calcareous or chalky soils; well distinguished in summer by its numerous clusters of greenish-white, sweetscented flowers ; and still more conspicuous in autumn and winter from its tufts of featlery white fruits, whence it gets the popular name of "Old Man's Beard."-Fl. May, June. Perennial

2. 'I'насі́стrum (Meadow-rue).-Perennial ; Teaves compound, stipulate; stipules united to the leaf-stalts; sepals $4-5$, imbricate, petaloid; petals 0 ; stamens many, yellow; carpels few, 1-ovuled; fruit an etrerio of achenes without awns. (Name from the Greek thallo, I flourish.)

1. T. alprmum (Alpine Meadow-rue).-Stem unbranclied ; leares bi-ternate, glaucous beneath; flowers in a simple terminal raceme, drooping; sepals purplish.-A graceful little plant, 4 to $10 \mathrm{in}$. high, 


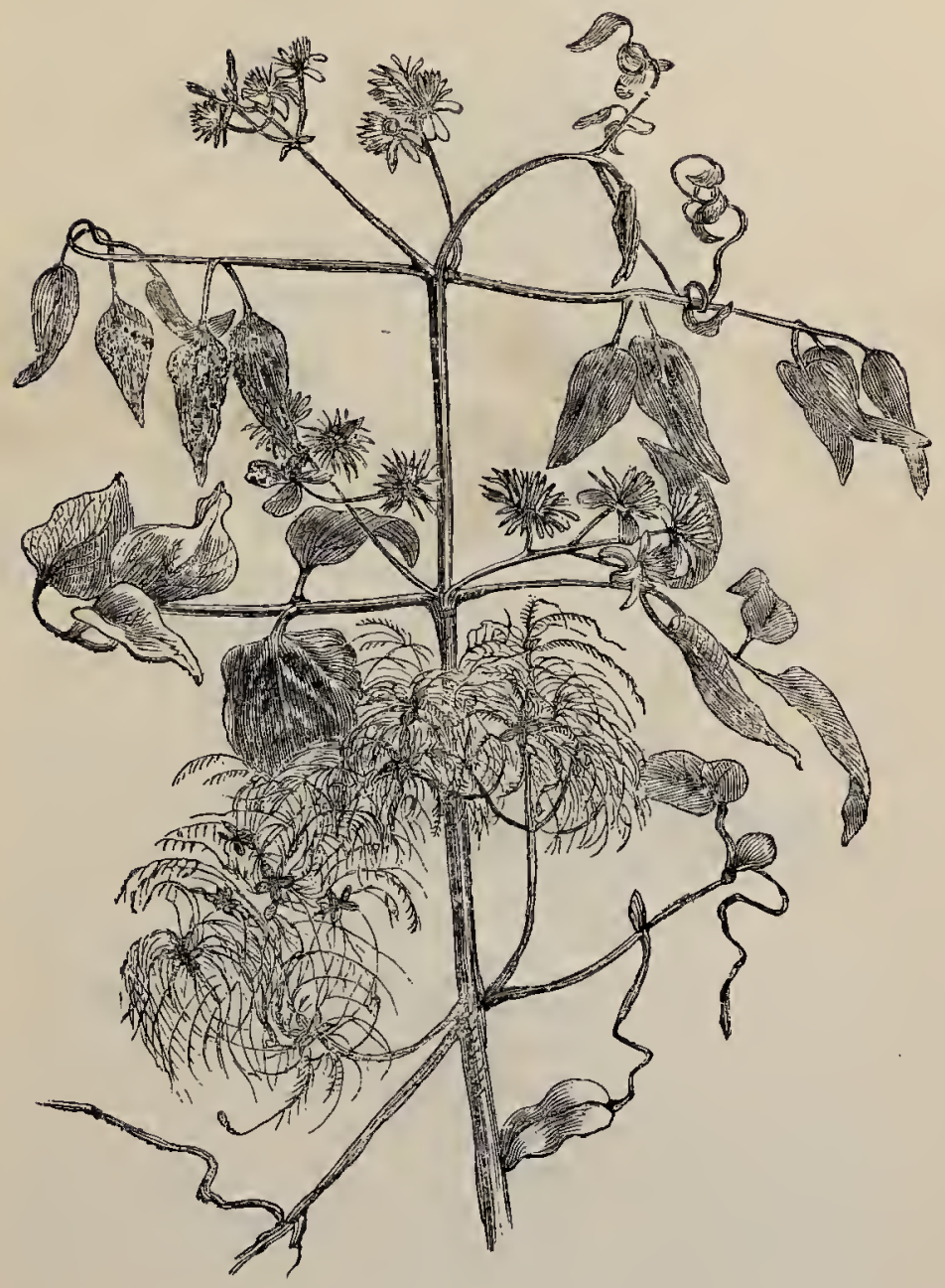

CLÉMATIS VITÁLBA (Tr゙aveller's Joy). 
occurring on the mountains of Wales and Scotland.Fl. June-August.

2. T. chuénsé (Sand-dune Meadow-1ne).—Stem 6 -18 in. high, branched, rigid, zigzag, furrowed,

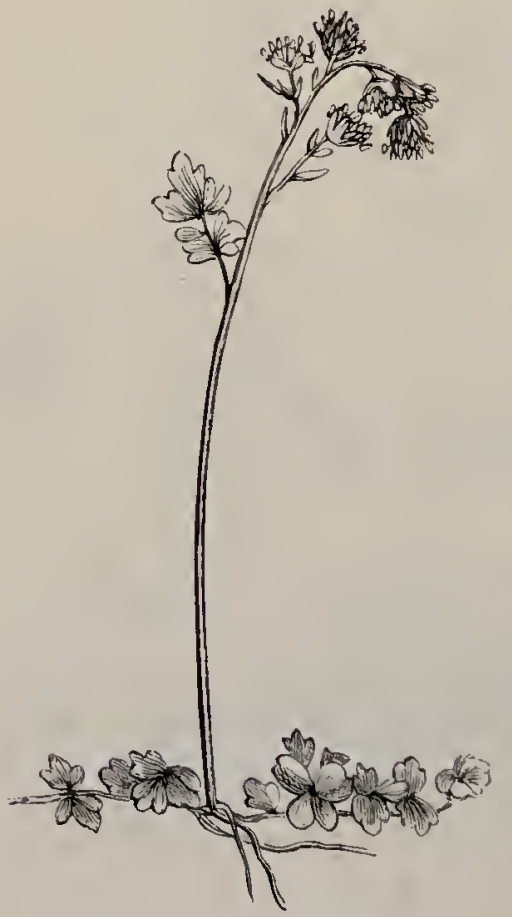

Tiralictrum alpinum (Alpine Meculow-prue). leafless at the base; leaves tripinnate, stipulate ; stipules with spreading auricles; leciflets 3-7-lobed; flowers in a loose, broad, spreading; compound. raceme, on slender stalks, drooping, with pale purplish sepals and conspicuous jellow stamens. On sandy seashores.-Fl. June -August.

3. T. collinum (Hill Meadow-rue).Grows in stony places and differs from $T$. dunénsé, chiefly in reaching a larger size and in having a narrower cluster of flowers witl suberect branches.

4. T. május (Greatcr Mcadow-rue). - Stem 3 feet high, solid, flexuous, branched, leafy at its base; leaves tripinnate, stipulate; stipules with reflexed auricles; leaflets large, variable, 3-5-lobed; flowers in a loose, leafy, compound raccme, greenish-yellow. In damp, bushy, and stony places, chiefly in the now'th.-Fl. July, August.

5. T. Kóchii, which reaches 4 feet and has a hollow, less furrowed stem, smaller leaflets, horizontal auricles 
to the stipules, and no leaves among the flowers; grows only in the Lake district.

6. T. flávum (Yellow Meadow-rue).--Stem erect, branched, furrowed, 2-4 feet high ; leaves bipinnate;

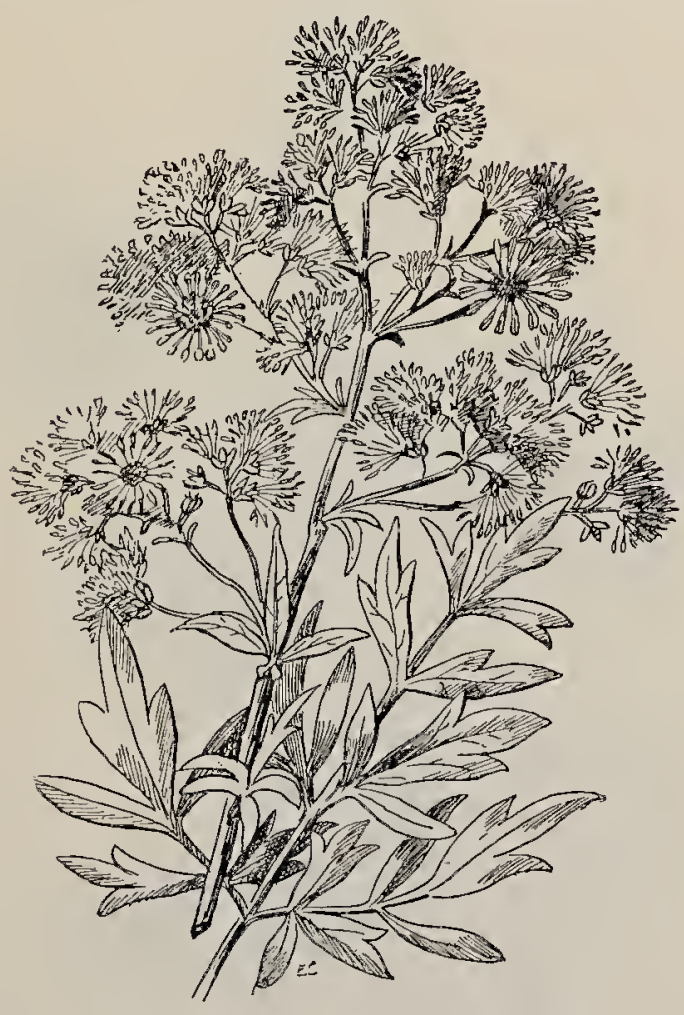

THALfCTRUM FLÁVUM (Yellow Meadow-rue).

flowers crowded, erect, pale yellow. - Not uncommon about the banks of ditches and rivers.-Fl. July, August.

3. Anemóne (Wind-flower).-Perennial herbs with underground stems; leaves radical, deeply lobed; 
flowers solitary, with an involucre of three leafy, lcbed bracts some distance below each; sepals $4-20$, petatoid, imbricate; petals 0 ; stamens many; carpeis many, 1-ovuled; fruit an etrerio of achenes. (Name

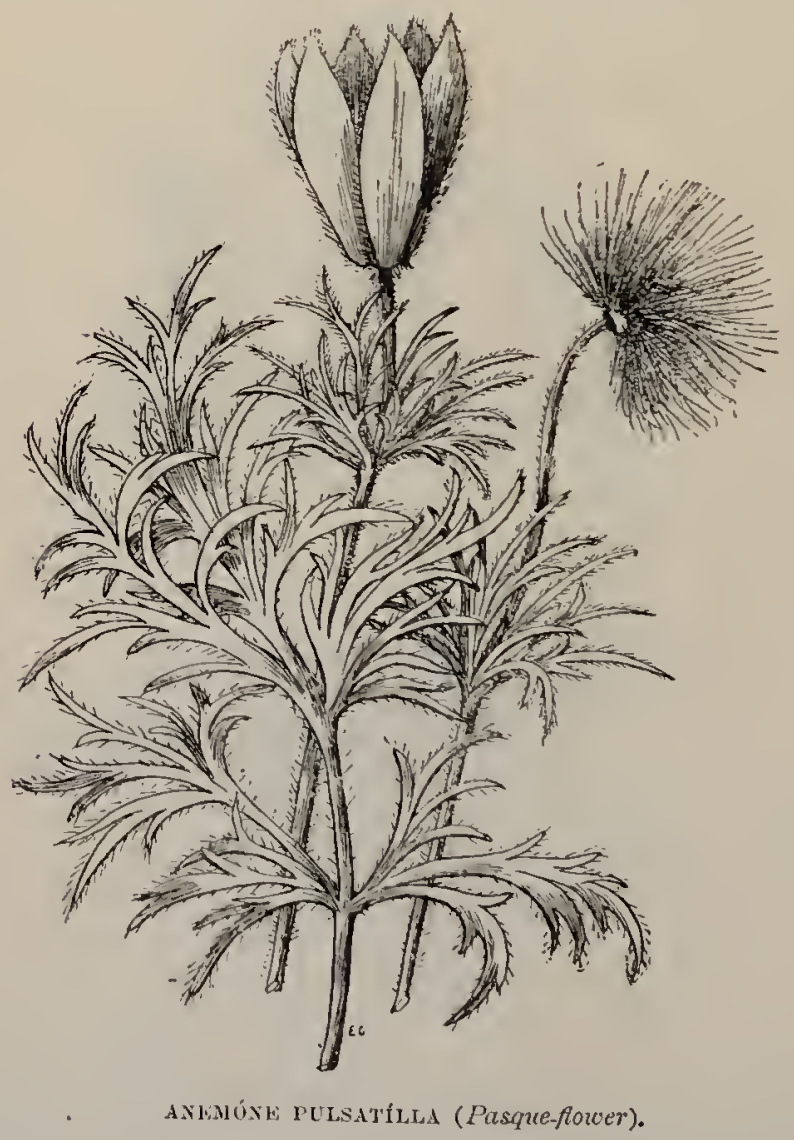

from the Greek anemors, the wind, from the exposed situations in which they grow.)

1. A. Pulsatilla (Pasque-Hower).-Silky, 4-10 in. high; leaves tripinnate, with linear segments, 
increasing after flowering; involucre sessile, with linear segments; flowers drooping in bud, $1 \frac{1}{2}$ in. across ; sepals violet, silky outside, slightly reflexed;

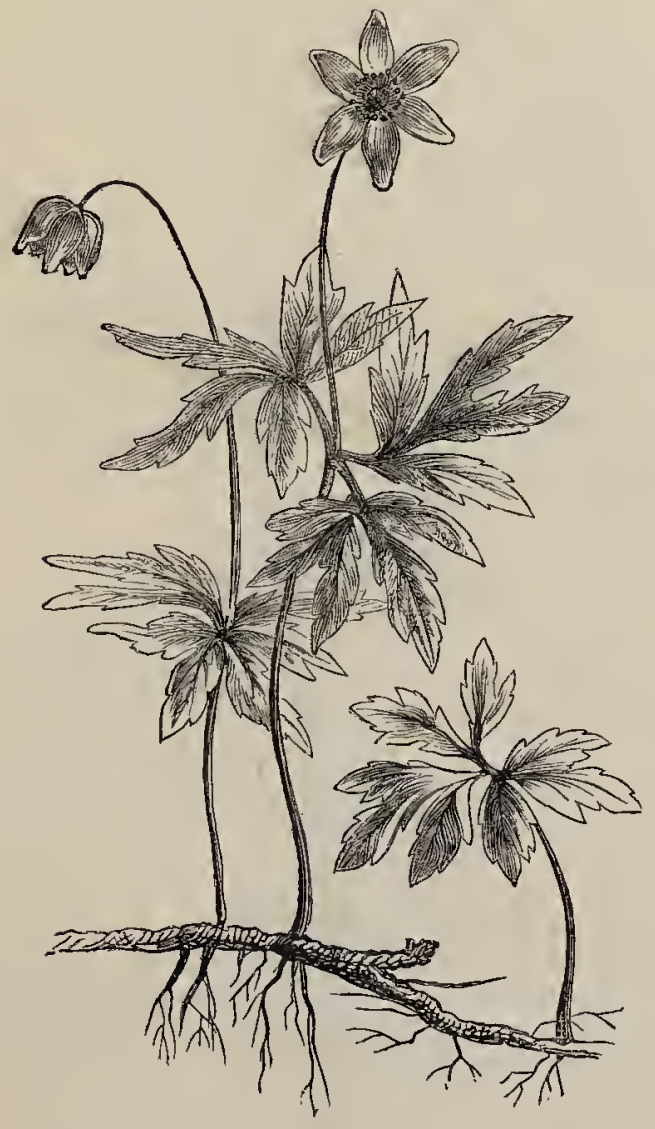

ANEMÓNE NEMORÓSA (Wood Anemone).

stamens yellow; achenes with feathery awns; peduncle lengthening after flowering.-In high pastures; rare. Its beautiful flower's appear about Easter-tide(Pâques), 
from which the plant derives its popular name.-Fl. March--June.

2. A. nemorása (Wood Anemone).-4-8 in. high; leaves radical, petiolate, bi-ternately lobed; involucre stalked, leaves resembling the radical ones; flowers drooping, $1-1 \frac{1}{2}$ in. across ; sepals 6 , petaloid, white, or tinged with pink, very rarely blue, glabrous, spreading; achenes without awns, downy. One of our most beautiful, though also one of the commonest, spring flowers.-Fl. March-May.

3.* A. ranunculóides (Yellow Anemone), with ternate or quinate leaves, sub-sessile involucre and yellow sepals, and

4.* A. apennina (Apennine Anemone), with numerous narrow blue sepals and erect flowers, both flowering in April, are occasionally met with as escapes from cultivation.

*4. Adónis (Pheasant's-eye).-An annual herb, with much-divided leaves; sepals 5 , imbricate; petals 5-10; carpels many, 1-ovuled; fruit an etrerio of achenes without awns. (Named from Adonis, a beautiful youth, who, according to Greek legend, was killed by a wild boar, his blood colouring the neighbouring flower.s.)

1.* A. autumnális (Autumn Pheasant's-eye).(i--8 in. high, with tripinnatifid leaves, finely cut into linear segments, and scarlet petals, black at their bases, flowering in September, occurs as a weed in cornfields, but is not a native.

5. Mrosúnus (Mouse-tail). $-\Lambda$ small annual herb; leaves radical, linear; inflorescence several 1-flowered scapes; sepals 5, spurred; petals 5, tubular ; stamens few ; carpels numerous, arranged spirally on an elongated floral receptacle, 1-ovuled; fruit an etrerio of 


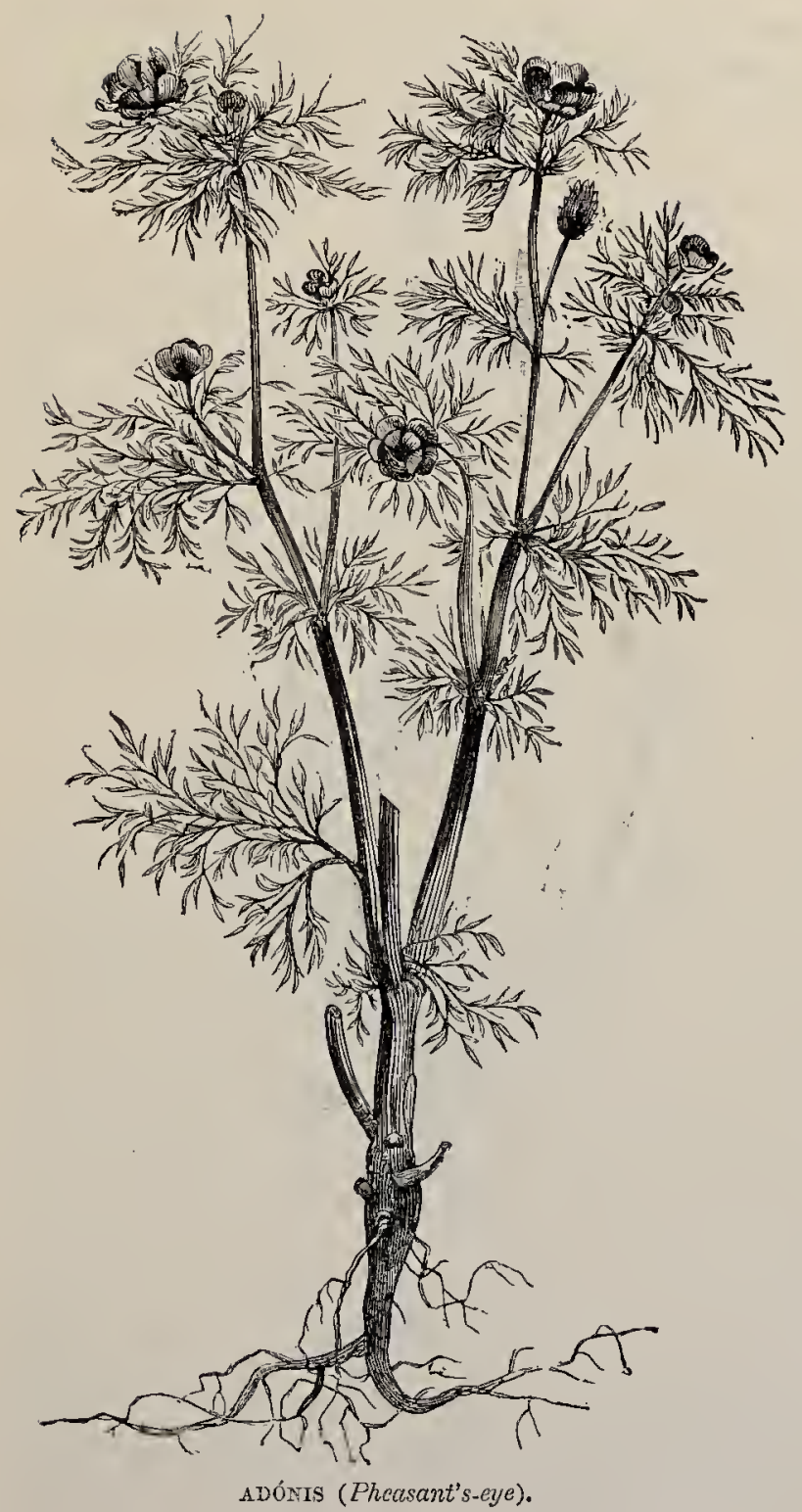


achenes, without awns. (Name from the Greek muos oura, mouse's tail.)

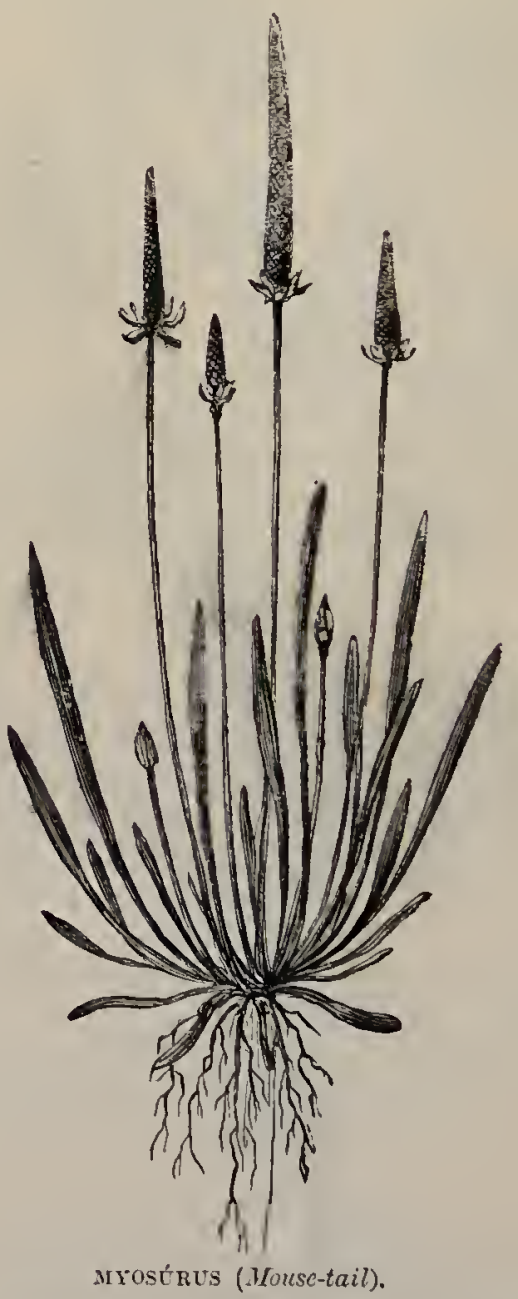

1. M. minimus (Mousetail). $-1-5$ in. high; laves fleshy; pechuncle $1-4$ in. high; petals pale yellowish; receptacle $1-1 \frac{1}{2}$ in. long, tapering.- 
This little plant grows in cornfields, generally in damp places, and is easily distinguished from every other British plant by the arrangement of its carpels, which resembles a mouse's tail.-Fl. A pril-_e une.

6. Ranúroulus (Crowfoot, Buttercup, \&c.).Herbs, annual or perennial; leaves entire, palmately lobed, or compound, sometimes with membranous stipules; sepals 5, rarely 3, imbricate, deciduous; petals 5 or more, with a nectary at the base, yellow or white; stamens many, yellow; receptacle globular or oblong; carpels many, 1-ovuled; fruit, an etærio of achenes, apiculate. (Name, the diminutive from the Latin rana, a frog, an animal which frequents the kind of places where these plants grow.)

* Petals white, with a yellow claw.

1. R. aquátilis (Water Crowfoot).-This was Linnæus' collective name for a very puzzling group of plants, which botanists now consider as at least nine or ten distinct species. They are all water-plants with submerged leaves deeply cleft into hair-like segments, and broad membranous stipules. The chief forms are: $R$. circinátus, with large flowers, no floating leaves, and the segments of the submerged ones rigid and spreading in one plane; $R$. fluitans, with much longer leaf-segments all lying parallel, leaves often a foot long, but flower-stalks shorter; R. pseudo-fuxitans, with similar but shorter leaves, and much longer peduncles; R. trichophyllus, with small flowers, and the leaf-segments rigid and spreading, but not in one plane ; $R$. Drouétii, in which the leaf-segments collapse into a tassel when taken from the water; $R$. heterophlyllus, with large flowers on stalks as long as the lcaves, submerged leaves col!:"psing into a 
tassel, and 3-lobed floating leares; I. peltitus, in which the segments of the submerged leaves spread out when taken from the water; R. Baudotii, with stouter Hower-stalks and tloating leaves deeply divided

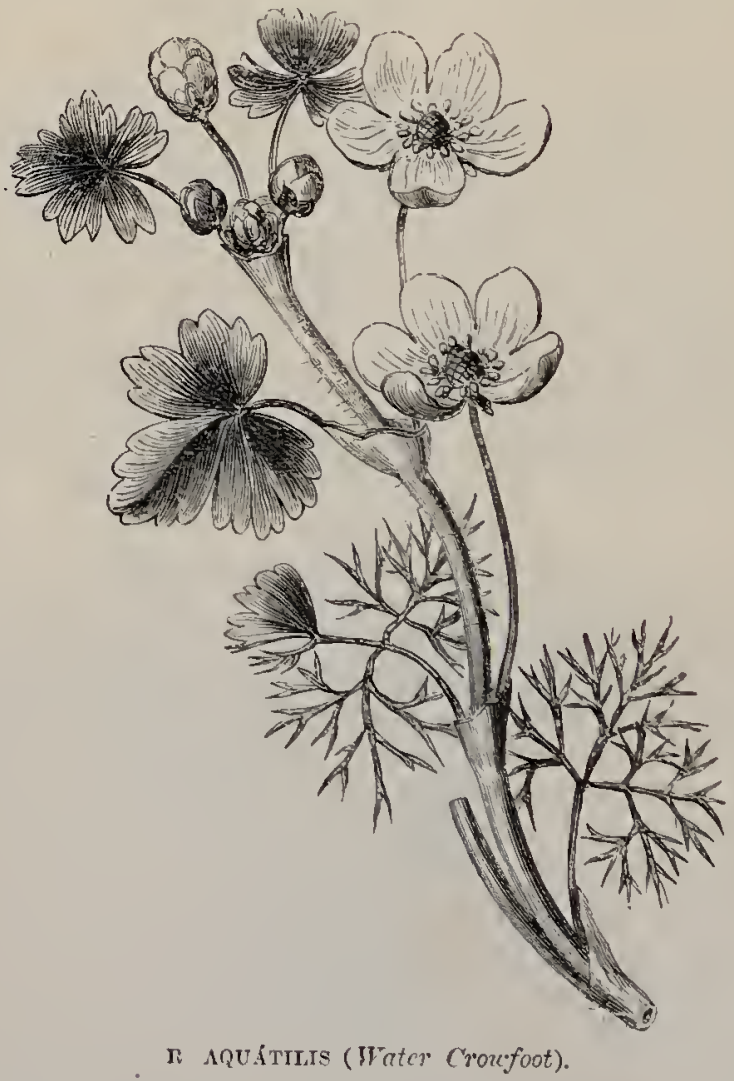

into wedge-shaped serments; and $R$. intermédius, with small pinkish llowers on short slender stalks, and selilom any submerged leares. The forms without floating leares are the "long mosses in the stream" of Tennyson. 'Those with floating leaves oceur in standing water, - Fl. May-September. 
2. 1i. Lenomándi (Mud Crowfoot),-Floating or creeping on mud; leaves all reniform, crenate; flowers $\frac{1}{2}$ in. across.-Fl. June-August.

3. R. hederáceus (Ivy-leaved Crowfoot)._-Leaves all reniform, 5-lobed, often with a black spot on them; flowers very small; petals scarcely longer than the calyx.-Growing in water or on mud.-Fl. MaySeptember.

\section{粎 PetaIs yeliow. Terrestrial。}

4. R. scelerátus (Celery-leaved Crowfoot).-- Stem 1 -2 feet high, lollow, with abundant very acrid juice; lecues glabrous, glossy, cut into three oblong lobes; flowers very small, pale yellow; fruit an oblong etrerio. - Growing in watery places.-Fl. May - September. Annual.

5. R. Flámmula (Lesser Spenrwort).--Stem creeping at the base, 4-18 in. high; lecues petiolate, ovate, or lanceolate, hairy or glabrous ; flowers $\frac{1}{2}-\frac{3}{4}$ in. across. Named from its cousing inflammation or redness of the skin.-Growing in wet places.-Fl. June-August. Pcrennial.

6. R. réptons (Prostrate Spearwort).-A slender cleeping form with linear leaves, occurs rarely in the north; and

7. R. petioláris, with its carlier radieal leavés reduced to recurred subulate petioles, grows under water near the shores of lakes in the north-west of Scotland.

8. R. Lingur (Great Spenrwort) - Stem erect, hollow, 2-3 feet high ; cauline lcaves lanceolate, sessile, $6=10$ in. long, but carlier submerged ones cordate and obtuse; flowers 2 in. across. - The largest British species, an uncommon but handsome plint, growing in walery places. (Named from the slape of the leaf.)-Fl. June-September。 Porennial.

9. 12. auricomus (Goldilocks).- Root fibrous ; stem 
slender, about a foot lighl, neatly smooth; radical leaves long-stalker, reniform, 3-T-loberl; cauline leaves sessile, palmatifid, with sub-entice lobes;

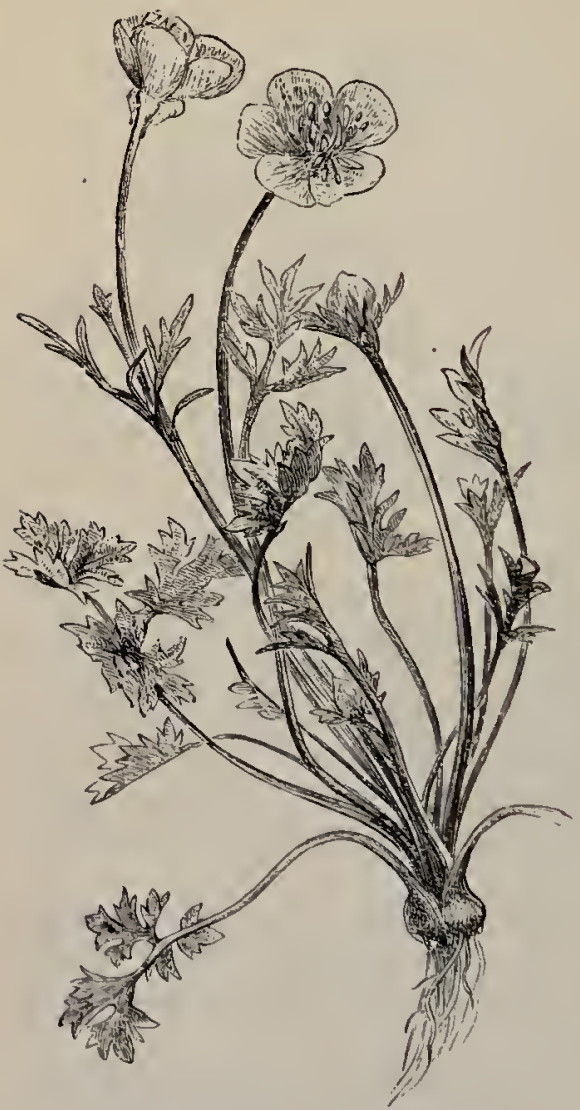

R. BuLbósus (Bulbous Butternj). $\frac{3}{4}$ in. across ; sepals spreading, downy, jellow ; pelals often partly absent. -In copses.-Fl. April, May. Perennial.

10. R. ácris (Buttercup).--Root tibrous; stem sometimes a rhizome, without runners; raclical. leaves palmately $3-7$ lobed, lobes deeply cut; cauline leaves 3-lobed with entive linear lobes; peduncle branched, not furrower, 13 fect high, hairy; flowers 1 in. across; sepals downy, spreading; carpets glabrous. Meadows. - Fl. April - Sertem ber. Pereminial.

11. R. répens (Creeping Buttercup) -Differing mainly in its less height, loug runners, and furowerl hairy pedunde. A troublesome weed in meadows and waste ground-Fl. MayAugust. Perennial.

12. R. bulbusme (Bubbous Buttercup).-Jiftoring 
mainly in its stem, about 1 foot high and bulbous at the base; glabrous, furrowed peducle ; and reflexed sepals._-Meadow:-_T. May, June. Perennial.

13. R. sárdous (Pale Hairy Buttelcup).-Root fibrous; stem 6-18 in. high, hairy; leaves lobed; peduncle furrowed, with sprealding or reflexed hairs; flowers 1 in. across; sepals reflexed; petals pale yellow;

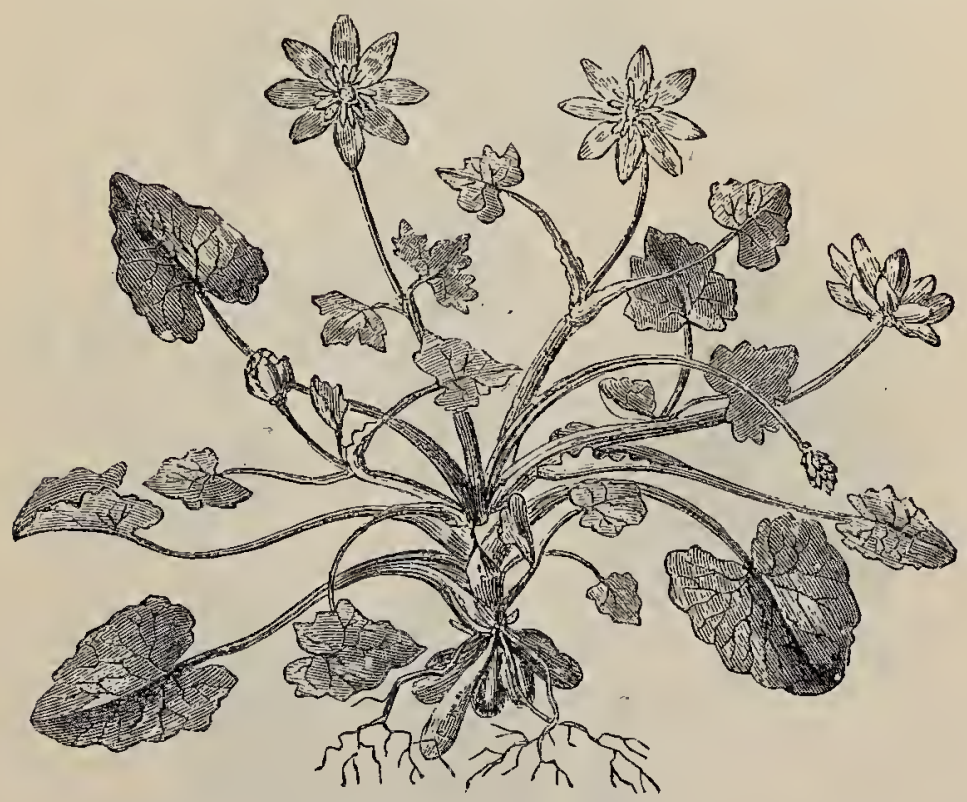

R. TICÁRIA (Lesser Celendine).

carpets compressed, with small warts near the margin. -Waste places.-Fl. June-October. Annual.

14. R. parviftoms (Small-flowered Crowfoot).Differing in its prostrate, hairy stem; less divided lecres; flowers not more than $\frac{1}{4}$ inch across; and hooked tubercles on the carpels.-Dry waste places.Fl. May-August. Annual.

15. R. arvérsis (Corn Crowfoot). - Nearly glabrous ; stem erect; leaves deeply 3-lobed, with linear-lan- 


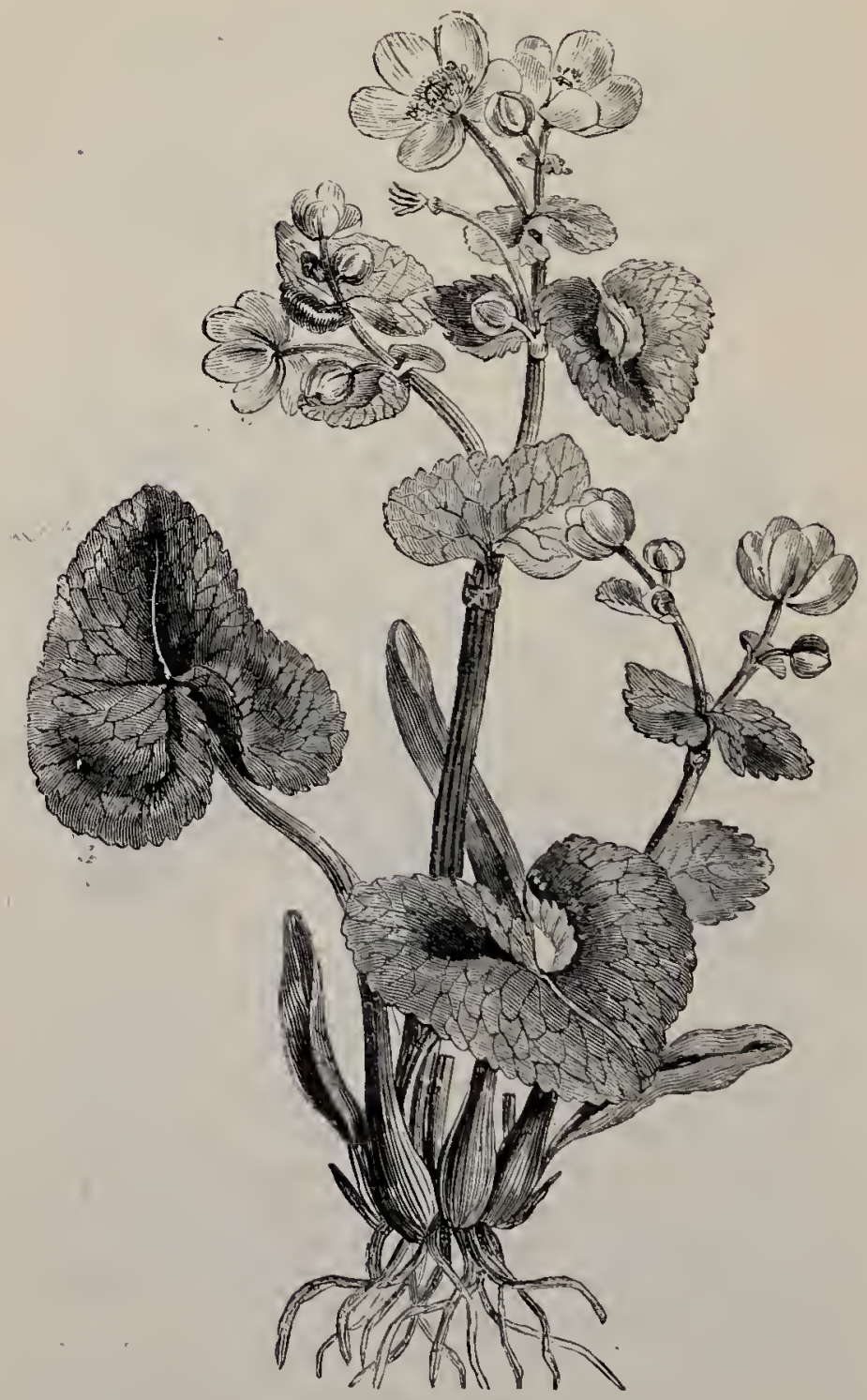

Cíchua (Blarsh Marigold), 
ceolate lobes; flowers $\frac{1}{2}$ in. across ; sepals spreading; petals pale yellow; carpels few and very spinous.-Cornfields. - Fl. May-July. Annual.

16. R. Ficánia (Lesser Celandine).-Glabrous. Root fasciculate; leaves mostly radical, coldate, stalked, angular, or crenate; flowers about 1 in. across; sepals $3-5$; petals 8-12, acute, golden-yellow; carpels small, smooth. One of our brightest spring flowers, studding every bank witli its numerous glossy starlike flowers, the favourite of the poet Wordsworth, not to be confounded with the Greater Celandine (see p. 39)._-Fl. March-May. Perennial.

7. Cáltha (Marsh Marigold). - Aquatic glabrous herbs, with five yellow, imbricate, deciduous sepals, no petuls, and a ring of $5-10$ sessile manyovuled carpels forming follicles in the fruit. (Name from the Greek liatathos, a cup.)

1. C. pulústris (Mar'sh Marigold, Water Blobs).A handsome plant, resembling a gigantic Buttercup, abundant in marshes and by the sides of streams. Leaves large, kidney-shaped, and glossy, with large membranous stipules; flowers 1 -2 in. across; sepals golden-yellow.-Fl. March-May. Perennial.

8. Tróclius (Globe-flower). - Erect perennial herbs ; leaves palmately lobed; sepals 5-15, petaloid, imbricate, concave; petals 5-15, narrow, clawed; carpels 5 or more, forming sessile follicles. (Name from the Scandinavian troll, a witch.)

1. T. europícus. (Globe-flower, Witches' Gowan).A large and handsome plant, 1-2 feet high, common in gardens, and growing wild in the mountainous parts of Scotinnd, Wales, and the North of England. Sepals orbicular, concave, converging into the form of 
2 globe, pale yellow; petals and stamens included.Fl. Iune-A ugust. Perennial.

9. Helléborus (Hellebore).-Perennial herbs;

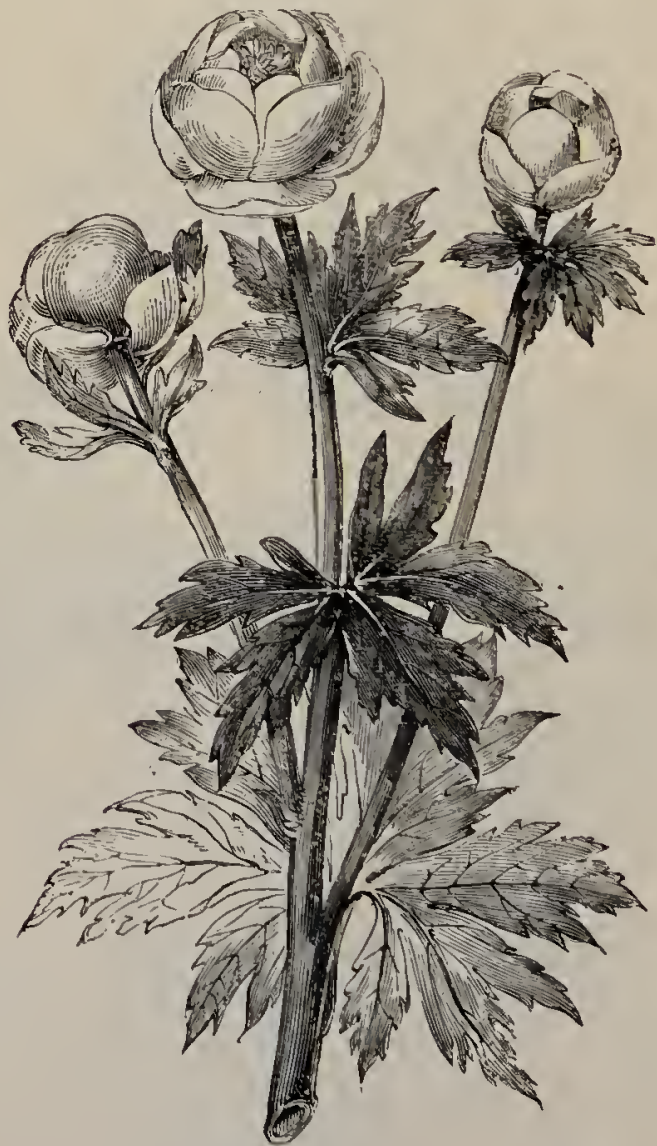

Trótutus (Globe-povter).

Zeaves palmately or pedately lobed; sepals 5, large, herbaceons, imbricate, persistent; petals 5-10, small, tubular, 2-lipped, clawed; firut of $3-10$ sessile 


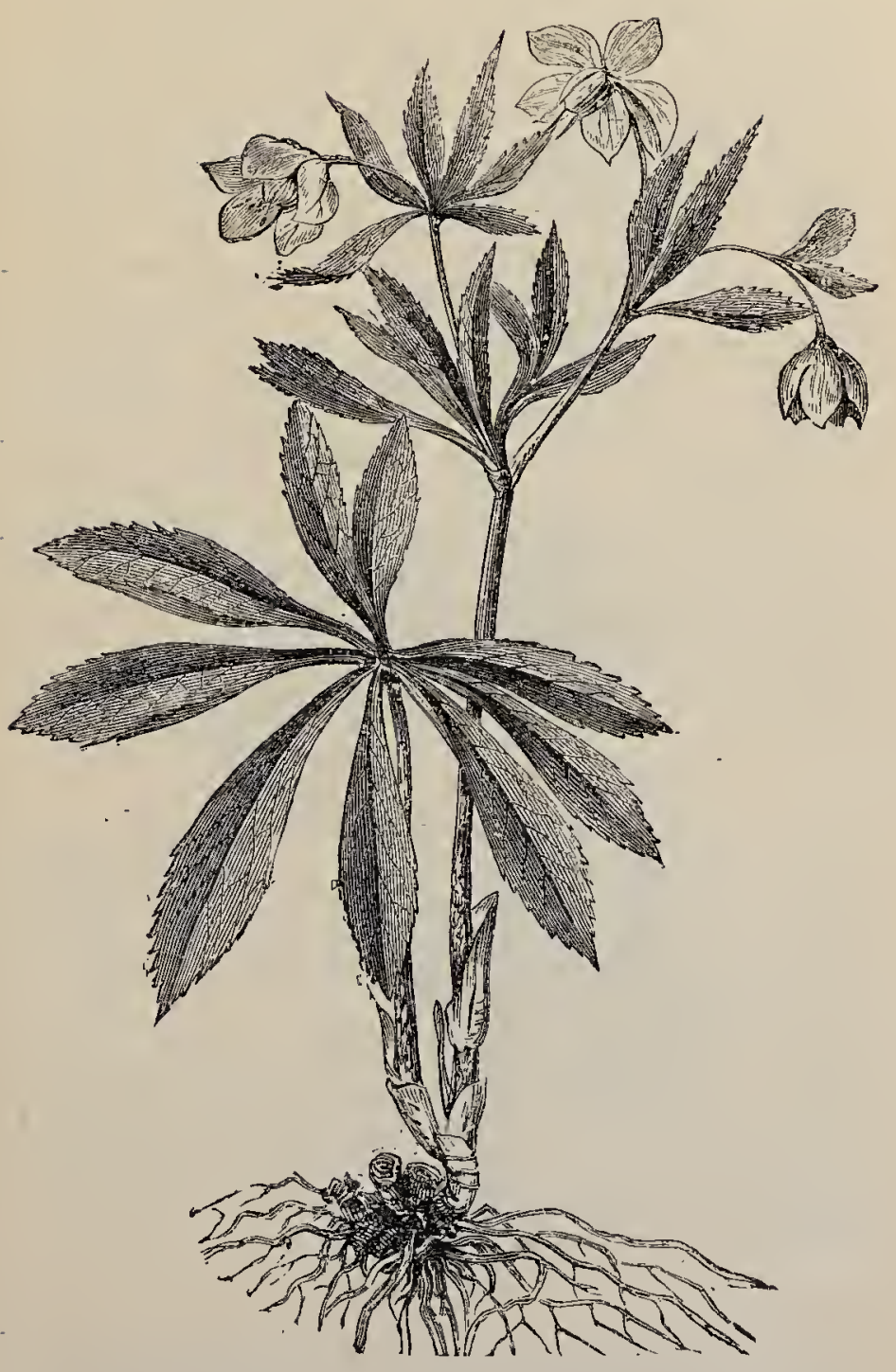

MELLÉBORUS FIRLDLS (Gren Hellure') 
follicles. (Nime from the Greek helein, to take away and bora, foor, from its use as an emetic.)

1. II. viridis (Grcen Hellebore, Bear's-foot).-A herbaceous perennial, about 1 foot high; leuves palmatisect, 5-7 lobed; flourers $1 \frac{1}{2}-2$ in. across ; sepals green, spreading; lutuls containing honey, which is said to be poisonou.-Thickets on chalky soil.-El. March, April. Perennial.

2. II. fítidus (Stinking Iiellebore, Setterwort).Stem perennial, 1-2 fect ligh ; tears pedate; flowers 1 in. across, drooping; sepuls green, tipped with dill purple, converging. Best distinguished from the preceding by its leaves, which are not dirided to a common centre, and by the purplish huc of its sepals. - Thickets ou challzy soil.-1i. Februny-April. Peremnial.

Both specics are somewliat doubtful natives, generally found near houses. Small flies may sometimes be found caught in the honey of the tubular petals. II. níger, a handsome species, with large white or rose-coloured flower's, is the well-known Christmas Rose of our gardens.

*10. Tríntuí (Winter A conite).-A small perennial herb with a lleshy rhizome; leaves palmatisect; flowers solitary; sepals 5-8, decidnous, yellow; petals small, tubular, 2-lipped, with a long claw; follicles 5-6, stalked. (Name from the Greek eros, spring, and ánthos, flower.)

1.* Li. Tyyemalis (Winter Aconite).-Stem 4-6 in. high; leaves orbicular, deeply 3-7-lobed, glossy, lobes linear-oblong, obtuse; involucre, of sessile leafy bracts, just below the solitary, golden-yellow flower. -Common in gardens, and sometimes naturalised.Fl. January-March. Perennial.

11. Aquiliata (Columbine).-An erect perennial herb; leaves 2-3.ternate; flowers handsome, 1-2 


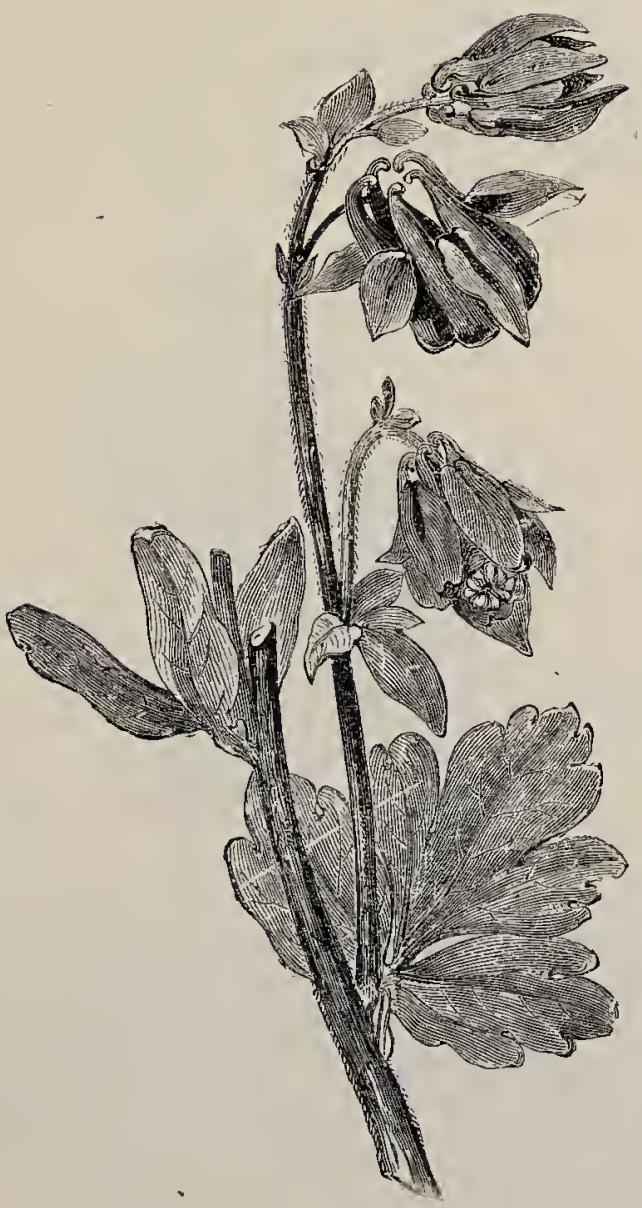

SQUTEGIA (Columbine). 
in. across; sepals 5, petaloid, deciduous; petals 5, each with a long spur; follicles 5. (Name from the Latin aquila, an eagle, the claws of which the spurs of the petals are supposed to resemble.)

1. A. vulyáris (Columbine). - The only British species, common in gardens, to which in spring it is very ornamental, with its, delicate glaucous leaves; and no less so in summer, with its curiously-shaped and variously-coloured flowers. When growing wild,

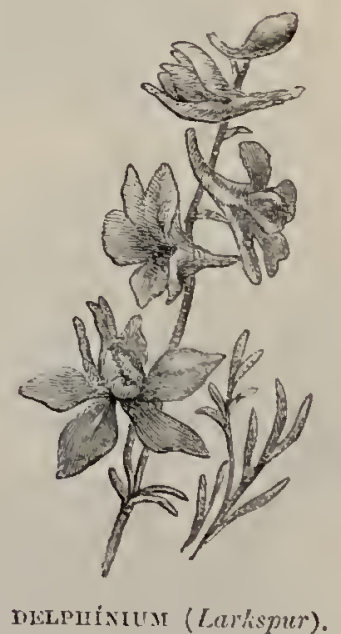

its flowers are usually bhe, purple, or white. It may be distinguished from all other British flowers by having each of its five petals terminated in an incurved horu-like spur. It derives its name, Columbine, from the fancied resemblance of its flowers to a nest of cloves, columbe being Latin for a dove. - Woods and heatlis._Fl. May-July. Perennial.

*12 Derpuínum (Larlispur). - Erect herbs; leaves divided; fluwers in racenes, monosymmetric; sepals 5 , 
petaloid, deciduous, the posterior one with a long spur; petals 2-4, the two posterior ones spured and enclosed within the spur of the calyx; fruit of $1-5$ follicles. (Name from the Greek delphis, a dolphin, from a fancied resemblanee in the form of the flower,

1* D. Ajácis (Larkspur).-About a foot high'; leaves cut into many linear lobes; flowers $4-16$ in a raceme, 1 in. across, blue, white, or pink; fruit of 1

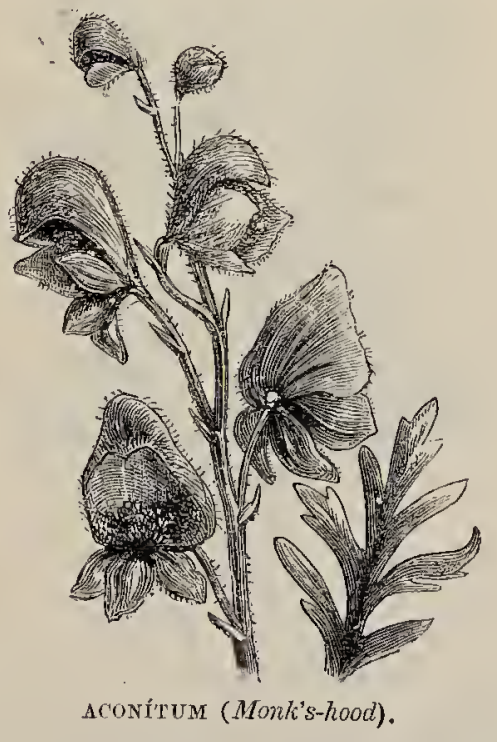

pubescent follicle. $-\Lambda$ doubtful rative, though of ten in considerable quantity in sandy or chalky cornfields. -Fl. June, July. Annual. Several species are grown in gardens.

31. Aconítum (Monk's-hood).-- Erect perennial herbs ; leaves palinately lobed; flower's racemose, monosymmetric; sepals 5, petaloid, deciluous, the 
postcrior one hooled; pete? 2 -5, the two posterior ones tubular, with long claws, enclosed within the hooded sepal; follicles 3-5. (Name classical, but of incertain origin.)

1. A. Nrapellues (Monk's-hood, Wolf's-bane).-1-2 feet high ; rhizome fusiform, black; teaf-loles pinnatifid; raceme unbianched; flowers 1 - $1 \frac{1}{2}$ in. across.

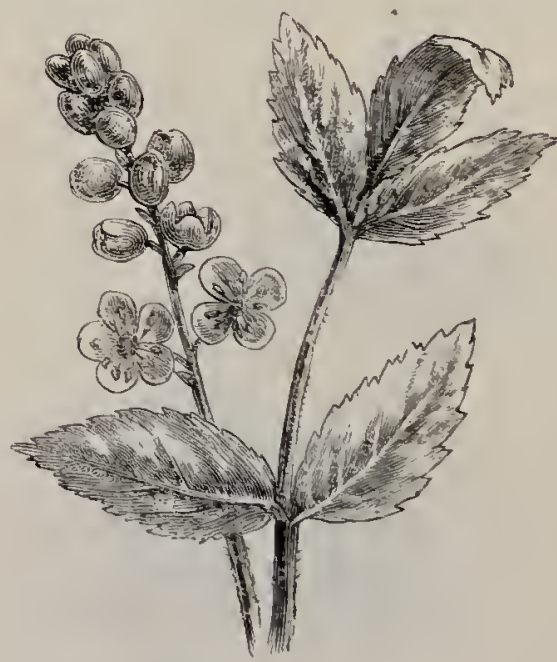

ACT.Á1 (Euncberry).

purpli-bobluc. A common garden plant, remarkable for the curious structure of its flower, especially the hammer-like honey-containing petals enclosed under the hood. The name Nupenlys is a diminutive of napus, the Latin for a turnip, from the shape of the rhizome; but the whcle plant, and especially this rhizome, is very poiconous. It derives its name of Wolf's-bane from being used to poison the bait in wolf-traps.-Damp slindy vlaces,-Fl. JuneSeptember. Perennial. 
14. A leaves ternately enmpound; flowers small, in erowded raeemes; sepals $3-5$, petaloid, earlueous; petals 4 , minute, or absent; fruit of one, many seeded carpè, berry-like. (Name from the Greek acte, the elder, from the similarity of the leaves of the two plants.)

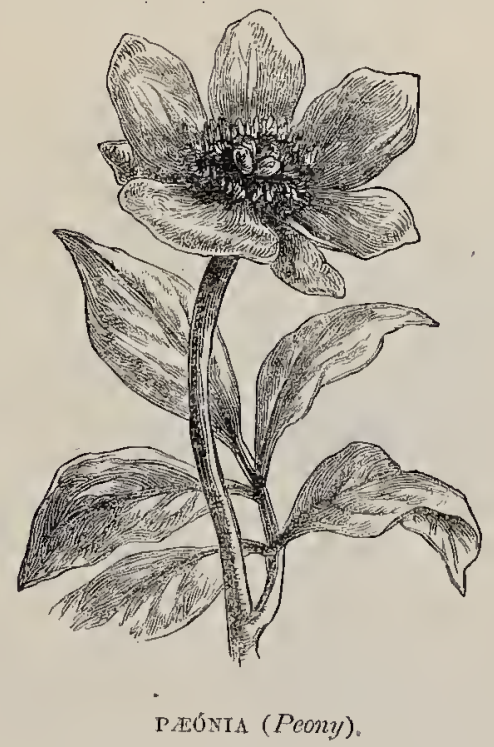

1. A. epicáta (Baneberry, Herb Christopher).--The only British species, 1 - 2 feet high ; leares bi-ternately pinnate; flowers white; fruit blaek.-Woods on limestone in the Nolth.-Fl. May. Perennial. Poisonous.

*15. Prénia (Peony).-Perennial herbs or shrubs; leaves bi-ternate; flowers large; sequls 5, persistent; petals 5-10; finit of 2-5 follicles. (Named fiom Pron, the legendary physician, who cured the wounds of the gorls in the 'Trojan war.)

1. $P$. corallána (Peony), - A herb 2 feet high with 
faseiculate roots; leares glaueous beneath; flowers crimson; follicles recurved, downy... A cultivated plant, naturalised on Steep Holm, ar islond in the Severp.--Fl. May, Jume. Perennial.

\section{Orn, II.-Berbituef.-Tue Barberry FA:IILY.}

Herbs or slirubs with seattered simple or compound leaves and polysymmetic flowers. Sepals 3, or 4 or 6 in two whorls, of ten petaloid. Petals either equal in number to the sepals and opposite to them, or twiee as many, often witl nectaries at their baces. Stamens equal in number to the petals, and opposite to them. Anthers opening by two valves turning upwards. Carpel 1, 1-ehambered. Seeds 1 or more. Growing prineipally in mountainous parts of the tem. perate zolles.

1. Búrmens.-Spinousshrubs with yellow wood and astringent barls; sppals 6 , deciduous; pelals 6 , cacls with 2 neetaries at the base; stcmons 6 ; frut berrylike, $1-3$-seeded.

*. Emmb́num.-Sepals 4 , deciduous; petals 8 , in two whorls, inner slipper-shiped; stamens of; fruit a many-seeded folliele.

1. Búnewis (Buberry).--Leaves spinously-dentate, or redueed to 3 - 7 -fid sines; flowers in racentes; yellow, with ? or 3 minute brizeteoles. (Name said to be of Arabie origin.)

1. B. vulgairs (Bubbery).-The only Britislı species. A pretty slumb, not uneommon in woods and hedges, with yellow wool and 3-forked spines. Its yellow flowers liang in drooping elusters; the filanuts are elastie and irritable, so tlat when touched ever so lightly by the legs of an insect thoy 
spring upward and throw their pollen outward. The oblong berry-like firuts are orange-red when ripe and gratefully acid, and may be made into an agreeable preserve. 'The shrub is often rooted out by farmer's as a fungus which lives part of its life on Barberry leaves is the cause of "rust" in wheat. Several species furnish a yellow dye, and others are cultivated

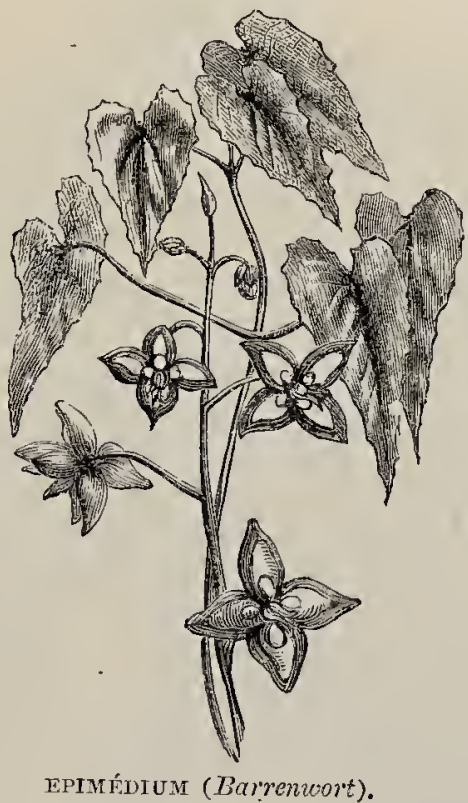

in gardens, as are also several members of the allied genus Mahónia.-Fl. May, June. Perennial.

*2. Eprmántum (Barrenwort). - Leaves bi-ternate; flowers red, with yellow, honey-berring, inner petals. (Name of Greek origin, indicating its resemblance to a Median plant.)

1.* $E$. alpinum (Alpine Barrenwort).-A graceful plant, less than a foot high, occurring here and there 
in subalpine woods in Scotland and the North of Fngland; but not indigenouः. Its delicate green leaflets are ovate-cordate, acuminate and serrate.-Fl. May. Perennial.

\section{ORD. III.-NYHPHAŔCE.-WATER-LILT} FAMILY.

Perennial aquatic herbiceous plants, with grenerally orbicular floating leares which are involute in vernation, and large, often fragrant, flowers. Sepuls $3-6$, gradually passing into petals, and thesc into stamens, both petals and strmens being inserted on a fleshy disk, which suriounds the ovary; over!l manychambered, many-seeded, with a sessile, radiate stifma. 'The starchy rhizones and seeds of some species are eaten.

Nelumbium speciósum, the Sicred Lotus, with peltate leaves rising above the water, and its cmpels imbedded separately on the upper surface of a funnel-shaped receptacle, though represented in ancient Egyptian at, is no longer found in the Nile, but is renerated by Buddhists throughout bisteru Asia. Another nember of this order, Tictória régia, a native of South America, onc of the most beautiful of aquatic plants, produces blossoms 15 inches and leaves over (i) feet in diameter.

1. Nxupu.íl.-Sepuls 5-6; petals many, small, hypogynous ; stemens many, hypogynous.

2. Castíla.-Sepals 4 ; petuls many, many-seriate, adnate to the disk; stemens many, adnate to the disk.

1. Nrupiáa (Yellow Water-lily)._. Flowers yellow, globose; sejuls concave; fruit ovoid, fleshy, its carpels separating when ripo. (Named from its 
growing in places which the nymphs were supposed to haunt.)

1. N. Tútea (Common Yellow Water-lily, Brandybottle).-Leaves submerged and membranous, and

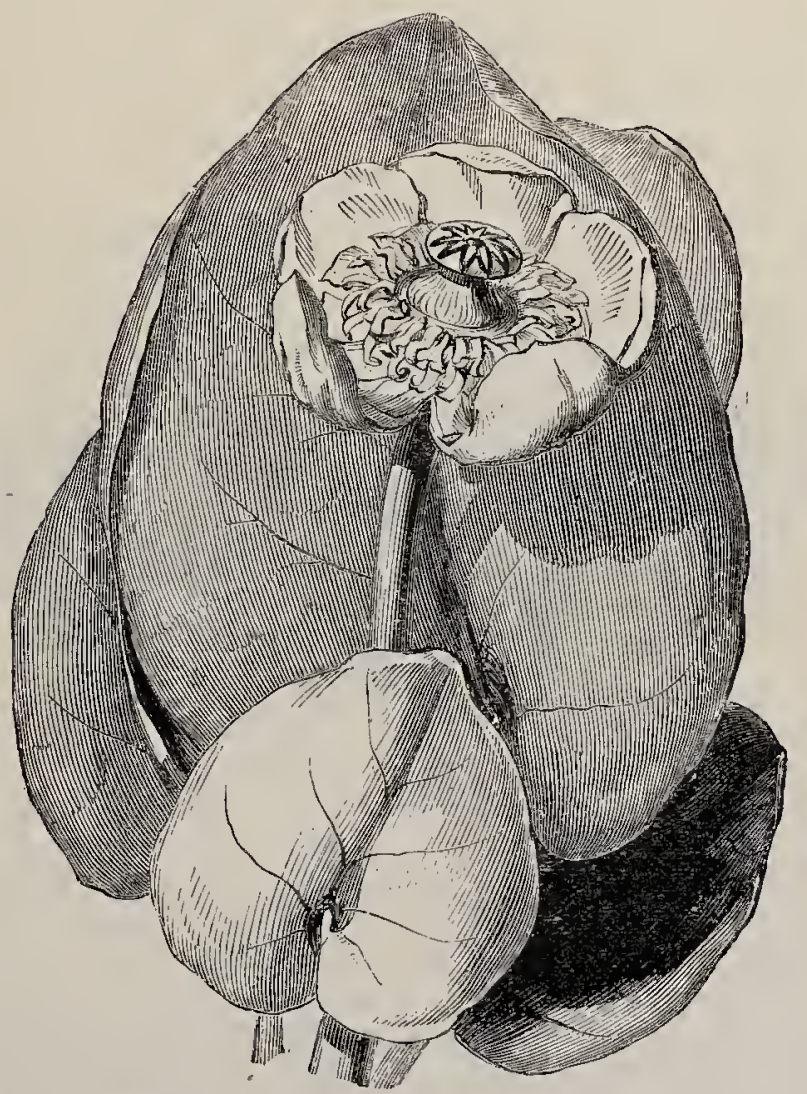

NYMPHEA LÚTEA (Common Fellow Water-lily).

floating and leathery. Jlower smelling like brandy, whence it is called Brandy-bottle. Stigma with 14_-20 rays, not extending to its margin. Rivess 
and ditches, frequent. The Turks prepare a cooling dink from the flowers, which they call L'ufer (' corruption of the Arabic name Nuphar).-Fl. July. Perennial.

2. N. mumila (Least I'ellow IVater-lily). - A much smaller plant, differing mainly in having only 8-10 stigmatic rays, which extend to its nargin, forming acute teeth. It grows in several lakes in the

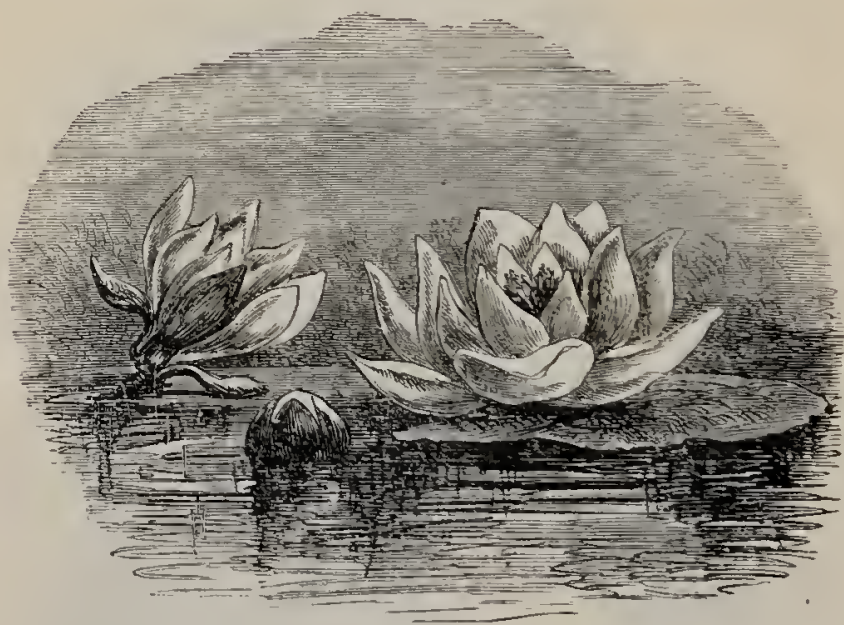

CAstilla specrósa (White Waterdüly).

Jighlands and at Ellesmere, Shropshire.-Fl. July, A ugust Perennial?

2. Castália (White Water-lily).-Howers white, expanded ; fruit ripening under water and dissolving into pulp. (Name from Castatia, a spring on Mount Parnassus ${ }^{7}$ the haunt of Apollo and the Mînses.)

1. C. speciosa (White Water-lily).-Leaves sll floating, 5-10 in. across: sepals green outsile, white inside; stigmu with 15-20 rays, yellow. The only 
British species, and, perhaps, the most magnificent of our native flowers, ililiabiting clear pools and slow rivers. The flowers rise above the water in tha middle of the day and expand, closing once more and sinking towards eveuing. - Fl. June-August. Perennial.

\section{Grd. IV. Papayeráce, - -The Poppy Family.}

Herbaceous plants, abounding in a milky narcotic juice. Flowers usually pendulous in the bud, conspicuous and polysymmetric; sepals 2, soon falling off, concave; retals 4, crumpled in wstivation ; stamens indefinite, liypogynous; frut at capsule; seeds

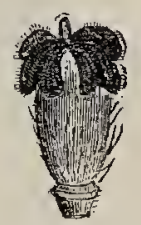

Ovary of the Popky.

generally scattered over the surface of incomplete partitions, which radiate from the sides of the capsule, but do not meet at the centre. The narcotic juice of the unripe capsules of Papiver somniferum, the Opium Poppy, which is commonly grown for ornament in our gardens, yields opium, laudanum, and morphia, most valuable medicines. An infusion of ripe "poppy-heads" or capsules is also used as a fomentation; and the seeds of all poppies contain a considerable quantity of a mild and wholesome oil.

* Finit al glubose capsute, opening by pores.

1. PapÁver. Stiyma sessile, rayed; capsule open. 
ing by pores below the stigma; placentas forming partial partitions.

2. MeconóPsis.--Style short; stigma of 4-6 rays; capsule opening by pores below the style; placentas less developed.

\section{* Fruit pod-7ike, opening by valves.}

3. Graúclum.-Flower yellow; stigma 2-lobed, sessile; capsule 2-valved and more or less completely 2 -chambered.

4. Renirin.-Foner violet; stigma 2-4 lobed, sessile; capsule 2-4 valved, 1-chambered.

5. Chendónium.-Flower yellow; stigma 2-lobed; capsule 2-valved, 1-chambered.

1. Papáver (Poppy).-Annial heibs with white milky juice. Letres lobed or cut; flowers on long stalks, pendulous in the bud; scprits 2, caducous; petals 4, crumpled in the bud; stomens indefinite; stigme of 4-20 sessile rays on a disk, below which the pores open. (Name classical, of uncertain etymology, perhaps connected witl the Kicltic papa, pap, because administered to induce sleep.)

\section{* Cupsutes smooth.}

1.* P. somiform (Opium Poply).- Smooth witl the cxception of a few sprearing bristles on the peduncle, ghancons; leceres amplcxicaul ; flowe large, whitc, with a purple stain at tle base of eacl petal; but of many other colours in garden virieties; capsule globular and smootli. Common in gardens and as an escape, but not indigenous. Opium is procured by puncturing the unripe capsules and collecting the juice which exulcs and hardens. The seeds yield a wholesome oil, which is not narcotic.-Fl. July, August. Amuual. 
2. P. Rithéess (Common Poppy, Corn Rose). Hispid with spreading or adpressed hairs; leaves pinnatifid; flowers 3-4 in. across; petals deep scarlet, often black at the base; capsule nearly globular, smootll. Common in cornfields. (The name from the Greek:

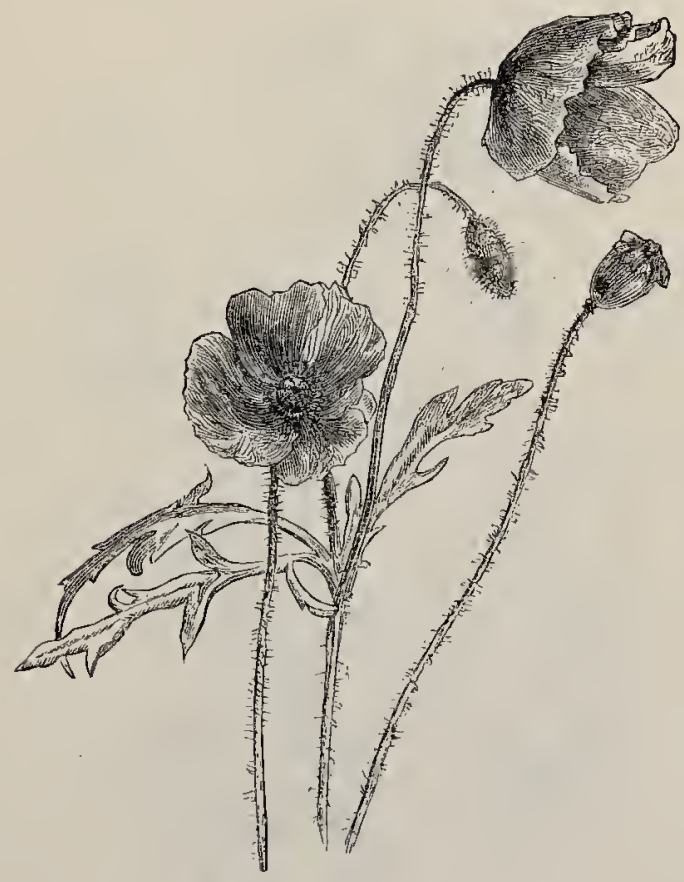

PAPAVER RIA FAS (Common Rad Poppy).

rhoia, a pomegranate, which it resembles in its fruit.) -Fl. June, duly. Annual.

3. P. dúbium (Long Smooth-headed Poppy).Hispid with adpressed hairs; leaves pinnatifid; flowers large, scorlet; petals in unequal pairs; capsule obovoid, smooth.--In cultivated fields.-Fl. MiayJuly. Annual. 
* Capsules bristly.

4. P. Argemóne (Long Rough-lieaded Poppy).- I- ispid; leaves bipinnatifid; flcwers less than 2 in. across; petals light scarlet, black at the base ; capsule

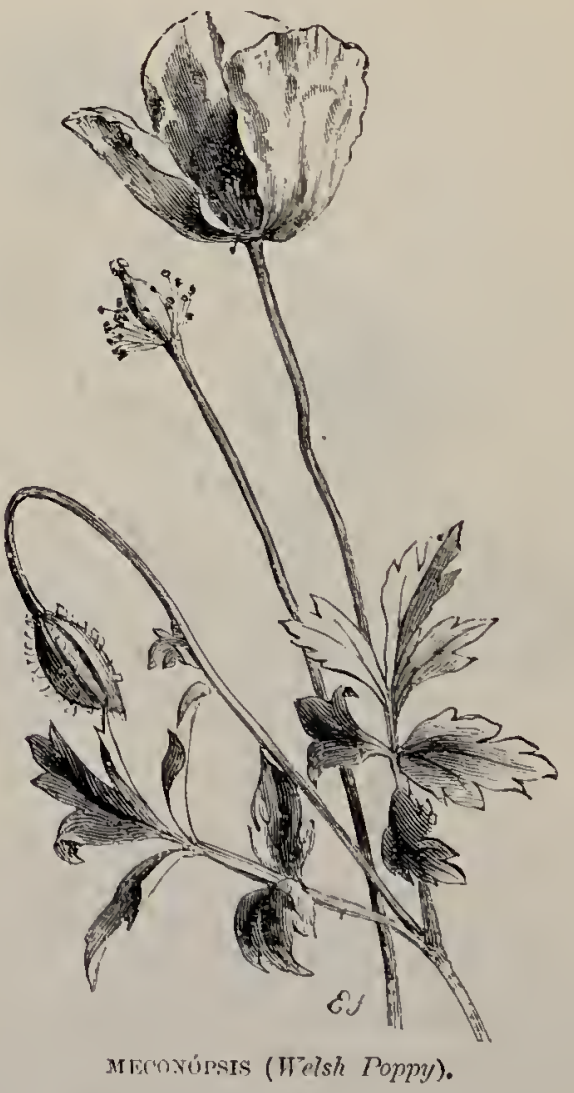

club-shaped with elect bristles. The smallest British species, occurring sparingly in cornfield: (The name Argenóne, the Greek for Poppies, may be derived from argima, cataract, referring to a former medical 
use, or from argos, slothful, from their nareotic effects.) - Fl. May-July. Annual.

5. P. hýbridum (Round Rough-headed Poppy).Hispid; leaves bipinnatifid; flowers $1-2$ in. across; petals deep scarlet, often black at the base; capsule nearly globular, hispid with spreading bristles.-

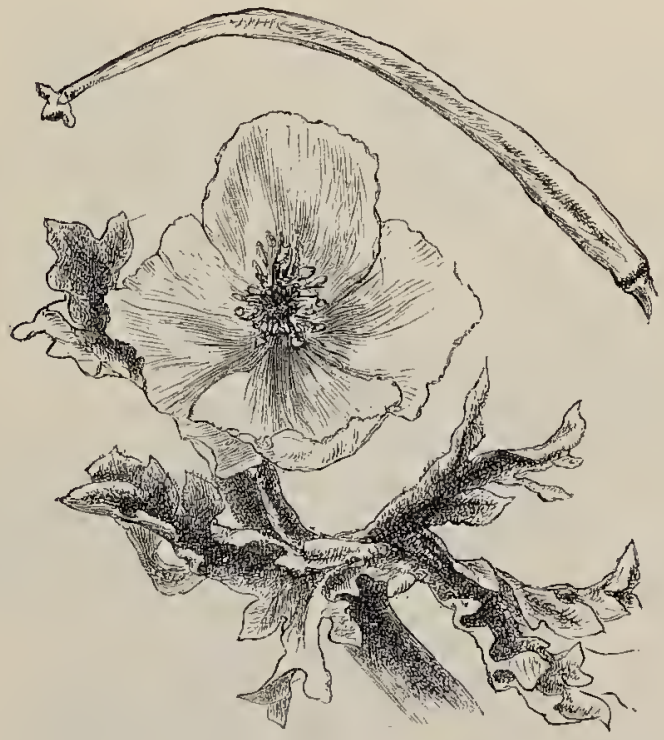

(HLAUCIU⿺ (Horned Popmy).

Sandy fields, not common. - Fl. May - July. Annual.

2. Mrconópsis (Welsh Poppy).-Perennial herbs with yellow juice. Leaves pinnate; flowers on long stalks, pendulous in the bud; differing from Papaver in having a short, persistent style, and a stigma of 4-6 free-spreading lobes. (Name in Greek signifying bearing resemblance to a Poppy.) 
1. M. cámbrica (Yellow Welsh Poppy).-The only British species, ensily distinguisheil from any of the foregoing by its pale yellow flowers and juice of the same colour; and from the Horned Poppy by its slender growth, and green, not glaucous, foliage.Rocky and shady places in the west.-Fl. June, July. Perennial.

3. Glaf́cium (ITorned Poppy).-Glancous lierbs with yellow juice. Leaves lobed or cut; flowers on long stalks; carpels 2, forming a long pod-like capsule; stigma 2-lobed. (Name from the glancous hue of the foliage.)

1. G. fláum (Yellow Horned Poppy).-The only indigenous British species. Leaves wavy, embracing the stem; pod 6-12 in. long, curved, with minute tubercles. A handsome plant, conspicuous on the sea-shore from its hoary foliage, large golden-yellow flowers, and long pods, which might at first sight be mistaken for flower-stems bare of leares.-Fl. JuneAugust. Biennial.

2.* G. hhenicem, with scarlet petals, black at the hase and hiary pods, only occur's oceasionally as an escape.

4. Rembris (Violet Horned Poppy).-Annual herbs with yellow juice. Lemes pinnatificl flowers violet, fugacions; om?!n one-chambered ; frit poulike. (Name from J. F. Romer, a German botanist.)

1. R. hịhrida, with an 3-ralved capsule, 2-3 in. long, occuis rarely in dry cornfields in Cambridgeshire and Norfolk, and is probably not indigenous.

5. Chelnóniom (Celandine).- - Perennial herbs with yellow juice. Jacares pinnate; flowers yellow; curpels 2 ; capsulc 1-chambercol, poul-like, 2-ralved. (Named from the Greek chelúlon, a swallow, because, accord- 
ing to Pliny, that bird discovered that its juice was efficacious in restoring sight to its young when blinded.)

1. C. majus (Greater Celandine).- - The only British species; not uncommon in waste places and village

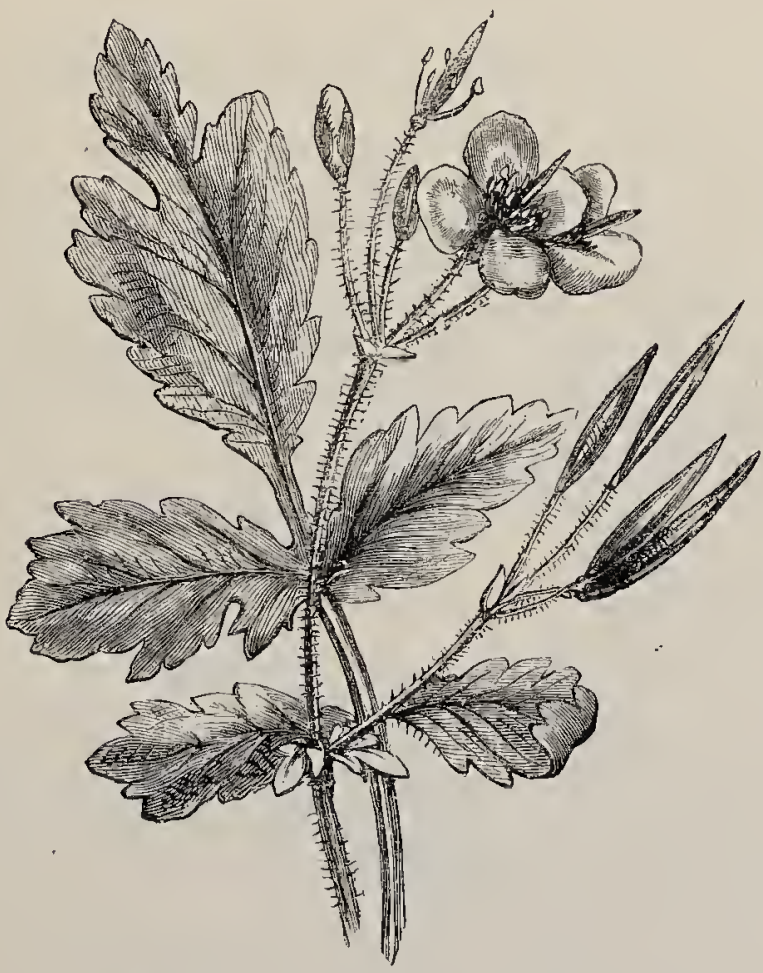

Chelidgrium majus (Common Celandine).

hedgerows. Leanes glancous, imparipinnate and obtusely lobed; flowers in umbellate clusters, $\frac{3}{4}-1$ in. across; capsale $1 \frac{1}{2}$ in. long.-El. May--August, or as Pliny tells us, from the time of the arrival of the swallows until them departure. Peremnial, The 
abundant orange-yellow juiee is a violent acrid poison, but is a popular remedy for warts, and is said to have been used successfully in oplithalmia.

*The Lesser Celandine, Ranúnculus Ficária (see p. 19), bears little resemblanee either in appearanee or properties to this species.

\section{Ord. T.-Fumariáne.e.-The Fumitory Fimity.}

Herbaceous plants witli watery juiee. Leaves divided; flocers in bractente racemes, monosymmetric; sepals 2, small, deeiduous; petals 4, usually in dissimilar pairs, the outer ones larger, and one or both swollen or spurred at the base, the inner ones partly cohcrent; stamens really 4 , but apparently 6 , diadelphous, each set consisting of one whole and two half (dimidiate) stamens ; carpels 2 ; oxury I-chambered; seed.s crested.

1. Níckena.-Fruit a compressed, 2-ralved, manyscederl capsule.

2. Fumíra. - Wrut a globose, indehiseent, 1seeded achene.

1. Níckena (Corydalis). - Herbs witlı much divided glabrous leaves and bracteate meemes of small monosymmetric flowers: petals connivent; the npper. one spurred; rripule many-seeded. (Name from Noöl Josepl Neeker.)

1. $N$. claviculata (Climbing Corydalis). - Stem slcnder, climbiug ; leares glancous, pinnate, ending in branched tendrils; flowers yellowish-white; spur very short. A clambering plant, with deliente green stcms and foliage, rising to the height of severnl fect, by the lelp of the bushes mong which it grows. The only indigcnous species.-F. J Ine-August. Annual. ('The Greek name Corydatis was cmployed for this or some allied plant by Galeu.) 
* 'Two other species are natur.lised in Britain : $N$. bulbósa, a perennial with a tuberous rhizome, unbranched aërial stem, no tendrils and purple flowers, and $N$. Tútea, not uncommon on old walls, with many short stems, no tendrils and bright yellow flowers.

2. Fưária (Fumitory).-Annual herbs differing

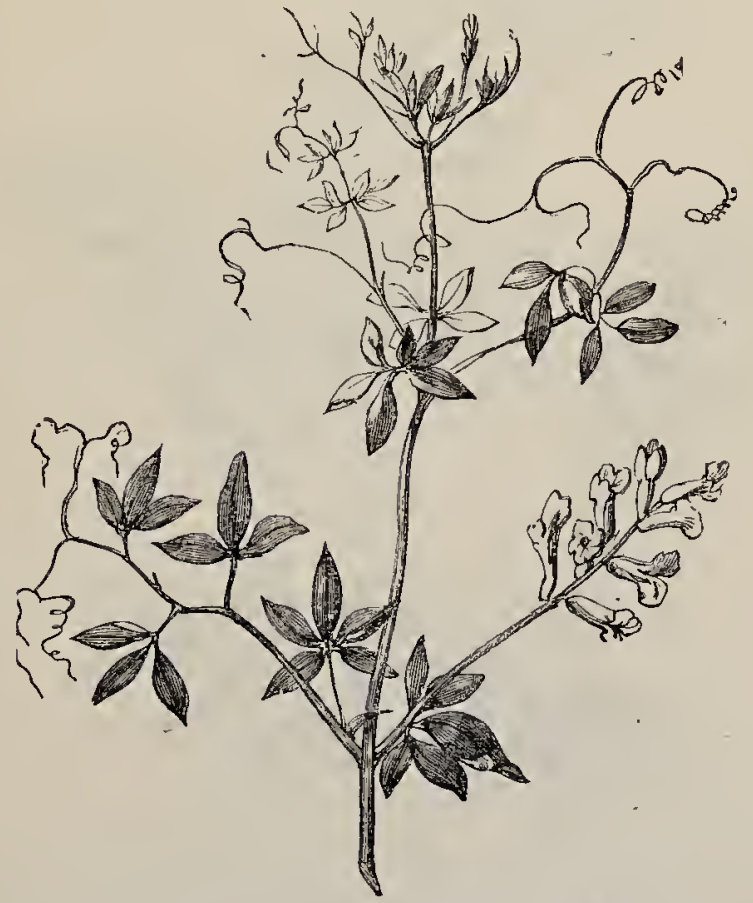

NÉCKERA CIAVICULÁTA (ClimZing Corydalis).

little from Néclera except in having only two ovules in the ovary, only one of which forms a seed in the indehiscent fruit. (Name from the Latin fumus terrer, smoke of the earth, these smoke-like glaucous weeds 
being supposed to spring without seed from the vapours of the ground.)

1. F. capreotáta (Rumping Fumitory).-Generally climbing by means of its twisted leaf-stalks, $1-2$ feet high; flowers pale pink or crean-coloured, tipped with crimson in short, few-flowered lacemes; sepals as broad

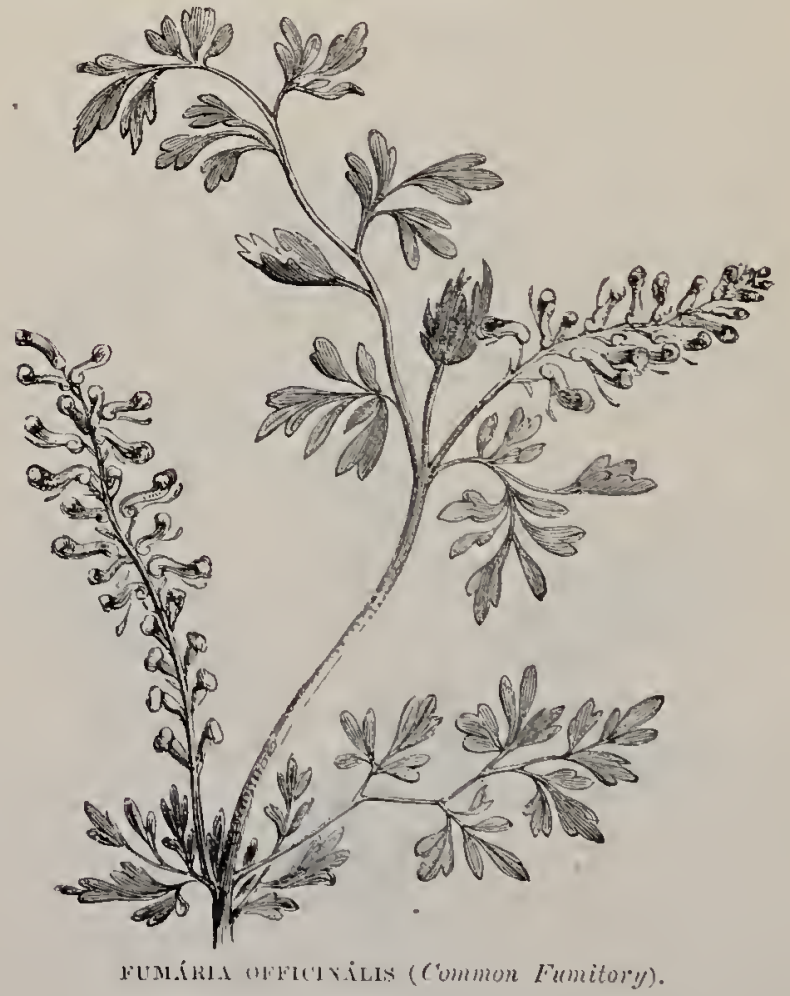

as the corolla and half as long; fruit globuse, slightly compressed, smooth. Including four forms known as

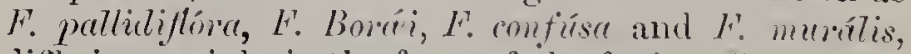
differing mainly in the form of the fruit. Borders of fields; common.--Fl. Nay-September. Annual.

2. H. officinúlis (Common Fumitory). - Erect, 
smaller than $F$. capreoláta; leaves more divided; flowers smaller, rose-coloured, tipped with crimson, in long, many-flowered racemes; sepals narrower than the corolla; fruit obovate, notched-Fl. MaySeptember. Annual.

* F. densiftón'a, a weaker plant with short racemes, elongating after flowering, and roundish sepals, broader than the corolla; $r$. parviftora, with small pale flower in dense racemes, with minute sepals; and $F$. $V$ cillantii, with lax racemes, are less common specie:.

\section{Ord. VI.-Crucífere. -The Cabbage Family.}

A very large, very natural, and very importint Order; well described by the name Cruciferce, or cross-bearing, there being invariably 4 petals, which are placcl crosswise. They are mostly herbs with a watery juice and pungent taste. The leaves are radical and cauline, the former in a

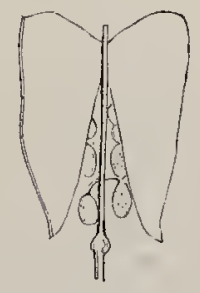

Siiicle of Shepherd's Purse.

rosette; the latter scattered and exstipulate. The flowers are in an ebracteate raceme. There are 4 sepals, the two lateral ones of ten pouched at the base; 4 petals, placed diagonally; and 6 stamens, in 2 whorls, the two outer, opposite the lateral (pouched) sepals, shorter, the 4 inner longer, whence Linnæus classed all the members of this Order in his class 
Tetradynamia (see 1 . xxii.). There are usually 4 honey-secreting glands on the receptacle, one in front of each sepal. There are two carple, united to form a dry pod-like fruit. This is generally compressed and dehisces by valves, when if elongated it is termed a silimea, if short and brosd, a siticle. A partition, or septum, dividing it into two chambers crosses its interior, either parallel with the valves, i.e., across the longer transverse diameter (latisept), or at right angles with them (angustisept). In some genera the pod is divided into several transverse, 1-seeded joints, when it is termed a lomentum. The seeds are small, exalbuminous, and oily. Their relatively large cotyledons are variously placed with reference to the radicle or primary embryonic root, this root being either incumbent, or folded against the back of one cotyledon, or accumbent, folded against the edges of both. 'I'he plants of this Order are rich in nitrogen and sulphur, and have an unpleasant odour when boiling or rotting. In a wild state they are almost always pungent and even acrid; but none of them are poisonous, and many of them have valuable stimulant properties, besiles their use in medicine as antiscorbutics, or remedies auainst scurvy. Under cultivation many of them become more succulent and form sonie of our most useful regetables, such as the cabbage, turnip, radish, cress, and sea-kale. 'T'here are at least 1,200 speries, mostly natives of the temperate zone, chicfly in the old World. They form a considerable proportion of the regetation of Aretic latitudes.

Sub-order I. Silipusar. Fimil a latisept siliqua.

Tribe 1. Arabider. Cotyledons accumbent.

$$
\text { * Strigma s-lobed. }
$$

1. Matríozi.-Stigma of two erect lobes; flowers large, lilac or violet. 
*2. Cheiránthus. - Stigma of two spreading lobes; flowers large, yellow; pod compressed with two promineat longitudinal ribs.

$$
\text { ** Stigma small, undivided. }
$$

3. Nastúrtium._-Calyx spreading; pod cylindric; values convex; seeds minute, 2-seriate.

4. Barbaréa.-Calyx erect; pod 4-angled; seeds 1-seliate.

5. Árabis.-Pod lineal, flat, obtuse; valves with one longitudinal rib or several veins, not elastic.

6. Cakdamíné.-Pod flat; valves veinless, separating with an elastic spring; seeds 1 -seriate.

\section{Tribe 2. Sisymbriece. Seeds 1-seriate; cotyledons incumbent.}

*7. Húsperis.-Stigma 2-lobed, decurrent; pad 4-angled; valves keeled, 3-veined; hairs spreading.

8. Sisŕmbrium. - Stigma undivided; pod cylin. dic or 4-angled; values convex, 1-3-reined; hairs spreading, or absent.

9. ERŕsinum-Stigma undivided, or notched; poel 4 angled; valves keeled, 1-veined; hairs adpressed, forked.

Tribe 3. Brássiceie. Cotyledons incumbent, folded longitudinally; flowers yellow.

10. Brássica._- Pod nearly cylindric; seeds 1seriate.

11. Diplotáxis.-Pocl compressed; seecls 2-seriate.

Sub-order II. Latisépter. Fruit a latisept silicle.

Tribe 4. Alyssinere. Cotyledons accumbent.

*12. A uŕssun.-Petals entire ; poct roundish, compressed, few-seeded. 
13. Drába.-Petals entire; pod oval or oblong, compressed ; seeds numerous, 2-seriate.

14. Eropníla.-Petals 2-cleft ; pod oval or oblong, compressed or turgid; seeds numerous, 2-seriate.

15. Cochleárra.-Petals entire; pod globose or nearly so ; valves very convex, keeled; sceds numerous, 2 -seriate.

Tribe 5. Camelínece. Cotyledons incumbent.

*16. Camelína.-A tall herb, with cauline leaves, sessile, auricled; pod ovate, inflated, beaked; style persistent.

17. Suburária.-A small aquatic plant; leaves subulate; pod oval-oblong; values boat-shaped; seeds numerous.

Sub-order III. Angustiséptu. Frut an angustisept. siticle.

Tribe 6. Lepidinee. Cotyledons incumbent; flowers white.

18. Búrsa.-Pod inversely heart-shaped, flat; valves boat-shaped, keeled; seeds many.

19. Coronórus.-Pod reniform, 2-lobed, indehiscent, 2-seeded.

20. Lepínum. - Pod roundish, compressed, keeled, 2-4-seeded.

Tribe 7. Thlaspulece. Cotyledons accumbent; flowers

21. Truíspi-Petals equal; pod rounded, flat, notched; values boat-shaped, winged at the back; seeds numerous.

22. Iвíris.-Petals unequal; prod ovate, notched; values boat-shaped, winged at the back; seets 2. 
23. Teesdília.-Pelals unequal; pod roundish, notched; valves boat-shaped, keeled; seeds 4.

24. Hutchíssia.-Petals equal; pod elliptic, entire; valves boat-shaped, keeled; seerds 4 .

Sab-order IV. Lomentácece. Fruit indeliscent or iomentaceous.

Tribe 8. Isatílece. Pod indehiscent, 1-chambered, 1-şeeded; cotyledons incumbent.

*25. Ísatis._Pod compressed; valves keeled.

Tribe 9. Cakitinece. Lomentum 2-jointed.

26. Crámbé.-Lower joint seedless; upper 1seeded.

27. CakílÉ.-Each joint 1-seeded.

Tribe 10. Raphénere. Lomentum tapering or monitiform, many-seeded.

28. Ráphanus.--Pod smooth, inflated; style persisting as a beak.

1. M M Athíla (Stock).-Herbs, sometimes shrubby, downy with stellate hairs; sepals erect; petals with long claws; seeds winged. (Named in honour of Matthiolus an Italian physician.)

1. M. sinuáta (Great Sea Stock). -Stem herbaceous, spreading 1-2 feet; leaves oblong, downy, the lower ones sinuate-toothed; flowers 1 in. across, purple, fragrant by night; pods rough, glandular. -South and south-west coasts.-Fl. May-August. Biennia].

2. M. incana (Hoary Shrubby Stock).-Stem 
shrubby, erect, branched, 1-2 feet, hoary; leaves lanceolate, generally entire, hoary; flowers $1-2 \mathrm{in}$. across, purple; pods eglandular.-Cliffs in the Isle of

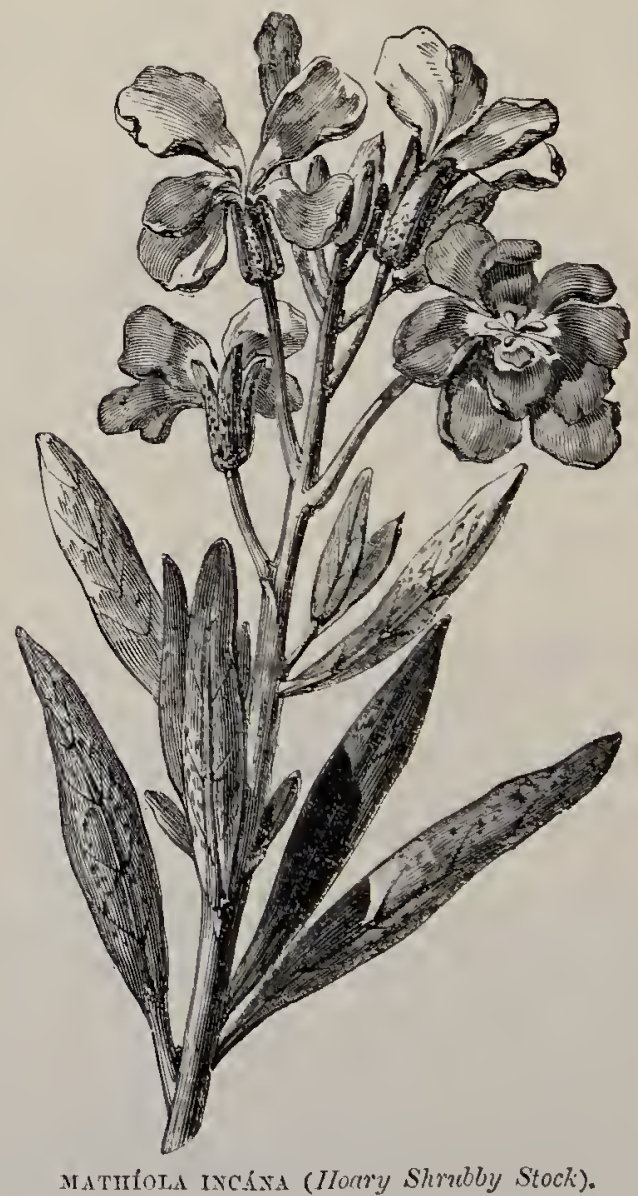

Wight.-El. May, June, Perennial, The "Queen Stock" of gardens. 
*2. Cheiránthus (Wallflower).-Herbs, sometimes shrubby, pubescent with adpressed bipartite hairs; sepals erect; petals with long claws; seeds compressed. (Name said to be of Arabic origin.)

1.* C. Cherin (Wallflower).-Stem shrubby; leaves

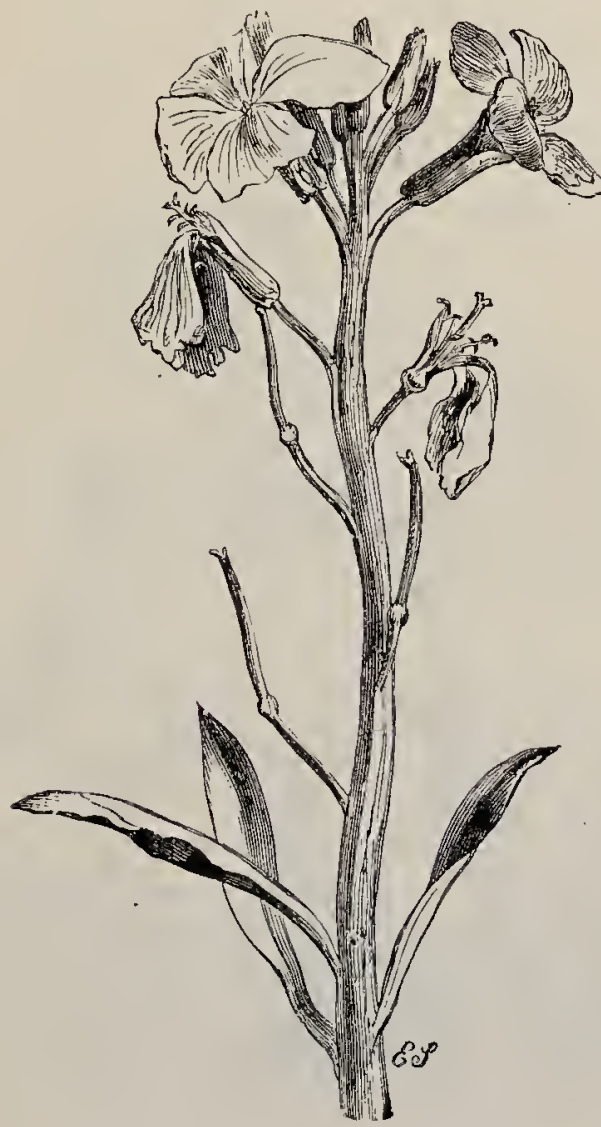

CHEIRÁNTHUS CHEfRI (Wallilnwer).

lanceolate, acute, entire; flowers 1 in. across, yellow, fragrant; pods 4-angled.-Not indigenous; but naturalised on many old walls._Fl. A pril_-June. 
Biennial. Many varieties, with red and brown flowers, are cultivated in gardens.

3. Nastúntium (Watercress).-Glabrous, mostly aquatic herbs ; flower's small, yellow or white; sepals

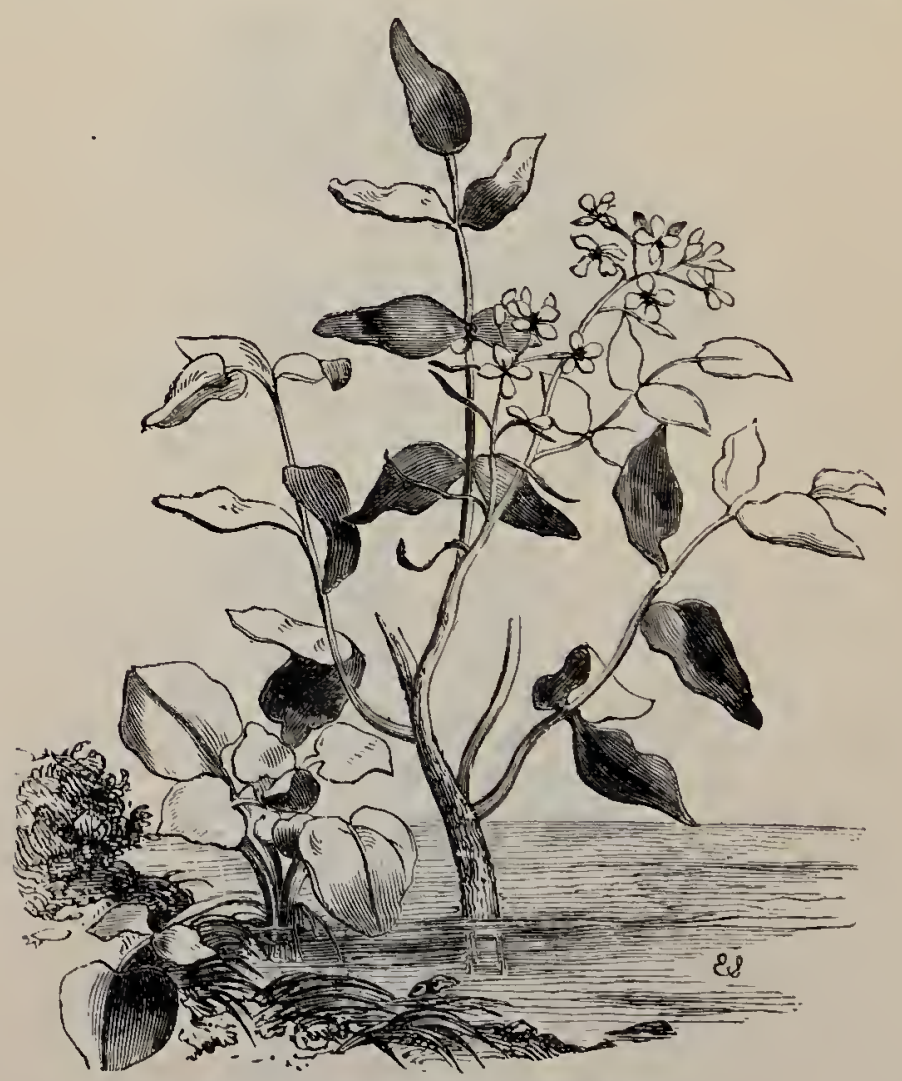

NASTÚRTIUM OFFICINÁLÉ (Common Watercress).

spreading; petals with short claws. (Name from nasus tortus, a distorted nose, on account of the pungent properties of the genus. The possession of 
similar properties caused a widely dissimilar plant, the Tropreolum of our gardens, to be also originally called Nasturtium.)

\section{* Flowers white.}

1. N. officinálé (Common Watercress).-Leaves pinnate; leaflets 7-13, ovate or oblong, sub-cordate, sinuate-dentate, glabrous, - Abundant in rivulets and extensively. cultivated as a salad. The only plant likely to be mistaken for it by watercress gatherers, Ápium nodiflónum (see p. 298), has hollow leaf-stalks. and serrated leaflets, which watercress has not.-Fl. May-October. Perennial.

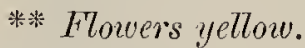

2. N. sylluéstré (Creeping Yellow Cress).-Rhizome creeping; leaves deeply pinnatifid ; leaf-segments lanceolate; flowers minute; petals twice as long as the calyx; pods linear.-Watery places.-Fl. JuneSeptember. Perennial.

3. $\dot{N}$. palustré (Marsh Yellow Cress).-Root fibrous; lecuves lyrate, pinnatifid; flowers $\frac{1}{8}$ in. across; petals not longer than calyx; pods oblong.-Watery places.-Fl. June-October.

4. N. amphiflizm (Amphibious Yellow Cress).Roots fibrous; rhizome short, stoloniferous; leaves pinnatifid or deeply serrate; petals twicc as long as the calyx; pods short and broad.-A large plant, 2-4 feet high, growing on the banks of rivers, or partly submerged, remarkable for its numerous runners or stolons.-Fl. June-September, Perennial.

4. BarbarÉa (Winter Cress).-Erect, branched, glabrous, biennial herbs ; stem angular ; petats yellow, 
clawed; pods straight, stiff, 4-ıngled, acuminate. (Dedicated to St. Barbara.)

1. B. vulyáris (Common Winter Cress).-Lowev leaves lyrately pinnate, the terminal lobe roundish; upper, obovate, toothed; raceme lax; flowers small.Common in moist waste ground, where it may be

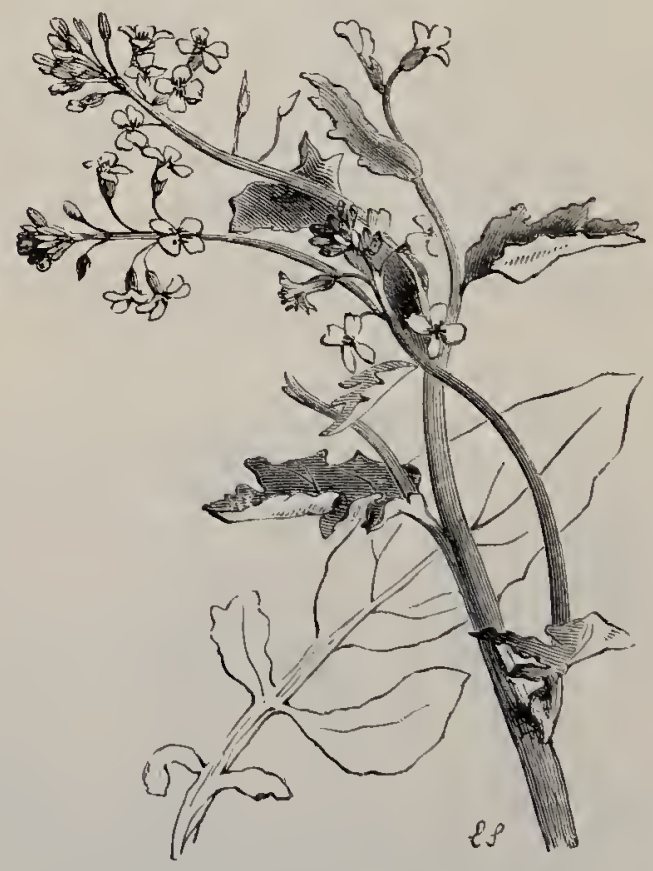

DARBARÉA VULGÁRIS (COMmon Winter Cress).

readily recognised by its smooth, shining, dark green levves, and its erect, angular stem, bearing numerous bright yellow flowers. Three forms, differing chiefly in the size of their petals and the direction of their pods, are distinguished as $B$, arcuata, B. stricta, and B. intermédia.-A variety with double flowers is 
frequent in gardens under the name of Yellow Rocket.-Fl. May-August. Biennial.

2.* B. préco $x$ (American Cress), differing in a more slender habit, narrower leaves, larger flowers in a closer raceme and longer pocls, and flowering earlier, is a common garden escape, being grown as a salad.

5. Árabis (Rock Cress).-Herbs growing in dry places, mostly local in Britain; radical leaves spathulate; flowers small ; sepals short; petals clawed; pods linear, compressed, keeled, not elastic. (Name from Arabia, the native country of several of the species.)

1. A. alpina (Alpine Rock Cress).-A low-growing plant, with its cauline leaves downy with branched hairs, lanceolate, acute, amplexicaul, toothed, and its pods erect, on spreading liairy stalks, occurs in the Isle of Skye. Perennial.

2. A. petróa (Mountain Rock Cress).-Generally glabrous; stem $3-8$ in. high, branched below; radical leaves lyrately pinnatifid; cauline leaves subentire, stalked ; flowers corymbose, white, tinged with purple.-On rocks in Wales and Scotland.-Fl. June -August. Perennial.

3. A. stricta (Bristol Rock Cress), with hispid, sinuate-dentate radical leaves, sessile cauline leaves and cream-coloured flowers, grows on limestone rocks at Bristol and Cheddar.-Fl. March-May. Perennial.

4. A. ciliáta (Ciliate Rock Cress), with leaves smooth on both sides, but fringed with forked hairs at the edges, and white flowers, grows on rocks by the sea near Tenby, and in the South and West of Ireland. -Fl. July, August. Perennial.

5. A. hirsúta (Hairy Rock Cress).--Hispid ; stems many, about 1 foot high, with numerous cauline leaves, heart-shaped at the base and amplexicaul; flowers small, white. A stiff, erect plant, frequent on walls and banks.-Fl. June-August. Biennial. 


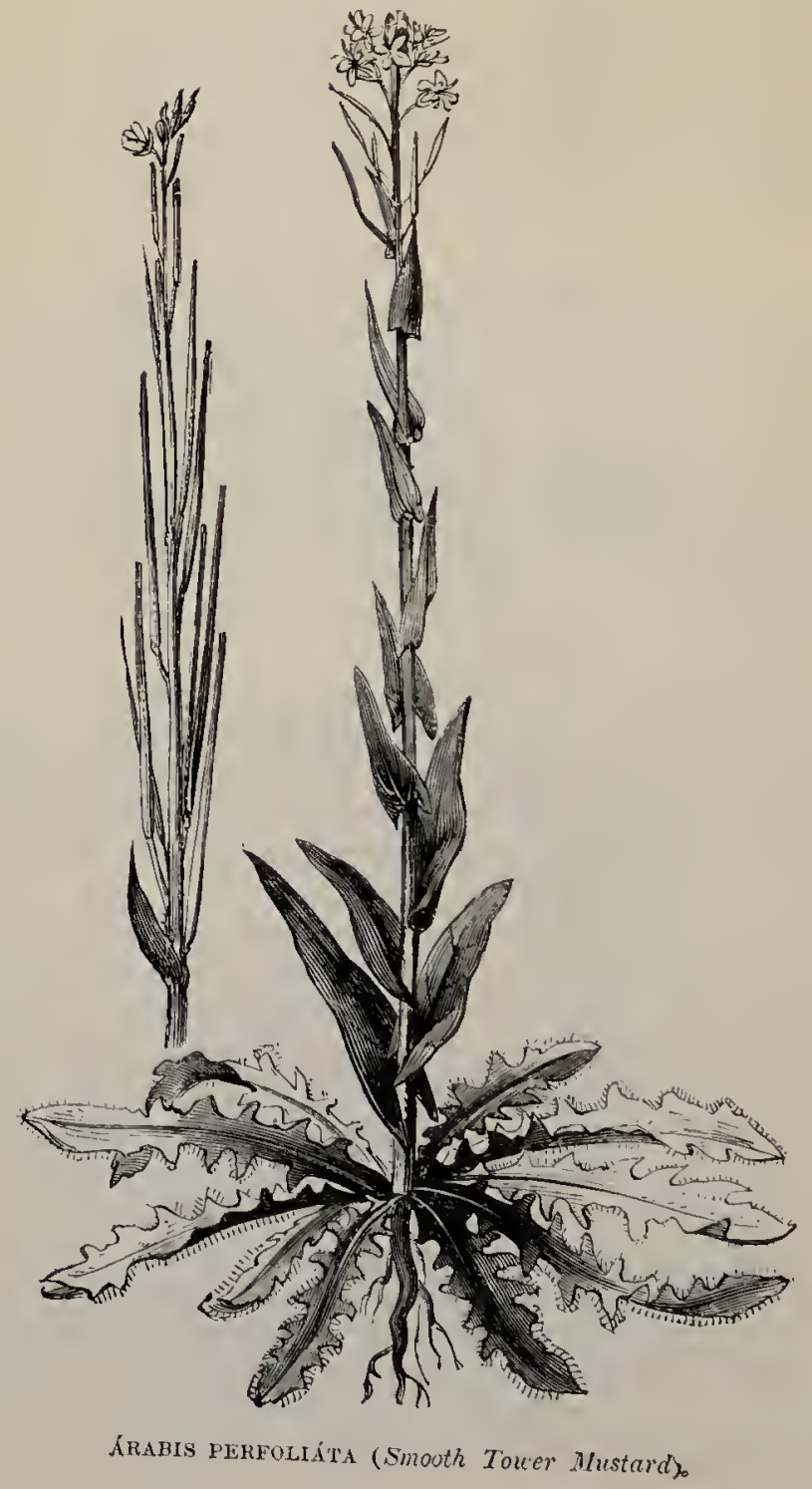


6.* A. Turrita (Hairy Tower Mustard), naturalised, but very rare, on old walls, chiefly at Oxford and Cambridge, has an erect stem, over a foot high, with forked hairs, amplexicaul cauline leaves, and bracteate yellow flowers.-Fl. May-July. Perennial.

7. A. perfoliáta (Smooth Tower Mustard). - Erect, glaucous; stem 1-2 feet high, unbranched; radical leaves, toothed, hairy, and soon withering; cauline leaves glabrous, triangular, entire, auricled; flowers pale yellow.--It grows on banks and cliffs; but is local.-Fl. May-July. Biennial.

6. Cardamíné (Bitter Cress).--Bitter herbs, mostly widely distributed, glabrous; leaves pinnate; flowers conspicuous, either individually or from corymbose aprangement; pods linear, compressed, elastic. (Name from the Greek kardia, the heart, damao, I overpower, from the supposed properties of the genus.)

1. C. amára (Large-flowered Bitter Cress). - Stem 1 -2 feet bigh, with runner's ; leaves pinnate; leaflets angular, those of the radical leaves roundish, those of the cauline leaves oblong; flowers $\frac{1}{2}$ in. across ; petals white; anthers purple.-River-sides; not common.Fl. A pril-June. Perennial.

2. O. praténsis (Lady's Smock, Cuckoo Flower). -Stem about a foot high; leaves pinnate; leaflets of radical leaves roundish, angular, those of the cauline leaves linear-lanceolate; flowers $\frac{1}{2}-\frac{3}{4}$ in. across; petals lilac or white; anthers yellow.-Moist meadows; a familiar spring favourite. A variety is sometimes found wild, which is remarkably proliferous, the leaflets, and even the leaves of the flower, producing buds when they come in contact with the ground.Fl. April-June. Perennial.

3. O. hirsúta (Hairy Bitter Cress).-Stem erect, with few leaves; leaves similar to those of $C$. praténsis, sometimes hairy; flower's very small, white; stamens 


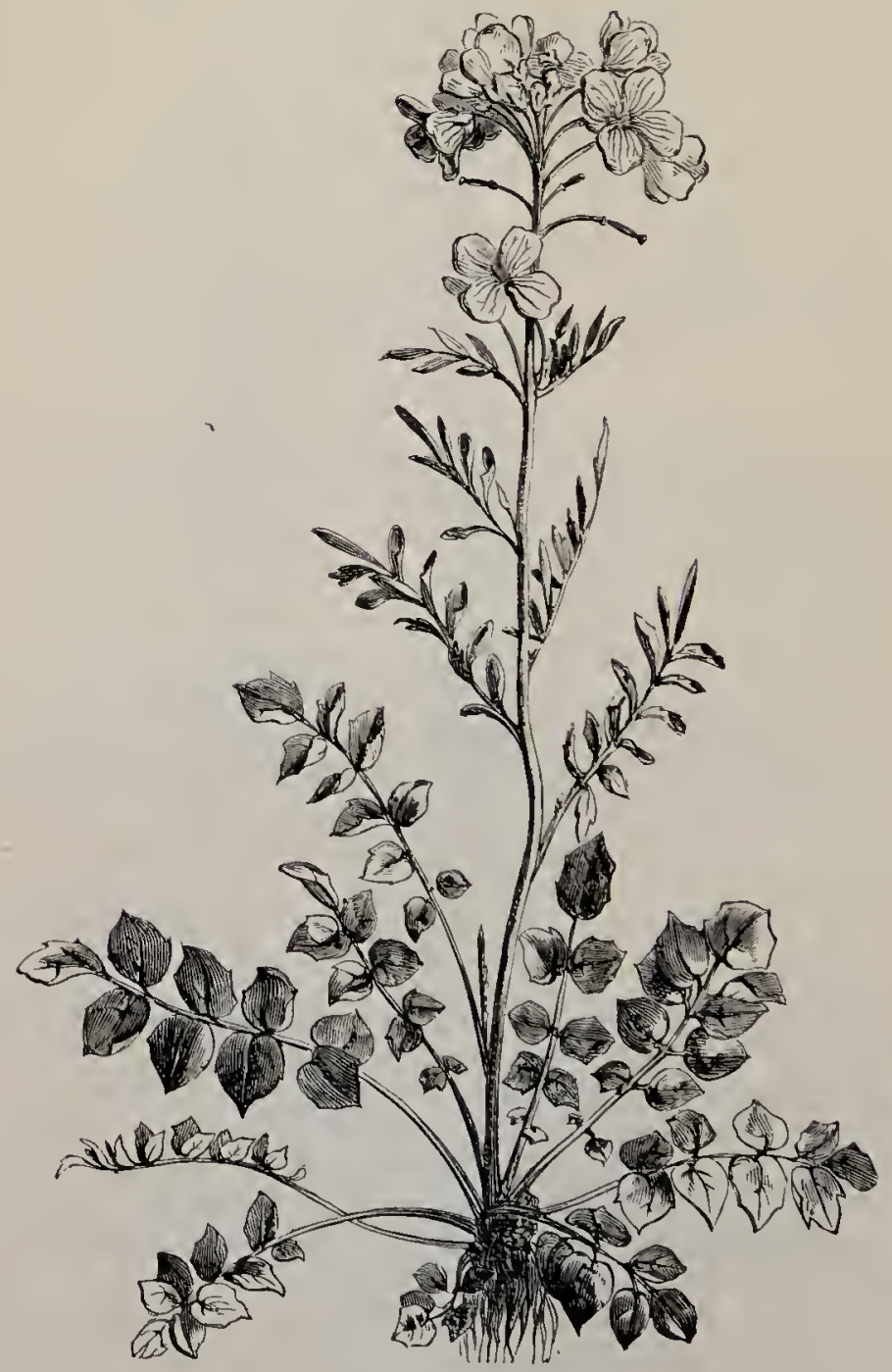

CARDAMiné PRATÉnsis (Cuckoo Flouer, or Lady's smock). 


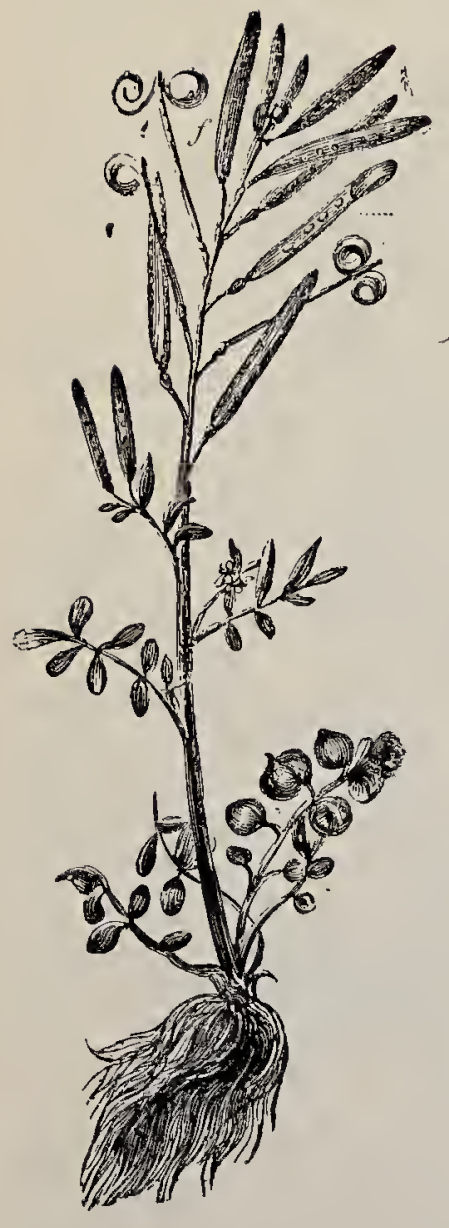

CARDAMíń́ HIRSUTA (Hairy Bitter Cress).

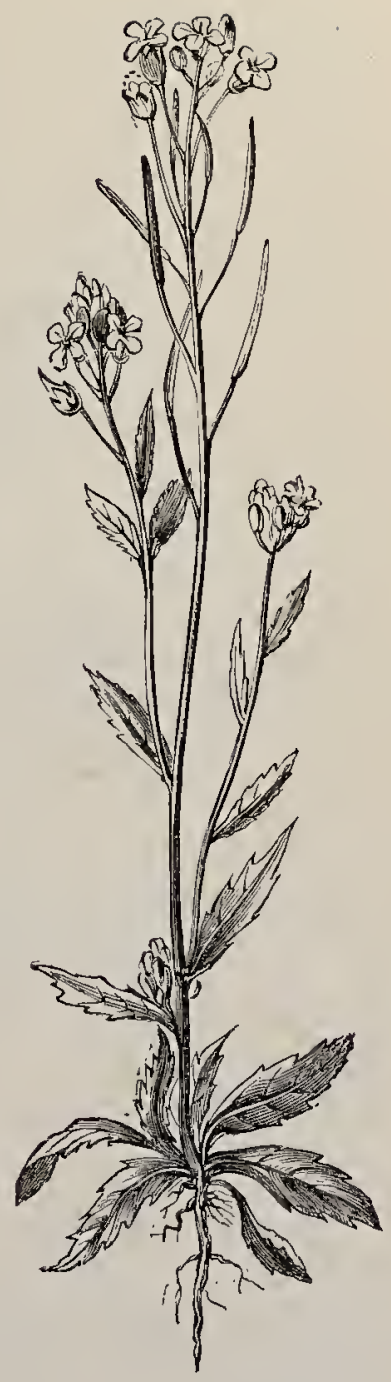

SISÝMBRIUM THALIÁNUM, p. 60, (Thale Cress). 
only four; anthers yellow.-A common weed everywhere, varying in size according to soil and situation, from 6-18 in. in height. In dry localities it ripens its seeds in April, or even in March, and withers away; but in damper places continues in flower all the summer. The very small white flowers are soon overtopped by the lengthening pods, the valves of which, when ripe, curl up elastically, scattering the seeds to a considerable distance.-F]. March-August. Annual.

4. C. flexuósa (Wavy Bitter Cress). - Almost equally common, differs in having a more wavy and more leafy stem, and usually six stamens and a longer style.-Shady places. -Fl. April-September. Biennial or perennial.

5. C. impátiens (Narrow-leaved Bitter Cress).-A stout, erect, g]abrous, leafy plant; leaves with fringed stipule-like auricles; leaflets narrow; flowers $\frac{1}{4}$ in. across, white.-Moist rocks, chiefly limestone; rare. - Fl. May-August. Annual.

6. C. bullútera (Bulbiferous Coral-root).-An erect, unbranched plant, with lower leares pinnate, upper leaves simple, lanceolate, serrate, or entire, easily distinguished from any other British plant in the Order by its rose-coloured or purple flowers, $\frac{1}{2}-\frac{3}{4} \mathrm{in}$. across, the white, tootli-like lnnobs on its rhizome, and the dark purple bulbils in the axils of the upper leaves.Shady places, chiefly in the South-east of England; rare.-Fl. April-June. Perennial.

*7. Hésperis (Dame's Violet).-Erect, stout, leafy plants; leaves simple; flowers large; seprals erect, lateral pair gibbons ; petals clawed; pocls long, slender, cylindric, constricted between the seeds. (Name from the Greek héspurros, evening, from its being fragrant in the evening.)

1.* H. matronátis (Dame's Violet) is a garden 
escape, with ovate-lanceolate, serrate, acuminate leaves, and white or lilac flowers, $\frac{3}{4}$ in. across.-Fl. AprilJuly. Biennial.

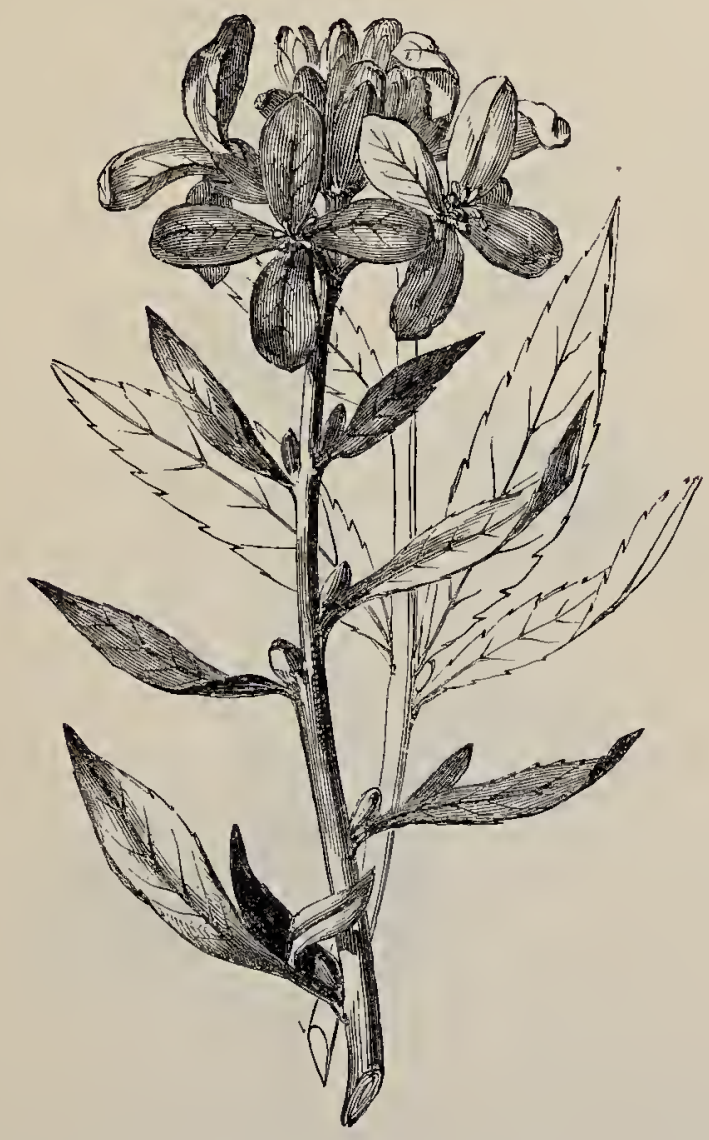

CARDAMINA BULBfFERA (Bulbiferouts Coral-root).

8. SisÝmbridu (Hedge - mustard)-Annual or biennial herbs, with unbranched hairs or none; flowers 
in lax racemes, generally yellow; pods narrow, linear. (Name of Greek origin.)

1. S. Thatiánum (Thale Cress or Wall Cress).-Stem erect, slender, 6-10 in. high, branched; leaves mostly radical, simple, oblong-lanceolate, serrate, pubescent; flowers minute, white; pods linear, obscurely four-angled, ascending, twice as long as their stalks.-Common on dry banks and walls._Fl. A pril -October. Annual.

2. S. officinálé (Common Hedge-mustard).- Stem

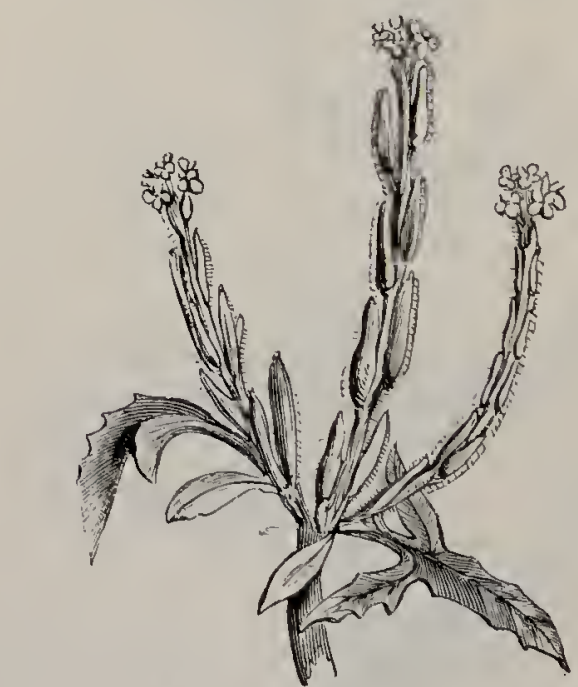

SISYMBRIUM OFFICINRTÁ (Common Hedge-mustarl).

1-2 feet high, rough; branches horizontal; leaves hairy, deeply lobed, with the points tumed backward (runeinate), the terminal lobe large; flowers small, yellow; poils downy, closely pressed to the stem, subnlate.-It grows in waste places and by roadsides, where it seems to havo a peculiar aptitude for eollecting and retaining dust.-Fl. June, July. Annual. 
3. S. Sóphia (Flixweed.).-Downy; stem slender, erect, branched; leaves twice pinnatifid, segments nar. row, linear; flowers small, greenish yellow; petals shorter than the calyx; pods terete, narrow, con-

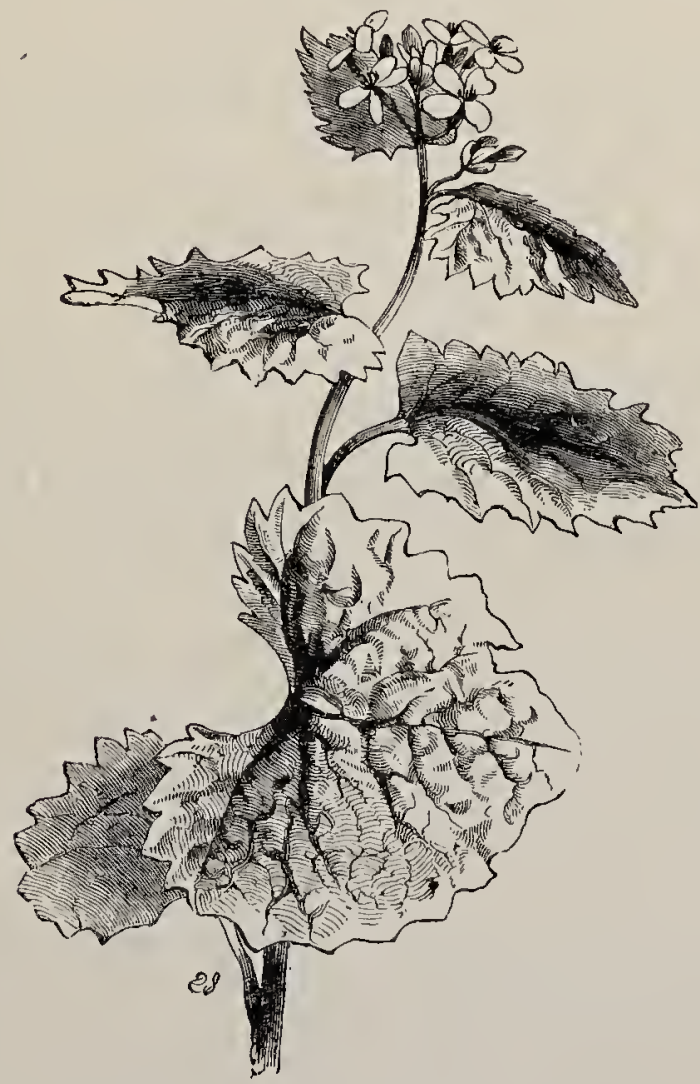

SISÝMBRTUM ALIIARIA (Garlic Mustard).

stricted between the numerous seeds. -.Waste places; not uncommon.-Fl. June-August. Annual. By the old herbalists it was called Sóphia chivirgorum, 
"Wisdom of surgeons," from its use in nealing wounds.

4. S. Irio (London Rocket).-Glabrous; stem erect, branched; leaves runcinate, dentate; flowers small, yellow; jods narrow, linear, four times as long as their stalks.-A leafy plant about 2 feet high, occurring in waste ground near old towns, but rare. It is known as London Rocket because it covered the ground in the spring after the Great Fire of 1666.-Fl. July, August. Annual.

5. S. A7liária (Garlic Mustard, Jack-by-the-Hedge, or Sauce-alone).-Stem erect, slightly branched, 1-2 feet high; leaves broadly heart-shaped, stalked, coarsely toothed, with prominent veins; flowers $\frac{1}{4}$ in. across, white, corymbose; pods $2 \frac{1}{2}$ in. long.-Hedgerows; common.-Fl. April-June. Annual. An early flowering and attractive hedge-plant, with delicate green leaves and snow-white flowers; but the whole plant emits, when gathered, a nauseous scent of garlic. It was formerly used as a sauce.

Two other species are naturalised, $S$. polycerátium; a prostrate form with flowers and pocks in threes in the axils of bracts, growing near Bury St. Fdmunds; and S. pannónicum, near Crosley, Luncaslire, with runcinate leaves, spreading sepals, and pedicels nearly as thick as the pods.

9. Eห⿻́sıuчu (Treacle-mustard). - Hoary lierbs, with adpressed forked hairs; lear's simple, without auriales; pods narrow, linear, compressed; ralves keeled, 1-veined. (Name from the Greek èrı, I draw blisters.)

1. E. cheiranthoidles (Worm-seed, Treacle-mustard). -Stem erect, branched, 1 to 2 feet high; leaves lanceolate, acute, slightly toothed, witl three-forked hairs, dull green; flowers small, yellow; sepals whitish; pods 1 in. long, erect, on short-spreading 
stalks.-Generally in cultivated ground; uncommon. -Fl. June-August. Annual.

2.* E. perfolićtum (Hare's-ear Treacle-mustard), with glaucous oval leaves and cream-coloured flowers, occurs as an escape.-Fl. May_July. Annual.

10. Brassica (Cabbage, Mustard, \&c).-Herbs, with long racemes of conspicuous flowers, and long, nearly cylindric pods and seeds in one row. (Name, the Latin name for cabbage.)

\section{* Sepals erect.}

1. B. olerácea (Wild Cabbage). - Rhizome stout, branched; branches usually decumbent, tortuous, fleshy; leaves glabrous, glaucous, obtuse, often a foot across; racemes elongated; flowers 1 in. across, pale yellow; pods $2-3$ in. long, beak subulate.-Sea-cliffs in the south and west.-Fl. May-August. Biennial. The original of all the varieties of garden cabbage, including broccoli, cauliflower, kohl-rabi, \&c.

2. B. campéstris (Navew).-A group-name for a series of weeds occurring in cultivated ground, probably not wild, according to Sir Joseph Hooker, "in this or any other country."-Riadical leaves lyratelypinnate, dentate; cauline leaves ovate-lanceolate, acute, auricled, amplexicaul; racemes corymbose.-Fl. June-September. This group includes B. Nápus (Rape or Cole-seed), with a fusiform root, and all its leaves glabrous and glaucous, and yellow flowers, which is cultivated for the sake of the Colza and Carcel oil pressed from its seeds, the refuse being used, under the name of oilcake, for feeding cattle; B. Rutabaga (Swede), with a turnip-shaped root and all its leaves glaucous, the radicat ones hispid and the cauline ones glabrous, and buff flower's, the roots of which are used as cattle-food; and $B$. Riapa (Turnip), 
with turnip-shaped root, lower leaves hispid but not glaucous, upper leaves glaucous and glabrous, and

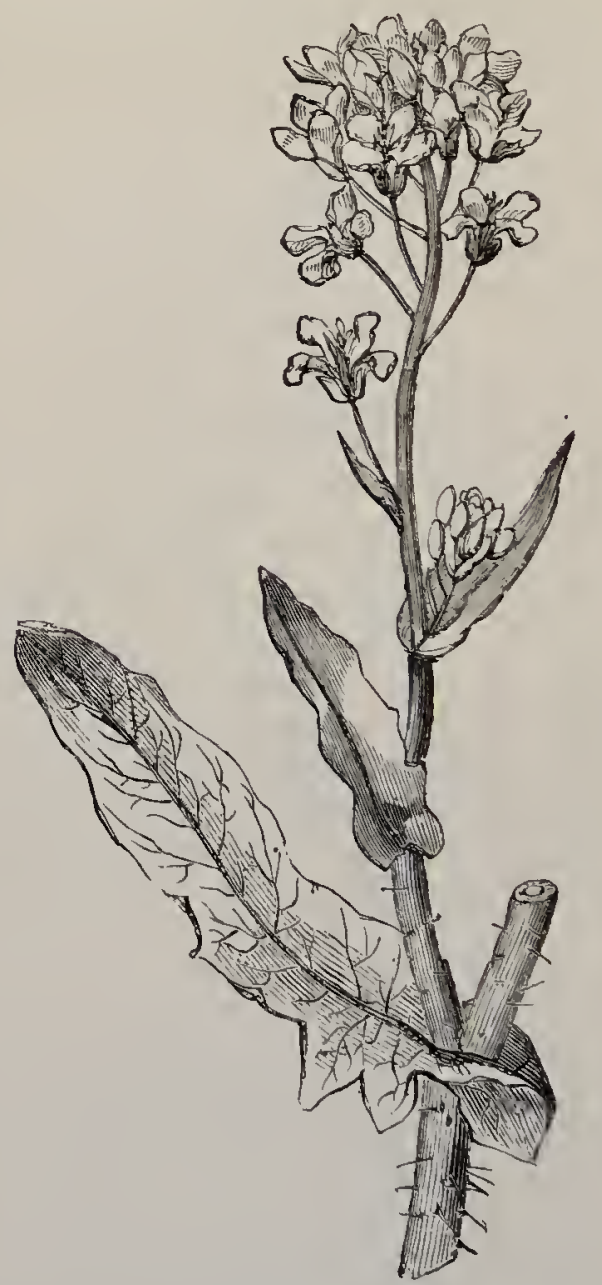

BRÁssica CaMpéstris (Common Wild Naverc).

bright yellow flowers, which is perhaps the most truly wild and ancestral form. 
3. B. monénsis (Isle of Man Cabbage).-Rhizome stout, woody; stem $6-24$ in. high, usually prostrate; leaves mostly radical, glabrous, deeply pinnatifid; flowers bright lemon-yellow, veined with purple. - Sandy sea-shores on the west coast of Britain; rare. -Fl. May-August. Perennial.

4. B. Cheiranthus (Jersey Cabbage) is an allied species, found in the Channel Islands, differing in having an erect leafy stem, $1-3$ feet high and hispid leares.

\section{* Sepals spreading.}

5. B. Sinapiożdes (Black Mustard). - Stem 2-3 feet high, branched, hispid; lower leaves large, rough, lyrate ; upper leaves linear-lanceolate, stalked glabrous; flowers $\frac{1}{3}-\frac{1}{8}$ in. across, yellow; pods erect, adpressed, 4-angled, glabrous, beak short, subulate.-Fl. June -August. Annual. Its seeds yield table mustard.

6. B. adpréssa, growing in sandy places in the Channel Islands, is more branched and has very short pods.

7. B. Sinapistrum (Wild Mustard, Charlock).Hispid; leaves lyrately pinnatifid, rough; flowers sub-corymbose, $\frac{1}{2}-\frac{3}{4}$ in. across, bright yellow; pods spreading, linear, many-angled, generally hispid, $1 \frac{1}{2}-2$ in. long, constricted.-A common weed in cornfields, sometimes springing up in profusion from recently disturbed ground, though previously unknown there.-Fl. May-August. Annual.

8. B. alba (White Mustard).-Hispid with reflexed hairs; flowers $\frac{1}{2}$ in. across, yellow; pods spreading, 2 in. long, hispid, with a flat, two edged, sword-like beak.-Waste ground.-Fl. June, July. Annual. Seedlings of this species are-largely eaten, with those of Cress (Lepidium sativum), as salad.

11. Diplotáxis (Rocket) has spreading sepats; but 
differs from the mustards in its flattened pocks with membranous valves and seeds in two rows. (Name from the Greek diplos, double, taxis, rank or row.)

1. D. tenuifólıa (Wall Rocket). - Slender, branched, 1-2 feet high; stem woody below; leaves deeply divided into long narrow segments, glaucous;

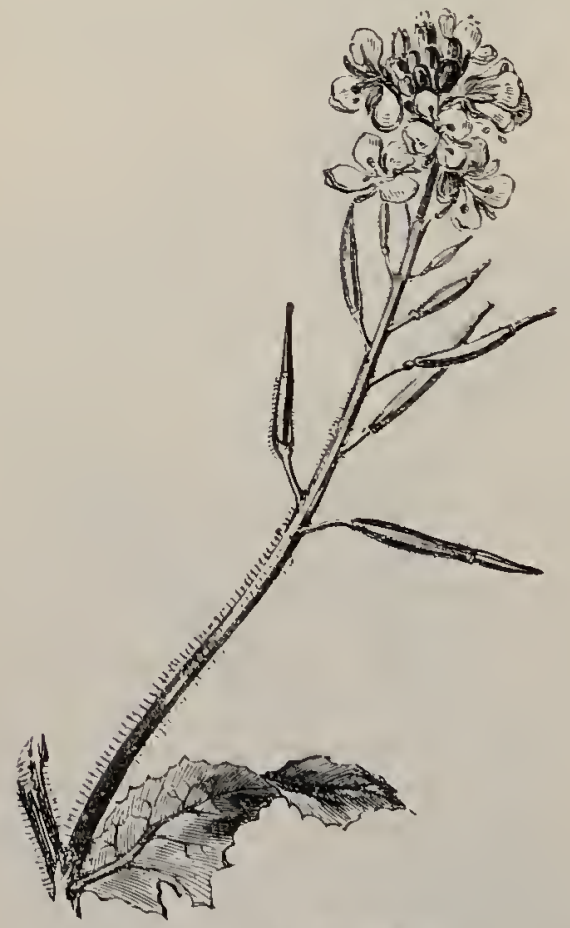

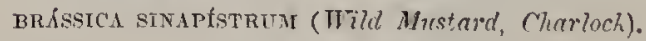

flowers $\frac{3}{4}$ in. across, light yellow, fragrant; prods short, linesr, erect, on very long slender stalks.-On old walls.-Fl. June- September. Perennial.

2. D. murclis (Sand Rocket), a less branched, hispid, herbaceous, and generally annual species, grows in waste ground, especially near the sea. 
*12. Alyssum, a genus of small plants, mostly hoary with adpressed hairs, with simple leaves, small white or yellow flowers, and rounded, few-seeded pods, includes three alien species, sometimes naturalised : $A$. incánum, $A$. calycinum, with stellate hairs; yellow flowers ; and persistent sepals; and $A$. marítimum, with bi-partite hairs ; white, sweet-scented flowers, and deciduous sepals.

13. DRÁвA (Whítlow-grass).--Small herbs, mostly perennial and hoary with stellate hairs; leaves small, simple, the radical ones in a rosette; flowers small, white or yellow; pods compressed. (Name from the Greek drabé, acrid.)

\section{* Flowers white.}

1. D. murális (Speedwell-leaved Whitlow-grass)。 - Stem leafy, branched, about a foot high; leaves rough. with stellate hairs, egg-shaped, blunt, toothed, em. bracing the stem; pedicels spreading horizontally.Limestone hills in the West of England; rare. Fl. April, May. Annual.

2. D. incánce (Twisted Whitlow-grass). - Stem leafy, branched, 4-14 in. high; leaves hoary with stellate down, lanceolate, toothed; pods twisted.Mountains, and sandhills near the sea; uncommon.Fl. June, July. Perennial.

3. D. rupéstris (Rock Whitlow-grass). - Stems several, 1--2 in. high, almost leafless; leaves rosulate, stellately pubescent, ciliate.-In crevices of the rocks and among moss on the summits of some Highland mountains; very rare.-Fl. July, August. Perennial.

\section{* Flowers yellow.}

4. D. ä̈zóïles (Yellow Alpine Whitlow-grass) - 
Stem lcafless, 1-5 in. high; leaves rosulate, linear, glabrous, ciliate; petals slightly notched.-On rocks and walls at Pennard Castle, near Swansea, where it forms dense tufts with bright yellow flowers. - Fl. March-May. Perennial.

14. Eróphila (Vernal Whitlow-grass). - Small herbs with simple rosulate, hairy radical leaves: slender leafless scapes; flowers minute; petals deeply

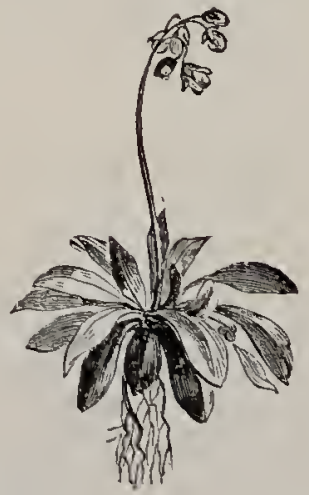

ERópHILA VULGÁRIs (I'ernal Whitlou-grass).

bi-lobed, white. (Nrme from the Greek éros, spring, philo, I love.)

1. E. vulyáris (Long-podded Whitlow-grass).-Pods compressed, twice as long as broad.-Common on wall and dry banks-Fl. February-May. Annual.

2. E. prócox (Short-podded Whitlow-grass).-Pods compressed, orbicular. A less common form.

3. E. inflata, found on Ben Lawers, has inflated seed-pods, twice as long as broad.-Fl. June, July.

15. Cochleária (Scurvy-grass).-Glabrous herbs, 
with simple, often fleshy leaves; small white flovers; and nearly globose pods. (Name from the Latin cochlear, a spoon, from the shape of the leaves in

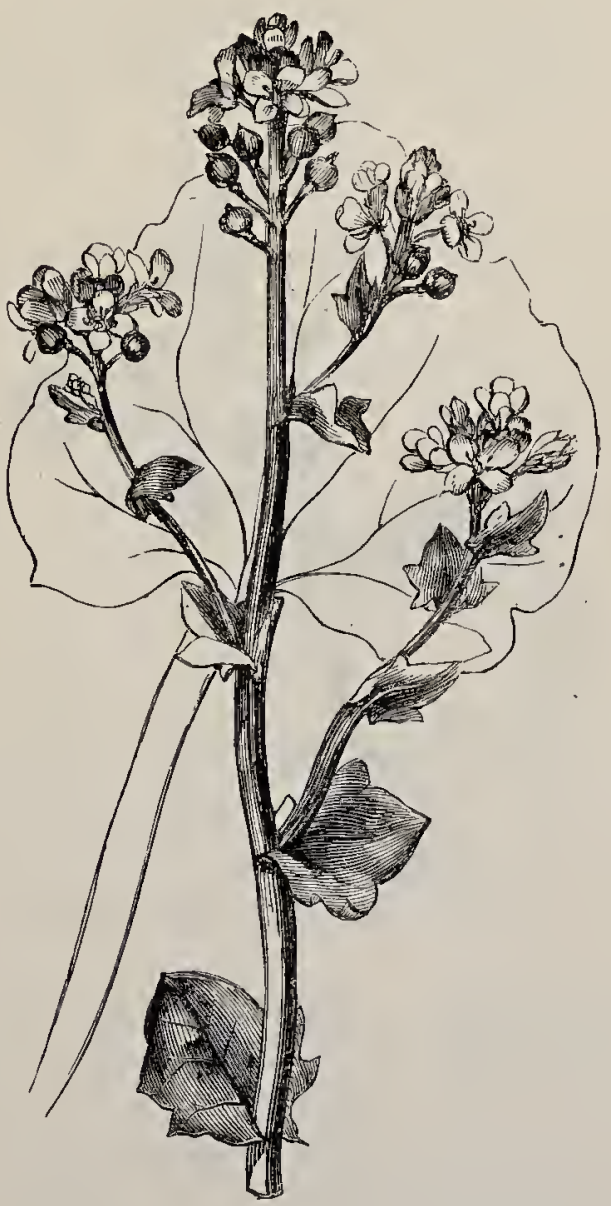

COCHLERRIA OFFICTNÁtS (Common Scu*vy-grass).

some species.) The plants of this genus derive their English name from the relief which they afford to 
sailors suffering from scurvy, in consequence of their being debarred from the use of fresh vegetables, This antiscorbutic quality is shared to an equal degree by other plants of the Order; but these were most readily available from growing near the sea. Steam navigation and the consequent shortening of voyages, preserved vegetables, and the use of lime-

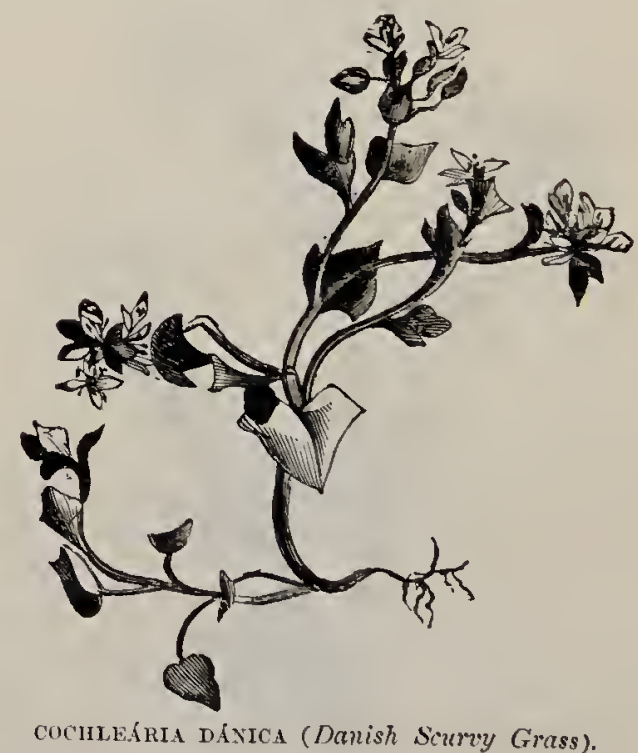

juice have, however, rendered this dreadful disease much less common.

* Tralues of the porl with prominent dorsal veins.

1. C. officinalis (Common Scurvy-gr'ass). - Stem often much branched, 10 in. high; radical leaves stalked, orbicular or reniform, cordate ; cantine leaves amplexicaul, lobed; flowers in rather larke corymbs ; 
pod nearly globose. - On muddy aea-shores; common. -Fl. May, June. Annual.

2. C. alpina (Alpine Scurvy Grass).-A smaller form with an obovoid pod.-.-On lofty mountains.

3. C. danica (Danish Scurvy Grass).--Another small form, with stalked, deltoid leaves and an ovate pod.-Cliffs and hedges near the sea; common.-Fl. March-August. Biennial.

4. C. ánglica (English Scurvy Grass).-Branches 10-18 in. long; radical leaves not cordate, fleshy; flowers and pods larger than in $C$. officinatis, the latter somewhat elongate, nearly $\frac{1}{2}$ in. in length.-Muddy sea-shores; common.-Fl. May-August. Annual.

Two other small species allied to C. dánica, C. graenlándica, with fleshy leares, and $C$. micácea, a perennial with long claws to its relatively large petals, are found in the North of Scotland.

*** Talves of the pod without dorsal veins.

5.* C. Armorácic (Horse-radish)._Rhizome stout, long, cylindric, white and pungent; branches 2-3 feet high; radical leaves 8-12 in. long, on stalks a foot long, oblong, wavy, crenate; cautine lecues sub. sessile, lanceolate, serrate; flowers small; pods not ripening in England.-Waste-ground; a common escape from kitchen gardens ; but not indigenous.-Fl. May-June. Perennial.

*16. Camelína satíva (Gold of Pleasure) is another escape from cultivation. It has tell, slender stems; with obtuse, auricled canline leaves; small yellow fowers and obovoid inflated pocts.-Fl. June, July. Annual. (Name from the Greek chamai, dwarf, linon, flax.) The plant is cultivated for the oil in its seeds.

17. Subulária (Awl-wort).-A small submerged 
aquatic herb; leaves all radical, subulate (awl-sliaped); flowers few, small, white, on a scape, $1-3$ in. long, sometimes perfected under water. (Name from the Latin subula, an awl.)

1. S. aquatica (Water Awl-wort). - The only species,

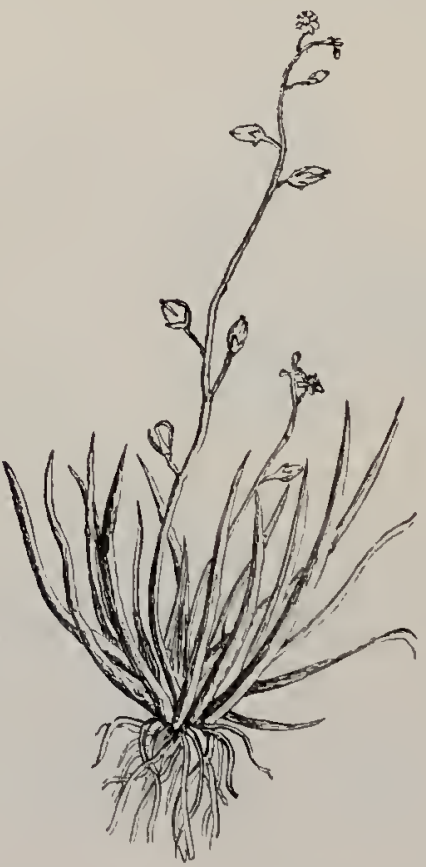

SUBULARIA AQUATICA (Water Aul.wort).

common on the gravelly bottoms of mountain lakes -Fl. June-August. Perennial.

18. Búrsı (S'hepherd's Purse).-Aunual herbs, floweis small, white ; pedicels slender; pods compressed, inversely heart-shaped; ralees boat-shaped, keeled, but not winged. (Name, the Latin for a purse.) 
1. B. pastóris (Common Shepherd's Purse).-A common weed, to be found in almost every part of the world, varying considerably in size, and the division of its leaves. The whole plant is more or less rough with branched hairs; root tapering; stem 6-16 in,

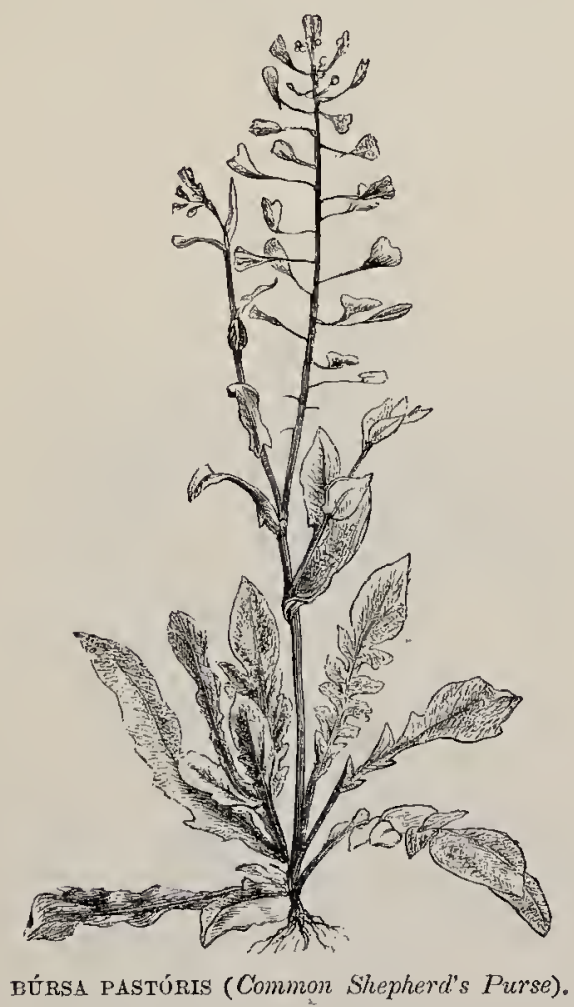

high, branched; radical leaves pinnatifid; cauline leaves auricled; petals sometimes converted into stamens,-Fl. nearly all the year round. Annual.

19. Corónopus (Wart-cress)._-Branched, prostrate 
herbs ; flowers minute, white, in short lateral racemes; pods reniform, indehiscent, or splitting into two indehiscent lobes; seeds one in each lobe. (Name from the Greek korónos, a raven, pous, foot.)

1. C. didymus (Lesser Wart-cress).-Stem prostrate, branched, slender, hairy, a foot or more in length; leaves finely pinnatifid or bi-pinnatifid;

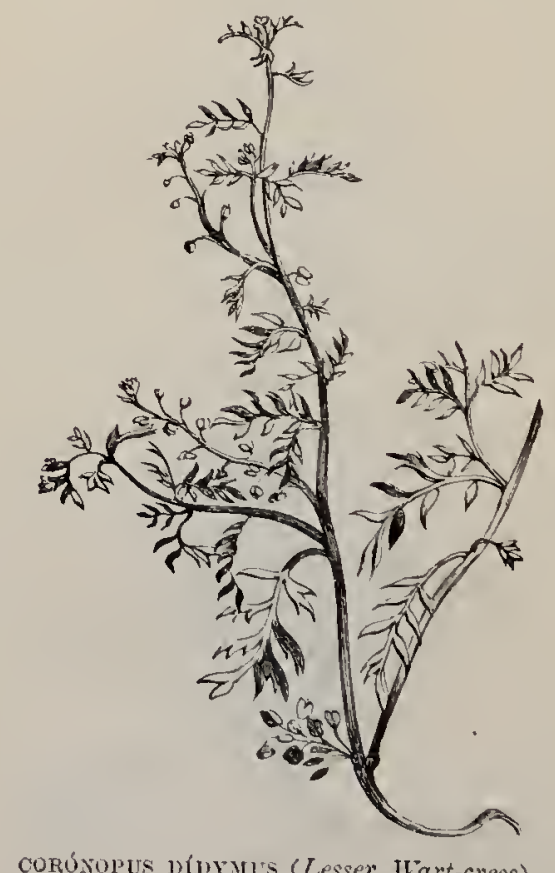

pods separating into two hard, wrinkled lobes. Wasteground near the sea in the south-west. It emits a very powerful smell, like that of Pepper-cress, especially when trodden on, or in lot weather; and has a particularly nauseous taste. - Fl. July-Septem. ber. Annual.

2. C. Ruéllii (Wart-cress or Swine's-cress)._Gla- 
brous, less branched and with larger, less divided leaves and larger pods than C, dídymus. The pods are indeliscent. A common roadside weed.-Fl, June-September, Annual.

20. Lepídiun (Pepperwort).--Herbs with small white flowers; some of the petals or stamens of ten absent; pods rounded or obcordate, much compressed, generally 2-seeded; valves keeled or winged. (Name from the Greek lepis, a scale, from the flattened pods.)

\section{* Style minute.}

1. L. Tatifólium (Broad-leaved Pepperwort, Dittander).-WThe largest British species, glabrous and glaucous ; stem 2-4 feet high, erect, much branched, leafy, with runners; radical leaves stalked, ovate, lanceolate, serrate, often a foot long; cauline leaves sessile, lanceolate; flower's numerous, small, white, in leafy panicles; pods oval, not notched or winged, downy.-In salt marshes; rare.-Fl. July, August. Perennial.

2. L. ruderálé (Narrow-leaved Pepperwort).-A smaller plant, glabrous or slightly pubescent; stem a foot high, branched; radical leaves pinnatifid with narrow segments; cautine leaves linear, entire; petals absent; stamens 2 ; pod oval, notched, winged at the top.-Waste places near the sea; uncommon.-Fl. May, June. Annual.

3.* L. sativum (Common Cress).-A similar plant, occurring as an escape from cultivation; pod more completely winged. Annual.

***at Style distinct.

4. L. campéstré (Field Pepperwort). - Pubescent: 
stem 6-18 in. high, erect, slightly branched; leaves hoary, upper ones arrow-shaped at the base; anthers yellow; pod rough with minute scales; style not

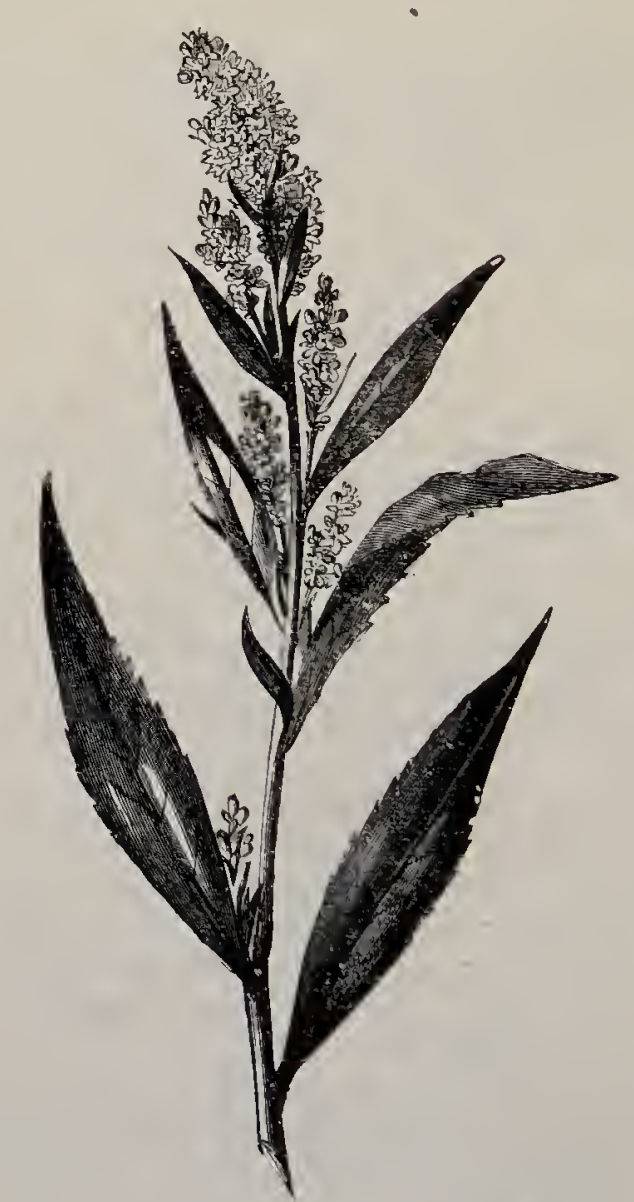

LifṔldum Latifólium (Broad-leaved Peppemort).

longer than the notch in the pod. A common weed. - II. May-August. Annual or biennial. 
5. L. hirtum (Hairy Pepperwort). - Nore downy, more woody, and more branched; anthers violet; pod less scaly; style much longer than the notch. As common as L. campéstré.-Fl. April-August. Perennial.

6.* L. Drába.-Stem flexuous, leafy, a foot in height, branched; leaves hoary, oblong, lower ones stalked, upper ones arrow-shaped at the base ; flowers many, small, corymbose, long-stalked ; pod cordate,

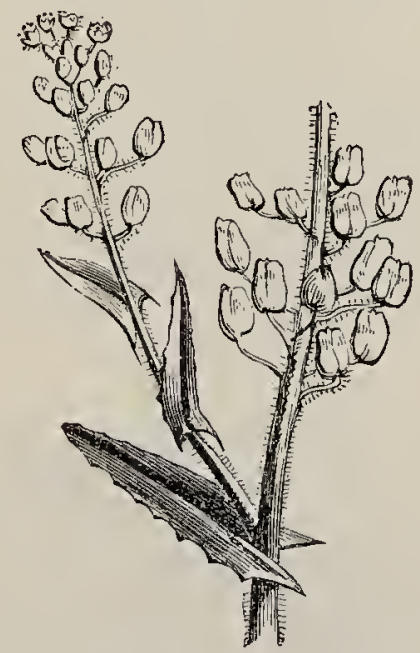

LepídIUM CAMpístré (Field Peppernort).

constricted between the valves; valves swollen; style slender. Not indigenous.-Fl. May-June. Perennial.

21. Thuáspi (Penny Cress). - Glabrous herbs ; radical leaves rosulate; cauline leaves sessile, sagittate; flowers small, white; petals equal, obovate; pod rounded, flat, notched; values boat-shaped, winged; 
seeds numerous. (Name, the old Greek name of the genus, connected with thlao, I flatten.)

1. T. arrénsé (Mithridate Mustard, Penny Cress). Stem slender, erect, a foot high ; cauline leaves oblong,

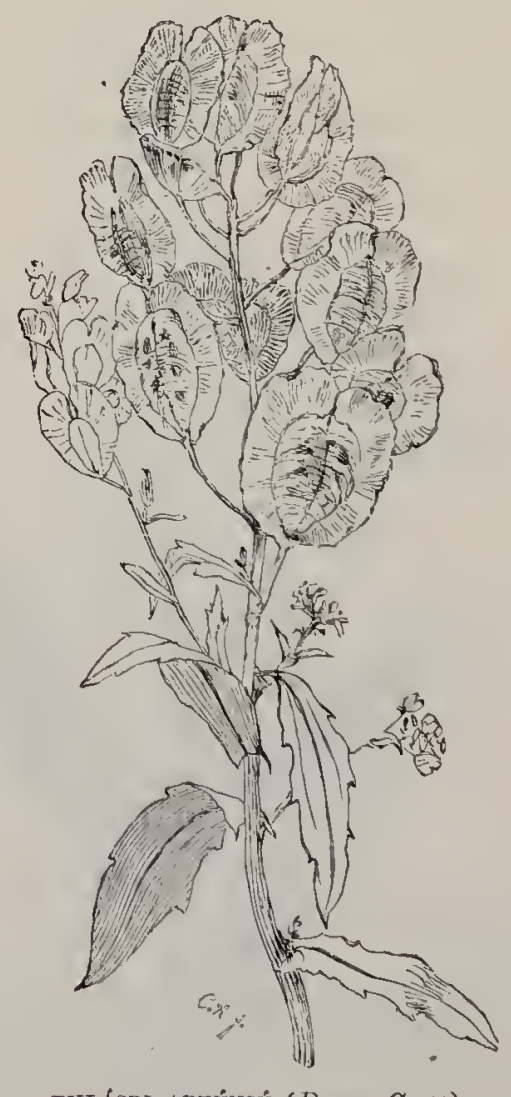

THLAsPt ARtíisé (Penuy Cress).

sagittate, toother; flowers much smaller than the pods, in a lengthening raceme; pods round, flat, with very broad wings, and a deep notch, $\frac{1}{2}-3$ in. across. -Fields; frequent. It derives its popular names 
from the resemblance of its seed-vessels in size and shape to silver pennies, and from having formerly been used in a medicine known as the Mithridate confection.-Fl. all the summer. Annual.

2. T. perfotiátum (Perfoliate Penny Cress).-A smaller, much-branched species; stem-leaves ressile, oblong, heart-shaped at the base, amplexicaul, but not truly perfoliate; flower's minute; pod small, inversely heart-shaped; style very short.-Waste places on a limestone soil in Oxfordshire, Gloucestershire, Wiltshire, and Middlesex; but very rare.-Fl. April, May. Annual.

3. T. alpéstré (Alpine Penny Cress).-Another small species, but little branched; stem-leaves arrowshaped at the base; flowers and pods rather larger than in T. perfoliatum; style longer than the notch of the pod.-Mountainous limestone pastures in the North of England; rare--El. June-August. Perэnnial.

22. IBúris (Candytuft). 一Small branched glabrous herbs; flowers corymbose, white or red, rendered conspicuous by their corymbose arrangement and by the two outer petals in each flower being much enlarged; pod ovate, notched; values boat-shaped, winged; seeds 2. (Name from Iberia (Spain), where many species grow.)

1. I. amára (Bitter Candytuft).-Stem 6-10 in. high; leaves sessile, oblong-lanceolate; racemes lengthening after flowering; flowers white or red; pocls small; wings pointed above; style longer than the wings.-Chalky fields in the South and East of England.-Fl. July. Annual. Commonly grown in gardens.

23. Teesuáuta.-Small, annual, glabrous herbs ; 
leaves all radical, pinnatifid; flowers minute, white, on i corymbose scape; petals generally unequal; pod roundish, notched, keeled; seecls 4. (Named after Robert Teesdale, a Yorkshire botanist.)

1. T. mudicañis (Naked-stalked Teesdalia).-The only British species, a minute and not inelegant plant with leaves closely pressed to the ground and several slender leafless scapes, 2-4 in. high; two outer petals twice as long as the others.-Dry banks; not common.-Fl. April-June. Annual.

24. Hutchírsia.-A small annual much-branched herb, with pinnatifid leaves; flowers minute, white,

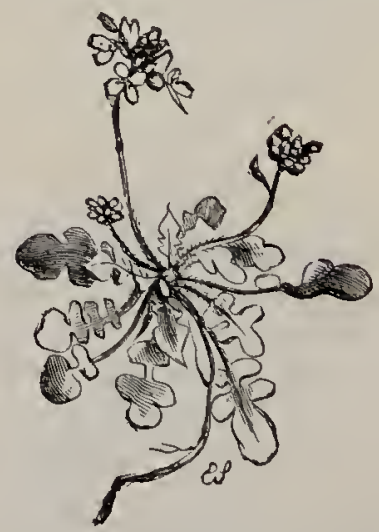

TEESDAta NUDronólis (Naked-stalked Teesdatia).

in racemes, which lengthen after flowering; petals equal; pod minute, compressed, keeled; seeds 4. (Named after Miss Hutchins, an Irish botanist.)

1. H. petráa (Rock Hutchinsia).- - The only British species, a pretty little plant, from $2-5 \mathrm{in}$. high. Lecues elegantly pinnatifid; pods elliptic.-Limestone rocks, chintly in the West of England; rare.-Fl. March-May. Annual. 
*25. Ísatis (Woad).-Tall, erect, branched herbs; cauline leaves sagittate; flowers yellow; pods pendulous, indehiscent, 1-chambered, rounded, compressed, broadly keeled, 1-seeded. (Name, the Greek name of the genus.)

1.* I. tinctória (Woad).-Glabrous, glaucous, 14 feet high; radical leaves, stalked, oblong; flowers

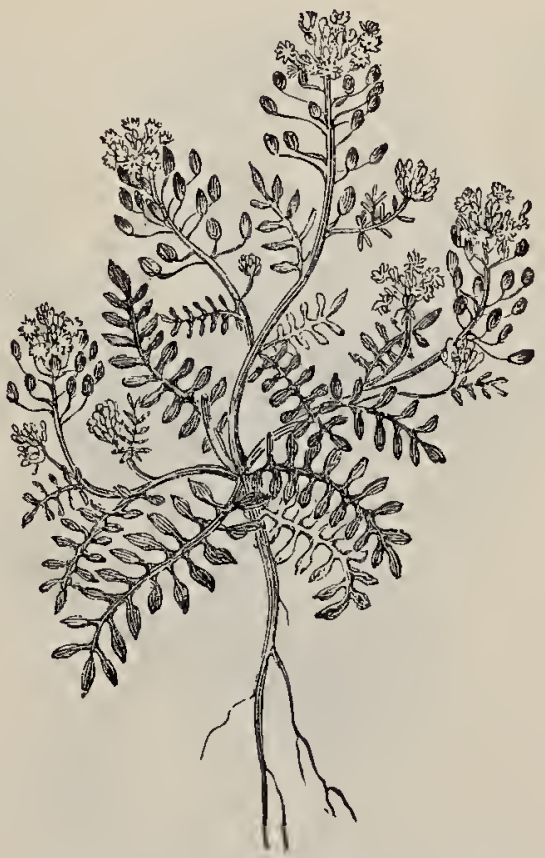

HUTChissia PETR fa (Rock Hutchinsia).

small, corymbose; pods on lengthening racemes.Waste places, not indigenous; rare.--Fl. JulyAugust. Biennial. - The ancient Britons stained themselves with this plant, and it is still grown as a dye. 
26. Crámbí (Sea-kale).--Perennial herbs with stems stout, branched; leaves broad; flowers white, in compound racemes; pods indehiscent, 2-jointed, the lower joint seedless, the upper globose, 1-seeded. (Name from the Greek, hrambe, cabbage.)

1. C. maritima (Sea-kale).-Glabrous, glaucous; leaves wavy, toothed, fleshy. This is the plant which

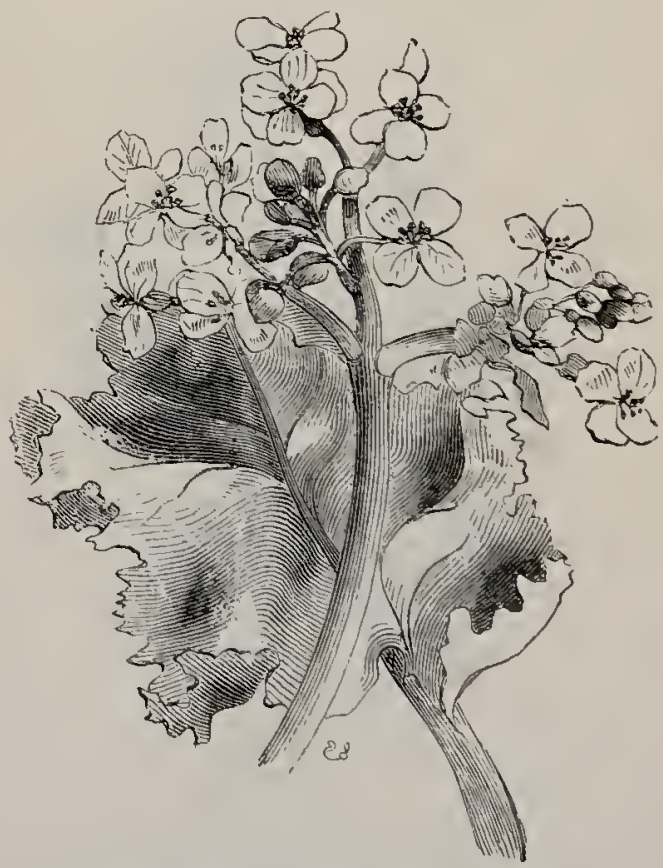

CRAMB FA MátTIMA (Sea-kale).

is so well known in gardens as a vegetable. The part eaten is the leaf-stalk blanched by being kept from the action of light. It is found on many parts of the ren-const, and differs in no respect from garden specimens as they appear when the forcing is over.-Fl. June-August. Perennial. 
27. CakíLÉ (Sea Rocket).-A large, fleshy, branched herb; flower's white or lilac; corymbose; pods indehiscent, 2-jointed, 4-angled, each joint 1-seeded. (Name of Arabic origin.)

1. C, maritima (Purple Sea Rocket).- -The only British species, common on sandy sea-shores, growing

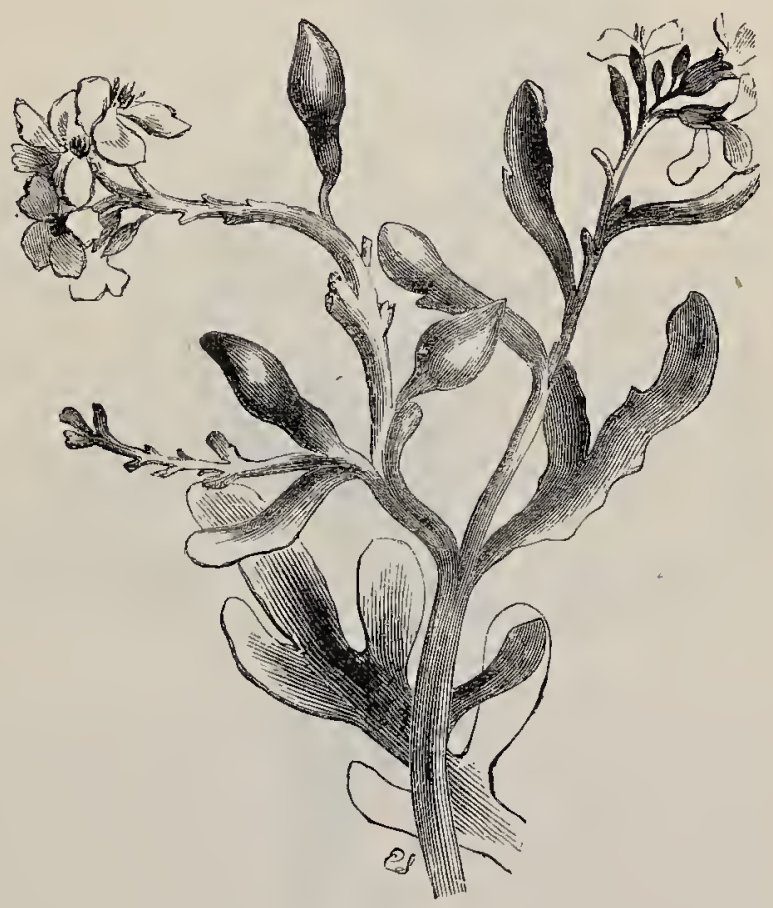

Cakflé Marítma (Purple Sea Rocket).

in a bushy manner, with zig-zag branched stems, bearing fleshy, variously-cut, glaucous leaves, and corymbs of lilac flowers. The seed-vessels are of very curious construction, each containing two seeds, of which the lower is erect, the upper pendent.--Fl. June-September. Annual. 
28. Ráphanos (Radish).--Radical leaves lyrate; flowers in long racemes; petals purple-veined; pod an elongated, inflated, smooth Jomentum with a slender beak. (Name of Greek origin, signifying early appearance or rapid growth.)

1. R. Raphanistrum (Wild Radish, White Char.

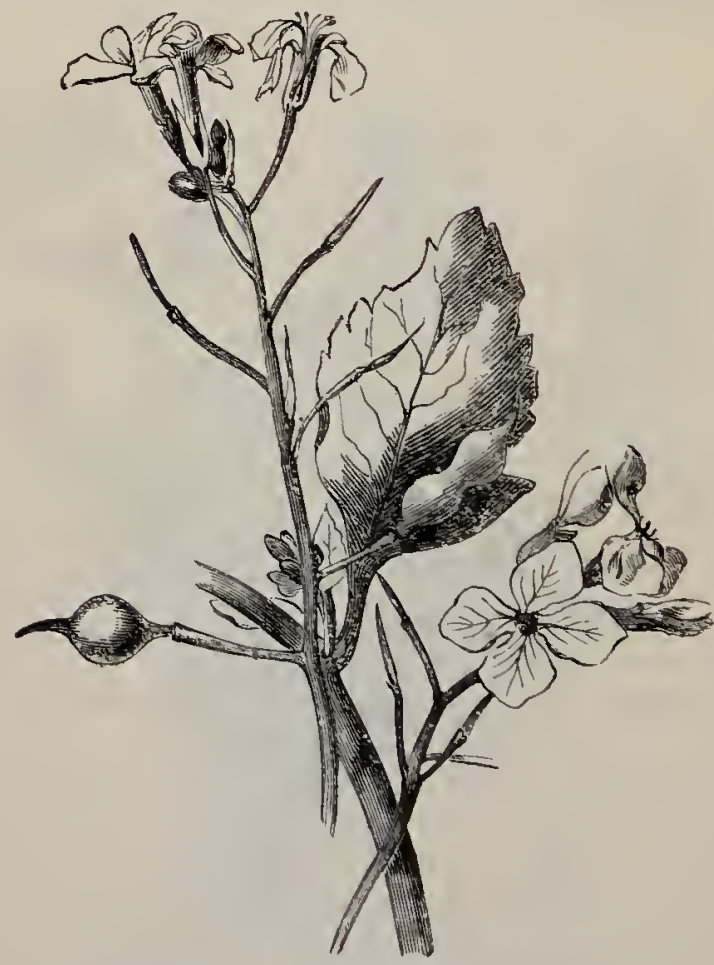

RAPAANUS RAPHANETREM (Wild Radish).

lock).-A bristly or almost prickly plant, 1-2 feet high, with horizontal, Jyrate leaves, and rather large. straw-coloured or white flowers veined with purple; well distinguished when in seed by its long-beaked pods, which have from $3-7$ one-seeded joints. Corn?- 
fields.-Fl. May-September. Annual. This is the original of the garden radish.

2. R. marítimus (Sea Radish).-Leaves composed of small and large segments arranged alternately (interruptedly pinnatifid); flower's smaller, yellow, rarely white; pod with $2-4$ joints, deeply con. stricted.-Sea-cliffs in the south and west; rare.Fl. July, August, Biennial.

\section{Ord. VII.-Resedácele.-Mianonette Family.}

Herbaceous or somewhat shrubby plants, with scattered stipulate leaves, and their flowers in bracteate racemes. Sepals 4-7, persistent; petals 4-7; dist. large, hypogynous ; stamens 10-24, inserted on the disk; ovcry of 3 united carpels, 1-chambered, opening at the summit; stigma 3-lobed, sessile ; seeds many, on 3 parietal placentas ; fruit a capsule. Most members of the Order inhabit Europe and the adjacent parts of Asia and Africa. Reséda odoráta (Mignonette), a native of Egypt, is a favourite garden plant on account of the delicious perfume of its flowers.

1. Rest́da (Mignonette). - Flowers monosymmetric; petals unequal, with a broad claw and ligule, the posterior ones with a multifid limb. (Name from the Latin resedo, I calm, from supposed sedative properties.)

1. R. Rútea (Wild Mignonette).-A bushy plant, 1-2 feet high; leaves 3 -cleft, lower ones pinnatifid; flowers in short, broad, conical racemes, yellowish; sepals 6, linear ; petals 6, very unequal.-On chalky soil.-Fl. June-August. Biennial.

2. R. Lutéola (Weld, Dyer's Rocket, Yellow-weed). -A taller plant than the last, $2-3$ feet high, with long, linear, blunt, undivided, shining leaves; long 
terminal racemes of yellowish flowers; sepals 4.-Waste places, especially on a chalk or limestone soil. It was formerly used to dye wool yellow, or, with

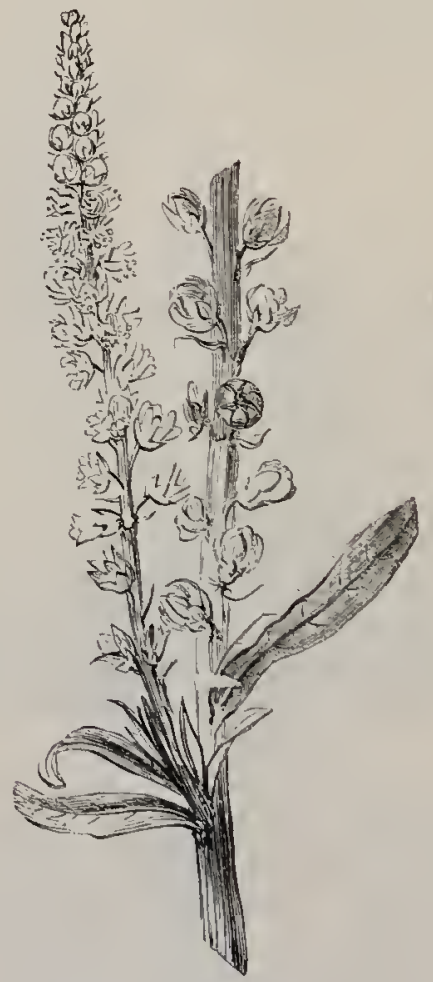

RESĹDA LUTLiols (Dyer's Rocket).

indigo, green.- Fl. June-August. Anmual or biennial.

3.* IR. allue (Shrubby Rocket), with glaucous pinnate leaves, white flowers, and usually 5 sipals, not uncommon in gardens, occurs as an escape.-Fl. June-August. Biennial. 


\section{Ord, ViII. Cistínede-The Rock-Rose Family.}

Mostly shrubby, but sometimes herbaceous plants, often with viscid branches; leaves opposite, entire; flowers conspicuous, polysymmetric, white, yellow, or red, lasting a very short time; sepal; 3 or 5 , unequal, the three inner twisted in the bud; petals 5 , twisted, when in bud, in a direction contrary to the sepals; stamens indefinite; carpels 3, united; ovary 1 . chambered; style single; stigmas 3 ; capsule 3 -valved. The plants of this Order are almost confined to the South of Europe and North of Africa. The only species which possesses any remarkable properties is C'zstus Créticus, which affords the balsam called Gum Ladanum.

1. Helí́nthemum (Rock-Rose). -Sepals 5, the two outer either smaller or wanting; petals 5 ; stamens numerous; ovules many; capsule 3-valved. (Name from the Greek hélios, the sun, and unthos, a Hlower, because the flowers expand in the sunshine.)

1. H. Chamcéstus (Common Rock-Rose).-A beautiful little prostrate undershrub; leaves with fringed stipules, obloug, green above, hoary beneath; flowers in bracteate racemes, 1 inch across, yellow; the two outer sepals very small, the inner apiculate; the stamens, if pinched, spread out, and lie down on the petals.--Dry places ; common._-Fl. July-_September. Perennial.

There are four other British species of Helianthemum, which are all of local occurrence, and rare: H. suttátum (Spotted Rock-Rose), a herbaceous annual, with ebracteate yellow flowers, with a bloodred spot at the base of each petal, found in Corls and the Channel Islands. $I I$. Bréveri, differing from $I I$. guttátum chiefly in having bracts, found in Anglesea. 11. nạ?fólium (Hoary Rock-Rose), a shrubby 
plant with leaves very hoary beneath and exstipulate, and small bracteate yellow flowers, found on limestone rocks in the west. H. polifólium (White Rock-

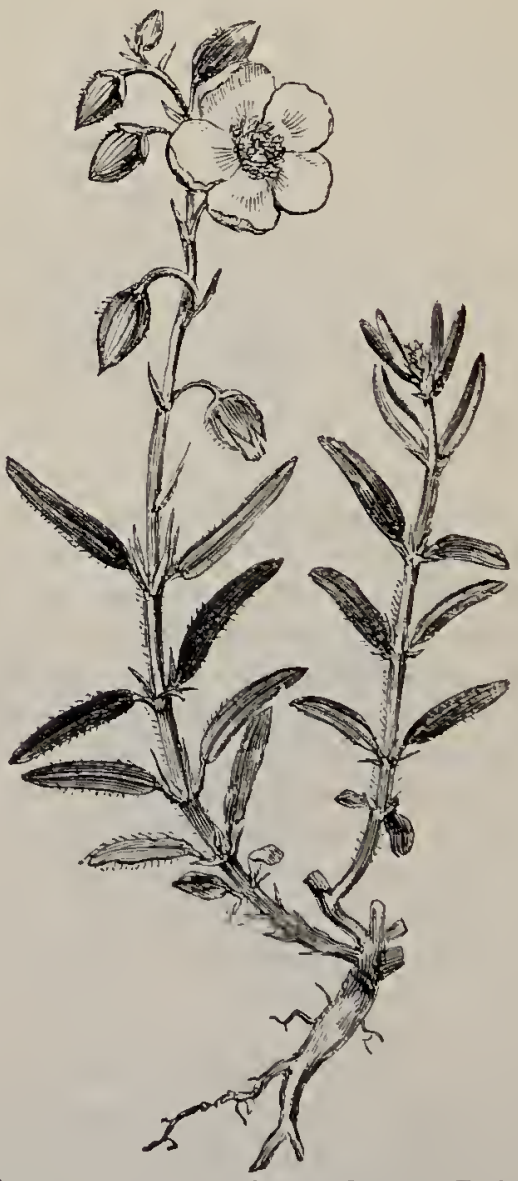

HELIANTHEMUM CHAM.ecfstus (Common Rock-Rose).

Rose), a small shrubby species, with stipulate leaves, hoary on both surfaces and bracteate white flowers, grows on Brean Down, Somerset, and near Tiorquay, 
Or\%. IX.-.-Violácede.--The Vlolet Family.

A beautiful and important Family of herbs or shrubs, inhabiting most regions of the world. Those which grow in temperate regions are mostly herbaceous; but in the tropical regions of South America there are many shrubby species. Leaves scattered, stipulate, simple ; flowers monosymmetric ; sepals 5; petals 5, 1-spurred; stamens 5, with the connective produced beyond the anther-lobes; carpels 3 ; ovary 1-chambered; style swollen above; stigma cup-shaped; ovules many, parietal ; capsule 3-valved. Most of the species possess emetic and laxative properties similar to those of Ipecacuanha.

1. Víoua (Violet).-Sepals 5, auricled at the base; petals 5, the lower one spurred; anthers united into a tube, the two lower ones furnished with nectariferous tail-like appendages, which are enclosed within the spur of the corolla. (Name, the Latin name of some fragrant flower.) Some species have two kinds of flowers, one opening in spring, conspicuous, but yielding little or no seed; the other not opening (cleistogene) and often apetalous, produced, on short peduncles, in autumn, and yielding abundant seed.

* Stipules small: With cleistogene fowers.

1. V. palustris (Marsh Violet).-Rhizome creeping; leaves heart- or kidney-shaped, quite smooth; often purplish beneath; sepals obtuse; petals delicate lilac, with darker veins; spur very short, obtuse.Bogs ; common.-.Fl. April-July. Perennial.

2. $V$. odoráta (Sweet Violet).-CRunners long; leaves heart-shaped, slightly downy, especially beneath; petioles with deflexed hairs; flowers fragrant, deep 
purple, lilac, pale rose-colour, or white; bracts above the middle of the flower-stalks; sepals obtuse; smor nearly straight, short, obtuse, inflated towards the end. One of the most highly prized of all our wild flowers, unrivalled in fragrance, delicacy, and variety

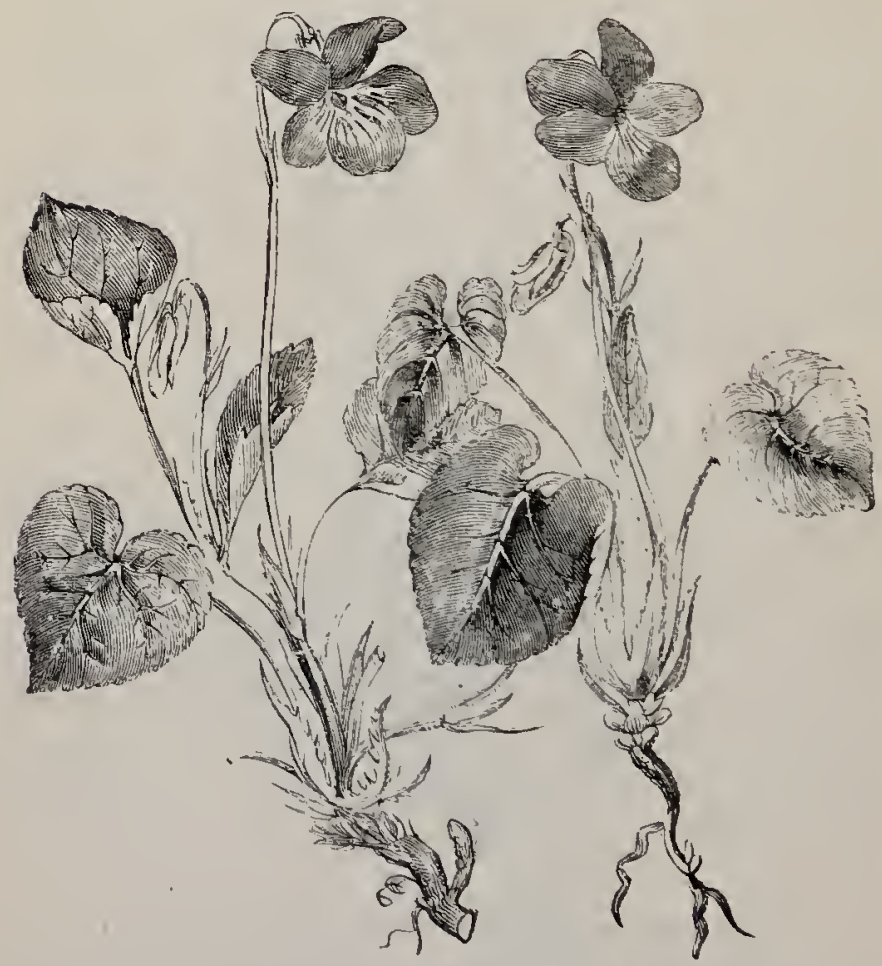

VIOLA ERICETOKRUM, and V. ODORATA.

of tinting, and doubly welcome from its appearing early in spring. The flowers are sometimes used as a laxativo for chilhen, as a sweetmeat, or as a chemical test, being chinged to rell by acids and to groen by alkalies.-Fl. Murch, April. Peremial. 
3. V. hirta (Hairy Violet).-Pubescent, without runners; leaves heart-shaped, rough; petioles with spreading hair's; flowers scentless, pale violet or white; bracts below the middle of the flower-stalks; sepals obtuse ; spur long, compressed, hooked, obtuse. -Common on dry, especially calcareous, soils.-Fl. April-June. Perennial.

4. V. silvéstivis (Pale Wood Violet)...Stem distinct, without rhizome or runners; lewves heart-shaped, lanceolate, nearly glabrous, radical, rosulate; flovering-branches axillary; flowers scentless; sepals acute; auricles minute; petals oblong, narrow, lilac, lower with few paralle], nearly simple, veins at its base; spur blunt, compressed, not furrowed, usually darker than the petal.-Common in copses and hedgerows. -Fl. April, May. Perennial.

5. V. Riviniána (Dark Wood Violet).-Stem distinct, without rhizome or runners; lecues broadly heart-shaped, nearly glabrous, radical, rosulate; flowering-branches axillary; flowers scentless; sepals acute; auricles prominent, notched; petals broadly obovate, blue, lower with many branched dark veins at its base; spur blunt, thick, furrowed, usually yellowishwhite.-More generally distributed than the last, to which it is closelyallied.-F]. April, May. Perennial.

6. V.rupéstris (Hill Violet). - A sinall compact plant, with large flowers, differing from the last mainly in the downiness of the young leaves, flowerstalks, and capsules; is very rare, occurring in upland pastures in Teesdale.-Fl. May, June. Biennial.

7. V. ericetórum (Dog Violet). - Primary and lateral stems lengthening and flowering, but without runners; lecives ovate-coldate, acute; flowers bluislpurple, scentless; sepals acute; spur obtuse, yellow, longer than the auricles of the sepals.-Heaths and sandy places; common. The popular name of this species implies a reproach for its want of perfume:Fl. April, May. Perenniul. 
8. V. láctea, an alliel form, distinguished by its ovate-lanceolate leaves, which are not heart-shaped at the base, its serrate, lanceolate stiputes, and its narrow grey petals, occurs in turfy bogs.

9. $V$. stagnina.- Rhizome slender, with runners; primary and lateral stems flowering and elongating; lea'es ovate-lanceolate, sub-cordate; petioles winged at the top; stipules linear-lanceolate, serrate; petals pale lilac, or white; spur very short, blunt.-Turfbogs ; rare.-Fl. May, June. Perennial.

** Stipules leafy, pimnatifid. No cleistogene flowers.

10. V.tricolor (Pansy, Heartsease).-Stem ascending, angular, branched; Teaves long-stalked, ovateoblong, crenate; stipules large, lyrately pinnatifid; bracts minute, high up on the peduncle; petals spreading, unequal, pale yellow or purple, longer than the sepals.-Cultivated fields, common. The cultivated varieties are countless.-Fl. May-September. Annual.

11. $T$. arvénsis (Field Pansy). - An allied and almost equally common form, differs chiefly in having erect, yellow, or white petals, which are not longer than the sepals. Annual.

12. $V$. Curtisii, a rarer form, has a branched rhizome with rumners, the petals rather longer than the sepals, the upper purple, the lateral ones blue, and the lower yellow. It occurs on sandy shores in the West of England and Treland. Perennial.

13. V. lútea (Yellow Mountain Violet, or Mountain Pansy). - R7izome branched with runners; stem angular, ascending; leaves oblong, crenate; stijules palmately pinnatifid, not lyrate, terminal lobe narrow; petals spreading, longer than the sepals, yellow, purple, or parti-coloured.-Mountain pastures in the north.-Fl. June, July. Perennial. 
Ord. X. Polygalíced.-The Milkwort Family.

Herbs and shrubs with bitter, emetic, and laxative properties. Leaves scattered, exstipulate, simple; flowers in racemes, monosymmetric and of ten showy; sepals 5, unequal, the two inner larger and petaloid; petals $3-5$, more or less united; stamens 8, diadel. phous in two sets of four, epipetalous; anthers 1 chambered, opening by pores at the summit; carpets 2 , united into a 2-chambered ovary; omules one in each chamber; placentation axile; frut a capsule. Several species are said to be valuable medicinally. Polygala Sénega (Snake-root), a North American plant, is reputed to cure snake-bites. Kraméria (Rhatany), obtained from South America, is an astringent, undoubtedly useful in cases of dysentery, and furnishes also a red infusion, used to adulterate port-wine.

1. PolÝgaLA (Milkwort).-The British species are all small herbs. Sepals 5, the two inner coloured, wing-shaped, persistent; petals $3-5$, united, the lower one keel-shaped and crested; capsule compressed, 2-valved; seeds downy, with an aril at the base. (Name from the Greek, signifying much mitk, being supposed to increase the yield in cows.)

1. P. vulgáris (Common Milkwort, Gangweed).Stems prostrate, ascending, leafy; leaves scattered, linear-lanceolate; racemes terminal; bracts 3, at the base of each flower, the central one as long as the pedicel, the lateral ones shorter; flowers blue, pink, or white, $10-20$ in a raceme; veins of wing-sepals branching and reuniting freely, the central vein ending in a mucro or projecting point; no cilia on bracts, sepals, or capsule.-Common on heaths and ảry pastures, especially on chalky soil.-Fl. June-August. Perennial.

2. P. opyptera is a local form with wore prostrate 
and spreading growth, narrower leaves, smaller, more distant, and more deflexed flowers, and narrower wingsepals.

3. P. serpyllácea, a mor'e widely-distributed form, has a slender, wiry, flexuose, prostrate stem; lover leaves opposite; flowers few and small; winy-sepals

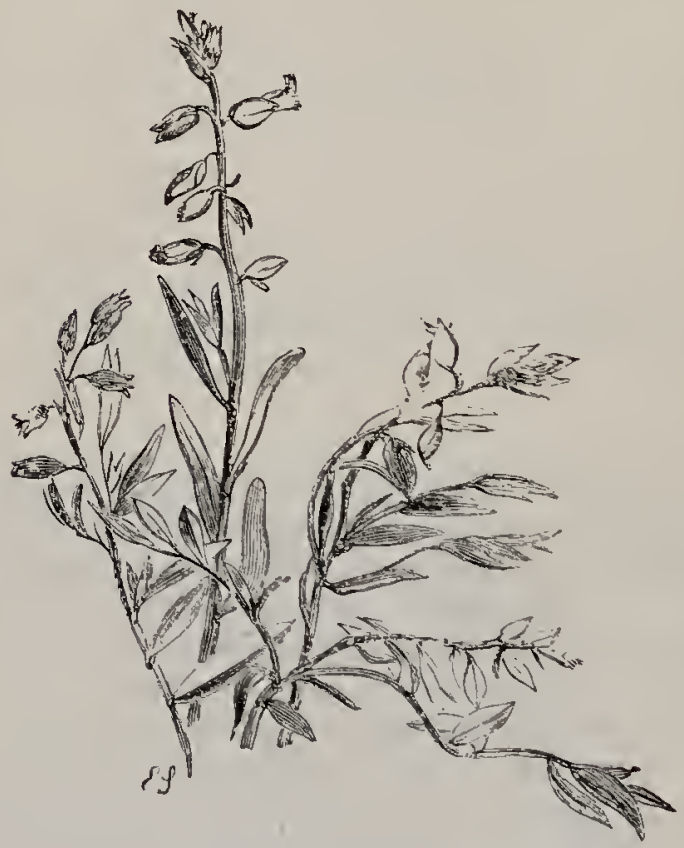

POLYGALA VULGARIS (Common Nilkicort).

broad, with the principal veins with few branches between them.-Common on heaths.

4. P. calcárea (Chalk Milkwort).-Leaves tufted, the lower ones large and fleshy, obovate; flowerinybranches axillary; flowers large; wing-sepals broad, with prominent central vein united nea $0^{\circ}$ its middle with the branched lateral one:--Clialk downs, chiefly in the South-east of Jugland.-Fl. May. Pelennial 
5. P. amára, found in Kent, has also its leaves in a rosette and fleshy; but its flowers are small, distant,

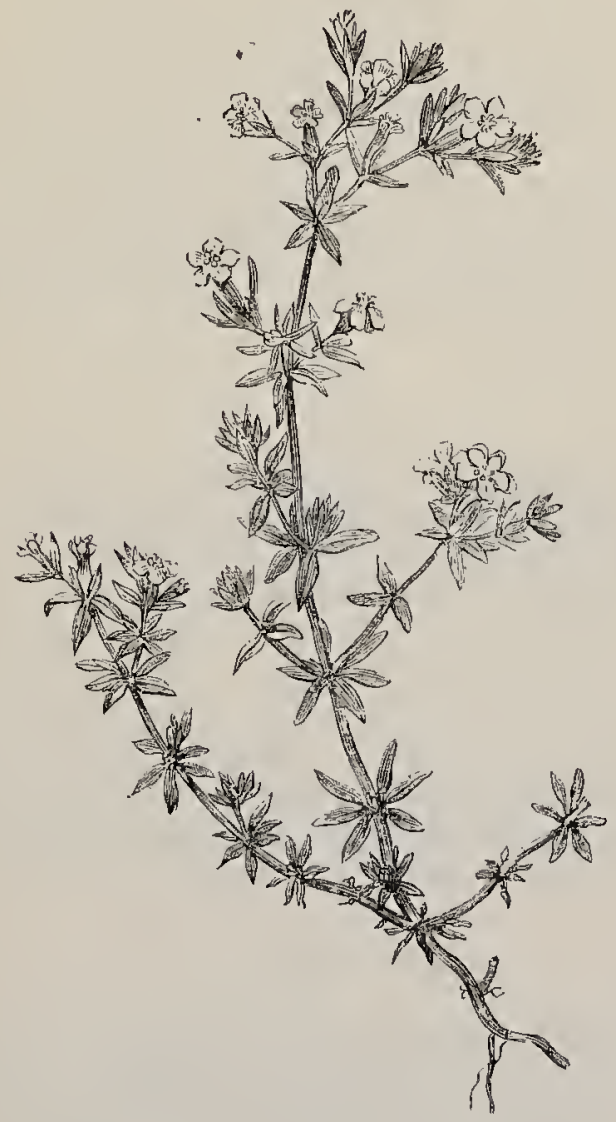

FRANKÉNIA LETIS (Smooth Ser-Meath).

and blue; its wing-sepals narrow, linear-oblong; and it is only two or three inches high.

6. P. austriaca, found in Teesdale, has larger and more compactly grouped pinls flouers. 
Ord, XI. Frankeníacz.e.-The Sea-Heath Family.

Herbaceous or somewhat shrubby plants with branched stems, whorled exstipulate leares with a nuembranous sheathing base, and numerous small axillary polysymmetric flowers. Sepals, peta7s, and stamens 4-6 each, the sepals united and persistent, the petals with claws and ligules; carpets 2-5; oravy 1-clrambered; ovules many, parietal; capsule 2-5. valved. The species of the only genus in the Order inhabit temperate and sub-tropical regions, mostly near the sen.

1. Frantínia (Sea-Heath).-Style divided above into three oblong lobes bearing the stigma. (Name. from John Franken, a Swedish botanist.)

1. $F$. Teevis (Smooth Sea-Heath).-A small procumbent plant, with wiry stems; leaves crowded, narrow, rolled back at the edges, smooth, fringed at the base; flowers rose-coloured.- Salt marshes on the soutl-east coast.--Fl. July, A ugust. Perennial.

Another species, $F$. minerulénta (Powdery SeaIf cath), with obovate leares, pulverulent beneath, formerly grew on the Sussex const, but is now extinct.

\section{Ord. XII. Caryophylláce..-The Pink Fanilx.}

All extensive and well-marked Order of herbaceous plants, chiefly Arctic, Alpine, European, and W. Asiatic. 'The stems, which are sometimes roody below, are generally swollen at the nodes or joints : the lecres always opposite and simple, mol of ten glaucous; the flowers polysymmetric, and frequently large and ornamental, mostly red or white, in 
cymes. Sepals 4-5, distinct, or with a calyx-tube below ; petals 4-5, distinct; stamens 4-10, usuaily twice as many as the petals, hypogynous; carpels 2-5, united into a 1-chambered or imperfectly 2-5-chambered ovary with free-central placentation; styles 2-5; ovules numerous; capsule opening by twice as many teeth or valves as there are styles. Though no members of the Order are put to much us, the Pinks, Carnations, and Sweet Williams are favourite garden flowers; and our hedges are much indebted for their showy appearance in spring to the great White Stitchwort, and in summer to the Red and White Campions. Botanists subdivide this large Order into three sub-orders.

Sub-Order T.-Siténere.-Campion Tr•ibe. Leaves eirstipulate; sepals 5, united into a tube; petals 5, clawed; stamens 10, united at their base and inserted with the petals on the elongated axis below the ovary; styles distinct.

* Two or more imbricate bracteoles below calyx.

1. Dịńnthus.--Styles 2 ; capsule 1-chambered, opening at the top with 4 valves; seeds flattened.

*** Without bracteoles.

*2. Saponária.-. Styles 2 ; cupsule 1-chambered, opening at the top with 4 valves; seeds rounded.

3. Suńné.-Petals generally with a ligule; styles 3 , rarely 5 ; capsule imperfectly 3 -chambered, opening at the top with $3-6$ valves.

4. LÝchnis,-Styles 4-5; capsule 1- or imperfectly 5 -chambered, opening at the top by $4-10$ teeth. 
Sub-Order II.-Alsince.-Chichweed Tribe. Leaves exstipulate; sepals distinct; stamens not united; ovary not stalked; styles distinct.

5. Howósteum.-Sepals 5 ; petals 5, toothed at the margin; stamens $3-5$; styles 3 ; copsule cylindric, opening at the top with 6 teeth, many-seeded.

6. Cerástiur. -Sepals 5; petals 5, usually bifid; stamens 4-10; styles 3, 4, or 5; capsule cylindric, opening at the top with 5-10 teeth, many-seeded.

7. Streluíria. - Sepals 5; petals 5, deeply bifid; stamens usually 10 ; styles $3-5$; capsule globose, opening with $6-10$ valves or teeth, many-seeded.

8. Arenária.-Sepals 5; petals 5, entire or slightly emarginate; stamens 10 , rarely 5 ; styles 3 , rarely 4 ; capsule 3-10-valved.

9. Sagína. - Sepals 4-5; petals 4-5, minute, entire, or absent; stamers 4-10; styles 4-5; capsule 4-5-valved, many-seeded.

Sub-Order III.-Polycárpar.-S'murry Tribe. Leares with membranous stipules; sepuls 5, distinet; petuls 5; stamens 3-10 free; styles 3-5; capsule not stalliced.

10. Spéraula.-Petals entire; stamens 5-10; styles 5 , free ; cansule 5-valved, many-seeded.

11. Búds.-Petals entire; stamens 5-10; styles 3 , rarely 5, free; capssule 3-valved, rarely 5-valved, many-seeded.

12. Potró́rpon.-Sepals keeled at the back, hooded at the end; petals emarginate ; stomens $3-5$; styles 3 , short, united at base: copsule 3 -valved, manyseeded.

1. Dińntuus (Pink). - Herbaceous plants with narrow, grass-like leaves, of ten tufted: flowers solitary or fascicled; caly, tubular, 5-toothed, with bracteoles. below it ; petals $\tilde{5}$, long-clawed, of ten toothed ; stamens 
10, united at the base ; onary 1-chambered; stules 2 ; capsule opening with 4 valves at the top ; seeds flattened. (Name in Greek signifying flower of Jupiter, from its beauty.)

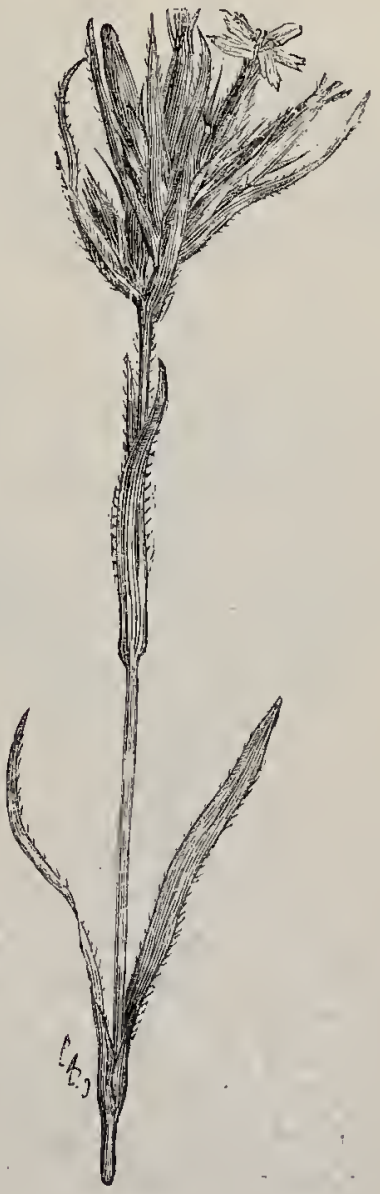

Díntruts armíria (Deptford Pink).

* Fower's fascicled.

1: D. Arméria (Deptford Pink).-Stems few, erect 
1-2 feet high, downy ; leaves linear, downy, lower obtuse, upper acute; bracteoles lanceolate-subulate, downy, as long as the calyx; calyx 1-2 in. long; petals rose-colour dotted with white, toothed. Hedgerows on dry soil; rare.-Fl. July, August. Annual.

2. D. prólifer (Proliferous Pink).-Stems few, erect, about a foot high, smooth; Teaves roughish at the edge; bracteoles brown, membranous, pellucid ; flowers opening one at a time, rose-colour.-Gravelly pastures ; rare.-Fl. June-October. Annual.

\section{* Flowers not fasidicl.}

3. D. deltoídes (Maiden Pink). - A much-branched plant, with stems $6-12$ in. high, roughish ; leates downy, rough ; bracteoles 2 , half as long as the calyx : flowers $\frac{3}{4}$ in. across, rose-coloured, with white spots and a dark ring in the centre, scentless : petals toothed. -Gravelly banks; not common.-Fl. June-September. Perennial.

4. D. cúesirs (Cheddar Pink). - Stems many, 4-10 in. high; leaves glaucous, with rough edges; bracteoles 4, roundish, shortly pointed, one-fourth as long as the calyx; flower solitary, 1 in. across, rosecoloured, scented; petals much cut.-Limestone rocks, Cheddar, Somerset.-Fl. June, July. Perennial.

5.* D. plumarius (Common Pink). - Stem about a foot ligh, $2-5$-flowered; leaves rough at the edge; $b r a c$ teoles roundish-ovate, mucronate, one-fourth as long as the calyx; flower 1 in. across, pale pink, or white, fragrant; caly.r-teeth ciliate, shorter than the capsule; petals downy, cut as far as the middle of the blade.Naturalised on old walls. - The origin of the garden Pinks. - Fl. June-August. Perennial.

6.* D. Caryophyj7lus (Clove Pink, Carnation, or . Clove Gillyflower).-Glabrous and glaucous, branched, $1-2$ feet high; leaves with smooth edges ; flowers $1 \frac{1}{2}$ 
in. across, rose-pink, fragrant; caly. $x$-tecth not ciliate, longer than the capsule; petals glabrous, notched.--

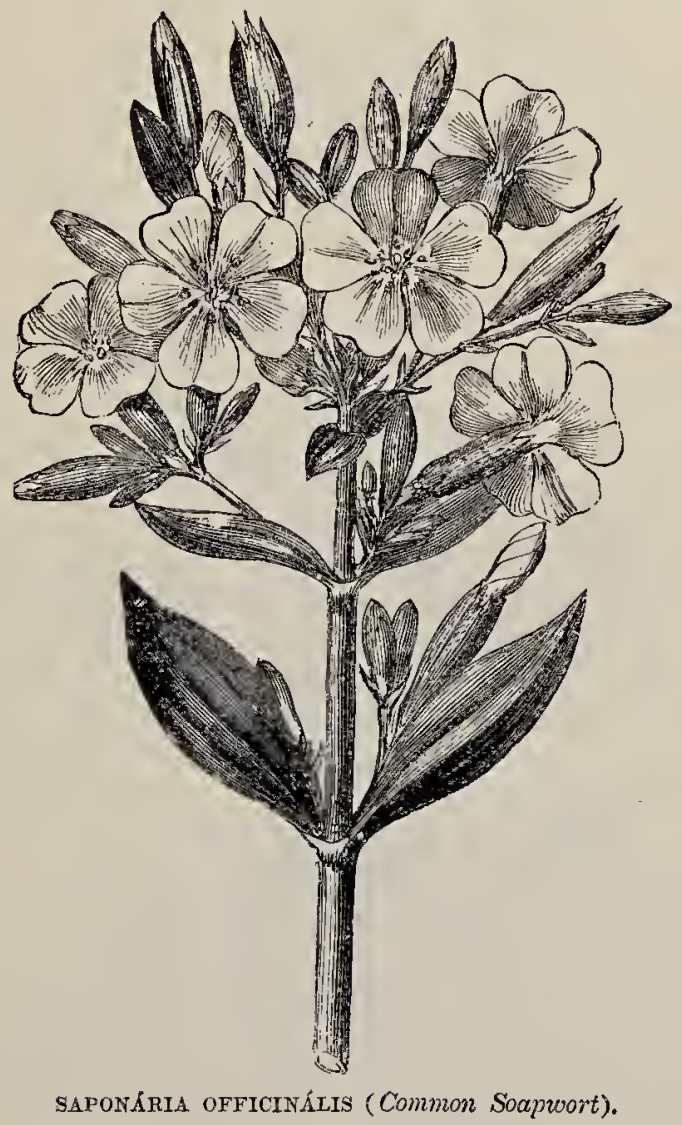

Naturalised on old walls.-The origin of the garden Carnations.-Fl. July, August. Perennial.

*2. Saponária (Soapwort) - Herbs with conspicuous flowers in panicled or fascicled cymes ; calyw 
tubular, ebracteate; capsule 2-chambered at the base, 4-valver at the top; seeds rounded. (Name from the Latin sapo, soap, the plant abounding in a soapy juice.)

1.* S. officinátis (Common Soapwort).-A robust, succulent plant, $2-4$ feet high, with broad, pointed, smooth leaves, and handsome flesh coloured flowers, which are often double.- Irdges near villages; not indigenous.-Fl. August, September. Pereunial.

3. Sintivé (Catchfly).-Herbaceous, often riscid, plants; caly.x ebracteate, inflited, 5-toothed, 10veined: petals 5, with long narrow claws, and usually a double ligule at the base of the blade : styles usually 3 ; capsule usually 3-chambered in its lower half and 6-ralved above. (Name said to be from the Greek sialon, saliva, alluding, as does the English name, to the viscidity of some species. This property protects the honey in the flowers from "umbidden guests," insects that crawl up the stem and would not crosspollinate the flowcrs : but thesc plants are apparently not insectivorons, the captured insects not being $\mathrm{di}$ gested ol absorbed.)

1. S. Curibalus (Bladder Campion, White Bottle). -Geneally glabrous and glaucous : but a downy variety (var. puberula) is occasionally found. Stem erect, from 1 to 2 feet high; leaves oblong, acute ; flowers many, drooping, panicied, scented at night; caly.x inflated, bladder-like, with a network of veins, often tinged with purple: pctals white, deeply cloven, seldom with any ligule. A common weed.-Fl. June -A ugust. Perermial.

2. S.marítima (Sea Campion).-Stems numerous from the same root, prostrate, spreading: leares oblong, acute; flowers few or solitary, larger than those of the last; petals slightly cleft into two broad segments, each with a ligule at the base of the blade. 
Common on the sea-shore, less so by mountain streams. - Fl. all the summer. Perennial.

3.* S. Arméria, with a viscid stem, stnooth leaves, a many-flowered corymbose cyme, and notched white petals with ligules, occurs as a casual, but is not indigenous.-Fil. July. Annual.

4. S. cónica (Striated Corn Catchfly).-Stem erect, forked, hairy, 6-12 in. high ; leaves narrow, downy;

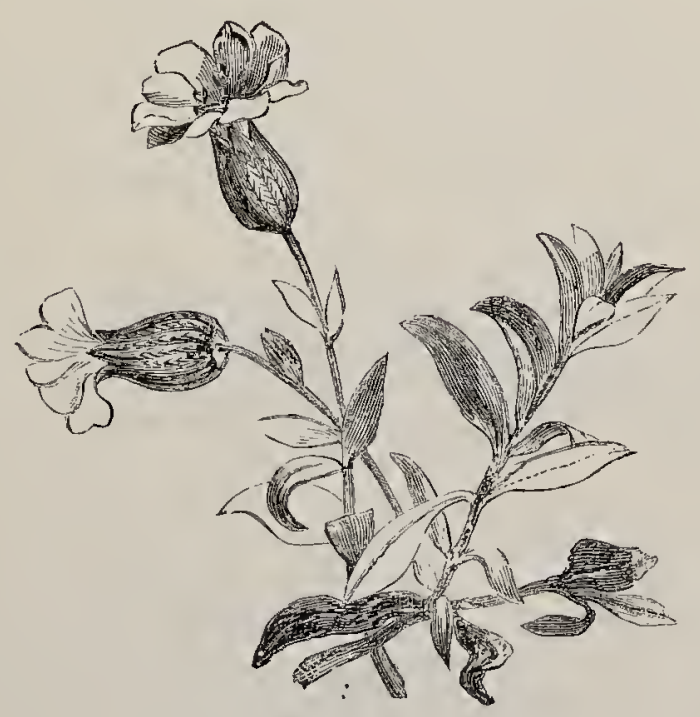

SILENE MARÍtma (Sea Campion).

flowers small, numerous, erect; caly $x$ conical, with 30 furrows; petals rosy, cleft, with ligules._Sandy fields; very rare.-Fl. May-July. Annual.

5. S. anglica (English Catchfly). - Hairy and viscid, 6-12 in. or more high; stem erect or branched; leaves narrow : flowers small, in lenfy raccmose cymes; caly.x with green pubescent ribs and bristle-like teeth; petals white or pink, bifid, with 
ligules ; capsules drooping.--Gravelly fields; not uncommon.-F]. all the summer. Annual.

6. S. quinquevertnera, found chiefly in the Channel Islands, differs in its petals, which are white, with a red spot on each (whence the specific name meaning "Five Wounds"), and are not cleft.

7. S. acaútis (Moss Campion).-Densely tuf ted, bright-green, moss-like; stem much branched; leaves narrow, friuged at the base; flowers piak or white, short-stalked, solitary, erect, $\frac{1}{2}$ in. across ; caly, $x$ tubular, smooth, with 10 veins; petats slightly notched with notched ligules.-Confined to the summits of our loftiest mountains, where it forms a matted turf gay with blossoms.-FI. June-August. Perennial.

8. S. Otites (Spanish Catchfly).-Stem erect, atout a foot high, viscid, with whorled branches; Teaves few, narrow ; flowers small, erect, yellowish; petals narrow, not notched, without ligules; stamens and carpets generally on separate plants. - Sandy fields in the East of England.-Fl. June-August. Perennial.

9. S. mítans (Nottingham Catchfly).-Pubescent and viscid, about $1 \frac{1}{2}$ feet high; branches opposite, 3 -forked; flowers large, white ol pink, all drooping one way, most expanded and fragrant in the evening ; calye tubular, swollen in the middle; petals deeply cleft, with ligules.-On limestone rocks and castlewalls ; not common.--Fl. May-July. Perennial.

10* S. itática (Italian Catchfly), a tall, viscid, pubescent species, with trichotomous erect panicles, bifid petals without ligules, and a long stalk to the capsule, occur's as a casual in Kent.

11. S. noctiflóra (Night-flowering Catchfly).Softly pubescent and viscid, about a foot high ; stem erect, repeatedly forked ; flowers erect, reddish-white, rather large ; caly $x$ witl 10 green hairy ribs; petals deeply notched, unrolliug about sunset, and closing early in the morning, very fragrant during the night. 
-Sandy and giavelly fielis ; not common.-Fl. July, August. Annual.

4. LÝchnss (Campion).-Herbaceous plants differing in no invariable characters from Siléné; but generally with 5 styles and 5 or 10 teeth to the capsule. (Name from the Greek luchnos, a lamp, probably from the orange flowers of some specics.)

1. L. alba (Evening Campion).-Hairy, 1-3 feet high ; leaves ovate-lanceolate ; flowers in loose dichasial cymes, 1 in. across, white, or rarely reddish, fragrant in the evening, diœcious ; caly,r greenish, inflated, teeth long; petals deeply bifid, with ligules; capsule conical, 10-toothed, the teeth erect.-Fields and hedgerows; common.-Fl. all the summer. Biennial or perennial.

2. L. dioíca (Red Campion).-A closely-allied species, differing chiefly in its reddish calyx with shorter teeth, petals red, rarely white, and sub-globose copsule with recurved teeth.-Copses and hedgebanks ; common.-Fl. May-July. Perennial.

3. L. Flos-cúculi (Ragged Robin).-A pretty and well-known marsh plant, with a reddish-green angular stem, 1-2 feet high, the lower part of which is roughish, with short stiff deflexed hairs, the upper part slightly viscid; leaves very narrow; flowers loosely dichasial, rose-coloured, or very rarely white; caly.x tubular, 10-ribbed, with red veins ; petcls deeply cut into linear diverging segments ; capsule 5 -toothed. - Fl. in May and Tune, when the cuckoo is in full song, whence its specific name. Perennial.

4. L. Viscária (Red German Catchfly).-Stem simple, about a foot high, viscid at the nodes ; leaves lanceolate, sub-glabrous; flowers few, large, rose-red; petals slightly notched; capsule distinctly stalked, 5-toothed, 5-ehambered when young.-Dry rocks in North Wales and Scotland; very rare.-Fl. June-Augrist, Perennial. 
5. L. alpina (Red Alpine Campion). -A small, tufted, glabrous species with red flowers, confined to the summits of northern-mountains.

6. L. Githágo (Corn-Cockle).-Downy with dense

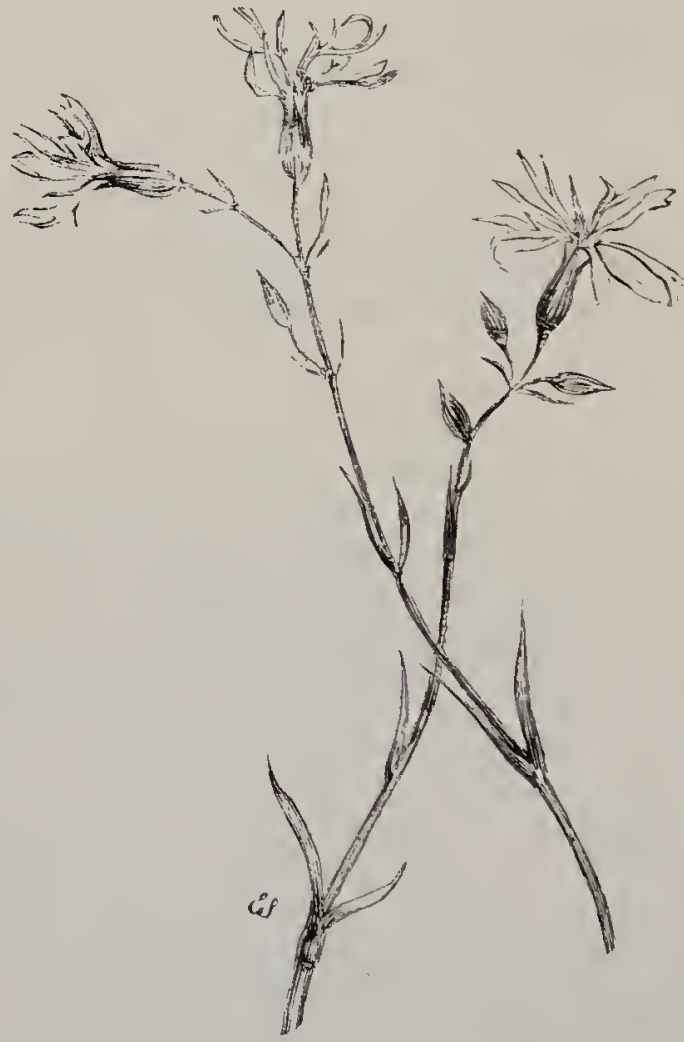

LFCHAS FLOS-CÉCULI (Ragged Robin).

white hairs; stem erect, 2-3 feet high; Teares narrow; flowers solitary, $1 \frac{1}{2}-2$ in. across; caly.x woolly, ribbed, with leafy teeth much longer than the corollat petuls bluish-pink, obovate, undivided, with- 
out lirules; capsule 5-toothed.-A handsome cornfield weed, the large seeds of which are rather diff-

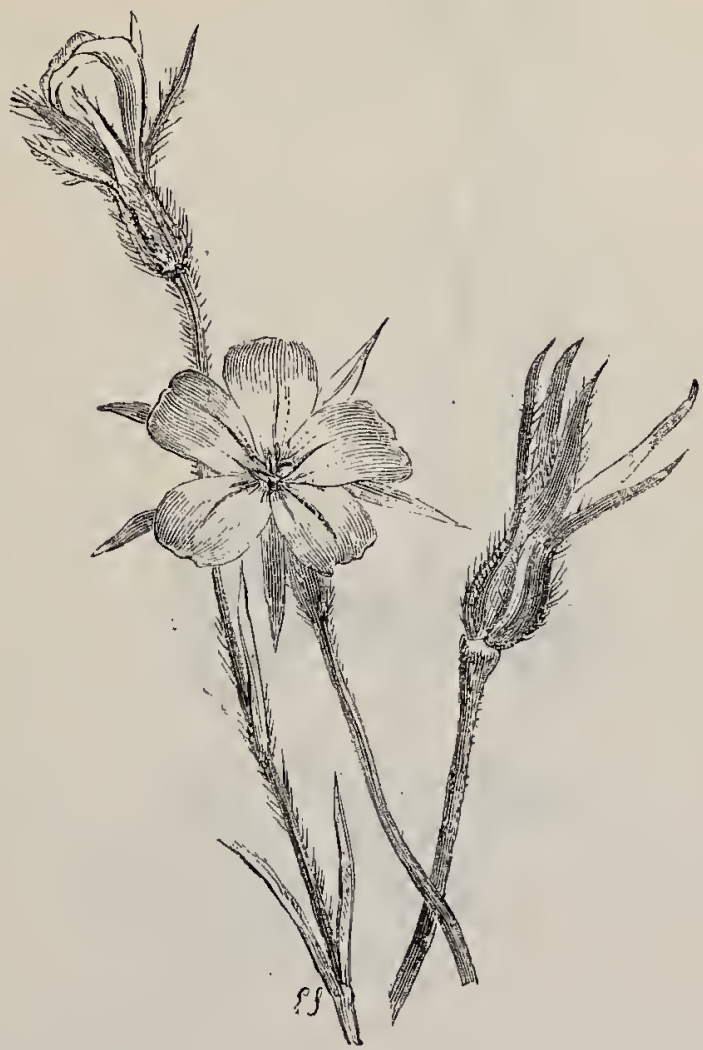

IÝCHNIS GITHAGO (Com-Cockle).

cult to separate from corn; less common than formerly.-Fl. June-August. Annual.

5. Holósteum (Jagged Chickweed). -- Annual, viscid herbs with flowers in umbellate cymes; sepals 5 , putals 5, toothed; stamens $3-5$, rurely 10 ; styles 
3 rarely 4 or 5 ; capsule cylindric, 6 -, or rarely 8- or 10 -

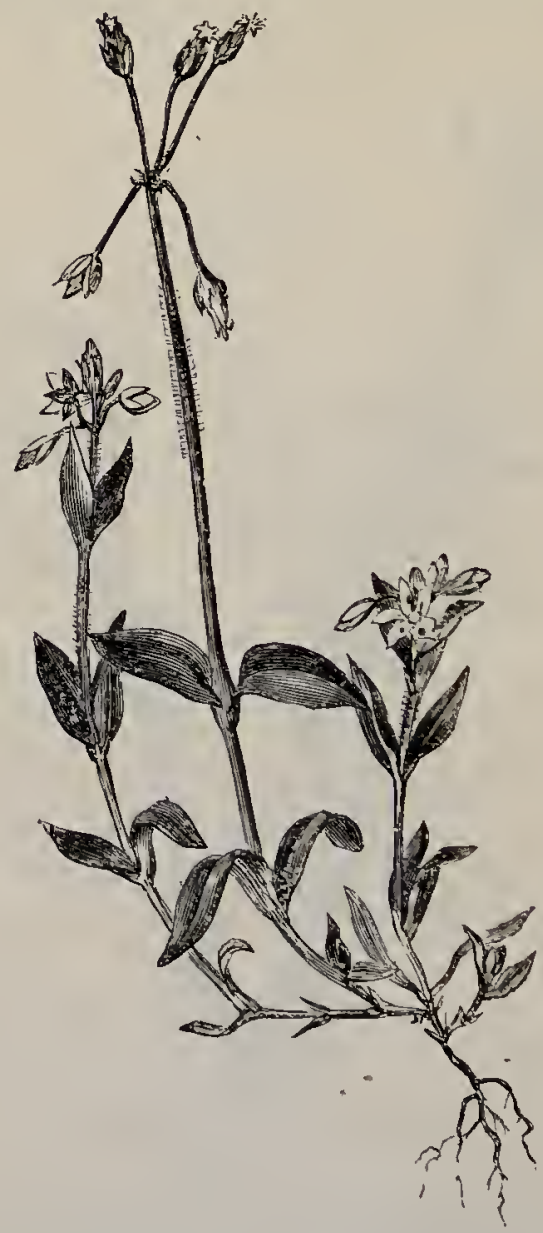

HOLósteum UMBELLATUM (Umbelliferons Jagged Chichaeed).

toothed, many-seeded. (Name in Greek signifying all bone, of uncertain application.)

1. H. umbellátum (Umbelliferous Jagged Chick- 
weed).-The only British species, 4-5 in. high; stems smooth below, hairy and viscid above; 7eaves ovate; flowers in terminal umbellate cymes about 5 together, their pedicels bending downward after flowering and rising again in fruit; sepals white with membranous edges; petals white or pale pink, a little longer... Old walls in Norfolk and Suffolk; very rare. -Fl. A pril. Annual.

6. Cerástium (Mouse-ear Chickweed). - Pubescent, or rarely glabrous, herbs, with white flowers in terminal dichasial cymes; sepals 5 , rarely 4 ; petals as many, rarely absent, generally bifid; stamens 10 , sometimes 5 or 4 ; styles usually 3 or 5 ; ovules many; capsules cylindric, often incurved, usually 6 - or 10 toothed. (Name from the Greek keras, a horn, from the shape of the capsule in some species.)

* Sepals longer than the petals : petals not notched.

1. C. quateméeltum (Upright Mœnchia)._Glabrous, glaucous, erect, $2-6$ in. high; leaves linear, acute, rigid; flowers few, relatively large, opening only in sunshine; sepals 4, acute, with broad white membranous margins; petals, stamens, and styles 4 each; capsule 8-toothed.-Dry places.-Fl. May, June. Annual.

** Sepals as long as the petals: petals bifid.

t Capsules nearly straight. Annual.

2. C. tetrándrum (Four-stamened Mouse-ear Chickweed).-Hairy and viscid, 4-12 in. high; stem forking from the base; leaves oval or oblong; bracts broad, oval, leafy ; flovers $\frac{1}{4}$ in. across ; sepals acuminate with narrow membranous margins; pecticel 2 or 
3 times as long as the capsule.-Dry places near the sea.-Fl. April-October. Annual.

3. C. púmituin (Dwarf Mouse-ear Chickweed).Viscid; stem branched at the root; leaves spathulate; flowers in terminal forked cymes; upper. bracts and sepals with narrow membranous margins; pedicel

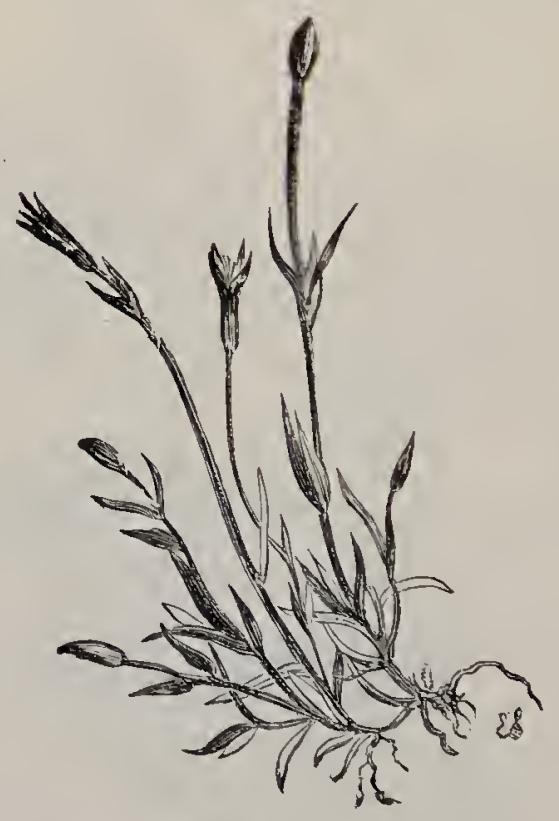

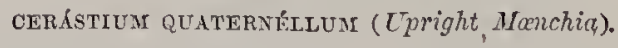

short, curved in fruit; capsule slightly curved.-Dry banks in the south; rare.-Fl. April, May. Annual.

4. C. semidecandrum (Five-stamened Mouse-ear Chickweed).- Downy, sometimes viscid; stem erect or decumbent, 1-10 in. high, branched from the base; leaves broally ovate; bracts with their upper half membranous; sepals with broad membranous margins; stamens 4,5 , or 10 ; pecticel at first reflexed, 
afterwards erect.-Dry places; common.--Fl. April, May. Annual.

\section{† Capsutes curved.}

5. C. glomerátum (Clustered Mouse-ear Chickweed).-Stem erect, hairy; leaves ovate; flowers in

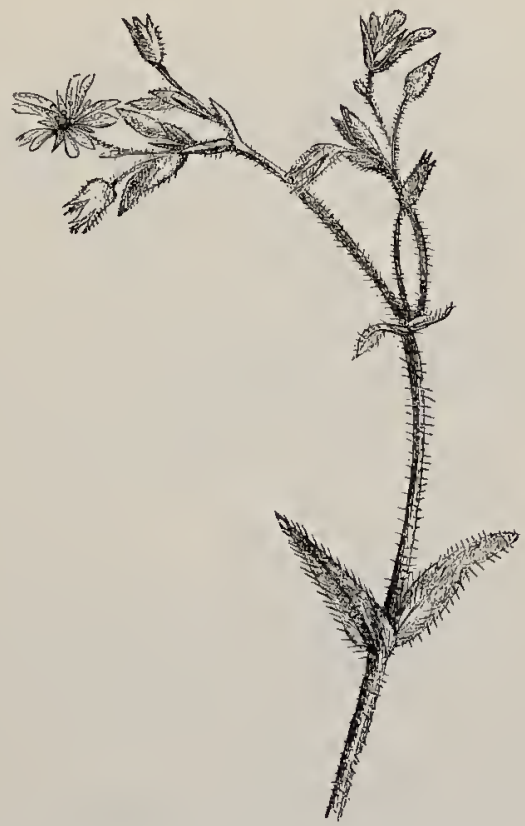

CERASTIUM TRIVIALÉ (Wayside Mouse-ear Chickweed).

tufted cymes, short-stalked; bracts leafy, hairy ; sepals with narrow membranous margins, hairy.-Dry places ; common.-Fl. April-_September. Annual.

6. C. triviálé (Wayside Mouse-ear Chickweed).Stems mostly procumbent, downy, or with lines of pubescence; leaves oblong-lanceolate; flowers few, in 
loose cymes, on lengthening stalks; secondary bracts: sometimes with membranous margins; sepals obtuse, with broad membranous margins; stamens 5 or 10 . A common weed, with inconspicuous white flowers and straggling stems, generally covered with dust. The seed-vessels, when ripening, lengthen and curve. -FJ. all the summer. Biennial or perennial.

*** Sepals half as long as the petals. Perennial.

7. C. alpinum (Alpine Mouse-ear Chickweed).-. Pubescent with white silky hairs; stem prostrate or ascending; leaves broadly ovate; flowers few, sometimes an inch across; bracts and sepals obtuse, with narrow membranous margins. Alpine rocks in the north.-Fl. June-A ugust. Perennial.

8. C. areticum (Arctic Mouse-ear Chickweed).Pubescent with short yellowish hairs ; stem prostrate, tufted; flowers usually solitary; sepals with broad membranous margins. Otherwise resembling $C$. alp $\mathbf{\varepsilon}-$ num.-Mountains of Wales and Scotland; rare.-Fl. May-August. Perennial.

9. C. arvénsé (Field Mouse-ear Chickweed).-Hairy, prostrate, ascending; branches $6-10$ in. high ; leaves linear-lanceolate; flowers numerous, in forked cymes; bracts and sepals acute, with membranous margins.-Dry fields; not common.-Fl. April-Angust. Perennial.

10. C. trigymum (Alpine Stitchwort). - Stem 4-8 in. long, slender, decumbent, much branched below, with a line of pubescence shifting from side to side at each node; leaves small, narrow, oblong, glabrous ; flowers $\frac{1}{2} \mathrm{in}$. across, on very slender stalks, 1-3 in a cyme.-By Scotch Highland streams; rare. -Fl. July, August. Perennial.

7. Steldíria (Stitchwort). - Slender, usually 
glabrous herbs, with leaves grass-like or short and broad; flowers white, in dichasial cymes; sepals and petals 5 each, rarely 4 , the latter bifid; stamens 10 , rarely 8 ; styles 3 , rarely 5 ; ovules many; capsule 6-, rarely 5-valved. (Name from the Latin stella, a star, from its star-like blossoms.)

\section{* Sepals not united: styles 5 : capsule with 5 bifid valves.}

1. S. aquática (Great Chickweed). - A muchbranched, straggling plant; stem angular, brittle, 1-3 feet long, covered with glandular hairs; leaves ovatecordate, acute, ciliate, the lower ones stalked ; flowers solitary in the angles of the stems.- Wet places, but not general.-Fl. July, August. Perennial.

\section{* Sepals not united: styles 3 : capsule with 6 entire valves.}

2. S. némorum (Wood Stitchwort).-Resembling the last in habit, but sometimes glabrous; leaves rough on the upper surface; flowers $\frac{1}{2}-\frac{3}{4}$ in. across, on very slender stalks in a loose much-branched cyme; sepals with narrow membranous margins.-Damp woods, chiefly in the north.-Fl. May-August. Perennial.

3. S. média (Chickweed).--Prostrate or ascending, varying considerably in size; stem with a line of hairs alternating from side to side; leaves glabrous, succulent, ovate, shortly pointed, the lower ones with ciliate stalks; flowers small, axillary; sepals hairy, with a narrow membranous margin, as long as the petals; petals deeply 2-cleft, or absent; stcmens 3, 5, or 10.-Waste plaees and as a weed in gardens ; abundant.-Fl. all the year round. Annual.

4. S. umỏrósa (Perennial Chickweed).-A more erect, slender, glabrous form, with ovate-acuminate leaves and glabrous sepals. - Shady places; not common. Perennial. 
5. S. Holóstea (Greater Stitchwort, Satin-flower, or Adder's-meat).-Stem 1-2 feet high, nearly erect, 4-angled, rough-edged, brittle at the nodes; leaves sessile, narrow, tapering to a long point, ciliate;

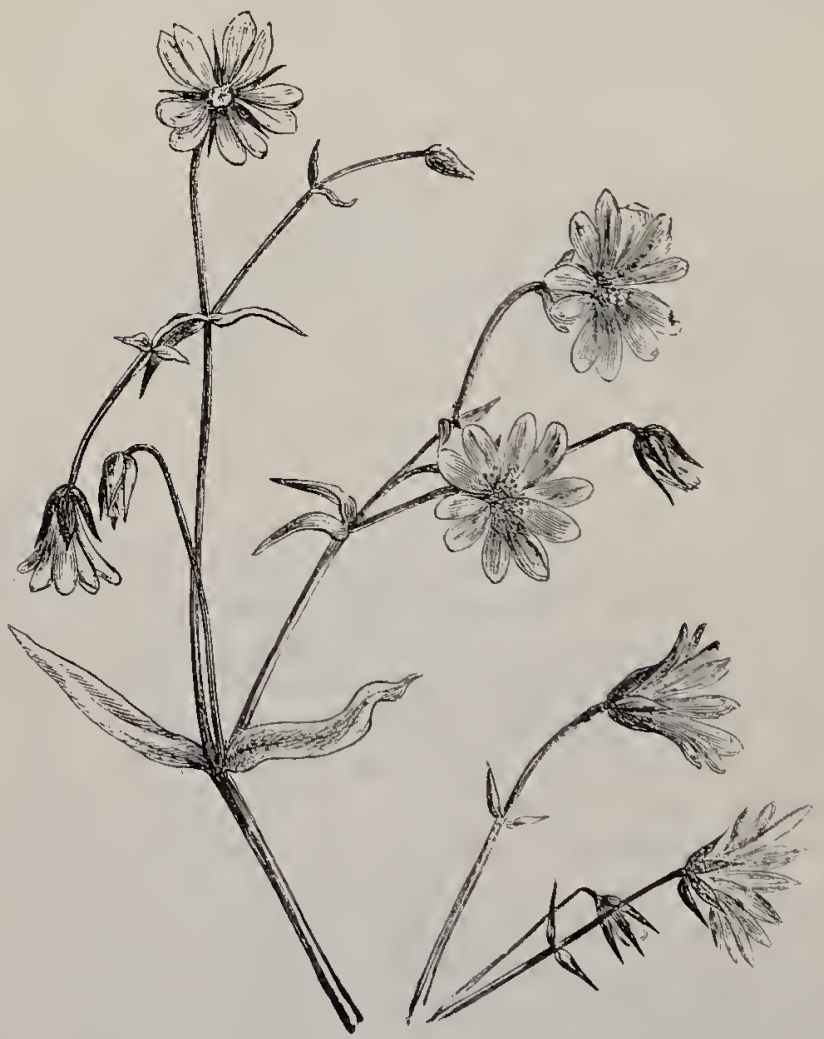

STELLARIA HOLÓSTEA (Greater Stitchwort).

flowers few, $\frac{3}{4} \mathrm{in}$ across, in leafy dichasial cymes, with slender'stalks ; petals deeply 2-cleft.-Among the most ornamental of our spring flowers, scarcely less conspicuous with its delicate green leaves than its 
snow-white petals. The stems do not die down to the ground in the winter, as is the case with most herbaceous perennials, but though dead to all appearance, they send out delicate green tufts very early in the year, so that the flowering stems, especially in bushy places, seem to have made an unusually rapid growth. -Fl. April_June. Perennial.

****** Sepals united in a conicul tube: styles 3 : capsule 6-valued.

6. S. palústris (Glaucous Marsh Stitchwort).Glabrous, glaucous ; stem slender, erect, 4-angled, 612 in. high; leaves sessile, narrow, tapering, entire; flowers few, in a loose cyme, $\frac{1}{2}-\frac{3}{4}$ in. across ; bracts and sepals with membranous margins; petals very deeply 2-cleft, much longer than the 3-veined sepals. - Marshy places; not common.-Fl. May-August. Perennial.

7. S.graminea (Lesser Stitchwort).-Glabrous, not glaucous; stem straggling, 1-3 feet high, 4-angled; leaves sessile, very narrow, acute, ciliate; flowers smaller than in the last two species, in loose cymes; bracts membranous; petals very deeply cleft, scarcely longer than the 3-veined sepals.-Dry heathy places; common.-Fl. May-August. Perennial.

8. S. uliginósa (Bog Stitchwort).-Slender, straggling or erect, $3-18$ in. high ; stem 4-angled, glabrous; leaves broadly lanceolate, with a stiff tip, smooth, sometimes ciliate; flowers few, $\frac{1}{4}$ in. across, in loose cymes; petals deeply 2-cleft, shorter than the 3 -veined sepals.-Boggy places; common.-Fl. May, June. Perennial.

8. Arenária (Sandwort).-Small herbs often tufted, with white flowers in dichasial cymes; sepals 5 ; petals 5 , entire or slightly notched, rarely absent; 
disk annular or glandular ; stamens 10 , rarely 5 ; styles 3 -4 ; capsule short, with $3-4$ valves, which may be bifid. (Name from the Latin arenc, sand, many species growing in sand.)

* Leaves aul-shaped: disk annula $:$ capsule with 3-4 entire valves: seeds numerous.

1. A. vérna (Vernal Sandwort). - A small tufted plant; leaves subulate, acute, 3-veined; flowers nearly solitary, comparatively large, $\frac{1}{3}$ in. acioss, on slender stalks; petals longer than the sepals.-Rocky places in mountainous districts; rare.-Fl. May-September. Perennial.

2. A. sulcáta (Alpine Sandwort).-Smaller in all its parts, more yellow-green and less compact in growth, with blunt leaves, and petals shorter than the sepals, is very rare, being confined to the summits of some of the Scotch mountains.-Fl. July, August. Perennial.

3. A. uliginósu (Bog Sandwort). - A loosely-tufted form with ascending stems, veinless leaves and flowers 1-3 together, on slender stalks. - Grows by a stream in Teesdale.-Fl. June, July. Perennial.

4. A. tenuifólic (Fine-leaved Sandwort). - An erect, slender plant, 4-6 in. high; stem much forked; leaves acute, 3-5-veined; flowers small, numerous, in the forks of the stem; petals shorter than the sepals.-Dry places, chiefly in the eastern counties; rare.-Fl. May-August. Annual.

* Leaves broad: dist annular : capsule with 3 tifid valves : seeds numerous.

5. A.trinérvia (Three-veined Sandwort). - A weak, straggling, downy plant, about a foot long, approaching the Chickweed (Stellária média) in habit, but at 
once distinguishable by its undivided petals; leaves ovate, acute, 3-5-veined, ciliate, the lower ones stalked; flowers solitary, from the forks of the stem and axils, on long slender stalks; sepals longer than the petals, 3-veined, the central vein hairy.-Damp shady places; common.-Fl. May, June. Annual.

6. A. serpyllifólia (Thyme-leaved Sandwort).-A

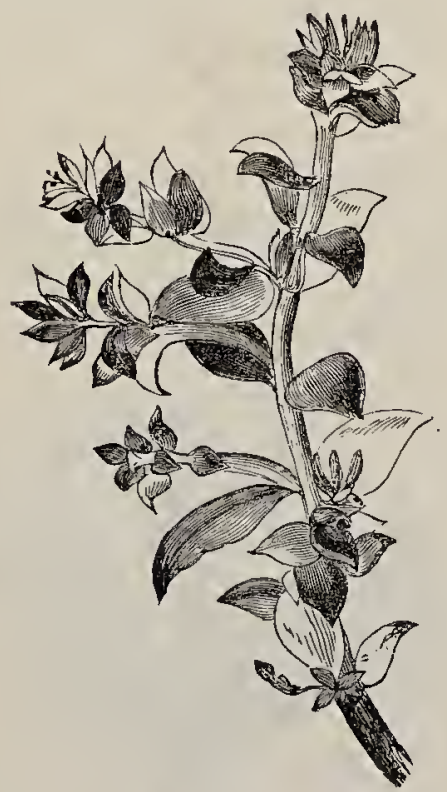

arendria peplö̈des (Sea Purslane).

repeatedly-forked, sub-erect, grey-green, downy plant, $3-6$ in. higl, with recurved hairs; leaves ovate, acute, roughish; sessile, 1-3-veined; flowers inconspicuous; sepals acute, with 3 hairy veins.-Dry places; common.-Fl. June-August. Annual.

7. A. ciliáta (Fringed Sandwort) is a small, matted, prostrate, downy species, with spathulate ciliate leaves and large nearly solitary flowers, growing on lime- 
stone mountains in co. Sligo.--Fl. June, July Perennial.

8. A. norvégica (Norwegian Sandwort).-Differs mainly in being more succulent, and nearly glabrous, its leaves not being ciliate. It occurs in the Orkney and Shetland Islands.--Fl. July, August. Perennial.

9. A. góthica (Gothland Sandwort), more tufted, less succulent, more downy, with leaves ciliate at the base with curved hairs, is closely allied.-On limestone in West Yorkshire.-Fl. Jun --September. Annual (?).

******* Flowers polygamous: dist of 5 or 10 interstaminal glands: capsule 3-valied: seeds few.

10. A. peplóäles (Sea Purslane).-A low, succu-

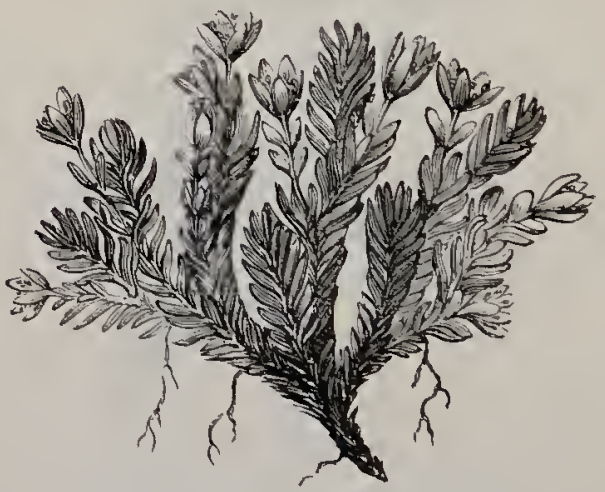

ARENÁRIA SEDOIIIDES (MTossy Cyphel).

lent, dark-green, glabrous, marine plant; rhizome creeping; hranches ascending, forked, $4-8$ in. high; leaves decussate, ovate, acute, sessile, recurved; flowers small, in the forks of the stem, often diccious; sepals obtuse, with membranous margins; capsule large, globose, fleshy; seeds 1-2, large.-Forming 
tangled masses on sandy sea-shores. - Fl. MaySeptember. Perennial.

11. A. sedóides (Mossy Cyphel), -A denselytufted, yellow-green prostrate plant forming cushions 6-12 in. across, with a long tap-root; leaves crowded, narrow, ciliate; flowers solitary, greenish, being generally apetalous and diøcious; capsule and seeds small. -Summits of Scottish mountains.--Fl. June-August. Perennial.

9. Sacíra (Pearl-wort).-Very small tufted plants with awl-shaped leaves united at their bases; small stalked tetramerous or pentamerous flowers; petals shorter than the sepals, sometimes minute or absent; ovules many. (Naine in Latin signifying fatteniny meat, totally inapplicable to these minute plants.)

* Sepals, stamens, styles, and values of capsules 4 : petals minute or absent.

1. S. maritima (Sea Pearl-wort).-A creeping, ascending, glabrous plant; stem slender and forked, with long internodes, brittle, often reddish; leaves fleshy, blunt or apiculate; pedicels erect; sepals broad, blunt, with incurved tips, sub-erect in fruit.-Sea-shores ; common.-Fl. May - September. Annual.

2. S. apétala (Annual Pearl-wort).--Branches slight, hairy, ascending; leaves linear, awned, ciliate at the base; pedicels erect; sepals blunt, spreading in fruit in the form of a cross. -Dry places.-Fl. May-September. Aunual.

3. S. cilicita (Ciliate Pearl-wort). - Nearly glabrous, prostrate; leaves linear, awned, ciliate; sepals adpressed to the ripe capsule.-Heaths and dry places._Fl. May, June. Annual.

4. S. procúmbens (Procumbent Pearl-wort). -Glabrous, prostrate; branches spreading from a central 
rosette; leaves usually fascicled, linear, awned; pedicels curved downwards after flowering, but afterwards erect; sepals sometimes 5, spreading in fruit.Well known to gardeners as a troublesome and prolific weed in gravel paths.-Fl. all the summer. Perennial.

5. S. Bóydii (Braemar Pearl-wort).-Glabrous, densely tufted, forming cushions; intemodes very short; leaves recurved; peduncles short, erect; sepals 4 or 5, always erect; petals absent; capsule globose.

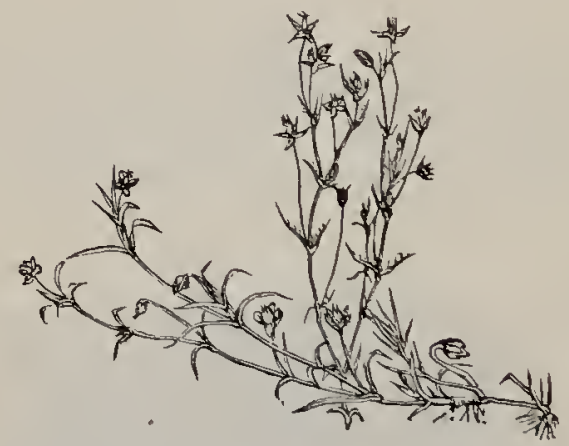

SAGINA PROCÓMBENS, and S. APÉTALA.

-A very distinct form, found in Braemar. Perennial.

** Sepals, petals, styles, and valves of capsules usually 5 : stamens 10 : petals at least half as long as sepals.

6. S. Limnái (Alpine Pearl-wort) distinguished from S. procúmbens by its longer petals, 10 stamens and sepals adpressed to the capsule.-Highland mountains; rare.-Fl. June-August. Perennial.

7. S. nivális (Snow Pearl-wort). - Glabrous, densely tufted; leaves acuminate; pedicels always erect ; petals smaller than in $S$. Linncei.-Highland mountains; very rare.-Fl. June-August. Perennial. 
8. S. subuláta (Awl-shaped Pearl-wort).--Glandular-hairy, tufted; leaves linear, awned, ciliate ; pedicels curved after flowering. Closely allied to S. Limnéi.

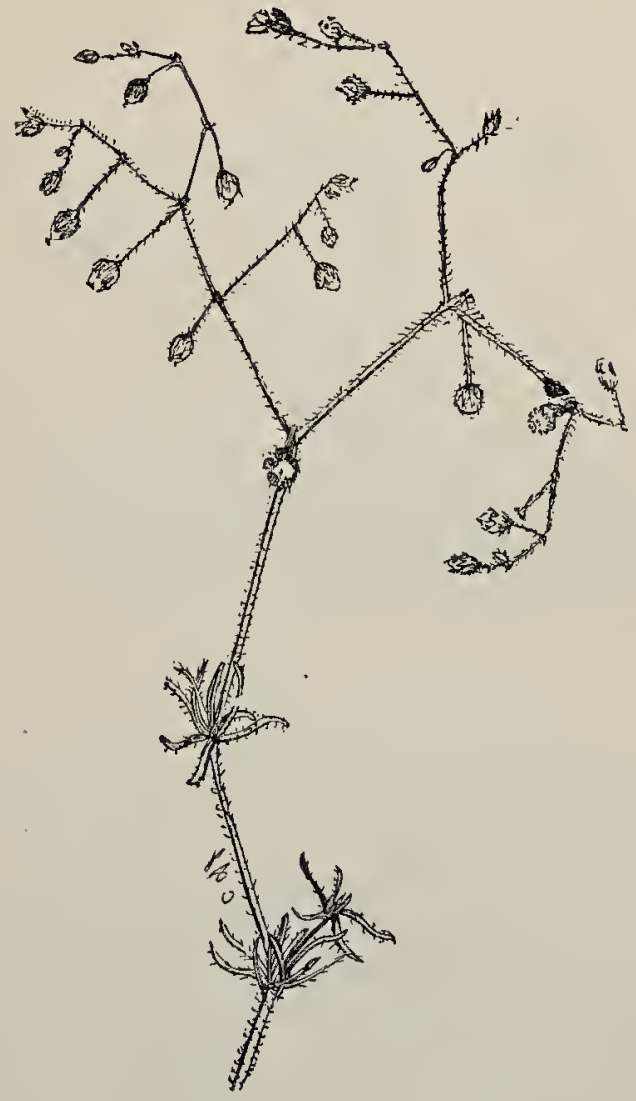

SPÉRGULA ARVÉNSIS (COM-Spurrey).

—Dry places ; frequent.-Fl. June-August. Perennial.

9. S. nodósa (Knotted Spurrey).-The largest and largest-flowered species, $3-4$ in. high, glabrous 
or glandular-hairy; upper leaves tufted; peduncles axillary, always erect, 1-2-flowered; flowers $\frac{1}{4}$ in. across; petals much longer than the sepals.-Wet sandy places; common.-Fl. July, August. Perennial.

10. Spéraula (Spurrey).-Annual herbs with forked branches; whorled leaves with small membranous stipules; flowers in panicled cymes, pentamerous; petals entire; seeds numerous. (Name from the Latin spargo, I scatter, from scattering its seeds.)

1. S. arvénsis (Corn Spurrey).-More or less pubescent and viscid; stem 6-18 in. high, with many knee-like bends; leaves cylindrical, rather fleshy; flowers white, $\frac{x}{4}$ in. across, on slender stalks which bend down in fruit.-A common weed in sandy cornfields, and occasionally cultivated.-Fl. JuneAugust. Annual.

11. BÚDA (Sandwort-Spurrey).-Prostrate plants, differing chiefly from Spérgula in liaving only three valves to their capsules, and generally three styles. (Name of unknown etymology.)

1. B. ॠúc (Field Sandwort-Spurey).-A small, branching, pubescent plant; leaves linear, flat, pointed; stipules united, lanceolate, silvery, tom; flowers rosy, $\frac{1}{4}$ in. across.-Common in sandy places.-Fl. June - September. Annual.

2. B. marina (Seaside Sañdwort-Spurrey).-A nearly allied, glandular-pubescent for'm; leaves fleshy, blunt; stipules broadly triangular, usually entire; fowers pink with a white base; petals shorter than the sepals; stamens less than 10.--Near the sea.-Fl. June-September. Annual.

3. B. média (Perennial Sandwort-Spurrey).-A 
nearly allied, but glabrous, larger, and stouter form; flowers $\frac{1}{2}$ in. across; petals lilac or white, as long as the sepals; stamens 10.-Muddy salt-marshes.-Fl. June-September. Perennial.

4. B. mpéstris (Rock Sandwort-Spurrey).-A nearly allied, but glandular-pubescent form, with leaves fascicled and pointed, which occurs rarely on rocks near the sea.-Fi June-September. Perennial.

12. Polyoúrpon (All-seed).-Annual herbs with flat leaves; membranous stipules; minute flowers in crowded, bracteate cymes; sepals keeled; petals emarginate; stamens 3-5; styles 3 ; ovules many. (Name from the Greek polús, many, kárpos, fruit.)

1. P. tetraphyillum (Four-leaved All-seed).-A small prostrate branched plant; lower leceves in whorls of 4 , upper opposite; flowers many, minute, greenishwhite; stamens 3.-On the south-west coast ; rare.Fl. June, July. Annual.

\section{Ord. XiII. Portulácee.-The Pursuaje Family.}

Smooth, succulent herbs or shrubs with simple, entire leaves; and monosymmetric flowers opening only during sunshine. Sepals 2, united at the base; petals usually 5 ; stamens $3-5$; carpets 3 , united into a 1 chambered ovary, with a style usually 3 -fid, few ovules and basal placentation. The capsules open either transversely or by 3 valves. Many species have large showy flower's; but those of the British representatives of the Order are small and white. The common Purslane (Portuláca olerácea) has been cultivated in warm countries as a pot-herb from very early times, and occurs as a weed at Richmond, Surrey. 
*1. Claytónia.-Petals free; stamens 5.

2. Móntia. - Petals united at the base; stamens 3.

*1. Crartónia. - Naturalised North American plants with stalked raclical leaves, exstipulate; flowers in terminal cymes; sepals 2, united at the base, persistent; petals 5, not united; stamens 5, epipetalous ; capsule 3-valved, 3-seeded. (Named in honour of John Clayton, an early collector in Virginia.)

1.* C. sibírica.-Often a foot high; radical leaves

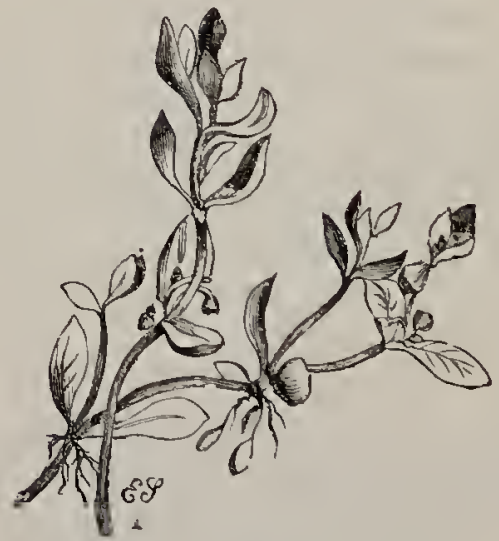

MÓNTIA FONTÁNA (Water Blinis).

ovate, acuminate; cautine leaves opposite, sessile; petals bifid.-A garden escape.-Fl. A pril-July. Annual.

2.* $C$. perfoliáta, 4-12 in. high; radical leaves rhomboid, fleshy; cantine leaves connate; petals nearly or quite entire.-A garden escape.-Fl. April-July. Annual.

2. Móntia (Blinks).-A small annual herb; leaves opposite, or nearly so; flowers solitary or in few- 
flowered cymes ; sepals 2 , united at the base, persistent; corolla of 5 united petals, 3 smaller than the rest, tube split to the base in front; stamens 3 , inserted in the throat of the corolla; stigmas 3 , capsule 3 valved, 3-seeded. (Named in honour of J. de Monti, an Italian botanist.)

1. M. fontána (Water Blinks).-The only species, an unpretending little plant, tufted and pale green, with spathulate entire leaves, well marked by the above characters and common in wet places.-Fl. May-August. Annual.

Ord. XIV. Tamariscing.t. - -The Tamarisk Family.

Shrubs with whip-like branches, minute scale-like leaves, and lateral spikes of small flowers; sepals 5, rarely 4 , imbricate, persistent; petals 5 , rarely 4; imbricate; stamens 4-10, with versatile anthers; capsule 3-5-valved, 1-chambered; seeds many, tufted with down at the extremity. They are found only in the eastern half of the northern hemisphere, and are most numerous on the shores of the Mediterranean; but though preferring the seaside, they are not unfrequently found on the banks of rivers, and occur, also, in the desert, especially where the soil is impregnated with salt, as in the neighbourhood of Mount Sinai, where a species of Tamarisk, very like the common one, produces a sugary substance called Manna by the Arabs. The bark is astringent, and several species are remarkable for the large quantity of sulphate of soda contained in their ashes, and for the galls which they bear on their branches. These are highly astringent, and are used both in medicine and in dyeing.

*1. TámarIX.—Styles 3-4, spreading; stigmas feathery ; seeds basal. (Name from Tamaris, a river in Spain, now the Tambra, where Tamarisk abounds.) 
1.* T. gállica (Common Tamarisk).-A handsome evergreen shrub or small tree, with long flexible

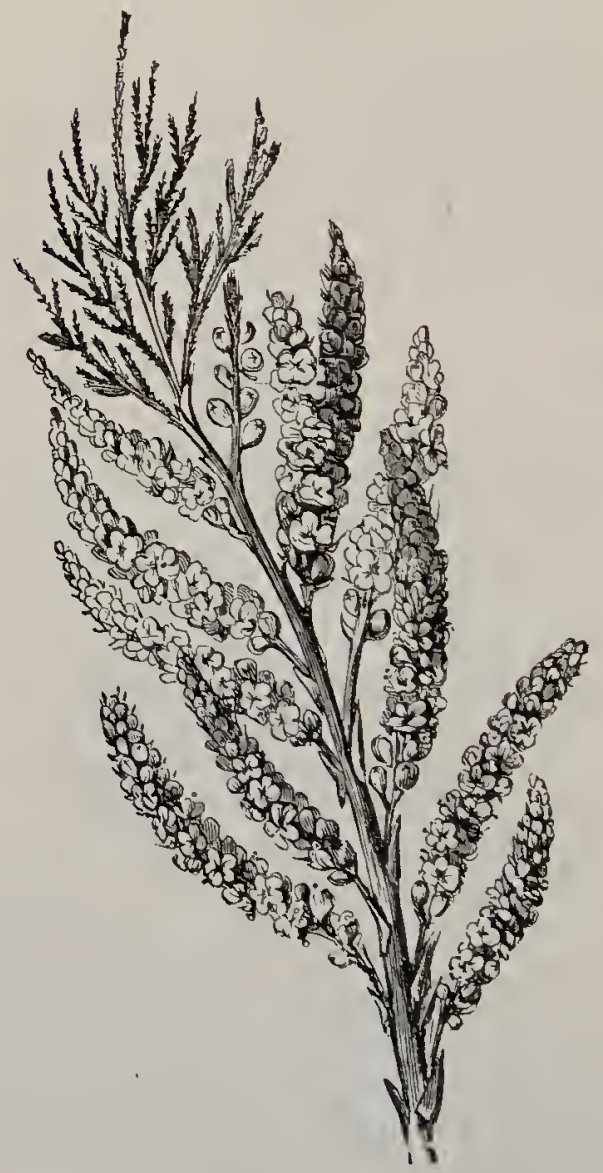

TAMARIX GÁLLIOA (Common Tamarisk).

reddish branches, and closely adpressed scale-like leares which give the tree a light feathery appearance. The flowers are rose-colour.--Though extensively planted 
on the south and east coasts, this shrub is not indigenous.-Fl. July-September.

Ord. XV. Elatíne艮.-The Waterwort Family.

Mostly minute aquatic annual herbs, with prostrate stems, rooting at their nodes; and opposite, stipulate leaves; sepals, petals, and carpels $2-5$, each; sepals free or united; stamens equalling, or twice as many as, the petals; ovary syncarpous, 2-5-chambered,

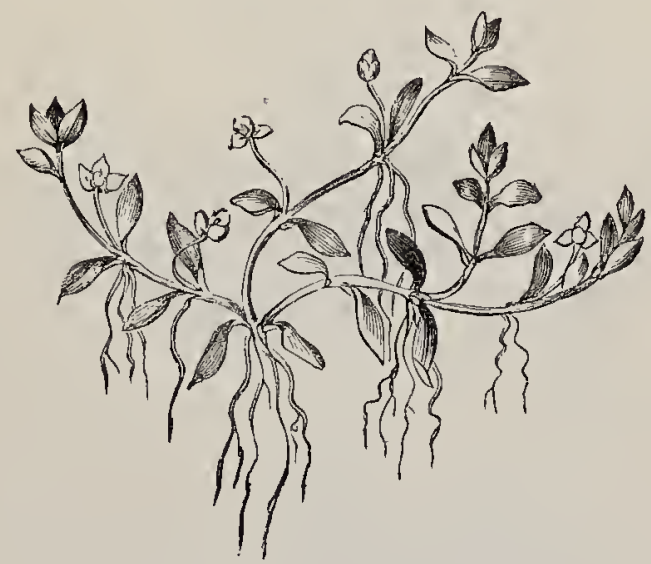

ELATINÉ HEXÁNDRA (Six-stamened Waterwort).

with as many styles and valves to the ripe capsule; seeds wrinkled, numerous; placentation axile. These plants are found in most parts of the world.

1. Elatíné (Waterwort).-Very small glabrous plants; leaves spathulate; flowers minute, axillary; seeds cylindric, furrowed, and transversely striated. (Name of Greek origin.)

1. E. hexándra (Six-stamened Waterwort).-A minute plant, forming turfy beds on the margin of 
lakes, or entirely submersed. When left by the subsiding water it assumes a bright red hue. Flowers inconspicuous, stalked, 3-merous; stamers 6. Rare. -Fl. July-_September. Annual.

2. E. Hydropiper (Eight-stamened Waterwort, Water Pepper).--Differing in having sessile, 4-merous flowers ; stamens 8. Growing in similar situations to the preceding, but even rarer.-Fl. July, August, Annual.

\section{Ord. XVI. HypericíNeE.-THE St. JoHN's.wort Fanily.}

Herbs, shrubs, or trees, with opposite, exstipulate, simple leaves, generally dotted with pellucid glands, and conspicuous yellow polysymmetric flowers, generally in cymes; sepals 5, rarely 4, imbricate; petals of the same number as the sepal:, twisted when in bud; stamens 3 or 5 , much branched near the base and known as polyadelphous; carpels 3-5, syncarpous; styles 3-5; firit a capsule or nuculane, $3-5$-chambered and valved, the valves curved inwards; seeds numerous, minute. Mlost of the species are aromatic and resinous, and some contain a yellow juice, which has purgative, astringent, and tonic properties. They occur in most parts of the world, the only British genus being that which gives the Order its name, Hypéricum.

1. HypírIoun (St. John's-wort).-Leaves sessile; Howers in cymes; sepals 5 ; petals 5 , usually very oblique; stamens 3 or 5 , much branched; styles 3 , rarely 5; fruit 3 or 5 -chambered. (Name from the Greek hupereition, Pliny also using hypericum, though usage lias made it hypéricum.) 
* Shrubs : sepals unequal: petals deciduous: stamens 5 , branched at the base.

1. H. Androsćmum (Tutsan).-A handsome, shrubby, glabrous plant, 2-3 feet high; stem compressed; leaves large, ovate, with a strong resinous

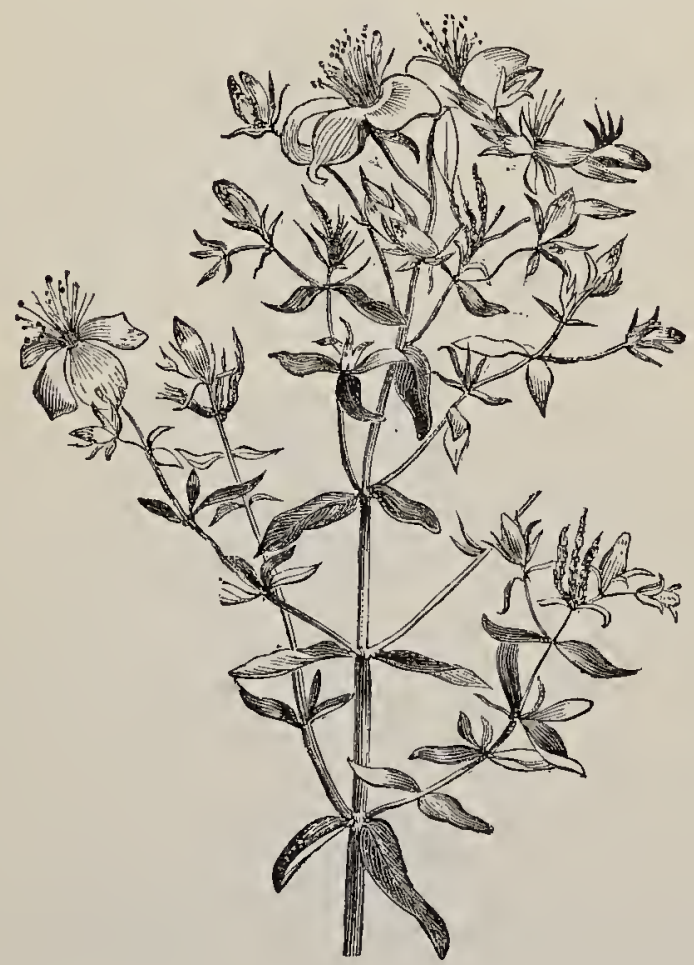

HYPÉRICUM PERFORATUM (Perforated St. John's-wort).

smell, which they retain for some time after drying; flowers $\frac{3}{4}$ in. across, in conspicuous cymes; petals very oblique; styles 3 , recurved ; fruit glossy, black, berry-like.-Woods and hedges; not common, except in Devon and Cornwall._-Fl. Jume-August. Perennial. 
2.* H. hircinum, a taller, more-branched shrub, with flowers $1_{2}^{1}$ in. across and narrow, acute, deciduous sepals, occurs in shrubberies, but is not indigenous.-Fl. July_September. Perennial.

3.* H. elátum, a closely allied species with a 2edged stem and winged pedunele, occurs under similar circumstances.

4.* H. calyénum (Large-flowered St. John's-wort, Park-leaves).-A low glabrous shrub, about a foot high; stem square; leaves $2-4$ in. long; oblong, blunt, leathery; flowers solitary, terminal, 3--4 in. across, very handsome; styles 5.-Common in gardens and shrubberies, and naturalised in sereral places.Fl. July-September. Perennial.

*** Herbs : sepals united, not fringed: petals persistent: stamens 3, branched at the base: styles 3 .

5. H. perforátum (Common St. John's-wort). Stem erect, 2 feet high, 2-edged; leaves elliptic-oblong, copiously dotted with pellucid glands, veins opaque; sepals erect, lanceolate, acute.-Woods and hedges; common. This plant and its congeners derive their popular name from coming into flower about the feast of St. John Baptist(O.S.) -Fl. July-_-September. Perennial.

6. H. dúbium (Imperforate St. Jolnn's-wort). - Very like the last, but with stem 4-sided, with 4 elevated lines; leaves with pellucid veins, but few glands; sepals reflexed, ovate, blunt, with black glands on the back.-Moist places; not common.-Fl. July, August. Perennial.

7. H. quadrátum (Square-stalked St. John's-wort). -An allied species with 4-winged, branched stem; leaves with many pellucid glands and veins; and sepals erect, lanceolate, acuminate.-Wet places; common. -Fl. July, August. Perennial.

8. H. undulátum (Wavy St. John's-wort). - 
Another closely-allied form, with a 4-edged stem; leaves with wavy edges, many pellucid glands and veins; black glands on the edges of the stem, the under surface of the leaves, and the sepals; flowers in loose cymes; and sepals erect, ovate-lanceolate, acuminate.-In bogs in Devon and Cornwall; rare.Fl. July. Perennial.

9. H. humifúsum (Trailing St. John's-wort).-A prostrate, glabrous species ; stems spreading, slender, 2-edged, 3-9 in. long; leaves oblong, obtuse, with minute pellucid glands and black glands under their revolute margins; sepals unequal; stamens 5-7branched.-Walls and gravelly banks; common.-Fl. July, August. Perennial.

\section{*** Herbs: sepals fringed with glands; stamens 3, branched: styles 3 .}

10. H. linarifolium (Narrow-leaved St. John'swort).-Stem erect, terete, 6-12 in. high; leaves linear, blunt, revolute; sepals lanceolate, acute, with glandular teeth and black glands below ; stamens about 10-branched.-Devon, Cornwall, and Jersey; very rare.-Fl. July, August. Perennial.

11. H. púlchrum (Small Upright St. John's-wort).A slender, glabrous plant; sten erect, round, 12-18 in. high; leaves cordate-amplexicaul, with pellucid glands; flower-bucls stajned with red; sepals obtuse, fringed with sessile glands; petals fringed with glands. -Heaths and woods; common.-Fl. July, August. Perennial.

12. H. hirsútum (Hairy St. John's-wort). -Stem erect, round, hairy, about two feet high ; leaves slightly stalked, pubescent, with pellucid glands; sepals narrow, acute, fringed with stalked glands.-Woods, especially on calcareous soil-Fl. July, August. Perennial. 
13. II. montánzm (Mountain St. John's-wort). A similar plant, but glabrous, with sessile leaves, with black glands on their margins. - Limestone hills; not common.-Fl. July, August. Perennial.

14. H. elódes (Marsh St. John's-wort).--A shaggy plant; stems creeping, ascending; leaves roundish, densely clothed in shaggy down; flowers few, pale yellow; sepals fringed with red-stalked glands.Spongy bogs; common.-Fl.July, August. Perennial.

\section{Ord. XVII. Malvácem.-The Mallow Famili.}

A large and important family of herbaceous plants, shrubs, and trees, with scattered, stipulate leaves, which are palmately veined and lobed. The flowers are polysymmetric and generally conspicuous, and are in most cases furnished with an epicaly.x or involucel of bracts; sepals 5 , more or less united at the base, valvate in bud; petals 5 , twisted in bud ; stamens originally 5, but much branched and carried up on a tube, so as to appear indefinite and monadelphous; carpels many in a whorl, generally united, each 1. seeded; styles as many as the carpels, distinct or united; frit a regma. There are about a thousand species in the Order, mostly natives of tropical regions, where they form a large proportion of the vegetation, the number of species gradually decreasing towards the poles. They all agree in containing a large quantily of mucilage, and being totally destitute of unwholesome qualities. In some species, this mucilage, extracted by boiling the plant, especially the root, is employed medicinally in allaying irritation, both external and internal, as, for instance, in the manufacture of guimauve lozenges. The inner bark of several tropical species is used as a substitute for hemp; but the less strong, though most valuable of all textile substances, cotton, consists of the long 
unicellular hairs on the seeds of various species of the genus Gossǵpium, which belongs to this Order. The Hollyhock (Althéc rósea), several species of Iribiscus, Málopé, and other genera, are favourite ornamental garden flowers.

1. Alth危a. Epicalyw of $6-9$ connate bracts.

2. Lavatríra. Epicalyx of 3 connate bracts.

3. Málva. Epicalyx of 3 distinct bracts.

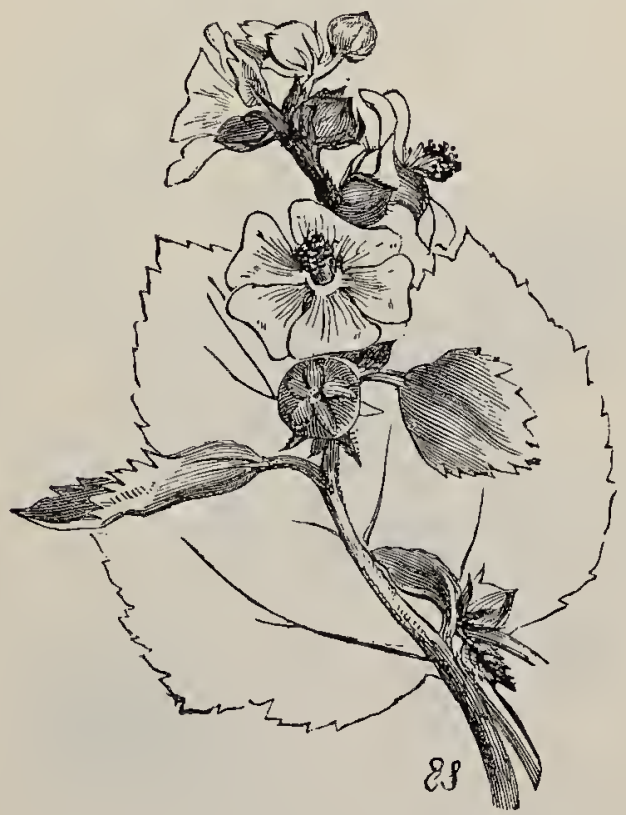

AITHÁA OFFICTNÁLIS (Common Marsh Mallow).

1. Aцтнев (Marsh Mallow).-Hairy herbs, with lobed leaves; axillary or racemose flowers ; an epicalyx of 6-9 united bracts; sepals and petals 5 each; staminal tube long; styles many; fruit dividing into indehiscent 1-seeded cocci. (Name from the Greek áltho, I cure, from its healing properties.) 
1. A. officinális (Common Marsh Mallow).--Hoary with stellate down; stem $2-3$ feet high; leaves shortly stalked, thick, sub-orbicular, 3-5-lobed;

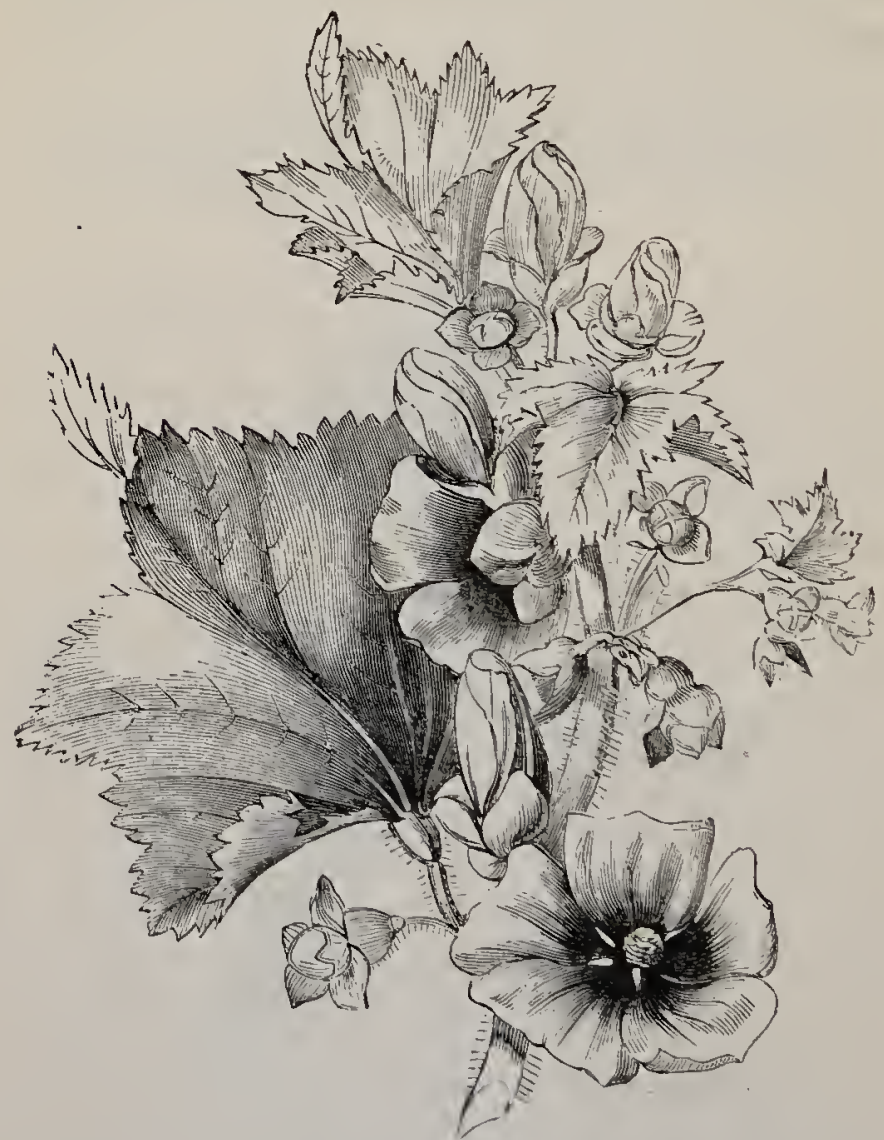

Lavatéra ARBórea (Sea Tree-Mallow).

flovers in axillary cymes, $1-2$ in. across, blushpink.-Marshes near the sea; local. The starry down is a beautiful object for the microscope.-Fl. August, September. Perennial. 
2. A. hirsúta (Hispid Marsh Mallow).-A hispid or bristly plant, about a foot high, with leaves longstalked, reniform, 3-5-lobed, and solitary axillary rose-pink flowers, an inch across, occurs near Cobham, Kent.-F'l. Juce, July. Annual or biennial.

2. Ijavatéra (Tree-Mallow).--Tall hairy plants, with more or less lobed leaves; axillary flowers; an epicalyx of 3 united bracts; and other characters mainly as in Althcéc. (Named in honour of the two Lavaters, Swiss physicians, friends of Tournefort.)

1. L. arbóreca (Sea Tree-Mallow). $-A$ tall and handsome plant, $3-12$ feet high, with a thick woody stem; soft, downy, 7 -angled leaves; and abundance of rose-coloured flowers, with darker veins, $1 \frac{1}{2}$ in. across, resembling those of the Common Mallow (Málua sylvéstris), but of a deeper colour towards the centre.-On sea-cliffs and stacks; rare.-Fl. July -October. Biennial.

2.* L. sylvestris, a smaller, herbaceous species, closely resembling Málva sylvéstris, but differing in being hispid with stellate hairs, giving it a greygreen colour, and in having the bracts of its epicalyx united, occurs, perhaps introduced in ballast, in the Scilly Isles.-Fl. June, July. Annual or biennial.

3. Málva (Mallow).--Glabrous or hairy herbs; leaves angled or lobed; flowers axillary; epicalyw of 3 distinct bracts; and other characters mainly as in the two preceding genera. (Name from the Greek málaké, soft, in allusion to its emollient mucilage.)

1. M. moścháta (Musk-Mallow).-Hairy, light green; stem erect; leaves long-stalked, deeply palmately 5-7-lobed, lobes pinnatifid, with a faint musky odour when rubbed, especially in hot weather; flowers large, handsome, rose-coloured, crowded 
towards the top of the stem; fruit hairy.-Hedges and borders of fields; frequent. A white variety is occasionally found and is grown in gardens.-Fl. July, August. Perennial.

2. M. sylvéstris (Common Mallow).-A robust, erect, branched, herbaceous, downy plant; leaves

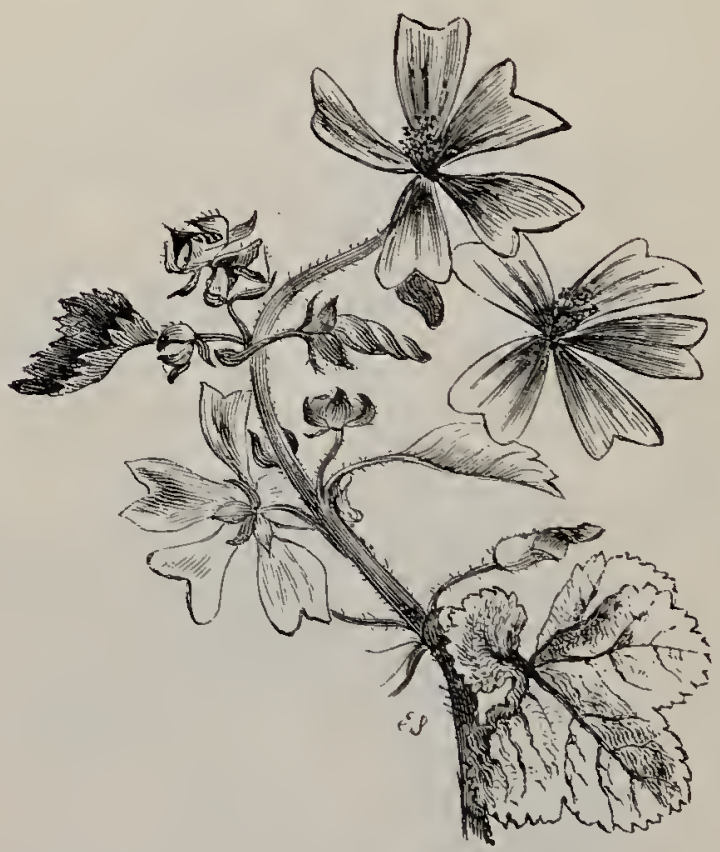

MALYA SYLVÉSTRIS (Common Mallow).

lobed, but not deeply divided, crenate-serrate; flowers showy, lilac with crimson veins; frut glabrous.Waste ground; common.-Fl. June-September. Perennial.

As the season advances, the leaves lose their first deep-green hue, and the stems put on a ragged appearance. Children gather and eat the unripe 
seed-vessels, which they call "cheeses": they are insipid, but not unwholesome. The pollen is a beautiful object for the microscope, being studded with minute prickles, which cause it to adhere to the hairy legs of bees visiting the flowers. The crimson veins on the petals serve the insects as "honeyguides": the stamens ripen and discharge their pollen before the circle of styles mature their stigmas, and subsequently these styles bend over so that the stigmas can collect pollen, brought from other flowers by insects, off the withered recurved filaments.

3. M. rotundifólia (Dwarf Mallow).-A smaller prostrate species; leaves roundish, heart-shaped, with 5 shallow lobes; flowers less than an inch across, pale pink, without honey-guides; fruit downy.Waste places, common. Its flowers are seldom visited by insects, and mature their anthers and stigmas simultaneously. - Fl. June-September. Perennial.

* $M$. verticilláta, an erect species with petals not longer than its sepals; * $M$. pusílla, a prostrate annual form resembling $M$. rotundifólia, but with shorter petals; and * $M$. parviftóra, a branched form with acutely-lobed leaves and short petals, occur occasionally, but are not indigenous.

Ord. XViII. Tiliácea.-The Linden Family.

A considerable family, mostly tropical, of trees, shrubs, and, rarely, herbs; Teaves scattered, stipulate; flowers cymose, polysymmetric; sepals 5, rarely 4, valvate when in bud; petals equalling the sepals in number, often with a scale and pit at their base, sometimes wanting; stamens numerous; carpets 2-10, syncarpous; style single; stigmas and chambers of ovary as many as carpels; fruit dry or baccate, with one or more seeds in each chamber. 
They all have a mucilaginous, wholesome juice, and many of them are remarkable for the toughness of their fibrous inner bark. Tute, for example, is the product of the East Indian genus Corchorus, and Russian bast is obtained from the Linden (Tília).

1. Tília (Linden). Trees with oblique, cordate, serrate leaves; cymes with a large leafy bract adherent

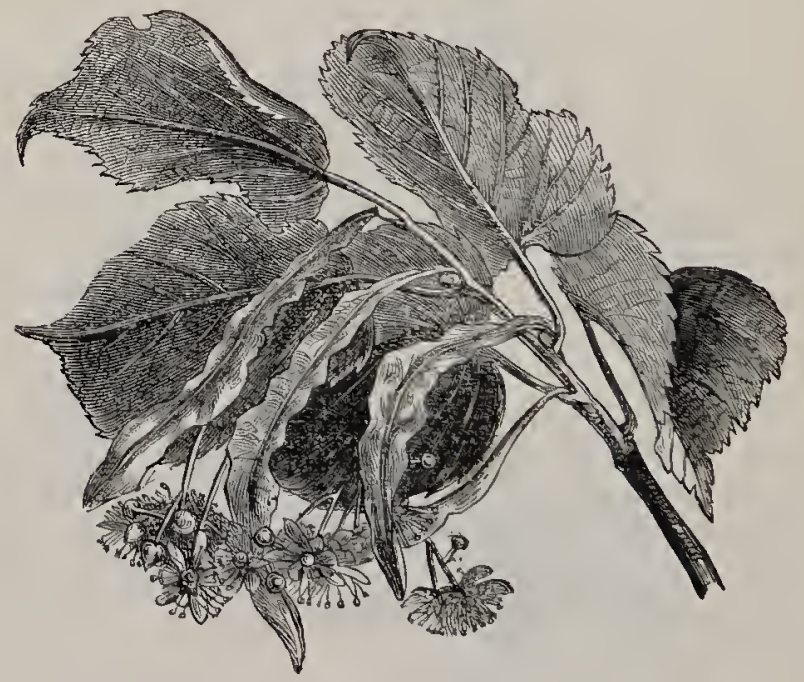

Tflid vuladis (Common Lime).

to the peduncle; sepals 5 , deciduous; jetals 5 ; stamens many; ouary 5-chambered, capsule 1-chambered, indehiscent, 1-2-seeded. (Name, the Latin name of the tree. The Euglish name, now generally written Lime, was Line in Shakespere's time.) A peculiar interest attaches to the Linden from its having given a name to the immortal Linneus. It is questionable whether any species of the genus is indigenous in Britain. 
1. T. platyphýllos (Large-leaved Linden), a large tree, with its young shoots hairy; leaves thin, downy beneath, longer than their stalks ; and fruit woody, 5 -angled and dowily.-Old rocky woods in the West of England.-Fl. June, July.

2.* T. vulgáris (Common Lime), the chief form in our parks and avenues, glabrous except woolly tufts at the branching of the veins on the under side of the leaves; leaves thin, "twice as long as their stalks; fruit woody, not ribbed or angled when ripe, downy.-Hedgerows and plantations.-Fl. July.

3. T. cordáta (Small-leaved Linden), which has most claim to be considered indigenous, glabrous except woolly tufts, as in the last; leaves thick, leathery, scarcely longer than their stalks; fruit faintly ribbed, thin, brittle, downy.-Old woods.-Fl。 July, August.

\section{Ord. XIX. Línefe.-The Flax Family.}

Herbaceous, rarely shrubby plants, with slender stems; narrow, simple, entire leaves; and polysymmetric, 3-5-merous flowers; sepals imbricate, persistent; petals twisted when in bud, falling off very soon after expansion ; stamens alternate with the petals, united at the base into a ring with staminodes between them; capsule approaching a globular form, 3 -5-chambered, each chamber incompletely divided by the in-growth of the midrib of the carpellary leaf ; seeds 2 in each chamber. The flowers are in many cases highly ornamental, providing our gardens with vivid blue; crimson, orange, and white blossoms; but the most useful characters of the Order are the toughness of the fiore contained in their stems, the mucilaginous nature of the outer ccat of their seeds, and the oil obtained from the seeds themselves when crushed. The flax of commerce, Linum usitatissimum, has for 
ages supplied the valuable textile substance which derives from it the name "linen"; the mucilaginous seeds are employed in "linseed" poultices; and, when crushed, yield "linseed oil," the chief oil used in painting, and the refuse "oilcake," used as food for cattle.

1. Rádiola._Flower's tetramerous; sepals trifid.

2. Línum.-Flowers pentamerous; sepals entire.

1. Rádiola (Flax-seed, All-seed).-A minute annual herb; stem filiform, repeatedly forked; flowers terminal and in the forks; sepals 4, deeply and

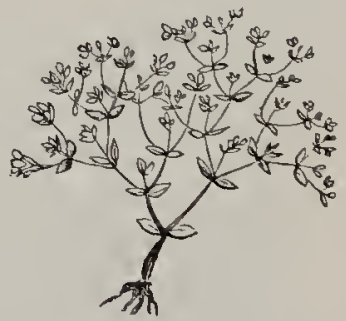

RADIOLA LIXÍIDES (Thyme-leared Flax-seed).

acutely 3-cleft, united below ; petals 4, fugacious. (Name, a diminutive from the Latin rádins, a ray, from the radiating brancles.)

1. R. Tinóides (Common Flax-seed), the only species, a minute plant, never exceeding four inches in height, bearing ovate-acute leaves and a large number of minute white flowers, which, as the plants generally grow many together, often prevent its being overlooked.-Damp heaths ; frequent.--Fl. July, August. Annual.

2. Lf́num (Flax).--Herbs or small shrubs; leaves scattered, or rarely opposite; flowers in cymes, pen. 
tamerous ; sepals 5, entire; petals 5, fugacious; disk of 5 glands opposite the petals; stamens 5 , with 5 staminodes between them; ovary 5 -chambered, chambers divided almost into 2 ; styles 5 ; ovules 10 ; fruit capsular. (Name, the Latin name of the plant, perhaps of Keltic origin.)

1. L. cathárticum (Cathartic Flax).-A very slender,

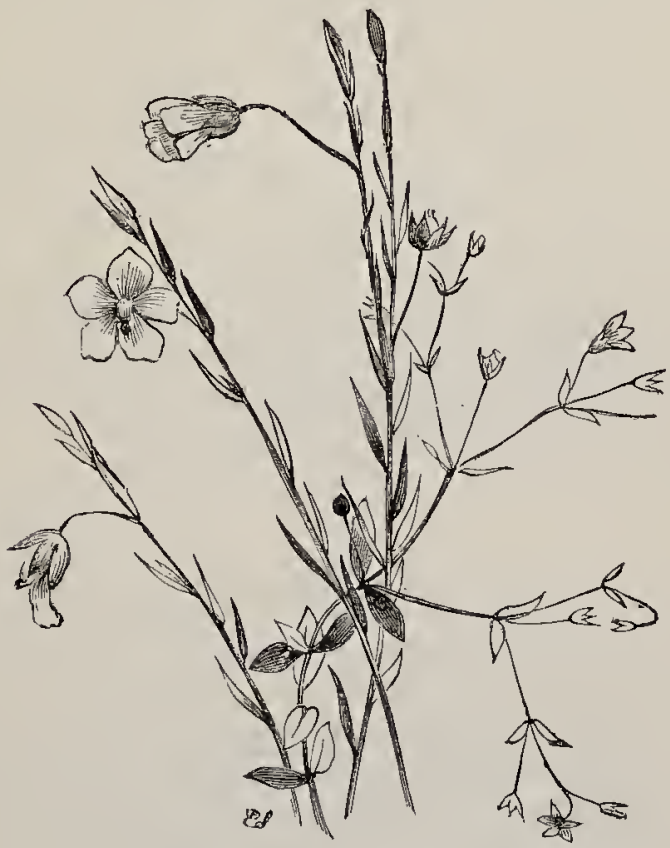

LFAUM ANGUSTIFÓLIUM, and I. CATHÁRTICUM.

much-branched, glabrous plant, rarely exceeding 6 in. in height; leaves mostly opposite, linear-oblong; flowers numerous, $\frac{1}{4} \mathrm{in}$. across, white, in dichasial cymes, drooping before expansion; sepals pointed, 1-veined.-Dry pastures; common.--El. June-August. Annunl.

2. L. perénné (Perennial Flax).--A slender plant 
about a foot high, with wiry stems; rery narrow, scattered, sessile. leaves, tapering to a point; sepals obovate, obtuse, obscurely 5-veined, glabrous; petals a beautiful sky-blue, but so fugacious as scarcely to bear being gathered. Challzy places; rare.-Fl. June, July. Perennial.

3. L. angustifólium (Narrow-leaved Flax).--Like the last; but irregularly branched and distinctly marlsed by its sharp-pointed, elliptical, 3-veined sepals, and by the lighter, more lilac, blue of its flowers.-Dry pastures in the southern and wostern counties; frequent.-Fl. Mày--September. Annual or perennial.

4.* L. vsitatissimun (Common Flax), though not a native plant, is not unfrequently found as an escape from cultivation. It is distinguished from the preceding by its stems being mostly solitary, instead of several from the same root, by its somewliat broader and more distant leaves, by its ciliate, ovate, 3-veined, pointed sepals, by its notched, blue petale, and by its larger size.--Fl. June, July. Annual.

Ord. XX. Geraniácem.--The Crane's-bill Family.

A considerable Order, two tribes of which, the Oralidece and Baleaminea, are sometimes treated as distinct Orders. They are mostly herbaceous; their leaves are usually stipulate; fiowers conspicuous, either polysymmetric or monosymmetric, and usually pentamerous; sepals, petals, and carpels $3-5$ each; stamens 5-10; ovar! 3-5-chambered, with 1, 2, o1 more seeds in each chamber. The Order takes its name from the elongated axis or carpophore, to which the styles of the members of the Tribe Geraniece adhere in the flower, and from which they separate and curl up when the carpels are ripe. The members of this Tribe are often astringent and aromatic, abounding in volatile oil; those of the Oxalidece are 
remarkable for the quantity of oxalic acid contained in their foliage, and some have edible tubers. All three tribes furnish beautiful plants to our gardens. Most of the species grown as Geraniums, which are derived mainly from South Africa, belong truly to the allied genus Pelargónium, which differs in having the posterior sepal wider than the rest, and provided with a tubular spur containing nectar, which is adherent to the flower-stalk, so that the flower is monosymmetric.

Tribe I. Geríniex.-The Cranes-bull Tribe.-Fiouers polysymmetric : sepals imbricate: fruit a bealied regma separating into five indehiscent cocci: styles persisting as awns.

1. Geránium. - Siamens 10; awns recurvad, smootl.

2. Eróntum. - Stumens 5; staminoles 5; auns spiral, bearded.

Tribe II. Oxalínes.--The Wood-Sorrel Tribe.Flowers polysymmetric: sepals imbricate: stamens 10 : fruit a capsule.

3. Óxalis. - Leaves ternate: seeds with an elastic testa.

Tribe IIL. Batsamínez.-The Balsam Tribe.Flowers monosymmetric: sepats petatoid, the posterior spurred: stamens 5: finit a capsule, bursting elastically.

4. Iмpátiens. - Leaves simple; sepals 3 ; pats 3.

1. Gerániun. (Crane's-bill). - Herbs with swollel nodes, rarely shrubs; leaves simplc, stipulate, lobed; flowers on 1-2-flowered axillary peduncles; stamens 10,5 of which are alternately larrer, and hare glands 
at their base ; styles persisting as smooth awns which curve upwards from the long beak (carpophore) of the fruit. (Name from the Greek géranos, a crane, from the beaked fruit.)

\section{* Perennial.}

1. G. sanguineum (Bloody Crane's-bill).-An exceedingly handsome plant with hairy stems; abundant foliage, radical leaves nearly round, with 7 deepiy-cut lobes, each of which is 3-cleft, cauline leaves 5- or 3lobed ; flowers $1-1 \frac{1}{2}$ in. across, crimson or pink, solitary, on long stalks.-Dry rocks and shores; not common.-Fl. July-September.

2.* G. striátum with slender; erect, hairy stem, 18 in. liigh, and 2-flowered peduncles bearing white, red-rcined flowers, occurs as an escape.

3.* $G$. nodósum, a similar species, with glabrous stem and red flowers, is also an escape.

4.* G. phreum (Dusky Crane's-bill).--A tall, erect plant with Teaves 5-7-lobed, serrate; dingy, purplishblack flowers with mucronate sepals; and corpels hairy below, wrinkled above, not uncommon in gardens, occurs also as an escape in plantations. - El. May, June. Perennial.

5. G. syluáticum (Wood Crane's-bill).-A tall, erect, hairy species; leaves palmate, 7 -lobed, lobes cut and serrate; flowers purplish-blue or rose-colour ; petals with bearded claws; stamens awl-shaped, fringed; carpels hairy; fruit-stalls erect.-Woods and pastures, chiefly in the north; rare.-Fl. June, July. Perennial.

6. G. praténsé (Meadow Crane's-bill). - The largest British species, erect, downy, sometimes 4

(1) Particular care should be taken when comparing specimens wit lithe above descriptions, to examine the radical leaves, for the canline leaves vary even on the sime plant to such a degree as to defy description. 
feet high ; differing from the last in having stalks to the cantine leaves; narrow stipules; la rger, blue-purple flowers, over an inch across ; very large points to the sepals; more slender and less hairy filaments; and

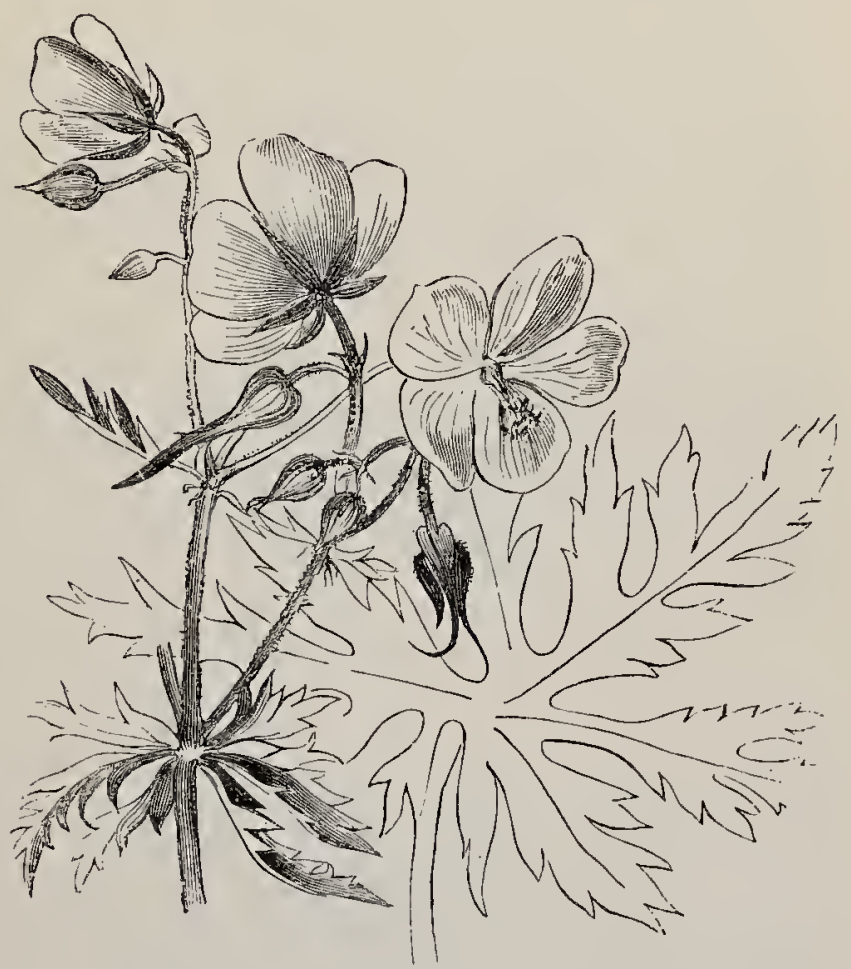

GERÁNiUm pratérsé (Meadow Crane's-bil.).

deflexed fruit-stalls.-Moist meadows and river-sides; common:-FJ. June--September. Perennial.

7. G. pyrenä́zum (Mountain Crane's-bill).—Stem spreading, 2 feet high, downy, with long hairs intermixed; radical leaves reniform, 7-9-lobed, lobes oblong, obtuse, 3-cleft and toothed at the end : flowers 
$\frac{1}{2}$ in. across; sepals mucronate; petals notched, twice as long, bright red.-Poad-sides and meadows; uncomımon, seldom indigenous.-Fl. June-August. Perennial.

\section{* Anmal or biennial.}

8. G. móllé (Dove's-foot Crane's-bill).-Prostrate, very softly pubescent; leaves roundish, lobed and cut; flowers $\frac{1}{3}-\frac{1}{2}$ in. across, rose-colour or lilac; sepals mucronate; petals bifid ; fruit wrinkled, glabrous.Fields and waste places; common.-Fl. all the summer. Annual.

9. G. pusillum (Small-flowered Crane's-bill). Resembling the last, but smaller, prostrate, vcry softly pubescent; leaves roundish, more decply lobed; flowers $\frac{1}{3}$ in. across, lilac; sepals mucronate : petals notched; carpels keeled, downy with adpressed hairs, not wrinkled.-Waste ground; common.-Fl. all the summer. Annual.

10. G. rotundifólium (Round-leaved Crane's-bill).Also resembling $G$. mólle, downy, with more distant hairs ; flowers $\frac{1}{3}-\frac{1}{2}$ in. across, flesh-pink ; petals not notched; carpels keeled, with spleading hairs, not wrinkled.-Waste places; not common.-Fl. June, July. Annual.

11. G. disséctum (Jagged-leaved Crane's-bill).Hairy, not downy ; stems spreading : leaves roundish, divided almost to the base in $5-7$ segments witl linear lobes: peduncles very short; flowcrs $\frac{1}{4}-\frac{1}{2}$ in. across, bright red; sepuls with long points; petals bifid ; carpels not wrinkled, with erect hairs. - Waste places; common.-Fl. all the summer. Annual.

12. G. columbinum (Long-stalked Crane's-bill).Stems spreading, nearly glabrous ; wanches 1 -2 feet . leaves similar to those of the last, but on much longer stalks; peduncles longer than the leaves ; pedicels very long and slender; flowers $\frac{1}{2}-\frac{3}{4}$ in. across, often 
drooping, bluish rose-colour ; sepals with long points, petals emarginate; carpels with few small hairs.Dry hedgerows; not very common.-Fl. June, July. Annual.

13. G. Túcidum (Shining Crane's-bill).-A beautiful and distinct species, a few inches high, glabrous and glossy; stems and leaves generally tinged with red; leaves nearly round, 5-lobed ; flowers small, rosecolour; sepals wrinkled, with long points; petals shorter, entire.-Old walls and stony places; common.-Fl. all the summer. Annual.

14. G. Robertianum (Herb Robert).--One of the most generally diffused and best known species, well distinguished by its red, hairy, succulent, spreading stems; ternately or quinately divided leares with pinnatifid segments, acquiring in autumn the same reddish hue; and bright pink elegantly-veined flowers $\frac{1}{2}$ in. across, with long, pointed sepals, viscir with glandular hairs, and obovate, entire petuls. There is a white-flowered variety. The whole plant has a strong smell.--Hedgerows and waste ground; very common.--Fl, all the summer. Annual.

2. ERónıum (Stork's-bill)._-Herbs with swollen nodes ; leaves stipulate; flowers on 1-many-flowered axillary peduncles; petals rather unequal, sometimes deficient; stamens 5, with alternating staminodes, with glands at the base of the former; styles persisting as spirally twisted awns furnished with long elastic bristles on the inner side. ${ }^{1}$ (Name from the Greek eródios, a stork, from the beaked fruit.)

(1) These awns, which become spirally twisted when ripe, often spring to a consideralle distance from the parent plant. Being hygroscepic they uncurl when moistence. The combined action of the awn and the bristles on it thus gives to the carpel the power of locomotion at every change in the moisture surrounding it, and serves to bury the seed.vessel. A twisted carpel, if moistened and laid on a she et of paper, will soon crawl an ineh or more away from the spot on which it was laid. 
1. E. cicutárium (Hemlock Stork's-bill).-Stems prostrate, hairy : leaves bi-pinnatifid, with lanceolate stipules; peduncles many-flowered; flowers in umbel-

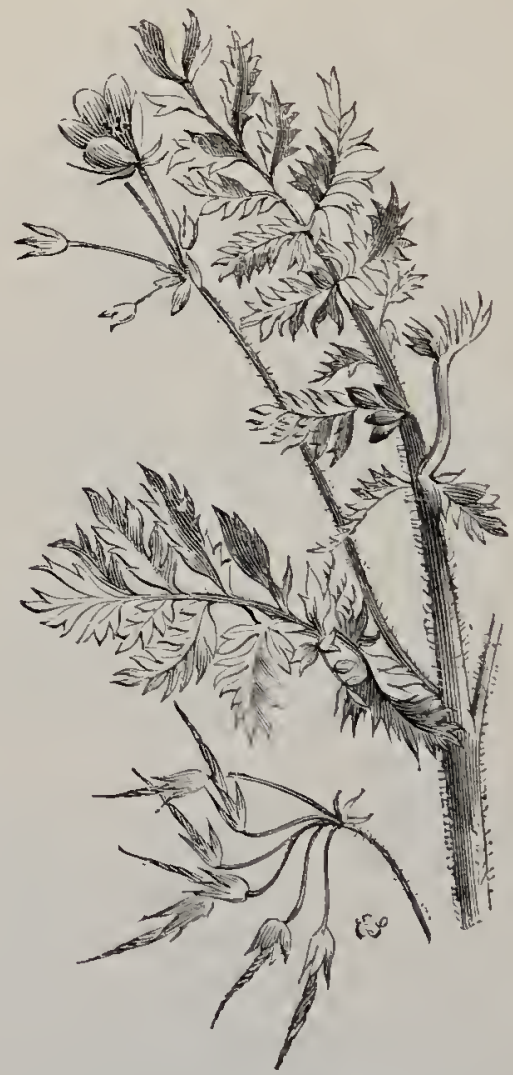

ERODIUM CICUTARIUM (Hemlock Storl's-bill).

late cymes, rosy or white: petals entire, rather unequal, two often spotted at the base, fugacious.Waste places, especially near the sea ; common.-Fl. all the summer. Annual. 
2. E. moschatum (Musk Stork's-bill)._A larger and stouter species, of a deeper green, covcred with spreading hairs, somewhat clammy to the touch, and emitting, when handled, a strong scent of musk; leaves less deeply cut, with broadly-ovate, obtuse stipules; flowers pink.- Waste places; rare, not indigenous inland.--Fl. June, July. Annual.

3. E. mar"ítimum (Sea Stork's-bill).--A small

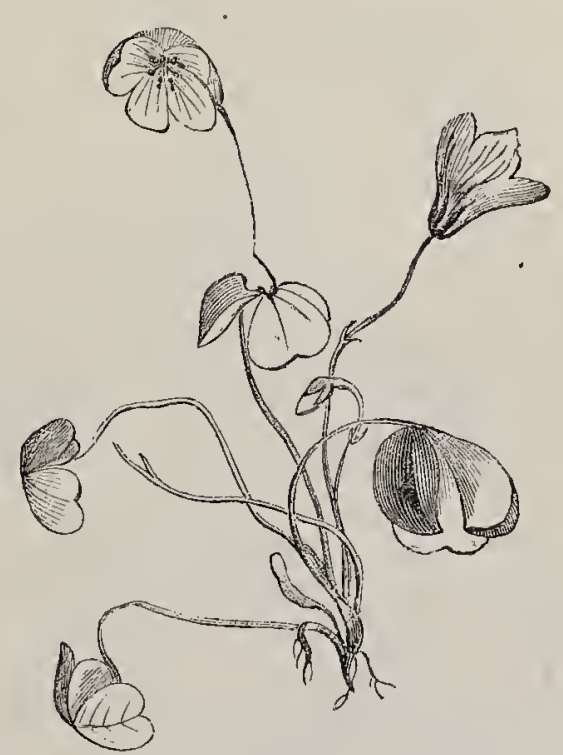

ÓXALIS ACETOSÉLAA (Common Wood-Sorrel).

plint, roughish, with minute hairs, and sending out several leafy stems, which lie remarkably close to the glound; the leares are not pinnate, as in the other British species, but ovate, corclate, and crenately lobed; and the preduncles bear one or two minute, generaly apetalous, flowers. - Sandy places near the sea, cspecially in the West of England; rare. Like many other seaside plants, it is not unfrequently met with 
in inland, mountainous districts, occurring plentifully on Dart moor, in Devonshire, many miles from the sea. -Fl, all the summer. Perennial.

3. Óxalis (Wood-sorrel). -Acid herbs with sensitive, ternate leaves; flowers on axillary, 1-or moreflowered peduncles, polysymmetric; sepals 5, united below, imbricate; petals 5 , often united below, convolute; stamens 10, monadelphous, the 5 outer ones shorter; an'any 5-chambered; styles 5; fruit a capsule; seeds with an elastic testa, which splits hygroscopically, throwing the body of the seed to a distance. (Name from the Greek ox'us, acid.)

1. O. Acetosellla (Common Wood-Sorrel, Alleluia). -An elegant little plant with a creeping rhizome and delicate, radical, trefoil, hairy leaves, which, though not so sensitive as some foreign species, fold together vertically at night, being thus protected from radiated cold. The peduncle has two bracts about the middle and is single-flowered; and the flowers have obovate white or lilac-veined petals. Apetalous, cleistogene seed-yielding flowers are proüuced later in the season, as in the violets (see p. 89). - W Woods and shady places; common.-Fl. April-August. Perennial.

2.* O. comiculata, a downy plant with prostrate branched stem without rumners, and 2-3-flowered peduncles bearing yellow flowers, may be indigenous in Devon and Cornwall.-Fl. June--September. Annual.

3.* O. stricta, a nearly glabrous erect plant with runners and 2-8-flowered peduncles bearing yellow flowers, occurring also in the west, is not indigenous. -Fl. July, August. Biennial.

4. Impítiens (Balsam).-Sueculent herbaceous plants with simple leaves and monosymmetric flower's; 
sepals 3, petaloid, deciduous, imbricate, the posterior one forming a wide-mouthed spur; petals 3 , the anterior one broad, symmetrical, the two lateral ones

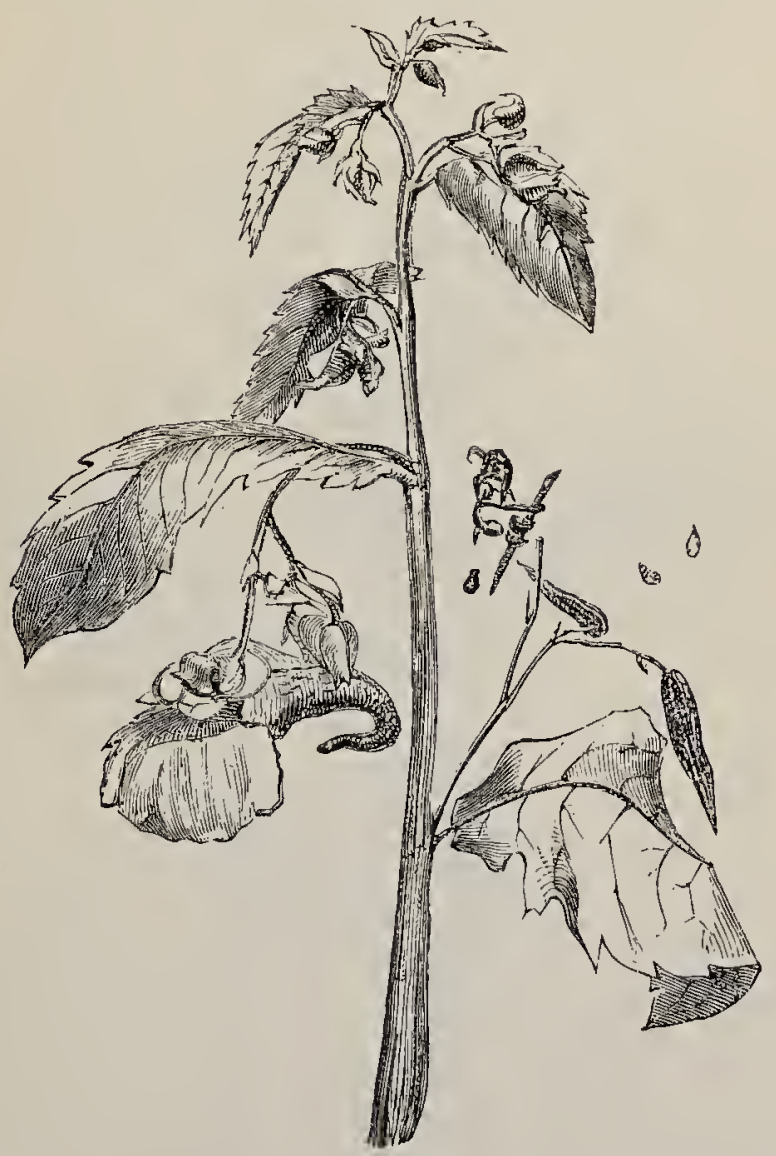

IMPATTENS YOLÍ-TÁTGERE (Balsann).

unequally 2-lobed; stamens 5, with short coherent filaments; ovary 5-chambered, many-ovuled; fruit a capsule with 5 elastic valves. If the capsule be 
touched when approaching ripeness, its valves instantaneously curl into a spiral form, and spring with considerable force many feet from the plant, dropping the seeds by the way. Cleistogene flowers also occur. (Name from the Latin impatiens, referring to the sudden movement of the ralves of the capsule.)

1. I. Noli-túngere (Touch-me-not), an elegant plant 1..2 feet high; stem swollen at the nodes; leares ovate, coarsely serrate, obtuse; peduncles 1-3flowered; flowers large, yellow spotted with orange; spur slender, loosely recurved. - Moist shady woods and river banks in mountainous districts in the north ; rare.-Fl. June-September. Annual.

2. * T. biflór a, a North American species, 2-3 feet high, with acute, ovate, serrate leares, orange flowers, and a spur closely recurved and emarginate, is naturalised by the Tillingbourne, the Wey, and the Thames in Surrey, the Colne in Middlesex, and Bucks and elsewhere.-Fl. June-August. Annual.

3.* T. parviflóra, a Russian plant, 6-is in. high, with 3-12-flowered pectuncles, and small yellowish flowers with a short straight spur, is naturalised in many places.-Fl. July-September. Annual.

\section{Ord. XXI. Tlicine.e.-The Houty Tribe.}

'This Order, which is also known as Aquifoticicece, consists of trees and shrubs with scattered, simple, and generally evergreen and leathery leaves, and axillary 'ymes of small, white, or greenish flowers ; sepals 3 -6, united, imbricate, persistent; petals 4-6, deciduous, imbricate; stamens equalling the petals in number, and alternate with them; filaments awl-shaped; anthers 2-clambered, opening lengthwise; ovary superior, 2-6-chambered; style short or absent; stigma nearly sessile, lobed ; firit diupaceous, fleshy, in dehiscent, containing 2-6 bony, one-seeded "stones." 
They occur in various parts of the world, the common Holly being the only European species. Nearly all the members of the Order possess astringent, tonic properties, the leaves of the Holly, for instance, being used as a substitute for quinine in cases of

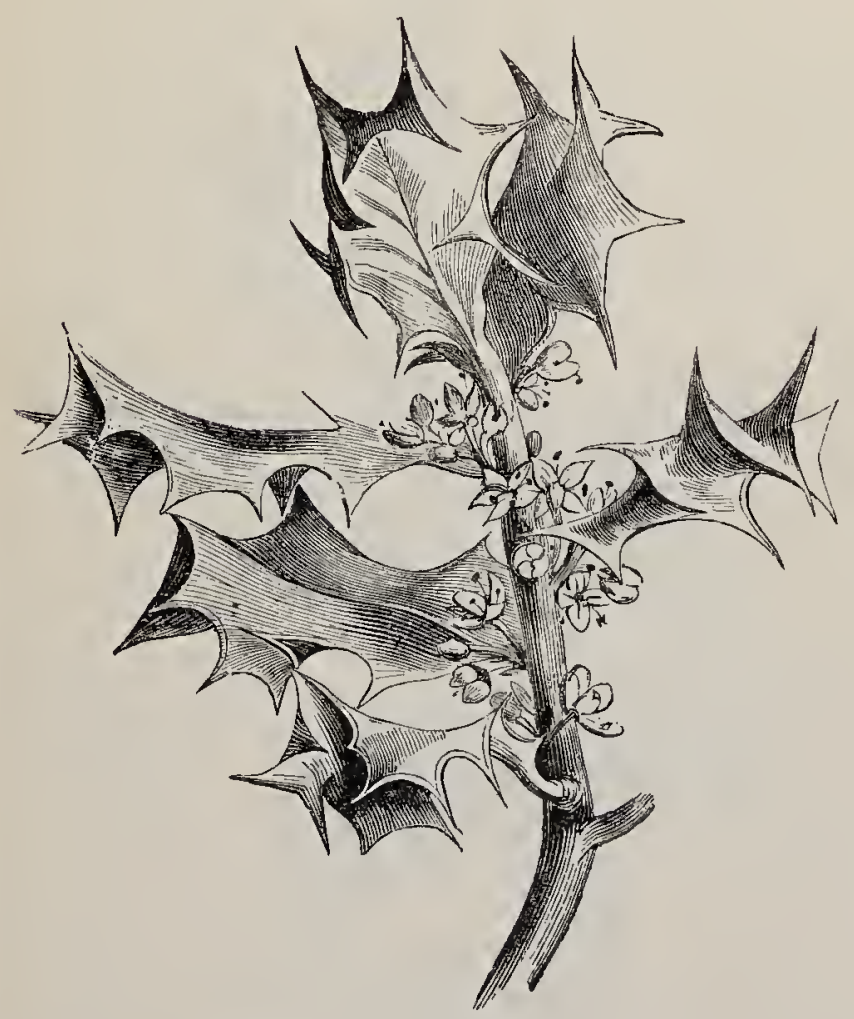

ILEX AQUTFÓLIUM (Conmon Holly).

intermittent fever. The leaves of Ílex Paraguayenesis, a South American species, furnish Parnguay or Maté Ten, which is extensively used throughout South America. The tea itself is properly known as yerba 
de matê, mate being the name for the gourd which is used as a teapot. The leaves of the common Holly are used as tea by the peasantry in the Black Fo' est.

1. Ítex (Holly).---Trees and shrubs; sepals 4 or 5 ; petals 4 or 5 , generally united as a rotate corolla; slamens 4 or 5 , adherent to the corolla-tube; stigmas 4 or 5 ; berry round, containing 4 or 5 stones. (Name applied by the Latins to some tree, probably Quércus Ilex, the Holm Oak, but not to our Holly.)

1. I. Agrifólium (Common Holly).-The only British species, a shrub or small tree, with smooth ash-grey bark and slightly downy twigs; leaves evergreen, glossy, with cartilaginous waved spinous inargins, those on upper branches of ten having only the one spine at the apex; flowers white, sub-diecious; forit scarlet, rarely yellow. The wood, which is white, and remarkably close-grained, is much used by cabinet-makers for inlaying and ebonising; and the bark furnishes bird-lime. The berries, it should be borne in mind, are Porsoxous. The name Aquifólium means needle-leaved, and Holly may be a corruption of the word "holy," from the use to which its boughs are applied in ornamenting eliurches at Christmas. The Holly is prrticularly abundant on sandy soil, under the trees of our old forests.-Fl. MayA ugust.

\section{Series II. CALTCIFIoR E. Ord. XXIT.- XXXVI.}

Petals and stamens perigynous or epigynous ; orary superior or inferior.

\$Stemens perigynous; orany generally superior. 
Ord. XXII. Celastrínez.-The Spindele-tree Family.

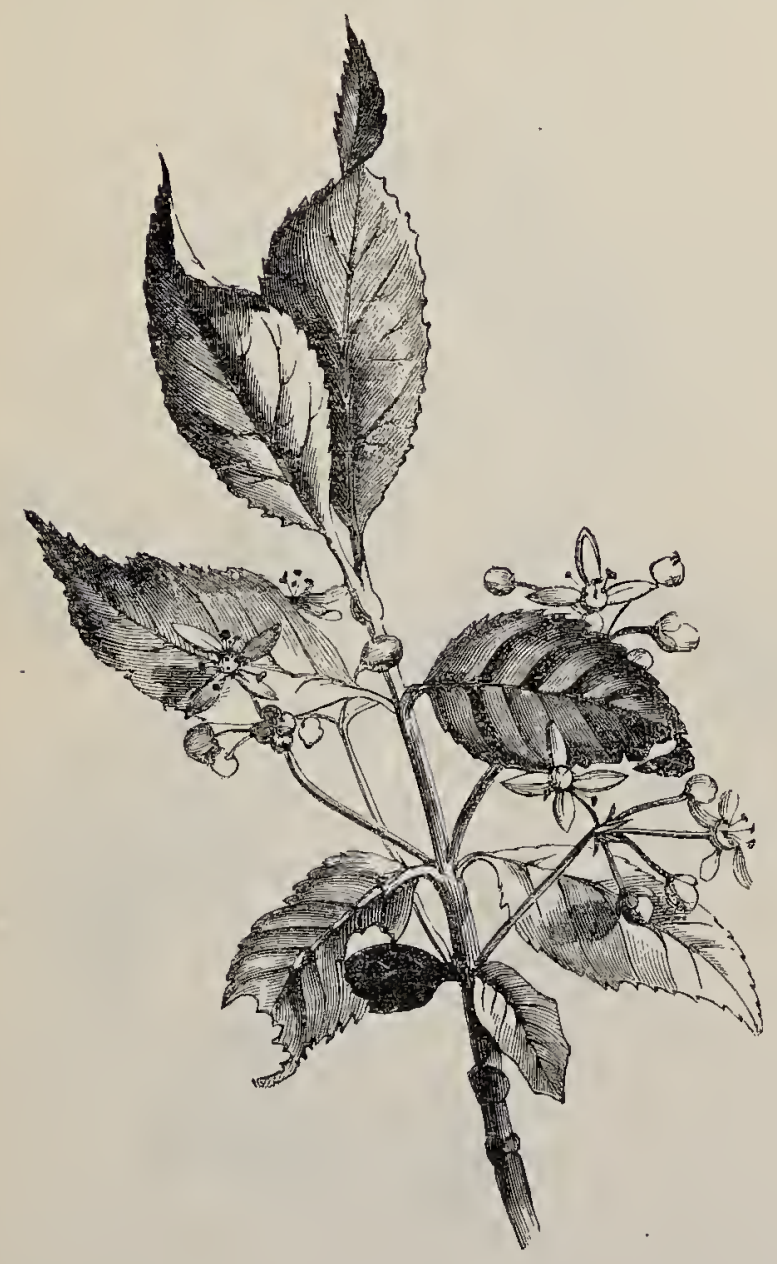

FLOWER OF EUÚNYMUS EUROPÁUS (Common Spindle-tree).

A rather large and widely distributed Order of trees and shrubs, containing only one British 
species, and not many others of much interest. They have simple teaves, and small cymose flowers; sepals 4-5, united, imbricate; pretals and

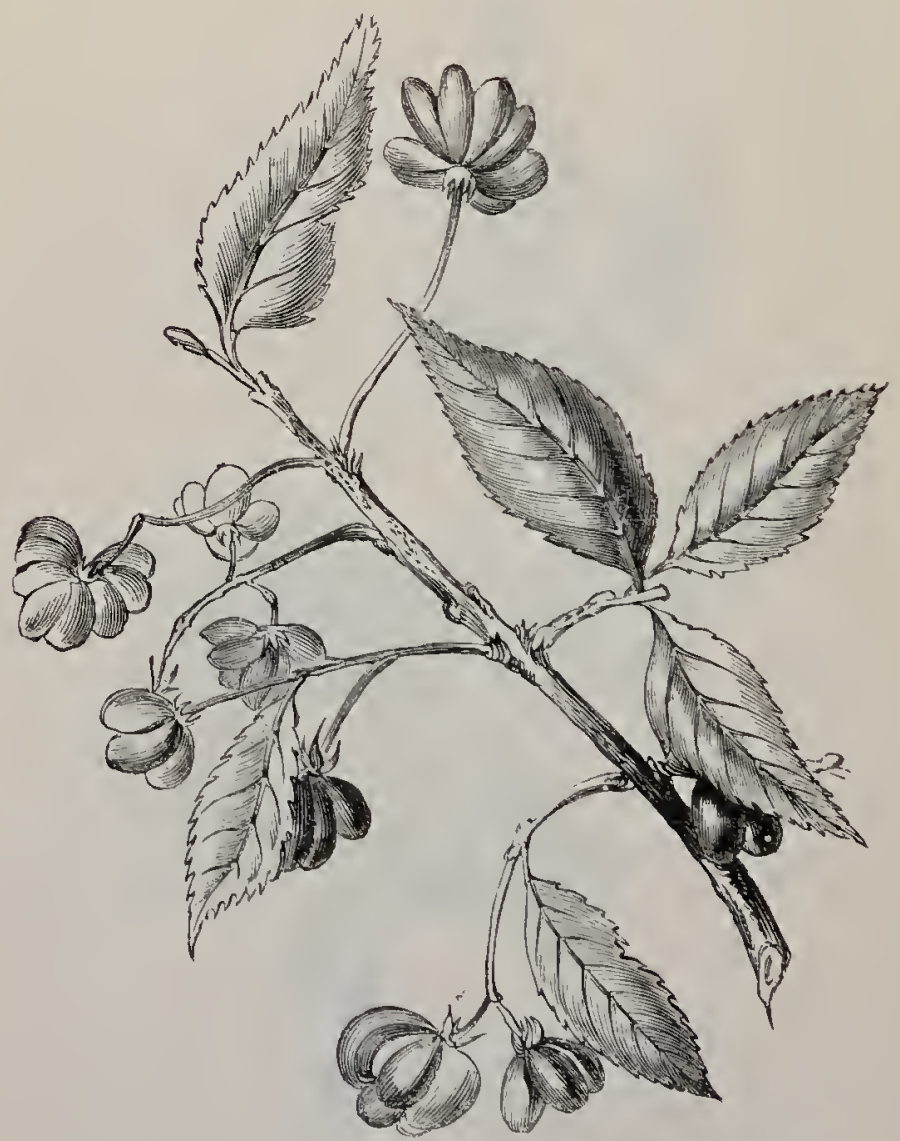

FRUTT OF EUÚNTMUS IUROP. EUS (Common spindlo-tre?)

stamens both equal in number to the sepals; orary sunk in the disk, 2-5-chambered; omles 2 in each chamber; seeds usually wrapped in a fleshy aril. 
1. EuónYmus (Spindle-tree).--Trees or shrubs with opposite leaves; flowers in axillary cymes, with a broad 4-5-lobed fleshy disk; fruit a fleshy 3-5-angled capsule, with $3-5$ chambers and valves; seeds solitary in each chamber. (Name from the Greek euónumos, lucky, in allusion to the poisonous character of the fruit, as fairies are called " good people "from fear.)

1. E. europaeus (Common Spindle-tree, Prickwood). -A shrub well marked by its smooth, green, angular branches; glossy, ovate-lanceolate, minutely serrated leaves; loose clusters of small greenish, usually tetramerous, flowers; and, above all, by its deeply-lobed capsutes, which, when ripe, are rose-coloured, and split so as to disclose the seeds covered by a scarlet aril, which Tennyson describes as-

"The fruit that in our autumn woodlands looks a flower." The wood was formerly used for skewers, spindles, and charcoal.-Fl. May, June.

\section{Ord. XXIII. Rhámneæ.-The Bucrithorn Famuly.}

Trees or shrubs, with simple leaves, ninute stipules, and small greenish flowers; sepals 4 or 5 , united, valvate; petals $4 \mathrm{or}^{\circ} 5$, inserted in the throat of the calyx, or absent; stamens 4 or 5 , opposite the petals; ovary superior, or half superior, 2-4chambered, surrounded by a fleshy disk; fruit fleshy and indehiscent, or dry and separating into three divisions; seeds one in each chamber. Zizyphus Lótus is reputed to have been the food of the aneient Lotus-eaters, the Lotophagi mentioned by Homer in the Odyssey. It is a prickly shrub with numerous purplish berries, of the size of sloes, with mealy pulp of a delicious flavour, and large stones. Other species of this genus produce the jujube, well known in this countiy as a sweetmeat. 
Z. spina-Christi and Paliurus aculeatus, prickly shrubs, common in the East, are severally believed by many

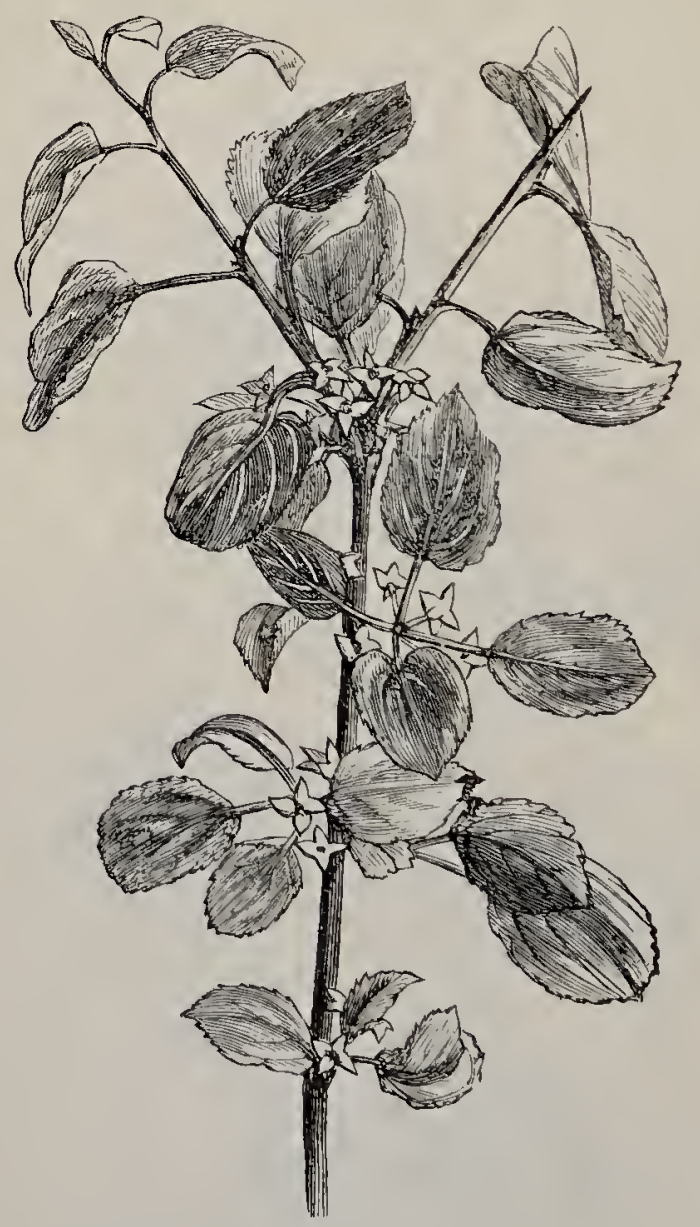

RHAMNUS CATHRRTICUS (Common Buckthorn).

persons to have formed our Blessed Saviour's crown of thoras, The berries of species of lihámnus aro 
used as dyes, in making sap-green paint, and in medicine, an extract of $R$. Purstiánus being considerably employed under the name Cascara sagrada, "sacred bark"; but they are too violent and uncertain in their effects to be used with safety. Two species of this renus are the only British representatives of the Order.

1. Rhámnus (Buckthorn).- Shrubs or small trees; leaves scattered; flowers sometimes unisexual; caiyx urceolate; fruit drupaceous, with 2-41-seeded stones. (Name from the Greek rhammos, a branch.)

1. R. cathúrticus (Common Buckthorn).-A stiff, much-branched shrub, 5-10 feet high; branches opposite, terminating in spines; teaves ovate serrate; flowers in crowded axillary cymes, yellowish-green, tetramerous, diccious; style 4-clcft; fruit with 4 stones, black, powerfully cathartic. These, if gathered before they are ripe, yield a yellow dye; when ripe, they form, if mixed with lime-water and gum-arabic, the pigment known as Sap- or Bladder-green.Woods, chiefly on chalk.-Fl. May-July.

2. R. Frángula (Alder Buckthorn, Black or Berrybearing Alder). - A shrub, 6-10 feet high, with rather slender, smooth, dark, spineless branches not opposite one another; obovate, entire, deep green leaves; greenish-white flowers; style simple; fruit with 2 stones. Used under the name Dogwood for gunpowder charcoal.-Woods; not uncommon.-Fl. May, June.

\section{Ord, XXIV. Acerínea.-The Mapde Family.}

Strictly speaking, a tribe in the large Order Sapindácece, to another division of which the Soap-berry, the Horse-Chestnut, and the Litchi belong. The Maple Tribe are trees with opposite, stalked, deci- 
duous leaves palmately-veined; racemose, polysymmetric flowers, which are often polygamous, the lower

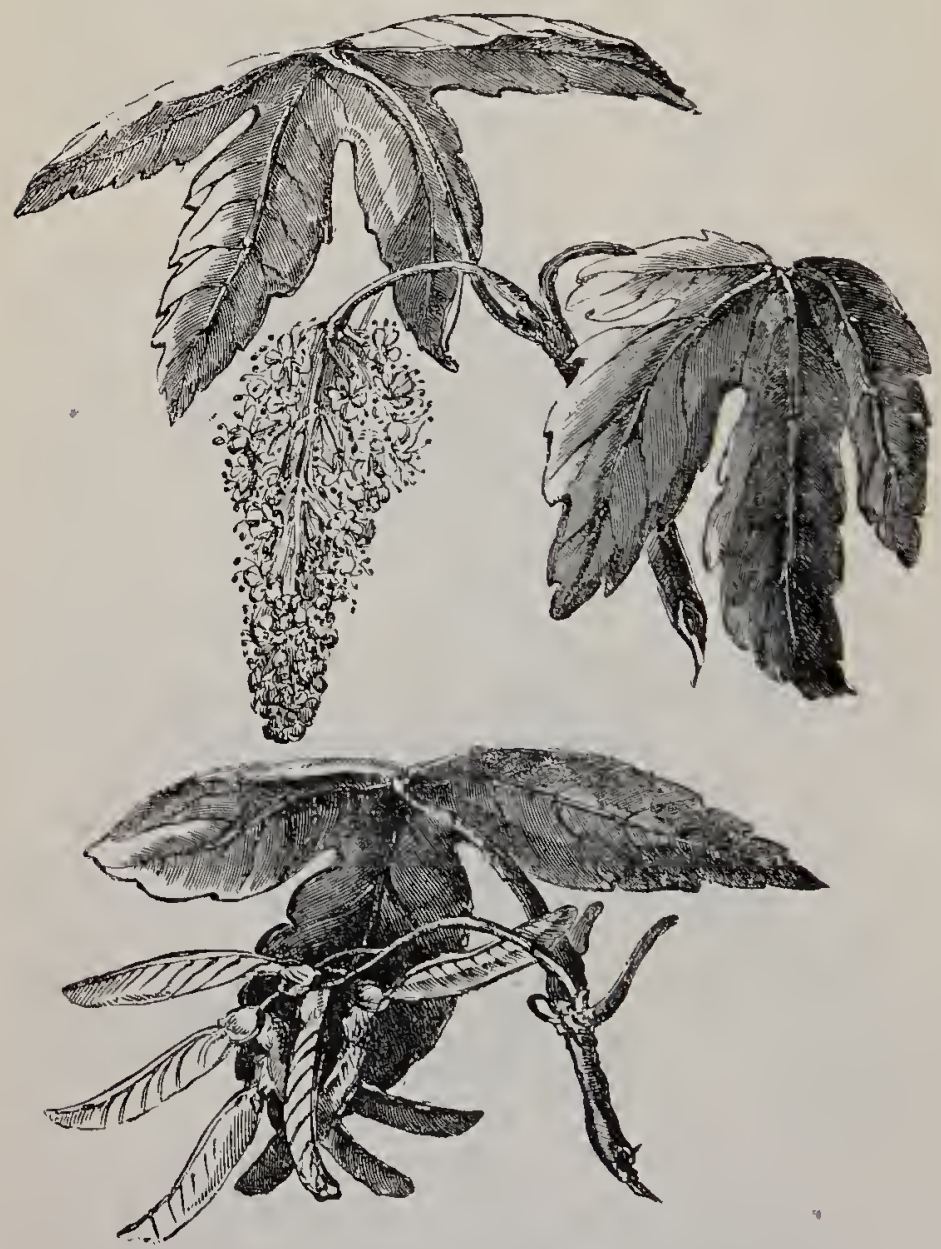

AOER DSEÚDO-PLATAKUs (Greater Niaple or Sycamore).

ones being usually staminate and the apper perfect; caly. 2 divided into 5 parts (occasionally 4-12), im- 
bricate, deciduous; petals of the same number, imbricate or absent; stamens usually 8, inserted on a ring-shaped disk beneath the ovary; ovary laterally compressed 2- (rarely 3-4) lobed and chambered; style 2-lobed; fruit a 2-winged, 2-4-seeded samara. North America is rich in Maples, their vividly tinted leaves giving a great charm to autumn woodlands. Several species, especially Ácer saccharinum, abound in sweet sap, from which maple sugar is mauufactured; and the timber of some species is valuable. Bird'seye Maple is a knotty variety of $A$. saccharinum : the white wood of the Sycamore ( $A$. Pserido-plátanus) is largely used in Scotland, under the misleading name of Plane, in turnery for bread-platters, butter-dishes, and moulds, \&c.; and gnarled specimens of the Common Maple (A. campéstré) were formerly employed in making the rare and beautiful "mazer" bowls.

1. Ácer (Maple)._-Leaves simple, lobed; sepals and petals 5 each; carpels 2 , each with a long wing. (Name the Latin ăcer, which it is suggested may have been connected with the Keltic ac, a point, maple-wood having been used for spears or other pointed instruments.)

1.* A. Pseúdo-plátanus (Greater Maple or Sycamore).-A large and handsome tree, introduced into England before the fourteenth century, and now completely naturalised; lecues $4-8$ in. across, 5lobed, unequally serrate; racemes pendulous; ovary hairy; wings of samara scimitar-shaped, divergent, each $1 \frac{1}{2}$ in. long. The name Sycamore is due to an erroneous identification of this tree with Ficus Sycomórus, the Mulbcrry- or Sycamore-Fig of Palestine.-Woods.-Fl. May, June.

2. A. campéstré (Common or Hedge-Maple), a small tree, with very rugged, corky, fissured bark; leaves 
2-4 in. across, 5-lobed, lobes obtuse ; racemes erect; wings of samara oblong, horizontally divergent, each $\frac{1}{2}$ in. long.-Woods and hedges; common.-Fl. May, June.

The leaves of both species of Maple are commonly spotted with round black patches produced by a parasitic fungus, Rhytisma acerínum.

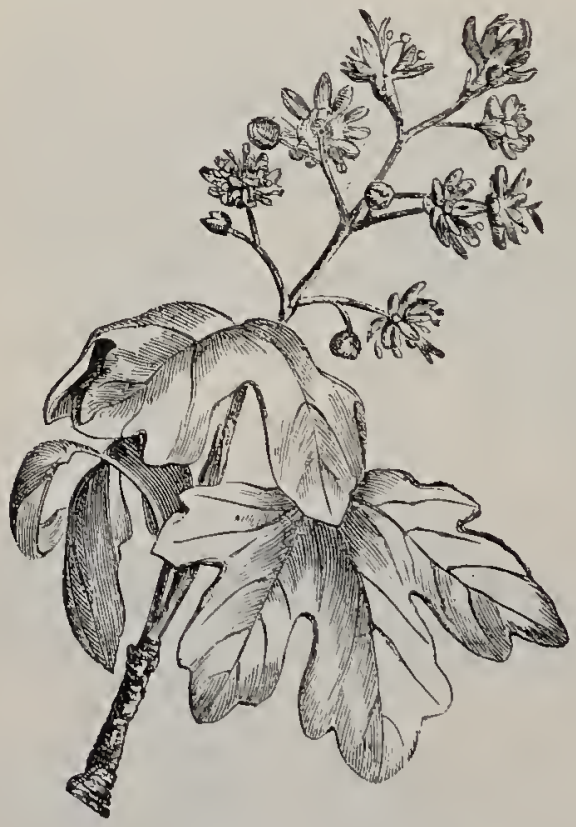

ÁCER CAMPÉstré (Common Maple).

Ord. XXV. Lequminós.e.-Tine Pea Famrax.

The second largest Order of Dicotyledons, contain. ing nearly 7,000 species, ranging in size from ininute herbs to huge trees, is yet a very natural one. They have scattered and usually stipulate leaves, which are seldom simple; of the 5 more or less united sepals, forming the inferior calys, the odd one is anterior; 
there is only a single carpel, which usually forms a 1-chambered ovary, ripening to a legume, or dry pod dehiscing down both sutures; and the seeds are exalbuminous. Though agreeing in these characters the Order as a whole is subdivided into three sub-orders, only one of which, the Papitionacéce, is represented by British species. This sub-order is marked by the additional characters that its flowers are monosymmetric ; that the coroun of 5 petals is papilionaceous; and that there are 10 stamens, either monadelphous or diadelphous, 9 being mited by their filaments and the posterior one separate. In a few exotic species the legume becomes fleshy and drupaceous ; but then the papilionaceous flower remains as a means of identification; whilst in the sub-orders in which the flower is not papilionaceous the fruit remains the characteristic legume. Among British species the chief varieties of form in the pod are those of the Bird's-foot (Ornithopus) and others, where it is imperfectly jointed, and in Medick (Medicago), where it is often spirally twisted, so as to resemble a snailshell. Many members of the Order display peculiar irritability in their leaves. Almost all the plarts of the Order which have compound leaves fold them together in what is called "sleep" at night; but the species of Mimósa, particularly $M$. púdica and $M$. sensitiva, which are known as Sensitive plants, close up in a remarkable manner when touched; whilst those of the Telegrapl plant (Hedysámum gýrans) are in constant motion. The Order is represented in all parts of the world and competes with the Graminea and Palmacere in its great and varied utility to man. The seeds of many species, under the general name of pulse, afford most nutritious food, exceptionally rich in nitrogen, for man and other animals-Peas, Beans, and Lentils, for example; others supply valuable fodder, such as Clover, Vetches, and Lucerne; the Posewoods are the best known of many excellent. 
timber-trees; Gum Arabie, Gum Tragacanth, and the Wattle Gums of Australia are products of the Order; Wattle-bark, Catechu, and Kino are among the valuable astringent substances used in tanning; Logwood and Indigo are the chief dyes in the Order. Not a few are poisonous, especially in the seed, of which the Laburnum is a familiar example. Others, the seeds of which are eminently nutritious, have properties of an opposite nature residing in other parts of the plant. The roots of the Kidney Bean, for instance, are dangerously narcotic. Many species are used in medicine, such as Tamarinds, Liquorice, and Senna. The excessively poisonous Ordeal Bean of Calabar (Physostigma) contains an alkaloid which is of use in ophthalmic surgery, as it contracts the pupil of the eye. The sweet pods of the Carob-tree (Ceratónia Síliqua) are known as Locust beans, or St. John's Bread, being supposed by some to have been the food of St. John the Baptist in the wilderness. They are eaten by children; but are chiefly used to fatten cattle. There are about eighty British species in the Order, the species of Genista, Furze, Broom, and Restharrow-about 10 in all-being shrubby or woody, and the rest herbaceous. For convenience of reference the British genera are arranged in three groups, comprising six tribes, as follows :- -

Group 1.-Leaves without tendrits, of 1 -3 leaflets.

Tribe 1. Genistea.-Shmuls: leaflets entire: stamens monadelphous.

1. Genísta.-Caly.x 2-lipped, the upper lip deeply 2-cleft, the lower with 3 teeth.

2. Úrex.-Calyx 2-lipped, yellow.

3. Cŕrosus. - Calyr 2-lipped, the upper lip with 2 minute teeth, the lower with 3 . 
Tribe 2. Trifóliece. Merls (rarety sturubs) : leaflets 3, generally toothed: stamens usually diadelphious.

4. Onónts.-Herbs or shrubs: catyx 5-cleft: stamens monadelphous.

5. Trigoníma. - Racemes short : pod longer than calyx, curved, dehiscent.

6. MedrcáGo.--Racemes short : pod usually spiral.

7. Meuró́tus.-Racemes long: port short, indehiscent.

8. Trifólıum.-Flowers capitate : pod short, indehiscent.

Group II.-Leaves without tendrils, imparipinnate: Teaflets 5, or more.

Tribe 3. Lótece.-Herbs: leaflets entire: stamens monadelphous or diadelphous: pod 2-ratved, without a Tongitudinal septum.

9. Anтrústis.--Caly.x inflated, enclosing the short pocl: stamens monadelphous.

10. Lótus.-Calyzx not inflated: stamens diadelphous: pod longer than calyx.

Tribe 4. Astragalécp.-Herbs: Teaflets entire: stamens diadelplous: pod 2-valved, with a Tongitudinal sepirum.

11. Astrágatus - Keel of corolla blunt

12. OxÝtropis. - Keel of corolla pointed.

Tribe 5. Hedysárece-Herbs: stamens diadetphous: pod indehiscent, jointed.

13. Orníthopus.-Pod curved, with many oval, 1-seeded joints. 
14. Hippocrípis. - Pod with many crescentshaped, 1-seeded joints.

15. Oxóbrychls.--Pod straight, 1-seeded.

Group III.-Leaves paripinnate, often ending in a tenclrit.

Tribe 6. Treiece.-Herbs: leaflets often toothed: stamens diadelphous: pod 2-ialued.

16. Vícia._Styjle thread-like.

17. Líthrrus.--Style flattened.

1. Genísta.-Shrubs, sometimes spinous; Teares simple, entire; flowers in racemes, bracteate, generally yellow ; calyx shortly 2-lipped, upper lip deeply 2-cleft, lower lip with 3 teeth; stamens monadelphous, 5 short with versatile anthers, and 5 alternating with them, long with basifixed anthers. (Name said to be connected with the Keltic gen, a shrub.)

1. G. Anylica (Petty or Needle Whin).-A low shrub, about a foot high, with tough curved branches, armed at intervals with slender, very sharp, recurved spines, the upper branches leafy, without thorns and flowering; 7eaves ovate-lanceolate; racemes short; Tegumes smooth, inflated. The yellow flowers (like some others belonging to this Natural Order) turn green in drying.-Heaths; common.-Fl. May, June. Perennial.

2. G. pilósc (Hairy Green-weed).-A low shrub with prostrate, furrowed, much-branched, spineless stems; obovate leaves, silky beneath; small yellow silky flowers in short racemes ; and downy tegumes.Dry heaths in the south; rare.-Fl. May, and again in autumn. Perennial.

3. G. tinctória (Dyer's Greenweed, Woad-waxen). -A low shrub, about a foot high, with tough, erect, 
spineless, glabrous branches; bright green, lanceolate, ciliate leaves; flowers yellow, in long racemes, glab-

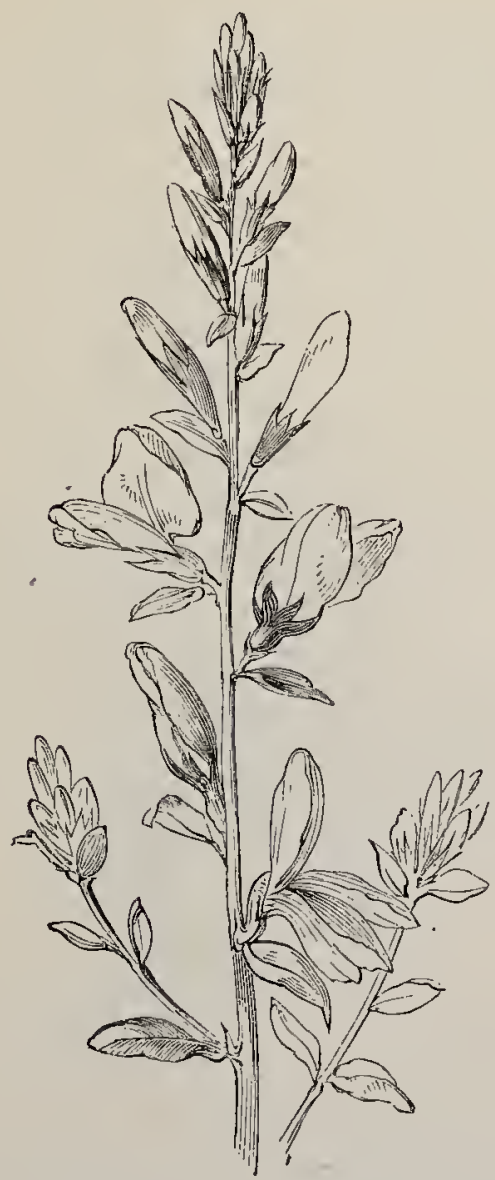

GEntsta Tinctórra (Dyer"s Greenued, Toond-vecexen).

rous; and legumes smooth. It grows chiefly in pastures on a clay soil, and was formerly used as a yellow dye, This was probably the Planta genísta 
that formed the badge of the Plantagenet family,Fl. July-September. Perennisi.

2. Útex (Furze).-Densely spinous shrubs; teares in the seedling termate, afterwards spinescent; flowers axillary, yellow, with small bracts; caly,x yellow, deeply 2-lipped, upper lip obscurely 2-toothed,

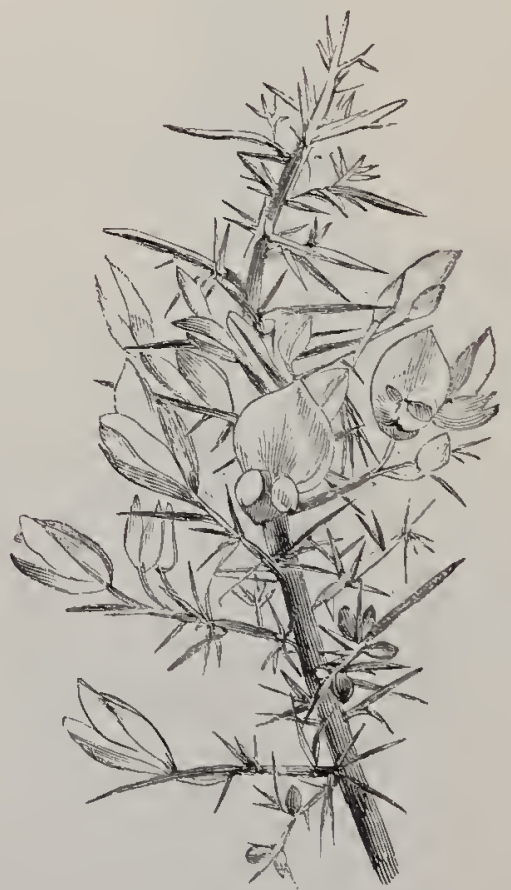

ÚLEX EUROP.EUs (Common Fur:e).

lower 3-toothed; stamens monadelphous, alternately short with veratile anthers, and long with basifixed ones; legrume swollen, few-seerled, scarcely longer than the calys. (Name said to be connected with the Keltic ec or ac, a prickle.)

1. U. europreus (Common Furze, Gorse, or Whin). 
-A much-branched, spreading shrub, copiously beset with branched spines, almost leafless; bracts ovate, not adhering closely to the calyx ; caly, shaggy, very obscurely toothed; winy-petals longer than the keel; pod black, with brown hairs, bursting elastically with a crackling sound, especially in hot weather, scattering the seeds on all sides.-Commons, everywhere. Perhaps no plant is so characteristic of English scenery. It attains maturity in about four year's, but in sheltered places grows until it reaches a height of 10 or 12 feet. It will not thrive in hot or in very cold climates, being uncommon even in the Higllands of Scotland.-Fl. February-June, and again August, September. Perennial.

2. U. Gállii (Larger Dwarf Furze).-A shrub, 2-5 feet ligh with ascending branches with strong curved spines; bracts very minute, adpressed ; flowers small, orange; caly $x$ downy, with diverging teeth; wingvetals rather longer than the keel.--Heaths; common. -Fl. Angust-November. Perennial.

3. U. nánus (Lesser Dwarf Furze).-A smaller, more prostrate shrub, witl short, straight, weak spines; bracts very minute, adpressed; flowers small, pale yellow; caly.s downy, with diverging teeth; wing-petals shorter than the keel.-Heaths, chiefly in the south ; less common than U. Gállii.-Fl. JulySeptember. Perennial.

3. CÝtrists (Broom).-CShrubs, rarely spinous; leaves simple or ternate, with minute stipules; calyiv 2-lipped, the upper lip minutely 2-toothed, the lower 3 -toothed; stanclard petal broadly ovate; stamens monadelphous: style curved or coiled; pod fiat, manyseeded. (Name Classical.)

1. C. scoparius (Common Broom).-The only British species, well distinguished by its numerous, slender, erect, green, angular branches, small, scat- 
tered, simple or ternate leaves, large yellow flowers, with spirally-coiled styles, and black pods, which are

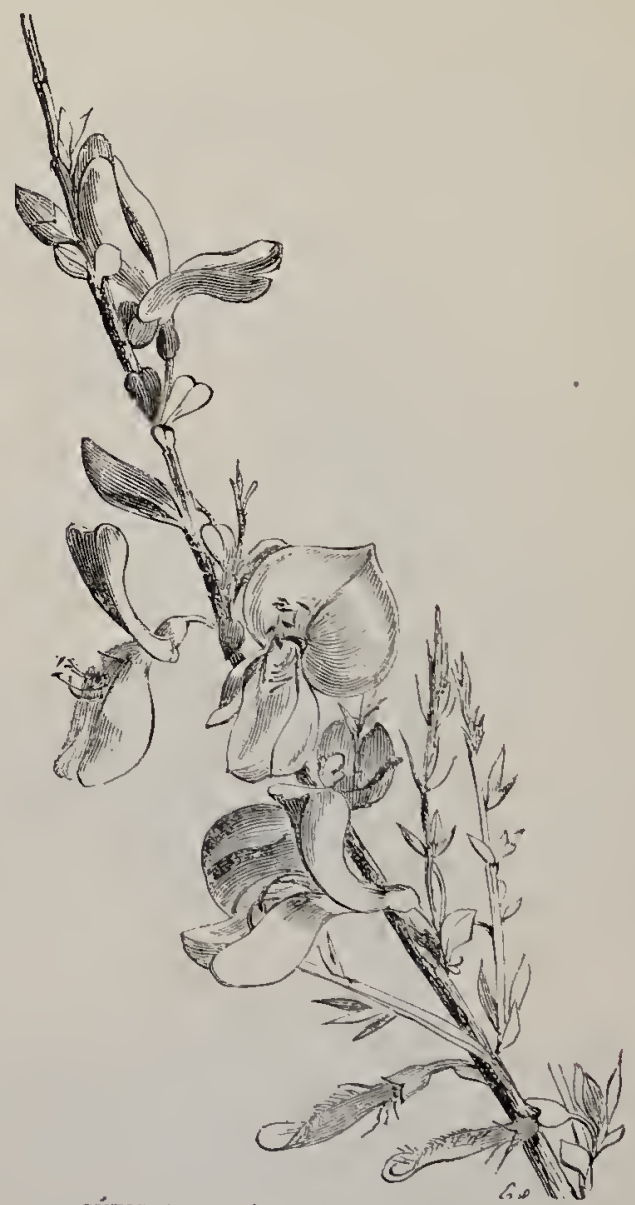

critisus scophriUs (Common Broom).

hairy at the margin.-Sandy places; common,--Fl. May, June. Perennial.

* The Laburnum is a member of the same genus. 
4. Onónis (Rest-harrow).--Small shrubs, rarely lierbaceous, hairy and generally viscid; Teaves pirlnate; leaflets 3, toothed; stipules adnate to the petiole ; flower's pink ; caly $x$ 5-cleft ; standard broad ; keel incurved, pointed; stamens monadelphous ; style curved; pod not compressed. (Name of Greek origin, connected with ŏnos, an ass.)

1. O. répens (Creeping Rest-harrow, Wild Liquor-

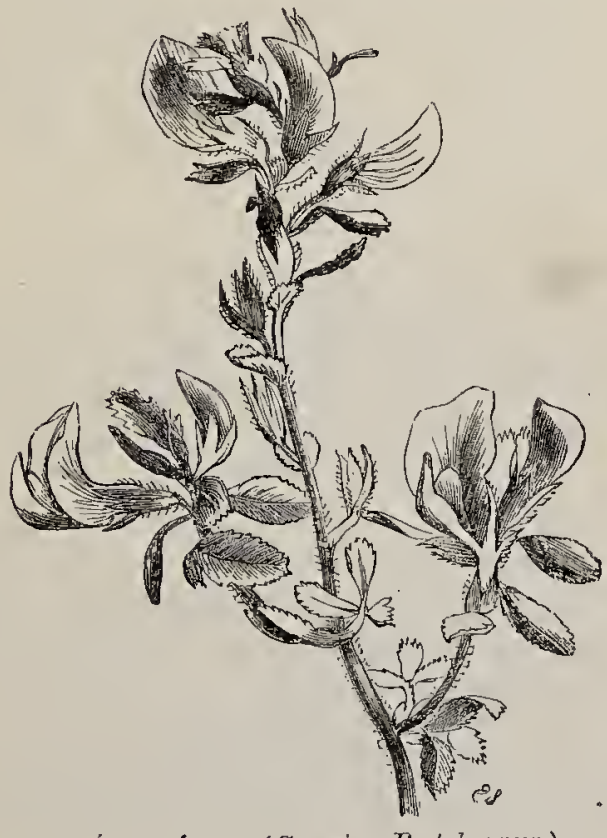

oNóxIS RÉPENS (Creeping Rest-harrow.)

ice).-A prostrate, shrubby plant with runners, hairy, viscid, most commonly without spines; leaflets oblong; fiowers axillary, solitary, and of a handsome bright pink; pod shorter than the calyx. The plant has a powerful odour and derives its name of Restharrow from its tough branches.-Dry pastures and 
sandy shores; common.-Fl. all the summer. Perennial.

2. O. spinósc (Erect Rest-harrow).-A sub-erect species, without runners, with two lines of hairs, less viscid and less strongly scented than the last, usually spinous; leaflets oblong; flowers differing slightly from thase of $O$. répens; pod longer than the calyx.Waste places; frequent.-Fl. all the summer. Perennial.

3. O. rectináta (Small Spreading Rest-harrow) is a small, spreading, herbaceous species, viscid and hairy, with reflexed pods, which has only been found in Alderney, Devon, and Galloway.-Fl. June, July. Annual.

5. TRIgonḱLL (Fenugreek).-Herbs, often strongly scented; Teaves as in On nis ; flowers solitary or in short racemes; caly, 5 -tootlied; stamens diadelphous; pod compressed, longer than the calyx, manyseeded. (Name, the old Greek name denoting threeangled, from the form of the corolla.)

1. $T$. purpuráscens (Bird's-foot Fenugreek).-A small, sleuder, prostrate, glabious plant, witl small pink and white flowers, $1-3$ together, and straight, 6 -8-seeded pods, twice as long as the calyx, dehiscent.-Dry sandy places; not common.-Fl. JulleAugust. Anuual or biennial.

The name Fenugrech comes from femum yrecum, Greek hay, this plant being used to scent inferior
hay.

\footnotetext{
6. Medicáco (Medick).--Herbs with leaves as in the two preceding genera; small yellow or violet flowers, in short racemes; caly.x 5-toothed; stamens diadelphous; pod sickle-shaped or spirally coiled, often spiny, generally indeliscent. (Name of Greek
} 
oligin, denoting that the plant so named was introduced from Media.)

\section{* Perennial: sometimes monadelphous : pods dehiscent, without spines.}

1.* M. sativa (Lucerne).-An crest species, $1-2$ feet high; stem hollow; leaflets oblong, toothed, apiculate; flouers large, in short, close racemes, usually purple; pod in 2-3 loose spiral coils, downy. A cultivated plant, said to have been introduced into Greece from Media by Darins.-Fl. Jume, July. Perennial.

2. 11. sylvéstris (Wood Medick).--An allied form, with more solid stem; large jellow or dark green flowers; and compressed pods, semicircular or ringshaped, downy.-Sandy places in Norfolk and Suffolk.-Fl. June, July. Perennial.

3. M. falcáta (Sickle Medick).-An allied but prostrate form, with large yellow flowers and a falcate or sickle-shaped pod.-Found in similar situations.Fl. June, July. Perennial.

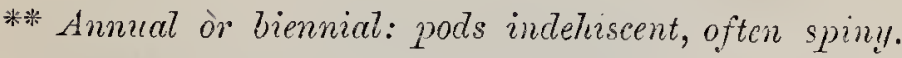

4. II. Tupulina (Black Medick, or Nonsuch).--A prostrate, spreading herb; leaflets inversely eggshaped, tinely toothed; flowers small, yellow, subsessile, in dense oblong heads; pods black, kidneyshaped, 1-seeded. Resembling some of the smaller Clovers, from which it may be distinguished by its pods not being enclosed within the calyx.-In pastures; common.-FJ. June-August. Annual or biennial.

5. M. denticuláta (Toothed Medick). - A glabious species; leaflets inversely hear't-shaped; stipules jagged ; flowers yellow, solitary, or 2-5 together ; pocts in 2 or 3 loose spiral coils, witl a double row of spines. Sandy places; rare.-Fl. April-August. Annual. 
6. M. arábica (Spotted Medick).--A glabrous species; Teaflets inversely heart-shaped, with a purple heart-shaped spot in the centre; stipules toothed; flowers yellow, solitary, or 2-4 together ; pods in 2-6 compact spiral coils, with a double row of spines, forming a prickly ball.-On gravelly soil in the South and West of England; not uncommon. In Cornwall, under the name of Spotted Clover, this plant is con-

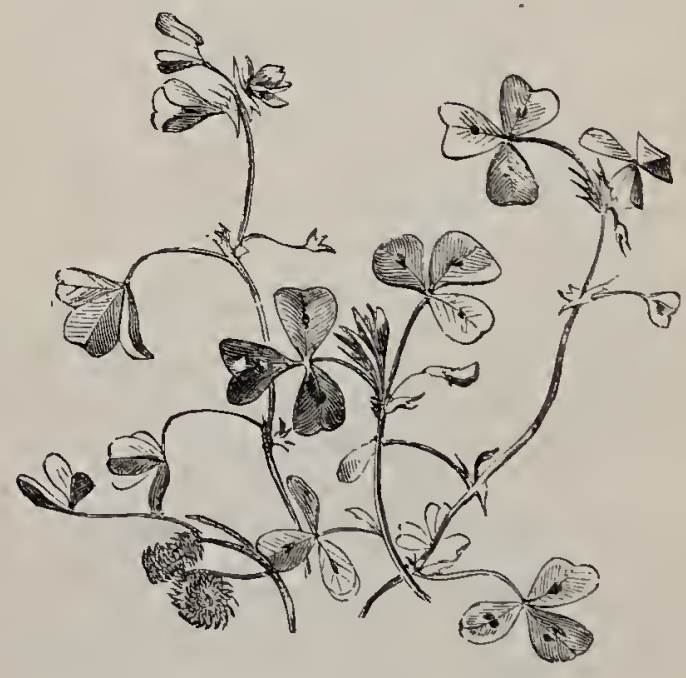

IAEDICAGo ARíbICA (Spotted Merick).

sidered very mjurious to pasturage.-Fl. May-_September. Annual.

7. M. mínima (Little Bur-Medick).-A downy prostrate species; 7eaflets inversely egg-shaped; stipules slightly toothed; flowers yellow, solitary, or $2-6$ together; pods in 4 or 5 compact spiral coils, with a double row of spines.--Sandy places; rare.-Fl. May -July. Annual. 
7. Melicótus (Melilot).--Tall, annual or biennial, fragrant herbs, with leaves as in the preceding genera; small, drooping, yellow or white flowers in long racemes ; caly $x$ 5-toothed; stamens diadelphous; pods short, straight, indehiscent. (Name of Greek origin, from meli, honey, and lotos, the plant so called.)

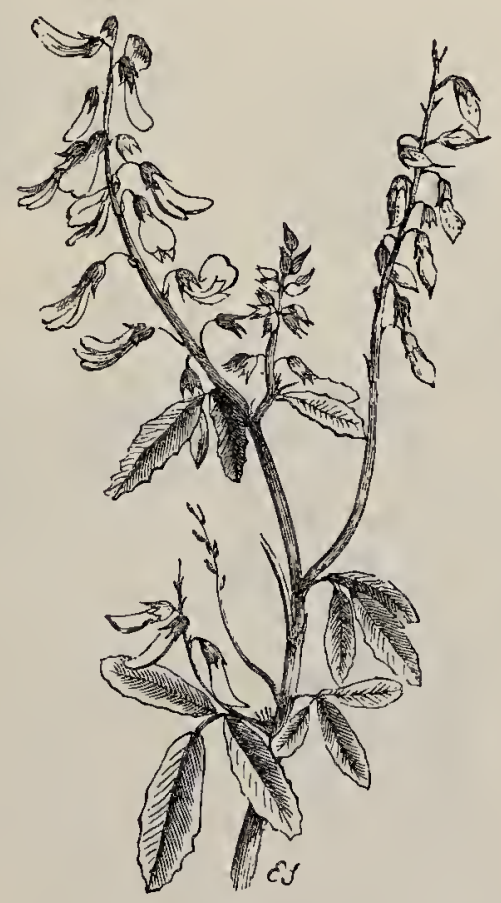

MELILÓtuS OFFICINÁIIS (Common Yellow Mielilot).

1. M. officinátis (Common Yellow Melilot).-An erect, branched, slightly woody plant, $2-3$ feet high; leaflets light green, linear-ovate, toothed; flowers small, yellow, in long, erect, 1 -sided racemes; pods compressed, ovoid, acute, hairy, black when ripe, 1-2-seeded. While drying, this plant smclls like 
woodruff; or new hay.-Waste places; not uncommon.-Fl. June-August. Annual or biennial.

2.* $M$. alba (White Melilot), differing in liaving smaller white flowers and smooth pods, is much less

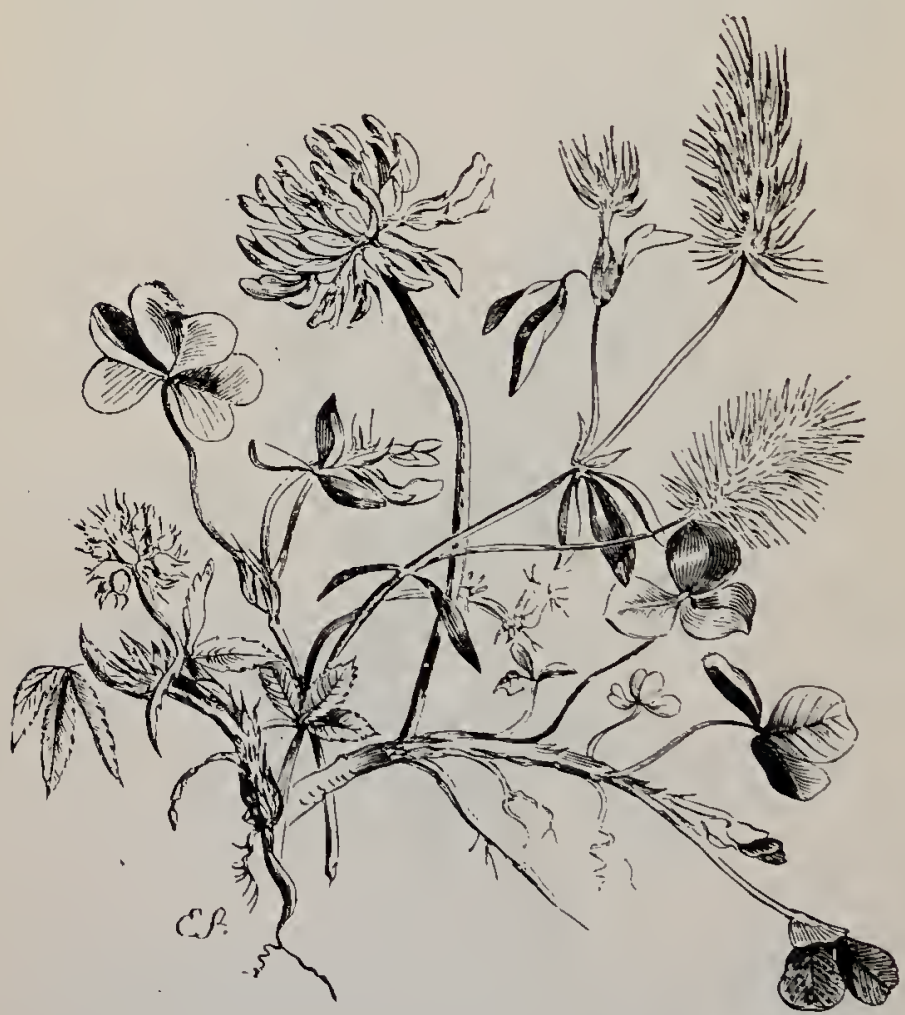

THIFÓ.IUM STRICTUM, SUBTERRANEUM, RÉPENS, and ARTÉNSÉ.

common and doubtfully native.-Fl. July, August.

3.* M. aménsis, a biennial species, witl pale yellow or white flowers and smooth pods, becoming olive-brown when ripe; and 
4.* M. inclica, a small, slender annual with very small pale yellow flowers and smooth, globose pods, becoming olive-green when ripe, occur in waste places.

8. Trifódud (Clover, Trefoil). - Herbs with ternate leaves; stipules adnate to the petiole; flowers sessile or sub-sessile, in heads or spikes, rarely solitary, red, white, or rarely yellow; caly. $x$ unequally 5-toothed; petals persistent; stamens diadelphous; pod small, nearly enclosed in the calyx, indehiscent, 1-4-seeded. (Name from the Latin tri, three, and fólium, a leaf.)

* Heads few-flowered, awillary : throat of calyn nalced.

i. T. subterráneum (Subterranean Clover).-A curious little plant, with prostrate, branched, hairy stems ; and small axillary heads of white flowers, $3-5$. together, with numerous 5-toothed abortive calyces which cover the pods, as the head bends abruptly downwards after flowering, burying itself in the ground.-Dry sandy places; uncommon.-Fl. May, June. Annual.

Heads many-flowered, teminal : throat of calyn with a roing of hairs: pod 1-seeded.

\section{$\dagger$ Heads ovoid on globose.}

2. T. praténsé (Red Clover).--Leaflets broad, notched or entire; stipules broad, terminating abruptly in a long bristle; flower's red, or sometimes white, in terminal, secsile, dense roundish-oblong heads; caly.x hairy, its bristle-like teeth half as long as the corolla. - The common Clover of meadows, where it forms a valuable part of the hay crop. 
There are also improved cultivated varieties. The corolla tubes abound in honey, on which account children often call them Honeysuckles. The Howers are very sweetly-scented.-Fl. All the summer. Perennial.

3. I. méclium (Zigzag Clover).--Not unlile the last, but distinguished by its more slender, erect, zigzag habit; narrower, elliptical, slightly hairy leaflets; lanceolate, not abrupt, stipules; and loose, stalked, round heads of flowers.-D Dry pastures and bushy places; common. It thrives better than $T$, praténsé, in dry soils.-Fl. June-September. Perennial.

4. T. ochroleúcon (Sulphur-coloured Trefoil).-Erect, 6 -18 in. high, downy; lower leaces on very long stalks; flowers cream-coloured, turning brown as they fade, in terminal, stalked, dense heads, which are at first globose, afterwards ovate.-Dry pastures in the eastern counties; rare.-Fl. June-August. Perennial.

5. T. squamósum (Teazel-healed Trefoil).-Stem spreading, usually procumbent; stipules awl-shaped, very long; flowers small, pink, in terminal, stalked, roundish heads; calygr-teeth awl-shaped, ciliate, shorter than the corolla, finally becoming enlarged, broad and spreading. - Salt marshes in the South of England.Fl. June, July. Annual.

\section{t+ Heals cylindric, during or after flowering.}

6.* T. incarnátum (Crimson Clover).-Erect, downy, with spreading hairs; leaflets obornte; stipules ovate, blunt; flowers deep crimson, in solitary, terminal, stalked, cylindric heads $1-3$ in. long; calyx-teeth hairy, shorter than the corolla, spreading in the fruit. - A common fodder crop, sometimes escaping.-Fl. June, July. Annual. 
7. T. Molinêrii (Large-headed White Trefoil).Perhaps the original wild form of the preceding, from which it differs in being shorter, and in having ad. pressed hairs and white or pink flowers in conical heads about 1 in. long.-On the cliffs at the Lizard, Cornwall.-Fl. June, July. Annual.

8.* T'. stellátum (Starry-headed Trefoil).-A prostrate form, with terminal, stalked, globose heads of small cream-coloured flowers, and hairy calyx-teeth spreading remarkably in a star-like manner in fruit. -Occurs as a casual on the shingle near Shoreham, Sussex.-Fl. June; July. Annual.

9. T. arvénsé (Hare's-foot Trefoil). - Softly hairy, erect, branched ; fiowers small, pale pink, in terminal, stalked, cylindric heads about 1 in. long, and almost concealed in the long, very soft, russet hairs of their calyces.-A very distinct species; common in sandy places.-Fl. July_September. Annual.

**** Ileads many-flowered, terminal and axillary.

† Throat of calyx with a ring of hairs: pod 1-seeded.

10. T. Boccóni (Boccone's Trefoil).-A small. pubescent erect species, 2-6 in. high, with oblong stipules with bristly points, and sessile dense conical heads, usually 2 together, of small white flowers. -Grows in dry places at the Lizard._Fl. July. Annual.

11. T. striátum (Soft Knotted Trefoil).-A prostrate, ascending, silky species with small rose-coloured flowers in sessile, terminal and axillary, ovate downy heads; and a ribbed calyx swelling after flowering.-Dry places, especially near the sea; frequent.-Fl. June, July. Annual.

12. T. scábrum (Rigid Trefoil)._A small downy, prostrate plant, with inconspicuous white flowers in sessile, dense, ovoid, terminal and axillary heads, which 
become prickly from the rigid, spinescent, spreading calyz-teeth when in fruit.-Dry places; often growing with the preceding, but less common.-Fl. MayJuly. Annual.

\section{† Throat of calyyx glabrous : pod 2-4-seeded.}

13. T':glomerátum (Smooth Round-headed Trefoil). -Very similar to the preceding, but glabrous and with rounder heads of purplish flowers and more leafy broad calys-teeth, which are spinescent and reflexed in fruit.-Gravelly places near the sea; rare.-Fl. June. Annual.

14. T. suffocátum (Suffocated Trefoil).-A small, slender, glabrous, prostrate plant, with its stem usually buried in sand; small white flowers ino void heads, which are often confluent; calyx-teeth lanceolate, longer than the corolla, recurved but not spiny in fruit.--Sandy sea-shores; rare.-Fl. June, July.
Annual.

15. T. strictum (Upright Round-headed Trefoil). -A small, ascending, glabrous species; leaflets linearlanceolate, toothed; flowers small, rose-coloured, in stalked globose heads; caly.x-teeth subulate, spreading. -Rocks, Jersey and the I.izard, where it was first found by the Rev. C. A. Jolnns in 1847 ; very rare.Fl. June, July. Annual.

\section{*******ar Heads many-flowered, axillary: throat of calyx:}

16.* T. hýbridum (Alsike Clorer).-A tall, erect, branched, glabrous plant; petioles long; stipules leafy, ovate-lanceolate; flowers white or pale pink, becoming brown; in stalked, globose, drooping heads ; caly/2 -tceth nearly equal, subulate, crect.--A cultirated plant, introduced from Alsike, near Upsala, Sweden.-Fl. June-September. Perennial. 
17. T'. répens (White or Dutch Clover).-Stem creeping; leaflets often with a white band and a purplish spot near the middle; flowers stalked, white, sometimes tinged with pink, fragrant, fading to

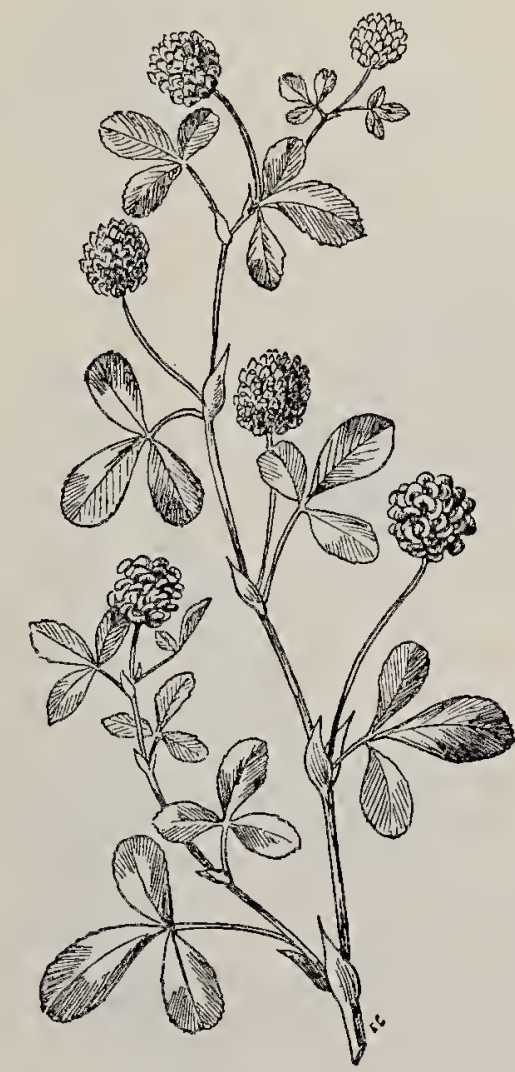

TRIFÚLIUM PROCÚMBENS (Hop Trefoil).

brown and bending downwards, in roundish heads; pod 4-seeded.-Abundant in meadows, where it forms excellent pasture. In a variety commonly cultivated in gardens, under the name of Shamrock, nearly the 
whole of the centre of each leaflet is tinged with dark purple. The real Shamrock is probably this species or any other "3-leaved grass"; but some antiquarians contend that, as Ireland was well-wooded in St. Patrick's time, it was probably a leaf of the WoodSorrel (Oxalis Acetosella) that the Saint selected to illustrate the doctrine of the Trinity. On St. Patrick's Day (March 17th) the distinctive characters of the trefoils are scarcely developed.-Fl. all through the summer. Perennial.

18. T. fragiferum (Strawberry-headed Trefoil) has the habit of the preceding; but the flowers are rosecoloured, and the large globose heads of inflated calyces, enclosing the 1-2-seeded pods and often tinged with pink, are not unlike the fruit from whicl the plant is named.-Damp meadows; not very common.-Fl. July, August, Perennial.

19.* T. resupinátum, a similar species, but with shorter peduncles, smaller bracts, and reversed (resupinate) flowers, occurs as a casual._-Fl. July.
Annual.

20. T. mocúmbens (Hop Trefoil).-A small, downy plant with dense oval heads of about 40 yellow flowers, resembling Medicágo lupulina in labit, but at once distinguished when in fruit by the tawny, hoplike heads of withered flowers, the standard petals persisting and arching over the pods; style shorter than the pod. Dry pastures; abundant.-Fl. June - August, Annual.

21.* T. agrárium, a closely-allied form with the style as long as the pod and the heads larger, occurs as
a casual.

22. T. dubium (Lesser Yellow Trefoil), with much smaller heads than $T$ : procúmbens, 4-20-flowered, turning dark brown, is even more common in dry places.-Fl. J !nne-August. Annual.

23. T. filfórmé (Slender Yellow Trefoil)._A small, prostrate, very slender, slightly hairy species, with 
very small 2-7-flowered loose heads, is much less common.-Fl. June, July. Annual.

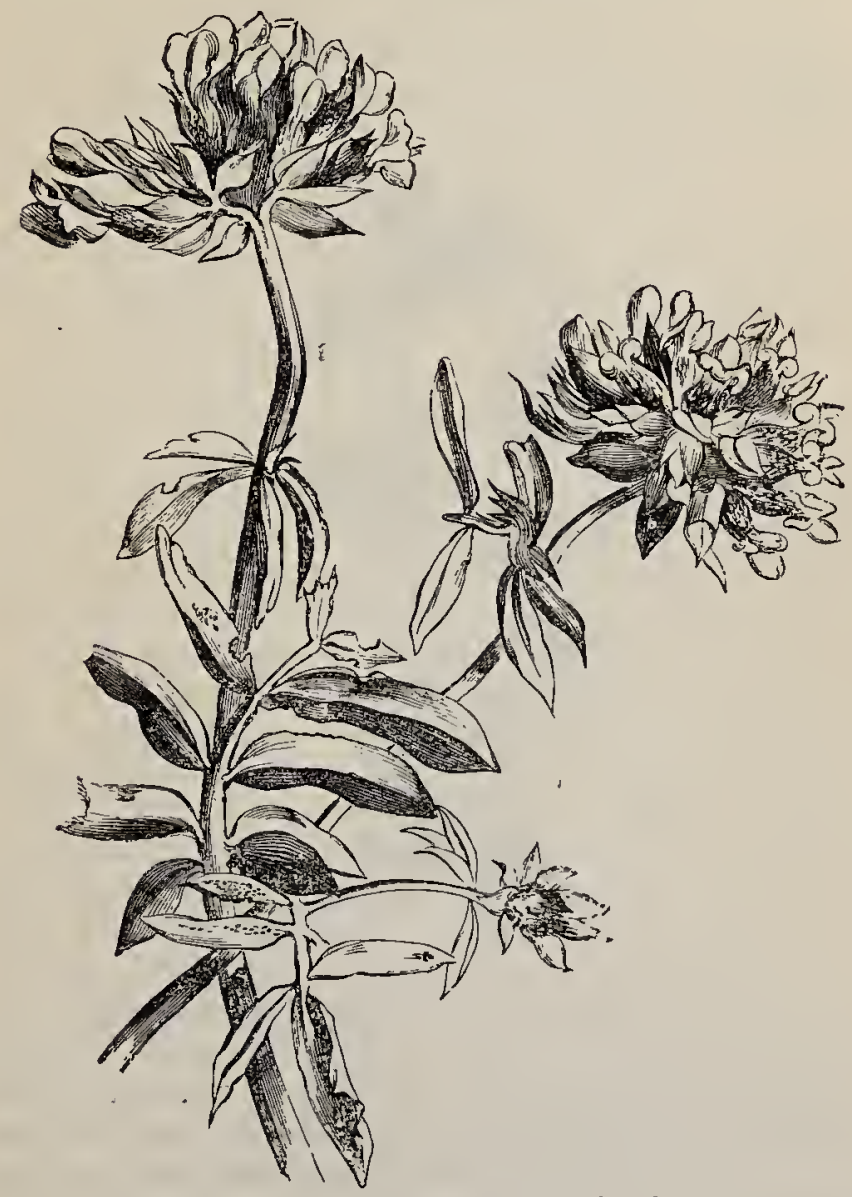

ANTHÍLLIS VULNEŔrRL (Common Lady's Fingers).

9. ANтнÝLLIS (Kidney-Vetch).-Herbs or shrubs; leaves imparipinnate; flowers in capitate cymes; calyw inflated; petals with long claws; stamens monadelph- 
cus; rod enclosed in the calyx, 1-seeded. (Nawic of Greek origin.)

1. A. Vulnerária (Kidney-Vetch, Lady's Fingers). -The only British species, a handsome, herbaceous, silky plant, with pinnate leaves (the terminal leaflet largest), and yellow flowers, with pale inflated calyces.

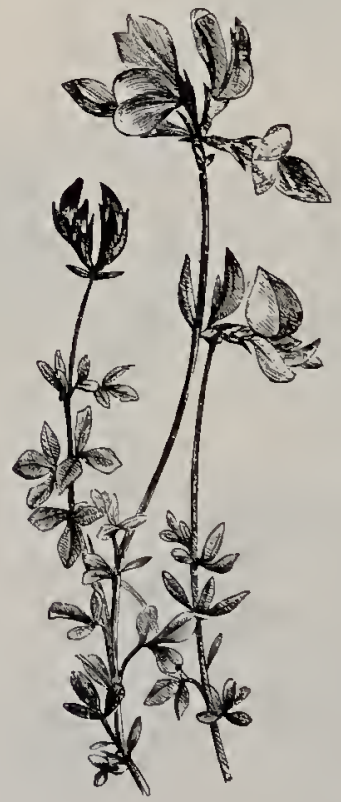

Lótus CORNiculatus (Cummon Bird's-foot Tiefonl).

The dense, many-flowered heads of flowers grow two togrether at the end of each stalk, like the two lobes of a kidney. There are white and red-flowered varieties.-Dry pastures.-Fl. June-August. Pel-
ennial.

10. Lótus (Bird's-foot Trefoil).--Herbs or undershrubs; leaves of 4 or 5 leatlets; stipules minute or 
absent; flowers in long-stalked, capitate or umbellate, cymes; calyx not inflated ; stamens diadelphous ; poct longer than the calyx, straight, cylindric, manyseeded. (Name of Greek origin.)

1. L. corniculátus (Common Bird's-foot Trefoil).A pretty familiar flower; stems prostrate, ascending; leaves usually almost glabrous, or with few or many long soft hairs; flowers in umbellate cymes, 5-10 together on long peduncles and very short pedicels, generally deep orange in the bud, and varying in the same umbel from bright yellow to deep brownishorange; calyx-teeth erect in bud, two upper oness converging; pods about an inch long, diverging like the toes of a bird.-Pastures ; abundant-Fl. JuneSeptember. . Perennial.

2. L. ténuis (Ŝlender Bird's-foot Trefoil), differing in its more slender, thread-like stem, narrower, pointed leaflets, and fewer and smaller flower's, grows in damp places, and is less common.

3. L. uliginósus (Greater Bird's-foot Trefoil).Generally hairy, but sometimes glabrous, $1-3$ feet high ; stems tubular, weal, and usually supported by surrounding plants; leaflets obovate; peduncles very long; flowers deep yellow, 5-12 together; calywteeth, while in bud, spreading like a star, two upper ones diverging.-Damp places; common.-Fl. July, August. Perennial.

4. L. angustźssinus (Least Bird's-foot Trefoil).-A much smaller plant than $L$. comiculátus, prostrate, hairy, with shorter pecluncles; flowers solitary or 2 together, small, yellow, fading green; pods an inch or more in length. - South of England, near the sea; very rare.-Fl. July, August. Annual.

5. L. hispidus (Hispid Bird's-foot Trefoii), a closelyallied, more silky form, with flowers 2-4 together, not fading green, and pods not more than $\frac{3}{4} \mathrm{in}$. long, occurs very rarely, near the sea, in Dorset, Devon, and Cornwall.-Fl. July, August. Annual. 
11. Astrágalus (Milk-vetch).-Herbs with stipulate, imparipinnate leaves; flowers in axillary racemes or spikes; calyx with 5 sub-equal teeth; corolla with blunt keel; stamens diadelphous; porl witl a longitudinal septum, 2-valved. (Name from the Greek astrágalos, a pastern bone, but not applicable to this genus.)

1. A. alpinus (Alpine Milk-vetch). - A slender, prostrate, hairy plant, with 10-12 pairs of oblong leaflets; free stipules; shortly-stalked, close racemes of a few drooping flowers, which are white or pale blue, tipped with purple; and pendulous pods covered with black hairs. - Occurs very rarely on Scottish mountains.-Fl. July. Perennial.

2. A. dánicus (Purple Milk-retch).-A similar species, with 8-10 pairs of leaflets; connate stipules, opposite the leaf; peduncles longer than the leares; flowers many, ascending, in ovoid heads, purple; and erect pods.-Dry soil, in the eastern counties; rare.-Fi. June, July. Perennial.

3. A. glycyphýllos (Sweet Milk-vetch).-A much larger species; stems $2-3$ feet long, stout, prostrate, zigzag, glabrous; leaflets in $5-6$ pairs; stipules free; flowers in short-stalked, dense, short racemes, creamyyellow; pods erect, curved, smooth.-Thickets on a chalky or gravelly soil; uncommon.-El. Jume, July.
Perennial.

12. OxÝtropis.- - Herbs, distinguished from Astrógalus mainly by having $九$ mucronate point to the keel of the corolla. (Name from the Greek oxús,
sharp, trópis, a keel.)

1. O. uralénsis (Hairy Mountain Oxytropis).-A low plant; leaves radical ; leaflets in about 12 pairs; peduncles longer than the leaves, erect, silky, 6-10flowered; flowers bright purple; pods erect, silky.Dry mountain pastures in Scotland; rare.-Fl. June,
July. Perennial. 
2. O. campéstris (Yellowish Mountain Oxytropis).-A larger, hairy, but less silky species, with peduncles scarcely longer than the leaves, and yellowish flowers tinged with purple. Occurs only in the Clova mountains.-Fl. June, July. Perennial.

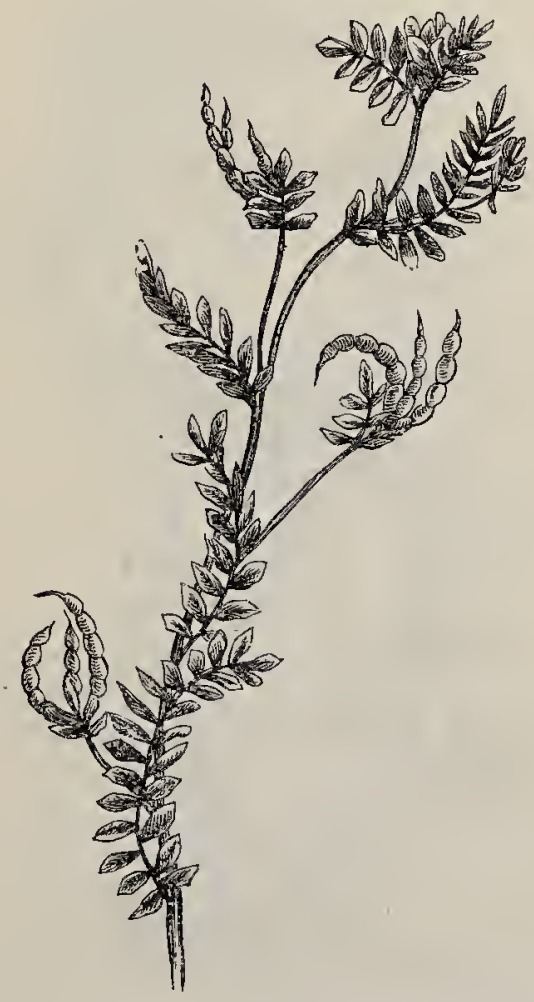

ORNÍTHOPUS PERPUSflLUS (Common Bird's-foot).

13. Orníthopus(Bird's-foot).-Slender, hairy herbs ; leaves imparipinnate; flowers few, minute, in longstalked heads; stamens diadelphous; pods curved, indehiscent, with many oval, 1-seeded joints. (Name 
from the Greek poús, a foot, ornithos, of a bird, from the shape of the fruits.)

1. O. perpusíllus (Common Bird's-foot). - A pretty

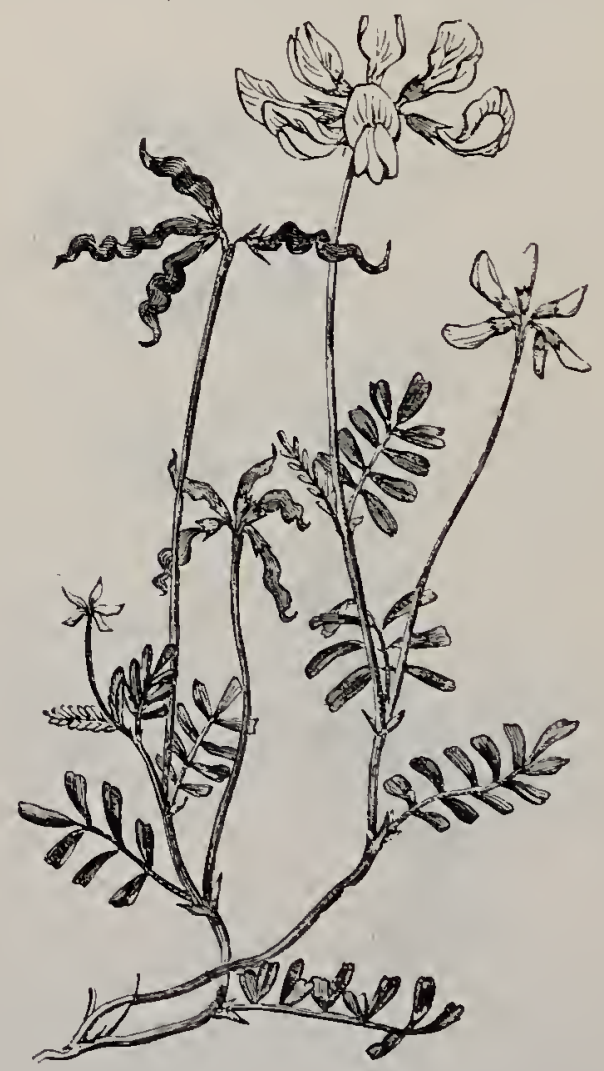

HIPPOCRÉPIs comósA (Tifted Horseshoe-retch).

little plant, with spreading, prostrate, slender stems; downy leaves of $13-25$ leaflets; exceedingly small cream-coloured flowers, veined with crimson, with a leaf below each head; and curred 7 -2-jointed pods, 
ending in a claw-like beak. - Sandy heaths ; frequent. -Fl. May--August. Annual.

2. 0 . ebracteatus (Sand Joint-vetch). - A very

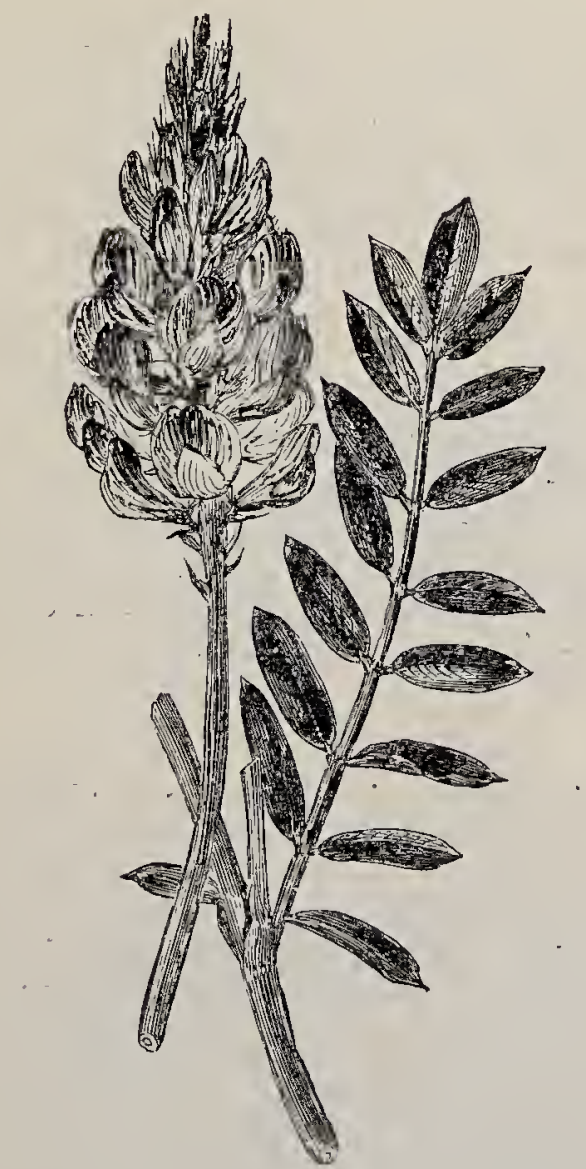

ONÚBRYCHIS VICLEFÓLIA (Common sainfon).

similar plant, nearly glabrous, glaucous, with larger, yellower flowers; no leaf below the head of flowers; and 10-14-jointed, less constricted pods,-Occurs in 
the Scilly and Channel Islands.-Fl. June-August. Annual.

- 14. HippocrépIs (Horseshoe-vetch). - Low-growing, glabrous herbs; leaves imparipinnate; leaflets many; flowers yellow; petals long-clawed; keel incurved, pointed; stamens diadelphous; pod flat, breaking up into 3-6 1-seeded horseshoe-shaped joints. (Name from the Greek hippos, a horse, krepisis, a shoe.)

1. H. comósa (Tufted Horseshoe-retch).-The only British species, a nearly prostrate plant, with long, much-branched stems, woody at the base; leafiets $7-17$; and umbellate heads of $6-10$ yellow flovers. It might be mistaken for Lótus conniculátus; but the pinnate leaves and pods resembling a series of horse-shoes, united by their extremities, serve to distinguish it. - Chalky banks in the South of England. -Fl. May-August. Perennial.

15. Oxóbrycins (Sainfoin).-Herbs; leaves umparipinnate; stipules membranous; flowers in axillary spikes or racemes; stamens diadelphous; pod compressed, indehiscent, straight, 1-seeded. (Name from the Greek onos, an ass, brecho, I bray.)

1. O. vicicefólin (Common Sainfoin, Cock's-head).-The only British species, a handsome plant; pubescent with adpressed hairs; stems $1-2$ feet long, ascending, stout; leaflets 17-25, oblong, apiculate; flowers in ovoid, compact racemes, rosy-red, with darker veins; pod semicircular, toothed along its lower (curved) margin.-Chalky and limestone hills, perhaps indigenous in the South-east of England; but often cultivated as fodder.-Fl. June--August. Peren. nial. 
16. VícIa (Vetch.)--Herbs, generally climbing by the tendrils which terminate their paripinnate leaves; leaflets generally many; flowers in axillary racemes; stamens diadelphous; style thread-like, with a small xing of down near the extremity, or a tuft on the under side; poct compressed, 2-valved. (Name, the classical Latin name, originally derived, according to 'Théis, from the Keltic gwig, German wiclien, Greek bition, French vecce.)

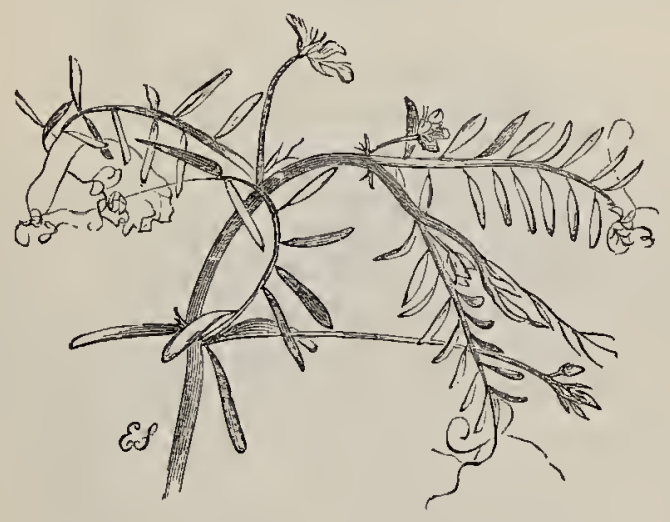

VICIA HIRSÚtA (Hairy Tare).

* Annuals : leaflets few : flowers few: siyle with a riny of down. (Tares.)

1. V. hirsuita (Hairy Tare).-A slender, muchbranched, hairy plant, forming tangled masses of stems and leaves; leaflets 12-16; flowers 1-6 together, minute, pale blue; pods sessile, hairy, 2seeded.-Fields and hedges; very common. This, though a mischievous weed, is not the Tare of Holy Scripture, which is supposed to be the Darnel (Lólium temuténtum).-Fl. May-August. Annual. 
2. $\quad$. gemélla (Smooth Tare).-More slender, less branched, almost glabrous ; leaflets $6-12$; flowers 1-2 together, minute, pale blue; porls shortly stalked, glabrous, 3 - 5 -seeded. - In similar situations with the last, but less common.-Fl. May-August. Annual.

3. V. grácitis (Slender Tare), a closely-allied form, with 6-8 leaflets; flowers twice as large, $1-4$ logether and pods longer, 5-8-seeded, occurs in the South of Ergland.-Fl. May-August. Annual.

\section{** Perennials: leaflets many: flowers very many: style with a ring of hairs.}

4. V. Crácea (Tufted Vetch)._-Leaflets about 20 , narrow, pointed, silky, with branched tendrils; stipules half-arrow-shaped, entire; flowers crowded in 1 -sided, 10-30-flowered racemes, blue and purple. -Bushy places; very common. One of the most. ornaniental of British plants, adorning the tops of the hedges with its bright flowers.-Fl. JuneAugust. Perennial.

5. T. Órobus (Bitter Vetch).-A branched, herbaceous plant, with many prostrate stems; leaflets $14-20$, oblong, acute, without tendıils ; stipules halfarrow-shaped, slightly toothed; flower's in loose, Isided, 6-20-flowered lacemes, purplis-h-white.-Rocky woods, mostly in the north.-Fl. May-September. Perennial.

6. T. sylética (Wood Vclch).-A large and beautiful species, with a long stem, 3-6 feet high, climbing by means of its branched tendrils; leafiets about 16, elliptical, abrupt, with a short point; stipules crescent-shaped, reeply toothed at the base; flowers in loose, 1-sided, 6-18-flowered 1acemes, creamcoloured, with bluish reins.-Mountainous woods; not common.-Fl. June-August. Perennial. 
**** Leaflets many : flowers ferv: style tufted below stigma on one side.

7. T. sépium (Bush Vetch).-Leaflets 12-16, ovate, obtuse, decreasing in size towards the apex of the

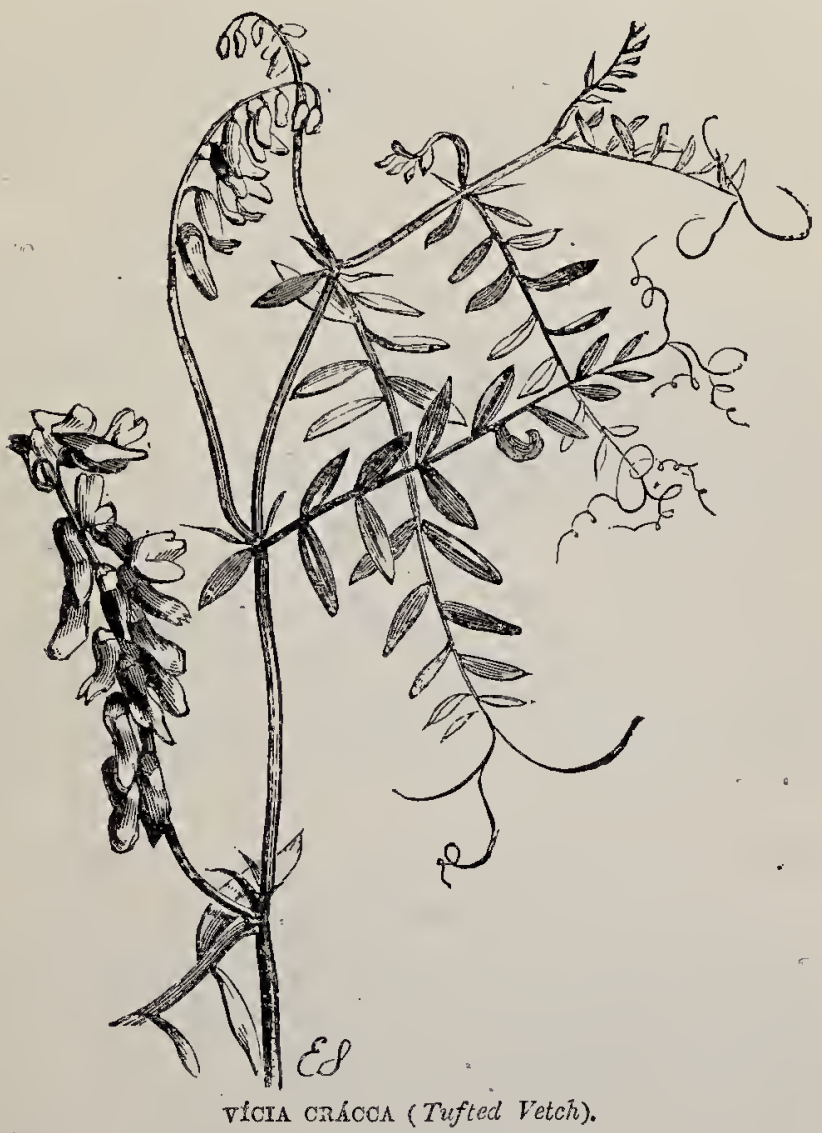

leaf ; fiowers in nearly sessile axillary clusters of 4-6, bluish purple; pods smooth.--Woods and hedges, very common.-Fl. May-August. Perennial. 
8. V. lútea (Rough-podded Yellow Vetch)._About 2 feet long, prostrate; leaflets 10-14; flowers solitary, sessile, rather large, pale yellow; pods hairy. -Sea-coast; rare.-Fl. June-August. Perennial.

9.* V. Tevvigáta (Smooth-podded Vetch), a smaller form, which is glabrous, and has pale blue or whitish flovers, has been found on the beach at Weymouth.

10.* $V$. hybrida, differing from $T^{\top}$. túteci in having reddish-yellow flowers with a hairy standard petal, is recorded from Glastonbury Tor and from Swan Pool, near Lincoln.

11.* V. sativa (Common Vetch).-Stem stout, about 2 feet high; leaflets 10 - 14, oblong, mucronate, the lower ones often obcordate; stipules half-arrowshaped, toothed at the base, often with a dark blotch ; flowers large, in pairs, blue and purple or red; pods ascending, parallel to the stem, $2-3$ in. long, linear, silky.-Fields; common as an escape, being extensively cultivated as fodder for cattle.-Fl. AprilJune. Annual.

12. $V$. angustifótia (Narrow-leaved Vetch).-A slender form, closely allied to the preceding, but with very narrow leaflets, red flowers, and spreading pods. Occurs truly wild.-Dry places; common.-Fl. May,
June. Annual.

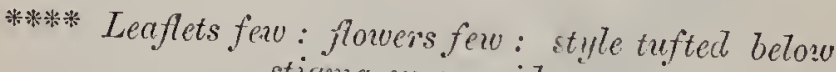 stigma on one side.}

13. V. Tathyróïdes (Spring Vetch).-Nearly allied to the last, but very much smaller, prostrate, and rarely exceeding 6 in. in length; $;$ lextlets $2-6$;
stipules entire, not marked with a dark spot; flowers
solitary, sessile, small, purple; solitary, sessile, small, purple; pods glabrous.-Dry places; not common.-Fl. April-June. Annual.

14. $V$. bithýnica, 1-2 feet long, trailing and smooth, with $4-8$ leaflets, and solitary (rarely $2-3$ together), stalked, purple flowers, with paler wing- 
petals, hairy calyx, and long, hairy pods, occurs rarely in bushy, gravelly places near the sea.-Fl. MayAugust. Perennial.

17. Láthyrus (Vetchling).-Herbs, closely allied to Vicia, but with fewer leciflets, broader petals, and a flattened, longitudinally bearded style. (Name of Greek origin.)

* Anmuals: no true leaflets: flowers solitury.

1.-L. Áphaca (Yellow Vetchling).-A pretty trailing glabrous plant, remarkable for being entirely destitute of leaflets, the place of which is supplied by a pair of very large ovate-hastate stipules at the base of each tendril ; flowers ycllow.--Sandy and gravelly fields in the south; rare.-Fl. May-August. Annual.

2. L. Nissólia (Crimson or Grass Vetchling).-A beautiful and well-marked species, with upright slender stems, 1-3 feet high ; leaves reduced to grasslike linear parallel-veined phyllodes, $3-6$ in. long, without tendrils; flowers small, deep crimson.-Grassy places in the south; not common.-Fl. May-July. Annual.

\section{* Leaflets 2; with tendrils: flowers ravely solitary.}

3. L. Tirsîtus (Rough-podded Vetchling), with its flowers pale blue, with a crimson standard, in pairs, and hairy pods, occurs, very rarely, in Essex and Surrey.-Fl. June, July, Annual.

4.* L. sphcericus, with solitary flowers, has been found in Hertford-hire.

5. L. praténsis (Meadow Vetchling).-A climbing plant, 2-3 feet long; with angular stem; lanceolate leaflets, large, arrow-shaped stipules; short tendrils ; 


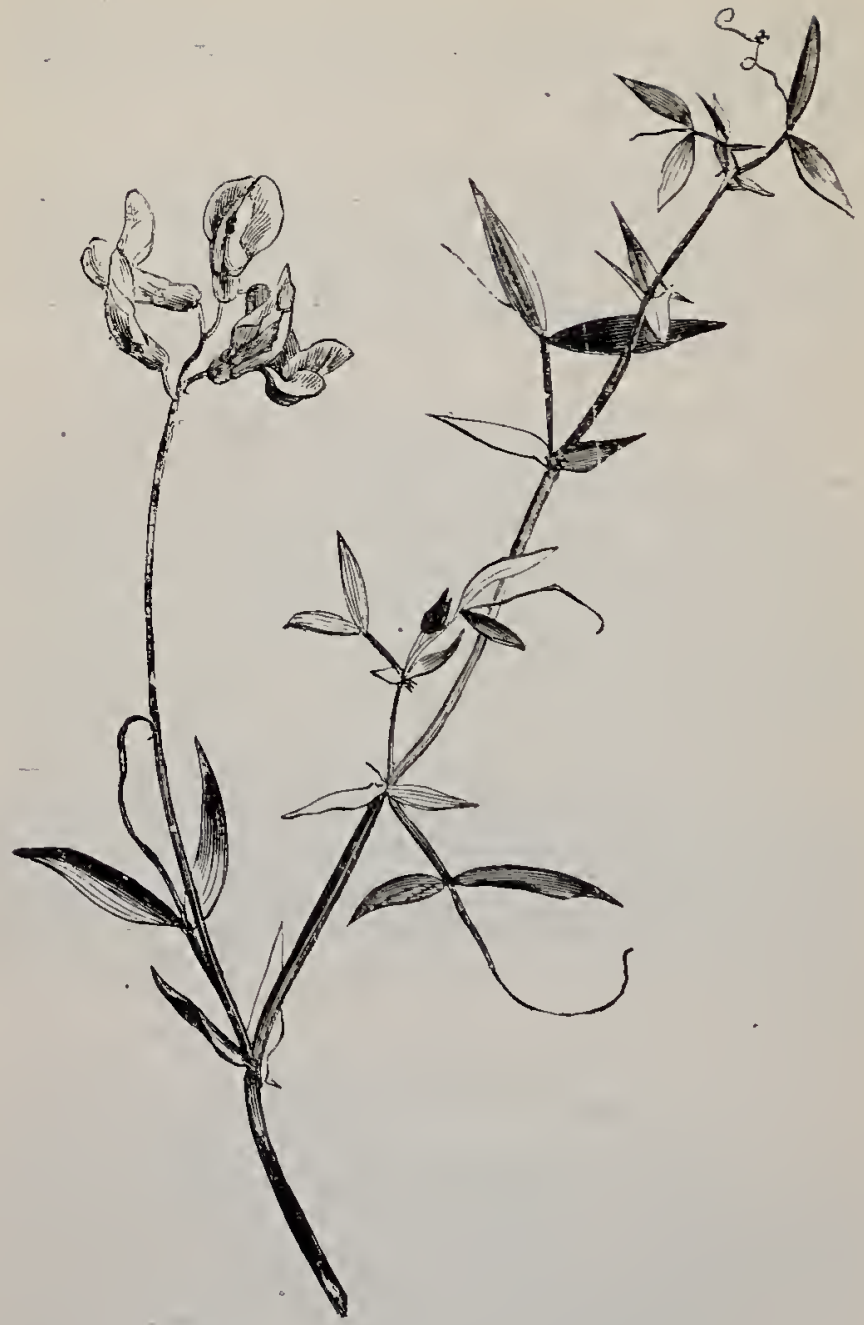

LÁTHYRUS PRATĹXSIS (Meadore Tetchling).

long peduncles: fiover: 3-12 together, pedieellate, showy, bright yellow, all turning one way.-Hedges 
and meadows; very common.-Fl. June-September. Perennial.

6.* L. latifótius (Everlasting Pea), with broad oval lecuftets and pink flowers, more than an inch across, occurs only as an escape from gardens.

7. L. 'tuberósu: (Peas Earth-nut), with edible tuberculate roots; angled stem; ov:te leaflets; large half-arrow-sliaped stipules; and long peduncles bearing 2 to 5 crimson flowers, $\frac{3}{4}$ in. across, occurs rarely in Essex, where it may have been introduced by the Dutch in the sixteenth century.-Fl. June-August. Perennial.

8. I. syluéstris (Narrow-leaved Everlasting Pea).A clambering plint, glabrous and crlaucous; stems winged, 2-6 feet; leaflets sword-shaped; flowers $\frac{3}{4}$ in. across, with rose-coloured standard aud greenish-yellow wings tinged with purple, not so handsome as those of the garden species.-Rocky thickets; not uncommon.-F]. June--September. Perennial.

***** Perennials : leaflets 4-10 : tendrits slcort : flowers 2-10 together.

9. L. patústris (Blue Marsh Vetchling)._A climbing plant, smaller than the last; stem winged; leaflets $4-8$, very narrow, acute ; flowers bluish-purple, $2-6$ together.-Boggymeadows; rare.-Fl.June-August. Perennial.

10. I. marétimus (Seaside Everlasting Pea).Stem prostrate, glabrous, glaucous, angled, not winged; leaflets 6-10, egg-shaped; peduncles shorter than the leaves, 5-10-flowered; flowers purple, variegated with crimson and fading to blue.-Pebbly sea-shores; rare.-Fl. June-August. Perennial.

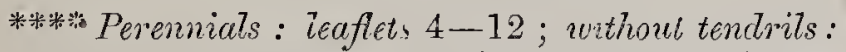
flower:s 2-8 together. (Bitter Vetches.)

11. L. montánus (Tuberous Bitter Vetch).-Root 
tuberous; stem simple, erect, winged; leaflets 4-8, oblong, glaucous beneath; stipules half-arrow-shaped; flower's axillary, purple, variegated with purple, fading to green or blue.-Woods; common. A pretty spring Vetch, growing in similar situations with the Wood Anemone, but appearing somewhat later. - It may be at once distinguished by being destitute of tendrils, the place of which is supplied by a soft, bristle-like

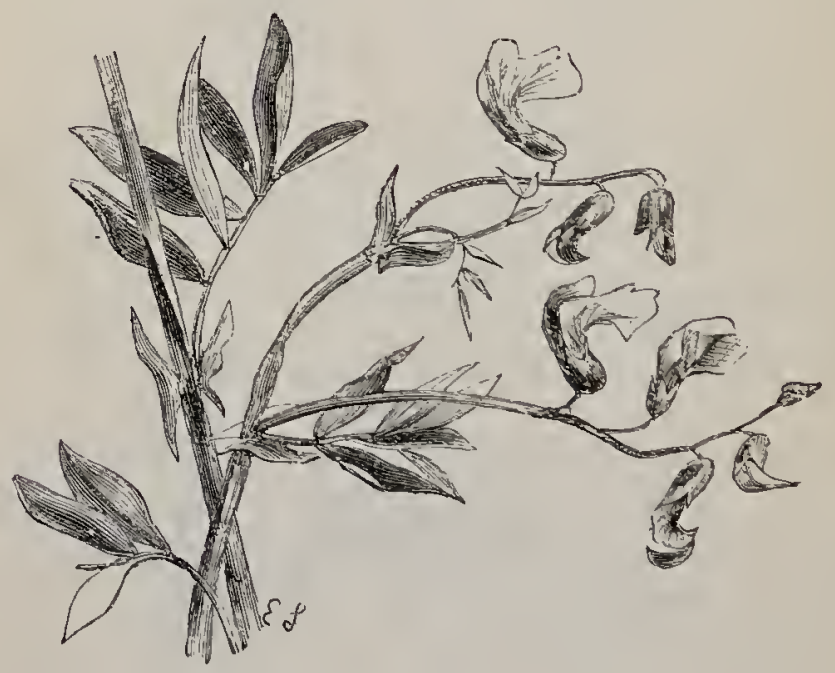

LATHYRUS Montints (Tuberous Bitter Vetch).

point. The tubers were eaten in the Srottish Highlands, under the name of Cormeille, a very small quantity being said to allay hunger.-Fl. May-
August. Perennial.

12. L. níger (Black Bilter Vetch), distinguished by its branched, angled, but not winged stem, and its very narrow stipnles, occurs rarely in rocky woods in Scotland. It turn; black when dried.-Fl. JuneAugust. Perennial. 


\section{Ord. XXVI. Rosácex.-The Rose Family.}

A large and important Order occurring in all parts of the world, and comprising about a thousand species of trees, shrubs, and herbs. They mostly agree in having scattered, stipulate leaves; polysymmetric and generally pentamerous flowers; segals united, usually 5 , the odd one being posterior, occasionally 4,8 , or 10 : petals 5 , perigynous; and stamens indefinite. In the number of the carpels, their cohesion, and still more their adhesion, and in the forms of fruit resulting from their fertilisation, the members of the Order present great diversity; so that, natural as is the Order as a whole, it is subdivided, as naturally, into seven tribes. The Prunece are trees and shrubs of the North Temperate Zone, the bark of which often exudes a somewhat insoluble gum; the leaves are simple and, with the seeds, generally yield a considerable quantity of the deadly poison, prussic or hydrocyanic acid ; and the fruit is a drupe or stonefruit, consisting, that is, of one carpel with a skin or epicarp, flesh or mesocarp, stone or endocarp, and containing one kernel or seed. Plums, Cherries, A pricots, Almonds,. Peaches, and Nectarines belong to this tribe, as do also the common Laurel, or CherryLaurel, as it is best to call it, and the Portugal Laurel. Our cultivated Plums are varieties of Prúnus doméstica, the fruit of which has a waxy bloom. Cherries are the fruit of various species of a sub-genus Cérasus, said to be named from a city of Pontus, whence the Roman general Lucullus introducerl a superior kind, B.c. 67. They have a polished epicarp, as have also the evergreen Cherry-Laurel (P. Lauro-cérasus) and Portugal Laurel (P. Tusitanica). The crushed leaves of the Cherry-Laurel give off' a vapour containing prussic acid, and are therefore used by entomologists for killing insects. P. Armenáaca, with woolly epicarp and smooth stone, is the Apricot; Amýgdalus pérsica, 
with a wrinkled stone and a woolly epicarp, the Peach, of which the Nectarine is a smooth variety; and $A$. communis, with woolly skin, stringy flesh, and a punctured surface to the stone, the Almond. This species is wild from Afghanistan to the Barbary States, and is extensively cultivated in the South of Europe. There are two varieties, one yielding the sweet, the other the bitter AImond. Jordan Almonds, which are considered the best sweet almonds, are brought from Malaga; bitter almonds from Mogador. Many fatal cases are recorded of poisoning by the Oil of Bitter Almonds. 'The Spirece are herbs or shrubs, the fruit of which consists of a ring of follicles. Several species of Spirćca are ornamental garden plants. The Rúbece are mostly shrubs, and their fruits, which include the well-known Raspber'y and Blackberry, are etrerios of drupels. The shoots of the brambles are astringent. The Potentillex, which include the Strawberry (Fragária), are mostly herbs, and their fruits are etrerios of achenes, the 1seeded carpels being dry and indehiscent, though borne in the Strawberry on a fleshy outgrowth from the receptacle. Some members of this tribe are astringent and tonic. The Poteriéce are herbs, often without petals, and sometimes wind-pollinated, which have their $1-3$ achenes enclosed within the calyxtube. The Rósew are shrubs with a characteristic form of etario of achenes, the numerous carpels being enclosed in a fleshy calyx-tube. Rose-water and Attar of Roses are made from the petals of Rósa centifólia and $R$. clamascéna, 100,000 Roses, the produce of 10,000 bushes, being said to yield only nine drams of Attar. This costly perfume is largely adul. terated with "Oil of Geranium," the produce of a fragrant grass. A conserve used in medicine is prepared from the pulp of the fruit of the Rose, or "hip" as it is called. Lastly, the Pómece are trees or shrubs with the characteristic fruit known as a 
pome, in which the $1-5$ horny or stony carpels ars imbedded in a fleshy adherent calyx-tube, comprising the Apple, Pear, Quince, Medlar, Rowan, and Hawthorn. All the cultivated varieties of Apple are derived from the wild Crab, Pýms Málus, and the Pears from a thorny tree, with a hard astringent fruit, Pýrus communis. The wood of the Pear is very closegrained and is used in making T-squares. The fruit of the Rowan, and some other species, yields malic acid, and the. leaves as much prussic acid as those of the Cherry-Laurel.

Tribe 1. Prúnece.-Leaves simple: calyx deciduous: fruit a drupe.

1. Prúnus.-Stone smooth.

Tribe 2. Spirece.-Calyx persistent: carpels 5 or more : fruit an etcerio of follicles.

2. Spirét-Sepals 4-5; carpels 5-12.

Tribe 3. Rúbece.-Caly.x persistent: carpets many: fruit an etcrio of drupels.

3. Rúbus._Receptacie convex, spongy; ovutes 2 in each carpel.

Tribe 4. Potenitilece.-Calyx persistent, with an epicalyx : carpels 4 or more : oviles 1 in each carpet: fruit an etcerio of achenes.

4. DrÝas.--Leaves simple; scape 1-flowered; styles becoming feathery.

5. GÉun. - Leaves pinnate; scape several-flowered ; styles becoming hooked aw $x_{i s}$.

6. Fragúaria.-Lecuves ternate; achenes on fleshy receptacle; style not elongating.

7. Potentíli. - Leaflets 3,5 , or many, palmate or pinnate ; achenes on dry receptacle; style not elongating. 
Tribe 5. Poteriéce.-Petals 5 or absent : carpels 1-5: fruit 1-5 achenes (1-seeded ${ }^{2}$ ) enclosed in small dry caly,c-tube.

8. Alchemílda. - Sepals 4 or 5 , with an epicalyx; petals absent; stamens $1-4$; achenes 1 -5.

9. Agrimóxia.-Sepals 5 ; petals 5 ; stamens 12 20 ; achenes 2.

10. Роти́rium.-Sepals 4 ; petals absent; stamens $4-30$; achenes $1-3$.

Tribe 6. Rósece.-Petals 5 ; carpels many, 1-sected, enclosed in the large fleshy calyy-tube.

11. Rósa.-Sepals 5 ; petals 5 ; stamens indefinite.

Tribe 7 . Pómece.-Petals 5 ; carpets 1-5, 1-2seeded; fruit a pome.

12. PÝRus.-Finit 2-5-chambered; core horny.

13. Cratégus.-Fruit 1-5-chambered; core stony.

14. Сотолеáster. - Fruit 2-5-chambered; core stony, projecting.

1. Prúnus (Plum, Cherry).-Trees or shrubs; Teaves simple, serrate, with glands on the petiole; sepals 5, deciduous; petals 5, white; stamens 15-20; fruit a drupe with a smooth stone. (Name classical.)

* Leaves convolute: drupe glaucous.

1. P. spinósa (Blackthorn or Sloe).-Branches very - spinous with blackisll bark; leaves narrow, clliptical, smooth above, slightly downy near the midrib below; flowers mostly solitary, appearing before the leaves; fruit nearly round, $\frac{1}{2}$ in. in diameter, black and very austere.-Woods and hedges; abundant. A well-known bush deriving its name from the hue of its bark, which is much darker than that of the Haw. 
thorn or Whitethorn, as it is often called. The leaves are said to be used to adulterate tea, and the fruit, which is so austere that a drop of its juice placed on the tongue will produce a roughness on the throat and palate perceptible for a long time, is said to enter

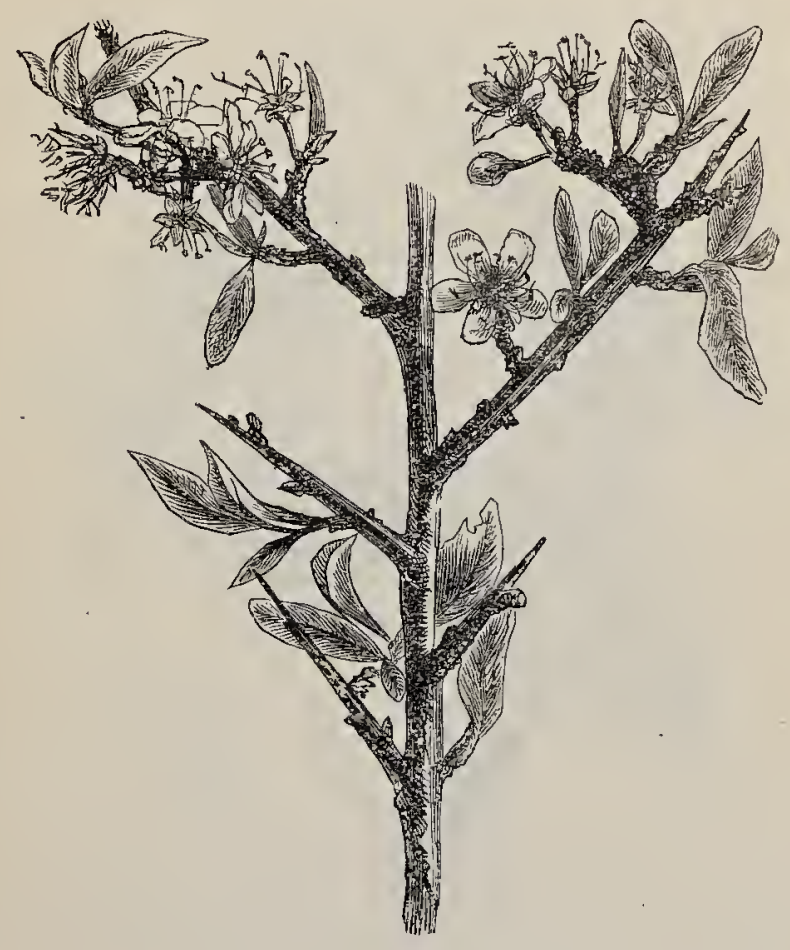

PRÚNUS SPINóSA (Sloe or Blaclithorn).

largely into the composition of spurious port vine.Fl. March, April. Perennial.

2. P. insitítia (Bullace).-Branches ending in a spine, with brown bark; leaves elliptical, downy beneath; flowers in pairs, appearing with the leaves; frist globose, pendulous, nearly 1 in. in diameter, 
black or yellow, more palatable than the sloe.Woods and hedges. Larger than the last.-Fl. A pril, May. Perennial.

.* P. doméstica (Wild Plum).-.A small tree with-

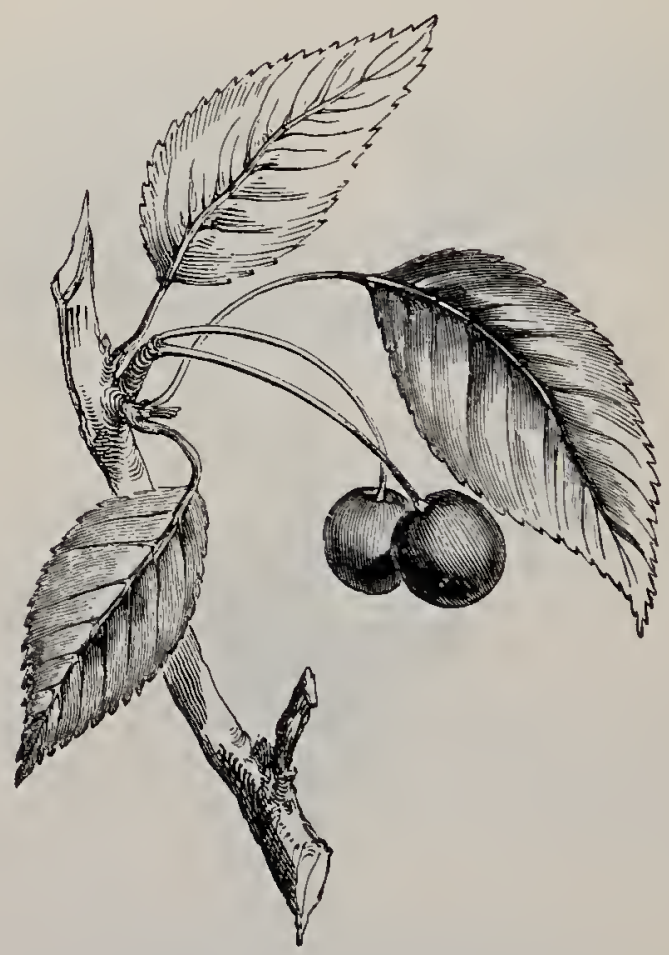

PRÚxUS RVIUM (Gean).

out spines, with brown bark; Teaves downy on the veins beneath; fruit oblong, an inch or more in diameter, sweet.-The original of our cultivated Plums, not indigenous in Europe-Fl. April, May. 
* Leaves condupticate: drupe polished.

4. P. Ávium (Wild Cherry, Gean).-A tree 20-30 feet high, with smooth bark and few or no suckers; leaves drooping, abruptly pointed, downy beneath;

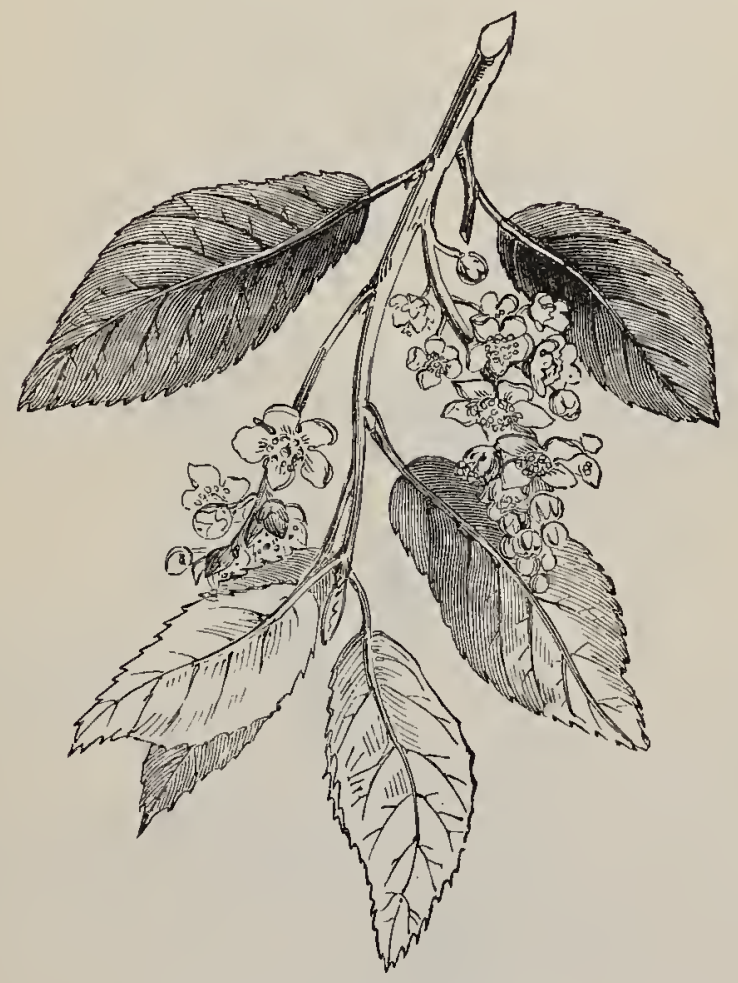

PRÚNUS PÁDUS (Bird Cherry)

flowers in umbels; calyx-tube contracted above; fruit heart-shaped, bitter, black, or red.-Woods and hedges; common. A highly ornamental tree, not only on account of its elegant white flowers in spring, but even more so in autumn, when its leaves 
assume a bright crimson hue. As soon as it is ripe the fruit is greedily devoured by birds. This species is the origin of the Morella Cherry.-Fl. May. Perennial.

5. P. Cérasus (Dwarf or Red Cherry). - A shrub not more than 8 feet high, with redder bark and many suckers; leaves not draoping, smooth on both sides; flowers in umbels; caly. $x$-tube not contracted; fruit round, juicy, acid, and red. The origin of the sweet varieties of cultivated cherries.-Hedges; less common.-Fl. May. Perennial.

6. P. Pádus (Bird Cherry).-A handsome small tree; leaves narrow, egg-shaped; flowers in pendulous racemes ; fruit ovoid, black, bitter.-In the North of England not uncommon in a wild state, and common elsewhere in shrubberies. The clusters of flowers and drupes are not unlike those of the Portugal I aurel, a nearly allied species, but the leaves are not evergreen. -Fl. May. Perennial.

2. Sprr我A.-Herbs or shrubs; teaves scattered, generally stipulate; flowers numerous, snull, in cymes; sepals 4 or 5 , persistent ; carpels 5 or more; orules 2 or more in each carpel; fruit a ring of follicles. (Name from the Greek spéira, a coil.)

1.* S. salicifólza (Willow-leaved Spirea). - A shrub witl simple exstipulate leaves and spike-like clusters of rose-coloured flowers.-Moist woods in the north and in Wales; not indigenous.-Fl. July, August. Peremnial.

2. S. Ulmária (Meadow-sweet, Queen of the Meadows). - $\Lambda$ tall, herbaceous plant, 2-4 feet liggh ; lecues interruptedly pinnate, white and downy beneath, terminal leaflet very large and lobed; flowers in densely crowded, erect, compound cymes, creanywhite, very fragrant.-Moist places ; common.-Fl. June-August. Perennial. 
3. S. Filipéndula (Dropwort). - A herb about a foot high, with short rhizome and nodulose rootlets; leaves

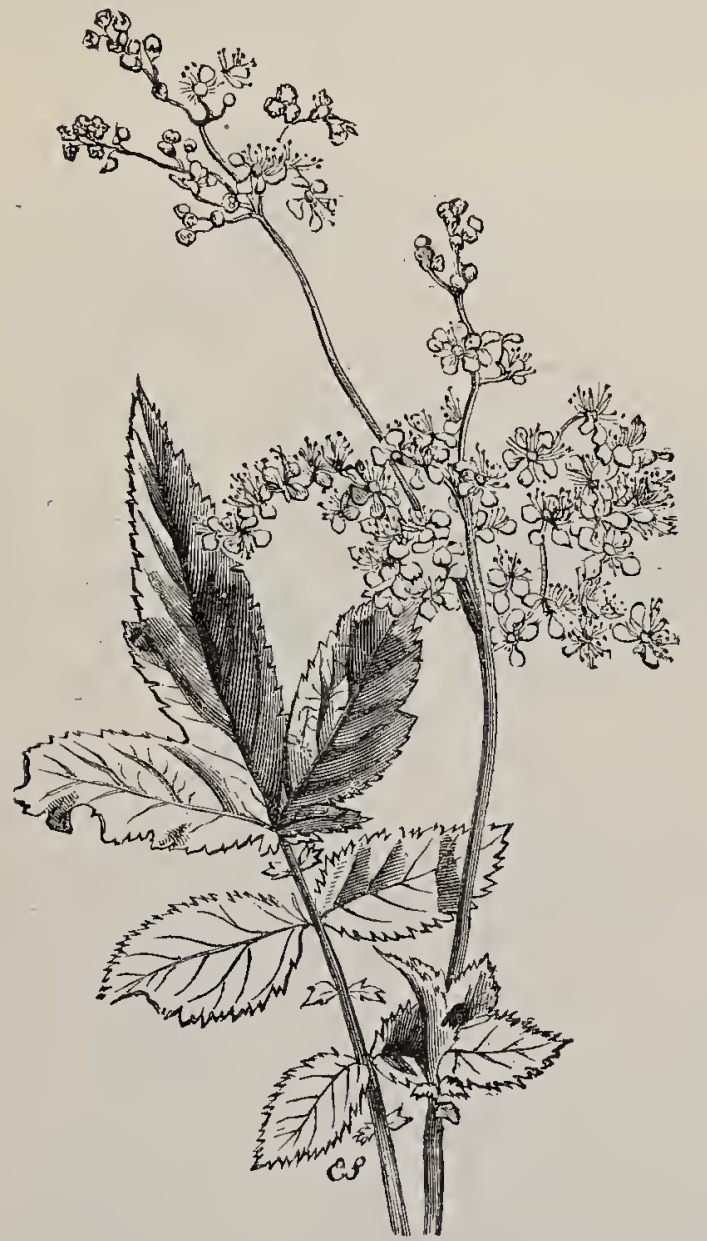

SPIREA ULMRRIA (Meadow-sweet, Queen of the Meadows).

interruptedly pinnate, leaflets cut into narrow serrated.segments; flowers in crowded, erect, compound 
cymes, pink externally in bud, when open, white and scentless.-Dry pastures on a limestone soil. Distinguished from the preceding by its elegantly cut foliage, pink buds, and whiter, scentless blossoms. A double-flowered variety is common in gardens.-Fl. June, July. Perennial.

3. RúBus (Bramble).--Shrubs or herbs, usually prickly; leaves scattered, stipulate; flowers in terminal and axillary clusters, rarely solitary, white or pink; sepals 5, persistent; petals 5; carpels many, on a convex, spongy receptacle; ovules 2 in each carpel; frut an etærio of 1-seeded drupels. (Name classical.)

1. R. idaus (Raspberry). $-A$ shrub with many suckers, and nearly erect, round, glaucous, prickly stem : Teaves pinnate, of $3-5$ leaflets, white and hoary beneath ; flowers drooping; fruit hoary, red, or ambercoloured, separating from the receptacle when ripe. - Rocky woods; common. The origin of the garden raspberry, which differs but little from it.-FI. May -August. Perennial.

2. R. fruticósus (Bramble or Blackberry)..-The collective name for a large number of closely allied forms, which, though many of them have fairly definite distinctive characters, are difficult to discriminate. They agree in being shrubs, without suckers, with prickly stems; leaves of $3-5$ leaflets arranged palmately or pedately; flowers in erect compound panicles; and fruit claret-colour or black, not separating from receptacle when ripe. Nearly a hundred species have been described as British, besides many named varieties; but it will be suflicient here to describe the nine nain groups under which these puzzling forms are arranged. Group I., SuberéctiStems usually sub-erect, rarely rooting at the tip, glabrous or very slightly bairy, without bristles or gland-tipped hairs, witl priclles mostly equal and 
confined to the angles of the stem; stipules linear; leaves, when mature, green beneath; sepals green, with narrow white margin; drupels numerous. Group II., Rhamnifólii_Stems high-arching, often rooting from a callus at the tip and thus giving rise

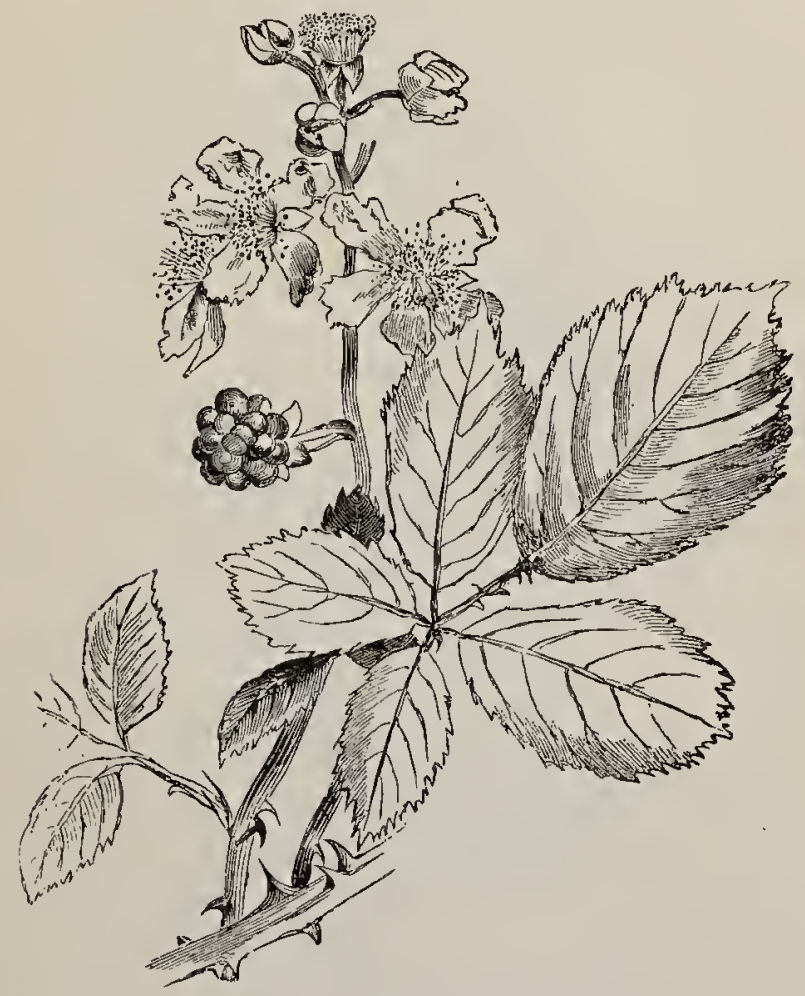

RÚBUS FRUTió́sUS (Blackberry).

to a multitude of individuals, glabrous, or with few hairs, usually without stalked glands; prickles mostly equal and confined. to the angles; sepals grey, or white-felted, with no conspicuous white margin, often reflexed in fruit; fruit large, black, juicy. Group 
III., Discolbres-Stems arched or prostrate, rooting at the end, with adpressed hairs and equal strong prickles, with no stalked glands; leaves quinate, white-felted beneath; sepals grey, reflexed in fruit; petals often pink; drupets small. Group IV., Sitvátici-Stems arched, prostrate, rooting at the end, with spreading hairs, moderate-sized nearly equal prickles, and few stalked glands or bristles; leaves usually green beneath; sepals usually refesed in fruit; petals sometimes deep pink. Group V., Egrégii-Stems arched or prostrate, generally with some scattered stalked glands and bristles, with subequal prickles chiefly on the angles; flower-stath's with some stalked glands; sepals seldom reflexed. Group VI., Rácluloe-Stems generally low-arching and rooting, rough throughout with numerous bristles and stalked glands, with subequal prickles, the larger ones nearly confined to the angles; flover-stalks with numerous short-stalked glands and bristles. Group VII., Koehteriuni-Siems low-arching or prostrate, rooting, clothed with very unequal scattered prickles, bristles and stalked glands, the larger prickles strong; petals often pink. Group VIII., BellardiániUsually small, low-growing plants; stems mostly prostrate and roundish, rooting and often glaucous, densely clothed with unequal stalked glands, bristles and weak prickles; leaflets all stalked; stipules filiform. Group IX., Césii (Dewberry)-Stems lowarching or creeping, roundish or slightly angular, rooting, glaucous, with prickles mostly slender; flowers large; fruit of a few large drupelets, often with a grey bloom.- Most of the species flower from June to August, and ripen their fruit in September and October.

3. R. saxátilis (Stone Bramble). - A small herbaceous species; stem rooting, $1-2$ feet high, with few scattered bristles, or none; leaves of 3 leaflets; flowers few together, umbellate; petals small white; 
fruit of $1-4$ distinct scarlet persistent drupels on a flat receptacle.-Stony places, chiefly in the North.Fl. June-August. Perennial.

4. R. Chamcemórus (Cloudberry).--A very distinct species, with a long subterranean rtizome;

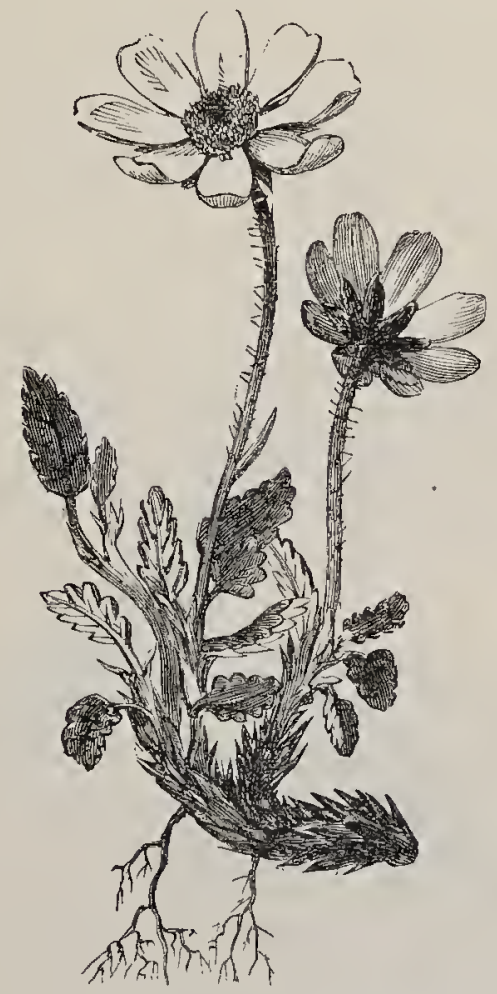

DRYAS OCTOPÉTALA (Mountain Avens).

flowering-branch erect, 4-8 in. high, without prickles; leaves obtusely 5-7-lobed; flowers large, terminal, solitary, white, diœcious; fruit of a few large drupelets, first red, then orange, with the colour, fragrance, and taste of apricots.-Alpine 
peat-bogs in the north. This fruit, the amrons of Scotland, moltebeere of Norway, or maroshka of Northern Russia, makes a delicious preserve.-Fl. June, July. Perennial.

4. Dryas (Mountain Avens).--Prostrate tufted herbs; leaves simple, white beneath; stipules adnate to the petiole; flowers large, solitary; sepals 8 or 9 in one whorl, valvate, persistent; petals 8 or 9 ; carpels many, sunk in the calyx-tube, one-oruled; styles persistent, feathery; fruit an otwrio of achenes. (Name from the Greek dricas, from the resemblance of the leaves to those of the oak.)

1. D. octopetala (Mountain Arens).-The only British species; Teares oblong, coarsely crenate-serrate, hoary beneath; flowers an inch or more across, white; petals 8.- In mountainous, chiefly limestone, districts in the north ; rare. An easily recognised and handsome flower.-Fl. June, July. Perennial.

5. G6um (Avens).-Erect herbs; Teares lyratelypinnate; stipules adnate to the petiole; scape usually several-flowered; sepals 5 , persistent, with an epicalyx of 5 bracteoles; petals 5 ; carpels many, 1-ovuled; styles persistent, jointed, hooked; fruit an etrrio of achenes. (Name from the Greek geno, I taste, the roots being aromatic.)

1. G. urbanum (Common Avens, Herb Benet).An erect, hairy plant, $1-2$ feet high; radical leaves pinnate; cantine leaves ternate; stipules leafy, rounded and cut; flowers erect, $\frac{1}{2}-\frac{3}{4}$ in. across, yellow; upper joint of the stiff persistent style shorter, smooth.-ITedges and thickets; common.-Fl.JuneAugust. Perennial.

2. G. viváté (Water Avens) - A handsome plant, stouter and more hairy than the precediug, differing in having smaller stipules; drooping flowers, $1-1 \frac{1}{2}$ 
in. across ; reddish-brown sepals; obcordate, yellow, pink-tinged, veined petals; a stalk or carpophore below the fruit; and the two joints of the persistent style equal and hairy.-Damp places; not uncommon.-Fl. May-July. Perennial.

$G$. intermédium, partaking of the characters of

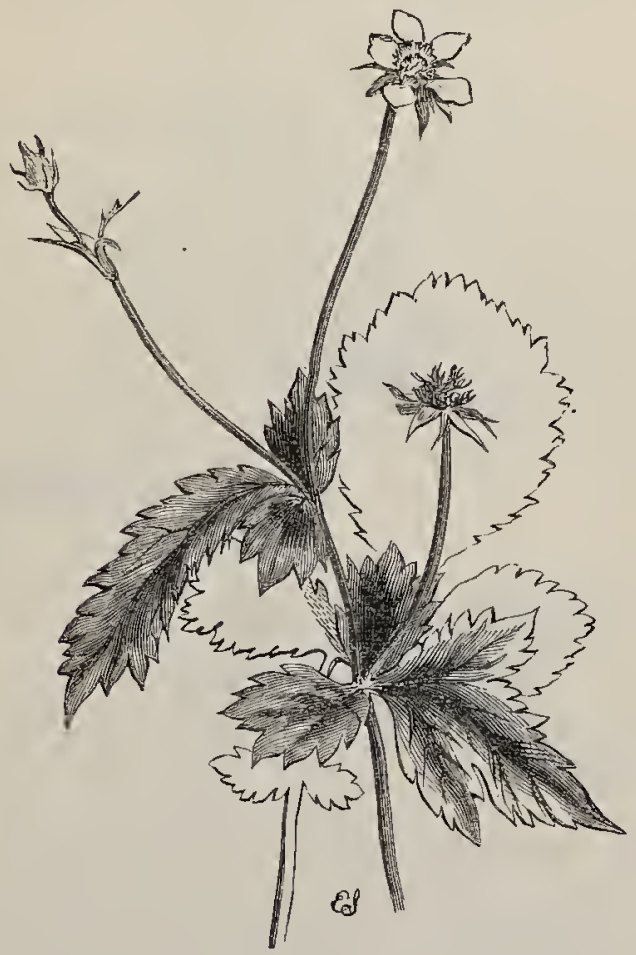

GÉum urbánum (Common Avens, Herb Benet).

both the above species, is probably a hybrid between them.

6. Fragária (Strawberry).-Herbs with runners; teaves generally ternate; stipules adnate to the petiole; 
sepals 5 ; persistent, with an epicalyx of 5 bracteoles, valvate; petals 5; corpels many, 1-oviled; styles lateral, persistent; fruit an etærio of achenes which are sunk in the surface of a fleshy receptacle. (Name from the Latin fraga, strawberries, which is probably connected with fragrans, fragrant.)

1. $I^{T}$. vésca (Wood Strawberry).-Leaflets sessile,

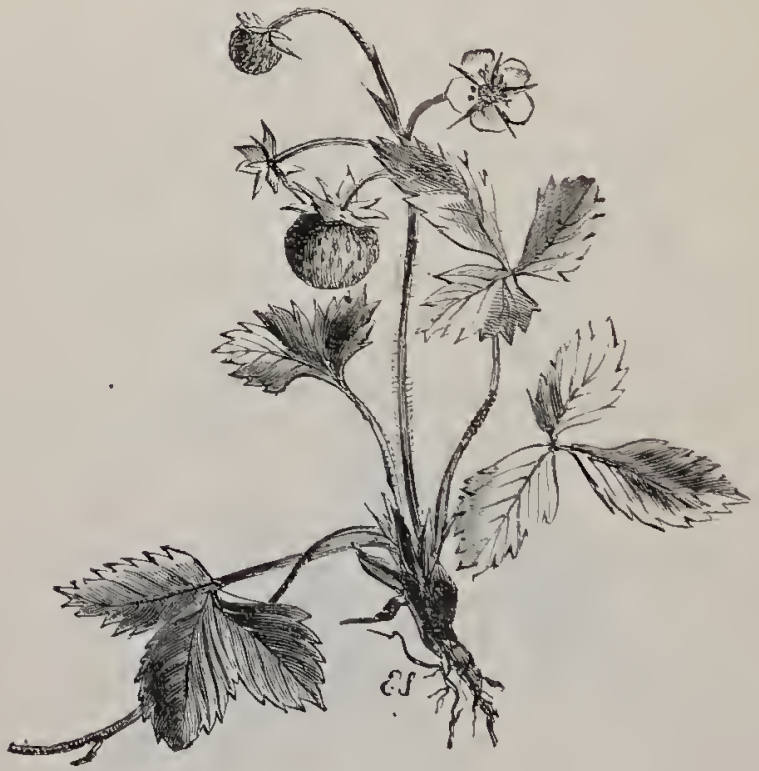

IRAGSRIA TÉscA (Tood Strawberry).

bright green, hairy; peduncle erect, few-fowered, with spreading hairs; pedicels drooping in fruit, with adpressed hairs ; flowers white, $\frac{1}{2}$ in. or more across ; calya reflexed in fruit.-Woods and thickets; common. A well-known plant, distinguished by the above characters from the Barren Strawberry (Potentifla Fragariástrum), which is often mistaken for it by young botanists. The Strawberry apparently derives 
its name from the custom of laying straw between the rows of plants in gardens.-Fl. April--July. Perennial.

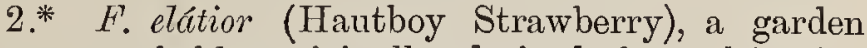
escape, probably originally derived by cultivation from the preceding, is larger, more hairy, with spreading hairs, and has stalked leaflets and some diœcious flowers.-Fl. June-September. Perennial.

7. Potentílda (Cinquefoil). - Herbs, rarely shrubby; leaves pinnate or palmate of 3,5 , or more leaflets; stiputes adnate to the petiole; flower's generally yellow or white ; sepals 5, or rarely 4, persistent, with an epicalyx of 5 or 4 bracteoles; petals 5 , rarely 4 ; stamens 4-10, or many; carpels 4-10, or many, 1-ovuled; fruit an etærio of achenes on a small dry receptacle; style not elongating. (Name from the Latin potens, powerful, from the medicinal properties of some species, especially, perhaps, of P.palustris, an astringent tonic.)

* Stamens many: achenes many, glabrous or nearly so: receptacle concave.

1.* $P$. norvégica, with stem erect, 8-10 in. high; leaves palmate ; and flowers yellow in crowded terminal racemes, has been found in Burwell Fen, Cambridgeshire, and in Yorkshire; but has probably been introduced with Norwegian timber. Annual.

2.* P. hirta, with stem erect ; leaves of $5-7$ muchtoothed leaflets, obovate on the radical and linear on the 'cauline leaves, is also not indigenous.

3. P. Fragariástrum (Barren Strawberry).-Prostrate, without runners, silky; leaves ternate; leaflets obovate, crenate, very hairy beneath; peduncles slender; flowers white, not more than $\frac{1}{2}$ in. across ; petals short, notched.-Banks and hedges; abundant. 
One of the earliest spring flowers, often confounded by beginners with the wild strawberry, from which the above characters serve to distinguish it.--Fl. January-May. Perennial.

4. P. vérna (Spring Cinquefoil). - A small woody hairy plant, about $5 \mathrm{in}$. long; leaves of $5-7$, obo-

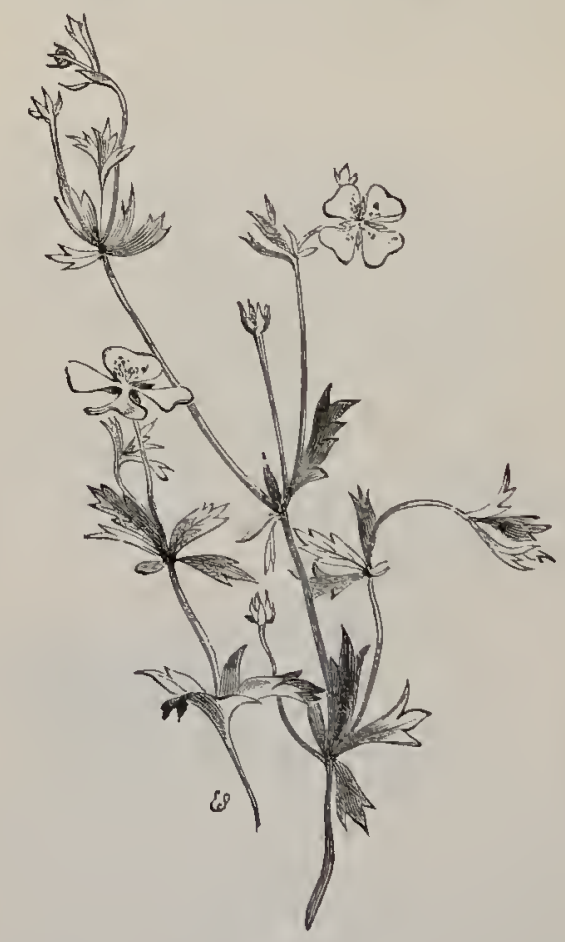

POTENTLLA SILVÉSTRIS (Common Tormentil).

vate serrate leaflets, hairy on the edge and on the veins beneath; flowers yellow, $2-3$ together, $\frac{1}{2}$ in. across.-Dry pastures; not common.-Fl. AprilJune. Perennial.

5. P. rúbens (Alpine Cinquefoil).-A larger, nore erect, but closely allied species; stem 4-10 in. 
high; flowers 1 in. across.-Alpine rocks in Scotland, Wales, and the North of England ; rare.-Fl. June, July. Perennial.

6. P. silvéstris (Common Tormentil). - A small, sub-erect plant; rhizome woody; stems 6-10 in. high, slender, leafy, with curly hairs; leaves of 3 , or

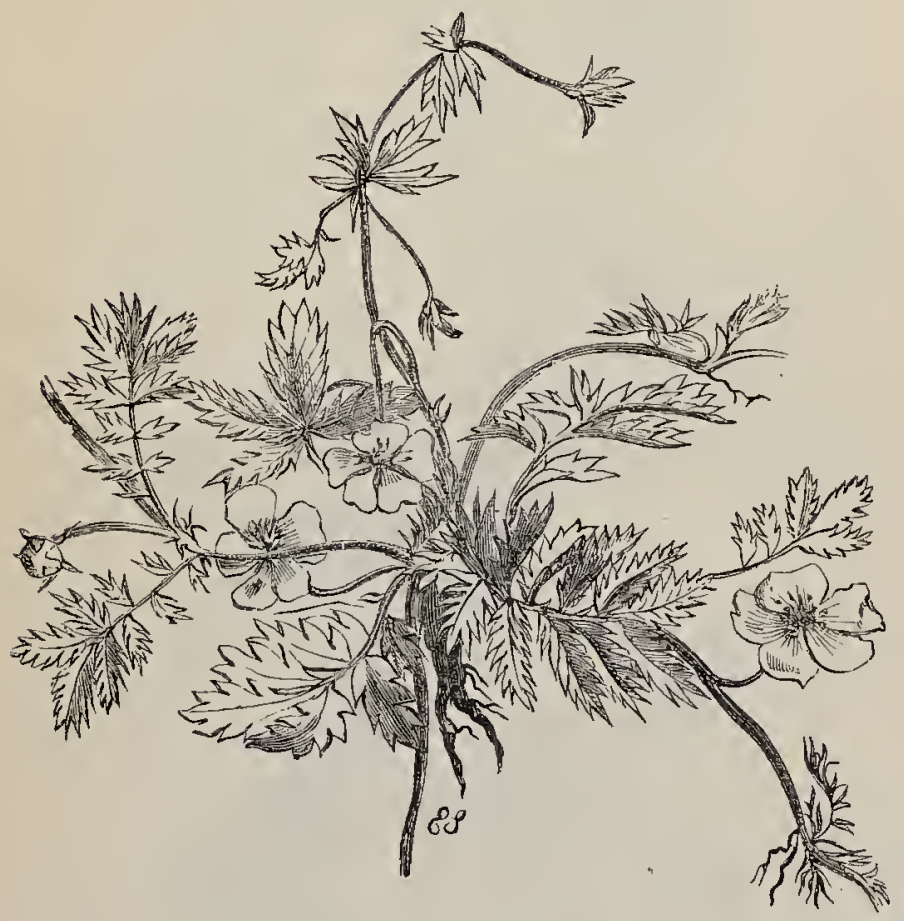

POTENTÍLLA ANSERÍYA and P. RÉPT'ANS.

rarely 5, cuneate, lobed lenflets; cauline leaves sessile; stipules leafy, deeply cut; flowers in corymbose cymes, not more than $\frac{3}{4}$ in. across, yellow, usually with 4 sepals and 4 petals,-Banks and heaths; very common-Fl, all the summer. Perennial. 
7. P. procúmbens (Trailing Tormentil)._A very closely allied species, differing chiefly in a more

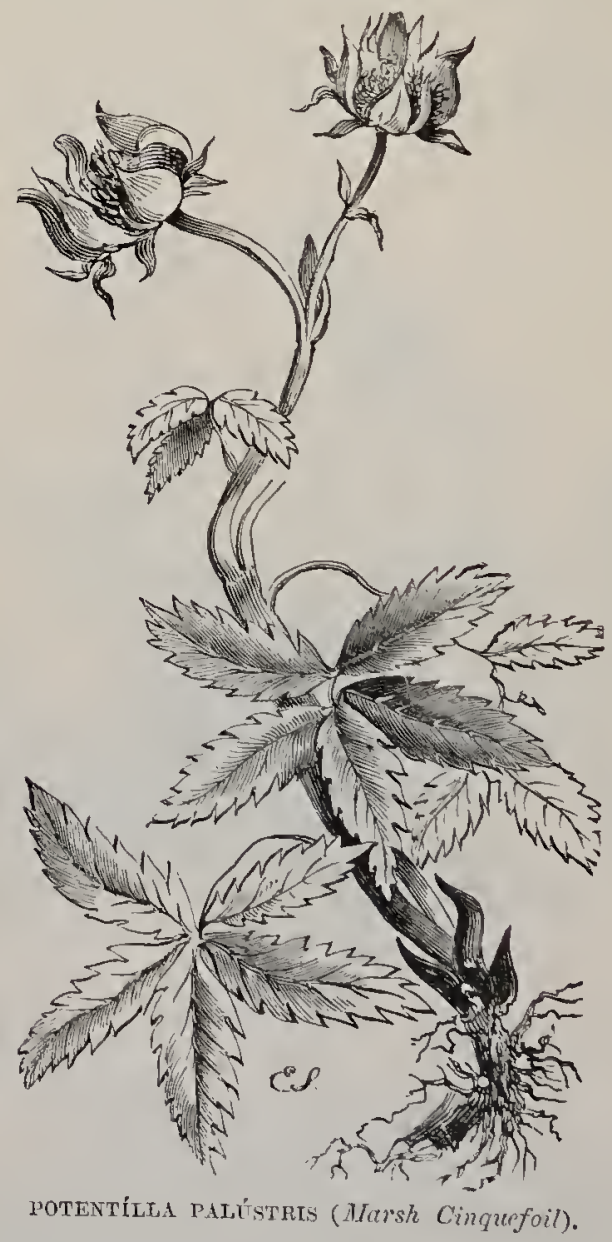

prostrate habit, the cauline leaves being stalked and the flou'er's being solitary, or nearly so, and rather 
larger._-Woods and banks; common,- - Fl. JuneAugust. Perennial.

8. P. réptans (Creeping Cinquefoil).-Stem slender, creeping, rooting at the nodes; leaves quinate, stalked; leaflets obovate, serrate, hairy ; flowers solitary, about an inch across, yellow ; sepals and petals 5 each.-Meadows and waysides; common. Hybrids between this species and the two preceding occur.Fl. June-August. Perennial.

9. P. Anserína (Silver-weed, Goose-grass).--A familiar, easily recognisable plant, with r'unners; leaves interruptedly pinnate; leaflets deeply serrate or pinnatifid, densely silky, with white hairs on the under side or on both surfaces; flowers solitary, yellow, much as in the preceding.-Roadsides ; common.-Fl. June-August. Perennial.

10. P. rupéstris (Rock Cinquefoil), a tall, erect species, 1-2 feet high, with pinnate leaves of $3-7$ leaflets and large white flowers, is found only on limestone rocks in Montgomeryshire.-Fl. May, June. Perennial.

11. P. argéntea (Hoary Cinquefoil). -Stem nearly prostrate; leaves quinate, white underneath with adpressed wool, their edges rolled back; flowers small, yellow, several together.-Dry gravelly places; not common.-Fl. June, July. Perennial.

\section{** Stamens many: achenes many, hairy: receptacle} very hairy.

12. P. fruticósa (Shrubby Cinquefoil). $-A$ muchbranched shrub, 2-4 feet high; leaves pinnate, of 3 -5 leaflets, silky, revolute; flowers large, yellow, several together, terminal.-Rocky places in the North of England and West of Ireland; rare.-Fl. June, July. Perennial. 
* Stamens many : achenes many, smooth : receptacle conical, spongy, downy.

13. P. palüstris (Marsh Cinquefoil).-A stout, her. baceous plant, about a foot high; rhizome woody; stems ascending, reddish brown, leafy; leaves pinnate, of 5-7 leaflets; stipules large, membranous; flowers few together, large, dingy purplish-brown; sepals

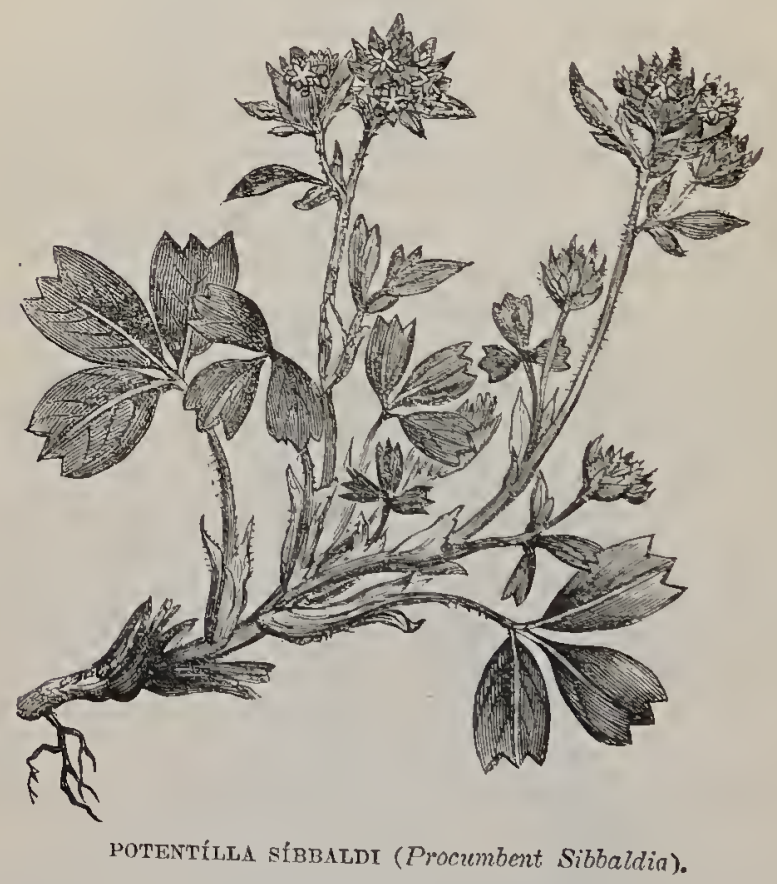

larger thon the petals.--Peat-bogs; frequent.-Fl. June, July. Perennial.

***** Stamens 4-10: achenes 4-10, glabrous : receptacte concave, downy.

14. P. Síbbaldi (Procumbent Sibbaldia).-A small 
prostrate plant; leaves ternate ; leaflets wedge-shaped, ending in 3 points, hairy; flowers few, small, yellow, in crowded terminal cymes.-Dry summits of Highland mountains ; rare.-Fl. June, July. Perennial.

8. Alchemílid (Lady's Mantle).-IHerbs with simple, orbicular, more or less divided stipulate leaves ;

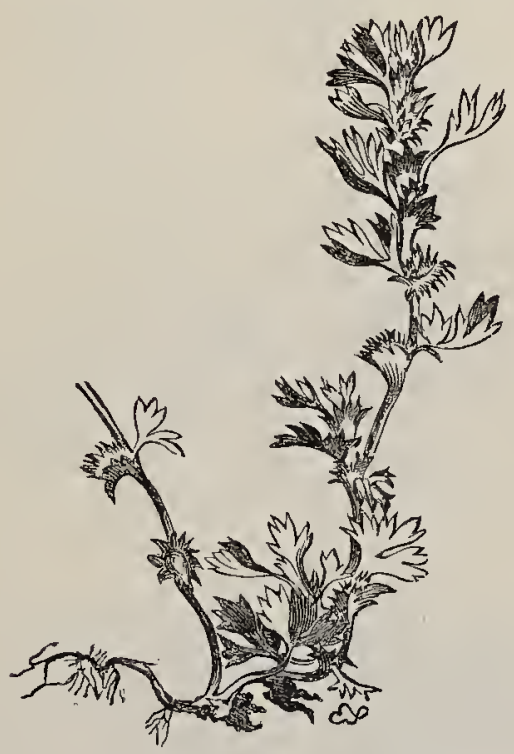

ALCHEMílLA ARVÉnSIS (Field Lady's Mantle).

flowers minute, in corymbose cymes, generally tetramerous, apetalous; calyw, with an epicalyx, persistent ; stamens $1-4$, inserted at the mouth of the calyx-tube; disk annular at the mouth of the calyx-tube ; carpels $1-5$, 1-ovuled; styles lateral ; fruit, $1-4$ achenes within the calyz-tube. (Name said to indicate the value of the genus in alchemy).

1. A, arvénsis (Parsley Piert, Field Lady's Mantle). 
-A small inconspicuous hairy weed, $3-8 \mathrm{in}$. long; leaves small, 3-lobed, lobes wedge-shaped, and cut, as also are the stiputes; flowers minute, crowded in the axils of bracts, greenish, concealed by the leaves.Dry places ; common.-Fl. May-August. Annual.

2. A. vulgáris (Common Lady's Mantle).-A herbaceous plant about a foot high; leaves large, kidneyshaped, plaited, softly downy, $7-9$ lobed, on long stalks, serrate; stipules ochreate, toothed; flowers numerous, small, yellowish-green, in loose branching cymes.-Moist hilly pastures ; common.-Fl, JuneAugust. Perennial.

3. A. alpina (Alpine Lady's Mantle).-A beautiful plant with small palmate leaves of $5-7$ oblong, serrate leaflets, lustrously white and satiny, almost metallic underneath; flowers inconspicuous.-Mountains ; not common.-Fl. June-August. Perennial.

4. A. argéntea (Silver Lady's Mantle).-An allied

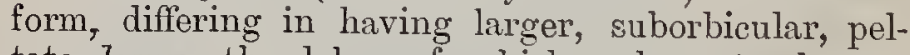
tate leaves, the lobes of which only extend twothirds of the distance from their margin to their base. -Occurs in the North of Scotland.-Fl. June, July. Perennial.

9. Agrimónia (Agrimony).-Herbs with stipulate, pinnate, serrate leaves and terminal bracteate spikelike racemes of small yellow flowers; sepa7s 5, imbricate, persistent; petals 5 ; stamens $12-20$; carpels 2, 1-ovuled, within the spinous calyx-tube; fruit of 1 or 2 achenes. (Name of Greek origin.)

1. A. Eupatória (Common Agrimony).-A slender, herbaceous plant, $1-2$ feet high, shaggy with soft hairs; leaves interruptedly pinnate, deeply toothed; flowers shortly stalked and distant on the long, tapering spike-like raceme; caly $x$-tube obconic, deeply furrowed, spinous round its month, woody in fruit.Fields and roadsides; common.-Fl. June-August. Perennial. 
2. A. odorata (Scented Agrimony).-A closely allied species, more branched, with an aromatic resin. ous scent, with flowers larger and closer, and the caly $x$ -

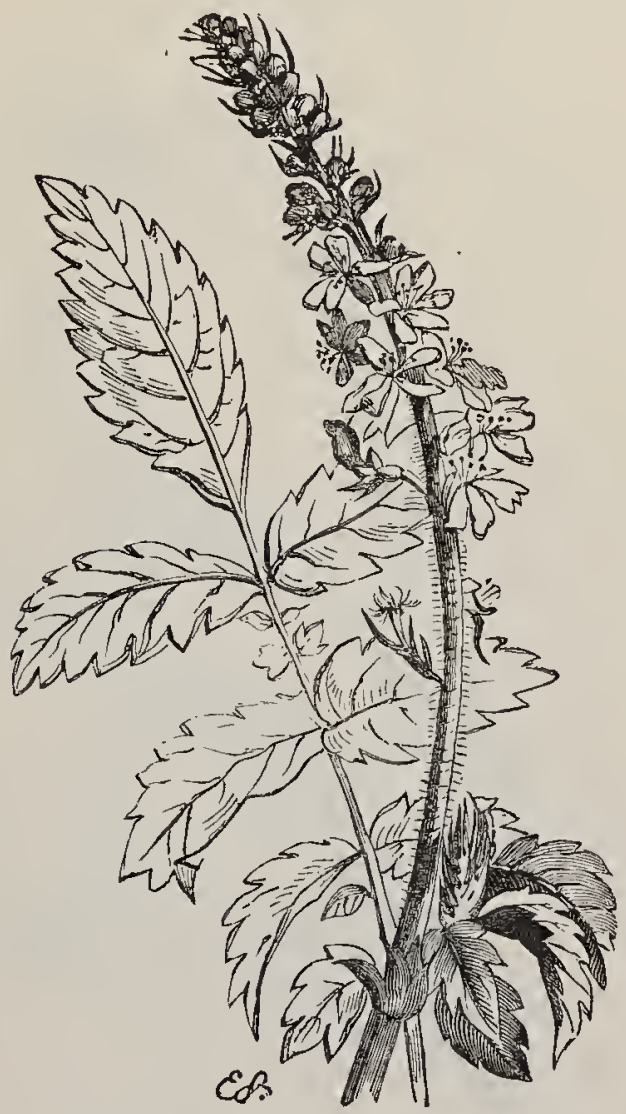

AGRIMÓNTa EUPATÓRLa (Common Agrimony).

tube bell-shaped and not furrowed. Less common. -Fl. June, July. Perennial. These two species are said to be tonic, and are made into tea by village herbalists. 
10. Potérfum (Burnet).--Erect herbs with pinnate leaves; stipules adnate to the sheathing petiole ; flowers small, in dense long-peduncled capitate cymes, often polygamous; calyx-tube persistent, with 4 winged

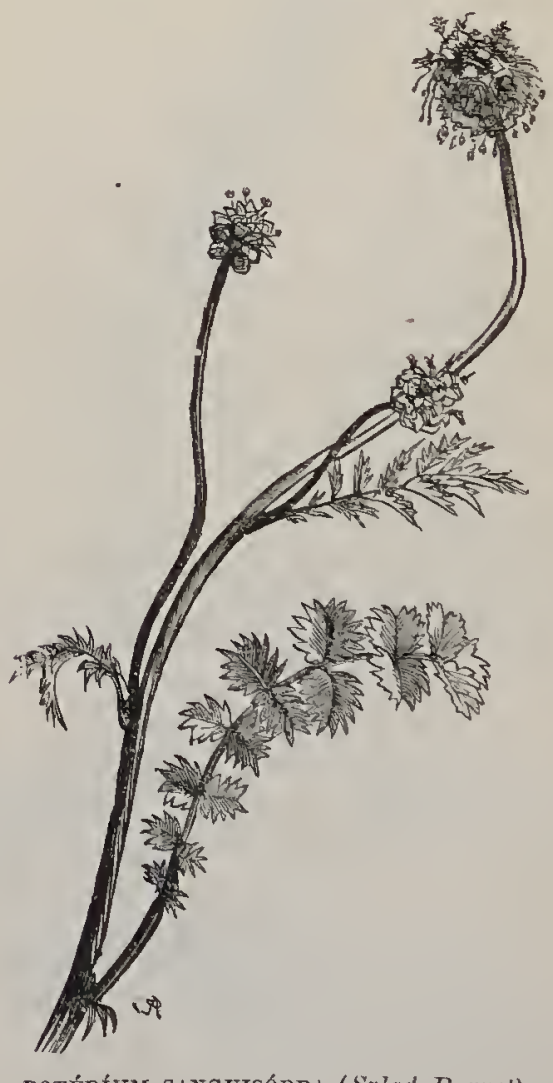

POTÉRIUM SANGUisóRBa (Salad Burnet).

angles in fruit; sepals 4, imbricate, deciduous; petals absent; stamens 4-30 with slender filaments and pendulous exserted anthers; carpels 1-3, 1-ovuled, only one ripening; stigma tufted; achenes solitary, 
enclosed in the hardened calyx-tube. (Name from the

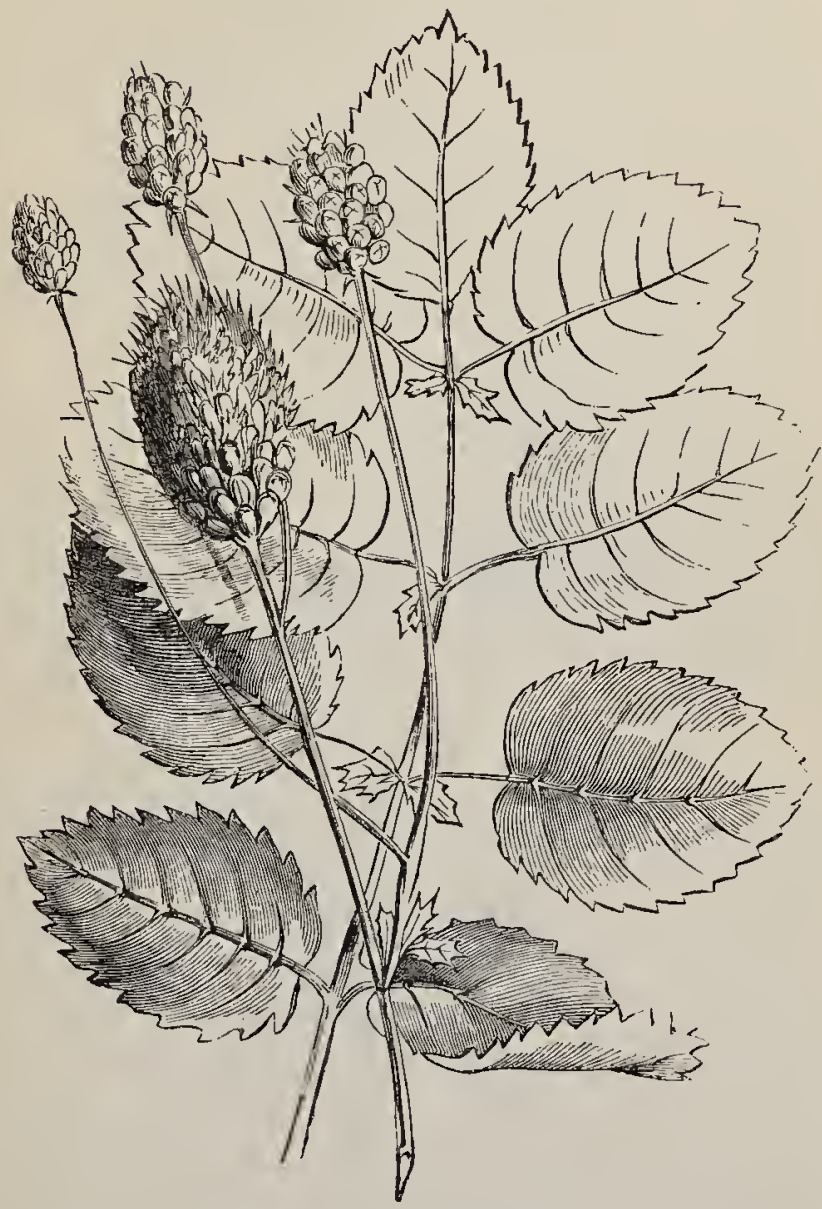

POTÉRÍU OFFICINRLÉ (Great Bumet).

Greek poterion, a tankard, one species being used in cool drinks.)

1. P. Sanguisórba (Salad Burnet).-Glabrous, or 
nearly so, about a foot high; leaves of $5-10$ pairs of oblong, coarsely serrate leaflets, having the taste and smell of cucumber; peduncle angular; flower-heads reddish, the upper flowers producing their crimson stigmas bcfore the lower ones produce their 20-30 pendulous stamens; calyx-tube with netted veins between the 4 wings. - Dry pastures, especially on a calcareous soil.-Fl. June-August. Perennial.

2.* $P$. polygamum (Prickly Salad-Burnet).-A closely-allied species with a larger fruit and prickly wings to the calyx-tube.-Cultivated on chalky soil. -Fl. June, July. Perennial.

3. P. officinálé (Great Burnet).-A tall erect branched plant; leaves pinnate of $9-13$ oblongcordate, serrate, distinctly stalked leaflets ; flowers in oblong or cylindric, long-stalked heads, purplishbrown, all perfect; stamens 4, not exserted; calyrtube in fruit smooth between the 4 wings.-Damp meadows; not uncommon.-Fl. June-August, Perennial.

11. Rósa (Rose).-Whrubs, usually prickly ; Teaves pinnate, selrate; stipules adnate to the shenthing petiole; flowers terminal; calyx-tube persistent, fleshy, contracted at the mouth, with 5 leafy, imbricate sepals; petals 5 ; stamens indefinite, inserted on the disk at the mouth of the calyx-tubc; carpels generally numerous, in the bottom of the calyx-tube, I-ovuled; frit, an etrelio of achenes. (Name Classical).

Botanists differ widely in their conceptions of the specics of this difficult genus; but the indigenous British forms fall into some twelve or thirteen fairly distinet groups, most of which are accepted by all authorities and their sequence generally agreed upon. Hybrids, however, occur between members of different groups. In collecting herbarium specimens of Roses, a twig bearing a fully-formed fruit, with the sepals still on it, should be preserved. 
1. R. pimpinellifólia (Burnet or Scotch Rose).-An erect, much-branched shrub, 1-4 feet high, covered with very unequal, nearly straight prickles, passing into stiff bristles and glandular hairs; leaves of 7-9 simply serrated, smooth leaflets; flowers

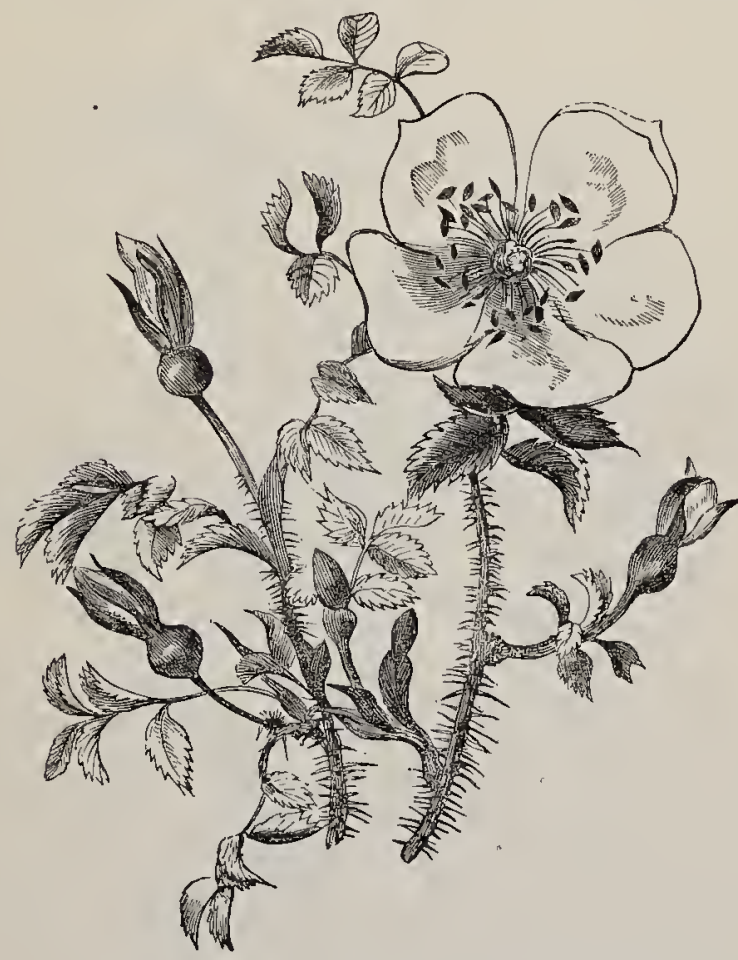

RÓSA PIMPINELLIFólia (Burnet-leaved Rose).

solitary, white; sepals undivided, smooth ; fruit subglobose, dark purple.-Dry sandy places, especially near the sea; common,-Fl. May, June. Perennial.

2. R. involúta differs in having its leaves usually doubly serrate and downy, and glandular beneath; 
its flowers $1-3$ together; and its fruit red.-Chiefly in the north.-Fl. June. Perennial.

3. R. hibérnica (Irish Rose) has stout, curved prickles; leaflets simply serrate, glabrous above, glaucous and slightly pubescent beneath; flowers 1-12 together; sepals pinnate, smooth; fruit red. Chiefly in the north; rare.-Fl. May-August. Perennial.

4. R. móllis (Soft-leaved Rose).-A tall, erect bush with scattered, uniform, nearly straight, slender prickles; leaflets ovate, doubly serrate, softly downy, especially beneath; flowers $1-3$ together, deep rosecolour ; sepals slightly pinnate, persistent, connivent in fruit; fruit globose, glandular, red.-In the north. -Fl. June, July. Perennial.

5. R. tomentosa (Downy-leaved Rose). - Stem erect with stout, arching branches, 6-10 feet long, with mostly uniform, slender, straight or slightly curved prickles; leaflets doubly serrated, downy, especially beneath; flowers 1-3 together, pink or white; sepals very pinnate; fruit oblong-urceolate, red.-Hedges and thickets; common.-Fl. June, July. Perennial.

6. R. rubiginósa (Sweet Briar).--An erect, compact bush with many prickles, the larger ones hooked, the smaller unequal, straight; leaflets doubly serrate, downy, and glandular beneath, mostly rounded at the base, very fragrant; flowers $1-4$ together, deep rosecolour; sepals very pinnate, persistent; firuit pearshaped, becoming globose, red.-Chiefly on chalk. The Eglantine of the poets, with the exception of Milton, whose "twisted eglantine" is the Honeysuckle. -Fl. May-July. Perennial.

7. R. micrantha (Small-flowered Sweet Briar).-A small bush with long arched branches, equal hooked prickles, and faint odour ; leaves doubly serrate, downy and glandular beneath, rounded at the base; flowers 1 in. across, on bristly stalks, pale rose-colour'; fruit 
smali, urceolate, scarlet.-Not common.-Fl. July, August. Perennial

8. R. sépium (Slightly-scented Briar).-A similar species, differing in having rather unequal hooked prickles intermixed with a few bristles and glandular hairs; leaflets less rounded at the base; flowers

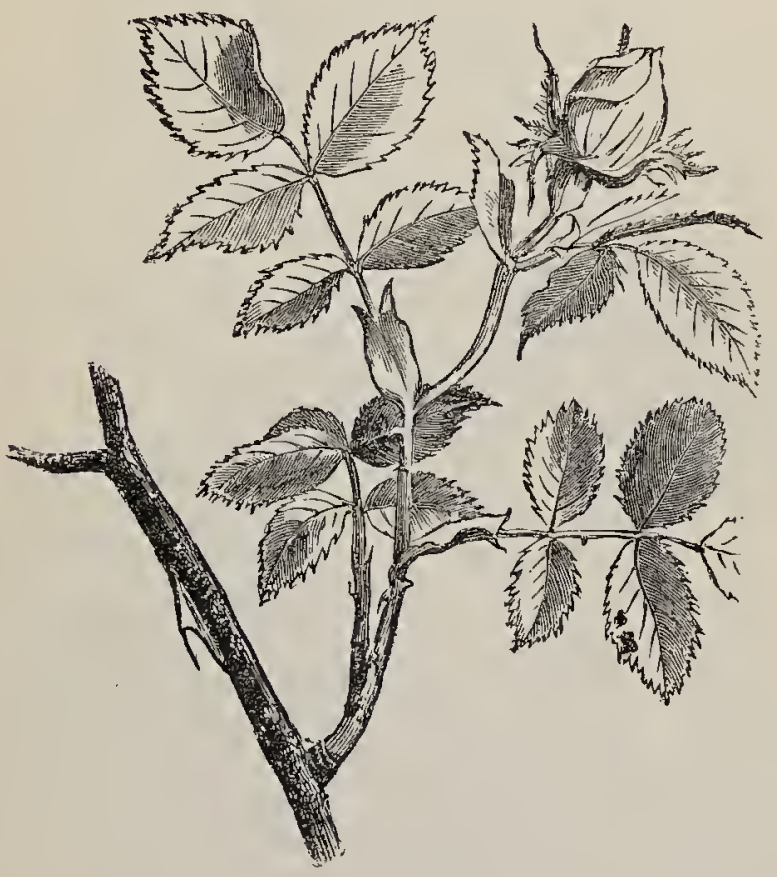

Rósa CaníNa (Dog-Rose).

usually with smooth stalks; sepals more pinnate and persistent.-Local ; uncommon.-Fl. June. Perennial.

9. R. obtusifólia (Blunt-leaved Rose).-A large bush with long, arching, glabrous branches, and large hooked prickles; leaflets doubly serrate, broadly 
rounded at the base, glandular and with prominent veins beneath; flowers white or pale pink, generally with smooth stalks; sepals reflexed and deciduous; and fruit small, sub-globose. These forms, not very sharply separated from the following, seem to be local.

10. R. canina (Dog-Rose).-Large bushes with long arched branches with uniform hooked prickles; leaflets mostly without glands, or with a few on the veins beneath; flonvers few together or solitary, generally on smooth stalks; sepals pinnate, reflexed, falling before the fruit changes colour; styles free.-Hedges and bushy places; abundant. This is the Common Hedge Rose, a flower belonging exclusively to summer, and welcomed at its first appearance scarcely less warmly than the early Primrose in spring. The colour of the flower varies from white to a deep blush, and the leaves also differ considerably; but the above characters will be found to include all the principal varieties.-Fl. June, July. Perennial.

11. R. glaúca (Glaucous Rose), a group more locally represented, differ's in having its leaflets often glaucous, and not glandular beneath, and its sepals ascending after the fall of the petals, and not falling until after the fruit has become crimson.

12. R. stylósa (Close-styled Rose).-A tall, erect bush with uniform, stout, strongly-hooked prickles; leaflets eglandular, pubescent beneath ; peduncles long, bristly; sepals pinnate, reflexed, deciduous; styles united into a central column.-Uncommon, - Fl. June, July. Perennial.

13. R. arvénsis (Trailing Rose).-A glabrous, trailing species with purple branches; leaflets glaucous beneath; flowers white; sepals purple, slightly pinnate, reflexed, deciduous; styles united in an exserted column ; fruit sub-globose, small._-Woods and hedges; common in the South of England.-Fl. JuneAugust, Pereinial. 
12. PÝrus (Service, Pear, Apple, Medlar, and Rowan).-Trees and shrubs; leaves deciduous, simple or pinnate; stipules deciduous; flowers in terminal cymes; calyx-tube urceolate; sepals 5 ; petals 5 ; stamens many; carpels 2-5, imbedded in the calyxtube, 2-ovuled; fruit a 2-5-chambered pome; core

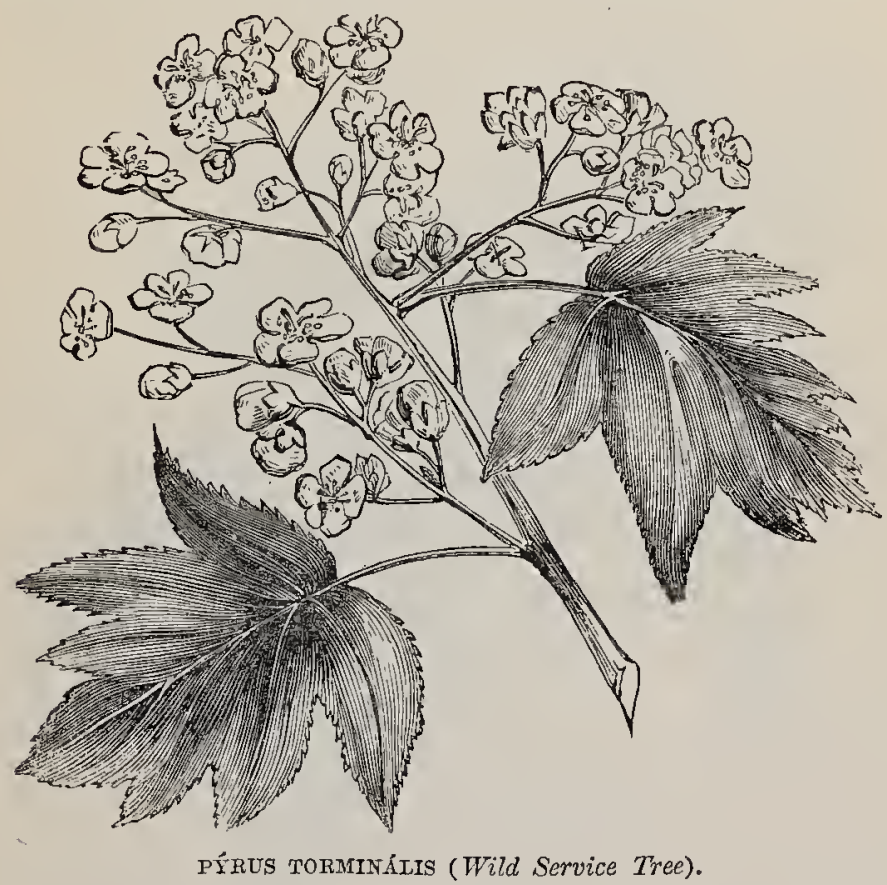

brittle, horny or bony ; chambers 1-2-seeded. (Name Classical.)

1. P. torminatis (Wild Service Tree). - A small tree with downy twigs; leaves glabrescent, simple, 6-10-lobed, cordate, serrate; lobes triangular; flowers many, small, white, in compound corymbose cymes; fruit small, green, spotted with brown, 2chambered, 2-seeded; core brittle.-- Woods and 
hedges in the South of England. The mottled fruit is sold under the name of Chequers.-Fl. A pril, May. Perennial.

2. P. Áric (White Beam).-A shrub or small tree; leaves large, egg-shaped, irregularly lobed and serrate, snowy-white-felted beneath, with 5-14 veins on each side; flowers and fruit much as in the preceding;

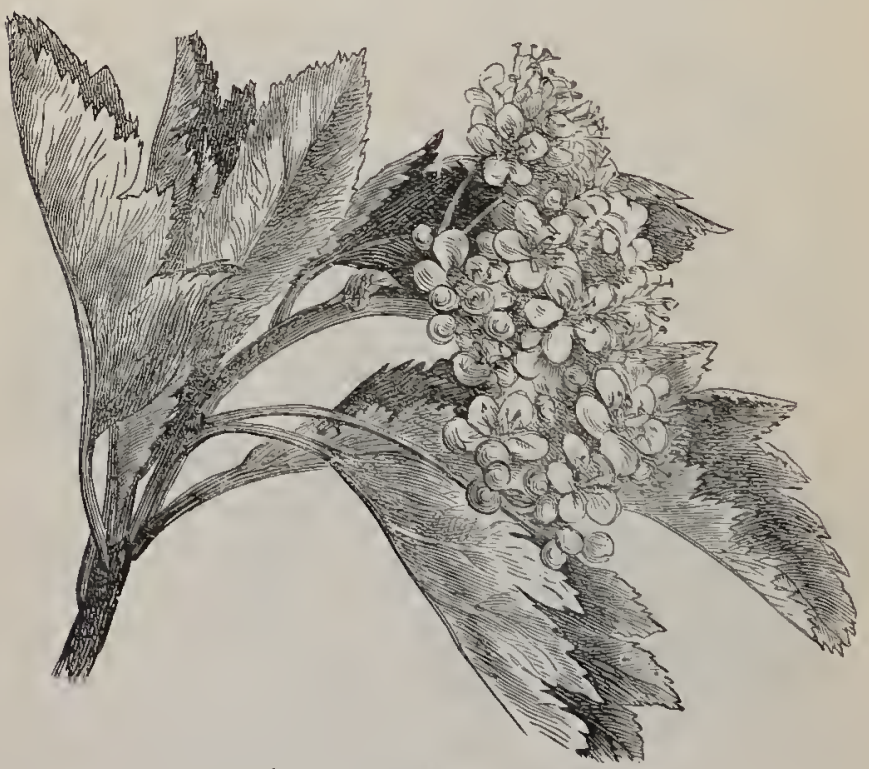

PÝRUS RRLA (White Beam).

but the latter dotted with red.-Chalky banks and limestone rocks.-Fl. May, June. Perennial.

3. P. rotundifólic (Round-leaved White Beam), differing chiefly in its leaves, which are rounded at the base, more lobed and greyish beneath, and its brown fruit, occurs rarely in woods in the west.

4. P. mánima (Least White Beam).-A small, spreading, much-branched, slender shrub; leaves 
linear-oblong, pinnately 3-4-lobed, ashy-felted beneath; flowers small, creamy-white; fruit small, globose, coral-red, bitter.-Limestone rocks, Breconshire.-Fl. June. Perennial.

5. P. intermédia (Broad-leaved White Beam).-A

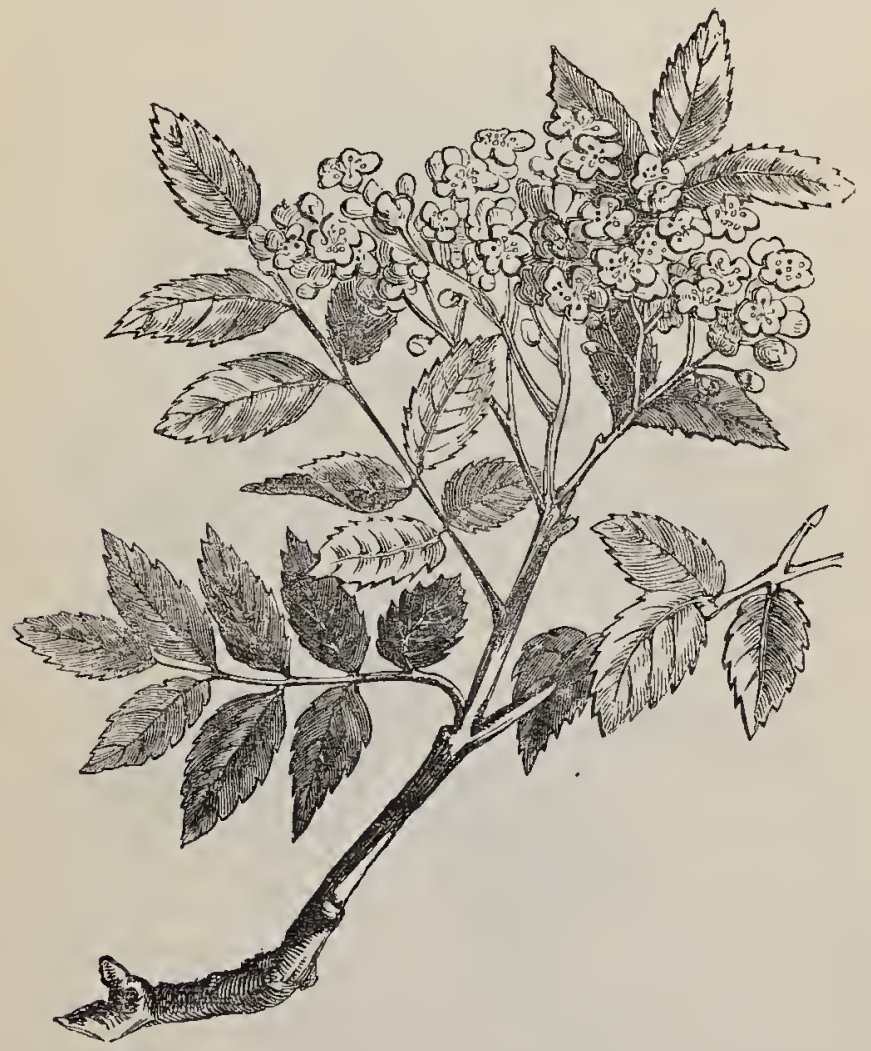

PÝRUS AUCUPÁRIa (Fowlers' Service-tree).

small tree with leaves similar to those of the preceding, with 5-9 veins on each side; but with dark or reddish-brown fruit.-Occurs rarely in hilly woods. -Fl. Mày. Perennial. 
6. P. pinnatifida, with leaves pinnate at the base, deeply pinnatifid at the apex, and grey-webbed beneath, may be a hybrid between the preceding species and the Rowan.-Arran in the Clyde. Perennial.

7.* P. doméstica (Service-tree). - A small tree with

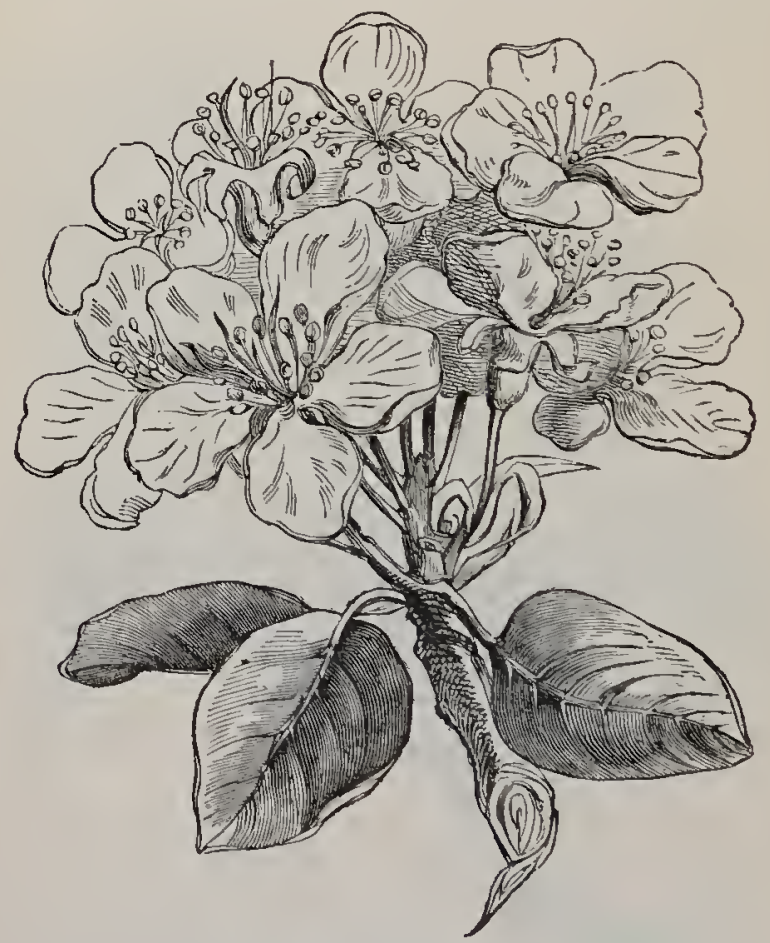

PÍRUS COMMÚNis ( Hilld Pear).

pinnate, serrate leaves, downy beneath, and a small pear-shaped fruit, did occur in Wyre Forest, Worcestershire; but was not indigenous.-Fl. May. Perennial.

8. P. Aucupária (Rowan-tree, Mountain Ash, 
Fowlers' Service).-One of the most elegant of British trees, small, with smooth roan or ash-grey bark; leaves pinnate, of 13-17 leaflets, serrate, glabrescent; flower's small, cream-white, in large, corymbose

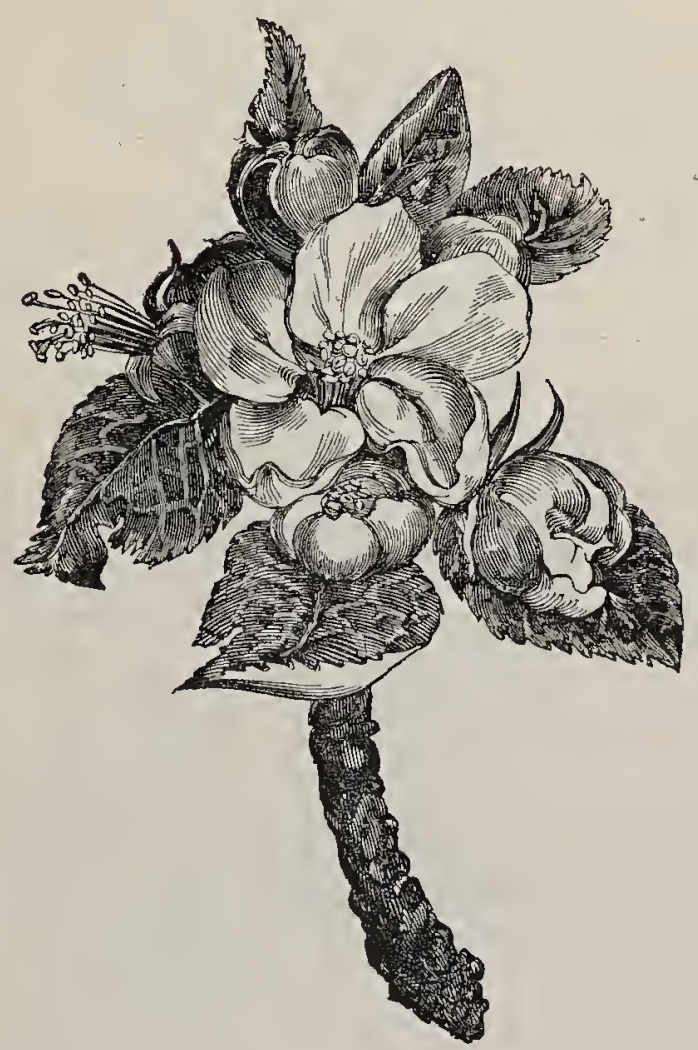

pyrus hílưs ( $C r a b$ Apple).

cymes; fruits globose, scarlet, with yellow flesh, 2-4chambered. - Mountainons woods; common. The fruit is eaten in Northern Europe, and is used as a lure by fowlers, whence it derives one of its English 
names and its specific name, from the Latin auceps, a fowler.-Fl. May, June. Perennial.

9. P. commúnis (Wild Pear).-A shrub or small tree, often bearing spines at the extremities of its branches; leaves simple, ovate, serrate; flowers an inch across, white, in corymbose cymes ; fruit tapering at the base, 5-chambered, woody and worthless when wild ; core horny.-Woods and hedges; uncommon. The origin of garden Pears.-Fl. April, May. Perennial.

10. P. cordáta (Lesser Pear) is a small form of bushy habit, with cordate leaves and more globose fruit, found near Plymouth.-Fl. May. Perennial.

11. P. Málus (Crab Apple).-A small spreading tree without spines; leaves simple, ovate, serrate; flowers white, delicately shaded with pink, in a sessile umbellate cyme; styles united below; firut globose, with a hollow at the insertion of the stalk, yellow or reddened, intensely acid, 5-chambered.Woods and hedges; common. Formerly used in making verjuice and pomatum, so called from pomum, an apple.-Fl. May. Perennial.

12.* P. germánica (Medlar).- - A small, muchbranched, spinous tree, with large, simple Teares, white flowers, $1 \frac{1}{2}$ in. across, on short stalks, and a remarkable globose fruit, with large, leafy, persistent sepals and 5 bony 1-seeded carpels exposed at the top. -Hedgerows; but probably not truly wild. Well known in a cultivated state.-Fl. May, June. Perennial.

13. Cratégus (Hawthorn).--Shrubs or small trees, often spinous; leaves simple, lobed; stipules deciduous; flowers in terminal corymbose cymes; sepals 5 ; petals 5 ; stamens many; carpets $1-5$, enclosed in the calyxtube, each 2-ovuled; fruit a pome with a bony core. (Name from the Greek $k r a t o s$, strength, alluding to the 
hardness of its wood, which is the best substitute for boxwood for engraving purposes.)

1. C. Oxyacántha (Hawthorn, Whitethorn, or

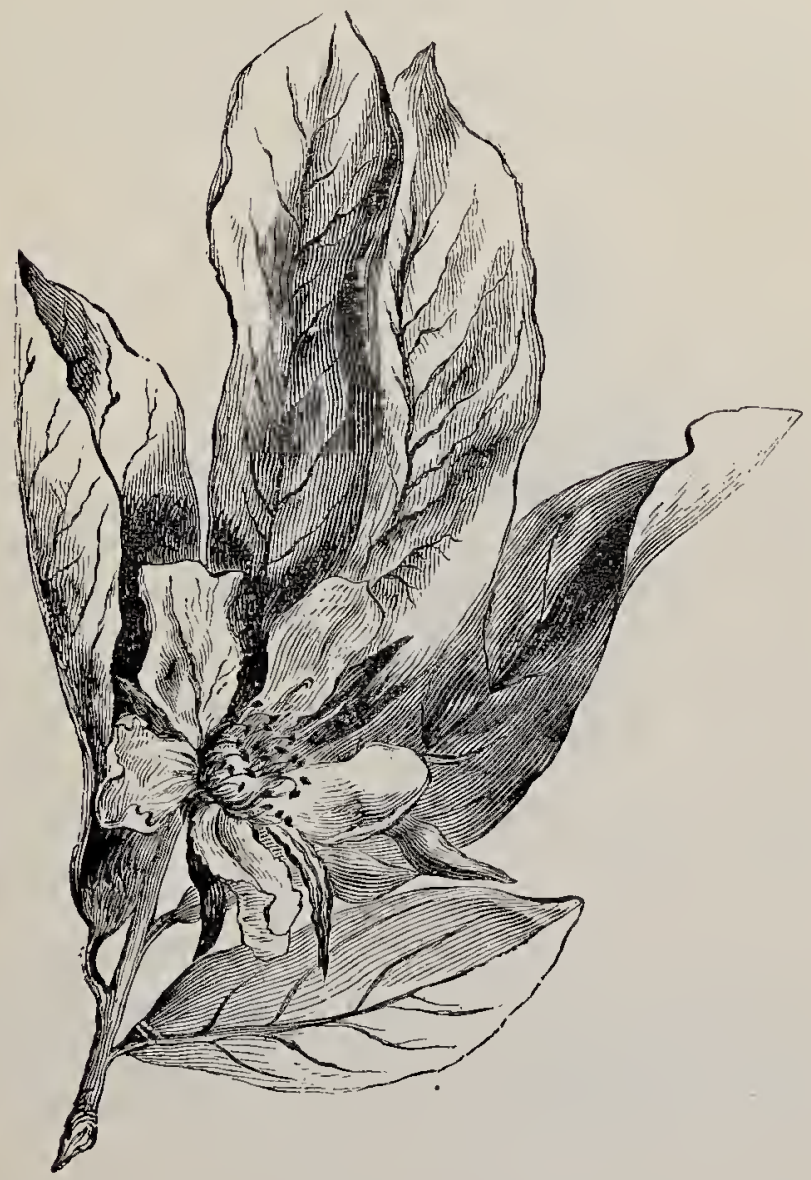

PYRUS GERMÁNICA (Common Medlar).

May).-A small, round-headed, much-branched, spinous tree, which, though it varies considerably in its mode of growth, shape of leaf, and colour of flower 
and fruit, is so well known as hardly to need description. Its leaves are deeply pinnatifid and appear before the blossoms; the flowers are generally white and heavily scented, the anthers pink with brown pollen, and the fruit usually sub-globose, scarlet, or crimson, of $1-3$ carpels. The name Hawthorn is derived from haey, a hedge; although, therefore, the fruit is generally called a haw, that name is derived

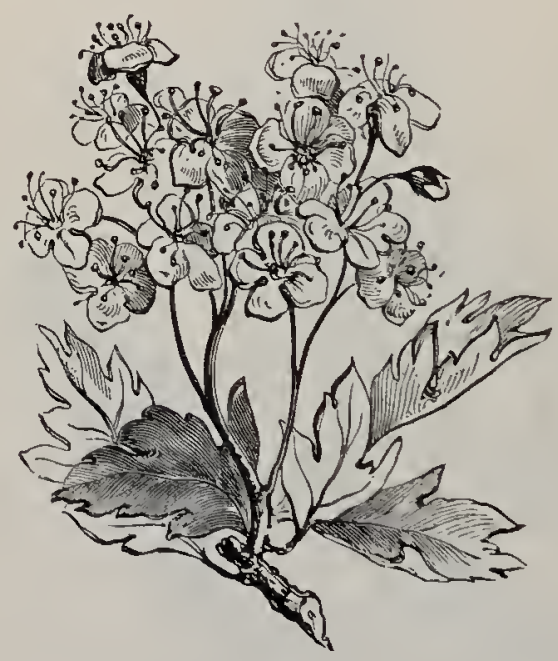

ORATLEUS OXYACANTIA (Hauthorn).

from the tree which produces it, and the tree does not, as is frequently supposed, take its name from the fruit which it bears.-FI. May. Peremnial.

14. CoTONEÁsTen.-Shrubs or small trees; stipules deciduous; flowers solitary, or nearly so, small; sepals 5 ; petals 5 ; stamens many; carpels $2-5$, adherent at their backs to the calyx-tube, but not co- 
herent; fruit a 2-5-cnambered pome with a bony core. (Name Classical).

1. C. integérrimus.-A small pubescent shrub, with roundish leaves; minute rose-pink flowers, few together; and small, pendulous, globose, shining red fruits.-Occurs on limestone rock at Great Orme's Head, Caernarvonshire.-Fl. May, June. Perennial.

\section{Ord, XXVII. Saxifrágez,-The Saxifrage Family.}

Shrubs and herbs abounding in temperate and cold climates, but within the tropics confined to lofty mountains. They have polysymmetric and generally 5 -merous flowers; sepals 5, rarely 4, united at the base and generally partly adherent to the carpels; petals equal in number and alternate to the sepals, imbricate, or rarely absent; stamens 4-10, perigynous; carpels usually 2, rarely 3-4, united below; styles usually distinct; ovules many; fruit of two follicles, a 1-2-chambered capsule, or a berry. Most members of the Order have slightly astringent properties, and some few are bitter and tonic. Several species of the genus Ribes have berries with an agreeable acid flavour; others are mawkish. The extensive genus Saxifraga contains many tufted mountain plants that contribute greatly to the beanty of alpine vegetation.

1. Saxífraga--Herbs; petals 5; stamens 10 , rarely 5 ; ovcriy 2-chambered; styles 2 .

2. Cinrysosplíniun. - Small succulent herbs; petals absent; stamens 8 or 10 ; ovary 1-chambered; styles 2.

3. Parníssin.-Herbs; flowers large, solitary; petals 5 ; stamens 5 , with five alternating staminodes ; ovary 1-chambered; stigmns 3 or 4 .

4. Ríbes.-Shrubs; petals 4 or 5 ; stamens 4 or 5 ; ovary 1-chambered; styles 2 ; finit a berry. 
1. Saxífracia (Saxifrage).-Herbs, mostly perennial; Teaves both radical and cauline, with sheathing petiotes; flowers in cymes, white, yellow, or rarely purple or red ; sepals 5, imbricate; petals 5; stamens 10, rarely 5 ; carpels 2, united below, forming a superior, or half-inferior, 2-chambered ovary, with parietal placentation, numerous ovules, and 2 styles; fruit of 2 follicles or united below into a capsule. (Name in Latin signifying rock-breaker, many of the species growing in crevices of rocks).

\section{* Flower's morple.}

1. S. oppositifólia (Purple Mountain Saxifrage).A low-growing, tufted, glabrous plant, with trailing stems; small, opposite, and decussate fleshy leaves: and relatively large, solitary, bright purple flowers. Alpine rocks in the north.-Fl.April, May. Perennial.

\section{番米 Flowers crowded, white.}

2. S. nivális (Clustered Alpine Saxifrage).-An alpine plant, $3-6$ in. high ; Tecees all radical, obovate, crenate, thick, red beneath; flowers rather large, white, 4-12 together, in a compact hend.-High mountains in the north; rare.-El. July, August. Perennial.

\section{*** Flowers in loose cymes, white, with two colonired dots on each petal.}

3. S. stelláis (Starry Saxifrage).-A mountain plant, 3-5 in. high; leaves in a rosette, scarcely stalked, oblong, wedge-shaped, conrsely toothed; flowers rather large, few, white, with two yellow spots on each petal.-By mountain rivulcts in the north._Fl. Junc, July. Perennial.

4. S. Gêum (Kidney-shaped Saxifrage), with reni- 
form, tufted, leathery, toothed leaves and small white flowers dotted with pink ;

5. S. hirsúta, more hairy, with oval leaves; and

6. S. umbrósc (St. Patrick's Cabbage, London Pride, or None-so-pretty), with obovate leaves, are closely allied, rare species, occurring on mountains in the West and South-west of Ireland. The last is a wellknown garden plant, making itself at home even in the smoky gardens of London, and occurs in many places as a naturalised escape.-Fl. June. Peren. nial.

********ar Flowers yellow.

7. S.Hîrculus (Yellow Marsh Saxifrage).-A handsome species, about 6 in. high, with runners; stem erect, branched, leafy, downy above; ralical leaves in a rosette, lanceolate; cauline leaves linear; flowers large, solitary, or nearly so, yellow, spotted with scarlet.-Wet moors ; rare.-Fl. August. Perennial.

8. S. aizó̈̈des (Yellow Mountain Saxifrage).-A smaller, more tufted, prostrate and branched species; leaves very narrow, fleshy, fringed; flowers like those of the preceding, but smaller. Wet places in the mountains in the north and in Ireland. Fl. JuneSeptember. Perennial.

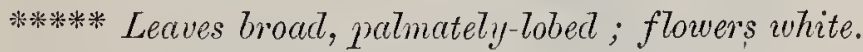

9. S. tridactylites (Three-fingered Saxifrage),-A small, very hairy, and viscid species with glandular hairs, rarely more than 3 in. high, usually tinged with red, branched; leaves palmately 3-5-lobed, segments linear-oblong; flowers minute, numerous, scattered.-On walls and dry places; common. Generally covered with dead flies, though there is in its case no evidence that they are digested or assimilated.-Fl. April-July. Annual. 
10. S. rivuláris (Alpine Brook Saxifrage).-A small, tufted, slender, succulent, slightly glandular, prostrate species; leaves reniform, palmately 5-lobed, on slender stalks; flowers 1-3 together, small, white.

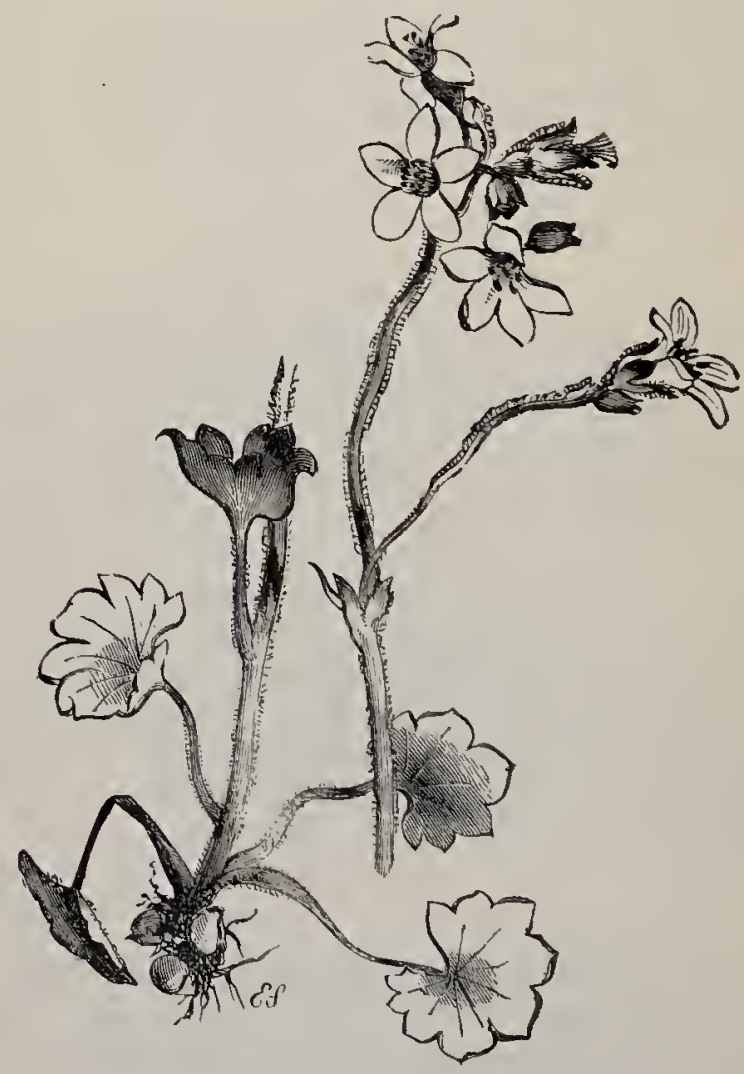

SAXfFraga GRANULÁtA (White Meadow Saxifrage).

- By streams near the summits of Highland mountains; rare.-Fl. July, August. Perennial.

11. S. cérnua (Drooping Bulbous Saxifrage).-A small, erect, unbranched species, with scaly bulbs in 
the axils of its stalked, reniform, palmately-lobed leaves and a solitary, drooping, flower, which in Scotland is generally replaced by a reddish bulbil.-Occurs only on the summit of Ben Lawers.-Fl. June-August. Perennial.

12. S. granuláta (White Meadow Saxifrage).-A pretty plant, closely allied to the preceding; stems slender, leafy, $10-12$ in. high, with numerous brown, downy, bulb-like tubers, as big as peas, at their base; radical leaves stalked, reniform, palmatelylobed; cantine leaves sessile, more deeply cut into more acute segments; flowess in a loose cluster, 1 in, across, inclined, pure white.-Gravelly banks and meadows; not uncommon. A double variety is grown in gardens.-Fl, April-June. Perennial.

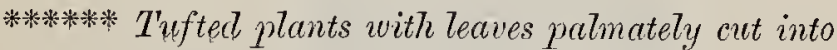 narrow segments; flowers white.}

13. S, ccespitósa (Tufted Alpine Saxifrage), distinguished by the obtuse lobes of its leaves, with few small, crowded flowers, occurs very rarely on alpine summits, forming bright green cushions.-Fl. MayÁugust. Perennial.

14. S. Sternbérgii, a very hairy glandular species, with 3-4-lobed leares, the lobes lanceolate, acute, fringed, occurs on alpine rocks in the South-west of Ireland.-Fl, July. Perennial,

15. S. decípiens, a closely-allied form, with $3-7$ lobed leaves, the lobes abruptly acuminate, occurs in North Wales,

16. S, grcentándica, another closely-allied form, 1-2 in. high, densely tufted, with few cauline leaves; leaves broadly wedge-shaped, palmately $3-5$-fid, with ovate-lanceolate acute lobes, and few flower's, has been recorded from Ben Lawers,

17. S. hírta (Hairy Saxifrage), with 3-5-lobed teaves, very finely cut into bristle-pointed lobes and 
flowers $2-4$ together, with subulate sepals and oblong 3 -veined petals, the sides of which are inflexed, occurs on the Galtee Mountains.-Fl. July. Perennial.

18. S. hypnóides (Mossy Saxifrage).-With trailing barren shoots and erect flowering ones; leaves mostly 3-cleft, bristle-pointed, with narrow, fringed segments and narrow triangular acute sepals.Occurs somewhat frequently in mountainous districts, and is often grown in gardens.-Fl. May-July. Perennial.

2. Chrysosplénidu (Golden Saxifrage).-Small succulent herbs; leaves exstipulate; flowers minute,

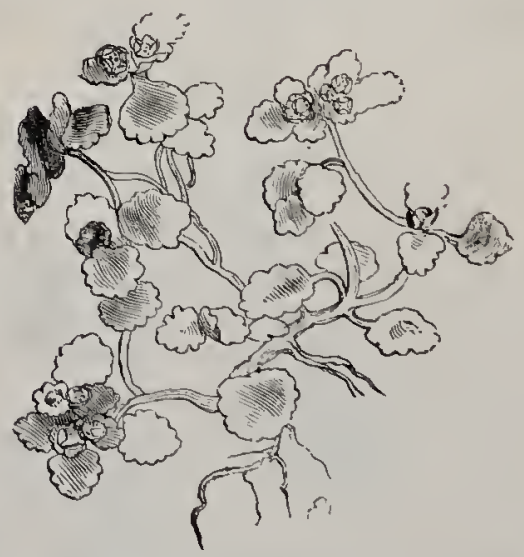

chrysospténium opposithilutum (Common Golden saxifrage).

green or yellow, apetalous; sepals 4-5, obtuse, imbricate; stamens 8.-10, epigynous ; ovary inferior, 1-chambered; styles 2 ; oules many, parietal ; fruit a capsule. (Name from the Greek churusos, golden, and splēn, the spleen, probably from some supposed medicinal virtues.)

1. C. oppositifólium (Common Golden Saxifrage). -A small aquatic plant about $2-6$ in. high, with 


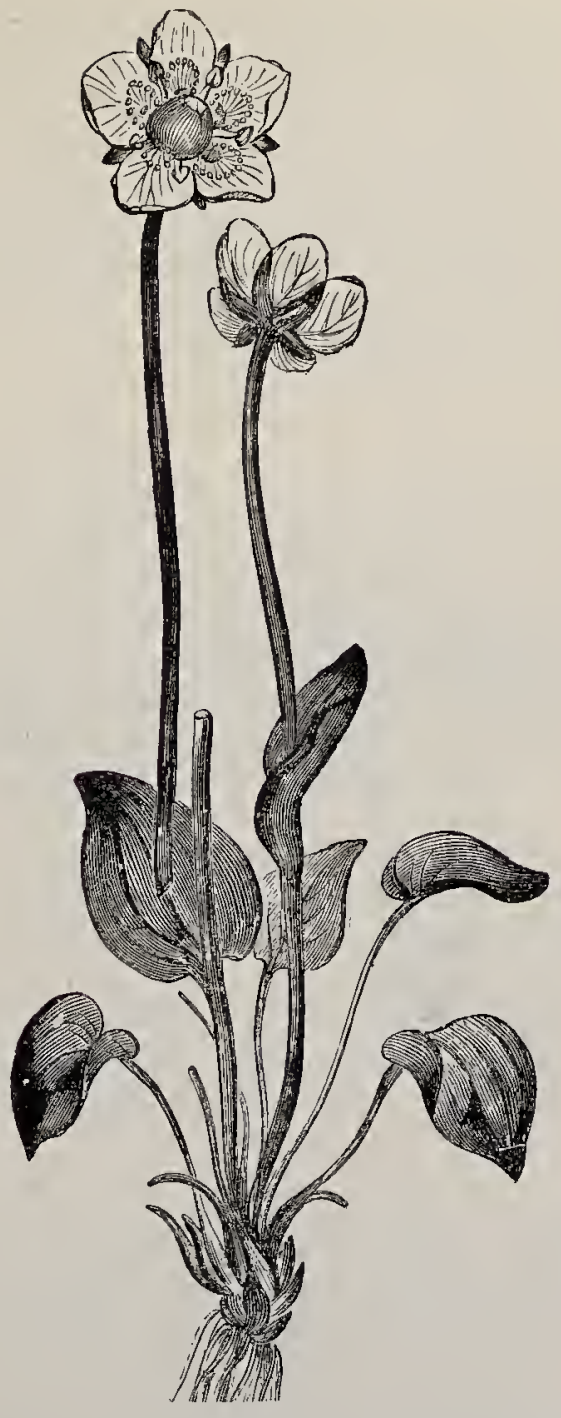

PARNÁSSIA PALÚSTRIS (Common Grass of Pumassus). 
a creeping stem, rooting below; leaves bright green, opposite, orbicular ; flowers minute, 4-merous, yellowish-green, in flat terminal clusters:-Damp shady places ; common.-Fl. April-July. Perennial,

2. C. alternifólium (Alternate-leaved Golden Saxifrage).-A very similar plant with an erect stem, alternate, reniform lerves and deeper yellow flowers, grows in similar situations, but is less common. These little plants sometimes form a true peat.-Fl. April-June. Perennial.

3. Parnássia (Grass of Parnassus).-Glabrous herbs, with radical, exstipulate, entire leaves and large solitary flowers on slender, erect peduncles; sepals 5, imbricate, persistent; petals 5, thick; stcmens 5, alternating with 5 staminodes; ovary superior, 1-chambered ; oveles many, parietal ; stigmas $3-4$, sub-sessile; fruit a capsule. (Named, from its beauty, after Mount Parnassus, the liome of the Muses.)

1. P. palistris (Common Grass of Parnassus).An exquisitely beautiful plant; leares ovate-cordate, long-stalked; flowers 1 in. across, ivory-white, benutifully veined, on peduncles $8-10$ in. high; strminodes, fan-shaped scales, friuged with 9-13 white hairs terminating in yellow wax-like glands.-Bogs, principally in the north.-Fl. August, September. Peren-
nial.

4. Ríbes (Currant and Gooseberry).-Shrubs, sometimes spinous; lenves scattered, lobed, plaited; flowers solitary or in bracteate racemes; sepals 4 or 5, superior; petals and stamens equal to the sepals in number; ovary inferior, 1-chambered; styles 2; fruit a berry; seeds with a pulpy testa. (Name Arabic, applied originally to the Rhubarb.) 
1.* R. Grossulária (Gooseberry), well distinguished by its spines below the leaf-buds, either single or 2-3 togetler ; leaves plaited, 3-5 lobed, crenate; flowers 1-3 together, greenish, drooping; sepals marcescent; petals minute, white; fruit glandular-hairy or glabrous.-Hedges and woods, an escape. The variety Uva-crispa, with smooth berries, may be wild.-FI. April, May. Perennial.

2. R. alpínum (Tasteless Mountain Currant).-

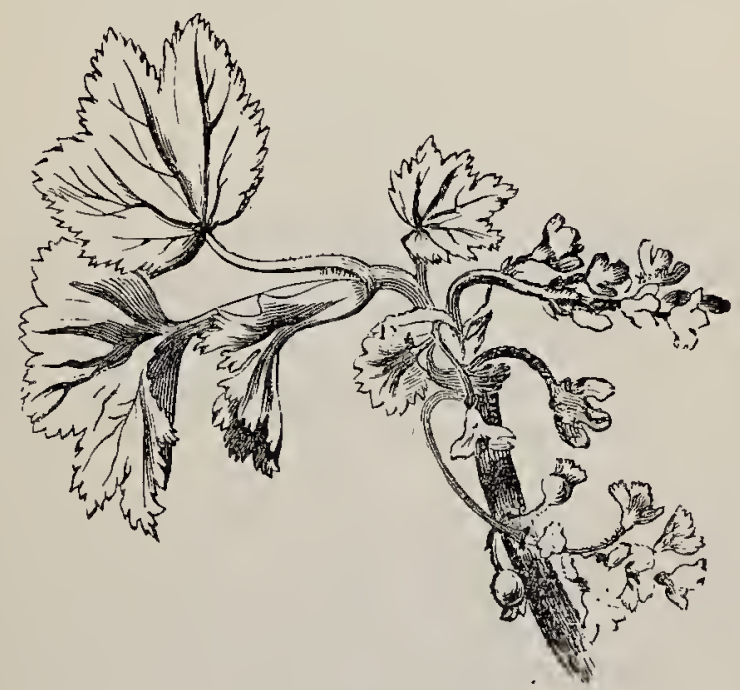

RfBFs NíGRUM (Black Currant).

Without spines and almost glabrous; with diœcious yellowish flowers in erect racemes, very long lanceolate bracts, and scarlet, insipid berries.-Mountainous woods in the north; rare.-Fl. April, May. Perennial.

3. R. rúbrum (Red Currant).-Without spines; leaves bluntly 5-lobed; racemes pendulous or erect, glabrous or downy; bracts short, ovate.-Truly wild 
in woods in the north. The origin of the Red and White Currants of our gardens.-Fl. April, May. Perennial.

4. R. nágrum (Black Currant).-Without spines; leaves acutely 3-5-lobed, dotted witl glands beneath; flowers in downy pendulous racemes, with a separate single-stalked flower at the base of each ; calyer downy; berry black.-Damp woods; occasionally wild. Easily distinguished, at all seasons, by the strong perfume of its buds and leaves.-Fl. April, Miay. Perennial.

\section{Ord. XXVIII. Crassulácez.-The Storecrop Family.}

Herbs or shrubs, remarkable for their thick, fleshy, simple leaves and generally succulent habit, and for theil' star-like polysymmetric flowers, inhabiting most parts of the world, especially South Africa, and growing in the driest situations, where not a blade of grass can live, on naked rocks, old walls, or hot sandy plains alternately exposed to the henviest dews of night and the fiercest rays of the noonday sun. They have the power of laying in during the rainy season a large store of moisture, which they obstinately retain, requiring no further nourishment, save what they derive from the atmosphere. A common British species, Sédum. Teléphium, Orpine or Livelong, will grow for montlis, if suspended by a string from the ceiling of a room, without being once supplied with water. An African species, Bryophýllum calyćmum, will not ouly grow if similarly treated, but if its leaves be gathered, they will send out young shoots or offsets from the notches on their margin. Herbarium specimens of nembers of this Order had better be plunged for a short time in boiling water before being pressed or they will continue to grow. Sepals $3-20$, more or less united at the base; petals equal in number to the sepals, perigynous; stamens the same, 
or twice as many in two whorls, those of the inner whorl shorter ; ovaries as many as the petals, 1-chambered, free ; fruit a ring of follicles; seeds in a double row. One or two species are used in medicine, their roots being astringent. The leaves are generally acrid, containing malic or tartaric acid.

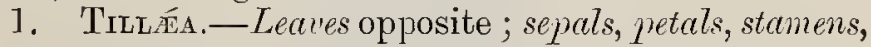
and carpels 3-5 each; follicles 2-seeded.

2. Cotrú́nor.-Leaves scattered; sepals, petals, and carpels 5 each; petals united; stamens 10.

3. SÉnum.-Sepals, petals, and carpels 4-6 each ; petals free; stamens $8-12$.

*4. Sompervívum.-Leaves scattered; sepals, petals, and carpels $6-20$; stamens 12-40.

1. Trus «a.-Small herbs; leaves opposite, entire; flower's minute; sepals, and sometimes the petals, united below; sepals, petals, stamens, and carpels 3-5 each; follicles 2 or more seeded. (Named after Michael Angelo Tilli, an Italian botanist.)

1. T. muscósc (Mossy Tillæa).-A minute, tufted, prostrate, smooth plant with small, opposite, oblong, blunt leaves and solitary, subsessile, 3-merous, or rarely 4-merous, greenish whitc flowers, tipped with red.--On sandy heaths in the south and east. It has somewhat of the habit of a Sarnina, from which, however, it is very distinct. - Ill. June, July, Annual

2. Cotylédon (Pennywort).-Mostly succulent herbs with scattered, peltate leaves ; flowers in terminal spikes or racemes, 5-merous; petals united; stamens in 2 whorls; carpels each with a hypogynous scale at its base ; styles slender, follicles many-seeded. (Name from the Greek kotulé, a dish, from the shape of the leaves.) 
1. C. Umbílicus (Wall Pennywort).-A remarkably succulent, glabrous plant, with orbicular, crenate, peltate leaves, depressed in the centre; and terminal racemes $6-18$ in. high, of short-stalked, pendu-

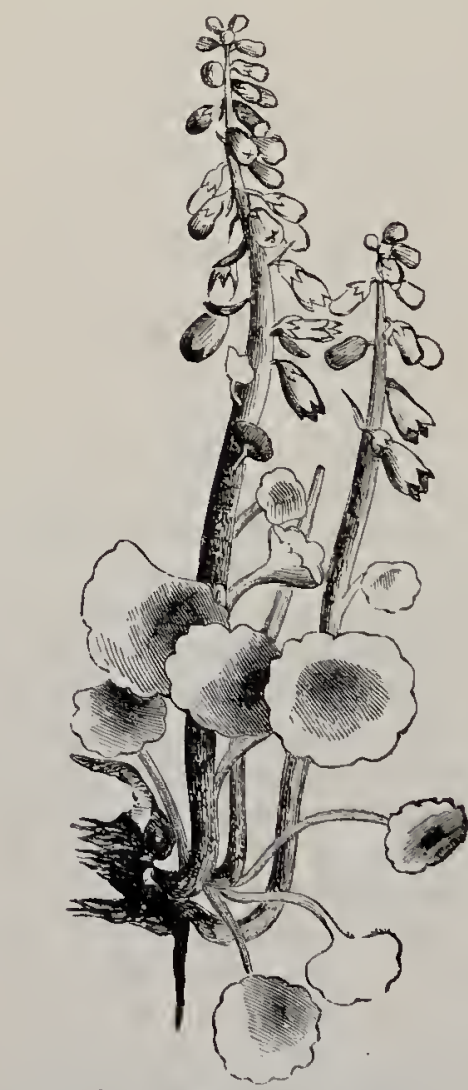

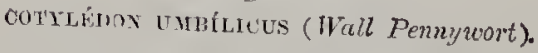

lous, greenish-yellow flowers.- - Walls and rocks, chiefly in the west. 'The plint often takes a pink tinge in fading, and the leaves are well-known to children by the name of "penny pies."-Fl. June-August. 
3. SÉdum (Stonecrop).-Wucculent herbs; flowers usually cymose, 5 -merous, rarely 4-merous; petals free; stamens in 2 whorls; hypogynous scales entire or

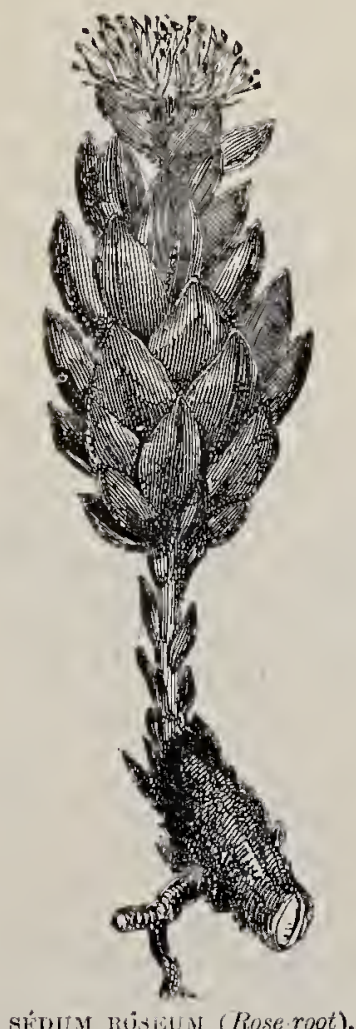

notched. (Name fi'om the Latin sédeo, I sit, from the prostrate habit of the genus.)

* With a thich rhizome; leaves broad and flat.

1. S. róseun (Rose-root).-Rhizome 2-3 in. long, branched, woody, having the scent of rose-water; 
stems 6-10 in. high, annual, unbranched; leaves broad, glaucous, acute; flowers in compact terminal cymes, greenish-yellow, 4-merous, dicecious.-On mountains in the north and in Ireland, and on sea-cliffs; not common.-Fl. May-August. Perennial.

2. S. Teléphium (Orpine, or Livelong).-The largest British species, growing about 2 feet high, and well distinguished by its large, broad, ovate, serrate leaves and terminal dense corymbose cymes of crimson 5-merous flowers.-Rocky thickets; not uncommon, but often an escape from gardens.-Fl. July, August. Perennial.

\section{***aves nearly cylindric; flowers white.}

3. S. villósum (Hairy Stonecrop). - A small species with hairy, viscid stems and leaves; and pinkish white flowers, few together.- Wet mountain pastures in the north.-Fl. June, July. Biennial.

4. S. album (White Stonecrop). - I glabrous species with prostrate barren stems and erect reddish flowering stems 6-10 in. high; fores sub-cylindric, blunt, $\frac{1}{2}$ in. long, bright green; flowers white, in many-flowered corymbose cymes.- Rocks and walls; not common.-Fl. July, August. Pelenmial.

5.* S. das̆y̆híllum ('Whick-leaved Stonecrop). - A small, very glaucous, pink-tinged, slightly viscid, and prostrate species with fleshy, almost globular leaves, and white flowers, of ten streaked witl pink.-Occurs as an escape on old walls.-Fl. June, July. Perennial.

6. S. Guylicum (English Stonecrop).-A small plant 3-4 in. high, with stems prostrate, ascending; leaves small, scattered, crowded, fleshy, spurred at the base beneath, pale green or tinged with red; flowers star-like, whitc, spotted with red, in two-forked cymes; petals very sharply pointed; anthers bright red.-Rocky and sandy places, especially near the sea. -Fl. June-August. Annual. 
**** Leaves nearly cylindric; flowers yellow.

7. S. ácré (Biting Stonecrop, Wall-pepper).-Very like the preceding in habit and growing in similar situations; but distinguished by its thicker, more. crowded, and intensely acrid leaves and golden-yellow flowers in 3-cleft cymes.-Wall, rocks, and sandy ground; common.-Fl. June, July. Perennial.

8.* S. sexanguláré (Tasteless Yellow Stonecrop), distinguished from the preceding by its crowded leaves

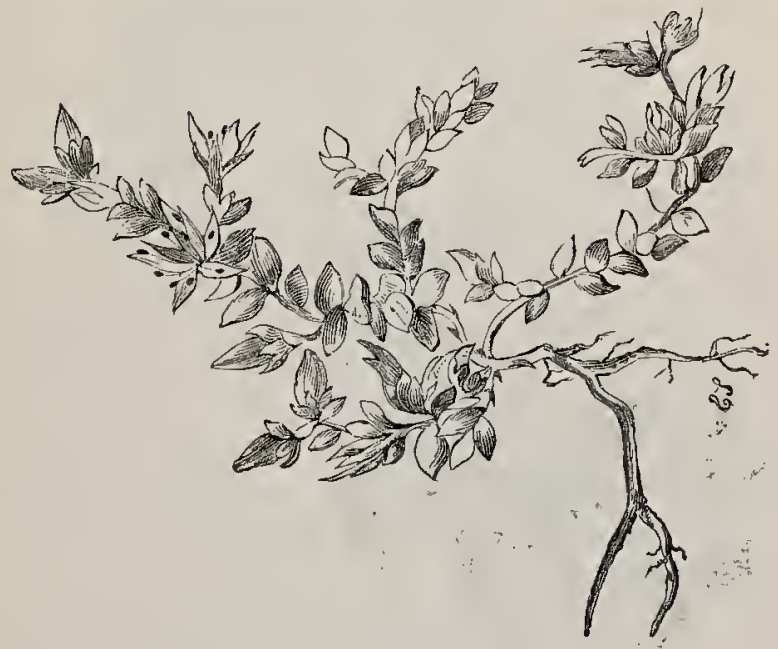

SÉDUM ÁCRÉ (Biting Stonecrop).

more distinctly in 6 vertical rows, and by its acute sepals, occur's on old walls, chiefly in Kent, but is not indigenous.-Fl. July. Perennial.

9.* S. refléxum (Recurved Yellow Stonecrop).Easily distinguished from any of the preceding by, its slender but tough stems, 6-10 in. high, with spreading, or reflexed, awl-shaped, pointed, and sometimes glaucous leaves, flowers often 6-merous, bright or pale yellow.-Walls and dry bauks; not uricommon, 
but seldom, if ever, indigenous.-Fl. July, August. Perennial.

10. S. rupéstié (Rock Stonecrop), an allied species, with densely imbricated, adpressed, glaucous leaves, slightly tlattened, and flowers in corymbose cymes,

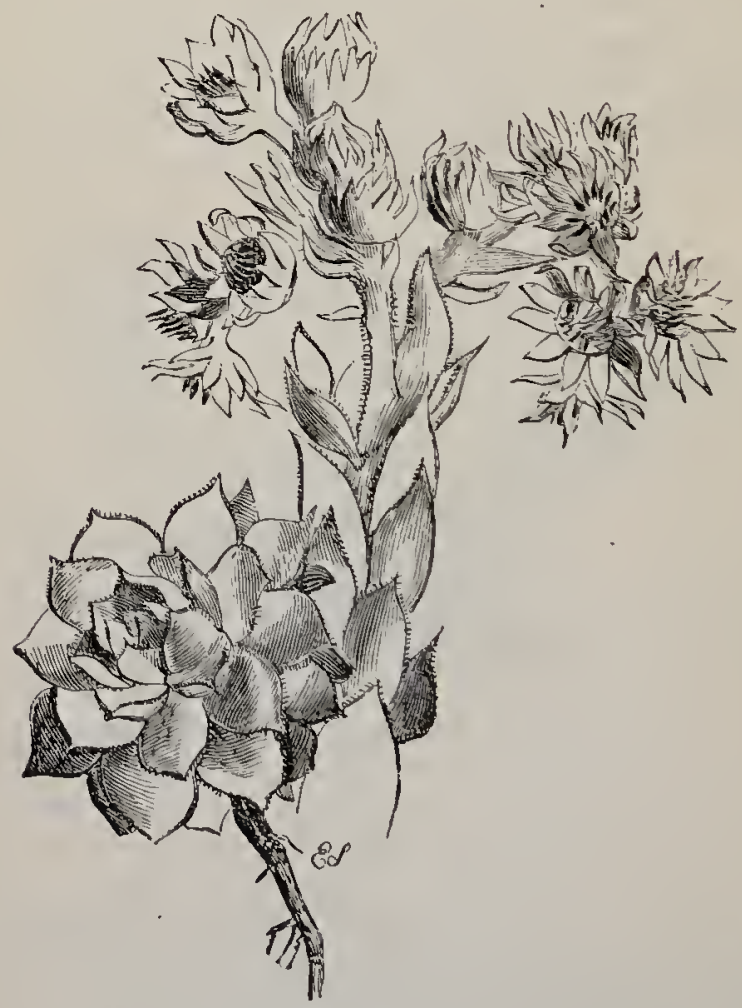

SEMPERVÍvUM TECTóRUM (Common Honse-leek).

occurs wild on limestone at St. Vincent's Rocks, Bristol ; Cheddar ; and the Great Orme's Head; and elsewhere generally as an escape.-Fl. June, July. Perennial, 
11. S. Forsterianum (Welsh Stonecrop), a species very closely allied to the preceding, but with bright green, not glaucous leaves and flowers in round-topped or capitate cymes, grows on wet rocks in Wales, Shropshire, and Somerset.-Fl. June, July. Perennial.

*4. Sempervívum (House-leek). - Succulent plants with dense rosettes of sessile radical lecues, giving off offsets from their axils; flowers in branched cymes, 6--20-merous; stamens in 2 whorls, the inner usually barren; hypogynous scales fringed; follicles manyseeded. (Name from the Latin semper, always, vivo, I live.)

1.* S.tectórum (Common House-leek).-A common but scarcely indigenous plant, growing on the roofs of cottages and outhouses. The leaves are thick and juicy, edged with red-purple, ciliate, mucronate, and in compact rosettes. The dull 1ed-purple flowers are in scorpioid cymes, and are usually 12 -merous. The inner whorl of stamens frequently have anthers containing ouvles, like those in the carpels, which, however, never mature as seeds. The leaves contain malic acid.-Fl. June, July. Perennial.

Ord. XXIX. Droseríceæ.-The Sundew Family.

An interesting group of herbaceous marsh plants widely dispersed over the globe, but specially common in Australia. They will grow on wet sand or moss, depending only for water on the substratum, and their roots are accordingly small. Their chlorophyll is often little developed, the whole plant being reddish, and the leaves in several genera covered with insectivorous glandular hairs. The flowers are polysymmetric and usually 5 -merous, the sepals and petals 
being imbricate, the stamens in $1-4$ whorls, the carpels sometimes reduced in number, with distinct styles, and forming a 1-5-chambered, many-seeded capsule. In Drósera, the largest genus and the only one represented in Britain, the leaves have manypointed lobes or tentacles, each ending in a gland exuding a viscid fluid, especially when the sun is shining, so that they appear as if tipped with dew, whence the various names of these plants. These tentacles are at first spreading and the fluid neutral; but on capturing a small fly, or on contact with any nitrogenous substance, the fluid becomes acid and the tentacles bend towards the centre of the leaf, where the fly is digested. Dionća muscipula (Venus' Fly-trap), a native of Carolina, has non-glandular tentacles round the margin of the leaf and a few long hairs on its upper surface. When these hairs are touched by an insect the two halves of the leaf close together instantaneously by an electrical action, the tentaclos interlocking like the teeth of a gin, and an acid digestive fluid is then exuded by glands on the surface of the leaf. It has been experimentally demonstrated that the Sundews benefit by the animal food thus obtained.

1. Drósera (Sundew). - Stipules membranous, adnate to the petiole; flowers in 1-sided sympodial cymes, curled up circinately when in bud; sepals, petals, and stamens 5 each; styles 2-5, deeply 2-fid; capsule 1-chambered, 2-5-valved. (Name from the Greek drósera, dewy.)

1. D. rotundifólic (Round-leaved Sundew).--An exceedingly curious little bog plant, 2-6 in. high; leaves all radical, petiolate, spreading horizontally, round, with tentacles on the petiole, upper surface, and margin ; flowers on a slender, wiry, leafless scape, small, white, cleistogene, or opening very 
rarely in sunny weather.-Spongy bogs and heaths; common.-El. July, August. Perennial.

2. D. anglica (Great Sundew).-A larger, stouter species; leaves all radical, on very long stalks, which

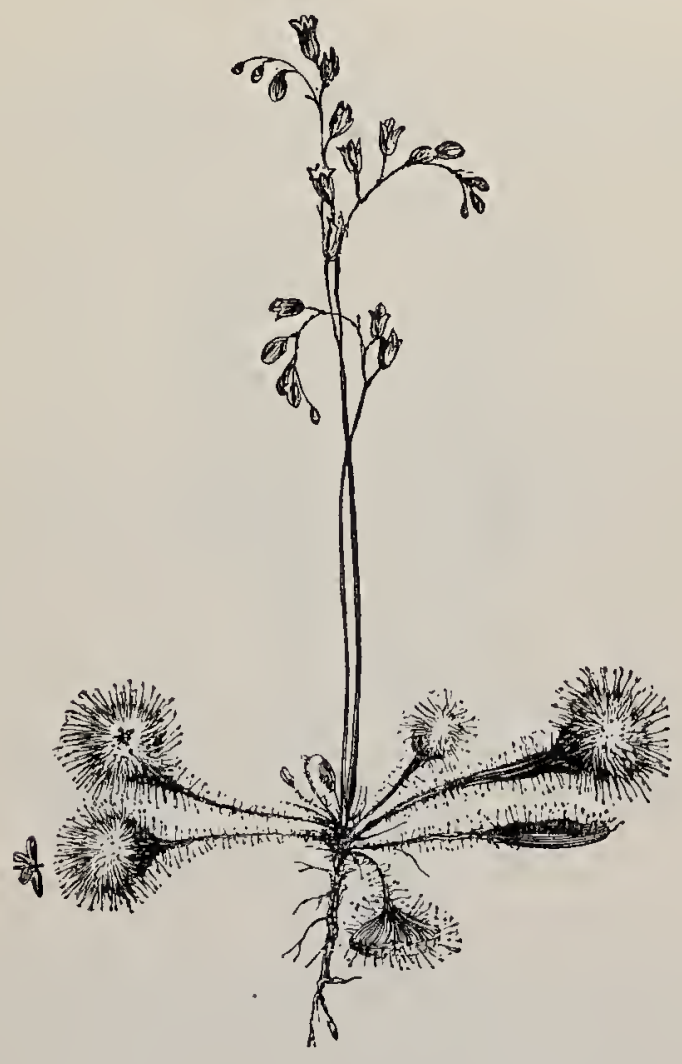

DRóSERA ROTUNDIFóLIA (Round-leaved Sundew).

are destitute of tentacles, erect or nearly so, obovate. -In similar situations to the last, but much less frequent.-Fl. July, August. Perennial.

3. D. intermédia (Long-leaved Sundew).- Very similar to the last, but smaller; leaves spathulate, not 
more than 2 in. long; peduncles curved at the base.-Occurring with $D$. rotundifótia, but less frequent.-Fl. July, August. Perennial.

Ord. XXX. Lythrariéz.-The Loosestrife Family.

Herbs, shrubs, or trees, with 4-angled branches; simple, entire, exstipulate, and generally opposite leaves, and usually polysymmetric flowers; sepals and petals 3-6 each; stamens equalling the petals in number, or $2-4$ times as many; carpels 2-6; fruit a many-seeded capsule, covered by the calyx, but not united to it.-Most members of the Order are tropical, and many of them possess astringent properties which are vitilised in dyeing. Lawsonia inermis is the Henna of Egrpt, which has been used for ages by the people of that country to stain their nails of an orange colour. It is also used to dye Morocco leather a reddish-yellow.

1. PÉplis. - Calyx bell-shaped, with 12 divisions, alternately smaller; petals 6 , minute, fugacious or absent; stamens 6 or 12 ; style very short.

2. Líthrom.-Caly, cylindric, with 12 divisions, alternately smaller; petals 6 ; stamens 6 or 12 ; style long.

1. Púrus (Water Purslane).-Small, weak, annual herbs; flowers minute, axillary.; caly $x$ campanulate, 12-lobed, the alternate lobes smaller; petals, perigynous, fugacious or absent; stamens 6 or 12 ; style short; capsule 2-chambered, 2-valved, many-seeded. (Name from the Greek peption, purslane, not origin. ally referring to this genus.)

1. P. Pórtula (Water Purslane).-A humble, glabrous, creeping, aquatic plant, with 4-angled stems; olposite, obovate, obtuse leares; and inconspicuous, 
solitary, axillary flowers.-Wet places ; common. The plant is usually tinged with red, especially when the ground in which it grows dries up.-Fl. July August. Annual.

2. LÝthrum(Purple Loosestrife).--Herbs or shrubs with 4-angled branches; entire leaves; flowers in spikes

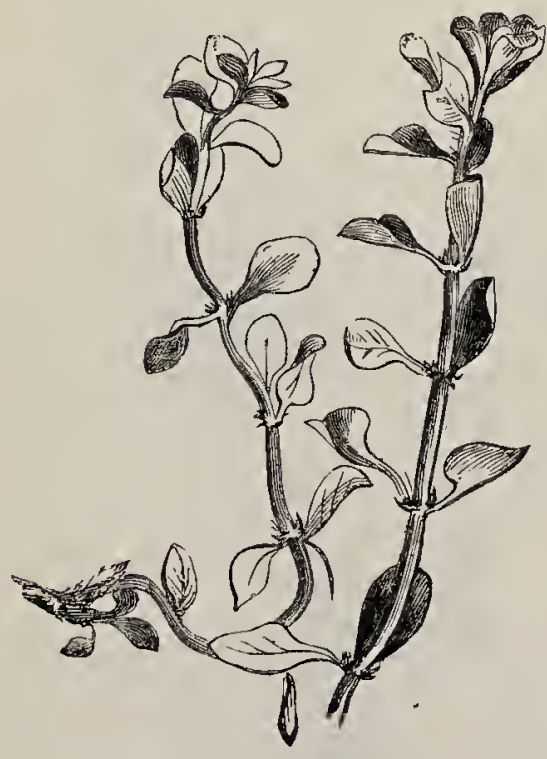

pḱptis fónluta (Water Furslane).

of axillary 1- or more-flowered cymes; calyx-tube cylindric, with 8-12 ribs and teeth, the alternate teeth smaller; petals 4-6, or absent; stamens 8-12 in 1 or 2 whorls, often lying to one side; ovary superior, 2-chambered; style long, thread-like ; capsule very many-seeded. (Name from the Greek luthron, gore, from the colour of the flowers.) 
1. L. Salicaria (Purple Loosestrife).-An exceedingly handsome plant, 2-4 feet high; rhizome

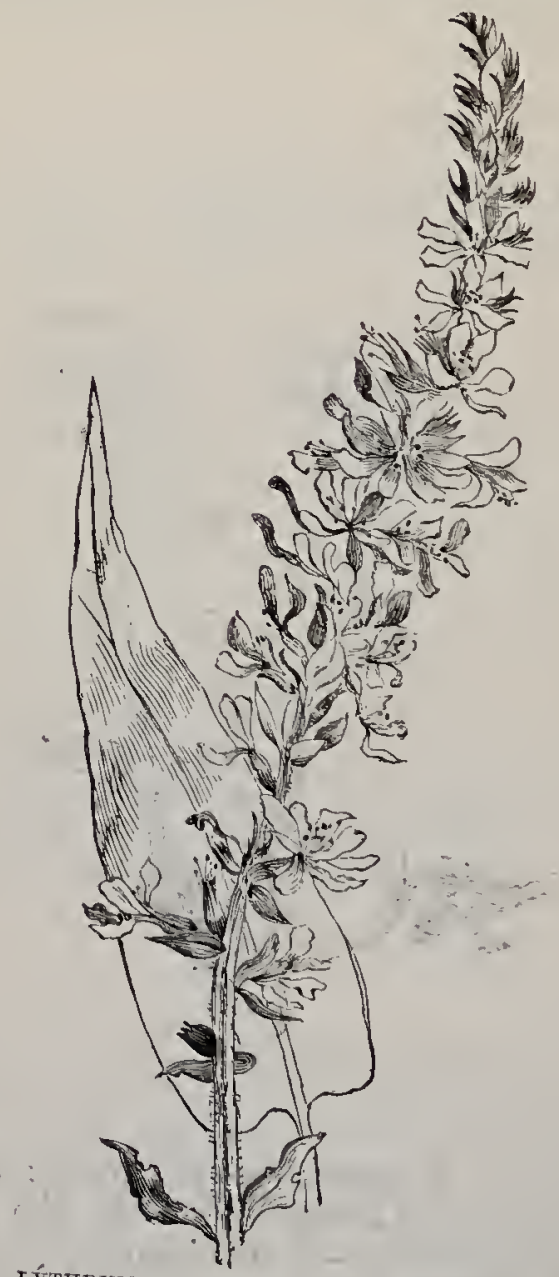

IÝmindur saticária (Purple Loosestroife).

creeping; stem 4-6-angled or winged; leaves opposite, or in wholls of $3-4$, decussate, lanceolate, cor- 
daté, acute; flowers in tall, tapering, leafy spikes of axillary glomerules or sessile cymes, about 1 in. across, red; calyx-tube 12-ribbed; petals wrinkled; stamens 12 in 2 whorls, both differing in length from the style; style in some plants longer than all the stamens, in others shorter than all of them, and in others intermediate between the two whorls.--River banks and ditches; common. Growing among sedges and rushes, its flower-spikes might, at a distance, be mistaken for Foxgloves, which, however, would scarcely grow in such a situation. The trimorphism of the flowers is connected with cross-pollination by insects, Darwin having shown that the pollen from any of the stamens most readily fertilises the stigma of a style of the same length, one, that is, on another plant. Long-styled, medium-styled, and short-styled plants grow together, and are equally numerous.-Fl. July_September. Perennial.

2. L. Hyssopifólia (H) ssop-leaved Purple Loasestrife) is a much smaller, mostly prostrate, glabrous plant, $6-18$ in. high, with alternate narrow leaves; small, pink flowers solitary in the axils; and 6 stamens.-It grows in moist, often inundated, places; but is rare.-Fl. June-October. Annual.

$\$ \S$ Stamens epigynous; ovary syncarpous, inferior.

Ord. XXXI. Haloráge衣.-The Mare's-Tail Family.

A small Order, comprising about 80 species of plants, mostly herbaceous aquatics, with exstipulate leaves, generally whorled; and inconspieuous flowers, often destitute of petals, and in several species having the stamens and carpels in separate flowers. The calyos is generally superior, adhering to the ovary and having sometimes 2 : or 4 sepals; petals 2 to 4 , or 
absent; stamens $1-8$; carpels $1-4$; capsule 1 :-4chambered, indehiscent; seeds solitary in each cham-

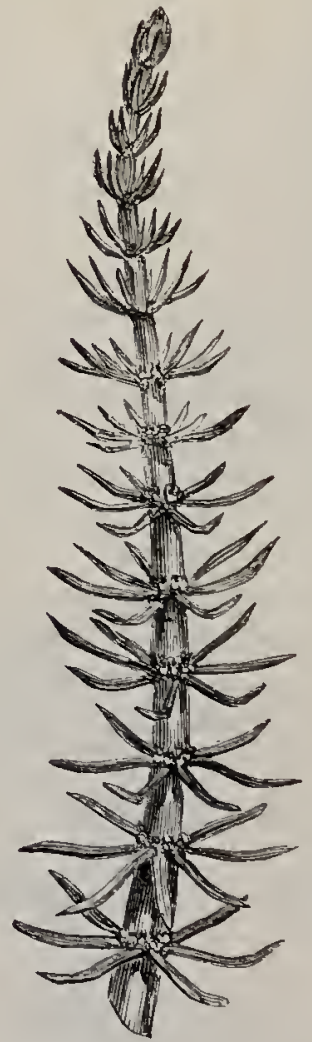

MIPPÚRIS VULGRTS (Common Mare"s-tail).

ber, pendulous. No member of this Order has any important use or known properties.

1. Hippúris.-Leaves whorled, entire; sepals 2, superior ; petals absent; stamen 1; carpet 1.

2. Myriophŕllum,-Leaves mostly whorled, pinnate; sepals 4, superior; petals 4 , or absent; stamens 
2,4 , or 8 , often in separate flowers from the carpels, but on the same plant (monoecious); carpels 4.

3. Callitríché. - Leaves opposite, entire; sepals and petals absent; stamen 1 ; carpels 4 (monœcious).

1. Hippúriśs (Mare's - tail). - Glabrous, aquatic herbs, with erect, unbranched, leafy stems; whorled, narrow, entire leaves; minute, axillary, solitary flowers; caly $x$ forming a minute, indistinctly 2-lobed rim to the ovary; petals absent; stamen 1 ; carpel 1 , 1 -seeded; fruit nut-like, indehiscent. (Name from the Greek hippos, a horse, oure, a tail.)

1. H. vulgaris (Common Mare's-tail).-The only British species, a singular plant, with erect, unbranched, jointed stems, tapering to a point, bearing whorls of 6-10 narrow leaves with hard tips, and inconspicuous flowers sessile in the axils of the upper leaves, and often without stamens.-Not uncommon in stagnant water. Not to be confounded with the genus Equisétum (Horse-tail), a plant allied to the Ferns, which also has a jointed stem and whorled, rigid leaves, but bears its fructification in terminal cones.-Fl. June-July. Perennial.

2. Myriophýldum (Water Milfoil).-_Glabrous, submerged plants ; leaves mostly whorled and pinnately divided into numerous hair-like segments; flowers small, solitary or in spikes, the lower often apetalous and pistillate, intermediate ones perfect, and the upper staminate, so that the inflorescence is polygamous ; sepals 4, rarely 2, united, superior; petals 4, 2 , or absent; stamens generally 8 , rarely 2 or 4 ; carpets 4 , with feathery styles; fruit dividing nto 4 nut-like, indehiscent, one-seeded cocci. (Name fron the Greek murios, countless, phullon, a leaf, from its much-divided leaves. 
1. M. verticillátun (Whorled Water Milfoil).-Bhizome creeping; stems floating, leafy; with short internodes; leaves with distant hair-like segments, collapsing when removed from the water; flower's white, in whorls of about 5 each, forming an elongated erect spike; bracts pinnatifid, longer than the flowers, the upper ones

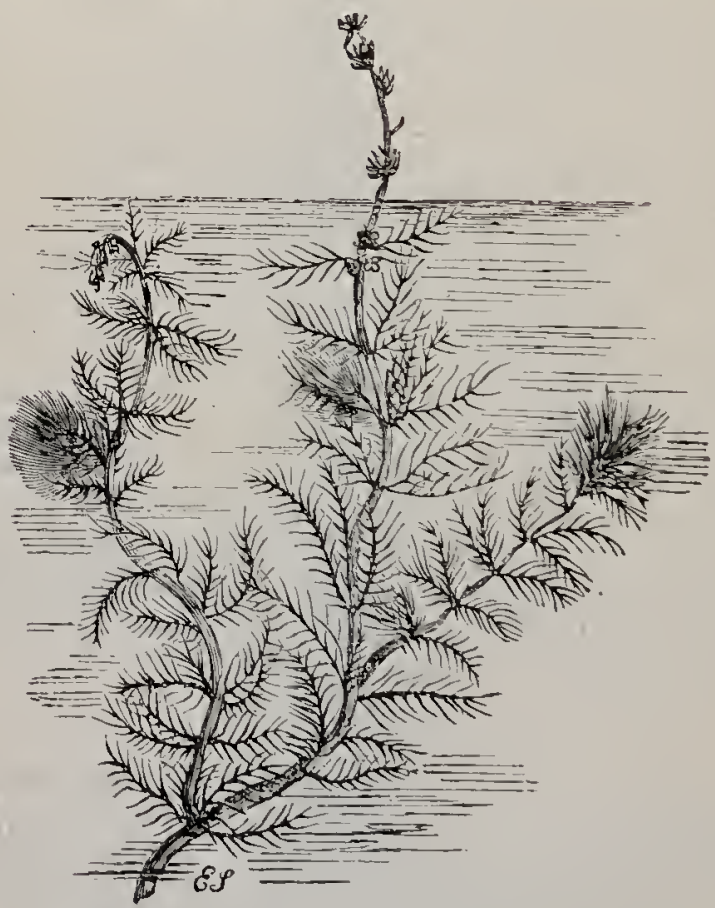

MYrophíluem spicḱtum (Spiked Water Milfoil).

without flowers in theil axils.- Stagnant water; not common. The whole plant is submerged with the exception of the spikes of inconspicuous flowers, which rise a few inches above the surface.-Fl. July, August. Perennial.

2. M. spicátum (Spiked Water Milfoil).-A very 
similar plant, with leaves 4 in a whorl and very small bracts, of which only the lower are pinnate, so that the whorls of flowers form a slender, erect, and apparently leafless spike. -More common than the preceding.-Fl. June--August. Perennial

3. M. alterniflórum (Alternate-flowered Water Milfoil).-Another similar plant, but more slender; leaves 3 or 4 in a whorl; bracts at the base of the

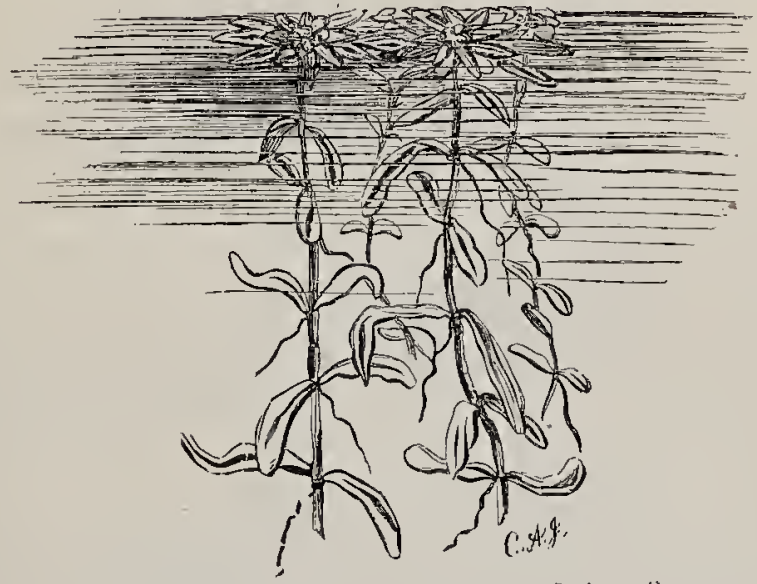

Callftriché véRNA (Vernal Water Starwort).

spike in whorls of 3 or 4 , pinnate, longer than the axillary pistillate flowers; those higher up opposite or alternate, entire or serrate, shorter than the staminate flowers, which thus appear to form a leafless spike which is nodding when in bud. The most frequent species.-Fl. May-August. Perennial.

3. Callítriché (Water Starwort).- Slender, submerged, aquatic plants; leaves exstipulate, opposite, simple, entire, the upper ones sometimes floating and often forming a rosette; flowers axillary, solitary, 
minute, monocious, without calyx or corolla, but usually with 2 white bracts beneath, consisting eithel of one stamen, or very rarely two, with a slender filament and a one-chambered anther dehiscing transversely, or of a 4-angled, 4-chambered ovary, with 2 slender styles ; fruit of 4 winged, 1-sceded, indehiscent cocci. (Name from the Greek kalos, beautiful, thrix, hair.)

1. C. vérna (Spring Water Starwort).-.Stems long, slender, sending out long thread-like silvery roots from the joints; the upper leaves ovate-spathulate, floating in a light-green star-like rosette, the stamens being the only parts of the plant actually abovo water; bracts straight, deciduous; styles erect; fruit sessile, with carpels swollen and bluntly keeled at the back.-Ponds and slow streams; common.-Fl. April-October. Annual or perennial.

2. C. stagnátis (Mud Water'Starwort). - A terrestrial form, with the upper leaves broad roundish, in a close rosette, or absent; bracts sickle-shaped, persistent; styles erect in flower, reflexed in fruit; carpels flattish, winged.-Chiefly on mud; common.-Fl. May-September. Annual or perennial.

3. C. polymórpha, as yet only recognised in a few localities, is similar, its bracts being persistent; but has stimmas 2_-4 times as long as the ripe fruit, and carpels scarcely winged.

4. C. hamuláta, usually very small; leaves mostly linear; bracts sickle-shaped, deciduous; styles long, diverging; carpels flattish with a blunt keel.Marshes, lakes, and streams.-Fl. June--September.
Anmual or perennial.

5. C. obtusángula has obovate leaves in a rosette; persistent bracts and styles; and unkeeled carpels.Ditches; apparently not common.-Fl. May-Septermber. Annual or perennial.

6. C. autumnális (Autumn Water Starwort).-Leaves all submerged, linear, obtuse, dark green; 
bracts absent; styles spreading; fruit large, dark brown; carpels with a broad wing.-Lakes; rare.Fl. June-October. Annual or perennial.

7. C. truncáta, differing in having lighter, more translucent leaves and bluntly keeled carpels, has only been observed in a few localities.

Ord. XXXII. Onagrarié.⿸.-The Willow-hers FamiLY.

Herbs, or rarely shrubs or trees, principally inhabiting the temperate parts of the globe, with simple, exstipulate leaves, and generally conspicuous, polysymmetric flowers, mostly 4-merous; sepals 4 or 2, valvate; petals 4 or 2 , contorted in the bud, or absent; stamens 2-8; ovary 1-6-chambered, usually 4-chambered; fruit a berry, or 4-chambered capsule. To this Order belongs the beautiful genus Fuchsia, with its coloured 4-cleft calyx and edible but insipid berries, natives of Mexico, Peru, Chili, and New Zealand. Many species of Enothêra, natives of America, with the exception of one Tasmanian species, are cultivated as garden plants, some bearing flowers 3 or 4 inches in diameter. Those with yellow or white flowers, which open in the evening, are called Evening Primroses. No member of the Order has any known properties of importance.

1. Epıróbiun.--Sepals 4 ; calyx-tube not prolonged above the ovary; petals 4 , red, pink, or white; stamens 8 .

2. LudwíGIa.—Sepals $3-5$; petals $3-5$; short, or absent; stamens $3-5$.

*3. CEnothéra.-Sepals 4 ; calyxi-tube prolonged above the top of the ovary; petats 4, yellow, white, or red ; stamens 8 .

4. Circas.-Sepals 2 ; petals 2, white; stamens 2. 
1. Epilóbium (Willow-herb).--Herbs or undershrubs with runners; flowers red or pink, rarely white or yellow; sepals 4, decidnous, springing direct from

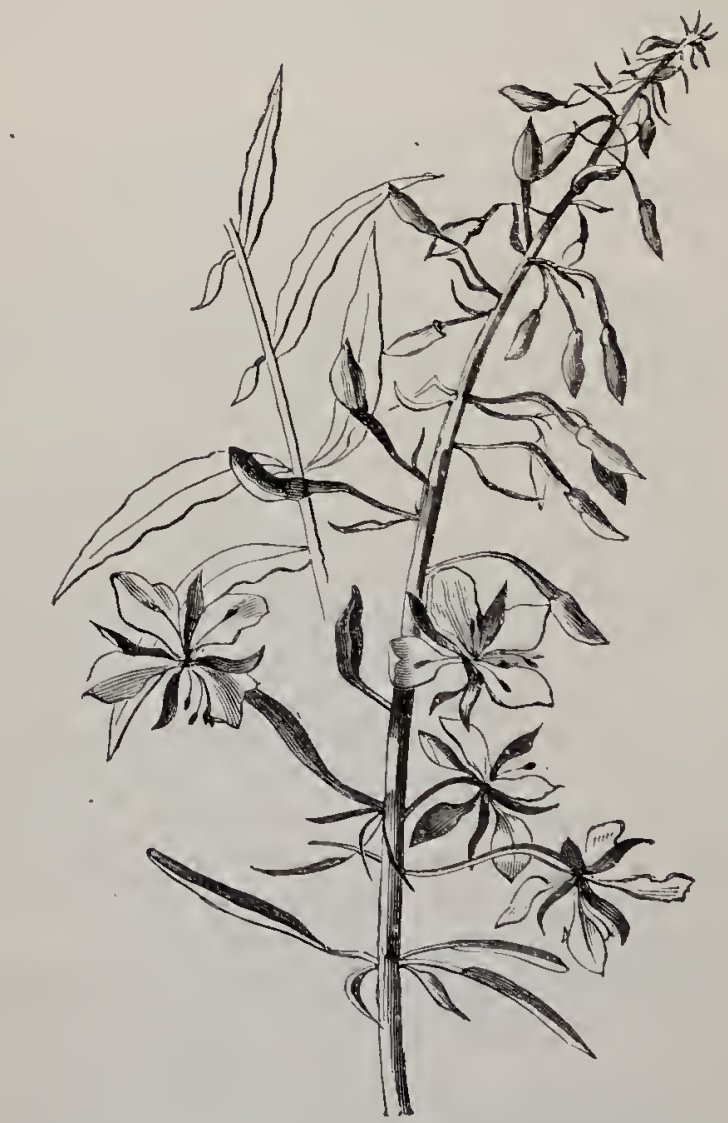

EPILÓBIUM ANGUSTIFót.IUA ( Riose-bay, or Freqch Willow).

the top of the ovary; petals 4, usually 2-lobed; stamens 8 , in two whorls, differing in length; style thread-like; capsule very long and slender, 4-cham- 
bered and 4-valved; seeds numerous, tufted with down. (Name from the Greek epi, upon, lobos, a pod, the corolla springing from the top of the long podlike inferior ovary.)

* Petals unequal in size; stamens bent downuards.

1. E. angustifólium (Rose-bay or French Willow).A handsome species, 2-6 feet high; stem erect, round, unbranched; leaves scattered, stalked, lanceolate, slightly toothed, glawcous beneath; flowers 1 in. across, rose-coloured, in a long, loose bracteate raceme; capsule $1-4$ in. long.-Damp woods, frequent; but sometimes an escape from gardens. Caution should be used in admitting it into a small garden, as its rhizomes creep extensively, and are very difficult to eradicate.Fl. July, August. Perennial.

\section{* Stem round; petals all equal; stamens erect; stigma 4-cleft.}

2. E. hirsútum (Great Willow Herb, Codlins and Cream).-A handsome downy spccies, 3-6 feet high, producing underground suckers; leaves opposite, oblong-lanceolate, clasping the stem, serrate; flowers nearly an inclı across, deep rose-colour, fragrant; petals broad....Wet places by ditches and rivers; common.-Fl. July, August. Percnnial.

3. L. parifióm (Snall-flowered Hairy WillowHerb).-Stem erect, $1-2$ feet high, little branched, downy, producing runners in autumn; leaves mostly scattered, sessile, lanceolate, toothed, hairy; buds erect; flower's small, pink.-Damp places; common.Fl. July, August. Perennial.

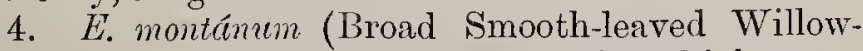
Her.b).-A small species, about a foot high; stem downy ; leaves mostly opposite, ovate, acute, serrate, 
glabrous or downy along the edges and veins only, the lower ones slightly stalked, sometimes in whorls of 3 ; buds drooping; flowers small, pink.-Dry places ; common.-Fl. June-August. Perennial.

5. E. lanceolátum (Spear-leaved Willow-Herb).A rather larger species, with an erect, branched, obscurely angled stem, pubescent with recurved hairs; leaves stalked, flaccid, mostly pendulous, oblonglanceolate, toothed; buds drooping; flowers small, pink.-Stony places in the south; rare. Fl. JulySeptember. Perennial.

***** Stem more or less 2-4-angled: pretals all equal; stamens erect; stigma linobbed, not 4-cleft.

6. E. róseum (Pale Smooth-leavel Willow Herb).Stem 1--2 fcet high, branching, with 2 sharp and 2 blunt angles; Tea'es long-stalked, ovate, toother, glabrous; buds drooping; flowers small, rose-coloured. -Moist places, chiefly in the south.-Fl. July, August. Perennial.

7. F. adnátum. (Square-stalked Willow-Herb).Stem 1-2 feet high, usually much branched, 2-4angled ; leaves sessile, dccurrcut, linear-oblong, much toothed, flat, yellow-green ; buds erect; flowers small, rose-pink.-Damp places; frequent.-Fl. July, Augus,t. Perennial.

3. E. obscumem, a similar plant, produces its copious thread-like runners in summer with leaves not in rosettes; its leaves are ovate-lanceolate, slightly toothed and dull; and its flowers small, with short, narrow, rose-red petals.-Damp places ; more common than the preceding.-Fl. July, August. Perennial.

9. H. Lámyi, as yet only recognised in a few localities, is allicd to $F$. adnátum: but differs in its leaves being shortly stalked, more shining, dark blue-green, smaller, molc distant, and less toothed; and its flowers 
larger and earlier in appearance.--Damp places.-Fl. June, July. Perennial.

10. E. palústié (Narrow-leaved Marsh WillowHerb).-Stem 6-18 in. high, round, with two lines of down on opposite sides, producing slender, small-leaved runners in summer, ending in bulbs in autumn; leaves narrowly lanceolate, wedge-shaped at the base, sessile; buds drooping; flowers small, pink. -Bogs ; common.-Fl. July, August. Perennial.

11. E. alsinefólium (Chickweed-leaved WillowHerb).-A low tufted, almost glabrous species; stems succulent, with two raised lines of down; leaves stalked, ovate, acute, serrate, glabrous, very thin, bright green, shining; buds drooping; flowers $\frac{1}{3}$ in. across, bright rose-coloured.- By mountain streams in the north.Fl. July, August. Perennial.

12. $E$. alpinm (Alpine Willow-Herb).-A still smaller form, with slender, not succulent stem ; obtuse, pale green leaves; and 1-3 pale rose-coloured flowers drooping in bud,-In similar situations to the preceding.-Fl. July. Perennial.

These plants are by no means easy to distinguish ; they vary considerably in many of their characters, and, where two species grow near to one another, hybrids between them occur frequently.

2. Iudwigra (Isnardia).-...IIerbs with entire leaves ; axillary, solitary, bractente flowers, usually 4-merous; sepals $3-5$, persistent; petals $3-5$, or absent; stamens 3-5; ovary 3-5-chambered; style short; stigma 3-5-lobed; outes many; fruit a capsule. (Named in honour of Carl Ludwig, Professor of Botany at Leipsic.)

1. L. paluistirs (Marsh Isnardia). - The only British species, a small, prostrate, glabrous planr, 6-10 in. long, with 4-angled, branched stems, rooting at the nodes ; opposite, stalked, ovate, acute, 


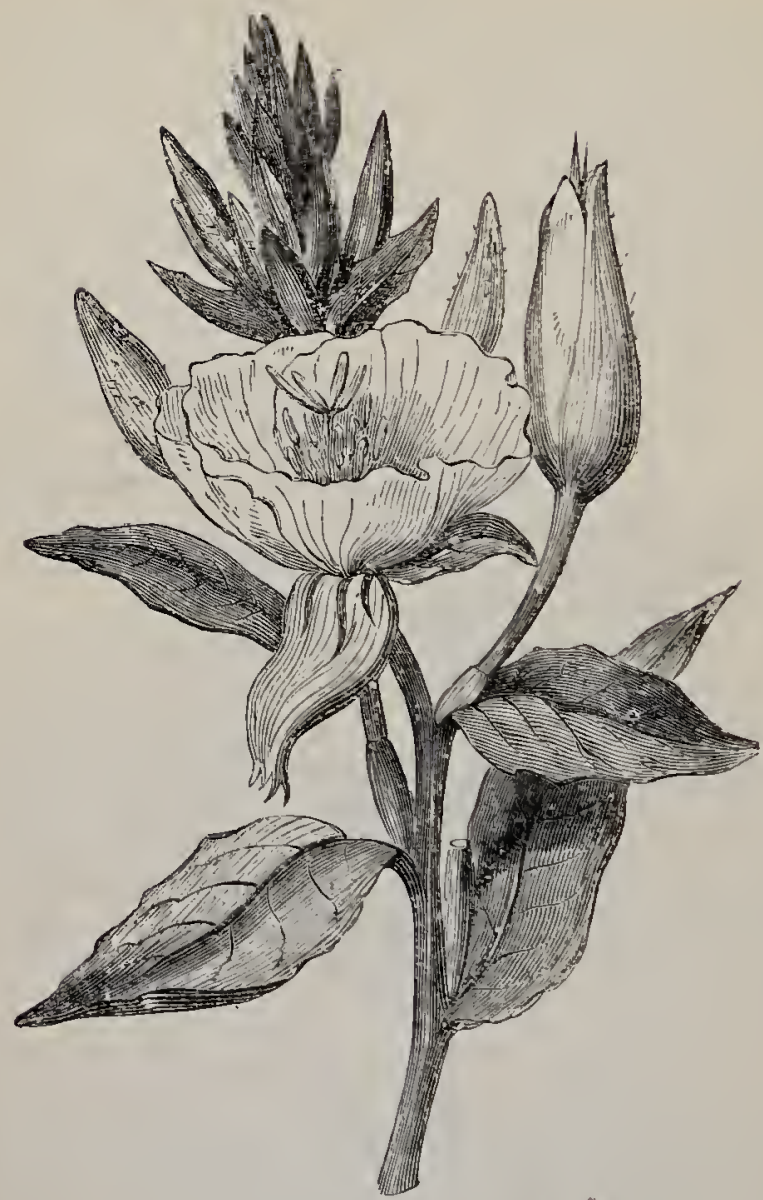

anotiéra biśxyis (Common Evening Primrose).

shining leaves ; and minute, axillary, sessile, apetalous, 4-merous flowers.-Boggy pools in the Now Forest and formerly in Sussex,-Fl. Jume, July.

*3. CEnothéra (Evening Primrose).-American 
herbs, with scattered leaves; large 4-merous flowers: calyx-tube prolonged above the top of the ovary and constricted so as to form a honey-chamber; sepals deciduous ; stamens 8. (Name in Greek oinothêras, employed by Theophrastus, signifying "catching the flavour of wine.")

1.* E. biénnis (Common Evening Prim rose).-A tall, stout herbaceous plant, $2-3$ feet high, with lanceolate smooth leaves; large, pale yellow, fragrant flowers, which open in the evening, and wither towards the middle of the next day; and a long capsule bluntly 4-sided and widest near its base. It is a native of North America, and is naturalised in a few places. Fl. July-September. Biennial.

2.* $\quad E$. odoráta (Eragrant Evening Primrose), differing mainly in having brighter green leaves, deeper yellow flowers, and a capsule widest near the top, is a native of Patagonia, naturalised at some points on the south-west coast. - Fl. July-September. Biennial.

4. Crróes (Enchanter's Nightshade).--Slender, (rect lierbs with creeping rhizomes; leaves opposite, stalked, toothed; flowers in racemes, small, white, 2-merous ; sepal: reflexed, deciduous; style slender; stigma 2-lobed; ovules 1 or 2 ; fruit indehiscent, covered with hooked bristles. (Name from Circe, the enchantress who bewitched Ulysses and his companions.)

1. C. lutetiána (Common Enchanter's Nightshade). -A slender herbaceous plant, pubescent with glandular hairs, 1-2 feet high, with round-stalked, ovate, spreading, dull leaves, and loose terminal and lateral racemes of minute white flowers, with pink stamens, suceeeded by 2-lobed bristly fruits.-Damp shady places; common, often a troublesome weed in damp gardens.-Fl. June-August. Perennial. 
2. C. alpina (Alpine Enchanter's Nightshade).-Closely resembling the last, but smaller, not exceed-

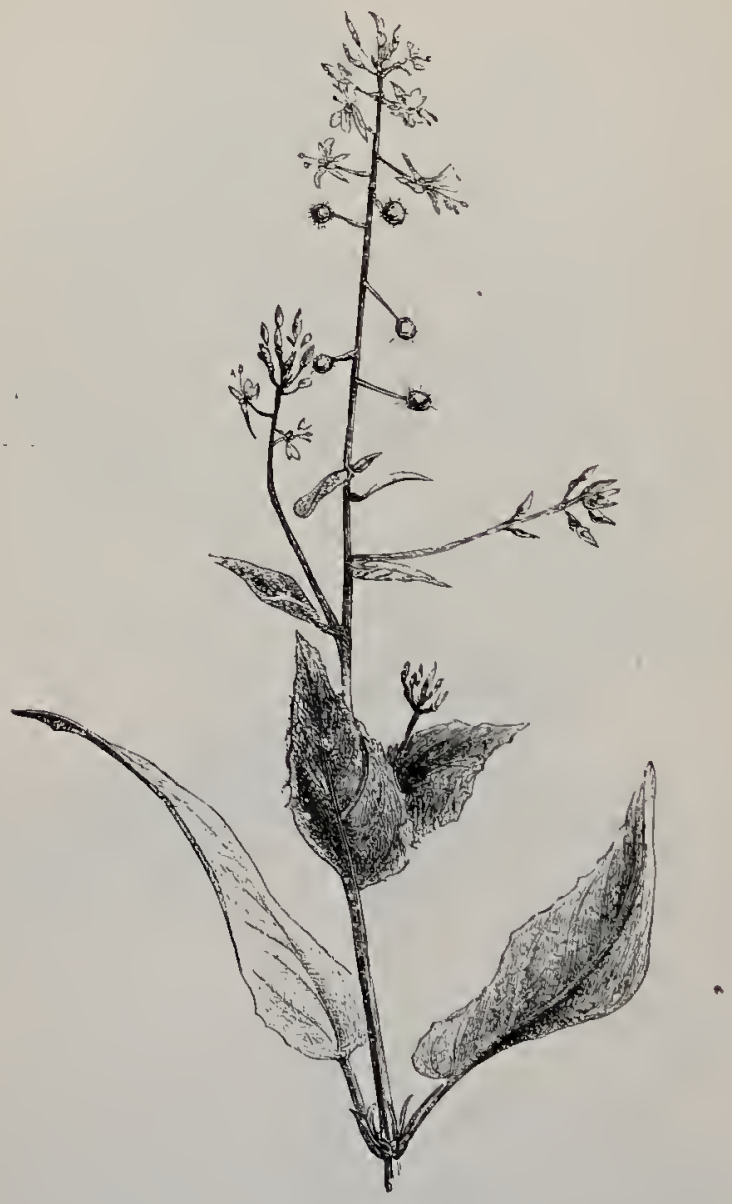

CIRCÁA LUTETIÁNA (Common Enchanter's Nightshade).

ing 8 in. in height, less hairy, less branched ; leaves cordate, shining, more deeply-toothed, and with 
Hat stalks. They are so delicate as to be nearly transparent when dried. 'The fruit is less bristly and 1-seeded.-Mountainous woods in the north.-Fl. July, August. Perennial.

Ord. XXXIII. Cuevrbitácez.-The Gourd Family.

A large and important Order, chiefly tropical, but having only one British representative. They are herbaceous plants with juicy stems, climbing by means of tendrils; scattered, exstipulate leaves which aro usually lobed and rough; pentamerous flowers which are often large, yellow, red, or white, and imperfect; and fruit either a berry or a gourd (pepo), horny externally when ripe. The caly.x is superior and 5-toothed; the corolla so united to the calyx-tube as to be sometimes scarcely distinguishable; the 5, more or less united, stamens, with twisted anther's, in distinct flower's from the 1-chambered ovary of 3 united carpels, either on the same plant (moncecious) or on different plants (dicecious). The style is short, the stigmas are thick, lobed and velvety, and the seeds flat. A great number of species are cultivated in Europe either for use or ornament. Many of them are bitter and violent purgatives, of which the common medicinal Colocynth (Citrullus Colocynthis) is an example. This species bears an oval fruit of a very bitter taste, and grows in sandy and desert placos. It is almost certainly the wild cucumber mentioned in $2 \mathrm{Kings}$ iv. 39, 40, as it still grows in profusion at Gilgal, and as its leaves, tendrils, and fruit, though somewhat smaller, are so similar to those of the garden cucumber (Cucumis sativus) that it might easily happen that the man sent out by the disciples of the prophet took them for a harmless plant and prepared a meal of them. The 
bitter taste mace the disciples at once fear that it was foisonous, such a taste being genelally believed by the Hebrews to indicate poison. (See Rev. viii. 10, 11). The Colocynth may also be the vine of Sodom of Deuteronomy xxxii. 32. The Squirting Cucumbers (Ecbatiuar), the fruit of which, when ripe, detaches itself from its stalk, squirting its juice and seeds backwards, is also a very powerful d!ug known as Elaterium. A case is even recorded of a person being taken dangerously ill from having merely carried a specimen in his bat. Many species of the Ordder, however, produce edible fruit, as, for instance, the numerous varieties of the Cucumber (Cucumis sativus), Melon (Cúcumis Mélo), and Water Melon (Cúcumis Citrúllus), and one of our finest vegetables, the Vegetable Marrow (Cucurbita ou'fera). The only British member of the Order, the White Bryony (Bryónia dióica), partakes of the properties of Colocynth, and its root is used in medicine. It is said that its tender sloots may be eaten boiled, and resemble Asparagus in flavour; but the shoots of the Black Bryony (Támus communis), a widely differant plaut, belonging to another Order, may have been meant; and, in either case, the experiment is a dangerous one.

1. Bryónia (White Bryony). - Slender climbing herbs, with palmately 3-5-angled or lobed leaves : calyat -tube campanulate; corolla rotate or campanulate; stamens 5, united in 3; style 3-cleft; fruit a globose berry. (Name from the Greek bre, I shoot, from the rapid growth of the shoots.)

I. B. dióica (White Bryouy).-The only British species, an elegant climbing plant, densely clothed with white hairs; tendrits umbranched; leaves large, light green, palmately 5-lobed, rough; flowers diceious, whitish, with green veins. The fertile (pistillate) 
flowers can be at once distingaished from the barren (staminate) ones by the presence of the globular ovary below the calyx. These are succeeded by globular scarlet berries, which hang about the bushes after the stems and leaves have withered. The berries of the

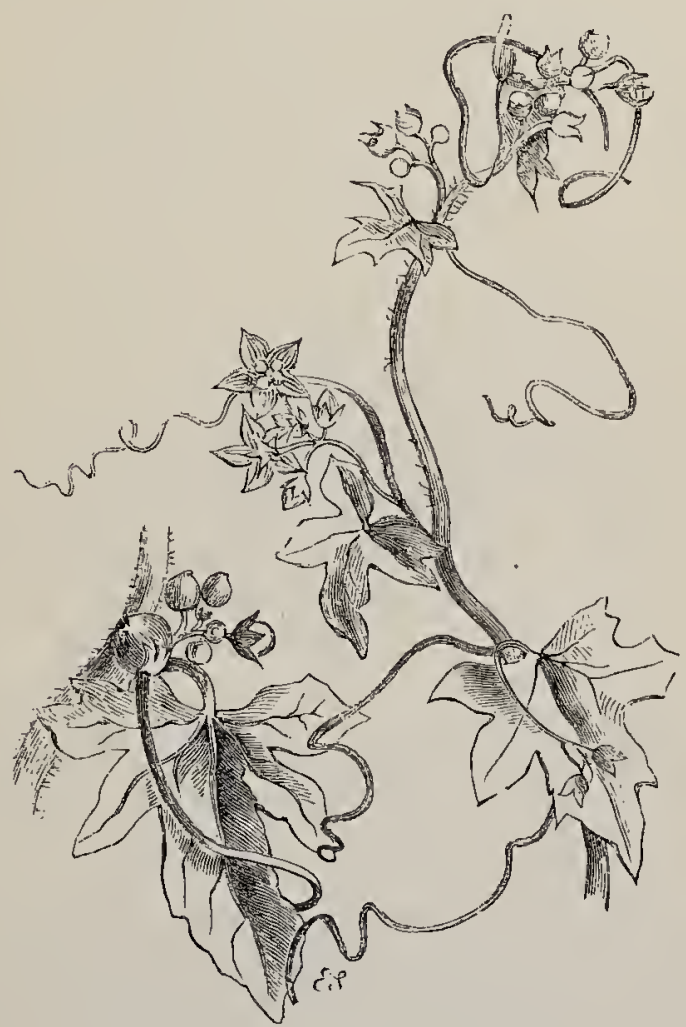

BRYÓNLA DIÓICA (White Bryony).

Black Bryony (T'amus commúnis), a twining plant without tendris, are larger and elliptical. Both should be a voided as probably poisonous.-Hedgerows; frequent, except in the north and west.-Fl. MaySeptember. Perennial. 


\section{Orb. XXXIV. Umbellífere.-The Parsley FAunLY.}

A large and very natural Order of herbaceous plants, comprising about 1,500 species, in 152 genera, mostly natives of the temperate region of the Northern Hemisphere. They have bollow or solid jointed stems, and in most cases pinnately divided, often decompound, leares, more or less sheathing at the base. The flowers are usually small, polysymmetric, 5-merous, white, and grouped in compound unbels: each flower; that is to say, is stalked, the stalks radiating from one point. Such a simple umbel occurs in three British genera-Hydrocótylé, Erýnyium, and Astrantic ; but in the others soveral such umbels, then known as secondary or partial umbels or umbellules, are collected into one juimary or yencral umbel. There is generally an involucre of bracts at the base of the primary umbel, and inrolucels at the bases of the secondary ones. The calyx is superior, 5-toothed, or more often reduced to a mere margin; the 5 petals usually end in inflexed points; and the 5 stamens (which, like the petals, with which they alternate, are epigynous) also bend invards in bud, but commonly mature before the stigmas. The 2 carpels are situated antero-posteriorly, one at the back, that is, and one at the front of the flower; and are united into an inferior, 2-chambered owar\%, crowned by a fleshy disli, which bears the petals and stamens; and there are 2 distinct styles. In the fruit, which is known as a cremocarp, the 2 carpcls cohere by their flattened inner faces, which form what is termed the commissurc, to a central axis or carpophore, which is often $Y$ shaped, and from which, as they ripen, they separate from below upward. The fruit ic often flattened, either dorsally, from front to back, that is, or in a direction at right angles to the commissure, so that this lateral plane is broad, or laterally, from side to 
side, or in a direction parallel to the commissure, which is, therefore, narrow. Each carpel or mevicarp is marked by vertical ridges, normally 9 in number, 5 primary, usually the more prominent, and 4 secondary alternating with them. Of the 5 primary ridges, the 2 nearest the commissure are termed lateral, and are often expanded into wings; the midrib down the back of the carpel is the carinal or dorsal ridye; and the two to the right and left of it are called the intermediate ridyes. The spaces between the primary

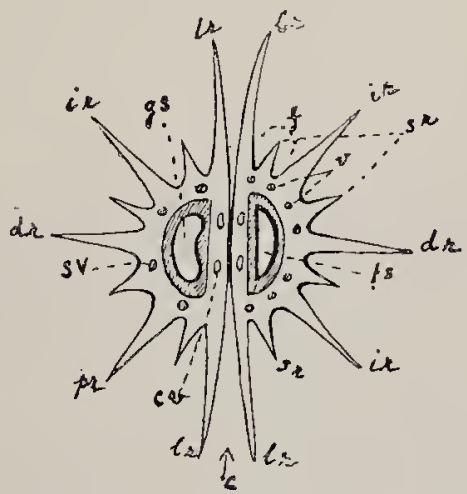

Diagram Section of Fruit of Umbellifer. $c$, commissure ; $d r$, dorsal or carinal ridge; $i r$, intermediate ridge; $l r$, lateral ridge; $m$, primary ridge; $s r$, secondary ridge; $f$, furrow; $v$, vitta; $s v$, solitary vitta; $c v$, commissural vitta ; $f s$, flat seed; $g s$, grooved seed.

ridges are culled furrows. In the wall of the fruit there are often long, narrow sacs called vittce or stripes containing coloured essential oil. They generally occur between the ridges, rarely in them. Normally there are 6 in each carpel, 4 between the primary ridges and 2 in the commissural face; but instead of being thus solitary in each furrow, they may be 2,3 , or more together, or they may be lewer in number. There is one pendulous secd in each carpel, containing horny allumen, and it 
is important to notice whether it is flat or grooved along the side facing the commissure. The ridges, vitta, and seeds are best examined by a lens on a cross section of a fruit; the so-called Caraway-seed, for instance, which is, accurately speaking, a mericarp or carpel. The Order being, as has been said, a very natural one, its genera agree in almost all their more obvious characters, and can only be accurately discriminated by minute differences, chiefly in the ripe fruit, such as the number, position, and shape of the ridges, the presence or absence of vitta, and the form of the seed. This renders the group a very difficult one for the young botanist. It has been divided into 9 tribes, six of which are represented by British plants. There arc about 70 British species belonging to 40 genera.

Among so large a number of species one would naturally expect to find a variety of properties, and such is to a certain extent the case; but from this point of view the members of the Order may be conveniently arranged in four groups. The first group comprises plants abounding in an acrid, watery sap, which is more or less narcotic and poisonous. Among these is the Hemlock (Coninm), the Water Hemlock (Cicute), the Fool's Parsley (. Ethisa), and the Water Dropworts (Enánthê). Every part of the Hemlock, especially the fresh leaves and green fruit, contains the alkaloid Conía, which is very poisonous. It acts on the nervous system, and is a valuable medicine in certain cases. Of all British Umbellifere, the most dangerons, prrhaps, are the Water Dropworts (Einainthê), their large, tuberous roots, resembling those of the Dahlia, being commonly exposed on the muddy banks of streams, and being thus easily got at by children and cattle.

The second group comprises plants the stems of which abound in a foetid gum-resin. Anong these the first place is held by Ascfoetida, the hardened 
milky juice of various species of F'erula inhabiting Persia and the neighbouring countries. This drug was held in high repute among the ancients for its medical virtues: it was supposed to be an antidote to poison, to restore sight to the blind, and youth to the aged; and was besides considered a certain specific against various diseases. Gum Gálbanum is the product of other species of Ferula, natives of the East.

The third group comprises plants the fruits of which abound in wholesome aromatic oils. The principal of these are well known under the names of Caraway, Coriander, Dill, Anise, and Cumin.

The fourth group comprises plants which contain some of the above principles in a very slight degree, or so modified as to form wholesome esculent vegetables. Among these, Carrots and Parsnips occupy the first place: Celery and Alexanclers, in their wild state, are too acrid to be used as food; but, when blanched by being earthed up or covered over, become mild and agreeable: Parsle!, Fennel, and Chervil, the last now out of use, are well-known pot-lierbs: Samplire affords the best of pickles: the sweet, aromatic, and tonic root of Eryngo and the steın of Anyelica (Archangélica officinalis) are candied as sweetmeats; and the root of the latter, which is fragrant and sweet when first tasted, but leaves a glowing leat in the mouth, is valued by the Lapps botl as food and as medicine. Several species produce underground tubers, which, under the name of pig-nuts or earth-nuts, are eaten by children and pigs.

Tribe 1. IIydrocotyléce. Umbel simple ; fruit much compressed laterally ; commissure narrou ; no carpopthore or vitte.

1. Hydnocótylé.-Creeping; leaves simple, peltate. 
Tribe 2. Sanicúlecp.-Umbel simple, capitate or irregularly compound ; fruit slightly dorsally compressed; commissure broad; no covpophore.

2. ERÝnerum.-Leaves spinous; umbets in dense heads; fruit scaly, without lidges or vittre.

*3. Astrántia. Leaves palmatifid ; bracts large, often coloured ; fruit without vitta.

4. Sanícula -Leaves palmatifid; mbels sub-globose, irregularly compound; fruit covered with hooked bristles, without ridges; vittie numerous.

Thibe 3. Amminece. - Umbels compound; fruitlaterally compressed ; commissure narow; mimamy ridges most conspicuous: vitto usually obuious.

* Fruit short, not winged; seed grooved in front.

5. Physospĺrmum. - Fruit globose, bladder-like, with slender thread-like vidges and solitary vitte.

6. Coníun.-Fruit ovoid, each carpel with 5 prominent wavy ridyes; carpophore undivided.

7. Smýrnium - Flowers yellow; carpels kidneyshaped, each with thrce prominent sharp ridges (dorsal and intermediate); withe sumerous; curpophore
forked.

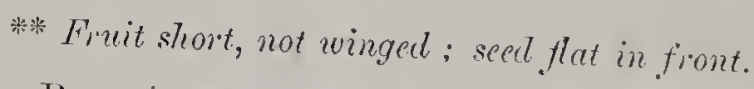

S. Bupleúnum.-Frect; leaves uncliridel; flower's yellow; petals with an inflexed point; carpophore
torked.

9. Trínia-Leares pinnate; flowers white, dicecious; carpophore forked; wittu 5, Jarge, in the bases of the tlick primary ridges.

10. Áprum.-Leaves pinnate or ternate; bracts absent; bracteoles many or absent; flowers white, perfect; prtals entire; rilges slender, prominent;
vitte solitury. 
11. Cró́ta.-Leavis pinnate; bracts few or absent; bracteoles several, small, unequal; sopals ovate, acute; petuls white, obcordate with a long inflexed tip; carpopture forked; ridges flit; vittce solitary, long.

*12. Áммг--Leaves pinnate; bracts with $3-5$ linear segments; sepals absent; petals white, obeordate with a long inflexed tip; carpoplore forked; rilges slender; vittce solitary.

13. CÁRUM.-Leaves pinnate ; bracts few or absent; sepals ineonspieuous; petals white, pink, or yellow; deeply notched with a long inflexed tip; carpopluore forked; ritges slender, blunt; vittoe solitary, rarely 2 together, as long as the fruit.

14. Síson.-Resembling C'amm, but with the upper lacues less divided, and vitte very short.

*15. Falcária.-G]abrous; Tower leaves ternate, uprer pinnatisect; bracts and bracteoles many ; flowes's white, often imperfeet; petals eurved; vittce solitary; carpophore forked.

16. Sívm.-Leaves pinnate; bracts and bracteotes many; sepals aeute; petcils white, entire, with an inflexed tip; carpophore not forked; ridges prominent, slender, blunt; vitta 3 or more together, long.

17. Agopónum.-Leaves biternate; bracts anci bracteoles few or absent; sepals absent; petals white, broad, unequal, with inflexed tip; ridges slender; vitte absent.

18. Prmpinílus.-Leuves pinnate; bracts generally absent; sepals ineonspieuous; petals white or yellow, deeply notehed with a long inflexed tip ; carpophore forked; ridges slender, prominent; vitte many together, long.

***** Fruit more or less beaked; seed grooved in front.

19. Conopónium:-Leaves triternate; lracts and lracteoles few, membrnnous; sepals absent; petals white, 'often unequal, '2-fid, with inflexed tip ; fruit 
shortly beaked; carpophore forked; ridges slender; vitte 3 together.

20. MÝrrHis. - Leaves decompound; bracts absent; bracteoles membranous; sepals inconspicuous; petals white, obcordate with a very short inflexed point; finit elongate but hardly beaked ; vidges sharp, prominent, almost winged; vittce absent.

21. Chжrophílum.-Leaves decompound; bracteoles several; sepals inconspicuous; petals white or yellow, obcordate, with inflexed tip; fmit hardly beaked; ridges blunt, not prominent; vittce solitary.

22. Scándx. - Leares decompound; bracteoles several; sepals inconspicuous; petals white, often unequal ; fruit $1-3$ in. long; ridges prominent, blunt.

23. Anthríscus.-Leaves decompound; bracteoles many, entire; sepals inconspicuous; petals white, with an inflexed tip; fruit short, shortly beaked; riclyes obscure.

Tribe 4. Sesclinece.- Tmbels compound; fruit globose. or ovoid, not latcrally compressed, mickly nor beated: commissure broad : primany ridges the most conspicuous : lateral ridges distinct, rarely uinged; vitte usually obvious.

24. Síseli.-Leaves 2-, 3-, or more, pinnate ; bracteoles many, entire; scpals small, acute; petals white, obcordate, with long inflesed tip ; fruit slightly dorsally compressed; carpopliore forked; ridges thick, blunt, prominent; vitte solitary or 2 together ; seed flit in front.

25. Fanículum.-Leares decompound; bracts and bractcoles absent; sepals inconspicuous; petals yellow, roundish, with a short, blunt, inflexed tip; carpopleore forlzed; ridges prominent, blunt; vitte solitary.

26. Críthuum.-Fleshy ; lecues 2-3-tennate ; bracts and bracteoles many, short; scpals inconspicuous; 
petals minute, white, broad, with long inflexed tip ; carpophore forked; ridges thick, acutc, slightly winged; vitte many ; seed loose, flat in front.

27. (ENي́nтhÉ.-Leaves pinnate; bracts few or none; bracteoles many, whorled; seprals lanceolate; petals white, obcordate with long inflexed tip; carpophore absent; styles sub-erect; ridges blunt, the lateral ones forming a corky rim round the carpel; vitte solitary; seed flat in front.

28. सтни́sA, differing mainly in having the bracts and bracteoles drooping and all on one side, a slender. forked carpophore, and reflexed styles.

*29. Silen.-Leaves 3-ternate; bracts 1-3; bracteoles several; sepals distinct; pelals obovate, with inflexed tip; fruit dorsully compressed; vitta onc under each secondary ridge.

30. Silád:-Leaves dccompound; bracteoles many ; sepals inconspicuous; petals yellowish, broad, with, incurved tip; carpophore forked; ridges slightly winged; vitte many, obscure; seed flat in front.

31. Méur.-Leares decompound; bracts linear'; bracteoles many; sepals inconspicuous; petals yellowish, narrowed at both ends, inflexed; carpophore forked; fruit much as in Sitúus, but dorsally com. pressed ; seed concave in front.

32. Ligústiudu. - Leaves 1-3-ternatc; bracts few; bracteoles many; sepals small; petals white or pink, with short claw, notched, with long inflexed point; carpophore forked; ridges acute, somewhat winged; vittce 2 or more together ; seed almost flat in front.

33. Secínum.-Leaves 2-pinnate; bracts usually absent; bracteoles many, subulate; sepals inconspicuous ; petals white, obcordate, noteled, inflexed; carnophore forked; fruit dorsally compressed; ridges with membranous wings, the lateral longest, diverging ; vitte solitary.

34. Análica,-Leaves 2-ternate; bracts few; 
bracteoles many; sepals inconspicuous; petals white, rotched, with short inflexed tip; car pophore forked; fireit much dorsally compressed; lateral ridyes with inembranous wings, parallel, thin; vitte solitary or 2 together.

*35. Archangélios, differing mainly in having minute sepals, thicker dorsal and intermediate ridyes, no vittce and loose seeds.

Tribe 5. Peneedáner.-Umbels componnd ; fruit mach dorsally compressed; primary ridges most conspienous, the lateral ones with broad winys closely face to face, the others slender ; vitte usually abrious.

36. Peucédanum.-Leates pinnate; hrots and bracteoles absent, few or many ; sejuls small or inconspicuous; petals yellow or white, with an inflexerl point; carpels flat; lateral vidyes forming thin, flat, contiguous, parallel wings; dorsal and intermediate vidges, slender ; vittce as long as the fruit, linear.

37. Herícleum.-Leaves pinnate with broad segments; outer flowers irregular ; petuls white or pink, obcordate with an inflesed point; frut as in Percédenum, but vitte short, club-shaped.

*38. 'Londýliun. - Leaces pinnate; bracts and bracteoles as many as the pedicels, linear ; sepuls subulate; petuls white or pink, sometimes 2-lobed, with inflexed tip; lateral ridges forming thick, flat, contiguous, parallel wings; dorsel and intermeliute ridyes slender'; vittce $1-3$ together.

Tribe 6. Caucalinex.-Umbels yonerally compound: secondary ridyes mone prominent than the primary, of ten prickly; vitter solitary, under the secondary riclyes.

*39. Consásurun.-Lentes decompound; bracts absent; lraeteoles few, thread-like; sepals acute; letals white or pink, 2-lobed, of ten irregular, point in- 
flexed; fruit globose; carpels coherent; riclyes low; vittce obscure; seed curved.

40. Daúcus.-Leaves decompound; bracts and bracteoles usually many, pinnatifid; sepals slender; petals white or red, notched, often irregular, with inflexed lobe; 4 secondary ridges, each bearing a low of prickles; seed flat in front.

41. CAÚCALIS.-Leaves pinnate; bracts few, entire or absent; bracteoles many; sepals acute or absent;

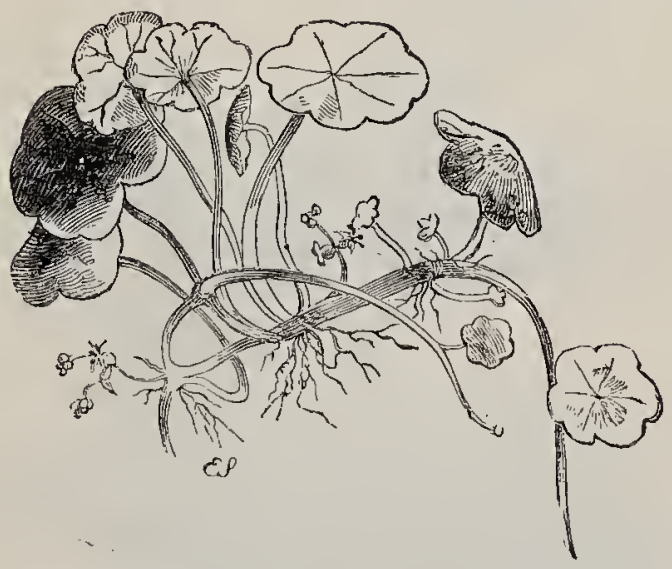

HYDRocútylé vutGARIS (Common White-rot, Darsh Pemynoort).

petals as in Daúcus; primary and seconclary ridyes with $1-3$ rows of prickles each; seed deeply grooved in front.

1. Hydrocótyú́ (Marsh Pennywort). _ Small creeping herbs; leaves simple, peltate, orbicular; flowers in simple umbels; fruit roundish, flattened. (Name from the Greek hudor, water, and kơtulé, a dish, from the shape of the leaves and place of growth.) 
1. H. vulgáris (Marsh Pennywort, White-rot). -The only British species, very unlike other British Umbelliferre, with round, smooth, shining, crenate leaves, $1-1 \frac{1}{2}$ in. across, with hairy stalks; and in-

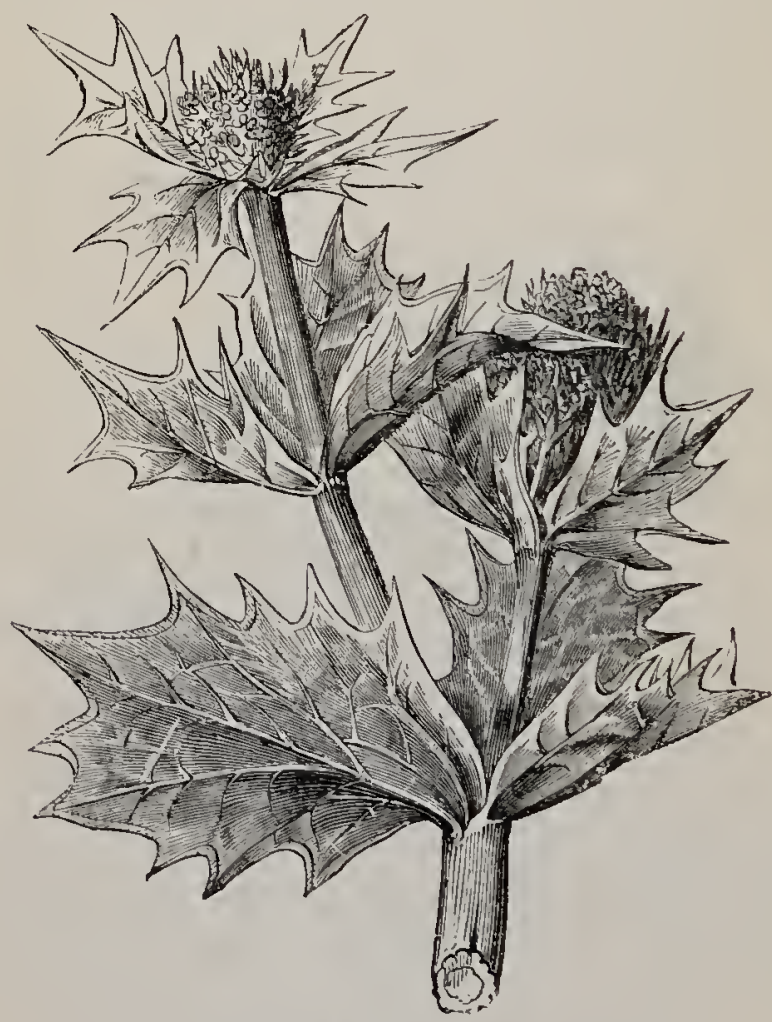

Jứ́fGTur MiRítimu (Sea Eryngo, Sea Holly).

conspicuous heads of a few, minute flowers, which never rise above the leaves, and require a close search to be detected at all.--Marshes and bogs; common.-Fl. May-August. Perennial. 
2. Erýngrum (Eryngo).-Stiff, branched, of ten glaucous plants: leaves reduced to spinous sheaths; flowers sessile, in dense heads with a spinous involucre; fruit covered with chaffy scales. (Name of uncertain etymology.)

1. E. marítimum (Sea Holly, Sea Eryngo).-A stout, stiff, prickly, glaucous plant, with more of the habit of a Thistle than of the Order to which it belongs. The large, fleshy, brittle rhizomes extend several feet into the sand. The stems are trichotomous and often prostrate; flowers grey-blue.-Sandy sea-shores ; frequent. The rhizomes used formerly to be candied as a sweetmeat.-Fl. July, August. Perennial.

2. L. campéstré (Field Eryngo), a taller, more erect, more slender, more branched and less glaucous species, with pinnatifid leaves, occurs on waste ground and ballast-heaps; but is very rare.-Fl. July, August. Perennial.

*3. Astríntia.-Erect plants; leaves palmatifid; umbels simple or irregularly compound, with involucres of large, simple bracts, which are often coloured; sepals leafy; petals white or pink, with a long inflexed point; fruit ovoid with 5 wrinkled toothed ridges and no vittæ. (Name from the Greek astron, a star, from the star-like involucres.)

1.* A. májor (Greater Astrantia).-Siem 1-2 feet; leaves 3-7-lobed, serrate, with bristly teeth; bracts ovate-lanceolate, white below, green tinged with pink above ; flowers white or pink. Naturalised in woods near Ludlow and Malrern,-Fl. JuneAugust. Perennial.

4. Sanícula (Sanicle).-.Slender, erect plants; leaves palmately-lobed; umbels small, irregularly com- 
pound, of few pedicels ending in capitate secondary umbels; bracts leafy; outer flowers without stamens, the inner without carpels; fruit covered with hooked

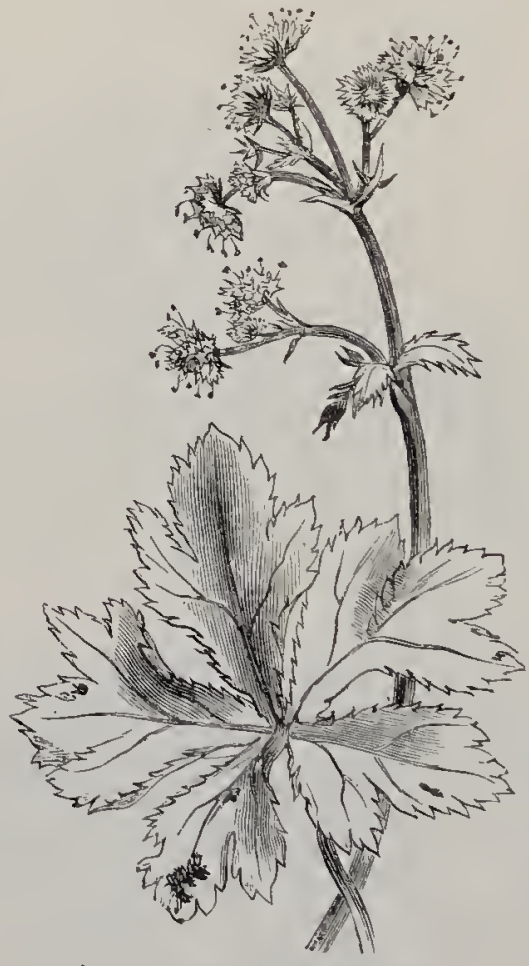

SANF́tula FUROP.ś (Wood Sanicle)

prickles. (Name, a diminutive from the Latin sano, I heal, from supposed healing qualities.)

1. S. europcéa (Wood Sanicle).-The only British species, a glabrous plant about a foot high; teaces 3-5-lobed, lobes 3-tid, serrate, glossy ; flowers du]k white, in small rounded heads.--Woods; common, often in dense shade.-Fl. June, July. Peremnial. 
5. Physospérmum (Bladder-seed).---Erect plants; leaves 3-ternate; leaflets wedge-shaped; umbels com-

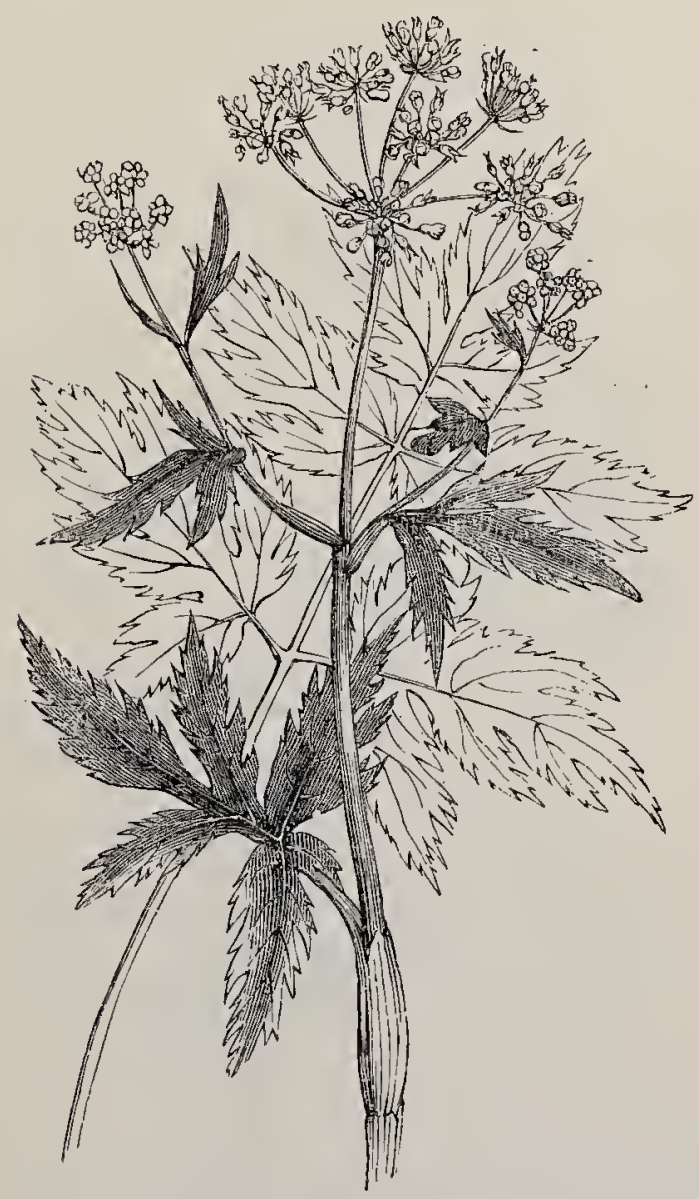

PHYSOSPLIM UM COMMUTATUM (Comish Bladder-seed).

pound; brocts and hracteoles few, linear ; flowers white; fruit broader than long, bladder-like; seed loose. 
(Name from the Greek phusa, a bladder, sperma, a seed.)

1. P. conmutátum (Cornish Bladder-seed).-A

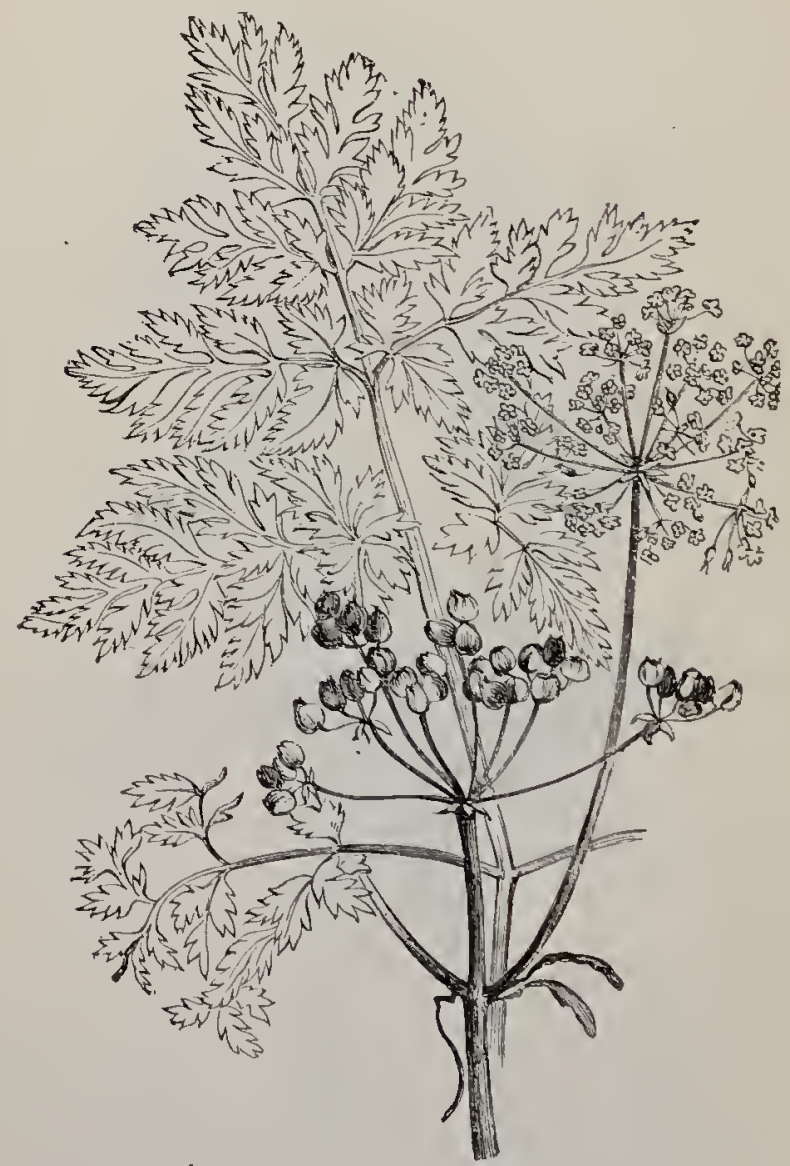

Conium maculátum (Common Hemlock).

glabrous plant, about 2 feet high, with ribbed, round, branched stem; long-stalked, 3-ternate Teares with downy margins and veins; and long-stalked, terminal 
and axillary umbeis.-It is found only near Bodmin, Cornwall, and Tavistock, Devon.-Fl. July, August. Perennial.

6. Coníum (Hemlock). - Tall, glabrous plants;

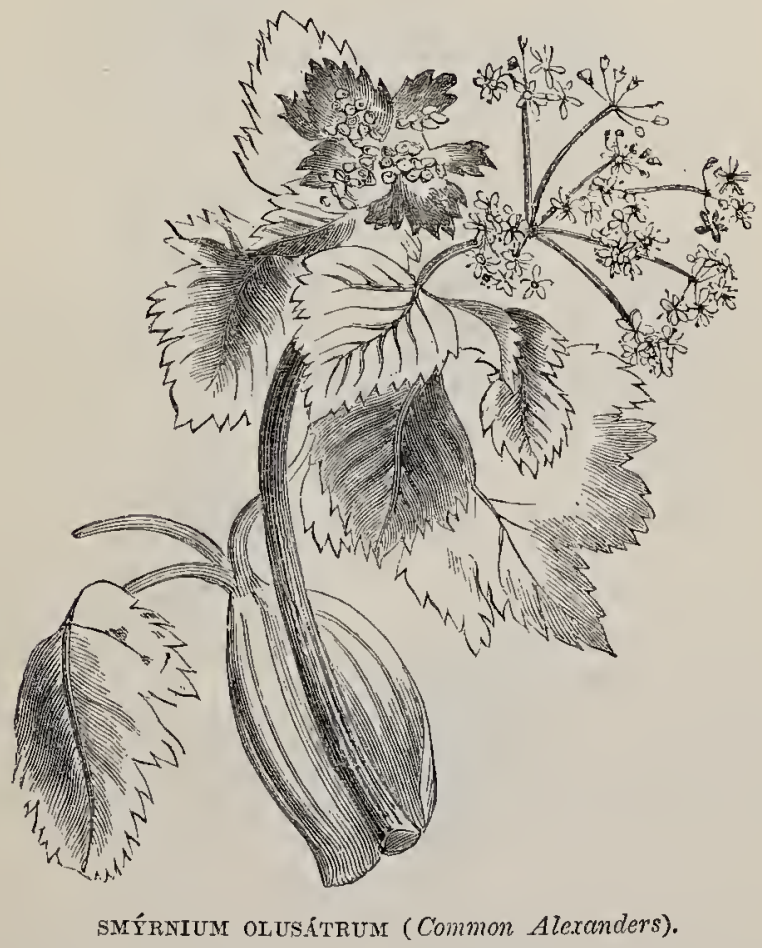

leaves pinnate; umbets compound ; bracts and bracteoles many, small; sepals absent; petals white, blunt, or with shortly inflexed tip. (Name from the Greek konéion, hemlock.)

1. C. maculatum (Common Hemlock).- The only British species, a much-branched, gracefully growing 
plant, usually from 2-4 feet high, but in sheltered situations sometimes more than double that height, with a slender, perfectly smooth, furrowed stem spotted with red; finely tripinnate leaves, which are also smooth; bracteoles on one side only of the base of the secondary umbels; and white flowers.-Hedges and waste places; common. Country people are in the habit of calling many Umbelliferæ by the name of Hemlock; but the true Hemlock may be reatily distinguished by the above characters and by its foetid smell. It is extremely poisonous.-Fl. June, July.
Biennial.

7. Suŕnviur (Alexanders).- Stout, erect, smooth plants; leaves 3-4-ternate, with broad segments; umbels compound; bracts and bracteoles few or none; sepals minute or none; petals yellow. (Name from the Greek smurna, myrrh, from the scent of some species.)

1. S. Otuscitrum (Common Alexanders). - A stout plant, 3-4 feet high; stem smootl, furrower, and hollow; leares broad, bright green, glossy, 3-4-ternate; umbels many, large, rounded; flovers greenishyellow; fruit dark brown or nenrly black when ripe, aromatic.-Waste ground, especially near the sea and among ruins. It was formerly cultivated, its young shoots being boiled and eaten.-Fl. April-June. Biemial.

8. Bupleúrum (Buplever).-Erect, smootl plants; lenues reduced to simple, entire sheaths; umbels compound ; bracts and bracteoles sometimes numerous and leafy; sepals absent; petals yellow, inflexed; fruit oblong; carpels with 5 usually prominent ridges. (Name said to be from the Greek bous, an ox, and pleuron, a rib, from the ribbed leares of some species.) 
1. B. rotundifótium (Common Hare's-ear or Thorowwax). - A singulal plant, well distinguished by its branched stem; perfoliate, roundish, ovate, glaucous

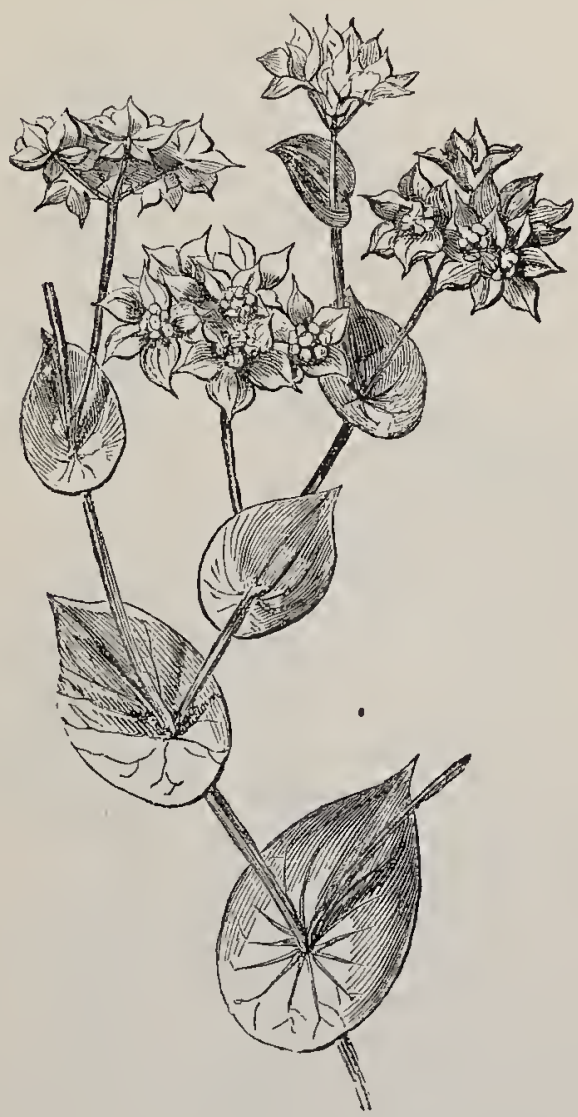

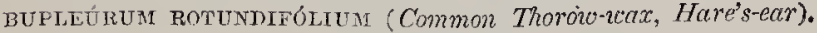

Teaves, and large greenish-yeliow, bristle-pointed bracteoles, thrice as long as the minute yellow flowers. Comfields on chalky soil ; rare.-Fl. July. Annual.

2. B. aristátum (Narrow-leaved Buplever), a small 
plant, 3-6 in. high, with pale, sword-shaped, 3-5veined, rigid leaves, and 3-5 large, sharp-pointed brateoles concealing the umbels of greenish fiowers, occurs on sandy banks near Torquay and Eastbourne, and in the Channel Islands.-Fl. June, July. Annual.

3. B. tenurssimum (Slender Buplever). - Stem slender, wiry, about a foot bigh ; Teares linear, acute, 3-veined; umbels small; bracts and braeteoles narrow, subulate; flowers minute, yellowish.- Salt marshes; rare.-FI. August, September. Annual.

4. B. falcátum (Sickle-leaved Buplever).--Stem erect, slender, hollow, 1-4 feet high ; Zeaves oblong-lanceolate, curved, acute, 5-7-reined, umbels small; bracts and braeteoles $2-5$, as long as the minute yellow flowers. - Near Ongar, Essex, and Herts.-Fl. Augu.st, September. Perennial.

9. Trínia (Honewort)._-Glabrous branched plants; leaves tripinnate; umbels compound, few-rayed ; lracts and hracteoles $1-3$ each; flowers white, dincious; sepals inconspicuous; petals with an inflexed tip, those of the staminate plants lanceolate, those of the pistillate plants ovate; vitte solitary, in the bases of the primary ridges. (Named in honour of Dr. Trinius, a Russian botanist.)

1. T. glabérrima (Honewort). - Glancous, 3-_ in. high; stem solid, stout, grooved; branches divergent; leaves spreading, with slender stalks and linear segments; bract solitary, 3-cleft, or absent; brceteoles 2-3-linear; flowers minute. - Dry limestone rocks, Bristol and South Devon; very rare.Fl. May, June. Perennial.

10. ÁpIUm.-Glabrous ; leaves pinnate or ternate; umbels compound, often in the forks of the stem; bracts absent; bracteoles many or absent; sepals 
absent; petals entire. (Name, the Classical name of this or some allied genus.)

1. A. graveotens (Wild Celery, Smallage).-Stem

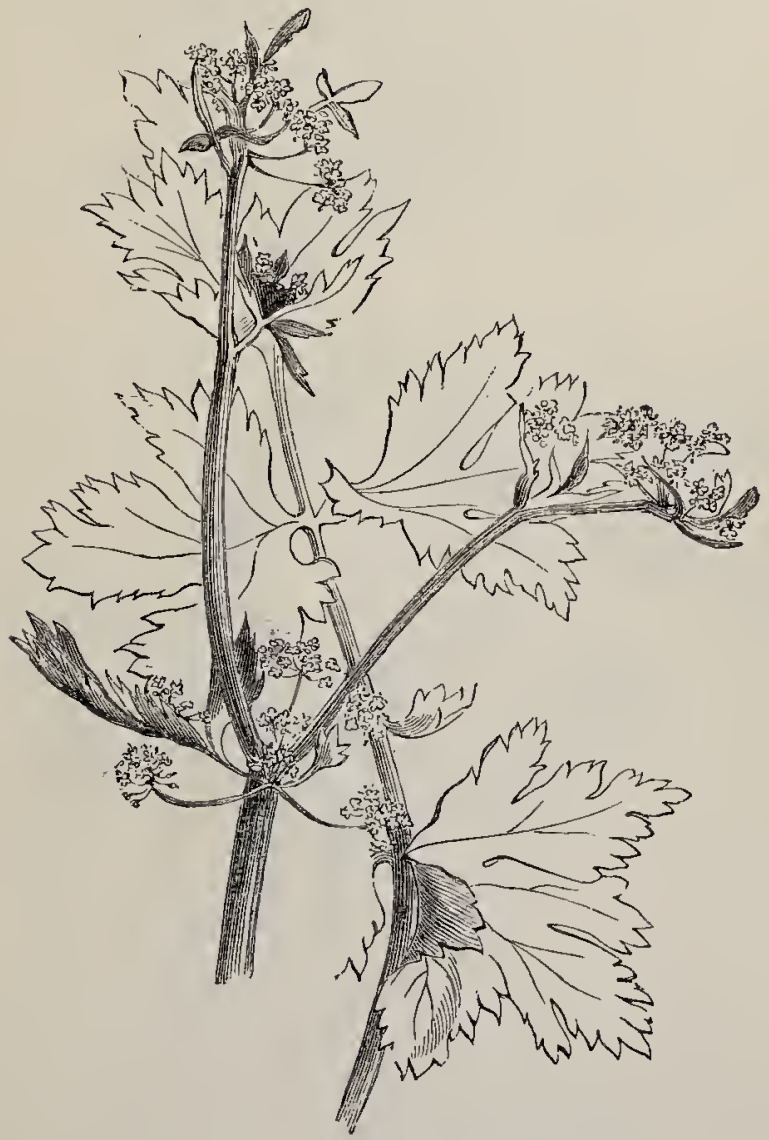

Áptum gravéolens (Wild Celery, Sinallage).

usually 1-2 feet high, furrowed, branched, and leafy, but sometimes nearly prostrate ; leaves pinnate ; lobes cut; umbels sessile or nearly so, terminal or 
axillary; bracteoles absent; flowers greenish-white, small.-Moist places near the sea; not uncommon. The origin of the garden celery, and unmistakably distinguished by its strong flavour and rank odour. In its wild stite, or until the leaf-stalks have been

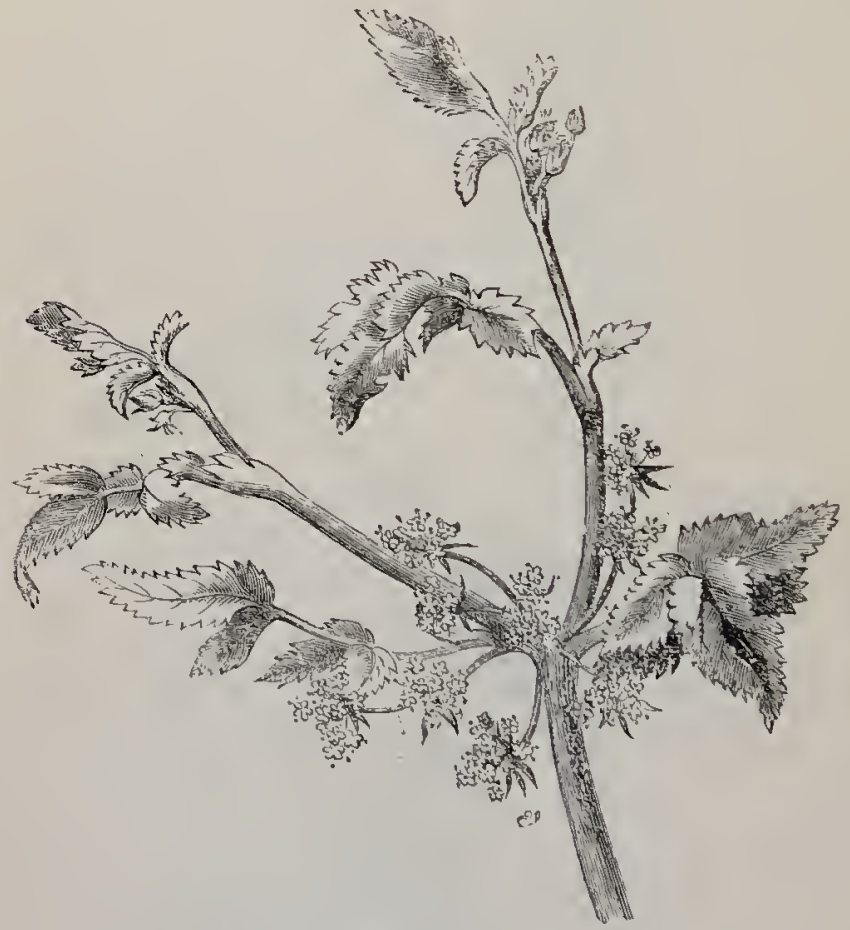

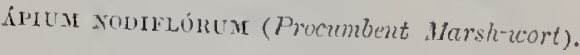

blanched by the exclusion of light, it is not eatable.Fl. June-August. Biennial.

2. A. nodiflórum (Procumbent Marsh-wort). -Stem prostrate and rooting, hollow; lecues pinnate; leaflets ovate, serrate, acute; umbets sessile, or nearly so; raiys unequal; bracteoles many, membranous; flowers small, white. - Ditches and rivulets; abundant. 
Growing with Watercress, this plant is sometimes mistaken for it; but its hollow stem and serrate leaves at once distinguish it, even when not in flower. --Fl. July, August. Perennial.

3. A. inundátum (Least Marsh-wort).--A small, usually submerged, occasionally creeping plant; steme stout, crooked; submerged leaves in hair-like segments; floating leaves pinnate with wedge-shaped leaflets; umbels above water, very small, of 2 -4 unequal lays ; flowers small, white.-Ponds; common.-Fl. June, July. Perennial.

11. Cić́ta (Water-Hemlock).--i'iall, glabrous plants ; Teaves 2-3-pinnate; umbels compound, manyrayed; bracts $1-2$, very narrow, or none; bracteotes several, small, unequal; sepals ovate, acute; petals white, with an inflexed tip; fruit constricted, with two globose carppels. (Name, a Classical Latin name for Hemlock.)

1. C. airósa (Water-Hemlock, Cowbane).--Root fibrous ; stem stout, hollow; lower leaves long-stalked, 2-3-pinnate; upper leaves 2-ternate; leaflets lanceolate, 2-serrate; umbels large, long-stalked, flit-topped ; flowers minute, white. - Ponds and ditches; rare. Very poisonous, as are also the species of CÉnanthé, to which also the name Water-Hemlock is often applied. -Fl. July, August. Perennial.

*12. Anur, represented by the one species $A$. május, a glaucous, scentlese, and tasteless plant, 624 in. high, repeatedly forked with diverging branches; pinnate lower leares with obovate, fimely ser'rate leaflets, decompound upper leaves with linear segments ; and stalked 10-30-rayed umbets of white flowers, with rough stalks, 3-5-lobed bracts with linear segments, and linear bracteoles, is only a casual introduction on ballast-heaps and in cornfields. 
13. Cárum. - Glabrous plants with pinnate or decompound leaves; compound umbets of white, pink, or yellow flowers, with many, few, or no bracts and bracteoles, and deeply-notched petals; and oblong

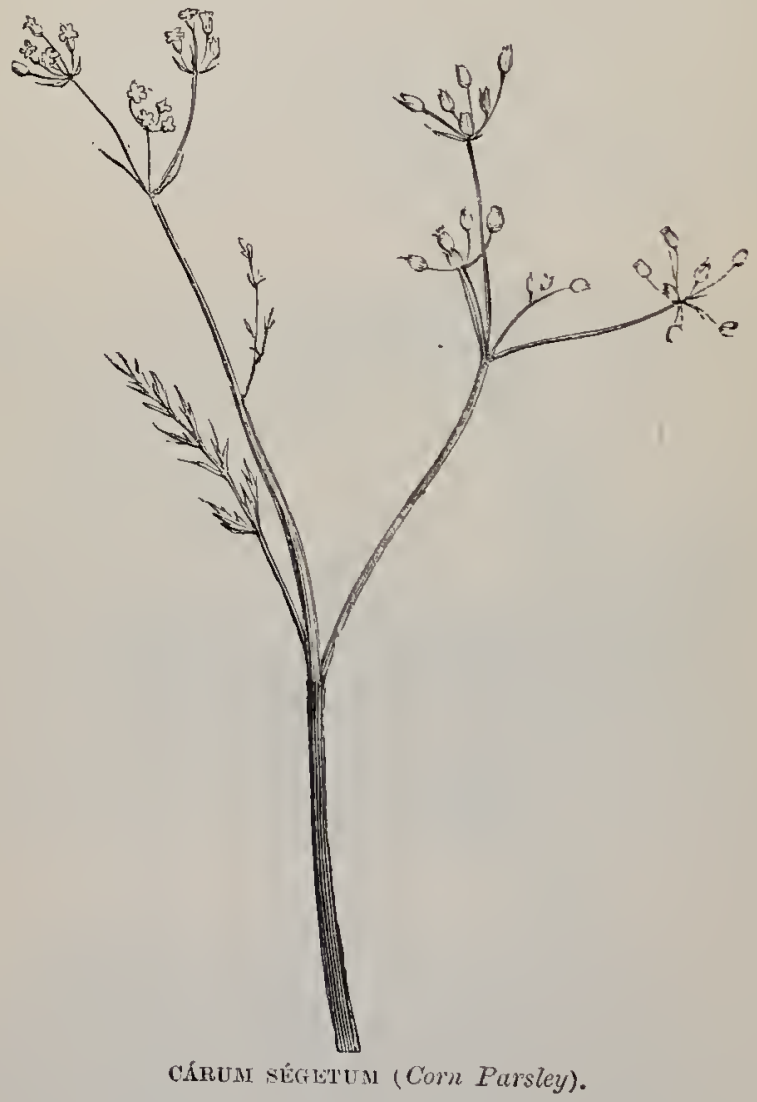

fruit with slender ridges. (Name said to be derived from Caria, in Asia Minor.)

1. C. verticillátum (Whorled Caraway). - An erect plant, 1-2 feet high, with leaves pinnately divided 
into very many hair-like segments and so crowded as to appear whorled; umbels flat-topped; pedicels slender; bracts and bracteoles many, short, reflexed; flowers white or pink. - Wet meadows, chiefly in the west; rare. Fl. July-August. Peiennial.

2.* C. Petroselinum (Common Parsley).-A glabrous, shining, erect, much-branched plant; stem $1_{--2}$ feet high, solid, ribbed; leaves tripinnate; flowers yellow.-A garden-escape, chiefly found on old walls. -Fl. June-August. Biennial.

2. C. ségetum (Cornn Parsley).-Well distinguished by its slender, branched stem, which is remarkably tough and wiry; its small pinnate leaves, of which the lower ones wither early, while the cauline ones are few, small, and inconspicuous; and the irregular, fewrayed umbels and small whitish fiovers.-Cornfields and waste places; not uncommon.-Fl. August, September. Biennial.

4.* C. Cárvi (Common Caraway).-Root spindleshaped; stem 1 -2 feet high, nuch branched; Teaves bipinnate, cut into linear lobes; umbels rather large and irregular, with rarely more than one bract ; flowers white. The aromatic carpels are the well-known "caraway seeds." It is a naturalised escape from cultivation.-Fl. June, July. Biennial.

5. C. Bulbocústanum (Tuberous Caraway).-Boot black, tuberous, as large as a chestnut; stem erect, 1-2 feet high, much branched; leaves 2-3-pinnate; leaflets cut into few slender lobes; bracts and bracteoles many, small, narrow; flowers white. Chalky fields in Cambridgeshire, Bedfordshire, Hertfordshire, and Buckinghamshire, and so abundant about Bal. dock, in Hertfordshire, that "the farmers tu'n their pigs upon the fallows to feed upon the roots." (Hooker and Arnott.)-Fl. June, July. Perennial.

14. Síson (Stone Parsley).-Differing from Cámım chiefly in having loss divided cautine leaves and very 
short, club-shaped vittce. (Name, the Greek for some allied plant.)

1. S. Amómum (Stonewort, Stone Parsley).-A slender plant, much like Cárum ségetum, 2-3 feet high, with a wiry, branched stem ; pinnate or bipinnate leaves with narrow leaflets; umbels few-rayed, irregular; bracts 2-4, subulate; secondary umbels small; bracteoles 2-4; flowers cream-coloured, very small.-Damp places on a chalky soil. The whole plant has a nauseous smell.-Fl. Augtist, September. Biennial.

*15. Falcária, represented by F. vulyáris, a stout glabrous plant with evenly serrate leaflets, resembling Cicúta virósa, which occurs as a cornfield casual in Kent and Hampshire. Perennial.

16. Siun (Water-Parsnip). - Glabrous plants; leaves pinnate, serrate; umbels compound; bracts and bracteoles many, flowers white. (Name said to be connected with a Keltic word siw, water.)

1. S. Zatifólium (Broad-leaved Water-Parsnip). - A stout plant, with a furrowed stem, 3-5 feet high; pinnate leaves of $5-13$ large, distant, lanceolate, acute, evenly serrate leaflets; and large, flat-topped, many-rayed umbels of small white flowers, with large leafy lanceolate bracts and bracteoles.-Watery places; not common.--Fl. July, August. Perennial.

2. S. eréctum (Narrow-leaved Water-Parsnip).Smaller than the last, and resembling Ápium nodiflórum, from which it may be distinguished by its very irregularly serrate cauline leaies, its umbels, which are not only opposite the leaves, but also stalked and larger, and its reflexed, and often cut, bracts and bracteoles.-Watery places; common.-Fl. August. Perennial. 
17. AॄGopódium (Gout-weed).-Glabrous; leâues 2-3-ternate, with broad leaflets; umbels compound,

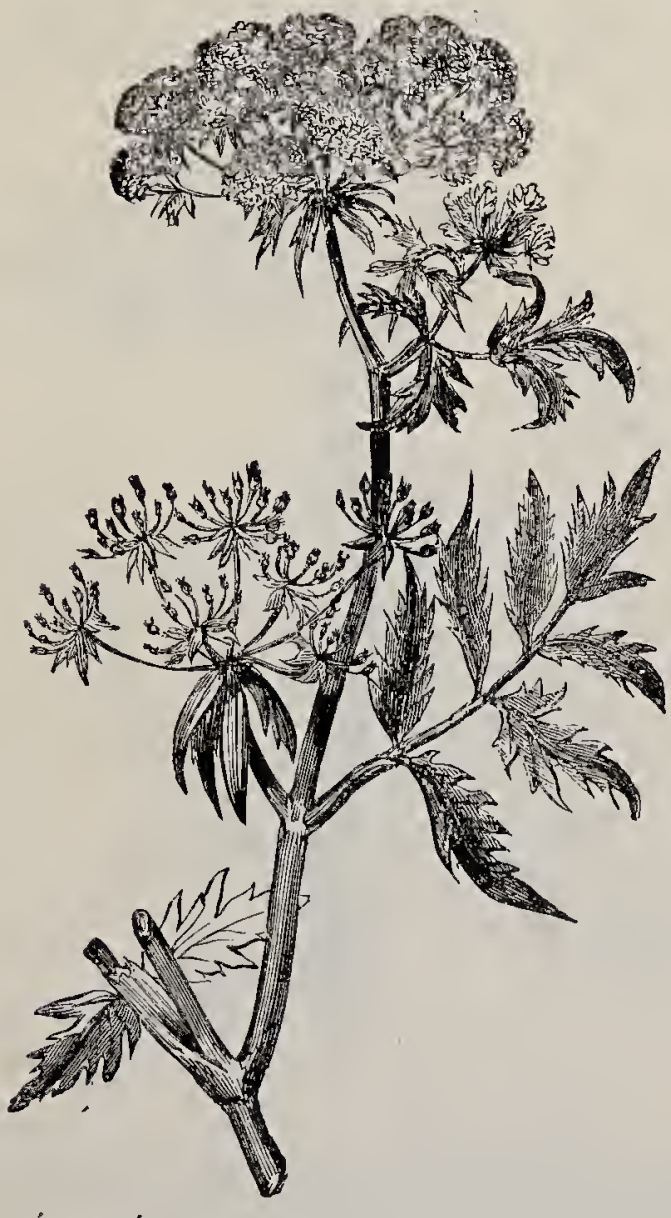

EfUM ERÉCTUM (Narrow-ieavel Water-Parsnip).

many rayed; bracts and bracteoles few or none ; flowers white. (Name from the Greek air, a goat, pous, a foot, from some fancied resemblance of the leaves.). 
1. A. Podagrária (Gout-weed, Bishop's-weed, Herb Gerard.)-Rhi:ome creeping, white, pungent, aromatic; stem about a foot high, hollow, furrowed; leaves mostly radical, large, 2-3-ternate; leaflets oblique, serrate.-A common and very troublesome

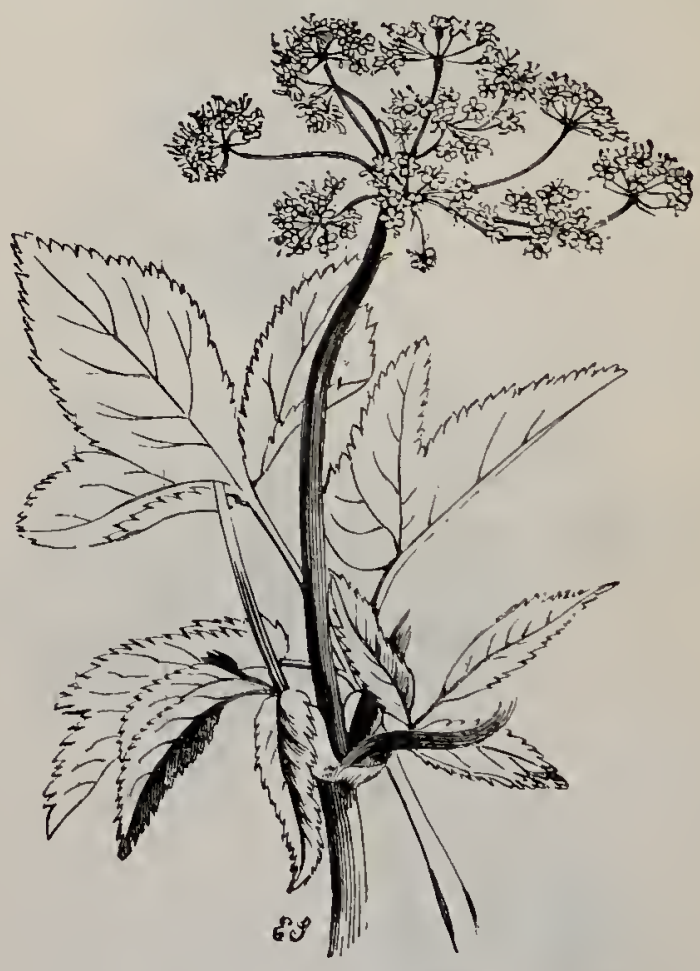

EGOPÓDIUM PODAGRARTa (Common Gout-2veed).

weed in shrubberies. The leaves used formerly to be boiled for food; but their flavour is strong and disagreeable.-Fl. May-July. Perennial.

18. Pimpinilla (Burnet Saxifrage).-Leaves pinnate; umbels compound; bracts none, or rarely one; 
flowers generally white; fruit oblong, crowned with the swollen bases of the reflexed styles. (Name said to be from the Latin bipennuta, in allusion to the bipinnate leaves.

1. P. Saxifraga (Common Burnet Saxifrage).-A slender plant, 1-2 feet high; stem round; lower

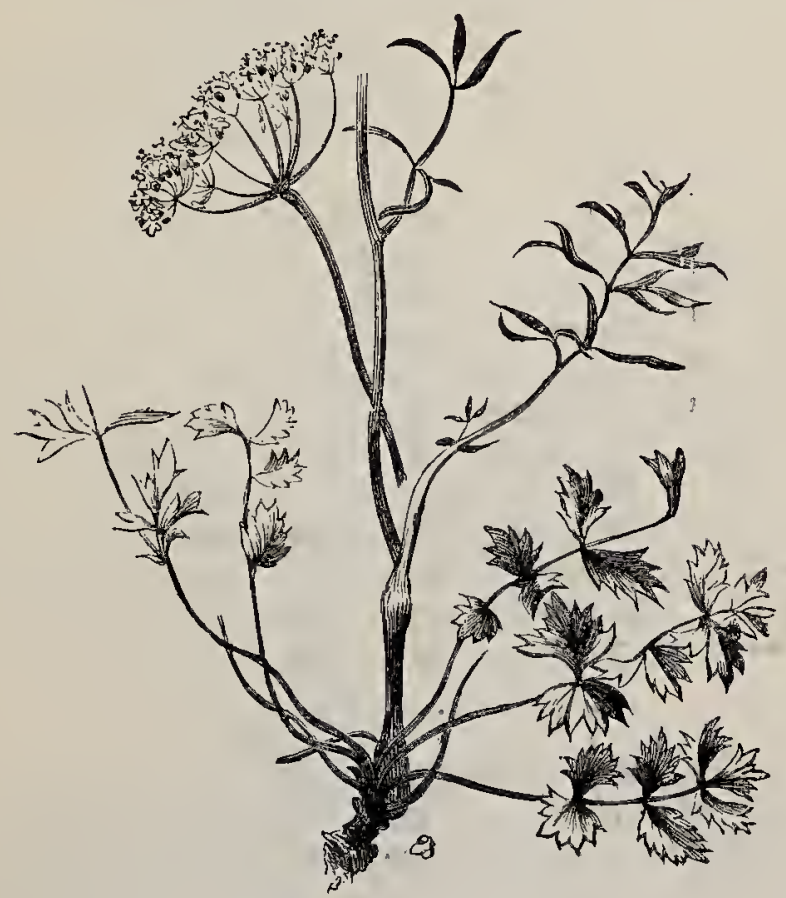

PIMpinétua saxifraea (Common Bumet Saxifrage).

leaves long-stalked, pinnate; leafiets orbicular, sharply cut; cauline leaves bipinnate, with linear acute segments.-Dry pastures; common.-Fl. July-September. Perennial.

2. P. májor (Greater Burnet Saxifrage).-Stouter and larger than the last; stem angular; leaves all 
pinnate; leaflets ovate serrate, the terminal one 3-lobed.-Shady places; not common.-Fl. July, August. Perennial.

19. Covopódurar (Pig-nut).-Glabrous plants with a tuberous underground stem; triternate leaves; umbels compound, many-rayed; bracts absent; brac. teoles few; flowers white; fruit oblong, crowned with the conical base of the erect styles. (Name from the Greek lionos, a cone, pous, a foot, from the conical epigynous disk.

1. C. denudátum (Common Pig-nut). - A very slender plant, about a foot high, bearing a few finely. divided, 3-ternate leaves and terminal umbels of white flowers. The tuber, which resembles a small potato in shape, and is covered by a thin, easily removable, brown skin, is eatable, but only fit for the food of the animal after which it is named. The plant much resembles Cárum Bubbocástanum, but differs in its brown, not black, tuber, its sinaller size, ternate, not pinnate leaves, fewer or absent bracts and bracteoles, large disk and erect styles.-Sandy pastures; common.-Fl. May, June. Perennial.

20. Mírrhis (Cicely).-Downy; Teaves decom. pound; umbels compound, many-rayed ; bracts absent ; bracteoles many, membranous; flowers white; fruit long, contracted at the sides with a deep furrow between the carpels; ridyes sharp, prominent, almost winged. (Name from the Greek murha, myrrh, from the
fragrance of the leaves.)

1. M. odoráta (Sweet Cicely).-Stem 2-3 feet high, furrowed and hollow; leaves large, tripinnate, cut, slightly downy; umbels terminal, downy ; bracteoles whitish, ciliate; flowers white; fruit remarkably large, an inch long, becoming dark brown.--Moun- 


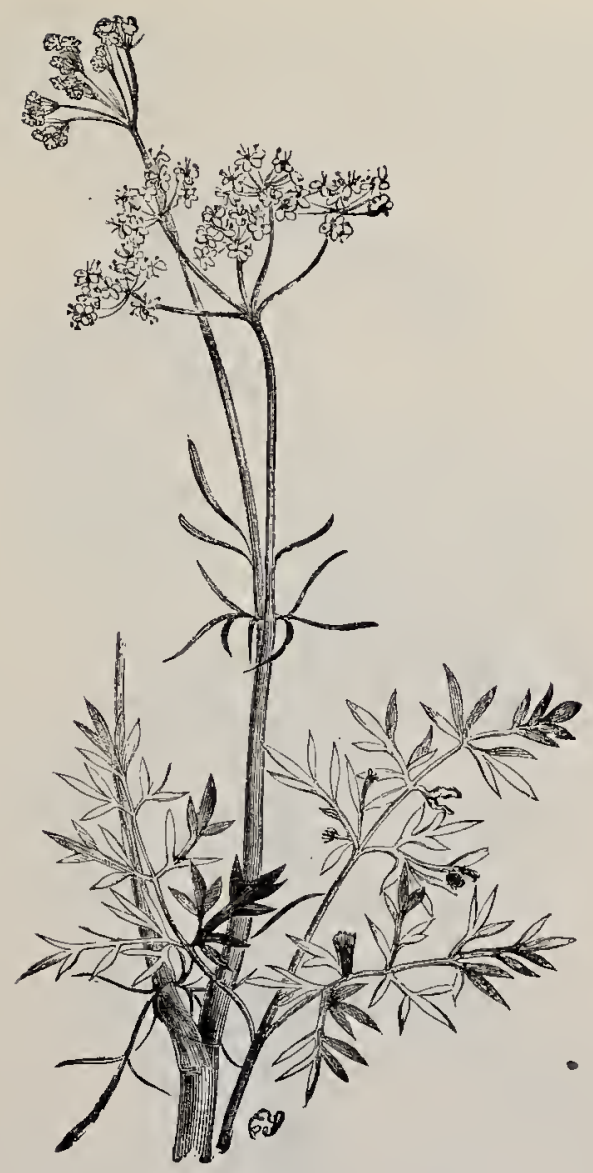

CONopónium DenUditum (Common Pig.nut).

tain pastures in the north. Remarkable for the sweet and highly-aromatic flavour of the leaves and fruit.-Fl. May, June. Perennial.

21. Chжrophýltum (Chervil).-Hairy plants ; leaves decompound; umbels compound, many-rayed; 
bracts absent or very few; bracteoles several; flowers usually white ; fruit shortly beaked, contracted at the sides; ridges blunt. (Name from the Greek chairo,

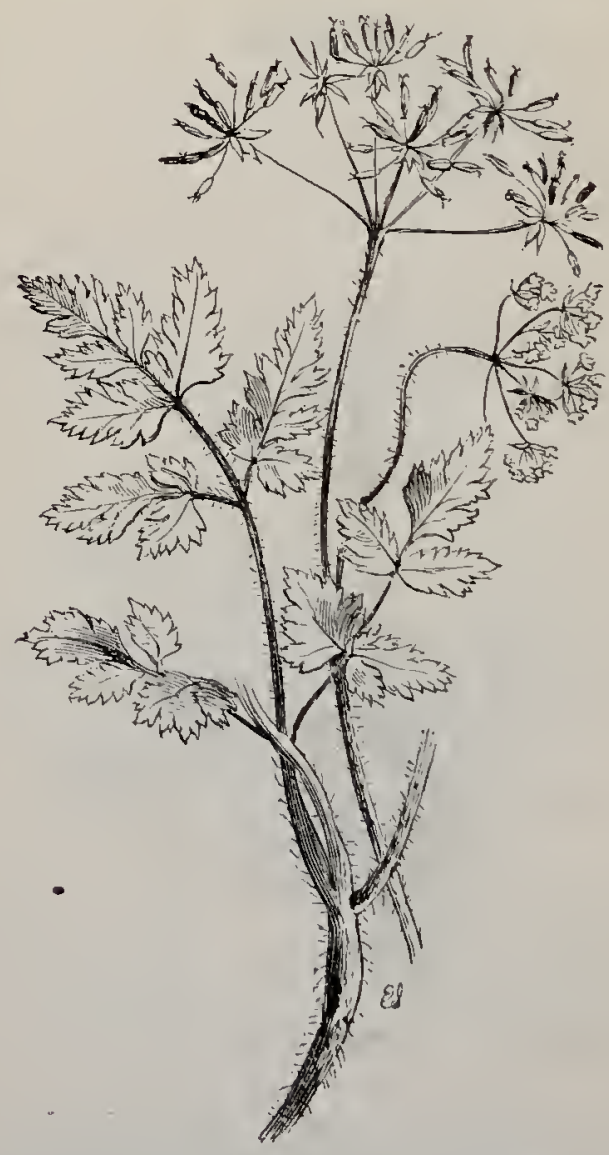

CH.EROPHILLUM TÉMULUM (Rough Cherrul).

I rejoice, and phullon, a leaf, from the agreeable odour of the leaves in some species.)

I. C:temmlum (Rongh Cherril).--The only British 
species; stem slender, 2-3 feet high, rough with short hairs, spotted with purple, and swollen below the nodes; leaves bipinnate, deeply lobed and cut, hairy, often making the plant conspicuous in autumn by their rich purple hue ; umbels terminal, drooping when in bud; bracts absent or very few; bracteoles

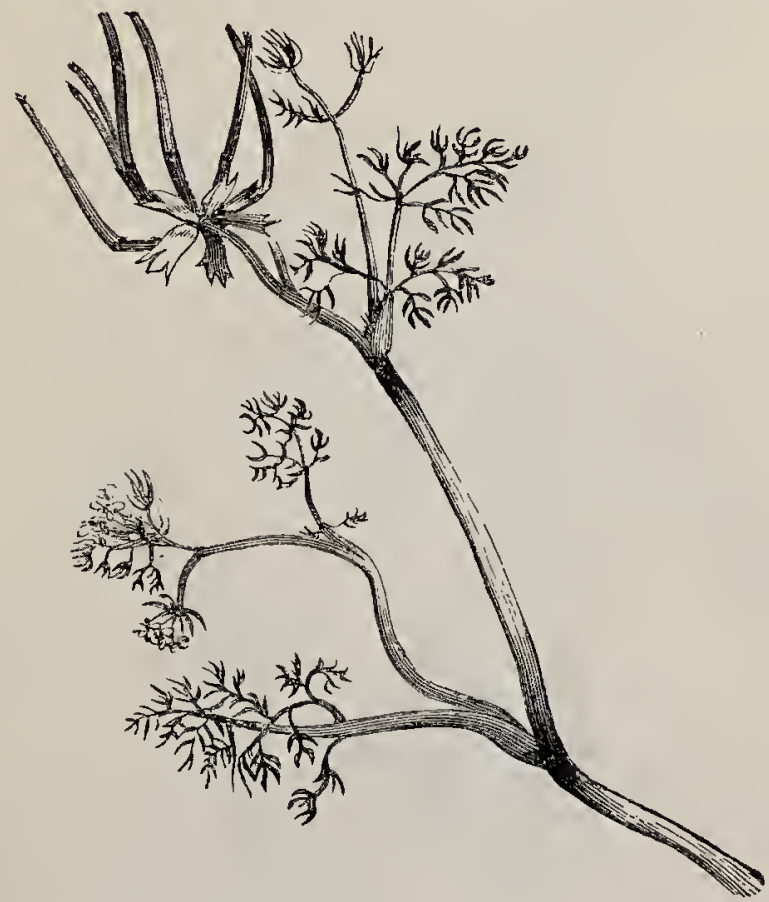

SCÁNDIX PÉCTEY VÉNERIS (Shepherd's Needle, Tenus' Comb).

several, fringed and deflexed; flowers white.-Woods and hedges; very common.-Fl. June, July. Perennial.

22. Scándix (Shepherd's Needle).-Herbs with pinnately decompound leaves, no bracts, several brac 
teoles, petals white and often unequal, and fruit produced into a very long slender beak. (Name, the Greek name for some allied plant.)

1. S. Pécten-Téneris (Shepherd's Needle, Venus'

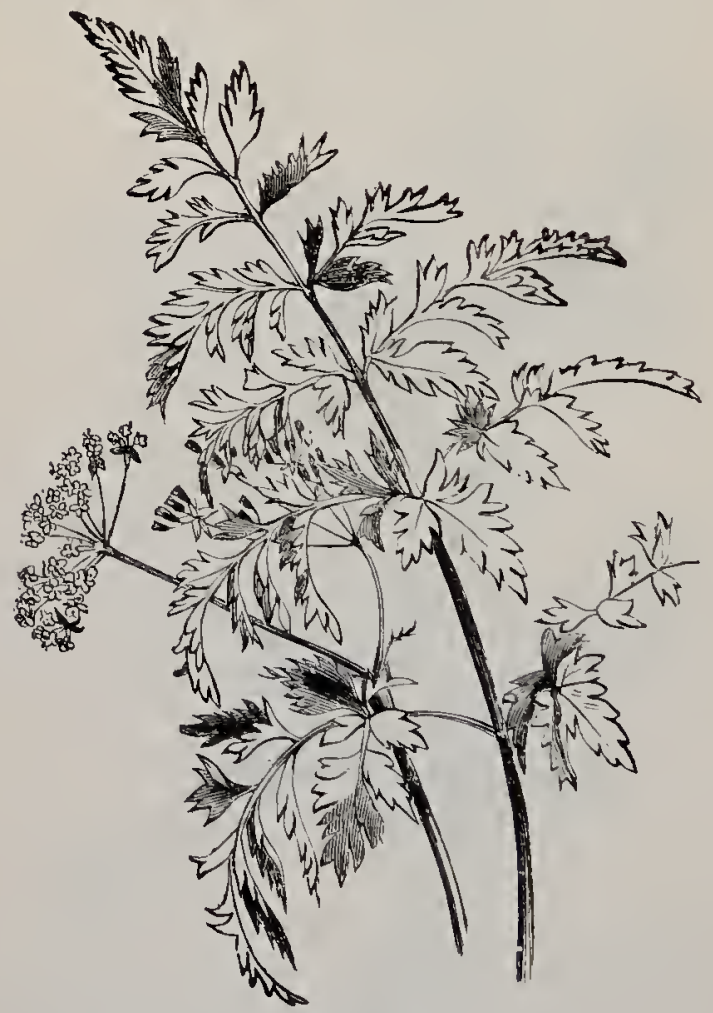

ANTHRíscus sYlvistris (Wild Beaked-Parsiey).

Comb).-A small plant, $3-9$ in. high, with finelycut bright-green leaves; few-rayed umbels of small white flowers; and long, beaked fruits.-A weed in cultivated ground; common. But for the ovary being 
inferior, this plant might be mistaken for an Eródium. -Fl. June-September. Annual.

23. Antrríscus (Beaked Parsley).--Hairy plants with decompound leaves ; compound umbels, nodding in bud ; bracts 1, 2, or none; bracteoles many, entire; petals white, with an inflexed tip ; fruit short, shortly beaked; ridges obscure. (Name, the Greek name of this or some allied plant.)

1. A. vulgáris (Common Beaked Parsley)._Stem 2-3 feet high, smooth, polished, slightly swollen at the nodes; leaves 3-pinnate, with blunt segments, slightly hairy beneath; umbels lateral, on rather short stalks, opposite the leaves; bracts absent; bracteoles 5 or 6 , with fringed edges; fruit bristly with hooked bristles.-Waste places; common.-Fi. May, June. Annual.

2. A. sylvéstris (Wild Beaked Parsley or Chervil). -Stem slightly downy below, smooth above; leaves 3-pinnate, coarsely serrate; umbels terminal on long stalks; bracts absent; bracteoles about 5, ovate-lanceolate, fringed; friit smooth.-Hedges; common. One of our early spring flowers.-Fl. April-June. Perennial.

3.* A. Cerefólium (Garden Chervil), is not a native plant, though sometimes found near gardens. It may be distinguished from the preceding by having only 3 bracteoles, lateral sessile umbels, and smooth fruit.-Fl. May, June. Annual.

24. SÉselu (Meadow Saxifrage)._-Erect branched plants; leaves 2-3- or more-pinnate; umbels compound; bracts and bracteoles many, entire; flowers white; sepals acute; fruit short, with no beak or bristles and blunt ridges. (Name of Greek origin.)

1. S. Libanótis (Mountain Meadow Saxifrage).- 
A stout plant, $1-2$ feet high, with a solid, furrowed stem; bipinnate lecues; hemispherical umbels ; hairy fruit; and persistent, reflexed styles-Chalk-hills,

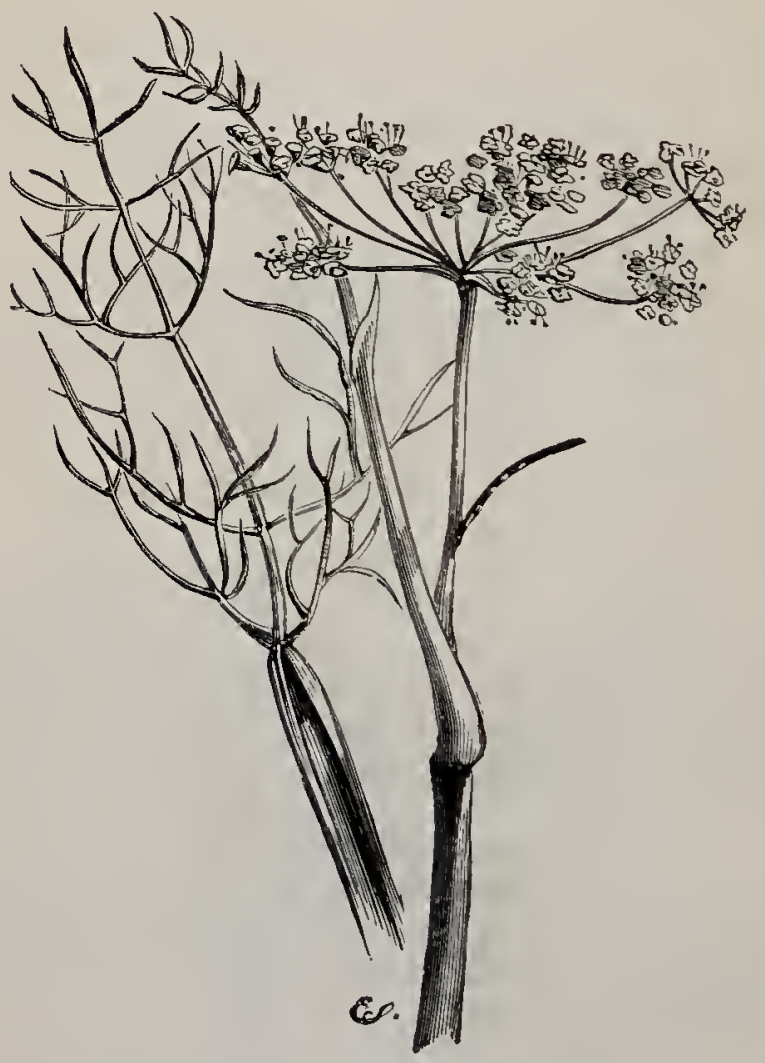

FENICULUM VULGÁRÉ (Common Fennel).

Cambridgeshire, Hertfordshire, and Sussex.-Fl. July, August. Perennial.

25. Fenículum (Fennel).--Tall, smooth plants, with decompound, pinnate leares with very narrow 
segments; ebracteate, compound umbels of yellow flover's with roundish entire petals with a short, blunt, inflexed tip. (Name, a diminutive from the Latin foenum, hay, to which it has been compared in smell.)

1. F. vulgáré (Common Fennel).-A well-known

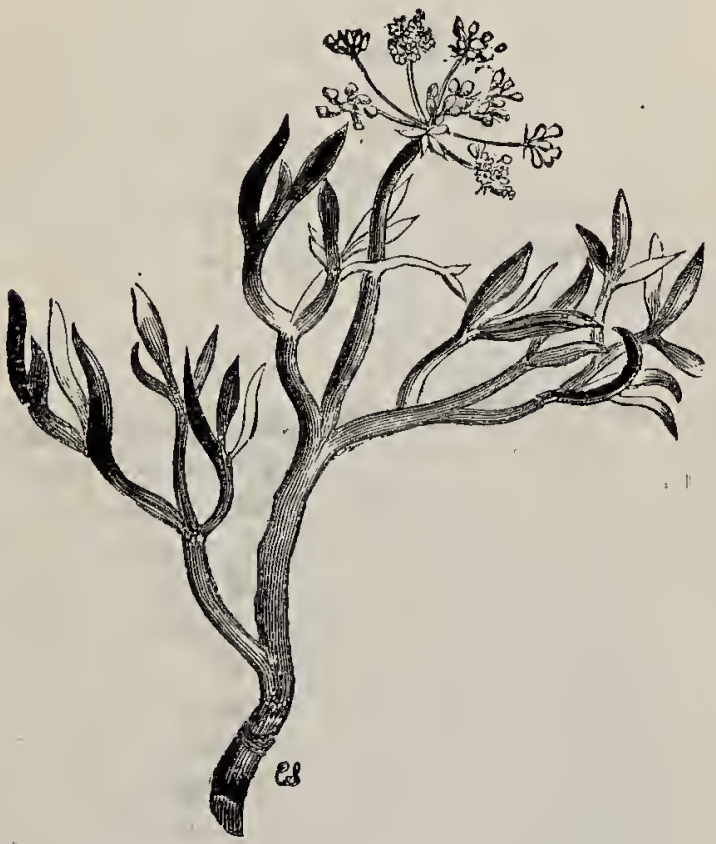

CRITHMUM MARÍTIMUM (Rock Samphire).

piant, with an erect stem; numerous leaves, deeply divided into soft, hair-like segments, and large terminal umbets of yellow flowers. - Waste places, especially near the sea. The whole plant is aromatic, and the chopped leaves are used in sauce for fish. Fl. July, August. Perennial. 
26. Críthmum (Samphire).-A smooth, fleshy, much-branched plant, with 2-3-ternate leaves ; compound, many-rayed umbels of minute white flowers; and short, smooth fruit with many vithe and loose seeds. (Name said to be from the Greek crithé, barley, from a fancied resemblance in the fruit.)

1. C. maritimum (Rock Samphire).-Well distinguished by its long, glaucous, fleshy leaflets. - Rocks by the sea. It has a powerful aromatic scent. The young leaves, if gathered in May, make, when sprinkled with salt and preserved in vinegar, one of the best of pickles. On those parts of the coast where Samphire does not occur, other fleshyleaved plants, especially salicómia herbácea, are sometimes sold under the same name.-Fl. July, August.

27. ENánthé (Water-Dropwort).-Bmooth plancs, mostly aquatic; lecues 1-3-pinnate; umbels compound; flowers white, the outer ones being often irregular and staminate; fruit surrounded by the styles. (Name from the crowned with the long erect flower, from the from the Greek oinos, wine, anthos, a 1. QE. fistulósa (Comme-like smell of the blossoms.) of many fleshy fibres; Water-Dropwort).-Root hollow, thin-walled, slem sending out rumners, leaves submerged, smooth; leaf-stallis hollow ; lower upper leaves pinnate, lollownate, with flat leaflets; segments ; umbels smallow, with distant, thresd-like bose in fruit, on holl, few-rayed, ebracteate, glomarshes; frequent.-Fl peduncles.-Ditches and ennial.

2. E. pimpinellöides (Callous-fruited Water-Dropwort).-Root-fibres tuberous ; stem furrowed; radical leaves bipinnate; uppermost leaves reduced to hollow
stalks; umbels 6-12-rayed, compact, flat-topped, with 
many linear bracts; fruit with a swollen, corky base. -Pastures in the south; rare.-Fl. June-August. Perennial.

3. E. silaifólia (Sulphur-wort Water-Dropwort). -A larger, stouter plant; root-fibres fusiform ; leaves bipinnate with linear, acute leatlets; fewer-rayed,

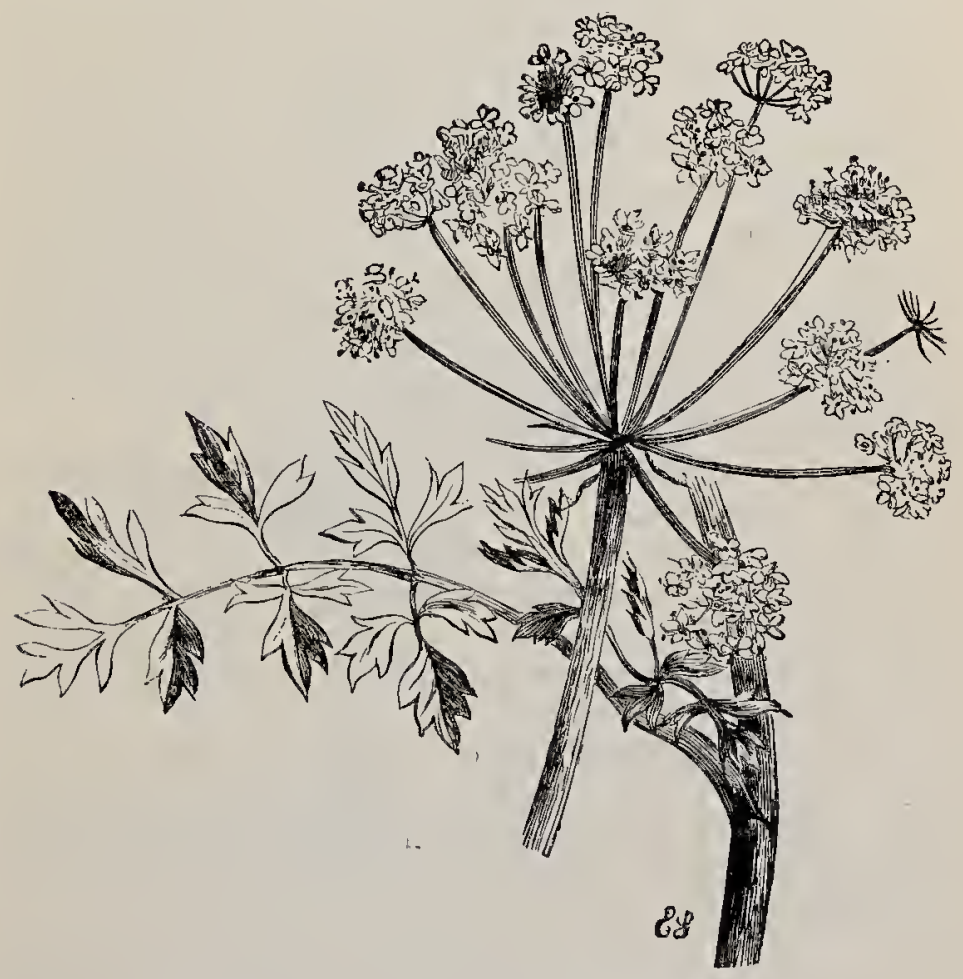

GENANTHE CROCÁTA (Hemlock Water-Dropwort).

less crowded umbels, with no bracts, but numerous bracteoles ; fruit much as in the last, but those in the middle of the umbel without the corky base.Marshes, chiefly in the south-east.-Fl. June, July. Perennial. 
4. E. Lachenátii (Parsley Water-Dropwort).-Rootfibres fleshy, but not tuberous; radical leaves bipinnate, bluntly lobed, soon withering ; cauline leaves with linear acute leaflets; secondary umbels distinct, spherical; fruit without a corky base.-Marshes; common.-Fl. July-September. Perennial.

5. (E. crocáta (Hemlock Water-Dropwort). -A large, stout plant, $3-5$ feet high, with large clustered tuberous roots, somewhat like those of the Dahlia; Teaves spreading, 3-pinnate, with sheathing petioles and stalked, variously cut, glossy leaflets; and large, many-rayed umbels with long pedicels. Watery places; common. This plant, which is often known as $W$ ater-Hemlock, and is sometimes mistaken for Celery, is very poisonous, and should not be allowed to grow in places where cattle are kept, as cows have often been poisoned by eating the roots.Fl. July. Perennial.

6. CE. Phellándrium (Fine-leaved Water-Dropwort, Horsebane). - Root of whorled fibres; stem erect, $2-3$ feet high, very thick at its base, with runners; leaves 3-pinnate, the lower ones submerged with diverging, hair-like segments; umbels lateral, sub-sessile.-Ditches and ponds ; frequent.-Fl. July - September. Biennial.

7. $E$. fluviáti7is (River Water-Dropwort). - A floating form, with 2-pinnate leares, the submerged ones pellucid with parallel, many-veined leaflets. - In running water, in the south.-Fl. July-September. Biennial.

28. सrнúsa (Fool's Parsley).-A smooth, leafy annual, distinguished by having a bract and $1-5$ bracteoles drooping and all on the outer side of the umbel, a globose fruit with sharp ridges and reflexed styles. (Name from the Greek aitho, I burn, from its acrid character.) 
1. AE. Cynáprum (Fool's Parsley).-A slender plant, about a foot high, with dark green, 2-pinnate leaves and terminal umbels of white flowers, with 3 very long, narrow bracteoles hanging down on the outer side of each secondary umbel._An evil-smell-

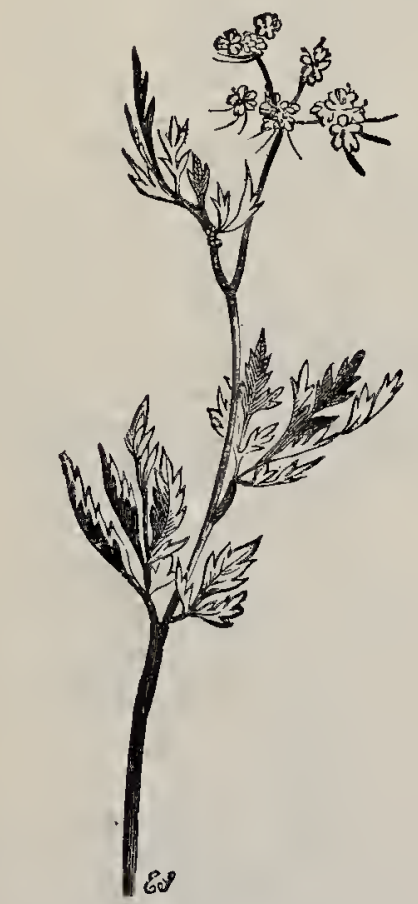

ATHHÚSA CYNÁPIUM (Fool's Parsley).

ing, poisonous, but common garden weed.-Fl. July, August. Annual.

*29. Siler is represented by S. trilobum, with long-stalked, 3-ternate smooth radical leaves; ternate cauline leaves; large terminal bracteate umbels; and large compressed fruits with one vitta under each 
secondary ridge, which is naturalised at Cherry Hinton, Cambridgeshire.

30. Siláus (Pepper Saxifrage).-Glabrous plants ; Teaves pinnately decompound; umbels compound; bracts 1,2, or none; bracteoles many ; flowers yellowish; fruit ovoid, with slightly winged ridges. (Name, the Latin name of some allied plant.)

1. S. flavéscens (Pepper Saxifrage, Sulphur-wort). -Stem angular, 1-2 feet high; Teaves 3-pinnate, with narrow opposite leaflets; umbets terminal; flowers dull, pale yellow, small; fruit dark brown.-Meadows; frequent. - "The whole plant being foetid when bruised, is supposed in some parts of Norfolk to give a bad flavour to milk and butter." (Sir J. E. Smith.) -Fl. June-September. Perennial.

31. MĹum (Spignel).-A smooth, aromatic plant; leaves pinnately decompound with crowded bristle-like segments; umbels compound, bracteate; bracts linear ; flowers yellowish; petals narrowed at both ends, inflexed. (Name, the Greek for this or some allied plant.)

1. M. Athamanticum (Spignel, Meu, or Baldmoney).-Well distinguished by its bipinnate leaces cut into numerous crowded, acute, bristle-like segments.-Dry mountainous pastures in the north. The whole plant, and especially the root, which is eaten by the Highlanders, is highly aromatic, with a flavour like Melilot, which it communicates to milk and butter when the cows feed on its leaves in spring - "Bald, or Bald-Money, is a corruption of Balder, the Apollo of the Northern nations, to whom this plant was dedicated." (Sir W.J.Hoolier.) - Fl. June, July. Perennial. 


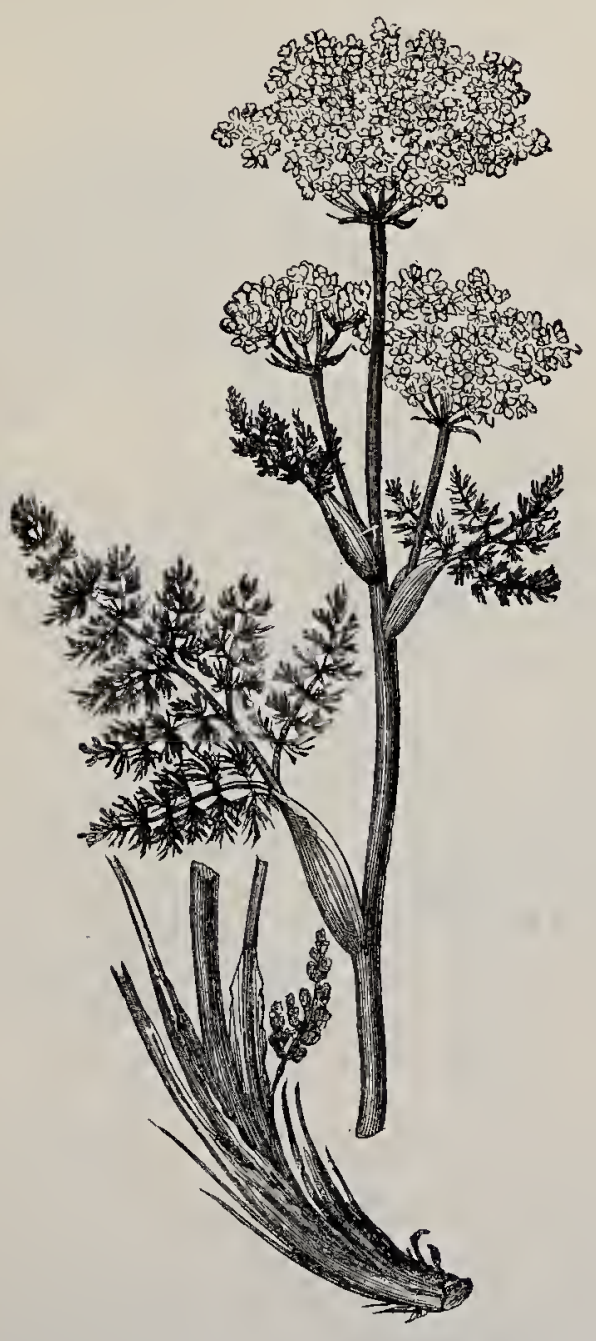

Méum athaMÁNTICUM (Spignel, Mou, or Bald-Money).

B $\quad$ B 2 
32. Ligústicum (Lovage). - Smooth plants; leaves 1-3-ternately pinnate; umbels compound, bracteate; petals white or pink, notched, with a short claw and long iuflexed tip; fruit short, somewhat winged; seeds loose. (Named from Liguria, the native country of a cultivated species.)

1. L. scóticum (Scottish Lovage). - Stem little branched, about $1 \frac{1}{2}$ feet high, tinged with red; leaves dark green, glossy, bitemate with large, broad, serrate leaflets: flowers reddish-white, with both bracts and bracteoles.-Rocky coasts in Scotland and Northumberland.-Fl. July. Perennial.

33. Seufnu.-Leaves bipinnate; leafiets pinnatifid; nmbel compound, many-rayed; bracts absent; bracteoles many, subulate; flowers white; frut 10-winged; lateral ridges broadest, diverging; vitte solitary. (Name from the Greek setinon, parsley.)

1. S. Carrifólia (False Millk Parsley)-Root-fibres stout, fusiform; stem elect, solid, $2-4$ feet high, angular, furrowed; lower leaves with short sheath and very long, channelled stalk, dull, dark green, greyer beneath; leaflets finely serrate, with a bristly apex; umbels terminal, large, compact, 20-30-rayed, flattopped; lracts absent or 1.-Moist, sliady places, Lincolnshire and Cambridgeshire. Resembling Peucéclamum jalústré, the Milk Parsley.-Fl. July,
August. Perennial.

34. Ancécrca. - Tall plants, with ternately bipinnate leaves with large segments; umbels compound, many-rayed; bracts few or none; bracteoles many, small; sepals indistinguishable; petals white; lateral riclges with membranous, parallel, thin wings; vitte solitary or 2 together. (Name from its angeive medi. cinai ploperties.) 
1. A. syleéstris (Wild Angélica).-A tall, stout plant, 2-4 feet high ; stem furrowed ; slightly downy, especially above, tinged with purple; leaves bipinnate; leaflets stalked, obliquely ovate, serrate; umbels large, with bracts and bracteoles; flowers white, tinged with

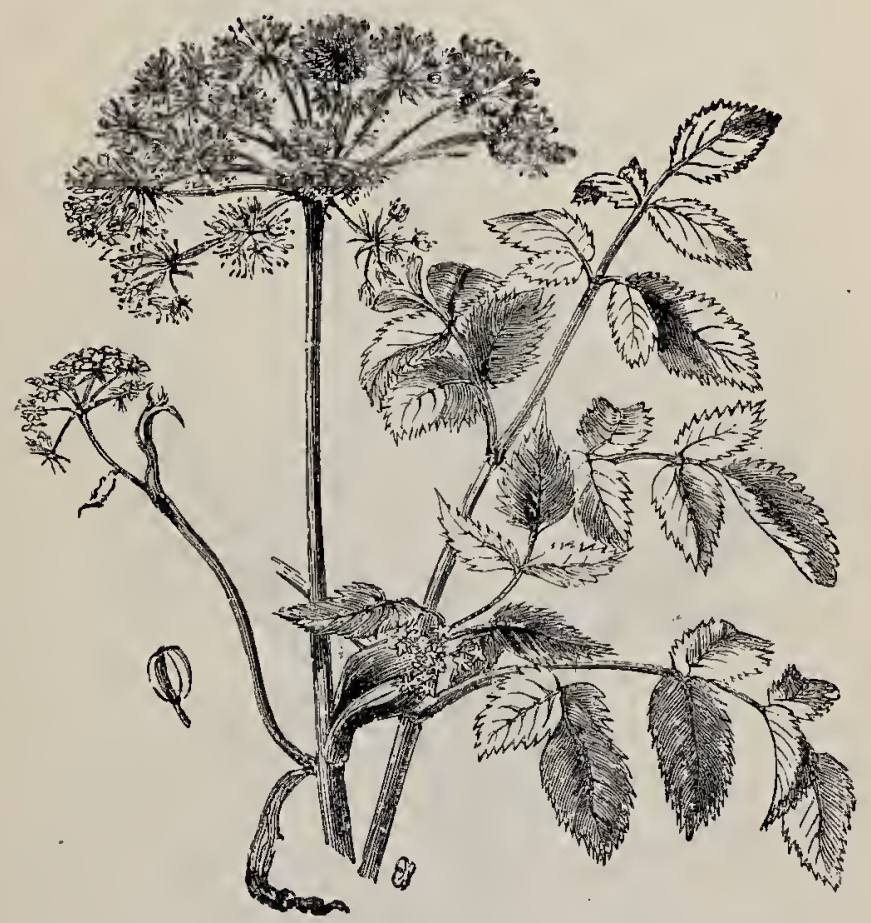

ANGÉLYCA SYLVÉSTRIs (Wild Angelica).

pink.-Wet places; common.-Fl. July, August. Perennial.

*35. Archangélica, differing from Angélica mainly in having minute sepals, thicker dorsal and intermediate ridges, no vittce, and loose seeds, is represented by $A$. officinális, a larger plant than Angélica sylvéstris, 
with leaves 2-3 feet across, decurrent leaflets and greenish-white flowers, cultivated for the sake of its aromatic stems (which are candied as a sweetmeat),

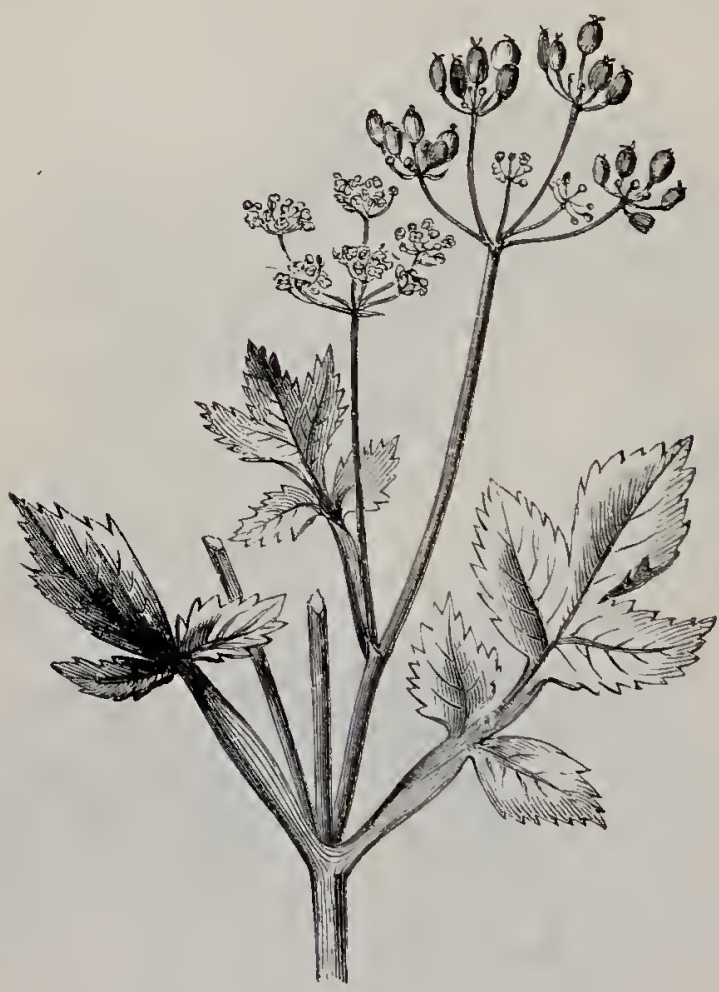

PEUCEDANUM SATÍVLM (Common Parsnip). and occurring only as an escape.-Fl. July--Sep-
tember. Perennial.

36. Peucédandm (Hog's-Fennel). - Leaves pinnate or ternate; umbels compound, many-rayed; bracts and bracteoles absent, few or many; sepals small or incon- 
spicuous; petals yellow or white; fruit flattened; lateral vidlges forming thin flat contiguous parallel wings ; vittce linear, as long as the fruit. (Name of Greek origin.)

1. P.officinálé (Sulphur-wort, Sea Hog's-Fennel).Smooth ; stem 2-3 feet high, round, ribbed; leaves $3-5$ ternate; leaflets long, linear, flaccid; umbels large, on diverging branches, many-rayed; bracts few, deciduous; flowers minute, yellow.-Salt marshes in Kent and Essex; very rare.El. July-September. Perennial.

2. P. patústré (Milk Parsley, Marsh Hog's-Fennel).-Smooth, with abundant milky juice, drying to a brown resin ; stem 3-5 feet high, furrowed, hollow; leaves 3-pinnate ; leaflets pinnatifid with narrow acuminate segments ; bracts many, deflexed, persistent; flowers white.-Marshes, chiefly in the south and east; rare.-Fl. July, August. Perennial.

3.* P. Ostrúthium (Masterwort).-A smooth, stout plant, 1-3 feet high ; stem round, furrowed, hollow; leaves long-stalked, biternate; leaflets few, large, broadly-ovate, cut and toothed; umbels large ; bracts absent ; flower's white.-Moist meadows in the north; rare. Formerly cultivated and now only an escape.Fl. June-August. Perennial.

4. P. sativum (Common Parsnip).-A downy erect plant, 2-3 feet high, with tap root; stem angular, hollow; leaves pinnate, glossy, downy beneath; leaflets $5-11$, sessile, ovate, serrate ; umbels terminal, ebracteate; flowers small, bright yellow.-Banks on calcareous soil ; not uncommon. Differing from the cultivated form chiefly in its smaller root.-Fl. July, August. Biennial.

37. Herácreum (Cow-Parsnip).-Large plants; leaves 1-3-pinnate; leaflets broad, lobed ; umbels compound, many-rayed; bracts deciduous; flowers white 
or pink, the outer ones irregular ; fruit as in Peucé. danum, but witl short, club-shaped rittce. (Named after the hero Heracles.)

1. H. Sphondýlium (Common Cow-Parsnip, Hog-

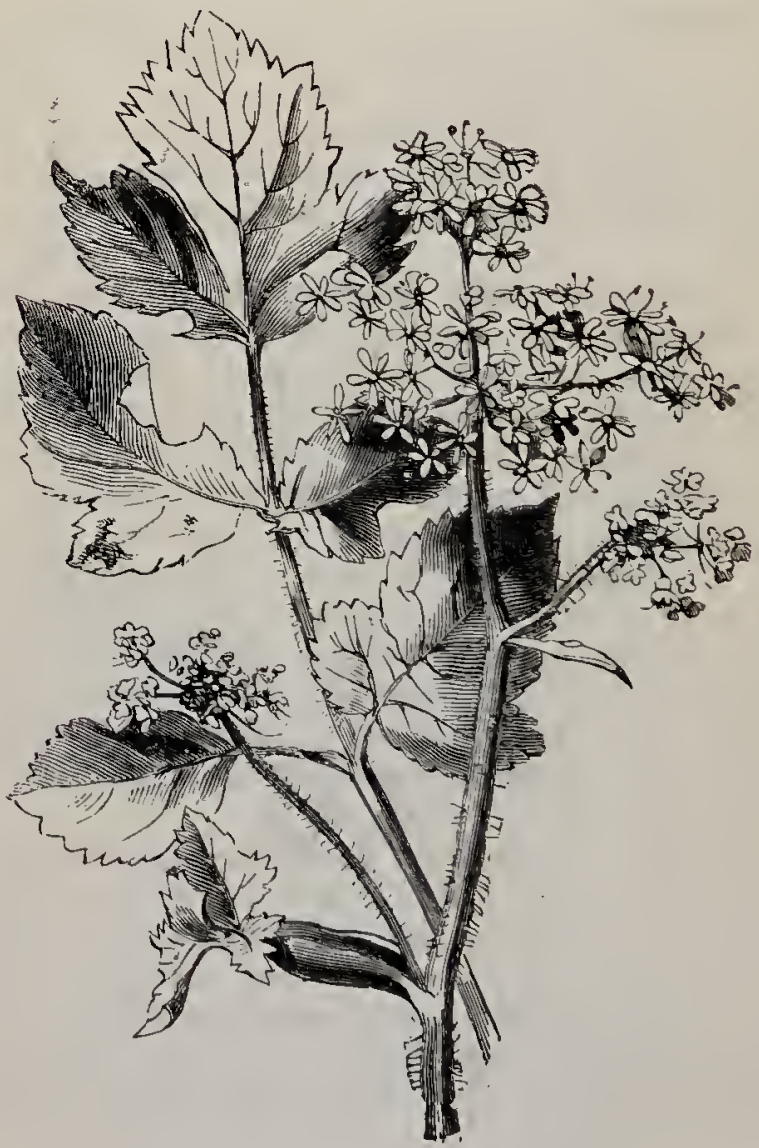

HERACLEUM SPHONDT́LIUM (Common Cov-Parsnip, Hog-weed.)

weed).-A very tall and stout plant, with a channelled hairy stem, 4-6 feet high ; large, irregularly cut, rough leaves; and spreading umbels of conspicuous 
white flowers.-Hedgerows; common. In spring the plant is remarkable for the large pale oval tufts formed by the sheathing bases of the cauline leaves distended with the flower-buds. In the outer flowers the symmetric enlargement of one deeply 2-lobed and inflexed petal, and the unsymmetric modification of those on either side of it, should be noticed. This, like many other Umbelliferæ, is often confounded by farmers with the poisonous Hemlock; but cattle eat it with impunity.-Fl. July. Perennial.

A gigantic handsome Siberian species, $H$. gigánteum, is commonly grown in shrubberies, and may occur as an escape.

*38. TondÝLICm (Hartwort).--Hairy annuals with pinnate leaves, linear bracteoles and thick wings to the fruit formed by the lateral ridges, is represented by T. máximum, a slender hispid plant with reflexed hairs and small, 6-8-rayed umbets of pink flowers, which occurs in waste places at Oxford, Eton, and Isleworth; but is not native.-Fl. June, July. Annual.

*39. Cobiándrum (Coriander), also slender annuals, but glabrous, with pinnately decompound leaves, few-1ayed compound umbels with no bracts, few thread-like bracteoles, petals often irregular, and very globose, slightly ridged fruit, is represented by C. sativum, an occasional escape from cultivation in the south and east. The name is derived from the Greek koris, a bug, from the fotid smell of the plant; but the pleasantly aromatic fruit is considerably used in confectionery.-Fl. June. Annual.

40. DaÚcus (Carrot).- - Hispid plants ; leaves pinnately decompound; umbels compound, many-rayed, 
the outer arching over the inner when in fruit ; bracts and bracteoles usually many, pinnatifid; fruit with 8

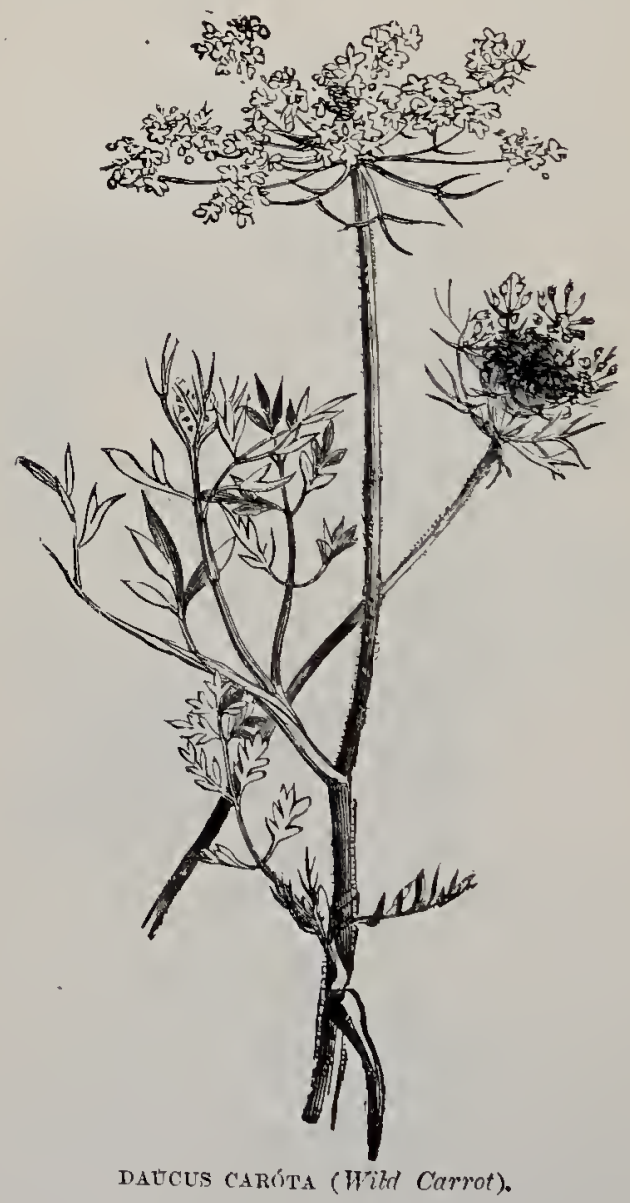

rows of prickles, one row on each secondary ridge. (Name, the Greek name of the plant.)

1. D. Caróta (Wild Carrot). - A tough, erect, bristly plant, with much-cut leaves and large con- 
cave umbels of dull white flowers, the central flower or secondary umbel deep red, in scent and flavour resembling the Garden Carrot._Fields ; common._Fl. June-August. Biennial.

2. D. gúmmifer (Seaside Carrot)._Differs in being more prostrate, rather fleshy, and having the umbel convex when in fruit. - Sea-shores in the south; rare. -Fl. July, August. Biennial.

41. CA ́́calis (Bur-Parsley),-Hispid plants; leaves 1-3-pinnate; umbels compound, or rarely simple, usually few-rayed: bracts few or none; bracteoles many; fruit with $1-3$ rows of prickles on each primary and secondary ridge. (Name, the Greek name of the plant.)

1.* C. latifólici (Great Bur-Parsley).--Stem 1-2 feet high, rough; leaves pinnate; leaflets lanceolate, serrate, decurrent; umbels 2-4-rayed; secondary umbels 4-6-rayed; flowers large, rose-coloured; fruit large, oblong, very prickly, with $2-3$ rows of recurver prickles on each secondary ridge.-Cornfields, especially on calcareous soil; very rare, not native.Fl. July. Annual.

2. C. daucóides (Small Bur-Parsley).-A somewhat bushy plant; stem deeply furıowed, hairy at the nodes; leaves $2-3$ pinnate; umbels terminal and lateral, of about 3 rays, without bracts; secondary umbels of about 3 rays, with bracteoles; flowers small, pinkish; frit large, with one row of prickles on each secondary ridge.-Chalky fields; not common.-Fl. June, July.-Annual.

3. $C$. arvénsis (Spreading Hedge-Parsley).-A hispid, much-branched plant, $6-18$ in. high; lecues bipinnate; leaflets. ovate-lanceolate, cut and toothed; umbels compound, long-stalked, terminal, 2-8-rayed; bracts 1 or none; bracteoles linear; flowers white or pink; fruit covered with spread- 
ing hooked bristles.-Hedges; common.-Fl. July, August. Annual.

4. C. Anthéscus (Upright Hedge-Parsley).-A tall, slender plant, $2-3$ feet high, with a solid rough

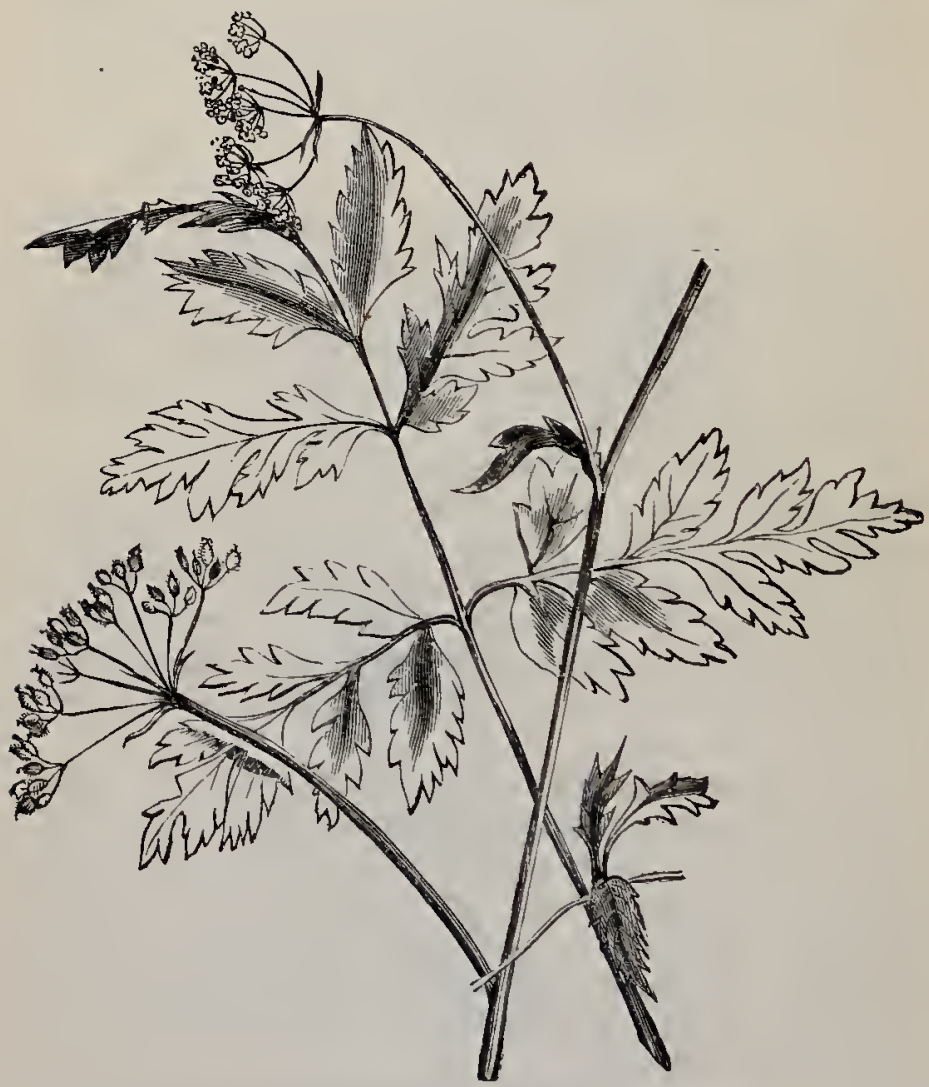

CAĹCaLIs AXTHRfscus (Upright Hedge-Parsley).

stem; hairy, bipinnate leaves ; ovate-oblong, cut and toothed leaflets; long-stalked terminal 5-12-rayed umbels with several bracts and liracteoles; flowers small, white or pinkish; fruit covered with incurved, not 
hooked, bristles.-Hedges ; abundant.-Fl. July, August. Annual.

5. C. nodósa (K notted Hedge-Parsley).-Well distinguished from all other British umbelliferous plants by its prostrate stem, its very small, almost globular, simple, lateral, and nearly sessile umbels of small pinkish-white flowers, and by the outer fruits in each umbel being covered with hooked bristles, while the inner are warty.-Fl. May-July. Annual.

\section{Ord, XXXV。 Aralí́cefe.-The Ivy Famul.}

Shrubs or trees, often downy with stellate hairs, chiefly tropical, and closely resembling the Umbelliferæ in the structure of their flowers, though not partaking of their dangerous properties. Caly $x$ superior, 5-cleft; petals 5-10; stamens, 5-10, epigynous; ovary 2-or more-chambered, with styles as many as the chambers, and 1 ovule in each charaber; fruit generally a berry. Only one species is a native of Britain; but this one, the Ivy, is so universally diffused as to be familiar to everyone. Ginseng, the favourite medicine of the Chinese, is the root of Panax Ginseng, a member of this Order; and their celebrated Rice-paper is the pith of Futsia papyrifera, a native of Formosa, also belonging to the Araliácex.

1. Hédera (Ivy)-Climbing shrubs; Teaves exstipulate, simple, scattered; flowers in simple umbels, 5-merous, polysymmetric; bery 5-chambered, 5seeded, with a parchment-like endocarp lining each chamber; albumen ruminate. (Name, the Classical Latin name of the plant.)

1. H. Hélix (Common Iry) - A woody plant with 
a stem sometimes 10 inches in diameter, trailung or climbing by adventitious simple rootlets; Teaves ever. green, leathery, dark green, glossy, and distinctly veined above, 5-lobed on the climbing stem, ovate and undivided on the free upper branches ; umbels confined

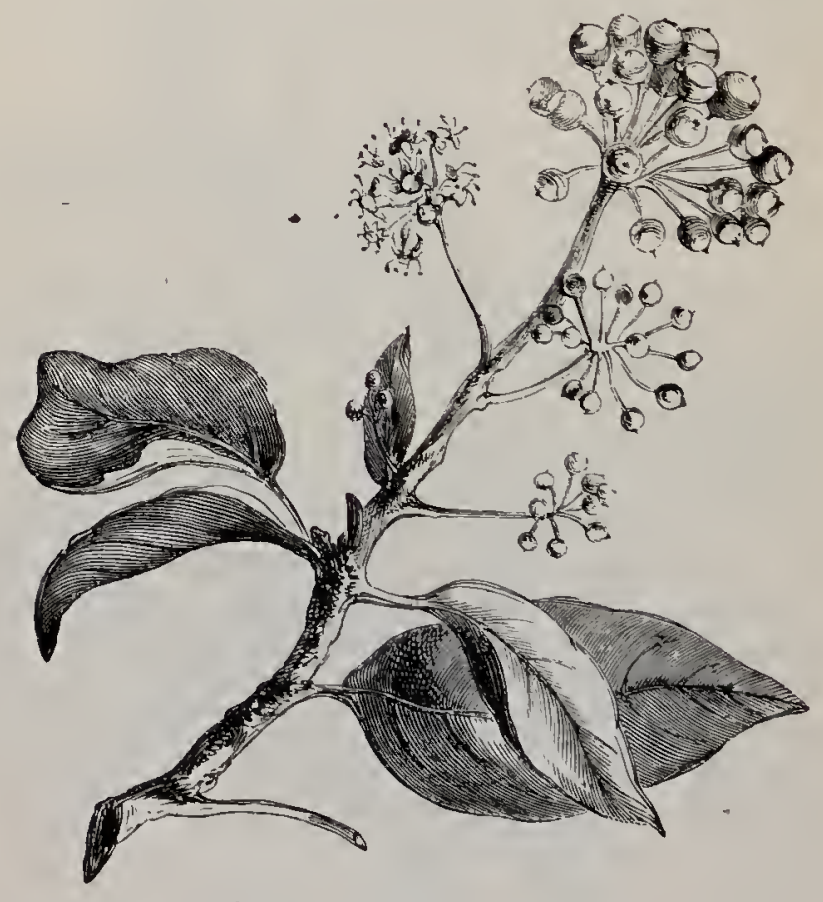

HÉDERA HÉLIX (Common Ivy).

to the upper free branches, globose, simple, downy with stellate hairs; flowers greenish-yellow; berries black; endocarp lilac._Banks, woods, rocks, and old walls; general.-Fl. October, November. Peren. nial. 
Ord. XXXVi. Cornáceer.-The Dogivood Family.

A small order, inostly shrubs or trees, inhabiting the temperate regions of the Northern Hemisphere. They have mostly exstipulate, opposite, simple leaves, small, polysymmetric flowers, which are generally tetramerous, and 1-4-chambered berry-like fruit, with stony endocarps; sepals 4, superior, valvate; petals 4-5, epigynous; stamens 4-5, epigynous; style single, thread-like; stigma simple or lobed. The Order contains few plants of interest. The evergreen known as the Spotted Laurel (Aúcuba japónica), now common in our gardens, is a member of the Order. The spots are a disease which is only slightly transmitted by seed; but the plant, being diocious, is largely multiplied by layers. The staminate plant is now grown separately, or it can be grafted on the pistillate shrub, so that the red berries are now commonly produced. Benthámia fragifera, a handsome shrub from the mountains of Nipal, was introduced into Cornwall in 1825, and, flowering and fruiting freely, is a pleasing addition to the shrubbery. Córnus flóride, the American Dogwood, a native of the United States, furnishes a wood useful for turnery and engraving, and the bark of this and other species is used as a substitute for quinine. The Cornus of the ancients was the Cornelian Cherry, Córnus máscula, whose little clusters of yellow starry flowers are among the earliest heralds of spring. Its fruit is like a small plum, with a very austere flesh, but after keeping it becomes pleasantly acid. The Turks still use it in the manufacture of sherbet, and the bark of the same species furnishes the red dye for their fez. Two species of Cornus are the only British representatives of the Order. 
1. Córnus (Cornel).--Herbs, shrubs, or trees ; leaves usually opposite; flowers small, white or yellow; petals valvate; ovary 2-chambered. (Name from the Latin, referring to the horny hardness of the wood.)

1. C. suécica (Dwarf Cornel).-Herbaceous; rhi-

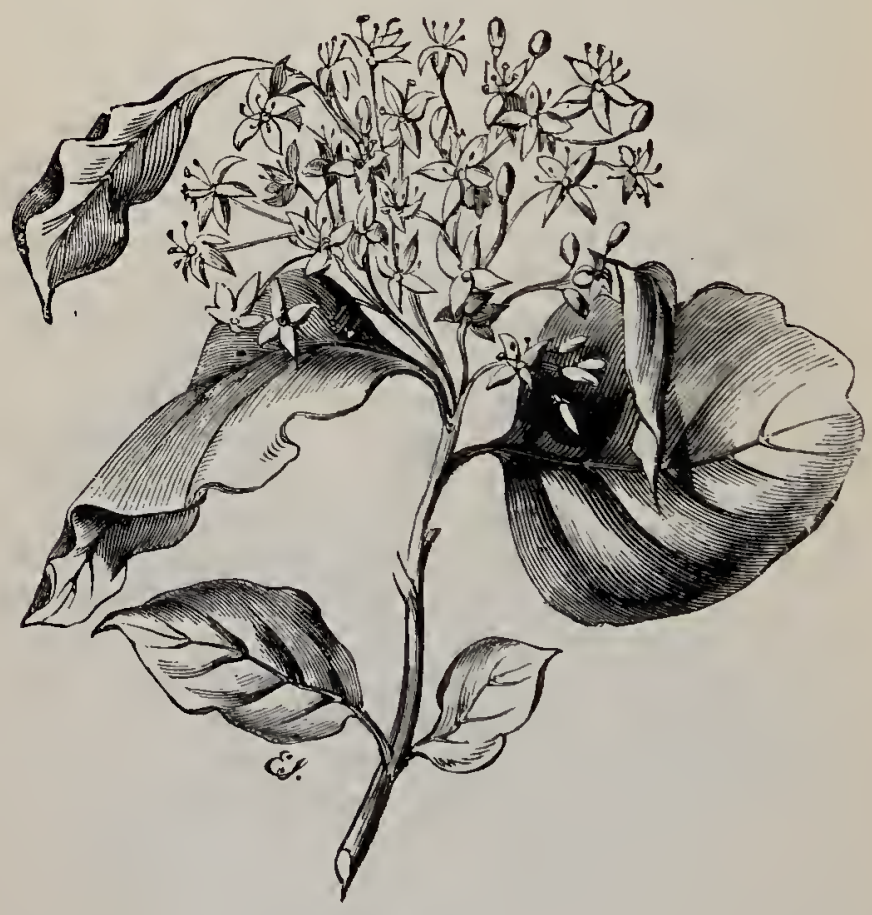

cónNus sangutNeA (Wild Comel, Dog-wood).

zome woody, creeping; stems annual, erect, about 6 in. high, slender; Teares opposite, decussate, ovate; flower's in a terminal umbel, minute, dark purple; bracts 4, large, ovate, yellow, tipped with purple, forming an involucre; fruit, a red berry.-Alpine moors in Scotland, and the North of England; rare. The fruit is said by the Highlanders to create appetite, 
and hence is called Lus-a-chraois, plant of gluttony.Fl. July, August. Perennial.

2. C. sanguinea (Wild Cornel, Dogwood).--Very different in habit from the preceding; a bushy shrub, 5-6 feet high, with opposite, ovate, acute leaves, and terminal, many-flowered, corymbose cymes of cream-white flowers; berries small, black-purple.Hedges and thickets, especially on a chalk or limestone soil; common. The wood, with that of the Spindle-tree (Euónymus européus) and Guelder Rose (Viburnum), which has a similar texture, and is therefore confused under the same name Dogwood, was used formerly for skewers. The leaves assume bloodred and dark purple tints early in autumn.-Fl. June. Perennial.

\section{Sub-Class II. GAMOPÉTALA.}

Having both calyx and corolla and the petals of the latter united.

SERIES I. EPÍGYNA.-ORD. XXXVII.-XLIII。

Orary inferior.

§tamens epipetalous.

Ord. XXXViI. Caprifoliáceze.-The Honeysuchle Faniley.

A small but very varied Order, comprising trees, shrubs, and herbaceous plants, principally confined to the Northern Hemisphere. The leares are usually exstipulate and opposite ; the flowers conspicuous and sometimes monosymmetric; sepals $3-5$, superior; petals 3-5, united; stamens 4-10, usually equal in number to the petals and alternate with them ; ovary 
3-5-chambered; fruit in most cases a berry. Such favourite plants as the fragrant Honeysuckle, the Guelder Rose, the Elder, and the elegant little plant upon which Linnæus fixed to commemorate his name, make the Order an interesting one.

1. A dóxa.-Herbs ; leaves ternate ; flowers small, green, 5 in a head; corolla rotate; stamens forked; berry with 4 or 51 -seeded chambers.

2. Sambúcus.-Trees or shrubby herbs; teaves pinnate; flowers small, in umbellate cymes, 5-merous; corolla rotate; berry with 3-5 1-seeded chambers.

3. ViBÚRNUnr.-Shrubs; leares simple; flowers in cymes, 5-merous; corolla rotate or bell-shaped; berny 1-seeded.

4. Linn éa.-Herb; leaves simple; flowers in pairs; corolla bell-shaped; stamens didynamous; fruit dry, 1 -seeded.

5. LonicÉra.-Shrubs; Teaves simple; flowers in cymose heads; corolla monosymmetric ; berry of 2 or 3 several-seeded chambers.

I. Avóxa (Moschatel).-A small glabrous, succulcnt herb; thizome creeping, scaly; leaves 2, radical, tcinate; flowers in a long-stallked terminal head of 5 , small, green, the 4 lateral ones 5-merous, the terminal one 4-merous; corolla rotate; stcmens 4 or 5, bifurcating at the base; anthers dimidiate; berry with l-seeded parchment-like chambers. (Name from the Greek signifying inylorious, from its lumble growth.)

1. A. Moschutellina (Common or Tuberous Moschatcl).-The only species, an interesting little herbaceous plant, 4-6 in. high; stem 4-angled; rredical leares long-stalked, ternate; leceflet.s triangular, lobed; cantine leaves or bracts 2, smaller, with sheathing petioles; flowers arranged as if on 5 sides of a cube.-Hedgerows; local, but widely diffused. The whole plant diffuses a musk-like scent, which, 


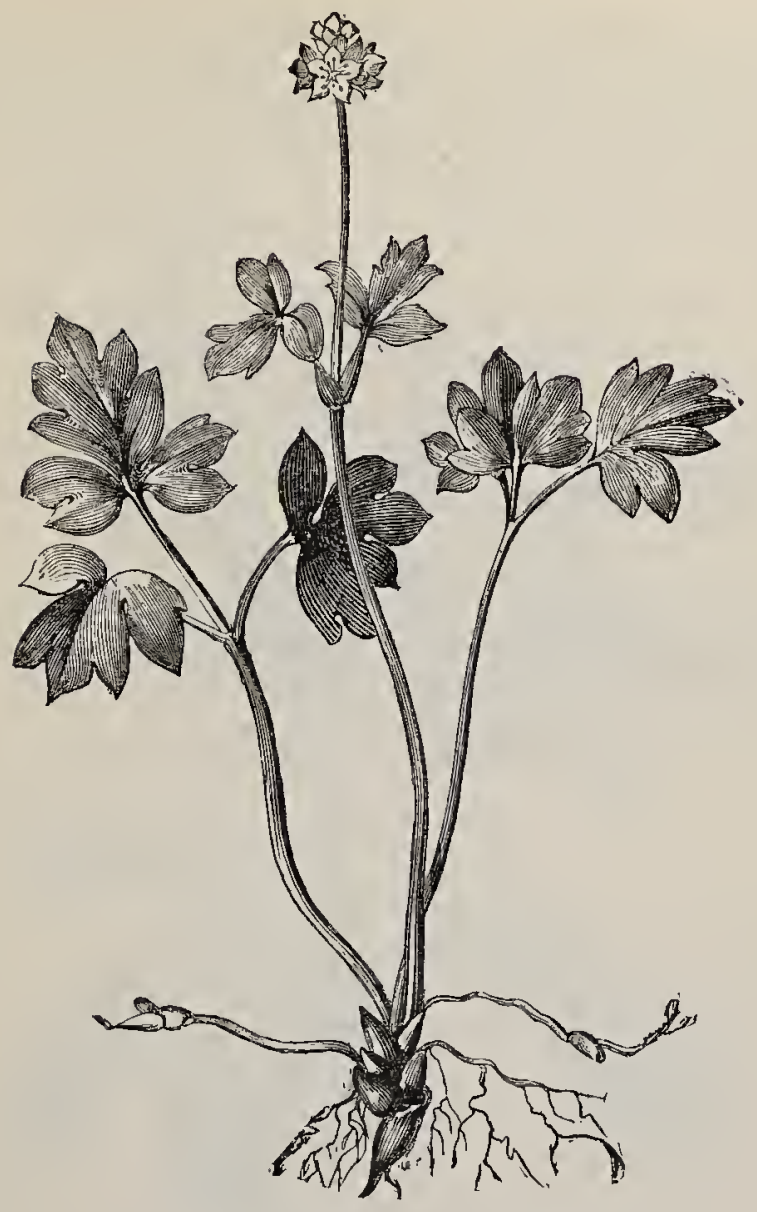

adóxa moschatellíNa (Common Moschatel).

however, is not perceptible if the plant be bruised.Fl. April, May. Perennial.

2. Sambúcus (Elder).-Trees, shrubs, or large herbs, remarkable for the large quantity of pith in

$$
\text { c } \mathbb{C} 2
$$


the young branches; leaves pinnate; flowers small, 5 -merous, in umbellate cymes ; sepals $3-5$; corolla rotate; stamens 5; ovary 3-5-chambered; ovules 1 in each chamber; fruit a berry with $3-5$ parchment-

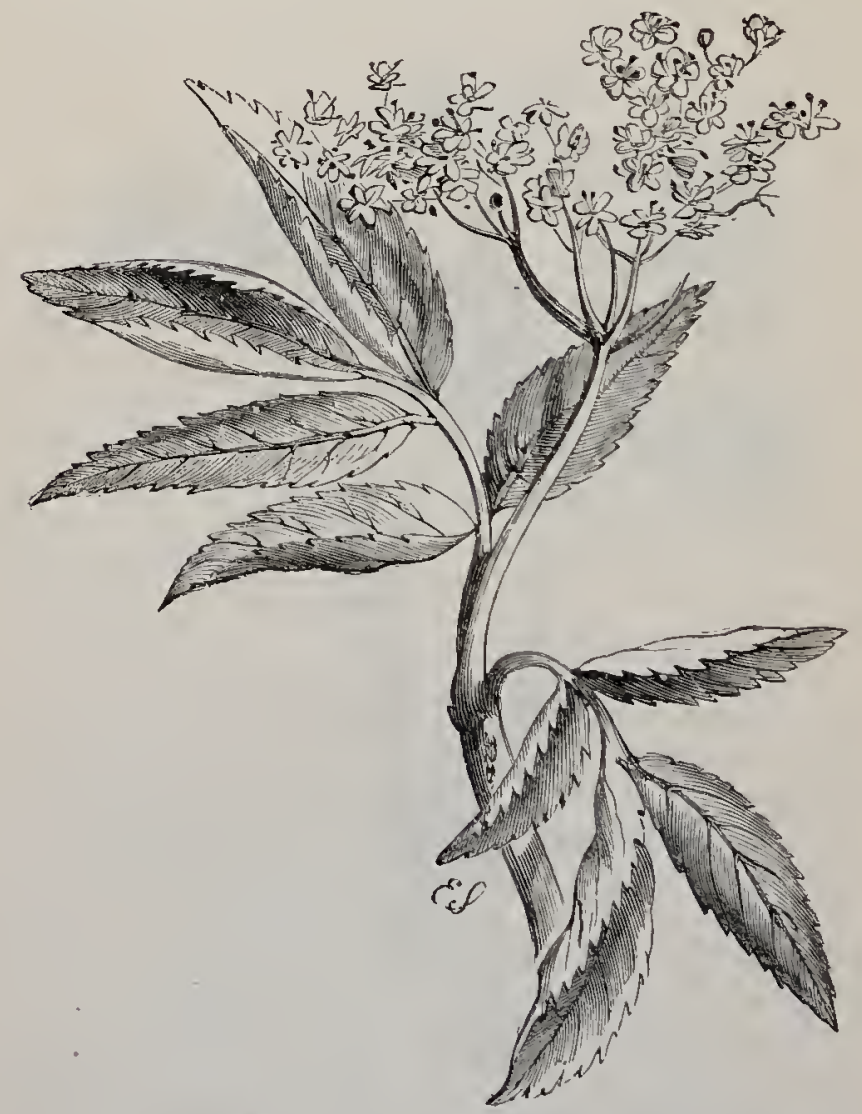

SAMBÚCUS NfGRA (Commion Elder).

like ondocarps. (Name from the Greek sambúké, a musical instrument, in making which elder-wood is supposed to have been employed.)

1. S. Nígra (Common Elder). - Stem woody, 
forming a small tree; bark corky; leaves with a strong, unpleasant odour; cymes with 5 principal branches; flowers cream-white, of a sickly smell ; berry small, globose, purple-black, polished, rarely green or white.-Hedges; common. The blossoms are used for making perfume ; the berries for wine. Evelyn,

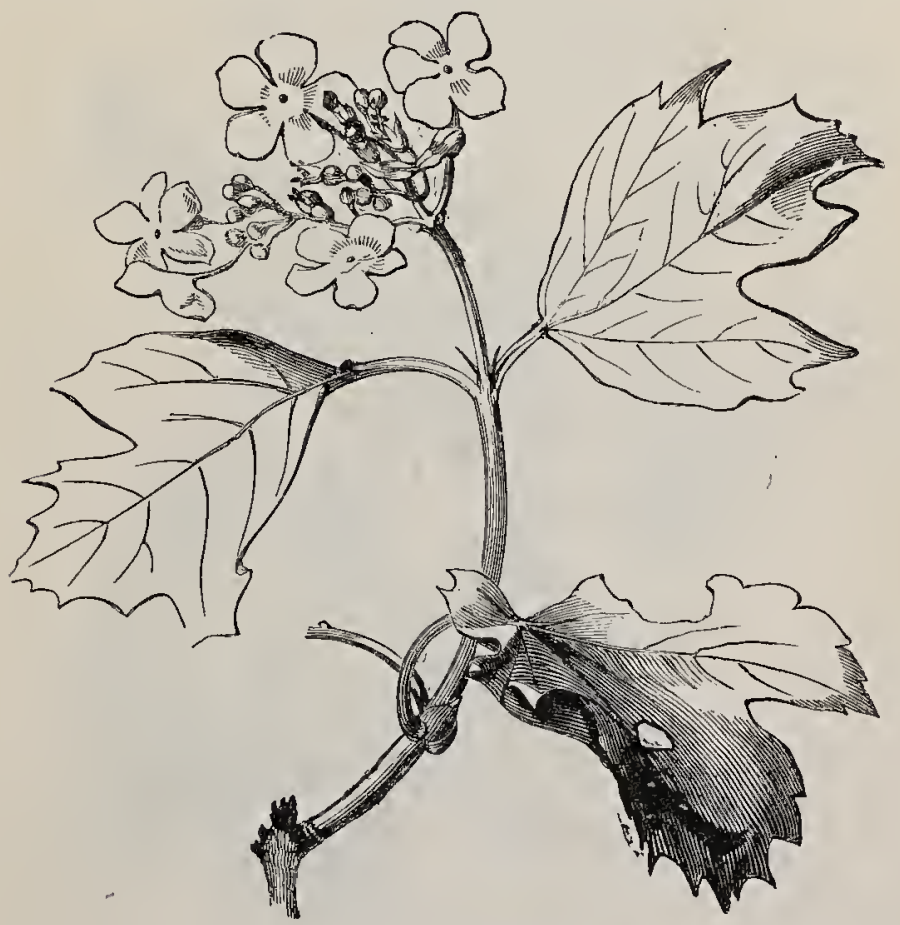

vibúnaum ópulus (Guelder Rose, Water Eller).

speaking in its praise, says: "If the medicinal properties of the leaves, bark, berries, \&c., were thoroughly known, I cannot tell what our countryman could ail for which he would not find a remedy, from every hedge, either for sickness or wound."-Fl. June. Perennial. 
2. S. Ébulus (Dwarf Elder, Danewort).-A large herbaceous plant, $2-4$ feet high, with ovate, serrate, leafy stipules, 3 principal branches to its cymes, and

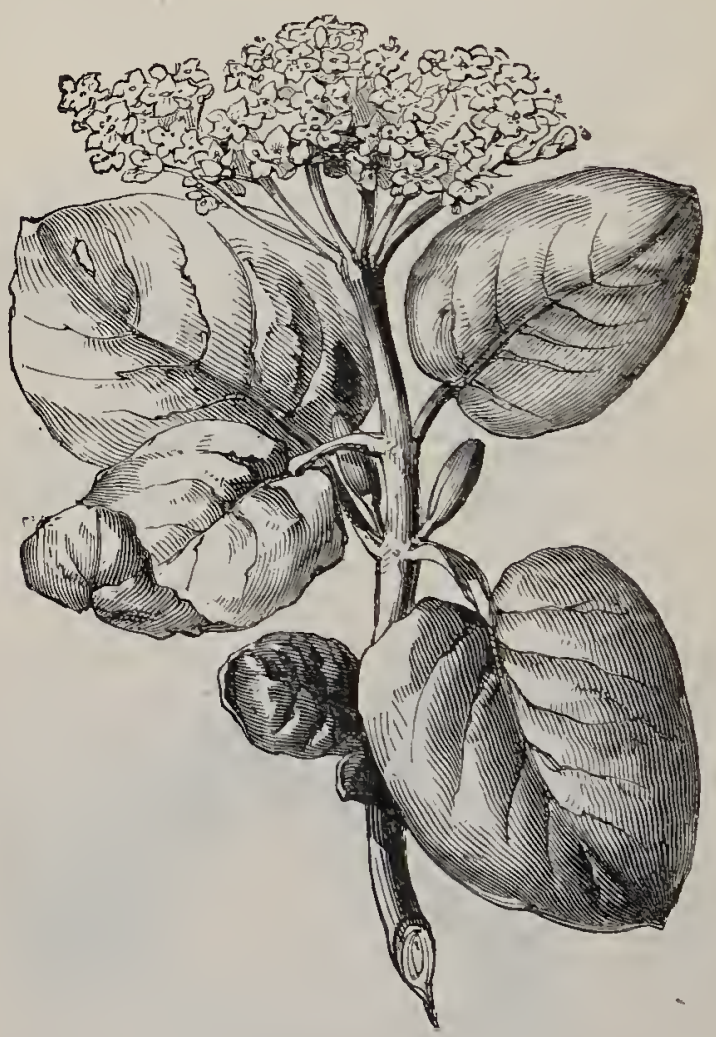

VIBÚRNUM IANTîA (Wayjaring-tree, Mealy Guelder Rose).

pink tips to its petals.-Bushy places; not uncommon.-- Fl. July, August. Perennial.

3. Vibúrnum (Guelder Rose). - Shrubs; leaves simple; flowers 5-merous, white or pink, in cymose 
clusters, small, or the outer ones male or neuter with large corollas; corolla rotate or bell-shaped; stigmas 3 , sessile; berry 1-seeded. (Name, the Latin name for this or some similar plant.)

1. V. Ópulus (Guelder Rose, Water Elder):-A shrub or small tree; bark very acrid; leaves smooth,

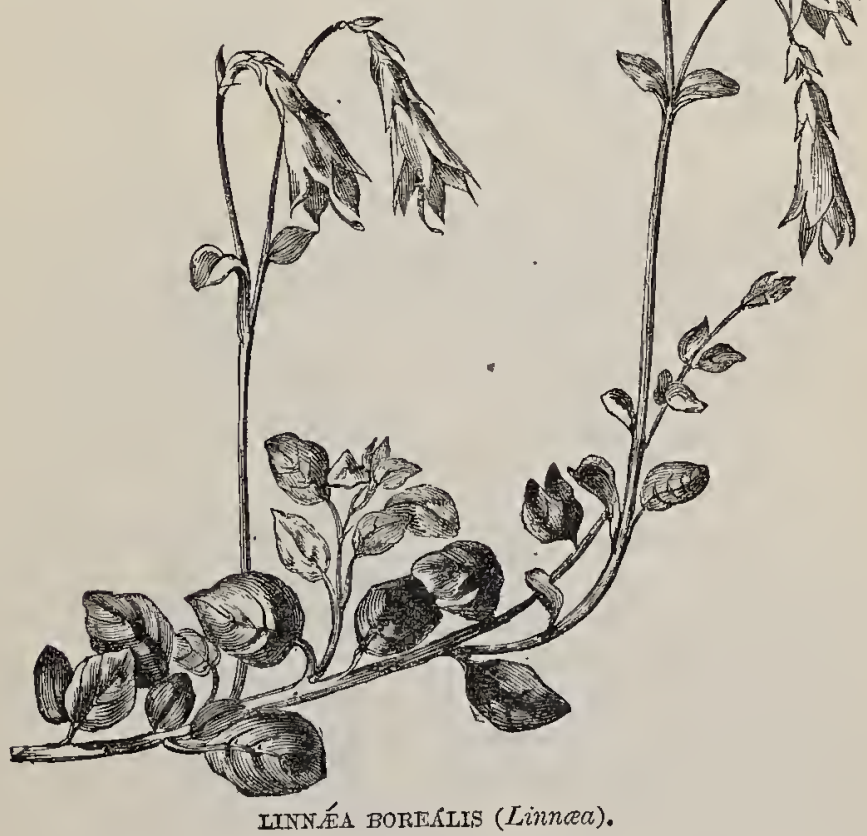

3-5-lobed, stipulate, with glands at the upper end of the stalk, assuming a rich vinous hue before falling; flowers in flat-topped cymes, the outer ones neuter with large snow-white corollas, rendering the bush conspicuous; berries slightly flattened, translucent, blood-red,-Moist woods and hedges; common. 
The berries are said to be sometimes fermented and eaten, a statement scarcely credible to anyone who has chanced to smell them. In the garden variety, known as the Snowball-tree, all the flowers are neuter and the cyme has become globular.-Fl. June, July. Perennial.

2. V. Lantána (Mealy Guelder Rose, Wayfaringtree).-A slirub, pubescent with stellate hairs; leaves elliptical, cordate, serrate, very downy beneath, exstipulate; cymes terminal; flovers small, white, all perfect; berries much flattened, scarlet, turning black when fully ripe.-Dry hedgerows, chiefly on calcareous soil ; not general.--Fl. May; June. Perennial.

4. LinnfeA.-A very slender creeping plant; leaves evergreen, exstipulate; flowers in pairs on ascending, 2-bracteate peduncles, with drooping 2bracteolate pedicels; corolla bell-shaped; petals 5 , slightly unequal ; stamens 4, 2 longer than the others; fruit seldom formed in Britain. (Name in honour of Cirl von Linné, the great Swedish botanist.)

1. L. boreális. - The only species, almost glabrous ; leaves ovate, obtuse, thick; flowers fragrant and of a delicate pink colour, crimson within.-Fir-woods in Scotland and at Hartburn, Northumberland. Deservedly regarded with peculiar interest as being the "littlc northern plant, long overlooked, depressed, abject, flowering early," which Linnæus himself sclected as therefore most appropriate to transmit his name to posterity.-Fl. July. Perennial.

5. Lonicíra(Honeysuckle).-Erect, prostrate or twining shrubs; leaves exstipulate, entire, sometimes connate; flower's generally in cymose heads, sometimes united by their ovaries; sepals 5 ; petals 5 , united in a tubular or funnel-shaped corolla with a bilabiate 
limb; stamens 5; berry of 2 or 3 several-seeded chambers. (Named in honour of Adam Lonicer, a German botanist.)

1. L. Periclýmenum (Honeysuckle, Woodbine).Stem twining; leaves ovate or oblong, glabrous or

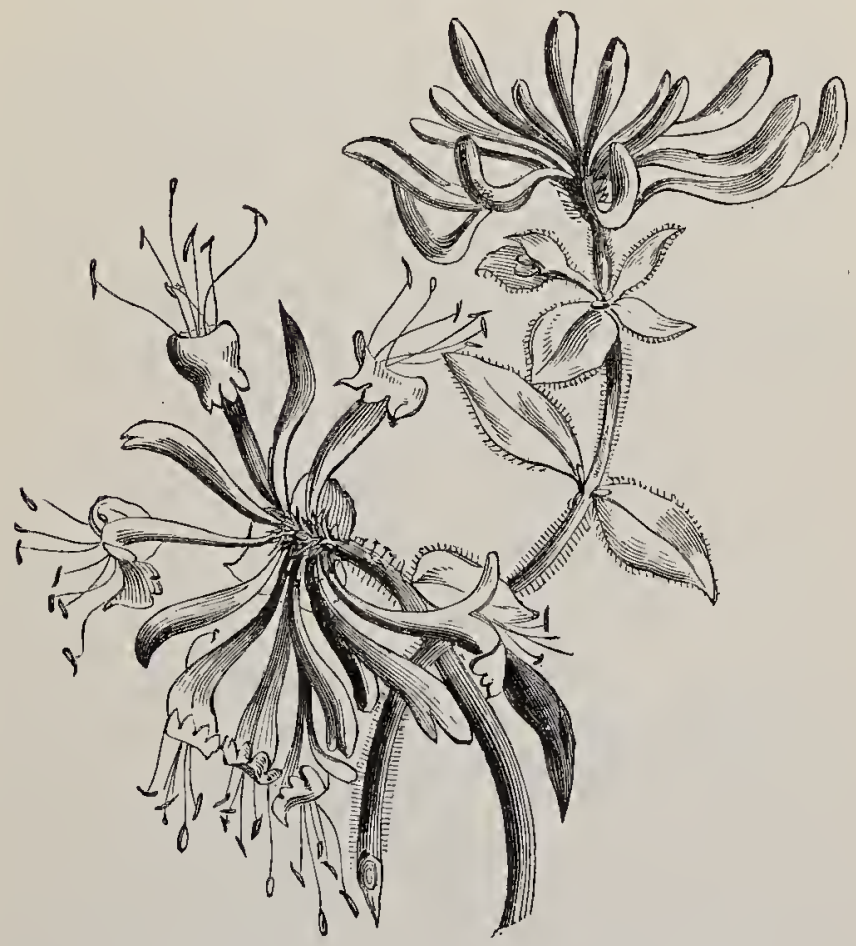

LONICÉRA PERICLÝMENUM (Honeysuckle, Woodbine).

slightly pubescent, glaucous below, not united at the base, sometimes lobed; Tlowers in stalked terminal heads, gaping, red outside, yellow within, very fragrant; berry globose, translucent, crimson.-A common and favourite twining shrub, the first to expand its 
leaves in spring, or rather in winter, and almost the last to blossom in autumn. Though highly ornamental to our woods, it is decidedly injurious to young trees, clasping them so tightly as to distort their growth. Handsome twisted walking-sticks (generally Hazel) are thus formed, but the growth of the tree is greatly checked.-Fl. July, and again in October. Perennial.

* Two other species of Honeysuckle are occasionally found in copses, but are not natives of Britain: L. Caprifótium (Pale Perfoliate Honeysuckle), distinguished by having the upper leaves connate, or united by their bases, and the flower-heads sessile; and L. Xylósteum (Upright Fly Honeysuckle), an erect shrub, with downy, stalked leaves, and pale yellow, scentless flowers, which grow in pairs in the axils.

Ord. XXXVIII. Rubíicere.-The Bedstrat Family.

Taken in its widest extension, this is a very large Order, containing more than 2,800 species, characterised by having opposite leaves, interpetiolar stipules, gamopetalous corollas, epipetalous stamens alternate with the petals, and an inferior ovary of 2 carpels. The majority, forming the tribe Cinchónec, are tropical trees and shrubs with small stipules, and comprise not a few species noted for the fragrance and beauty of their flowers, and some of the highest utility to man, as food or modicine. Among the food-plants, the Coffee (Cóffec arálica and C. Tiberiea) holds the first place, the seeds filled with horny albumen being the coffee-beans of commerce. Several species of Cinehóna, a genus native to the Andes, furnish Peruvian or Jesuits' Bark, from which Quinine is prepared; and Ipecacuanha is the root of Cephciêtis Ipecaeuanha, a small shrub growing in the damp forests of Brazil. The British species, however, all 
belong to a very distinct type. They are herbaceous plants, with slender angular stems, and leaves with such large stipules between them as to form a star-like whorl, whence they have been separated as the tribe Stellâte. Their flowers are small, polysymmetric and 4-6-merous; the sepals sometimes indistinguishable; corolla rotate or tubular; ovary 2-chambered; ovules 1 in each chamber; fruit dry, consisting of 2 indehiscent cocci. They belong to temperate and cold latitudes and possess no remarkable properties, except that of containing a red colouring matter in their roots, which is used as a dye. The most important is Reibia tinctória, the Madder, the roots of which, besides yielding the valuable dye, possess the singular property of imparting a red colour to the bones of animals that feed on them. Rúbic cordifótic is the Manjit, another valuable red dye, a native of India. None of the British species are of any great value, though the fragrance of the leaves of the Woodruff, when dried, is wellknown, the flcwers of the Lady's Bedstraw (Gátium verum) were used as rennet to curdle milk, and the seeds of the genus Gálium are said to be, when roasted, a good substitute for coffee.

1. RúBIa.-No distinct sepals; corolla wheelshaped, or bell-shaped, 5-lobed; fruit fleshy.

2. Gílıun.-No distinct sepals; corolla wheelshaped, 4-lobed; fruit dry.

3. Aspérula,-No distinct sepals; corolla bellshaped, 4-lobed; fruit dry.

4. Sherírdia.-Sepals 4-6; corolla funnel-shaped, 4-lobed ; fruit dry.

1. RúbIa (Madder).-Herbs with axillary and terminal cymes of small flowers ; calyx-limb ringshaped or absent; corolla rotate or campanulate, 5-lobed; stamens 4 ; styles 2, short; fruit a 2-lobed 
berry. (Name from the Latin mber, red, from the dye obtained from some species).

1. R. peregrina (Wild Madder).-The only British species, a long straggling plant, many feet in length; stems 4-angled, with recurved bristles on the angles; leaves 4-6 in a whorl, ovate, glossy above, with re-

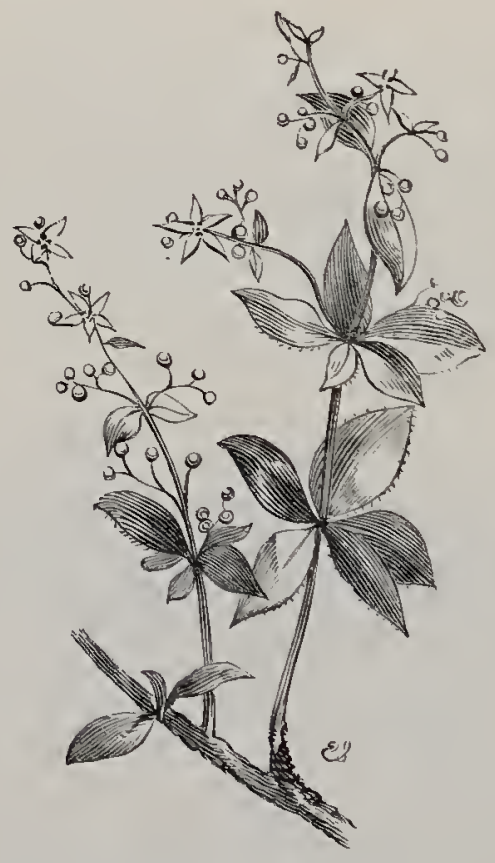

RÚBIA PEREgRíma (Tild Madder).

curved bristles on midrib and margin, nearly evergreen; flowers yellowish, in panicled cymes; coroth. 5-cleft; berives black, about as large as currants, remaining attached till late in winter.-Rocky places in the south and west; uncommon.-Fl. June-August. 
2. Gálium (Bedstraw).--Herbs differing chiefly from Rúbia in having a rotate, 4-lobed, rarely 5-lobed corolla and a dry fruit of 21 -seeded carpels. (Name from the Greek gala, milk, some species being used to curdle it.)

\section{* Leaves 3-veined.}

1. G. boreálé (Cross-leaved Bedstraw).-Stem erect, 1-2 feet high; leaves 4 in a whorl, smooth, lanceolate; flowers many, white; fruit rough, with looked prickles.-Damp rocky places in the north.-Fl. July, August. Perennial.

2. G. Cruciáta (Crosswort).-. Prostrate, about a foot long, hairy ; leaves 4 in a whorl, elliptic, soft and downy; flowers yellow, in 6-8-flowered axillary cymes, very fragrant, upper ones having pistils only, lower, stamens only; fruit smooth.-Dry banks; common.-Fl. May, June. Perennial.

\section{*** Leaves 1-veined; flowers in axillary and terminal. panicles; fruit smooth; perennial.}

3. G. vérum (Lady's Bedstraw).-Leaves about 8 in a whorl, very narrow (almost thread-like), revolute, downy beneath; Jlowers golden-yellow, rarely pale or green, in dense axillary and terminal panicles.-Dry banks ; abundant. The Highlanders use the roots, in conjunction with alum, to dye red, and the flowers to curdle milk.-Fl. June-September. Perennial.

4. G. eréctum (Upright Bedstraw).- Sub-erect; leaves $6-8$ in a whorl, lanceolate, with bristly margins; cyme with ascending branches; flowers white.-Banks and pastures; not common.-Fl. June and September. Perennial.

5. G. Mollúgo (Hedge Bedstraw).- Stem ascending, square, thickened at the nodes, smooth or hairy ; leaves $6-8$ in a whorl, oblong, with a bristly point 
and weak bristles on the margins; cyme with the lower branches horizontal or reflexed; flowers white. -Common everywhere in England, but rare in Scotland and Ireland.-Fl. July, August. Perennial.

6. G. saxátité (Heath Bedstraw). - A small prostrate, much-branched species; stem smooth; Teaves about 6 in a whorl, obovate, mucronate, fringed with a few prickles, which point forwards; cymes numerous, small, compact; flowers white.-Heaths; abundant.-Fl. June-August. Perennial.

7. G. sylvéstré (Mountain Bedstraw).-A similar but more erect and stiff species; leaves $6-8$ in a whorl, linear, awned, with prominent midrib and marginal hairs, not bristles.-Limestone hills; l'are, -Fl. June-August, Perennial.

8. G. palústré (Water Bedstraw).-Stems 1-3 feet high, weak, straggling, branched, smooth or rough with recurved prickles ; leaves $4-6$ in a whorl, blunt, linear, or on dry ground, oblong, frequently unequal, shining, with or without rough edges; flowers in loose, spreading panicles, white.-Watery places; common.-Fl. June-August. Perennial.

9. G. uliyinósum (Rough Marsh Bedstraw).-A smaller species; stems slender, brittle, about a foot high, with recurved prickles on the angles; leaves $6-8$ in a whorl, narrow, bristle-pointed, with recurved prickles on the margins; cymes ferw-flowered. -Watery places; common.-Fl. July, August. Perennial.

**** Leaves 1-reined; cymes mostly aritlary: flowers white; fruit hisprid or tubercled; annual.

10. G. únglicum (Wall Bedstraw). - A small spreading, slender, brittle species; lecues about 6 in a whor, narrow, mucronate, with forward-pointing bristles on the margins and recurved ones on the 
stems ; cymes small, bifurcating, few-flowered; flower's greenish; fruit minute, tubercled.-Oid walls and dry places in the south-east; rare.-Fl. June, July. Annual.

11. G. Apariné (Goose-grass, Cleavers).-Light

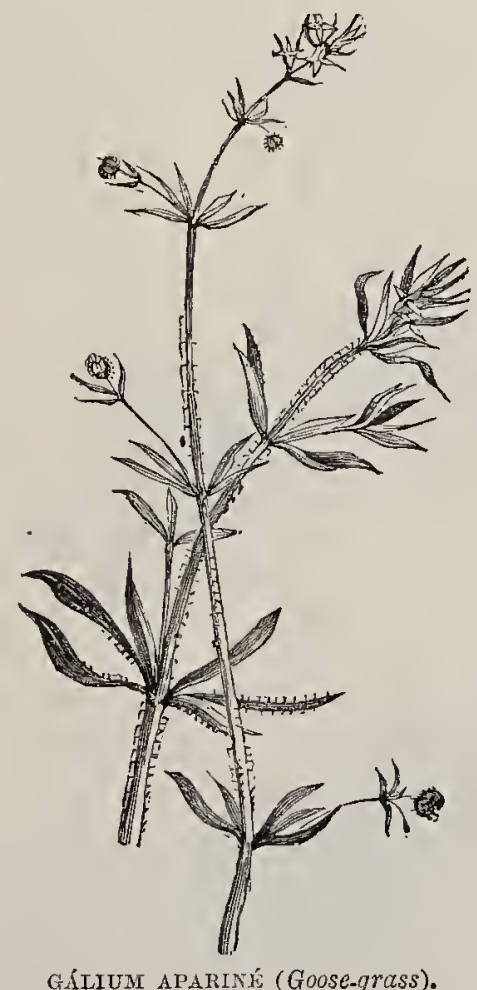

green, straggling, 3-4 feet long; stem and leaves very rough with recurved prickles; leaves $6-8$ in a whorl; flowers 2-3 together, white, axillary; fruit covered with short hooked prickles.-Hedges; very common. The stems, leaves, and bur-like fruits cling to the coat of any animal that touches them; whence 
is derived the popular name of Cleavers or Clivers. The plant is greedily devoured by geese.-Fl. JuneAugust. Annual.

12. G. Vaillántii, differing chiefly in having its flowers very minute, greenish and $3-9$ together,

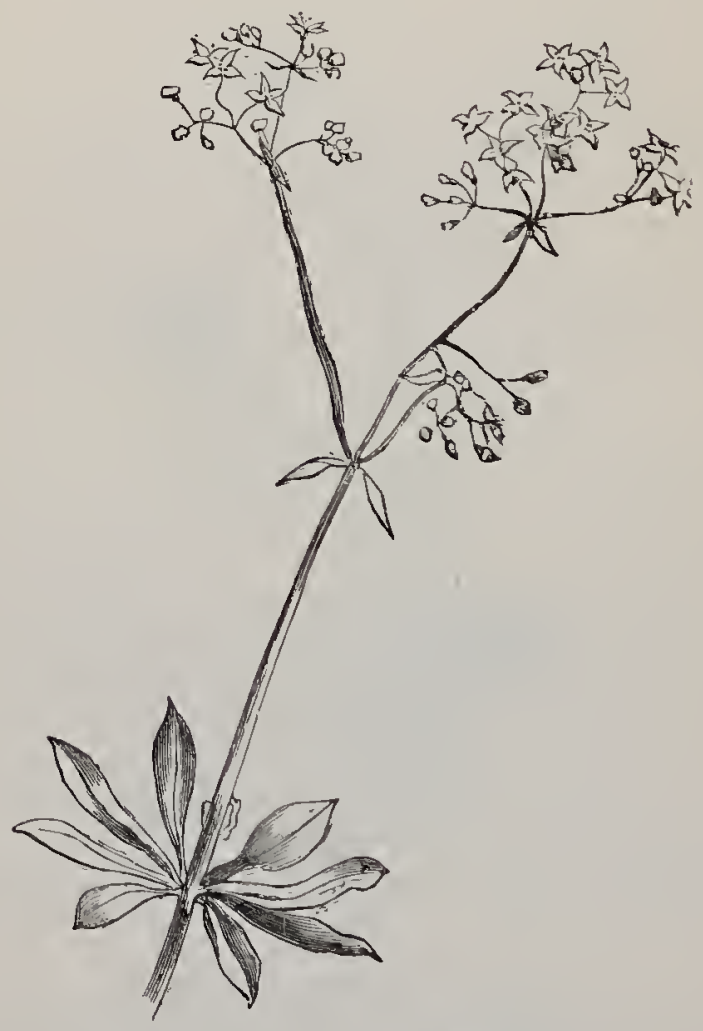

ASPÉRULA ODORRTA (Swect Hoodmiff).

occurs only in fields near Saffron Walden, Essex.Fl. July. Annual.

13. G. tricómé (Rough-fruited Cor'n Bedstraw).Resembling G. Apariné, but smaller and chiefly dis- 
tinguished by its large fruit, which has a granulated, not bristly, surface, and is borne on a recurved pedicel.-Dry chalky fields; not uncommon.-Fl. June-October. Annual.

3. Aspénula (Woodruff).-Herbs differing from Gálium mainly in the longer tube which makes the small, corolla bell-shaped or funnel-shaped. It may be white, pink, or blue. (Name, a dimintuive from

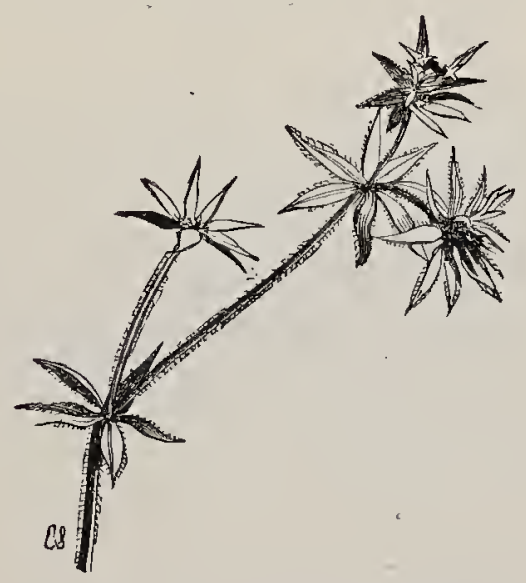

SHERÁRDIA ARVÉNSIS (Fïell Madder).

the Latin asper, rough, from the roughness of the leaves of some species.)

1. A. odoráta (Sweet Woodruff).--Almost glabrous, about 6 in. high, erect; leaves $6-9$ in a whorl, lanceolate, with forward-pointing prickles on their margins; flowers white, in stalked, terminal panieles; fruit rough with hooked hairs.-Woods; common. A deservedly favourite plant for its agreeable scent, when dried, of new-mown hay.-Fl. May, June. Perennial. 
2. A. cynánchica (Quinsy-wort).-Smooth, prostrate; leaves 4 in a whorl, linear, unequal; flowers in loose clusters, white or pink.--Dry banks and pastures, especially on a chalky or limestone soil ; local. It derives its name from having been formerly used as a remedy for quinsy or squinancy.-Fl. June, July. Perennial.

* Two other species, A. taurina, with 4 elliptic 3 veined leaves in a whorl, and A. arrénsis, with $6-10$ narrow leaves in a whorl and blue flovers, occur occasionally, but are not native.

4. Sherárdia (Field Madder).-A prostrate herb with whorled leaves, terminal sessile umbels of lilac flowers, 4-6 sepals, 4-lobed corolla, and diy fruit. (Named in honour of William Sherard, founder of the chair of Botany at Oxford.)

1. S.arvénsis (Field Madder). - A small, branched, spreading plant; leaves narrow, pointed, $4-6$ in a whorl; and flowers minute, lilac, resembling Aspérula arvénsis, but differing in its pointed leaves and distinct sepals.-Cultivated land; abundant.-Fl. April, October. Annual.

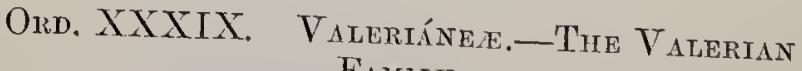 Family.}

A small Order of plants which aro mostly herbaceous, with opposite, exstipulate leaves, and small, usually asymmetric flowers in dichasial, of ten crowded cymes. The calyx is superior, becoming finally a border, or pappus, to the fruit ; the corolla, of $3-6$ united petals, is tubular and sornetimes pouched or spurred at the base; stamens 1 or 3 , rarely 5 , epipetalous; ovary with $1-3$ chambers, forming a diy indehiscent fruit, which is 1 -seeded, two of tho 
chambers being empty. The Order chiefly inhabits temperate countries, and the plants forming it are often strong-scented or aromatic. Many of them possess properties worthy of notice, but by far the most remarkable is Nardostáchys Jutamánsi, the Spikenard of Scripture, and the Nurdus of the ancient Classical authors. It grows in Bhotan, in India, where it is called Jatamansi. Even when green the young shoots are pleasantly fragrant; but its odorous quality is much strengthened by drying the plant. The radical leaves surrounding one of the young tufted shoots are torn up, along with a part of the very fragrant root, and having been dried in the sun, or by artificial heat, are sold as a drug. In ancient times this drug was conveyed by way of Arabia to Western Asia, and thus reached the Hebrews. Judas valued the box of ointment with which Mary anointed our Blessed Lord's feet at two hundred denarii ( $£ 6$ 9s. 2d.). By the Romans it was considered so precious that the poet Horace promises Virgil a cadus, or about three dozen modern bottles, of wine for a small onyx-box full of spikenard. It was a Roman custom in festive banquets, not only to crown the guests with flowers, but also to anoint them with spikenard. Other members of the Order still valued for a similar use are Valeriána céltica and $V$. saliúnca, which are believed to be the Saliúnca of Virgil and other ancient writers. They are natives of the mountains of Styria and Carinthia, where their roots are grubbed up with danger and difficulty by the peasants from rocks on the borders of eternal snow. They are then tied in bundles, and sold at a very low price to merchants, who send them by way of Trieste to Turkey and Egypt, where they are retailed a's a great profit, or passed on to India and the interior of Africa. They are used to scent baths. The roots of our common Valerian (Valeriána officinális) are used in medicine, being a porrerful stimulant to the 
nervous system in cases of hysteria or epilepsy. They have a very remarkable effect on cats, producing a kind of intoxication. The seeds of the Red SpurValerian (Centránthus rúber) were used in former times in the process of embalming the dead; and some thus employed in the twelfth century, on being removed from the cere-cloth in the present century, and planted, are said to have germinated. The young leaves of Lamb's Lettuce (Valerianélla) ar $\Theta$ eaten as salad, as also in Sicily are those of Centránthus.

1. Valmerána.-Corolla 5-lobed, pouched at the base; stamens 3; fruit 1-chambered, crowned with a feathery pappus.

2*. Centránthus.-Corolla 5-lobed, spurred at the base; stamen 1; fruit 1-chanbered, crowned with a feathery pappus.

3. Valerianélda.-Corolla 5-lobed, obconic; stamens 3 ; fruit 3-chambered, crowned with $3-5$ small sepals.

1. VALERÍ́Na (Valerian).-Flowers in corymbose, capitate, or panicled cymes, with bracteoles, sometimes sub-diocious; pappus deciduous; corolla generally monosymmetric with an obconic tube, pouched at its base. (Name said to be from the Latin váleo, I am well, from its medicinal virtue.)

1. V. dióica (Small Marsh Valerian).-Erect, unbranched, about a foot high with runners; radical leaves stalked, ovate; cauline leaves pinnatifid, with a large terminal lobe; flowers pinkish, in a terminal corymbose cyme; stamens and ovaries on different plants, the latter in smaller, more crowded, deeper coloured flowers.-Marshy ground; frequent.-FI. May, June. Perennial.

2. V. Mitánii (Great Wild Valerian).-Much taller and stouter than the last, but resembling it in 
habit and in the colour and smell of the flowers; with suckers; leaves all pinnate, of $13-21$ leaflets,

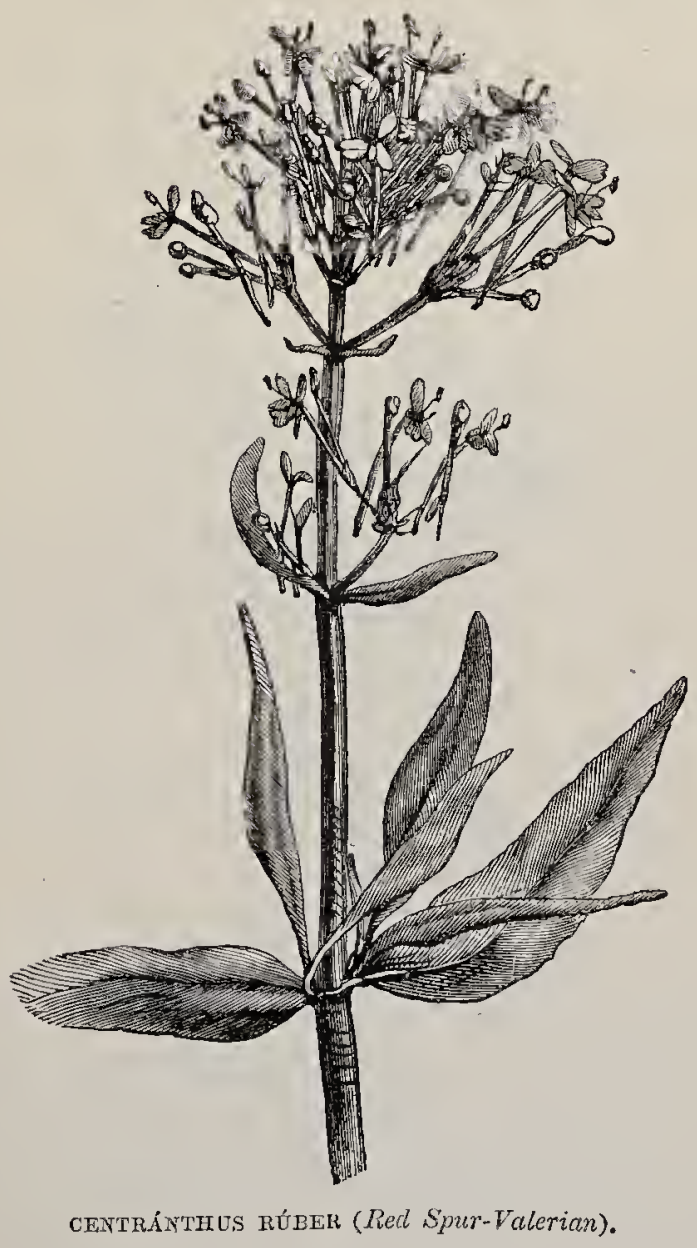

which are lanceolate, dentate--Damp places; not common. This is the species used in medicine, and 
the roots of which are so attractive to cats, and, it is said, also to rats._Fl. June, July. Perennial.

3. V. sambucifólia (Elder-leaved Valerian).Differs mainly in having runners and fewer (9-13), bronder leaflets.

4.* V. pyrenáica (Heart-leaved Valerian).-A large coarse plant, with very large, stalked, cordate, serrate leaves, sometimes occurring naturalised in plantations.-Fl. June, July. Perennial.

*2. Centránthus (Spur-Valerian). - Glabrous, leafy plants; flower's in terminal, panicled cymes, bracteolate; pappus deciduous; corolla with 5 unequal lobes, a long compressed tube, and a spur. (Name from the Greek lentron a spur, anthos a flower.)

1.* O. míber (Red Spur-Valerian).-Glaucous, $1-2$ feet high; leares entire, ovate, acute; flowers crimson, deep rose-red, or white-CChalk-pits, railway-banks, limestone-quarries, and old garden-walls ; common, but not indigenous. A very handsome garden plant. Fl. June-September. Perennial.

2.* C. Catcitrapa, differing chiefly in having pinnatifid cautine lectes, occurs as a garden escape at Eitham, Kent.

3. Valertanélda (Corn-salad). - Small plants, repeatedly forked; Teares simple; flowers minute, solitary or in crowded bracteate cymes in the forls of the branches; $c a^{7} y, x$ generally distinguishable as teeth on the fruit; corolla 5-lobed, obconic, polysymmetric; fruit generally of 2 empty barren and 1 fertile ( 1 -seeded) chambers. (Name, a diminutive of Vuleriána.)

1. $T$. olitórie (Common Corn-salad, Lamb's Lettuce). - Smooth, flaccid, brittle, 4-12 in. 
high; leaves long and narrow, a little toothed near the base, the upper ones clasping the stem; flowers very minute, pale lilac, in dense terminal leafy heads ; the fertile chamber of the ovary thick and corky at the back, crowned by the 3 calyx-teeth.-Cornfields;

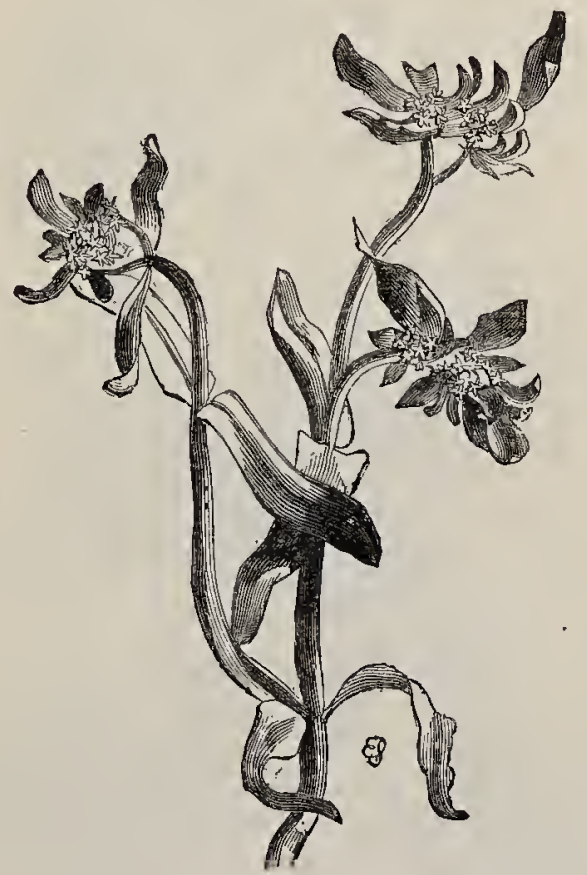

VaLerianéla OLIT́́ria (Common Corn-saled, Lamb's Lettuce).

common. It is sometimes cultivated as a salad.Fl. May, June. Annual.

2.* $V$. eriocárpa (Woolly-fruited Corn-salad), differing in having a hairy fruit, crowned by a large nearly regular, campanulate calyx, and with its fertile chamber not corky, occurs occasionally, but is not native.-Fl. June. Annual.

3.* $\quad V$. carináta (Keeled-fruited Corn-salad), 
differing in its blue flowers and oblong, boat-shaped fruit, crowned by 1 sepal, with its fertile chamber not corky and the two barren ones inflated, occurs rarely on banks, but is not native.-Fl. A pril--June. Annual.

4. V. vimósa (Sharp-fruited Corn-salad).--About a foot ligh, more slender than $V$. olitória; flowers solitary in the forks of a loose cyme, pale blue; fruit sub-globose, crowned by 1 erect tooth, with its barren chambers inflated and larger than the fertile one, which is not corky.-Cornfields ; rare.-Fl. June-August. Annual.

5. V. dentáta (Toothed Corn-salad).--Similar to the last; leaves much toothed towards the base; flowers flesh-coloured; fruit not inflated, crowned with the same unequally 4-toothed calyx.-Cornfields and banks; common.-Fl. June-August. Annual.

\section{Ord. XL. Dipsáce - -The Teazle Family.}

A small Order of herbaceous plants inhabiting temperate regions, and possessing no remarkable properties. The leares are generally opposite and exstipulate, and the flowers, like those of the Composite, are crowded together in heads with an involucre of bracts; but each flower is also surrounded by a calyxlike involucel of several more or less rigid bracteoles. The calyx is superior, expanding into a cup-shaped tube generally with a pappus; corolla tubular, with $4-5$ unequal lobes; stamens 4, epipetalous, not united; fruit dry, indehiscent, 1-seeded. The most striking distinction between the members of this and those of the following Order is the 4 free stamens in each flower, or floret, as it is often called. Dipsacus Fullónum is the Fuller's Teazle, a plant with large cylindric heads of flowers, which are embedded in stiff, hooked bracts. These heads are set in frames 
and used in dressing broad-cloth, the hooks catching up and removing all loose particles of wool, but giving way when held fast by the substance of the cloth.

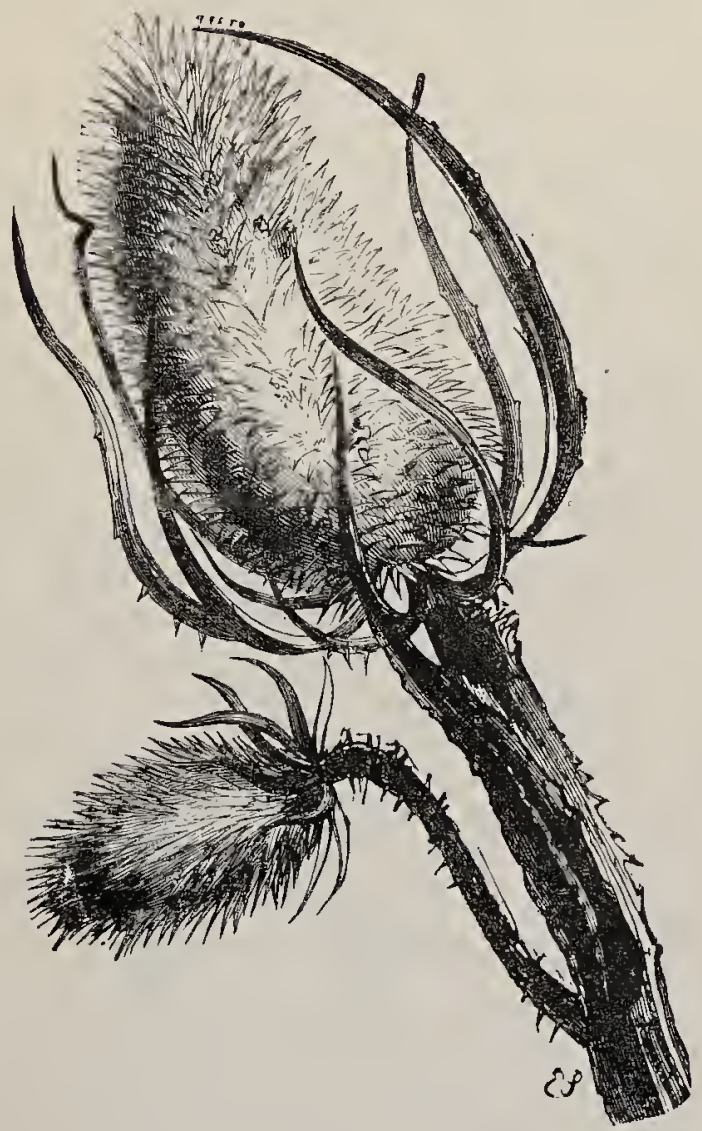

Dípsacus syutétris (Wild Teazle).

This is almost the only process in the manufacture of cloth which it has been found impossible to execute by machinery; for although various substitutes have 
been proposed, none has proved on trial exactly to answer the purpose.

1 Dípsacts. - Inner bracts spinous and prominent, forming rigid awns all over the head.

2. Scabiósa.-Inner bracts inconspicuous scales or hairs.

1. Dírsacus (Teazle). - Erect prickly plants; stems angular; lecuves usually connate at the base; heads usually elongated; with a columnar common receptacle; stiff spreading involucral bracts; prominent, spinous inner bracts; involucel 4-angled; calyx-tuthe cup-shaped; petals 4, unequal. (Name from the Greek cipsao, I thirst, in allusion to the water which usually collects in the hollows formed by the pairs of united leaves. This serves as a moat to prevent insects crawling up the stem to steal the honey in the flowers, which is destined for flying insect visitors who will carry pollen from flower to flower.)

1. D. syluéstris (Wild Teazle).-A stout plant, 3 - 6 feet high, with an erect prickly stem; large, bright green leaves, which are prickly undcrneath and united at the base; heads large, conical, covered with straight bristles; involucre curved upwards; flowers lilac, expanding in one or two bands half-way up the head and then both downwards and upwards. -Waste places; common.-Fl. July-September. Biennial.

2.* D. Fullónum (Fuller's Teazle) differs from D. sylvéstris mainly in having a more cylindrical head, a reflexed involucre, and hooked bristles on the receptacle. It is not known out of cultivation, except as an occasional escape, and is probably only a form of D. syluéstris.

3. D. pitósus (Small Teazle, Shepherd's Rod).Smaller than $D$. sylvéstris in all its parts, rough with bristles; leaves stalked, with a small leaflet at the 
base on each side; heads small, nearly globose, drooping in bud ; involucre reflexed; flowers white.-Moist

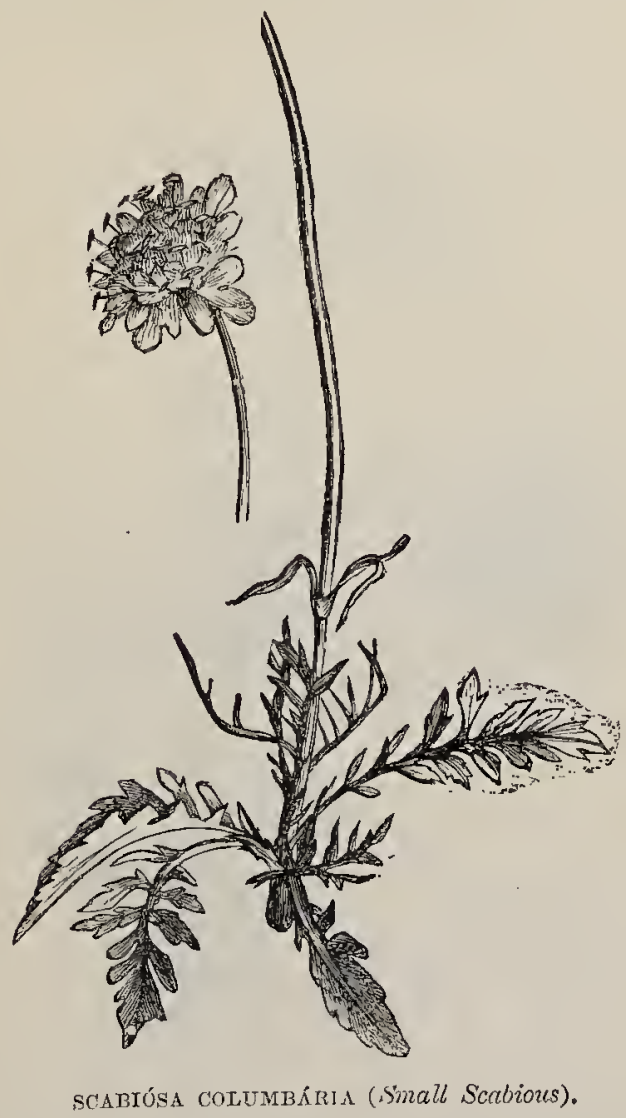

shady places; not common.-Fl. August, September. Biennial.

2. Scabiósa (Scabious).-Leaves entire or pinnatifid; heads hemispherical or flat; involucre of 1 or 2 
whorls of bracts; common receptacle hairy or scaly; involucel 4-8-angled, 4-5-lobed; outer florets often larger and unsymmetrical; caly, $x$-tube contracted at the top ; $\lim b$ cup-shaped, with $4-10$ stiff bristles;

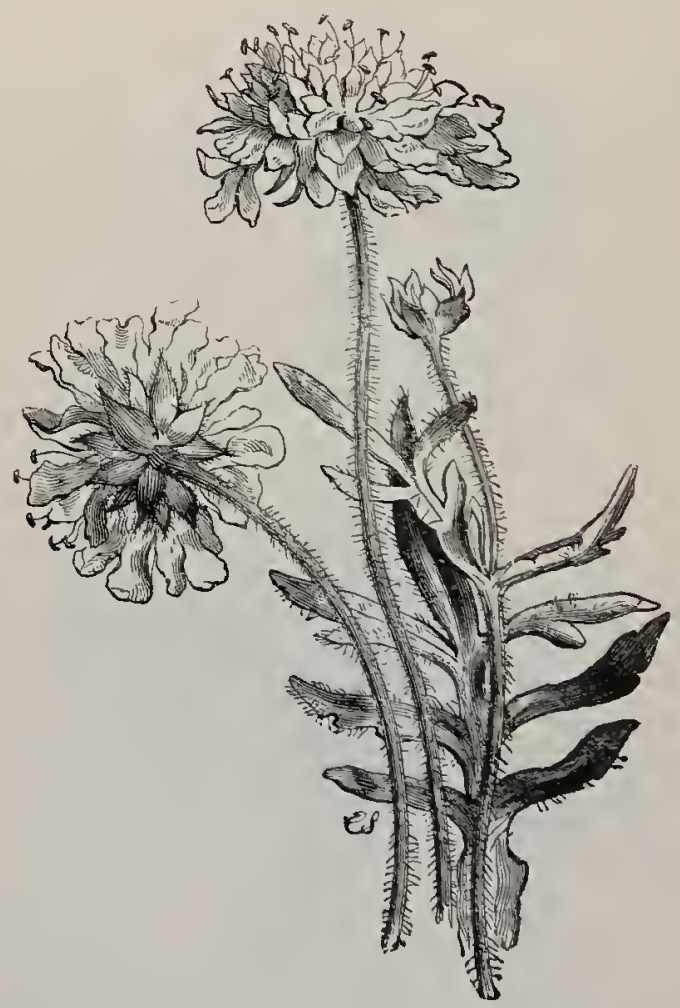

SCABIÓSA ARVérsis (Field Scabiours).

corolla 4-5-lobed, sometimes bilabiate; fruit nearly cylindrical. (Name from the Latin scabies, the leprosy, for which disease some of the species were supposed to be a remedy.)

1. S. Succísa (Premorse or Devil's-bit Scabious).- 
A slender, little-branched plant, with a short and abrupt rtizome, as if bitten off (premorse); a hairy stem ; few, mostly entire, oblong leaves; nearly globose heads of purplish-blue or white flowers, with a nearly symmetric, 4-cleft corolla. - Heaths and pastures; abundant. John Parkinson, in his "Theatrum Botanicum" (1640), alludes to the fable "that the Devile, envying the good that this herbe might do to mankinde, bit away parte of the roote, and thereof came the name Succisa, Devil's-bit."-Fl. JulyOctober. Perennial.

2. S. Columbária (Small Scabious).-Well distinguished from the last by its pinnatifid, lighter green leaves; heacls flatter at first; and flowers lilac, rather than purple, with a 5-cleft corolli, the outer ones being larger and very unsymmetrical.-Pastures on a calcareous soil; not uncommon.-Fl. JulySeptember. Perennial.

3. S. arvénsis (Field Scabious).-A tall bristly plant, 2-3 feet high, not much branched; rectical leaves simple; cauline ones pinnatifid; heads large, convex; flowers handsome, lilac, with 4-lobed corolles, the inner ones nearly symmetrical, the outer larger and bilabiate.-Cornfields and waysides; common.Fl. July-September. Perennial.

4. S. maritima, a species with all its leaves pinnatifid, an erect branching panicle of heads, and a 5-cleft corolla, has been found at St. Ouen's Bay, Jersey.

\section{Ord. XLT. Compósite.-The Composite Family.}

This is by far the largest of all the Natural Orders, containing as it does nearly 10,000 species, in 800 genera, or about one-tenth of all known Flowering Plants. These figures serve to illustrate the progress made by Botany during the last hundred years, since 
the total number of species known to Linnæus was only. 8,500. The Compósitce form a very natural Order, all agreeing in a large number of characters, especially in the capitate inflorescence, or crowding together of the florets, or little flowers, into a head, or "compound flower," as Linnæus called it, to which the Order owes its name, and in the union of the anthers referred to in the name of the co-extensive class Syngenésia in the Linnæan system. Though they manifest their success in the struggle for existence not only by their great number of genera and species, but also by a striking profusion of individuals, as is familiar to us all in the cases of Thistles, Daisies, Dandelions, \&c., and by a world-wide geographical distribution, they seldom reach the dimensions of shrubs, few of them being even woody. They must be considered, however, as on the whole the most highly organised members of the Vegetable Kingdom. Their leaves are exstipulate, generally simple, and mostly scattered. The heads are generally manyflowered, and are surrounded by one or more whorls of scales or bracts forming an involucre, which is often imbricated, the scales overlapping like the tiles of a house (Latin imbrex, a tile). The common receptacle, on which the florets are situated, varies in shape, being flat, concave, or convex, and in surface, being sometimes smooth and naked, and in other cases pitted or furnished with scales or bristles, known as pales. The florets, which are true flowers, though generally small, may be all alike in form or colour or both, as in Thistles, Dandelions, Groundsel, dc., or the outer or ray-florets may differ from the inner or lisk-florets in form, as in the Corn-Marigold, or in colour also, as in the Daisy. The calyx is superior, and there are 5 sepals, though they are seldom distinguishable, the $\lim \mathrm{b}$, if present, being generally represented by a pappus of hairs, which may be sessile on the fruit, as in the Thistle, or stalked, 
as in the Dandelion, when the fruit is termed beaked, the hairs themselves being feathery or plumose, as in the former, or simple or pilose, as in the latter. The corolla consists of 5 valvate petals, either tubular and polysymmetric, as in all the florets of Thistles and Groundsel and the disk-florets of the Daisy, or tubular below and ligulate or strap-shaped above, as in all the florets of the Dandelion and the ray-florets of the Daisy. The florets may be all perfect, as in Thistles and Dandelions; or the ray-florets may have no stamens, as in the Daisy, or be neuter, having neither stamens nor ovary, as in the Cornflower; whilst the disk-florets may be perfect, as in the Daisy, or exclusively síaminate, as in the Garden Marigold. Occasionally all the florets may be staminate or all carpellate, and then the two kinds of flowers may occur on the same plant (monocious), or on different ones (dioecious). The 5 epipetalous stamens usually have their filaments free but their anthers united (syngenesious), and there is of ten a tail-like appendage at the base of each anther-chamber. There are 2 carpels united to form a 1-chambered, inferior ovary, with 1 style, generally bifurcating above, the stigmas lining the inner surface of the fork. The tube of syngenesious anthers in the perfect florets is generally formed before the elongation of the style, which then grows up through it, sweeping the pollen out of the anthers by means of tufts of expelling hairs at the summit of its two branches, which do not diverge till afterwards. The fruit is a cypsele, or dry, indehiscent, 1-chambered, 1-seeded structure, often crowned by the pappus.

For convenience of reference, the Order is divided into three Sub-orders, comprising thirteen Tribes; but one of the Sub-orders and five of the Tribes contain no British plants, or any others of great interest. The two Sub-orders represented in Britain are the Tubuliflores and the Liguliflórce. In the 
Tubulifióne the florets are either all tubular and perfect, or the disk-florets are tubular and the rayflorets ligulate, the former being generally perfect and the latter carpellate or neuter. The members of this Sub-order have a watery juice. The Sub-order' Liguliflórce have all their florets ligulate and perfect, and have a milky juice. They are most abundant in the temperate regions of the Northern Hemisphere; the Tubuliflórce in the Tropics.

The Tubulifióre contain a variety of principles, so variously blended as to produce very diverse results. Bitterness, in a greater or less degree, is characteristic of many, and is often accompanied by the presence of resin, or volatile oil, so that the plants produce tonic, stimulant, or astringent effects. The Wormwoods (Artemisia), of which the Southernwood of gardens (A. Abrotanum), a fragrant shrub, used on the Continent in making beer, is one species, and the Tarragon (A. Dracúnculus), used to flavour vinegar, is another, are extremely bitter. The genera Anthemis and Matricaria, the Chamomiles and Feverfews, contain an acrid volatile oil that gives them their properties as febrifuges. The Coltsfoot (Tussilago) and Elecampane (Inulu ITelémium) contain gum so united with their bitter and astringent properties as to render them valuable sedatives. The oily seeds of the Sunflower (IIeliánthus ánnuss) are largely eaten in Russia, and the Jerusalem Artichoke, the tubers of which hold a high rank among our esculent vegetables, is another species (H. tuberósus) of the same gerus. The latter grows freely in any soil, and produces abundance of tubers, though it rarely flowers in England. It is called an Artichoke from the similarity of flavour in its tubers to the Globe Artichoke (Cýnara Scólymus), a 'Thistle in which the bases of the involucral bracts form the edible portion. The name "Jerusalem" is said to be a corruption of the Italian girasole, the Sunflower, and by an amusing transition, soup made 
from these Artichokes is called "Palestine Soup." The flower-heads of Suftower (C'árthamus tinctóric), which give a red colour, are the most valuable dye produced by the Order.

Among the Liguliflince, the Common Dandelion (Taráxacum officinálé) supplies a valuable medicinal extract; its blanched leaves are a wholesome salad; and its roots are used to adulterate coffee. The Lettuce (Lactúca satíu), besides its extensive use as salad, yields from the milky juice of its root $2 n$ extract with narcotic properties resembling those

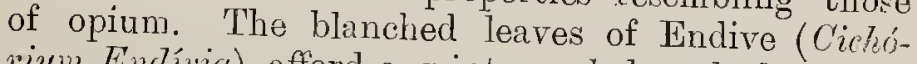
rium Enclivia) afford a winter salad, and the allied Chicory or Succory (C. Intybus) is also so used, though it is more cultivated for the sake of its roots, which are roasted and mixed with coffee. Salsafy (Tragópogon porrpifólius) and Ścorzonera (Scorzonérce hispanica) are also cultivated for the sake of their edible roots.

Sub-Orcler 1. Tubuliflórce-Florets all tubular, or only the ray-florets ligulate; juice watery.

Tribe 1. Eupatóriece.-Leaves nostly opprosite; florets all tubular and perfect; anthers not tailed.

1. Eupatóriun.-Heculs few-flowered; bracts imbricate, oblong; receptacte naked; styles much longer than the florets.

Tribe 2. Asteroíder.-Lecurss scattered; ray-florets ligulate, carpellute or neuter, or absent; aish-floret tubulcar, perfect.

2. SoLIdáco.-F'lorets all yellow; receptacle naked, pitted; pappus of one row of stiff hairs.

3. BÉLus.-Ray-forets white or pink; receptacle naked, conical; no pappus. 
4. Áster.-Ray-fioręs in one row, purple, or absont; receptacle naked, pitted; pappus of many lows of stiff hairs.

5. Erígeron.-Pay-florets in two or more rows; receptacle naked; pappus of many rows of stiff hairs.

Tribe 3. Inuloidea,-.-Leares scrittered: ray-florts Tigulate, yellow, or absent; aish-fio.ets tubular, perfect, usually yellow; anthers with 2 tristles at their luse; pappus-hairs generally stender, silky.

6. FiLígo.-Florets all tubular, the outer carpellate, the inner perfect; receptacle conical, with few scales at the margin; pappus of slender silk $\mathrm{r}$-hairs.

7. Antennárla.-Heads sub-diocious; florets all tubular; pappus hairy, that of the staminate florets with club-shaped hairs.

*8. AnápHalis.-Heads sub-dicecious; florets als tubular; pappus of one row of free, slender, slightly barbed bristles.

9. GNapháliun. - Florets as in Filago; receptacle flat, naked; pappus of slender silky hairs.

10. Ívura. - Ray-florets ligulate, yellow, carpellate; chish-florets tubular, perfect; receptacle naked; pappus of one row of hairs.

11. Puldcália.-Differing from Inula chiefly in having an outer row of short scales to the pappus.

Tribe 4. Helianthordea.-Leaves opposite; rayflorets ligulate, yellow, -earpellate or neuter, or absent; disk-florets tubular, perfect, yenerally yellow; receptacle scaly; anthers not trited; pappus of a few stiff scales or bristles.

*12. Xánthum.-Heads moncecious; staminate florets many; anthers free; carpellate floret. 2, enclosed by the spinous involucie. 
13. BíDens.--Ray-florets generally absent; if present, neuter ; pappus of $2-5$ barbed bristles.

*14. Galinsóga.--Ray-florets few, in one row; receptacle conical; pappus of 1 row of broad ciliate scales.

Tribe 5. Anthemidece.-Leaves scattered; ray-florets ligulate or tubular; anthers not taited; pappus absent or minute.

15. Achindía.-Ray-florets few, ligulate, whitr, broad; receptas ${ }^{y}$ scaly ; fruit compressed; no pappus.

16.-Dióris.-Florets all tubular, perfect, with 2 persist nt spurs at the base of the corolla; receptacle scaly; fruit compressed; no pappus.

17. Ánthemis.-Ray-florets in 1 row, ligulate, white, oblong, carpellate or neuter, or absent; recel.tacle convex, scaly; fruit not compressed; no pappus.

18. Chrysánthemum.-Ray-florets in 1 row, lighlate, white or yellow; receptacle flat or nearly so, naked ; no pappus.

19. Matricária.-Ray-florets in 1 row, ligulate, white; receptacle conical, naked; no pappus.

*20. Cótula.-Florets all tubular, the outer row carpellate; corolla 4 -lobed, with 2 spurs at the base; receptacle flat, naked; no pappus.

21. TanacÉTum.-Florets all tubular; receptacle naked, broad; fruit with a broad epigynous disk; no pappus.

22. A rtemísia. - Florets few, all tubular; receptacle naked, narrow ; fruit with a small epigynous disk ; no pappus.

Tribe 6. Sencionidecp.-Ieaves scattered; rayflorets ligulute, or absent; receptacle naked; anthers not tailed; parppus usually of yery soft hairs. 
23. Tussilágo.-Leares all radical; heads solitary, many-flowered; outer florets ligulate.

24. Petasí́tes.-Leaves all radical; heads numerous, in a raceme, many-flowered; outer florets tubulnr.

*25. Dononícum.-Involucral bracts in 2 or 3 rows, equal; ray-florets in 1 row, ligulate, without pappus; florets all yellow; pappus of the disk-florets of several rows of stiff hairs.

26. Sex́cio.-Iniolucral bracts in $1 \mathrm{row}$, equal; florets all yellow; ray sometimes absent; pappus of several rows of soft, slender hairs.

Tribe 7. Cynaroídech.-Leares scattered, usually spinous; bracts imbricute, spinous; florets all tubular and usually perfect; receptacle scaly; parpus generally present.

27. Cartína-Outer bracts spinous; imer chaffy and spreading; anthers tailed; paprus in 1 row, branched and feathery.

28. 'ÁRctium.-Involucre globose; outr" bracts hooked; anthers tailed; pappus in several rows of short simple hairs.

29. CírnuUs.-Leares decurrent; bracts spinous; anthers scarcely tailed; fruit compressed; rapmes in many rows of long, equal, rough hairs.

30. Cnícus. -Differing from. Cárduns mainly in its feathery papuns.

31. Onopórnon.-Differing from Cárdunes mainly in its honeycombed receptacle and 4-angled fruit.

*32. Mariána.-Resembling Cárduus, but with united filuments and silky pappus.

33. Saussúrea. - Bracts not spinous; anthors tailed; pamms in 2 rows, outer bristly, inner longer, feathery.

34. Serrátula.-Bracts not spinous; anthers not tailed; pappus in several rows of long unequal hairs, the inner longest. 
35. Centaúrea.-Outer florets usually large, unsymmetrical and neuter; pappus in several rows of short unequal hairs, the second row longest, or rarely absent. Sub-Order 2. Liguliflórce-Florets all ligulate;
juice mitky.

Tribe 8. Cichorácece.-Leaves scattered; florets Tigulate, 5-toothecl.

36. Crснórium.-Tinoluce of 2 rows, inner of 8 scales, reflexed after flowering; outer of 5 smaller loose scales; pappus a double row of small chaffy scales.

37. Arroséris.-Bracts about 12 in 1 row, converging after flowering; receptacle flat, naked, pitted; pappus reduced to a ring.

38. Lapsána.-Heads 8-12-flowered; bracts in 1 row, erect; receptacle flat, naked; pappus absent.

39. Pícris. - Bracts in 2 rows, the outer smaller and narrow, the inner equal; receptacte flat, naked; fruit beaked; pappus in 2 or more rows of feathery hairs.

40. Créprs.-Bracts in 2 rows, outer shorter"; receptacle flat, pitted; finit tapering or beaked; pappus of many rows of simple hairs.

41. Hier Ácrum.-Bracts many, imbricate, oblong; receptcicle nearly flat, pitted; fruit not beaked; puppus of one row of stiff, brittle, unequal, brownish hairs.

42. Ну росне́RIS. - Bracts many, imbricate, oblong; receptacle flat, scaly; fruit rough, often beaked; pappus feathery, often with an outer row of short bristles.

43. Lróntodon, - Bracts in 2-3 row:, the outer smaller ; receptacle flat, naked; fruii shortly beaked; pappus of 1 or 2 rows of hairs, the inner feathery.

44. Taríxacum,-Bracts in 2 rows, inner erect, 
outer often recurved; receptacle flat, naked, pitted: fruit rough, with a long slender beak; japmes of white, silky, simple hair's.

45. Lactúca.-Bracts imbricate, outer shorter ; receptacle flat, naked; fruit flattened, generally with a long slender beak; pappus of many simple hairs.

*46 Prenánthes.-Differing from Lactúca mainly

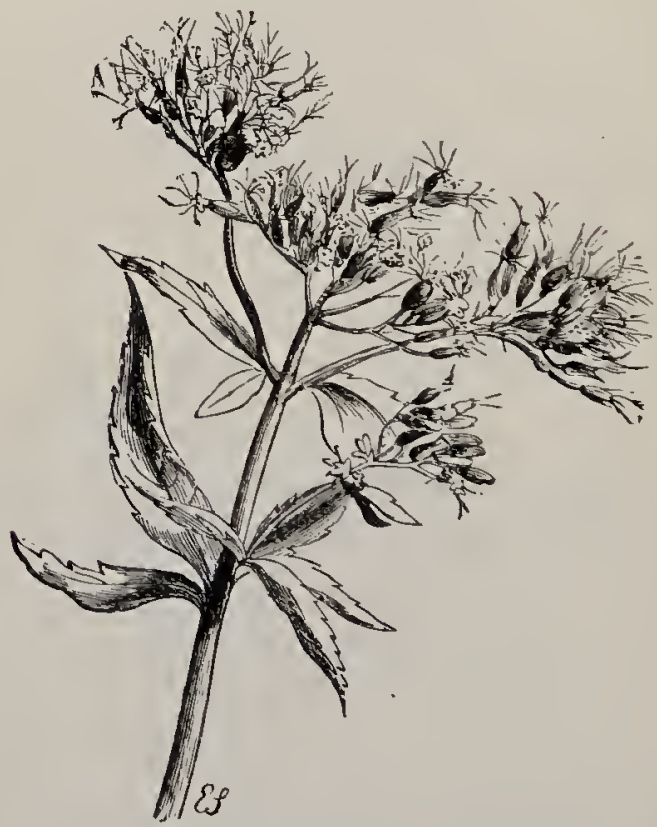

eupatókium canNabinem (Common Hemp Agrimony).

in having a less flattened, slightly ribbed, unbeaked fruit.

47. Sónchus.-Bracts imbricate in several rows; receptacle flat, naked, pitted; fruit much flattened, not beaked; pappus of many rows of white, simple, silky hairs.

48. Trragopóxon.-Biacts $8-10$, long, narrow, 
united below ; receptacle naked ; frut with longitudinal ridges, and a long slender beak; wappus of many rows of feathery hairs.

1. Eupatóriuli (Hemp Agrimony).-Herbs or undershrubs; leaves opposite; heads in corymbose

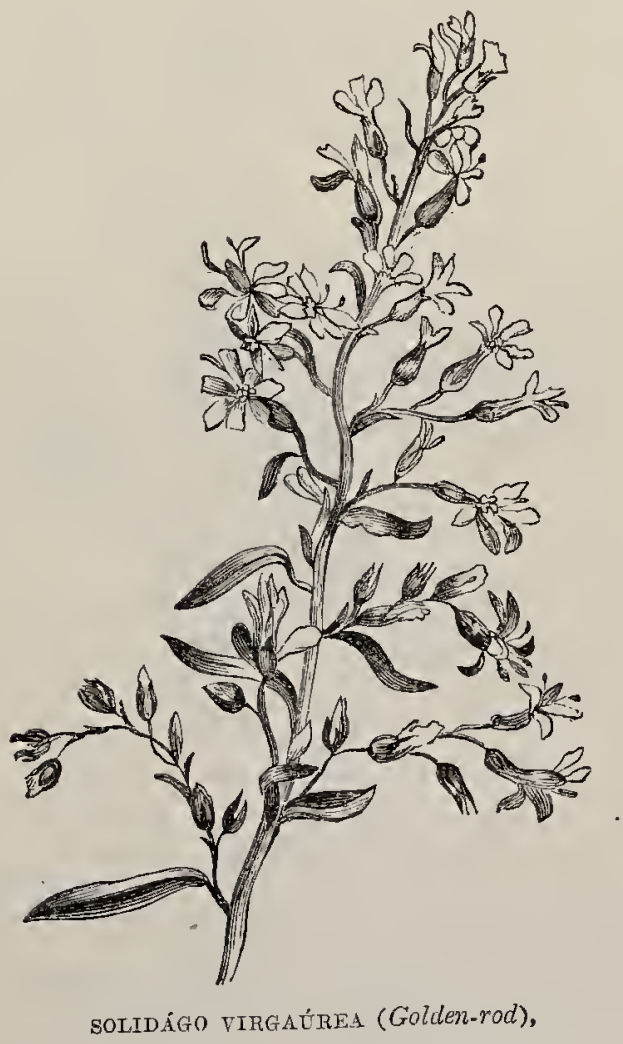

cymes, purplish, few-flowered ; involucral bracts imbricate, oblong; receplucte flat, naked; florets all tubular and perfect; styles much longer than the 
florets; pappus hairy. (Name from liithriclates Eúpator, who is said to have brought the plant into use.)

1. E. cannabinum (Common Hemp Agrimony).The only British species, a tall, downy plant, $3-6$ feet high, with a reddish stem; palmately 3-5-lobed

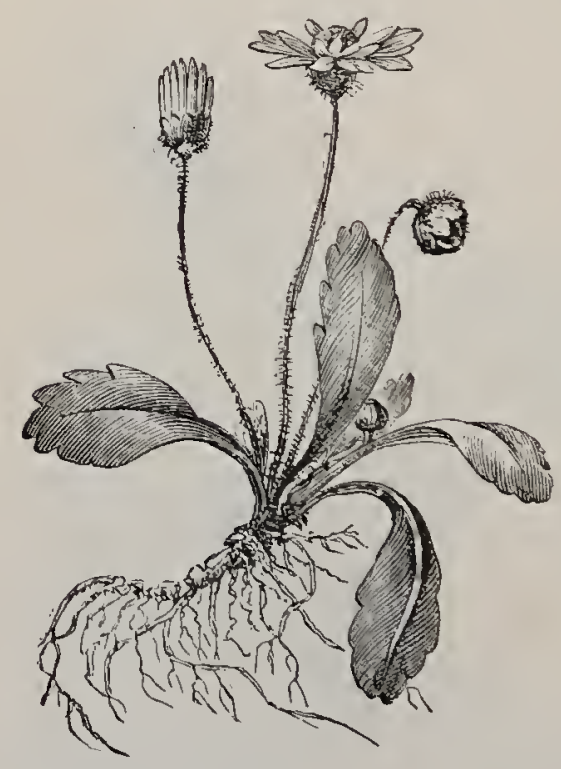

DELLLS PERLNNTS (COMmON Dairy).

lenves with lanceolate serrate leaflets: and terminal eorymbs of small crowded heacts of dull lilac flowers, remarkable for their very long, deeply cloven styles. -Moist places; common. Aromatic, and said to be tonic.-Fl. July-September. Perennial.

2. SoLtdígo (Golden-rod).-Herbs or undershrubs; leaves cauline, scattered, simple; heads in branched 
cymes, yellow, with ray-florets; bracts many, imbricate, adpressed; receptacle naked; pappus of one row of stiff hairs. (Name from the Latin solidare, to unite, from its supposed value in healing wounds.)

1. S. Virgaurea (Golden-rod).-The only British species, an erect, little-bianched plant, 2-3 feet high, with roughish, angular stems; simple, lanceolate, entire or serrate leaves; and conspicuous long terminal crowded clusters of small yellow heads.-Dry woods; common. On mountainous heaths a variety (var. cámbrica) occurs with short stems, broader leaves, and larger flower-heads._Fl. July-_September. Pei'ennial.

3. BúLuss (Daisy).--Small plants; leaves usually all radical; heads solitary; bracts in 1 or 2 rows, herbaceous, equal, blunt; receptacle naked, conical; ray-florets in 1 row, ligulate, white or pink; dist:florets yellow; fruit compressed; no pappus. (Name from the Latin bellus, pretty.)

1. B. perénnis (Common Daisy).- -The only British species; leaves obovate-spathulate, fleshy, in a radical rosette; scape 2-4 in. high; ray-florets generally white, tipped with crimson.-Pastures; very counmon. A universal favourite.-Fl. nearly all the year round. Pelennial.

4. Aster (Starwort).-Leaves scattered, simple; heads generally with 1 row of purple, blue, or white ray-florets; disk yellow ; bracts imbricate, herbaceous; receptacle naked, honeycombed; frut coinpressed, not beaked; pappus of many rows of stiff hain's. (Name flom the Greek aster, a star.)

1. A. Tripôlium (Sea Starwort). - A stout, succulent plant, $1-3$ feet high, with lanceolate, smooth, fleshy leaves, and corymbs of large handsome heads of flover's, 
the inner florets yellow, the outer purple. Salt marslies; abundant. Often rendered unsightly by being covered with mud; but in higher situations a

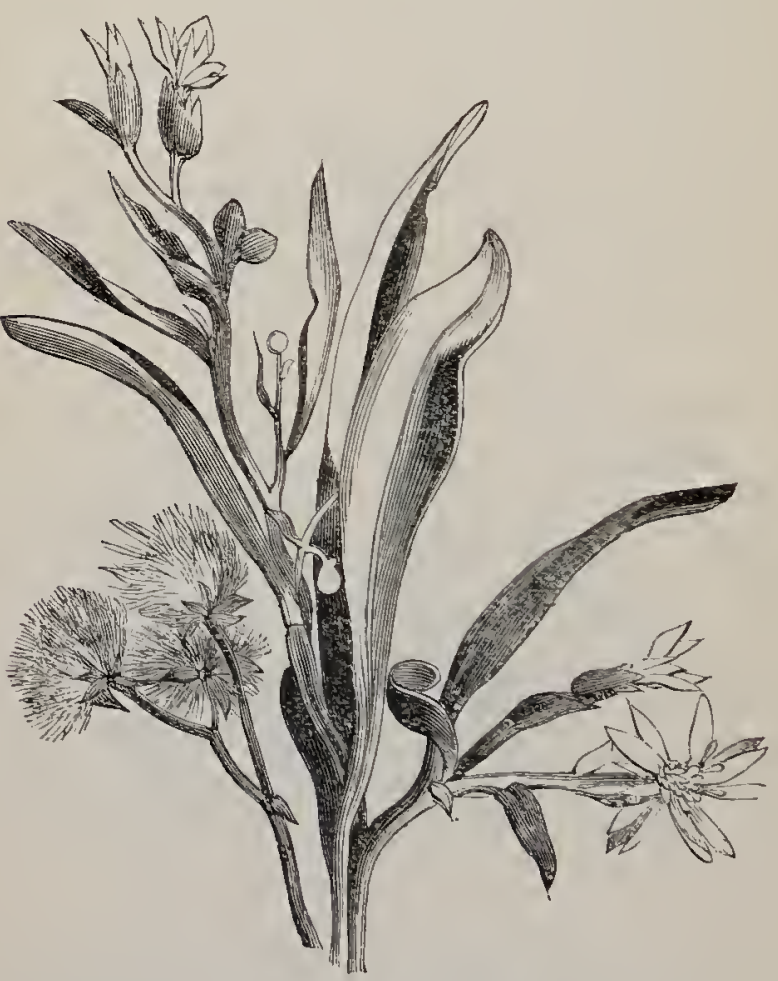

ÁSTER TRIPÚLILA (Sea Stanuort).

highly or'namental plant.--Fl. July - September. Perennial.

2. A. Linosýris (Flax-leaved Goldilocks). - A glabrous, erect, unbranched, herbaceous plant, 12-18 in. high, with leafy stem: linear entire Teares and a few heads of yellow flowers, with no ray, in a terminal 
corymb,-Limestone cliffs; very rare.-Fl. August, September. Perennial.

* Other species occur occasionally, such as $A$. salignus, naturalised at Wicken Fen, Cambridgeshirc ; but they are probably garden escapes.

5. Eríceron (Flea-bane).-Differing from Aster mainly in having 2 or more rows of ray-forets. (Name from the Greek erri, early, gerón, old, from the early appearance of the grey pappus.)

1.* E. canadénsé (Canadian Flea-bane).-An erect, corymbosely-branched herbaceous plant, $1-2$ feet high, with lanceolate ciliate leaves and numerous very small dingy yellow heads, with small purplish-white ray-florets, and a white pappus.-Waste places; a wced of local occurrence.-Fl. August, September. Annual.

2. E. ácré (Blue Flea-bane) -A much branched, hairy plant, 1-2 feet high ; leaves lanceolate, entire, obtuse ; branches al ternate, erect, bearing single heads which are corymbose and have a pale yellow disk, a dull pale blue-purple ray, and a very long, tawny papunes.-Dry places and walls; not common,-FI. July, August, Biennial.

3. E. alpínum (Alpine Elea-bane).-A hairy plant, 4-8 in, high, with leaves mostly radical, lanceolate; and generally solitarylargish heads with hairy involucre, and numerous, narrow, light purple ray-florets. Breadalbane and Clova mountains; very rare,-Fl. July, August. Perennial.

6. Filágo (Cudweed). - Slender woolly plants, with small scattered entire leaves; heads minute, in axillary and terminal clusters; bracts few, membranous, long, pointed, imbricate; receptacie conica 
with a few chaffy scales at its margin; florets few, all tubular, the outer ones without stamens; pappus of slender, silky hairs. (Name from the Latin filum, a thread, from the down covering the whole plant.)

1. F. cermánica (Common Filago or Cudweed).A singular little plant, $4-12 \mathrm{in}$. high, greyish; stem erect, cottony, terminating in a globular assemblage

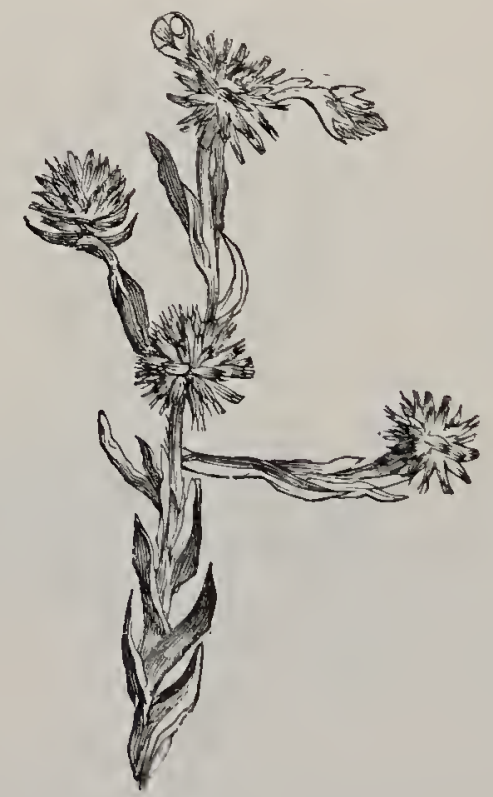

FILAGO GERMANTCA (Common Fulago).

o. heads, from the base of which two or more branehes spring, which are similarly proliferous; Teaves linear, acute, wavy; heads $20--40$ in each cluster, obscurely li-angled, reddish-brown ; bracts with smooth, yellowish tips. - Dry gravelly places; common. From its curious modo of branching, this species was called by the old botanists Herba impia (the undutiful plant), 
as if the young shoots were guilty of disicspect in overtopping the parent.-Fl. July, August. Annual.

2. F. apiculáta (Apiculate Cudweed).-A talier, more greenish species, with blunt apiculate leaves; heads larger than $F$.germánica, 10-20 in a cluster, prominently 5-angled, in clusters which often appear lateral from the development of only one proliferous branch, and are overtopped by 1 or 2 blunt leaves; bracts with smooth reddish tips.-- Sandy places; rare. The whole plant has a smell of Tansy.-Fl. July, August. Annual.

3. F. spathulata (Spathulate Cudweed).--Another closely allied species, whitish, shorter, branched lower down; Teaves spathulate; heads larger, 8-15 in a cluster, prominently 5-angled, in clusters overtopped by $2-3$ acute leaves; bracts with smooth yellow tips. -Dry fields; not common.--Fl. July, August. Annual.

4. F. mínima (Least Cudweed).-A smaller, erect, repeatedly forked, greyish plant, 4-6 high; leares linear-lanceolate, acute, adpressed, cottony; heads $3-6$ together in terminal and axillary clusters, brownish-yellow.-Dry gravelly places; common.--Fl. June - September. Annual.

5.* F.gállica (Narrow-leaved Cudweed).-A slender, repeatedly forked plant, with linear acute and afterwards revolute leaves longer than the yellowish flowerheads which are bor ne in axillary clusters of $2-6$ together.-Sandy fields in Essex, Hertfordshire, and Buckinghamshire; not indigenous.-Fl. July--September. Annual.

7. AntennáRIa (Everlasting).-Woolly plants with flower-heads diøecious or nearly so; florets all tubular; pappus of one row of hairs, those of the staminate florets club-shaped. (Name from the antennce of a, 
butterfly which the pappus-hairs of tho staminate florets resemble.)

1. A. dioíca (Cat's-foot, Mountain Everlasting, or Cudweed).-The only British species, a pretty little plant, 3-6 in. high, with numerous prostrate shoots; leaves spathulate, apiculate, green abore, coltony bulow ; heads 2-5, in a corymb, rendered conspicuous

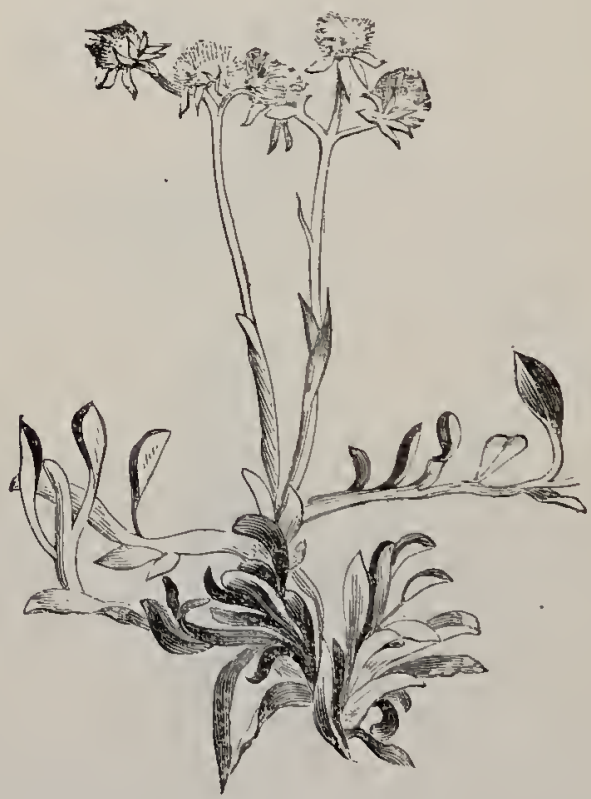

ANTEXNARIA DIOLCA (Montain Everlastmy).

by the white or rose-coloured involucre, which is of the texture commonly termed everlasting.-Mountain heaths and sandy places; frequent, especially in the north.-Fl. June-August. Perennial.

*. Anáphatis is represented by $A$, margaritácea, the White Everlasting of gindens, It is an erect, 
half shrubby, corymboscly-branched, leafy, cottony plant, 2-3 feet higl, witl runners ; linear-lanceolate acute leaves, $3-5$ in. long, smooth above; and small heads of yellowish flowers, with white involucres, in a compound corymb. It is naturalised in South Wales, the Channel Islands, and elsewhere.-Fl. July, August. Perennial.

9. Graphílium (Cudweed).-Woolly plints with small heads of tubular florets clustered in terminal or axillary fascicles; bracts adpressed, coloured; receptacle flat, naked; outer florets without stamens; anthers tailed; pappus of one row of slender, silky hairs. (Name from the Greek gnaphation, referring to the woolly down.)

1. G. uliginósum (Marsh Cudweed).--A small plant, 3-6 in. high, much branched, woolly, white; leaves narrow, downy, overtopping the terminal clusters of heads; bracts glossy, yellowish-brown.-Wet sandy places, especially where water has stood during winter; very common.--Fl. July-September. An. nual.

2. G. húteo-álbum (Jersey Cudweed).-A taller, less branched species with heads in dense, leafless corymbs, pale straw-coloured bracts, and red-tinged florets, is found chiefly in the Channel Islands.-Fl. July, August. Annual.

3. G. sylváticum (Wood Cudweed).--A white, cottony plant about a foot high, with an unoranched stem ; long, narrow, acute leaves; and a leafy, distant spike of yellowish heads. - Woods and gravelly heaths; common.-Fl. July-September. Perennial.

4. G. norvérficum (Highland Cudweed).-Differing in having broader leaves, a close spike of heads, and brown bracts.--Occurs only on the mountains of the Highlands.-Fl. August. Perennial.

5. G. supinum (Dwarf Cudweed). - A low tufted 
plant, with lecues mostly radical, and almost leafiess scapes bearing $1-5$ heads, also confined to Highland mountains,-Fl. July, August. Perennial.

10. ÍnULA (Elecampane).-Mostly stout, stifi,erect plants; leaves scattered, simple; heads yellow, with a ray; bracts herbaceous, imbricate in many rows; receptacle naked; anthers with two bristles at the base; pappus of one row of hairs. (Name probably a corruption of Helénzta, Little Helen.)

1. I. Helénium (Elecampane). - A stout plant, 3-5 feet high, slightly branclied; leaves oblong, wrinkled, downy beneath, toothed, the lower ones long-stalked, a foot or more in length, the upper ones sessile, amplexicaul; heads terminal, solitary, or nearly so, 3 ir. across, bright yellow; bracts broadly orate, downy.Meadows; not common and often only a naturalised escape. It was formerly cultivated as a tonic, and its rhizome is still candied and furnishes the Tin d'Aulnée of the French, being considered valuable in diseases of the lungs.-FI. July, August. Perennial.

2. I. Conỹza (Ploughman's Spikenard). -An erect, downy plant, 2-5 feet high ; leaucs dull green, ovatelanceolate, downy, toothed, $3-5 \mathrm{in}$. long, the lower ones stalked; heads in a branehed corymb, numerous, dingy yellow, with leaf-like bracts, the outer of which are blunt and revolute, and inconspicuous ray-florets. - Banks chiefly on a calcareous soil; not uncommon. -Fl. July-September. Biennial.

3. 1. salicína, a nearly glabrous species, 12-18 in. high, with narrov, toothed leares and terminal, solitary heads, $1 \frac{\mathrm{l}}{2} \mathrm{in}$. across, is found only on the shores of Louglı Derg, Galway.

4. I. crithmoúcles (Golden Sampliire).-Well distinguished from every other British plant, glabrous, yellow-green, 6 -18 in. high, slightly branched, with numerous very narrow, flesliy, blunt or $2-4$-pointed 
leaves, and solitary golden-yellow heads, 1 in. across. - Salt marshes and sea-cliffs in the west; rare.-Fl. July, August. Perennial.

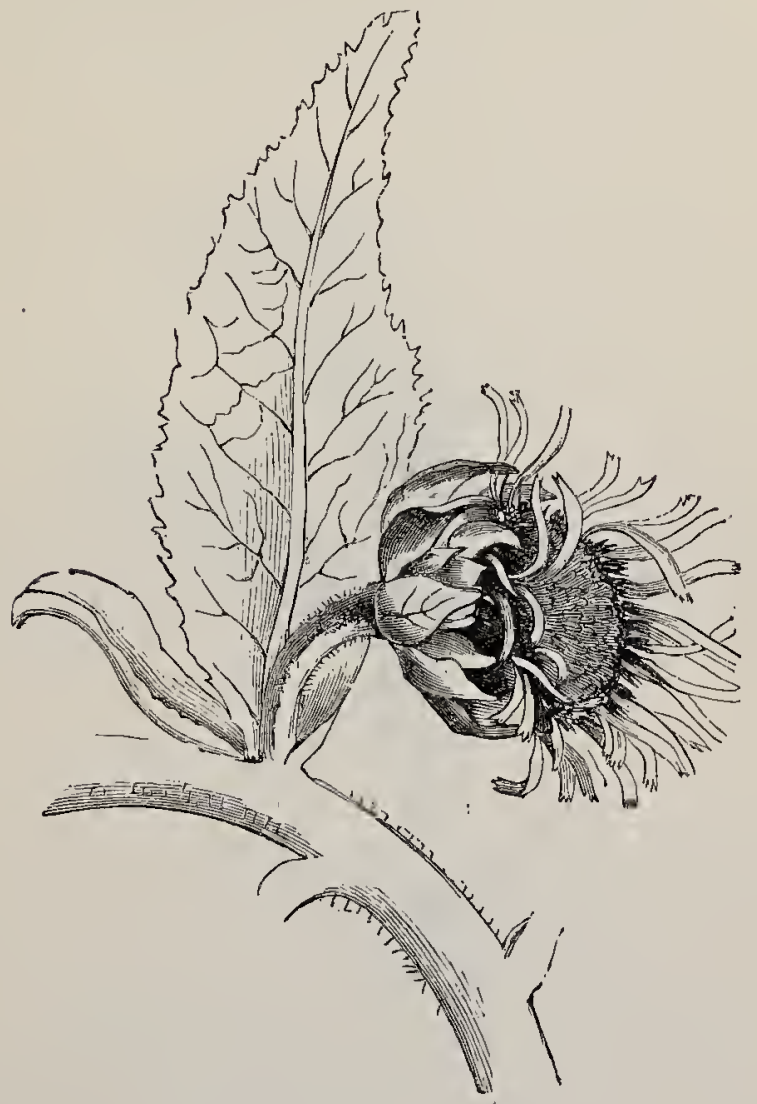

INULA HELÉNIUM (Elecampane).

11. Pulicária (Flea-bane).-Differing from Inula chiefly in having the bracts loosely imbricate in a few rows, and an outer low of short scales to the pappus. (Name from the Latin pulex', a flea, the strong smell 
of the plant, or its pollen, being supposed to drive away fleas.)

1. P. Aysentérica (Common Flea-bane).-From 1-2 feet high, growing in masses, and well marked by its woolly stem; soft, hoary, oblong, cordate, amplexicaul lecues; and few terminal, large, flat, golden-

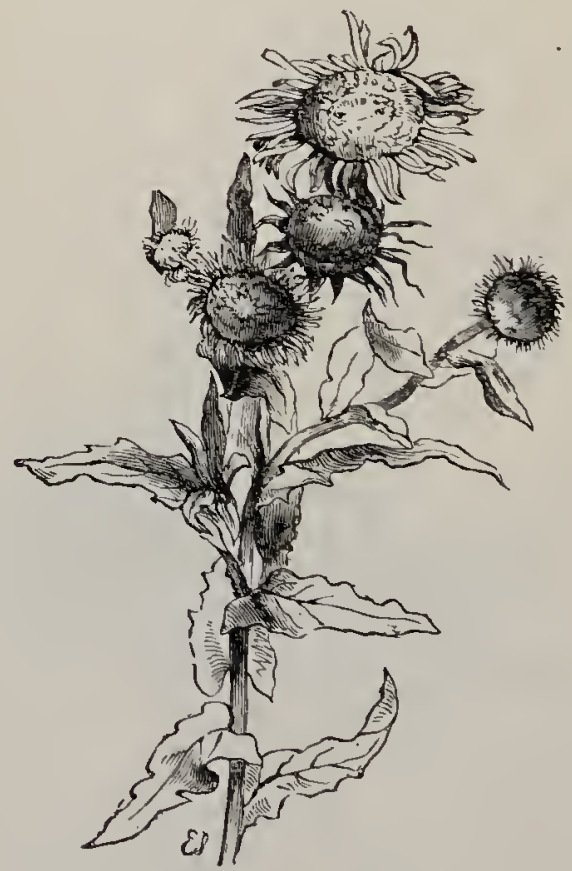

PULICARIA DYsETtérica (Common Flea-bane).

yellow heads, with bristle-like lincts and numerous narrow ray-florets longer than the disk.-Moist places; common.-Fl. July-September. Perennial.

2. P. vulgâris (Small Flea-bane).- - Resembling the last, but not more than half the size, nor by any means so hoary; stem hairy; leaves lanceolate, narrow 
at the base, sessile, hairy ; heads nearly solitary, $\frac{1}{2}$ in. across, with very short, erect ray-florets.-Sandy heaths, where water has stood, in the south, but not found in Scotland or Ireland; not common.-Fl, August, September. Annual.

*12. Xи́мтhium (Burweed).-A curiously annmalous genus with monoecious heads, the staminate ones having a few bracts in 1 row, a scaly receptacle, and numerous tubular florets with free anthers; whilst the carpellate ones consist of 2 florets, enclosed within a spinous involucre which hardens over their 2 fruits, and having no corolla, (Name from the Greek aanthos, yellow.)

1.* X. Strumárium (Common Burweed). - With cordate, 3-lobed, toothed leaves and two straight beaks to the fruit, and $2 * X$. spinósum (Spinous Burweed) with three spines at the base of each leaf, and a single straight beak to the fruit, are both casual eșcapes. -Fl. August, September. Annual.

13. Bínens (Bur-Marigold).-CGlabrous plants with leaves mostly opposite; heads nearly solitary, yellow; bracts in 2 or 3 rows, the outer spreading and often leafy; receptacle flat and scaly; ray-florets generally absent, or, if present, in 1 row; neuter ; fruit compressed, angular, the angles ending in a pappus of 2 -5 barbed bristles. (Name from the Latin bi, double, dens, a tooth, the teeth on the fruit being themselves toothed.)

1. B. cérnua (Nodding Bur-Marigold).-A somewhat succulent plant, $1-2$ feet high, with simple, lanceolate, serrate, glabrous leaves, and terminal, solitary, drooping, button-like heads of brownish-yellow florets, with several leafy bracts, but rarely any rayflorets. The şruit, which forms a pretty object for 
the polariscope, is oblong and terminates in 3 or 4 stiff bristles, each thickly set with minute recurved barbs, so as to take a tirm hold on the coat of any

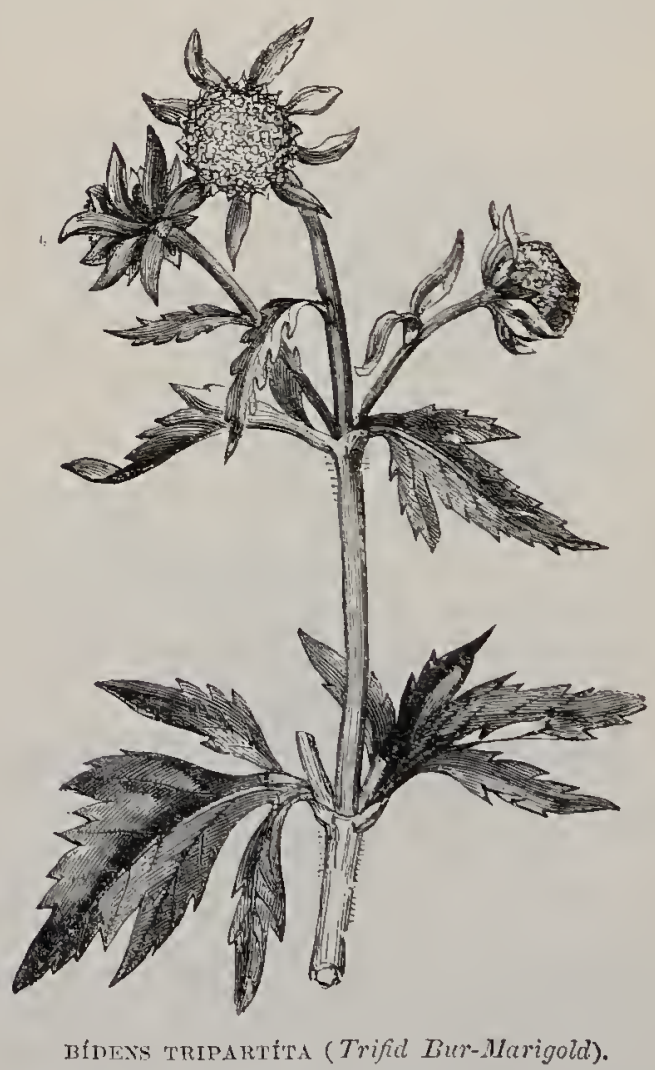

animal which comes in contact with them. - Watery places; frequent.-Fl. July-October. Annual.

2. B. tripartíta (Trifid Bur-MIarigold).-Distinguished flom the last by its stallied 3-partite leaves; smaller, nearly erect heads, which more often havo ray-florets; and 2 , or rarely 3 , bristles on the fruit. 
-Watery places; frequent.-Ti. July--September. Annual.

*14. GaLin Sócá, represented by $G$. parviflórct, an escape from Kew Gardens, now naturalised in many places, is a South American genus, with opposite, broad, serrate leaves and small heads, the $4-6$ short,

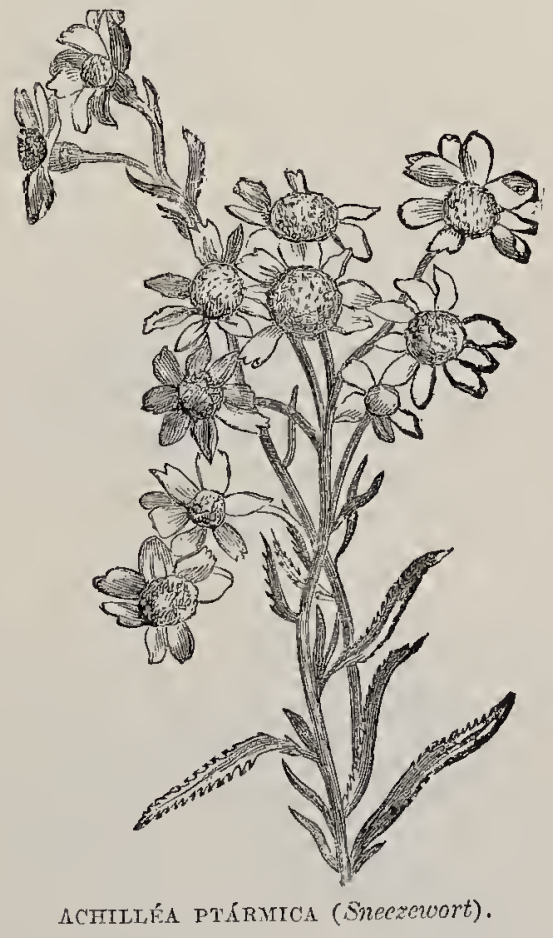

broad, white ray-florets of which, surrounding the yellow dish, might lead at first to the heads being mistaken for flowers of some other Order. (Named in honour of Don $M$. de Galinsoga, a Spanish botanist.) -Fl. July-October. Annual. 
15. Achilléa (Yarrow). - Stiff plants ; leaves scattered; heads in corymbs, with few, ligulate, broad, white ray-florets; flat, scaly receptacle; fruit compressed; no pappus. (Named after Achilles, with leference to supposed healing properties.)

1. A. Millefólium (Common Yarrow or Milfoil).Stems very tough, angular, 6-1 I in. high; lecues bipinnatifid, with a lanceolate general outline, woolly or slightly hairy; leaflets cut into hair-like segments; heads small, white, pink, or red, in dense terminal corymbs. Pastures and roadsides; very common. The plant has a strong, slightly aromatic odour, and is said to have the property of healing wounds. Its clusters of flowerheads might be supposed, by an unpractised eye, to belong to one of the Umbelliferr.-Fl. MaySeptember. Perennial.

2. A. Ptámica (Sneezewort).-Somewhat taller and mole slender than the last, from which it may be at once distinguished by its undivided, linear-lanceolate, serrate, glabrous lenes and larger hea $l s$ of flowers, of which both lisk and ray are white.-Moist ineadows, heaths, fc. ; common.-Fl. July, August. Perennial.

16. Diótrs (Cotton-weed).-An elect branched woolly plant; leaves scattered; heads sub-globose, yellow ; receptacle flat, scaly; florets all tubular and perfect; corolla with two ears or spurs at its base, which remain and crown the fruit; no pappus. (Name from the Greek $d i$, double, ous, otos, an ear, from the structure of the fruit.)

1. D. canticlissima (Seaside Cotton-weed).-The only species. 'The woody rhizome runs deeply into the sand; the many stout, ascending stems, about a foot high, are branched above, and thickly set with sessile, oblong, blunt leaves, which, as well as the rest of the plant, are covered with thick white cotton, 
and almost hide the small terminal heads of yellow florets.-Sandy sea-slıores; ral'e.-Fl. August, September. Perennial.

17. Anтнем1s (Chamomile). - Strongly-scented herbs; leaves scattered, bi-pinnatifid; heads solitary; receptrcle flat or convex, scaly; bracts with membranous margins, imbricate, in few rows; ray-florets in 1 row, ligulate, oblong, generally white, or rarely absent ; fruit not compressed ; pappus represented by a membranous ring. (Name florn the Greek anthas, a flower, from the value of its flower-heads as a medicine.)

1.* A. tinctória (Ox-eye Chamomile).-A muchbranched, cottony plant, $1-2$ feet high, with muchdivided leaves and large heads, with a hemispherical receptacle and both ray and disk bright yollow, resembling Chrysánthemum ségetum.-Fields; not indigenous.-Fl. July, August. Biennial.

2. A. Cótula (Stinking Chamomile).-Distinguished by its strong disagreeable odour; upright, branched stem; leaves repeatedly cut into hair-like segments, glandular-dotted, smooth; hends longstalked, with long conical receptrcle, white, neuter ray-florets and yellow dish.-Waste places ; common. Very acrid, blistering the hands of those who gather. it. -Fl. June-September. Annual.

3. A. arvénsis (Corn Chamomile).-A hoary or downy, much-branched plant; leaves cut into hairlike segments, but not dotted with glands; heads as in the last, but with conical receptacle and carpellate ray-florets. - Borders of cultivated fields ; frequent.Fl. June-August. Annual.

4. A. nóbilis (Common Chamomile). - Stems prostrate, much branched; leaves repeatedly cut into hair-like segments, slightly downy; hends as in the preceding, but drooping before expansion.-Gravelly 
and sandy places; frequent. Distinguished by its pleasant aromatic smell, resembling that of fresh apples, whence is derived its name of Chamomite,

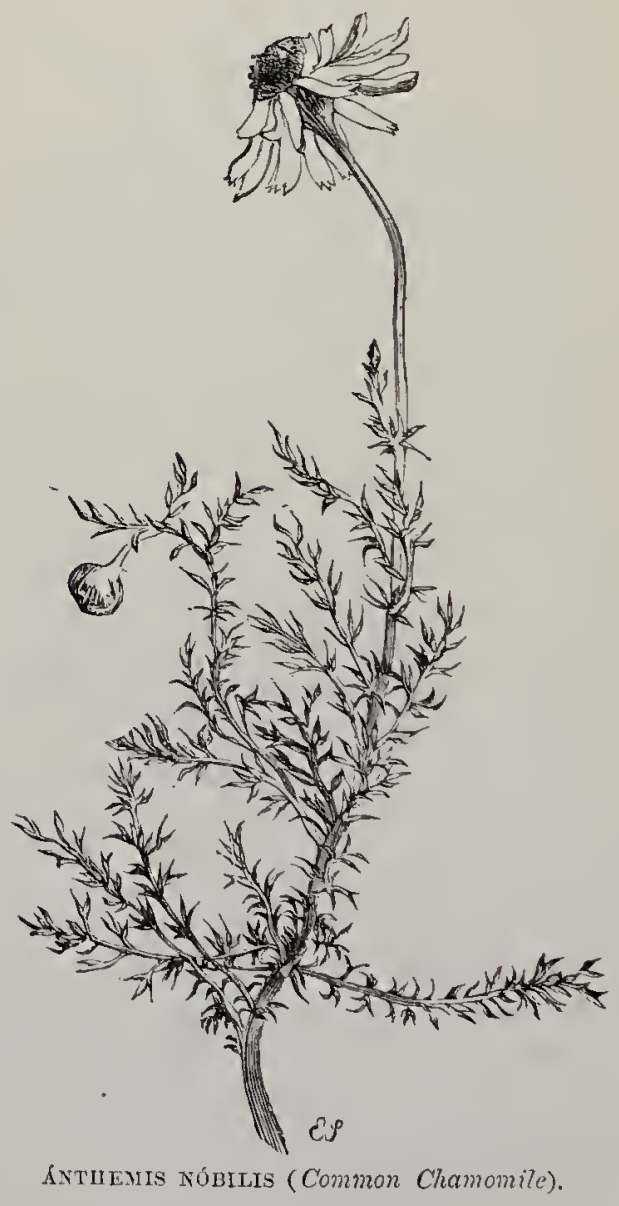

which in Greek signifies ground apple. The whole plant is very bitter, and is a valuable tonic.-.-Fl. Inly-September, Perennial. 
18. Chrssínthemum (Ox-eye).-Herbs or shrubs; leaves toothed or lobed, not decompound; heads solitary ; bracts with membranous margins, imbricate; receptacle flat or convex, naked; ray-florets in 1 row, ligulate, carpellate, white or yellow; no pappus.

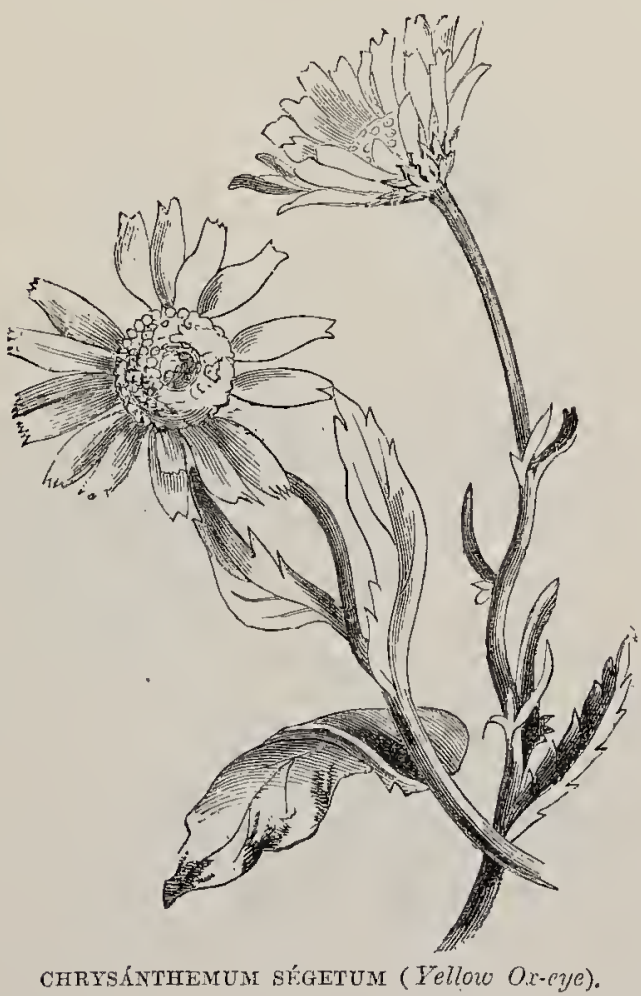

(Name from the Sreek chrusos, gold, anthos, a flower.)

1. C. ségetum (Yellow Ox-eye, Corn Marigold).Glabrous, glaucous; leaves obovate or oblong, acute, toothed and lobed, the lower pinnatifid and stalked, the upper amplexicaul; ray-florets golden-yellow.- 
Cultivated fields; abundant. The brilliant, golden blossoms contrast beautifully with the scarlet Poppies and blue Cornflowers.-Fl, June, July, and, in summer-ploughed fields, again in October and November. Annual.

2. C. Leucánthemum (Ox-eye Daisy, Moon Daisy). -Erect, slightly branched, glabrous or nearly so, but not glaucous; lower leaves stalked and auricled, upper sessile, pinnatifid at the base; bracts with a narrow dark purple membranous margin; ray-florets white.Meadows; abundant. Almost as weil known as the common daisy, and a great favourite with children, who sometimes string the flower-heads on a stout grass-straw, or bit of wire, making a very fair imitation of the plume formerly worn by soldiers. The plant is said to be destructive to fleas.-Fl. JuneAugust. Perennial.

3.* C.Parthénium(CommonFeverfew).--Pubescent, erect, branched above, 1_-2 feet high ; leaves stalked, pinnate; leaflets pinnatifid and deeply cut; heads many, corymbose, $\frac{1}{2}-\frac{3}{4} \mathrm{in}$. across ; receptacle convex ; ray-florets white, short and broad.- Waste-ground; not very common. Well marked by its repeatedly cut, curled, delicate green leaves which are conspicuous in mid-winter, and its numerous small flower-heads. The whole plant has a powerful and not unpleasant odour, which is said to be particularly offensive to bees. The English name is a corruption of Febrifuge, from its tonic properties-Fl. July-September. Perennial.

19. Matricíria (Wild Chamomile, Feverfew).Branched plants; leaves much divided into narrow segments, bracts imbricate, in few rows; receptacle broad, naked, becoming conical after flowering; rayflorets in one row, ligulate, white, or rarely absent ; no pappus. 
1. M. inodóra (Corn Feverfew, Scentless Mayweed).- Scentless, glabrous; stem erect, branched, angular; leaves sessile, repeatedly cut into numerous hair-like segments; heads solitary, 2 in. across ; bracts toothed and edged with brown; receptacle hemispherical, becoming conical; ray-florets white, ultimately

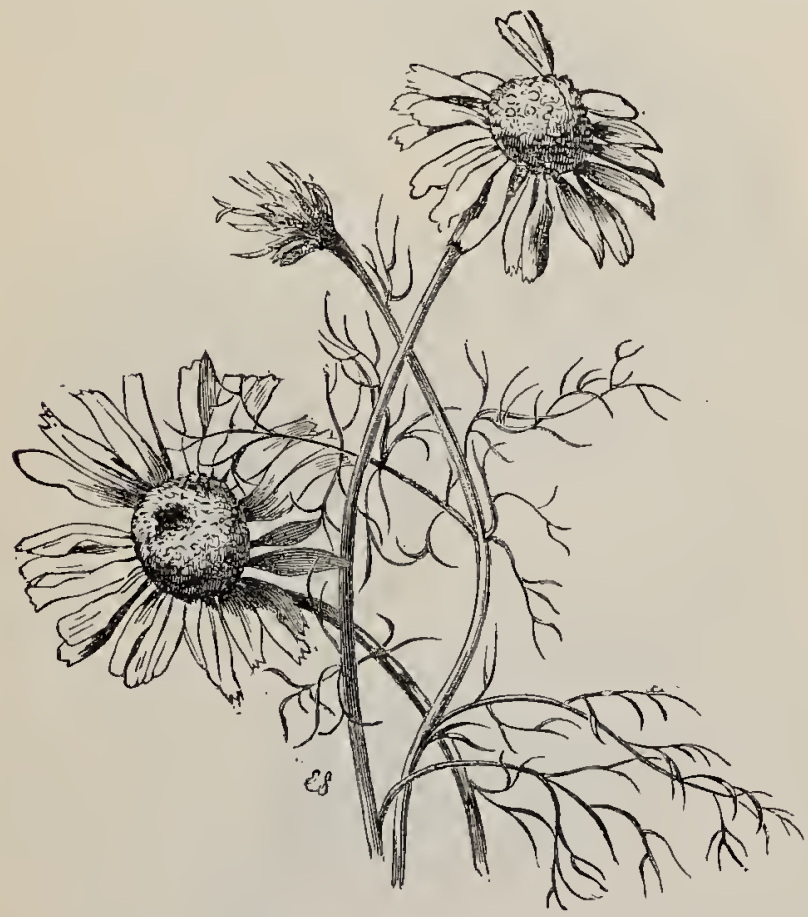

MATRICARIA INODÚRA (Corn Feverfere, Scentless May-veed).

reflexed.-Fields; abundant.-FI. June-October. Annual or Biennial.

2. M. marítima (Sea Feverfew).-Less erect and more fleshy; leaf-segments long; bracts with broad dark margins. - Sea-coast in the North of Scotland, Perennial. 
3. M. Chamomintu. (Wild Chamomile).-Aromatic, much-branched, glabious plant; Teaves bipinnate, repeatedly cut into very narrow hair-like segments; heads in corymbs, $\frac{1}{2}-\frac{3}{4}$ in. across; bracts

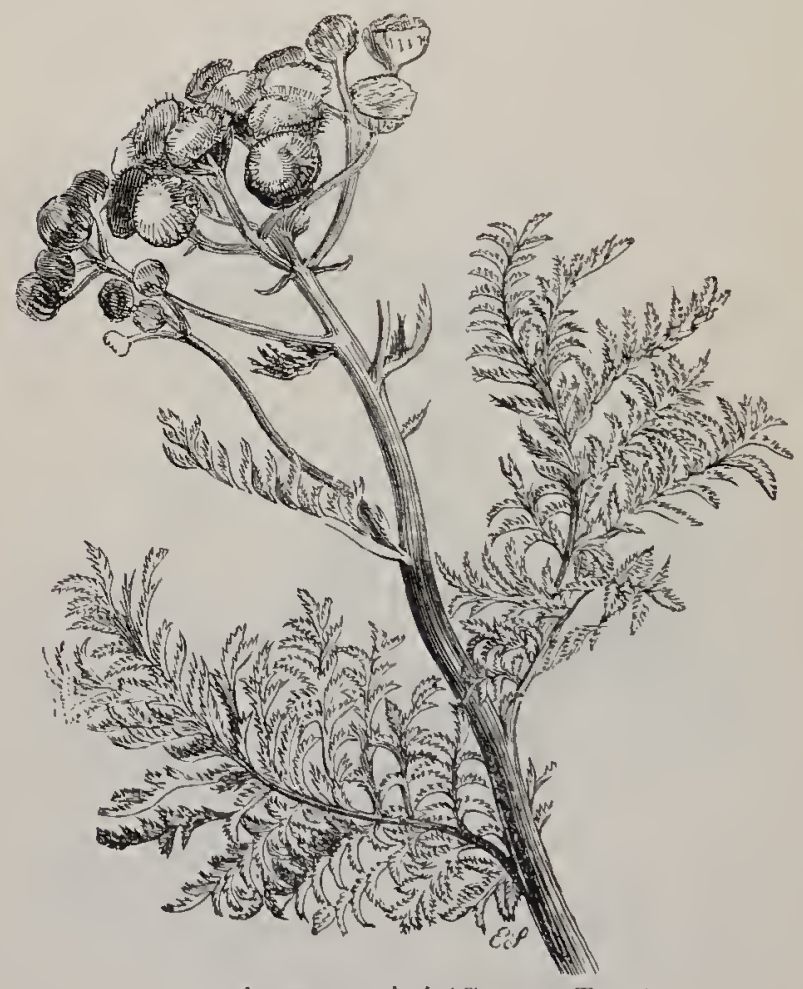

TAYACÉTUM VULGÁR̂́ (Common Tansy).

without membranous margins; receptacle conical, elongating during fruiting, hollow; ray-florets white, reflexed directly after flowering, or absent.-Cornfields; frequent. Its smell is fainter than that of Anthemis nóbilis, and the bracts and hollow receptacle 
serve to distinguish it from $A$. Cótula and Ilatricária inoctôra,--Fl. Juno-August. Annual.

'*20. Cótula, represented by C. coronopifólia, is a genus of branched annuals, with pinnatifid leaves, and small solitary heads of yellow tubular florets, with 4 lobed corollas. This species is glabrous, succulent, and creeping, with shining leaves and erect peduncles $1-2$ in. high. It is naturalised near Birkenhead.

21. Tanacétum (Tansy)._-Strong-scented herbs or undershribs; leaves scattered, much divided; heads solitary or corymbose, sub-globose, yellow ; bracts membranous at their edges; receptacle convex, naked; florets all tubular; fruit angular, crowned with a lobed membranous disk. (Name said to be from the Gieek athánaton, immortal.)

1. I'. vulgáré (Common Tansy),-The only British species, 2-3 feet high; stem angular, leafy; leaves deeply bipinnatifid, serrate; heads many, bright yellow, button-like, in a terminal corymb.-Hedges and waste ground; common. The whole plant is bitter and aromatic, and is not only used in medicine, but was the principal ingredient in a nauseous dish called Tansy Pudding. - Fl. August, September. Perennial.

22. Artemísia (Wormwood).-Herbs and undershrubs with a bitter or aromatic taste; leaves scattered; heals small, in racemes or panicles; bracts with membranous margins; receptacle naked, narrow; forets all tubular; no pappus. (Name from Ártemis, the Diana of the Greeks.)

1. A. Absinthium (Common Wormwood). - A bushy plant, $1-3$ feet high, with silky stems; teaves 
twice pinnatifid, with bluntish segments, silky on both sides ; heads many, small, panicled, hemispherical,

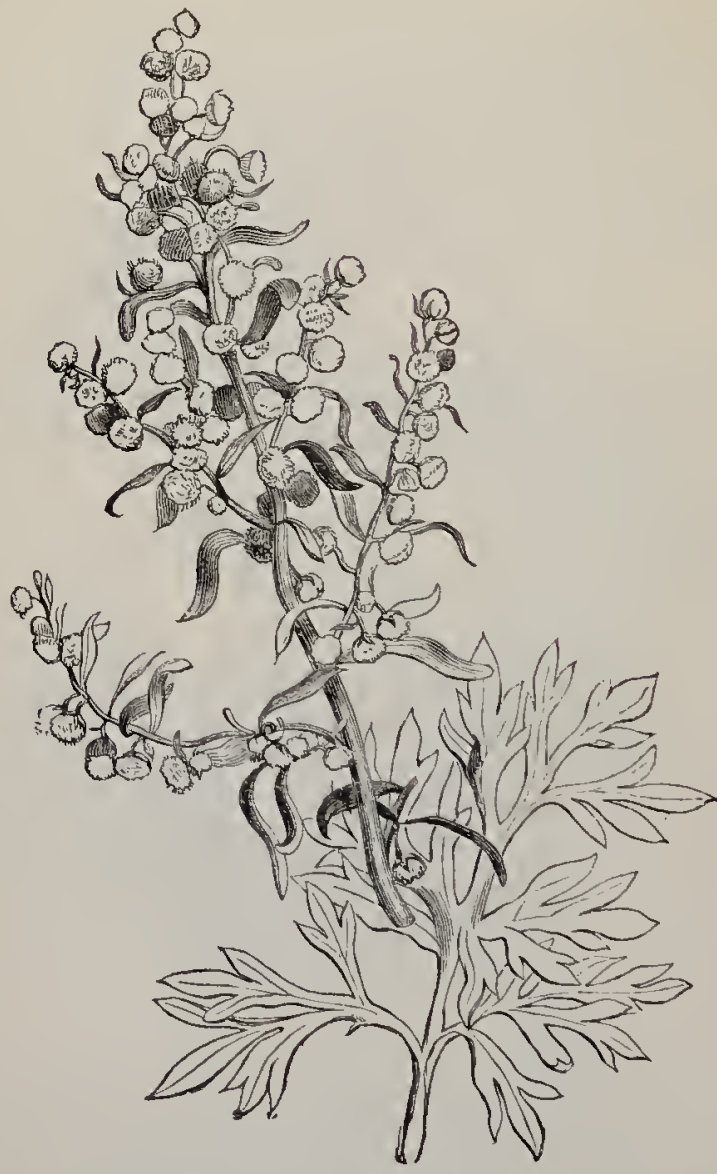

ARTEnfsia absinthiug (Common Wormzood).

drooping, dull yellow.-Waste ground; common. Bitter and aromatic, and much used in rural districts as a tonic.-Fl. July-September. Perennial. 
2. A. vulgáris (Mugwort).-Taller and more slender than the last, and well distinguished by the absence of aromatic odour, and the leaves which are green above and white with wool beneath and pinnatifid

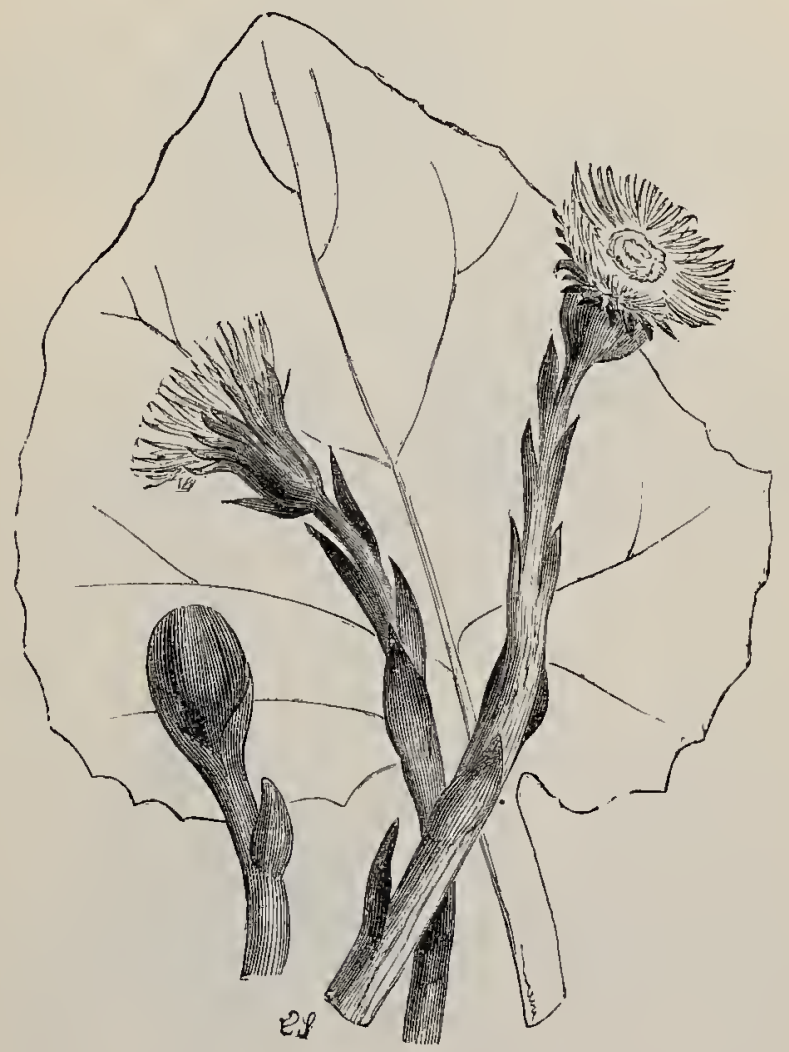

TUSSILAGO FÁRFARA (Colt's-foot).

with acuie segments; heads reddish or brownishyellow.-Hedges, and waste places; abundant. An infusion or tea of this plant is a rural remedy for rheumatism.-Fl. JuIy_September. Perennial. 
3. A. compéstris (Field Wormwood). - Stems prostrate until flowering; lecues pinnatifid, with very slender acute segments, silky when young, but becoming glabrous.-Sandy heaths in Norfolk and Suffolk; rare.-Fl. August, September. Perennial.

4. A. maritima (Sea Wormwood).- Somewhat resembling $A$. Absinthium, but smaller; leares twice pinnatifid with many, very narrow, blunt segments, with white down on both sides; heads in racemes, drooping or erect, reddish.- Salt marshes; frequent. -Fl. July-_September. Perennial.

23. Tussicágo (Colt's-foot). - Rhizome creeping; leaves large, radical; heads solitary, yellow, manyflowered; bracts narlow, in 1 row; receptacle naked; ray-florets narrow, in several rows; dish-florts few; pappus of slender, silky hairs. (Name from the Latin tussis, a cough, from the use to which it is applied.)

1. T. Farfara (Colt's-foot). - The only species; leaves, which do not appear until the flowel-heads are withered, l'oundish, cordate, and angular, cobwebby above, with dense, white down beneath; peluncles with scale-like bracts, elongating after flowering; heads bright yellow, about 1 in. across, drooping before expansion; pa?pus snow-white.-Clayey fields; abundant. A pernicious weed, the leaves of which are made into cigar's for asthmatic persons. The down on their under surfaces was formerly used as tinder, and the goldfinch flequently lines its nest with the pappus.-Fl. February, March. Perennial.

24. Petasímes (Butter-bur). - Leaies large, broad, radical, produced after the flowers; heads numerous, pul'plish or white, in a raceme, many-flowered; florets all tubular, sub-dicecious. (Name from the Greek pétasos, an umbrella, from the large size of the lesves.) 
1.P. officinatis (Common Butter-bur).-The only indigenous species, the largest, and, where it abounds,

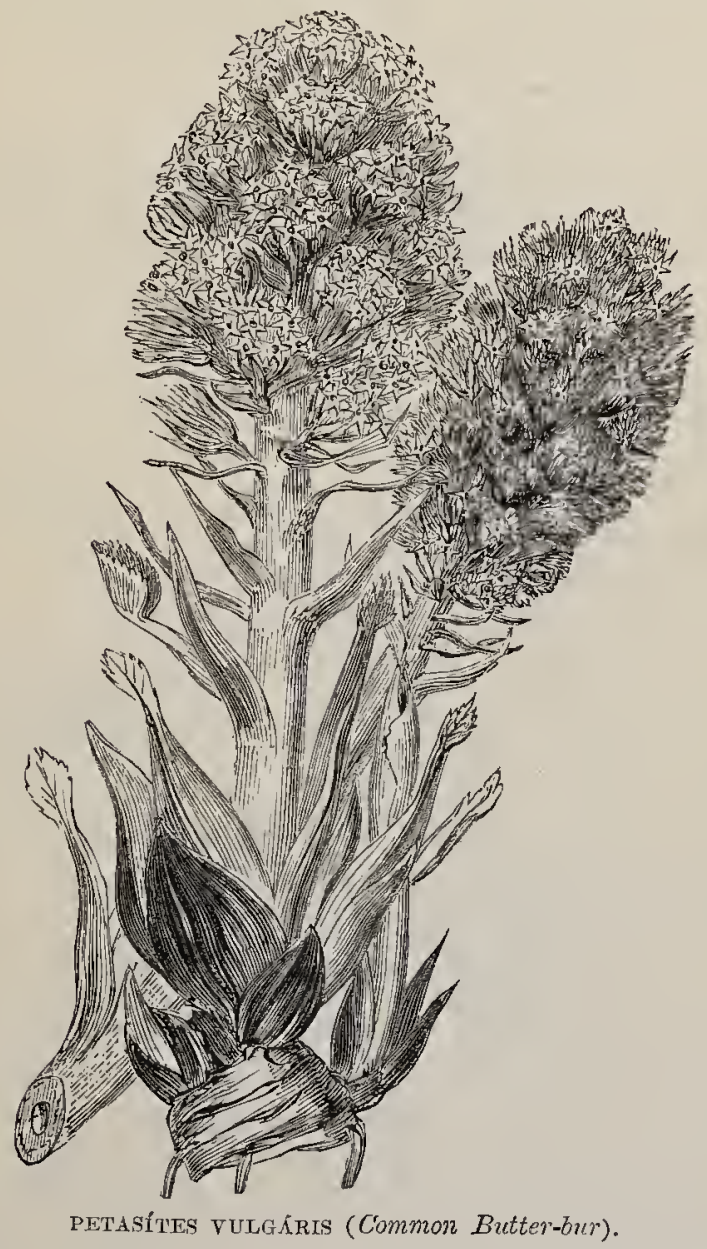

the most pernicious of all the weeds which this country produces. Leaves kidney-shaped, $1-3$ feet in diameter, downy, appearing after the flowers; 
heads dull lilac, many flowered, in a raceme, on a short fleshy peduncle with sheathing bracts terminating in small blades.--Marshy meadorvs and river-banks; common. Planted near beehives by Swedish farmers, on account of its early flowering.-Fl. JanuaryMarch. Perennial.

* $P$. frágrans (Winter Heliotrope), with cordate leaves and a loose panicle of a few dingy but sreetscented heads'with ligulate fertile florets, flowering very early in January, and $* P$. albus (White-flowered Butter-bur), with much smaller, deeply scalloped leaves and white flowers, are common in shrubberies, almost hiding the ground with their leaves, thriving beneath the shade of trees and shrubs, but overpowering all herbaceous plants, and eventually, it is said, even the shrubs themselves. Botl are occasionally naturalised, the former in the south, the latter in Scotland.

*25. Doronícur (Leopard's-bane).-Radical Teaves stalked; cauline Tecues scattered, amplexicaul: heals terminal, nearly solitary, large, yellow; fracts in $2 \mathrm{ol}^{*}$ 3 rows, narrow, acute, equal; receptacle conical; rayflovets in 1 row, ligulate, with no pappus; mapus of disk-florets of several rows of stift hairs. (Name of uncertain et ymology.)

1.* D. Pardatiánches (Great Leopard's-bane).Stem 2-3 feet high, erect, solitary, hairy, hollow; leuves cordate, soft; the earlier flower-heads overtopped by the later.-D.rmp, hilly woods; rare, not indigenous.-Fl. May-July. Pereunial.

2.* D. pluntugineum (Plantain-leaved Leopard'sbane), differing in having ovate leaves and solitary heads of flower's, is very rare and not indigenous. Fl. Jume, July. Perennial.

26. Senécio (Groundsel, Ragrvor't). - A large genus 
of herbs and undershruhs; leaves scattered; heads usually yellow, corymbose, or solitary; bracts in 1 row, sometimes with a few smaller scales at their base, narrow, adpressed, herbaceous ; receptacle naked ;

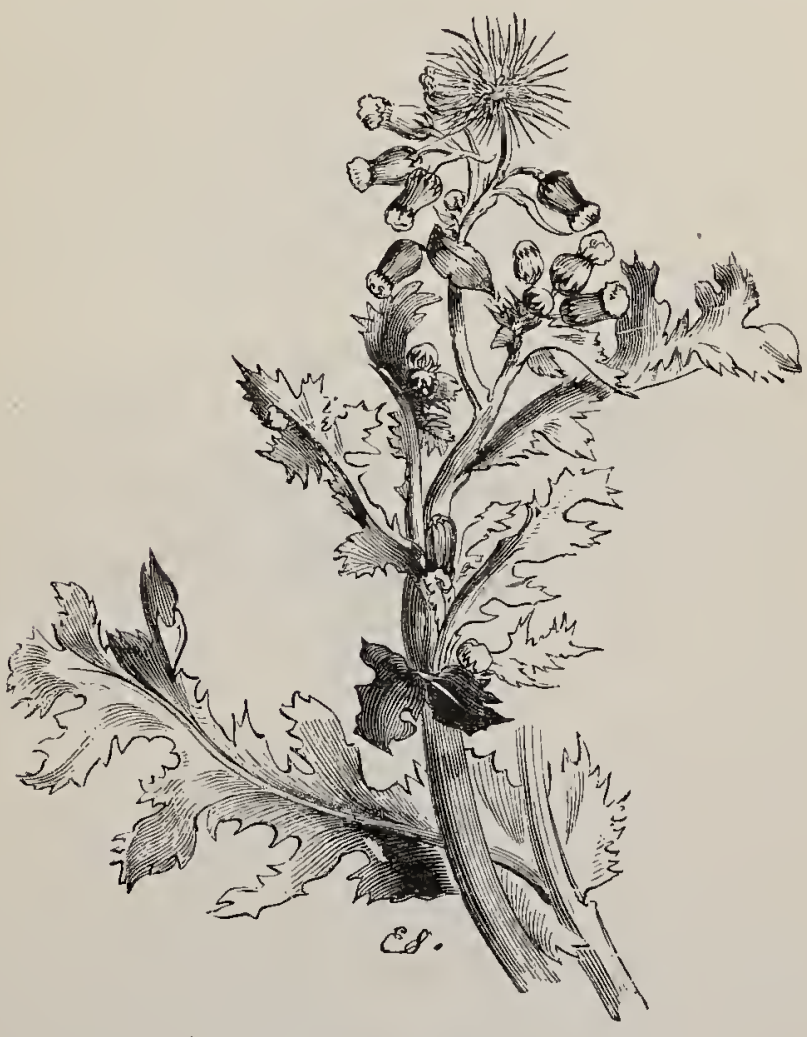

SENÉCIO VLLGÁRIS (Common Groundsę).

ray sometimes absent; pappus of several rows of soft, slender hairs. (Name from the Latin senex, an old man, from the white or grey hairy pappus.)

1. S. vulgáris (Common Groundsel). - Leaves halfamplexicaul, deeply pinnatifid, toothed, not sticky ; 
heads few, drooping; outer bracts very short, with black points; ray absent.-A common weed in cultivated ground; a favourite food of many small birds. - Fl. al] the year round. Annual.

2. S. syluáticus (Mountain Groundsel.)-_Distinguished from the last by its larger size, it being 1-2 feet high and branched; by being fetid and slightly sticky; by its more copiously cut, pinnatifid, often hoary leaves, with narrow, toothed lobes; and by its many conical rather than cylindrical heads of dull yellow fowers, which are in a corymb and sometimes have a few small rolled back ray-florets.-Dry, gravelly places; common.-Fl. July-September: Annual.

3. S. viscósus (Viscid Groundsel)._-Differing from the preceding in being more viscid, with glandrular hairs, and in having fewer heads with outer bracts half as long as the inner ones.-Dry waste places ; local.Fl. July-September. Annual.

4.* S. squálidus (Inelegant Ragwort).-Inapprapriately named, as it is by far the prettiest Britisl species. About a foot high, much branclied; leaves irregularly lyrately pinnatifid with narrow segments, glabrous; heads few, in a very loose corymb; outer bracts fer and very short; ray spreading.-On old walls at Oxford, Bideford, Cork, \&c.; but not indigenous.-Fl. June-October. Annual.

5. S. emcifótius (Hoary Ragwort), - About 2 feet high, erect; stems angular, cottony, witl curled hair's; leaves regularly pinnatifid, witl slightly rolled back narlow lobes, cottony beneath; heads in a dense corymb; auter bracts half as long as the inner ; ray spreading.-Dry banks on a limestone or chalky soil; not uncommon.-Fl. July, A ugust. Perennial.

6. S. Jacobica (Common Ragwort). -Almost glabrous; stem erect, 2-3 feet high; leares pinnatifid, glabious, generally lyrate, the upper ones auricled; heads large, bright yellow, in a dense corymb; ray 
spreading, or rarely absent.-Waste places ; abundant. -Fl. June-September. Perennial.

7. S. aquáticus (Marsh Ragwort).-Resembling the last, but of more slender, looser habit; radical leaves stalked, undivided, toothed; cauline leaves irregularly lyrately pinnatifid; heads in a loose corymb.

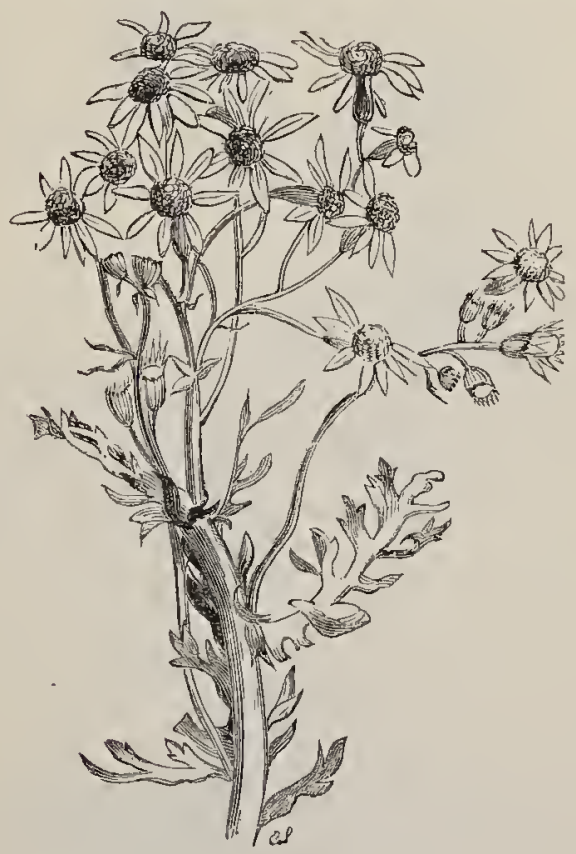

SENÉCIO JACOBÁA (Common Ragwort).

—Wet places ; abundant._Fl. July, August. Biennial.

8.* S. saracénicus (Broad-leaved Ragwort).—Stem erect, 3-5 feet high, smooth, solid ; leaves lanceolate, irregularly serrate, sessile, or nearly so, glabrous; heads many, in loose downy corymbs; ray-florets few.-Moist meadows; locally naturalised.-Fl. July, August. Perennial. 
9. S. paludôsus (Great Fen Ragwort).-A large aquatic plant, 5-6 feet high; stem slightly cottony, hollow; Teaves lanceolate, sharply serrate, cottony beneath; heads in loose corymbs ; ray-florets many.Fens in the eastern counties; rale-LI. May-July. Perennial.

10. S. palustris (Marsh Fleawort). - A stout plant, 2-3 feet high, shaggy; stem hollow; leaves sessile, broadly lanceolate, half-clasping, the lower ones wavy and toothed; heads many, in a crowded corymb; with no outer scales to the involucre; ray spreading.-Fens in the eastern counties ; rare.-Fl. June, July. Biennial.

11. S. campéstris (Field Fleawort). - A small, shaggy plant, $6-8$ in. high, with an unbranched stem; radical leaves shortly stalked, oblong, nearly entire; cautine leaves lanceolate; heads $1-6$ in a simple corymb. - Chalky downs; rare.-Fl. May, June. Perennial.

12. S. squthulafótius (Maritime Fleawort).-An allied species, $1-3$ feet high, shaggy and unbranched, with spathulate radical leaves and large, clasping cantine leaves.-Occurs on rocks near Holyhead.-Fl. June, July Biennial or Peremnial.

27. Carlíxa (Carline Thistle). - Stifi, spinous plants; leaves pinnatifid; outer bracts leafy, spreading, with spinous teeth, immer longer, narrow, chaffy; receptacle flat, deeply pitted; flonets all tubular; corolla 5-toothed; anthers tailed; fruit silky, with bifid hairs; pappus in 1 row, branched and feathery. (Name, the same as Carolina, from a tradition that the root of one species, $C$. acaútis, was shown by an angel to Charlemayne as a remedy for the plague which prevailed in his army.)

1. C. vulgaris (Common Carline Thistle).-The only British species, readily distinguished from every 
other British Thistle by the long inner bracts of the involucre, which are straw-coloured and glossy, and spread in a radiate manner so as to resemble petals. In dry weather they lie flat, but when the atmosphere

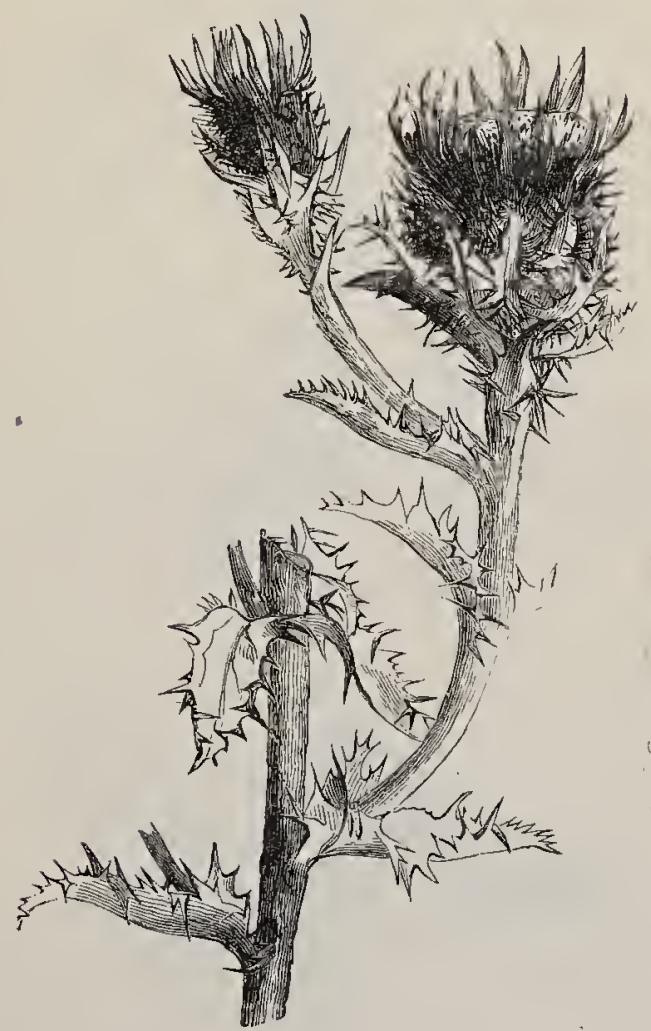

CARLÍNA VULGßRIS (Common Carline Thistle).

is moist, they rise and form, as it were, a penthouse over the florets. Their texture is like that of Everlasting Flowers; hence they scarcely alter their appearance when dead, and, as the whole plant is remarkably durable, they often retain their form 
and position till the succeeding spring. On the Continent the large white Hower-head of one species,

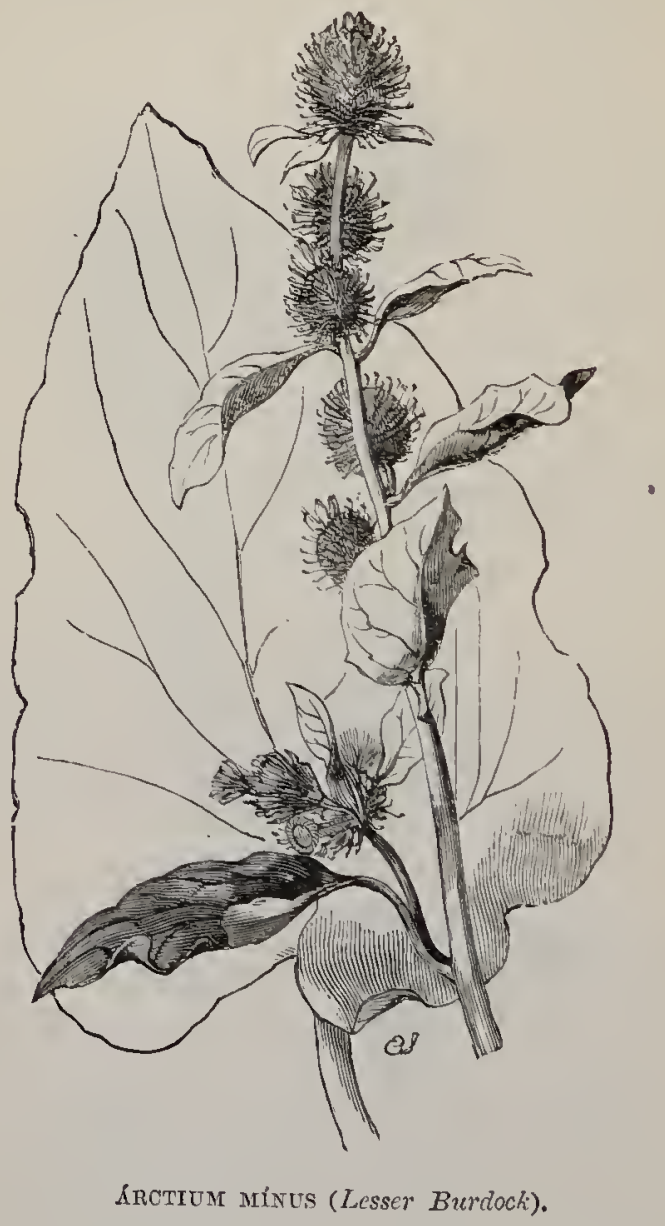

C. acaúlis, is often nailed upon cottage doors by way of a hygrometer, as it closes before rain.-Dry heaths. -El. June-October. Biennial. 
28. Árotiom (Burdock).-Stout, erect, branching plants, with very large, stalked, cordate leaves; a globose involucre of long, stiff, spreading, spinous, hooked bracts; flat, scaly receptacle; florets all tubular and perfect; anthers tailed; pappus in several rows of short, simple hairs. (Name from the Greek arktos, a bear, from the rough burs.)

1. A. május (Great Burdock).-A large and stout lierbaceous plant, remarkable for the picturesque character of its large, wavy leaves, which are often introduced by artists into the foreground of their landscapes. The petioles are solid; the flower-heads long-stalked, in a loose cor'ymb, hemispherical, very large; involucre glabrous and green, or sometimes interwoven with a white, cottony substance; florets purplish-red. - Waste places; not uncommon. The hooked spines of the involucre attach the heads when in fruit to the coats of animals, so that they are conveyed to a distance.-Fl. July, August. Biennial.

2. A. nemorósum (Wood Burdock). - A smaller species; leaves coarsely crenate; petioles hollow; heads smaller, sub-sessile, ovate, in a raceme, usually 3 together on a branch; heads webbed. - Local._- Fl. July, Angust. Biennial.

3. A. minus (Lesser Burdock).-A still smaller form, with coarsely-toothed, radical leaves; hollow petioles; and shortly-stalked, globular heads, not exceeding $\frac{3}{4}$ in. across, sub-racemose; involucre green, slightly webbed.-Waste places; the commonest form. -Fl. July, August. Biennial.

4. A. intermédium (Intermediate Burdock).-A form of intermediate size, about 3 feet high, with crenate radical leaves, a slender tube in the petioles, and slightly-stalked, sub-racemose, hemispherical heads, twice as large as those of $A$. minus, with purplish and usually much webbed involucres.-..Waste places; not uncommon.-Fl. July, August. Biennial. 
29. Cárdưs (Thistle).-- Erect herbs; Teares spinoustoothed, decurrent, forming very spinous wings to the stem; involucre globose, of many, imbricate, spinous bracts; receptacle deeply pitted, scaly; florets all

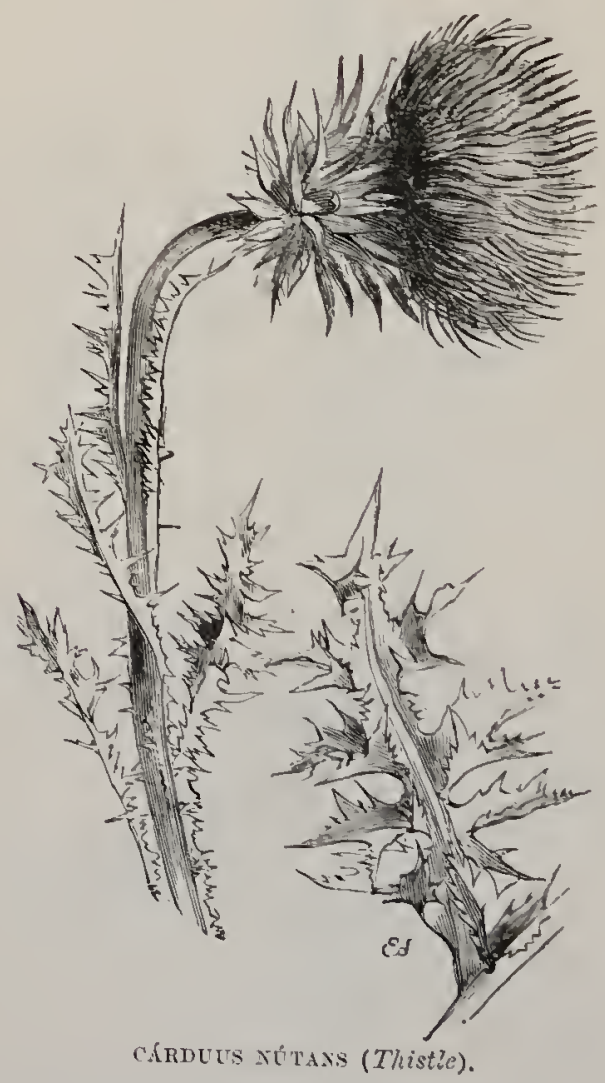

tubular; filaments free, hairy; fruit compressed; palpus in many rows of long, equal, shining, white hairs. (Name, the Latin name of the group.)

1. C. pycnocéphatus (Slender-flowered Thistle).Stems 2-4 feet high, slightly-branched, hoary, with 
broad, continuous, deeply-lobed, spinous wings; leaves cottony beneath ; heuds many, clustered, cylindrical, small; Tracts glabrous, subulate, very long, erect; florets pink. - Sandy waste places, especially near the sea ; frequent.-FI. June-August. Biennial.

2. C.nútcns (Musk Thistle).-A very handsome

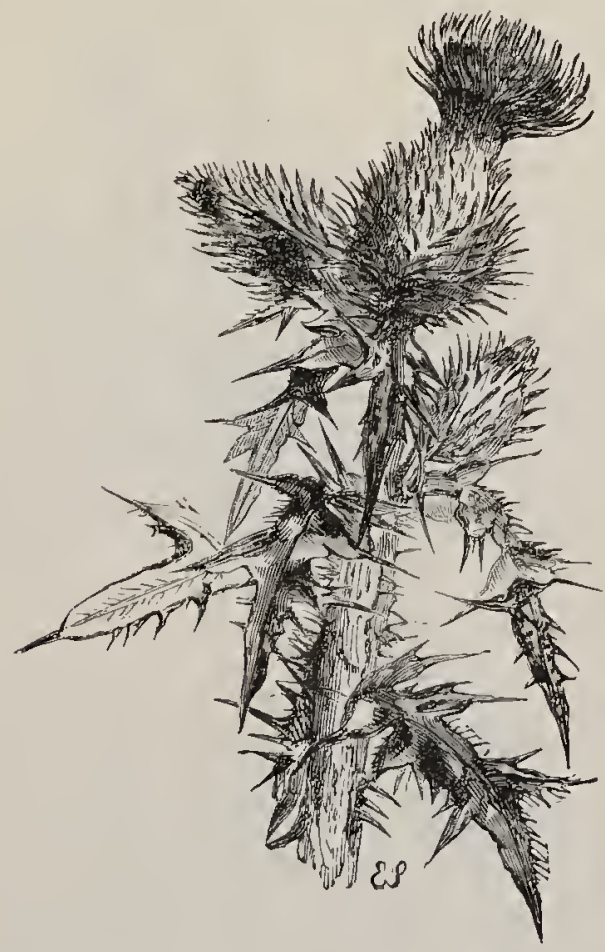

CNfCUS LANCEOL $\hat{T}$ TUS (Spear Plume-Thistle).

plant, about 2 feet high, with a furrowed, cottony stem, interruptedly winged; leaves deeply-lobed, spinous, woolly on the veins beneath; heads large, solitary, drooping; bracts lanceolate, spinous-pointed, cottony, the outer ones reflexed; florets crimson.- 
Waste places, especially on chalk downs; fiequent. The flowers have a powerful musky odour.-Fl. May -October. Biennial.

3. C. crispus (Welted Thistle).- A branched, very spinous plant, 3-4 feet high; stem continuously winged; heads small, erect, clustered, roundish ; bracts linear, erect, or spreading, webbed, slender; florets deep purple, or sometimes white. - El. June - August. Annual or Biennial.

30. CNícus (Plume-Thistle).-Differing from Cárduus mainly in having a feathery papus. (Name from the Greek Rnizo, I prick.)

1. C. Zanceolútus (Śpear Plume-Thistle).-Stem 2-5 feet high, winged by the decurrent spinous leaves; leaves pinnatifid, with bifid lobes, the segments lanceolate, entire, and ending in a strong spine, white and dorvny beneath; heads terminal, mostly solitary, sometimes 2 or 3 together, stalked, egsshaper, about an inch across; 7rects linceolate, spinous, spreading, woolly; florets dull purple. - Waste places and hedges; abundant.-Fl. July-Octobel: Biennial.

2. C.erióphomes (Woolly-headed Plume-Thistle).Stem 3-5 feet high, not winged; len'es lalf clasping at the base ; heads $2-3$ in. across, globose, with a thick white wool and long reflexed spines to the imrolucre.Waste ground on calcareous soil; local.-Fl. JulySeptember. Biennial.

3. C. palustris (Marsh Plume-Thistle).- The tallest of British Thistles, 3-10 feet high, consisting of a single, stout, hollow stem, branched towards the summit, and spinously winged throughout by the decurent leares, which are thickly armed with short, often brownish spines and are usually downy beneatl ; heads small, egg-shaped, in a terminal leafy cluster; bracts adpressed, slightly 
webbed ; florets deep crimson, or sometimes white.Moist places; abundant, - Fl. July-September. Biennial.

4. C. tuberósus (Tuberous Plume-Thistle).-Root of spindle-shaped, tuberous fibres; stem 2 feet high, single, erect, round, hairy, leafless above; leaves not

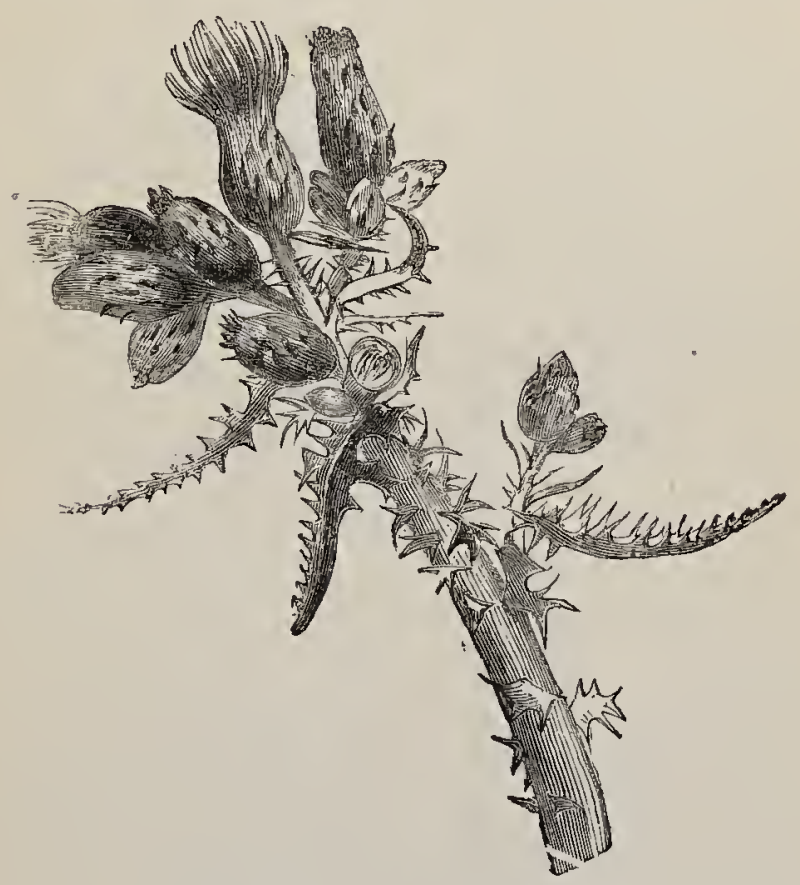

CNÍCUS PALÚSTRIS (Marsh Plume-Thistle).

decurrent, deeply pinnatifid, fringed with minute prickles; hecds generally solitary, large, egg-shaped; florets crimson. - Grows only in Wiltshire. - Fl. August, September. Perennial.

5. C. praténsis (Meadow Plume-Thistle).-A small plant, 12-18 in. high, with fibrous roots; a cottony 
stem, giving off runners; few leaves, mostly radical, soft, wavy, fringed with minute spines, not decurrent; and generally solitary heads, with adpressed, slightly cottony brects and crimson florets.-Wet meadows; not general.-Fl. June-August. Perennial.

6. C. heterophýllus (Melancholy Plume-Thistle).Stem 2-4 feet high, elect, cottony, furrowed, slightly branched above, with runners; leaves large, clasping, not decurrent, serrate with minute spines, smooth above, white and downy beneath; head large, solitary, egg-shaped, handsome; bracts downy; florets redpurple.-Moist mountain pastures.-Fl. July-Sep-
tember. Perennial.

7. C. acaúlis (Ground Thistle).-A low plant, stemless, or nearly so, and so readily distinguished from all other British species; radical leares pinnatifid, spinous, glabrous; head solitary, almost sessile; flovets crimson.-Dry giavelly or chalky pastures; not general, but abundant in many southern districts.-Fl. JulySeptember. Perennial.

8. C. arénsis (Creeping Plume-Thistle).-A handsome weed, $2-4$ feet high, with a creeping $\%$ hizome; stem erect, leafy, angular, not winged; leaves sessile, pinnatifid, wavy, very spinous; heads numerous, stalked, corymbose; bracts broad, adpressed, spinouspointed; florets dingy light purple, musk-scented, diocious, the staminate ones in sub-globose, and the calpellate ones in egg-shaped heads, the two forms of the plant growing in separate patches.-Fields; very common.-Fl. July-September. Perennial.

Besides these species there are several hybrids between them.

31. Onorórinon (Cotton-Thistle).--Diflering from Cardurs mainly in its honeycombed receptacle and 4-angled firit. (Name of Greek origin.)

1. O. Acántrium (Scottish Thistle).-A stout, 
hoary, or woolly plant, 4-5 feet high; stem erect, branched, with a broad spinous wing to its summit; leaves wavy, pinnatifid, decurrent, woolly on both surfaces; heads many, large, globose, cobwebby; bracts green, recurved, fringed witl minute spines; florets pale purple.-Dry waste-places, especially in the south. Cultivated as the national emblem in Scotland.-El. July--September. Biennial.

*32. Mariána (Milk-Thistle). - Represented by the species $M$. láctea, is not an indigenous genus. It was called by the early botanists Cárdurs Marice, or "Our Lady's Thistle," and is a stout, glossily glabrous plant, 2-4 feet high, with white veins to its large leaves; large globose heads of rose-coloured florets; united filaments, and a papmus of many rows of silky white hairs. - Waste placcs.-Fl. June, July. Biennial.

33. Saussúrea.-Werbs, not spinous, with heads of bluish-purple, perfect, tubular florets, in corymbs; lnacts imbricate, in many rows, not spinous; receptacle flat, scaly; anthers tailed; pappus in 2 rows, the outer bristly, the inner longer, feathery. (Named in honour of the two de Saussures, Swiss naturalists).

1. S, alpina (Alpine Saussurea).--The only British species, 8-12 in. high, downy; leaves oblong-lanceolate, toothed, cottony beneath; heads $2-3$ in. across, in a dense terminal corymb; involucre ovoid, woolly; florets light purple, scented like Heliotrope.-Alpine mountains; rare.-Fl. August. Perennial.

34. Serrátula (Satw-wort).--Herbs with simple, sometimes pinnatifid, serrate leaves, and generally diøcious heads, with imbricate, not spinous bracts, a scaly receptacle, florets all tubular, crimson or white, 
anthers nearly, or quite, without tails, and a pappus of several rows of unequal stiff hairs, the innel longest.

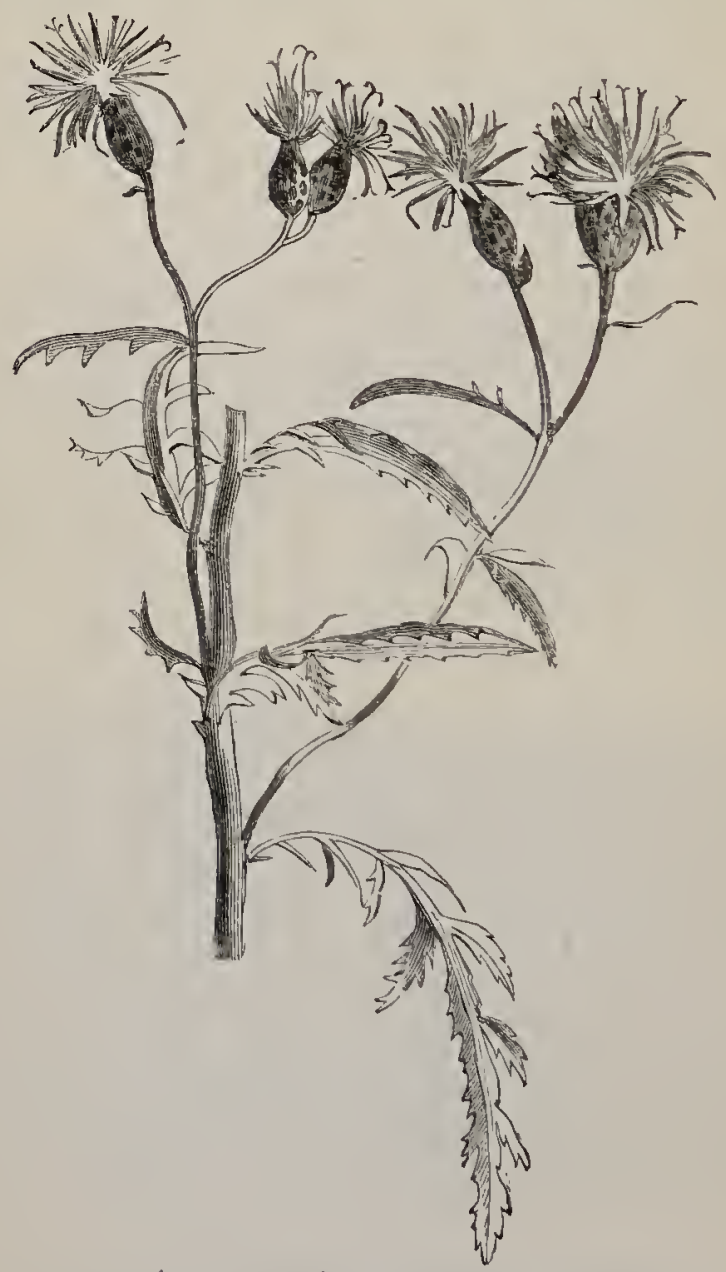

SERrATULA tINCTÚRIA (Common Sale-zeort).

(Name from the Latin, meaning saru-toothed, with reference to the leaves.) 
1. S. tinctoria (Common Saw-wort). - The only British species, a slender plant, $1-2$ feet high, with a stiff, erect, angular stem, slightly branched above; lear'es deeply lyrately pinnatifid and serrate; heads few, small, in a loose corymb; outer bracts smooth, adpressed; inner tinged with red; florets crimson.Pastures; frequent.-Fl. August. Perennial.

35. Centauréa (Knapweed). - Wiry herbs with leaves sometimes spinous; heads egg-shaped or globose ; bracts imbricate, adpressed, membranous, ol' sometimes spinous, or fringed ; receptacle flat, bristly; florets all tubular, but the outer usually large, unsymmetrical, and neuter. (Name from the Centaur Chiron, who is fabled to have healed wounds with some such plant.)

1.* C. Júcec (Brown Radiant Knapweed) is a garden escape, with crimson florets, the outer ones larger; pinnatifid outer bracts, and irregularly jagged inner ones.-Fl. August, September. Perennial.

2. C. nígra (Black Knapweed Hard-head). - A tough-stemmed plant, $1-2$ feet high; lower leaves toothed, often with a few small lobes at the base, uper narrow, tapering; heads terminal, globose, with, or more commonly without, a ray; bracts brown or almost black; the outer ones egg-shaped and fringed with spreading bristles; florets deep crimson; pappus very short, tufted.-Meadows; abundant.-Fl. June - September. Perennial.

3. C. Scabiósa (Great Knapweed, Matfellon).Larger and stouter than the last, from which it is distinguished by its pinnatifid leaves, almost always rayed heads, bracts downy, with a broad brown fringed tip and margins, bright crimson florets, and longer pappus.-Dry pastures; common,-Fl. July-September. Perennial.

4. C. Cýanus (Cornflower, Blue-bottle).-One of the prettiest of flowers, $1-2$ feet high; stem erect, 
slender, grooved, slightly branched, cottony ; leaves linear-lanceolate, the lower ones toothed ; heads about an inch across; involucre egg-shaped, cobwebby ; bracts with toothed, membranous margins; receptucle with silvery bristles; ray-florets few, large, bright blue;

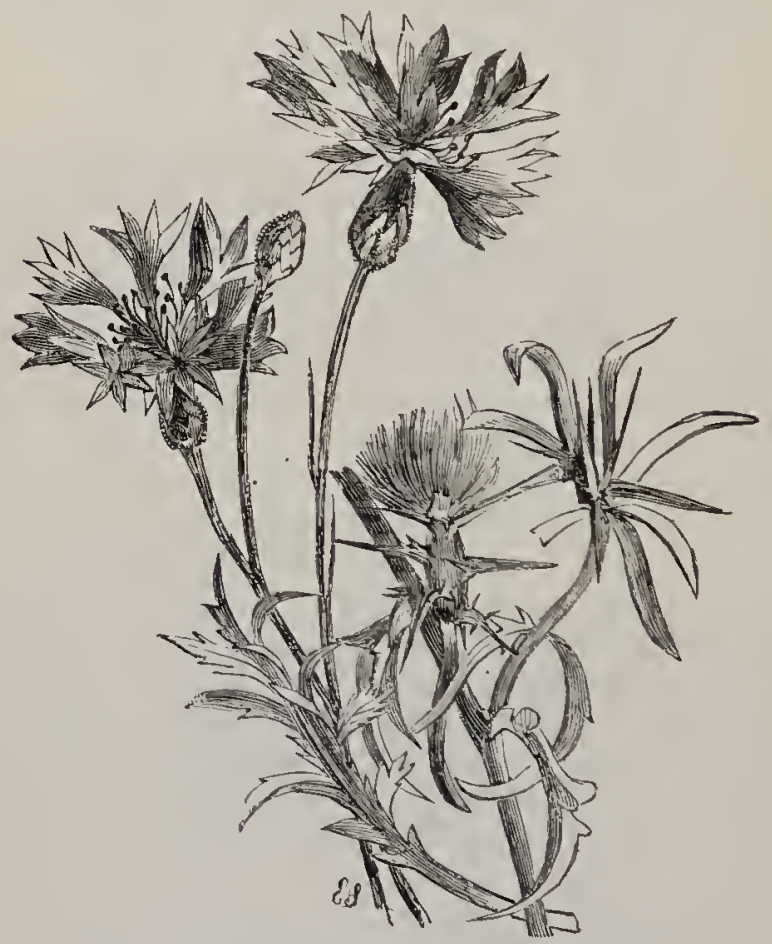

Centauréa CÝanus and C. Carcítrapa (Corn Bize-bottle and Star-Thistle).

disl-florets with dark purple anthers.-Cornfields; frequent. When mixed with Poppies and yellow Coln-marigolds, it forms as brilliantly coloured a bouquet as can be imagined. Children sometimes string the outer florets with a needle and thread into a wreath, which, when pressed, will retain its colour 
for a long while. Recently expanded flowers should be chosen, or they will fade--Rose-coloured, white, and dark purple varieties are common in gardens, and are occasionally found wild.-Fl. July, August; and, in turnip-fields, again in October and November. Annual or Biennial.

5. C. paniculata, with a loosely corymbose stem, rather cottony, and cylindric heads of pinkish florets, and

6. C. áspera, a prostrate species, with long, slender branches, linear leaves, terminal, solitary heads, 3-5 spines to each outer bract, and purple florets, are confined to the Channel Islands.

7. C. Calcitrapa (Common Star-Thistle).-A stout, spreading, stiff, branched species; leaves pinnatifid, bristle-pointed; heads lateral, sessile; bracts each ending in a long, stiff, spreading, yellow spine, channelled along its upper surface; florets rose-purple.-Gravelly and sandy places in the south; rare. The spines resemble the cruel iron instrument called Caltrops, which was used to lame cavalry horses in war, the instrument being so constructed that, in whatever position it lies, one point sticks upwards.-Fl. July, August. Annual.

8.* C. solstitiális (Yellow Star-Thistle), with stems winged by the decurrent bases of the entire hoary leaves and terminal heads, with very long, needle-like spines and yellow florets, occurs as a casual in cultivated land.-Fl. July-September. Annual.

36. Crснórium (Chicory).--Stout herbs with a milky juice; leaves simple, radical, and scattered; heads axillary; outer bracts 5, small, adpressed; inner 8 , reflexed after flowering; florets all li@ulate, 5-toothed; pappus a double row of small, chaffy scales. (Name of Classical origin).

1. C. Intybus (Succory, or Wild Chicory).-Well 
distinguished by its tough, angled, alternately branching stems, clasping leaves, and large heads of delicate blue, ligulate florets, each of which is distinctly 5toothed. - Waste places, especially on chalk. Sir James Edward Smith, the founder of the Linnean Society, thus alludes to his early attraction to this beautiful flower:- "From the earliest period of my

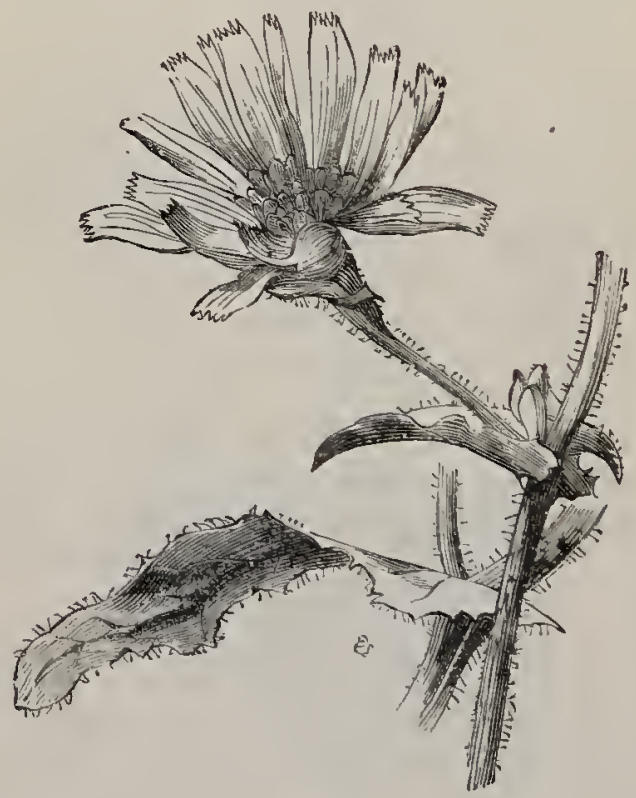

crcmónIum fNTrots (Tild Chicory, or succory).

recollection, when I can just remember tugging ineffectually with all my infant strength at the tough stalks of the Wild Succory, on the chalky hills about Norwich, I have found the study of nature an increasing source of unalloyed pleasure, and a consolation and a refnge under every pain."-Fl. JulyOctober, Perennial. 
37 Arnóseris (Lamb's Succory).-A small plant with milky juice; radical leaves and a few small heads of yellow florets with an involucre of about 12 bracts,

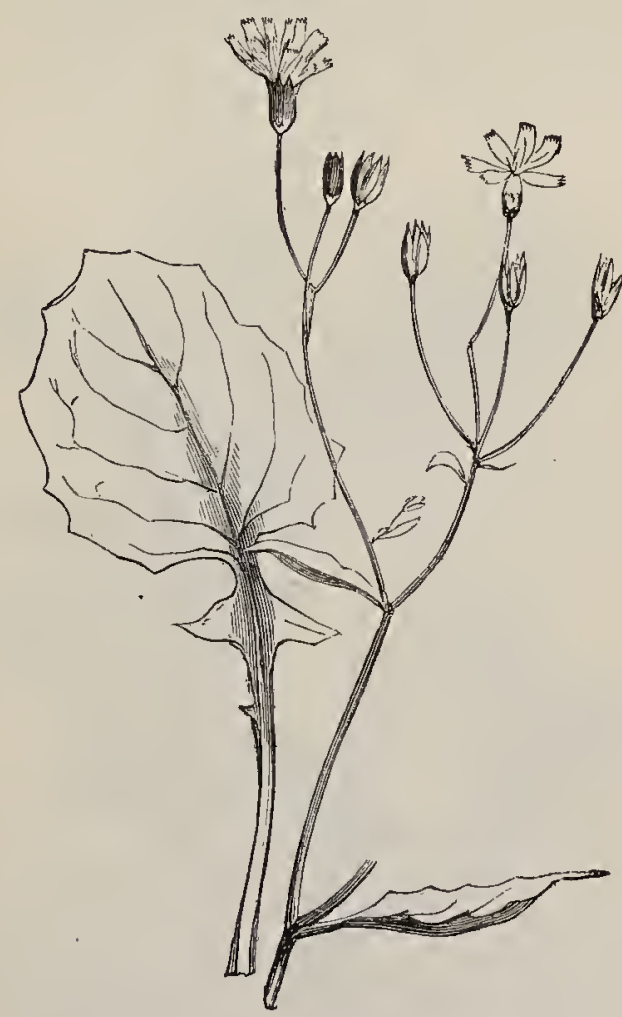

IAPSANA COMMÚNIS (Common Nipplewort).

converging and strongly keeled after flowering. (Name from the Greek arnos, a lamb, seris, succory.)

1. A. pusitla (Lamb's or Swine's Succory)....The only species; stem branching cymosely, each branch overtopping its predecessor, thickened and hollow upwards, $3-8$ in. high; leaves radical, obovate, 
toothed; heads terminating the branches, $\frac{1}{3}$ in. across -Dry places; rare.-Fl. June-August. Annual.

38. Lapsána (Nippletvort). - Slender, erect, branched plants with milky juice; scattered leaves;

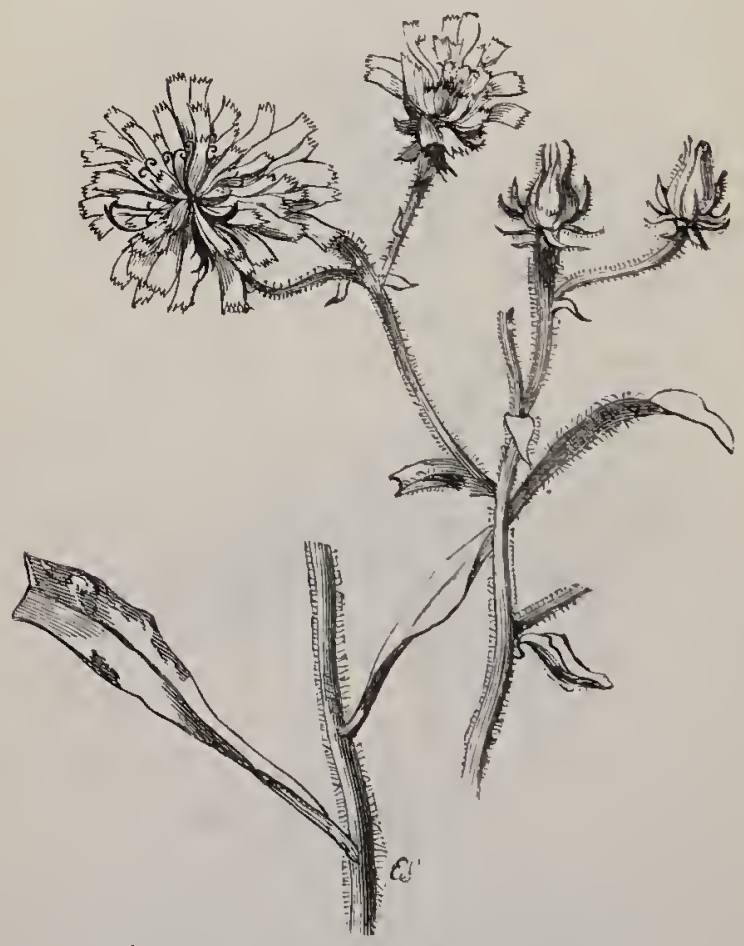

pínis heraciónes (Hawk-need Picris).

and small heads of $8-12$ yellow florets, with $]$ row of erect bracts. (Name, an old Latin name.)

1. L.comminis (Common Nipplewnt). - The only

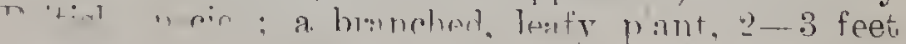


stalked; cauline leaves small, dentate; heads numerous, $\frac{1}{4}$ in. across ; bracts linear, stiff, keeled.-Waste places and hedgerows; abundant.--.Fl. July, August. Annual.

39. Pícris (Ox-tongue).-Hispid, branched plants with a milky juice; leaves mostly scattered, simple, toothed; heads of yellow ligulate florets, with bracts

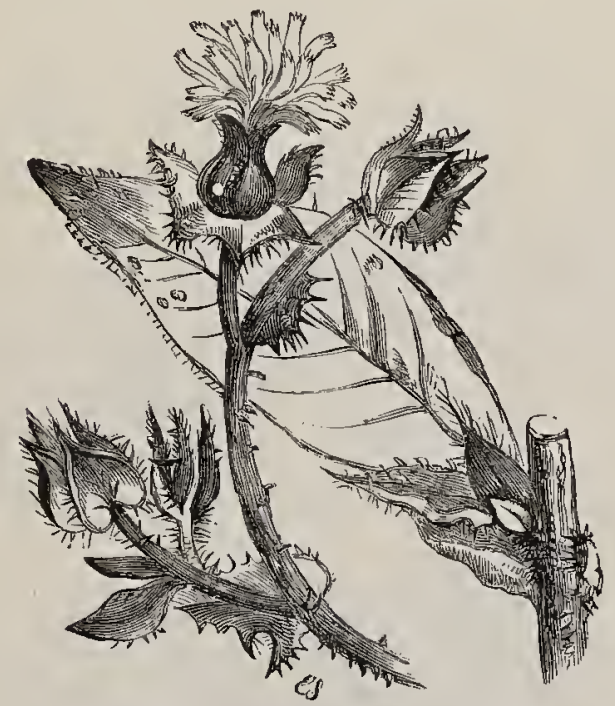

PfCRIS ECHIOĹDEs (Bristly Ox-tongue).

in 2 rows; fruit brown, curved, transversely wrinkled; pappus of 2 or more rows of feathery hairs. (Name from the Greek picros, bitter.)

1. P. hieracioüdes (Hawkweed Picris).-A slender, erect plant, 2-3 feet high, corymbosely branched above; stems rough with hooked bristles; leaves narrow, rough, and toothed; heads numerous, yellow, 1 in. across, with hracts on the peduncles.-Waste places ; common._Fl. July-September. Biennial. 
2. P. cchioüles (Bristly Ox-tongue). - A stout, much-branched plant, 2-3 feet high, well distinguished by its numerous prickles, each of which springs from a raised white spot, and by the 5 large ovatecordate bracts below each of the terminal heads of yellow flowers.-Waste places; common.-Fl. June - October. Annual.

40. CRÉPIs (Hawk's-beard). - Branched plants with a milky juice; leaves chiefly radical; heads small, in panicles, yellow, or tinged with red; bracts many, linear, in 2 rows, the outer shorter; fruit tapering or beaked; pappus of many rows of simple hairs. (Name said to be the Greek Tirepris, a slipper ; but, if so, apparently inappropriate.)

1. C. fótida (Fetid Hawk's-beard).-A hispid plant, about a foot high, branched from below ; Teares runcinate; pedunctes long, thickened upwards, bracteate; heads corymbose, drooping when in bud, $\frac{3}{4}$ in. across, bright yellow; fruits many-ribbed, with long, slender beaks, those in the centre longer.Chalky places in the south-east; rare.-Fl. June, July. Biennial.

2. C. tararacifólia. - A hispid plant, 1-2 feet high, branched above; stem ribbed and furrowed, stained with red; leaves runcinate; pectuncles very slender, not thickened above; heads erect when in bud, yellow, the outer florets brownish-red beneath; fruts slender, all equally long-beaked.-Calcareous soils; local.--Fl. June, July. Biennial.

3.* C. setósa.-Occurring as an introduced plant, chiefly in clover-fields, is hispid, $1-3$ feet high ; stem erect, branched from the base, angular, furrowed, and leafy; umper leaves large, sagittate; peduncles slender, stiff, deeply grooved, not thickened above; heads erect whon in bud; fruits slender, all equally long-beaked.Fl. July, August. Annual or biennial. 
4. C. virens (Smooth Hawk's-beard).-A variable plant, 6 in. to 3 feet in height, glabrous below; stem much branched, furrowed; upper leaves linear, sagittate; heads numerous, sub-corymbose, $\frac{1}{4}-\frac{3}{4}$ in. across,

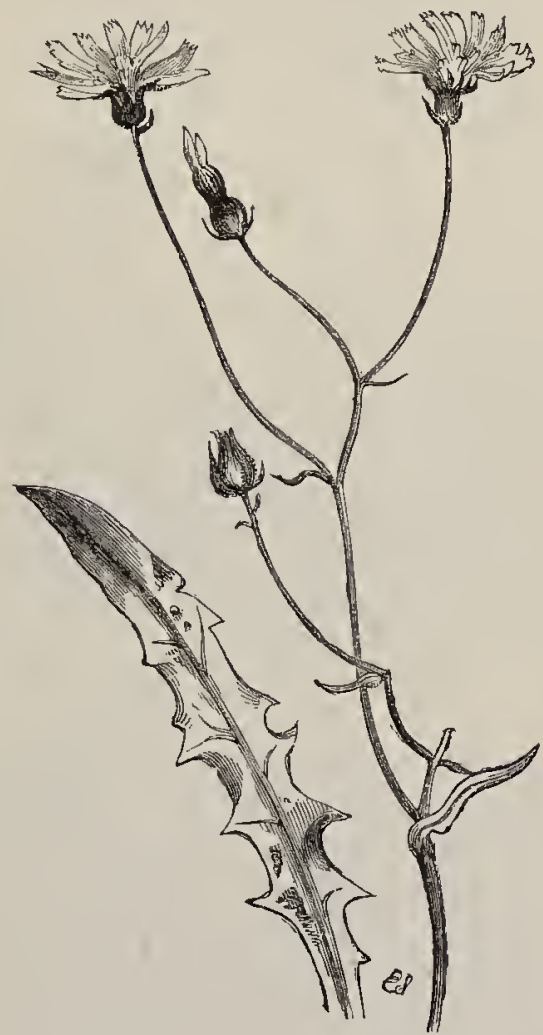

CRÉPIS VIRENS (Smooth Hawk's-beard).

yellow; outer bracts adpressed, linear, inner ones smooth within; fruit not beaked; pappus silky.Waste ground and cottage-roofs ; common.-Fl. June - September. Annual.

5. C. biénnis (Biennial Hawk's-beard). -A stout 
hispid plant, resembling $C$, tararacifólia, but not red-staincd; stem 1-4 feet high, channelled; Teaves large, runcinate, irregularly lobed; heads $\frac{3}{4}-1 \mathrm{in}$. across; outer bracts spreading, inner downy within; fruit slender, but not beaked.-Chalky soils in the south ; rare.-Fl. June, July. Biennial.

6. C. succiscéfólia (Blunt-leaved Hawk's-beard).A slender plant, 2-3 feet high; leaves oblong, blunt; heads few, yellow; bracts with glandular hairs, the outer ones short, adpressed; fruit manyribbed, not beaked.-Woods in the north; rare.-Fl. July, August. Perennial.

7. C. paludósa (Marsh Hawk's-beard).-A slender, unbranched, mostly glabrous species, about 2 feet high; stem angular, leafy ; leaves large, runcinate, with tapering points, the lower ones stalked; the upper ones heart-shaped at the base, clasping; peduncles very slender; heads few, corymbose, yellow, erect in bud; bracts with black glandular hairs; frut slender, many-ribbed, not beaked; pappus of stiff, brittle, brownish hairs. - Damp woods, mostly in the north. Fl. July-September. Perennial.

41. Hierácium (Hawkweed). -- Perennial flants with milky juice, often hairy; leaves chiefly radical; heads yellow, or rarely orange; lnaets many, imbricate, unequal; receptacle nearly flat, without scales, pitted; anthers not tailed; fruit not beaked; pappus of 1 now of stiff, brittle, unequal, simple, brownish hairs, of ten with a crenate disk below. (Name from the Greek hicrax a hawk.) The most difficult genus in a difficult Order, and one in which botanists do not at all agree as to what constitutes a species. Bentham recognised about 7 British species, Sir Joseph Hooker 12, and Mr. F. J. Hanbury enumerates 104 as species, arranged under 15 groups. This large number, most of which are rare forms from the Scottish mountains, arises 
from the recognition of minute characters which prove constant under cultivation. "Variable as the genus is," says Sir Joseph Hooker, "it is a curious fact that the sequence of the species is so obvious as to have been recognised by all botanists; and that this sequence represents to a very considerable extent the

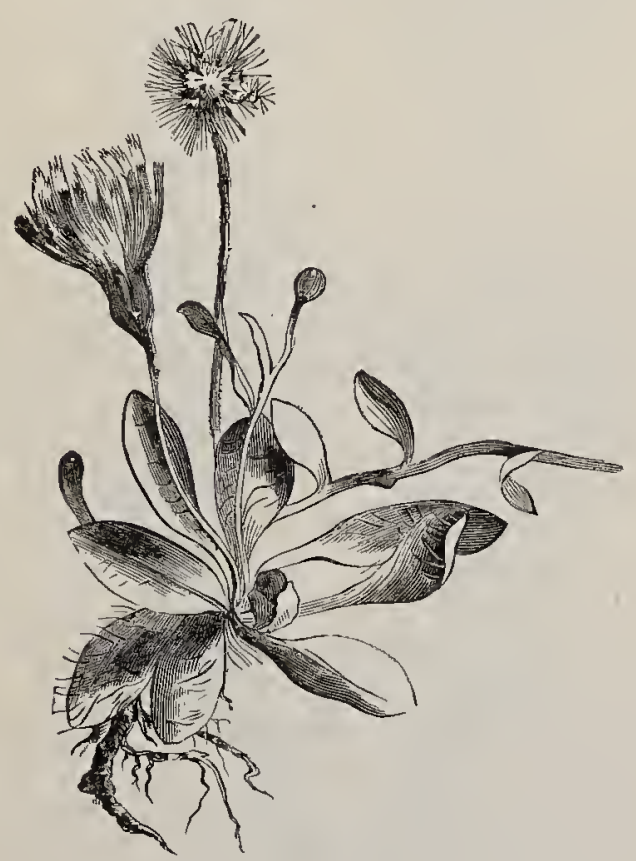

HIERÁCIUM PILr,SÉLLA (Moutse-ear Hawkweed).

spread of the species in altitude and area in the British Isles." The following are among the most common and marked types:-

1. Ir. Pilosélla (Mouse-ear Hawkweed).-A silky plant with long, soft hair: and slender leafy runners;

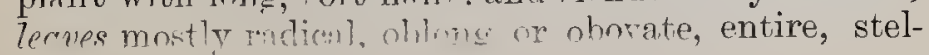


lately hoary underneath; Teads solitary, on scapes 2-10 in. high, bright lemon-yellow or reddish-brown beneath.-Dry banks; common.-Fl. May-August. Perennial.

2.* H. aurantíacum (Orange Hawkweed).-A garden escape, larger than the last, often without runners, and readily recognisable by its deep orange flower-heads which are collected in a dense corymb and have dark bracts.-Fl. June-August. Perennial.

3. H. murórum (Wall Hawkweed). - A vely variable plant, $1-2$ feet high, usually more or less hairy, sometimes glaucous, with a rosette of ovate radical leaves, and rarely more than one leaf on the stem, sometimes none; heads 2-6 together, each generally less than an inch across, yellow.-Walls, rocks, heaths ; common.-Fl. June-September. Perennial.

4. H. vulyátum (Common Hawkweed). -Another very variable plant, from $12-18 \mathrm{in.}$ high; radical leaves narrow, in a loose rosette, lanceolate, toothed, with the teeth pointing towards the apex, often spotted with red; cautine leares few; heads many, panicled or corymbose, about an inch across, yellow ; involucie hoary with down.-Woods and banks; common.-Fl. July-September. Perennial.

5. H. borećlé (Shrubby Hawkweed).-As variable as the preceding species, 2-4 feet high, with stiff, ascending branches; stem usually hairy below, with stellate down above, often reddish, leafy ; no radical leaves; cautine leaves lanceolate, toothed; heads many, in a leafy corymb; peduncles woolly ; involucre blackish-green, nearly glabrous.-Woods and banks; common.-Fl. August, September. Perennial.

6. H. umbellátum (Narrow-leaved Hawkweed).A tall, remarkably erect, nnbranched plant, 1-4 feet high; stem stiff, leafy, hairy below; leaves sessile, linear, toothed; heads in a terminal, almost umbellate, corymb, large, yollow; peduncles with stellate down, 
slender, stiff, bracteate; involucre usually dark green, glabrous, with recurved tips.- - Stony thickets; common.-Fl. July_September, Perennial.

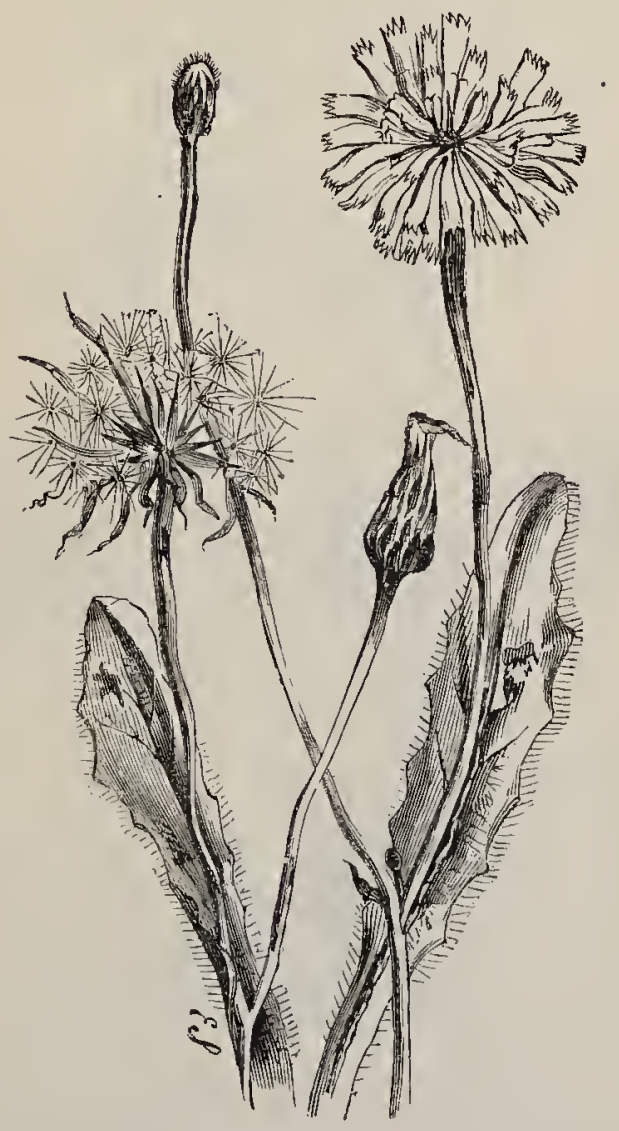

HYPOCH ÉRIS RADICÁTA (Long-rooted Cat's-ear).

42. Нуросн 质IS (Cat's-ear).-Plants with a milky juice; leaves all radical, pinnatifid ; bracts many, imbricate, oblong; receptacle flat, scaly; florets all ligu- 
late, yellow; fruit rough, beaked; pappus of 1 row of feathery hairs, usually with an outer row of short bristles. (Name of Greek origin, supposed to indicate its fitness for hogs.)

1. H. glábra (Smooth Cat's-ear). - An almost gla-

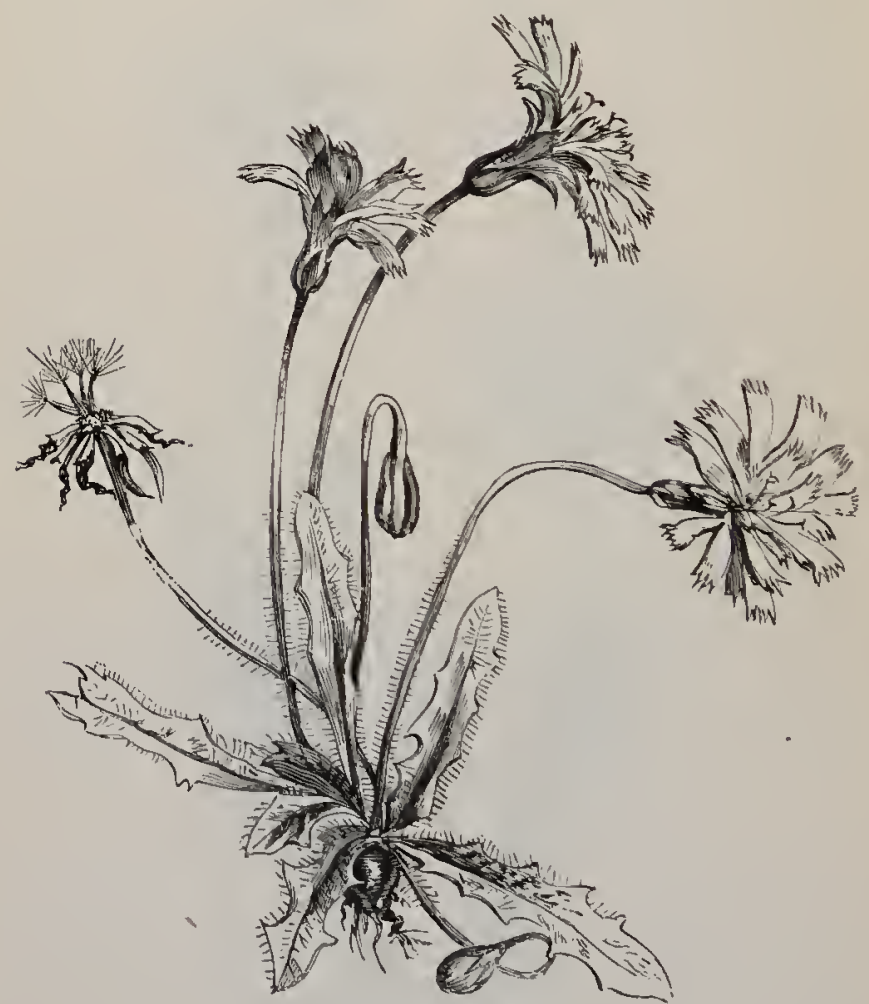

LEONTODON HíRTUS (Hairy Thrincia).

brous plant, $3-10$ in. high; leaves spreading in a circle on the ground, oblong; scapes several, branched; heads small, yellow; involucre as long as the florets. -Dry gravelly places; not common,-Fl, June-August. Annual. 
2. H. radicáta (Long-rooted Cat's-ear).--A hispid plant, about a foot high ; leaves all radical, blunt, sinuate, or runcinately pinnatifid, bristly; peduncles long, branched, smooth, slightly swollen above, and with a few scales; heads large, yellow; involucre shorter than the florets.-Hedges and waste places; common.-Fl. June-September. Perennial.

3. H. raculáta (Spotted Cat's-ear).-A hispid plant, about a foot high; leaves obovate, not lobed, toothed, rough, often spotted above; heads seldom more than one, large, deep yellow ; bracts fringed with curly hairs._Chalky and limestone hills; rare.-Fl. July, August.

43. Leóntodon (Hawk-bit)._-Herbs with milky juice; leaves all radical, obovate, toothed or pinnatifid; heacls on scapes, yellow; bracts in 2 or 3 rows, the outer smaller; receptacle flat, naked; fruit scarcely beaked, pappus of 1 or 2 rows of stiff hairs, the inner feathery. (Name from the Greek leon, a lion, octous, odontos, a tooth, from the runcinate leaves.)

1. L. hirtus (Hairy Hawk-bit or Thrincia).-A small plant, $4-6$ in. high ; leaves spreading, more or less lobed, rough, with forked or simple bristles; peduncles leafless, unbranched, somewliat hairy, often purplish; heads less than an inch across, yellow, drooping when in bud.-Dry places; common.-Fl. June-September. Biennial.

2. L. hispidus (Rough Hawk-bit)._A similarly hispid plant, often with forked hairs; leaves oblonglanceolate, runcinate; peduncles fewer, longer, more swollen above than in the preceding, green; heads $1 \frac{1}{2}$ in. across, drooping when in bud, yellow.-Meadows and waste places; common.-Fl. June-September. Biennial.

3. L. autunnális (Autumn Hawk-bit.)-A tall plant, 2-3 feet high ; leaves narrow, toothed or pin- 
natifid, only hairy on the ribs beneath; scape branched, bracteate, swollen above; heads large, erect when in

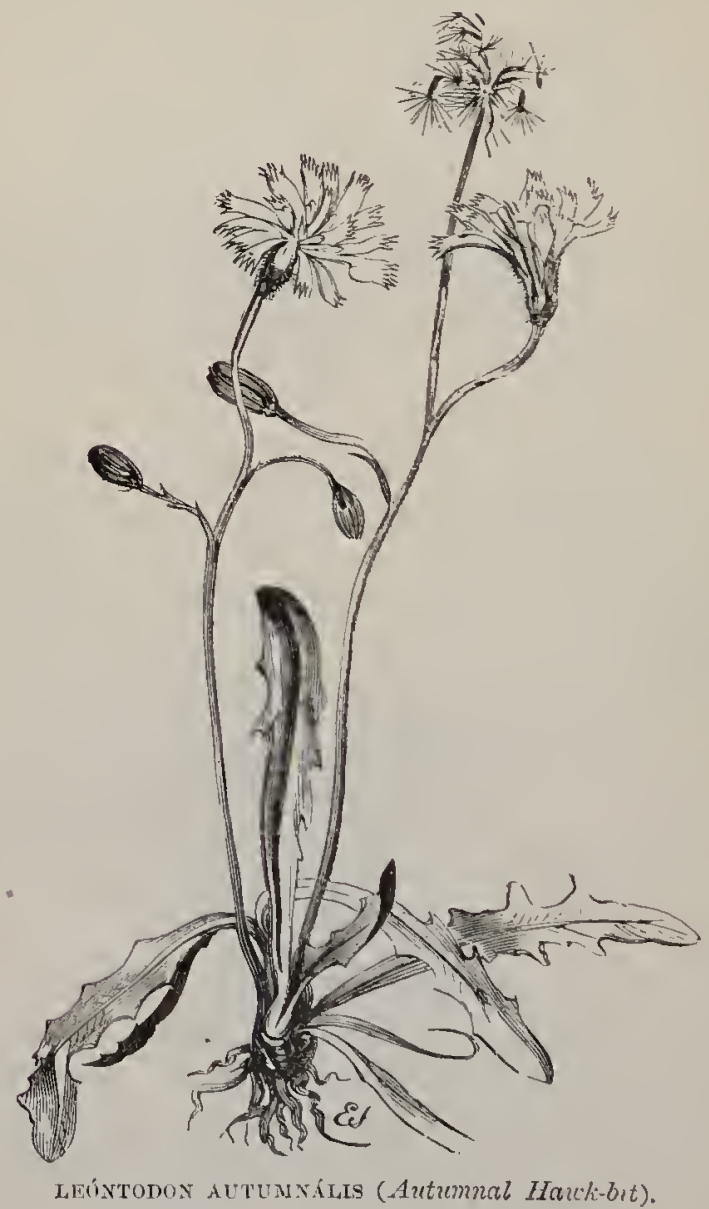

bud, deep-yellow ; papmes of a single row of brownish feathery hairs.-Meadows and comfields; abundant. - El. July-September. Perennial. 
44. Taráxacum (Dandelion).-Herbs with a milky juice; leaves all radical, runcinate; peduncles hollow, leafless, unbranched; herds solitary, yellow; bracts in 2 rows, the inner erect, the outer of ten recurved; receptacle flat, naked, pitted, becoming more convex in the fruit stage; fruit libbed, with a long, slender beak; pappus of white, silky, simple hairs in many rows.

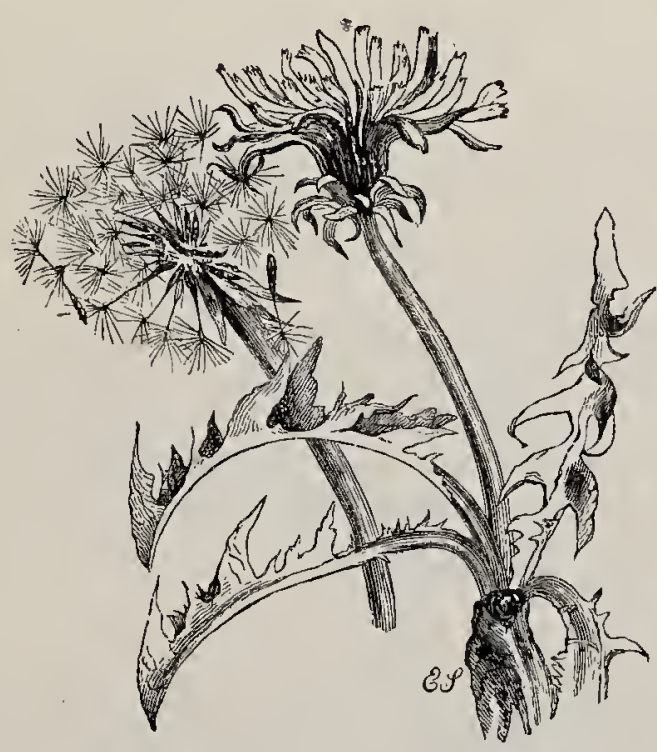

TARÁXACLM OFFICINÁLté (Common Dandelion).

(Name from the Greek, referring to its medicinal character.)

1. T. officinálé (Common Dandelion).-A nearly glabrous plant, with a long black tap-root, well distinguished by the above characters, especially the runcinate leaves, smooth, hollow peduncle, and reflexed outer bracts. The heads, when in fruit, become globular, and are known to children, who amuse themselves by blowing off the separate fruit:, as What's o'clocks, or 
Clocks. Dandelion, from the French Dent-de-lion, lion's tooth, is the name applied by the unobservant to many other yellow-flowered members of the Order. -Meadows; abundant. The dandelion is a valuable medicine, and is also eaten as a salad.-Fl. MarchOctober. Perennial.

45. Lactúca (Lettuce),-Erect, leafy herbs, with a milky juice; leaves scattered, the upper ones often auricled; heads generally small, in a panicle, yellow, or rarely purple ; bracts imbricate, the outer shorter ; receptacle flat, naked; florets usually few; fruit flattened, generally with a long, slender beak; papmus of many simple hairs. (Name of Classical origin, referring to the milky juice.)

1. L. virósa (Acrid Lettuce).-An acrid, glaucous, prickly plant, $2-4$ feet high; leaves spreading horizontally, with bristles along the mid-rib beneath, the lower ones often spotted with black, the upper ones clasping, with down ward-pointing auricles; heads small, pale yellow, in a loose, slender, spreading panicle; fruil black.-Dry banks ; not uncommon.Fl. July, August. Biennial.

2. L. Scariola (Prickly Lettuce).-A closely allied species, less prickly, with more erect branches and leares, the upper leaves sagittate and clasping, grey firuit and a less acrid juice.-Waste places; rare. This may be tho origin of the Garden Lettuce (L. satina).-Fl. July, August. Biennial.

3. L. saliyna.-A slender, less bristly, almost glabrous plant, with upper teaves linear, entire, acuminate, hastate at the base, and heads in lateral tufted clusters. -Chalky places in the south-east, especially near the sea ; rare.-Fl. July, August. Biennial.

4. L. murális (Ivy-leaved Lettuce). - A slender, glabrous plant, $1-2$ feet high, leafy below ; stem round, hollow; leaves lyrately pinnatifid, variously 
COMPOSITE FAMILY.

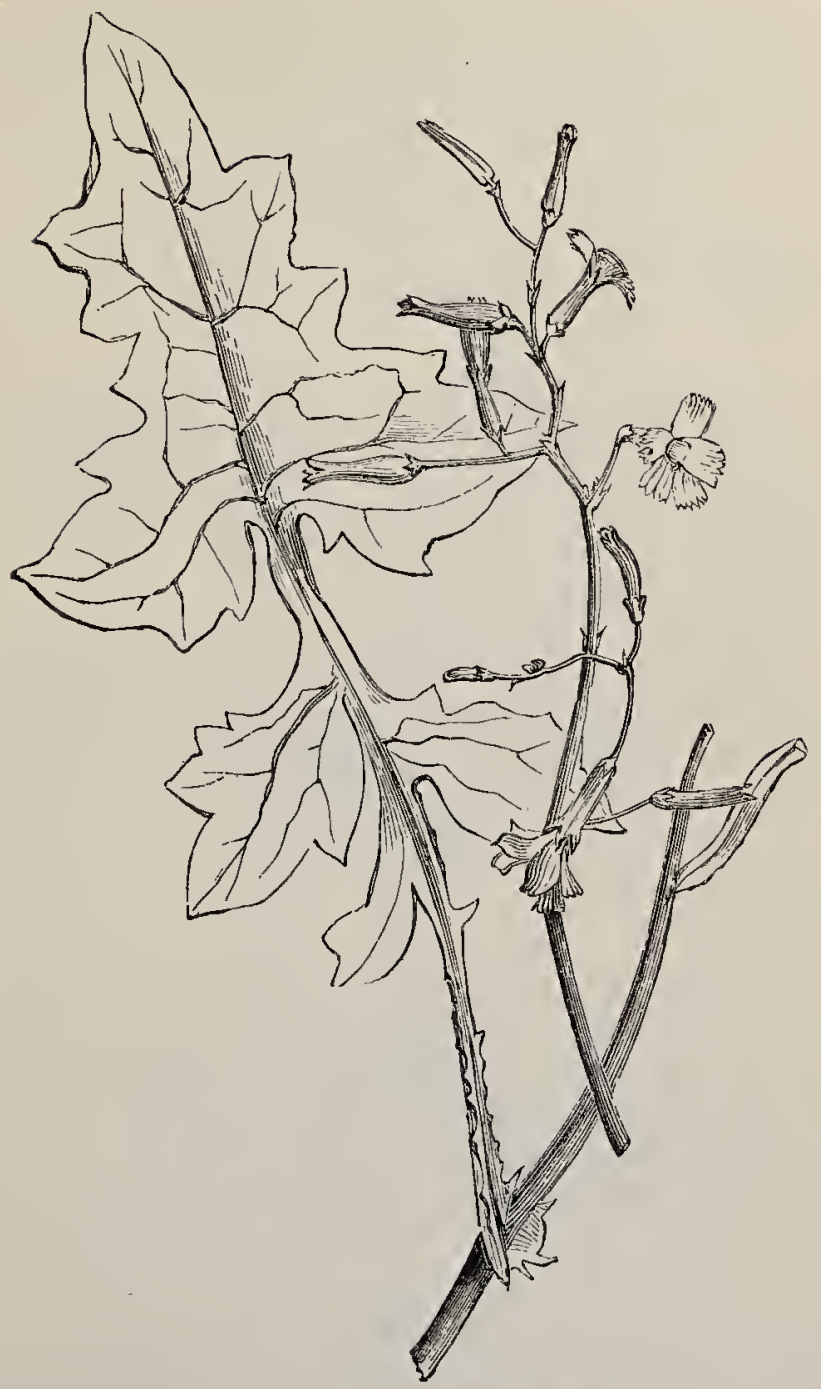

ZAOUÚCA MURAXIS (Ivy-leaved Lettuce). 
cut, glaucous beneath, auricled; heads small, yellow, in a slender, angular, spreading panicle, each containing 5 florets, and so resembling a flower with 5 petals; fruit black. -Old walls and woods; not uncommon.Fl. June-September. Biennial.

5. L. alpince (Blue Sow-thistle). - A very handsome plant, about 3 feet high, succulent, unbranched, and leafy, with pale blue heads, 1 in. across; in a raceme, grows on the Clova mountains, but is rare.

*46. Prenínthes is represented by the one species $P$. purpúré, an erect, unbranched plant with oblonglanceolate leaves, amplexicaul, slightly toothed, and glaucous beneath, and drooping heads of purple florets on peduncles, which is naturalised in some Scottish localities. Perennial.

47. Sóncuus (Sow-thistle).-Merbs with milky juice, generally succulent; laves scattered, toothed or pinnatifid; heads yellow, in corymbs : bracts imbricate in several rows; receptacle tlat, naked, pitted; fruit much flattened, not beaked; pamms of many rows of white, simple, silky hairs. (Name of Greek origin, said to refer to its juice being wholesome; but this is doubtful.)

1. S. oleráceus (Common Sow-thistle, Milk-thistle). -Usually glabrous, 2-3 feet high, erect, branched; stem hollow; leaves more or less pimnatifid, toothed, often prickly, the upper ones clasping, with spreading sagittate auricles; firut ribbed and transversely wrinkled.-Wasto places, and as a weed in gardens; common. This plant is a farourite food for rabbits. -Fl. June-August. Annual.

2. S. ásper (Rough Sow-thistle) las more spinously-toothed zeaves with rounded auricles, and ribbed, but not transversely wrinkled, fruit. - It occurs under the same circumstances as the preceding, and is almost as rommon.-Fl. June-August. Annual. 
3, S. arvênsis (Corn Sow-thistle).--Stem 2-4 feet high, tubular, angular, usually unlranched below; leaves variable, waved, almost spinous, glaucous beneath, the lower ones runcinate, heart-shaped at the

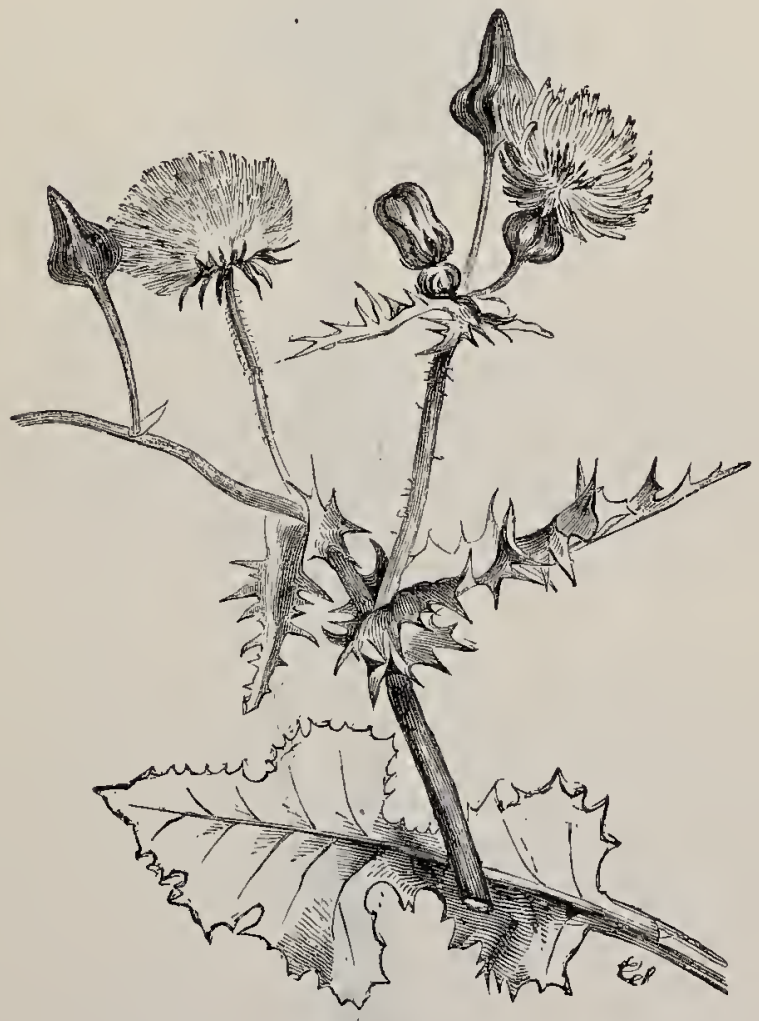

SóNCHUS OLERÁCEUS (Common Sonv-thistle, Mill-thistle).

base, the upper ones with rounded aurictes; heads corymbose, large ; involucre and peduncles hairy with glandular hairs. - In similar situations with the last, from which it may be distinguished by its much 
larger flower-heads and generally unbranched stem.Fl. August, September: Perennial.

4. S. paluistris (Marsh Sow-thistle).-A much

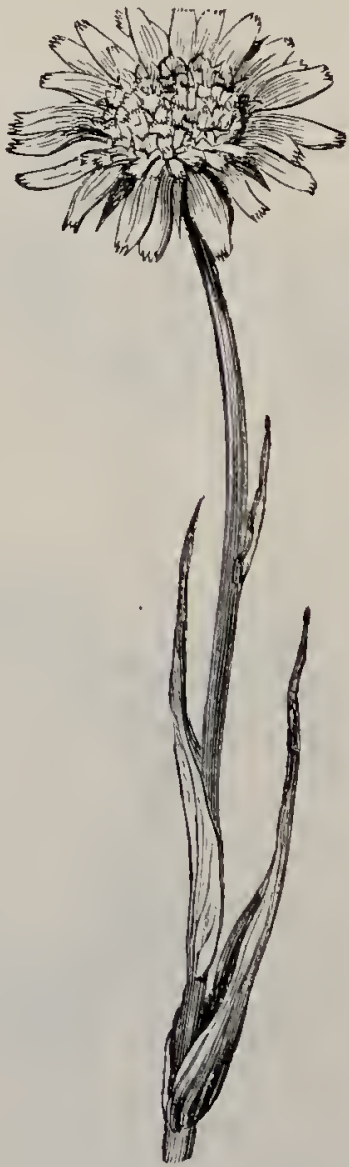

TRAGOPÓgON PRATÉTs: ( Iellow Gont's-beard).

taller plant than either of the preceding, growing 4-7 feet high, unbranched; Tecoves narrow, arrowshaped at the base, finely toothed; heads corymbose, 
large, lemon-yellow; involucre and peduncles hairy with glandular.hairs.-Marshes in the south-east; very rare.

48. Tragopógon (Goat's-beard).-Erect, glabrous, generally unbranched herbs with a milky juice; leaves scattered, entire, sheathing; heads solitary, yellow or purple; bracts 8-10, long, narrow, in one row, united below; receptacle naked; fruit with longitudinal ridges and a long, slender beak; pappus of many rows of feathery hairs. (Name from the Greek tragos, a goat, porgon, a beard.)

1. T. praténsé (Goat's-beard, Jack-go-to-bed-atnoon).-An erect, glaucous plant, about 2 feet high, with very long, tapering, channelled, grass-like leaves; flower-stalks slightly thickened above; involucre about as long as, or longer than the florets; heads solitary, large, yellow, closing at noon; pappus feathery, on a long stalk, interlaced so as to form a kind of shallow cup.-Meadows and waste places; common.-Fl. June, July. Biennial.

2.* T' porrifolium (Salsify), resembling the last, but with purple heads, though not a British species, is occasionally found in moist meadows. It was formerly much cultivated for the sake of its fleshy taproot, which was boiled or stewed, forming a very delicate esculent; but its place is now supplied by Scorzonéra hispánica.

$\S \S$ Stamens on the ovary (epigynous).

Ord. Xlit. Campanulácea.-The Bell-Flower Family.

A considerable Order of herbaceous or slightly shrubby plants, with a bitter, acrid, milky juice, 
which chiefly inhabit the temperate regions of the Northern Hemisphere. They have mostly scattered, exstipulate leaves and conspicuous blue, white, or rarely red, flowers, which, except in the genus Lobetia, are polysymmetric. The sepals, petals, and stamens. are 5 each, the caly, $x$ being gamosepalous, superior, and persistent, the corolla epigynously calycifioral, polysymmetric, except in Lobélia, and withering on the fruit, and the stamens alternating with the lobes of the corolla, and in Jasioné and Lotétia united by their anthers. There are $2-5$ carpels united in a 1,2 , or more-chambered inferior orary, with a single hairy style, simple or lobed stiyma, and numerous outes in each chamber, the placentation being axile. The fruit is a dry capsule, crowned by the withered calys and corolla, and splitting, or opening by valves, at the side or top. Many species of the Order are highly ornamental ; but few are valuable either as food or medicine. The roots of Cumpanula Rapinculus were formerly cultivated for the table, under the name of Rampions or Ramps. Lobetia is more acrid than the other genera, the rare British species $L$. urens, deriving its name from the blistering properties of its juice. The Nortl American species, L. inflata (Indian Tobacco) is useful in small doses in asthma, but in large doses is a powerful emetic and narcotic poison. L. cardinatis (Scarlet Cardinal), one of our most brilliantly-coloured garden flowers, is also very acrid. Some species of this genus contain a good deal of caoutchouc.

1. Lobília.-Corolla bi-labiate, the upper lip split to the base of the tube; anthers coliering in a tube.

2. J.sioni:- H7owers in lieads; corolla rotate with linear lobes; anthers united at the base.

3. Waulenbénaia.-Corolla polysymmetric, campanulate, 5-fid ; anthers free; capsule half-superior, 3-chambered, opening by valves at the top.

4. Phyteúisa.-Corolla polysymmetric, 2-lipped, 
with 5 long linear segments; anthers free; copsule 2 -3-chambered, bursting at the sides.

5. Campánula.-Corolla polysymmetric, campanu-

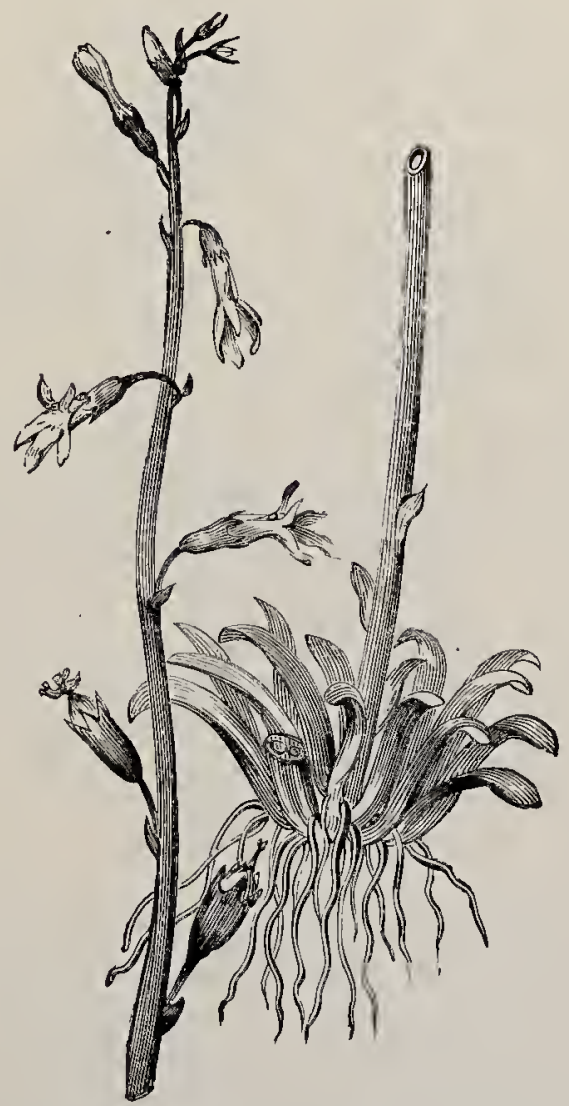

LOBELIA DORTMÁNA (Water Lobelia).

late, 5-fid; anthers free; capsule 3-5-chambered, opening by lateral pores below the sepals.

6. Serculária. - Corolla polysymmetric, rotate; 
anthers free; capsule long, 3 -5-chambered, opening by lateral pores between the sepals.

1. Lobécta.-Herbs with their flowers in telminal racemes; calyx superior, 5-fid; corolla bi-labiate, the upper lip split to the base into 2 erect or recurved lobes, the lower with 3 pendulous lobes; stamens 5, epipetalous, with united anthers; capsule 2-3-chambered, 2-3-valved. (Name from Matthias de Lobel, a Flemish botanist of the sixteenth century, who lived for many years at High gate.)

1. L. Dortmánna (Water Lobelia).-A submerged aquatic plant, forming a matted base at the bottom of the water; leares all radical, almost cylindrical, of 2 parallel tubes; scape slender, erect, cylindric, almost leafless, hollow, rising above the water; flowers distant, drooping, pale lilac, bracteate-Mountain lakes with gravelly bottoms.-Fl. July, August. Perennial.

2. L. úrens (Acrid Lobelia). - Stem angular, leafy, witl an acrid, milky juice; lea'es obovate, toothed; fourers purple, erect or spreading, with long bracts. A heath near Axminster, Deron; very rare.-Fl. August, September. Perennial.

2. Jasíoni (Sheep's-bit).-Herbs with both radical and cauline leaves; flowers small, in terminal heads, with an involucre of many bracts; celly.u 5 -fid ; corolla rotate, deeply diviled into 5 linear lobes; stamens 5 , united by their anther's; cupsule 2 -chambered, 2-valved. (Name of uncertain origin.)

1. J. montánce (Sheep's-bit, Sheep's Scabious).The only British species, about a foot high, and strongly resembling a Scabious or one of the Composito, but differing from the former in its united anthers, and from the latter in its 2-chambered 
capsule. The leaves are oblong, bunt and hairy; the heads of flowers lilac-blue.-Dry heathy places; common. The whole plant, when bruised, has a

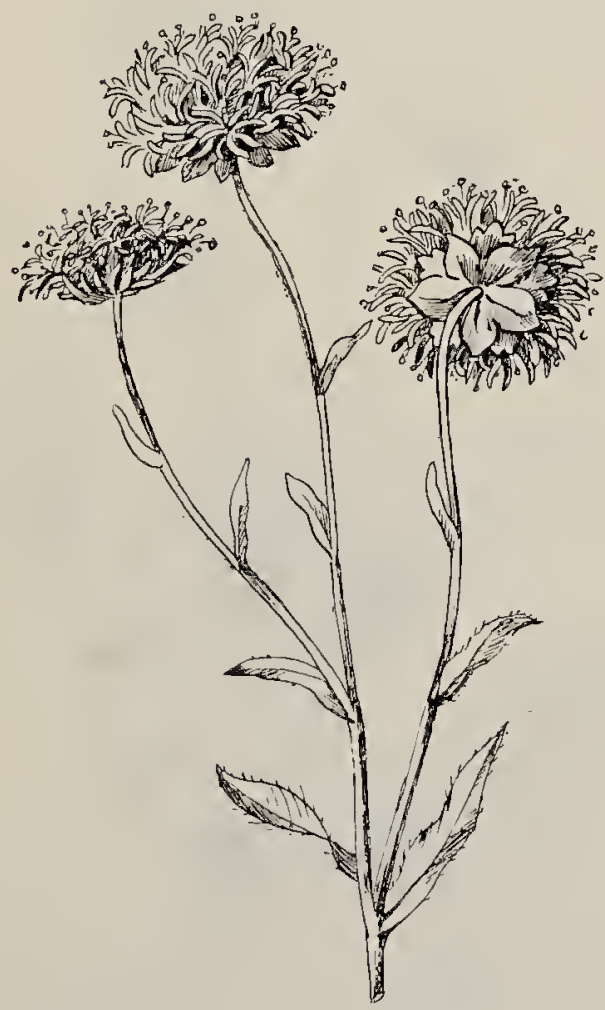

JAsLoNÉ MONTAXA (S̄heep's Scabionts).

strong and disagreeable smell._Fl. June -September. Perennial.

3. Wahlenbérgia (Ivy-leaved Bell-flower). - A slender herbaceous plant, closely resembling the genus 
Campánula, with a campanulate, 5-fid corolla and 5 free anthers; but with a half-superior ovary which splits when in fruit by valves above the sepals. (Named

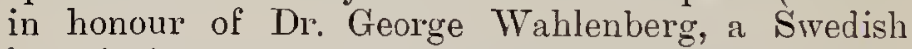
botanist.)

1. IV. Tederácea (Iry-leaven Bell-flower).-An

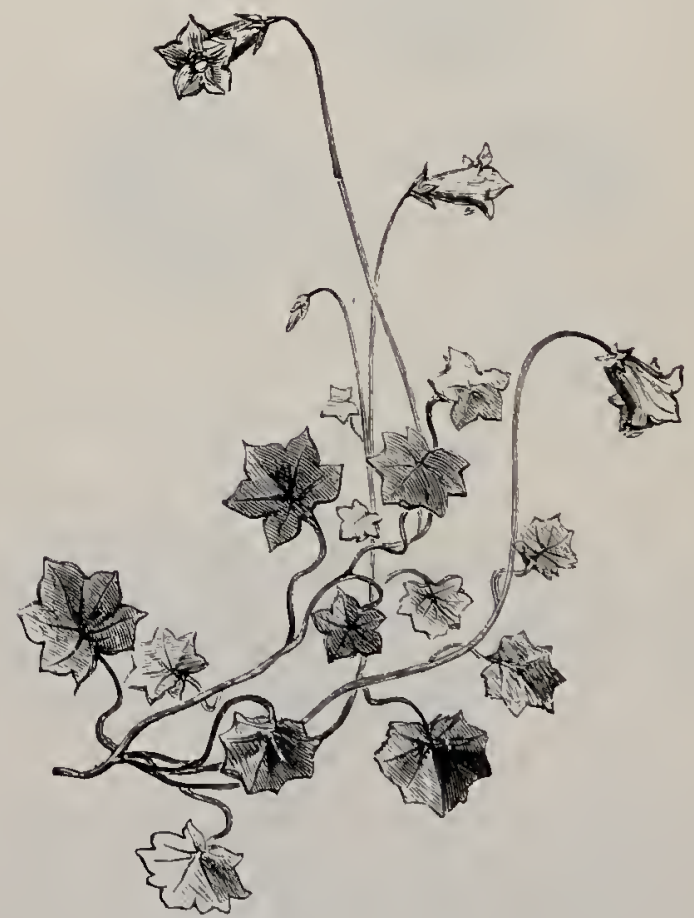

WAHLENBÉRGIA HEDERICEA (T'y-leaved Bicll-flower).

exquisite little plant with straggling, thread-like stems, $4-6$ in. high, or when among grass or ruslies climbing by their help to a height of $12 \mathrm{in}$. or more; leaves stalked, palmately 5-lobed, of a remarkably fine texture and delicate green; flowers solitary, on long stalks scarcely thicker than a hair, slightly drooping, 
pale blue.-Wet peaty places in the south, of ten growing with the Bog Pimpernel and the Cornish

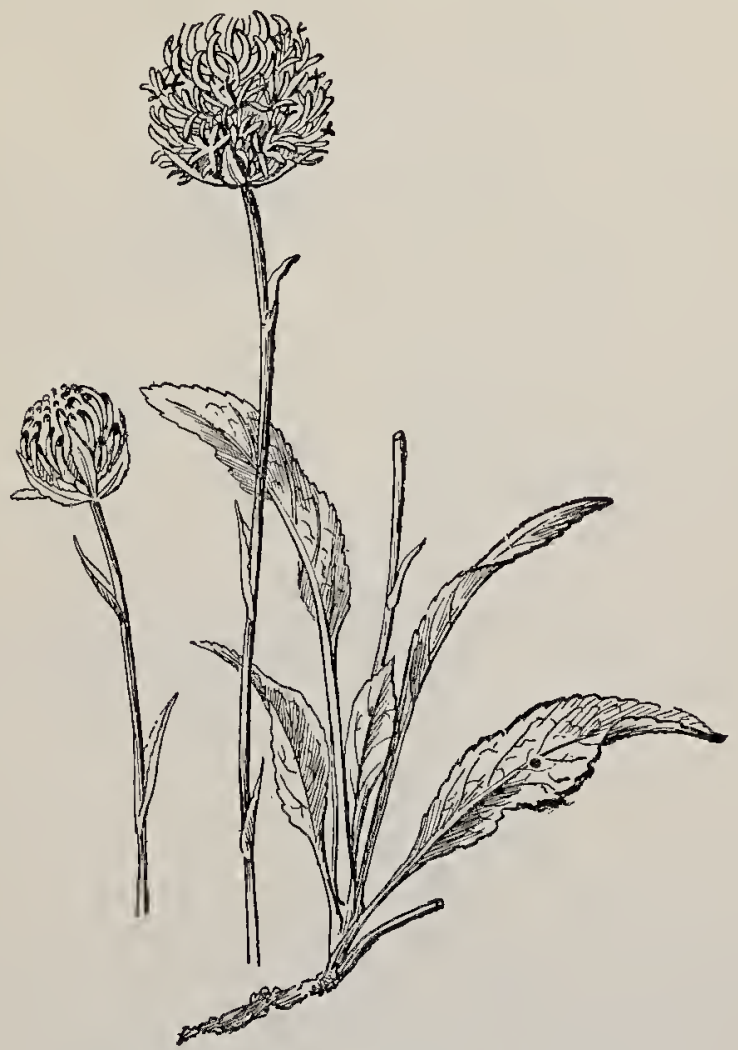

PHYTECMA OREICULARÉ (Round-heaáti Kampion).

Moneywort, plants scarcely less beautiful than itself. -Fl. July-September. Perennial.

4. Phyteúma (Rampion).--Herbs with both radical and cauline leaves and flowers in dense spikes or heads, with an involucre of several bracts; calyx 
superior, 5-fid ; corolla polysymmetric, rotate, deeply divided into 5 long linear segments; filaments broad at the base; unthers free; capsule 2-3-chambered, bursting at the sides. (Name apparently connected with the Greek pluton, a plant.)

1. $P$. orbiculáré (Round-headed Rampion).-A singular plant, consisting of a solitary, erect, leafy stalk, about a foot high, with stalked, ovate, crenate radicul leaves and few sessile, linear, cuutine ones; flowers deep blue in a globose terminal head, which becomes oblong when in fruit.-Chalky downs in the south-east; local.-Fl. July, August. Perennial.

2. P. spicátum (Spiked Rampion). - A taller species with oblong heads of cream-coloured flowers, formerly cultivated for the sake of its edible root, is found only in Sussex._Fl. May_July. Perennial.

5. Campánula (Bell-flower).-Herbs with usually stalked radical leaves; cautine leaves scattered; caly. $2^{\circ}$ superior, 5 -fid; corolla bell-shaped, with 5 broad and shallow lobes; filaments broad at the base; anthers free; capsule not elongated, 2-5-chambered, opening by lateral pores below the sepals. (Name, a diminutive from the Latin campana, a bell.)

1. C. glomerita (Clustered Bell-flower).-A stiff, erect plant, 3-18 in. high; stem simple, roughish, leafy; leaces crenate, lough, the lower stalked and heart-shaped at the base, the upper sessile, embracing the stem; flower's nearly sessile, deep violet-purple, funnel-shaped, erect, in terminal and axillary clusters, each $\frac{3}{4}$ in. across.-Dry pastures, especially on a chalky soil; frequent._Fl. July-October. Perennial.

2. C. Trachélium (Nettle-leaved Bell-flower, Wild Canterbury Bells). - A remarkably rough plant, 2-3 feet high, with angular stem; leaves very like those of the nettle, strongly serrated and bristly, stalked, ovate-lanceolate, acute; flowers in axillary clusters of 
2-3, on short stalks which are recurved when in fruit, large, $\frac{3}{4}$ in. or more across, blue-purple, lighter than C. glomeráta, bell-shaped.-Woods and hedges; frequent.-Fl. July-October. Perennial.

3. C. latifólia (Giant Bell-flower).-A stout species,

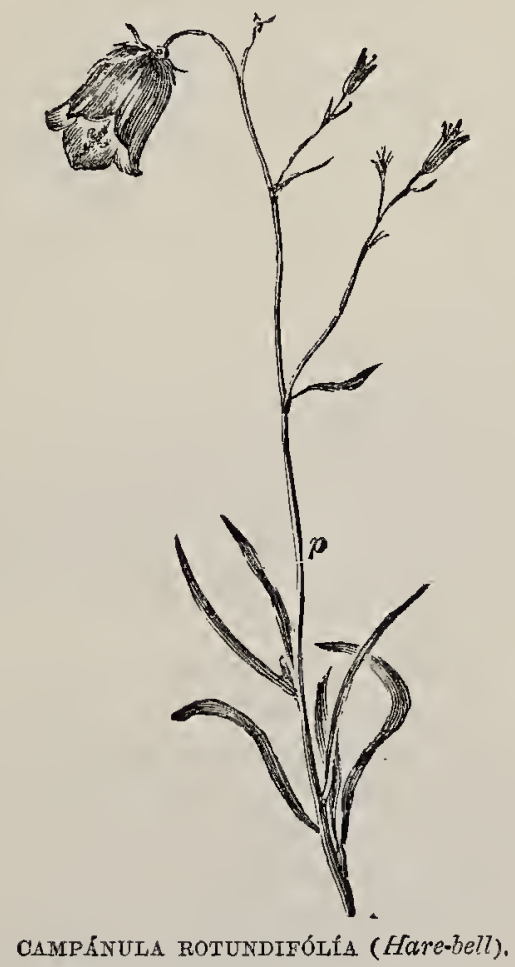

3-4 feet high, with furrowed stem; leaves ovatelanceolate, acuminate, doubly-serrate, hairy, lower ones stalked; flower's very large, stalked, bell-shaped, deep blue or white, hairy within.-Woody glens in Scotland; common; less common in England.-Fl. July, A ugust. Perennial.

4. C. rapunculoúdes (Creeping Bell-flower). - A 
downy plant, $1-2$ feet ligh, with runners; lectres unequally crenate-serrate; flowers in a loug raceme with small bracts, large, briglıt blue, drooping, all on one side of the stem.--Hedges; very rare. - Fl. July, August. Perennial.

5. C. rotunclifólía (Harebell).-A glabrous plant, with a slender, angular stem; radical leaves, roundisl, kidney-shaped, notched, stalked, very soon withering; cauline leaves very narrow, tapering; flowers in a raceme, drooping, about an inch across, light blue, or rarely white.-Heaths and dry places; abundant. This species is the Bluebell of Scotland; but the name Harebell is sometimes incorrectly applied to the Wild Hyacinth, the Bluebell of England (Scitla festátis). The specific name rotunctifólia (roundleaved) seems inappropriate when we only look at the cauline leaves, which are long and narrow; but is peculiarly applicable to the radical ones, as they appear in winter or early spring, at which season Linneus is reported to have noticed them on the steps of the University at Upsala.-FI. July-September. Perennial.

6.* C. persicifólía, a glabrous species, $1-2$ feet high, with round stem, with runners; smooth, feathery, slightly serrate, narrow leaves; large, of ten solitiry, blue or white flowers witl entire lanceolate sepals, occasionally occurs as a naturalised plant in woods. Fl. July, August. Perennial.

7. C. Rapinculus (Rampion).-A tall species, 2-3 feet ligh, with angular stem and clustered panicles of rather small, erect, pale blue flower's with awl-shaped recurved sepals.-Gravelly and sandy places in the south; local.-Fl. July, August. Biennial.

8. C.pátula (Spreading Bell-flower), distinguished by its rough stem, loose panicles of wide, cup-slaped, purplish-blue flowers and awl-shaped sepals toothed at the base.-Hedges and copses, chiefly in the west; local.-Fl. July, Angust, Biennial. 
6. Speculária (Venus' Looking-glass). - Small herbs with purple or white flowers; coinolla polysymmetric, rotate; anthers free; capsule long, 3-5-chambered, opening by lateral pores above the middle or between the sepals. (Name from the Latin speculum, a mir'or, from its bright flowers.)

1. S. hijbrida (Wild Venus' Looking-glass). - A small plant, 4-12 in. high, with a rough, wiry, angular, seldom-branched stem; oblong, rough, wavy leaves; small, terminal flowers with a caly, much longer than the purple rotate corolle; and an elongated, generally triangular capsule tapering at both ends.Cornfields, chiefly in the south.-Fl. June--September. Annual.

\section{Orid. Xliti. Vaccinícees.-The Cranberry Family.}

Small shrubby plants, inhabiting temperate regions, especially mountainous and marshy districts. Leaves scattered, simple, often evergreen; caly $x$ superior, of 4-6 lobes, which are sometimes so small as to be scarcely perceptible; corolla 4-6-lobed, urceolate, bell-shaped or rotate; stamens 8-12, free, epigynous; anthers opening by 2 terminal pores, and often furnished with 2 bristle-like appendages which act as lever's in the process of insect-pollination; ovary 4-10-chambered, surmounted by a flat disk; style simple; fruit a true berry, juicy; seeds small, many in each chamber of the ovary. By some botanists these plants are placed in the same Order as the Heaths, from which they differ chiefly in having an inferior ovary. The leaves and bark are astringent, the berries slightly acid and agreeable to the taste. Cranberries, the fruit of Schollera Occycócus and S. mucrocurpus, are largely imported, the former from Russia, the latter from Clicago, for making 
tarts. Several members of the Order are cultivated for their pretty flowers.

1. Vaccínicu.-Corolle campanulate or urceolate, 4-5-fid.

2. Schóllera.--Corolla rotate, with 4 linear, reflexed segments.

1. Vacciniur (Whortleberry).-Low shrubs with scattered, often evergreen, lecues : caly.x superior, 4 -5-lobed, sometimes with the lobes so short as to be scarcely perceptible; corolla campanulate or urceolate, 4-5-fid; stamens 8-10; anther-chambers prolonged upwards into tubes ending in pores; berry globose, 4-5-chambered, many-seeded. (Name of doubtful etymology.)

1. T. Vítis-İ́cu (Cowberry, Red Whortleberry). - A low, straggling shrub with evergreen inversely egg-shaped leates, resembling those of the Box, dotted beneath, the inargins rolled back; flowers pink, in terminal crowded drooping clusters; corolla 4-cleft; anthers without bristles; beries red.-Nountainous heaths, chiefly in the nortl.-Fl. June, July. Perennial.

2. T. uliyinósum (Bog Whortleberry, or Great Bilberry).-Stcm woody, rounded; leares not evergreen, inversely egg-shaped, entire, glaucous, and strongly veined beneath; flowers small, pale pink; anthers with two bristles at the back; berry small, dark blue, glaucous.-Mountainous bogs in the north. -Fl. May, June. Perennial.

3. V. Myrtillus (Whortleber'y, Bilberry, Whinberry).-A small branched shrub, 6-18 in. higl); stem acutely angular'; teures not evergreen, egg-shaped, cerrate; flowers solitary, drooping, nearly globular, Hesh-coloured, wax-like, larger than in the last; anthers with two bristles; berny dark blue, glaucous, larger than in the last.-Woods; abundant. The 
berries, which are popularly known as whorts, have an agreeable taste, and are often made into tarts; but

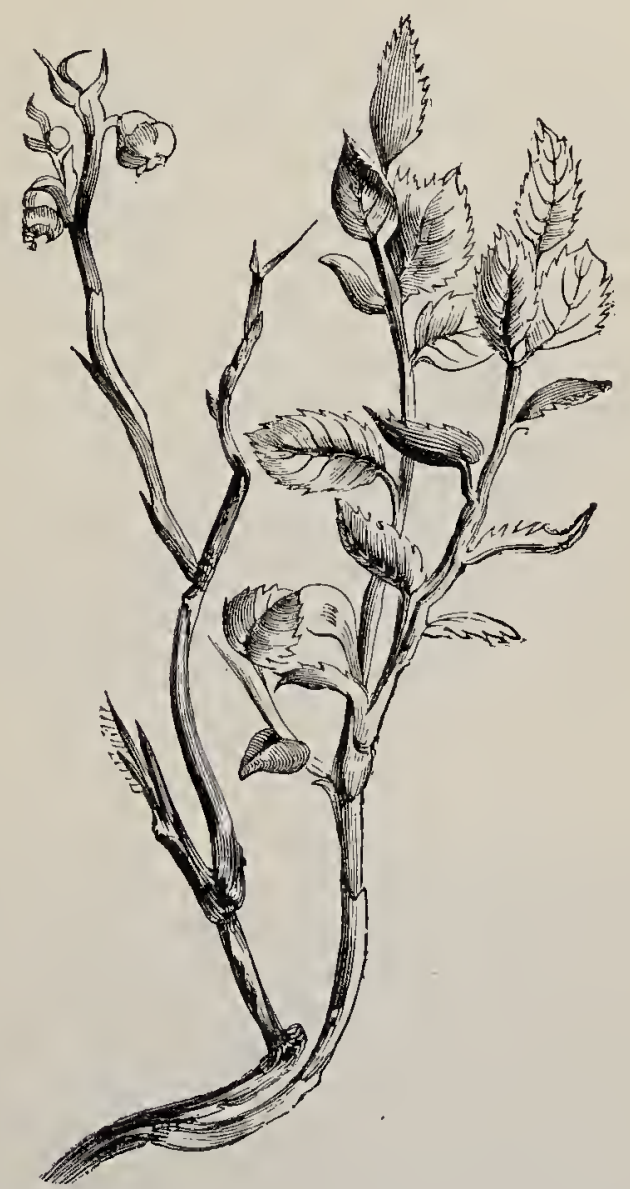

VACCLIUI MYRTÍLIUS (Whortlcbery, Bilbery, Whinberry).

when thus used are rather mawkish unless mixed with some more acid fruit. - Fl. April - June. Perennial. 
2. Schólufera (Cranberry.) - Sleuder, woody undershrubs, with small, scattered, evergreen leaves; terminal, drooping flowers ; caly.e 4-lobed; corolla rotate, with 4 linear, reflexed segments; stamens 8 ; anthers without bristles, the chambers prolonged into tubes; berry globose, 4-chambered, many-seeded. (Name in honour of Frederic Adam Scholler, a Saxon botanist.)

1. S. Occycóccus (Cranberry, Marsh Whortleberry). -A very low plant, with very slender, straggling, wiry, prostrate stems, rooting at intervals ; Teaves evergreen, egg-shaped, revolute, glaucous beneath ; flower's solitary, terminal; corolla bright red, rotate, with 4 long, linear, reflexed segments; lerrics dark red.-Pent-bogs, principally in the north.-Fl. JuneAugust. Perennial.

\section{Series II. IIYPóGTNA-Orn, XLIV.-LXI.}

\section{Orary superior.}

$\S$ Stamens free.

Ord. Xliv. Ericáce.e-The Неath Fanily.

A large Order, mostly of shrubs and small bushy trees with evergreen, often rigid, mostly opposite or whorled, simple teares. Many of them are remarkable for their "social" nature, large tracts of country being often entirely covered with a few species, and known from this as "heaths." They are most abundant in South Africa, and are, therefore, often called "Cape plauts" by gardeners; whilst other genera are so distinctively North American as to give rise to the namo "American garden," for borders in which they aro grown. They are common also in South America, in Europe, and in the mountainous parts of 
Asia, chiefly outside the Tiopics. Their flowers are mostly polysymmetric ; the caly, $x$ inferior, $4-5$-cleft, persistent; rorolla hypogynous, usually urceolate or campanulate, 4-5-cleft, often withering and remaining attached to the plant; stamens equal in number to the segments of the corolla, or twice as many, inserted witl the corolla, or slightly attached to its base; anther's opening by pores, and generally furnished with two bristle-like appendages; overy superior, many-chambered, many-ovuled, with a hypogynous disk; style single, straight; fruit 3-5-chambered, dry or succulent, many-seeded. The extensive genus Enica (Heath) contains no species possessing useful properties; but briar-root pipes are made from $E$. arborea, the name briar being a corruption of the French bruyère. The Common Ling, or Heather (Calluna Erica), is astringent, and is sometimes used in dyeing; its tough branches are a common material for brooms; its flowers are a favourite resort of bees; and its buds, shoots, and seeds enter largely into the food of moor-fowl. Of the plants belonging to the Order which produce juicy, berry-like fruits, the fruit is, in some instances, edible. Árbutus Únedo bear's an abundance of handsome fruits, which, when thoroughly ripe, are not unpalatable, and which, from their ontward resemblance to strawberries, give the plant its English name, Strawberry-tree. Some species, especially of Kálmia and Azalea, possess dangerous narcotic properties. The Canadian partridge is stated to be poisonous to human beings after feeding on Kalmia berries, and the honey which poisoned Xenophon's Greeks during the famous retreat of the Ten Thousand was probably that of Azalea pontica, which still grows on the shores of the Black Sea and is known to possess this property.

1. Árburus.-Leares broad; corolla globose, deciduous; stamens 10 ; fruit fleshy, tubercled, 5-chambered, many-seeded. 
2. Anctostáphyzos. - Fruit fleshy, smooth, 5chambered, 5-seeded; otherwise like Arbutus.

3. Andrómeda.-Fmit a dry, 5-chambered, 5 -ralved capsule; otherwise like Ábutus.

4. CamLóna.-Leaves small; sepals 4, coloured, longer than the corolla; corolln bell-shaped, 4-cleft, persistent; stamens 8 ; capsule 4-chambered, septicidal; seeds. few in each chamber.

5. ERíca.-Leaves small; sejals 4; corolla bellshaped, tubular, or urceolate, 4-cleft, persistent; stamens 8; capsule 4-chambered, loculicidal; seerls many in each chamber.

6. Loiseleúris.--Leares small; sepals, petals, and stamens 5 each ; corolla bell-shaped, deciduous ; capsule $2-3$-chambered, septicidal.

7. Bryántuus.-Sepals 5 ; corolln urceolate, 5-fid, deciduous; strmens 10 ; capsule 5-chambered, septicidal.

8. Borĺtтa.-Sepals 4; corolla urceolate, 4-fid, deciduous; stamens 8 ; capsute 4-chambered, septiciditl.

9. Pínoua.-Herbs; lennes chiefly ladical, broad; seprots 5; pretals 5, free, incurved; stamens 10 ; crppsule 5 chambercel, loculicidal.

10. Monuses.-Petals united; anthers prolonged into tubes; otherwise mainly like Pýrola.

1. Ándurus (Strawberry-tree).-Trees or shrubs with scattered, broad, usually evergrcen leaves; flowers in terminal panicles, 5-merous ; corolla globose, deciduous ; stamens 10 ; frut fleshy, tubercled, 5-chambered, many-seeder. (Name, the Classical Latin name of the plant.)

1. A. Unedo (Strawberry-tree).-A beautiful erergreen tree with a rough, reddish bark; large, elliptical, tapering, smooth, serrate, deep-green leares; numerous terminal clusters of drooping creamy-white 
flowers; and nearly globular, scarlet, berry-like fruits, rough with minute hard grains.-A - About the lakes of Killarney, abundant and truly wild; common in English gardens, and naturalised about Clifton. The flowers are in full perfection when the fruit of the preceding year is ripening; and then the tree presents its most attractive appearance. The fruit is so much

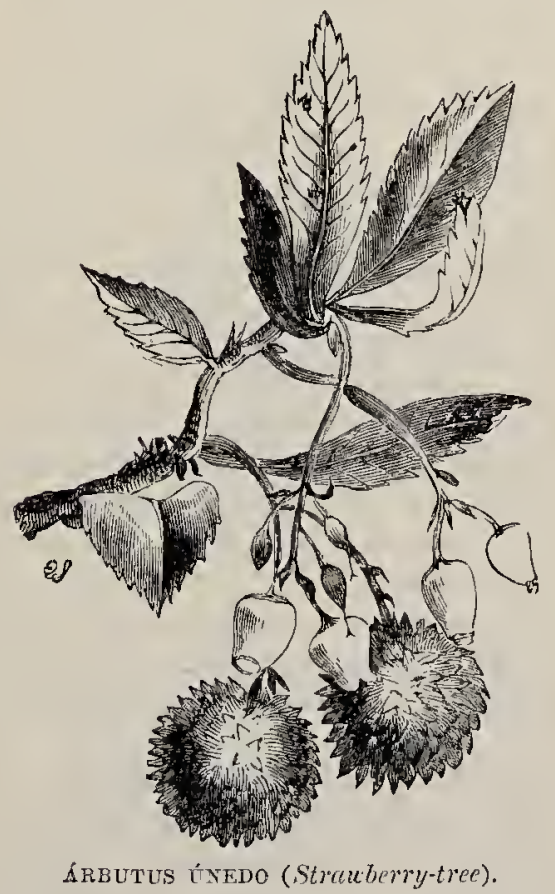

less agreeable to the taste than to the eye as to have originated Pliny's name Unedo, "One-I-eat," as if no one would wish to try a second; but birds are very fond of it.-Fl. September, October. Perennial.

2. Австоsтíphylos (Bear-berry).-Prostrate under- 
shrubs with smaller leaves; but only differing essentially from Árbutus in having a smootl fruit with only one seed in each of its 5 chambers. (Name from the Greek arctos, a bear, staphulé, a grape.)

1. A. alpinc (Black Bear-berry).-A small, prostrate shrub; leaves obovate, serrate, thin, wrinkled, shortly stalked, not evergreen; floxer's white; fruit fleshy, smooth, black.-Dry barren spots on Highland mountains ; rare-_Fl. May_-July. Perennial.

2. A. Unca-ársi (Red Bear-berry).-Resembling the preceding in its mode of growth, but the leares are entire, leathery, and evergreen, turning red in antumn ; flowers rose-coloured; and fimits scarlet.Mountainous heaths in the north; abundant. The leaves are used in medicine as an astringent, and the fruit is a favourite food of moor-fowl.--Fl. May, June. Perennial.

3. Annrómedi.-Shrubs and trees, differing from Arbutus mainly in their dry, 5-chambered, 5-valved capsute. ("Named in allusion to the fable of Anctromeda, who was chained to a rock, and exposed to the attack of a sea-monster; so does this beautiful tribe of plants grow in dreary and northern wastes, feigned to be the abole of preternatural monsters." - sir ir. $r$. Hoolier.)

1. A. polifúlia (Marsh Andromeda). - The only British species, a small, leafy, evergreen shrub with slender, prostrate stems, scattered lanceolate leaies, revolute and glancous beneath, and terminal clusters of stalked, drooping, pink flowers.-Pent-bogs, chiefly in the north.-Fl. May-September. Perennial.

4. Callúna (Ling, Heather).-A much-branched under-shrub with small, opposite, imbricate leaves numerous, stalked, bracteate, small flowers; caly. of 
4 coloured sepals, longer than the corolla; corolla bellshaped, 4-cleft, persistert, lilac; stamens 8 ; capsule 4-chambered, septicidal: seeds few in each chamber.

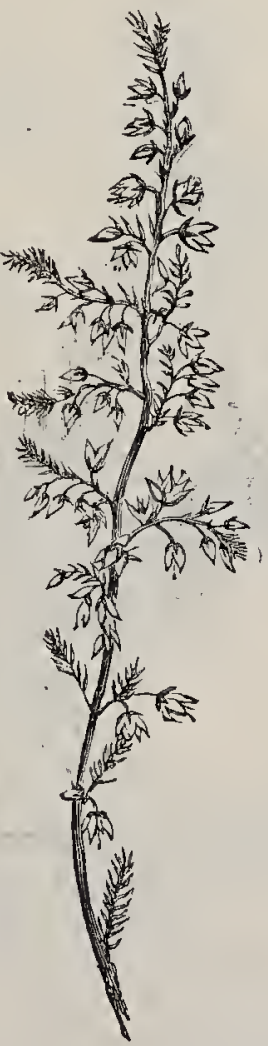

CALLÚNA ERÍCA (Ling, or Heather).

(Name from the Greek kalluno, I cleanse, from the use of the twigs to make brooms.)

1. C. Erica (Ling, or Heather).-The only species. The small leaves are more or less downy (sometimes even hoary), and, being arranged in opposite and 
decussating pairs, give the stem a 4 -sided appearance. There are 4 small green bracts below each flower, and 4 rose-coloured sepals concealing the very small, bellshaped, 4-cleft corolla.-Heaths and moors; abundant. The flowers persist long after the fruit is ripe,

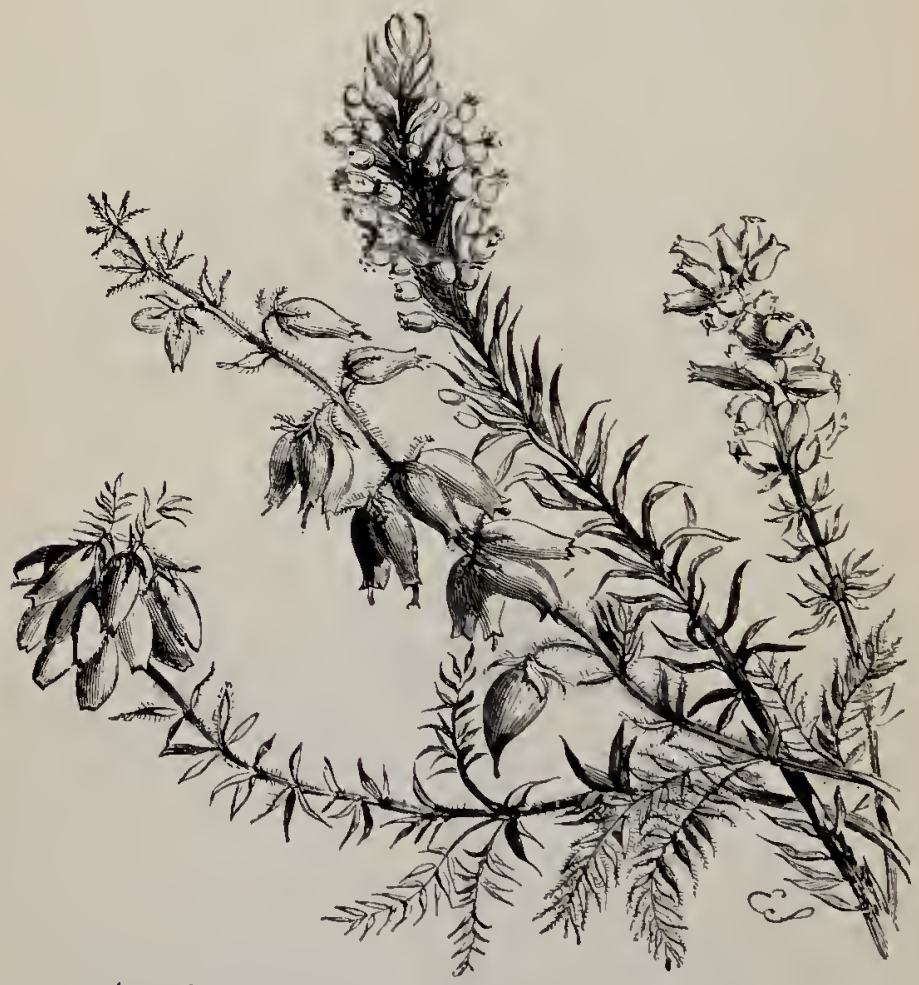

FRICA TFTRALIX, E, CILIRIS, F, YÁCANe, and E. CIXÉnEA.

often, indeed, until the next year's flowering. A beautiful double-flowered variety has been found in Cornwall._Fl. June-August. Perennial.

5. Eríca (Heath).-Wiry, much-branched undershrubs with small, narrow, stiff, generally whorled 
leaves; bracteate flowers; sepals 4; corolla bellshaped, tubular or urceolate; stamens 8; capsule

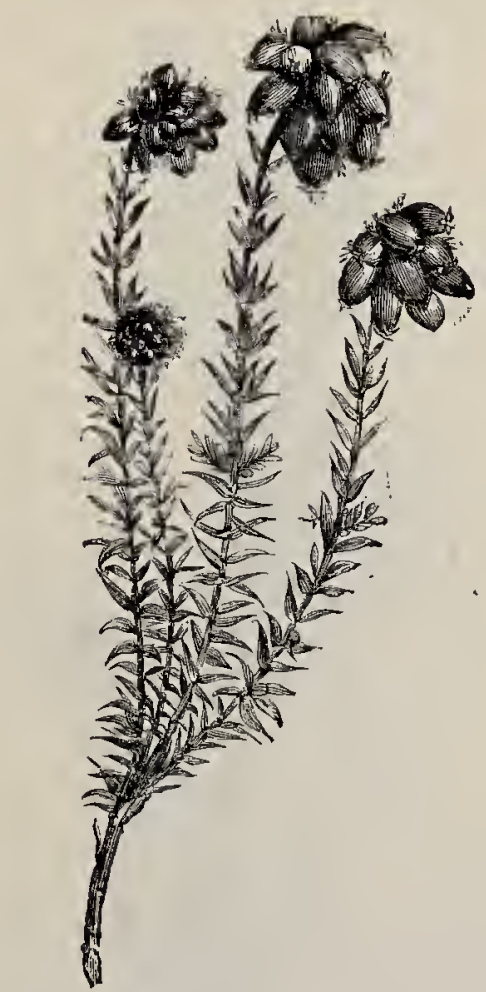

ERÍCA TF́TRALIX (Cross-leared Heath),

4-chambered, 4-valved, loculicidal, and septifragal. (Name from the Greek ereice.)

1. E. ciliairis (Ciliated Heath).-By far the most beautiful of all the British species; leares 3 or 4 in a whorl, downy above, glaucous beneath; flowers in terminal, interrupted, one-sided, spike-like racemes, ovoid, half-an-inch long, crimson, enclosing the 
stamens.-Wandy heaths, Cornwall; near Corfe Castle, Dorset; and Galway.-Fl. June-September. Perennial.

2. E. Tétralix (Cross-leaved Heath).-Well dis-

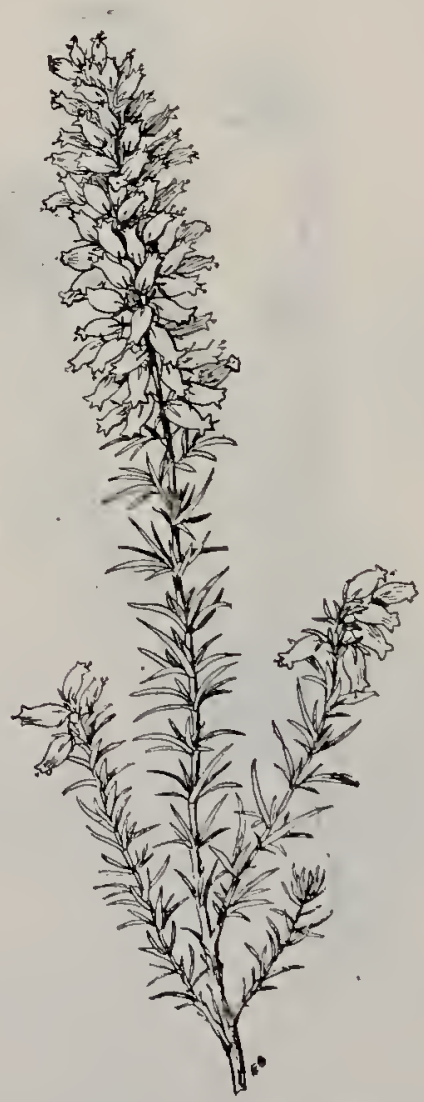

ERICA CINEREA (Fine-lecued Heath;.

tinguished from all other English species by its narrow, fringed leanes being placed cross-wise, and by its terminal, one-sided heads of drooping, rose-coloured flowers. The part of the flower nearest the stem is of 
a lighter colour than that which is exposed, where it deepens to a delicate blush, the whole flower appearing as if modelled in wax. It is sometimes found

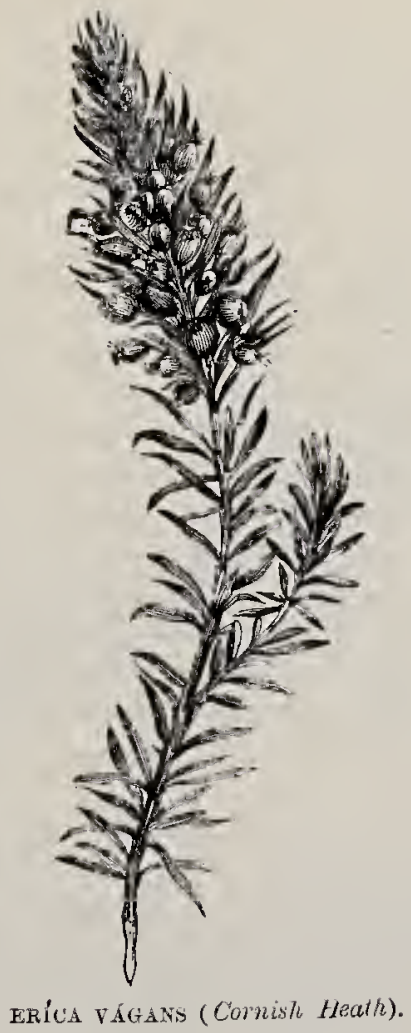

of a pure white-Heaths; abundant.-Fl. JulySeptember. Perennial.

3. W. Macháii (Mackay's Heath), differing in being more bushy, more glabrous, with broader lecues, and more numerous heads of smaller flowers, occurs only in Connemara.

4. E. cinéren (Fine-leaved Heath). -The commoincst 
British species, a bushy plant, with tough, wiry stems, very narrow, smooth lecu'es, 3 in a whorl; and ovoid, deep rose, or sometimes white, flowers in irregular, whorled, leafy clusters, not confined to one side of the stem.--Heaths; abundant.-Fl. JulySeptember. Perennial.

5. E. vágans (Cornish Heath).-Stems much branched, 2--4 feet high, very leafy in the upper parts; leaves $3-5$ in a whorl, crowded, very narrow, smooth; flowers light red, rose-coloured, or pure white, bell-shaped, in a leafy, regular, tapering cluster ; stamens forming a ring outside the corolla until they have shed their pollen, when they droop to the sides, dark red in the red varieties; light red in the white.-Covering many thousands of acres on the Goonhilley Downs, and on other heatls on the serpentine of the Lizard in Colnwall, almost to the exclusion of $E$. cinérea and E. Tétratix.-Fl. July-September. Perennial.

6. E. malitemanea (Mediterranean Heath), with leaces 4 in a whorl, a coloured colyst, pink corolla, and less prominent anthers, well known as a garden plant, occurs also in Connemara.-Fl. April, May. Pelennial.

6. Loiselívrua.-A small, trailing shrub witl small, opposite lecues: sepals, petals, and stamens 5 each; corolla bell-shaped, deciduous; capsule 2-3. chambered, septicidal. (Name from $\mathbf{I}$. Loiseleur Deslongchemps, a French botanist.)

1. L. mocrumbens (Trailing Azalea).-The original and only Azalea of Linnaus, very different in habit from most of the plants cultivated under the name of Azaleas. The stems are prostrate and tangled; the lenres small, smooth, rigid, and evergreen, with the margins remarkably rolled back; the flowers Hesh-pink, in terminal tufts, with red pectuncles and 
sepals.-Highland mountains.-FI. May, June. Perennial.

7. Bryínthus (Menziesia). - Small, evergreen shrubs with scattered leaves and few drooping, umbellate flower's; sepals 5; corolla urceolate, 5-fid, deciduous; stamens 10 ; capsule 5-chambered, septicidal. (Name from the Greek bruon, a moss, anthos, a flower.)

1. B. taxifótius (Scotch Menziesia).-A small shrub, naked below, very leafy and hairy above; Teaves crowded, shortly stalked, linear, minutely toothed, revolute; flower-stallis covered with glandular hairs; flowers in terminal tufts, lilac.-Sow of Athol, Perthshire; very rare._Fl. June, July. Perennial.

8. Borḱtтs (St. Dabeoc's Heath). -A small, evergreen shrub with scattered leures and drooping flower's in terminal, 1-sided, loose, leafy racemes; sepals 4; corolla urceolate, 4-fid, deciduous ; stamens 8; capsule 4-chambered, septicidal. (Name of unknown etymo$\log y$.)

1. B. cantábrica (St. Dabeoc's Heath, Irish Menziesia).-The only species, a small shrub with ovate, revolute leaves, bright green and glossy above, white and downy beneath; and large, crimson, or sometimes white, flowers. - Mountainous heaths in Connemara; rare.-Fl. August. Perennial.

9. Pírola (Winter-green).-- Herbaceous plants with slender, creeping rhizomes; short, almost woody, unbranched stems ; simple, smooth, evergreen, broad, chiefly radical leaves: flowers in a bracteate raceme, drooping to one side; sepals 5, persistent; petals 5, free, incurved; stamens 10 ; capsule 5-chambered, 


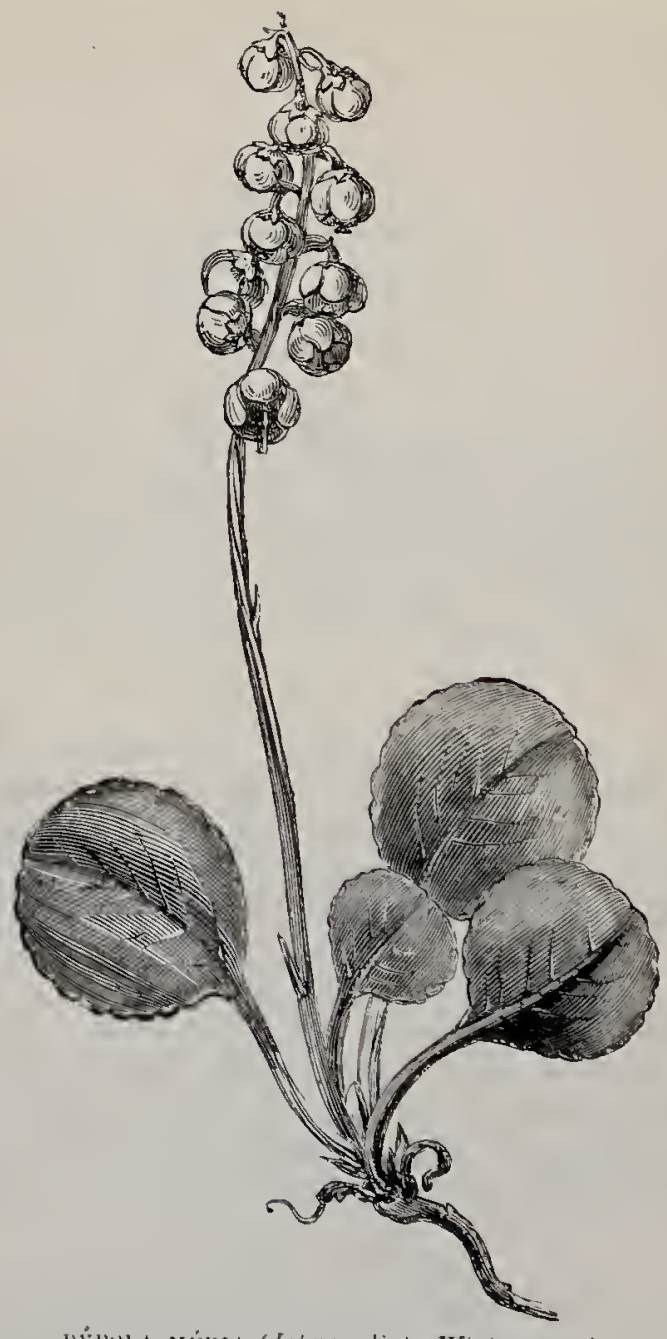

I’ÝHLA MÉnA (Intermediate Hinter-green).

loculicidal. (Name, a diminutive from Pyrus, a pear, from a fancied resemblance in their leaves.)

1. P. rotundifólic (Round-leaved Winter-green). 
- Leaves entire or slightly crenate, on long, slender stalks; flowers numerous, pure white in a long raceme; style longer than the petals, bent down, and, at the extremity, curved upwards.-Moist woods ; rare.-Fl. July_September. Perennial.

2. P. média (Intermediate Winter-green).-Flowers less expanded than in the preceding, milk-white, tinged with pink; style erect, nearly straight, longer than the stamens, projecting beyond the corolla. Woods; local.-_Fl. July, August. Perennial.

3. P. minor (Lesser Winter-green).--Hower numerous, very shortly stalked, globose, nearly closed, pale pink; stamens as long as the short style; stigmea large, included within the flower.-Woods and heaths; more common in the north.-Fl. June-August. Perennial.

4. P. secunda (One-sided Winter-green).-Flowers greenish-white, all hanging to one side, nearly closed ; stamens as long as the long, straight style, or nearly so ; stigma exserted.- - Rocky woods in the north ; rare.Fl. July. Perennial.

10. Monḱses (Single-flowered Winter-green).Differing from Pýrola in having a solitary flower with slightly united, spreading petals, and anther's prolonged into tubes. (Name from the Greek monos, alone, from its solitary flowers.)

1. M. grancliffóra (Single-flowered Winter-green). -A remarkably pretty plant, with several roundish, smooth, serrate, radical leaves, and a single, large, elegant, white, highly fragrant, long-stalked flower:-Woods in the morth of Scotland; rare.-Fl. July. Perennial.

Ord. XLV。 Monotrópex.--The Bird's-nest Family.

A small group of brown saprophytic herbs, with little or no chlorophyll, living in and upon doad 
leaves $\mathrm{m}$ woods in the North Temperate Zowe They

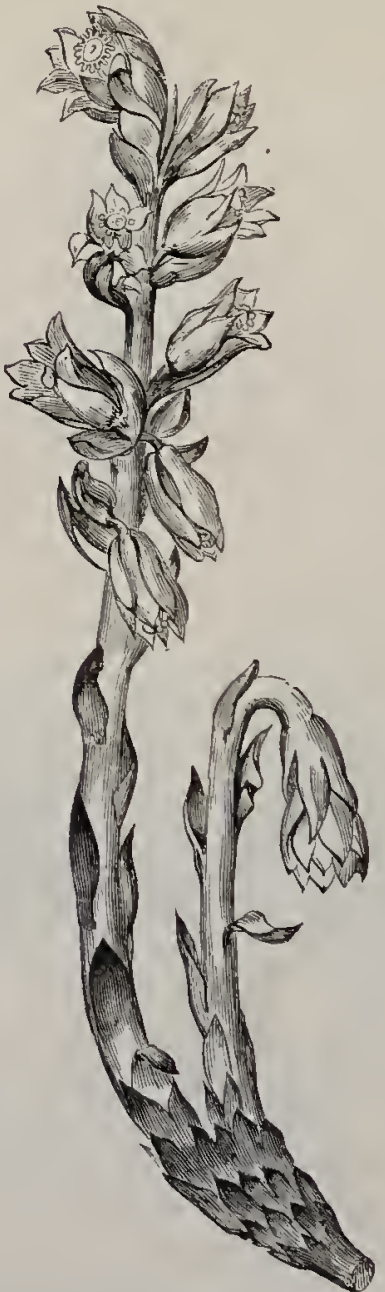

HYPóptTýs MnNótropa (Pine Rird's-ntest, Fir-rape).

have fleshy, scaly rhizomes; unbranched stcms ; scattered Teaves reduced to scales; flowers generally in 
racemes, campanulate, 4-6-merous ; stamens 8-10, hypogynous; anthers kidney-sli:ued, 1-chambered; ovary 4-5-chambered, superior ; style single ; stigma flat; ovules many in each chamber, axile; capsule 5 valved, loculicidal; seeds minute, with a loose testa.

\section{Hypópitys (Bird's-nest). - Terminal flower} 5-merous; lateral ones 4-merous; sepals and petals membranous, saccate at the base; stamens 10 in the terminal, 8 in the lateral flowers; stigma not lobed. (Name from the Greek hupo, under, pitus, a pine-tree, from the situation in which the plant occurs.)

1. II. Monotropa (Fir-rape, Pine Bird's-nest.) - The only British species, with an unbranched juicy stem, clothed throughout with scaly bracts, and terminating in a drooping, one-sided raceme of brownish-yellow flowers, which eventually turn almost black.-Woods near the roots of Fir and Beech; local. This plant must not be confounded with the Bird's-nest Orchis (Néttia Níchs-ávis) or with the Broom-rapes (Orobanché), in both of which the flowers are monosymmetric, the former 3-merous, the latter bilabiate and didynamous.-Fl. June-August. Perennial.

\section{$\S \S$ Stamens epipetalous.}

Ord. XLVI. Plumbagíne. - The Thrift Family.

A small group of herbaceous or somewhat shrubby plants, with undivided fleshy leaves; polysymmetric, perfect flowers in panicles or heads ; calyxinferior, tubular, 5-cleft, plaited, persistent, membranous, and often coloured, approaching the texture of EverlastingHowers; corolla 5-cleft nearly to the base; stamens 5 , opposite the petals; ovary of 5 carpels, 1-chambered; styles 5 ; fruit dry, 1-seeded. 'They inhabit salt marshes and the sea-shore of most temperate 
regions, and solne are found also in mountainons districts. Their properties are various : some are astringent and tonic, some intensely acrid, and many contain iodine; but, like many other maritime plants, they lose the peculiar salts which they contain in their natural localities when growing at a distance from the sea. Thrift (Arméria), for example, as a maritime plant contains iodine and soda; but as a mountain or garden plant exchanges these two substances for potash. The root of Staticé Caroliniana is one of the most powerful astringents known, and several species of Plumbayo are so acrid that the fresh root is used to laise blisters. Several kinds of Sea-Lavender (Stäticé) are ormaments to our shores, and others are cultivated in our conservatories.

1. SrÁtrcÉ-Flozvers in one-sided panicled cymes.

2. Aruéria.-Flowers in dense bracteate heads.

1. STáticḱ (Sea-Laveuder).-Leaves all radical; flowers in spike-like, one-sided, spreading, branched cymes; style smooth. (Name from the Greek statizo, I stop, from its use as an astringent.)

1. S. Limóminm (Common Sea-Larender).-Leares long-stalked, oblong, l-ribbed, pinnately reined, tipped with a point, smooth; flower-stalk, a leafless, angular scapc, branched near the summit into many spreading spike-like cluster's; flowers blue-lilac, scentless.Muddy sea-coasts; not infrequent.-Fl. JulyNovember. Perennia].

2. S. rariflína (Few-flowered Sea-Lavender'), diflering mainly in laving more erect branches and fewer flowers, is less common.

3. S. auriculufölia (Spathulate Sea-Laventer), distinguished by its leaves being oblong near the base and vider above (spathulate), with short stalks and 2-3-veined, and by its flower-stalks being branched, below the middle, into several erect tufts of lilac 
flowers, is not uncommon on rocky coasts.-Fl. July, August. Perennial.

4. S. reticuláta (Matted Sea-Lavender).-Leaves blunt, 1-ribbed, short-stalked; flower-stallks rough,

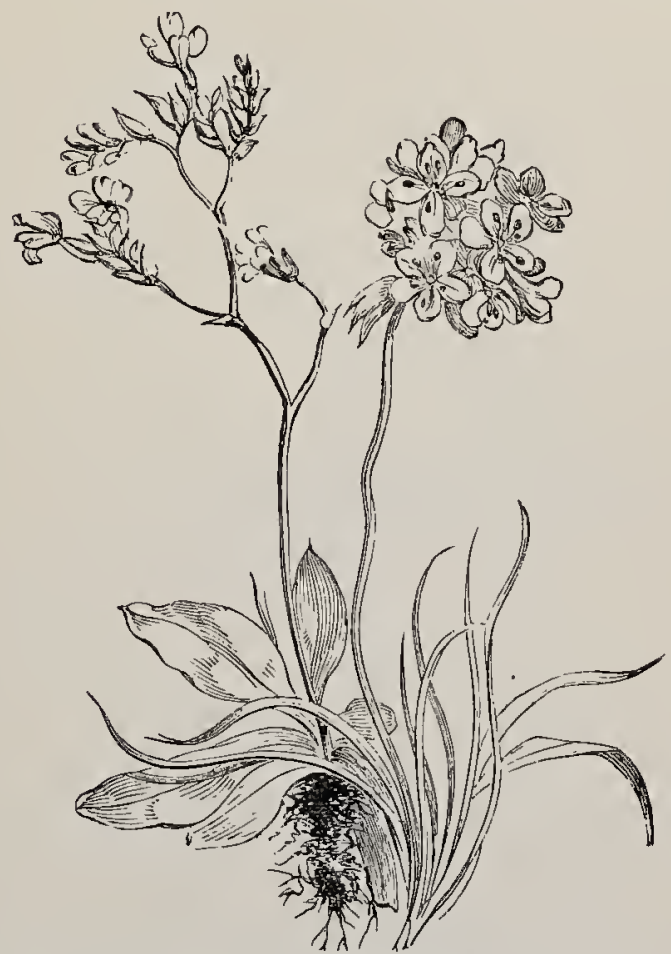

STÁTICÉ SPATHULATA (Spathulate sea-Lacender) and ARMËRIA MARITIMA ( $T$ hrift).

divided almost from the base into numerous zigzag branches, the lower of which are flowerless.-Salt marshes of Lincoln, Norfolk, and Cambridge.-Fl. July, August. Perennial.

2. Amuśnia (Thrift)._Leaves all radical, very 
narrow; flowers in dense heads of bracteate cymes, with a reversed, tubular, membranous involucre; petals cohering, persistent; styles laairy. (Name said to be from the French armoires, wardrobes, perhaps from the custom of putting some plant among linen as a perfume.)

1. A. maritima (Thrift, Sea-Pink).-Leares linear, 1-nerved, fleshy, pubescent, forming dense tufts or balls; flower-stalks leafless, downy, unbranched scapes, $3-6$ in. high, their summits cased in brown membranous sheaths; flowers rose-coloured, in roundish heads, intermixed with chaffy bracts; fruit almost winged by the dry, chaffy calyx. - Sea-shores and the tops of mountains; common.-Fl. April-October. Perennial.

2. A. plantaginea, a larger, smooth species, with broader, 3-5-veined leaves, occurs in Jersey.-Fl. June-August. Perennial.

Ord. XlVit. Prmuláce.,-The Primrose Family.

Herbaceous plants, mostly low-growing, inhabiting principally the colder regions of the Northern Hemisphere, and in lower latitudes ascending to the confines of perpetual snow. The leaves are exstipulate and mostly simple; the flowers polysymmetric and perfect. The caly $x$ is inferior, except in the Brookweed (Samolus), persistent and 5-cleft, or ravely 4-cleft, or in the Chickweed IVinter-green (Trientalis) 7-cleft; the corolla of as many lobes as the calyx, but in the Sea-Milkwort (Glarix) absent. The stamens equal in number the lobes of the corolla, and are opposite to them: the syncarpous ovary is 1-chambered with a free central placenta and numerous ovules, a single style, and a rounded, unlobed or, as it is called, "capitate" stigma. Several of our most favourite wild flowers are members of 
this Order. The Primrose, the name of which is corrupted from mimerolles, mimerula, or mimula, meaning the earliest little flower, is the welcome harbinger of spring; the Cowslip is scarcely less prized for its rural associations than for its beauty and fragranoe; and the Scarlet Pimpernel, or "Poor Man's Weather-glass," is as trusty a herald of summer weather as the Primrose of spring. The Polyanthus, Auricula, and other species of Prímula are garden favourites, and several species of Cýclamen are commonly grown in conservatories. The Primulacece have few medicinal properties of importance: the flowers of the Cowslip are made into a pleasant soporific wine; and the leaves of the Auricula (Primula Auricula) are used in the Alps as a remedy for coughs.

1. Hotróxia-Calyw inferior, 5-cleft almost to the base; corolla salver-shaped, with a short tube; capsule with 5 valves cohering at the top.

2. Prímula.-Leaves radical; flowers in umbels; calyy inferior, tubular, 5-cleft; corolla salver- or funnel-shaped, with a long, cylindrical tube; capsule 5-valved, with 10 teeth.

*3. Cŕclamen.-Stem a large corm ; leaves radical ; flowers solitary ; caly $x$ inferior, bell-shaped; 5-cleft; corolla with a short, bell-shaped tube and reflexed, long, 5-cleft $\operatorname{limb}$; copsule opening with five teeth.

4. Lxsimáchia.-Leaves cauline; caly $x$ inferior, 5-cleft to the base; corolla yellow, rotate or cupshaped ; capsule indehiscent or 2-5-valved.

5. Trientális. - Leaves cauline; calya inferior, 7 partite, or rarely $5-9$; corolla white, rotate, without a tube; capsule opening with 5 revolute valves.

6. GLaÚx.-Leaves cauline; caly. inferior, bellshaped, 5-lobed, coloured; corolla absent; capsule 5valved.

7. Avagáluis. - Leaves cauline.; caly $x$ inferior, 5 cleft to the base ; corolla rotate or funnel-shaped, with 
little or no tube; filoments hairy; copsule splitting all round.

8. Centúnculus.--Leaves cauline; calyx inferior 4 or 5 -cleft to the base; corolla with an inflated, subglobose tube, 4 or 5-cleft; stamens 4 or 5 , with smooth filaments; capsule splitting all round.

9. Símolus.-Leares radical and cauline; caly.

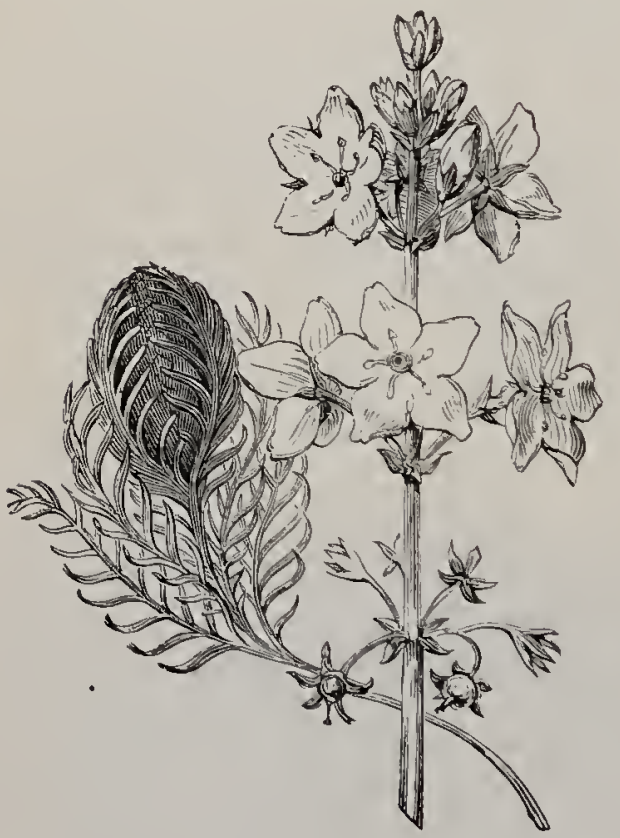

HOTTÚNIA PALISTRIS (Winter Fiolet).

half-superior, 5-cleft, persistent; corolla salver-shaped: capsule opening with 5 reflexed teeth.

1. Hotrónia (Water Violet).-Floating aquatic plants witl whorled, finely divided, pinnate, submerged leaves: flowers whorled, stalked; caly $x$ 5-cleft almost to the basc; corolla salver-shaped, with a short 
tube ; stamens 5 ; capsule many-seeded, with 5 valves cohering at the top. (Named after Peter Hotton, Professor of Botany at Leyden.)

1. II. pralustris (Water Violet).--The only British species, with large, handsome, lilac flowers with a yellow eye, arrangad in whorls around a smooth, succulent, leafless stalk, which rises several inches out of the water.-Ponds and ditches; local.-Fl. May, June. Perennial.

2. Prímula (Primrose).--Plants with a rhizome, latical, simple leaves and flowers in umbels with an involucre; calye tubular, 5-cleft; corolla salver-or' funnel-shaped, with a long, cylindrical tube ; stamens 5 , epipetalous, included either in the throat of the corolla-tube, or, on other plants, half-way down it; style short in the former case, long in the latter; capsule 5-valved with 10 teeth. This helerostyly is connected with insect-pollination, the short-styled form having its stigma dusted with pollen from the similarly-situated anthers of a long-styled plant, and vice versâ. (Name a diminutive from the Latin Mrimus, first, from the early flowering of many species.)

1. $P$. acúulis (Primrose).-Among the most welcome of spring flowers, and almost too well known to need any description; leaves obovate, tapering downward, wrinkled, hairy beneath, toothed; umbels usually with very short pectuncles and long, pink, hairy pedicels; flowers an inch or more across; caly. $x$ with 5 longitudinal plaits and acute teeth; corolla of a pale yellow, or, as artists of ten maintain, a delicate green, turning green in drying, or occasionally white, red, or lilac, with a flat limb, having a faint but characteristic fragrance.--Banls and woods; abundant.-Fl. December-May. Perennial.

?. P. v'éris (Cow lip).-Almost an equal favourite; leaves ovate, abruptly contracted below; umbels with 
a long, erect, downy peduncle, short pedicels, and

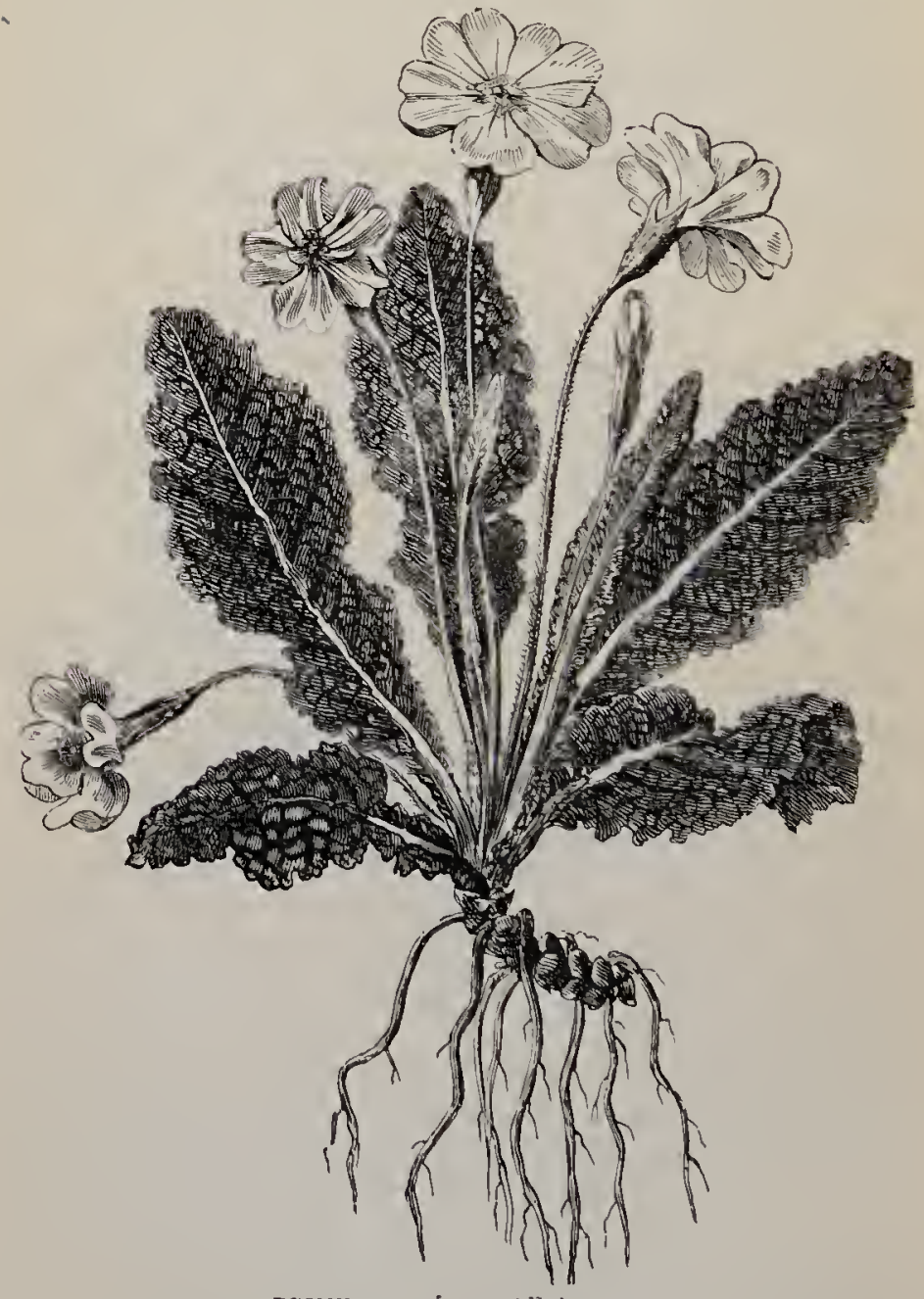

PRIMUla dCÁUlis (Primrose).

drooping flowers; caly, bell-shaped with short, broad 


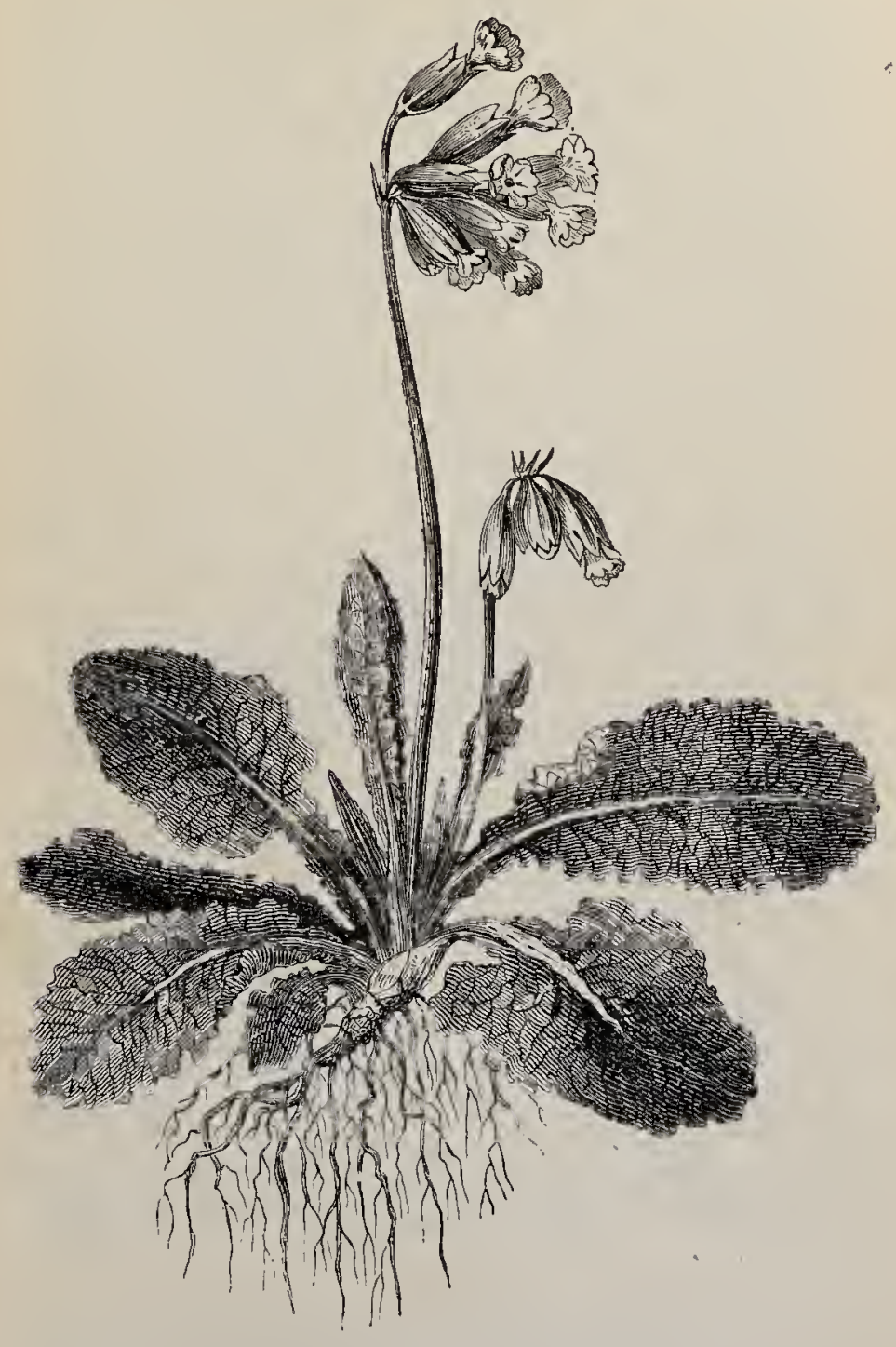

PRIMUla véris (Cowslip, Pargle). 
teeth ; corolla funnel-shaped, deep yellow, with 5 reddish spots in the eye, fragrant.-Pastures; common. Among the many pleasing purposes to which these flowers are put by chillyen, none is prettier than that of making Cowslip Balls. The method is as follows: -Choosing only such umbels as have all the flowers open, pick them off as close as possible to the top of the peduncle and hang them, close together, along a string about $1 \frac{1}{2}-2$ feet long, stretched between the backs of two chairs. When the string is full, carefully loosen its ends, and raising them gently tie them together, so drawing all the flower-heads into a ball. - Fl. April, May. Perennial.

3. P. elcitios (Oxlip).-Lectes like those of the Cowslip; umbel long-stalked: flowers not drooping, salver-shaped, but smaller and paler; and more buff than those of the Primrose, with a smell of apricots; calye tubular ; corolla flat, not concave.-Woods in North-west Essex and neighbouring parts of Hert=, Cambridgeshire and Suffolk only. The name Paigle is applied locally to this species and elsewhere to the, Cowslip.-Fl. April, May. Perennial.

4. P. farinósa(Bird's-eye Primrose).-Leares small, obovate, crenate, covered below with a white or sulphur-like meal; umbels on peduncles 2-8 in. high ; caly.r-teeth long, linear, obtuse : covolla lilac, with a yellow eye, lobes distant.-Mountain pastures, from Yorkshire northwards.-Fl, June, July. Perennial.

5. P. scótica (Scottish Primrose).-Resembling the last, but only half its size, with broader lcaves, shorter and broader caly, $x$-teeth, and a deeper blue-purple corolla with its lobes touching, is a rare species growing in the Orkneys, and in a few places in the extreme north of Scotland.-Fl. May-September. Perennial.

*3. Cŕclanes (Sow-bread).-.-Plants with large, tuber-like, underground stems; radical, petiolate, broad 
leaves; flowers solitary, drooping, on long, leafless, erect peduncles, which twist spirally when in fruit; caly,x 5-cleft; corolla with a short, bell-shaped tube and long, reflexed lobes to its limb: capsule opening with 5 teeth. (Name from the Greek, referring to the round corm.)

1.* C. hederufölizm (Ivy-leaved Sow-bread).-The only species found in Britain; but a doubtful native. Remarkable for its globular, turnip-like, brown corm, and nodding pink flowers with reflexed petals. The leaves are produced after the flowers. As the fruit ripens, the flower-stalk curls spirally and buries it in the earth. The corm is intensely acrid.-Woods in Kent, Sussex, and Surrey.-Fl. August-_September. Perennial.

4. Lxsmíchia (Loosestrife).--Plants of various habit with entire, cauline leares ; caly $x$ 5-6-cleft to the base ; corolla rotate or cup-shaped, yellow in British species; capsule generally 5-valved. (Name in Greek having the same meaning as the English name.)

1. L. thyisiffora (Tufted Loosestrife).-A stout, glabrous, erect plant with runners, unbranched above; leaves opposite, sessile, lanceolate; flowers small, numerous, in dense, stalked, axillary racemes, yellow, dotted with orange.--Marshes, mostly in the north; rare.-Fl. June, July. Perennial.

2. L.vulgáris (Great Yellow Loosestrifè).- -A stout, pubescent, erect, branched plant, several feet high, with runners; leaves opposite, or $3-4$ in a whor', sessile, ovate-lanceolate; flower's rather large, subcampanulate, yellow, dotted with orange, in terminal panicled cymes.-River-banks; common.-Fl. July, August. Perennial.

3.* L. prenctáta, a naturalised exotic, is a smaller, downy plant, with fewer flower's and petals fringed with glandular hairs, 
4.* L. ciliáta, an American species naturalised in Cumberland, is taller and has subcordate leaves on ciliate stalks, and 5 staminodes between the stamens.

5. L. Nummulária (Money-wort, Herb-twopence, Creeping Jenny).-A very pretty glabrous plant,

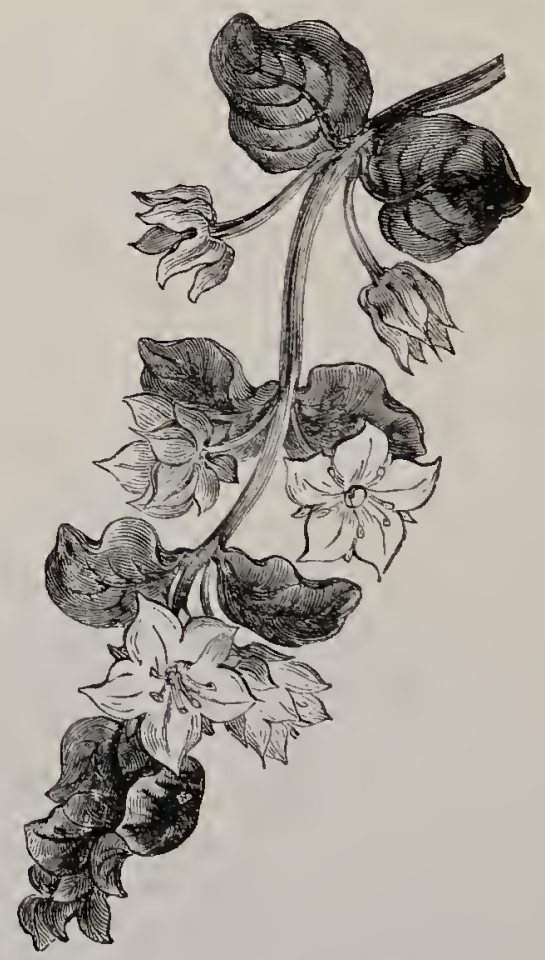

LYSIMACHIA NUMMUT_RRIA (Money-uort).

with creeping stcms, often more than a foot long; leaves opposite, ovate, slightly stalked, shining ; flowers rather large, cup-shaped, solitary, or in pairs in the axils, yellow.-Banks of rivers and damp woods; common. It often drapes wet banks very gracefully, and is much planted on rockeries. Its leaves some- 
times turn rose-pink in autumn.-Fl, June, July. Perennial.

6. L. némorum (Yellow Pimpernel, Wood Loosestrife). -A very graceful plant, approaching the Scarlet Pimpernel in habit, but somewhat larger and more glossy; stem spreading, often reddish: leaves opposite, shortly stalked, ovate, acute ; flowers solitary, on very slender, axillary peduncles, bright yellow, star-like and very.

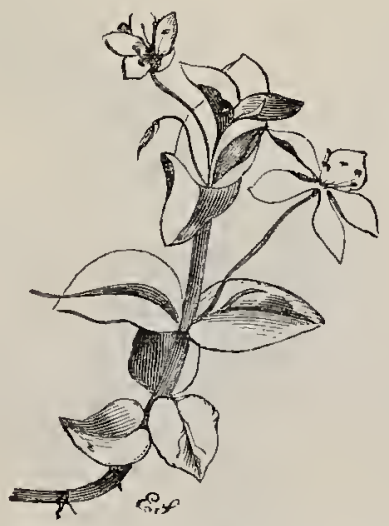

LYSIMÁCHI NF́MORUM (Thod Loosestrife, Fellow Pimpernel).

pretty, from $\frac{1}{2}-\frac{2}{3}$ in. across. - Shady woods ; common. -Fl. May-August. Perennial.

5. Trientális (Chickweed Winter-green).-Glabrous plants with slender, creeping rhizomes; erect, unbranched stems, a single whorl of 5 or 6 leaves, and a few white flowers on slender peduncles; calyy $5-9$ cleft; corolla rotate; stamens 5-9; copsule opening with 5 revolute valves. (Name of doubtful etymo$\log \mathrm{y}$.)

1. T. europía (Chickweed Winter-green).-The only European species, and the only British plant 
referred to the Linnean Class Heptandria, though the stamens are not invariably 7 in number. It grows $4-6$ in. high, has large, obovate lect'es and delicate

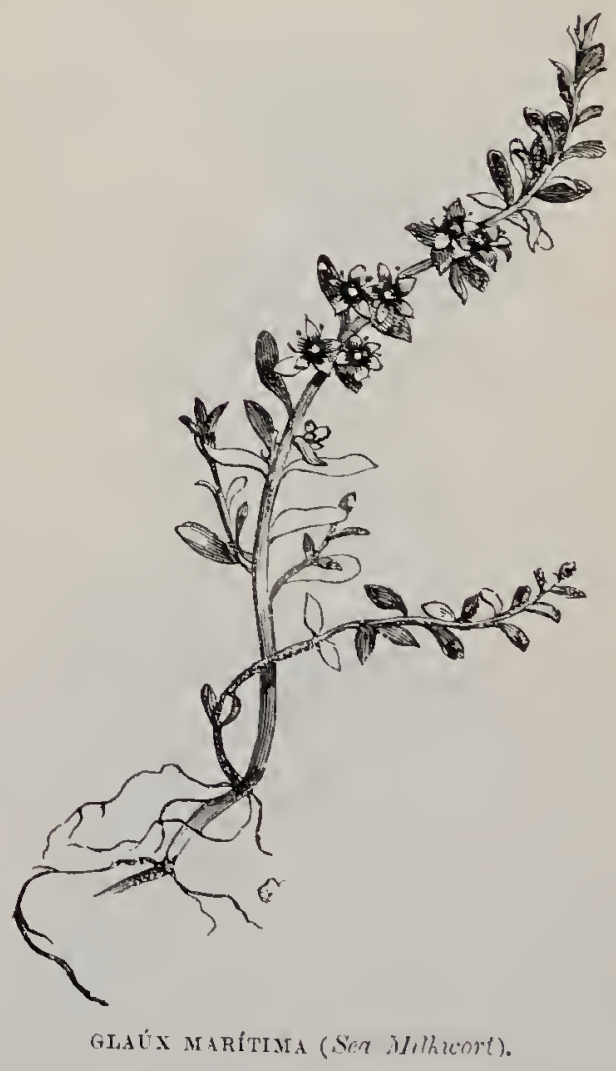

white flowers. - Woods from Yorkshire and Lancashire northwards.-Fl. June, July. Perennial.

6. GLaúx (Sea-Milkwort), containing only one species, G. marítima, a small, glabrous, fleshy, marine 
plant, 3-6 in. high, growing in thick patches, resembling Arenária peplóides in its habit, with numerous ovate, entire, opposite and decussate leaves, and axillary pink flowers which are destitute of corolla.-Sea-shores and salt-marshes; common. (The

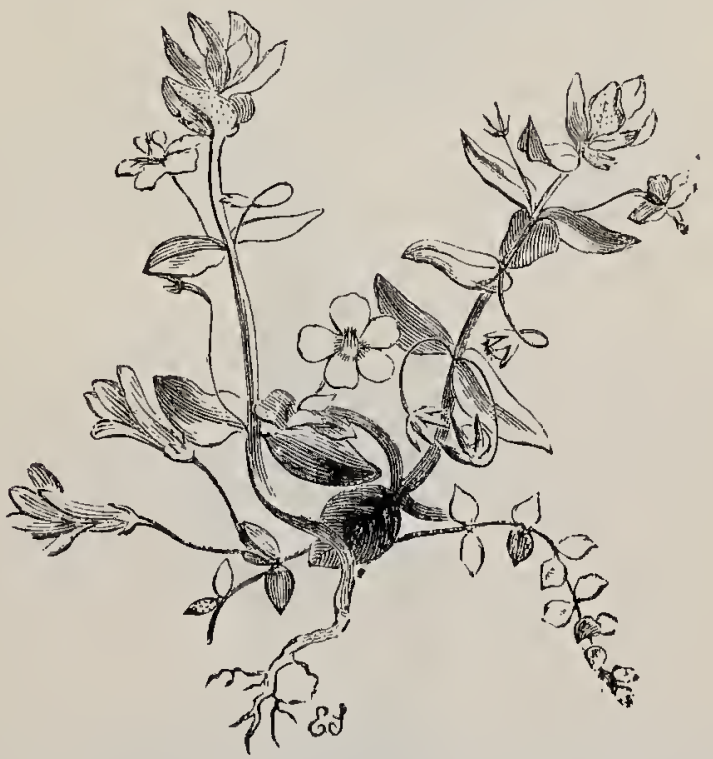

ANAǴlluis ARVÉNsis (Scarlet Pimpernel) and A. TENíld (Bog Pimpernei).

name is from the Greek glaukos, sea-green.)-Fl. June -August. Perennial.

7. Anagálutis (Pimpernel).- Slender little plants with opposite, entire lenvcs ; axillary flowers on threadlike stalks; corolla rotate or funnel-slaped; filaments hairy ; capsule splitting all round. (Name in Greek denoting that the plant excites pleasure.)

1. A. arvénsis (Scarlet Pimpernel, Poor Man's 
Weather-glass). - A pretty little plant, generally prostrate; leaves sessile, ovate, dotted beneath; petals crenate, fringed with minute glandular hairs, expanding only in fine weather, usually bright scarlet, but occasionally pink, white with a red eye, all white, or perhaps blue.-Cultivated ground; abundant.-FI. May-October. Annual.

2. A. cerilea (Blue Pimpernel). - A more erect plant, without the fringe to its petals, which are usually bright blue; but perhaps occasionally red. Much less common.-Fl. May-October. Annual.

3. A. tenélla (Bog Pimpernel). - A beizutiful little

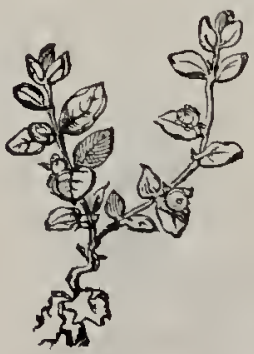

CENTÚNCULUS MiNTMUS (Chafiveed).

plant with very slender creeping stems, $3-4$ in. long; small, roundish, stalked leaves, shorter than the flower-stalks; and erect, funnel-shaped, rose-pink flowers, larger than those of the Scarlet Pimpremel. Boggy ground and sides of rivulets; common.-Fl. June-August. Perennial.

S. Centúnculus (Chaffiweed, Bastard Pimpernel). - Minute plants, with leaves partly opposite, partly scattered; flowers axillary, sub-sessile, minute, often 4-merous; corolla with an inflated, sub-globose tube; - filaments not hairy; capsule splitting all round. (Name of doubtful etymology.) 
1. C. minimus (Chaffweed, Bastard Pimpernel.) -

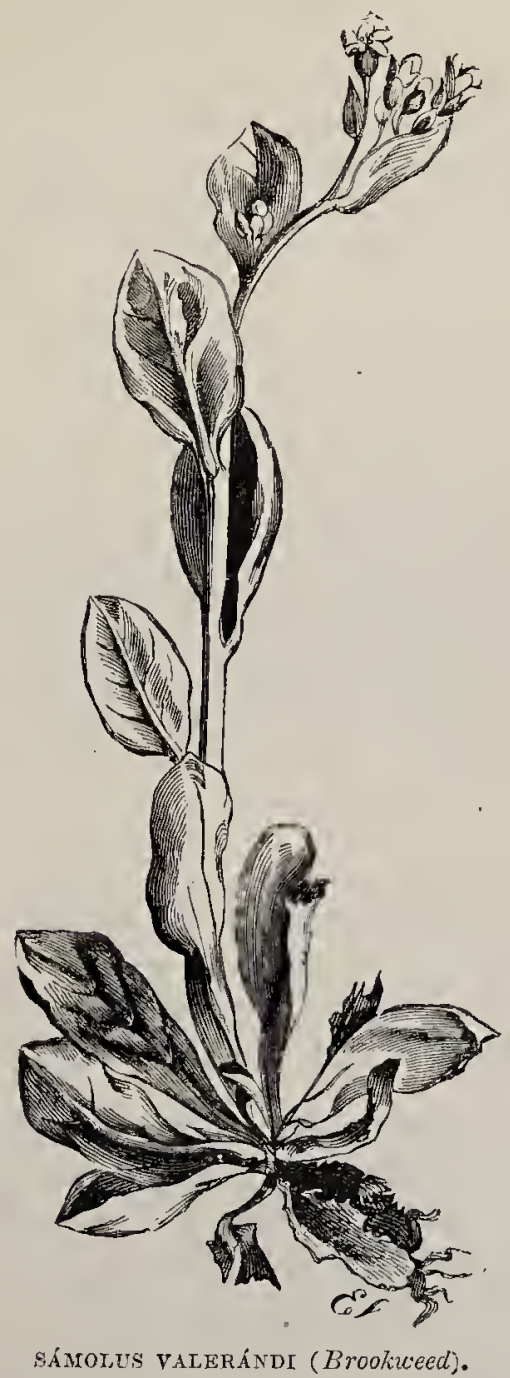

The only British species, one of the smallest among M M 2 
British flowering plants, rarely exceeding an inch in height, and often much less. It is nearly allied to the Pimpermels, and at the first glance might be mistaken for a stunted specimen of Anagallis arvénsis. It is sometimes branched; but very frequently consists of a single stem, 6 or 8 ovate, acute leaves, and as many inconspicuous, nearly sessile, pale pink flowers.-Damp gravelly places, especially where water has stood during winter.-Fl. June-August. Annual.

9. Sánouds (Brookweed).-Leaves partly radical partly cauline, and scattered; flowers in a terminal, bracteate corymb ; caly $x$ half superior, 5-cleft, persistent; corolla salver-shaped, white: stamens 5 , epipetalous, alternating with 5 staminodes; capsute opening with 5 reflexed teeth. (Name said to be from the island of Samos, where Valerandus, a botanist of the sixteenth century, gathered our British species.)

1. S. Valerándi (Brookweed). - The only British species, a smooth, pale green, herbaceous plant, with blunt, fleshy leaves, and one or more terminal clusters of very small white flowers, erowded at first, but finally becoming distant, resembling in this respect the habit of some Crucifere.-Watery places; common.-Fl. June-September. Perennial.

\section{Ord. Xlvìit. Olé́cee,-The Olive Famli.}

'Trees or shrubs, chiefly inhabiting the temperate regions of the Northern Hemisphere. Their branches are opposite, and often end in conspicuous buds; the leanes, also opposite, are either simple or pinnate, and exstipulate; and the flowers are in panicled cymes. The caly,x is either 4-cleft, inferior and persistent, or absent; the corolla either polysymmetric, hypogynous, of 4 united or free petals, val- 
vate in bud, or absent; stamens 2; ovary 2-chambered, with 2-3 ovules in each chamber; style 1 ; fruit a samara, a capsule, or berry-like, seldom perfecting more than 2 seeds. By far, the most important plant in the Order is the Olive (Olea europarea), from which it takes its name, one of the earliest plants cultivated by man. Its bark is bitter and astringent, and its wood remarkably close-grained, handsomely mottled, and durable. The fruit is fleshy and drupe-like, enclosing a hard stone, and the oil is expressed from the fleshy pericarp. The Lilac (Syringa valgaris) is a favourite in our shrubberies. Fráminus Omus, the Flowering or Manna Ash of Souther'n Europe, also occasionally grown, has white flowers, and exudes a sugary substance known as manna, which is sometimes used in medicine. The wood of this gonus is valued for its strength and elasticity.

1. Fráxinus.-Leaves mostly pinnate; calyo and corolla absent; fruit a pendulous single samara.

2. Ligústrum. - Leaves simple ; caly $x$ cup-shaped, 4-toothed; corolla funnel-shaped; 4-lobed; fruit a nuculane.

1. Frúxinus (Ash).-Trees with deciduous leaves, generally pinnate; polygamous flowers, with or without a 4-merous calyr and corolla; fruit a compressed samara, winged at the tip. (Name, the Latin name of the tree, perhaps referring to the ease with which it may be split.)

1. F. excélsior (Common Ash).-A noble tree, characterised by the smooth, light, ash-coloured bark: of its younger branches, of which the lower ones droop, and curve upwards agin at the extremities; by its large, black, terminal buds ; by the large, unequally pinnate leaves of $9-15$ leaflets, which are lanceolate and serrate; by the dense clusters of flowers, sonie consisting only of two purple-black stamens, others 
only of an ovary, and others of both; and by the tufts of pendulous seed-vessels, popularly called "keys," which remain attached to the tree until the spring. A variety is occasionally found with only the terminal leaflet to its leaves.- Woods and

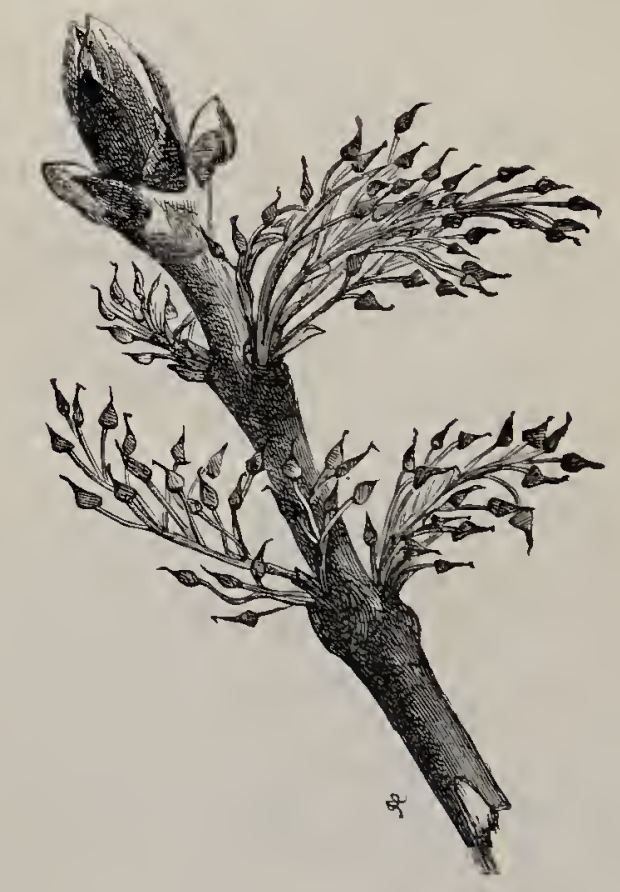

FRAXINUS EXCÉLAIOR (Ash).

hedges; common.-Fl. April, May, before leafing. Perennial.

2. Ligústruar (Privet). - Shrubs with simple, often evergreen leaves; flowers perfect, in terminal panicled cymes; cally $x$ cup-shaped, 4 -toothed, deciduous ; corolla funnel-shaped, with 4 spreading lobes; fruit globular, berry-like. (Name, the Classical name of the plant, 
connected with ligare, to bind, from the use made of the twigs.)

1. L. v'ulgáré(Common Privet).-The only British

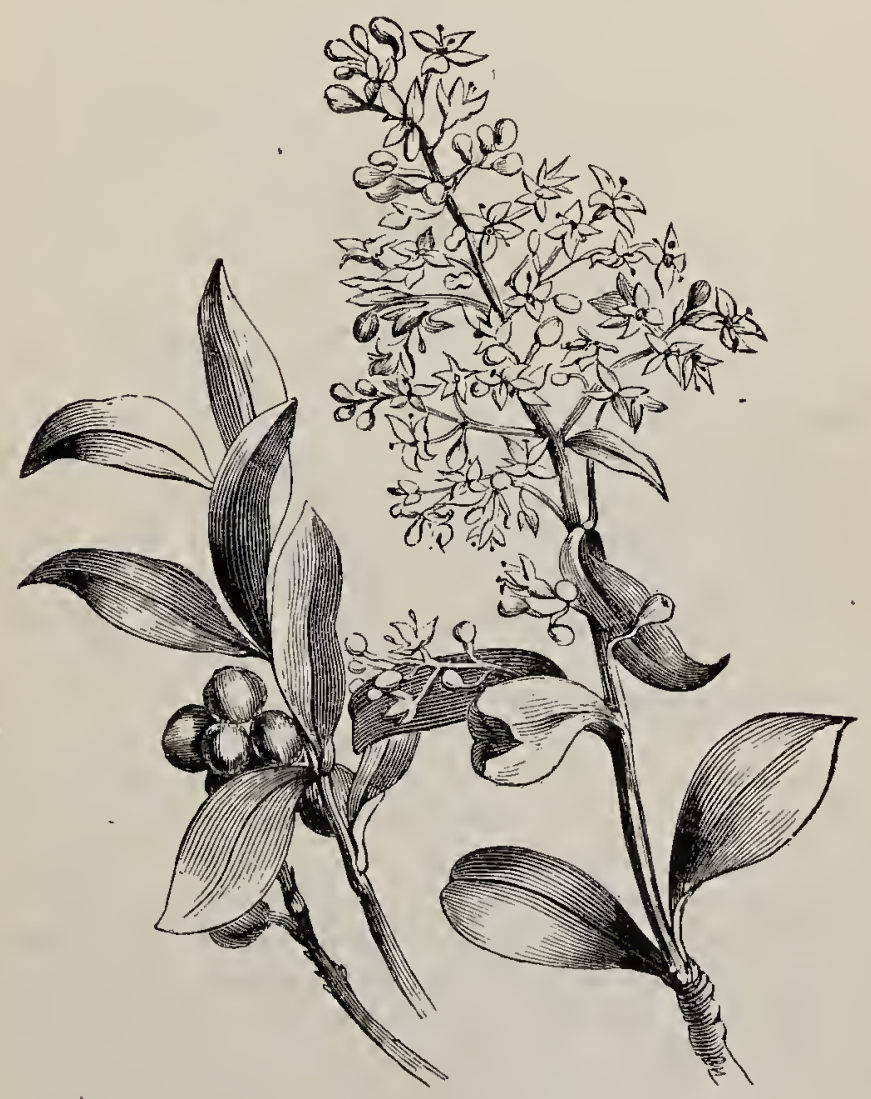

LIGÚSTRUM VULGÁRE (Privet).

species, a common hedge-bush, with opposite, smooth, elliptical, nearly evergreen leaves; dense panicles of white, sickly-smelling flowers, and polished, globular, black, berry-like friits. It is commonly used for 
garden-hedges in towns, not being injured by smoke. -Fl. June, July. Perennial.

\section{Ord, XliX. Apocynáce.e-Periwinkle Family.}

Trees, shrubs, or herbs, mostly tropical, poisonous, and abounding in a milky juice; leaves simple, opposite; flowers showy, polysymmetric; calyx 5-cleft, persistent; corolla 5-lobed, the lobes twisted when in bud, and when expanded usually oblique ; stamens 5, inserted in the corolla-tube; ou'ary 2-chambered; fruit various. The beantiful Oleander (Nérim Oleánder), common in greenhouses, is a member of this Order. It is very poisonous, the wood, when powdered, being sometimes used to kill rats. It is related that in 1809, when the French troops were before Madrid, a soldier formed the unfortunate idea of cutting branches of Oleander (which in Spain is rery common and reaches a considerable size) to serve as spits and skewers for their meat when roasting. The wood having been stripped of its bark, and brought in con= tact with the meat, was productive of most direful consequences, seven soldier's dying out of twelve who ate of the roast. A number of species in the Order belonging to the genera Trahea, Willughbeia, and Lanclolphie, natives of Tropical Africa and the Malay Archipelago, are valuable sources of indiarubber; and a few other genera contain medicinal plants. Vinct, the only genus represented among Britisl plants, is astringent and acrid.

1. Vínca (Periwinkle).--Slender, trailing plants with evergreen leaves: solitary salver-shaped flowers with 5 oblique lobes to the corolla: style resembling the shaft of a pillar surmounted by a double capital, fruit of 2 erect, slender, many-seeded, indehiscent 
carpels. (Name from the Latin vincio, I bind, from the cord-like stems.)

1. V. minor (Lesser Periwinkle).-Stem trailing, rooting, sending up short, erect, leafy shoots, which bear the flowers; leaves and sepals glabrous; corolla

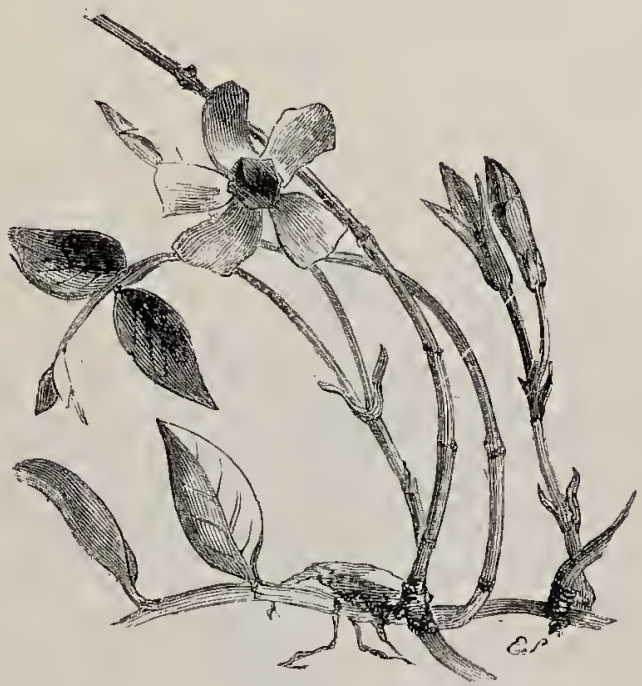

VINCA Mínon (Lesser Periwintile).

1 in. across, violet, with a tube thrice as long as the calyx-lobes. - Woods, especially in the West of England, where it often entirely covers the ground with its glossy leaves. A white variety occurs in Devonshire, and in gardens it is often met with bearing variegated leaves and double purple, blue, or white flowers.-Fl. March-June. Perennial.

2.* $V$. májor (Greater Periwinkle).-A more erect plant, much larger than the last, with the margins of its lecues and sepals minutely fringed, and the latter as long as the corolla-tube, is not indigenous, 
occurring only near houses.-FI. April, May. Perennial.

\section{Ord. L. Gentiáneæ. - The Gentian Family.}

An Order comprising between 400 and 500 species, distributed throughout all climates, from the regions of perpetual snow to the hottest parts of South America and India; but mainly northern and subalpine. Under the Equator they do not occur below 7,850 feet above sea-level; in the Himalayas and in the Rocky Mountains species reach altitudes of 16,000 feet; in Southern Europe Gentiána mrostráta grows at 6,000-9,000 feet above the sea; on Behring's Straits and on the Straits of Magellan species occur just above the level of the sen; but they are rery rare both in the Arctic and Antarctic Regions. In Soutl America and New Zealand the prevailing colour of the flower is said to be red, and in Europe it is blue, yellow and white being uncommon. They are mostly herbs, erect and glabrous, with opposite, simple, sessile lecues, and often large, brilliantly coloured flowers which are polysymmetric and usually 5-merous. The caty, is inferior, persistent, ustally 5 -, but sometimes $4-8$-cleft; corolla often persistent, twisted when in bud, with lobes equalling those of the calyx in number, and of ten fringed about the mouth of the corolla-tube; stamons equalling in number, and alternate with, the lobes of the corolla; carpels 2, united in a 1-chambered ovary, with 1 style and 2 stigmas; finit a many-seeded capsule. All the members of the Order are intensely bitter, and form valuable tonic medicines. Gentianca lietea, collected in the mountains of. Central and Southern Europe, is the species most commonly employed; but there is little doubt that other species might be employed with equally good effect. 
1. Mrcrocála.-Little branched; flowers yellow, 4-merous; caly, $x$ tubular ; corolla funnel-shaped; stigma undivided.

2. Blackstónia.-Leaves perfoliate; flowers yellow; caly $x$ deeply 6-8-cleft; corolla rotate, 6-8-lobed; stamens $6-8$; stigma 2-4-cleft.

3. Erythrea.-Flowers mostly 5-morous; corolla

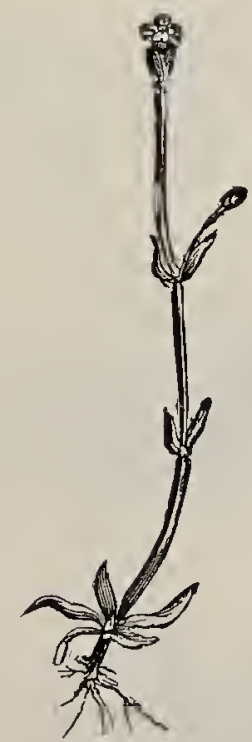

MICROCÁLA FILIFóRuIS (Least Gentianella).

funnel-shaped; anther's becoming spirally twisted; stigmas 2.

4. Cicḱndia. - Branched; flowers pink, 4-5merous; calyx-lobes divided to the base; corolla salvershaped; stamens 4 ; stigma 2-fid.

5. Gentiána.-Flowers mostly 5-merous; corolla funnel- or salver-shaped, tube subclavate; anthers not twisted; stigmas 2.

6. Menyánthes.-Leaves scattered, ternate; flowers 
5-merous; corolla funnel-shaped, with 5 lobes, induplicate in the bud, fringed all over the inner surface.

7. Limnánthemus. - Leaves simple, orbicular, floating; flowers 5-merous; corolla rotate, with 5 lobes, induplicate in the bud, fringed at the base only.

1. Microcáda (Gentianella).-A minute, slender, little-branched plant; flowers small, yellow, 4-merous; calyx tubular; corolla funnel-shaped; stamens 4; anthers not twisted; style not persistent; stigma undivided. (Name from the Greek micros, small, kalos, beautiful.)

1. M. filiförmis (Least Gentianella). - The only British species, a minute, slender, glabrous, plant, 2--4 in. high, but little branched; leaves subulate, soon withering; flowers yellow, only expanding in bright sunshine.- Sandy heaths in the south, where water has stood during the winter; rare--Fl. JulyOctober. Anmual.

2. Buacistóxia (Yellow-wort).-Erect, glaucous plants with perfoliate leaves: flowers in loose dichasial cymes, yellow, 6-8-merous; caly.r. deeply lobed; corolla rotate; mary 1-chambered, manyovuled; style not persistent, stigma 2-4-cleft. (Named in honour of Joln Blackstone, an English botanist of the 18 th century.)

1. B. perfolicita (Perfolinte Yellow-wort).-The only British species, an erect plant, 12-18 in. high, remarkable for its glaucous hue, and for its pairs of leanes, which are rather distant, and are united at the base (connate) with the stem passing through them, whence the name Profiate. The flowers, which are large and handsome, are yellow, and expand only 
between 9 o'clock in the morning and 4 p.m.-Chalk and limestone pastures; not uncommon.-Fl. JuneSeptember. Annual.

3. Erythráea (Centaury).-Erect, herbaceous

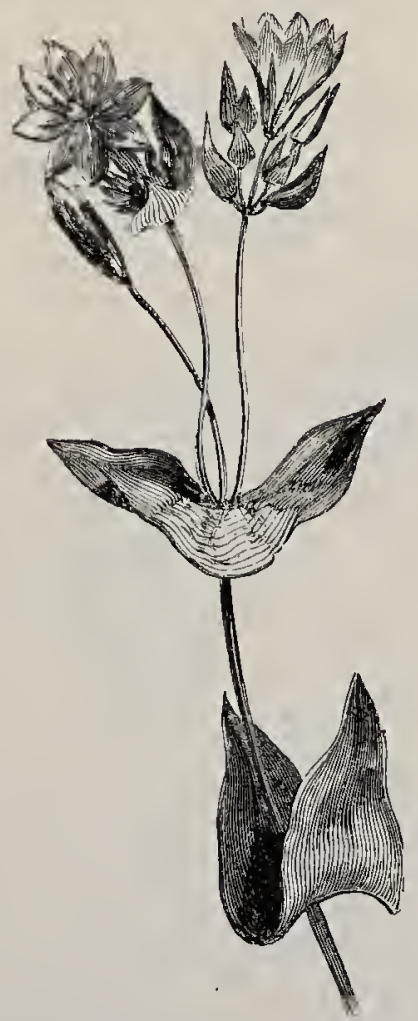

BLACKSTÓNIA PERFOLÍ́tA (rerfoliate Fellow-unt).

plants with angular stems; leaves sometimes united at the base; flowers in terminal, trichasial cymes; corolla funnel-shaped, usually 5-lobed, pink, white, 
or yellow; stamens 4-5; anthers becoming spirally twisted; style simple, not persistent; stigmas 2. (Name from the Greek enuthros, red, from the common colour of the flowers, the English name, like the Latin, Centariea, referring to the Centaur Chiron,

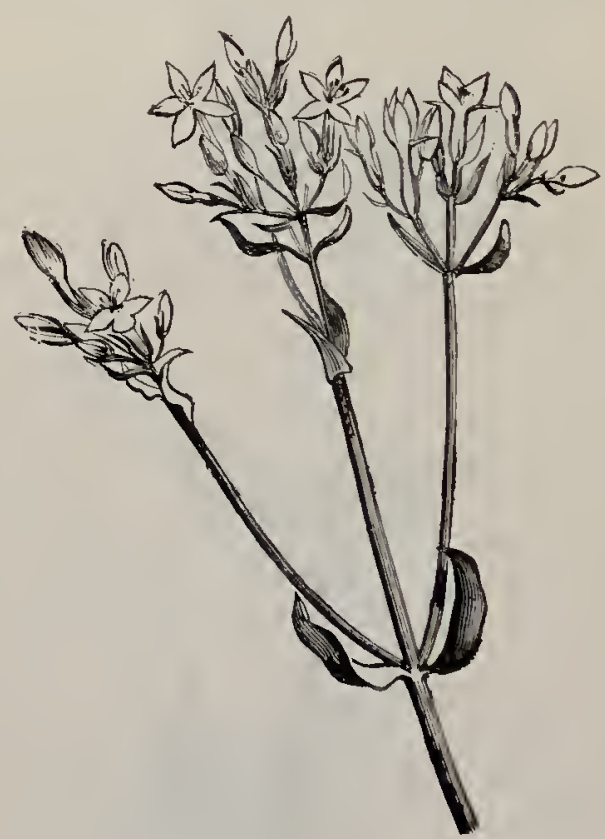

ERYTHRE EN OENAÚRIUAt (Common Centaury).

who in Greek mythology was famous for his medicinal skill.)

1. E. Centaúrium (Common Centaury). - A pretty plant, 2-18 in. ligh, with square, erect, green stems, much branched above; leaves elliptic-oblong, with strong parallel ribs, and remarkably smooth; flower's in terminal, corymbose, trichasial cymes, rose-pink, or rarely white, only opening in fine weather ; caly. half as long as corolla-tube; filaments springing from the 
top of the corolla-tube.-Dry pastures and waste places ; common.-Fl. July, August. Annual.

2. E. latifólice (Broad-leaved Centaury), a stunted form, with broadly elliptic leaves, and flowers in dense; trichasial tufts, with caly,x as long as the corollatube, and filrments as in the last, occurs only on the sandy shore near Liverpool.-Fl. June--September. Annual.

3. E. littorális (Dwarf Tufted Centaury), a similar, stunted, but unbranched form, with oblonglinear, blunt leaves above and spathulate radical ones, occurs more frequently on sandy shores.-Fl. July, August. Annual.

4. E. pulchélla (Dwarf Centaury), a minute, slender plant, resembling Microcála filifón mis, $1-8$ in. high, but much branched, with a few stalked flowers, rose-pink, as in the other species, with catyx rather shorter than the corolla-tube, occurs also on sandy shores, or on wet sand at inland localities.-FI. July-September. Annual.

5. E. capitata (Tufted Centaury) has an unbranched stem, not more than $3 \mathrm{in.} \mathrm{high,} \mathrm{broadly} \mathrm{ovate,}$ distinctly 3-nerved leaves, a cylindrical corolla-tube and a caly $x$ equalling it in length, and differs from all the other forms in its filaments springing from the base of the corolla-tube,-Downs in the Isle of Wight and Sussex.-Fl. July, Augist. Annual or Biennial.

4. Cicíndia (Guernsey Gentianella), represented by the species C. pusilla, is even smaller and more slender than Microcála. It is from 1-4 in. high ; has spreading branches; linear leaves; pink flowers, and caly, $x$-lobes not apparently united into any tube at their base.- Sandy commons, sometimes flooded, in Guernsey._Fl. July--September. Annual.

5. Gentiána (Gentian).-Herbs with opposite, sessile leaves; flowers mostly 5-merous; corolla funnel- or 
salver-shaper, tube widening upwards and then constricted, blue, purple, or lilac, or rarely pink in British

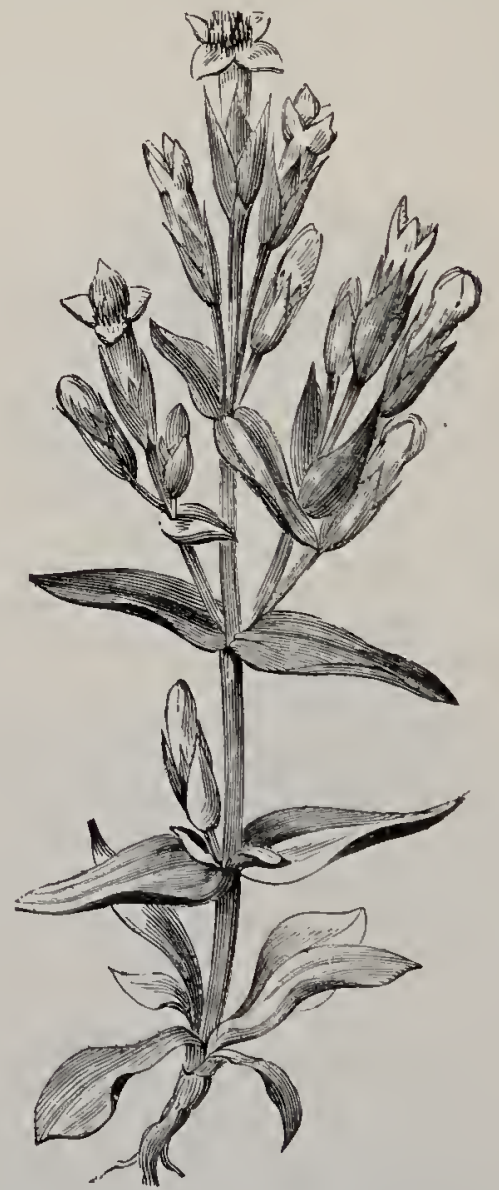

GENTIKNA CAMPRSTRIS (Ficld Gentan).

species; anthers not twisted: stigmas 2. (Name from Gentius, King of Illyria, who is said to hitve discovered its medicinal value.) 
1. G. Pneumonánthé(Marsh Gentian).--Stem erect, leafy, umbranched, 4-10 in. high, with one or two large, bell-shaped, deep blue, or very rarely pink, flowers with 5 green stripes and with no fringe in the throat of the corolla-tube.--Boggy heaths; rare.-Fl. August, September. Annual.

2. $G$. vérna (Spring Gentian). - A tufted plant with runners and rather large, solitary, sessile, intensely blue fiowers, with 5 smaller 2-cleft segments between the lobes of the corolla.-Wet limestone rocks in Teesdale and in Ireland; very rare.-Fl. April-June. Perennial.

3. $G$. nivális (Small Alpine Gentian).-A more erect, slightly branched species, with flowers smaller than in the last, several together and shortly stalked. - Summits of Highland mountains; very rare.-Fl. - August, September. Annual.

4. G. Amarélla (Common Autumn Gentian).-A remarkably erect plant, with a square, leafy, purplish, much-branched stem, 6-12 in. high; numerous, rather large, 5-merous flowers, which only expand in bright sunshine; caly, $x$ with 5 nearly equal lobes, a little shorter than the cylindrical tube of the lurid, purplish-blue corolla, the throat of which is fringed with hairs.-Dry chalky pastures; common-Fl. August, September Annual.

5. $G$ germánica (Scarce Autumn Gentian), differ ing in having unequal lobes to the caly $x$, much shortes than the obconic tube of the bluish-lilac corolla, is also a larger and stouter, but rare plant.

6. G. campéstris (Field Gentian)--Resembling G. Amarélla in habit, but distinguished by its 4-cleft caly $x$, of which the two outer lobes are much larger than the inner two, and by the pale lilac 4-cleft, salver-shaped corolla.-Dry pastur'es; common.-Fl. July-October. Annual.

7. G. báltica (Baltic Gentian), with a corolla-tube shorter than the caly.x, which resembles that of 
G. campéstris, occurs on downs in Norfolk, Suffolk, Devon, Cornwall, and North Wales.-Fl. AugustOctober. Annual.

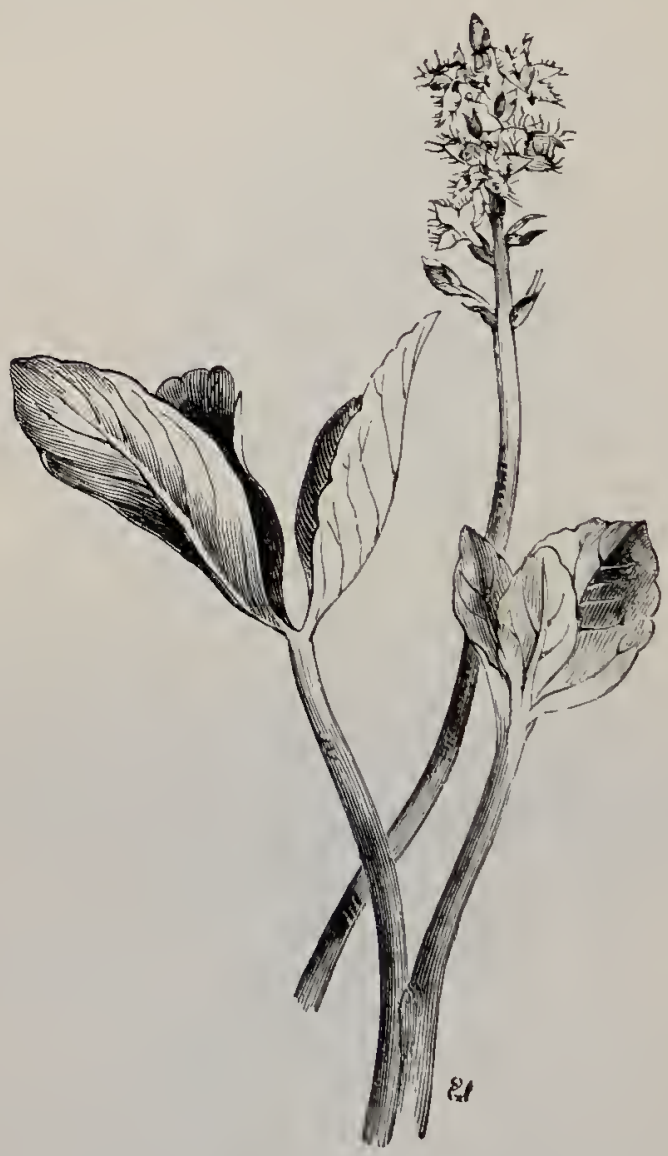

MENYANTHES TRIFOLIÁTA (Buck-bean, Marsh Trefoil),

6. Meryántues (Buck-bean, Bog-bean, Marsh Trefoil), represented by the one species $M$. trifoliata, is the only British plant in the Order with divided 
leaves. The stem scarcely rises above the water or wet ground in which it grows, but is overtopped by the large, ternate leaves, which in shape and colour somewhat resemble those of the Windsor Bean, and have

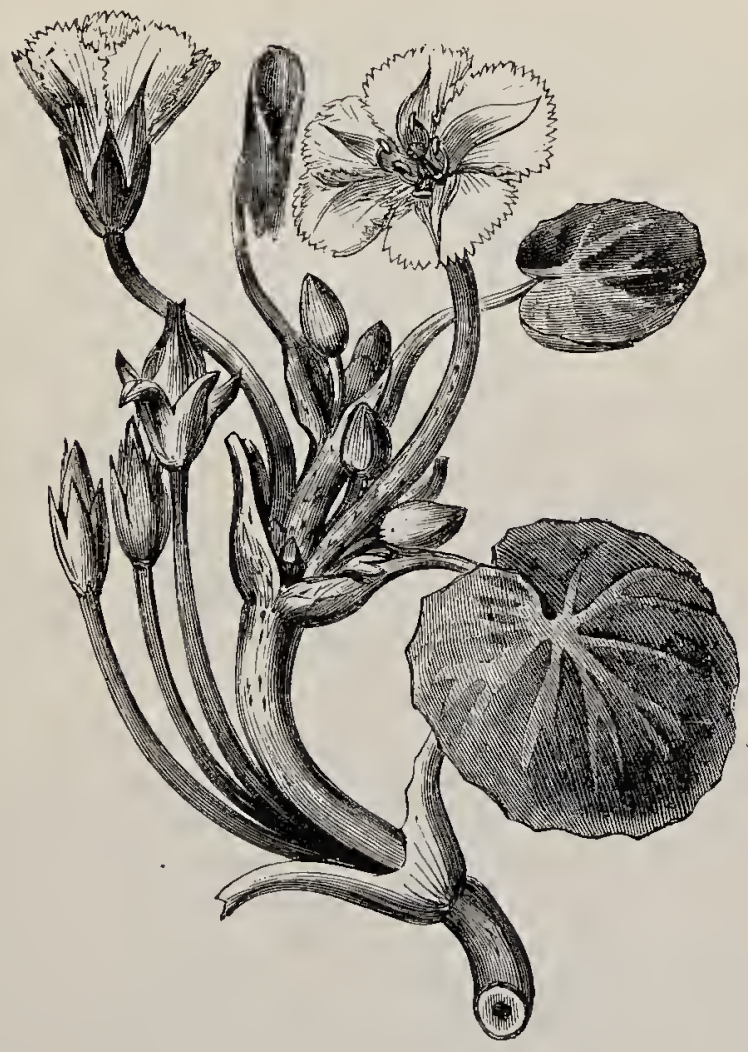

IIMNÁNTHEMUM PELTATUM (Water Villarsia).

sheathing bases to their petioles, opposite to one of which rises a long-stalked raceme of exceedingly beautiful flowers. 'These, when in bud, are pink, and when fully expanded have the inner surface of the 5 fleshy 
petals thickly covered with a white, lace-like fringe.Spongybogs; common.- -Therhizome is intensely bitter, and is said to be the most valuable of tonics.-Fl. May -July. Perennial.

7. Lmmánthemum (Villarsia). - Aquatic plants with simple, orbicular, floating leares; flowers yellow, 5 -merous, in umbels; corolla rotate, induplicate in bud, fringed at the base only, decidnous. (Name from the Greek limné, a pool, anthos, a flower.)

1. L. peltátum (Water Villarsia). - The only British species, with the habit of a Water-lily; the leaves nearly round, deeply cordate, polished, spotted with purple; flowers an inch across, yellow, and fringed.--Ditches communicating with the Thames, and elsewhere in the south; rare.--Fl. July, August. Pcrennial.

Ord. LI. Polemoníceem,-This Jacob's Ladiez Favilu.

A small Order of herbaceous plants, often wion showy flowers, mostly natives of the western temperate parts of America, and unknown within the Tropics. They have a deeply 5-cleft, persistent, inferior cailya: polysymmetric, 5-lobed corolla; stamens 5, inserted on the corolla-tube; ouar!y 3-chambered; style single; stigma 3-cleft; capsule 3-chambered, 3-valved. None of the species possess remarkable properties, but several are favourite garden flowers, such as Phlox, Polemónium, and Cobeco.

1. Polemónium (Jacob's Ladder). - Leaves scattered, unequally pinnate; cally campanulate; corolla rotate; stamens bearded at the base and lying on one 
side of the flower; chambers of the capsule manysecded. (Name, the Greek name of the plant.)

1. P. corúleum (Jacob's Ladder, Greek Valerian). -The only British species, a tall, erect plant, 1-2 feet high, with an angular, hollow stem; smooth,

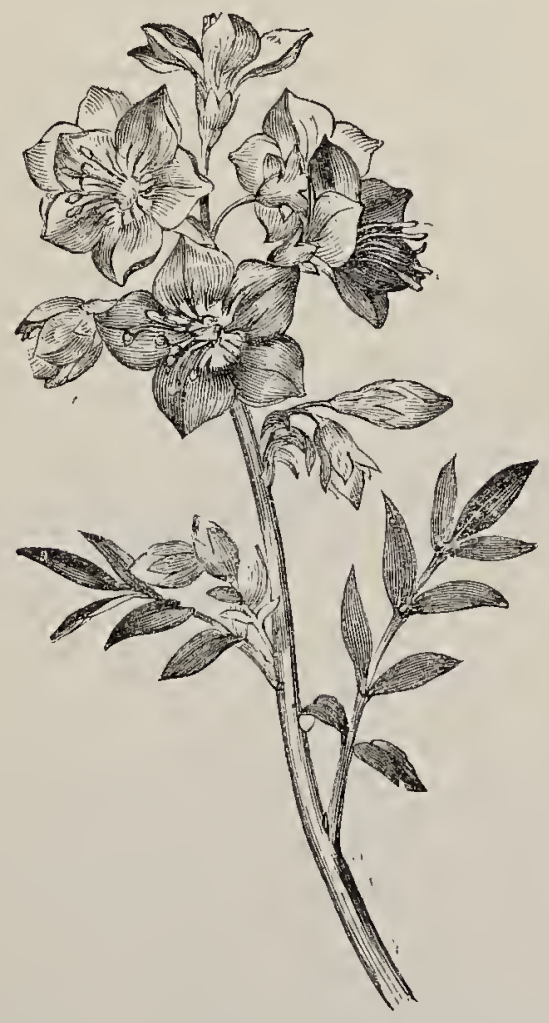

P. CERÚleum (Greek Valerian, Blue Jacob's Ladder).

pinnate leaves with $13-25$ leaflets; and numerous blue or white flower's, about an inch across, in a terminal cluster.-Woods in the north; rare. A common garden flower, not easily rooted out where it has once established itself, -Fl. June, July. Perennial. 
Ord LiI. Boraginee.-The Borage Famly.

A considerable Order of herbs or shrubs, principally natives of the warmer temperate regions of the old World, with scattered leares, which are usually covered with hairs or bristles rising from a swollen base. This character was considered by Linnaus sufficiently constant to give to the Order the name Asperifólice, or Rough-leaved plants; but the present name of the Order is preferable as being more comprehensive, a few species in it having perfectly smooth leaves. MIost member's of the Order bear their flowers in rolled up, scorpioid racemes, a few expanding at a time. The calyy is inferior, deeply $5-$, or rarely 4-cleft, and persistent; the corolla hypogynous, 5 -, or rarely 4-cleft, frequently laving teeth at the mouth of the tube, and nost commonly blue or purple. Many, when first opening, however, are of a pink hue, which subsequently deepens, so that it is not unusual to see flowers of different tints in the same cluster. The stamens are 5, inserted on the corolla and alternate with its lobes; the carpels 2, forming a 4-parted, 4-seeded ovary, with a single, gynobasic style; and the fruit a regma of 4, rarely 2 , one-seeded nutlets. They possess no remarkable properties, but abound in a soft alkaline mucilage, which gives a coolness to beverages in which they are steeped, on which account Borage is an ingredient in claret-cup. The roots of Alkanet and some others contain a red substance which is used as a dye. Mylosútis patustris, the Feryiss-mein-nicht of German romance, has now obtained the English name " Forget-me-not," formerly applied for very unromantic reasons to Ájuga Chamápitys.

1. Crnoghóssum,-Calyy 5-cleft ; coroll a polysymmetric, funnel-shaped, its mouth closed by prominent blunt scales; nutlets with hooked bristles. 
*2. Aspérugo.-Calya with 5 leafy lobes and smaller alternate teeth; corolla polysymmetric, funnel-shaped, with rounded scales in the throat; nutlets flattened, tubercled.

3. Sŕmphyтum.-Caly. deeply 5-cleft; corolla polysymmetric, bell-shaped, closed with 5 awl-shaped scales ; stamens short, included.

4. Borágo.-Calyw deeply 5-cleft; corolla rotate, its throat closed with 5 short, erect, notched scales; filaments forked; anthers prominent, converging in a cone.

5. Ancrúsa.—Calyze deeply 5-cleft ; corolla salvershaped, with a straight tube, its throat closed by prominent blunt scales; stamens included.

6. Lyoópsis.-Calyx deeply 5-cleft; corolla oblique, funnel-shaped, with a bent tube; otherwise like Anchuisa.

7. Pulmonária.-Calyie-tube long, 5-cleft; corolla salver-shaped, polysymmetric, its throat naked; stamens included; nutlets smootl.

8. Preumária.-C'alyix-tube short, deeply 5-cleft; corolla funnel-shaped; stamens long, exserted; nutlets Hieshy.

9. Mrosótis.-Calyx 5-cleft; corolla salver-shaped, its lobes blunt, twisted when in bud, and its throat nearly closed by blunt scales ; nutlets smooth.

10. Lithospéraum.-Caly. $x$ deeply 5 .cleft ; corollu funnel-shaped, its throat naked or with 5 minute scales; stamens included; nutlets stony.

11. Éснium.-Calya deeply 5.cleft; corolla monosymmetric, sub-campanulate, its throat naked ; stamens very long, unequal in length, exserted.

1. Cynogitóssum (Hound's-tongue).—Coarse, hairy, herbaceous plants, with small flowers in forked, usually ebracteate cymes; caly $x$-5-cleft; corolla polysymmetric, funnel-shaped, its month closed by 
prominent blunt scales; stamens included; nutlets covered with hooked bristles; style rigid, persistent.

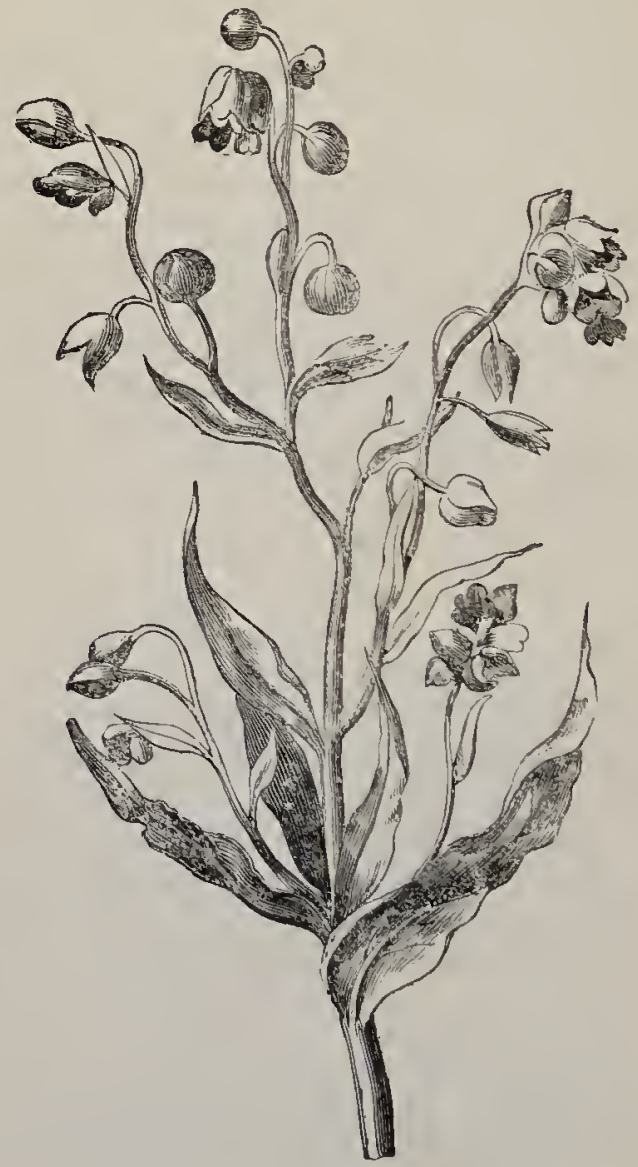

CYNOGIOSSUM OFFICTXILt (Common Hounl's-tongue).

(Name from the Greek glossa, a tongue, cinos, of a dog, from the shape and roughness of the leares.)

1. C. officinálé ("ommon Hound's-tongne) - A stout, herbaceous plant, $1-2$ feet high, with large, 
downy leaves with adpressed hairs, lurid red-purple flowers, and large, flattened mutlets, covered with barbed prickles, so as to stick to the wool of arimals or the clothes of passers-by as closely as burs. The whole plant has a strong disagreeable smell, like that of mice.-Waste ground.-Fl. June, July. Biennial.

2. C. germánicum (Green-leaved Hound's-tongue). -A more slender plant with leaves green above, not downy, with few spreading hairs, and reddish flowers, changing to blue.--Shady places in the Midland and Eastern counties; rare.-Fl. May, July. Biennial.

*2. Aspérugo (Madwor't), represented by one species, $A$. procímbens, with prostrate, angular stems, thickly set with rigid, curved bristles, and few, small, blue flowers, solitary in the axils of the upper leaves, occurs rarely in waste ground, but is not indigenous. (Name from the Latin asper, rough.) - Fl. May -. July. Annual.

3. Sýmphytum (Comfrey).-Coarse, rough plants with enlarged roots; cauline leaves often decurrent; flowers in terminal cymes; corolla bell-shaped, dilated above the middle, with 5 short lobes, and the throat closed with 5 awl-shaped, fringed scales; stamens included; nutlets smooth. (Name from the Greek simphro, I unite, from its supposed healing qualities).

1. S. officinálé (Common Comfrey).-A. large and handsome plant, $2-3$ feet high, with branched, leafy stems, winged in the upper part; leaves elliptical, acute, decurrent; and purple, pink, or white flowerss in 2-forked, drooping clusters. - Watery places and banks of rivers; common. Often introduced into gardens, from which it is ver'y difficult to eradicate it when it has once established itself, owing to the brittleness of its fleshy roots, the least bit of which will grow.-Fl. May, June. Perennial. 
2. S. tuberósum (Tuberous Comfrey). - A smaller and more slender plant with a scarcely winged stem, longer-stalked radical, and scarcely decurrent cavline

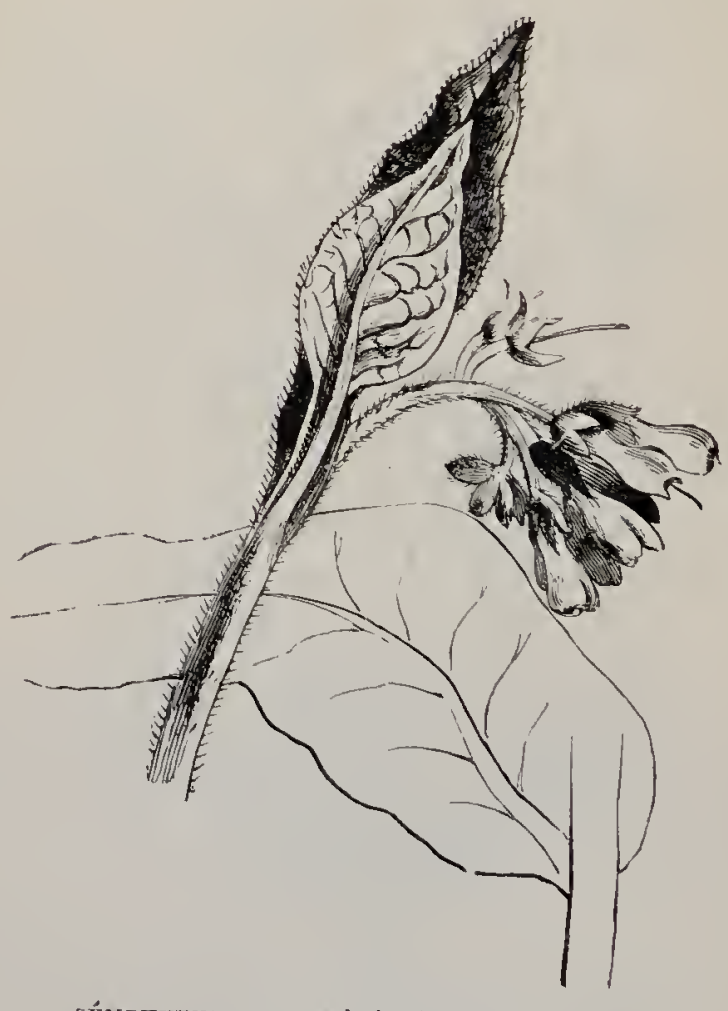

SÝMPHYTTUM OFFICINALÉ (Common Coinfrey).

Teaves.--Damp woods in the north; rare.-Fl. June, July. Perennial.

*4. Boríco (Borage) is represented by one species, B. officinatis, about 2 feet high, with both stems and leaves thickly covered with stiff, whitish, 
bulbous bristles. The flowers, which are large, bright blue, and very handsome, grow in terminal, drooping clustars, and may readily be distinguished from any other plant in the Order by their prominent purpleblack anthers. A variety occurs with white flowers.

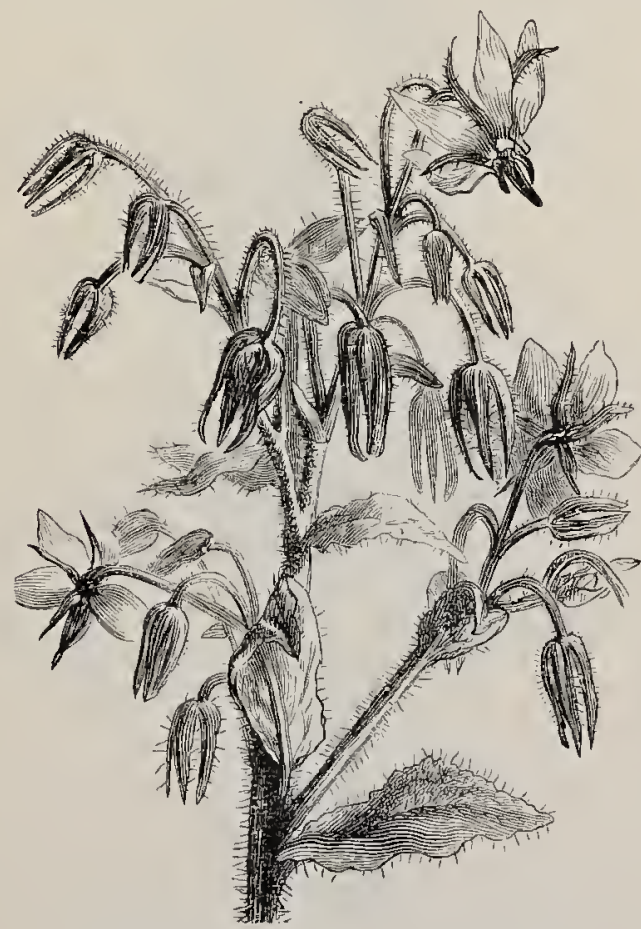

BoRAGO OFFICINÁLIS (Common Borage).

-Waste places; not indigenous. The juice has the smell and flavour of cucumber, which is, therefore, often substituted for Borage in claret-cup.-Fl. June, July. Biennial.

*5. Anchósa (Alkanet). - Herbaceous, bristly plants with a deeply 5-cleft calyx, and a funnel- 
or salver-shaped corolla with a straight tube, and its throat closed by prominent blunt scales. (Name from the Greek anchousa, paint, from the use of the root as a dye.)

1.* A. officirális (Common Alkanet).-A soft, hairy plant with an angular stem ; narrow, lanceolate

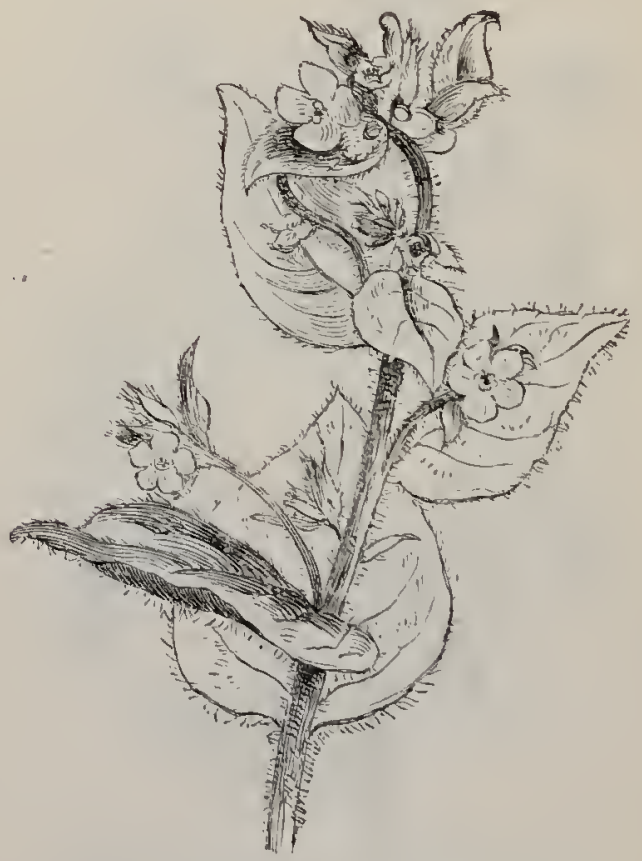

ANCHÚSA SEMPERYfRENS (Eicrgreen Alkanet).

leaves: and forked one-sided cymes of violet flowers; caly.e longer than the funnel-shaped corotla.-An occasional escape from gardens.-Fl. Jume-July.

2.* A. semperiens (Evergreen Alkanet). - A stout, bristly plant with deep green, ovate leaves, and long-stalked, axillary, crowded clusters of rather 
large flowers, which are of an intense azure blue and have a short tube to the corolla.-Not generally con-

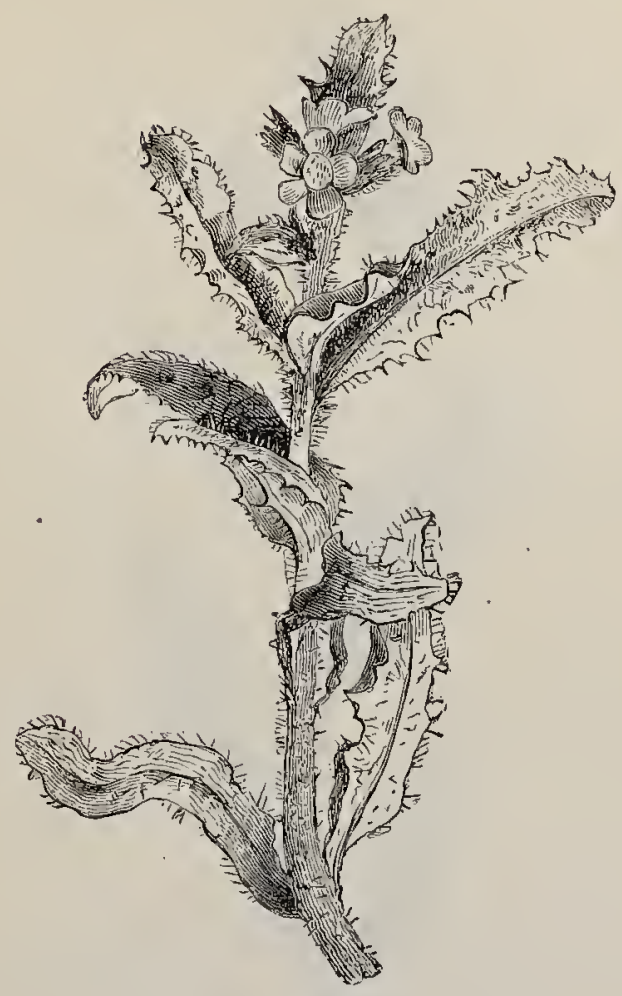

urCóPsIs ARTÉNSIS (Small Brgloss).

sidered a native; but not an uncommon hedge-plan in Devonshire.-Fl. May-August. Perennial.

6. Lycбрsis (Bugloss).-Differing from Anchúsa chiefly in having a bent tube and an oblique limb to the corolla. (Name in Greek signifying "a wolf's face." from some fancied resemblance in the flower.) 
506 BORAGINEE.

1. L. arvénsis (Small Bugloss). - The only British species; a branched, prickly plant, 6-18 in. high,

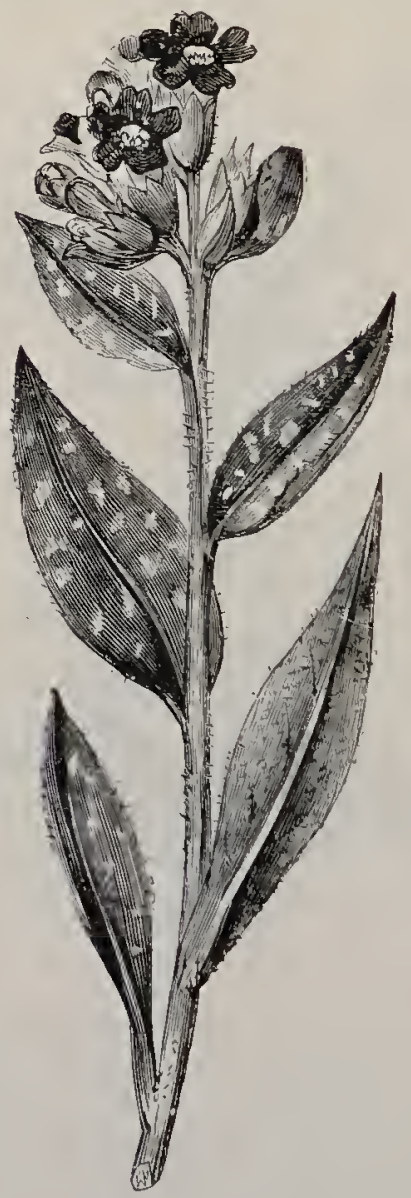

PULMONARIA OFFICINÁlis (Common Lunguort).

with oblong, wavy leaves, and forked, curved clusters of small blue flowers. - Waste ground ; common, especially near the sea.-Fl. June, July. Annual. 
7. Pulmonária (Lungwort).- - Herbs with a creeping rhizome; radical and cauline leaves; terminal cymes of flowers with long, 5-cleft caly $x$; salver-shaped, polysymmetric corolla with naked throat; included stamens; and smooth mutlets. (Name from the Latin pulmo, the lungs, its spotted leaves being supposed, according to the old doctrine of "signatures," to indicate its value in lung-clisease.)

1. P. angustifólia (Narrow-leaved Lungwort).About a foot high; leaves narrow-lanceolate, the upper ones sessile, of ten spotted with pale green; flowers pink in bud and afterwards deep blue.-Woods in Dorsetshire, the Isle of Wight, and the New Forest. -Fl. February-June. Perennial.

2. P. officinális (Common Lungwort).-Leaves ovate, always spotted; flowers pale purple.-Woods; rare. (Generally an escape from gardens.-Fl. A pril, May. Perennial.

8. Preumária (Smooth Gromwell, Lightwort).Herbs with radical and cauline leaves, and blue-purple flowers in terminal cymes; calyx-tube short, deeply 5cleft ; corolla funnel-shaped ; stamens long, exserted; nutlets fleshy. (Name from the Greek pmention, the lungs.)

1. F maritima (Seaside Smooth Gromwell). - The only British species, a singular plant about 18 in. high, with fleshy, glaucous leaves, without bristles, but sprinkled with hard dots, which are very evident in dried specimens; flowers blue-purple, crimson in bud. - Sea-shores in the north. When fresh the plant is said to have the flavour of oysters.-Fl. May, June. Perennial.

9. Myosótis (Mouse-ear, Scorpion-grass).-Herbs with stalked radical, and sessile cauline leaves, and terminal 1-sided clusters of small, generally blue 
flowers ; calyx 5-cleft; corolla salver-shaped, with blunt lobes, twisted in bud, and throat nearly closed by blunt scales ; nutlets smooth. (Name from the Greek, signifying a mouse's ear, from the shape of the often downy leaves.

1. M. cespitósa (Tufted Water Scorpion-grass).A tufted, light green, rather shining plant with a short, not creeping rhizome; stem much branched from the base with slender branches, downy with adpressed hairs ; blunt lecues ; and long, slender racemes of short-stalked, sky-blue flower's, $\frac{1}{6}$ in. across.Watery places ; common.-Fl. May-Augnst. Perennial.

2. M. palustris (Forget-me-not).-A light green, rather shining, almost glabrous plant, with few spreading or adpressed hairs, a creeping rhizome with runners; blunt, apiculate leaves, the cauline ones sessile or decurrent; and terminal, lenfless, 1-sided clusters of bright blue flowers, nearly $\frac{1}{2} \mathrm{in}$. across, with a yellow eye, and a small, white scale at the base of each lobe of the corolla.-Watery places; common. Few flowers have been more written about than the Forget-me-not, yet there is great disagreement among writers as to the plant to which the name properly belongs. It was once applied to the Ground-pine (Ájuga Chamrepitys) on account of its strong taste of turpentine: some appear to lave had the Alkanet in view; other's, the Speedwell ; and others, again, some of the smaller and less brilliantly coloured species of Myosótis._El. May-August. Perennial.

3. 1I. répens (Crceping Water Scorpion-grass).Rhizome short with leafy runners above ground; stem angular, slender, branched, with long, spreading hairs ; leaves acute ; flowers sky-blue, with a yellow-eye, $\frac{1}{3}$ in. across, in long, slender clusters with a few leaves at the base, and very slender, long pedicels bending downward in fruit.-Wet places ; common._El. June -August. Perennial. 
4. M. alpéstris (Mountain Forget-me-not). - A short, erect plant, with long, soft, spreading hairs; radical leaves on long, slender stalks, pointed; flowers deep bright blue, $\frac{1}{3}$ in. across, in short clusters, with short, thick pedicels, and flat, short-tubed corollas,

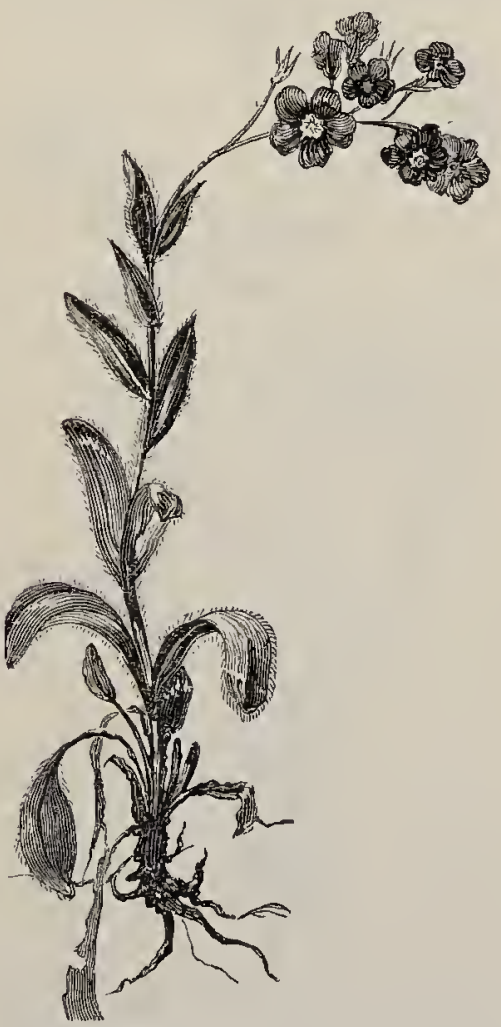

MYOSÓTIS ALPÉSTRIS (Mountan Forget-me-not).

sweet-scented in the evening.--Mountains in Yorkshire and Scotland; rare.-F]. July, August. Perennial.

5. M. syluáticu (Wood Forget-me-not). - A taller, erect plant, without rumners, with spreading hairs; radical leaves on sliort, broal stalks, blunt; flowers 
bright blue, $\frac{1}{3}$ in. across, in clusters becoming very loose in fruit; caly $y$ with hooked bristles.-Dry woods; rare.-Fl. May--September. Perennial.

6. M. arvénsis (Field Scorpion-grass).-A closely allied species, $6-18 \mathrm{in}$. high, roughish with spreading bristles; radical leaves stalked; flower's very small,

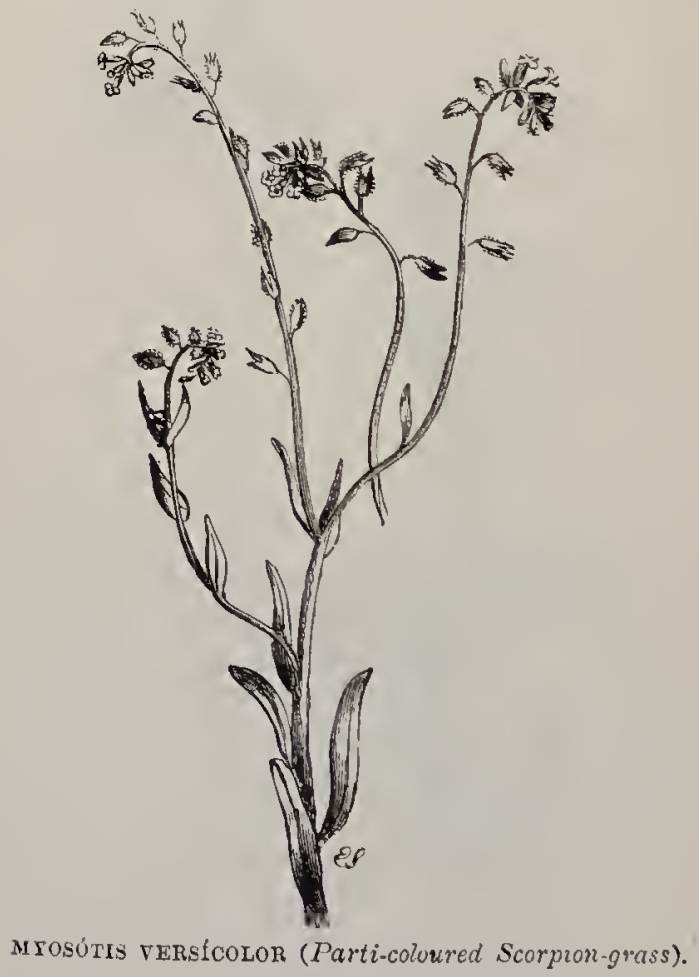

$\frac{1}{6}$ in. across, usually concave, pale blue, on long, slender, spreading pedicels; caly.x with hooked bristles.Cultivated land and waste places; the commonest species of the genus.-Fl. June-August. Annual. 7. M. colline (Early Field Scorpion-grass).-A slender, erect or prostrate plant, of ten only about 3 in. 
high; leaves oblong, blunt; flowers minute, bright blue (never pink or yellow), on short pedicels in long, slender, leafless clusters, with a solitary flower some distance below them in the axil of the uppermost leaf ; calyx with hooked bristles.-Dry banks; common. On its first appearance, in April, the flowers are buried among the leaves; but the stems finally lengthen into racemes, and as the season advances the whole plant drios up and disappears.-Fl. April-July. Annual.

8. MT. versicolor (Parti-coloured Scorpion-grass). A very distinct species, less than a foot high ; stem leafy below, naked above ; leaves sessile, linear-oblong, sub-acute ; flowers very minute, in clusters, on long, leafless stalks, tightly coiled up, when in bud, in the scorpioid manner which gives these plants the name of Scorpion-grass, at first pale yellow, afterwards blue. -Fields and banks; common.-Fl. A pril---June. Annual.

10. Lithospérnum (Gromwell).-Herbs, sometimes shrubby, with flowers in leafy clusters; calyz deeply 5-cleft; corolla funnel-shaped, its throat naked, or with 5 minute scales; stamens included; nutlets stony. (Name from the Greek Tithos, a stone, sperma, seed, from its hard nutlets.)

1. L. purpúreo-cerúleum (Purple Gromwell), with prostrate, barren stems, and erect flowering ones, 1-2 feet high, with large, bright blue-purple flowers, occurs rarely in woods on chalky or limestone soil, chiefly in the south.-Fl. May_-July. Perennial.

2. L. officinálé (Common Gromwell, or Grey Millet).-Distinguished by its erect stems, 1-3 feet high, much branched towards the summit, and generally growing 5 or 6 from the same root; oblong, acute, sessile leaves, bristly above, hairy beneath ; small yellowish-white flowers, and, above all, by its highly polished pearl-grey, stony nutlets, which remain on

o 02 
the dead, leafless shoots in autumn-Dry places; not unfrequent.-Fl. June-August. Perennial.

3. L. arvénsé (Corn Gromwell)._-Stem about a foot high, solitary, erect, branched; lecues narrow, hairy; flower's small, cream-white; caly, lengthening when

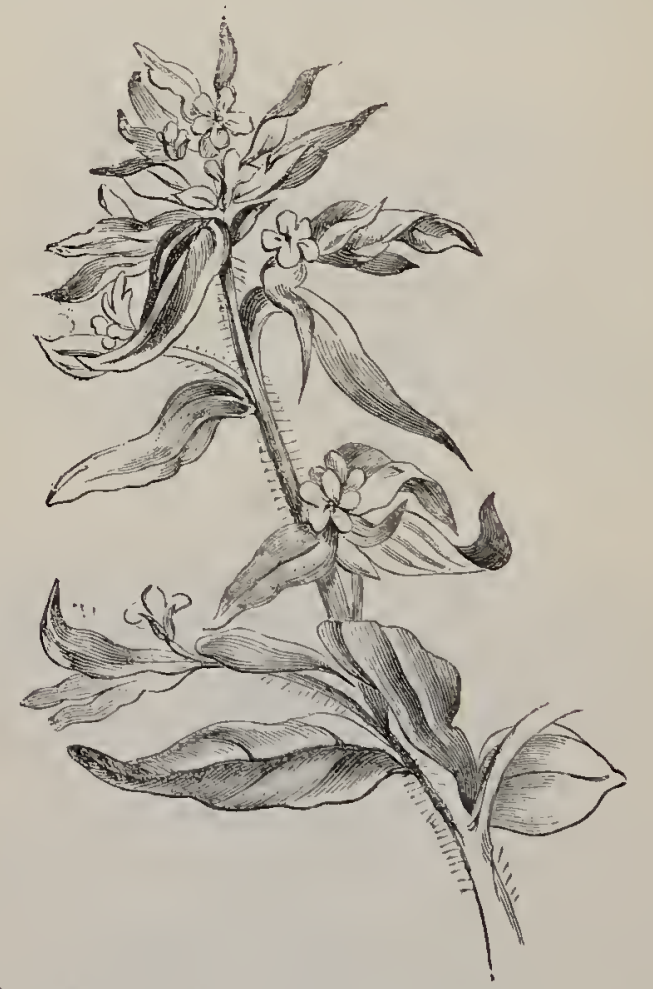

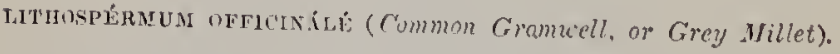

in fruit, and containing 3 or 4 brown, wrinkled nuilets.-Cornfields; common.--Fl. May-July. Annual.

11. Écritur (Viper's Bugloss)._Usually large, rough herbs with their flowers in scorpioid cluster's; 
calyx deeply 5-cleft; corolla monosymmetric, sub campanulate, its throat naked; stamens very long,

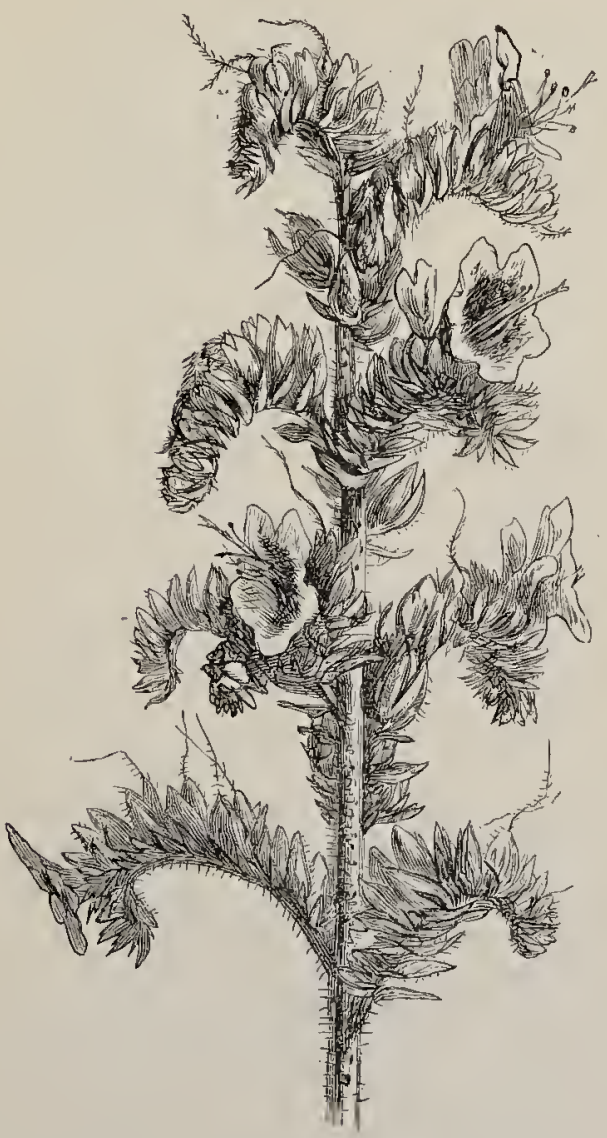

ECHIUM VULGÁRÉ (Common Vip̣er's Bugloss).

unequal in length, exserted. (Name from the Greek echis, a viper, against the bite of which it was formerly considered an antidote.) 
1. E. vulgáré (Common Viper's Bugloss). - A handsome plant, 2-3 feet high, remarkable for its bristly, or almost prickly stems and leaves, and numerous curved, lateral spikes of flowers, which on their first opening are bright rose-coloured and finally of a brilliant blue.--Dry places; common. The roots are very long and tapering, and descend perpendicularly into the loose soil in which the plant usually grows. There is a white-flowered rarjety. The name Bugloss is of Greek origin, signifying $0 x^{2} s$ tongue, referring to the shape and reughness of the leaves.-Fl. June-August. Biennial.

2.* E. plantagineum, with narrower leaves and more spreading spikes of dark violet flowers, occurs in Cornwall and Jersey.-Fl. June-September. Biennial.

\section{Ord. LiII. Convolyuláce.e-The Brxpweed Family.}

An extensive and lighly valuable family of plants, most of which are herbaceous climbers, with large and very beautiful flowers. They are most rbundant within the Tropics. They have frequently a milky juice: their leaves are scattered and exstipulate; their sepals 5, inferior, imbricate, often very unequal, persistent; their corolla monosymmetric, hypogynous, plaited, gamopetalous, 5-toothed, deciduous ; stamens 5 , inserted on the base of the corolla-tube ; ovary of 2-4 united carpels, few-seeded, surrounded below by a fleshy, ring-shaped cist ; style single, 2-4-forked; fruit a 1-4-chambered capsule. As medicines they occupy an important station. The roots of Vóluntus Scammónic, a Syrian species, furnish scammony; jalap is prepared from a similar gum-resin which abounds in the roots of several species of Exogónium, beautiful Mexican climbers, with large, trumpet- 
shaped flowers; and Batátas edúlis is no less valuable as a food in tropical countries, its roots, known as sweet potatoes, abounding in starch and sugar, and being very nourishing. Cúscuta (Dodder) is a parasitic genus, with branched, climbing, thread-like stems, no leaves, and globular heads of small, wax-like flowers. The seeds germinate in the ground, and the young plants climb the stems of adjoining plants, sending out root-like suckers into them and then losing their connexion with the ground. One species found in Britain grows upon Flax, with the seeds of which it has probably been introduced; and others grow on Furzes, Heaths, Clovers, and other plants.

1. Vólvulus. - Leafy, twining plants with 2 large bracts enclosing the calyx.

2. Convócvulus. - Leafy, twining plants with small bracts distant from the flower.

3. Cúscuta.-Leafleš, twining parasites.

1. Vótuulus (Bindweed).--Slender, twining plants with milky juice; scattered lecues, often sagittate; bracts large, leafy, enclosing the calyw; corolla trumpet-shaped, 5-plaited, slightly 5-lobed; capsule 2-chambered below, 1-chambered above, 2-valved (Name, a diminutive from the Latin volvo, I twine.)

1. V. sépium (Great Bindweed).---A glabrous, twining plant with stout, fleshy, creeping rhizome; leaves arrow-shaped, with abrupt lobes ; tracts large, heartshaped, close to the flower and entirely enclosing it when in bud; flowers solitary, on square peduncles, large, pure white; fruit not often perfected.-Bushy places; common. A most mischievous weed in gardens, not only exhausting the soil with its roots, but strangling with its twining stems the plants which grow near. Its handsome flowers are among the largest which this country produces.-Fl. June- September. Perennial. 
2. V. Soldanélla (Sea Bindweed). - A very beautiful species; stems not climbing, usually almost entirely buried beneath the sand; leaves fleshy, roundish or kidney-shaped; brects large, ovate, close to the Hower';

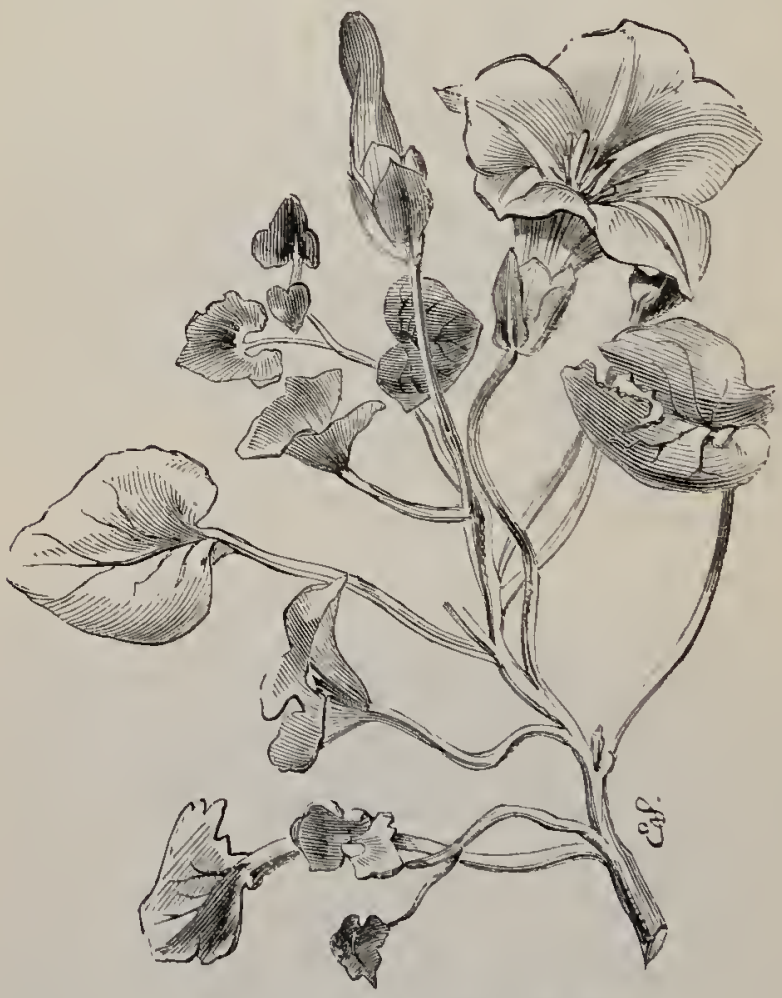

vólvulus solmaxilla (sed Bindueed).

flowers solitary, almost as large as those of the pre. ceding species, pale rose-coloured, striped with red or yellow, on 4-sided, winged stalks.--Sandy sea-shores; frequent. The flowers generally expand in the - morning and close before night.-Fl. June--August. Perennial. 
2. Convótvulus (Bindweed), differing mainly in having small lreets low down on the peduncle. (Name, a diminutive from the Latin convólvo, I entwine.)

1. C. arvénsis (Field Bindweed).-A beautiful, though destructive twining plant; leaves arrowshaped, with acute lobes; bracts 2, small, linear, distant from the flower ; flower's 1-3 together, white or rose-coloured, with darker red plaits, handsome and fragrant, opening only in sunny weather.-A common weed in light soil, either trailing along the ground among short grass or climbing the stalks of corn or any other support.-Fl. June-September. Perennial.

3. Cúscuta (Dodder).-Slender, branched, twining, leafless parasites, with thread-like stems, generally reddish, and small flowers in compact globular heads ; caly.x 4-5-cleft; corolla bell-shaped, 4-5-cleft, generally with scales below the epipetalous stamens; ovary 2-chambered, 4-seeded; capsule bursting transversely; seeds almost without cotyledons. (Name of doubtful etymology.)

1. C. europxa (Greater Dodder), with a calyw of blunt sepals, much shorter than the yellowish corolla, and the scales in the corolla-tube short, notched, and pressed to the sides of the tube, grows on Nettles, Thistles, Vetches, and other herbaceous plants.-Fl. July-September. Annual.

2. C. Epithymum (Lesser Dodder), with a reddish caly $x$ of acute sepals, shorter than the white corolla, the scales as long as the corolla-tube, fringed and converging, and the stamens exserted, grows on Furzes, Heaths, Thymes, and other shrubby plants, and is the commonest species. Soon after flowering the stems turn dark brown, and in winter disappear, - Fl. July- . October. Annual. 
3.* C. Epilinum (Flax Dodder), with green stems, whitish flowers in small clusters, acute sepals as long

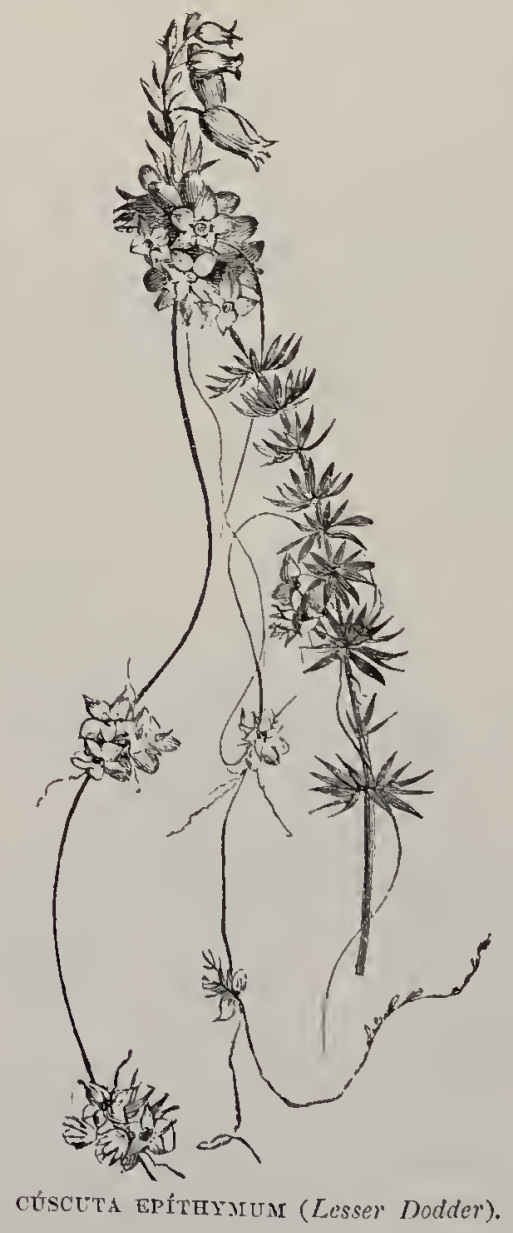

as the corolla, and adpressed fringed scales, is some times very destructive to Flax.-Fl. July, August. Annual. 
4.* C. Trifólii (Clover Dodder), with reddishyellow stems; white flowers; lanceolate, red-tipped sepals as long as the corolla, and converging scales half as long as the corolla-tube; grows chiefly on Clover.-Fl. July--September. Annual.

\section{Ord. LIV. Solanácee,-The Nightshade Fariliy.}

A large and highly important Order, containing about 1,000 species of herbaceous plants and shrubs, which inhabit most parts of the world except the coldest, and are most abundant within the Tropics. Their leaves are exstipulate and scattered, but occasionally appear, owing to adhesion, to spring in pairs ; and the cymose inflorescences are similarly sometimes above the axils of the leaves. The flowers are polysymmetric and pentamerous, rarely 4-merous; caly.r. inferior, deeply cleft; corolla hypogynous, gamopetalous, plaited when in bud; stamens in one whorl, alternate with the petals; anthers bursting either by terminal pores or by slits down their inner surfaces; ovary 2-chambered; style 1; stigma simple; fruit a 2-4-chambered capsule or nuculane ; seeds numerous. The prevailing property of the members of this Order is narcotic, and many are, in consequence, highly poisonous. In others, certain parts of the plant have poisonous properties, the rest being harnless, and some even containing a large quantity of nutritious matter. The genus Solánum is a very extensive one, comprising as many as 600 species. First among these in importance stands the Potato (S. tuberósum), a native of Chili, which was introduced into Spain between 1580 and 1585, and into Ireland by Thomas Herriott, who brought it from Virginia in 1586. It was first planted on Sir Walter Raleigh's estate at Youghal, co. Cork, and was cultivated for food in that country long before its value was known in England; 
but John Gerard grew it in his garden in Holborn before 1597 , the year in which his "Herbal" was published, in the frontispiece to which work he is represented holding a flowering branch of the potato. Its leaves and fruit are narcotic; but its tubers contain no noxious matter, abounding in an almost tasteless starch, on which account it is less liable to clog on the palate than any other vegetable food except bread. S. Melongena, the Egg-plant, a common greenhouse plant, is remarkable for bearing a fruit of the size and colour of a pullet's egg ; S. Dulcamára, the Woody Nightshade, or Bittersweet, a common English plant, with purple and yellow flowers and scarlet fruit, has narcotic leaves; and $S$. nígrum, a smaller species, common as a weed in England and most other comntries, except the coldest, with white flowers and black fruit, is narcotic to a dangerous degree. Átropa Belladónna, a stout, herbaceous plant, with dingy purple, bell-shaped flowers, is the Deadly Nightshade, so-called from the poisonous nature of every part of the plant, especially the fruit, which is large, black, and shining, and of a very attractive appearance. It contains a substance known as alropine, which possesses the singular property of contracting the iris and thus dilating the pupil of the eye, on which account it is extensively used by oculists when operations are to be performed, and, it is said, by ladies to enhance their. beauty, whence it derives its specific name. The Mandrake (Mandragora officinális) was anciently thought to possess miraculous properties. It was said to shriek when taken from the ground, and to cause the instant death of anyone who heard its cries. The person who gathered it, therefore, always stopped his ears with cotton, and harnessed a dog to the root, so that, in his efforts to escape, he uprooted the plant, and instantly fell dead. The forked root was then trimmed so as to resemble the human form. Tobacco is the foliage of several species of Nicotiana, a violent poison when re- 
ceived into the stomach, though commonly employed in other ways without apparent il] effects. Hyoscyamus niger, the Henbane, a stout, herbaceous plant with sticky, fetid leaves, and cream-coloured flowers veined with purple, is a powerful narcotic, and in skilful hands scarcely less valuable than opium. Datuira Stranónium, the Thorn Apple, bearing large, white,trumpet-shaped flowers, and prickly capsules, is also a dangerous poison, though employed with good effect in several nervous and other disorders, especially asthma. Phýsalis Allelkéngi, the Winter Cherry, is remarkable for bearing a scarlet fruit enclosed in the enlarged calyx, which also turns scarlet, but, after exposure to autumn wet, decays, leaving the fruit hanging within a network of its veins. The genus Cápsicum affords Cayenne pepper, which is prepared by grinding the dried fruits; and Tomatoes are the fruit of the genus Lycopérsicum.

1. Solánum.-Corolla rotate, the segments spreading or reflexed ; anthers opening by pores; fruit a 2chambered nuculane.

*2. LÝcrus. - Corolla funnel-shaped, segments spreading; anthers opening lengthwise; fruit a 2chambered nuculane.

3. Átropa.-Corolla bell-shaped; finit a 2-chambered nuculane.

*4. Datúra.-Corolla long, funnel-shaped, folded angularly; fruit a 4 -valved capsule.

5. Hyoscŕamus. - Corolla short, funnel-shaped, with unequal lobes: capsule opening transversely.

1. Socáncu (Niglitshade).-Herbs's or shrubs with scattered or paired leaves; polysymmetric, purple or white flower's; rotate corolla with a short tube, and spreading or reflexed, valvate lobes; exserted, convergent anthers, opcning by pores; and a 2-4-chambered, fleshy, many-seeded, berry-like fruit. (Name of doubtful origin.) 
1. S. Duleamára (Woody. Nightshade, Bittersweet). - Frequently, though incorrectly, called Deadly Nightshade; well marked by its shrubby, clam.

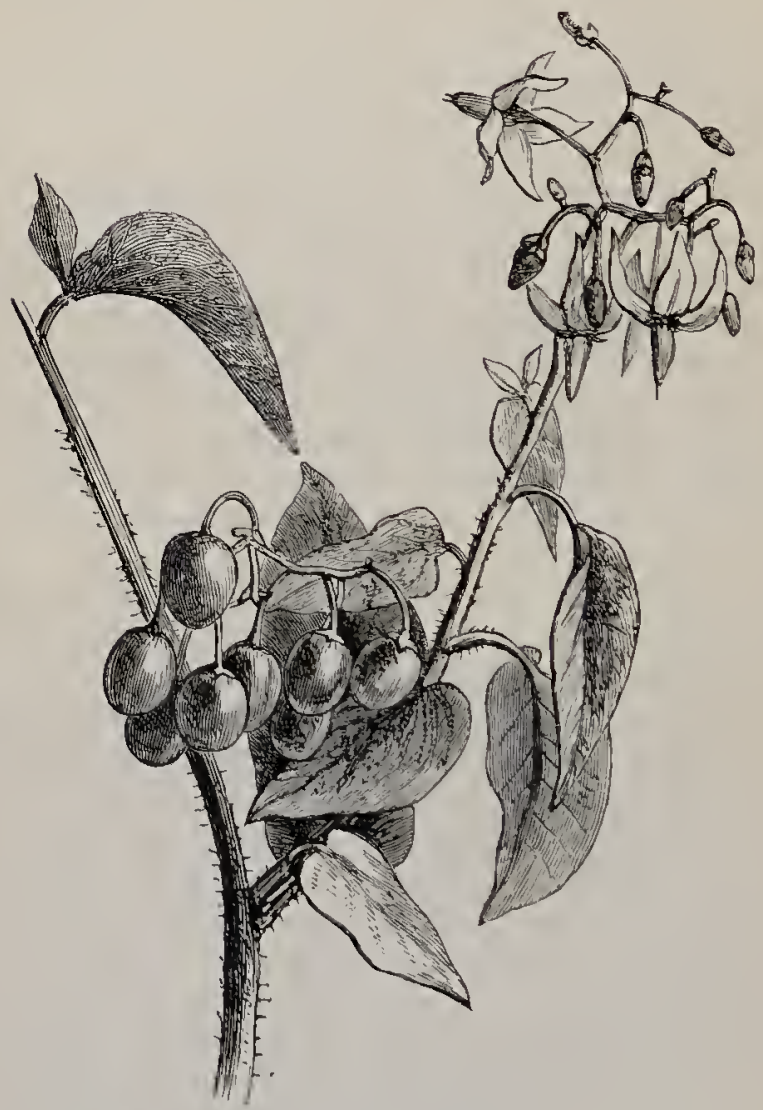

Solanum dULCaMáRA (Woody Nightshade, Bittersweet).

bering stem climbing among bushes to a height of 8 or 10 feet; leaves ovate, acute, cordate, hastate, or eared at the baso; flowers in loose drooping clusters, purple with 2 green spots at the base of each petal; aniliers 
yellow, uniting in the form of a cone; fruit oval, scarlet, berry-like. - Hedges, and luxuriantly near water; common.-Fl. June, July. Perennial.

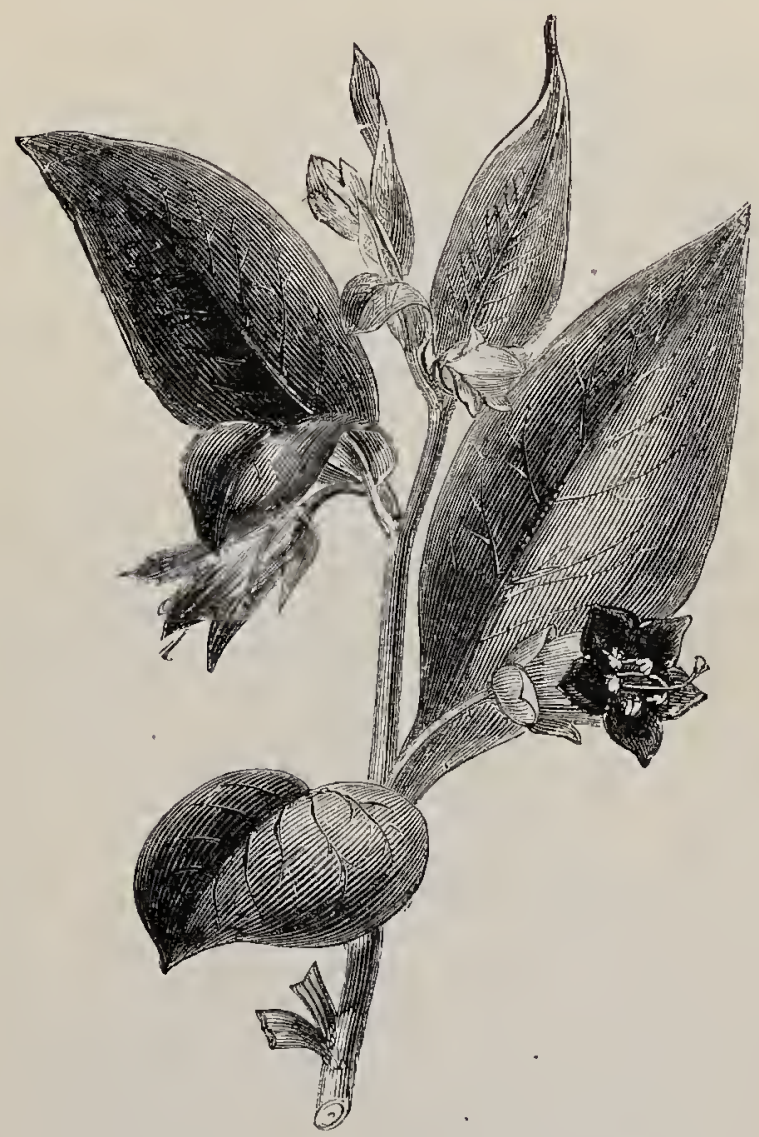

Atropa Beiladónna (Deadly Nightshade, Diwale).

2. S. nígum (Black Nightshade).-A branching, erect, herbaceous plant, gencrally less than a foot high; lecoves stalked, ovate, wavy, bluntly toothed; flowers few, drooping, white, with yellow anthers; 
fruit globular, generally black, but rarely yellow or red.-Waste ground; common.-Fl. July-October. Annual.

*2. Líciun, represented by $L$. barbarum (The Duke of Argyll's Tea-tree), an African shrub naturalized in many places, especially near the sea, straggling, with long, pendulous, and sometimes spinous branches ; fleshy, glabrous, lanceolate leaves; purple, funnel-shaped flowers with a short corolla-tube, green throat, and black honey-guides ; and red, berrylike fruit. Suggested as a substitute for tea.-Fl. June-August. Perennial.

3. Átropa (Deadly Nightshade), represented by one species, A. Belladónna, a stout, branched, erect, herbaceous plant, 3-4 feet high, with runners; leaves large, stalked, ovate, acute, generally in unequal pairs ; flowers solitary, nxillary, drooping, bell-shaped, lurid puple; calyz lenfy, persistent ; fruit globose, black, polished, resembling a cherry, 'but for the persistent calyx,-OOld quarries, and among ruins, especially on chalk and limestone soils; not common. The most dangerous poisonous plant in Britain, its berries being fatally attractive to children. A strong emetic, a dose of magnesia, and to keep the patient from dozing are the best precautions in cases of poisoning by its berries, pending the arrival of medical aid. (Name from Atropos, one of the Fates, who was supposed to cut the thread of human destiny.) - Fl. June-A ugust. Perennial.

*4. Datúra, represented by D. Stramónium (Thorn Apple), a coarse, strong-smelling plant, 1-2 feet high, with widely diverging 2-3-furcate branches; large, ovate, glabrous, simuatedentitc leaces; large, 
erect, white flowers on short stalks in the forks of the branches; and a densely spinous, ovate, 4-valved

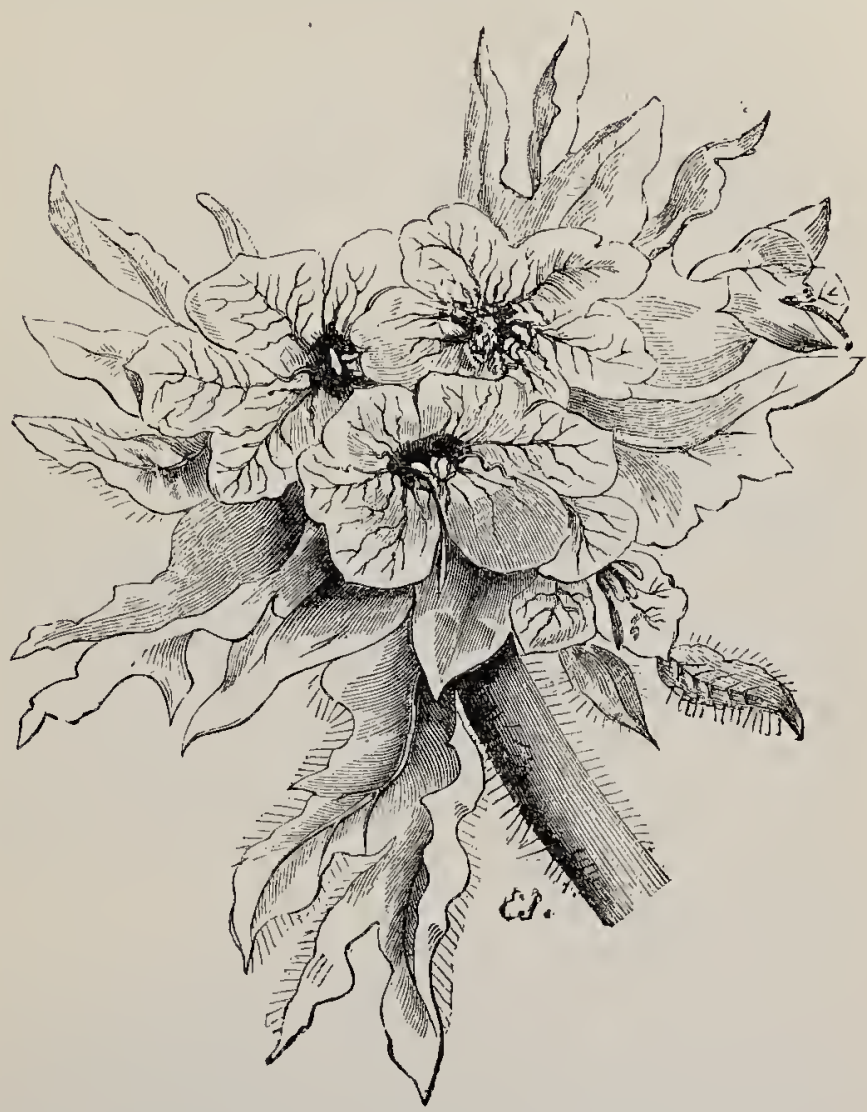

HTOSCÝALUS NígER (Conmon Uenbane).

capsule. - Waste places; rare. (Name of Arabic origin.)_Fl. June, July. Annual.

5. Hroscŕanus (Henbane). - Strong - smelling, often sticky herbs; calyw bell-shaped, persistent; 
corolla with a short tube and 5 unequal, blunt, spreading lobes; stamens lying on one side; anthers opening lengthwise; ovary 2-chambered; capsule opening transversely by a lid, many-seeded. (Name in Greek signifying $H o g^{\prime}$ s-bean.)

1. $H$. niger (Common Henbane). - The only British species, an erect, branched, herbaceous plant, $1-3$ feet high, with large, viscid, downy leaves, and funnel-shaped, cream-coloured flowers, generally with purple veins and a dark eye, arranged in a double row along the upper side of curving branches, succeeded by 2-chambered capsules, which are enclosed by the calyx, and open by lids which fall off when the sceds are ripe.-Waste places, on dry soil, especially near the sea; frequent. The whole plant has an exceedingly disagreeable smell of mice, and is dangerously narcotic, especially at the time when the seeds are ripening. An extract is used in medicine, and is often of great service, producing the effect of opium without the anplensant symptoms which frequently follow the administration of that drug. The capsules and seeds of Henbane, smoked like tobacco, are a rustic remedy for the toothache; but convulsions and temporary insanity are said to be sometimes the consequences of their use. - Fl. May - August. Annual or Biennial.

Ord. LV. Serophulakina.-Figwort Famli.

A large and important Order, containing nearly 2,000 species, of which some are shrubs, but the greater number are herbaceous, inhabiting all parts of the world, from the Arctic regions to the Tropics. Their leaves are generally simple, and their flowers monosymmetric; calyx 4-5-lobed, persistent ; coroila otten 2-lipped or personate; stamens usually 4, 2 long and 3 short (didynamous) sometimes 2 or 5 ; 
ovary 2-chambered; style 1 ; stigma 2-lobed; capsule 2-chambered, 2-4-valved, or opening by pores. The general character of the species is acrid and bitter, and some have powerful medicinal properties. The powdered leaves of Foxglove (Digitúlis puppurea) lower the pulse, and, if taken in large doses, are poisonous. Euplerásic (Eye-bright), the "Euphrasy" of Milton, makes a useful eye-water. Among foreign genera, Gratiola is said to be the active ingredient in the once famous gout medicine, "Eau médicinale." Euphrásia, Bártsia, Pediculáris, Rhinânthus, and Melampỹrum are partly parasitic, thoir roots being generally attached to those of grasses, and their leaves small in proportion to their size and copious flowering and seed-production. The Foxgloves, Snapdragons, Toadflaxes, and Mulleins have showy and crnamental flowers, and, together with several specias of Verónica, are garden favourites.

\section{* Stamens 5.}

1. Verbáscur.-Corolla rotate, with 5 slightly unequal lobes; stamens hairy.

\section{* Stamens 4, didynamous.}

2. Lináru.-Corolla personate, spurred; copsule opening by pores.

3. Antirkhínum.-Coroila personate, swollen at the base ; capsule opening by pores.

4. Scrophulária.-Corolla nearly globose, shortly 2-lipped; capsule 2-valved.

*5. Mímulus.-Catyr 5-toothed; corolla 2-lipped, gaping; seeds many.

6. Limosḱlda.-Leaves radical, linear; corolle short, bell-shaped, 5-cleft, nearly polysymmetric; anthers 1-chambered.

7. Sibthórpia. - Leaves round; corolla short, ro- 
tate, 5-cleft, nearly polysymmetric; anthers 2-chambered.

8. Digitátis._Ca7y $x$ in 5 deep, unequal segments; corotla irregularly bell-shaped, with $4-5$ shallow lobes.

9. Euphrásia.-Leaves opposite; caly $x$ 4-cleft; corotla 2-lipped, upper lip with 2 spreading lobes, lower lip in 3 nearly equal lobes; seeds many.

10. Bártsis - Leaves opposite; calyyx 4-cleft ; corolla 2-lipped, upper 7ip arched, entire, tover tip with 3 reflexed lobes; seeds many.

11. Pediculáris.-Leaves scattered; caly $x$ inflated, 4-toothed; corolla gaping, lower lip 3-lobed; seeds many.

12. Rhinánthus.-Lecues opposite; ealy inflated, 5-toothed; eorolla as in Peclicularis; seeds flattened, winged.

13. Metampírum.-Lenves opposite; calyx tubular, 4-toothed ; corolla much as in Pediculáris ; seecls 2-4, not winged.

\section{***** Stamens 2.}

14. Verónica._Coroll c rotate, unequally 4-cleft, the lower lobe nartowest.

1. Verbáscum (Mullein).-Erect, woolly piants with scattered leaves, and nearly polysymmetric, 5merous flowers in spikes; corolla rotate, with 5 slightly unequal lobes; stamens 5, hairy; capsule 2-valved, many-seeded. (Nime a corruption of the Latin Barbaseum, meaning "bearded.")

1. V.Thápsus (Great Mullein).-A stout,herbaceous, unbranclied plant, $2-5$ feet high, remarkable for its large, flannel-like lectes, woolly on both sides and decurrent, and club-shaped spikes of yellow flowers. Two of the stamens are longer than the rest, and have white hairs on their filaments.-Roadsides ; common. 
This plant, together with Burdocks and Foxglove, is

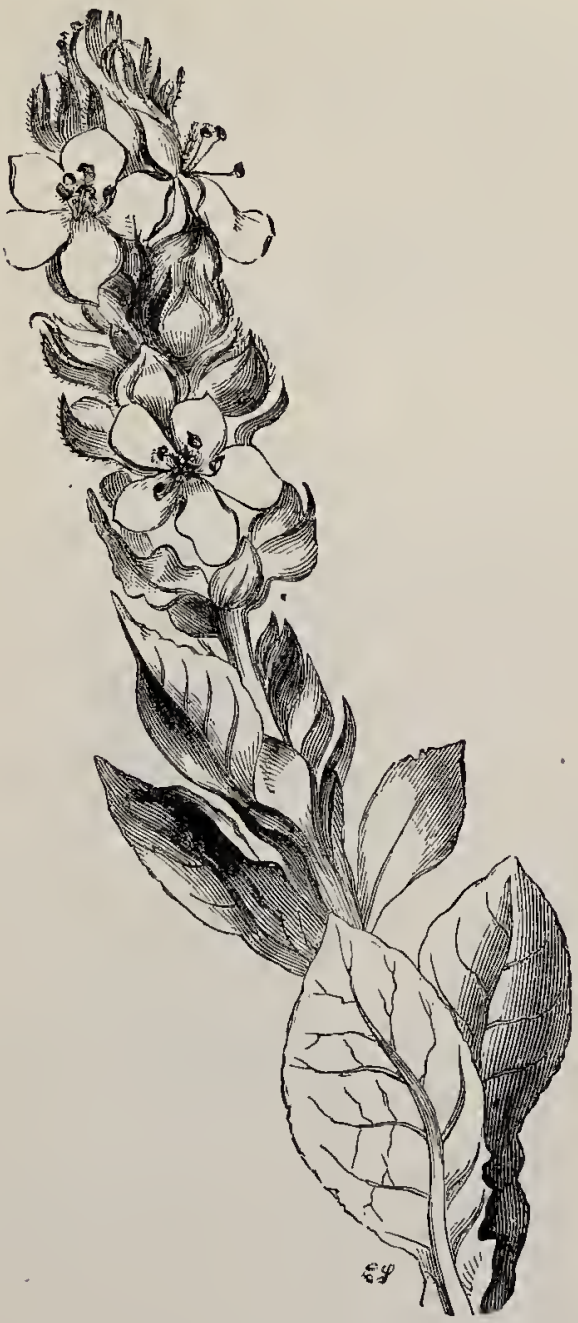

YERBÁSCUM THÁPSUs (Great Mullern).

often introduced by painters into the foreground of landscapes.-Fl. June-A ugust. Bienmial. 
2. V. pulventéntum (Hoary Mullein).-Stem 2-3 feet high, round, mealy; lecu'es broad, with stellate hairs on both sides, not decurrent; fowvers smaller, bright yellow, in panicles; stamens nearly equal, scarlet, with white hairs.-Norfolk and Suffolk.-Fl. July. Biennial.

3. V. Lychnitis (White Mullein).-A similar species, with angular stem; lecu'es nearly smooth above; and small, cream-coloured or white flowers. - Chiefly on a chalky soil; rare.-Fl. June-August. Biennial.

4. V.nígnum (Dark Mullein).-A handsome plant, not so stout or so tall as $V$. Thiopsus, and of a darker hue; stem angular; Teaves stalked, oblong, cordate, with stellate down, especially below; flowers rery numerous, bright yellow, in dense tufts on a long, crowded spike; stcmens covered with purple hairs.Hedges and roadsides; local._-Fl. June-October. Biennial.

Several hybrids between the above four species occur.

5. T. virgátum (Primrose-leared Mfullein).-A stout species, 3-4 feet high; leares doubly serrate, with few glandular hairs, the upper ones slightly decurrent; flowers yellow, in a panicle, crowded; stamens with purple hairs.-Gravelly banlss; rare.-Fl August. Bienuial.

6. V. Blattária (Moth-Mullein). - A tall, slender plant, with smooth, shining, oblong, crenate leaves, the lower ones often lobed and embracing the stem, and with large, handsome, yellow or cream-coloured flowers in loose tufts on a long, interrupted spike; stamens with purple hairs.-Gravelly places; rare, except in the south-west.-Fl. July, August. Biennial.

2. Livíria (Toad-flax).-Mostly herbs, with bracteate flowers, often in spikes or racemes; corolla per- 
sonate, spurred; stamens 4, didynamous; capsute opening by pores. (Name from the Latin limum, flax, which some species resemble in their leaves.)

1.* L. Cymbalária (Ivy-leaved Toad-flax, Mother-

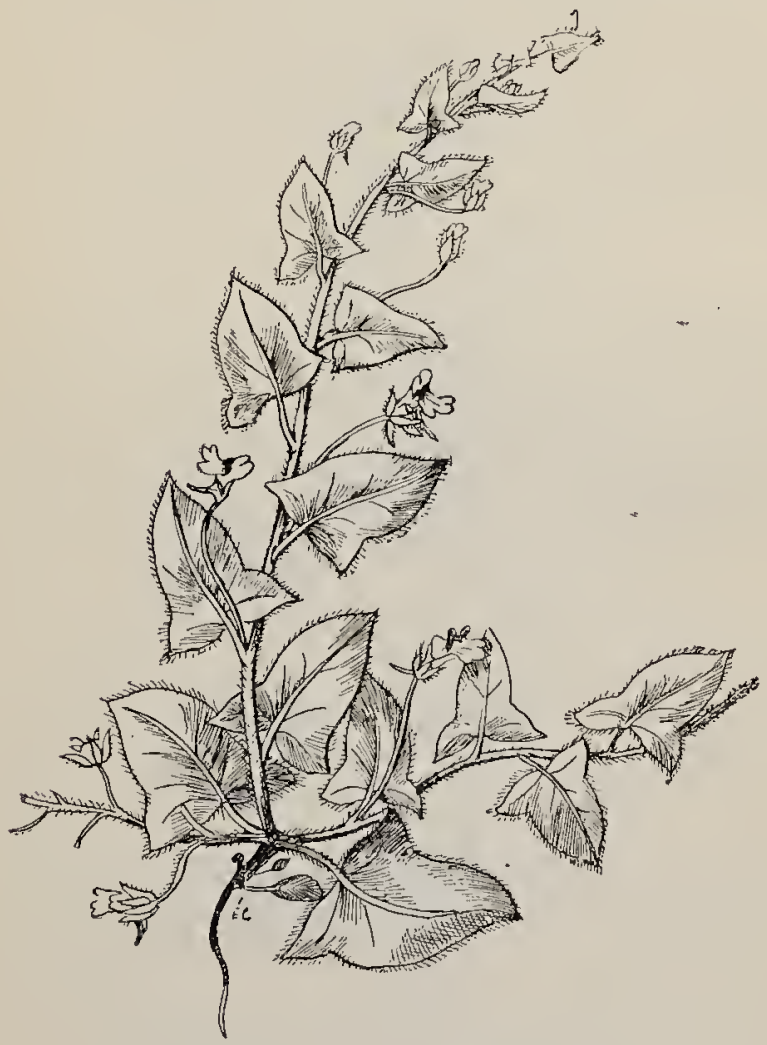

LINÁRIA ELATINA (Sharp-pointed Fluellen).

of-thousands). - Not a native species, but quite naturalised, growing freely from seed besides extending widely by means of its long, rooting stems; leaves smooth, 5 -lobed, cordate, rather fleshy, purple on the under surface; flowers small, solitary, lilac,-On old garden 
walls; common.-Fl. nearly all the year round. Perennial.

2. L. Elátina (Sharp-pointed Fluellen).-A small, prostrate plant, with downy stem and leceres, the latter

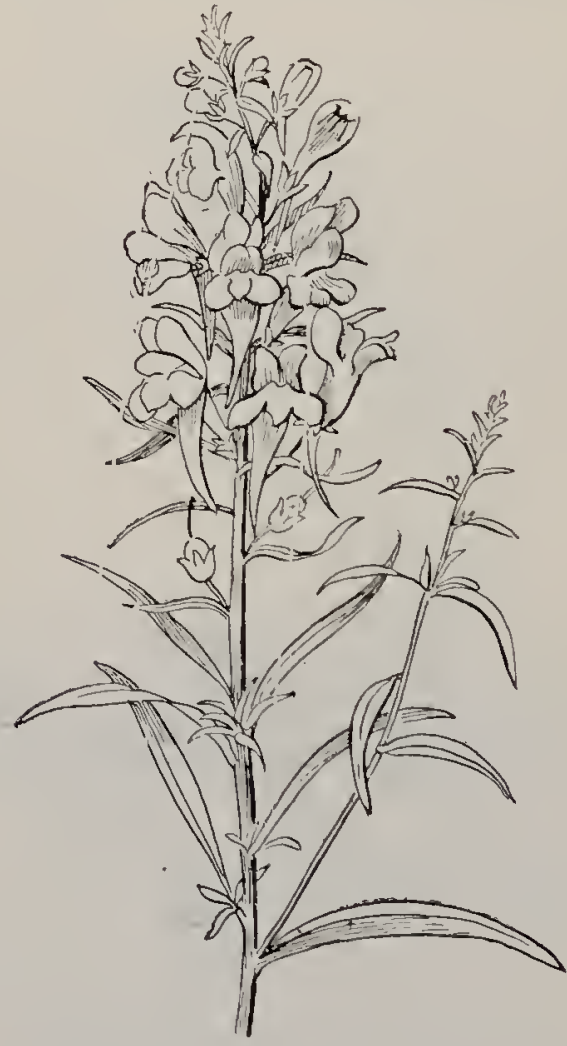

IINARII TIIGARIS ( Fellore Toad-fax).

hastate; flowers small, solitary, axillary, on long, slender pellunctes; corolla with upper lip purple, lower yellow, the spur straight.-Cornfields ; frequent.-Fl. JulyOctober. Annual.

3. Id syuria (Round-leaved 'load-flas, Male Fluel- 
len).-Resembling the last so closely that it might be mistaken for a luxuriant specimen of it; but with roundish-ovate leaves and rather larger flowers, with the spur bent up at a right angle to the corolle.-It grows in similar situations to, and sometimes with, L. Elátina, but is less common.-Fl. July-October. Annual.

4. L. répens (Pale blue Toad-flax).-A slender, erect plant, about a foot high, with glaucous, linear leaves, and pretty pale lavender, purple-veined flowers in a spike-like terminal raceme.-C Calcareous soils; rare.-Fl. July_September. Perennial.

5. I. vulgáris (Yellow Toad-flax).-An erect, herbaceous plant, 1-2 feet high, with numerous, crowded, linear, acute leaves, glabrous, and sometimes glaucous; and dense, spike-like, terminal racemes of large, yellow flowers. - Hedges; very common. The variety known as Peloric, with a polysymmetric, 5spurred corolla, is rare.-Fl. June-October. Perennial.

6. L. viscilla (Least Toad-flax).-A small, erect plant, less than a foot high, sometimes branched, with scattered, linear', blunt, downy, viscid leaves, and small, solitary, axillary, short-spurred, pale lilac flnwers.Cornfields on dry soil ; frequent.--Fl. May - October. Annual.

Several other species occur on ballast heaps near the sea, or as garden escapes, but have no claim to be considered natives.

3. Axtrrenínum (Snapdragon).-A genus of herbs differing from Linária mainly in having a pouch-like swelling, instead of a spur, at the base of the corolla. (Name from the Greek anti, against, r.tis, r. rinos, the nose, from the mask-like appearance of the flowers.)

1.* A május (Great Snapdragon).-A stout, handsome plant, with numerous leafy stems; leaves lanceo- 
late; flowers large, personate, pouched, crimson, pink or white, in many-flowered, dense, bracteate, spikelike, terminal racemes; sepals ovate, blunt, much shorter than the corolla. - In limestone quarries and

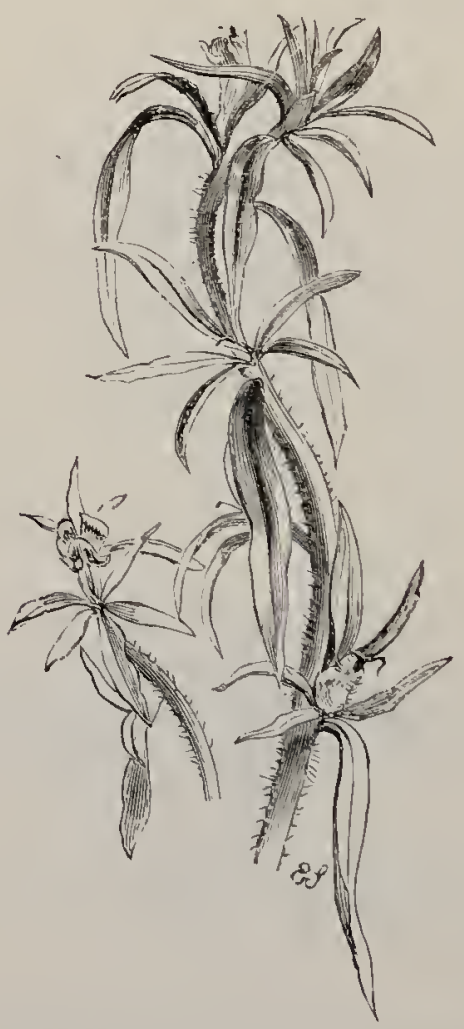

ANTIRRHLXIM ORÓNTIUM (Lesser Shapdragon).

chalk-pits, and on old walls; conmon, but not indigenous. In gardens varieties occur with many beautiful colours and veinings. Children derive much amusement from pinching the flowers between the finger and thumb, when the palate opens, as if in 
imitation of the fabulous monster from which it derives its name.-Fl. July-September. Perennial.

2. A. Oróntín (Lesser Snapdragon). - A much smaller and more slender plant, generally less than a foot high, with linear leaves, and a few, small, axillary,

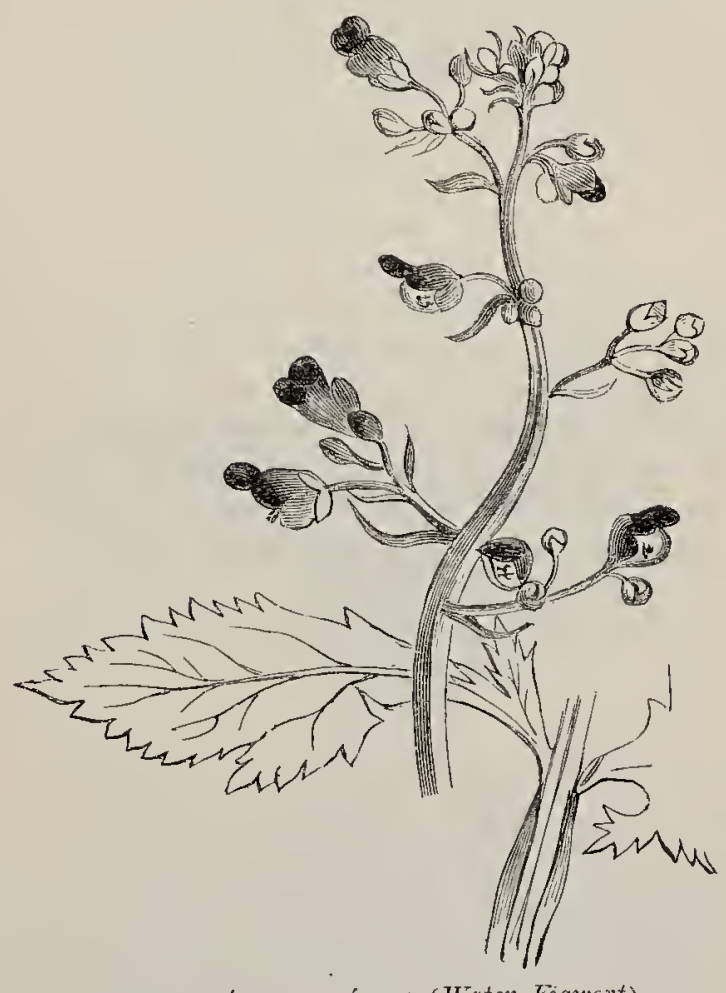

SCROPHULÁRIA AQUÁTICA (Water Figuort).

rose-coloured flowers with linear sepals much longer than the corolla.- Cornfields in the south; not common.-Fl. July_September. Annual.

4. Scrophulária (Figwort). - Strong-smelling, 
stout herbs, with leaves mostly opposite, and flowers in panicles; corolla nearly globose, shortly 2-lipped; stamens 4, or with a staminode; capsule 2-valved. (Name from its former use in the treatment of scrofula.)

1. S. aquática (Water Figwort).-A tall, herbaceous plant, $2-5$ feet high, with a square stem with the angles winged; leares smooth, oblong, cordate, blunt, crenate-serrate ; flowers almost globular, chocolate-brown, in close, many-flowered panicles, with linear, blunt bracts. - Sides of streams and ditches; common. The stems, though hollow and succulent when dead, become rigid and prove very troublesome to anglers, owing to their lines becoming entangled in the withered capsules. - Fl. July-September. Perennial.

2. S. umbrosa (Shade Figwort).-Resembling the last, but with sharply serrate, acute leaves and flowers in loose, few-flowered panicles, with leaf-like, lanceolate, acute fracts. - Wet places; uncommon. - Fl. August, September. Perennial.

3. S. nollósa (Knotted Figwort).-Another similar, but smaller species, with a thick, fleshy, knotted whirome; stem 2-3 feet high, square, with blunt angles; leaies smooth, ovate, acute, doubly and acutely serrate; and flowers greenish-brown, in loose panicles, with small, lanceolate, acute lracts. - Moist bushy places; common.-Fl. June, July. Perennial.

4. S. Scorochónia (Balm-leaved Figwort), with downy, wrinkled, crenate leaves and leaf-like bracts, is found only in Cornwall, Devon, Treland, and the Channel Islands.-Fl. July, A ugust. Perennial.

5.* S. remátis (Yellow Figwort). - A very distinct plant, about 2 feet high, with slightly 4-angled stem; broad, crenate, pale green leaves and bright yellow flowerr. - Waste places; local. Appearing early in spring, and resembling a Calcolumic, this is 
the most ornamental British species.-Fl, AprilJune. Perennial.

*5. Mímulus (Monkey-flower).--Herbs with square stems, opposite tecties, and conspicuous, solitary, axillary flowers; calyx 5-cleft, 5-angled ; corolla 2-lipped, gaping, the upper lip 2-lobed and reflexed; seed.s many. (Name from the Greek mimo, an ape, from the form of the flower.)

1.* M. Túteus (Yellow Monkey-flower).-A pretty

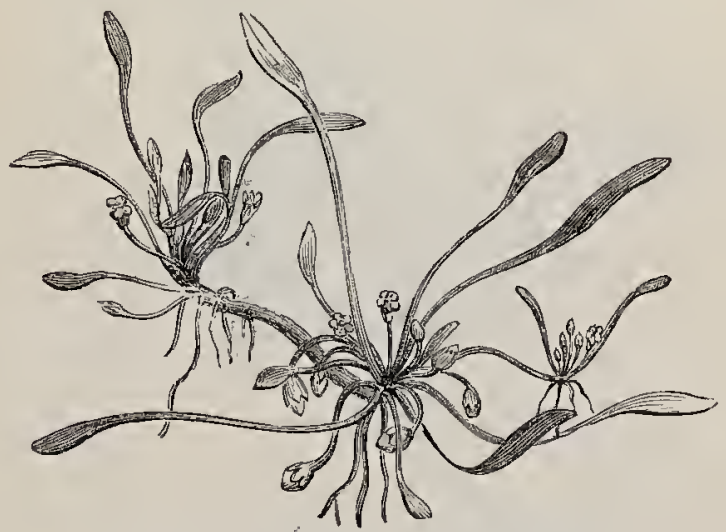

LIMOSÉLLA AQUÁTICA (Common Mudwort).

North American plant, with hollow creeping stems, ovate, veined leaves, and large, yellow, funnel-shaped flowers, which has escaped from cultivation and become naturalised by the sides of many streams. Some of its cultivated varieties have the flowers blotched with brown or red.-Fl. June-September. Perennial.

6. Linosétua (Mudwort). - Small, tufted, creeping, glabrous, aquatic plants, with radical, linear 
leaves, and minute, solitary, axillary flowers; corolla short, bell-shaped, 5-cleft, nearly polysymmetric; stamens 4, with 1-chambered anthers. (Name from the Latin limus, mud, from the character of the places in which the plant grows.)

1. L. aquática (Common Mudwort).-The only British species, a small plant, throwing up from the

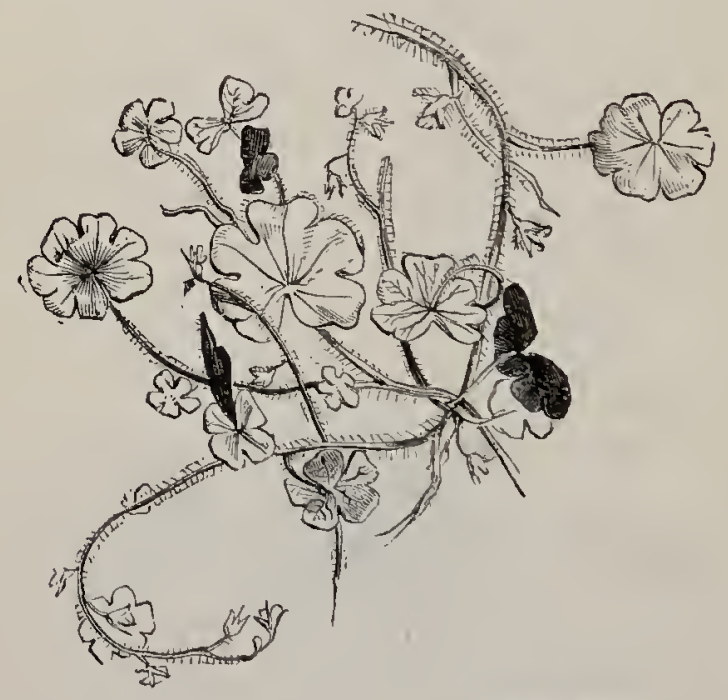

SIBTHÚRPA EUROPA (Cornish Woney-wort).

roots a number of smooth, spathulate lecers on long stalks, and minute, pale pink or white flowers on shorter stalks.-Watery places; not common.-Fl. July-Scptember. Annual.

7. Sibthórpia (Cornish Money-wort).-Slender, creeping, hairy plants, with rounded, lobed, stalked leaves, and small, solitary, axillary flowers; caly, in 5 deep, spreading segments; corolla short, rotate, 5 . 
eleft, nearly polysymmetric; anthers 2-chambered; copsute mearly round, flattened at the top. (Name

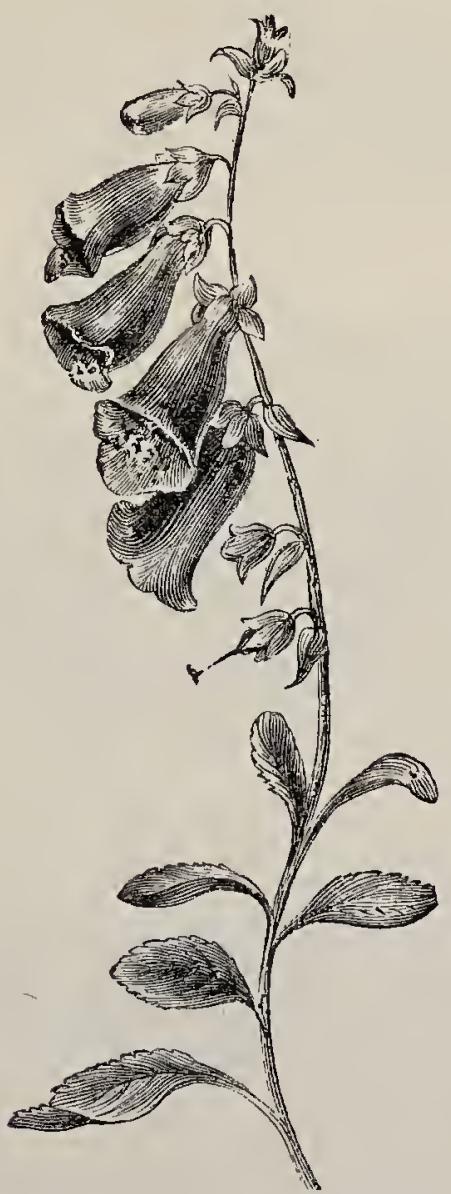

DIGITALIS PURPU்REA (Purple Foxglove),

in honour of Dr. Humphrey Sibthorp, Professor of Botany at Oxford from 1747 to 1783 .)

1. S. europeda (Cornish Money-wort).--The only 
British species, an elegant little plant, with slender, thread-like stems creeping along the ground in tangled masses ; small, round, notched, downy leaves of a delicate green; and very minute, pale pink and yellow flowers.-Banks of springs and rivulets in Cornwall, and occasionally in other southern counties. In habit it approaches Hydrocótylé vulgáris (Marsh Penny-wort), but it is smaller and downy and its leares are notched. Fl. June-October. Perennial.

8. Digitílis (Foxglove),-Tall plants with radical and cauline leaves, and large, monosymmetric, bellshaped flower's in a long, terminal raceme; caty, deeply and unequally 5-lobed : corotla slightly 4-5notched, hairy inside; capsule ovate. (Name from the Latin cligitus, a finger; from the glove-like shape of the flower:)

1. D. enpurece (Purple Foxglove),-The only British species, a stately plant, 2-6 feet high, with large, wrinkled, downy leaves, and a tall, slightly branched, tapering raceme of numerous handsome, deep rose-coloured, bell-shaped flowers, which droop as they expand. On the inside the corolla is beautifully spotted; and it occasionally occurs of a pure white.-Woods; common; but not on limestone. 'The name forglove is a colruption of foll's-ylore ; that is, Fairies' glowe. 'The leaves yield a valuable medicine, which is, however, poisonous in large doses.Fl. June-September. Bieunial.

9. Euphrásia (Eye-bright). - Partially parasitic plants with opposite cut lcaves, and flowers in a bracteate spike; caly, 4 -cleft; corolla 2 -lipped, the upper 7ip with 2 spreading lobes; the lower lip in 3 nearly equad lobes; anther's spurred at the base ; capsute flattened, blunt, or notched; sceds numerous, ribbed. 
(Name from the Greek enphiociscmo, I clear, in allusion to its use as an eye-lotion.)

1. E. officinatis (Common Eye-bright).-An elegant little plant, $2-6$ in. high, with deeply cut lecues, and numerous white or lilac flowers veined with purple, and with the middle lobe of the lower lip yellow. - It is common in pastures; hut it is so variable that

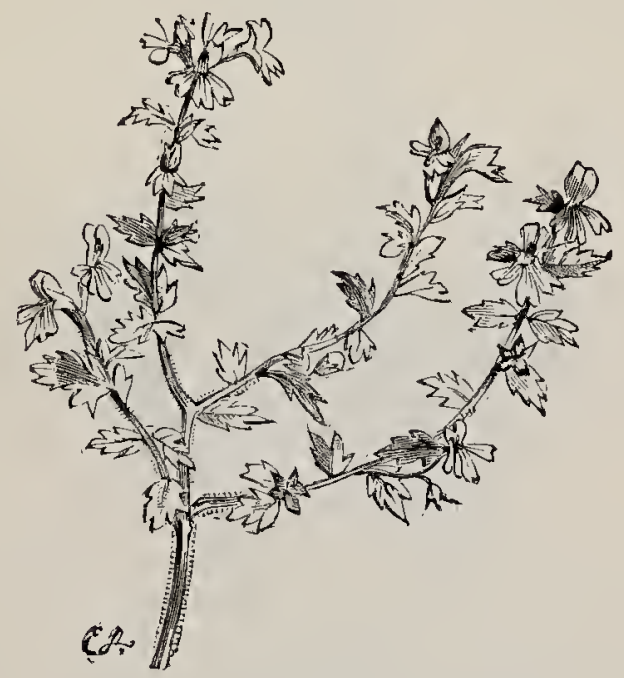

EUPHRÁSIA OFFICINÁLIS (Common Eye.bright).

botanists distinguish a number of forms differing in the bracts, size of flowers, capsules, and seeds. On the mountains and near the sea the stem is scarcely branched, and the leaves are fleshy; but in rich soil it assumes the habit of a minute shrub. An infusion of this plant makes a useful eye-lotion.-Fl. May-September. Annual.

10. Bírtsia.-Partially parasitic plants with opposite leaves, and flowers in branched spikes with leafy bracts; calyw 4-cleft; corolla 2-lipped, the upper lip 
arched, entire, or notched, not spreading, the loner $l_{i j}$ with 3 reflexed lobes; capsule flattened, blunt; seeds numerous, angular. (Name in honour of Jolın Bartsch, a Prussian botanist.)

1. B. Oclontites (Red Bartsia).-A much-branched,

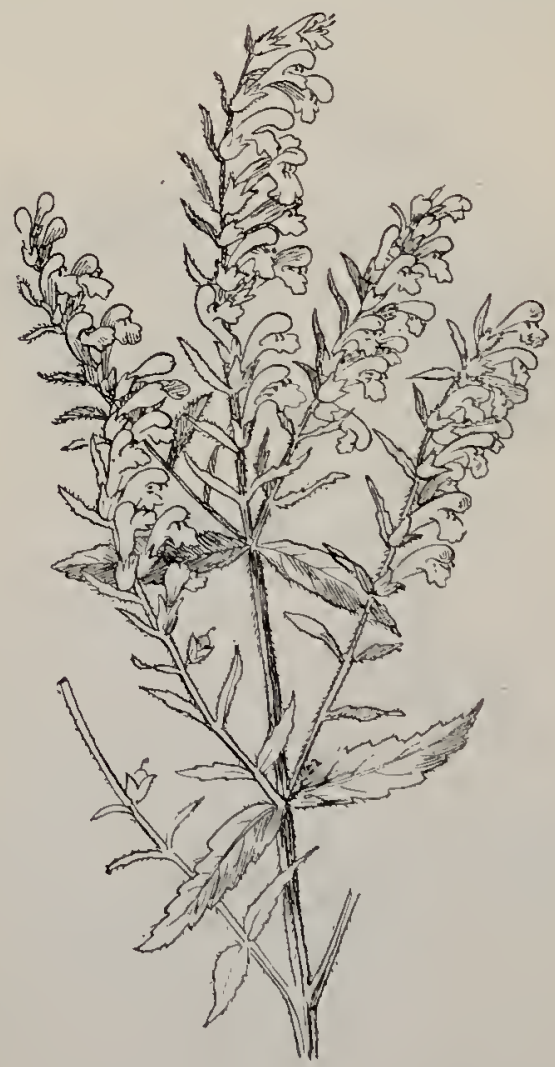

BARTSIA nDONTítes (Rel Rurtsia).

erect, herbaceous plant, $6-12$ in. high, with linearlanceolate, dingy, reddish-green tecr'es, irregularly toothed, and numerous one-sided spikes of small, pink 
flowers. While flowering the spikes usually droop at their ends. - Cornfields and waste places; common.Fl. June--September. Annual.

2. B. viscósa (Yellow Viscid Bartsia).-An erect, clammy plant with sessile, ovate-lanceolate, deeply serrated leaves, the lower opposite, the upper scattered : and axillary yellow flowers. - In the south and west; rare. Somewhat resembling the Yellow-rattle (Rhinánthus Crísta-gálli), but at once distinguished by its clamminess. It looks very different in Sussex, where it is less than a foot high and unbranched, from what it does at the Lizard, where it is more than twice as tall and much branched.-Fl. June-October. Annual.

3. B. alpina (Alpine Bartsia), a low, unbranched species, with opposite, ovate leaves, and dull purpleblue flowers in a short, leafy spike. - Mountain pastures in the north; rare--Fl. June-August. Perennial.

11. Pediculáris (Red-rattle).--Partially parasitic plants, with scattered lecues, and flowers generally red, in bracteate spikes or racemes; caly.x inflated, somewhat leafy, unequally 5-toothed; corollu gaping, upper lip arched, flattened vertically, lower $7 i p$ flat, 3-lobed; crepsule flattened, oblique; seeds angular. (Name from the Latin pediculus, a louse, the plant being supposed to produce lice in sheep.)

1. I. palústris (Marsh Red-rattle).-An erect, branched, herbaceous plant, 6-18 in. high, neally glabrous, with reddish branches; leaves deeply pinnately cut; flowers large and crimson, in a leafy raceme; caly. downy.-Marshes and bogs; common. It is often a conspicuous plant, overtopping the surrounding herbage.-Fl. May-September. Annual.

2. I'. sylvática (Dwarf Red-rattle).-Distinguished from the last by its humbler growtb, being prostrate 
and only branched at the base, and by its rose-pink

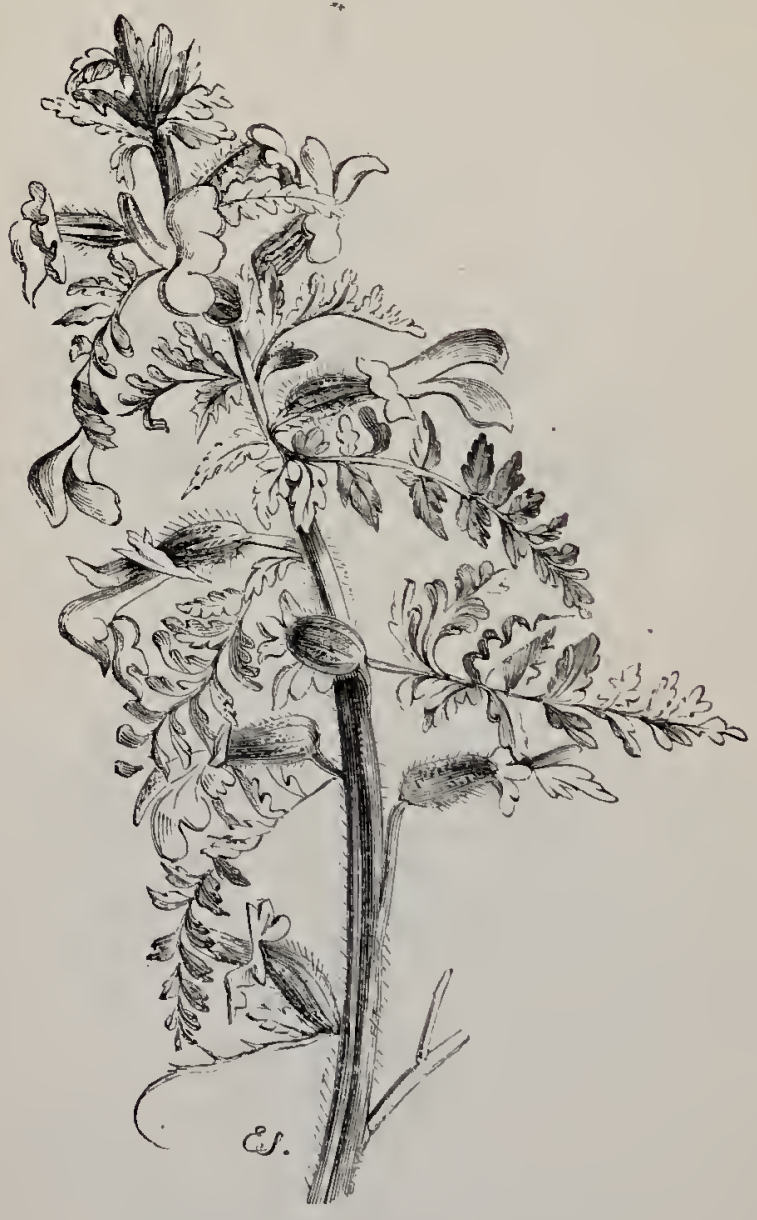

PEDICOLIRIS PItífTRIS (.Marsh Red-rattle)

fouers with a smooth calyx-Damp heaths; common. -Fl. April, August. Perennial. 
12. Rhinánthus (Yellow-rattle).--Partially parasitic plants, with opposite, serrate lecues, and yellow flowers spotted with violet in one-sided spikes with toothed bracts; seeds flattened, winged; otherwise

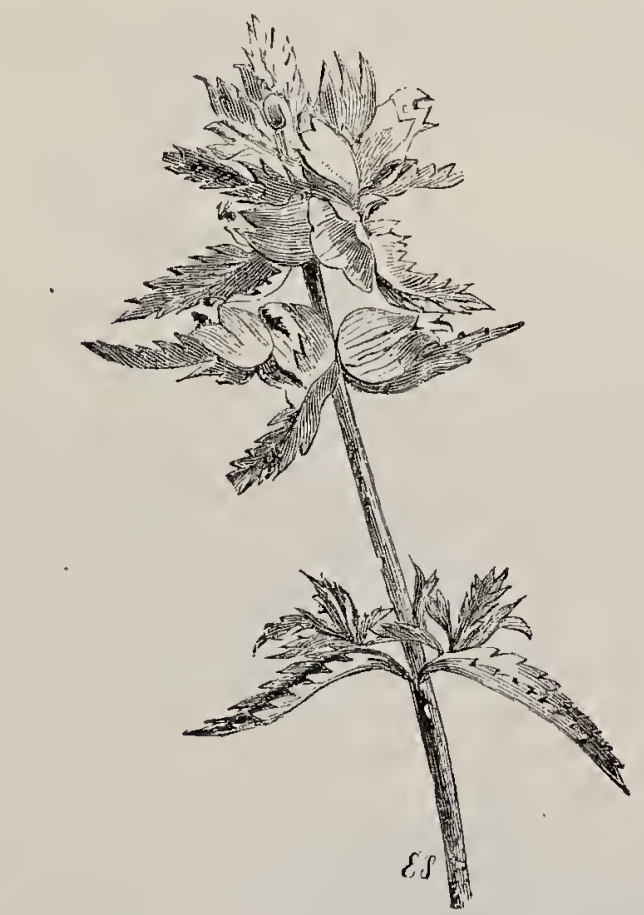

RHIXANTIUUS CRÍsTd-GÁLL (Cock's-comb, Tellow-rattle).

much as in Pedicuturis. (Name from the Greels rhis, rhinos, the nose, anthos, a flower, from its shape.)

1. R. Crísta-gálli (Yellow-rattle, Cock's-comb).An erect, somewhat rigid plant, 12-18 in. high, seldom branched; leaves oblong-lanceolate, serrate; flowers yellow, in a loose spike, with green, ovate, deeply serrate bracts, and conspicuous, pale, inflated calyces.-Pastures; common. The rattling of the 
ripe seeds in the capsule is a sign in Sweden that the hay is ready to cut; but in England hay-making begins when the plant is in full flower.--Fl. June. Annual.

2. IR. májor (Large Yellow-rattle), a taller, much. branched species, has its flowers in crowded spikes, and a yellowish bract, ending in a fine green point, below each flower.-Cultivated fields; local.-Fl. July, August. Annual.

13. Melampx́rum (Cow-wheat).-Partially parasitic plants with opposite leaves; calyx tubular, with 4 narrow teetls; corolla much as in Pediculáris, but with the sides of the upper lip reflexed; seeds 2-4, not winged. (Name from the Greek melas, black, puros, wheat, the seeds being said to make flour black when ground and mixed with it.)

1. M. cristátum (Crested Cow-wheat).-A hand. some plant, about a foot high, with linear-lanceolate, entire leaves and yellow flowers tipped with purple, in dense, 4-sided spikes, with cordate, toothed, ovate bracts rose-coloured at the base, the lower ones recurved.Woods in the eastern counties; rare.-Fl. September, Uctober. "Annual.

2. 11. arénsé (Purple Cow-wheat). - Also a handsome species, taller, with losy flowers witl a yellow throat and deep red lips, in loose spikes with ovatelanceolate, pinnatifid, rose-red bracts.-Cornfields in the south-eastern counties; very rare.-Fl. July, August. Annual.

3. M. maténsé (Common Yellow Cow-wheat).-A slender plant, about a foot high, with opposite pairs of straggling branches below ; leaves in distant pairs, lanceolate, smooth; flowere axillary, in distant pairs, all turning one way; corolla 4 times as long as the calyx, pale yellow, closed, lower $7 i p$ longer than the upper.-Woods; common. According to Einnreus, 
cows are fond of it, and the best and yellowest butter is made where it abounds; but the name praténsé (growing in meadows) is inappropriate, as it is rarely

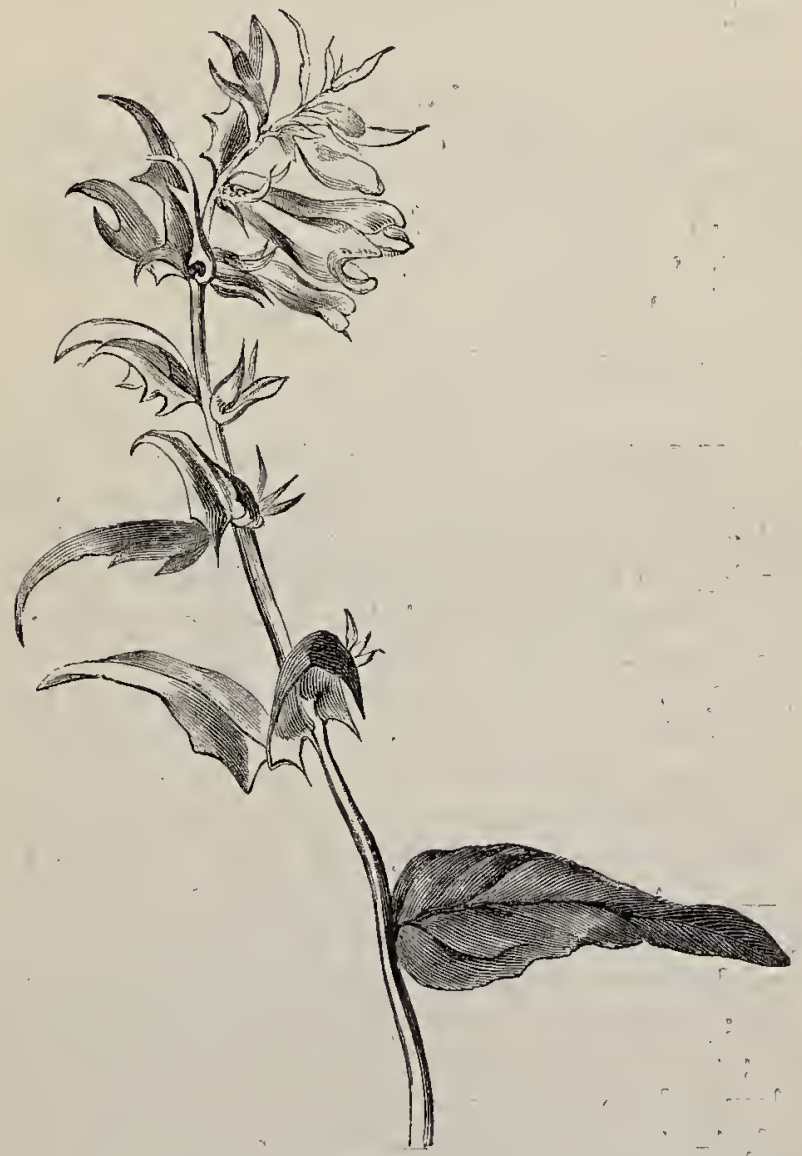

MELAMPŕRUM PRATÉxstí (Common Yellow Cow-wheat).

found in such situations.-FI. June--September, Annual.

4. I. syluaticum (Sub-alpine Yellaw Cow-wheat), 
differing from the last in having sub-erect, deep yellow flowers with the corotla only twice as long as the calyx and with its tips open and equal, occurs rarely in mountainous woods in the north.--Fl. July, August Annual.

14. Verónica (Speedwell).-Herbs or shrubs, with flowers usually blue; corolla rotate, unequally $t$ cleft, the lower lobe narrowest; stamens 2, exserted. (Name of doubtful origin, perhaps a variant of Betónica, or perhaps a mediceval Latin word corrupted from the Greek Beronizé.)

*Annual; prostrate; flowers solitary, aritlary; linacts scattered.

1. T. hectercefóliu (Ivy-leaved Speedwell).--Leares stalked, 5-7-lobed, cordate, bearing in the axil of each leaf a pale blue flower, the stalk of which is bent back when in fruit; seprals cordate, ciliate; capsule of 2, much swollen, 2-seeded lobes.-A common weed everywhere.-Fl. March-August. Annual.

2. $V$. polita (Grey Field Speedwell). - Lecres stalked, irregulas ly serrate; flowers bright blue, $\frac{1}{3}$ in. across, on stalks longer than the leaves : sepals broadly ovate, sub-acute ; cuprute of 2, turgid, generally hairy, 8-12-seeded lobes.-Fields and waste places; common.-Fl. April-September. Annnal.

3. $V$. agréstis (Green Field Speedwell).-Wtems several, long,prostrate ; lea'es stalked,cordate, regularly serrate; flowers $\frac{1}{6}$ in. across, on stalks shorter than the leaves; sepals linear-oblong, blunt; corolla pale blue, tho lower lobe white; capsule of 2 , turgid, hairy, keeled, 4-6-seeded lobes.-Fields and waste places; common.-Fl. April-September. Annual.

4.* V. Tournefórtii (Tournefort's Speed well).-A stouter, prostrate, hairy species, with shortly-stalked, cordate, obtuse, coarsely serrate leaves; large, bright blue flowers $\frac{1}{2} \mathrm{in}$. across, on stalks longer than the 
leaves ; sepals lanceolate, ciliate; capsules of 2, diverging, sharply-keeled, hairy, 5 -8-seeded lobes.-Cultivated ground; introduced about 1826, but now general. Fl. April-September. Annual.

* Flowers in terminal racenes; corollu-tube zery short.

5. V. triplayzlos (Finger-leaved Speedwell), distinguished by its erect, branched stem, 4-8 in. high ; palmately 3-7-lobed leaves; and dark blueflowers in a loose, few-flow cred raceme.-Sandy fields in Yorkshire, Norfolk, and Suffolk; rare.-Fl. April-June. Annual.

6. V. vérna (Vernal Speedwell).--An erect, hairy, leafy little plant, $2-4 \mathrm{in}$. high ; with pinnatifid leaves and numerous minute, pale blue flowers.-Sindy places, Norfolk and Suffolk; rare.--Fl. May, June. Annual.

7. I. arvénsis (Wall Speedwei!).-A slightly larger, downy plant, $4-18 \mathrm{in}$. high, often covered with dust, with two lines of hairs along its branches; leaves slightly stalked, ovate-cordatc, crenate ; flowers inconspicuous, pale blue, many, but almost concealed among the crowded upper leaves or bracts.-Walls and dry places; abundant.-Fl. April-October. Annual.

8. V. serpyllifólia (Thyme-leaved Speedwell).A small plant, with prostrate or slightly ascending, downy stems ; ovate or elliptic, slightly crenate, blunt, rather leathery leaves; and several many-flowercd racemes of very light blue flower's, $\frac{1}{4} \mathrm{in}$. across, striped with dark blue veins; capsules inverzely heart-shaped, with a long, persistent style.-Waste ground ; common.-Fl. May-July. Perennial.

9. $\quad V$. alpina (Alpine Speedwell), differing from the last in being more erect, with larger leaves; fewer, more crowded, darker blue flowers, and a very short persistent style; occurs only on Highland Scottish mountains.-Fl. July, August. Perennial.

10. $V$. firúticuns (Blue Rock Speedwell).-Nearly 
glabrous; stem much branched, woody; Teaves leathery; flower's few, $\frac{1}{2}$ in. across, brilliant blue, very handsome, on stiff, sub-corymbose stalks; capsules ovate.-Lofty Scottish mountains; rare-Fl. July-September. Perennial.

***** Perennial; flowers in temuinal racemes; corollatube longer than broad.

11. T. spicáta (Spiked Speedwell).-Wtem erect, branching at the base, about 6 in. high; leares thick, nearly sessil, ewith a wedge-shaped base, serrate above the middle; flowers $\frac{1}{4}$ in. across, bright blue, in a long, dense spike.-Chalk downs in Cambridgeshire and Suffolk : rare.-Fl. July, August. Perennial.

12. V. hýbrida (Tall Spiked Speedwell) is larger, reaching 18 in., and has stalked leaves, rounded at the base and serrate throughout.-Limestone cliffs in the west; rare.-Fl. July, August. Perennial.

\section{***** Ieremial; Teares all opposite; flowers in axillary racemes.}

13. T. officinális (Common Speedwell). - A haily plant with prostrate, ascending stems, with short hairs all round; oval, shortly-stalked, serrate leares; and erect, many-flowered, spike-like racemes of lilac or pale bluc flower's, $\frac{1}{6} \mathrm{in}$. across.-Dry pastures, heaths, and woods; common. The leaves are astringent and bitter, and are sometimes made into tea.-Fl. MayAugust. Peremnial.

14. V. Chamérly/s (Germander Speedwell, Blue Speedwell, Bird's-eye).-A well-known and farourite plant; stem ascending, with two lines of hairs; leares sessile, hairy, deeply serrate: flowers bright blue, $\frac{2}{2}$ in. across, in a long-stalked, slender, loose racenre: capsule shorter than the calyx.-Hedge-banks; abundant. No 
one can have walked in the country in spring without admiring its cheerful blossoms, but few perhaps notice the singular pair of hairy lines, which traverse the whole length of the stem, shifting from side to side whenever they arrive at a fresh pair of leaves, and serving to conduct rain-water to the root. It is some-

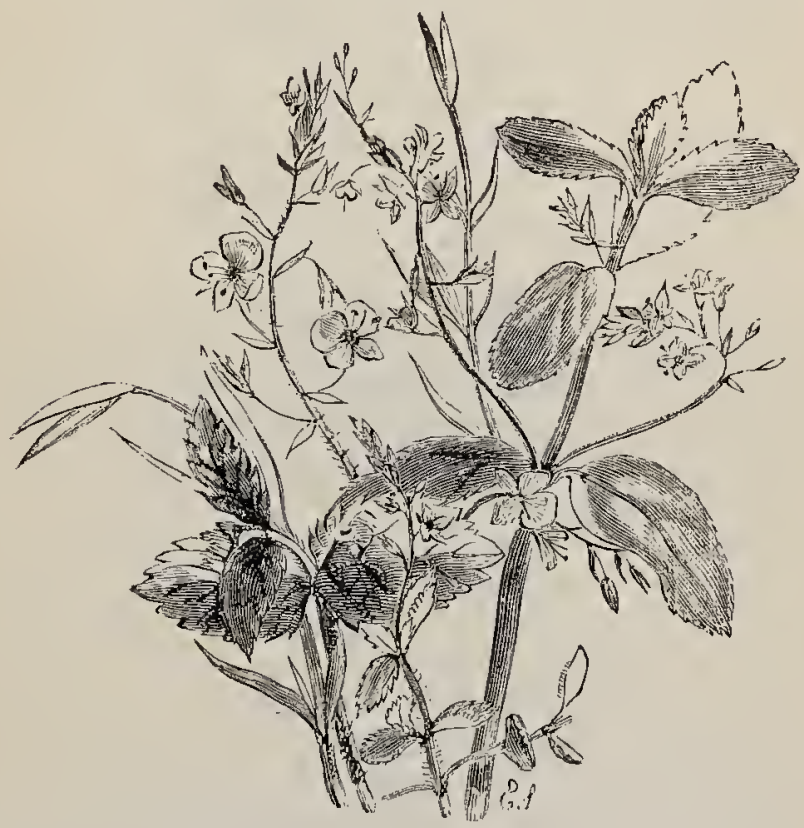

VERÓNICA CHAM ÉDRTs (Germander Speedwell), v. OFFICTNÁLIS (Common Speedwell), V. SCUTELLÁTA (Marsh Speedwell), and V. BECCABtiAGA (Broolitime).

times erroneously called Forget-me-not.-Fl. AprilJune. Perennial.

15. T. montána (Mountain Specdwell).-A similar species, but with stem hairy all round; leaves stalked; fewer, smaller, paler flower's in a shorter raceme; and capsule much longer than the calyx.-Moist woods; common.-Fl. May-September: Perennial. 
16. $V$. scutellata (Marsh Speedwell).--A weak straggling, generally glabrous plant; lecues sessile, linear-lanceolate, slightly toothed; flowers pale pink in alternate racemes; capsules of 2 lar.ge, flat, round lobes

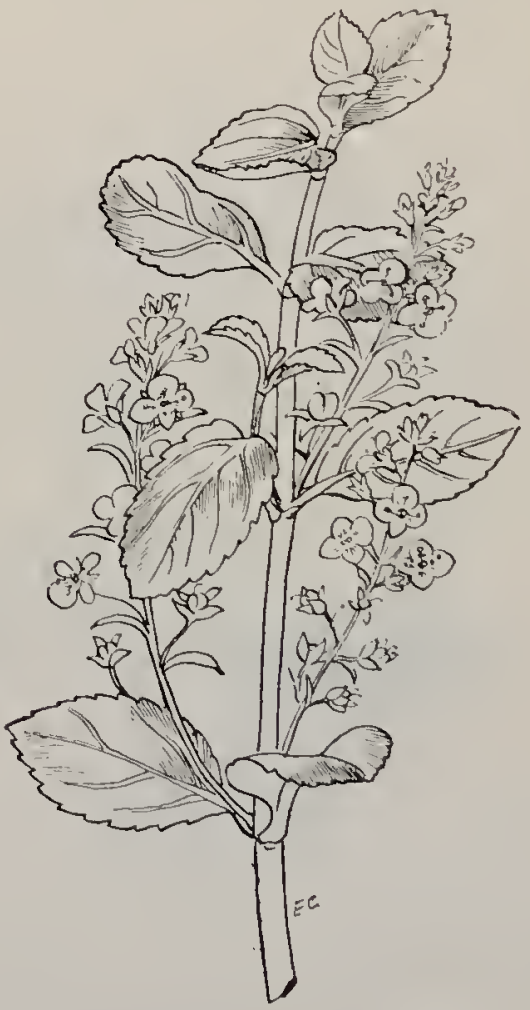

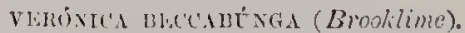

on slender reflexed stalks.-Marshes; common.-Fl. June-August. Peremnial.

17. $T$. Anagállis-aquática (Water Speedwell), - A stout, glabrous, succulent, erect, slightly-branched plant, 1-2 feet high; stem hollow; leat's sessile, some- 
times anricler, lanceolate, serrate ; flowers $\frac{1}{5}$ in, across, pale pink or white, in opposite racemes.-Stagnant water ; common.-Fl. June-August. Perennial.

18. T. Beccabúnya (Brooklime). — A very similar species, but smaller, with stem rooting at the base; stalked, oval, blunt, slightly serrate lecres; and opposite racemes of bright blue flowers, $\frac{1}{3}$ in. across.Brooks and ditches; common, growing with Water. cresses and Water-Parsnip.-Fl. May-September. Perennial.

\section{Ord. LVi. Orobanchácez, - Broom-rape Family,}

A small Order of succulent, brownish plants, all of which are either parasitical on the roots of other plants or are partly saprophytes, living, that is, upon decaying organic matter. They have no true lecues, but are more or less clothed with fleshy, pointed scales, which are most abundant near the base of the stem. The flowers are large for the size of the plant, and arranged in a spike or raceme, with one or more scale-like bracts at the base of each flower. The calyr. is persistent; the corolla monosymmetric, usually '2lipped, imbricate in the bud, persistent; stamens 4, didynamous; ovar? in a fleshy disk, 1.chambered, many-ovuled; style 1; stigma 2-lobed; capsule 2valved; seeds small, numerous, parietal. The seeds, it is said, will lie buried for some years in the ground without germinating, until they come in contact witl the young roots of some plant adapted to tlieir wants, when they immediately sprout, and seize on the points of the roots, which swell, and serve as a base to the parasite. There are but two British genera belonging to this Order, Oroluanctié and Latrocéc, some species of which are confined to particular species of host plants, whilst others have a widel range. The species of Orobunché are difficult to discriminate, 
1. Orobánchú.-Upper lip of corolla erect, 2-lobed.

2. Lathr.́. - Fowers secund; upper lip of corotla arched, entire.

1. Oroвíxсhе́ (Broom-rape). - Parasites with fiowers in a many-sided spike, with $1-3$ bracts below each ; caly $x$ of 2, lateral, usually 2-cleft sepals ; corolla gaping, 4-5-clefi, its upper lip erect, 2-lobed, its base persistent. (Name from the Greek órobos, a retch, ancho, I strangle, from the injurious effects produced in the plants to which they attach themselves.)

\section{* Bracts 3 under each foreer.}

1. O. pranoitrea (Blue Broom-rape)...t slender, tough, unbranched species, with pale blue flower. with purple veins, occurring on Miifoil.-Southern counties ; rare.-Fl. June, July. Perennial.

2.* O. ramósa (Branclied Broom-rape), distinguished by its branched stem, occurs on the roots of Hemp, with the seeds of which it is introduced, but is very rare.-Fl. August, September. Annual.

\section{** Bracts one to each florcer.}

3. O. mújor (Greater Broom-rape).-A stout, viscid, leafless, club-like plant, of a reddish-brown hue, with stem much swollen at the base, and clothed with tapering scales, which pass into bracts as they ascend the stem ; flowers crowded into a dense spike; corolla reddish-yellow, tubular, the lower lip 3-lobed, the middle lobe blunt and longer than the others : stamens inserted at the base of the corolla, smooth below, downy above; style downy; stigme of 2 diverging yellow lobes.-On the roots of Furze, Broom, and other shrubs of the Order Cegpuminóse ; frequent.Fl. May-August. Perennial. 
4. O. mibra (Red Broom-rape).-A small, reddish species, $4-8$ in. high, witl a loose spike of dull red

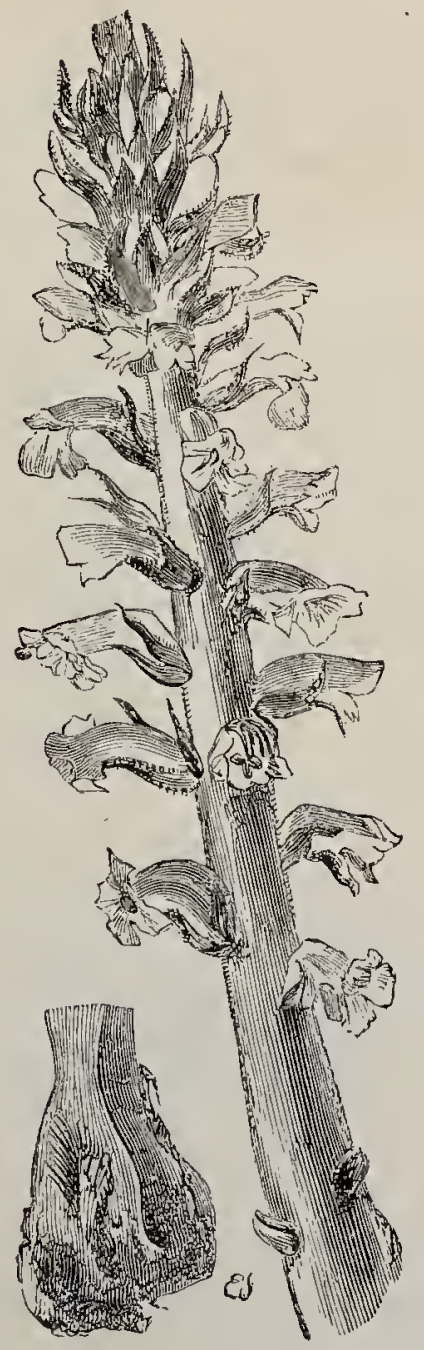

OROBÁNCHÉ MÁJOR (Great Broonz-rape). 
sweet-scented flowers, with a downy corolla and pale pink, 2-lobed stigmr.-On the roots of Thyme when growing on basaltic rock in Scotland and Ireland, and on magnesian rock at the Lizard; rare.-Fl. June, August. Perennial.

5. O. campoliyllacea (Clove-scented Broom-rape), a similar, but stouter, brown species with reddish-brown or purplish flowers, with hairy stamens and a dark purple stigma, grows on the roots of Gutium Mollugo (Hedge Bed-straw) in Kent.-Fl. June, July. Perennial.

6. O. clátior (Tall Broom-rape).-A tall, yellow plant, 2-3 feet high, with many-veined sepals; corolla slightly compressed above, lobes of lower lip nearly equal, acute; stamens hairy; stigma yellow.On Centaniéa Scubiósa; rare-Fl. June-August. Perennial.

7. O. Picridis (Picris Broom-rape).-A pale species, abont a foot high, with 1 -3-reined sepals: toothed, nearly equal lobes to the lower lip of the corolla; stamens hairy below; stigma purple-On Picris hierchcioülcs, rare.-Fl. July. Perennial.

8. O. Mécloce (Iry Broom-rape). - A purplish species, about a foot high, with. loose spitic: 1-veined sepuls: nearly glabrous stamens, and yellow stigma.On Ivy; uncommon.-Fl. June, July. Perennial.

9. O. minor (Lesser Broom-rape).-A slender, yellow-brown or purplish species, about a foot high, with a loose spilie; many-veined, ovate, acuminate sepuls; white or yellowish corollatiml, stamens hairy below, smooth above; style nearly smooth; stigme purple.-Chiefly upon Clovers, but oceasionally on various other plants; frequent.-Fl. June, July. Annual.

10. O. amethigsta (Purple Broom-rape), with its corollu much curved at the base, and the middle lobe of the lower lip much the longer, occurs rarely on Darucus gúmmifer.-Fl. Jume. Annual. 
2. Lathréa (Toothwort). - A pale, pink-tinged, fleshy plant, partly parasitic, partly saprophytic, with

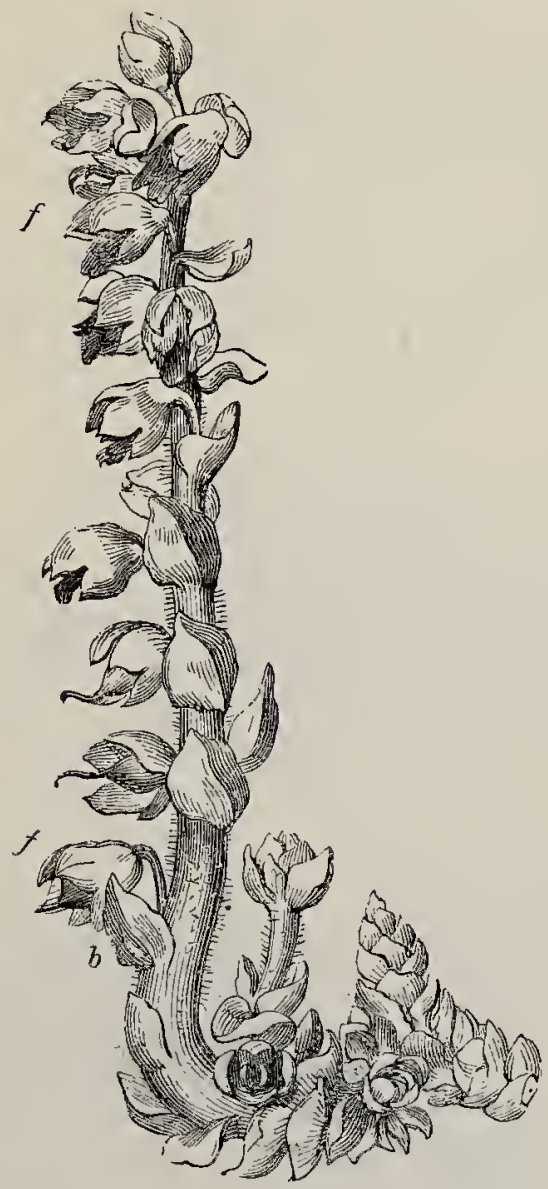

LATHRAEA SQUAMARIA (Toothwort).

its flowers in 2 rows down one side of the stem ; calyx bell-shaped, 4-cleft; corolla gaping, 2-lipped, the upper lip arched, entire, deciduous, the tube presistent. 
(Name from the Greek lathraios, hidden, from its growth in shady places.)

1. L. Squanaric (Toothwort).-The only species, a remarkable pale plant, with a fleshy, branched rhizome thickly clothed with tooth-like seales, which are hollowed out into glandular cavities; each branch bears a 1 -sided raceme of drooping, dull reddish flowers, with a broad bract at the base of each.Among dead leaves and on the roots of Hazel, Elm, \&c. The glands in the hollows of the buried scales probably aid in the absorption of liquid organic food from the decaying leaves.-Fl. A pril, May. Perennial.

Ord. LViI. Lentibularié.e.-Butterwort Family.

Herbaceous plants living in water or in marshy ground, bearing either undivided radical leaves, or much divided cauline ones with numerous small bladders on them. Their flowers are monosymmetric, and either solitary or racemose; the calyy inferior, persistent; corolla 2-lipped, spurred, deciduous; stamens 2 ; ovary superior, 1 -chambered; stmle 1, very short; stigme of 2 unequal lips; capsule 2 -valved, many-seeded. The two British genera, Ltricularia, the Bladderworts, and Pinguicula, the Butterworts, wro both of them carnivorous. The former are sub. merged, rootless plints with finely divided leaves, bening minute bladders, furnished with trap-doors, which capture water-Heas and other minute aquatic animals, and yellow thowers which rise above the surfaco of the water to open. The Butterworts are small, terrestrial plants with rosettes of radical leaves with inrolled margins, and viscid, glandular surfaces which capture small flies. Their solitary purple florvers hase some resemblance to violets. "Pingriculd vulgaris (Common Butterwort) has the property of 
giving consistence to milk and of preventing it

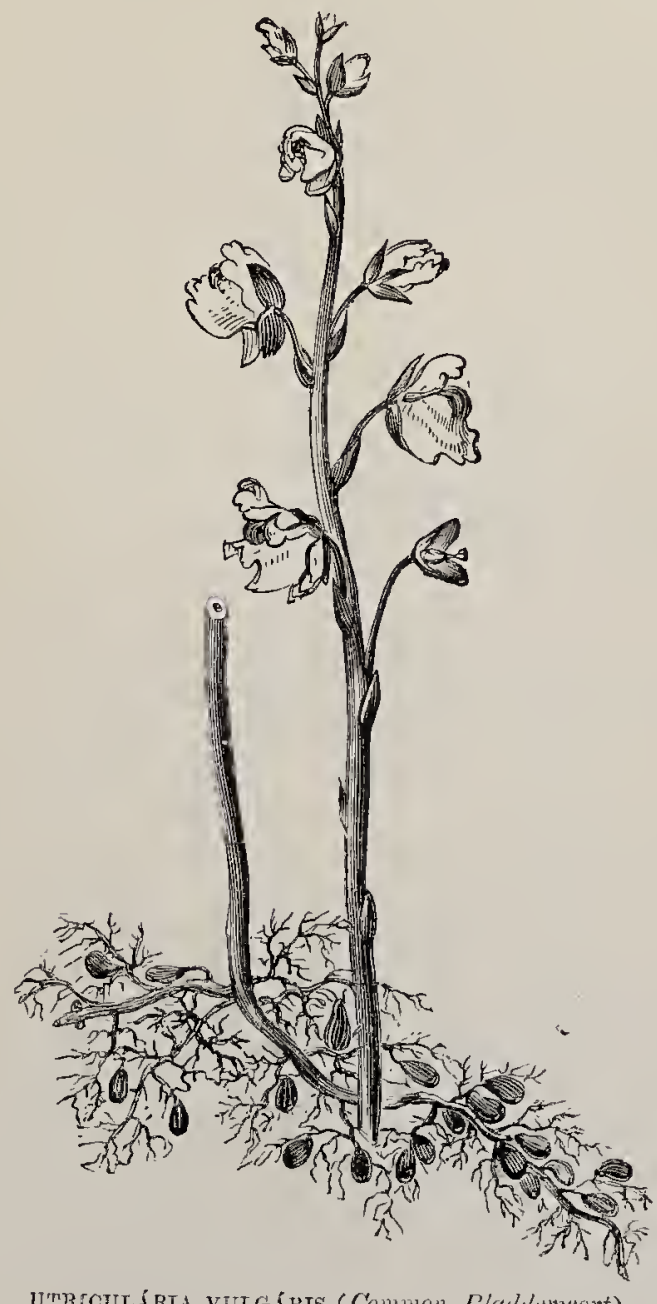

U'RROULARIA VULGŚRIS (Common Dladerwort).

separating into either whey or cream. Linnæus says that the solid milk of the Laplanders is prepared by 
pouring it, warm from the cow, over a strainer on which fresh leaves of Pinguicula have been laid. The milk, after passing among them, is left for a day or two to stand, until it begins to turn sour; it throws up no cream, but becomes compact and tenacious, and most delicious in taste. It is not necessary that fresh leaves should be used after the milk is once turned; on the contrary, a small portion of this solid milk will act upon that which is fresh, in the manner of yeast."-(Lindley).

1. UtriculáRIA. - Submerged, aquatic plants with much divided leaves bearing bladders; calyx of 2 equal sepals; corolla personate.

2. Prnguícula.-Terrestrial plants with radical leaves and solitary flowers; calyx 2-lipped, upper lip 3-cleft, lower 2-cleft; corolla gaping.

1. Utriculária (Bladder'wort).-Submerged, rootless, aquatic plants with floating, much-divided leaves, with thread-like segments, bearing small bladders; flowers few, in a raceme, monosymmetric, yellow: calyx of 2 equal sepals; corolla personate, spurred; stamens 2, lateral. (Name from the Latin utriculus, a little bladder.)

1. $\zeta$. vulgúris (Common Bladderwort).-A remarkable submerged, aquatic plant; leaves pimately divided, ciliate, and bearing bladder's $\frac{1}{5} \mathrm{in}$. Iong; flowers $4-8$, on a stout scape $6-12$ in. high, in a loose raccme; bracts ovate, thick, about one-third the length of the pedicels; corolla bright yellow or orange, with nearly equal lobes, and conical acute spur adpresscd to, and half as long as, the lower lip.Ditches and pools; frequent.-Fl. Junc-August. Pcrennial.

2. $U$. neglícta (Overlooked Bladderwort). - A morc slender species with leaves pinnately divided and ciliate, bearing bladder's $\frac{1}{10}$ in. long; brocts lanceolate, 
not more than a quarter as long as the slender, nearly erect pecticels; upper corolla-lip 2 or 3 times as long as the broad, flat, lower one, lemon-yellow ; spu conical. -Pools ; rare.-Fl. June-September. Perennial.

3. U. mínor (Lesser Bladderwort). - A small, slender species with repeatedly forked, not ciliate leaves bearing bladders $\frac{1}{1} \frac{1}{2}$ in. long; and $2-6$-flowered racemes of small, pale yellow flowers, with equal corolla-lobes and a very short, blunt spur.--Pools and ditches; not common.-Fl. June--September. Perennial.

4. U. intermédia (Intermediate Bladderwort).Leaves distichous, repeatedly forked, ciliate; bladders $\frac{1}{5}$ in. long, on slender stalks, separate from the leaves; flowers $3-4$ in a raceme, pale yellow; rpper corollalip twice as long as the lower; spur conical, acute. --Pools and ditches; rare.-Fl. July-September, Perennial.

2. Pinguícula (Butteriwort).-Marsl plants with small roots; a rosette of cntire, involute, viscid, radical leaves; and solitary flowers on long, erect pedicets; calyix 2-lipped; upper lip 3-cleft; lower 2cleft; corolla gaping, spurred. (Name from the Latin pinguis, fat, from the greasy leares.)

1. P. vulgávis (Common Butterwort).-A singular and very beautiful plant. The root is fibrous, and has a very loose hold on the soft ground in which it grows. The radical leaves are oblong, pale green, and of a peculiar, parchment-like, frosted appearance. The flowers are $\frac{2}{3} \mathrm{in}$. long, violet, and liandsome, growing in a nodding manner on a peduncle 3-4 in. long, with very unequal corollc-lobes and a short, tapering spur.-Bogs, heaths, and wet rocks, principally in the north. Fl. May-July. Percnnial.

2. P. grandifióra (Large-flowered Butterwort). A larger and yet more beautiful plant, with broader 
leaves, flowers 1 in. long, with a longer and often notched spur.--Bogs in co. Cork and Kerry.-Fl. May-July. Perennial.

3. P. alpina (Alpine Butterwort). - Smaller than

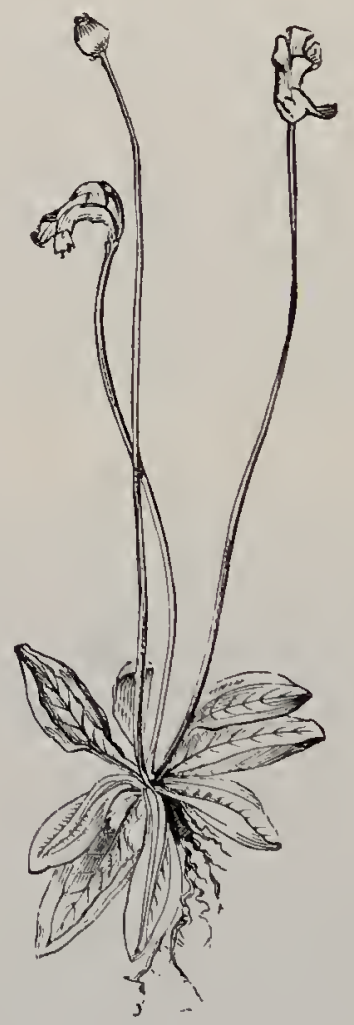

pinguícula lusitánica ( $\mathrm{Pa}^{\prime} e$ Bittericort).

$P$. vulgáris, with yellowish-white flowers, $\frac{1}{2} \mathrm{in}$. long, on short, smooth peduncles, and with a very short, conical spur.-Bogs in Ross and Skye--Fl. May, June. Perennial. 
4. P. lusitanica (Pale Butterwort).-The smallest British species, with greenish-white, veined leaves, downy peduncle, and pale lilac flowers $\frac{1}{3}$ in. long, with a yellowish throat, nearly equal corolla-lobes, and blunt, cylindrical spur, curved downwards.-Bogs in the South-west of England and the West of Scotland and Ireland.-Fl. June-September. Perennial.

\section{Ord. LViII. Verbenácee.-Vervain Family.}

A considerable, but mainly tropical Order, closely allied to the Labiatce, comprising trees, shrubs, and herbs, with opposite, exstipulate leares, and perfect, monosymmetric, bracteate flowers; calyx inferior, tubular, imbricate, persistent ; corolla hypogynous, with a long tube, usually 2-lipped, imbricate; stamens didynamous, epipetalous, or rarely 2 only; ovary 2 or 4-chambered; style 1; stigma sometimes 2-cleft; seeds 1 or 2 in each chamber. Many of them are aromatic and fragrant, such as Aloyssia citriodóra, formerly called Verbena triphyylla, the Lemon-plant of gardens, well known for the delicious fragrance of its rough, lanceolate leaves. Many species of Verbéna from America are cultivated for their brilliantly coloured flowers; and, though it is now little thought of, great virtues werc in ancient times attributed to the one British representative of the Order, the common Vervain, insomuch that it was accounted a holy plant, and is said to have been used to sweep the tables and altars of the gods. By far the most valuable plant in the Order is the Teak (Tectóna grándis), a native of India and Burma. The trunk of this tree sometimes attains the height of two hundred feet, and its leaves are twenty inches long by sixteen broad. The timber somewhat resembles mahogany in colour, but is stronger. For shipbuilding teak is unequalled.

1. VerbéNa (Vervain).-Herbs or undershrubs 
with 4-angled stem; opposite leaves; flowers in brac-

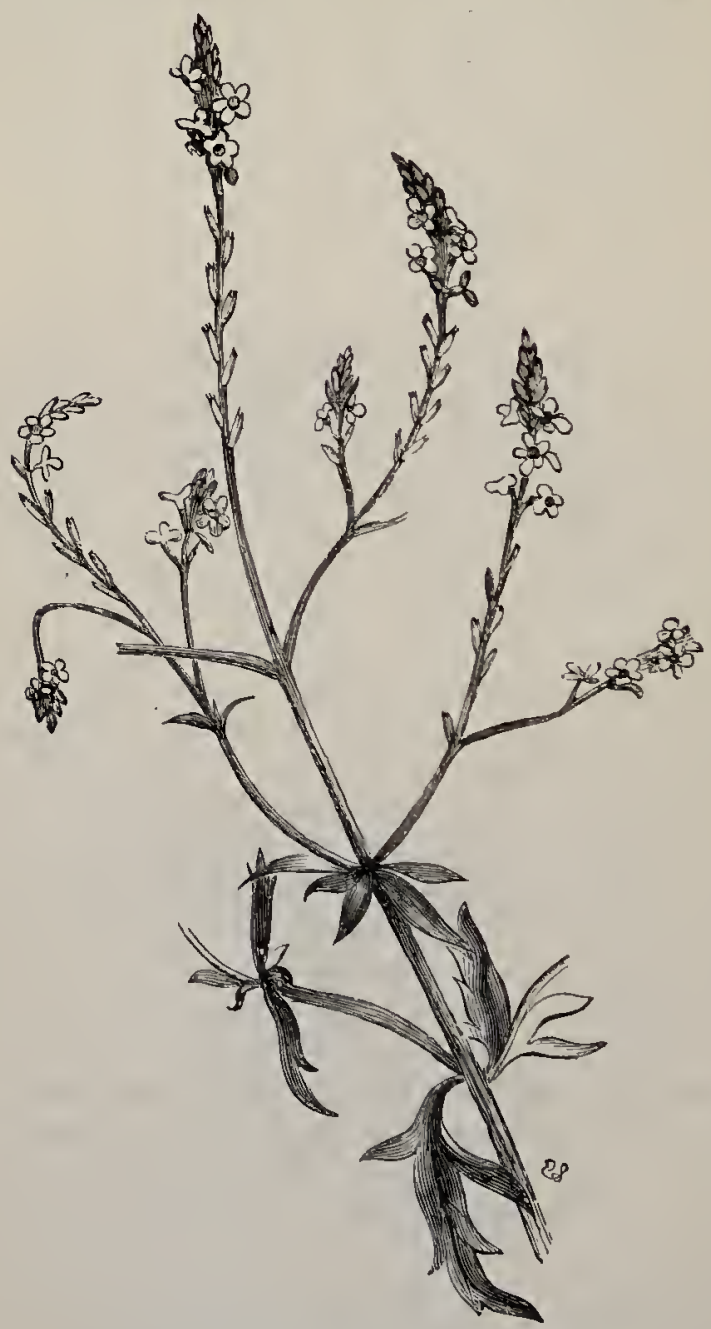

VERBENA OFFICINAIIS (Common I'Train).

teate, terminal spikes or racemes; caly, unequally 
5-cleft; corolla salver-shaped, unequally 5-cleft ; stamens included; fruit of 41 -seeded nutlets. (Name, the Latin name of the plant.)

1. V.officinális. - The only British species, a slender, tough-stemmed plant, $1-2$ feet high, with few roughish, 3-cleft leaves, and small, lilac flowers in very slender, terminal, compound spikes.-Waste ground; common.-Fl. July_September. Perennial.

\section{Ord, LIX.-Labiáta.-The Labiate Family.}

A large and clearly defined Natural Order; comprising upwards of 2,500 species of herbs and shrubs, which agree in having square stems; opposite, decussate, simple, exstipulate leaves; and bilabiate, or 2lipped flowers in axillary cymes, forming generally verticillasters or false whorls. The caly, $x$ is inferior, tubular, persistent, and 5-cleft; the corolla hypogynous, monosymmetric, and mostly 2-lipped (bilabiate); the lower lip larger and 3-lobed, the upper less distinctly 2-lobed; the stamens 4, didynamous, or rarely 2 , maturing before the stigmas (protandrous); ovar!" superior, of 2 united carpels, deeply 4-lobed, with a single style arising from the base of the lobes (gynobasic); stigma 2-cleft; firit a regma of 4 nutlets, each containing a single seed. They occur mostly in warm and temperate climates, and are remarkable for not possessing injurious properties in any single instance. Most of them have strong aromatic perfumes, which are often pleasant, owing to the presence of abundance of volatile or essential oil, from which camphor-like, solid substances can be extracted. Menthol, for instance, is obtained from various species of Mint (Méntha). It is a valuable remedy in nouralgia. Patchouli (Pogostémon Pátchouli) is a favourite perfume, and Lavender (Lavándula vera) is not only also a perfume, but has medicinal uses as a stimulant. Several 
kinds of Mint, especially Peppermint (Méntha piperíta) and Pennyroyal (M. Pulégium), are much used in medicine. Rosemary (Rosmarinus officinális) is remarkable for its undoubted power of encourag. ing the growth of the hair and curing baldness, and is an active ingredient in most pomatums. It is one of the plants used in the preparation of Eau de Cologne and Hungary water, and the admired flavour of Narbonne honey is ascribed to the bees feeding on the flowers of this plant, as that of the honey of Hymettus is indebted for its flavour to Wild Thyme. Our aromatic pot-herbs, the leaves of most of which are used in a dried state, are all members of this Order. Among them are Mint (Méntha v'riddis), Sage (Śálvia officinális), Thyme (Thýmus vulgáris), Basil (Úcinum Baśticum), Marjoram (Origanum Mur. jor'ina), and Savory (Scituréia). The tuber's of Stáchys tuberiferc have been introduced from Japan, under the name of Chinese artichokes, as a substitute for potatoes. Several species of Sage (Sátria) are also cultivated for the sake of their brilliantly coloured blos. soms.

* Sirmens 4, distant, the turo upper shorter: nutlets free smooth or nearly so.

† Corolla subreenular; stamens spreading.

1. Míntha.-All four stamens perfect.

2. Lŕcopus. -Two upper stamens aborted.

t+ Corolla 2.limped.

3. Orfanum.-Calyx with 5 equal teeth; stamens diverging.

4. ThÝnus.-Prostrate; leaves small; caly $x 2$. lipped; stamens diverging. 
5. Calavíntha.-Coiolla-tube straight; stamens converging at their tips.

*6. Meuíssa.-Corolla-tube curved; stamens converging at their tips.

** Stamens 2 ; anther's distractile; nutlets free, smooth or nearly so.

7. Sálvia.-Celyax and corolla both 2-lipped.

**** Stamens 4, the two upper longer; nutlets free, smooth.

8. NÉpeta.-Caly $x$ with 5 nearly equal teeth; corolla with flat upper lip.

***** Stamens 4, parallel, the 2 upper shorter; nutlets free.

+ Calyx 2-lipiped.

9. Scuteldárta. - Caly $x$ closing over the fivit; 2 lower anthers 1-chambered.

10. Prunélda. - Caly.x closing over the fruit; anthers all 2-chamberer ; filaments forked.

11. MexítT1s.-Calyx inflated; anthers exserted.

it Calyn with 5-10 equal or sub-equal teeth.

12. Marrúbium.-Caly $x$ tubular, 10-toothed; anthers included.

13. STÁchys.-Calyx sub-campanulate, with 5 equal teeth; anthers smooth, bursting lengthwise.

14. Galeópsis. - Calya sub-campanulate, with 5 prickly teeth; anthers fringed, bursting transversely.

* 15. Leonúrus. - Caly $x$ sub-campanulate, with 5 prickly teeth ; anthers smooth, warty, bursting lengthwise. 
16. LÁmiUM.-Calyx sub-campanulate, 5-toothed; anthers hairy, bursting lengthwise.

17. Bállota. - Calyx funnel-shaped, with 5 broad, spreading, prickly teeth; anthers smooth, bursting lengthwise.

*⿻丷木光米米 Stamens 4, parallel, the 2 upper shorter ; nutlets united, wrintiled.

18. Térorium.-Calyx tubular, 5-toothed; upper lip of corolla deeply 2-cleft.

19. ÁJugA. - Caly.x ovoid, 5-cleft; upper lip of corolla very short, notched.

1. MÉntha (Mint).--Strongly-scented herbs, with creeping rthizomes and runners; flowers small, in many-flowered whorls, often crowded, with small bracts, into terminal spikes; calys with 5 equal teeth; corolla campanulate, nearly polysymmetric; 4-lobed, with a very short tube; stamens 4, equal, erect, distant, smootli ; mutlcts free, smootl.. (Name, the Classical name of the gronp.)

* The species are very difficult to distinguish, graduating into one another, and apparently also forming hybrids.

† Whorls forming terminal spilies, with minute bracts.

1. M. rotundifólia (Round-leaved Mint).-A viscid plant, 1-3 feet ligh; stem somewhat woody, usually much branched; Teaves sessile, broadly elliptical, remarkably blunt, often cordate, much wrinkled, and nearly smooth above, shaggy beneath; flowers lilac or white, in dense, cylindrical, slightly interrupted spikes; bracts lanceolate; corollı hairy.Waste ground; not common. The scent is acrid and powerful, but not agreeablc.-Fl. August, September, Perennial. 
2. M. alopecuroides, intermediate between the preceding and following species, has its mnners underground; its leaves slightly stalked and very hairy, but not felted, beneath, and its spites short and stout, or

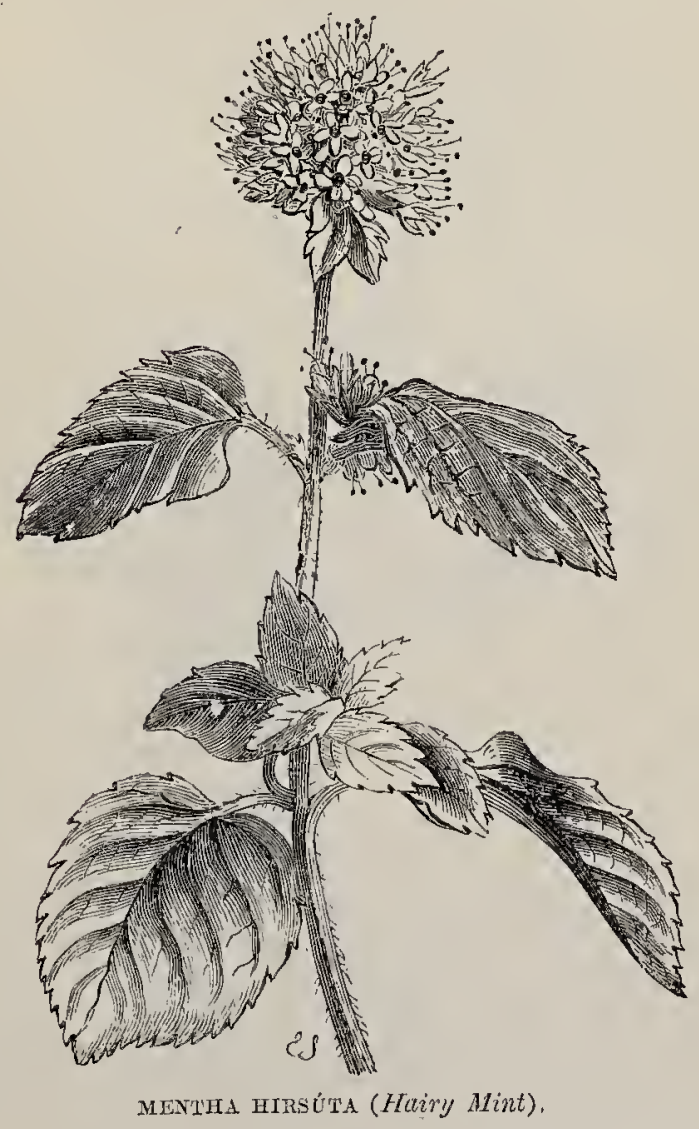

conical-cylindrical.-Chiefly in the East of England; rare.-Fl.-August, September. Perennial.

3. M. longifólia (IIorse Mint).-A strong- but sweet-scented plant, usually growing in masses, $2-3$ 
feet high, with sub-sessile, oblong-lanceolate, acute, serrate leaves, more or less hairy above, silky and white beneath; flowers lilac, in a dense, slender, nearly or quite uninterrupted spike; bracts awlshaped ; corolla hairy.-Damp waste ground; frequent. -Fll. Augnst_September. Perennial.

4.* M. viridis (Spearmint).-Probably a cultivated form of the preceding, escaped from gardens; leaves sessile, glabrous, lanceolate, acute, serrate; spitie slender, cylindrical, interrupted; corolla smooth. -Wet places; rare.-This is the form commonly cultivated as a pot-herb, and is distinguishable by its pungent smell.--Fl. August, September. Perennial.

5. M. piperíta (Peppermint). - A smaller, more slender, glabrous species, $1-1_{2}^{1}$ feet high, with stalked, ovate-lanceolate, acute, serrate leaves; spikes short, lax, blunt, and intermpted below ; bracts litnceolate; caly $x$ often red.-Wet places; uncommon. Perhaps a cultivated form of .I. hirsita.-Fl. JulySeptember. Perennial.

6. M. pubéscens (Downy Mint). - Stem 12-18 in. high; lcaves stalked, ovate-oblong, serrate, hairy above, woolly beneath; spitice cylindric, stout, dense, interrupted below.-Middle and South of England only; rare.-Fl. August, September. Perennial.

7. M. hirsúta (Hairy Mint, Capitate Mint). The commonest and one of the most variable of the Mints, growing in extensive masses in wet places, 1-4 feet high, with a strong smell ; leares stalked, ovate, scrrate, acute, downy on both surfices ; flowers pale livender, in axillary and terminal rounded heads, hairy.-Banks of rivers and marshes; abundant. The Bergamot Mint (11. citrita) is a glabrous form. -Fl. July-Septembcr. Percnnial.

\section{it Whorts in the arits of leafy biacts.}

8. 1. sativa (Marsh Whorled Mint)..- With 
difficulty separated from the preceding ; but growing 2-5 feet high, with leaves green, though hairy on both surfaces, and with all the whorls of flowers

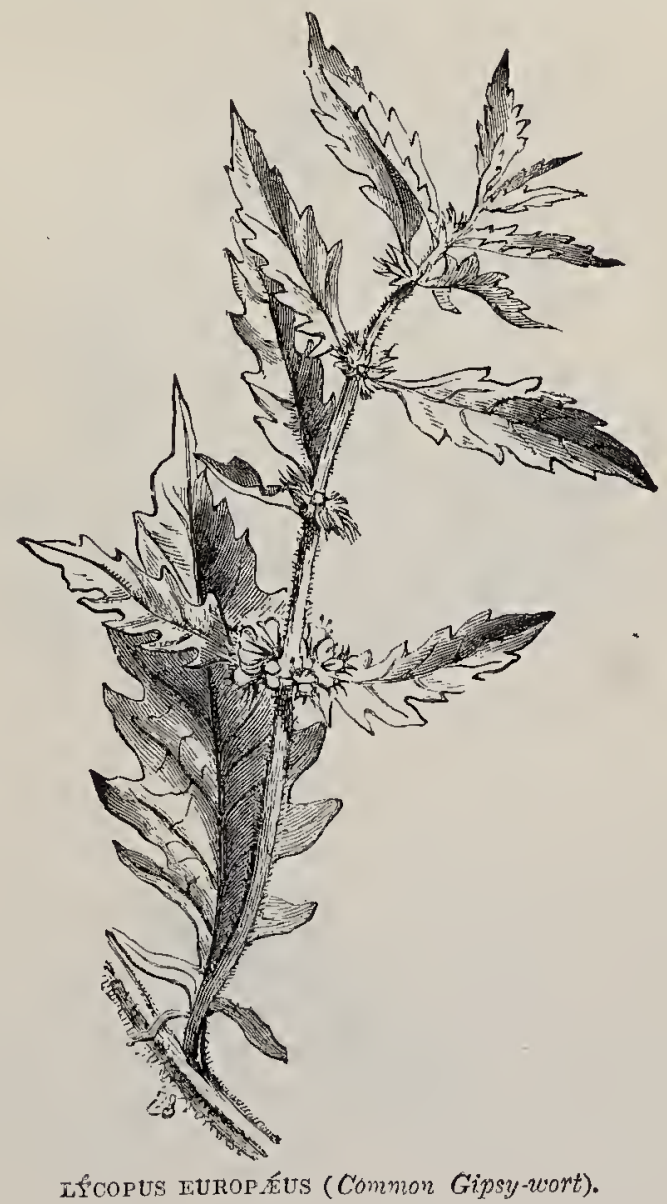

separate, all the bracts leafy, and the uppermost ones sometimes with no flowers in their axils; calyx-teeth lanceolate-acuminate. -- Wet places; common.-Fl. July_September. Perennial. 
9. M. rubra (Red Mint), a less hairy plant with red veins to its leaves, is a not uncommon form of the preceding.

10. M. grácilis (Slender Mint), includes slender, green, and nearly smooth forms with the leaves, especially the upper ones, sessile or nearly so, and the smell of Basil.

11. M. gentitis has spreading, rather thick leaves, nearly all of one size and hairy along their veins. It is a not uncommon type.

12. M. arvénsis (Corn Mint), a branched, downy plant, 6-18 in. high, with stalked, ovate, serrate, hairy leaves, either acute or blunt, all nearly equal in size; and small lilac flower: in dense, distant whorls ; caly $x$ bell-shaped, with deltoid teeth, hairy. This last is the most constant character by which to distinguish the forms of this group from the four preceding ones. -Cornfields; common. The plant has a strong smell.-Fl. July-September. Perennial.

\section{ttt Whorls distant, in the anits of the louer leaves.}

13. M. Putégium (Pennyroyal),-The smallest of the genus, and very different in habit from any of the others; the stems are prostrate; the leaves small, shortly-stalked, ovate, nearly smooth; the flowers red, in distant, globose, many-flowered whorls; caly. downy, its mouth closed with hairs.- Wet heathy places; not common. The whole plant has an agreeable perfume and flavour, and it is commonly cultivated in cottage gardens to be made into a tea which is a rustic remedy for colds_-Fl. July_-September. Perennial.

2. Liforus (Gipsy-wort).-Marsh plants with toothed leaves and small sessile flowers in crowded axillary whorls; caly, $x$ bell-shaped, with 5 equal teeth ; 
corolla short, nearly polysymmetric, 4-cleft; stamens 4 , distant, the 2 upper ones not producing pollen; nutlets free, smooth. (Name from the Greek lúkos, a

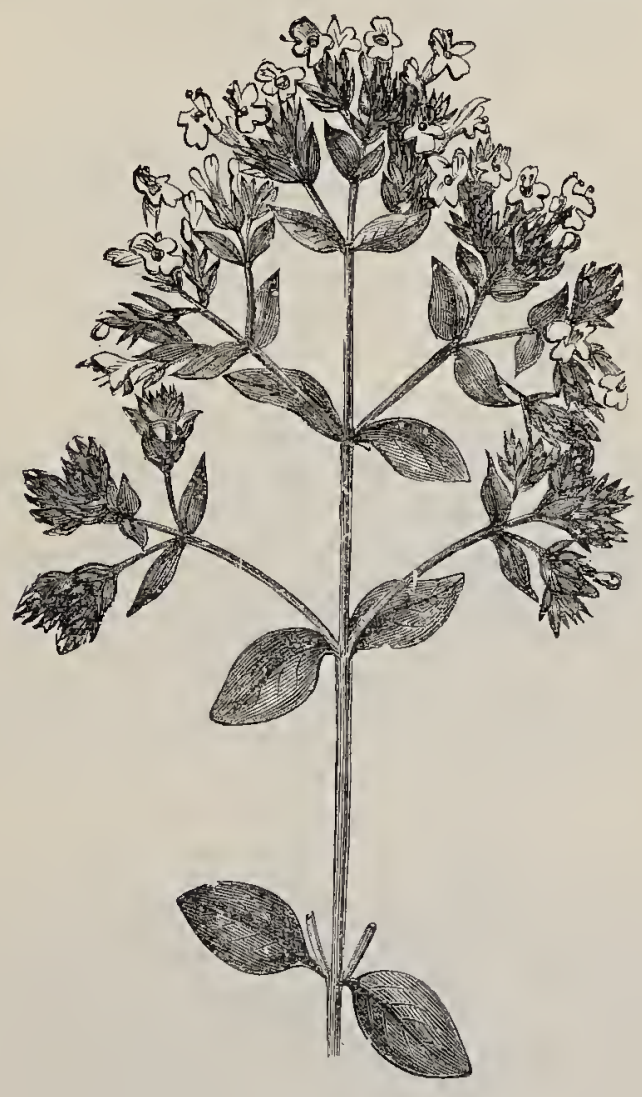

ORÍGAXUM VULGÁRÉ (Common Marjotam).

wolf, pous, a foot, from a fancied resemblance in the leaves.)

1. L. européeus (Common Gipsy-wort).-The only British species, with creeping rhizome and-rumers; 
slightly branched, erect, acutely 4 -angled stem $1-3$ feet high; sub-sessile, deeply cut or pinnatifid, nearly smooth leaves; and minute white flowers, dotted with red, in crowded whorls in the axils of the upper leaves. -Fl. June-September. Perennial.

3. Oríganum (Marjoram).-Aromatic plants, with their flowers crowded in corymbose cymes with imbricate bracts ; calyx with 5 equal teeth, 10-13-ribbed, the throat hairy; corolla obscurely 2-lipped; stamens 4, distant; nutlets free, smooth. (Name from the Greek óros, mountain, gános, joy, the plant growing on high ground.)

1. O. vulgáré (Common Marjoram).-The only British species, growing about a foot high, and distinguished by its shortly-stalked, broadly ovate, downy leaves and heads of rosy flowers crowded into a corymbose cyme, with deeply red-tinged, imbricate bracts forming 4-sided spikelets.-Dry bushy places, especially on chalk or limestone; common. The whole plant is fragrant and aromatic, and is frequently cultivated as a pot-herb.-Fl. July-September. Perennial.

4. ThÝmus (Thyme). - Small, prostrate, wiry, aromatic plants, much branched and of ten hairy; leaves small; flower's rose-colour, rarely white, in axillary or. spiked, few-flowered whorls; calyw 2-lipped, 10-13ribbed, the throat hairy; corolla obscurely 2-lipped, the upper lip notched, the lower 3-cleft; stamens 4, distant, usually exserted. (Name, the Classical name of the plant.)

1. T. Serpýllum (Mountain Thyme).-A wellknown and favourite little plant, forming a cushion with a fringe of prostrate, flowerless shoots, which in the next year send up erect flowering-shoots from 
near their bases; lecues obovate, fringed; flowers with deep red caly, $x$ and rose-coloured corolla, in terminal heads.-The commoner form in mountain districts. The whole plant diffuses a fragrant, aromatic perfume,

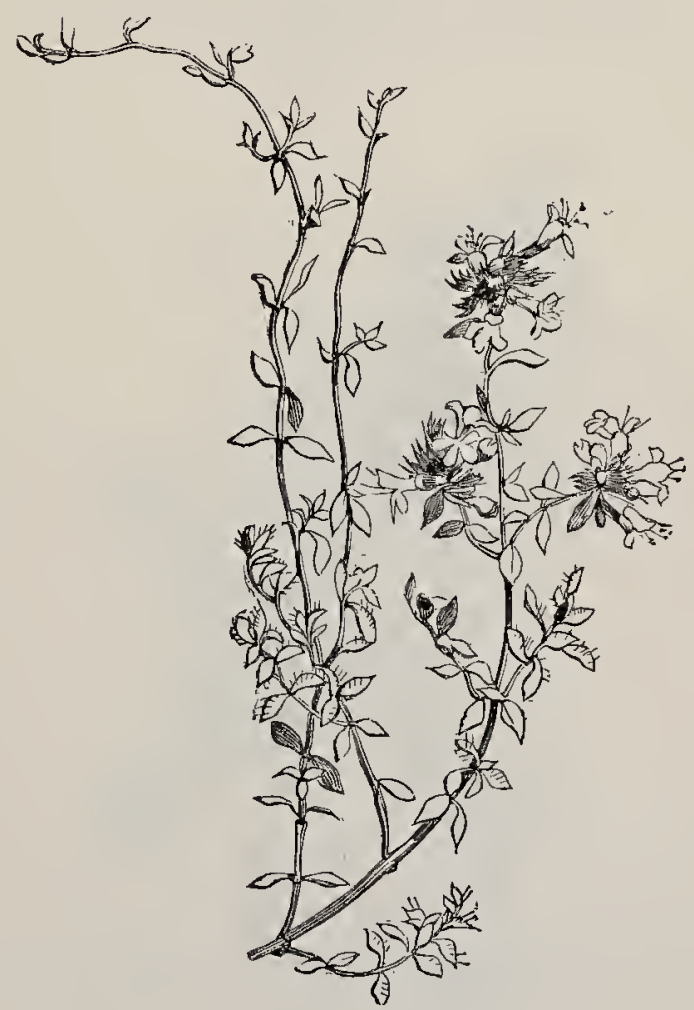

THỶMUs SERPTLUM (Wild Thyme).

which, especially in hot weather, is perceptible at some distance.-Fl. June-August. Perennial.

2. T. Chamédrys (Heath'Thyme).-Stems all ascending; . lecues ovate; flowers in axillary heads.-Heaths; not common.-Fl. June-September. Perennial. 
5. Calamíntha (Calamint).-Flowers either crowded in the axils or in loose panicles; calyx tubular, 2 lipped, 13-nerved ; corolla 2-lipped, with straight tube; upper lip nearly flat, lower spreading, 3-cleft; stamens 4 , converging at their tips; nutlets smooth. (Name from the Greek kálos, beautiful, mintha, mint.)

1. C. Clinopódium (Wild Basil).-A straggling,

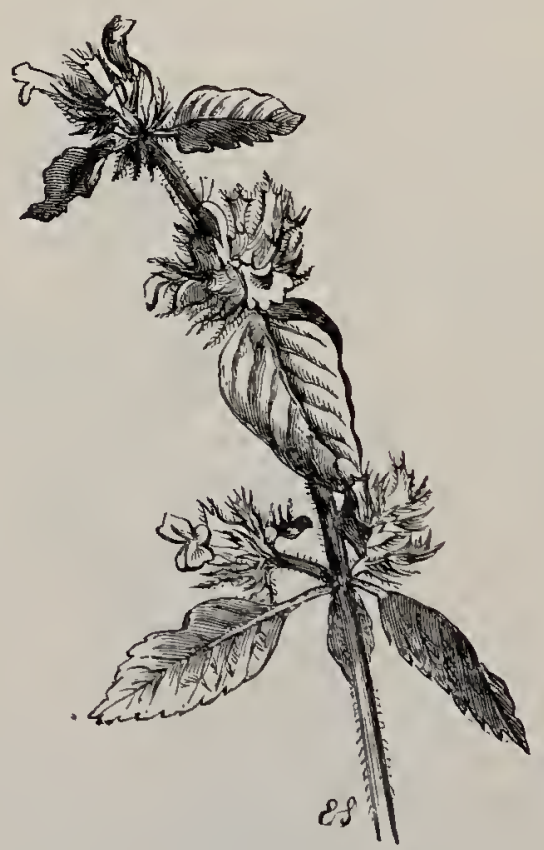

calamfNTHa clinopónium (Hild Basil).

softly hairy plant, $1-2$ feet high, with ovate, slightly toothed, stalked leaves; and rose-1ed flowers in crowded, many-Howered, mostly axillary whorls, with numerous, long, bristly bracts forming a kind of involucre.resembling a green foot-stool, whence the old generic name Clinopódium (foot-stool).-Dry bushy plants; 
common. The plant is fragrantly aromatic.-Fl. July_-September. Perennial.

2. C. arvénsis (Basil Thyme).-A small, bushy,

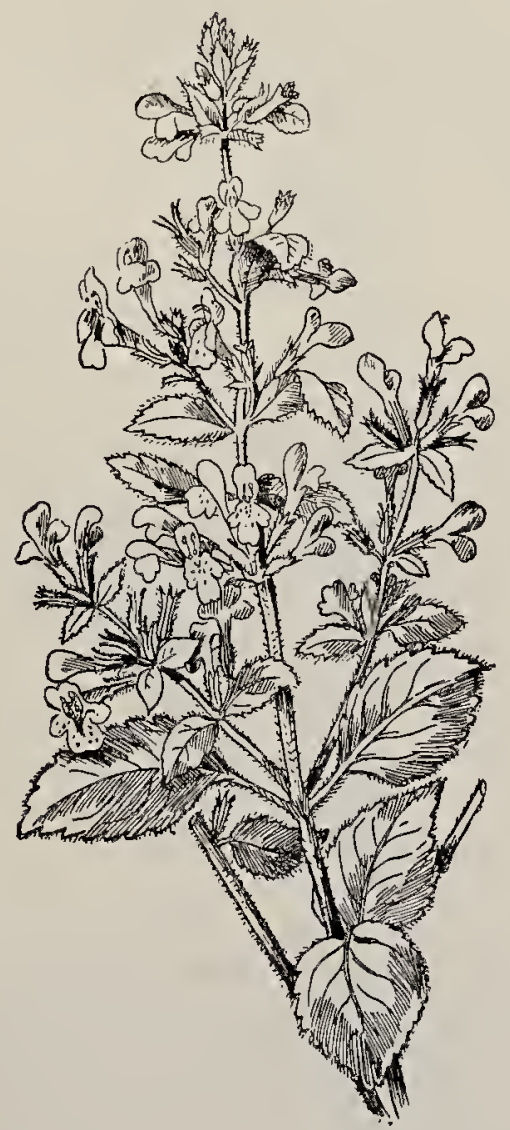

CALAMfNTHA OFFICINÁIIS (Common Calanint).

downy, herbaceous plant, $6-8 \mathrm{in}$. high, with ascending, branched stems; hairy, ovate, serrate, acute leaves on short stalks; and violet flowers in whorls of 
5 or 6 , with the calyx 2-lipped, the lower lip bulged at the base, and the corolla spotted with white and darker purple.-Dry places; frequent.-Fl. July, August. Annual.

3. C. pariflóra (Lesser Calamint).-Stems usually many, 12-18 in. high, with short, erect branches; leaves ovate, serrate, shortly stalked, pale beneath; flowers light purple, in forked cymes; calyx with short hairs on its teeth.-Dry banks; rare.-Fl. July, August. Perennial.

4. C. officinátis (Common Calamint.).-A larger, erect, bushy plant; with downy, ustually solitaly stem; long, ascending branches; leaves on rather long stalks, broadly ovate, slightly serrate, green on both sides, downy ; flowers light purple, in forked, axillary, fewflowered cymes with small pointed bracts in the forks ; calyx 2-lipped, with long hairs on its teeth, the teeth of the upper lip straight; lower lip of corolla with its middle lobc ion common. -Fl. July, August. Perennial.

5. C. sylucitica, an allied species, with larger, sharply serrate leaves and large flowers with the 3 upper teeth of the caly.r reflexed, and the 3 lobes of the lower lip of the corolla equal, occurs on dry banks in Hampshire and South Devon.-Fl. AugustOctober. Perennial.

*6. Moxíssa (Balm), a closely allied genus, differing from Calamintha mainly in its curved corolla-tube, is represented in England only by the one species, $M$. officinális, a hairy plant with numerous erect stems, 1-2 feet high ; stalked, ovate, crenate leaves, wrinkled above, paler beneath; and white flowers in shortlystalked, one-sided, axillary, few-flowered whorls.-It occurs as an escape only, in the south. (Name from the Greek melissa, a bee, bees visiting the flowers for honey.)-Fl. July, August. Perennial. 
7. SÁlvia (Sage).-Herbs or shrubs with calyw and corolla both 2-lipped, the latter gaping; stamens 2, with short filaments bearing a long versatile connective with an anther-lobe at each $\in$ nd (distractile),

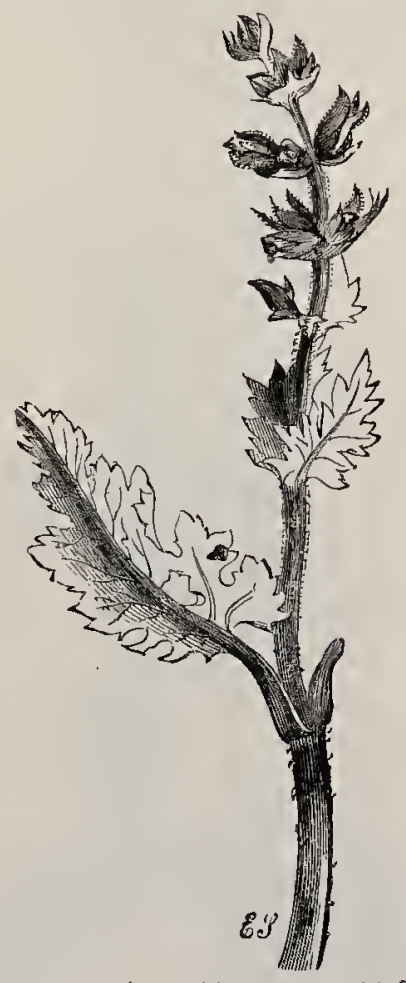

SÁLYIA VERBENACA (Clary, or Wíld Sage).

the upper only usually containing pollen. (Name from the Latin salveo, I am well, from the healing properties of Sage.)

1. S. Verbenáca (Clary, Wild Sage).-An aromatic, herbaceous plant, $1-2$ feet high, with few oblong, blunt, cordate, crenate, much-wrinkled leaves, wavy 
at the edge; and rendered conspicuous by its long

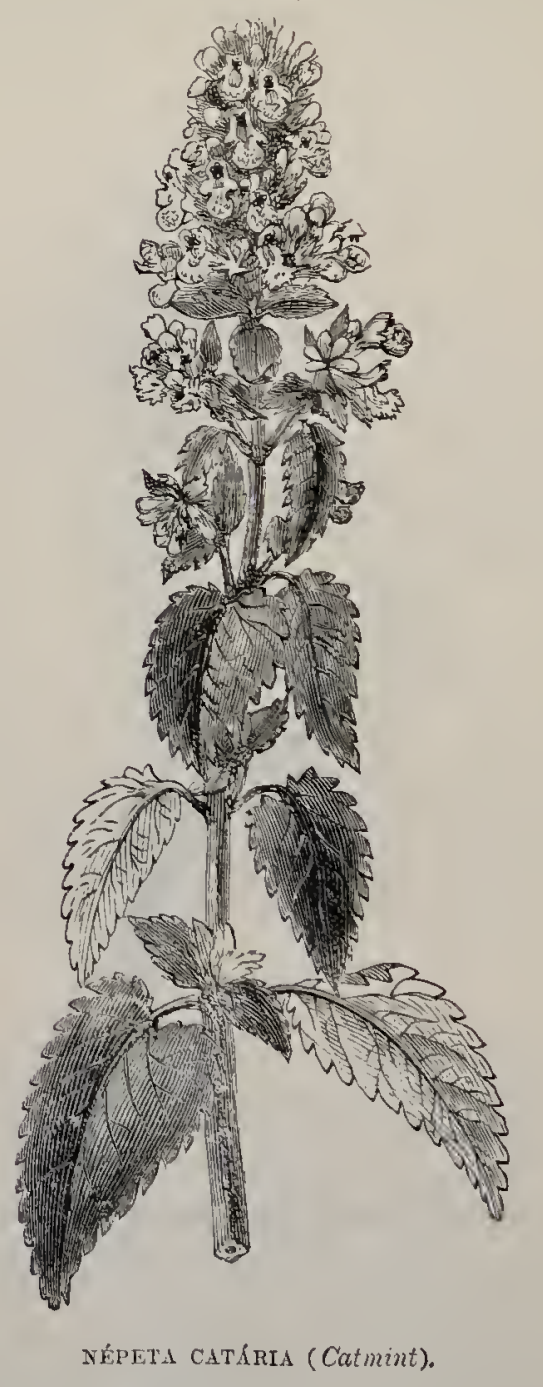

spikes of purple-blue flowers, the callyw of which is 
much larger than the corolla, while at the base of each flower are 2 ovate-cordate bracts.-Dry pastures, especially near the sea, or on a chalky soil; frequent. The fruit was formerly used in eye-lotions.-Fl. MaySeptember. Perennial.

2. S. praténsis (Meadow Clary), distinguished by its large blue corolla with a viscid lip, is a rare species,

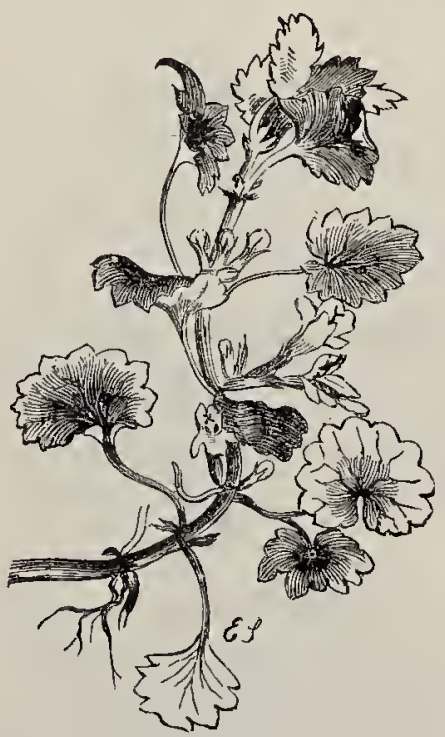

AÉPENA GLECHÓMA (Gronnd Ivy).

occurring in dry fields in Kent, Oxfordshire, and Cornwall.-Fl. June--August. Perennial.

8. Népeta (Catmint).-Herbs with a tubular, 5 toothed, 15-ribbed calyx; the tube of the corolla longer than the calyx, slender below, dilated at the throat; upper lip flat, notched; lower 3-lobed, with a large middle lobe; 2 front stamens the shortest. (Name of doubtful origin.) 
1. N. Catária (Catmint).--Stem erect, branched, 2-3 feet high, white with mealy down; leaves ovate, cordate, serrate, whitish beneath ; flovers small, white, dotted with crimson, in dense whorls, which towards the summit of the stem are so close as almost to form a spike.-Hedges and waste ground; not uncommon. The whole plant has a strong aromatic odour, resembling Pennyroyal, and peculiarly pleasing to cats, whence it derives its name.-Fl. July-September. Perennial.

2. N. Glechóma (Ground Ivy, Ale-hoof).--A favourite spring flower, with creeping stems ; kidney-shaped, crenate, roughish leaves; and bright blue-purple flowers which grow 3 or 4 together in the axils of the leaves. The whole plant has a strong aromatic odour' which, though scarcely fragrant, is far from disagreeable. It is bitter, and was formerly used in brewing, as hops are now; and in rural districts its leaves are dried and made into tea. At a distance its blossoms are often mistaken for sweet violets.-Fl. MarchJune. Perennial.

9. Soutellária (Skull-cap). - Herbaceous or shrubby plants, with flowers generally solitary or in pairs in the axils; cally $x$ bell-shaped, 2-lipped, upper lip with a concave seale on its back, which finally closes like a lid over the fruit; corolla much larger than the calyx; stamens 4, parallel, the 2 lower with 1-chambered anthers. (Name from the Latin scutella, a little dish, from the lid of the calyx.)

1. S. yalericulata (Greater Skull-cap).--A handsome plant, 12 -18 in. high, generally branched, with shortly-stalked, oblong-lanceolate, cordate, crenate leaves, and rather large, bright blue flowers in 1sided pairs in the axils; corolla-tube white inside, much longer than the calyx. Soon after the corolla has fallen off, the upper lip of the calyx closes on the 
lower, and gives it the appearance of a capsule with a lid; when the fruit is ripe it opens again.-Banks of rivers and ponds; frequent.-Fl. July-September. Perennial.

2. S. minor (Lesser Skull-cap).-A much smaller,

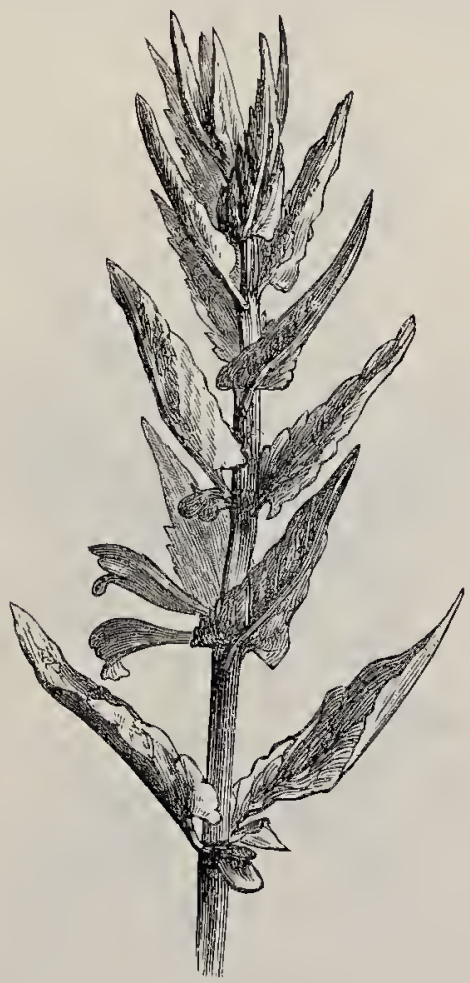

SCUTELLÁRI a GALERICULÁTA (Greater Skull-cap).

more slender little plant, only $4-8$ in. high, with subsessile, ovate, obtuse leaves; and small, pale pink flower's, with a caly 2 like that of the preceding species. -Boggy places; not common, except in the West of England.-Fl. July-October. Perennial. 
10. Prunélla (Self-heal).-Small, hairy plants with their flowers, in whorls of about 6 , collected into dense, terminal heads with 2 broad, rounded, leafy bracts beneath each whorl; calyx sub-campanulate, 2-lipped, flattened, and closed when in fruit ; stamens 4, parallel, all with 2-chambered anthers and forked filaments. (Name said to be from a German word for

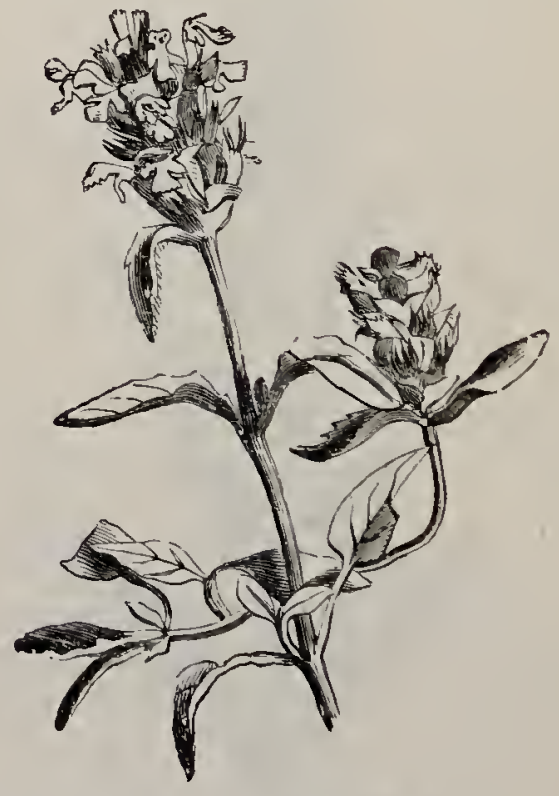

PRUNÉLLA VULGARIS (Self-hcal).

the quins $\%$, for which complaint it was considered a specific.)

1. P. vulgâris(Self-heal).- The only British species, easily distinguished by its whorls of blue-purple, or rarely white, flowers, which are collected into a cylindrical head, having two kidney-shaped, acuminate, purple-edged bracts beneath each whorl, and a pair of ovate leaves at the base of the head.-Pastures and 
waste ground ; very common.-Fl. July-September. Perennial.

11. Metítris (Bastard Balm), represented by only one species, M. Melissophýllum, a very handsome

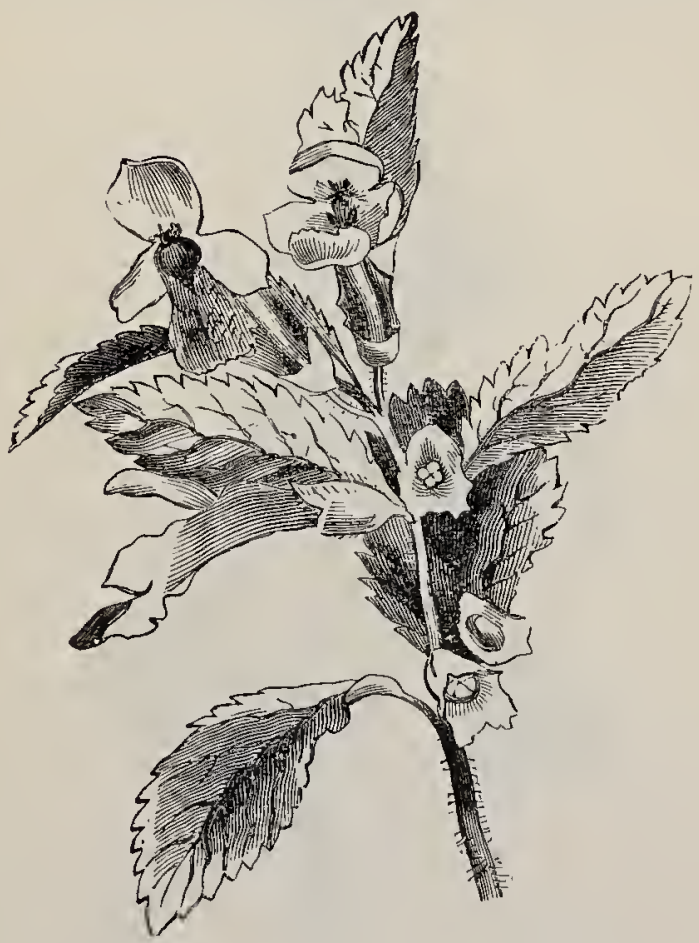

MEIfTTIS MELISSOPHÝLIUM (Will Balm).

plant, 1-2 feet high, with large, oblong-ovate, serrate, slightly hairy leaves, and conspicuous white flowers, spotted or variously variegated with bright rose-colour. The caly, $x$ is membranous and inflated.Woods in the south and west; rare.-The foliage has an offensive smell while fresh, but in drying ac- 
quires the flavour of new hay or Woodruff. (Name from the Greek melitta, a bee, another form of metissa, referring similarly to its supply of honey.) - Fl. May, June. Perennial.

12. Marrúbium(White Horehound).-Woolly, her-

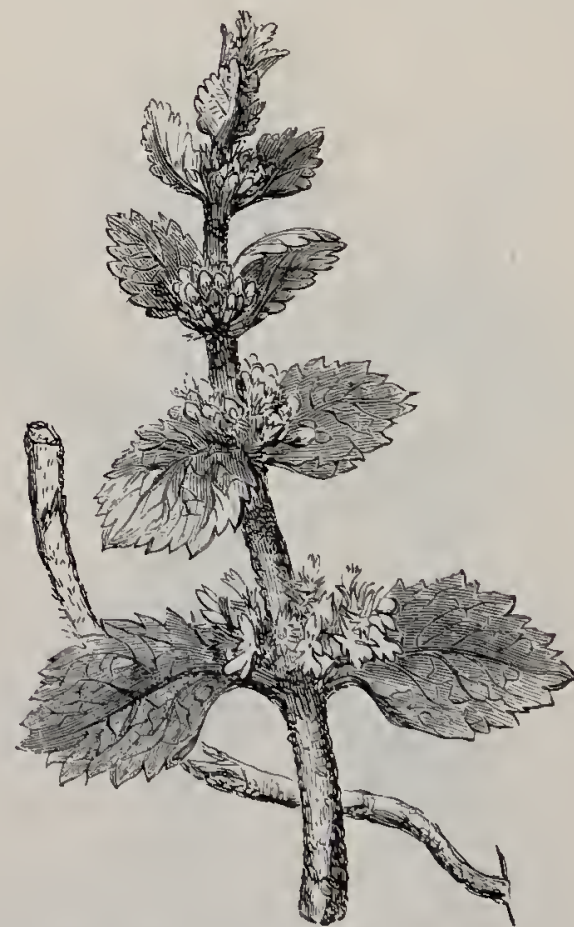

MARRÚBIU VULGÁRE (Hhite Horehonnd).

baceous plants with small flowers in whorls in the axils of leafy bracts: calyx tubular, 5-10-ribber, with 5-10 somewhat prickly teeth, and a hairy throat; corolla with tube longer than the calyx, unequally 2-lipped; "pper $7 i_{p}$, strisight, very narrow, deeply 2-cleft, lower 3-lobed, the middle lobe the 
largest ; anthers inclurler. (Name, the Classical Latin name.)

1. M. vulgáré (White Horehound).---The only

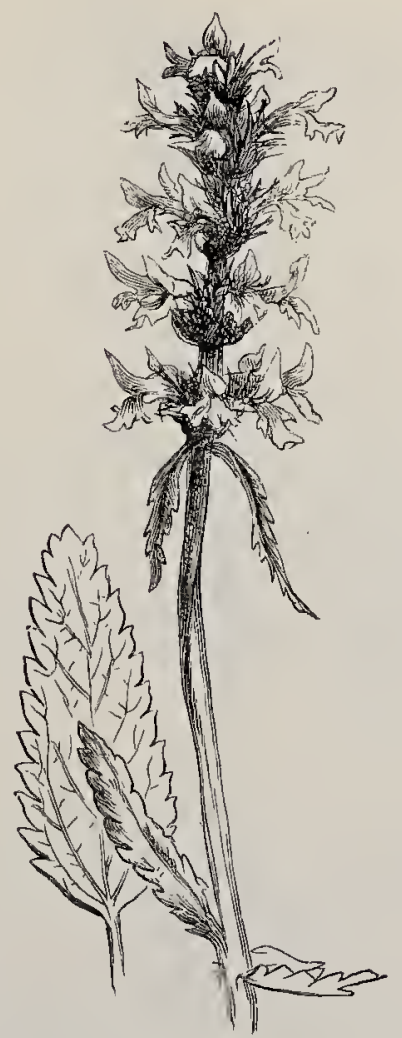

STÁCHYs BETÓNICA (Wood Betony).

British species, well distinguished by its bushy stem, $1-2$ feet high, covered with white woolly down, by its wrinkled, ovate, crenate leaves, a d its dense whorls of small white flowers, of which tle culyr-teeth are sharp and hooked.-Waste ground; not uncommon,--The 
whole plant is aromatic and bitter, and is a common remedy for coughs-Fl. July-September². Perennial.

13. Stáchys (Woundwort).-Herbs or shrubs with their flowers usually in terminal spikes; calyx sub-campanulate, 5-10-ribbed, with 5 equal teeth; corolla with tube as long as the calyx; upper Tip arched, Tower 3-lobed, the side lobes bent back before withering; stamens 4, the 2 lower the longest; anthers bursting lengthwise. (Name from the Greek stachus, an ear of corn, from the spike-like inflorescence.)

1. S. Betónica (Wood Betony).-A common and very pretty woodland plant, 1-2 feet high, with a siender, seldom branched stem; characteristically shaped oblong, obtuse, cordate, deeply crenate leaves, of which the lower ones are stalked; and an interrupted terminal oblong head or spitic of deep crimson, rose-coloured, or rarely white flowers with 2 or 3 pairs of sessile leaves beneath the lower whorls. - Fl. JuneAugust. Perennial.

2. S. germánica

(Downy Woundwort).-Stem erect, woolly, 2-3 feet high; leaves with matted, white, silky hairs, wrinkled, cordate, the lower stalked, ovate-oblong, the upper sessile, lanceolate; flower's rose-colour, in interrupted, dense, manyflowered whorls.-On a chalky soil; very rare.-Fl. July, August. Biennial.

3. S. alpina (Hill Woundwort). - Stem erect, little branched, velvety, glandular at the top, 1-2 feet high, herbaceous ; leares oval-linceolate, cordate, distinctly and regularly crenate-serrate, acuminate, velvety on both sides, green above, paler beneith; the lower long-stalked, the upper sessile; flowers purple, 5-12 in each axil, in a distantly interrupted spike; bracteotes linear-lanceolate, nearly ns long as the calyx, reflexed, velvety; cally, bell-shaped, with 
slightly unequal teeth and glandular hairs; corolla

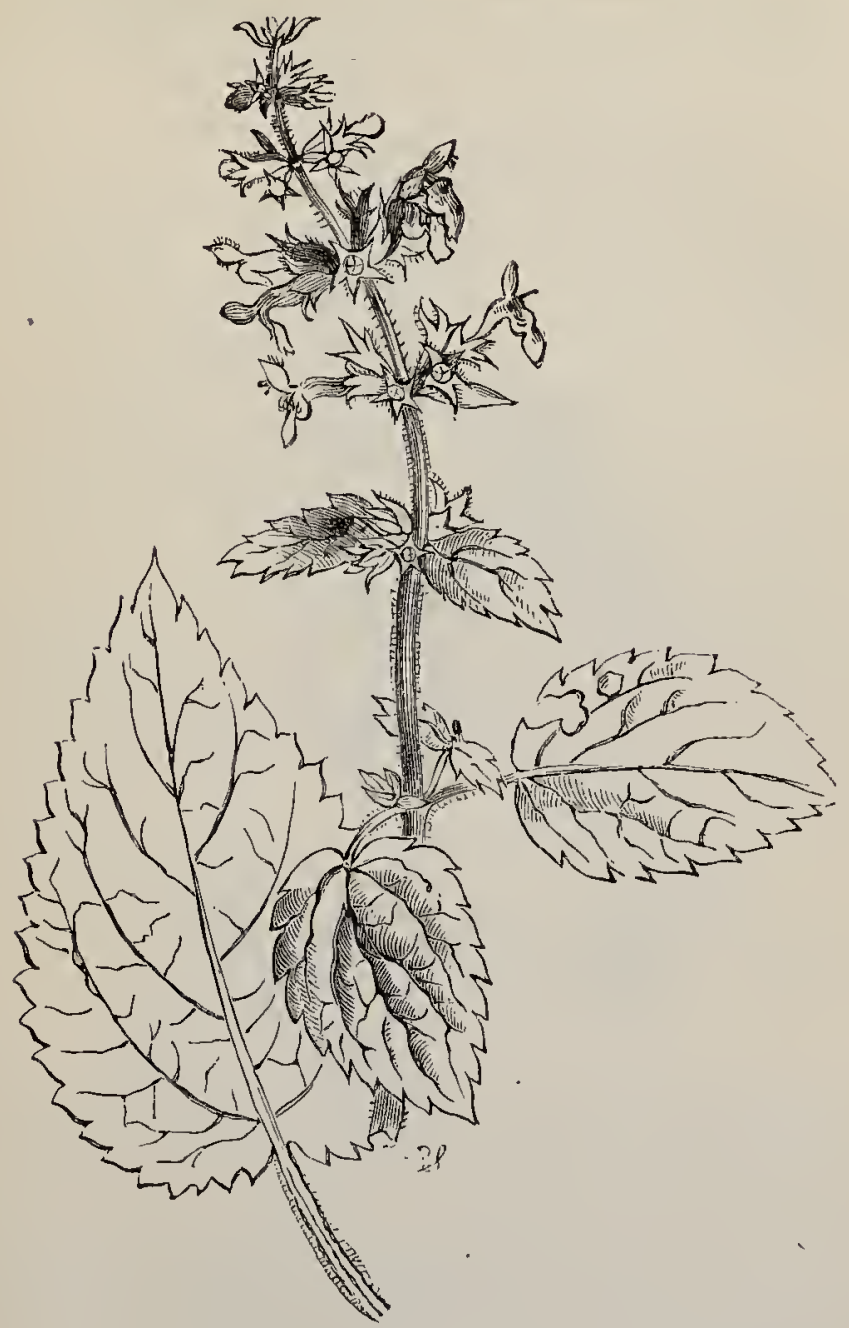

STÁCHYS SYLVÁTICA (Hedge Wonnduort).

: woolly outside, longer than the calyx, spotted; upper 
lip obovate, obtuse, bearded at the apex; loner lip emarginate; nutlets large, brown, smooth.-Woods on calcareous soil ; found in Gloucestershire, in 1897, by Mr. Cedric Bucknall.-Fl. July, A ugust. Perennial.

4. S. patústris (Marsh Woundwort).-Stem erect, stout, hollow, 1-3 feet high, hairy; teares linearlanceolate, acute, crenate-serrate, the lower shortlystalked; flowers dull light red, in a long, terminal, interrupted spike of 6-10-flowered whorls.-Marshes; common.-Fl. July-September. Perennial.

5. S. syluática (Hedge Woundwort).-A similar species, but more coarsely hairy, with solid stem; Teceves all stalked, ovate-acuminate, cordate, coarsely serrate; flowers dull dark red.-Woods and hedges; common.-Fl. July, August. Perennial.

6. S. arvénsis (Corn Woundwort). - A smaller, more slender, slightly hairy species, with stem spreading; ascending branches, 6-18 in. ligh ; ovate, obtuse, crenate leaves; flowers pale pink, very small, $4-6$ in a whorl ; corolla scarcely longer than the calyx; nutlets warty.-Cornfields and other cultivated ground; an abundant weed.--Fl. April-Norember. Annual.

7.* S. ámua, with its upper leaves lanceolate and flowers yellowish, has occurred in cornfields in Kent.Fl. August, September: Annual.

14. Galeópsis (Hemp-nettle).-Herbs with spreading branches; serrate leaves: flowers in dense, manyflowered axillary and terminal whorls; caly.x bellshaped, with 5 prickly teeth, 5-ribbed; corolla with an inflated throat; upper lip arched; lower 3-lobed, with 2 erect teeth on its upper side : 2 lower stamens the longest; anther's exserted, fringed, bursting transversely. (Name from the Greek galé, a weasel, ópsis, resemblance.)

1. G. intermédia (Rare Red Hemp-nettle).-A 
softly pubescent plant, $6-18$ in. high, with many ascending branches, and the stem not thickened at its nodes; leaves ovate-lanceolate, serrate throughout; flowers rose-red, in separate whorls; corolla-tube equal-

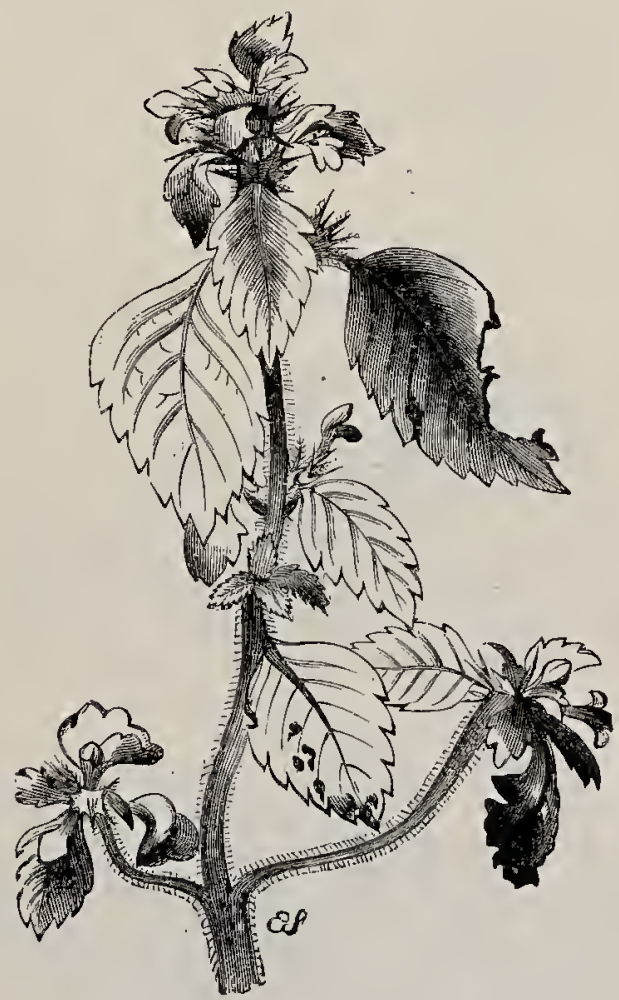

GaLEÓPSIS tŕtrahit (Common Hemp-nettle).

ling the calyx. - Cultivated ground; a rare casual.Fl. July-October. Annual.

2. G. angustifólia (Common Red Hemp-nettle).An allied species, with narrower, linear-lanceolate leaves, only partially serrate, the upper whorls of flowers not separate, and the corolla-tube much longer 
than the calyx.-Gravelly and sandy cornfields; not uncommon.-Fl. July - October. Annual.

3. G. ochroléuca (Downy Hemp-nettle). - A very similar plant, but with gland-tipped hairs on its upper. part; ovate-lanceolate, deeply serrate, soft, downy leaves; and large, pale yellow flowers. - Sandy cornfields; rare.-Fl. July, August. Annual.

4. G. versícolor (Large-flowered Hemp-nettle). - A large, stout, hispid plant, $2-3$ feet high, with stem swollen at its nodes; leaves long stalked, oblong-ovate, acuminate, coarsely serrate; corolla large, yellow, usually with a broad red spot on the lower lip, tube much longer than the calyx, upper lip arched, as broad as long.-CCornfields; frequent._Fl. July, August. Annual.

5. G. Tétratrit (Common Hemp-nettle).-A closelyallied species, not reaching so great a height, with more strongly ribbed calyrit, with teeth as long as its tube, and a smaller, generally rose-colonr and white corolla, its tube not longer than the caly.x, and its upper lip flatter and longer than it is broad.-Cornfields; common,_Fl. July-September. Annual.

*15. LEonúnus (Motherwort).-Erect, herbaceous, plants, with lobed leaves: dense, distant, axillary whorls of small flowers; caly,re bell-shaped, with 5 prickly, spreading teeth; corolla with the upper lip nearly flat, very hairy above; anthers sprinkled with hard, shining dots, bursting lengthwise. (Name from the Greek leon, a lion, wira, a tail, from some fancied resemblance in the plant.)

1.* L. Carliaca (Common Motherwort).-Distinguished from all British plants of the Order by its radical leaves, which are on long, slender stalks, and are deeply palmately 3 -5-lobed. The stem is $2-4$ feet high, branched mainly below, and very leafy. The upper lere'es are narrow and entire, or nearly so, 
and, when not in flower, the plant resembles Mugwort (Artemisia vulgaris) in habit. The flowers are

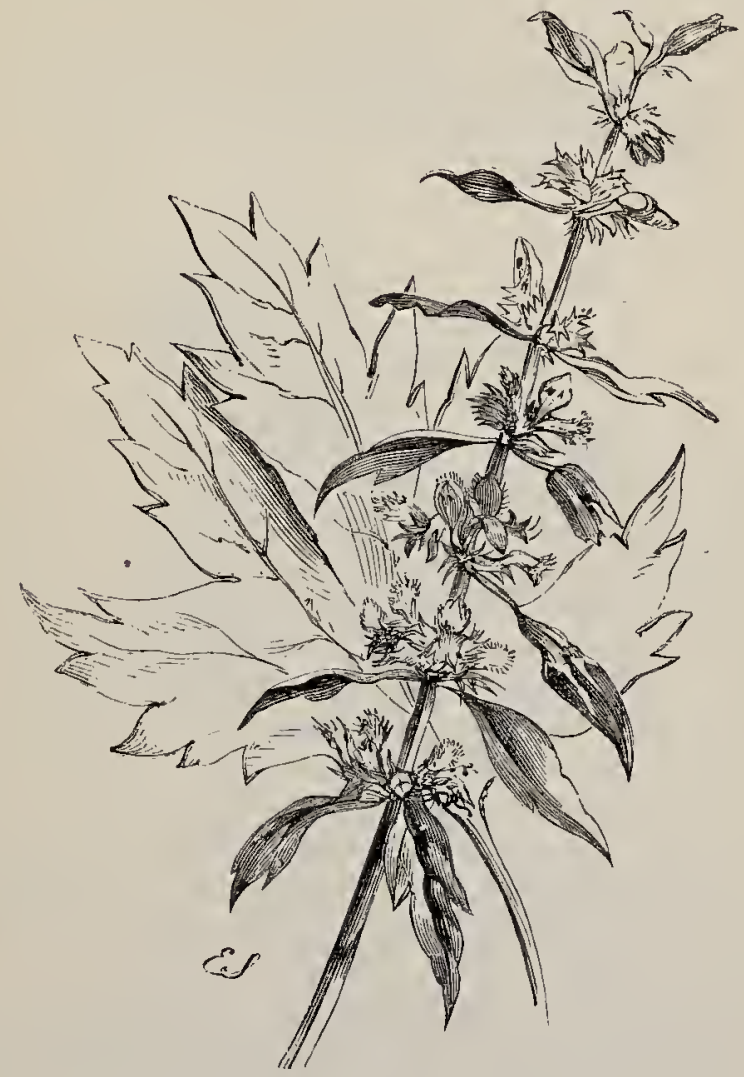

LEONĆRUS CARDÁACA (Common Motherwort).

pink, and their whorls of prickly calyces are consp1cuous.-Hedges and waste places; raje and not in digenous._Fl. July-September. Perennial.

16. Lámium (Dead-nettle).-Hairy herbs with 
leaves so closely resembling those of the Stinging Nettles that many persons are afraid to handle them, though the square stems in the case of the Deadnettles, and the small, green flowers in spiked clusters in that of the Stinging Nettles, are sufficient to distinguish them from one another. The Dead-nettles have their flowers in many-flowered whorls in the axils of leafy bracts; caly,x tubular or bell-shaped, 5toothed; corolla with an inflated throat, arched upper. lip, 3-lobed lower Tip; stamens 4, the 2 lowest the longest; anther's generally hairy, bursting lengthwise. (Name from the Greek laimos, the gullet, from the shape of the corolla.)

1. L. amplexicaúlé (Henbit-nettle).-Stem 4-10 in. high, branched from the base; lower leaves longstalked, roundish, deeply cut; upper sessile, amplexicaul, kidney-shaped; flowers orimson, in distant whorls; caly, small, very downy, with teeth converging in fruit; corolla with long, slender tube-Dry waste places ; common.-Fl. May-August. Annual.

2. L. intermédium (Intermediate Dead-nettle).Intermediate between the preceding species and $L$. purpureum, but most resembling the former' stouter and more succulent; caly.x slightly hairy, teeth much longer than the tube, not converging in fuit; corollatuhe only slightly longer than the calyx.-Cultivated ground, chiefly in Scotland.-Fl. June-September. Annual.

3. L. Ty̧bridum (Cut-leaved Dead-nettle),-More nearly allied to L. purpureum; stem 6-18 in. high ; leares all stalked, incise-dentate, the lower cordate, the upper wedge-shaped at the base; flowers red, in crowded, sub-terminal whorls; culy, $x$-teeth about as long as the tube; corrotla-tube not longer than the calyx._-Waste places ; frequent. - Fl. A pril_-October. Annual.

4. L. purpuireum (Red Dead-nettle).--Stem 6-18 in. high; leaves all stalked, crenate, blunt, cordate or 
kidney-shaped, commonly tinged with red, the upper ones crowded; flowers small, red, or rarely white, in crowded, sub-terminal whorls; calyx-teeth about as long as the tube ; corolla-tube longer than the calyx.A very common weed in cultivated ground, and by waysides.-Fl. April-October. Annual.

5.* L. maculátum (Spotted Dead-nettle).-Most

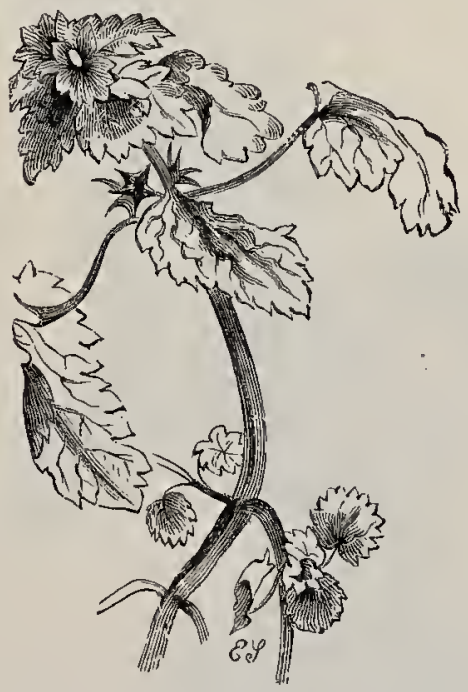

IÁMIUM PURPÚREUM (Purple Dead-nettie).

closely allied to the following; stem $6-18$ in. high; leaves all stalked, cordate, ovate, much wrinkled, deeply serrate, and almost always with a white stripe down the middle; flowers large, rose-colour, rarely white; caly $x$ teeth broad, recurved, as long as the tube; corolla-tube longer than the calyx, and abruptly dilating at the throat.-Waste places; an escape from cultivation. Fl. June-September. Perennial.

6. L. album (White Dead-nettle).-A common but 
not inelegant weed, 6-18 in. high ; lecues all stalked, cordate, ovate, acuminate, deeply serrate, sometimes blotched with white; flowers large, white; calyx-teeth

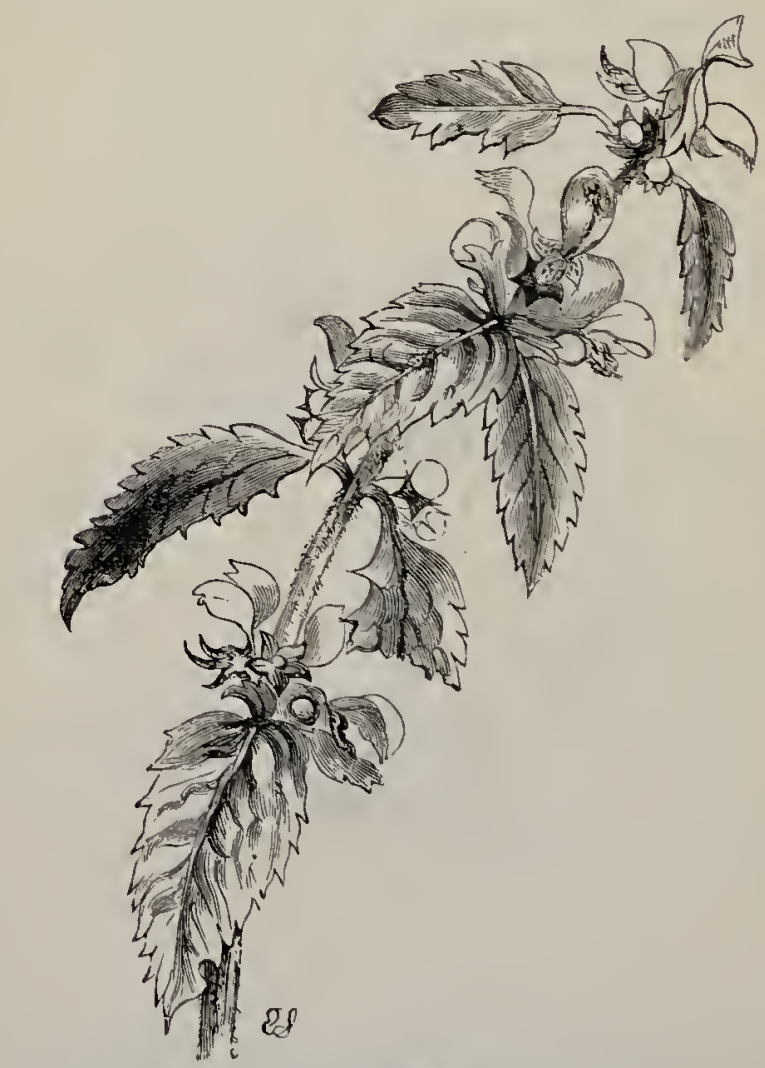

LAMIUM GALEỎBDOLON (Fellow Heasel-snout, Archangel, Jellow Dead-netile).

narrow, straight, with long, slender points as long as the tube; corolla-tube longer than the calyx, and gradually dilating upwards; anthers black.-Hedges and warte ground; abundant.-Fl. May-Decembel. Perennial. 
7. L. Galeóbdolon (Yellow Dead-nettle, Weaselsncut, Archangel). - Resembling the White Deadnettle in habit, but rather taller and more slender;

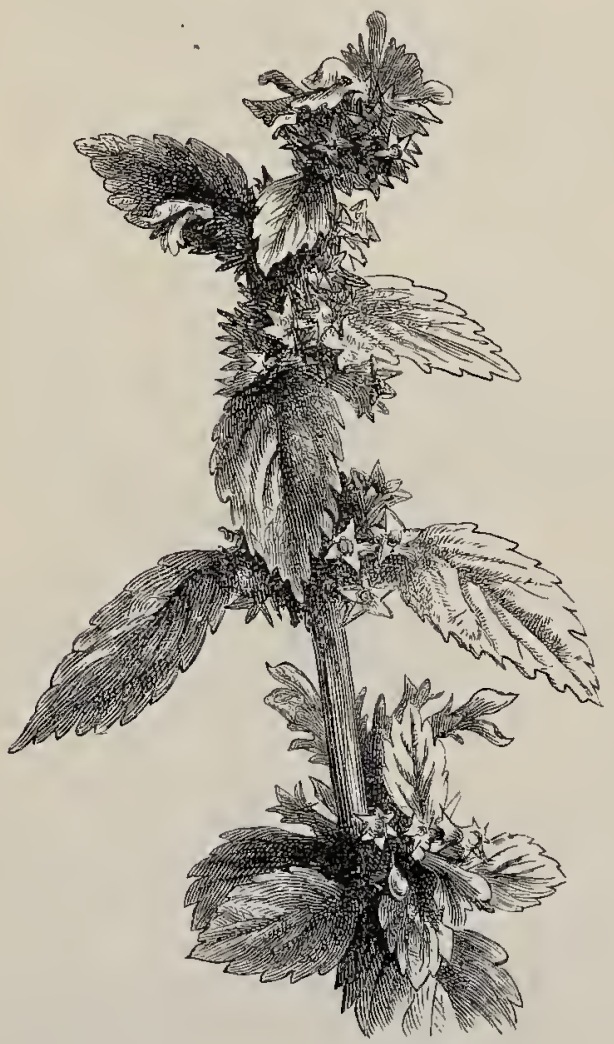

BÁLLOTA NÍGRA (Black Horehound).

leaves ovate, acuminate, coarsely serrate; flowers yellow, with red spots on the lower lip, in distant, $6-10$ flowered whorls, large and handsome; anthers smooth.-Copses ; frequent.-F]. May, June. Perennial. 
17. Bállota (Black Horehound).-Hairy, herbaceous plants, with small fiowers in dense, axillary whorls, with leafy bracts; caly $x$ funnel-shaped, with 5 equal, broad, spreading, prickly teeth; corolla unequally 2-lipped, upper. lip erect, concave, lower 3lobed, the middle lobe largest, heart-shaped; stamens 4, the 2 lower the longest; anther's exserted, smooth, bursting lengthwise. (Name in Greek signifying rejected, from the offensive smell.)

1. B. nigra (Black Horehound).--The only British species, a tall, bushy plant, hairy with reflexed hairs, much branched; leaves stalked, ovate-cordate, downy, wrinkled, crenate; flowers numerous, light red, in numerous distant, 6-12 flowered whorls. - Waste ground; frequent. The odour of the whole plant is particularly strong and offensive.-Fl. July, August. Perennial.

18. Té́cridm (Germander).-Herbaceous plants with flowers in whorls of $2-6$, the upper ones in loose, terminal, 1-sided racemes; caly.x tubular, 5 toothed; corolla with short tube, upper lip small, deeply 2-cleft, lower lip 3-cleft, the middle lobe much the largest; stamens 4, parallel, the 2 upper shorter ; mutlets united, generally wrinkled. (Name from Teucer, who is said to have been the first to use it in medicine.)

1. T. Bótrys (Cut-leaved Annual Germander).-A downy, glandular plant with long hairs ; stem erect, 4-8 in. high, much branched from the base; leares all stalked, ovate, pinnatifid, into 7-11 linear', obtuse segments; flowers rose-colour, in axillary, 4-6flowered whorls; calyx large, inflated, pouched at the bass. - Chalky fields in Surrey; very rare. - Fl. August, September. Annual.

2. T. Scórdium (Water Germander).-A hairy plant with creeping rhizome and rumers; branches 
4-10 in. high ; leaves sessile, oblong, coarsely serrate ; flowers rose-colour, in distant axillary, 2-6-flowered whorls; calyx scarcely pouched.-Wet places; rare. -Fl. July, August. Perennial.

3.* T. Chamédrys (Wall Germander).-A similar

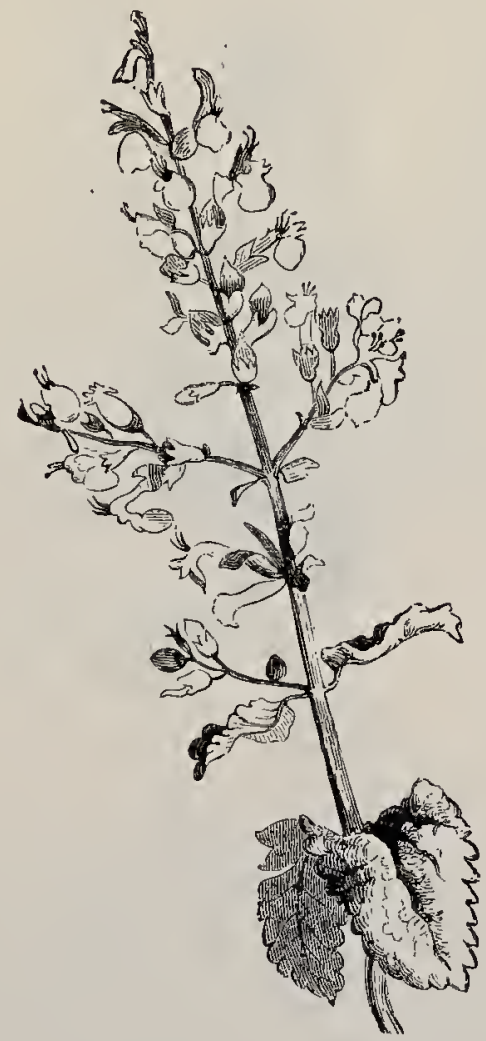

TEÚCRIUM SOORODónia (Wood Germander, Wood Sage).

but rather larger, much-branched plant, woody below, with stalked, ovate, cuneate, incised-crenate leaves, the upper ones smaller and nearly entire; flowers large, handsome rose-colour, in whorls of $5-6$, the upper 
ones in terminal, leafy, 1-sided racemes; calyx hardly pouched.-Old walls; rare. Formerly employed as a tonic; but now scarcely used, except by rustic practitioners.-Fl. July-September. Perennial.

4. T. Scoroclónia (Wood Germander, Wood Sage).

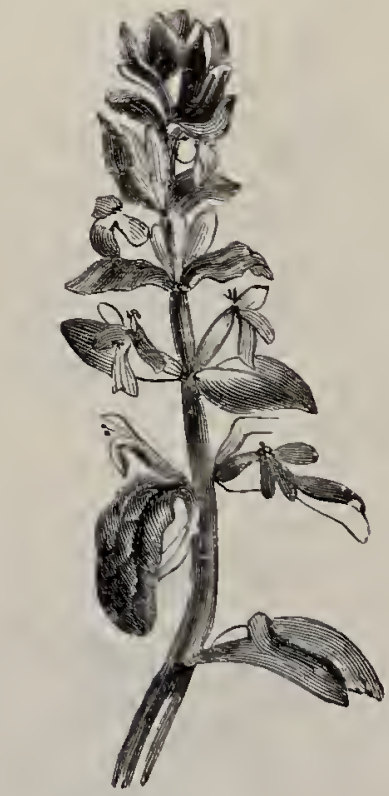

AJUch réptans (Common Bingle).

- Stem erect, about 2 feet high, with stalked, orate, cordate, crenate, wrinkled, sage-like leaves; and lateral and terminal, 1-sided, racemose clusters of small, yellowish-white flowers: caly,x pouched at the base.-A common woodland plant. The whols plant is very bitter, and has been used as a substitute for hops.-Fl. June--September. Peremnial.

19. Áruga (Bugle).-Werlus with lenfy bracts; calyx ovoid, 5-cleft; corolla with a long tube, the upper. 
Tip very short, notched, lower 3 -cleft, the middle lobe broader and notched; nutlets united, wrinkled. (Name said to be corrupted from the Latin Abiga.)

1. A. réptans (Common Bugle).-Well marked by

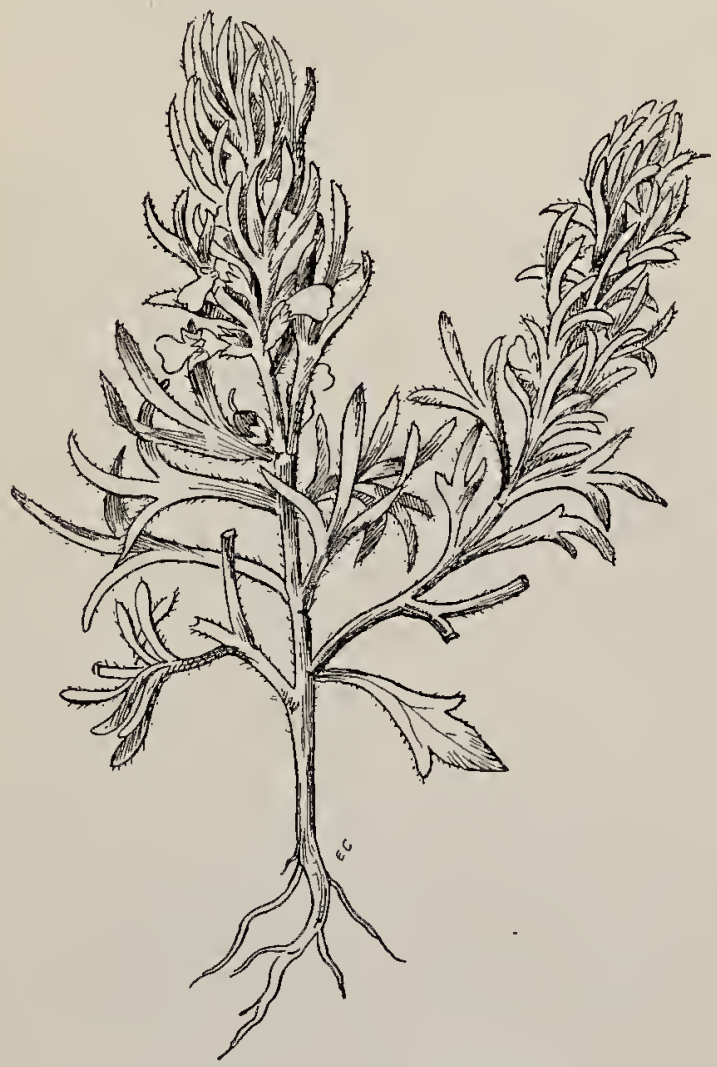

ÁJUGA CHaMÁPITYS (Ground Pıne).

its solitary erect stem, $6-9$ in. high, with long, creeping muners; lower leares stalked, obovate, obtuse, almost glabrous; upper leaves sessile, tinged with blue; flowers blue, or ravely white, in 6 -10-flowered 
whorls, the upper of which are crowded into a spike. -Moist meadows and woods; common.-Fl. May, June. Perennial.

2. A. piramidátis (Pyramidal Bugle).-A hairy plant with underground offsets and short rumers not produced until autumn ; leaves gradually diminishing upward; flowers blue, all crowded into a 4-sided pyramidal spike.-By mountain streams in the northwest; very rare.-El. May-July. Perennial.

3. A. Chamápitys (Ground Pine).-Very different in appearance from any other British plant in the Order, a hairy, tufted, herbaceous plant, $3-6$ inches high, with branched, spreading, reddish-brown, viscid, turpentinous stem; hairy leaves divided almost to the base into 3 linear segments; and solitary, axillary, yellow flowers, with red spots on the lower lip of the corolla.-Chalky fields in the south-east; rare.-Fl. May-Angust. Annual.

\section{Ord, I.X. Plantagínę.-Plantaln Fanily.}

A small Order of herbaceous plants of humble growth, with many, usually radical, ribbed or fleshy leares. The flowers, which, being mostly wind-pollinated, are conspicuous from their long stamens, grow in spikes and are polysymmetric ; the caly, $x$-parted, imbricate, persistcnt; corolla 4-parted, chaffy, imbricate ; stamens 4 , alternate with the segments of the corolla, and having very long, thread-like, exserted filaments, and large, versatile anthers ; oxany superior, 1-, 2-, or rarely 4-chambered; style 1, slender ; stigma hairy; fruit a capsule splitting transversely or not at all; seeds 1 , 2 , or many in cach chamber. Several species in the Order are common in Great Britain as wayside, meadow, and maritime plants, and some of them are almost world-wide in their distribution. The seeds abound in a tasteless mucilage, which has been used 
as a substitute for Linseed in medicine, and to stiffen muslin.

1. Plantágo.-Terrestrial plants with perfect flowers in spikes.

2. Littorḱlia.-Waterside plants with stamens and carpels in different flowers; staminate flowers solitary, stalked; carpellate flowers sessile.

1. Plantágo (Plantain). - Terrestrial herbs with perfect flowers in spikes; calyy 4-cleft, the segments reflexed; corotla tubular, with 4 spreading lobes; stamens 4, very long; ovary 2-4-chambered; capsule splitting all round. (Name, the Classical Latin name.)

1. P. májor, (Greater Plantain, Way-bread).Leaves radical, ascending, broadly oblong, on long, channelled stalks, 3-7-ribbed; flowers in a very long, tapering spike, on a short, cylindrical stalk; anthers purple; capsule 2-chambered, 8-16-seeded.--Borders of fields and waysides; abundant. Well known for its spikes of fruit, the seeds in which are a favourite food of cage-birds.-Fl. May-September. Perennial.

2. P. médía (Hoary Plantain, Lamb's-tongue).Leaves downy, broadly elliptical, on short, flat stalks, lying so close to the ground as to destroy all vegetation beneath, and even to leave the impression of their 5-9 ribs on the ground; flowers in a close, cylindrical spike, shorter than that of $P$. major, but on a longer, cylindrical, downy peduncle, fragrant, and conspicuous from their lilac bracts, and filaments, and cream-coloured anthers; cajsule 2-chambered, 2seeded.-Meadows on a dry soil ; common.--Fl. June -October. Perennial.

3. P. lanceoláta (Ribwort Plantain). - Leaves nearly glabrous, ob-lanceolate, tapering downwards, slightly and irregularly toothed, 3-6-ribbed, erect; flowers in a short, ovoid or cylindric spike, on a long, angular stalk; bracts and sepals black-tipped; fila- 
ments and cuthers white; capsule 2-chambered, 2seeded,-Meadows; abundant. Under the name of Cocks and Hens this plant is well known to children, who amuse themselves by striking the heads one

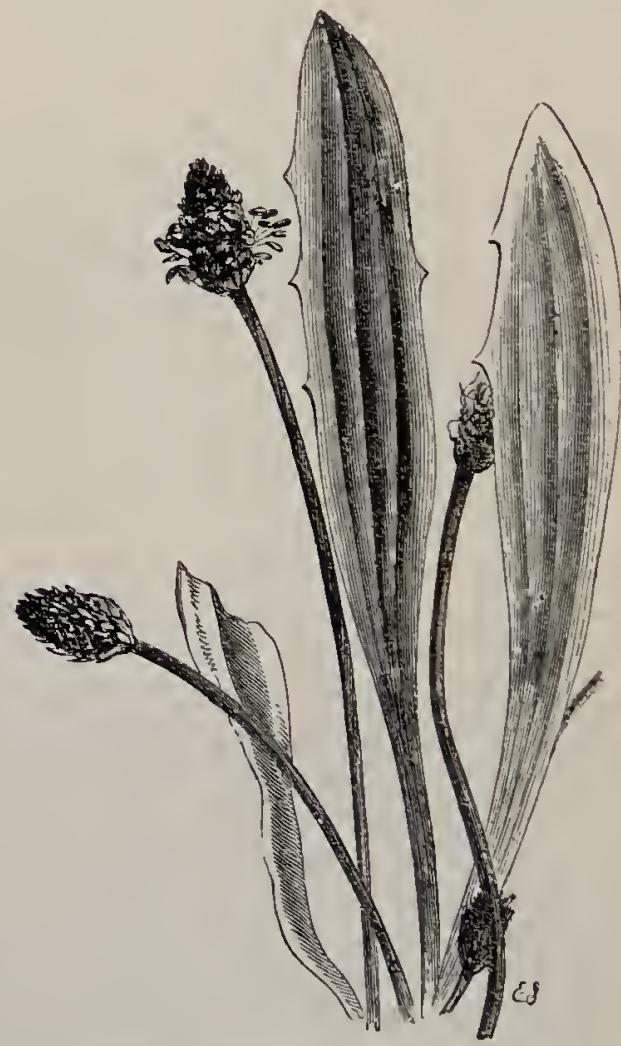

PLANTÁgO LaNCEOLÁ (Riburt Plantain).

against another until the stalk breaks.-Fl. MiryOctober. Perennial.

4. P. maritina (Seaside Plantain). - Easily distinguished from the rest of the genus by its long, linear, groover, fleshy, 3-5-ribbed leaves, which are 
woolly at the base; the flower-spike is cylindrical and varies in length, as does its cylindrical stalk; stamens pale yellow; capsule 2-chambered, 2-seeded. - Sea-

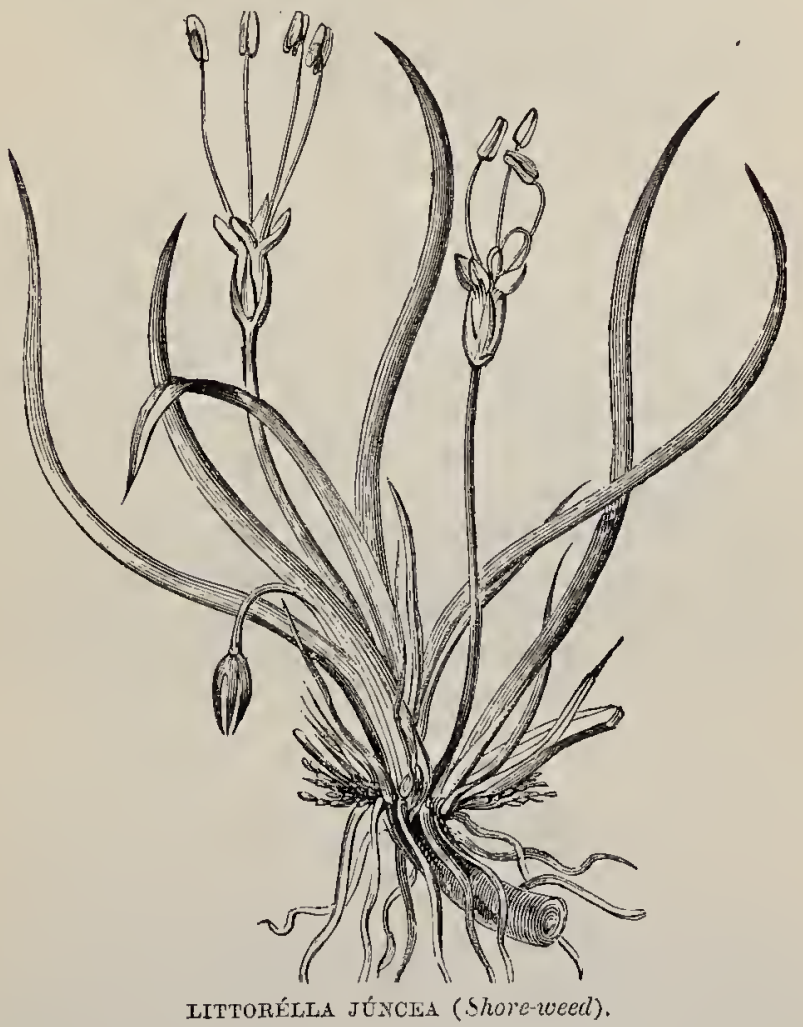

shores and tops of mountains ; common,-Fl. JuneSeptenuber. Perennial.

5. P. Corónopus (Buck's-horn Plantain). - The only British species with divided leaves. They are linear and usually pinnatifid, and more or less downy; the flower-spitie is slender; stamens pale yellow; capsule 3-4 chambered, 3-4-seeded.-Gravelly places, 
especially near the sea; common.-Fl. June-August. Annual or biennial.

6.* $P$, arenária (Sand Plantain), a downy, branching, leafy plant, with sessile, linear leaves, and an ovoid spitie on a long stalk, has occurred casually on sand-hills in Somerset and Jersey.

2. Littorélia (Shore-weed).-A genus comprising only the one species, $L$. juncen, which is not unlike Plantágo maritina in habit; but has runners, and when under water forms a matted turf. Its Teares are all radical, linear, fleshy, flat above and curved beneath, and nearly glabrous. The solitary staminate flowers each rise on a peduncle $2-4 \mathrm{in}$. high, have 4 sepals, a tubular, 4-lobed corolla, and 4 long, exserted stamens with large anthers. The 2 or 3 carpellate flowers, sessile among the leaves, have $3-4$ sepals, an urceolate, 3-4 lobed corolla, and a 1-chambered, 1-2 ovuled ovary with a long stiff style.-Marshes and lake-margins; common. (Name from the Latin littus, a shore.)-Fl. June-September. Peremial.

\section{Or1. LXI. Tllecebrácez.-The ḰTot-grass FayiLY.}

A small Order of small, branching, often tufted, herbaceous plants, mostly natives of warm, dry climates. A few ouly are found so far north as Great Britain, and nearly all of these are confined to our southern counties. They hare simple, sessile leaves, generally entire and with membranous stipules: minute, perfect, and cymosely arranged flowers; sepals usually 5, sometimes 4 , persistent, and closing over the fruit; petals 5, minute, alternating with the sepals, sometimes wanting; stamens $1-10$, opposite. the petals when equalling them in number; ovary 
superior, 1-chambered, 1-ovuled ; style 2-3-fid ; fruit enclosed in the calyx, dry, indehiscent, 1-seeded.

1. Ildécenrum. - Leaves opposite, not connate; sepals white, with long points; stigmas 2.

2. Herní́ria. - Leaves scattered and opposite, not connate; sepals green, blunt; stigmas 2.

3. Corrigíola.-Leaves scattered; sepals green, blunt, united at the base; stigmas 3 .

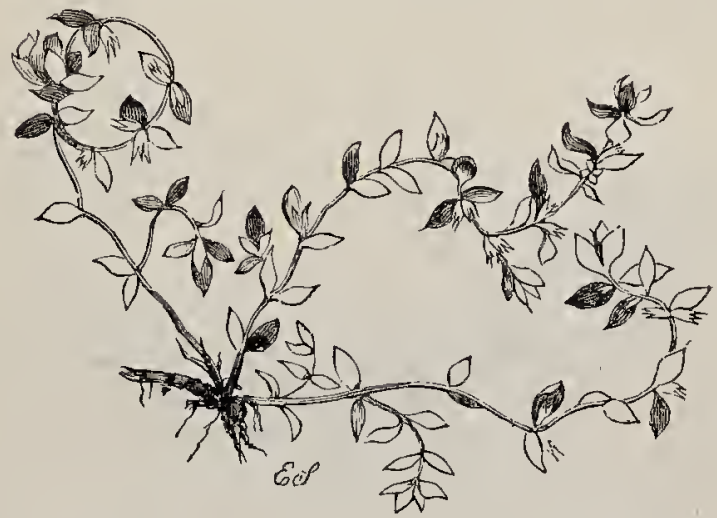

ILLÉCEBRUM VERTICILIATUM (Whorled Knot-grass).

4. Scleránthus.-Leaves opposite, connate; sepals $4-5$, united; petals absent; stigmas $2-4$.

1. Ildícébruns (Knot-grass).-A genus containing only the one species $I$. verticillatum (Whorled Knotgrass), is a pretty little glabrous plant, with slender, tangled, prostrate stems, of a red tint, glaucous, sessile, ovate leaves, and axillary whorls of white flowers, remarkable for their thickened white sepals terminating in a long, soft point.-In boggy ground and standing water, among other aquatic plants; not uncommon in Cornwall, but much rarer in Devonshire. (Name from the Latin illecebra, an attraction.) -Fl. July-September. Perennial. 
2. Herviória (Rupture-wort). - Small, prostrate plants with narrow, opposite, and scattered leave; crowded, minute, axillary, greon flowers ; sepals 4-5, united, blunt, green; petals $4--5$, resembling barren filaments, or absent; stamens $3-5$, inserted on a fleshy ring; stigmas 2, nearly sessile. (Name from the disease for which these plants were formerly supposed to be a remedy.)

1. H. glábra (Smooth Rupture-wort). - A small, prostrate plant, with much of the habit of Wild -Thyme; stems herbaceous, with minute decurved hairs; leaves oblong, pale yellowish-green, glabrous; flowers green, sessile, axillary, collected into a leafy spike.-Sandy soils, mostly in the eastern counties; rare.-Fl. July-September. Annual or biennial.

2. H. citiáta (Fringed Rupture-wor $\hat{\text { ) }}$ ).-A stouter plant, forming larger tufts, with minute, decurved hairs on the upper side only ; leares broader, orbicular, fringed, dark green; flower's larger, in distant clusters. -The I.izard, Cornwall; and Cruernsey ; very rare.FI. July August. Perennial.

3.* H. Thirkila (Hairy Rupture-wort).-Lenves elliptic-oblong, covered all over with straight, spreading hairs.- Sandy ground at Christchurch, Hampshire.-Fl. July, August. Annual.

3. Corrigiola (Strapwort).-Prostrate, glabrous plants, with scattered leuves with membranous stipules; flowers minute, sepals 5, green, blunt, united at the base, with membranous margins; petals 5 , as long as the sepals, white; stamens 5 , stigmas 3 , sessile. (Name a diminutive from the Latin corrigin, a strap, from the shape of the leaves.)

1. C. litoräis (Sand Strapwort). - A small but pretty plant with slender, spreading stems, which lie quite prostrate; linear-lanceolate, glaucous leaves; and crowded, terminal cymes of smill, white flowers.- 
Sandy shores, Start Bay, Devon, and Loe Pool, near Helston, Cornwall ; very rure.-Fl. July-October. Annual.

4. Sclerínthus (Knawel).-Small, inconspicuous weeds, with wiry, much-branched stems; opposite, connate, awl-shaped leaves without stipules; and small, - green flowers in axillary and terminal fascicles; perianth tubular, 4-5-cleft, with membranous margins to its

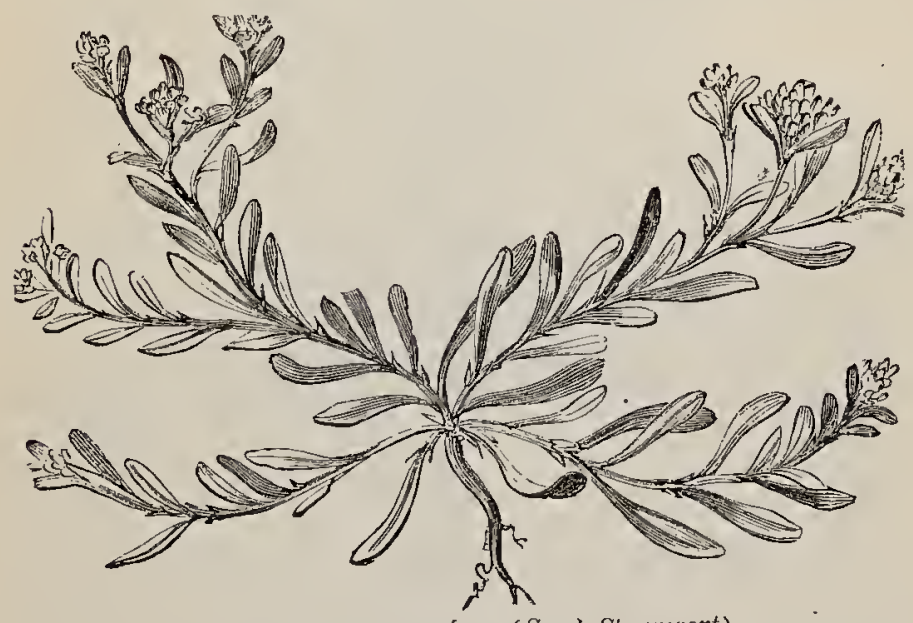

CORRIGIOLA LITTORÁLIS (Sand Strapuort).

segments ; stamens 1-10; ovary superior, 1-chambered, 1-ovuled; stigmas 2-4; fruit enclosed within the hardened perianth-tube. (Name from the Greek sclèros, hard, anthos, a flower, from the hardness of the perianth.)

1. S. ánnurus (Annual Knawel).-A small plant, 2-8 in. high, with numerous, much-branched, tangled stems; awl-shaped leaves, green flowers in clusters either in the forks of the stems or terminal sepals acute, with a narrow, whitish, membranous margin, spread- 
ing when in fruit.-Sandy fields ; common.-Fl. June - November. Annual or biennial.

2. S. perénnis (Perennial Knnawel)._-A prostrnte, glaucous plant, becoming reddish, with slightlybranched stem; sepals blunt, with a broad, white

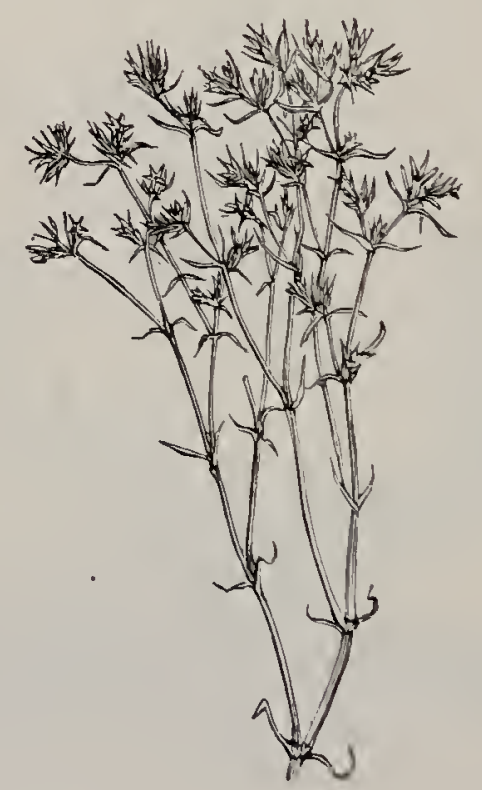

SCLERANTHUS ANNLUS (Ammal Knatel).

margin.-Sandy fields in the south; very rare. Perennial.

\section{Sub-Class III. INCOMPLÉTAE.}

Flowers having a calyx or corolla, or neither ; but never both. In this Sub-Class it is often doubtful whether the leaves which enclose the stamens and carpels of a flower should be called a calyx or corolla: the term perianth (from the Greek peri, around, and 
anthos, a flower) is therefore used to denote these organs, and must be taken to mean all the leaves, whether resembling sepals or petals, which enclose the other parts of the flower. Used in this sense, and applied to the preceding Sub-Classes, the calyx and corolla would be correctly called a double perianth.

\section{SERies I. MONOCHLAMÝDEȦ.}

Flowers generally with a perianth of one whorl.

\section{$\S$ Ovary superior.}

Ord. LXII: Amarantháce.f.-A maranth Family

A considerable Order of weedy plants, mostly tropical, with exstipulate leaves; membranous flowers; a persistent, 3 -5-partite perianth; ovary superior, 1-chambered. - Several members of the Order have brightly coloured perianths which render them garden favourites, such as Amaránthus cauclátus (Lovelies-bleeding), $A$, hypochondríacus and $A$. speciosus (Prince of Wales' Feather) and Celósia sristáta (Cock's-comb).- None of them are indigenous to Great Britain; but two species of Amaranth occur as casuals.

*1. Amaránthus (Amaranth).--Floversmonœeious; stamens $3-5$; stigmas 3 ; capsules 1-chambered, 1seeded. (Name in Greek signifying everlasting flower.)

1.* A. retroftéxus. - Stem erect, branched; flowers 5 -merous ; stamens 5 ; bracts membranous, awl-shaped, longer than the fruit.-Waste places near towns.Fl. August. Annual.

2.* Alitum:-Stem straggling, smooth, 1-2 feet high ; leaves ovate, long-stalked; flowers 3 -merous, in small, lateral clusters, and a small, leafless, terminal 
spike; stamens 3.-Waste places near towns.-Fl. August. Annual.

Ord. LXIII. Chenoponí́ce. -Goose-foot Family.

A considerible Order of herbaceous and somewliat shrubby plants, common weeds in many temperate climates and most abundantly represented in salt marshes and on the sea-shore. They have scattered, simple, extipulate leaves which are more or less in= clined to be fleshy; and small and inconspicuous, polysymmetric, sometimes monøecious or dincious flover.s. The perianth is 3-5-lobed, imbricate and persistent, decidedly partiking of the characters of a calyx, and sometimes, as in Atriplex, with a tendency to becom enlarged in the furiting stage. The stamens are 5 , rarely 1 or 2, springing from the base of the perianth and opposite its lobes; ovary superior or half-inferior, 1 chambered, 1-ovuled; style 2 or 4-cleft, rarely simple; stigmas undivided; fruit dry and indehiscent, enclosed in the perianth. Many of the plints of this Order are important articles of food for cattle or for human beings. Bétu maritima, a common sea-shore weed, is believed to be the origin of the cultivated Mangold Wurzel, the White or Sugar Beet so extensively cultivited in Germany and France for making sugar, and the Red Beetroot, which is eaten as a salad. Spinácia olerited, supposed to be a native of Western Asia, the lenves of whicli contain a large proportion of saltpetre, has long been cultivated as an esculent under the name of Spinach ; but the leaves of the Garden Orache (Atriplex hortensis), of the Australian Spinach (Chenopodium auricomum), of the Beet, and of other plants are used in the same way.

1. Chenoródum. - Leares flat; flowers perfect; perianth remainiug unaltered and not adhering to the fruit. 
2. Ве́тA.-Leaves flat; flowers perfect; fruit adhering to the fleshy perianth-tube.

3. Átrirtex.-Leaves flat; flowers imperfect; perianth enlarging, but generally not adhering to the fruit.

4. Saurcórnia,--Jointed, leafless plants; flowers perfect ; perianth fleshy.

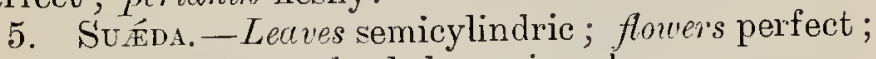
perianth-sergments not keeled or winged.

6. Sácsola.-Leclves awl-shaped; flowers perfect; perianth-segments developing a broad, transverse, dorsal wing.

1. Chenorónius (Goose-foot).- - Very variable and therefore difficult plants; stem angular ; lecves flat, often triangular, entire or lobed ; flowers minute, perfect, in axillary or panicled clusters; pericunth deeply 3-5.cleft, remaining unaltered, closing over the fruit; stamens $2-5$; stigmas $2-3$. (Name from the Greek chén, a goose, pous, a foot.)

* Leaves undividel, flowers 5-merous.

1. C. polyspérmum (Many-seeded Goose-foot).-A glabrous species, varying in size from 4 to 18 in. high, usually tinged with red; stem branched, spreading; leaves nearly sessile, ovate-elliptic ; flowers in branched, slender spikes; seeds flattened horizontally, shining, minutely dotted.--Waste ground; not common. A not inelegant plant, the numerous fruits not being concealed by the perianths.-Fl. August-October. Annual.

2. C. Vulvária (Stinking Goose-foot).-Distinguished by the extremely disgusting fishy smell of the greasy meal with which the plant is covered; stem spreading: leaves ovate-rhomboid, fleshy; flowers in small, dense spikes.-Waste places; not common.Fl. August, September. Annual. 
*** Leaves toothed or lobed; floncers 5-merons.

3. C. album (Fat Hen, White Goose-foot).-Perhaps the commonest species of the genus, $1-3$ feet high, succulent, and covered with a white meal ; leaves ovate-rhomboid, bluntly toothed, upper ones narrow, entire; flowers in branched, dense, clustering spikes, leafy below.-Waste places and cultivated ground; very common.-Fl. July-September. Annual.

*4. C. opulifólium (Guelder-rose-leaved Goosefoot).-A species which is not indigenous, with rounded, obtuse, dentate leaves : leafless clusters of flowers; and large, smooth, shining seeds.

5. C. ficifólium (Kig-leaved Goose-foot).-An erect, mealy plant, with limp, oblong-hastate, cuneate, toothed leaves, and flowers in a spike, with erect branches, leafy at the base only.-Cultivated ground in the East of England; rare.-Fl. August, September. Annual.

6. C. murálé (Sowbane, Nettle-leaved Goose-foot). -A nearly glabrous, fetid species, with rhomboidovate, mequally-serrate leaves, and flowers in short, densely panicled spikes with spreading branches.Waste ground, near houses ; uncommon.-Fl. August, September. Annual.

7. C. hybridum (Maple-leaved Goose-foot).-A large, stout, branched, nearly glabrous species with a heavy odour; leaves large, cordate, acuminate, with 2 -4 large, broad teeth on each side; flowers in leafless, axillary, corymbose clusters. - IVaste places, chiefly in Southern England; rare.-Fl. August, September. Annual.

8. C. urricum (Upright Goose-foot).-A nother large, stout, but little branched, slightly mealy species, with triangular, cuneate, toothed leaves, and flowers in small, distant, crowded clusters on an erect spike. Waste places in the south; uncommon.-Fl. August -October. Annual. 
**** Leaves mostly toothed; terminal flover only in each cluster 5-merous.

9. C. rúbrum (Red Goose-foot).-A tall, erect, leafy,

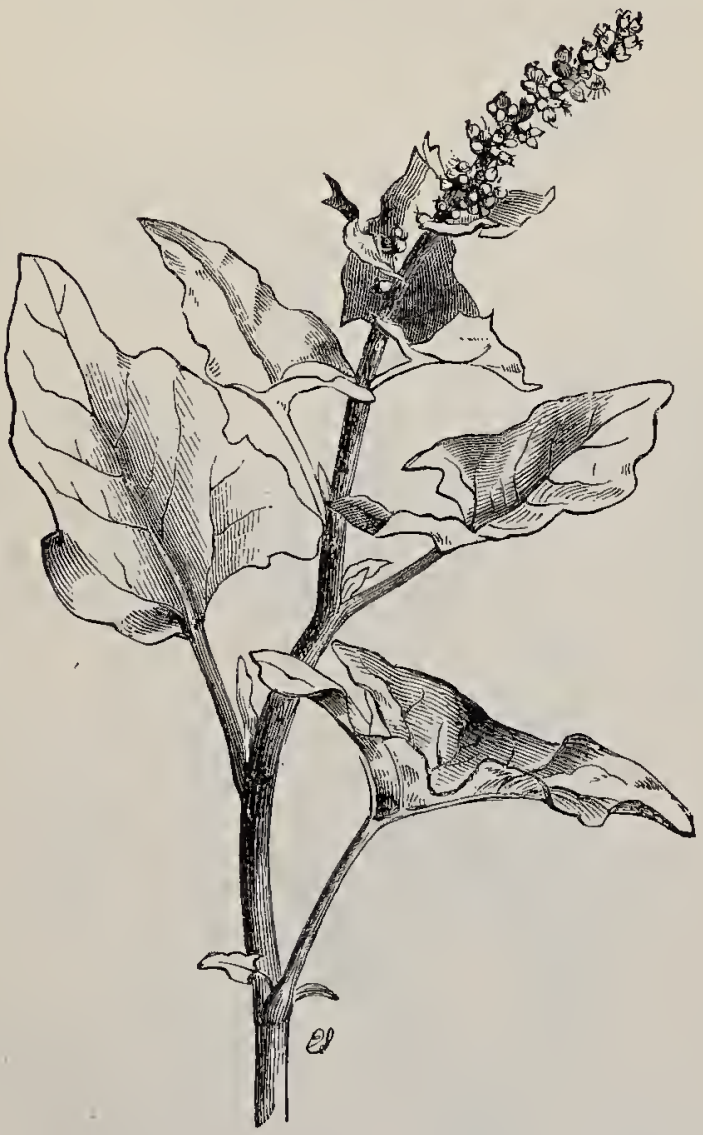

CHENOPÓDIUM BONUS-HENRÍCUS (Good King Henry).

smooth and shining species, with triangular, irregularly toothed leaves, and flowers in short spikes in leafy 
panicles.-W Waste places and salt marshes; frequent. -Fl. August, September. Annual.

10. C. hotryódes (Many-spiked Goose-foot). - A small, succulent, brittle plant, $4-5$ in. high, with triangular, scarcely toothed, fleshy lectes, and fiou'ers in dense panicles, leafy below.-Moist, sandy seashores in the south-east; rire.-Fl. August, September. Annral.

11. C.glaúcum (Oak-leaved Goose-foot). - A muchbranched, spreading, often prostrate, smooth and shining species, with oblong, sinuately-lobed terves which are mealy beneath; and flowers in erect, simple, short, dense, leafless spikes.-Cultivated ground; rare. -Fl. August, September. Annual.

12. C. Bomu-Henricus (Good King Henry, All Good, Mercury). - A dark green, succulent plant, 13 feet high, with large, succulent, triangular-hastate leaves and flowers in compound, leafless spikes.Waste places near rillages; common. The leaves are used as Spinach, and the plant is cultivated in Lincolnshire under the name of Mercury.-Fl. MayAugust. Perennial.

2. Вйт (Bcet).--Herbaceous plants with flat, almost entire leaves and spikes of perfect flowers in clusters of $2-3$ together; perianth deeply 5-cleft, persistent, becoming fleshy; stamens 5 ; stimmas 2; fruit 1 -sceded, adhering to the lleshy perianth-tube. (Name, the Latin naine of the plant.)

1. B. maritima (Ser Beet).-The only British species, a tall, succulent plant, about 2 feet high, with angular; striped stems, prostrate below, and spreading in a circle, with ascenuing branches; large, stalked, ovoid, fleshy, glossy leaves; and numerous, long, slender, leafy spikes of green flowers, which are arranged 2 or 3 together, with a small, lanceolate, leafy bract at the base of each.-Sen-shores; frequent. -Fl. June-October. Perennial. 


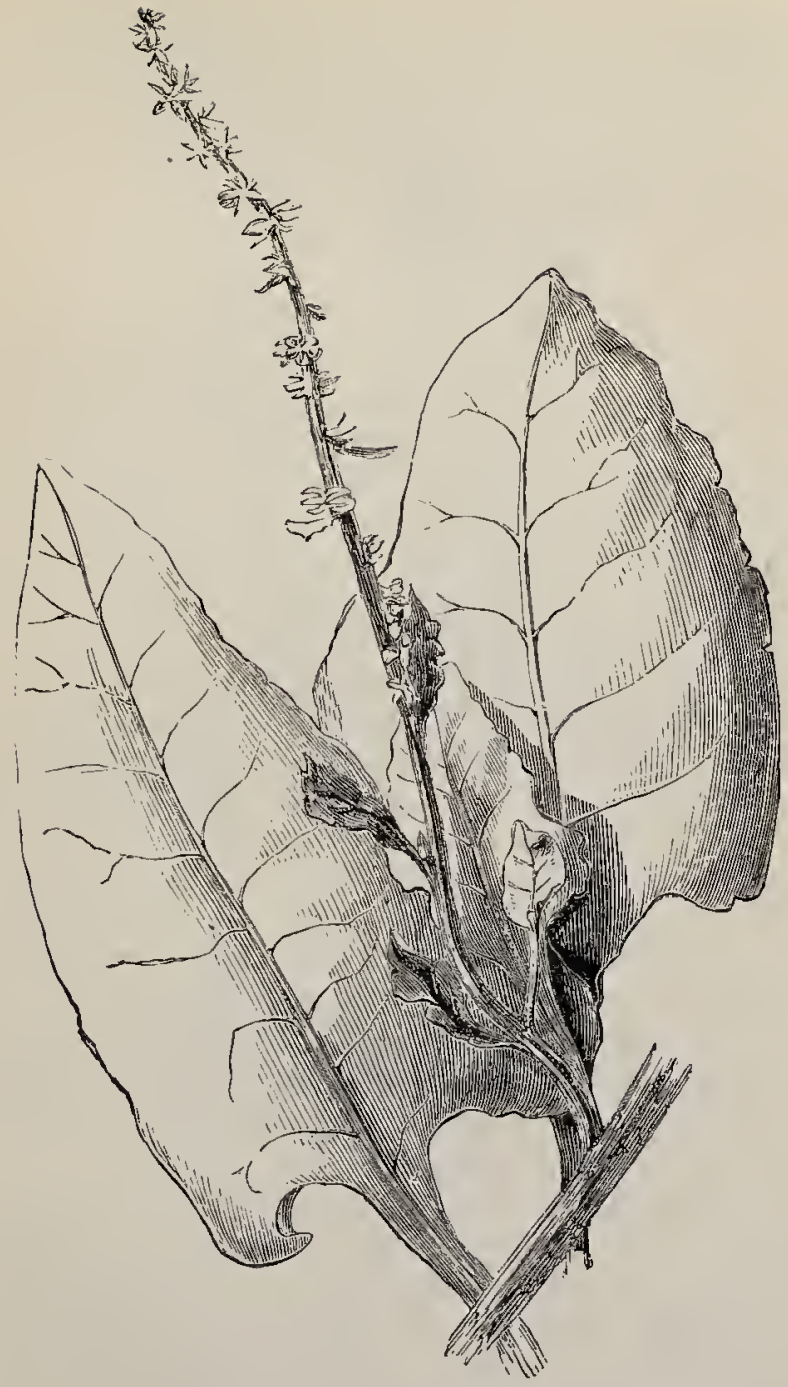

DÉtA MaRítiMa (Seq Betet). 
3. Átriplex (Orache).-Herbs or shrubs with flat, stalked, often hastate leaves; small, moncecious or dicecious flowers clustered in branched cymes; perianth 2-5-cleft; stamens 3-5; stigmas 2; fivit 1-seeded, covered by the enlarging but generally not adherent perianth. (Name, the old Latin name.)

\section{* Perianth not acherent to firit.}

1. A. littorális (Grass-leaved Orache). - An erect, mealy plant, with the stem striped with reddish, resinous lines; ascending branches; Teaces linear, usually quite entire, and never hastate; flowers in slender, terminal spikes of clusters; perianth-serments rhomboid or deltoid, toothed, with tubercles on the back. - Salt marshes; not common.-Fl. July-September.

2. A. pútula (Spreading Orache).-A common weed, mealy and often tinged with red; stem furrowed, spreading, often with the central branch erect and the rest prostrate, appearing as if they liad been bent down by force; lcaves triangular, cuneate, with 2 lobes spreading upwards from the lower angles, toothed, the rpper leaves lanceolate, entire; flou'ers clustered on simple, interrupted spikes; perianth of the fruit of 2 rhomboid leaves, which are warty on the back.-Cultivated and waste ground, and on the sea-shore; abundant, Distinguished from the genus Chenopodium, by the two perianth leaves enclosing the fruit.-Fl. July-October. Annual.

:. A. hastáta (Halberd-leaved Orache).-A nearly allied and equally common species, dark green, mealy, and differing mainly in its lower leares, which are triangular-hastate, witl lobes at the base, that is, which spread horizontally. The seeds are of two sizes, the larger brown and rough, the smaller black and smooth. - Growing in similar situations. - Fl. JulyOctober. Annual.

4. A. deltoídea (Deltoid-leaved Orache).-Another 
allied form, with all the leaves hastate; dense spikes of flowers in panicles; and almost all the seeds small,

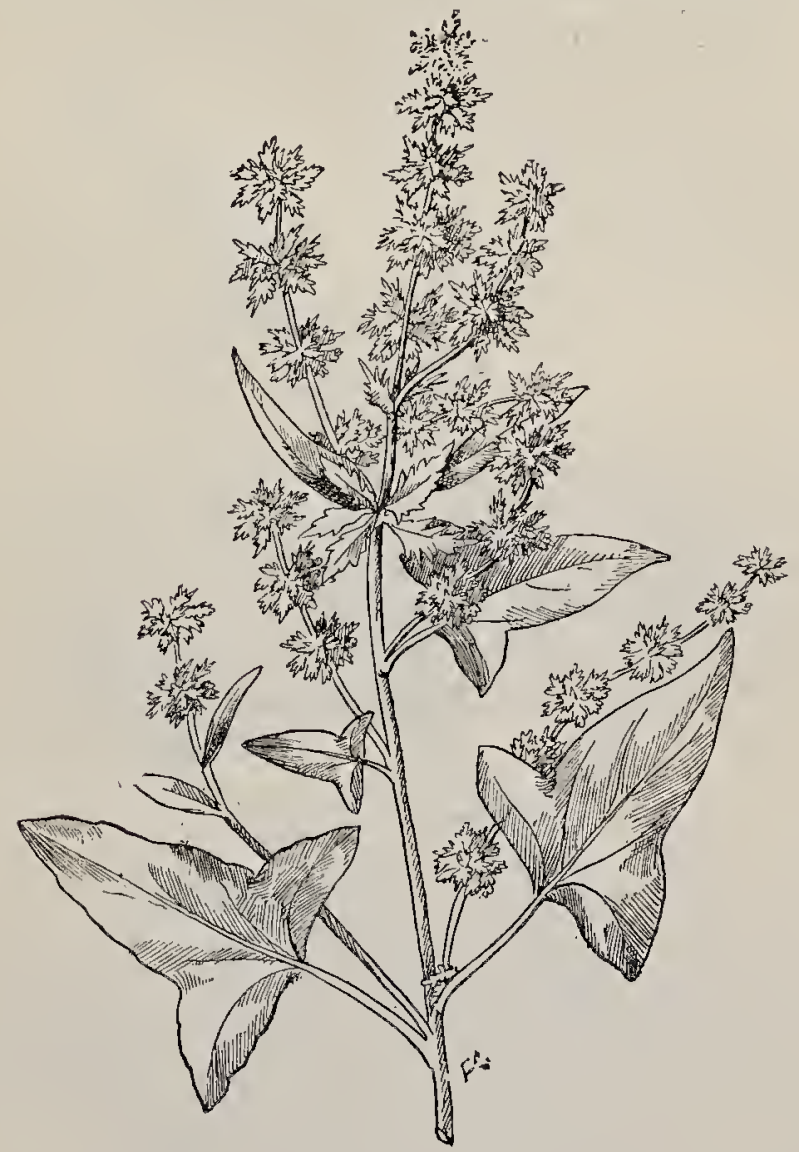

A'RIPLEX HASTATA (Haberd-leaverl Oraghe).

black, and polished.-Similar situations ; frequent.-Fl. June-October. Annual.

5. A. Babingtónii (Rose-coloured Orache).-A variable species, usually pale and very mealy, but 
sometimes greener; stem striped with red, spreading, with ascending branches; leaves mostly opposite, ovatetriangular, somewhat 3 -lobed at the base; flowers in simple, lax, leafy, terminal and axillary spikes;

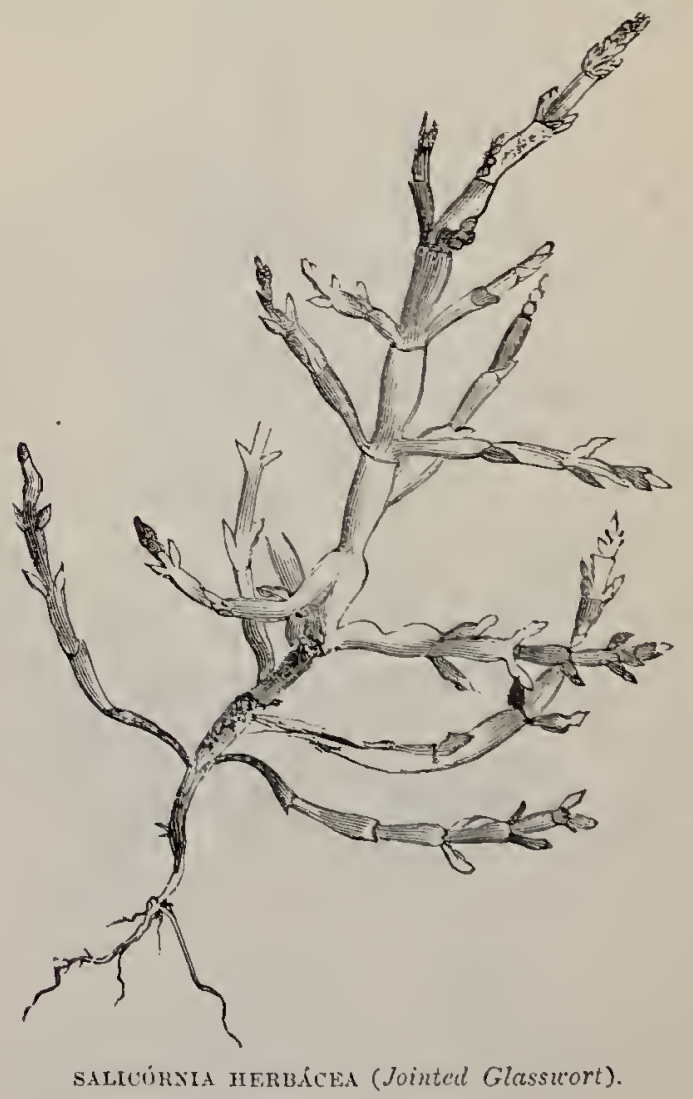

perianth leaves in the fruiting stage large, united so as to for $n$ a diagonal square a little rounded at its lateral angles.-Sea-shores; common._Fl. July-_September. Annual

6. A. laciniata (Erosted Sea Orache). A very dis. 
polysymmetric, axillary ; staminate flower's in catkins, with a 2-4-lobed tubular perionth, and 3-8 stamens sessile in the tube; carpellate flower solitary, with a tubular, 2-6-cleft perianth, and superior, 1-chambered, 1-ovuled ovary; style short; stiyma lateral; fruit an indehiscent nut, enclosed within the fleshy persistent perianth. The fruit of several species of Elceágnus is eaten in the East, and the flowers are highly fragrant, and abound in honey, which in some parts of Europe is considered a remedy for malignant fevers. The only British species is the Sea Buckthorn (Hippóphä rhamnoídes).

1. Hippóphaś (Sea Buckthorn).-A genus containing only the one species $H$. rhamnoides, the Sea Buckthorn, or Sallow Thorn, is a shrub, $4-8$ feet high, with branches ending in spines; leaves scattered, obovate, silvery; flowers small, greenish, appearing with the leaves ; stamens 4 ; berries orange-yellow, very juicy, acid.- Sandy shores on the east coast; rare.Fl. May. Perennial.

\section{Ord. LXVII. Urticáces.-Nettle Family.}

A large and difieult Order the limits of whieh are variously assigned by different botanists. In its widest sense it comprises over 1,500 species, natives of all climates, of all sizes, and of very various pro perties. They have leaves either opposite or scattered, but usually stipulate, serrate, and rough; flowers usually imperfect, small and green; periantic $3-8$ cleft and persistent, or wanting; stamens equal in number to the lobes of the perianth, and opposite to them; ovary superior, 1- rarely 2-chambered, 1rarely 2-ovuled; styles $1-2$; fruit dry, indehiseent, 1 -seeded. One large seetion of the Order, not repre- 
sented among British plants, has a milky juice often rich in rubber, and includes a number of edible fruits, or rather structures enclosing the fruits. The Cowtree, Palo de vaca, Arbol de leche, of South America (Brósimum Galactodéndron), contains an abundance of wholesome milk, closely resembling that of the cow. B.A ublétii, a large tree, also South American, yields the spotted heart-wood known as Snake-wood, Letter-wood, or Leopard-wood. Ficus elestica and other species yield the Indian rubber of India. The Fig (Ficus Cárica), the Bread-fruit (Artocapus incisifotia), the Jackfruit (A. integrifótia), and the Mulberry (Mórts núgra) are the chief edible fruits of the Order. The Paper Mulberries of Japan (Broussonétia papyriferea and allied species), the common Nettles (Urica), and the closely-allied Rhea or Glass cloth of India, $C^{*}$. (Boetrméria) nivea, and U. Prya, and the Hemp (Cánnabis sativa) are the chief fibre-yielding plants in the Order. The Elms (Utmus) are valuable timber-trees, and the wood of the Fustic (Maclura tinctoria) affords a valuable yellow dye. The bitter principle in the glands on the catkins of the Hop (Húmulus Luppulus) give it its value as a preservative in beer. The British species of Nettle are well known for the burning properties of the formic acil contained in the stinging hairs with which they are plentifully armed; but they are not to be compared to the effects of incautiously handling sone of the tropical species. In theso a slight sensation of pricking is followed by a burning heat, such as would be caused by rubbing the part with a hot iron; and soon the pain extends and continues for days, with symptoms like those of lock-jaw, death even being said to have been caused by it. This burning property is dissipated by heat; and the young shoots of the common Nettle, like those of the Hop, are, when boiled, an excellent substitute for Asparagus.

1. Úlrus.-Trees with distichous leares; perfect 
flowers in clusters; bell-shaped, 4-_-5-cleft, persistent perianth; styles 2 ; fruit a rounded, 1-seeded samara.

2. HúnuLus,-CTwining plants with opposite lobed leaves ; diocious flowers; staminate flower with 5-leaved perianth and 5 stamens; carpellate flowers in a catkin of large bracts; styles 2.

3. UrtíCA,-Herbs with opposite leaves and sting-

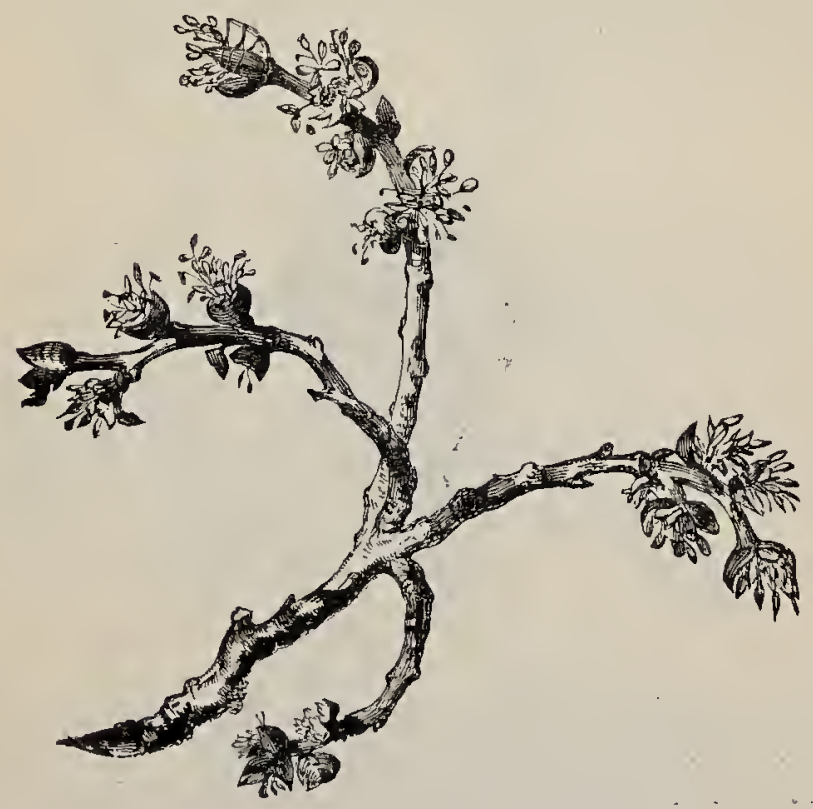

ÚLMUS CAMPÉSTRIS (Common small-leaved Elm).

ing hairs; flowers imperfect; perianth 4-5-cleft; style 1 .

4. Parietáris,-Herbs with scattered, exstipulate leaves; polygamous, 4-merous flowers; style 1.

1. Úures (EIm).--Trees with distichous, oblique; rough leaves, with stiputes falling early; flavers. 
perfect, in clusters, appearing before the leaves: perianth bell-shaped, 5- rarely 4-cleft, persistent; stamens 4-5; styles 2; orary superior, 1-2-chambered, with an ovule in, each chamber ; fruit a thin, membranous, 1-seeded samara. (Name, the Classical Latin name of the genus.)

1. U. montána (Wych Elm).-A large tree, with furrowed bark ; no suckers; downy twigs ; irregularly doubly serrate, obliquely eordate acuminate leaies; samara orbicular, with the seed-cavity below the

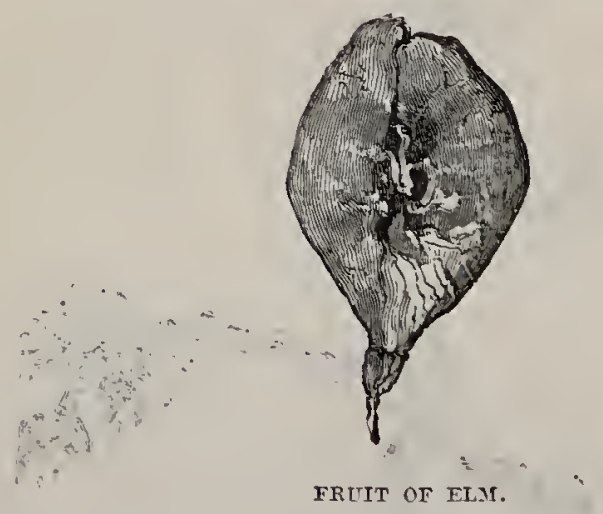

middle.-Woods, chiefly north of the Trent; eommon.-Fl. March, April. Peremial.

2. U. campéstris (Common EIm).-A large tree with furlowed bark; numerous suckers; samara obovate, with the seed-cavity above the middle.Hedgerows chiefly south of the Trent; seldom ripening sced.-Fl. March-May. Peremial.

2. Húnulus (Hop).-Twining herbs with opposite lobed leaves with connate stipules; minute, diceious flowers, the staminate in panicles, with perianth of 5 imbricate leaves and 5 stamens; the carpellate 2 
together in the axils of numerous bracts in a catkin; styles 2. (Name said to be from the Latin humus, rich soil, in which the plant flourishes.)

1. H. Lupulus (Common Hop).-A beautiful twin-

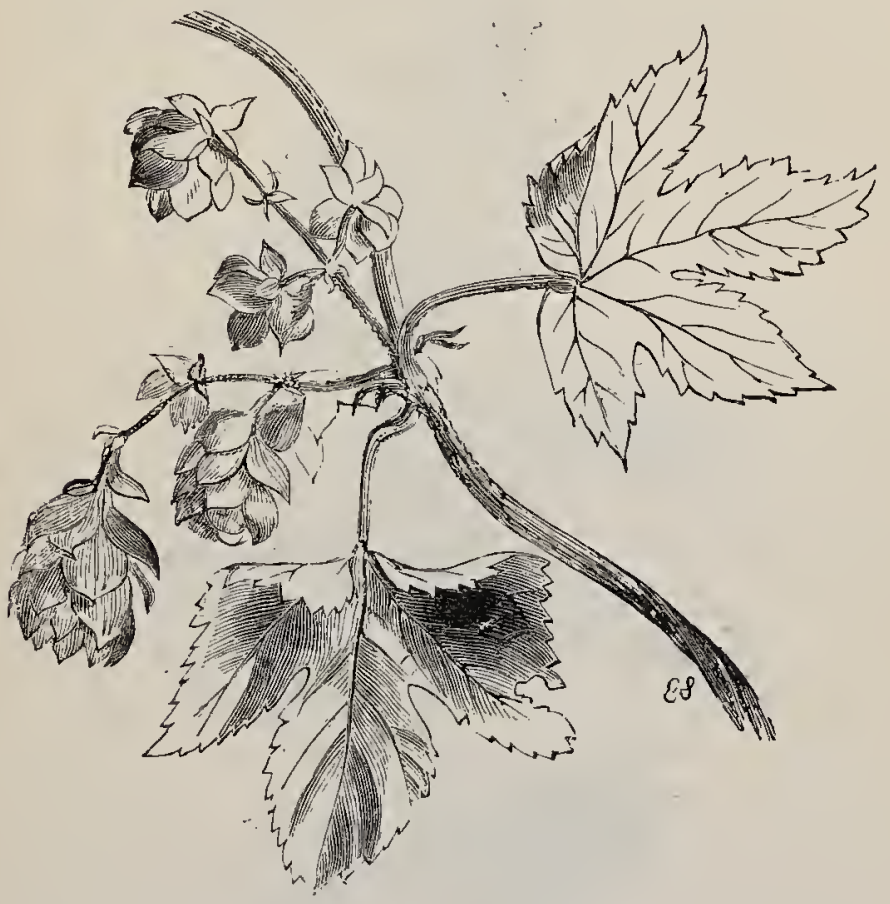

HúMulus lúpulus (Common Hop).

ing plant with very rough, almost prickl, and very tough shoots (bine); and palmately 3 -5-lobed leaves. The staminate plants known as "seeders" are common in a wild state; but not in hop-gardens. The ripe catkins are ovoid and yellow, theil bracts covered with resinous glands.-Hedgerows; common.-Fl. July, August. Perennial. 
3. URTícA (Nettle).-Herbs or shrubs with tough inner bark and stinging hairs; leaves opposite, stipulate; flowers bracteate, 4-merous; perianth imbricate, persistent; stamens and ovary in separate flowers.

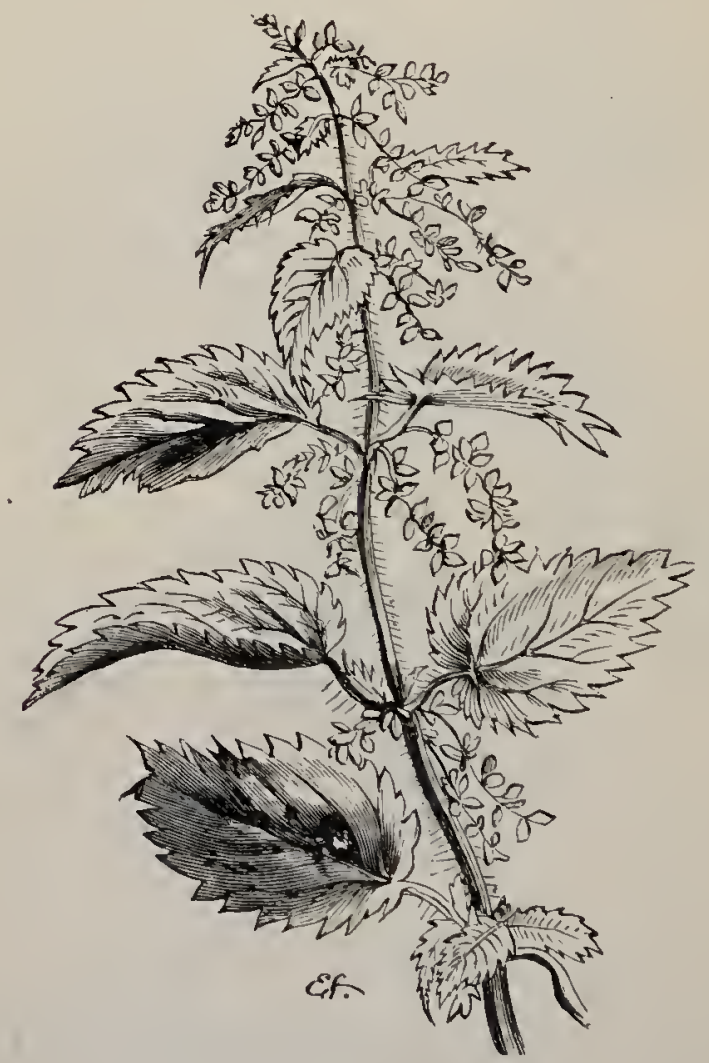

IRTtCA DIofCA (Great Nettle).

(Name from the Latin $w r$, I burn, from its stinging properties.)

1. U. dioica (Great Nettle).-Rhizome creeping with runners ; stem $2-4$ feet high, seldom branched 
pubescent; leaves generally cordate, deeply serrate; flowers in long, branched clusters.-A common weed, too well known to need further description.-Fl. June - September. Perennial.

2.* U. pilulifera (Roman Nettle). - With no hairs except the stings, 1-2 feet high; leaves ovate,

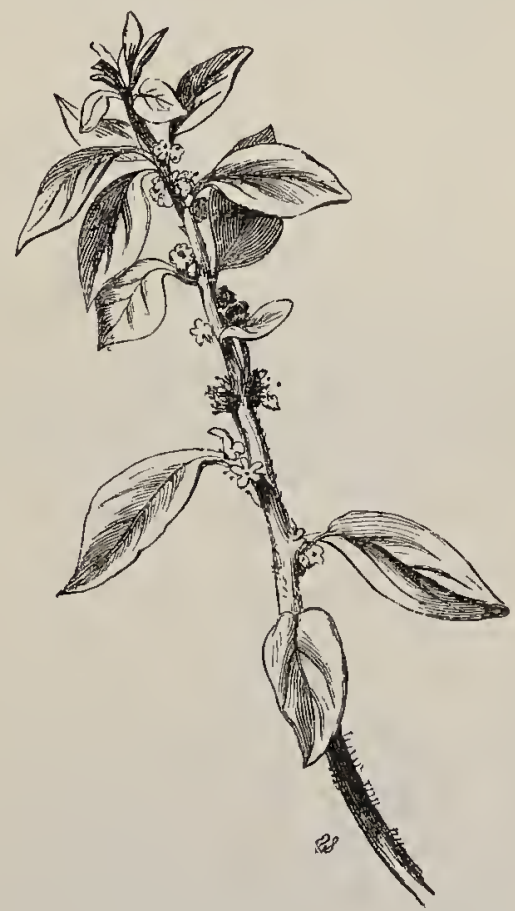

PARIETÁRIA OFFICINÁLIS (Common Pellitory-of-the-uall).

coarsely toothed ; fruit in globose, stalked clusters.-. Jn the East of England, chiefly near the sea; local. The most virulent British nettle.-Fl. June-August. Annual.

3. U. urens (Small Nettle).-Smaller than either of the other species, about a foot high, branched, with 
no hairs except the stings; flowers in short, seldom branched clusters, staminate and carpellate together. -Waste places; abundant.-Fl. June-October. Annual.

4. Parietária (Pellitory).-Pubescent herbs or shrubs with scattered, entire, exstipulate leaves ; polygamous, 4-merous flowers ; valvate, persistent perianth enlarging round the fruit. (Name from the Latin paries, a wall, where these plants often grow.)

1. P. officinális (Common Pellitory-of-the-wall).The only British species, a much-branched, bushy, herbaceous plant, with reddish, brittle stems; ovate, hairy leaves, and axillary clusters of small, hairy flowers. The fildaments are curiously jointed and elastic, so that if touched they suddenly spring from their incurved position and shed their pollen.-Cold walls; common. In rural districts an infusion of this plant was once a favourite medicine,-Fl. June-October. Perennial.

\section{$\S \S$ Orary inferior:}

Ord. LxVili. Aristolochíce.⿱一𫝀口-Birthwort FAMILX.

A small group of herbs or shrubs, often climbing, chiefly tropical, being very abundant in South America, but rare elsewhere. They have scattered, simple, exstipulate Teares, and usually solitary, axillary, perfect flowers. The perianth is attached to the ovary below, tubular above, with a wide mouth; stamens 6-12, epigynous; ovary 3-6-chambered; style 1 : stigmas radiate, equalling in number the chambers of the ovary ; fruit 3-6-chambered, many-seeded. The plants of this Order are generally bitter, tonic, and stimulant, sometimes acrid or aromatic. The dried and powdered leaves of Asarabacca (Asanum euro- 
porem) are used in the preparation of cephalic snuffs, exciting sneezing, and giving relief to headache and weak eyes. Virginian Snake-root (Aristolóchia serpentária) and other allied species are used as antidotes to the bite of venomous snakes. The juice extracted from the rhizome of a South American species is said to have the power of stupefying serpents if placed in their mouths; and African species are said to be used by Egyptian jugglers to stupefy the snakes with which they play tricks.

1. Asarum.-Perianth polysymmetric, bell-shaped, 3-cleft ; stamens 12.

*2. Aristolóchia. - Perianth monosymmetric, tubular, with a dilated lip ; stamens 6 .

1. Ásarum (Asarabacca). - Herbs with a stout rhizome; radical leaves; a solitary, purplish-green flower, with persistent, 3-lobed perianth ; stamens 12 ; ovary 6-chambered ; fruit capsular. (Name of Greek origin, said to denote that it was excluded from garlands.)

1. A. européum (Asarabacca).--The only species found in Britain, and perhaps not indigenous, a curious plant consisting of a very short, fleshy stem, bearing two large, dark-green, kidney-shaped, evergreen leaves and a solitary, purplish-green drooping flower.-Woods; very rare.-F]. May. Perennial.

*2. Aristolóchia (Birthwort).--Shrubby, often twining plants, with stalked cauline leaves, and axillary, coloured flowers, with a tubular perianth swollen at the base, lined with hairs and dilated on one side into a lip; stamens 6, inserted on the style; ovary 6-chambered ; fruit capsular. (Name in Greek denoting the supposed medicinal virtues of the genus.)

1.* A, Otematítis (Birthwort).-The only species 
found apparently wild in Britain, not indigenous, a singular glabrous plant, with creeping woody thizome; slender, erect, angular, unbranched stems; large; cordate, obtuse leaves, glaucous beneath; and yellow flowers, 4-8 together, expanding into an oblong lip. -Among ruins in the South of England : rare.-Fl. June-September. Perennial.

\section{Ord. LXIX, Lorantháceae.-Mistletor Family.}

An interesting Order of parasitic shrubs, comprising about 500 species, inhabiting tropical and temperate regions. Their leaves are usually opposite, fleshy, and evergreen; and the flowers inconspicuous and dicecious. The perianth consists of $4-8$ segments, sometimes united in a bell-shaped form and valvate in bud; the stamens equalling the perianth-leares in number, and opposite and adnate to them; the ovary inferior, 1chambered and 1-ovuled; and the fruit a viscid berry which adheres to the bark of the host tree. Soon a thread-like radicle is sent forth, which, from whatever part of the berry it proceeds, curves towards the supporting tree, pierces its bark, and finally roots itself in the growing wood. The Common Mistletoe is capable of growing on a great number of very different trees, having the power of selecting and appropriating to its own use such juices as are fitted for its sustenance. It may readily be propagated by attaching the fresh berries to the bark on the under side of a branch of the Apple. Great virtues were attributed to this plant by the Druids; but it has now no medicinal repute, though there is an enormous demand for it in connection with Christmas festivities.

1. Víscum (Mistletoe)._Flowers diœcious, small, green, clustered in the forks of the branches; perianthleaves 4, united; stumens many-chambered, opening 

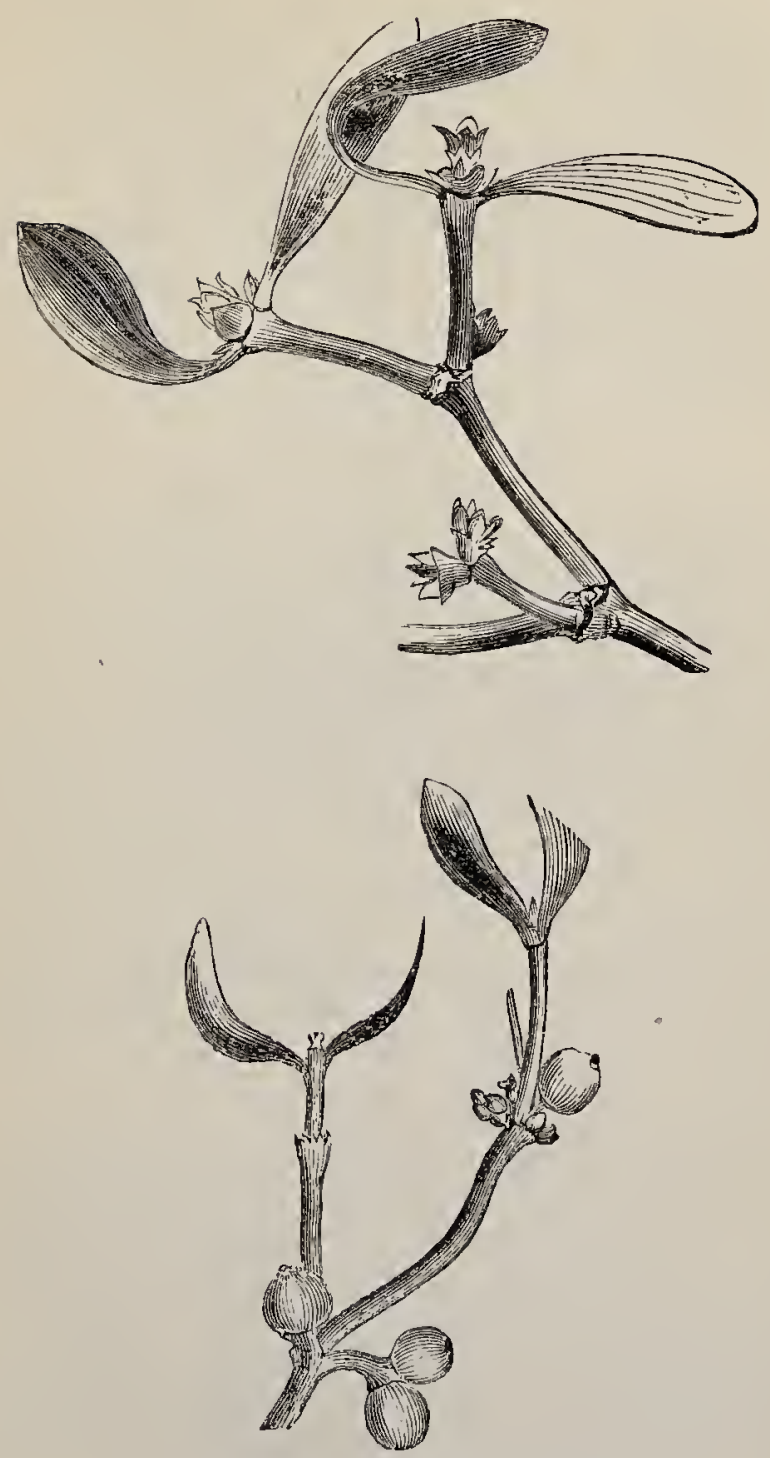

VIJCUM ALBUM (Common Mistletoe): 
by pores; stigma sessile. (Name, the Iuatin name of the plant, signifying birdlime $\mathrm{or}^{*}$ alluding to the sticky berry.)

1. T. álbum (Common Mistletoe).-The only British species, a yellow-green, glabrous, plant with bifurcating cylindric stems; thick, leathery, obtuse leaves, narrower on the staminate plants; berries waxen-white.-On the Apple and other trees, but very rarely on the Oak; chiefly in the south. Most conspicuous in winter, when its berries ripen.-Fl. March-May. Perennial.

\section{Ord. LXX. Santaláce死, Sandal-Wood Family.}

A small Order of herbs, shrubs, and trees, mostly root-parasites, which are widely distributed over the globe. They have mostly scattered, simple, exstipulate leaves; small flowers; perianth attached to the ovary, 3-5-cleft, valvate when in bud; stamens as many as the lobes of the perianth, and opposite and attached to them, with short filaments; orary 1-chambered; style 1 ; outes 2-5; frut liard, dry, indehiscent, 1-seeded. The only important product of the Order is the fragrant wood of the East India Sandal-wood (Sántalum álbum) and of the allied Australasian species, which is used for cabinet-work, incense, perfumery, and medicine. There is only one Britisl species.

1. Thésum (Bastard Toad-flax). — Slender herbs with narrow leaves; perfect flowers; periunth 4-5cleft, persistent; stomens $4-5$, each with a tuft of hairs at its base; style short; stigma undivided; ovules 3. (Name of doubtful origin.)

1. T. humifúsum (Bastard 'Toad-flax).-The only British species; a small plant with fibrous roots attached to those of various other plants; a yellow, woody rhizome; prostrate branches spreading in a 
circle; linear-lanceolate, 1-veined leaves, resembling those of a Toad-flax; and clusters of whitish flowers; bracts 3.-Dry chalky and limestone hills in the South of Englind ; rare.--Fl. May-July, Perennial.

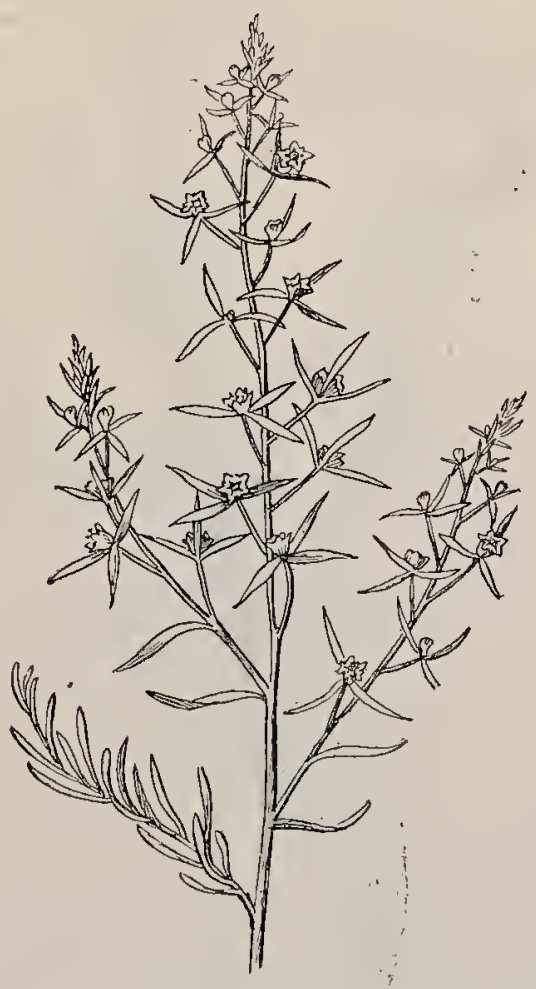

TIIÉSTUM IUUMF́́sUM (Bastard Toad-flax).

SERIES II. ACHLAMÝDEE.

\$ Flowers not in catrins.

Ord. LXXi. Empetráce, - - Crowberry Family.

A very small Order of small beath-like evergreen shrubs, of obscure affinities, inhabiting North Temperate, Arctic, and Sub-Antarctic regions. They 
have scattered, exstipulate leaves; minute, axillary, polysymmetric, polygamous flowers, with $4-6$ imbricate scales, either bracts or perianth-leaves; slamens

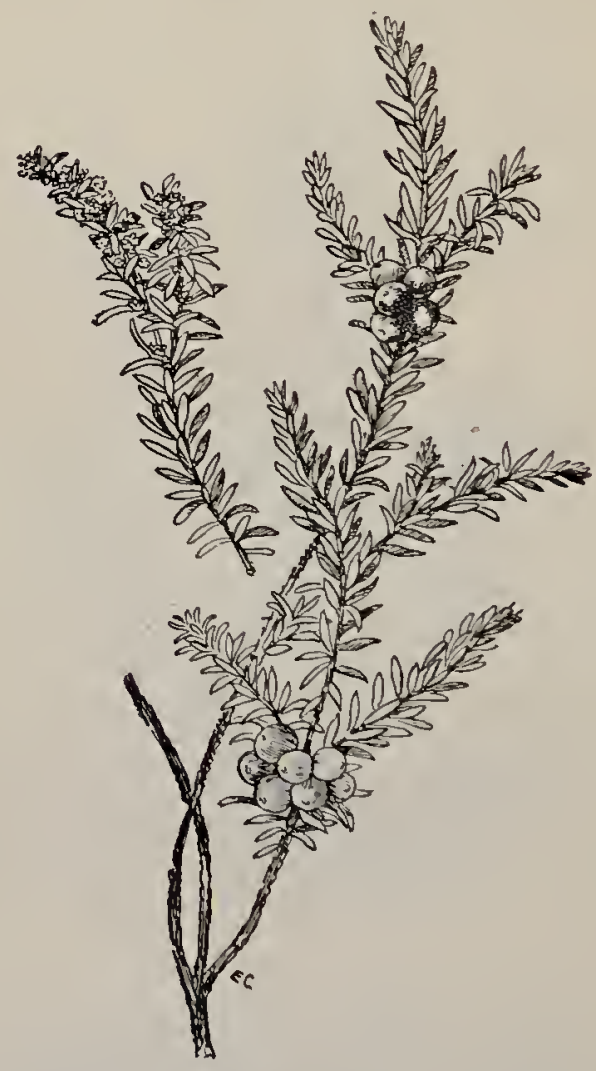

mMPÉTRuM xfGRuM (Black Crowberry).

3--4, alternate with the inner scales; orcicy 2-9. chambered, on a fleshy disk; style 1 ; stigma radiate; fruit fleshy, with bony, 1-seeded chambers. The slightly acid berries of the Crowberry (Empetrum nigrum), though umpleasantly turpentuous, are eaten- 
in Arctic regions, being considered as a preventive of scurvy. There is only one British species.

Eмpétrun (Crowberry).-FTower-scales 3 outer and 3 inner; slamens 3 ; style short; stigma peltate, 6-9-rayed ; berry globose, 6--9-chambered. (Name from the Greek en jétron, on rock, from the character of its habitat.)

1. E. núgrum (Black Crowberry, Crakeberry).-A small, prostrate, leafy shrub, with the habit of a Heath; stems much branched; leaves linear-oblong, so revolute that their margins mect at the back; flowers in the axils of the upper leaves, purplish; beries black.-Mountainous heaths in the north and west; frequent. 'The berries are much eaten by moor-fowl.-Fl. April-June. Perennial.

Ord. LXXII. Euphorbiáce五.-Spurae Fampily.

A large Order containing about 200 genera and 3,000 species distributed over most of the tropical and temperate rcgions of the globe, and comprising trees, shrubs, and herbs. Their aflinities arc obscurc; for, though the European species have no perianth, many tropical genera appear to possess one. They appear to be related on the one hand to Uricacece, and, on the other, to Matuácer. Many African species arc spinous, presenting a superficial resemblance to Cactúcec. Most plants in the Order have milky juice, which is often acrid and contains rubber and various alkaloids. The leaves are usually scattered and simple, and often have deciduous stipules. The fiowers are small, the stamens and carpets in separite flowers and accompanied by bracts or an involucre. In the large genus Euphórbia there is a cup-shaped involucre, with yellow crescent-shaped glands round its margin, enclosing several staminate flowers, each consisting of one 
stamen on a pedicel, surrounding one longer-stalked carpellate flower of 3 united carpels, with as many styles, stigmas, chambers to the fruit, and seeds. The fruit often separates elastically into its constituent carpels. Among so numerous an assemblage of plants, we should expect to find a considerable variety of properties, which, indeed, exists, though nearly all the Order agree in the acrid, narcotic, or corrosive character of the juice. A small quantity of the milky juice of one of our herbaceous British species of Spurge (Euphórbia) placed upon the tongue produces a burning heat in the mouth and throat, which continues for many hours, but may be allayed by frequent draughts of milk. The roots of several of the common kinds enter into the composition of some of the quack fever medicines; but they are too violent in their action to be used with safety. The Irish Spurge (E. Titérna) is extensively used by the peasants of Kerry for poisoning, or rather stupefying, fisl. So powerful are its effects, that a small creel, or basket, filled with the bruised plant, suttices to poison the fish for several miles down a river. The Capel-Spurge (E. Lathyris), a common weed in gardens, is a dangerous substitute for genuine capers, its unripe fruits superficially resembling the unopened flower-buds of Cápparis spinisa, an entirely distinct shrubby plant, indigenous to the South of Europe. Gum Euphorbium is a gum-resin obtained from Euphóbia resinétura, a native of the lower slopes of the Atlas Mountitins, by wounding the stems, and collecting the sap which exudes. Pliny relates that the plant was discovered by Juba, King of Mauritania, and named by hin after his physician, Emphorbus. It is an acrid poison, so violent in its effects as to produce severe inflammation of the nostrils if those who are employed in powdering it do not guard themselves from its dust. It was formerly employed for raising blister's, but is now only used in veterinary medicine, or for mixing with 
tinct plant, covered with silvery scales, giving the whole plant a whitish hue; stem buff-coloured, nearly without stripes, angular, spreading; leaves triangular, sinuate, sometimes toothed, mealy beneath ; perianthleaves of fruit rhomboid, 3-lobbed, united in a swollen, hardened base.-Sandy sea-shores; frequent.-Fl. July-October. Annual.

\section{*** Perianth aulherent to fruit.}

7. A. portulacoíles (Shrubby Sea Purslane, Crabweed. - A shrubby plant, mealy, with greyish scales, straggling; leaves mostly opposite, obovate-lanceolate, entire; flowers in terminal interrupted panicles; perianth sessile.--Sea-shore; frequent.-Fl. August-October. Perennial.

8. A.peclunculáta (Pedunculate Sea Purslane).-A herbaceous, slender, little-branched, mealy species, differing mainly in having an elongating pedicel to the fruit.-Muddy salt marshes on the east coast ; very rare.-Fl. August-October. Annual.

4. SalicóRnia (Glasswort, Marsh Samphire):-Singular jointed, fleshy, green, leafless, herbaceous plants with opposite branches, and minute, perfect flowers sunk in pits at the nodes; perianth fleshy, persistent; stamens 1-2; styles 2. (Name from the latin sal, salt, cornu, a horn, from the abundance of soda in the plant, and its horn-like branches.)

1. S. herbácea (Jointed Glasswort, Marsh Samphire).-An erect, herbaceous plant, $4-8$ in. high, with the joints of the stem thickening upwards and the branches all ending in tapering spikes of flowers.-Salt marshes; abundant. Formerly used in the manufacture of glass, and still used as a pickle, under the name of Samphire, in Lincolnshire and on other parts of the coast, being generally preferred to the 
Umbelliferous Críthmum.-Fi. August, September. Annual.

2. S. appréssa (Prostrate Glasswort).-A wellmarked, prostrate form with its branches closely adpressed to the soil and spreading in a triangular fanlike form, with cylindric internodes and acute spikes.On the coast of Kent ; very rare.

3. S. radicans (Rooting Glasswort). - Stem woody, prostrate; branches ascending ; internodes not thickening upwards; spikes blunt. - Salt marshes on the east and south coasts; rare. Much more branched and tufted, and browner in colour than $S$. herbácea.-Fl. August, September. Porennial.

5. Sureda (Sea Blite).-Maritime slirubs and herbs with scattered, fleshy leaves, semicircular in transverse section; and small, green, axillary flowers ; perianth deeply 5-cleft, often fleshy ; stamens 5; stigmas $2-5$ : perianth-segments in fruit neither keeled nor winged. (Name said to be from suced, soda, in which the plants abound.)

1. S. fraticósa (Shrubby Sea Blite).-A smooth, rather glaucous plant; stem woody, elect, $1-3$ fect high, with ascending branches; leaves semicylindric, blunt; styles 3.- Sandy and shingly beaches, mostly on the east coast ; rare.-Fl. July-October. Perennial.

2. S. marítima (Annual Sea Blite). - A low, straggling plant, smooth, glaucous, and reddish in winter, with slender branches rising $1-2$ feet; acute, semicylindric, short, Heshy leaves; flowers $1-5$ together ; styles 2.-Muddy sea-shores : common.-Fl. July-October. Annual.

6. Sátsola (Saltwort).-Shrubs aud herbs with sessile, fleshy, stiff'or spinous, awl-shaped leaves; 
small, axillary, perfect flowers; perianth deeply 5cleft; stamens 3-5; stimas 2-3; fruit 1-seeded, enclosed by the much enlarged, 5-winged perianth. (Name from the Latin sal, salt, the plants being rich in soda.)

1. S. Káli (Prickly Saltwort).-The only British species, a stiff, glaucous, hairy, much branched plant, with striped, angular stem seldom more than a foot high ; succulent, awl-shaped lerves, each terminating in a sharp spine; and solitary axillary flowers. Sandy sea-shores; common. - Fl. July, August. Arnual.

\section{Ord. LXIV. Polygonácee.-The Persicaria FANIILY,}

A considerable Order of herbaceous plants, chiefly natives of temperate climates, bearing scattered, simple leaves with sheathing membranous stipules, petioles dilated at the base and margins revolute in the bud. The flowers are generally perfect, small, numerous and growing in spikes or panicles, so that many members of the Order are handsome plants. The perianth is deeply 3-6-parted, often in 2 rows and coloured, imbricate in bud, persistent; stamens $5-8$, opposite the leaves of the perianth; ovary superior, ovoid, 3-sided, or compressed, 1-chanibered, 1-ovuled; styles 1-3 ; fruit a hard, flattened, or triangular, indehiscent nut, usually enclosed in, but not adherent to, the periantl. The properties residing in the leaves and roots are sometimes very different, the former being in many cases acid, and sometimes of an agreeable flavour, the latter nauseous and purgative. The powdered root of scveral species of Rherum affords the valuable medicine Rhubarb, and the leaf-stalks of the same plants are much used for making tarts, their sharp taste being attrioutable to the presence of oxalic and malic acids. The Common 
Solrel (Rúmex Acetósa) is sometimes used in the same way as Rhubarb-stalks, or as a salad; but the species mostly employed in cookery is $R$. scutátus, a native of Southern Europe. Other species of this genus are the Docks, known as troublesome weeds in most regions of the globe. The Buckwheat, or Beechwheat (Fayopýrum esculéntum), so called from the resemblance in shape between its fruits and those of the Beech, is probably a native of Central Asia. In America and some European countries the flour derived from its seeds is made into cakes or bread; but in England it is chiefly cultivated as a food for pheasants, which are very partial to it.

1. Polýgonum.-Perianth deeply 5-cleft; stamens $5-8$; styles $2-3$; fruit a triangular or flattened nut, not winged; embryo at 1 side of the seed; cotyledons flat.

*2. Fagopínum. - Perianth 5-cleft; stamens 8; styles 3 ; fruit triangular, not winged; embryo in the centre or axis of the seed; cotyledons large, leaf-like, and plaited.

3. Oxíria.-Perianth deeply 4-cleft, the 2 inner segmests larger ; stamens 6 ; styles 2 ; fruit a flattened nut with a membranous wing ; embriyo central.

4. Rúmex.-Perianth deeply 6-cleft, the 3 inner segments much larger ; stamens 6 ; styles 3 : fruit a triangular nut, covered by the enlarged inner perianthsegments ; embryo lateral.

1. PouÝgonum (Persicaria).-Herbaceous plants with stems often enlarged and bent at their nodes; leaves scattered, with ochreate stipules; flowers perfect, in spikes, racèmes, or panicles ; perianth deeply 5-cleft, the 3 outer segments sometimes enlarging in the fruiting stage ; stamens 5-8, with versatile anther's; ovary compressed or 3 -sidled; styles 2-3; fruit not winged; embryo lateral; cotyledons thin, flat. (Name 
from the Greek polús, many, gonu, knee, from the many knee-like nodes.)

* Twining plants; leaves sayittate; flower's in racemes ; stamens 8; styles 3, united; nut .3-sided.

1. P. Convólvulus (Black Bindweed, Climbing

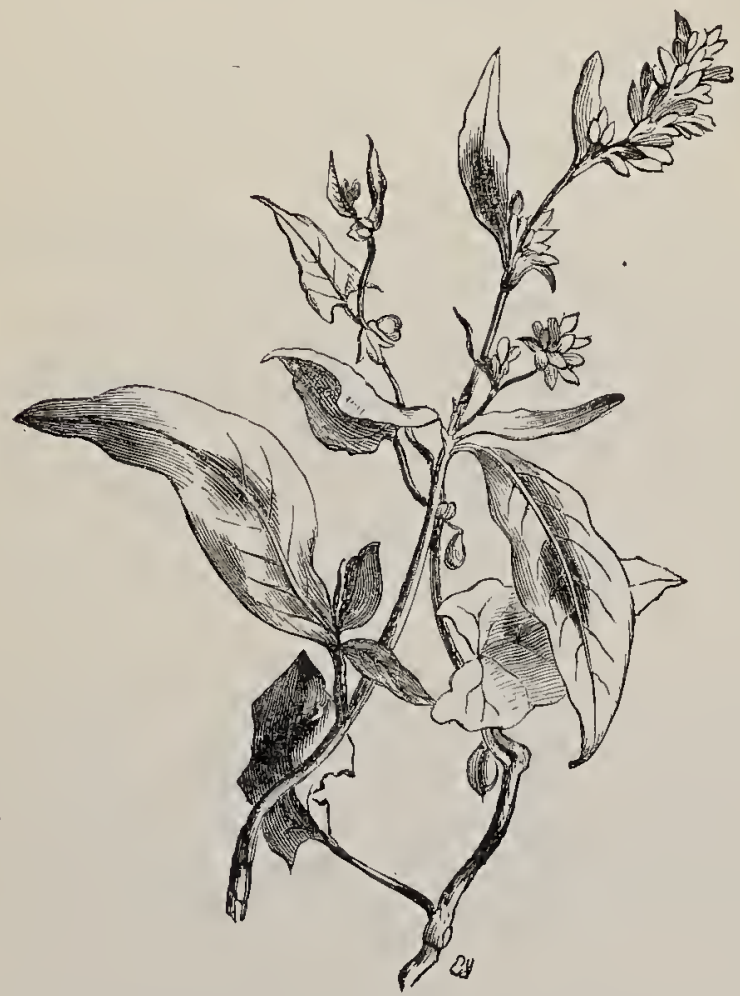

polígoxum Coxvólvulus (Climbing Persicaria).

Buckwheat, or Persicaria).-A mischievous weed with the habit of the Field Convolvulus (Convólvulus (arvensisis), twining round the stems of other plants 
and strangling them; leaves cordate-sagittate; flower's greenish-white, in erect, slender, axillary ard telminal racemes, bearing 4-10-flowered clusters; outcr perianth-segments bluntly keeled, green with white margins; fruit rather rough.-Cultivated ground ; abundant.-Fl. July-September. Annual.

2. P. dumetorum (Copse Buckwheat). - A similar but more luxuriant species, climbing to a height of 4 or 5 feet; flower-stalks more slender; outer perianthserments winged; nut smooth and shining-Bushy places in the South of England; rare-Fl. JulySeptember: Annual.

\section{* Mostly prostrate plants; Teaves narrow; stiputes silvery, torn; flowers aritlary, 1-3 together; stamens usually 8 ; styles 3 ; nut 3 -sidect.}

3. P. avicutáré (Common Knot-grass). - A common weed with branclied stem, usually prostrate, but varying greatly in size, and in rich soil often growing nearly erect; Tea'es lanceolate, with chaffy stipules; flowers minute, axillary, pink or greenish-white.Waste ground and roadsides; abundant.-El. May -October. Annual.

4. P. Ráii (Ray's Knot-grass). - Intermediate between the preceding and following species, resembling the former in habit, the latter in fruit. It has long, straggling, prostrate stems; lanceolate-elliptical, flat leaves which bend towards the stem and are often glaucous; and a large, smooth, shining mut which is longer than the perianth.-Sandy sea-shores; not uncommon.-Fl. August, September. Annual or perennial.

5. P. marítimum (Seaside Kinot-grass).-An allied, but more shrubby species, with prostrate, often mucl buried, stiff, and woody stem; fleshy leaves with revolute edges, diverging from the stem, netted with veins and often glaucous beneath. - Sandy sea-shores 
in the South-west of England; very rare.n-Fl. JulySeptember. Perennial.

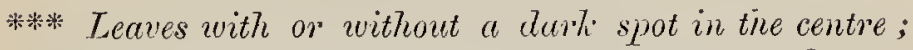
flowers in spites; stamens 4-8; styles 2-3; nut compressed or 3-sided.

6. P. Hydrópiper (Water Pepper, Biting Persicaria).-A vely acrid plant, creeping and rooting at the base, 1-3 feet high, much branched, with lanceolate, tapering wavy leaves, and well distinguished by its slender, drooping, loose spikes of greenish flowers; stamens 6.-Ditches and places where water has stood during winter; abundant. The fresh juice, though acrid, is of a not unpleasant flavour, and is said to cure pimples on the tongue.-Fl. August, September. Annual.

7. $P$. mimus (Creeping Persicnria).-A much. smaller and more slender species than the last, much branched, erect, or prostrate with ascending branches; leaves linear-lanceolate, flat, witl fringed stipules close to the stem; very slender, erect spikes of flowers which are only half the size of those of P. Hydropiper; styles 2-3, united for at least half their length.Wet gravelly places; not uncommon.-Fl. August, September. Anuual.

8. P. mité (Lax-flowered Persicaria).-Stem creeping and rooting below, 1-3 feet ligh, branched, slender; leaves lanceolate, wavy, with loose, funnelshaped, much fringed stipules; flowers in erect, slender, interrupted spikes ; stamens $5-6$; styles $2-3$, united for half their lengtl ; nut black, roughish, compressed.-Wet places; local.-Fl. June-September. Annual.

9. P. Persicária (Common Persicaria):-A common weed, $1-2$ feet high, erect or ascending, usually: 
swollen at the nodes, branched; leaves lanceolate, flat, with minute warts, often with a purplish-black blotch in the centre, more or less hairy on both sides; stipules loose, much fringed; flowers in a short, dense, erect, cylindrical spike, red or white; peduncle smooth; stamens 5-8; styles 2-3, united for half their length.-Waste an 1 damp ground; abundant.-Fl. July-October. Annual.

10. P. lapathifótium (Pale-flowered Persicaria).-A closely allied species; stem sometimes red or spotted, swollen at the nodes; leaves lanceolate, acuminate, smooth or downy, sometimes with a black blotch above, or glaucous below; stiputes close to the stem, with little or no fringe; flowers pale, in axillary oi terminal, cylindric spikes; peduncle rough; stamens $5-6$; styles 2, distinct. - Waste and damp places; common.-Fl. July-September. Annual.

11. P. maculátum (Spotted Persicaria)._-Smaller than the preceding, often prostrate, with very thick nodes; leaves lanceolate, tapering much at both ends, wavy, generally blotched, white and woolly beneath, with loose, shortly fringed stipules; spilies sometimes interrupted; peduncle rough; styles connected below. -Damp gravelly places; not common.-Fl. JulySeptember. Annual.

12. $P$. amphíbium (Amphibious Persicaria).-. Assuming such different forms when growing in the water and on land that they might well be taken for two distinct species. It has a slender, woody, branched rhizome cleeping in the mud, with branches about a foot high and erect, if on land, with sub-sessile, lanceolate, hairy leaves, or with floa:in! stems $2-3$ feet long, if on water, supported by long-stalked, floating, oblong, smooth leaves; flowers rose-coloured, in handsome oblong spikes; stamens 5 , with exserted anthers; styles 2, united for half their length; fruit Gattened. - Ditches and banks of pools ; common. - Fl. July-September. Pcrennial. 


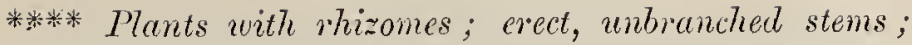
teminal, spike-lite racemes; stamens 8 ; styles 3 ; nut 3-sided.

13. P. Bistórta (Bistort, Snalkeweed, Snake-root). -A rather handsome plant, with a large, woody, twisted $r$ hizome, and several erect, simple stems $1-1 \frac{1}{2}$ foot high; leaves ovate, the radical ones on winged petioles and glaucous bencath; flowers pink, in terminal, cylindrical, dense spikes.-Moist meadows; frequent. The English names Bistort (twice twisted) and Snake-root allude to the form of the rhizome. It forms large circular patches in meadows, and also occurs in old-fashioned gardens, where its astringent rhizome was once grown as a medicine. The green shoots are eaten in Cumberland under the name of Easter Man Giants, which perhaps means Easter eating, from the French mangcant.-F1. June-September. Perennial.

14. P. viúparum (Viviparous Bistort, Alpine Bistort).-A slender plant, $6-8$ in. high, with a slender rhizome; a simple, erect stem; leaves linear-lanceolate, with their margins rolled back; flowers pink, in a slender, loose, blunt spike, which has small red bulbils in its lower part in place of flowers.-Mountain pastures, especially in the Scottish Highlands.Fl. June, July. Perennial.

*2. Fagopírum (Buckwheat), a genus differing frcm Polygonum mainly in the embryo, which is in the centre or axis of the seed, and has large, leaf-like, plaited cotyledons, is only represented in England by one species, the Common Buckwheat ( $F^{\top}$. esculéntum), probably a native of Central Asia, and not indigenous in Britain. It has erect, branched stems, about a foot high ; cordate-sagittate, acute leaves; and pinkish flowers in spreading panicles.-Sown as food for pheasants. - Fl. July, Ángust. Annual. 
3. OxÝRIA (Mountain Sorrel), a genus containing only the one species $O$. digyma, a plant resembling the Common Sorrel (Rúmex Acetósa) in habit, but shorter and stouter. It grows 8-10 in. high, and is smooth and rather fleshy. The leaves are all radical and kidney-shaped, with long stalks; and the flowers are green, and grow in clustered spikes. The perianth is deeply 4-cleft, the segments in 2 rows, the inner larger and persistent; stamens 6, with versatile anthers; styles 2 ; fruit a flattened nut with a broad, membranous wing.-Damp places near the summits of high mountains in the north; not uncommon. Name from the Greek oxus, sharp, from the pleasantly acid flavour of the stem and leaves.) - Fl. June-August. Perennial.

4. Rúmex (Dock, Sorrel).-Herbaceous plants with a rhizome; usually grooved stems; scattered lenves with tubular stipules; flowers in racemes or panicles of whorls; perianth deeply 6-cleft, the 3 inner segments enlarging in the fruit stage ; stamens 6 , with basifixed anthers; styles 3 ; stigmas feathery, wind-pollinated; fruit a triangular nut, covered by the enlarged inner periantli-segments; embryo lateral. (Name, the old Latin name of the plant.)

* Insipid plants (Docks), with leaves not hastate, and perfect flowers.

The species in this group hybridise freely, thus adding to the difficulty of discriminating between them.

1. R. conglomerátus (Sharp Dock).-A smooth, slender plant, 1-3 feet high, with few spreading branches; leaves oblong-lanceolate, not narrowing above the base, cordate or rounded at the base, acute; flowers in a panicle of distant whorls, leafy almost to the top ; 
inner perianth-segments linear-oblong, sub-acute, each bearing a large oblong wart.-Wet places ; common.FI. June-August. Perennial.

2. R. rupéstris (Shore Dock).-A nearly allied form, with a more compact, upright habit; leaves strap-shaped, rounded and narrowed at both ends; panicle tapering, whorls not very distant; inner perianth-segments large, narrow, oblong, blunt, with large warts. - On the south coast; rare.-Fl. JuneAugust. Perennial.

3. R. sanguineus (Bloody-veined Dock). - A smooth species with a slender stem, 1-4 feot high, with few ascending branches; leaves ovate-lanceolate, fiddleshaped, slightly wavy, usually cordate and with the veins tinged of a beautiful crimson : flowers in manyflowered, distant whorls forming a loose panicle, only leafy at the base; inner periarth-segments oblong, blunt, with a large, smooth wart on the outermost.-Roadsides and hedges; common. The form with green veins is the more frequent.-Fl. June-August. Perennial.

4. R. maritimus (Golden Dock).-A slightly downy, yellow-green plant, $1-2$ feet high, with ascending branches ; leaves short-stalked, linear-lanceolate, nar-. rowed at both ends, slightly wavy ; flowers in crowded, confluent, many-flowered whorls, in a leafy panicle with spreading branches ; inner perianth-segments triangular, acuminate, orange-yellow, with 2 bristly teeth, often longer than the segment, on each side, and each with a prominent, narrow, oblong wart.-Marshes, principally near the sea; rare.-Fl. July, August. Biennial.

5. R. Timósus (Yellow Marsh Dock).-A closely allied species, with the whorls distinct, looser, and fewer-flowered; the inner perianth-segments ovateoblong, with shorter, bristly teeth; and the nut much larger.-Marshes; less common than $R$. maritimus.Fl. July-September. Perennial. 
6. R. púlcher (Fiddle Dock).-A small, nearly smooth, straggling, branched plant; lower leaves fiddleshaped or oblong, with a heart-shaped base and narrowed above, with slender petioles; upper leaves lanceolate, acute; flowers in distant whorls forming a spreading, leafy panicle; imer perianth-segments palc-coloured, oblong, deeply toothed along the lower halves of their edges, with a network of veins, and on one of them a more prominent, oblong, prickly wart.Waste places on divy soil; not uncommon.-Fl. June -October. Biennial or perennial.

7. R. obtusifôtius (Broad-leaved Dock).-A tall, stont species, $2-3$ feet high, with ascending branches; lower leaves ovate-oblong, cordate, blunt, finely crenate, wavy, with slender stalks; upper oblong-lanceolate; flower's in distant whorls, leafless abore ; imner perianthsegments long, triangular, blunt, with netted reins and usually strong teeth at the base, and an ovoid red or brown wart.-Waste places; common.--Fl. JulySeptember. Perennial.

8. R. crispus (Curled Dock).-The commonest of the Docks, 1 -3 feet high, branched; leaves stalked, lanceolate, acute, wavy, and crisped; flowers in crowded whorls forming a panicle, with erect branches, leafy below, often tinged with a bright red; imer perianthsegments equal, cordate, blunt, netted, green or red, with a small, smooth wart. - Waste places; far too common.-Fl. June-October. Perennial.

9. IR. domésticus (Long-leaved Water Dock).-A very robust, smooth species, $1-4$ feet high; leaves very large, lanceolate, waved, and crisped, on semicylindric petioles with slightly raised edges; flowers in crowded whorls, forming a large, dense, lobed panicle, leafy at the base only; imer perianth-segments broadly cordate, membranous, netted, without warts. - Meadows in the north ; frequent; preferring spots liable to be flooded.-Fl. July, August. Perennial.

10. R. Hydrolápathum (Great Water Dock),-A 
picturesque plant, 3--6 feet high, erect, branched, smooth ; leaves often more than a foot long, lanceolate, acute, often cordate at the base, finely crenate on long petioles which are not winged; flowers green, in

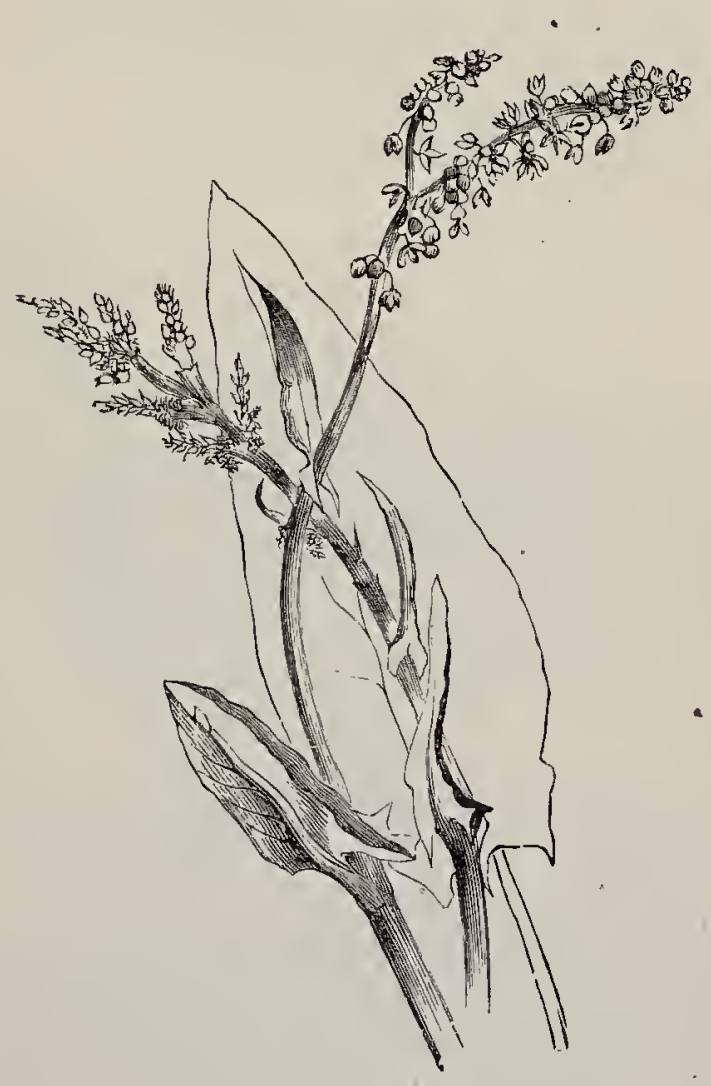

RÚMEX ACETÓSA (Common Sorrel).

crowded whorls, forming very large, almost leafless panicles; inner perianth-segments triangular, netted, with oblong tubercles.-River-banks frequent.-Fl. July, August. Perennial. 
* Acid heros (Sorrels) with leaves generally hastate and imperfect flowers.

11." R. alpinus (Monk's Rhubarb).-A slightly downy plant, with thick rhizome; stem stout, $2-4$ feet high ; tea'es roundish-cordate, not hastate, on lang channelled stalks; flowers monocious, in crowded, but not confluent whorls, forming a panicle with numerous erect branches, leafy at the base only; inner perianth-segments ovate, cordate, membranous, without warts. - Near cottages, formerly cultivated for its astringent rhizome and as a pot-herb.-Fl. July, August. Perennial.

12. R. Acetósa (Common Sorrel).-A slender, smooth plant, about 2 feet high, with simple, juicy stems; radical leaves on very long stalks, sagittate, glaucous beneath; upper leaues sessile ; stipules brown; flowers reddish-green, diøcions, in leafless panicles with erect branches; outer periunth-segments reflexed in fruit; inner round, membranous, with a minute wart at the base.-Meadows; abundant. Well known for its pleasing acid taste.-Fl. May-August. Perennial.

13.* $R$. scutitus (French Sorrel),-The species chiefly cultivated as a pot-herb or salad, with hastateovate, slightly fiddle-shaped leaves, is occasionally naturalised.

14. R. Acetosétla (Sheep's Sorrel).-Much smaller than $R$. Acetosa; $6-10 \mathrm{in.} \mathrm{high;} \mathrm{often} \mathrm{tinged,}$ especially in autumn, with a deep red; leaves lanceolatehastate; stimules silvery, torn; flowers dicecious, in leafless panicles with erect branches; outer prerianthsegments ascending, imner without warts.-Dry gravelly places; abundant._Fl. May-August. Peremnial.

Ord. LXV. Thymelédét.-Daphe Family. A small Order of plants, mostly shrubby, remark- 
able for their tough inner bark, which is of a highly acrid nature, causing excessive pain if chewed, and raising a blister if applied to the skin. They have undivided, exstipulate, laurel-like lectes; flowers generally perfect; perianth tubular, 4- rarely 5-cleft, coloured, imbricate; stamens 2-10, inserted in 2 rows in the perianth-tube; avary superior: 1-chambered;

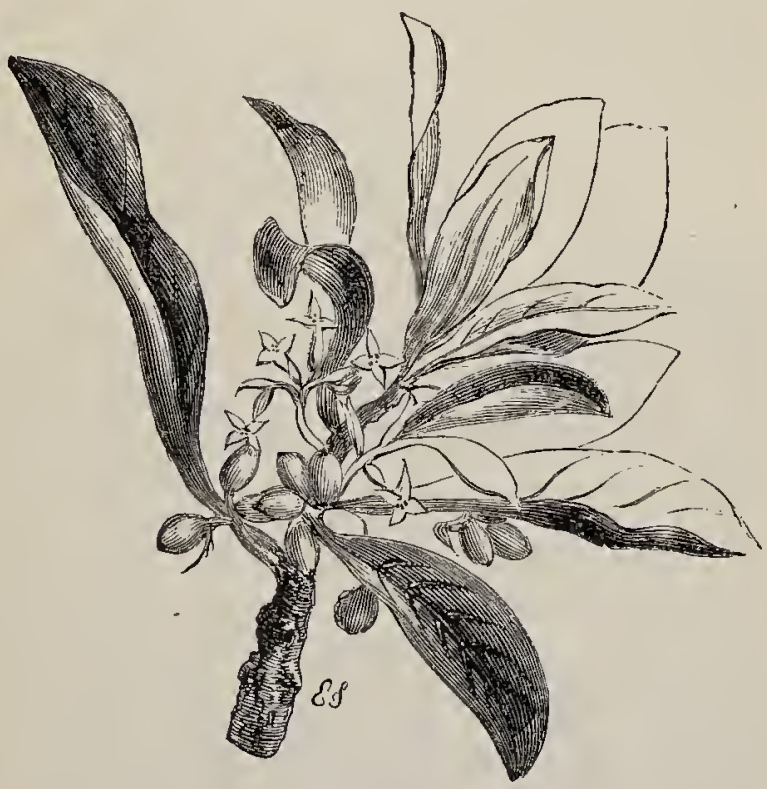

DÁPHNÉ LAURÉOLA (Śpurge Laurel).

stigma undivided ; fruit a 1-seeded nut or drupe. The bark of several species is used for making rope and paper, that of Lagétta linteária, the Lace-bark tree of Jamaica, for instance, which can also be pulled out under water into strong lace patterns. Dáphné japónica, $D$. indica, and other species are commonly cultivated in conservatories and gardens for the sake of the delicions fragrance of their blossoms. The 


\section{$\operatorname{tos} 637$}

berries of the Spurge Laurel (Dáphné Lauréola), the commoner of the two species which represent the Order in Britain, are poisonous to all animals except birds; and both the bark and root of the other British species, the Mezéreon (Dáphné Mezéreum), though used in medicine, are very violent in their effects.

1. Dáphné (Spurge Laurel).-_Shrubs with leaves usually scattered and evergreen; flower's fragrant; perianth tubular, with 4 spreading lobes; stcmens 8 , sub-sessile, included. (Name, the Greek for a Laurel, which it resembles in its foliage.)

1. D. Mezéreum (Mezereon).-A shrub with few erect branches; very fragrant, pink flowers, sessile, 3 together, appearing before the leaves; leaves stalked, obovate, acute, not evergreen; fruit red, ovoid.Woods; very rare.-Fl. February-A pril. Perennial.

2. D. Lauréola (Spurge Laurel).-A low shrub, about 2 feet high, very little branched, and remarkable for its smooth, erect stems, which are bare of leaves except at the summit. The leaves are smooth, shining, leathery, and evergreen; the flowers green, in drooping, axillary clusters, and in mild weather fragrant; the berries black, ovoid, and poisonous. -Woods; not common. If transplanted from the woods and potted, it may be employed with advantage as a stock on which to graft $D$. indica. The operation should be carried out in spring, with the leafy extremity of a shoot rather less in diameter than the stock.-Fl. January-A piil. Perennial.

\section{Ord, LxVi. Elatagace.,-Oleaster Family.}

A very small Order of shrubs and trees, native to the Northern Hemisphere, covered with scurfy scales; leaces undivided, exstipulate ; flow'er's dincious, small, 
rubber. The Australian Asthma Herb (E. pilulifera is now imported in considerable quantities. The Manchineel tree (Hipiomané Mancinélla) of South America has an intensely acrid white juice, the least drop of which, or even the smoke from the wood when burnt, causes temporary blindness; but other alleged actions have been much exaggerated. Its fruit, which is beautiful and looks like an apple, contains a similar juice, which so burns the lips of those who bite it as to guard the careless from any danger of eating it. Manioc (Manihót utilissima) is a shrub about 6 feet high, indigenous to the West Indies and South America, abounding in a milky juice of so poisonous a nature that it has been known to occasion death in a few minutes. It is used by the Indians to poison their arrows. The poisonous principle, however, may be dissipated by heat, after which the root may be converted into the most nourishing food. The roots are sometimes eaten by the Indians, simply roasted; and the heat of the sun even is sufficient to dissipate the noxious properties, for if it be sliced and exposed for some hours to the direct rays of the sun cattle may eat it with perfect safety. It is commonly, however, grated into a pulp and subjected to a heavy pressure until all the juice is drained off. This fresh juice is highly poisonous, but, if boiled with meat and seasoned, makes, under the name of Cassareep, an excellent soup, which is wholesome and nutritious. The pulp, which is caller cassava, requires no further preparation, being simply baked in the form of thin cakes on a hot iron. 'This bread is so palatable to those who are accustomed to it as to be preferred to that made of wheaten flour. By washing the pulp in water and suffering the latter to stand, a sediment of starch is produced, which, after being dried on hot plates, which partially converts it into dextrine, is the familiar, light, digestible, and nourishing tapioca. Caoutchouc, or rubber, is fur- 
nished in greater or less abundance by many plants of this Order, but especially by South American species of Hévea. The fragrant tonic, Cascarilla Bark, is produced by Croton Eleuthéria, a shrub belonging to this Order which is a native of the Bahamas; and the violently cathartic Croton-oil is extracted from the seeds of $C$. Tiglium, a native of the Malabar coast. Castor-oil is expressed from the seeds of Ricinus communis, which is frequentiy grown as an ornamental foliage-plant in English gardens under the name of Palma-Christi. The Box is the only British tree belonging to this Order, of the poisonous properties of which it partakes, though to a limited extent. In some parts of Persia it is very abundant; and in these districts it is found impossible to keep camels as the animals ale vely fond of browsing on the leaves, which kill them. No satisfactory substitute is known for the wood of this tree as material for the wood-engraver.

1. Euphórbia. - Imrolucre cup-shaped, containing 12 or more staminate flowers each of 1 stamen and 1 campellate flower with 3-lobed ovary; styles 3; stigmas 2-cleft ; fruit 3-chambered, 3-seeded.

2. Búxus.-Evergreen shrubs with opposite teaves; flowers monocious, bracteate, axillary; perianth of 4 12 leaves; stamens 4; orar!y 3-chambered, 6-seeded.

3. Mercurı́ńls.-Herbs with opposite, serrate leave: flowers mostly diccions; perianth of 3 leaves; stamens S-20; ovany 3-chambered, 2-seeded.

1. Eupiónbia (Spurge).-The British species all herbs with milky juice; leaves simple; flowers monncious, in cup-shaped, 4-5-lobed ine'olucre with roundish or crescent-shaped glands alternating with the lobes; staminate flowers each of 1 pedicellate stamen; carpellate flower solitary, drooping, pedicellate, of 3 united carpels; stimmas 2-cleft; fruit 3-lobed, 
3-seeded. (Name from Euphorbus, physician to Juba, an ancient king of Mauritania.)

\section{* Leaves opposite, stipulate.}

1. E. Péplis (Red Spurge).-A prostrate, glabrous, and glaucous plant, beautifully tinged with red, repeatedly forked; leaves opposite, stalked, blunt, auricled on one side at the base, thick, $\frac{1}{2}$ in. long; involucres axillary, with oblong glands.-Sandy seashores in the south; rare.-F.l. July-September. Annual.

** Leaves exstipulate, generally scatterect.

* Umbels mostly 5-rayed ; involucral glands roundish, without cusps.

2. E. Helioscópia (Sun Spurge). - Varying in size from a few inches to $1 \frac{1}{2}$ foot in height, generally glabrous, with obovate leaves serrate above the middle, and easily distinguished by the golden-green hue of its spreading umbel, which is large in proportion to the size of the plant, and has 5 rays which are often repeatedly forked; capsule smooth.-Cultivated ground; abundant.-Fl. June-October. Annual.

3. E. platyphÿllos (Broad-leaved Spurge). - A similar, erect, slightly branched, glabrous or hairy species, with curdate leaves, finely serrate above the middle, 3-5-rayed umbel, repeatedly forked; 7-8 staminate flowers in each involucre; capsule covered with hemispherical warts.-Fields, chiefly in the Eouth ; rare.-Fl. July-October. Annual.

4. E. stricta (Upright Spurge).-Closely allied to the preceding, but more slender, with more ascending branches, erect, 2-3 feet high; with thinner leaves; generally 3-rayed umbel; rarely more than 2 staminate flowers in each involucre; capsule only half the 
size, with longer, cylindric warts.-Woods on limestone in Gloucestershire and Monmouth; very rare. -Fl. June-August. Annual.

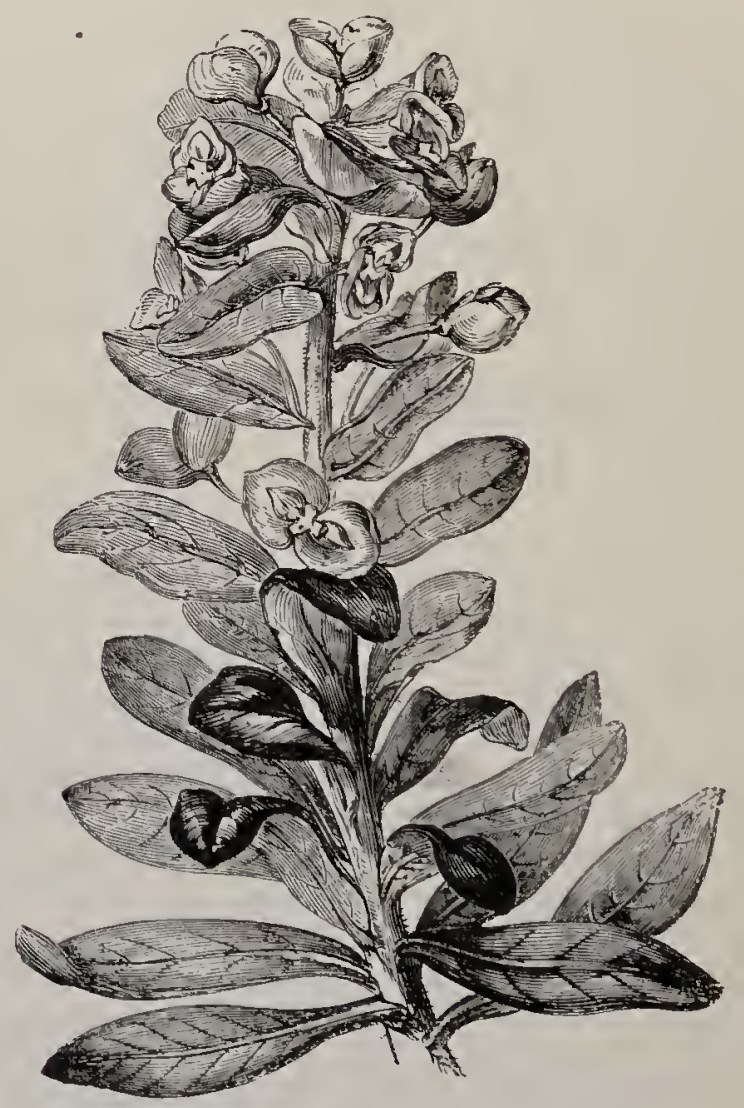

LUPHÓRDIA AMYGDALOfDES (I"ood Spurge).

5. E. Tibéma (Irish Spurge).-A downy plant, 1-2 feet high, scarcely branched, with thin leaves $2-4 \mathrm{in}$. long and an inch or more across, a 5 -rayed umbel and large capsules with cylindric warts.- 
Devonshire and Kerry, where it is used to stupefy fish.-Fl. May-June. Perennial.

6.* E. dúlcis (Sweet Spurge), an erect species, about a foot high, with obovate blunt leaves; an umbel of 5 long, 2-forked rays, with deltoid bracts; and a few prominent warts on the capsule, occurs only as an oscape from cultivation.-Fl. June. Perennial.

7.** E. corcthoüdes, a taller plant with its stem leafless below; leaves lanceolate, finely toothed, woolly; umbel of 5,2-3-forked rays; and woolly capsules; is also an escape.-Fl. May, June. Biennial.

8. E. pilósa (Hairy Spurge).-A tall plant, with its stem. leafy throughout and branched above; leaves broadly lanceolate, finely toothed mainly near the apex, slightly hairy; umbel irregular, of $4-6$ rays, which are first 3-forked and then 2-forked; bracts yellow, elliptical, smooth ; capsule usually hairy, with minute warts.-Woods, near Bath; very rare.-Fl. May, June. Perennial.

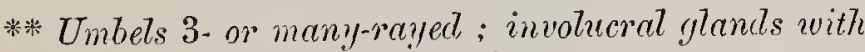 erescent-shaper cusps.}

9. E. amygdaloúdes (Wood Spurgo).-A shrubby, erect, leafy plant, with obovate-lanceolate, bluishgreen leaves, hairy beneath, which grows about a foot high the first year, elongating to 2 feet and flowering in the next season, with an umbel of 5 or more bifurcating rays, conspicuous in spring and summer with its golden-green bracts, which are united into a round cup, generally enclosing 3 involucres. A common woodland plant, conspicuous in autumn by the deep crimson tinge of its stems and leaves.-Fl. March, April. Perennial.

10. E. Esula (Leafy-branched Spurge).-Rhizome croeping; stem $1-2$ feet high, erect, slender, leafless below, unbranched, or with a few flowerless axillary 
branches; leaves oblong- or linear-lanceolate, sessile, thin, smooth, sometimes denticulate; umbel of 10 20 , long, slender, forked rays; bracts cordate, mucronate, not united; capsule rough.-Woods; rare, not indigenous.-Fl. June-August. Perennial.

11.* E. Cyparissias (Cypress Spurge).-A closely allied species, differing in having runners, having more crowded, more glaucous, narrower leaves; blunt bracts; and almost white seeds.-Occurs as an escape in similar situations.-Fl. June, July. Perennial.

12. E. Parálias (Sea Spurge).-A bushy, glaucous plant, often tinged with red; with many short, erect, stout stems leafless below ; crowded, imbricate, leathery, sessile, oblong, blunt leaves ; and an umbel usually of 5 sliort, forked rays. - Sandy sea-shores; not common. -Fl. July-October. Perennial.

13. E. portlándica (Portland Spurge). - A less robust plant with spreading, leathery, obovate, apiculate leaves ; involucral glands 4, with long cusps; seeds brown, pitted.-On the west and south coasts; rare.-Fl. April-September: Perennial.

14. E. Péplus (Petty Spurge).-A light green, glabrous, erect species, less than a foot high, with broudly ovate, stalked leaves, and repeatedly forked, 3-1ayed umbel; bracts ovate; involucral glancls 4, with long cusps. - A very common garden weed.-Fl. July -November. Anumal.

15. E. exígue (Dwarf Spurge).-A more slender little plant, usually branched near the ground, with linear leares: umbel of $3-5$ forked rays; bracts lanceolate. - Cornfields; common. - Fl. JuneOctober. Annual.

16.* 2. Láthyris (Caper Spurge).-A remarkable plant, 2--3 feet high, succulent, glaucous, tinged with purple, with numerous, spreading, linear-oblong or strap-like leaves, opposite and regularly decussate so as to form 4 vertical rows; umbel of 3 or 4 stout, unequal, irregularly forked rays; capsule very large, 
smooth, full of milky juice,-Chiefly a garden weed,

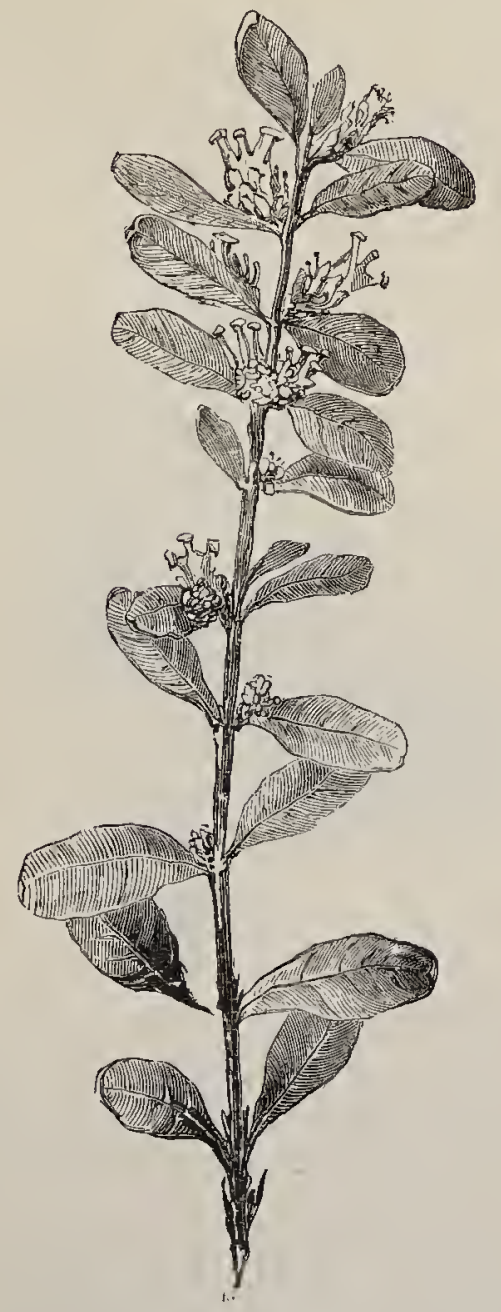

Búxus SEMPERVIRENS (Common Box.tree).

but perhaps wild in some woods.-Fl. June, July. Biennial. 
2. Búxus (Box).-Evergreen trees and shrubs; leaves opposite, exstipulate; flowers monœcious, axillary, bracteate, the staminate with 2 alternating pairs of perianth-leaves, the carpellate with $6-12$ in alternating whorls of 3 ; stamens 4 ; ovary 3-chambered, 3-lobed above; styles 3 ; outes 2 in each

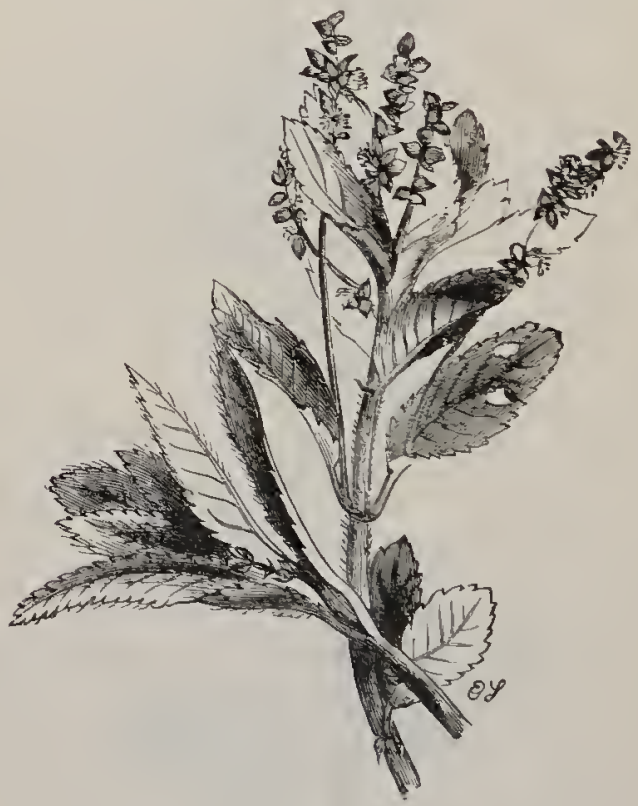

MERCURIALIS PERÉNvIS (Dog's Mercury).

chamber ; fruit capstilar. (Name, the Classical Latin name of the tree.)

1. B. sempervirens (Common Box-tree).-The only Europear species, a small, slow-growing tree, with rough, grey bark; twigs downy ; leaves oblong, obtuse, not more than an inch long; flowers crowded, sessile, minute, whitish.-Chalk hills in the south, probably indigenous. The juice is bitter and acridly poisonous, 
but not milky as in the Spurges. The close-grained, yellow wood, the only European wood which does not float in water, is unequalled for engraving. A dwarf variety is commonly used as an edging for garden borders -Fl. April, May. Perennial.

3. Mercuriális (Mercury).-Herbs with opposite, stalked, serratc, stipulate leaves; flowers mostly diocious; perianth of 3 leaves ; stamens 8-20 ; ovary 2-chambered; styles 2, long; ovules 2 ; fruit capsular. (Name in honour of the heathen god Mercury.)

1. M.perénnis (Dog's Mercury).-Rhizome slender, creeping ; stem solitary, erect, about a foot high, unbranched; leaves oblong-lanceolate, rough, hairy; flowers small, green, on peduncles springing from the axils of the upper leaves, the staminate ones in racemes, the carpellate in spikes.--Woods ; abundant. -Fl. April, May. Peremnial.

2. M. ánnua (Annual Mercury). - A much branched, nearly glabrous species, with sessile leaves of a light green, and sometimes with monocious flowers.-Cultivated land; not common.-Fl. JulyOctober. Annual.

\section{Ord. LXXIII. CeratophýlleÆ,-The Horwwort Family.}

An Order containing only the one genus Ceratophyllum, the Hornworts, a group of one or two species of submerged aquatic plants that are unimportant except from their structure, which is so distinct from that of any other known Dicotyledon as to render their affinities doubtful. They have long, slender, brittle, branched stems; whorled, sessile, exstipulate leaves, which are $2-4$ forked into antlerlike narrow lobes; and minute, axillary, monœcious 
flowers, enclosed in an 18-2-leaved involucre with bristle-like, persistent lobes. The stamens are 12-20, without filaments, but with 2 points to each anther; the oxary is 1-chambered, 1-ovuled; style 1, curred;

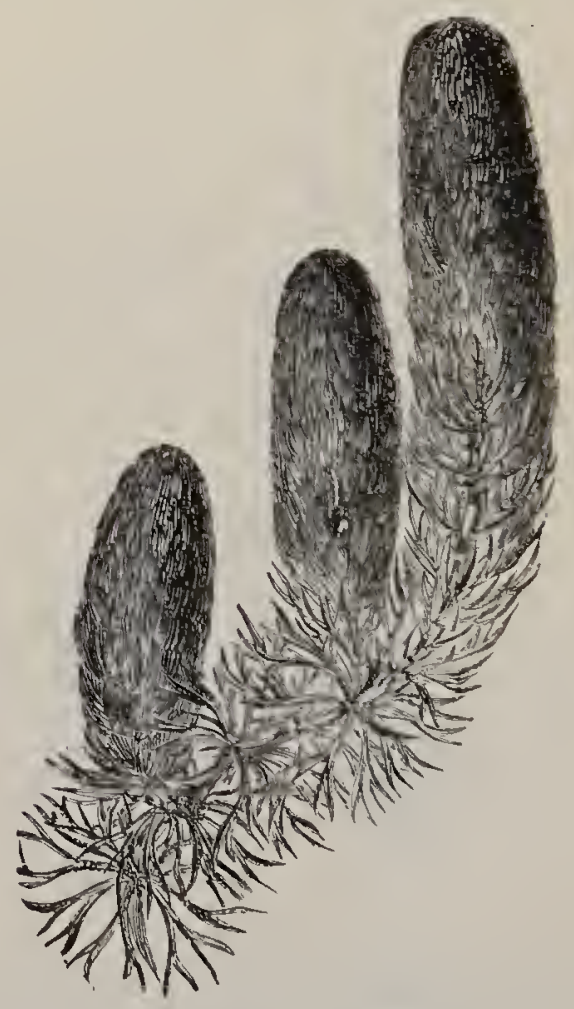

CERATOPHÍlLUM DEMÉRSUM (Common Hornuort).

fruit an indehiscent achene, sometimes with 2 spines at its base. (Name from the Greek keras, an antler, whullon, a leaf, from the form of the leaves.)

1. Ceratophýllium (Hornwort).

1. C. demérsum (Common Hornwort). - Lcares 
dark green; fruit with 2 spines at its base and terminated by the persistent, subulate, curved style.

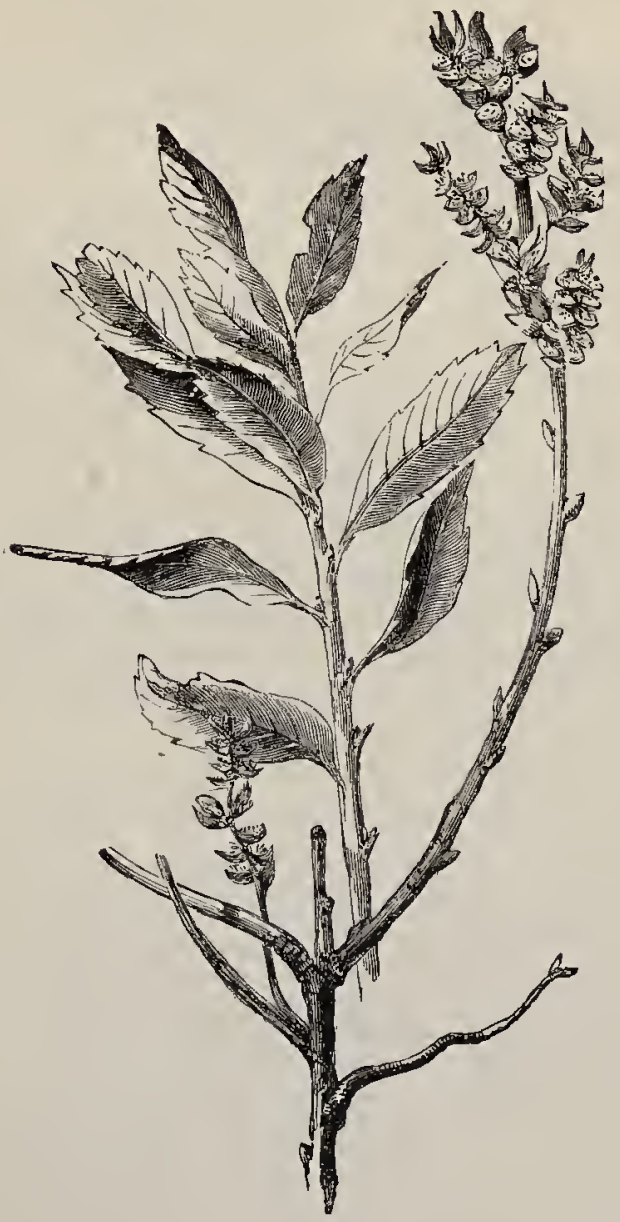

Myrfoa (Sweet Gale).

—-Slow streams and ditches, entirely submerged.Fl. June-September. Perennial. 
2. C. submérsum, paler green, without spines to the fruit and with a shorter style, occurs under similar conditions.

$\S \S$ Flowers in catkins.

Ord. IXXIV. Myricáceæ.-The Sweet Gale FAMILY.

A small group of shrubs and trees, widely distributed in temperate and tropical climates, and generally characterised by the excretion of wax. They have scattered, simple leaves; generally dicecious flowers in catkins; stamens 2-16; ovary 1-chambered, 1-ovuled; styles 2 ; fruit drupe-like, 1-seeded, covered all over with wax. Myrica cerifera, the Bayberry, Wax Myrtle, or Candleberry Myrtle of North America, and MI. cordifótia of South Africa have been used in candle-making. Yang-maes are the edible sub-acid fruit of $M$. Nari, a native of China and Japan. The aromatic leaves of the one European species, $M$. Gálé, are astringent and tonic and are used for tea and in rustic medicine.

1. Mrríca (Sweet Gale).-Stamens 4-S. (Name, the Greek name of the Tamarisk.)

1. M. Gálé (Sweet Gale, Bog Myrtle)._-A bushy, resinous shrub, $2-4$ feet high, flowering before leafing; leaves obovate-lanceolate, shortly-stalked, serrate towards the apex, fragrant when bruised; catkins sessile, erect, the staminate longer ; anthers and styles red ; crupe minute, 2 -winged by the adherent bracts. -Bogs; common.-Fl. May-July. Perennial.

Ord. LXXV. Cupuliferf.-Mast-bearing Fanily.

An Order variously limited by different botanists, but which may be taken as comprising 10 genera and about 400 species of trees and shrubs, widely dis- 
tributed over the globe and of very great value to mall as timber, for bark containing tannin and useful therefore in dressing leather, and for edible seeds. They have scattered, stipulate, simple leaves, either evergreen (in foreign species) or deciduous; and nonoecious flowers which are pollinated by the wind. The staminate flowers are generally in pendulous deciduous catkins, with 2-20 stamens in each flower; the carpellate flowers sessile in an involucre, each generally with a superior 5-6-toothed perianth, a 2 -3-chambered ovary, 2-3 styles, and 1 or 2 ovules in each chamber. The fruit is a dry indehiscent 1 - or rarely 2 -seeded nut, surrounded by the cupule or enlarged involucre, which gives its name to the Order; and the seeds are large, exalbuminous, with 2 , or rarely 3 , fleshy or mealy cotyledons.

Cork is the outer bark of Quércus Súber, an evergreen species of Oak mainly grown in Northern Spain. Its periodical removal in no way injures the vitality of the tree. The first crop which is cracked and furrowed is known as Virgin Cork. Quercitron, the bark of the North American Quércus tinctória, is mainly employed as a yellow dye. The bark of our Engiish Oak (Q. Róbur), Valonia, which is the acorncups, and Cameta, the young acorns of the Levantine Q. Afritops, are used in tanning; and the galls produced by insect puncture on $Q$. infectoria in the same country are one of the chief ingredients of ink. The bark of various species of Birch (Betula) is used in Canada for making canoes and moccasins, and in Russia for various utensils, as well as in tanning. The wood of the Alder (Alnus glutinósa) is burnt into charcoal for making gunpowder, and that of the Hornbeam (Carpinus Bétulus), on account of its toughness, is specially adapted to the manufacture of cog-wheels, as also is that of the American Live Oak (Quércus virens). The wood of the Quebec Birch (Bétula lénta) and that of the European B. verrucósa 
are largely used in making furniture, and that of the Beech (Fágus syluática) in Buckinghamshire, in chairmaking; whilst it is unnecessary to attempt to enumerate the uses of Oak timber. Chestnuts, the fruit of Castânea sativa, are an important article of food in Southern Europe, whilst in many countries acorns and beech-mast are of great value as food for pigs.

Tribe 1. BETuLf́. - All flowers in catkins; ovary of 2 1-ovuled chambers; fruit small, compressed.

1. BÉTULA, -Stamens 2 ; scales of fruit-bearing catlin thin, deciduous.

2. Auxus.-Stamens 4 ; seales of fout-bearing cathin woody, persistent.

Tribe 2. C'ORYLEE. - Staminate flowers in catkins; anthers tufted with hairs; carpellate flowers in pairs in axils of leafy bracts; orary 2-chambered; ovules 2. scales.

3. CARPínus.-Finiting spike with numerous leafy

4. Córylus. - Fruiting spilie with a few brown scales.

Tribe 3. Quercrnis.-Staminate flowers in catkins; carpellate flowers $1-3$ together in an involucre of numerous bracts, which enlarges in fruit; ovary 3 -6 chambered; oules 2 in each chamber.

5. Qúkrous. - Staminate florver's in a slender interrupted catkin; stiymas 3.

* (7. CASTÁNEA. - Staminate flowers in a long slender catkin ; stigmas 6 .

7. Fáaus.-Staminate flowers in a globose catkin ; stigmas 3 .

1. BÉtula (Birch).-Thees and shrubs; fowers all in catkins with 3 -lobed, deciduous scales; stamens 2, 
with forked filaments; anay compressed, 2-chambered, 2-ovuled; fruit small, winged, 1-seeded. (Name, the Classical Latin name of the tree.)

1. B.verrucósa (White Birch).-A beautiful forest tree which has been styled "the Lady of the Woods," with smooth, silvery-white bark, scaling off in transverse strips; copper-brown branches, often weeping; rhomboid, irregularly serrate leaves on long stalks, truncate at their base, and with raised veins on the

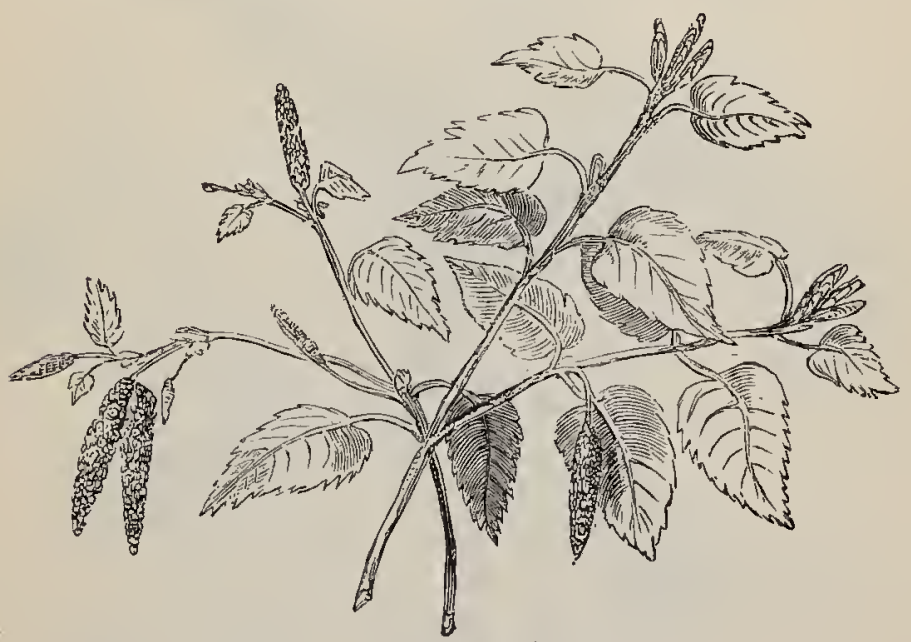

BÉTULA VERRUCósA (White Birch).

upper surface ; staminate catkins 1-2 in. long, pendulous; fruiting catkins sub-erect at first, deciduous. -Woods ; common.-Fl. April, May. Perennial.

2. B. pubéscens (Common Birch).-Often only a bush; twigs, and sometimes leaves, downy, or leaves glabrous and resinous; leaves always rounded at the base with the veins prominent on the under surface. -Woods; common.-Fl. A pril, May. Perennial.

3. B. intermédia, a small tree with leaves smaller, 
more orbicular, and more bluntly toothed than the preceding, and catkins only $\frac{1}{2}$ in. long, found in the Scottish Highlands, is probably a hybrid between the preceding and the following.

4. B. nána (Dwarf Birch). - A small shrub with

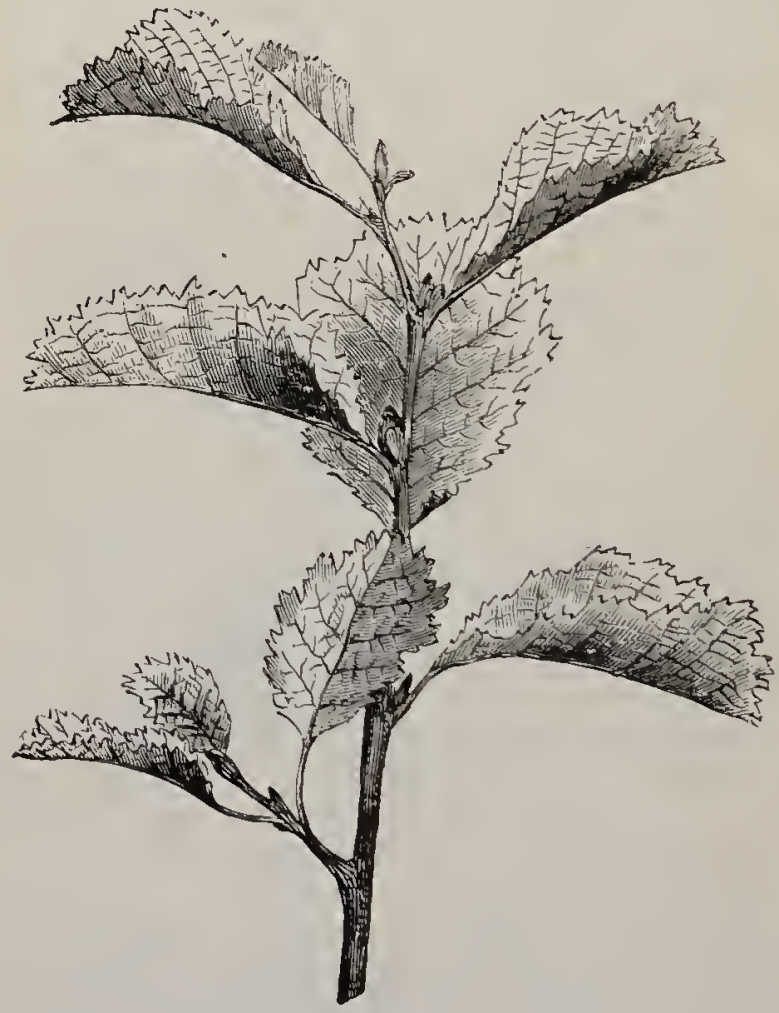

Sliver gutinósa (Common Alder)

short-stalked, roundish, crenate, glabrous darkgreen leaves, and cathins not more than $\frac{1}{2}$ in. lone.Mountain bogs in the north; rare. - Fl. May. 
2. Álnus (Alder).-Trees and shrubs; flowers all in catkins; stamens 3-5; frutting catkin short, with woody, persistent scales. (Name, the Classical Latin name of the tree.)

1. A. glutinósa (Common Alder). - The only

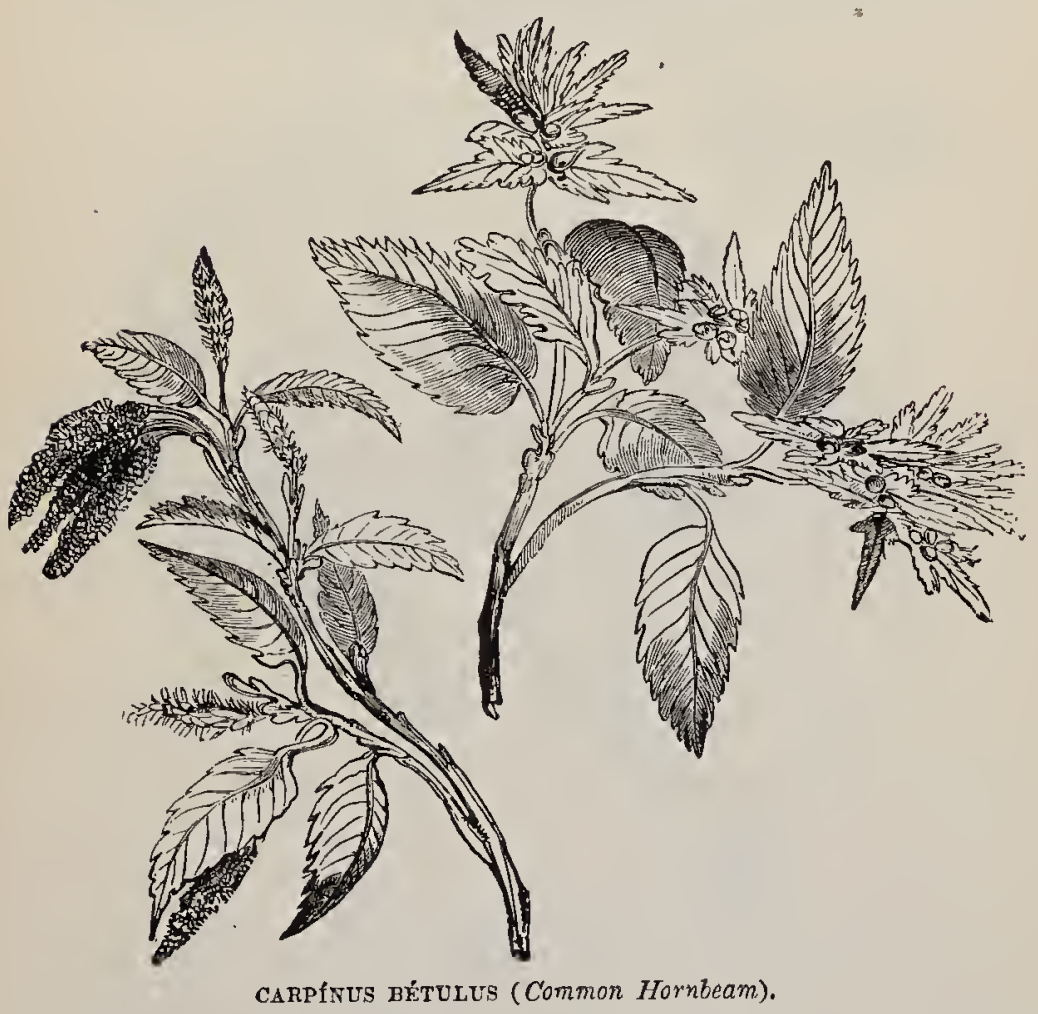

British species, a small tree with greyish-black bark; branches triangular when young; leaves shortly stalked, obovate, cuneate, blunt, wavy, serrate, glutinous when young, green on both surfaces; catkins appearing before the leaves, and the woody scales of the fruiting ones remaining long on the tree.-Swampy ground 
throughout most of the temperate regions of the globe.-Fl. March-April. Perennial.

3. Carpínus (Hornbeam). - Trees with deciduous leaves; staminate flowers in catkins; stamens 3-12,

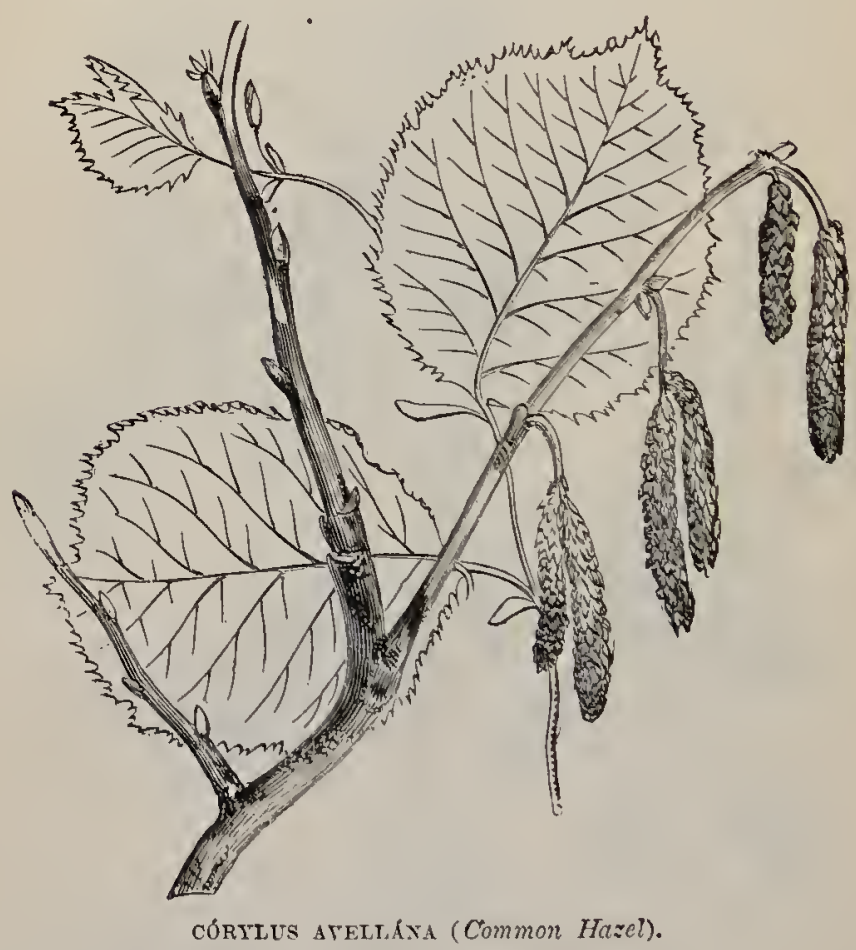

with forked filaments and tufts of hair on the anthers; carpellate flowers in pairs in the axils of leafy bracts, forming an erect spike in flower, becoming pendulous in fruit; ovary 2-chambered, 2-ovuled; styles 2. (Name, the Classical Latin name of the tree.) 
1. C. Bétutus (Common Hornbeam). - A small tree with smooth, light grey bark; elliptic-ovate, acute, doubly serrate, strongly plaited parallel to its pinnate veins when in bud; fruiting-catkins $2-4$ in. long, with large 3-lobed leafy bracts.-Clayey woods in the south; local. Valuable as fuel and for cogs. -Fl. May. Perennial.

4. Cónylus (Hazel).—Shrubs or trees with decidu-

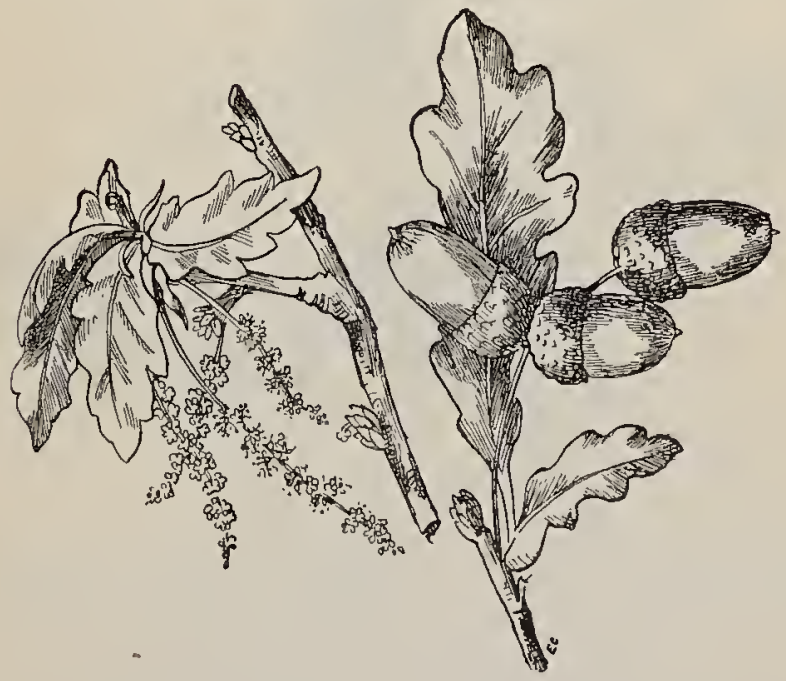

QUÉRCUS rórur (Common Oaki).

ous leaves; staminate catkins long, drooping, cylindric; stamens $4-8$, with short filaments and turfs of hair on the anthers; carpellate flowers in pairs in the axils of the upper bracts of a small head; ovary 2-chambered, 2-ovuled; styles 2, long, slender ; fruit a woody nut, enclosed in a withering leafy capsule. (Name, the Classical Latin name of the tree, from the Greek korus, a cup.) 
1. C. Avellána (Common Hazel).-A shrub or small tree with grey bark on stem, brown, hairy, and glandular on shoots; leaves roundish, obliquely cordate, irregularly serrate, pointed, plaited parallel to the midrib in bud; flowers preceding the leaves; staminate cattins 1-2 in. long, drooping, yellow ; carpellate flowers in small, sessile, ovoid, erect heads, with

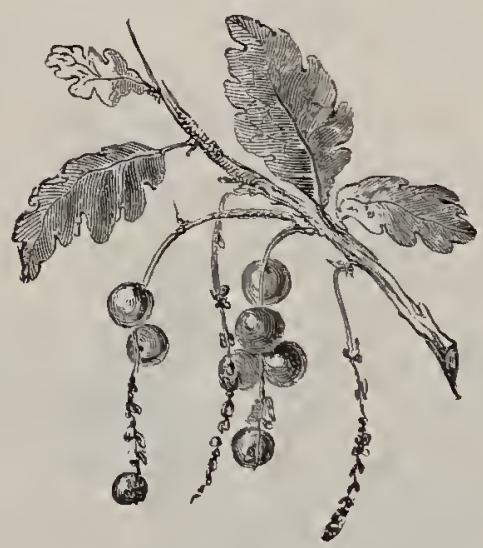

Currant-gails on the Oak.

imbricate bracts and crimson stigmas. - Woods; abundant.-Fl. February, March. Perennial.

5. Quḱrous (Oak).-Trees with deciduous (or, in forcign specics, evergreen) Teaves; staminate flowers in a slender, drooping, interrupted catkin ; stamens 10 , with slender, exserted filaments; carpellate flowers few, each enclosed in numerous imbricate scales, forming a cup in the fruit; ovary 3-chambered, 6-ovuled; fruit or acorn 1-seeded. (Name, the Classical Latin name of the tree.)

1. Q. Róbur (Common Oak).--A large tree, with deeply furrowed, corky bark; zigzag branches; obovate- 
oblong, sinuate leaves with blunt lobes, with or without stalks; flower's appearing with the leaves; cup with numerous, adpressed, triangular, blunt scales. There are three well-marked varieties: var. pedunculáta, the White Oak, with sessile leaves, downy beneath when young, and acorns on long stalks; var.

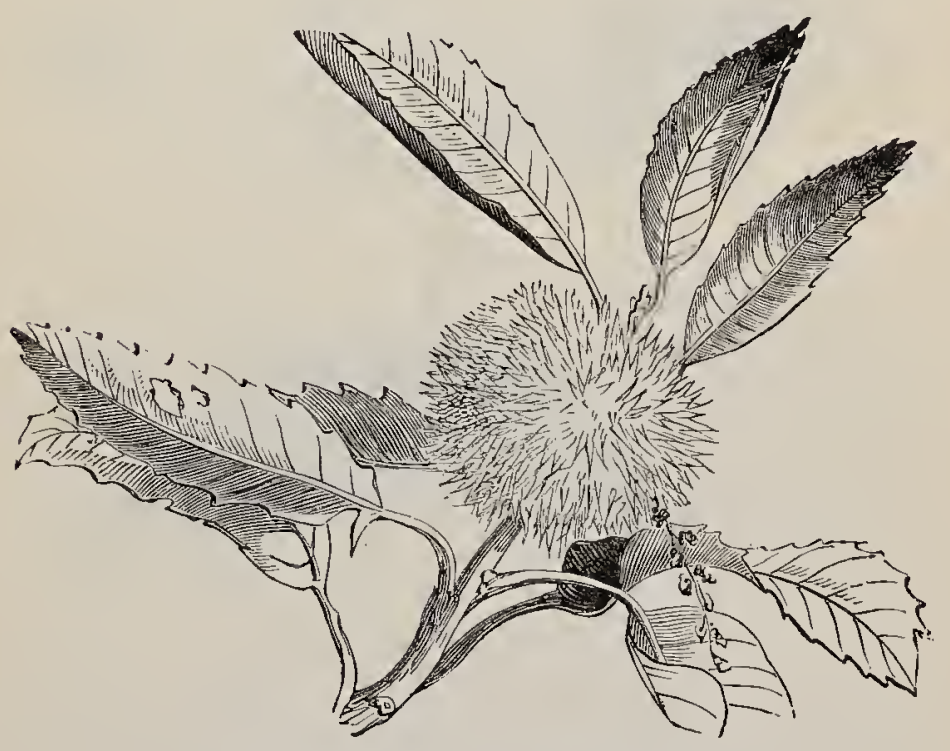

CASTÁNEA SATÍYA (Spanish Chestuut).

intermédia, the Durmast Oak, with short stalks to both leaves and acorns, leaves remaining always downy beneath, and very dark green acorns; and var. sessiliflóra, the Red Oak, with downy twigs, long leafstalks, leaves smooth beneath, and nearly sessile acorns.-Woods; common. 'The tree is attacked by numerous insects producing various galls, such as oak-apples, marble-galls, leaf -spangles, artichoke-galls, currant-galls, \&c.-Fl. April, May. Perennial. 
*6. Castánea (Chestnut). - Trees with long slender cathins, the staminate ones erect; stamens 8-20; carpellate flower's 3 together within a 4 -lobed, vely prickly cupule; stigmas 6 ; ovary 5-8-chambered;

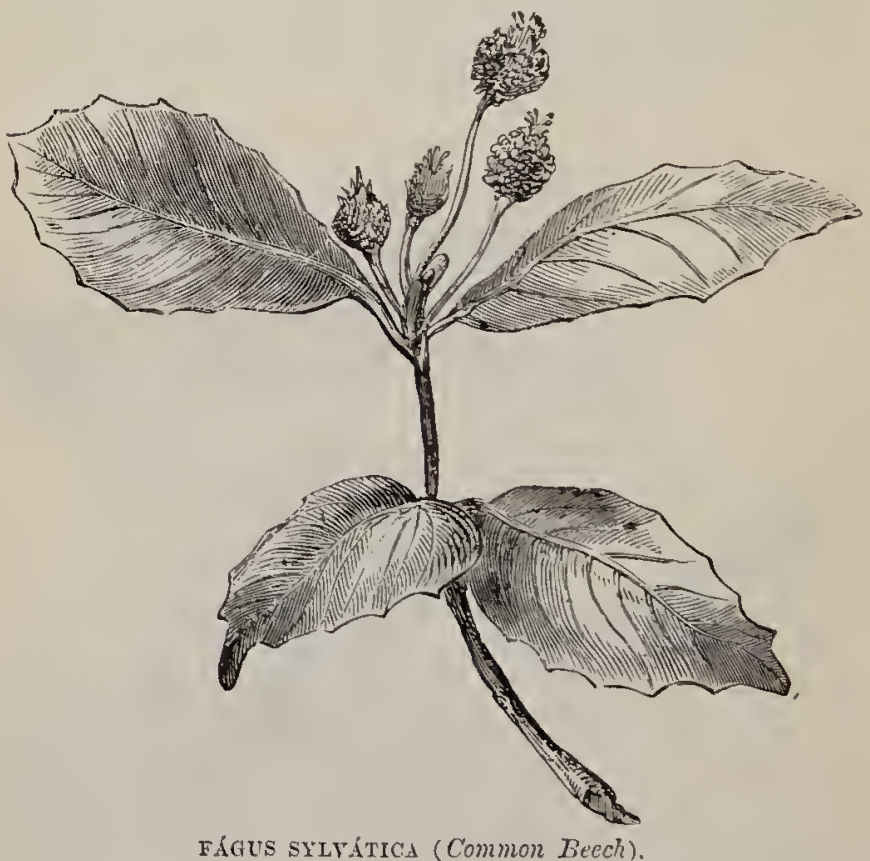

nut large, surmounted by 6-lobed perianth, 1-chambered, 1-3-seeded. (Name, the Clissical Latin rame of the tree.)

1.* C. sativa (Sweet or Spanish Chestnut).-A large and handsome tree with deeply furrowed kark; glossy, oblong-lanceolate leaves with bristly serrations; cathins 5-6 in. long.-Parks and plantations; common, but not indigenou.-Fl. May. Perennial.

7. Fíaus (Beech).-Trees with deciduous (or, in foreign species, evergreen) leaves; staminate catkins 
globose ; stamens 8-40, with slender, exserted filaments; carpellate flowers 2 -4 together within a 4 lobed, prickly cupule; stigmas 3 ; nut 3 -cornered, enclosed in the enlarged hardened cupule. (Name, the Classical Latin name of the tree.)

1. F. sylvática (Common Beech).-A large and beautiful tree with thin, smooth, olive-grey bark; long, pointed, chestnut-brown buds; glossy, ovate leaves, plaited parallel to the pinnate veins in the bud, silky when young.-Woods on dry soil, chiefly in the south.-Fl. April, May. Perennial.

\section{Ord. LXXXI. Salicíneæ.-Willow Family.}

A small Order of trees and shrubs of very obscure relationships, occurring mostly in the Arctic and North Temperate zone, the more northern forms being dwarf and shrubby. They have scattered, simpie, stipulate, deciduous leaves ; diœcious flowers in catkins, commonly appearing before the leaves; stamens 2-30; ovary 1-chambered; styles 2; ovules numerous; fruit a 2-valved, many-seeded capsule ; seeds covered with a tuft of silky hairs. The wood of Poplars and Willow grows in general so quickly that it is soft and of little value as timber; but it is used for cricket-bats, charcoal, and for paper-pulp. The flexible shoots of certain species of Willow, known as Osiers, are largely used as wicker-work; and the bark of many species is bitter and astringent, and contains an active principle known as salicine, which has some of the properties of quinine as a preventive of fever. There are only two genera in the Order.

1. Sálix. - Catkins usually erect; catkin-scales entire; stamens 2-5.

2. Pópurus.-Catkins drooping; catkin-scalescut; stamens $4-30$. 
1. Salix (Willow).--Trees or shrubs; leaves of various forms, but usually longer than they are broad, stalked, with prominent stipules; catkins usually erect or horizontal ; scales not cut; stamens 2-5, exserted; stigmas usually 2-lobed. (Name, the Classical Iatin name of the group.)

Shoots of these trees bearing catkins are popularly
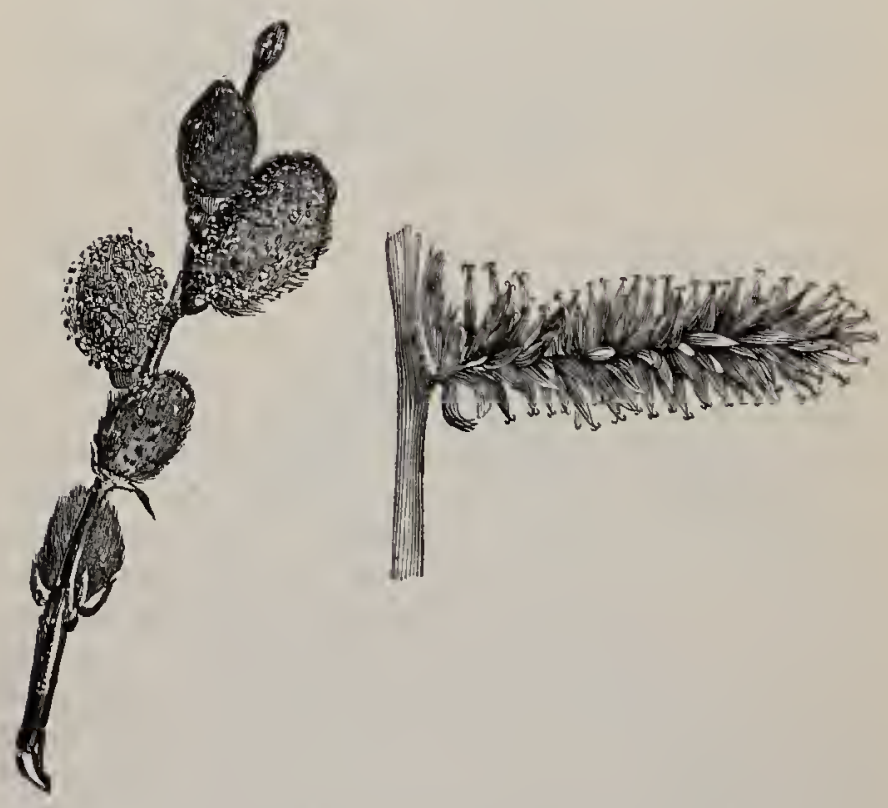

Staminate catkins of a Willow. Pistillate catkin of a Willow.

known as Palms, the staminate ones with their conspicuous yellow anthers, which mature about Eastertime, being called Gold Palm; and the carpellate ones corered with silky down, Silver Pussy-Palms. The 17 or 18 British species are somewhat variable: there is some difference in vegetative characters between the staminate and carpellate trees in each 
species; and the group is rendered one of the most puzzling in the plant world by the occurrence in a wild state of numerous hybrids. Only the leading types are here described.

* Leaves convolute; catkins moduced with the leaves; filaments free, hairy below; deciduous peduncle bearing leavss; capsule smooth. (Including the larger trees in the genus.)

1. S. pentándra (Bay-leaved Willow).-A shrub or tree, 6-20 feet high, with dark brown bark; handsome and fragrant broad, ovate, polished leaves, paler beneath; stamens 5 ; stigma 2 -fid.-River-sides in the north; frequent. The latest flowering Willow.-Fl. May, June. Perennial.

2. S. triándra (Almond leaved, French or Brown Norfolk Willow).-Naturally a tree 20-30 feet high, but cut down and treated as an osier; bark flaking; leaves oblong-lanceolate, 2-4 in. long, serrate, glalrous, paler beneath, with large stipules; stamens 3 . -River-banks and osier-beds; frequent-Fl. April, May. Perennial.

3. S. frágilis (Crack Willow, Withy).-Growing into a large tree with ascending, easily detached branches, but of ten treated as an osier; very smooth, highly polished, yellow, orange, or crimson bark; elliptic-lanceolate, serrate, glabrous leaves, 3-6 in. long, pale beneath, liairy beneath, with semicordate stipules; stamens 2; sigma 2-fid; capsule stalked.Osier-beds ; common.-Fl. April, May. Perennial.

4. S. álba (White or Huntingdon Willow, White Tree).-A large tree, but often pollarded, with furrowed bark; olive-green, silky, not easily detached twigs; lanceolate, acuminate leaves $2-4 \mathrm{in}$. long, silky on both surfaces, with small, ovate stipules ; stamens. 2; stigma 2.fid, recurved; capsule nearly sessile. The Golden Willow (S. vitellina) is a form with bright 
yellow twigs. - Wet places; common, but often planted.-Fl. April, May. Perennial.

*** Shrubs and small trees, mostly known as Sallou's or Osiers; cathins sessite when in flower; bracts on peduncle small or absent; cathin-scales discoloured at the tip; stamens 2 ; capsule sithy.

5. S. purpúrea (Purple Osier, Bitter Willow).A shrub with slender, tough twigs; dark red or purple bark; cathins appearing before the leaves, with purpleblack hairy scales; leaves folded equitantly in bud, lanceolate, serrate, glabrous; stamens 2, united; anthers purple, becoming black.-River-banks and marshes ; frequent.-Fl. April, May. Perennial.

6. S. viminális (Common Osier).-A shrub or small tree, with long, slender branches, silky when young, then polished; cattins appearing long before the leaves, with brown scales; leares linear-lanceolate, acuminate, 4-10 in. long, with revolute, wavy margins, silky beneath, with small, lanceolate stipules; stamens 2 ; anthers yellow; style long.-Wet places and osier-beds; common.-FI, April-June. Perennial.

7. S. Lappómem (Downy Mountain Willow).-A d warf shrub, with stout, brown branches; woolly buds; cathins preceding the leaves, with black scales with long, white hairs; Teaves elliptic-lanceolate, shaggy on both surfaces, with revolute margins and small or absent stipules; stamens 2 ; anthers yellow.-Highland mountains ; rare.-Fl. June, July. Perennial.

8. S. Cáprea (Goat Willow, Great Sallow).-A small tree, with smooth buds; cathins preceding the leaves, with hairy scales black at the tip; leaves broad, ovate, flat, with wavy, crenate-serrate margins, cottony beneath; stamens. 2 ; anthers yellow ; style very short; capsule with a slender stalk.-Dryish places; common.-Fl. April, May. Perennial. 
9. S. aurita (Round-eared Sallow).-A form closely allied to the following, distinguished by its small size, not exceeding 4 feet in height; reddish twigs; much wrinkled, obovate leaves, downy on both surfaces, reddish when young, with large, kidney-shaped, stalked stipules.-Damp roods; common._Fl. A pril, May. Perennial.

10. S. cinérece (Common Sallow).-A large shrub or small tree, closely allied to $S$. Cáprea, but witl downy buds and twigs; glaucous, obovate-lanceolate leaves, with reddish-brown hairs beneath, and large, semicordate stipules; anthers pale yellow. - Damp places; common. The earliest flowering British Willow.-Fl. March, April. Perennial.

11. S. phylicifólia (Tea-leaved Willow).-A handsome bush or small tree with spreading, bright chestnut branches and shining green leaves, glaucous beneath, ovate, with very small or absent stipules; catkins sessile, with black, acute scales; style long; capsule stalked.-By mountain streams in the north.-Fl. April-June. Perennial.

12. S. Arbúscula (Small Tree Willow). -A small, stiff, prostrate shrub, with yellow, downy twigs, becoming brown; ovate, smooth, fnely serrate leaves, silky and glaucous beneath; sessile, bracteate catkins, with rounded, reddish, downy scales, preceding the leaves; style long; capsule nearly sessile.-Scottish mountains ; rare.-Fl. June, July. Perennial.

13. S. répens (Dwarf Silky Willow).--A small, straggling bush with slender branches; silky buds; small leares, variable in shape, silky when young and on the under surface, shining above, with revolute margins and lanceolate or absent stipules; catkins short, on leafy peduncles, with silky scales; anthers yellow, becoming black; style short; capsule stalkerl. -Heaths; common.-Fl. April, May. Perennial.

14. S. lanáta (Woolly Broad-leaved Willow).-A beautiful little shrub with zigzag branches; downy 
twigs; large, black, hairy buds; broadly oval, leathery leaves, shaggy beneath, with large, semicordate stipules; and catkins with long, golden hairs.-Occurs by mountain streams in the North of Scotland; rare.Fl. May, June. Perennial.

\section{**** Small bushes; catlens on long leafy, not deciduous shoots; stanens 2.}

15. S. Myrsinites (Whortle-leaved Willow). -A small, stiff shrub with silky shoots; small, stiff, dark green, glossy, serrate, short-stalked leaves; catkinscales blackish ; capsules hairy.-Highland mountains ; rare.-Fl. June, July. Perennial.

16. S. herbácea (Least Willow).-A minute, herblike shrub with its stems spreading amongst stones or under the turf and sending up short twigs, 2-6 in. high, with brown buls a few round, blunt, serrate, slining, ciliate leaves; and small terminal catkins on 2-leaved peduncles. - Lofty mountain tops; not uncommon.-Fl. June. Perennial.

17. S. reticuláta (Reticulate Willow).-A similar, but lirger, buried form, much branched, with leaves strongly netted with veins on both surfaces; and much larger, subterminal catkizs on long leafy peduncles.-Scottish Highland mountains; rare.Fl. June-August. Perennial.

2. Pópului (Poplar).-Large trees with broad leaves on long vertically compressed stalks; drooping catkins with jagged scales; dish cup-shaped; stamens 4-30, not united ; stigmas 2-4-lobed. (Name, the Classical Latin name of the tree and, in spite of a difference in the quantity of the $o$, considered in both ancient Rome and modern France to be the tree of the people.)

1. P. álba (White Poplar, Abele).-A large tree 
with smooth grey bark; many suckers; spreading branches; downy buds and shoots; lecves cottony and snowy white beneath, cordate, more or less palmately lobed ; stamens 6-10; anthers red ; stigmas cruciform,

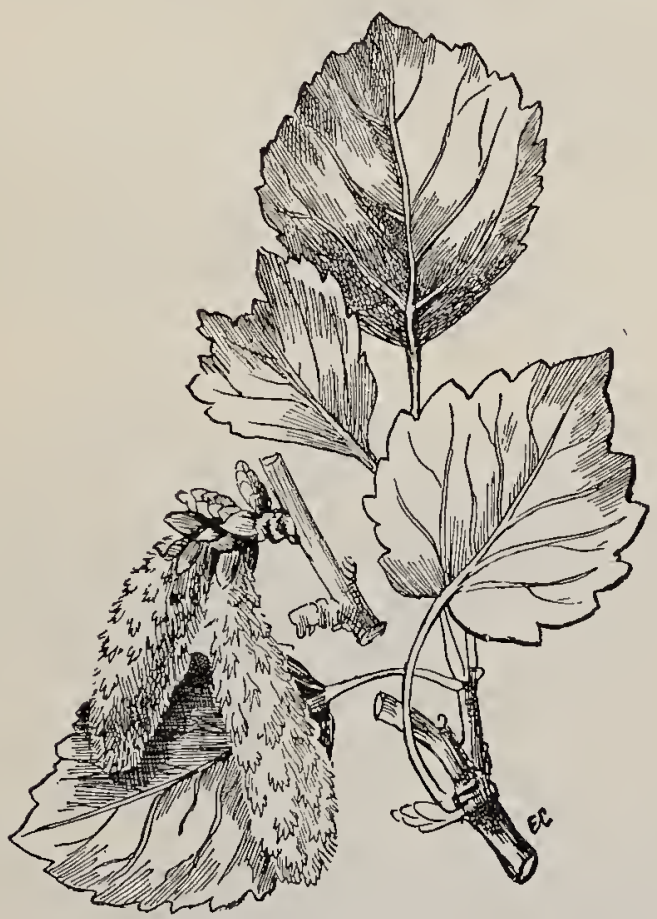

Pópulus thémula (Aspen).

yellow.-Damp woods ; frequent, but often planted.Fl. March, April. Perennial.

2. P. canéscens (Grey Poplar).-Leaves not lobed, with the exception of the youngest, slightly cottony and grey beneath; stigmas 2, wedge-shaped, 2--4lobed, purple.-Damp woods ; not common. Possibly a hybrid between the preceding and the following species.-Fl. March, April. Perennial. 
3. P. trémula (Aspen).-A tree with grey bark; many downy suckers; spreading branches; downy buds and shoots; leaves nearly round, acute, cordate, serrate, glabrous on both surfaces, or downy when young; stigmas 2, 2-fid, erect.-Woods ; common.Fl. MIarch, April. Perennial.

4. P. nígra (Black Poplar).-A large tree with grey bark; no suckers; spreading branches; sticky buds; glabrous shoots; rhomboid, serrate leaves, glabrous on both surfaces, silky beneath when young; stamens 12-20; anthers red; stigmas 2, roundish, 2-fid. - River-banks; not indigenous.-Fl. March, April. Perennial.

\section{Class II. MIONOCOTYLEDONS.}

In the plants belonging to this Class the embryo of the seed has only a single cotyledon or seed-leaf. Though in their earlier stages Palms develop a radicle or tap-root, no British representatives of the Class do so; nor, with the one exception of the Butcher's Bronm (Ruscus aculeatus), do they form woody stems. They have generally bunches of fibrous roots; their stems are often bulbs or corms, and are not commonly much branched. Internally there is no distinct pith, separable bark, or anmual rings of wood or bast, the vessels being grouped in scattered bundles whicli are most numerous near the outside of the stem, which, in consequence, is hardest near the exterior and sometimes hollow in the centre, especially among the Grasses. The leaves are generally simple, entire, and smooth, with parallel veins, or a regular network formed by transverse veins which are much finer than the longitudinal ones. The flowers are often destitute of a perianth, the place of which is supplied by hard, chaffy scales known as alumes. The sepals and petals, when present, the 
stamens and the carpels are generally 3 , or some multiple of 3 , in number.

Sub-Class I. PETALOÍdE Æ.

Flowers usually furnished with a petaloid and coloured, not a green or glumaceous, perianth.

Series I. EPÍGYNA.-Ord. IXXVII.-LXXXI.

Perianth superior; ovary inferior.

Ord. LXXVII. Hydrocharídee.-The Frog-eit Family.

A small Order of aquatic plants, often floating, with conspicuous, polysymmetric, diœcious flowers, enclosed, when in bud, in a sheath, or spathe; sepals 3 , green; petals 3 ; stamens $3-12$; carpels $3-6$, united into an inferior, 1- or many-chambered ovary; style 1 ; stigmas 3-9; fruit indehiscent, generally a berry, 1- or manychambered. Only three members of the Order occur in Britain, belonging to three different genera.

*1. ELLodÉa. - Leaves submerged, linear, whorled.

2. Hydrócharis.-Leaves orbicular, floating.

3. Stratrótes.-Leaves submerged, sword-shaped, serrate.

*1. Eimonéa camadénsis (American Water-weed, Water-thyme).-A submerged, dark green, translucent plant, with a long, slender, branching, brittle stem, rooting at its nodes ; leaves in whorls of 3 , linearoblong, fnely serrate; flowers floating, small, pink, dicecious, only the carpellate form commonly occurring, 
which has a very slender perianth-tube 4-8 in. long; 3 sepals; 3 petals ; 3 staminodes; ovary 1-chambered; style slender; stigmas 3 , ligulate.-Rivers, canals, and ponds; common. Introduced from America between

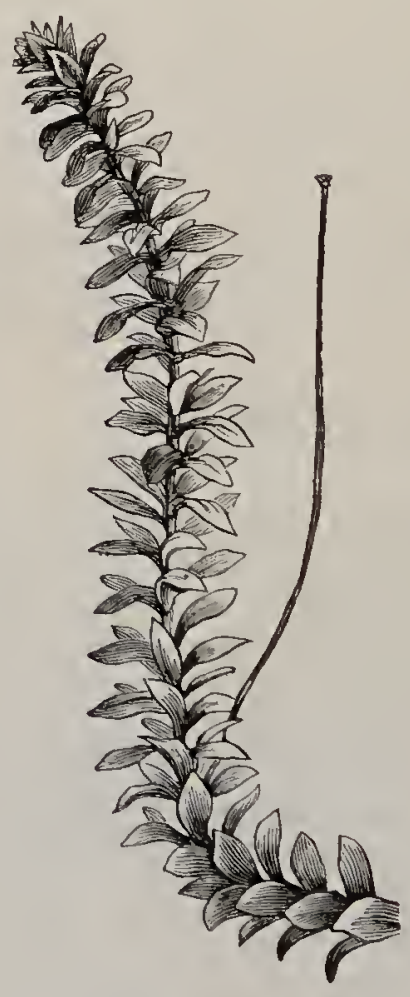

WLODEa CANADÉxsLS (American Hater-weed).

1836 and 1841. (Name from the Greek holodes, swampy).

2. Jyorócharis (Frog-bit), represented only by the one species $H$. Mórsus-ránce, a floating plant with 
creeping stems; roundish, cordate, stalked, floating leaves; and delicate white flowers which grow $2 \ldots 3$ together from a.pellucid 2-leaved spathe; stamens

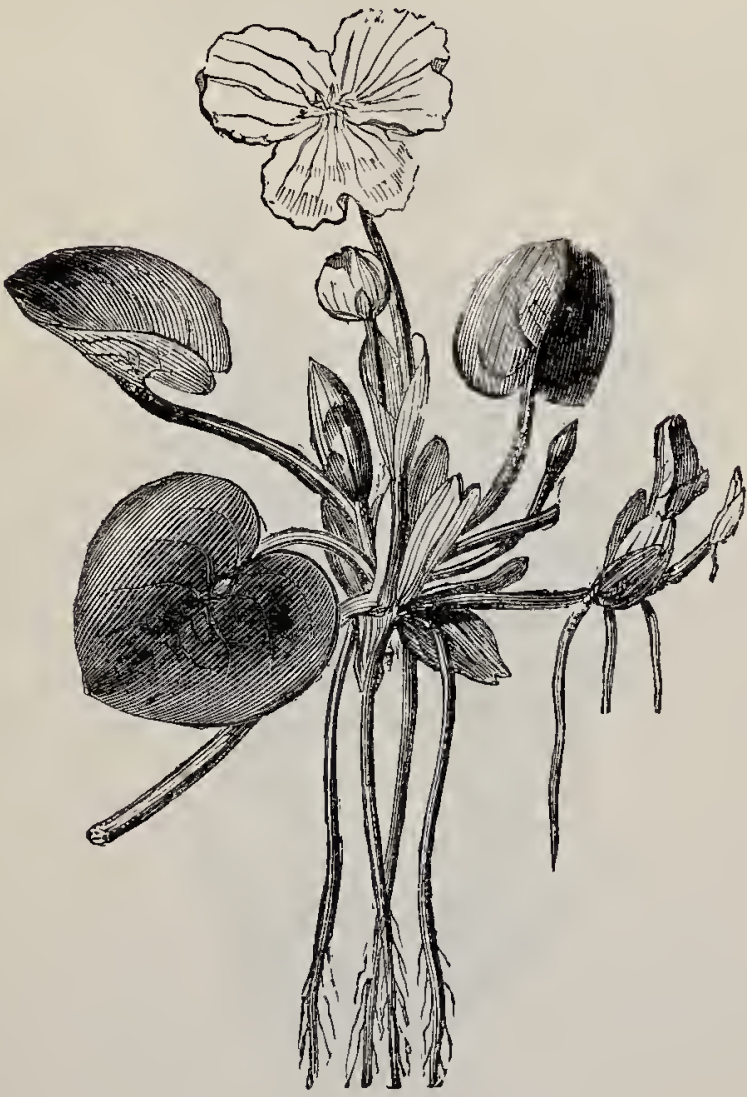

HYDRóCHARIS MÓRSUS.RÁN王 (Frog.bit).

9 -12; ovary 6 -chambered, many ovules ; styles $6 .-$ Ponds and ditches; not general. The cells of the seed-coat gelatinise in water and emit their spiral thickening. (Name from the Greek húdor, water, and cháris, elegance.)-Fl. July, August. Perennial. 
3. Stratiótes (Water Soldier), represented only by the one species $S$. aloïdes, a submerged plant. with runners creeping in the mud; its leaves all radical,

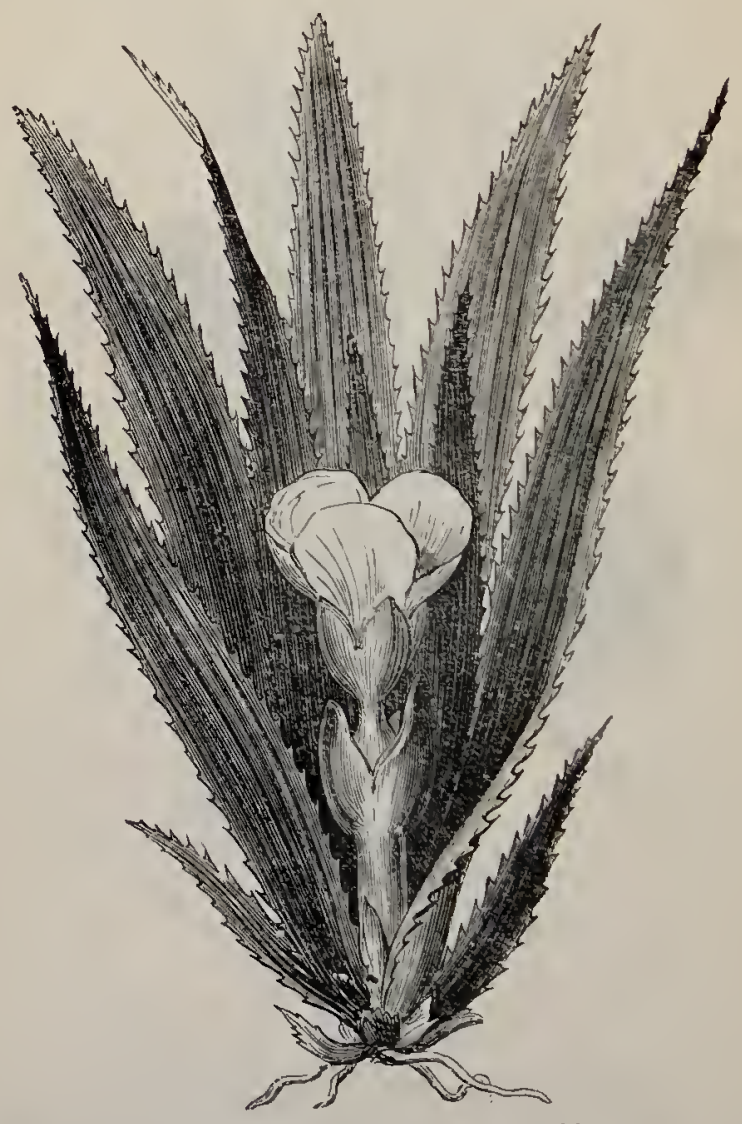

STRATIÓTES ALÓIDES (Water Sớdicr).

stiff, ascending, sword-shaped, spinously serrate like those of an Aloe, brittle, dark green ; flower-stalk 5-6 in. high, bearing at its summit a 2-leaved sleath, containing either several delicate white staminate flowers. 
each with 12 or more stamens and numerous staminodes, or one carpellate flower with 62 -fid styles and a 6-chambered, many-ovuled ovary.-Ponds and ditches in the North and East of England; rare. 'The plant rises to the surface before flowering and then sinks to the bottom. (Name from the Greek stratiótes, a soldier, from the sword-like leaves.)-Fl. June-August. Perennial.

Ord. LYXVIIT. Orchídez.-The Orchid Family.

A very extensive and most interesting Order of perennial herbaceous plants. They are to be found in all climates except the very coldest and driest; but are most abundant in hot, damp, equatorial regions, where they exist in the greatest profusion, not, as in temperate climates, deriving their nourishment from the earth, but from the moisture in the air. These epiphytes, as they are termed, cling to the trunks and branches of trees, to the stems of large ferns, or to the bare rock. In many of them the large and often gorgeously-coloured flowers are the only conspicuous part of the plant. They have greyish-green aerial roots which are furnished with a peculiar superficial structure adapted to the absorption of atmospheric moisture, and clustered, elliptical branches known as pseudobulbs, from the summit of which spring a few green, leathery leaves, and slender peduncles which hardly seem capable of producing the numerous blossoms, beautiful in form and colour, which they are destined shortly to bear. The British species have mostly rounded or palmate root-tubers, two or more glossy sheathing leaves, and a simple spike or raceme of flowers, which are in most cases red, pink, white, or greenish. They have 3 sepals, often petaloid; and 3 petals, the lowest unlike the rest, and frequently spurred. The structure of this lower lip of the 
corolla, or labellum, is often most singular, resembling some insect or presenting a fantastic caricature of some more important member of the animal kingdom. "There is," says Lindley, "scarcely a common reptile or insect to which some of them have not been likened." The stamens are united to the style into a central columm, only one, or rarely two, of them producing pollen, which, though sometimes powdery, is commonly united into 2 club-shaped masses, or pollinia, one in each chamber of the anther. The ovary is inferior, and often so twisted as to invert the flower, and so long as to be mistaken for a pedicel; it is 1-chambered, with 3 parietal placentas. 'The stigma is a viscid hollow in front of the column; and the fruit a 3-valved, many-seeded, capsule. The floral structure of the Order is, in spite of the raried form of the labellum, very uniform, and, in most species, clearly adapted to secure insect-pollination. The flowers have, in many cases, powerful odours and secrete honey; but in the spurred forms this honey is within the tissue of the spur, instead of being, as in other groups, in the cavity of the spur. The insect seeking honey is thus delayed by the necessity of boring for it, and meanwhile the stickiness of a gland, or retinaculum, at the base of the pollinium has time to set on the insect's head. The whole pollinium is thus removed from the anther, and, in some cases, while being borne to some other blossom, it bends, so as more effectually to strike against the stigma. As only a part of the pollinium is torm off by the viscidity of the stigma, the insect may thus pollinate many blossoms. The spur of Anqrécum sesquipedálé, a nativo of Madagascar, is no less than 9 inches long; but, as foretold by Darwin, hawk-moth has been found in the same island with a proboscis of even greater length. In some species the labellum is irritable. In Caleana nigrita, for instance, the column is a boat-shaped box resembling a lower lip, and the labellum forms a lid 
that exactly fits it, and is hinged on a claw which reaches the middle of the column. When the flower opens, the labellum turns round within the column, and falls back, so that, the flower being inverted, it stands fairly over the latter. The moment a small insect touches its point, the labellum makes a sudden revolu. tion, brings the point to the bottom of the column, and thus makes prisoner for a time any insect which the box will hold. With the exception of Vanilla, the long, dried pods of Vanilla planifólia and other species of that climbing genus, which is now extensively cultivated throughout the Tropics for the sake of the crystallisable aromatic substance vanillin, which renders it valuable as a flavouring for chocolate and other sweetmeats, no plant of this Order is extensively used in the arts. On account of their beauty and singular aspect, however, great attention has of late years been paid to the cultivation of exotic orchids; and by imitating their natural conditions of heat and moisture great success has been attained. If an orchid-house be well managed, some one or other of these curious air-plants may be seen in bloom at all seasons of the year, clinging to bits of wood or virgin cork, or simply suspended by wires from the roof.

\section{* Anther 1 only.}

1. MaLáxis.-A leafy plant; flowers stalked, not inverted; lip posterior, not spurred, entire; column short; pollinia 4, waxy, on one gland.

2. Líraris. - Leafy plants; flowers stalked; lip. anterior, not spurred, entire; column long; pollinia 4 , waxy.

3. Corallorhíza. - Brown saprophytes; flowers stalked, yellowish-green; lip anterior, 3-lobed, minutely spurred, white with red spots; cotumn short; pollinia 4 , free. 
4. Neótria.-Brown saprophytes; flowers stalked, light brown, hooded ; lip anterior, 2-lobed, pouched; column long; pollinia 2 , united; pollen powdery.

5 . Lístrera.-Leaves 2, opposite ; flowers stalked, green ; lip anterior, 2-4-lobed, not spurred; column very short; pollinia 2 , united; polten powdery.

6. SpIRÁnthes. - Leafy plants; flowers not stalked, in a spiral spike; lip anterior, not spurred, entire; pollinia 2, united; pollen powdery.

7. Goonxíra.-Leafy plants; flowers not stalked, in a spiral spike; lip anterior, pouched, entire ; pollivia 2, united; pollen loosely coherent.

8. Eprpóauxr-Brown saprophytes; flowers stalked, pale yellow, not inverted; lip posterior, 3-lobed, with a short, inflated spur; pollinia 2, united; pollen granular.

9. Cephaláxthera. - Leafy plants; flowers not stalked, erect, lip anterior, constricted and lobed, pouched; colxmn long; pollinia 2 , united; ovary twisted.

10. Fipipáctis. - Leafy plants; flowers stalked, drooping; lip anterior, constricted and lobed; column short; pollinia 2, united; ovary straight; pecticet twisted.

11. Orchis.-Leafy plants; flowers not stalked, hooded; lip anterior, 3-lobed, spurred; pollinia 2, distinct, with their glands in one pouch.

12. Áceras.-Leafy plants; flowers not stalked, hooled; lip anterior, 4-lobed, not spurred; pollinice 2, with their glands in one pouch.

13. OPHRxs.-Leafy plants; flowers not stallied; lip anterior, variously lobed, not spurred; pollinia 2, with their glands in distinct pouches.

14. Hermíniun.-Leafy plants; flowers not stalked; lip, anterior, 3-lobed, pouched; pollinia 2, distinct, on naked glands.

15. Habeníria.-Leafy plants; flowers notstalked; hooded; lip anterior, spurred; pollinia 2 , distinct, ou naked glands. 
16. Cypripédum.-Leafy plants; perianth spreading; lip large, inflated; pollen granular; ovary not twisted.

1. Matáxis (Bog Orchis), a genus containing only the one species M. paludósa, the smallest British orchid, 2-4 in. high, with angular stem; $3-5$ oval leaves, fringed with bulbils that grow into new plants; and numerous minute, yellowish-green flowers on twsited stalks, in a dense raceme.-In bog-moss; uncommon. Glowing as an epiphyte on the moss, and easily overlooked. (Name from the Greek malaxis, softening.) - Fl. July-September. Perennial.

2. Líparis.-- Very similar little plants, with usually only 2 leaves, inverted flowers on twisted stalks and a longer, slender column. (Name from the Greek liparos, greasy.)

1. L. Loesélii (Two-leaved Liparis, Fen Orchis).The only British species, with 2 oblong-lanceolate, acute, stalked, radical leaves ; a triangular peduncle, $4-8 \mathrm{in}$. high; and $6-12$ yellowish flowers on twisted pedicels in a loose raceme.-On bog-moss in the eastern counties; vely rare. An epiphyte.-Fl. June, July. Perennial.

3. Corallorhíza (Coral-root). - Brown plants, living in decaying vegetable matter, without true roots or leaves, but with a fleshy underground stem with interlacing branches resembling coral; brown, sheathing leaf-scales; a few small, stalked flowers, with a 3-lobed $l i p$ with a minute spur united to the ovary; a short column; and 4 distinct pollinia. (Name from the Greek korallion, coral, rhiza, root.) 
1 C. innata (Spurless Coral-root).-The only British species, a curious brown plant, 6-10 in. high,

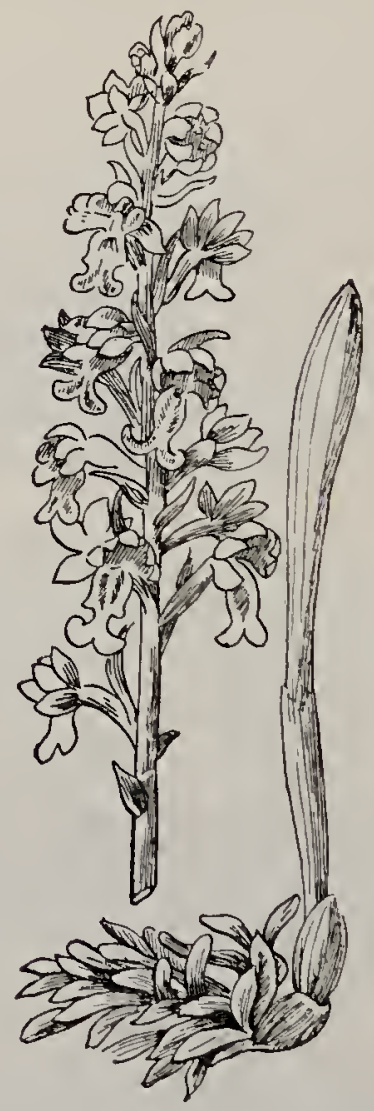

NEOTTIA NIDUS-ATIS (Bird's-nest Orchis).

with a few leaf-scales and a loose raceme of $4-8$ small, yellowish-green flowers with a white lip with red warts on it.-Boggy woods in Scotland; very rare.-Fl. July, August. Perennial. 
4. Neótria (Bird's-nest Orchis).-Brown saprophytes, with sheathing leaf-scales; flowers brown, in a raceme; sepals and lateral petals forming a hood; lip

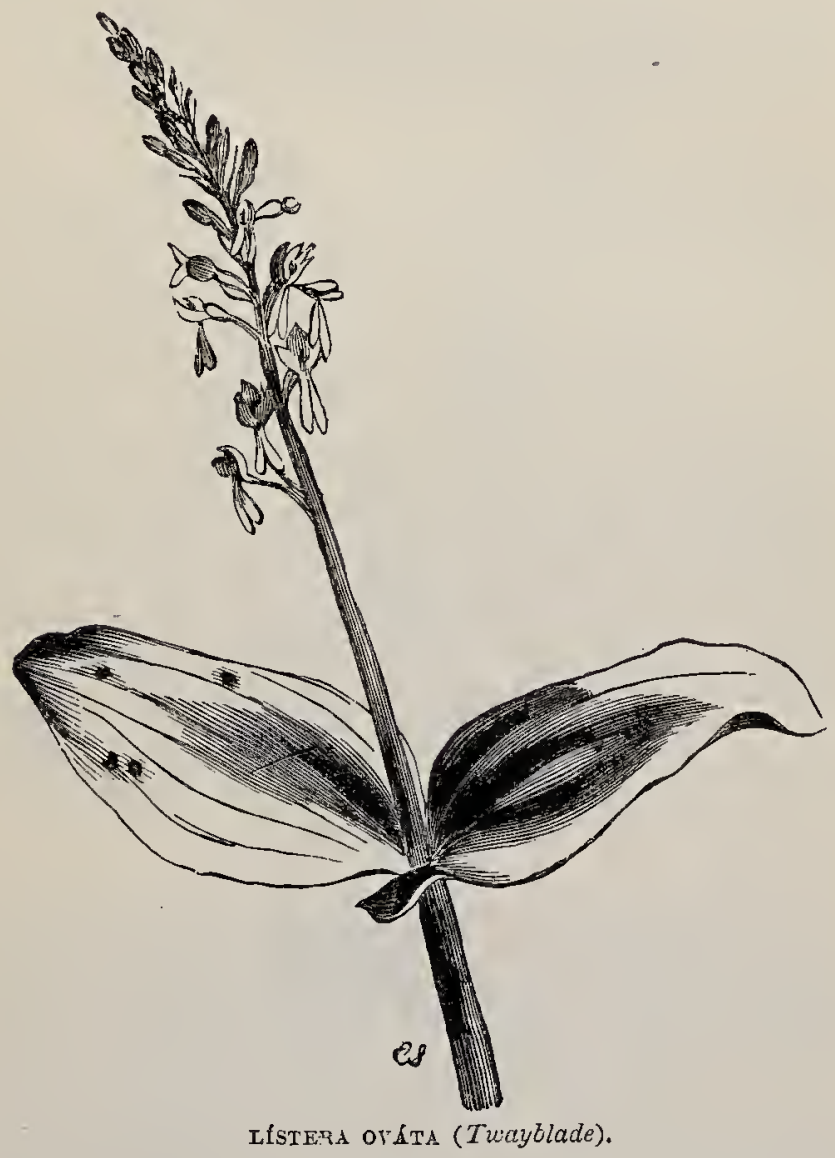

2-lobed, puched at its base. (Name from the Greek neottia, a bird's nest, from the interlacing fleshy roots.)

1. N. Nidus-avis (Bird's-nest Orchis).-The only 
British species, a pale brown plant, about a foot high, with a root of many interlacing fleshy fibres, from the extremities of which the young plants are produced; numerous brown leaf-scales and brown, stalked flowers. - Shady woods, especially among fallen Beech leaves; frequent.-Fl. June, July. Pcrennial.

5. Lístera (Twayblade).-Root of fleshy fibres; leaves 2, opposite; flowers stalked, green; sepals and lateral petals spreading; lip anterior, 2-4-lobed, not spurred. (Named in honour of Dr. Martin Lister, an English naturalist.)

1. L. cordáta (Lesser or Heart-leaved Twayblade). -A small, glabrous plant, 4-8 in. high ; stem angular, slender ; leaves sessile, membranous, orate-cordate, acute ; flowers few, small, greenish, in a loose raceme ; lip 4-lobed.-Hountain moors; uncommon.-Fl. June -September. Perennial.

2. L. ováta (Twayblade).-A coarse, pubescent plant, $1-2$ feet high, with a tapering stem round in section; large, broadly ovate, strongly ribbed leaves; and a long raceme of yellowish-green flowers with a 2-lobed lip.-Woods and orchards; common.-Fl. May_July. Pcrennial.

6. Spikínthes (Lady's Tresses).--Root tuberous; stem leafy; flowers in a spirally-twisted spike; tip not spurred, united to the base of the column; pollen powdery. (Name from the Greek speira, a spiral, anthos, a flower.)

1. S. autumnális (Autumn Lady's Tresses).-Root of 2 or 3 ovoid tubers; stem 4-8 in. high, slender, slightly pubescent; radical leaves ovate, acute ; flowers in a close spiral, white, fragrant in the evening.Dry downs; not uncommon. The flowers are arranged n a single row and the spiral turns either from left to 
right or from right to left. The leaves form a tuft just above the crown of the root, and wither before the flowers begin to expand. These are succeeded by

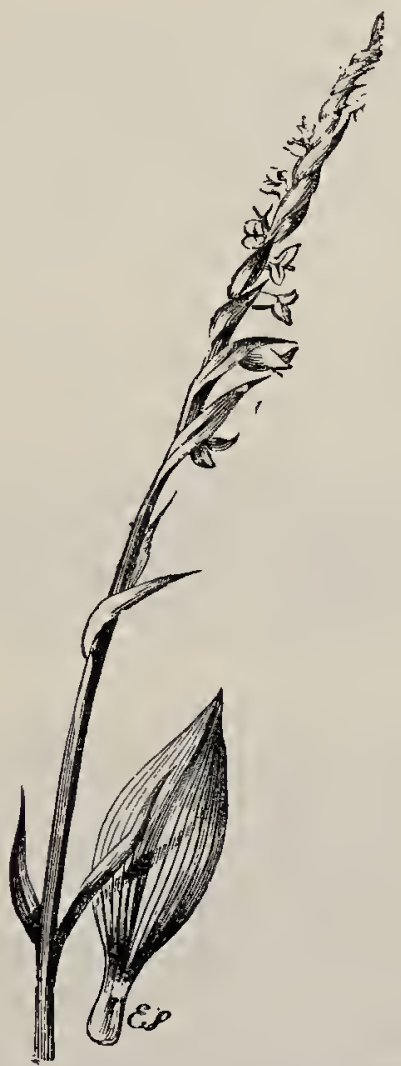

sPIRÁNTHES AUTUMnális (Autumn Lady's Tresses):

a tuft of new leaves which arise from the base of the old stem.-Fl. August-October. Perennial.

2. S. cestivális (Summer Lady's Tresses).—Root of several cylindrical tubers; stem 6-18 in. high, glabrous; radical leaves on the flowering stem, not in 
a lateral rosette; flowers more numerous, larger and more loosely arranged than in the preceding.-Bogs in the New Forest and Wyre Forest, Worcester; very rare.-Fl. July, August.

3. S. Romanzoffiána, a stout, leafy species, with much larger flower's in 3 spiral rows, is found in the south-west of Cork.-Fl. August, September. Perennial.

7. Goodyéra,-Closely allied to Spiránthes, but with a creeping rhizome, generally stalked leaves, and a pouch at the base of the lip. (Named in honour of John Goodyer, an English botanist of the 16th and 17 th centuries.)

1. G. répens (Creeping Goodyera).-A creeping species with a slender stem $4-8$ in. high; stalked, ovate, acute leaves with a network of veins, pubescent below ; flower's small, white, in a slender, spiral spike with linear, appressed bracts and glandular hairs.Fir woods, chiefly in East Scotland.-Fl. July, August. Perennial.

8. Eprógum, represented by one species, $E$. aphýllum, is a brown saprophyte with stalked, pale yellow flowers which are not inverted, and have a short inflated spur to their lip.--It has only once been found in a damp wood in Herefordshire. (Name from the Greek epi, up, pogón, lip, the lip of the flower being uppermost.

9. Cephalánthera (Helleborine). - Leafy plants with a creeping whizome; nearly distichous leaves; flowers in a few-flowered spike, not stalked, erect; lip anterior, constricted, lobed, and pouched; column long; ovary twisted. (Name from the Greek kephaté, head, anthera, anther, the anther forming a hend to the column.) 
1. C. rúbra (Red Helleborine).-A slender plant about a foot high, with lanceolate acute leaves and red flowers with downy ovaries shorter than the bracts.Woods on limestone in Gloucestershire; very rare. -Fl. June, July. Perennial.

2. C. ensifólia (Narrow-leaved Helleborine).-A very similar but taller plant, with white flower's and smooth oudries which are longer than the bracts.Woods ; local.-Fl. May, June. Perennial.

3. C. pállenis (White Helleborine).-Stem 1-2 feet high ; leaves 3-6 in. long, ovate-oblong, upper narrower; flowers rather large, milk-white, cup-shaped, in a loose spike; ovary smooth, shorter than the bracts. -Woods on calcareous soil ; rare.-Fl. June. Perennial.

10. Epipáctis (Helleborine). - A genns closely allied to the preceding, but with drooping flowers on twisted pedicels, with short columns and straight otaries. (Name of Greek origin, but of uncertain application.)

1. E. latifólia (Broad-leaved Helleborine).-Stem 1-3 feet high, solitary, downy ; leaves broadly ovate, ribbed; flowers green with a red lip, shortly stalked, in a long, loose, 1-sided raceme; tip of lip roundishcordate with a small recurved point; ovary downy, shorter than the green bracts.--Hilly woods; common.--Fl. August. Perennial.

2. E. méclia, a closely allied form, with longer and narrower leaves and tip of lip triangular-cordate, acute.--Woods; local.-Fl. August. Perennial.

3. E. violácea, another closely allied form, has many clustered stems, which, together with the leaves, are much tinged with red; yellow-green flowers tinged with pink; and the tip of the lip triangular-ovate, acuminate.-Woods in the South of England; rare.Fl. August. Perennial. 
4. IS. atrorítens (Dark-flowered Helleborine).Stem solitary, about a foot high; with smaller, oratelanceolate, acute leaves; flowers small, varying from dark yellow to a dingy blackish-red; tip of lip broader than long, rounded. with a short, abrupt point.Limestone cliffs, chiefly in the north; rare.-Fl. July. Perennial.

5. E. palústris (Marsh Helleborine).-Stem about a foot high, downy; leares lanceolate-acute: flou'ers few; sepals green, striped with red; petals white, striped with red; tip of 7 ip blunt, crenate; bracts shorter than the flowers.-Marshes; not uncommon. -Fl. July, August. Perennial.

11. Órchis. - Herbaceous plants with tuberous roots; leaves mostly radical, sessile, and sheathing; flovers not stalked, with a hood formed of the lateral petals: lip anterior, 3-lobed, with an empty spur; pollinia 2, distinct, with their glands in one pouch. (Name, the Greek name of the genus.)

\section{* Tubers oroid.}

1. O. hircina (Lizard Orchis)....Stem 1-3 feet high; flowers large, in a loose spilie; sepals and lateral petals green, spotted with red; $l i p$ over an inch long, strap-shaped, spirally coiled in bud, white, with red spots.-Woods on chalk in Kent and Suffolk; very rare. The flowers have an unpleasant goat-like smell. -El. May. Perennial.

2. O.pyramiclális (Pyramidal Orchis).-Stem 6-18 in. high ; leaves lanceolate, acute; flowers small, deep rose-colour, rarely white, in a dense pyramidal spike; $l_{i p}$ with 3 equal, oblong, truncate lobes, and a slender spur longer than the ovary.-Limestone pastures; frequent.-Fl. Juiy, August. Perennial.

3. 0. ustuláta (Dark-winged or Dwarf Orchis.) - 


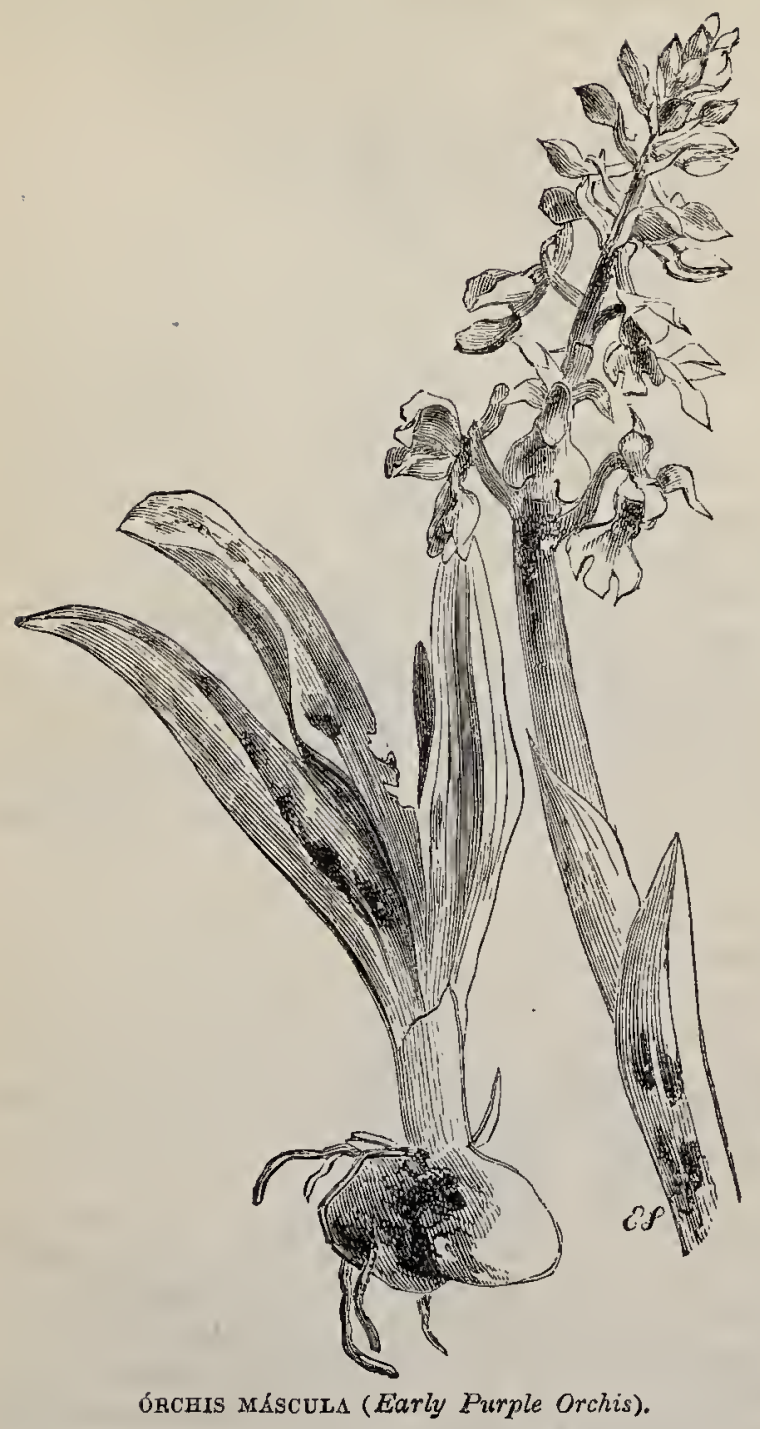


Stem 4-6in. high ; leaves oblong, acute ; flowers many, small, in a dense oblong spike, dark crimson at first, and, therefore, at the top of the spike, becoming white later, that is, lower down; spur much shorter than the ovary.-Upland calcareous pastures; not common.-Fl. May, June. Perennial.

4. O. purpúrea (Great Brown-winged Orchis).Stem stout, 1-3 feet high; leaves oblong, blunt; flowers in a dense spike, greenish-red, with a dark' hood, light rose-coloured, 4 -lobed, flat $7 \mathrm{ip}$, with raised, rough, red points, and short spul.--Woods on chalk in Kent and Sussex; rare.-Fl. May. Perennial.

5. O. mititáris (Military Orchis).-A closely allied but smaller species, with pale red flowers, with a pink hood, pink and white, 4-lobed lip with narrow, upcurved segments, and raised, rough, red points, and short spur.--Chalky hills in the South-east of England; rare.-Fl. May. Perennial.

6. O. Simia (Monkey Orchis).-A closely allied but more slender form, with dark red hood and the lobes of the lip all long, narrow, and crimson.Chalky hills in Berkshire, Oxfordshire, and Kent; rare.-Fl. May. Perennial.

7. O. Mório (Green-winged Meadow Orchis).Stem 6-12 in. ligh ; leaves lanceolate; flowers few, in a loose spike, deep crimson, rarely white; blunt, lateral sepals, and petals strongly marked with parallel green veins, and bent upwards to form a hood over the cotumn; $l_{i p}$ pale, spotted with crimson; spur. shorter than the ovary, blunt.-Neadows; frequent. - Fl. May, June. Peremnial.

8. O. máscula (Early Purple Orchis)._Stem 612 in. high; leares oblong-lanceolate, blunt, usually blotched with dull reddish-black; flowers few, in a lonse spike, crimson, mottled with lighter and darker shades, rarely white, each rising from a twisted ovary, and having a long, stout, blunt spur ; sepals spreading, not forming a hood.-Woods and pastures ; abundant. 
The colour of the flower, associated, as it often is, with Cowslips and Wild Hyacinths, is rich ard beautiful ;

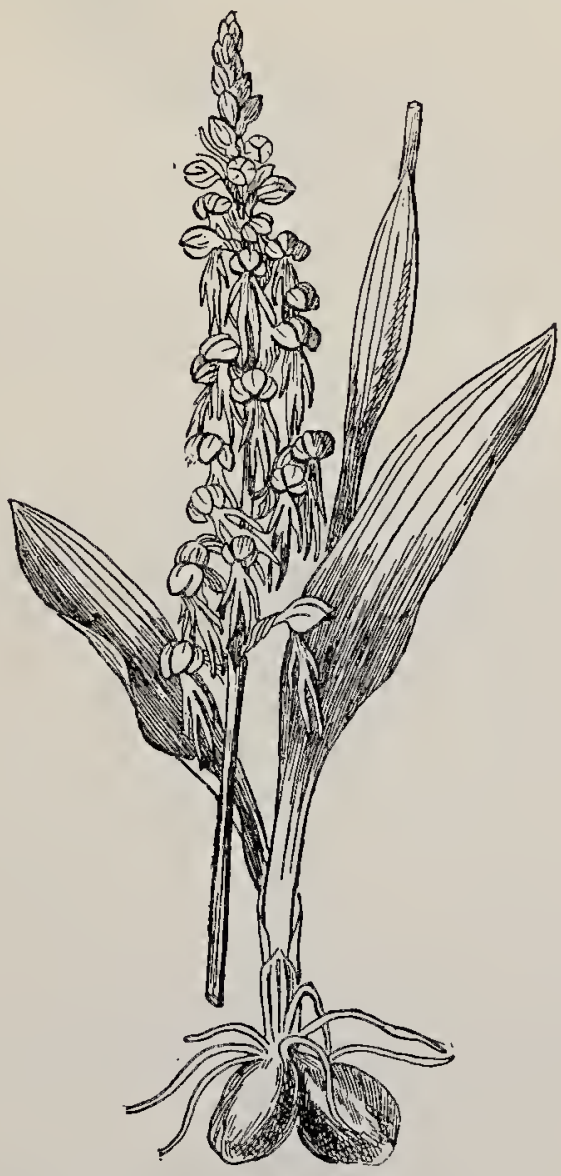

ÁCERAS ANTHROPÓPHORA (Mun-Orchis).

but the odour is strong and offensive, especially in the evening.-Fl. April-June. Perennial.

9. O. laxifórce (Lax-flowered Orchis), with un$3 \mathrm{c}$ 
spotted leaves, and large, bright red flowers in a loose spike, with long, $3-5$ veined bracts and reflexed sepals, occurs only in the Channel Islands.-Fl. May, June. Perennial.

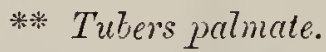

10. O. incarnáta (Crimson Marsh-Orchis)._-Stem about a foot high, usually hollow; leares radical and cauline, lanceolate, acute, concave at the tip, unspotted; flowers rose-coloured, in a dense spike ; bracts long, 3veined, green; sepals spreading; 7ip slightly 3-lobed; spur shorter than the ovary.-Marshes; frequent.Fl. June. Perennial.

11. O. Tatifótia (Marsh-Orchis).-A closely allied and very similar species; leaves generally with ringshaped spots, oblong, flat at tho tip.-MIarshes; less frequent.-Fl. May, June, of ten over before the preceding species flowers. Perennial.

12. O. maculáta (Spotted Orchis). - Stem about a foot high, solid; leaves oblong-lanceolate, radical, and cauline, with numerous squarish spots; flowers lilac or white, curiously marked with dark lines and spots, in a dense, oblong-pyramidal spike; bracts 3-reined, green ; lip deeply 3-lobed.-Moist heaths and commons; abundant.-Fl. Nay-July. Perennial.

12. Áceras (Man-Orchis).-Leafy plants with ovoid tubers; sessile flowers with a hood; lip anterior, long, 4-lobed, not spurred; jollinia 2 , with their glands in one pouch. (Name from the Greek $a$, without, keras, a hor'n.)

1. A. anthropophora (Man-Orchis).-About a foot high, with mostly radical leares; and a loose spike of curious little flowers with a large green hood, and a long, slender, yellow $7 i p$ with 2 lateral and 2 terminal lobes, like arms and legs.-Dry chalky places in the East of England; rare-Fl. June, July. Perennial. 
13. Óphrys (Insect-Orchis). - Leafy plants with ovoid tubers; sessile flowers; spreading sepals; lip

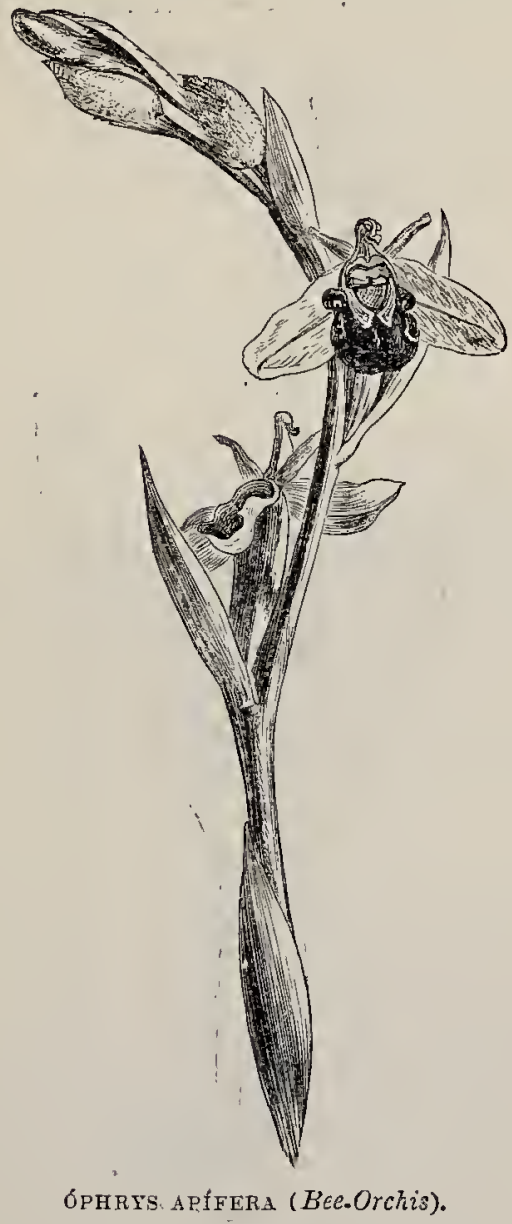

anterior, variously lobed, usually convex and velvety, not spurred; pollinia 2, with their glands in distinct pouches. (Name from the Greek ophrus, an eyebrow, from the markings on the lip.) 
1. O. apifera (Bee-Orchis).-A curious and beautiful plant, about a foot high, with short, oblong, mostly radical leaves and 3-6 flowers in a loose spike,

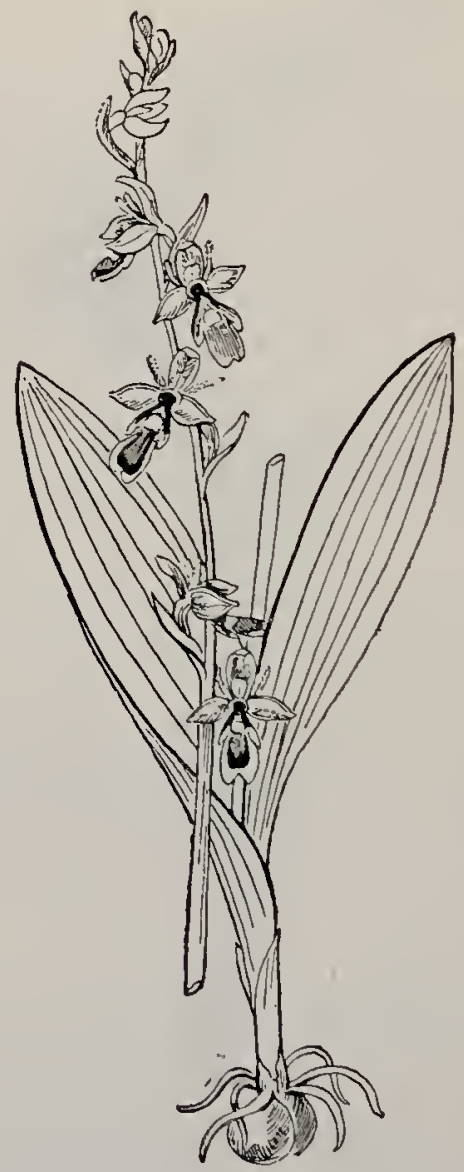

OPHRYS MUSCIFERA (Fly-Orchis).

with large, leafy bracts ; sepals white or pink, spreading, ovate; lip velvety, broad, brown variegated with yellow, convex, 5-lobed, the 2 lower lobes hairy, the 2 
lateral anterior ones bent under the lip and the terminal one long, acute, and usually also reflexed; pollinia falling forward and pollinating the stigma of the same flower.-O Open places on calcareous soil ; uncommon. No one who has heard that plants exist bearing the names of this and the three following species can well doubt their identity should they fall in his way.-Fl. June, July. Perennial.

2. O. arachníles (Late Spider-Orchıs) - A closely similar species chiefly differing in the lup, which is longer, velvety, dark purple variegated with yellow, with a flat, heart-shaped, green, terminal lobe.-Chalk downs in Kent and Surrey; very rare.-Fl. AprilJune. Perennial.

3. O. aranifera (Spider-Orchis).--A somewhat smaller plant with fewer flowers; green sepals; and deep brown hairy $l_{l}$, with smooth, yellowish markings and a notched apex without terminal lobe.-Chalk downs in the south-east; rare.-Fl. April, May. Perennial.

4. O. muscifera (Fly-Orchis). - A siender species, about a foot high, with few oblongr leaves, flowers $1-12$, in a loose spike; sepals green; lateral petals thread-like, resembling the antennæ of a fly; lip oblong, 3-lobed, brownish-purple wilh a bluish patch in the centre.-Shady places on caicareous soil; uncommon.-Fl. May-July. Perennial.

\section{Hervínicir (Musk-Orchis).-Leaiy plants} with ovoid tubers; few leaves; sessile flower's; perianthleaves incurved, lip anterior, 3-lobed, pouched; pollinia 2, distinct, with large, naked glands. (Name from the Greek hermin, a bed-post, from the shape of the tubers.)

1. H. Monórchis (Musk-Orchis).-A diminutive plant, generally $4-6$ in. high, with stalked tubers ; slender stem; raclical leaves 2, lanceolate, cauline 1 ; 
flowers minute, green, smelling like musk at night; sepals ovate; lip narrow, 3-lobed, pouched at the base,

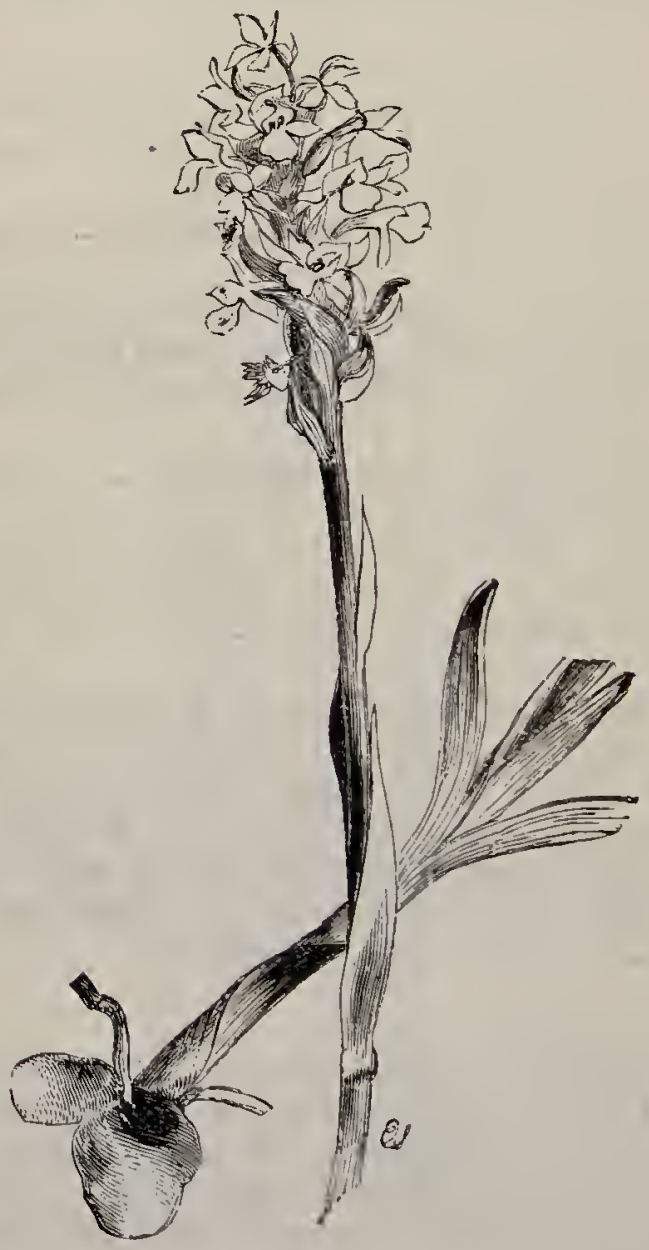

HABEN ARIA CONÓPSEA (Sweet.scented Orchis).

terminal lobe longest.-Chalky downs in the soutli; rare.-Fl. June, July. Perennial. 
15. Hábenária.-Leafy plants with sessile flowers with a hood ; Tip anterior, spurred; pollinia 2 , distinct; witl naked glands. (Name of doubtful etymology.)

1. H. conópsea (Sweet-scented Orchis).-About a foot high; tubers palmate; leaves oblong-lanceolate, acute, keeled; flower-buds red or deep lilac; flowers lighter, not spotted, very fragrant, in an elongated, cylindrical spike; bracts 3-veined; lip with 3 equal, entire lobes and a slender spur twice as long as the ovary.-Dry upland pastures; common.-Fl. June, July. Perennial.

2. II. intácta, a small species with ovoid tubers; stem 4-10 in. high; leaves often spotted; delicate pink flowers with an unequally 3-lobed $l i p^{\prime}$ and short spur, occurs only in limestone pastures in the West of Ireland._Fl. April-June. Perennial.

3. H. albida (Small White Habenaria) - A similar but rather large species, has roots consisting of numerous fleshy fibres; lower leaves oblong, blunt, upper lanceolate, acute; flowers small, yellowish-white, fragrant; bracts 3 -veined; lip with 3 unequal, acutely triangular lobes, and a sper shorter than the short ovary.--Hilly pastures, mostly in the north; uncommon.-Fl. June-August. Perennial.

4. II. viridis (Frog-Orchis).-Tubers palmate; stem $3-8$ in. high; leaves oblong, blunt, smaller upwards; flowers green, in a loose spike; bracts long, green ; li $l^{\prime}$ pale brownish-green, linear, flat; spur very short. - Upland pastures; common. - Fl. JuneAugust. Perennial.

5. H. brfólia (Lesser Butterfly-Orchis). - A singular, but not appropriately named, plant, for its flowers bear but a slight resemblance to a butterfly. It has 2 broad, glossy leaves at the root; the stem is slender and angular, about a foot ligh ; and the flowers white, very fragrant in the evening; sepals spreading; lip linear, strap-shaped, entire; spur slender, spreading, twice as longr as the ovary; anther- 
chambers parallel.-Moist heaths and the borders of woods ; common.--Fl. June, July. Perennial.

6. H. chloroleúca (Greater Butterfly-Orchis).-A

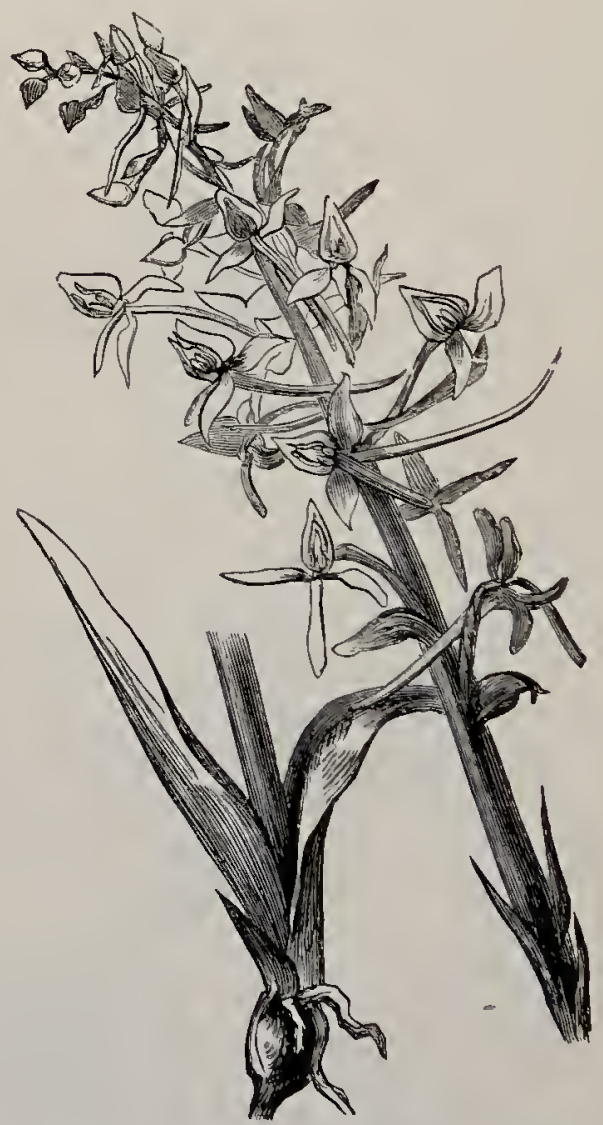

MABENARIA BIFÓLIA (Lesser butterfly-Orchis).

closely allied but larger species, with larger, greener fiowers, broader lateral sepals, a stouter spur bending downwards, and anther-chambers diverging at the. 
base. - In more moist situations; almost equally common.-Fl. July, Angust. Perennial.

16. Cypripéducm (Lady's Slipper), represented by only one species in Britain, C. Calceolus, one of the rarest, most beautiful, and interesting of our native plants; has a crecping rhizome; a downy stem, about a foot high, bearing 3 or 4 large, ovate, acuminate, ribbed leaves and 1 or 2 large flowers with broad, spreading, reddish-brown sepals and petals; and the distinctive large inflated lip of a pale yellow.-Woods on limestone in the North of England; very rare.(Name from the Greek Kupris, Venus, podion, a slipper.)-Fl. May, June. Perennial.

\section{Ord. LXXIX. Irider.,-Iris. Family.}

A considerable Order of herbaceous plants with fleshy, underground stems; long, narrow, often swordshaped, and equitant leaves; and showy flowers; perianth superior, petaloid, of 6 leaves in 2 alternating whorls, imbricate, and of ten persistent ; stamens 3, with extrolse anthers; ovary inferior, 3-chambered, manyovuled; style 1 ; stigmas 3 , often petal-like; fruit a 3-sided, 3-valved, many-seeded capsule. They are chiefly natives of warm and temperate, extra-tropical regions, and are most abundant in Cape Colony, where, at the time of its discovery by the Portuguese, the natives mainly supported themselves on the underground stems of plants of this Order, together with such shell-fish as were left on shore by the receding tide. Few species are used in the arts: Orris-root is the rhizome of Irisfiorentina and other species, which, when dried, has a perfume resembling that of Violets, and is used as an ingredient of tooth- 
powder; and Saffron, the dried stigmas of Crocus sativus, formerly used far more extensively than at present, as a dye and as a colouring agent in cooking andin medicine. Iris, Crocus, Ixic, Gladiolus, and others are favourite garden genera.

1. Írs.-Flowers polysymmetric; sepals reflexed ; sityle dividing into 3 broad, 2 -fid, petaloid lobes.

*2. Crócus. - Flowers polysymmetric, funnelshaped, with a long tube; style slender; stigmatic lobes widening upward.

3. Rostcḱa. - Flowers polysymmetric, with a short tube; style slender; stigmas 2-fid, lobes slencler.

4. Sisyrínehiusr.--Flowers polysymmetric, with a short tube; style short; stigmas undivided.

5. Guábionts. - Flowers monosymmetric; style slender; stigmatic lobes widening upward.

1. Íris(Fluwer-de-luce).--Herbaceous plants mostly with fleshy rhizomes; leares chiefly radical, swordshaped, equitant; flowers few, large, with a membranous spatho; perianth-tube short; sepals 3, large, petaloid, stalked, reflexed; petats 3 , erect, stalked; style stout, dividing into 3 broad, spreading, petallike lobes covering the stamens, bifid, with a transverse stigmatic line. (Name from the Greek iris, the rainbow, from the beantiful colouring of the flowers.)

1. I. fextidissima (Stinking Iris, Gladden, Roastbeef Plant.) -Stem compressed, with 1 sharp edge, about 2 feet high; Teaves weak; flowers a dull leaden hue or livid purple, rarely yellow, with no fringe down the seprals.-Thickets, chiefly on calcareous soil; not uncommon. The leaves are so acrid as to leave a burning taste in the mouth, or even to loosen the teetl. 'The whole plant, when bruised, emits a disagreeable odour. The bright scarlet seeds remain attached to the plant all through the winter.-Fl. May-August. Pereunial. 
2. I. Pseudácorus (Corn Flag, Yellow Iris). - A stout, aquatic plant with creeping, acrid rhizomes;

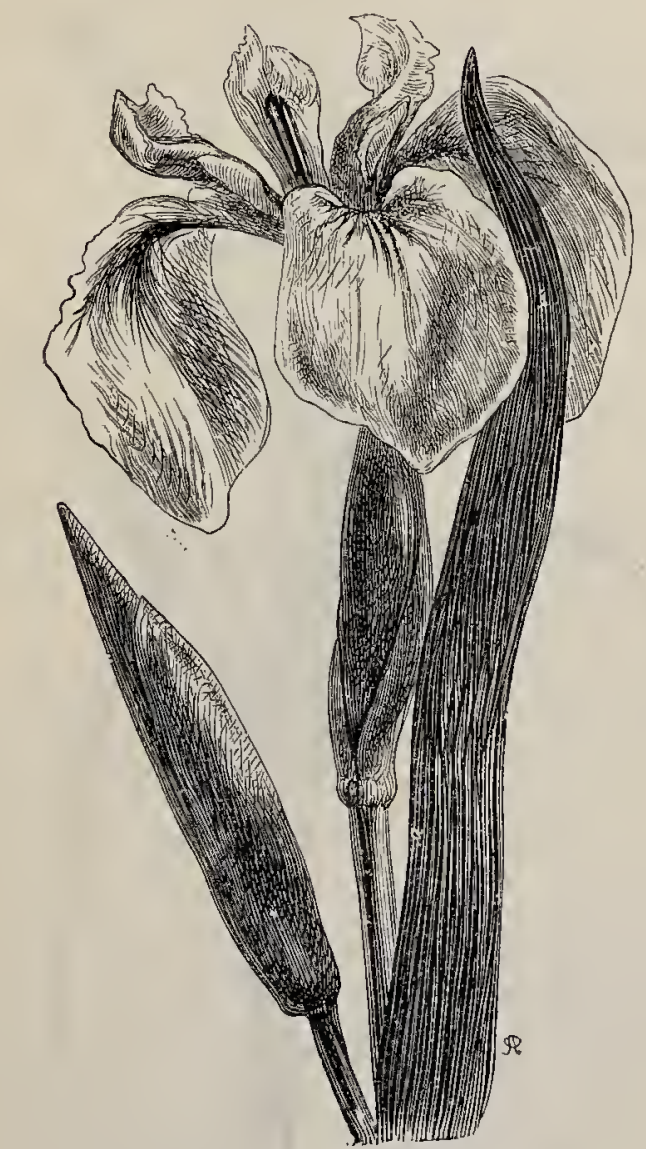

fris PSEUdÁCORUS (Yellow Iris, Flag, Corn Flag).

round stem, 2-5 feet high ; sword-shaped leaves; and large, handsome yellow flowers with unfringed sepals. -Marshes and river-banks; common. The rhizome yields a black dye, and the seeds, it is said, may be 
roasted and used as a substitute for coffee.-Fl. May - August. Perennial.

3.* I. tuberósa, with tubers, 4-angled leaves, and

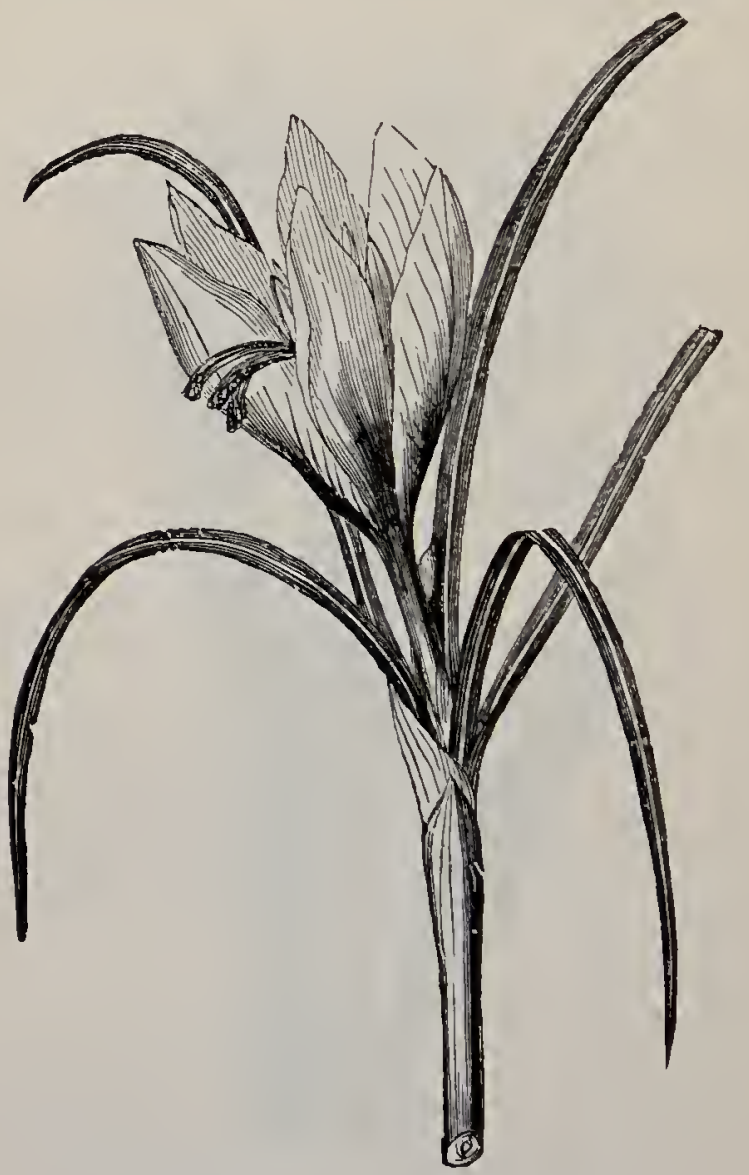

Crócus satirus (Saffron Crocus).

solitary, purple flowers, found at Penzance and at Cork, is one of several cultivated species occasionally found apparently wild. 
*2. Crócus.- Herbaceous plants with fleshy corms; no aërial stem; linear, radical leaves, white beneath, with revolute edges; and generally solitary, large, funnel-shaped flowers with a long perianth-tube; style slender; stigmatic lobes 3 , widening upwards; capsule pedicellate. (Name from the Greek krokos, saffron, and that from lirólié, a thread.) Several species are naturalised in various parts of England, such as C. vermus, the Purple Spring Crocus, in meadows at Nottingham and elsewhere, flowering in March and April; but the only species with any claim to be considered indigenous is C. nucliftómus (Naked-flowered Crocus), with leaves appearing in March, and solitary, purple flowers in September and October, occurring in meadows in the Midland counties. This genus must not be confused with the Colchicums, which are misleadingly called A utumn Crocuses or Meadow Saffrons, but belong to the Liliacer, having 6 stamens.

3. Romuléa.-A closely allied genus with a corm; short scape; linear, radical leaves; polysymmetric perianth with a short tube surrounded by a longer spathe; perianth-leaves 6 , recurved at the tip; stigmas 3, 2-fid, with linear segments. (Name from Romulus, founder of Rom e.

1. R. Columnce, the only British species, a small plant, 3-4 in. high, with a minute corm, very narrow leaves, and $1-3$ flovers on a short stalk, greenish outside, whitish, with purple veins and yellow at the base, inside.-It grows only on a sandy pasture called the Warren, at Dawlish, Devon, and in the Channel Islands.-Fl. March-May. Perennial.

4. Sisvrínchium (Blue-eyed Grass).-Fibrous rooted plants with linear, equitant, radical leaves; tall, umbellate scape; polysymmetric perianth with short 


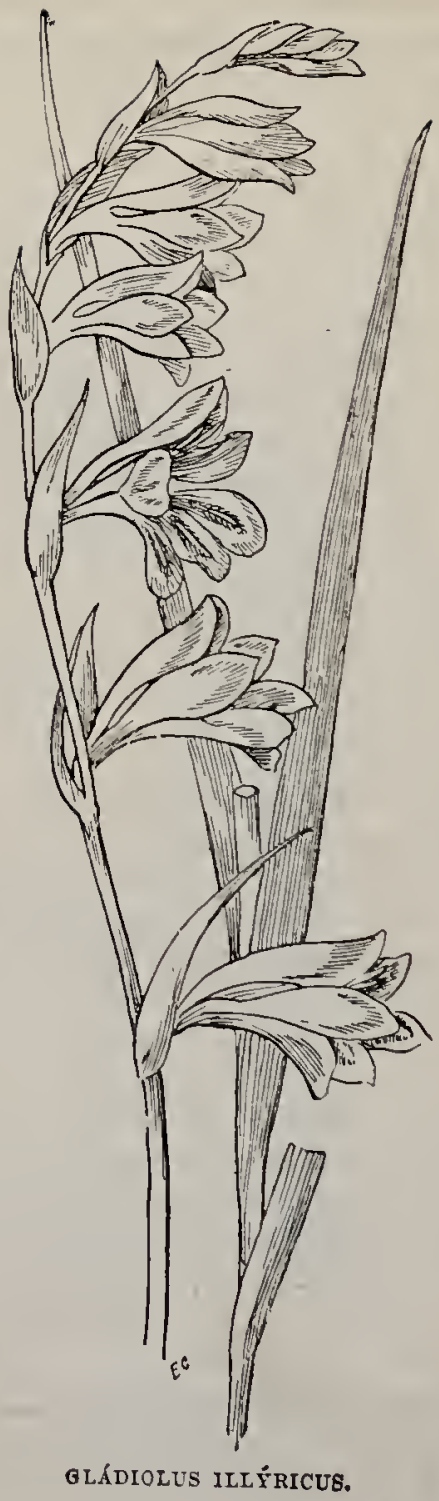


tube; short style, and 3 undivided thread-like stigmas. (Name of uncertain etymology.)

1. S. angustifólium (Narrow-leaved Blue-eyed Grass).- A pretty plant, about a foot high, with linear leaves and a 2-edged, winged peduncle bearing 1-6 blue flowers, with a short spathe and pointed perianth-leaves.-Bogs, Galway and Kerry.-Fl. July, August. Perennial.

2. S. califúmicum, a species with $4-5$ yellow flowers, with blunt perianth-lear's, a native of California and Oregon, was found in June, 1896, by Rev. E. S. Marshall, in marshy ground at Rosslare, co. Wexford.

5. GLádrouus. - Herbaceous plants with corms: leaves sword-shaped, equitant; flowers in a tall, 1-sided spike, monosymmetric, with a short, curved periantl-tube, and 6 segments, slightly 2-lipped; style slender; sirgmatic lobes 3 , widening upwards. (Name a Latin diminutive from gláclius, a sword, referring to the form of the leaves, pronounced with the accent on the first syllable, the $i$ having a sound like $y$.)

1. G. illyricus, the only British species. Corm ovate, small, with many bulbils and a sheath of slender, parallel fibres; stem $1-2$ feet high, leafy; leaves slender, glaucous; flowers crimson, $4-8$ in a spike; seeds narrowly winged.-In the New Forest and the Isle of Wight; rare.--Fl. June, July. Perennial.

\section{Ord. LXXX. Amaryllídeæ.-Amarýllis Family.}

An extensive Order, principally composed of herbaceous plants with bulbous stems, sword-shaped, radical 7eaves, and showy flowers, which are distinguished from the Liliaceæ by their inferior ovary, that organ in the 
Lily Family being superior. The perianth consists of 6 leaves in 2 whorls, sometimes with a tubular coronet at the mouth of its tube; stamens 6 , with versatile, introrse anthers ; oravy inferior, 3-chambered; style 1 ; stigma generally 3-lobed; fruit a many-seeded capsule, or rarely a $1-3$-seeded berry. Large and beautiful species belonging to this Order are found in abundance in Brazil, the East and West Indies, and especially Cape Colony. In the temperate regions they are less common, and by no means so showy. Numerous species are cultivated in cul gardens and conservatcries, though few, if any, are indigenous to Great Britain. The bulbs of many species are poisonous, some, it is said, to such a degree that deleterious properties are communicated to weapons dipped in their juice. Those of the Snowdrop (Galánthus nieális) and Daffodil (Narcissus Pseído-narcíssus) are emetic, and the flower's of the latter species are a dangerous poison: From the juice of the so-called American Aloe or Century - plant (Agávé americána) " pulqué," a fermented liquor which is a common beverage in Mexico, is prepared. This plant, called by the Mexicans "Maguey," is cultivated over an area of 50,000 square miles, the annual consumption of pulqué in the city of Mlexico alone amounting to the enormous quantity of eleven million gallons, so that the Government derive a considerable revenue from its sale. The plant attains maturity in a period varying from eight to fourteen years, when it forms flowers ; and it is only just before flowering that the juice can be extracted. The central stem with the flower-bud is then cut off near the bottom and the fleshy leaves are drawn over the carity thus left, and tied. Into this reservoir the juice distils, which otherwise would have risen to nourish the flowers. It is removed three or four times during the twenty-four hours, yielding from one to six quarts of liquor. The juice is then placed in earthen iars, and a little old pulqué is added, when it soon 
ferments and is immediately ready for use. When fresh, pulque is brisk and sparkling, and in time even Europeans prefer it to any other liquor; but when old it has an unpleasant odour, which has been compared to that of putrid meat. The Agave grows but slowly in England, and is so long before flowering as to have acquired the name Century plant. When it does flower it sends up a stem some 10-30 feet high from the centre of its chevaux de frise of spiled leaves, branched above and bearing some thousands of greenish flower's in a corymbose manner. These flowers secrete so much homey as to drip to the ground and moisten it, whilst the physiological eflort is so great that the plant usually dies after once flowering. The leaves of this species yield a fibre known as Pita or Mexican Grass, valuable for cordage and paper-making; Agáé vivípara yields Silk Grass; and $A$. sisulana, a native of Yucatan, now grown also in Jamaica, Ixtlo Grass or Sisal Hemp.

1. Narcíssus.-Perianth with 6 nearly equal segments united in a tube below with a bell-shaped coronet within.

2. Galántuus. - Perianth-segments 6, free, the outer larger, the inner notched; no coronet.

3. Leucósux.--Perianth-segments 6, free, equal, thickened at the point; no coronet.

1. Narcíssus (Daffodil).-Bulbous plants with linear, radical lecues ; a 2-edged peduncte; a membranous spathe; flowers large, solitary or umbellate, yellow or white, generally drooping, polysymmetric; perianth with 6 nearly equal petaloid segments in 2 whorls, united into a tube below, the mouth of which terminates in a bell-shaped coronet differing in colour from the perianth; stamens 6, alternately shorter, with versatile anthers. (Named after Narcissus, a youth said in Greek mythology to have been changed into a flower.) 
1. N. Pseúdo-narcíssus (Common Daffodil, Lent Lily).-A beautiful and favourite flower, with glau-

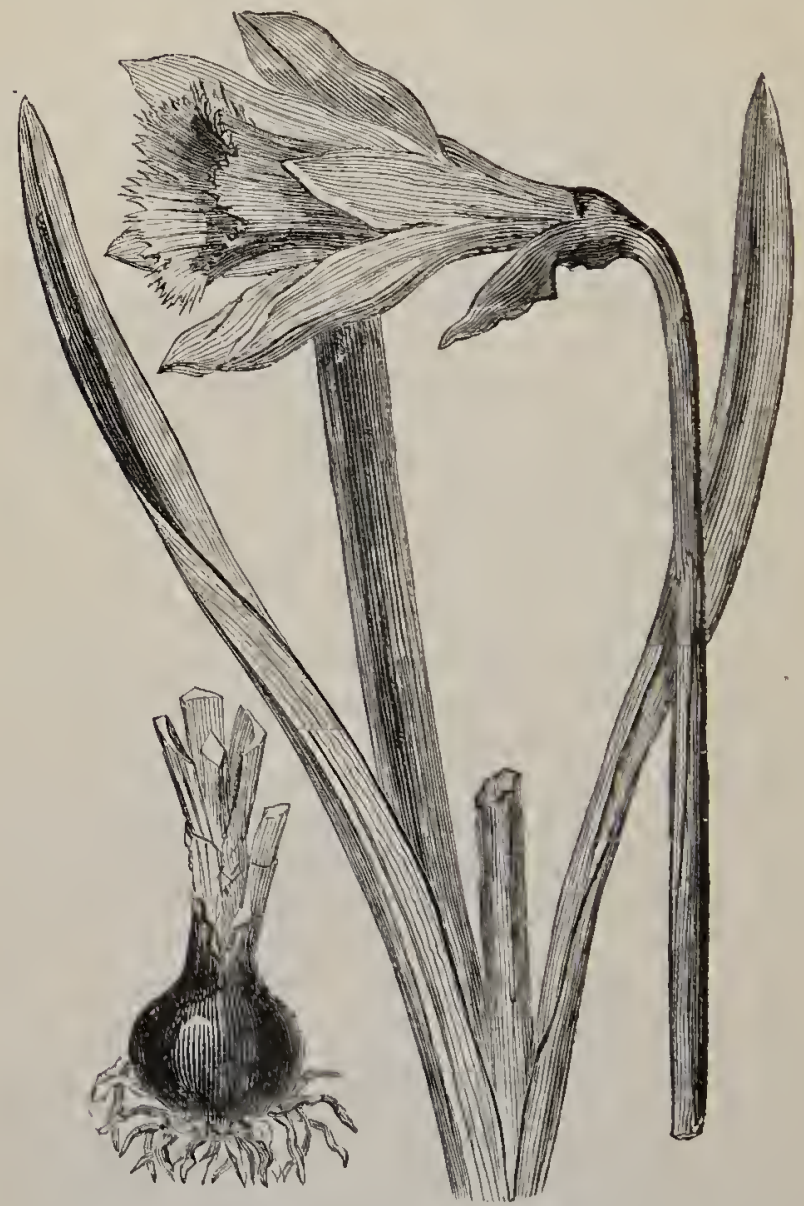

Narctssus PSEÚDo-Narcíssiss (Common Daffodll, Lent Lily).

cous, blunt, nearly flat lcuves; a hollow, glaucous pertuncte less than a foot high, bearing one flower, the long, bell-shaped, deep golden coronet of which is nearly 
as long as the pale yellow perianth-leaves, and is notched and curled at its margin.-Woods and pastures; frequent.-Fl. March, April. Perennial.

* Several other species of Narcissus, such as $N$. biflorus, with a 2-flowered scape, and $N$. poéticus, the

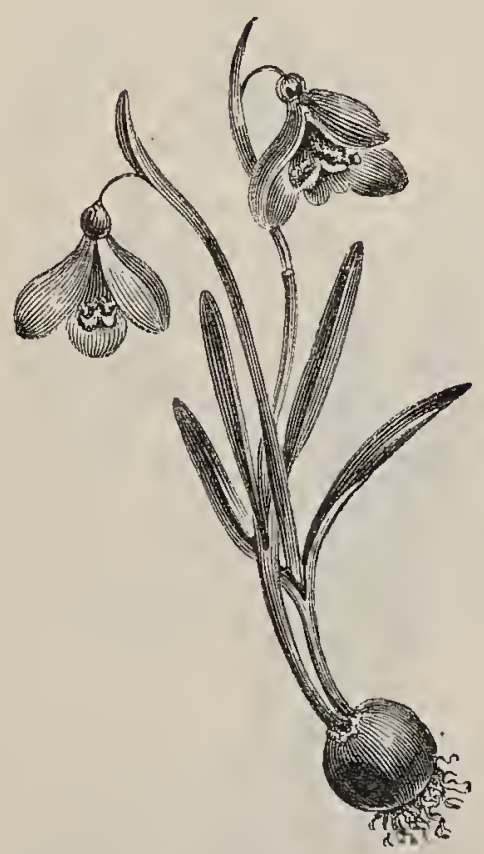

GALÁNTHUS NIVÁLIS (Snowdrop).

Pheasant's-eye Daffodil, with a spreading, white perianth, and small, yellow, cup-shaped, red-edged coronet, are occasionally found near houses, but are invariably the outcasts of gardens.

2. Gatánthus (Snowdrop).-Bulbous plants with 2 radical, linear lecues : flattened pechuncle; membranous spathe; solitary, drooping, white flower ; perianth 
of 6 free segments, the outer larger and more spreading, the inner erect, notched, greenish; no coronet. (Name from the Greek gala, milk, anthos, a flower.)

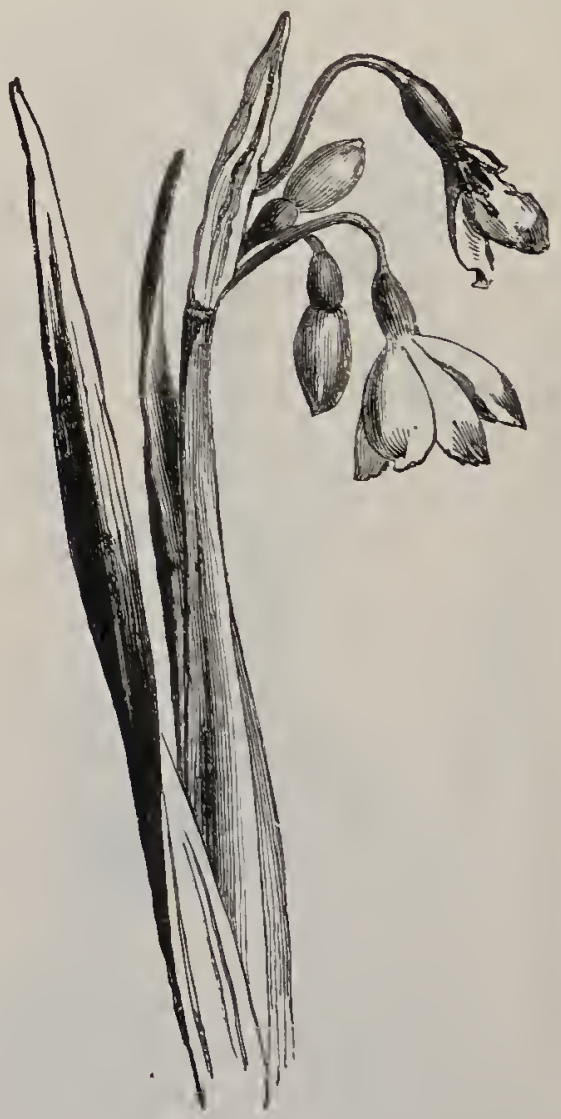

LEUCódur estfrus (Summor Snowfake).

1. G. nivális (Snowdrop).-Too well known to need description. The bulb is ovoid and $\frac{1}{2} \mathrm{in}$. across; the leaves glancous, keeled, blunt; the peduncle longer; the spatize colourless, transparent, with 2 green veins, 
2-fid ; the pedicel slender; the sepals obovats, concave, and more spreading in the wild form than in cultivated ones.-Woods in the west; doubtfully indigenous. Fl. January-March. Perennial.

3. Leucójum (Snowflake).-A closely allied genus, with more than 2 leaves ; 2 spathes ; 1 -6 flowers: and nearly equal perianth-leaves all thickened at their tips ; stamens 6, equal. (Name from the Greek leukos, white, ion, a violet.)

1. L. cestívum (Summer Snowflake).-A bulbous plant, about 2 feet high, producing its linear, blunt, glaucous, keeled leaves, which are about a foot long, in winter, and its 2-edged flower-stalk, which is rather longer and bears 2-6 rather large white flowers, in summer.-Wet meadows in the South-east of England; a doubtful native, common in gardens.-Fl. May. Perennial.

2. L. vérnum (Spring Snowflake). - A much smaller plant, producing its leaves and flowers, of which it only bears 1, or 2 together, in early spring.-Woods in Dorsetshire.-Fl. Eebruary-April. Perennial.

\section{ORd. LXXXI. Dioscóreæ.-YAM Family.}

A small Order of twining herbs or shrubs, which, with the exception of the Black Bryony (Támus commúnis), our one British species, are confined to tropical regions. They often have large tubers; their stems twine upwards in the direction of the hands of a clock ; the leaves somewhat resemble those of Dicotyledons, being distinctly stalked and net-veined; the flowers are small, inconspicuous, and diœcious, in axillary clusters; the perianth green, superior, of 6 equal segments in 2 whorls, persistent; stamens 6 , with introrse anthers; ovary inferior, 3-chambered; 
style deeply 3-cleft; fruit a dry, flat capsule, or, in Tamus, a berry. Dioscorea, the genus from which the Order takes its name, has large tubers, which, under the name of Yams, form as important an article of

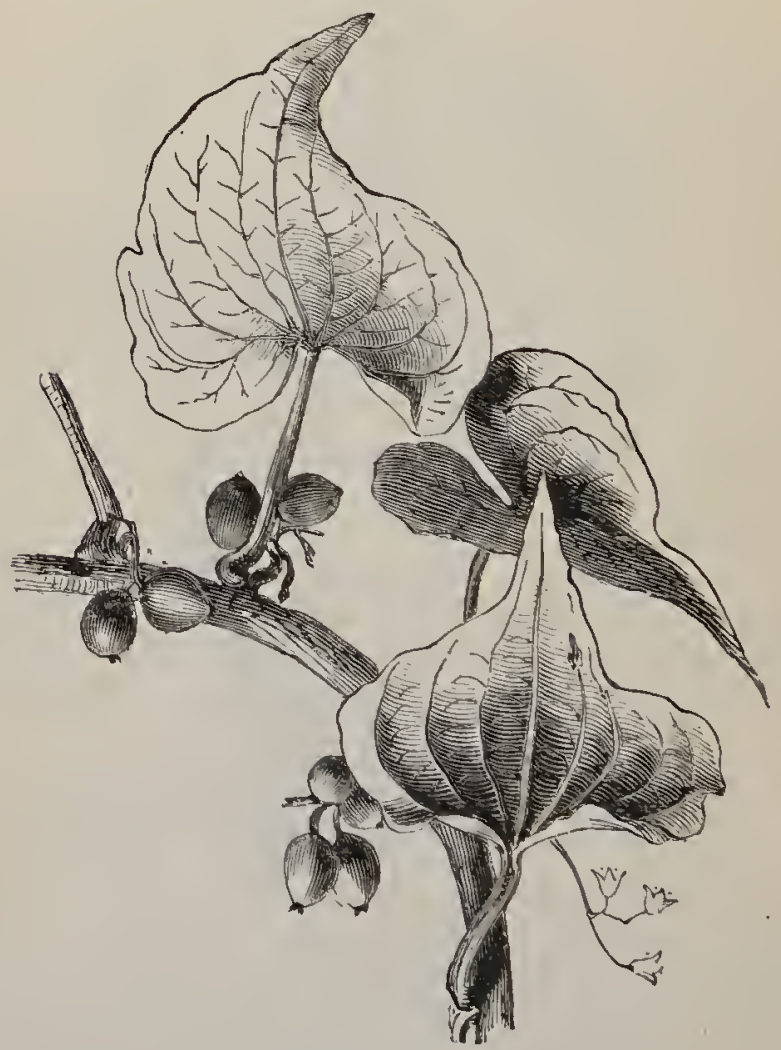

TAMU'S COMMÚNIS (Black Bryony).

food in tropical countries as the Potato in temperate climates. When growing they require support, like Hops. There are several species, $D$. sativa and $D$. aláta, natives of India, and $D$. Batátas, native of China. Their tubers sometimes weigh 30 or $40 \mathrm{lb}$., 
and the Chinese species yields enormous crops in France and Algeria, and is hardy in this country, but is not appreciated.

1. Táuus (Black Bryony).--Perianth bell-shaped; stigmas 2-lobed; berry few-seeded. (Name, the Classical Latin name of the plant.)

1. T. commúnis (Black Bryony).--The only British species, a handsome plant with a large, black tuber; a slender, green stem, twining among bushes to the length of many feet, and bearing numerous very glossy, cordate, acuminate leares, which in autumn turn to a purple bronze or to a bright lemon-yellow, and clusters of small, green flowers, which are succeeded by oblong scarlet berries. The plant at that season is very attractive; but the stem dies down to the ground in winter.-Hedgerows in England; common.-Fl. May, June. Perennial.

\section{SERIES II. HYPÓGYNAะ.}

Ovary superior.

\section{Ord. LXXXII. Liníceæ.-Liliy Fanily.}

An extensive family of plants comprising about 2,500 species, of which the majority are bulbous herbaceous plants with showy flowers. Some attain the dimensions of shrubs, or even trees, in which case they resemble the Palms in having no true separable bark or distinctly marked pith, and in the Teaves being never jointed to the stem. The leaves of Herb-Paris (Paris quadrifolia), a Bitish species, are net-veined, and so resemble those of Dicotyledons; but are not jointed to the stem. The perianth consists of $6-10$ leaves, generally similar and petaloid, 
but in 2 whorls, distinct, or united into a tube; stamens 6-10, epiphyllous, with anthers generally introrse; ovary, superior, 3- rarely 4-chambered; style 1; stigma simple, or 3-lobed; fruit a 3-chambered, many-seeded capsule, or berry-like, 3-5-chambered, 1-6-seeded. The Order is most abundantly represented in temperate climates, but its members attain their greatest size in the tropics. The Butcher's Broom (Rúscus aculeátus) is the only British species which forms a woody stem. The Dragon's Blood (Dracóna Dráco), which grows very slowly and only branches when of considerable age, was represented at Orotava, in T'eneriffe, by a giant specimen 70 feet high and over 48 feet in circumference, which is recorded to have been an ancient tree and apparently almost as large in 1406 ; but it was destroyed by a hurricane in 1867. The leaves of many species in the Order contain tough fibre, the New Zealand Flax (Phórmium tenax) being the most important of these. The Onion (Allium Cépa), the Leek (A. Pórum), and the Garlic (A. sativum) are among the most anciently cultivated of vegetables, and were given divine honours by the ancient Egyptians; whilst the young shoots of Asparagus are among the most esteemed delicacies of our modern kitchens. In medicine many members of the Order are of great value, among which aloes, the bitter, condensod juice of Alóe v'ulgáris, $A$. succotrina, and other species; squills, an extract of the Mediterranean Urginca Scilla; and the corms and seeds of Cólchicum autumnáté, used as a specific for gout, are well known. As ornamental plants the beauty of this Order has for ages been proverbial, many species of Lilium, Frvitillaria, Scilla, and other genera, the Lily of the Valley (Convallária majális), the Hyacinth (Hyacinthus orientális), and the Tulip (Trilipa) being among the most prized of our garden flowers. 
Section I. Asparágere.-The Asparagus Group.

Never bulbous ; fruit berry-like.

1. Rúscus.-Stem woody, with flattened, leaf-like branches, minute, scale-like leaves, diœcious flowers and united filaments.

2. Aspáraç্রUs. - Stem succulent, branched ; ultimate branches bristle-like; stamens not united.

3. Polygonátum. - Stem leafy; flowers axillary; perianth tubular, 6-cleft.

4. Maińnthemum. - Stem erect, with few leaves; flowers in a terminal raceme, generally 4 -merous.

5. Convaluária.-Leaves $2-3$, radical; flowers in a terminal raceme, bell-shaped, 6-merous.

Section II. AsphodÉLEe.-The Asphodel Group. Generally bulbous; leaves radical; scape leafless ; fruit a capsule.

6. Simíthis. - Not bulbous; leaves grass-like; flowers in a panicle, 6-merous.

7. Ácliun.-Flowers in an umbel, with a 1-2leaved membranous spathe.

8. Muscári. - Flowers in a bracteate raceme; perianth globular.

9. Scílita.-Flowers in a bracteate raceme; perianth blue, purple, or white, deciduous.

10. Ornitrógalum.-Flowers in a bracteate, sometimes corymbose raceme; perianth white, persistent, of 6 free, spreading segments.

Section III. Tulípex.-The Tulip Group. Bulbous; leaves radical and cauline; fruit a capsule.

*11. Lílium. - Flowers few, large ; perianth-leaves 6 , free, spreading, or reflexed, deciduous.

12. Fritullária. - Flowers few, large, drooping; 
perianth-leaves 6 , free, not reflexed, with a nectary at the base of each, deciduous.

13. TÚLIPA.-Flower solitary, large, erect; perianthTeaves 6 , free, without nectaries, deciduous.

14. GáGEA.-Flower's few, small, yellow, umbellate; perianth-leaves 6, free, without nectaries, spreading, persistent.

15. Llóxdia.-Flowers few, small, white; perianthleaves 6 , free, with transverse nectaries, spreading, persistent.

Seetion IV. Melantháce.e.-Colchieum Tribe.

Not bulbous; leaves mostly radical ; fruit mostly capsular.

16. Cómchicur. - Stem a corm; perianth with a very long tube.

17. NaRTHÉCIUM.-Stem prostrate, creeping: flowers in a raceme; perianth of 6 free, spreading leaves, golden-yellow, persistent; style 1; capsule 3-chambered.

18. TofrÉLds. - Stem a short rhizome; flowers in a raceme, small, greenish-yellow; perianth-leares 6 , free, spreading, persistent; styles 3 ; fruit of 3 follicles.

19. Páris.-Rhizome stout; stem erect, simple, bcaring 4 whorled leaves; flower solitary, terminal, grcen, generally 4-merous; fruit berry-like.

1. Rúscus (Butcher's Broom).--Shrubs with stout, creeping rhizomes; woody, branched stems bearing flattened, leaf-like, evcrgreen branches or "cladodes" in the axils of minute, scale-like, deciduous leaves; flowers diocious; perianth deeply 6-cleft, green, persistent; filaments united into a tube ; fruit berry-like, I-chambered, 1-2-seeded. (Name said to be from bruscus, a word of Koltic origin.) 
1. R. aculeátus (Butcher's Broom, Knee-Holly).The only British species, and only-British shrubby Monocotyledon, 3-4 feet high, with erect, dark green

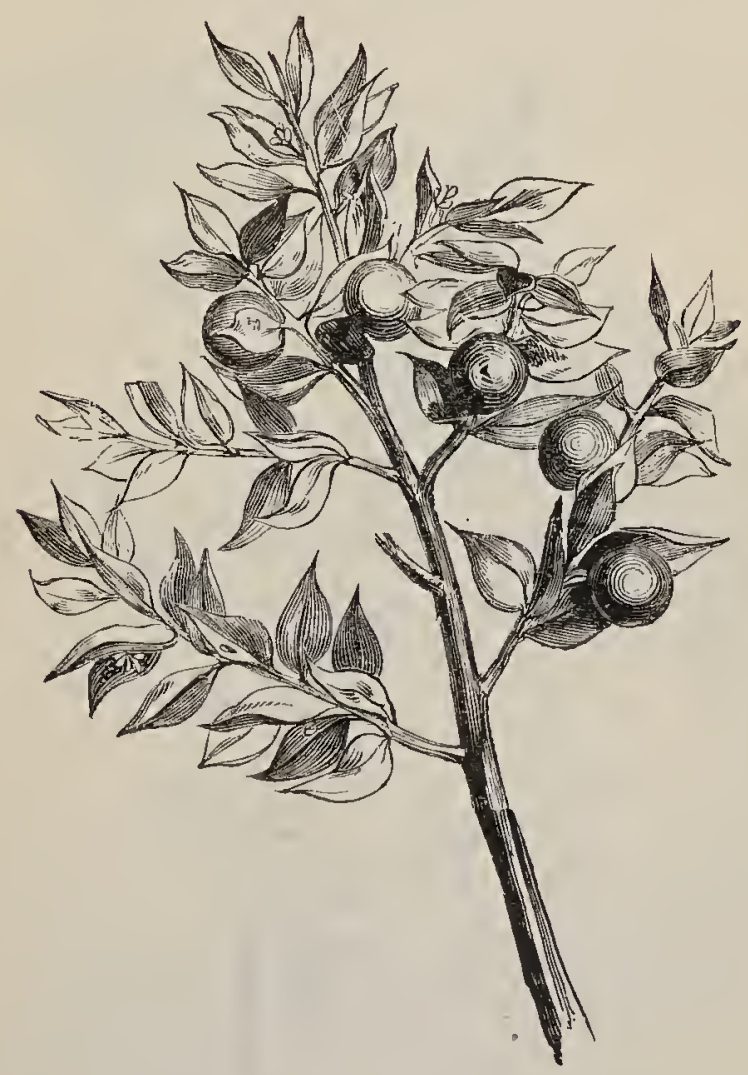

RỨSCUS ACULEátus (Butcher's Broom, Knee-Holly).

stems; ovate, dark green, flattened branches, each terminating in a sharp spine; flowers minute, green, growing singly from the centres of the flattened branches; berries as large as marbles, round, scarlet.- 
Woods in the south; uncommon.-Fl. FebruaryMay. Perennial.

2. Aspáragus.-Herbaceous plants with a stout

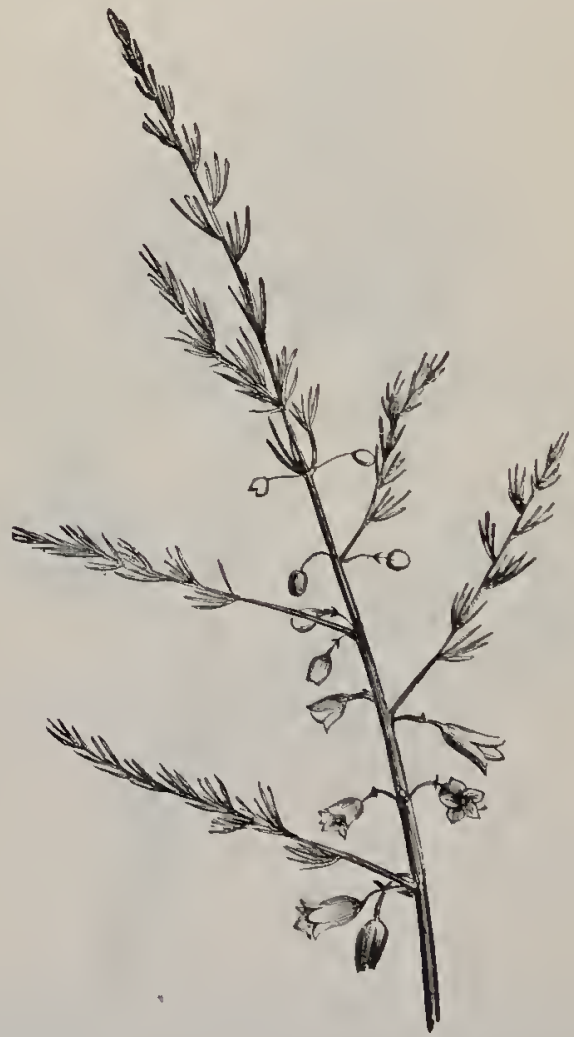

ASPARAGUS OFFICINíls (Common Asparagus).

whizome; branched stem bearing tufts of green, bristlelike branches in the axils of minute scale-like leares; flowers small, pendulous, often diœcious; perianth deeply 6-cleft, bell-shaped; stamens 6, distinct; stigmas 
3 ; firuit berry-like, 3-chambered, 3-6-seeded. (Name, the Greek name of the plant.)

1. A. officinális (Common Asparagus).-The only British species, differing chiefly in size from the culti-

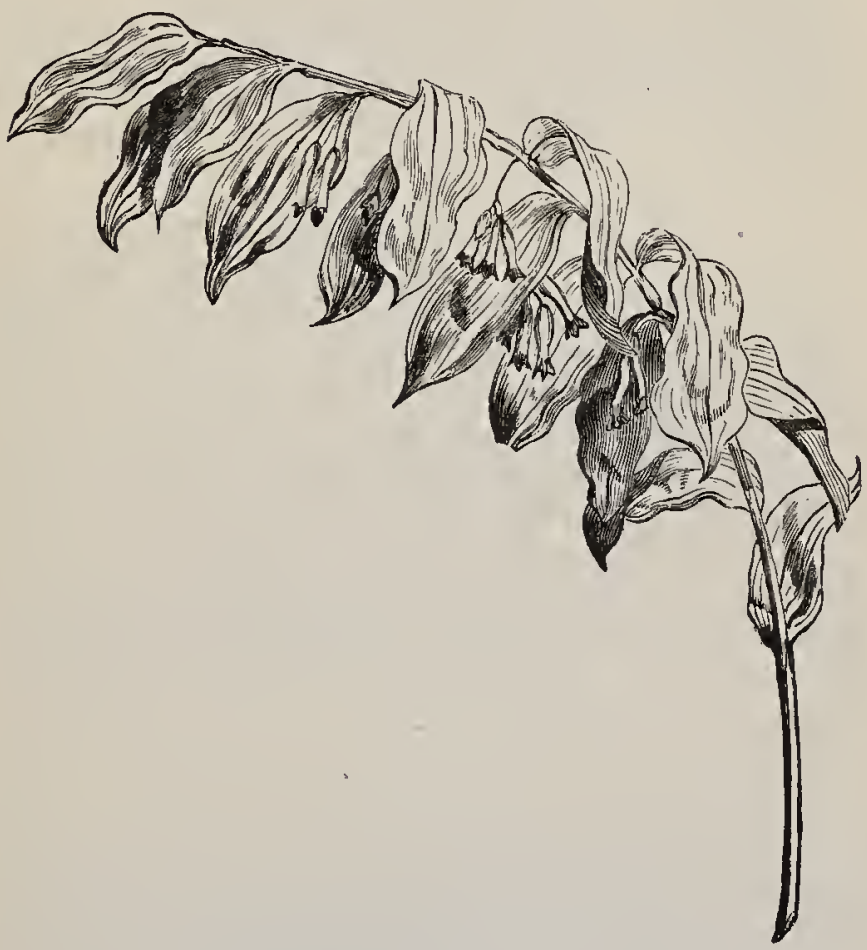

POLYGonátun multiflóRui. (Common Solomon's Seal).

vated plant, has its stem prostrate at its base, giving off ascending branches about a foot long, slender, and Hexuous; flowers $1-2$ together, yellowish-white; berry scarlet.-On the sea-coast in the south-west, especially near the Lizard; rare-Fl. July, August. Perennial. 
3. Polygonátum (Solomon's Seal).-Herbaceous plants with a fleshy rhizome; leafy stem; axillary flowers ; tubular, 6-cleft perianth ; stamens 6, free, included; fruit berry-like. (Name from the Greek polus, many, gonu, the knee, from the zigzag rhizome.)

1. $P$. verticillátum (Narrow-leaved Solomon's Seal).-Stem erect, 2 -3 feet high, angular; leaves sessile, linear-lanceolate, in whorls of $3-6$ : flowers greenish; berries red.-Woods in the north; rery rare.-Fl. June, July. Perennial.

2. P. multiflón (Common Solomon's Seal). - A striking plant, $1-2$ feet high, with a round, drooping stem, bearing numerous, scattered, oblong, acute leaces, which hang downwards; greenish-white flowers in 2-5-flowered axillary clusters, resembling oldfashioned bunches of seals; filaments hairy, and blueblack berries.-Woods; uncommon.-Fl. May, June. Perennial.

3. P. officinálé (Angular Solomon's Seal).-Differing from the preceding in being smaller, having an angular stem; thicker leaves; larger, usually solitary flowers; and smooth filaments.-Woods; rare.Fl. May, June. - Perennial.

4. Maránthesiun (May-Lily), of which the only species is M. Conullturia (Two-leaved May-Lily), a graceful little plant with a creeping, slender rhizome; in erect stem, 4-8 in. high, bearing 2 , scattered, stalked, cordate, acute leaves, and a terminal raceme of small, white, fragrant, 4-merous flowers, followed by spotted berries.-Woods near Scarborough, and elsewhere ; very rare, though commou in the North of Europe. (Name from the Greek maios, May, wrthemos, a flower.) -Fl. May, June. Perennial.

5. Convaliária (Lily of the Valley), represented 
by the one species $C$. majális, a beautiful plant with a creeping rhizome; leaves $2-3$, radical, ovate-lanceolate, with a sheathing petiole; flowers $6-12$, globular, pure white, in a terminal, drooping, loose, 1-sided raceme, with an angular peduncle; berries red.Woods on a light soil ; not common. An universal favourite in gardens for the beauty and fragrance of its blossoms. (Name from the Latin convallis, a valley.)-Fl. May, June. Perennial.

6. Simétuis, a genus represented by the one species S. bicolor (Variegated Simethis), a slender plant with fibrous roots; radical, grass-like, recurved leaves, $6-18$ in. long, and a forked, corymbose cyme, about the same height, of rather large, 6-merous flowers, purple outside, white inside; fruit a 3-chambered, 6-seeded capsule.-Formerly in fir-wonds near Bournemouth and in Kerry, very rare-Fl. May, June.. Perennial.

7. Áluium (Garlic).—Bulbous, strong-smelling plants, with radical leaves and flowers in an umbel or head, with a membranous, 1-2-leaved spathe and a leafless peduncle; perianth of 6 free, spreading segments; fruit a 3-chambered, 3-6-seeded capsule. (Name, the Classical Latin name of some species of the genus.)

1.* A. Ampelóprasum (Wild Leek)..-The largest species, 3-4 feet ligh, with a large bulb with large, stalked, lateral "cloves" or bulbils; a stout, leafy stem; distichous, flat, linear, folded, glaucous leaves with cylindrical sheaths; a globose umbel of greenislwhite flowers in a long pointed spathe, often with bulbils; the 3 outer filaments broader, 3-fid.-Rocky places ; rare, merely naturalised.-Fl. July, Angust. Perennial.

2. A. Scorodóprasum (Sand Leek).-A smaller 
plant, 2-3 feet high, with a slender, leafy stem; flat, linear, keeled, glaucous leaves with 2-edged sheaths; a loose head of red flowers in 2 short, pointed spathes, with red bulbils. - Sandy woods and fields in the north; rare.-Fl. May-July. Perennial.

3. A. spharocéphalum (Small Round-headed Garlic). -A similar but smaller species, with hollow leaves; round, compact umbels of red flowers without bulbils. Bristol and Jersey; very rare.-Fl. June-August. Perennial.

4. A. vineálé (Crow Garlic).-A similar plant with hollow, smooth leaves round in section; and dense, globose heads of red flowers with greenish or red bulbils.-Waste ground; common.-Fl. June, July. Perennial.

5. A. oleráceum (Field Garlic).-About a foot high, with fleshy, solid lecves, semicircular in section, grooved above and ribbed beneath; and a loose head of pale greenish or brownish-pink flowers in 2 spathes of unequal length, with bulbils; stnmens not 3-fid.Borders of field; uncommon.-El. July, August. Perennial.

6.* A. carinátum (Keeled Garlic).-A very similar species with linear, channelled leaves flat towards their tips, and rose-pink flowers with stamens twice as long as the perianth. - Naturalised in a few places.-Fl. August. Perennial.

7. A. Schonóprasum (Chives).-A pretty plant with a few straight, hollow leares round in section; and dense, globular, many-flowered umbels of pink flowers, with 2 short spathes, no bulbils, and included, undivided stamens.-Rocky pastures; very rare.-Fl. June, July. Perennial.

8. A. siburicum (Greater Chives), differing chiefly in its larger size, sometimes 2 feet high, and leates curving outwards and roughly ribbed, occurs on rocks, near the sea, in Colnwall._Fl. June, July. Perennial. 
9. A. triquétrum (Triangular-stalked Garlic).About a foot high, with a leafless, acutely triangular scape; radical, flat, linear, keeled leaves; flowers drooping to one side, in a loose umbel, with 2 short spathes and no bulbils; perianth-leaves white with a

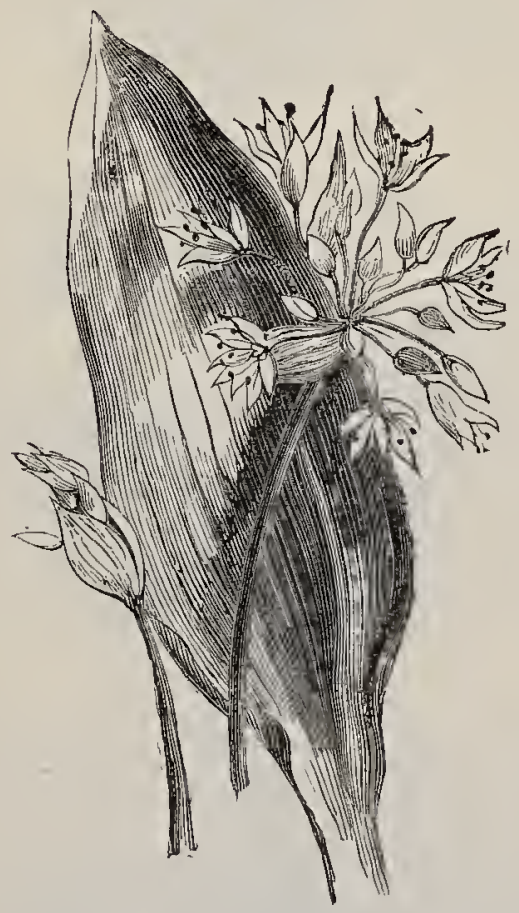

ALLIUM URSfNuM (Broad-leaved Gartic, Ramsons).

green midrib; stamens undivided, included.-Hedges and meadows, Cornwall and Guernsey; very rare.Fl. April-June. Perennial.

10.* A. paradóxum, with a scape leafy at its base, channelled, involute leaves, and a bell-shaped perianth, recorded from Linlithgow, is not indigenous. 
11. A.ursinum (Ramsons, Broad-leaved Garlic).The only common species of the genus, with broad, flat, radical leaves scarcely distinguishable from those of the Lily of the Valley; a triangular scape bearing a flat umbel of pretty white flowers with 2 ovate, acuminate spathes, no bulbils, and undivided, included stamens.-Woods and thickets; common. When bruised the whole plant emits an intolerable stench of Garlic.-Fl. May, June. Perennial.

8. Múscári (Grape Hyacinth).-Bulbous plants with radical leaves and globular, 6-merous flowers in a stalked, bracteate raceme; stamens included; fruit a 3-chambered capsule. (Name from the musk-like scent.)

1. M. racemósum (Grape, or Starch, Hyacinth).Leaves slender, prostrate, semicylindric, $6-12$ in. long ; scape shorter, bearing a short, cylindric, manyflowered, dense raceme of small, dark blue, ovoid flowers with minute bracts, the stalks lengthening after flowering.- Sandy fields in the eastern counties; rare.-Fl. April, May. Perennial.

9. Scílta (Squill).-Herbaceous plants with tunicate bulls; radical, linear teares; flourers 6-merous, in a raceme; perianth blue, purple, or white, deciduous; fruil a 3-chambered, many-seeded capsule. (Name, the Classical Latin name of the group.)

1. S. autumnátis (Autumnal Squill).-A little plant with a bulb the size of a walnut; leares $3-6$ in. long, appearing in autumn after the shortly racemose, reddish-purple flowers; bracts absent; perianthsegments free, spreading; anthers purple.-Dry pastures, especially near the sea, in the south; rare.-Fl. July-October. Perennial.

2. S. vérna (Vernal Squill).-A lovely little 
plant, about the same size as the last; with lecues broader and produced in spring before the corymbose clusters of fragrant, blue, star-like flowers, which

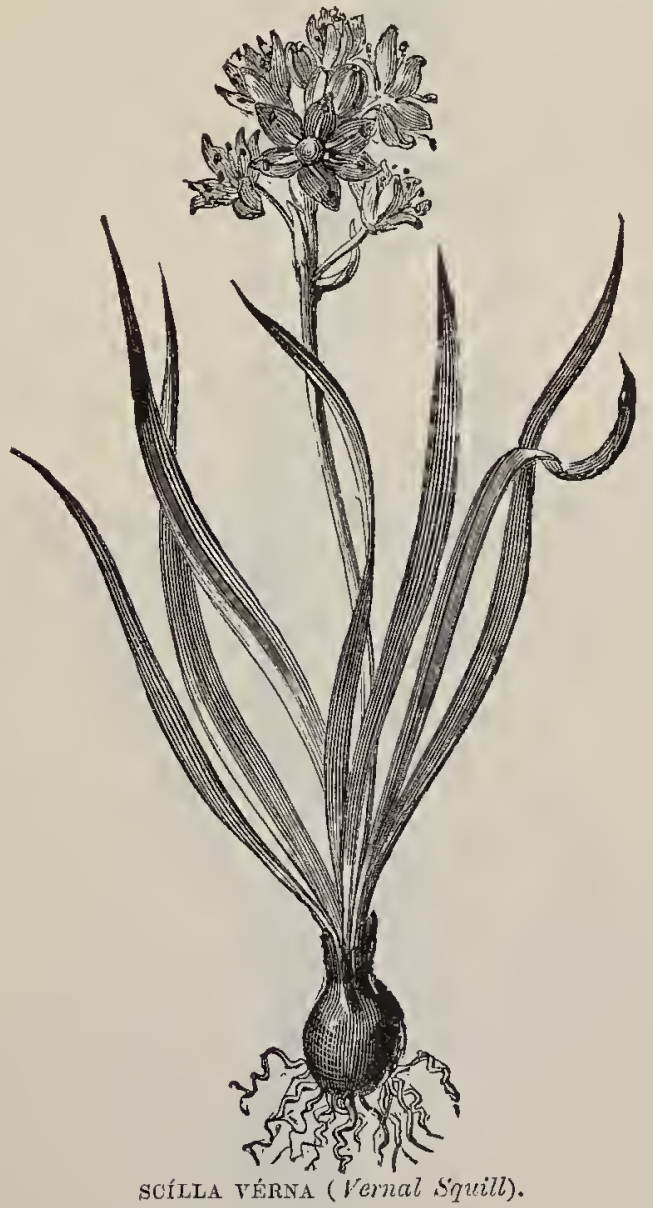

have lanceolate $b r^{r}$ cts. - Sea-coast in the west and north; uncommon. The turfy slopes of the seacoast of Cornwall are in many places as thickly studded with these pretty flower's as inland meadows 
are with Daisies. In a few weeks after their flower-

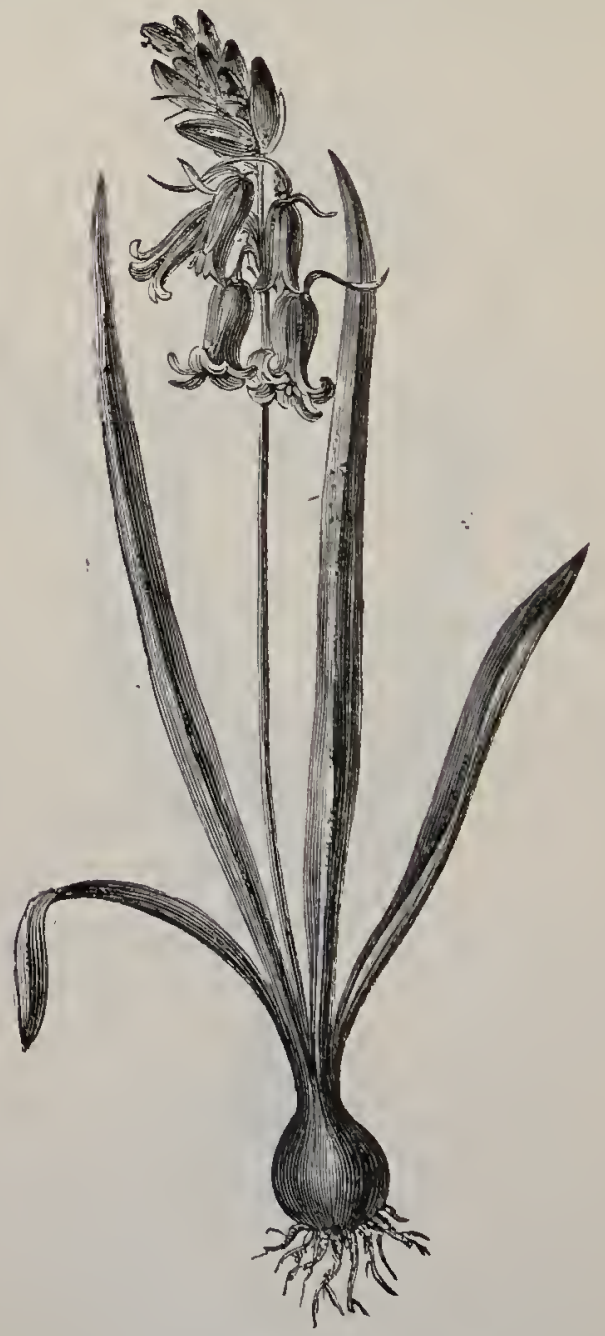

SChLA FESTLLIS (Tild Hyachnth).

ing no part of the plant is visible but the dry cap- 
sules containing black, shining seeds.-Fl. April, May. Perennial.

3. S. festális (Wild Hyacinth, Bluebell). - Too well-known a favourite to need much description.Leaves 10-18 in. long, sub-acute, produced in spring, before the stout, drooping, stalked, bracteate raceme of $6-12$ blue, rarely pink or white, pendulous flowers, which have a bell-shaped perianth of united segments, and yellow, included anthers.- Woods; abundant. The name Hyacinthus was originally given to some species of Lily into which the youth Hyacinthus was fabled to have been changed by Apollo. The petals were marked with dark spots, arranged so as to resemble the Greek word AI, alas! The present species, however, having no such characters on its petals, was named Hyacinthus non-scriptus (not written) by Linnæus, and was also at one time made into the distinct genus Agraphis. It is sometimes confused with the Harebell (Campánula rotundifólia), the Bluebell of Scotland.-Fl. May, June. Perennial.

10. Ornithógalum (Star of Bethlehem).-Closely allied to Scilla; but the flowers, which are in a bracteate, sometimes corymbose, raceme, are white or yellow, but never blue; the perianth, which consists of 6 free, spreading segments, has a nectariferous gland at the base of each, and is persistent; and the anthers are versatile. (Name from the Greek onnithos, bira's, gala, milk.)

1.* O. nútans (Drooping Star of Betinlehem). Bulb large; leaves a foot or more in length, glaucous; flowers few, large, white, greenish outside, in a loose, drooping raceme with long, slender bracts; filaments 3-fid.-Naturalised in fields; rare.-Fl. April, May. Biennial.

2.* O.umbellátum (Common Star of Bethlehem).Bulb smaller; leaves shorter, green, with a white 
stripe ; flowers 6-10, large, erect, white, with a broad green band externally, in a long-stalked, corymbose

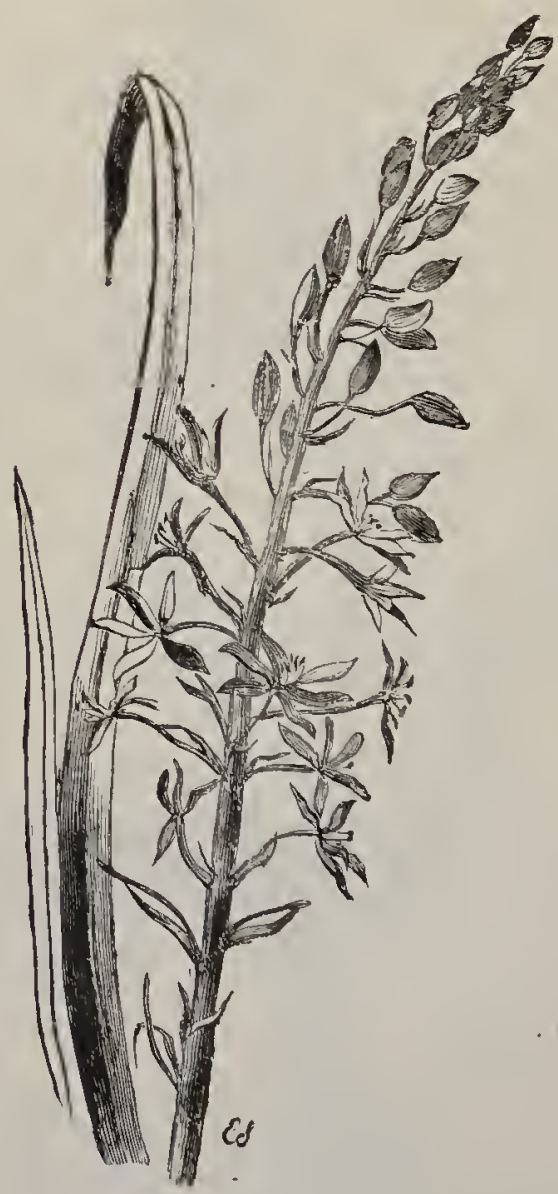

ORNITHOAAUM PYRENÁCUM (Spiked Star of Bethlehem).

raceme. - In the neighbourhood of houses, not indigenous; frequent.-Fl. April, May. Perennial. 3. O. pyrenáicum (Spiked Star of Bethlehem).- 
Bulb large; leaves long, narrow, glaucous, withering very early in the season; flowers numerous, in a long, erect raceme, with a stout, leafless peduncle about 2 feet high ; bracts lanceolate-acuminate; perianth-leaves green, with white margins inside. Woods in the south; rare, but very abundant near Bath, where the young shoots when in bud are sold as "French Asparagus."-Fl. June, July. Perennial.

*11. Lícium (Lily).-Herbaceous plants with scaly bulbs, cauline leaves, and large flowers with a deciduous perianth of 6 spreading, or reflexed, free segments, with a nectary; anthers versatile. (Name, the Classical name of some such plants.)

1. L. pyrenácum (Pyrenean Lily), - About a foot high, with scattered, linear-lanceolate leaves, and an umbel of a few, drooping, yellow flowers with black dots at the base of the revolute perianth-leaves. Near South Molton, North Devon; a garden escape.

2.* L. Mártagon (Turk's-cap Lily).--2 to 3 feet high, with downy stem; whorled, lanceolate leaves, and a raceme of drooping, pale violet or pink flowers with dark red warts on the revolute perianth-leaves.

Woods at Mickleham, Surrey; naturalised.-Fl. July-September. Perennial.

12. Fritillária (Fritillary). - Closely allied to Lilium, but with more drooping flowers with a bell-shaped perianth of which the segments are not recurved. (Name from the Latin fritillus, a dicebox, the common accompaniment of a chequer-board, which the marking of the flowers of some species resembles.)

1. F. Meleágris (Fritillary, Snake's-head). - The only British species, a beautiful plant, about a foot high, with a small butb of $2-3$ scales; stem round, 
'leafy, 1-8-flowered; leaves linear-acute ; flower drooping, generally solitary, shaped like a Tulip, curiously chequered with pink and dull red, rarely white.-

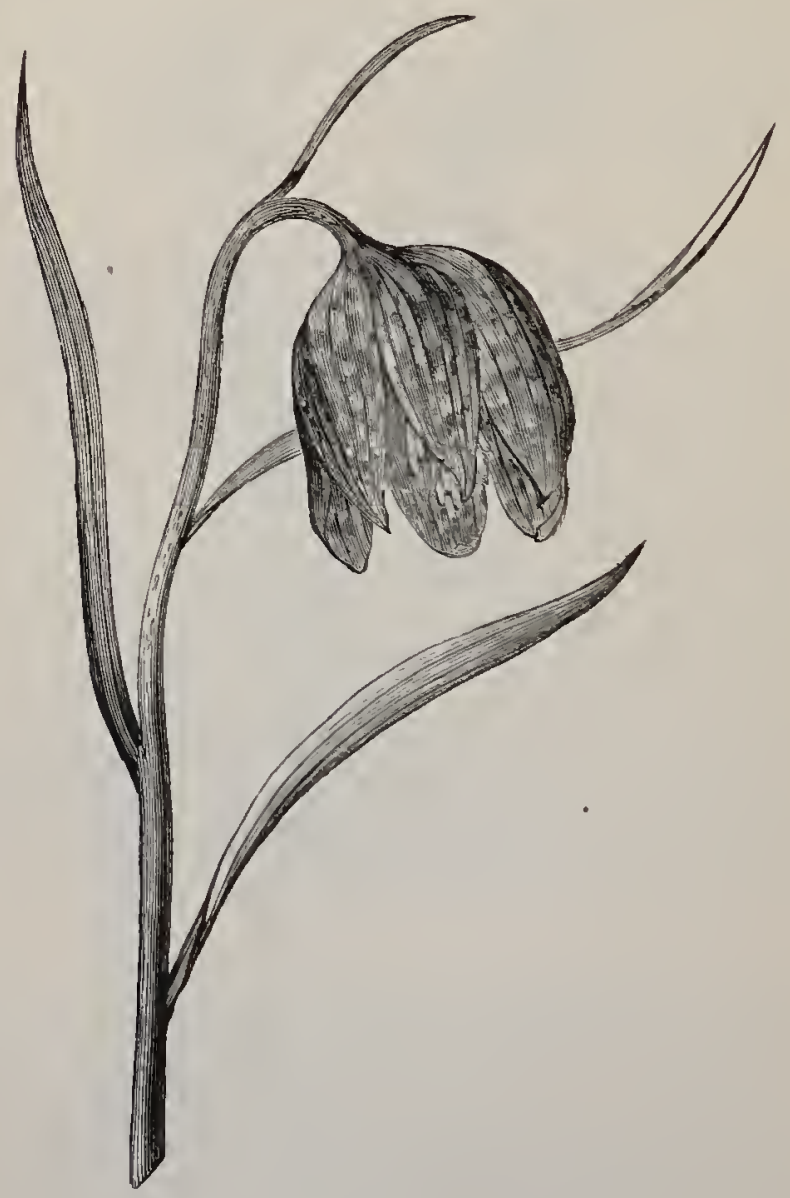

FRITILLARIA MELEÁGRIs (Fritillary, Snake's-head). Water meadows in the south; sare.-Fl. May.
Perennial. 
13. TúLIPa (Tulip).--Bulbous plants with radical and cauline leaves and usually large, solitary, erect flowers with bell-shaped, deciduous perianth of 6 free segments, recurved at their tips, without nectaries. (Name from the Persian tulipan, a turban.)

1. T. sylvéstris (Wild Tulip).-The only British species ; bulb chestnut-brown ; stem about a foot high, round, smooth ; leaves few, linear-lanceolate, glaucous; flower bright yellow, fragrant; perianth-leaves tipped with hairs.-Chalk-pits ; rare.-Fl. April, May. Perennial.

14. GágEa (Yellow Star of Bethlehem).-Bulbous plants with radical, linear leaves; few, small, yellow flowers, arranged in an umbellate manner; perianthleaves 6, free, without nectaries, spreading, persistent. (Named in honour of Sir Thomas Gage, an English botanist.)

1. G. fasciculáris(Yellow Star of Bethlehem).-The only British species; bulb small ; radical leaf commonly solitary, long and narrow; scape shorter than the leaves, with 2 opposite bracts and an umbel of yellow flowers.-Woods; local.-Fl. March-May. Perennial.

15. Llórdia (Spiderwort). - Small bulbous plants with slender, leafy stem; thread-like leaves; and 1 or 2 small, erect, white or yellow flowers; perianth-leaves 6 , free, with transverse nectaries, spreading, persistent. (Named in honour of Edward Lloyd, the antiquary, who discovered it in North Wales.)

1. L. alpina (Mountain Spiderwort). - A pretty little plant, with 3 -sided leaves, the radical ones longer than the 2-8 in. scape, which bears one white flower with red veins.-_Snowdon; very rare.-Fl. June, July. Perennial. 
16. Cócunicum (Meadow Saffron).-Underground stem a solid corm; leaves all radical, produced in spring; flowers mostly solitary, nearly sessile, erect, with a very long perianth-tube, resembling those of

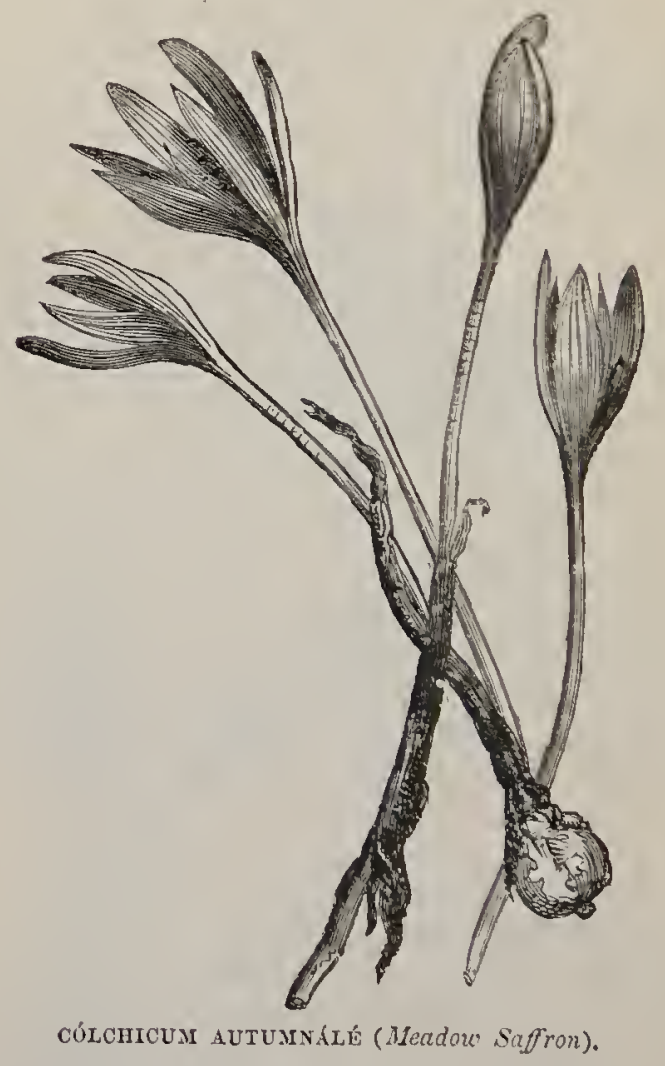

Crócus, but stamens 6, extrorse ; ovary superior; fruit a capsule. (Name of Greek origin, from Colchis, a country famous for medicinal herbs.)

1. C. autumnálé (Meadow Saffron, Autumn Crocus).-Leares lanceolate, dark green, glabrous, often 


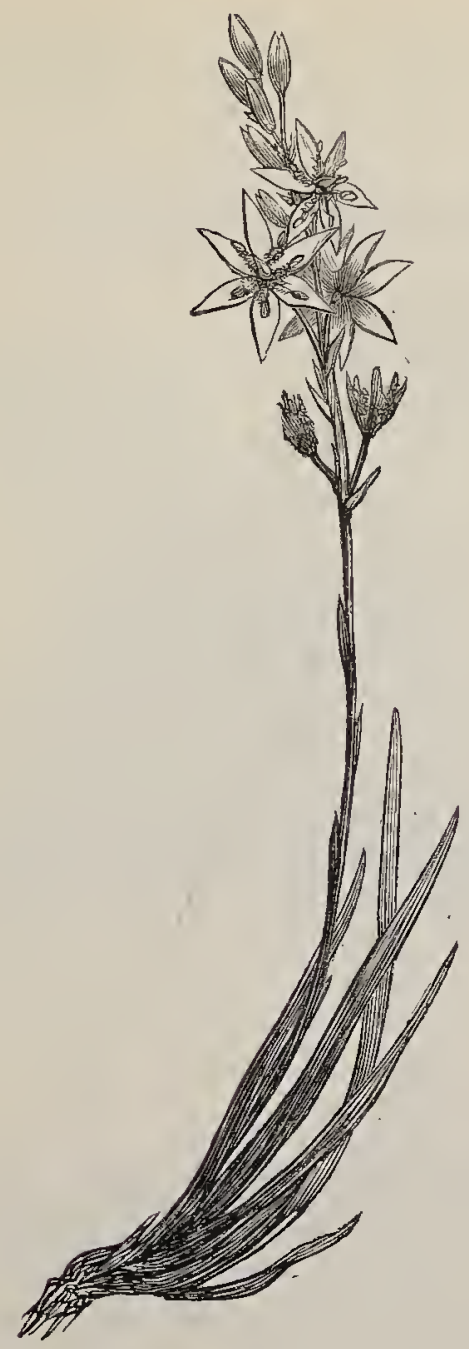

Narthécium ossffragum (Bog Asphodel).

a foot long, produced in spring and withering in summer; flowers light purple or white, presenting no 
conspicuous difference from Crocuses except their 6 stamens; ovary remaining underground until the spring after flowering, when they are borne up by the elongating peduncle and ripen.-Meadows, especially on limestone ; local._-Fl. September, October. Perennial. The leaves and fruit are poisonous to cattle.

17. Nartuéctum (Asphodel).-DStiff plants, with a creeping, ascending stem; sword-shaped, equitant leaves; flowers in a raceme; perianth-leaves 6, free, spreading, golden-yellow, persistent; style 1; capsule 3-chambered. (Name from the Greek narther, a rod.)

1. N. ossifragum (Bog Asphodel). -The only British species, an elegant little plant, $6-8$ in. high, with tufts of narrow, grass-like leaves, and a tapering spike of star-like, yellow flowers, followed by long, orange-red capsules.-The name ossifragum, bonebreaking, was given to this plant from its being supposed to soften the bones of cattle that fed on it. Other plants have had the same property assigned to them, but there is little doubt that in every case the diseases in question are to be traced to the noxious exhalations from the bogs in which the plants grow, rather than to the plants themselves.-Fl. JulySeptember. Perennial.

18. Tofiḱldor (Scottish Asphodel). - Very similar' to the preceding genus, but with greenish flowers and a fruit consisting of 3 many-seeded follicles. (Name in honour of $\mathrm{M}_{1}$. Tofield, a Yorkshire botanist of the 18 th century.)

1. T. palústris (Mountain Scottish Asphodel).The only British species, $4-6$ in. high, with tufts of distichous, narrow, sword-shaped leaves, and almost stalkless, dense spikes of small, greenish-yellow flowers, 
with 3 membranous bracts below each. - Boggy ground in the north; rare.-Fl. July, August. Perennial.

19. PÁris (Herb-Paris). - Plants with a stout

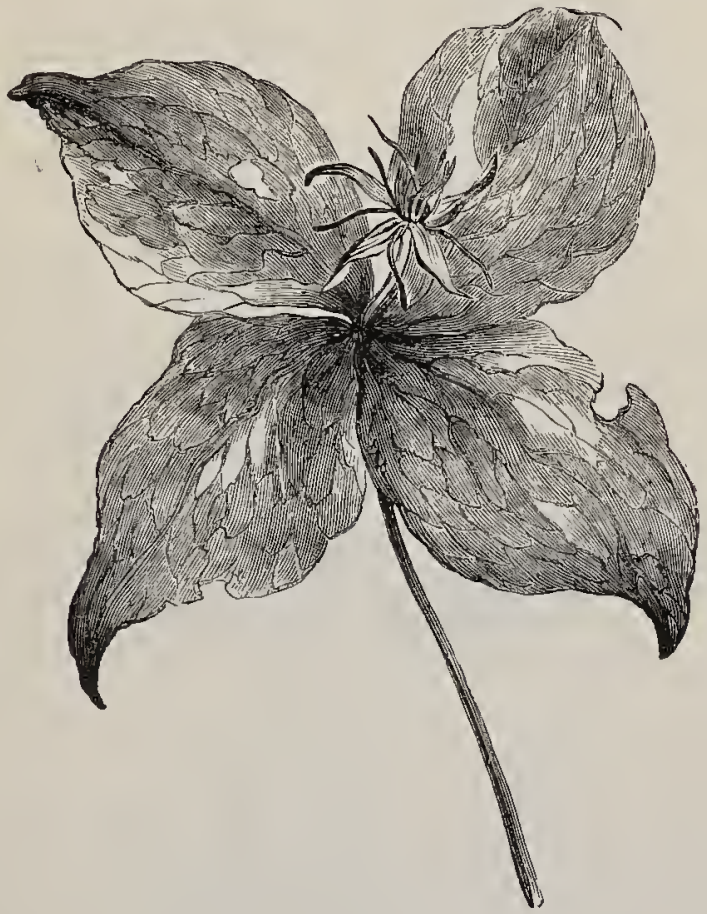

PÁIS QUADRIFólia (Four-leaved Herb-Paris, True-Love Knot).

rhizome ; erect, simple stem, bearing 4 whorled, netveined leaves, and a solitary, terminal, green, generally 4-merous flower, succeeded by a berry-like fruit. (Name from the Latin par, equal, on account of the equal number of leaves in the several whorls.)

1. P. quadrifólia (Herb-Paris, True-Love Knot). 
-The only British species, a singular plant, about a foot high, with 4 large, ovate, acute leaves; a rather large flower with narrow perianth-leaves and a black, 4-chambered berry.-Woods; rather local.-Fl. May, June. Perennial.

\section{Ord. LXXXIII. Juncáce无-Rush Family.}

An Order of plants mostly perennial and inhabiting marshy situations in temperate or arctic regions. They have mostly creeping whizomes; stems herbaceous, seldom branched, erect, often with considerable central pith; leaves often resembling the stems, and flled with a pith-like internal tissue, or flat; flowers small, green or brown, polysymmetric, and perfect, in cymose clusters; perianth inferior, of 6 free, membranous, imbricate, persistent leaves ; stamens 6, rarely 3 , with introrse anthers ; ovary $1-3$-chambered, 3 - or many-ovuled; style 1 ; stigmas 3 , slender ; fruit a capsule. The true Rushes (Juncrs) are, for the most part, social plants, single species covering wide areas of marsh or bog and often proving of considerable use in fixing the soil. The stems of the common species were formerly used to strew the stone floors of castle halls in lieu of carpets, for twisting into cordage, and for wicks for tallow candles; but are now seldom put to any use. The name Rush is extended to members of other Orders, the name Bulrusl being applied to Scirpus lacústris, which belongs to the Sedge Family ( genus Tylha, which gives its name to the Order Typhacex, whilst the name Flowering Rush is applied to Butomus umbellátus in the Order Alismácece.

1. Júncus.-Smooth plants generally with cylindric leaves; ovary generally 3-chambered; ovules many.

2. Juncoïnes.-More or less hairy plants, with flat loces; 1-chambered oury; ovules 3. 
1. JúnCUS (Rush)._-Smooth marsh plants, usually with a creeping thizome; cylindric leaves; membranous perianth; stamens 6 , rarely 3 ; or'ary $1-3$ -

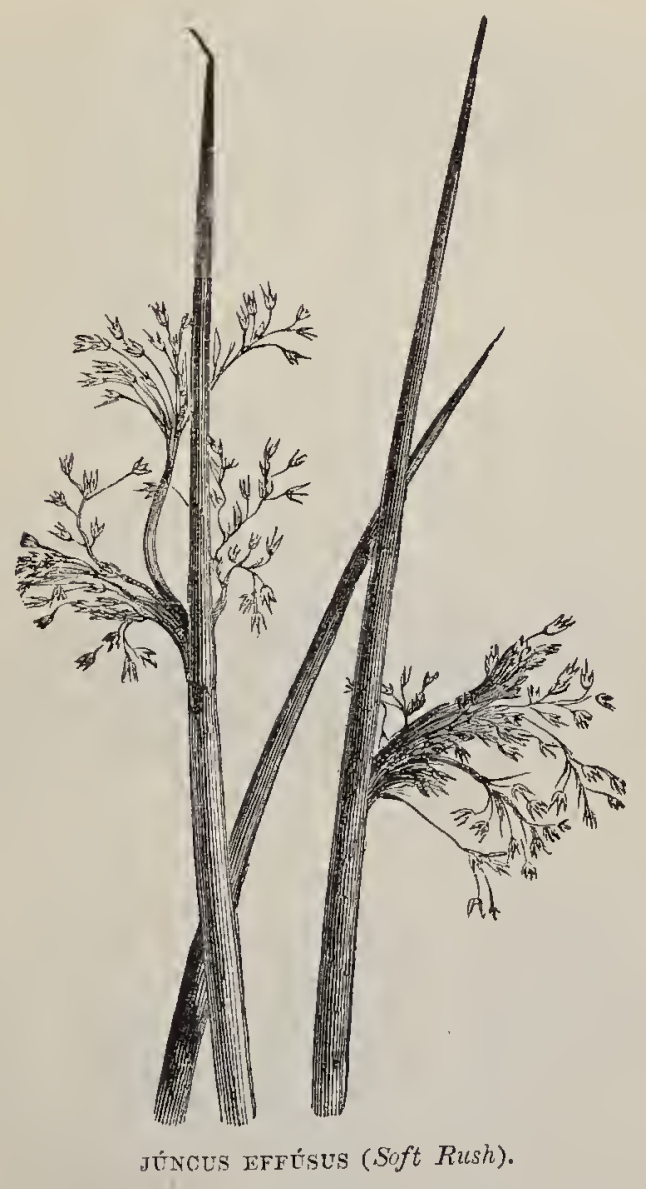

chambered, many-ovuled ; stigmas 3, wind-pollinated. (Name, the Classical Latin name of the plant, perhaps connected with jungo, I join, referring to the ancient use of the stems for twisting into cordage.) 
* Perennial; stems cylindric, tapering to a point ; leaves solud.

1. J. effusus (Soft Rush).--One of the commonest species, with soft, faintly striate stems, $1-3$ feet high; flowers olive-green, in a loose, spreading, branched panicle; perianth-leaves lanceolate, longer than the blunt capsule; stamens 3.-Marshy ground; abundant. -Fl. July. Perennial.

2. J. conglomerátus (Common Rush).-Mainly distinguished from $\int$. eff úsus by its usually more densely crowded, globose panicles of browner flowers and by its capsule ending in a point.-Marshy ground; abundant.-Fl. July. Perennial.

3. J. glaúcus (Hard Rush).-Distinguished by its rigid, slender, deeply furrowed, glaucous stems, 12-18 in. high; and very loose, much-branched, elect panicle of brown flowers, below the apex of the stem; perianth-leaves narrow, as long as the oblong, mucronate capsule; stamens 6.-Marshy places and roadsides ; common.-Fl. July, August. Perennial.

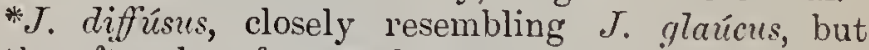
with softer, less furrowed stem, continuous pith, and obovoid capsule, is probably a lybrid between the two preceding species.

4. J. búlticus (Baltic Rush). - A widely creeping species, with few, rigid, very faintly striated stems, 1 -2 feet high ; flowers brown, in small, flat-topped, slightly-branched, erect panicles; perianth-leaves ovatelanceolate, as long as the ovoid, mucronate capsule; stamens 3.- Sandy shores in the North-east of Scotland; rare.-Fl. July, August. Perennial.

5. $J$. filifórmis (Thread Rush).--A very slender, pale green species, less than a foot high, with faintly striate stems; flowers few, pale, crowded in a small sessile cyme, about half-way up the stem; perianth-leaves 
lanceolate, longer than the roundish, blunt, mucronate capsule; stamens 6.-Stony lake shores in the north; very rare.-Fl. July, August. Perennial.

6. J. acútus (Great Sea Rush).-The largest British species, growing in circular tufts, with stout, rigid, sharply-pointed stems and leaves 3-6 feet high; brown flowers in a dense, branched, corymbose panicle; perianth-leaves half as long as the large, rounded, polished, mucronate capsule.-Sandy seashores; in great abundance in few places.-Fl. JuneAugust. Perennial.

7. J. marítimus (Lesser. Sea Rush).-Resembling the preceding, but irregularly tufted, with less stout, less rigid, erect, spinous stems, $1-2$ feet high ; similar leaves; very pale flowers in an interruptedly branched, erect panicle; perianth-leaves lanceolate, as long as the elliptic, mucronate capsule.- Salt marshes; frequent.Fl. July, August. Perennial.

8. J. triglúmis (Three-flowercd Rush).-WStems tufted, without runners, 3-6 in. high, round, leafless ; leaves radical, awl-shaped, channelled, formed of 2 tubes internally; flowers $2-3$, terminal; capsule pale red-brown.-Mountain bogs; rare.-Fl. July, Áugust. Perennial.

9. J.biglimis (Two-flowered Rush). $\rightarrow$ A very rare alpine species, 2-6 in. high, with leafless stems channelled down cne side; leaves radical, awl-shaped, compressed ; flowers 2, chestnut-brown.-Fl. July, August。 Perennial.

10. J.castáneus(Clustered Alpine Rush).-Another very rare alpine species; stem b-12 in. high, with runners and 2-3 channelled, hollow leaves; flowers bright brown, in 2-6-flowered, terminal, or sometimes also lateral, cymes; perianth-leaves lanceolateacute, half as long as the pointed, chocolate-brown capsule.-Bogs on the summits of lofty Scottish mountains; very rare.-Fl. July, August. Perennial. 
11. J. trifidus (Three-leaved Rusli).-Another small species, with a creeping rhizome; crowled, slender, erect stems, $2-8$ in. high; with one subulate leaf above, and others reduced to sheaths; flowers brown, $1-3$ together between 2 long, leafy hracts; capsule ovoid, acute, longer than the perianth.-Mountain bogs in Northern Scotland, forming dense matted masses.-Fl. July, A ugust. Perennial.

12. J. squarrósus (Heath Rush).-Well marked by its rigid stems and leaves. The stems are $6-12$ in. high, erect, stout, solid, occurring in tufts, but unbranched and generally leafless; leaves mostly radical, rigid, half as long as the stem, grooved; flowers 2-3 together, brown, in a terminal panicle; perianth-leaves ovate-lanceolate, as long as the blunt, bristle-pointed capsule.-Mloors and heaths; abundant. -Fl. June, July. Perennial.

13. J. témis (Slender Rush). - Stems abont a foot liigh, cylindric, very slender; leaies few, mostly ra lical, linear, grooved; flowers pale, some stalked, others not, in terminal panicles, shorter than the long, erect, thread-like bruts; perimenth-leaves lanceolate, longer than the spherical capsule. - Moist sandy places, chiefly in the north and west; very rare.-Fj. June-August. Perennial.

14. J. compréssus (Round-fruited Rush). - A slender plant, about a foot high, with tufted stems, hollow, round and leafy below, compressed above, with ono linear, grooved leaf above: flowers brown, in a compact terminal panicle; periunth-leaves ovaloblong, blunt, shorter than the nearly round, bristlepointed capsule.-Damp places; rare-_Fl. JuneAugust. Perennial.

15. J. Gerándi (Mud Rush). - Stems less tufted, 3siled above; perianth-leaves as long as the strongly mucronate capsule.-Salt marshes; common. - Fl. June-August. Perennial. 
* Perennial ; stems solid; leaves hollow. jointed internally.

16. J. obtusiflórus (Blunt-fiowered Jointed Rush.) -Erect, 2-3 feet high; stem and leaves smooth and round; flowers in clusters of $3-8$, in repeatedly

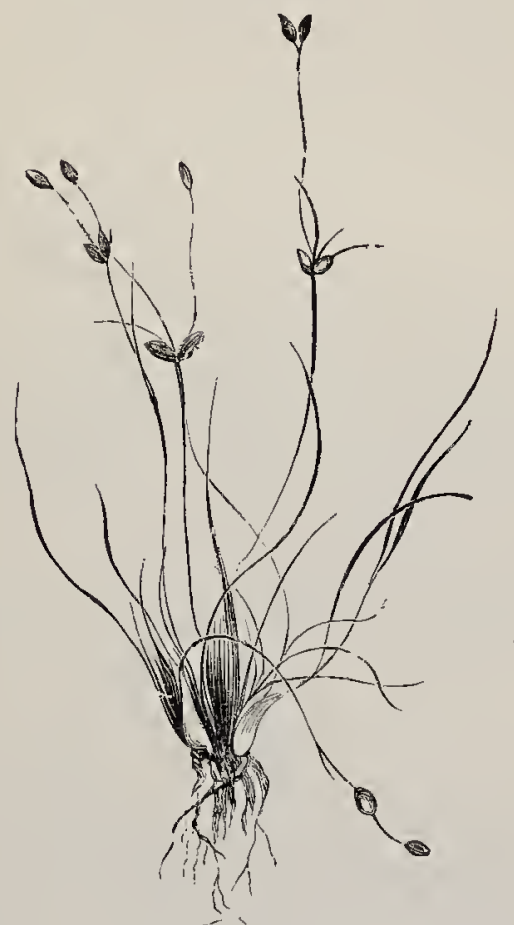

JúNCUS SUfínus (Lesser Jointed Rush).

branched, spreading corymbs, pale, often reddish; perianth-leaves blunt, as long as the ovate, mucronate, pale brown capsule.-Marshes; not common. - Fl. Tuly-September. Perennial.

17. J. (cutiflínus (Sharp-flowered Jointed Rush.) -Stem erect, $1-2$ feet high, slender, slightly com- 
pressed, 3-4-leaved; Teaves slightly compressed, very conspicuously jointed when dry; flowers dark chestnut-brown, in dense clusters of $3-12$, in a terminal, pyramidal, compound panicle; perianth-leaves acuminate, barely as long as the pale brown, beaked capsule. -Boggy places; common. - Fl. June-August. Perennial.

18. J. supínus (Lesser Jointed Rush).-A small and very variable plant, less than a foot high, erect or prostrate; with thread-like stems; bristle-like, slightly-grooved leaves; flowers in an irregular, littlebranched panicle of a few distant clusters; capsules pale brown, oblong, blunt, mucronate.-Boggy places ; common.-Fl. June-August. Peremnial.

19. J. aipinus (Alpine Jointed Rush).-Stem erect, about a foot high, 2-3-leaved; leares sessile, pointed, slightly compressed and striate, with few articulations ; flowers in clusters of $3-8$, in a repeatedly forked, erect, terminal panicle, black or dark brown; bracts acuminate; perianth-leaves blunt; capsule blackish, obtuse, mucronate, longer than the perianth-leaves.In the North of Scotland; rare. Perennial.

20. J. lampocárpus (Shining-fruited Jointed Rush). --Stem erect, 1-2 feet high, slightly compressed, 3-6-leaved; leaves compressed, with many internal divisions; flowers in clusters of $4-8$, in a repeatedlyforked, erect, terminal panicle; perianth-7eaces shorter than the large, dark brown, glossy capsule._Boggy places; common.-Fl. July, August, Perennial.

\section{**** Annual; stem hollow.}

21. J. bufómius (Toad Rush). — A very small species, 2-8 in. high, with slender, pale green, hollow, repeatedly-forked stems; few, narrow, bristlelike leaves; solitary, sessile, green flowers, which grow mostly on one side of the stem; and oblong, blunt capsules, shorter than the perianth. - Moist 
places; abundant, often in large patches.-Fl. June -August. Annual.

22. J. capitátus (Capitate Rush).-A very small, tufted plant, with naked, erect, unbranched, bristlelike stems, 1-4 in. high; radical, thread-like, channelled leaves, $1-2$ in. long; and large, terminal, bracteate heads of $3-10$ sessile, pale flowers; perianth-leaves with slender, awn-like points, twice as long as the pointed capsute; stamens 3.--Sandy places liable to flooding, West Cornwall and the Channel Islands.-Fl. May-July. Annual.

23. J. pygmééus (Pigmy Rush).-A very small, tufted plant, 1-2 in. high, with slender, littlebranched stems; leaves mostly radical, bristle-like; flowers in a few small clusters; perianth-leaves linear, acute, longer than the oblong-acute, 3-edged capsule. -Damp places near the Lizard.-Fl. May, June. Annual.

2. Juncoídes (Wood-Rush).-Differing from Júncus in having flat, more grass-like leaves more or less hairy, with long, weak, white hairs; flowers in clusters, with prominent anthers, wind-pollinated; capsute 1 chambered, 3-seeded. (Name formed from Juncus, and signifying rush-like.)

1. J. Fórsteri (Forster's Wood-Rush). - A slender plant, abcut a foot high ; leaves linear, hairy ; fiovers on 1-flowered, erect peduncles in a loose, slightly branched cyme; capsule 3-sided, acuminate.-Shady places on calcareous soil in the south; rare-Fi. March-June. Perennial.

2. J. pitósum (Broad-leaved Hairy Wood-Rush).A very similar plant, with broader, soft, slightly hairy leaves; fiowers 1-3 together; on peduncles which bend downwards in fruit; capsule 3-sided, blunt.-Woods; common.-Fl. April-June. Perennial. 
3. J. siluciticum (Great Wood-Rush).-A commou woodland plant, with more of the habit of a Grass than a Rush, sometimes nearly 2 feet high; leaves linearlanceolate, channelied, shining, with hairy edges;

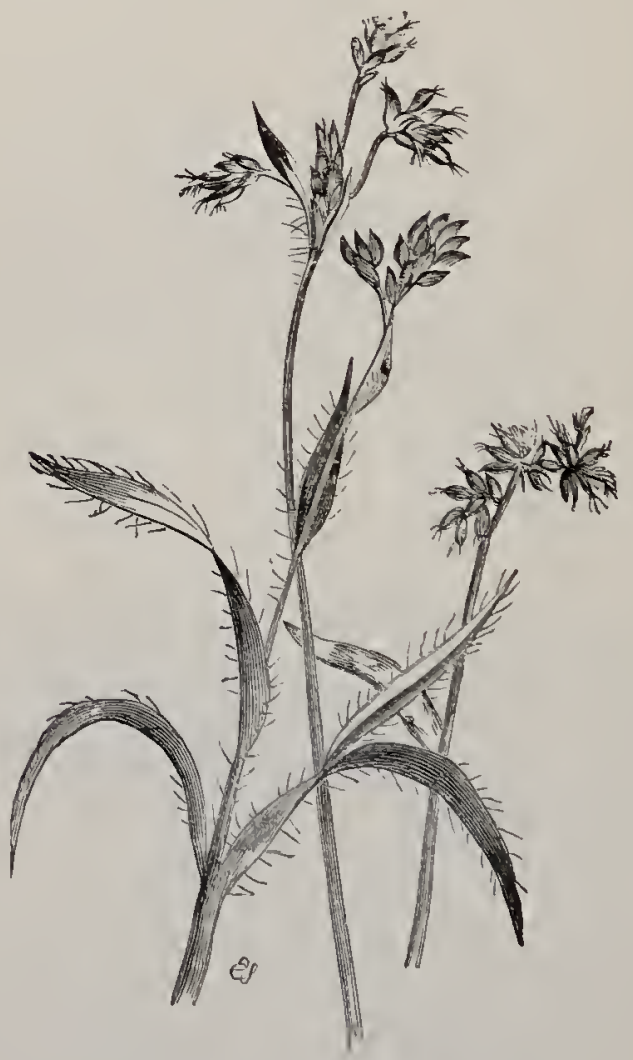

JUNCOLDES CAMPÉstré (Field Mood-Rush).

flowers 3-4 together, in a loose, doubly-compound, terminal panicle with long branches; perianth-leaves pale brown, awned, about as long as the ovoid, beaked capsule.-Woods; abundant.-Fl. AprilJune. Perennial. 
4. J. arcuátum (Curved Mountain Wood-Rush). -A small species, 2-5 in. high, with recurved leaves and a 3-5-rayed umbellate panicle of flowers in 3-5flowered clusters on drooping stalks.-Summits of lofty Scottish mountains; very rare.-Fl. July. Perennial.

5. J. spicátum (Spiked Mountain Wood-Rush).A slender species, 3-12 in. high, with a drooping, dense, spike-like panicle of flowers. - Mountains; rar'e. -Fl. July. Perennial.

6. J. campéstré (Field Wood-Rush, Good Friday Grass, Chimney-sweeps).-An. early spring meadow flower, 4-6-in high, with hairy, grass-like leaves, but distinguished by its panicles of 3 or 4 ovate, dense, 3-4-flowered clusters of dark brown, or almost black, flowers, suggesting a sweep's brush.--Pastures ; common.-Fl. March-May. Perennial.

7. J. eréctum (Many-flowered Wood-Rush).-A taller, stouter species, $8-20 \mathrm{in}$. high; with panicles of numerous many-flowered cluster's of flowcrs, sometimes pale brown, and sometimes on drooping peduncles. Heaths, mountains and moist situations ; common.Fl. June. Perennial.

\section{Ord. LXXXIV. Typhácele.-Reed-iace Famity.}

A small Order of marsh and water plants with creeping rhizomes; sword-shaped, linear leaves, sheathing at their bases; and numerous, small, monœcious flowers, which are only rendered conspicuous by being crowded in compact cylindrical spikes or globose heads, the staminate flowers being nearest the apex of the inflorescence; perianth of 3 scales, or a tuft of hairs, persistent; stamens 1-6, distinct, or united by theil. filaments; ovary superior, 1-chambered, 1-ovuled; fruit indehiscent, often angular from mutual pressure. The Order contains only two genera, both of which 


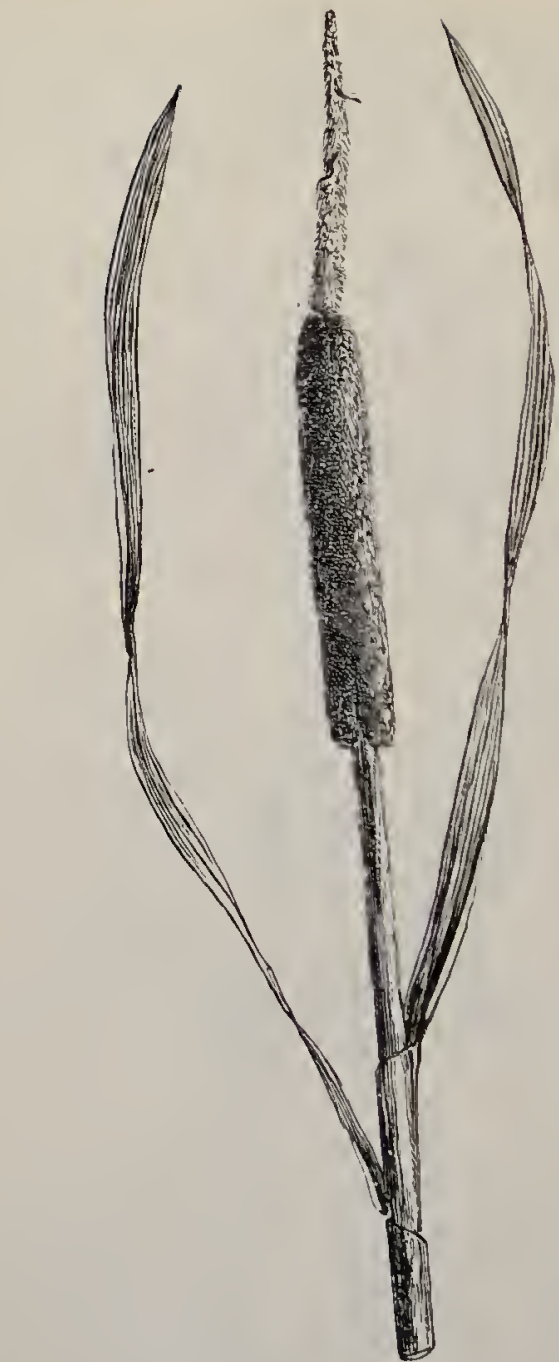

TÝPHA LATIFóla (Grexi Reed-1lace, or Cat's-tail).

are represented by common British species, the Burreeds (Sparganium) and the Reed-Maces (Týpha). The 
pollen of the latter is made into cakes in šcinde and in New Zealand.

1. TÝpHa. - Flowers in long, dense, cylindrical spikes.

2. Spargínium.-F'lowere in globular heads.

1. 'T́ÝrHa (Reed-Mace).-Herbaceous, aquatic plants with sword-shaped leaves; long, dense, cylindrical, brown spikes of pistillate flowers, surmounted by a more slender, deciduous spike of staminate ones; perianth of 2 or 3 slender hairs; stamens 3, monadelphous; ovary stalked; style slender. (Name from the Greek tuphos, a marsh, where these plants grow.)

1. T. latifólia (Great Reed-Mace, or Cat's-tail).Our largest herbaceous aquatic, often growing 6--8 feet high, with nearly flat, linear, glaucous lexves, and stout, cylindrical peduncles, surmounted by a club-like spike of pistillate flowers which is continuous with that of staminate flowers.-Ponds ; common. Often called Bulrush, a name properly belonging to the large rush-like Scirpus lacústris.-Fl. July, August. Perennial.

2. T.angustifótia (Lesser Reed-Mace,or Cat's-tail).Smaller and more slender, with narrow leaves grooved below, not glaucous, longer than the flowering stems, and the long, slender spike of pistillate flowers separate from the staminate one. - Ponds; less frequent. Both these species are now largely sold as ornaments. -Fl. July, August. Perennial.

2. Sparqánium (Bur-reed). - Graceful aquaties with sword-shaped leaves and flowers in distinct, dense, globular heads; perianth 3-6-leaved, membranous; stamens 2-3, distinct. (Name in Greek denoting a little band or strap, from the ribbon-like leaves.)

1. S. ramósum (Branched Bur-reed). - A large aquatic with erect, branched stem, 1-4 feet high; 
leaves erect, sword-shaped, triangular at the base with

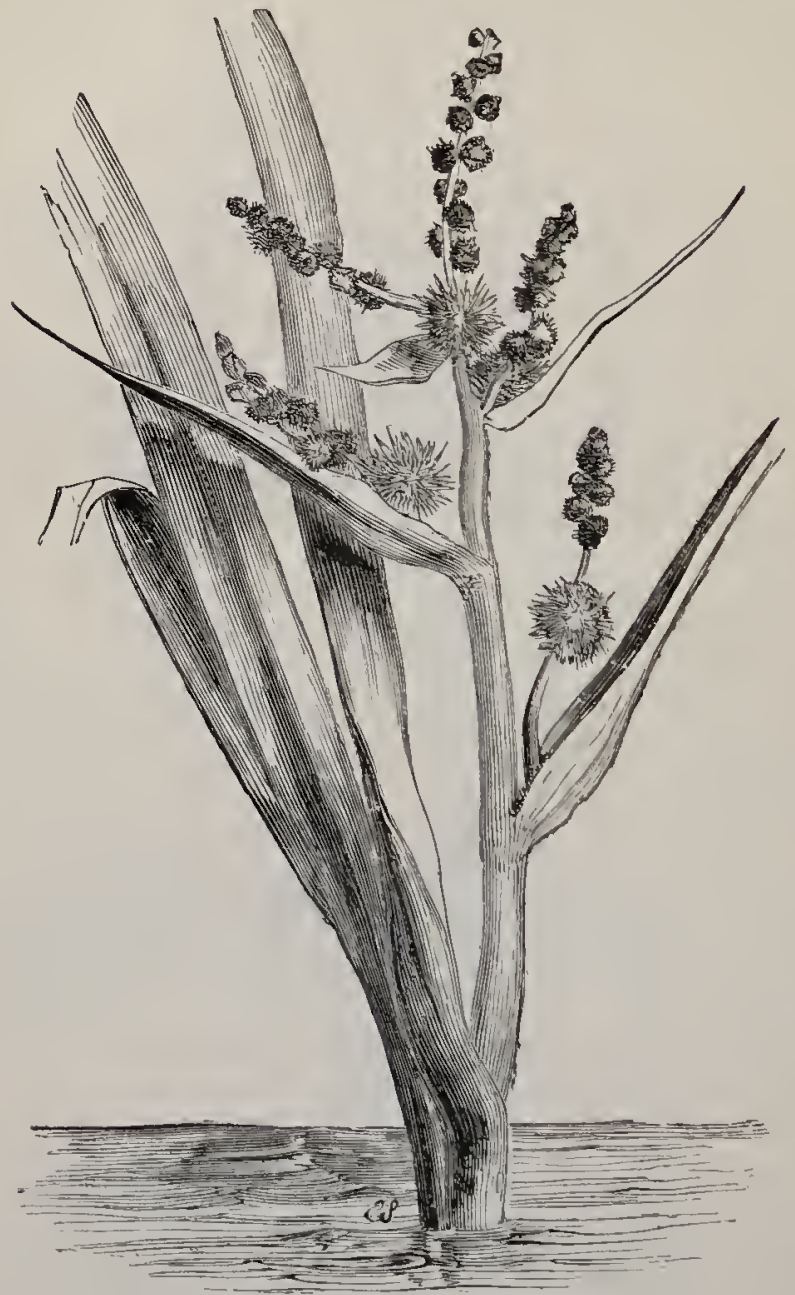

SPARGÁNIUM RAMÓSUM (Branched Bur-reed).

concave sides; linear bracts; 1-3 lower heads, larger, pistillate; upper, half the size, staminate, olive-brown 
in bud, deciduous; fruits broadly ovoid, abruptly and shortly beaked.-Ditches; common.-Fl. June, July. Perennial.

2. S. negléctum (Overlooked Bur-recd) -A very similar plant, differing chiefly in the fruits, which, when ripe, are obovate, tapering gradually into a long beak.

3. S. simplex (Unbranched Upright Bur-reed).A smaller plant with unbranched stem; leaves triangular at the base, with flat sides, sometimes floating; heads in a raceme, the lower pistillate ones shortly stalked; the staminate ones sessile, yellow; fruits resembling those of S. negléctum, but smaller.-Ditches ; common. -Fl. June-August. Perennial.

4. S. affiné (Floating Bur-reed).-A weak, unbranched, floating plant, with very long, grass-green, flat, floating leaves; several staminate heads; and stalked, long-beaked fruits. -Lakes ; rare.-Fl.August Perennial.

5. S. minimum (Least Bur-reed).-A more slender form, with pale, pellucid leaves; 1-2 staminate heads; and sessile, short-beaked fruits.-Lakes and ditches; more common.-Fl. July, August. Perennial.

Orn. LXXXV. Aroídeæ.-The Cuckoo-PINT Family.

A considerable Order of curious plants, many of which much resemble our Britich Lords-and-Ladies (Arum maculátum). They abound in tropical countries, and possess acrid or even poisonous qualities, which, however, may be dissipated by heat. They mostly have fleshy, underground stems, often large, starchy corms, with their small flowers on a simple fleshy peduncle or spadix, and enclosed in one large, sheathing spathe. The flowers are either perfect or 
monocious; the perianth absent or represented by $4-8$ scales; stamens 1-8; oury 1-3-chambered, superior; fruit berry-like. Some species of Amorphophállus, natives of tropical Asia, have enormous corms : the Dumb. Cane of the West Indies (Dieffenbáchic seguina) is so-called from producing, when chewed, a violent and painful swelling of the tongue and uvula: species of Caládium are cultivated for their variegated leaves; and those of Authurium for their spathes, which are sometimes a brilliant scarlet, for which reason the name Flamingo-flower has been applied to them. Zantedéscticia athiópica, under the name of Trumpet-lily or Calla, is one of the best known members of the Order. In South Africa it is known as the Pig-lily, pigs feeding on its corms. An attempt has been made to utilise the starch in these stems, but it is mixed with numerous needle-like crystals. These raphides, as they are called, are also abundant in our British Arum maculatum, an acridly poisonous plant, the corms of which were formerly, however, collected in the Isle of Portland for the manufacture of Portland Arrowroot. The Sweet Sedge (Ácoms Cálamus), another British species, has no raphides. This plant in olden times supplied the "rushes" with which, before the use of carpets had been introduced into England, it was customary to strew the floors of the great. As it did not grow near London, but had to be fetched at considerable expense from Norfolk and Suffolk, one of the charges of extravagance brought against Cardinal Wolsey was that he caused his floors to be strewed with fresh rushes too frequently. Its bitter rlizome is used in herb-beers, gin, and snuff. Mlost species of the Order give out a considerable amount of heat within the spathe at the time of flowering, so that the temperature rises noticeably above that of the extermal air. Many of them also have lurid colouring and a fetid odour. 
1. Árum,-Leaves hastate, net-veined; spathe convolute; flowers monocious; perianth absent.

2. Ácorus.-Leaves sword-shaped, parallel-veined;

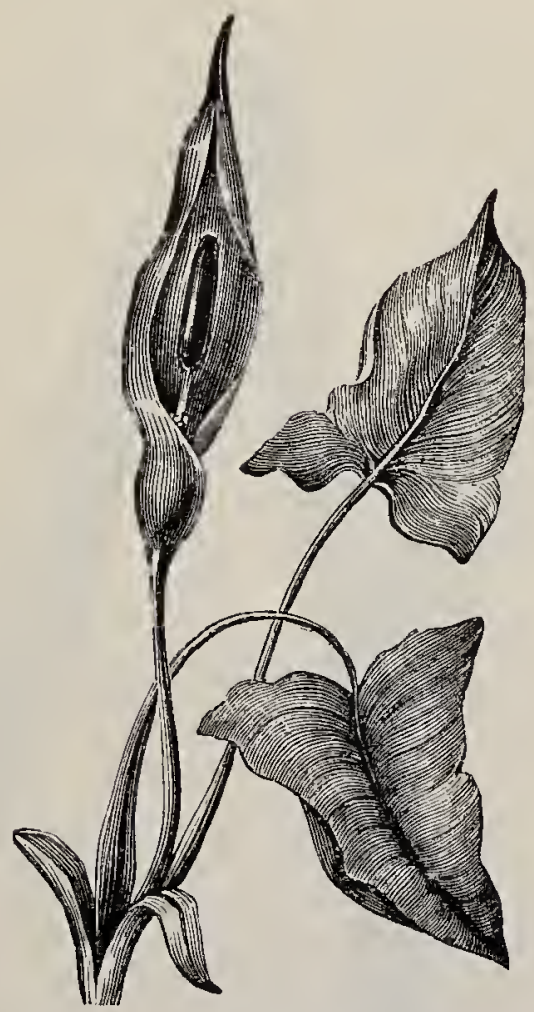

ÁUM MaCUlátuar (C'iclioo-pint, Wake-Robin, Lorl\$s-and-Ladies).

spathe leaf-like, not convolute; flowers perfect; perianth 6-leaved.

1. Áxun (Cuckoo-pint). - R7izome short, fleshy; leaves radical, hastate, net-veined, glabrous, with a sheathing petiole; spathe convolute, contracted above 
the base; spadix terminated by a club-shaped, naked, fleshy appendix; flowers monocious, the carpellate ones below, separated by some aborted ones from the staminate ones, above which are some more aborted

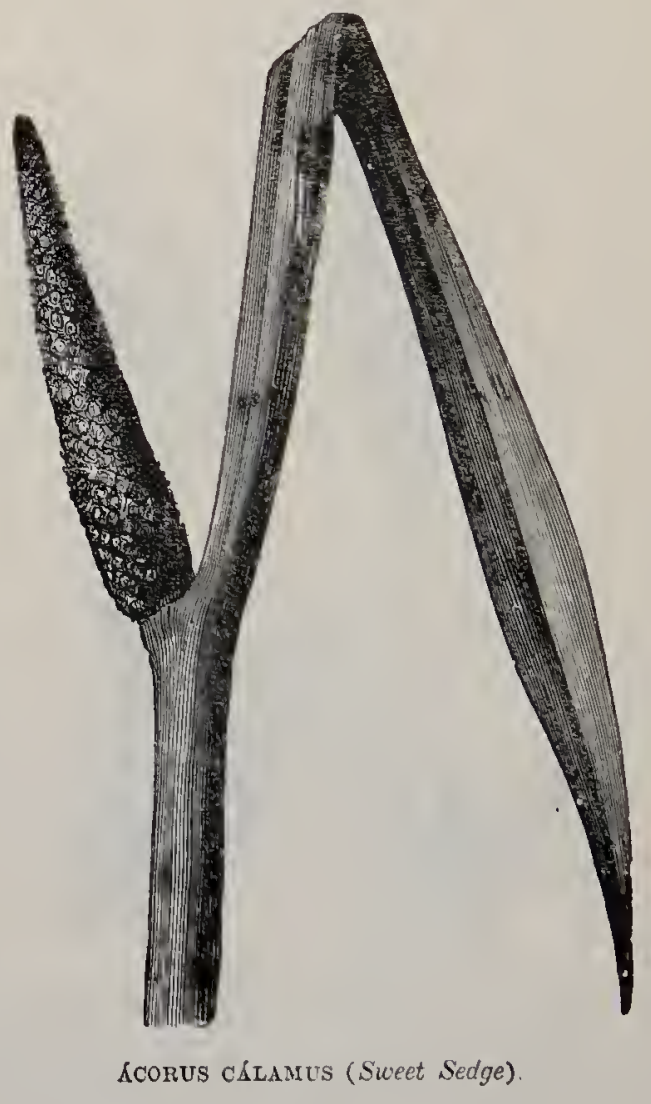

ones ; pericuth absent; fruit berry-like, 1-chambered, few-seeded. (Name, the Greek name of the plant.)

1. A. maculétum (Cuckoo-pint, Lords-and-Ladies, Wake-Robin),-A succulent, herbaceous plant, with 
large, glossy, arrow-shaped, radical leaves, which are often spotted with dark purple. The pale yellowgreell spathe is erect and twice as long as the spadix. They may be discerned wrapped up in the young leaf-stalks even before the leaves have risen above the ground. The appendiv is a rich crimson, dull purple, or light pink, which is easily rubbed off', or yellow. At the base of the spadix are numerous sessile ovaries or carpellate flowers; above them a row with aboited styles; yet higher up several whorls of purple sessile anthers or staminate flowers; and above them some aborted ones or staminodes. The spathe and appendix soon wither, leaving the ovaries, which finally become a mass of scarlet berries, conspicuous in autumn.-Hedges and woods; common.-Fl. April, May. Perennial. The berries are poisonous.

2. A. itálicum, a larger species, with larger, longerstalked, hastate, winter leaves, sometimes with yellowish veins; spathe three times as long as the spadix, nodding; appendix yellow,-Along the south coast; local.-Fl. June. Perennial.

2. Ácorus (Sweet Sedge).-Rhizome long: leaves radical, sword-shaped; spathe leaf-like, not convolute or contracted; spadix lateral, without an appendix; flowers perfect; perianth of 6 membranous segments; stamens 6 ; ovary 3-chambered, superior. (Name in Greek denoting that the plant has the power of curing diseases of the pupil of the eye.)

1. A. Cálamus (Sweet Sedge).- The only British species, an aquatic plant, with somewhat the habit of a Sedge, easily distinguished from all other British plants by the wavy margins of the leaves, the peculiar spadix, and the fragrance of the stems and leaves when bruised.-In water; rare.-Fl. June, July. Peren. nial. 
Ord. LXXXVI. Lemnáce.e.Duck-Weed Famuy.

A small group of widely-distributed, minute, green plants, floating in standing waters, composed of leaflike scales, with no distinction of stem and leaf, generally with unbranched, thread-like roots hanging downwards in the water, propagating themselres principally by offsets, but sometimes producing $1-3$ minute flowers, which are monocious, generally enclosed in a small, membranous spathe; perianth absent; staminate flowers each of a single stamen; carpellateflower a 1-chambered, 1-7-ovuled ovary; fruit bladdery, indehiscent.

1. Limna. - Roots present; flowers marginal; spathe membranous; stamens stalked, with 2 -chambered anthers.

2. WólfFia.-Rootless; flowers on the upper surface; spathe absent; stamens sessile; anthers 1chambered.

1. Línxa (Duck-weed).-Minute, green, floating plants, with simple or lobed scale-like fromcls; with thread-like roots; rarely producing $1-3$ flowers, enclosed in a membranous spathe, in a marginal cleft; stamens stalked, with 2-chambered anthers. (Name, the Greek name of the plant.)

1. L. trisúlca (Ivy-leaved Duck-iveed).-Fronds thin, pellucid, $\frac{1}{2}-\frac{3}{4} \mathrm{in}$. long, budding at right angles, obovate-lanceolate, each bearing 1 root. Bulbils are produced in autumn.- Stagnant water; frequent.Fl. June. Annual.

2. L. minor (Lesser Duck-weed).-Fronds compressed, opaque, paler beneath, not more than $\frac{1}{4}$ in. long; obovate, blunt, each bearing 1 root.-Stagnant water ; often so abundant as to cover the surface, where, with the insects which it harbours, it is greedily devoured by ducks. - Fl. June-A ugust. Annual.

3. L. yibba (Gibbous Duck-weed).-Fronds tlat 
above, hemispherical and spongy beneath, opaque, pale, $\frac{1}{4}-\frac{1}{2}$ in. long, obovate, blunt, each bearing 1 root.-Stagnant water; uncommon.--Fl. June--September. Annual.

4. L. polyrrtiza (Greater Duck-weed).-Fronds dark green above, purple beneath, compressed, $\frac{1}{4}-\frac{1}{2}$ in. long, broadly obovate, each bearing many clustered

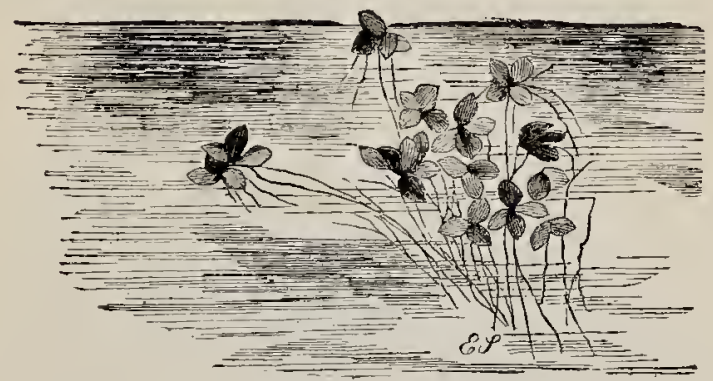

LÉMYA MÍYOR (Lesser Duck-weed).

roots.-Ponds and ditches; not common.-Flower not known in Britain. Annual

2. WótFFra, represented by the one British species, W. Michélii, is the smallest known flowering plant, the rootless, flattish, sub-globular fronds not being more than $\frac{1}{20} \mathrm{in}$. long.--Ponds near London. The flower is not known in Britain.-Annual.

Ord, LXXXVII. Alismáczæ.-W Water-Plantain FamiLr.

A small but widely distributed Order of aquatic plants, often floating, with leaves chiefly radical, with long, sheathing stalls; flowers usually perfect; perianth of 6 distinct lesves in 2 whorls, the 3 inner, 
or all, coloured; stamens 6, 9, or more, hypogynous; carpets 3, 6, or more, mostly free, superior, 1- or more- seeded; fruit of achenes or follicles.

1. Alíssia - Leaves erect; flowers in whorls, perfect;

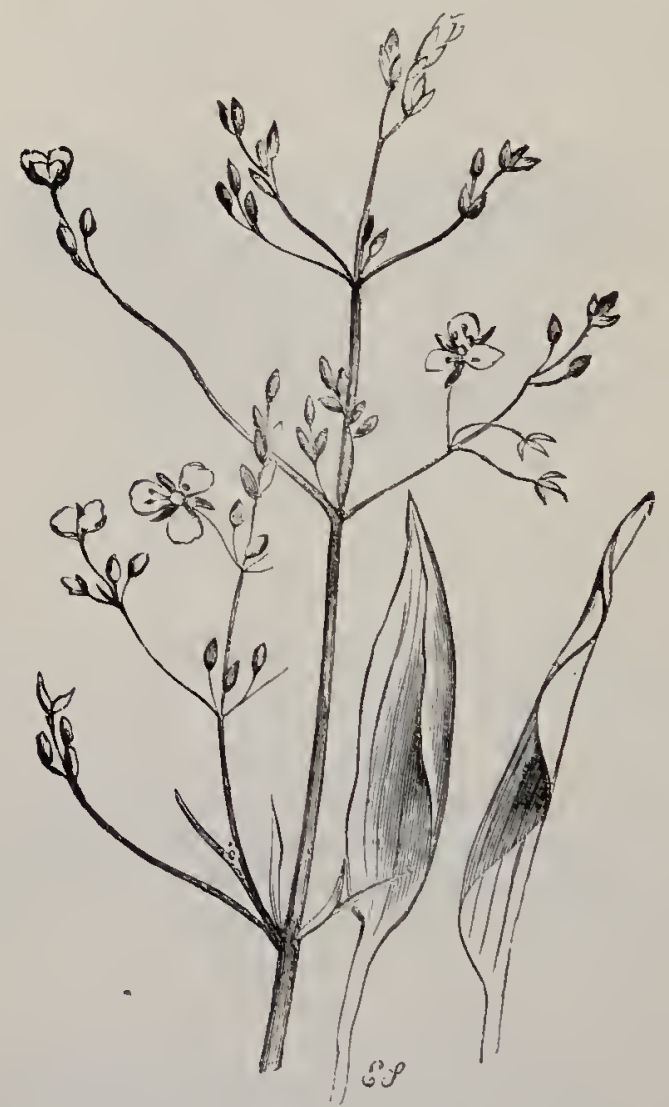

nifsma PLaNTÁGo-AQUATICA (Great Tater-Plantain).

outer perianth-leaves green; stamens 6 ; carpets numerous, free, 1-seeded, indehiscent.

2. Exísma - Leaves floating; flowers solitary; othervise as in Alisma. 
3. SAgitráRra.-Leaves el ect, arrow-shaped; flowers in whorls, imperfect; otherwise as in Alisma.

4. Damasónium. - Leaves flonting; flovers in whorls, perfect; carpets $6-10$, united at the base, 1-2seeded, dehiscent; otherwise as in Alisma.

5. Вútonus.-Leaves erect; flowers in an umbel, perfect; perianth-teaves all coloured; stamens 9 from the branching of the 3 outer ; carpels 6 , united at the base, many-seeded, dehiscent.

1. A tísua (Water-Plantain). - Aquatic plants with fibrous roots; erect leaves; flowers in whorls, perfect; outer perianth-leaves green; stamens 6 ; carpels numerous, free, 1-sceded, indehiscent. (Name, the Greek name of the plant, of doubtful etymology.)

1. A. Plantáyo-aquática (Great Water-Plantain).A stout, herbaceous plant, 2-3 feet high, with large, long-stalked, radical leaves, ovate-lanceolate, 5-7ribbed, like those of a Plantain; and a tall, erect, much-branched panicle of whorled flowers, the 3 inner perianth-lecues of which are very delicate, white or pale lilac, and soon fall off; carpels $20-30$ in a ling.--Margins of rivers, lakes, and ponds; common. -Fl. June-August. Perennial.

2. A. ranunculócles (Lesser Water-Plantain).Much smaller than the last, witl linear-lanceolate, 3 -ribbed leaves, some of which are submerged or floating and pellucid; flowers in 1 or 2 umbellate whorls, larger than in the last; carpels in a globose head.-Peaty bogs; not uncommon.-Fl. May--September. Perennial.

2. Eúswa (Floating Wnter-Plantain). - Roots fibrous; stem and leaves floating; flowers solitary from each node, stalked, white, with yellow claws to the petals; carpels 10-12; otherwise as in Alisma. (Name, another spelling of Alísma.) 
1. E. nátans (Floating Water-Plantain).-A slender, often very long plant with flowers about $\frac{1}{2}$ in. across. -Mountain lakes in the west; rare.-Fl. July, August. Perennial.

3. Sagittária (Arrow-head). - Roots fibrous; lear'es erect, arrow-shaped, the basal lobes directed

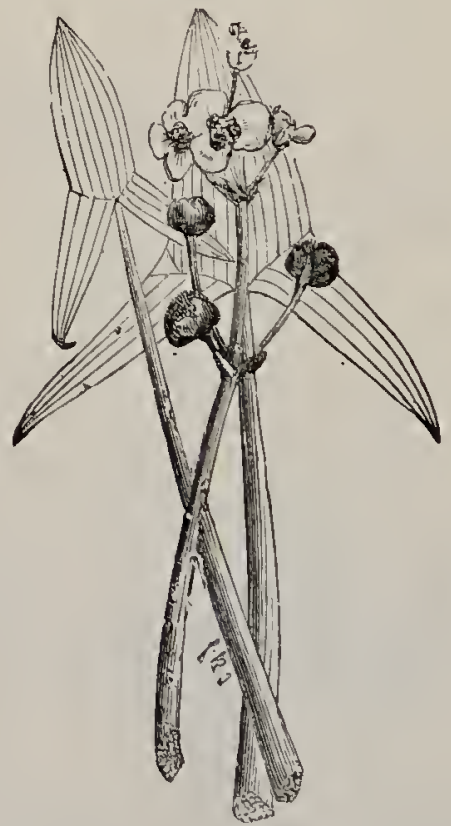

sagittafia SAgItTtFólia (Common Arrow-head).

downwards; flowers in whorls, monœcious, the upper ones larger and staminate; stamens indefinite; carpels numerous, free, 1-seeded, indehiscent, in a head. (Name from the Latin sagitta, an arrow, from the shape of the leaves.)

1. S. sagittifötia (Common Arrow-head).-The only British species, a pretty plant, easily distinguished 
by its arrow-shaped leaves and unbranched peduncle, with $3-5$ whorls, each of $3-5$ rather large, delicate, white or pinkish flowers, rising a few inches out of the

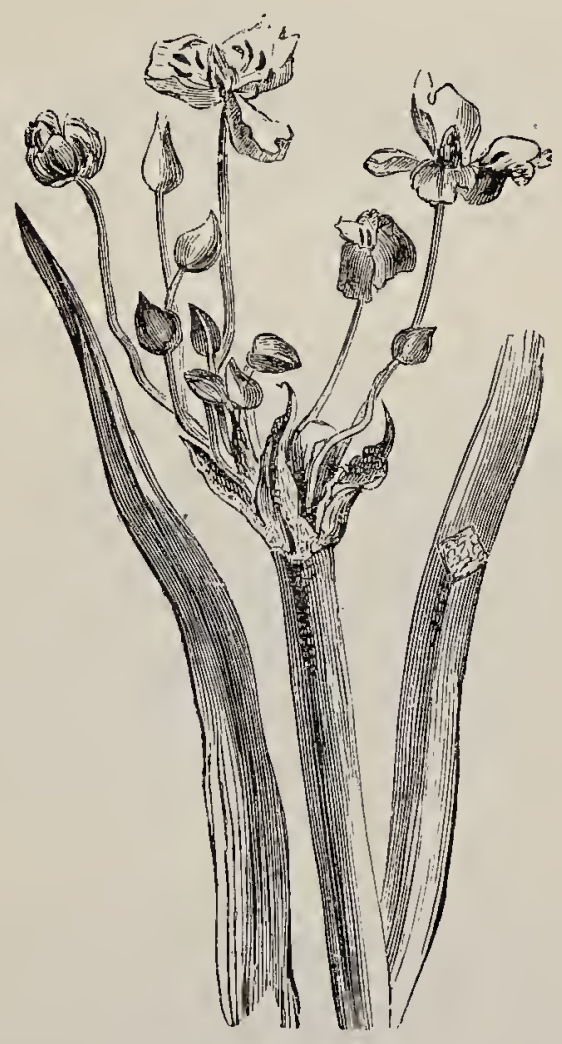

BútoMUS UMEELLf́tus (Flowering Rush).

water. - River's and ditches; not uncommon.-Fl. July-September. Perennial.

4. Damasónium (Star-fruit, Thrumwort).-A Aquatic plants with the habit of the Water-Plantains; but 
with floating leaves and $6-10$ carpels united at their b.se and spreading horizontaliy in the form of a star. (Name of uncertain origin.)

1. D. stellátum (Common Star-fruit).--The only British species; leaves long-stalked, cordate-oblong, 3 -5-ribbed, floating; flowers in 1-3 whorls, stalked, white, $\frac{1}{4}$ in. across, with a yellow spot at the base of each petal; fruit generally of 6 rather large, 2-seeded, long-beaked, dehiscent corpels. Gravelly ponds and ditches in the south; rare.-Fl. June, July. Perennial.

5. Búronus (Flowering Rush), represented only by one species, $B$. umbellátus, is a tall aquatic with a creeping rhizome; sword-shaped, radical lecures 2-4 feet long; and numerous handsome, rose-coloured flowers, 1 in. across, in a terminal, bracteate, simple umbel, on a cylindric peduncle $2-3$ feet high; the perianth-leaves are all petaloid; stomens 9 , with red anthers; carpets 6 , mited at the base, many-seeded, dehiscent down one side.- Stagnant water and slow rivers; not uncommon. (Name from the Greek lous, an ox, and témno, I cut; because cattle were apt to cut their mouths with the leaves of some plant to which the name was originally applied.)-Fl. June, July. Perennial.

\section{Ord. LxyXyiti. Naiadíce.e-Pond-weed Family.}

A small Order of aquatic and marsh planis, ustually with a creeping rhizome; slender, branched, jointed stems: lecues sheathing at the base, often floating, sometimes almost leathery, but more frequently thin and pellucid; flower's small, inconspicuous, olive-green, sometimes solitary, but more frequently in spikes; perimeth of 3-6 inferior, valvate scales, tubular, or 
absent; stamens 1-6, hypogynous ; carpels 1-6, 1-ovuled, indehiscent, sometimes in distinct flowers from the stamens.

1. Trialódariv,-Leaves linear; fowers ebracteate, perfect; perianth of 6 similar, erect, green leaves; stamens 6 ; carpels $3-6$.

2. Sch euchzíria. - Leaves linear; flowers bracteate, perfect; periunth of 6 similar, reflexed, green leaves; stamens 6 ; carpels 3 , united below.

3. Potamogíton.-Flowers in a spike, perfect; perianth of 4 leaves; stamens 4 ; carpels 4 , sessile.

4. Rúpria.-Flowers in a spike, perfect; perianth absent; stamens 2 ; carpels 4, at first sessile, afterwards each raised on a long stalk.

5. ZnNnich ḱlzia._Flowers axillary, monœecious; perianth absent; stamen 1; carpels 2-6; stigmas peltate.

6. Zostéra.-Flowers monœecious, arranged alternately in 2 rows on a long leaf-like spadix; perianth absent; stamen 1, sessile, 1-chambered ; carpel 1, sessile.

7. NÁJAS.-Flower's axillary, diocious; perianth absent or 4-lobed; stamen 1, sessile, 1-4-chambered; carpel 1, sessile; stigmas 2-4, awl-shaped.

1. Trighóchin (Arrow-grass).- Roots fibrous ; leaves linear ; flowers in an ebracteate raceme, small, green, inconspicuous, perfect; perianth of 6 similar, erect leaves ; stamens 6 ; ovar!! 3-6-chambered, superior ; stipmas feathery; fruit 3-6-seeded, separating into dehiscent carpels. (Name from the Greek treis, three, and gloclin, a point, from the pointed carpels.)

1. T. palústré (Marsh Arrow-grass).-A plant with something of the habit of Plantágo maritima, from which it may easily be distinguisled by its fewer flowers and slenderer raceme, as well as by the different structure of the flowers. It has rumers; leaves radical, 
linear, fleshy, 8-10 in. high; flowers in a loose raceme; fruit linear, angular, of 3 combined carpets. Marshy places ; common.-Fl. June--August. Perennial.

2. T. maritimum (Sea Arrow-grass),-Like the

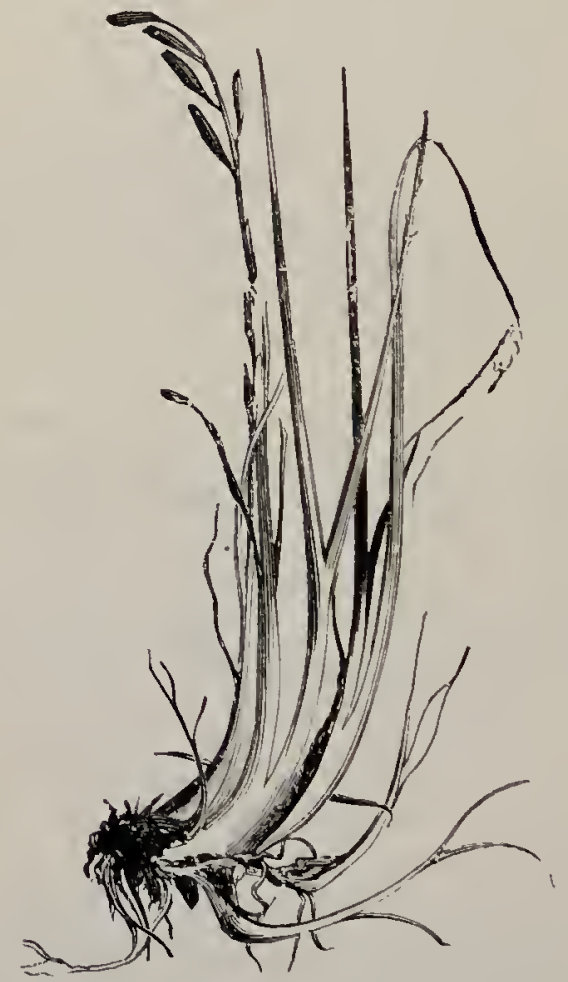

TRIGLÓCHIN PALÚSTRÉ (Marsh Arrow-grass).

last, but larger, stouter, and well distinguished by its rounded, ovoid capsule of 6 combined carpets.- Salt marshes; common,-El. May-September. Perennial. 
2. Scheuchzéria, represented by the one species S. palustris, has a long, creeping, rhizome; Zoaves linear, semicylindric, with swollen brown sheaths; flowers $4-6$, in a loose, bracteate raceme, perfect ; perianth of 6 similar, reflexed, green leaves; stamens 6 ; carpels 3 , united below.-Peaty bogs; very rare, found only in the north. (Name from the Swiss naturalists, the Scheuchzers.) Fl. July. Perennial.

3. Potamogéron (Pond-weed).-Floating or sub

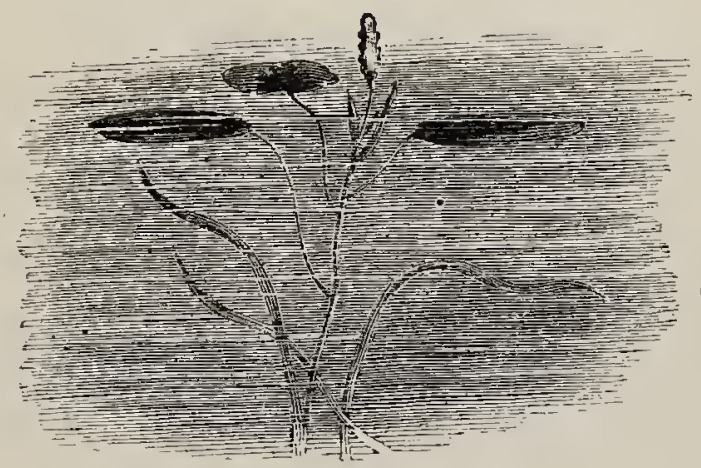

potanogéton Nitans (Floating Pond-weed).

merged plants, with translucent or opaque, leathery leaves, scattered or opposite, generally stipulate; flowers in a spike, perfect; perianth of 4 small, green, valvate, persistent leaves; stamens 4 ; carpels 4, sessile, free, 1-seeded. (Name from the Greek pótamos, a river, and géiton, a neighbour.)

* Leaves scattered, or the upper opposite, oblong, obovate or lanceolate, involute; stipules free.

1. P. nátans (Floating Pond-weed).-An aquatic plant, with cord-like stems, proportioned to the depth 
of the water in which it grows; upper leaves floating, on long stalks, smootl, leathery, elliptical to lanceolate, 2-6 in. long, with small auricles and very long; pointed stipules, lower not always present, submersed, reduced to very narrow linear phyllodes a foot long; flowers numerous, small, green, in dense cylindric spikes which rise above the surface of the water on stout, axillary peduncles: cumpls rather large, keeled, with a short beak.-Ponds and ditches; common.F]. June-September. Perennial.

2. P. polygonifótius.-A more membranous plant with long-stalked leaves, the "1 per" opposite, obovate to lanceolate, rounded at the base, low $)^{\circ}$ linear-lanceolate; flowers in slender spities on slender stalks; carpets very small, not keeled, red, witlı very short beak.-Ponds; very common.-Fl. June-September. Perennial.

3. $P$. fluitans. - A rare form with an unbranched stem; very long, submerged leaves and rather leathery, floating ones, and a firit resembling that of $P$. nátans.

4. P. colorátus (Plantain-leaved Pond-weed) Leaves mostly submerged, long-stalked, membranous, pellucid, beautifully netted, broader than those of the preceding species, elliptic-orbicular, on slender stalks, with sliort, broad, blunt stipulcs; very slender peduncles; carpels very small, rounded, green.-Peaty ditches; uncommon.-Fl. June-September. Perennial.

5. P. alpinus (Reddish Pond-weed).-Stem round, unbranched, $1-4$ feet long; leares reddish, lanceolate, translucent, upper short-stalked, broader, floating, or erect, rather leathery; lower submerged, sessile, manynerved; stimles large, blunt; flowers in stout spikes on stout stalks; carjels ovoid, pointed, keeled, red.Ditches; frequent.--Fl. July-September. Perennial.

6. P.sparganiifótius (Bur-reed-leaved Pond-weed), known only in Galway, has a sleuder, slightly- 
branched stem; long leuves, the upiper of ten absent, or long-stalked, floating, and rather leathery, the lower linear and many-nerved; and long stipules.

7. $\stackrel{P}{P}$. lanceolátus (Lanceolate Pond-weed).-A very rare species with very slender, fragile, stem; dark green, oblong, obtuse, pellucid, reticulate leaves, with slender, pointed stimules; flowers in short spikes on short, slender stalks, and carpets 3-toothed.-Rivers in Cambridge, Anglesea, and Down.-Fl. July-September. Perennial.

8. P. heterophygltus (Various-leaved Pond-weed).Stem slender, round, 2-4 feet long, much branched below; leaves flat, upper floating, opposite, leathery, elliptic, lower submerged, lanceolate, flaccid; stipules small; flower's numerous in dense spikes on stout, axillary and terminal stalks which thicken upward; carpels small, 3-keeled, witl a short beak.--Ditches; frequent.-Fl. June-September. Perennial.

9. P. falcátus. - A dark green or reddisla-green plant, with a tuberous rhizome; slender, round stem, branched below; leaves amplexicaul, entire, flat, upper leathery, with 6 opaque ribs on each side of the midrib, lower with 3 ; stipules herbaceous, persistent; flower's in a dense, cylindric spike about an inch long on a slightly longer peduncle; fruits small, dark green, rounded, keeled with a prominent beak,-Near Ramsey, Huntingdon.

10. P. nítens (Glistening Pond-weed).-A closely allied, much branched form, with numerous rooting branches springing from the axils of its upper leaves; leaves usually all submerged, scattered, recurved, with a wavy margin and a shining surfice; flowers in shorter spikes, thickening less upward. - Ditches; chiefly in the north; uncommon.-Fl. June-September. Perennial.

11. P. Rúcens (Shining Pond-weed).-The largest British species; stem stout, $3-6$ feet long; leares mostly submerged, shortly-stalked, 4-10 in. long, 
oblong-lanceolate, wavy, toothed, pellucid, manynerved; stipules large, long, keeled; flowers in a stout, dense, cylindric spike on a short, thick stalk, thickening upward; carpels small, rounded, with a short, blunt beak.-Lakes; frequent. - Fl. June - September. Perennial.

12. P. decipiens.-A closely allied form with sessile, broad, pointed, scarcely toothed leaves; short, scarcely winged stipules; and shorter flower-stalks.

13. P. angustifótirus - An allied, bùt smaller, much branched species; leaves long-stalked, with entire margins, upper floating, obovate-oblong, wedge-shaped at the base, rather leathery, lower often recurved; flower-spikes $1-2$ in., on very long stalks; earpels rounded.-Ponds; not common.-Fl. Jur.e-September. Perennial.

14. P.Griffithii, a rare form, with branched stem; leaves all submerged, $7-12$ in. long, 11-17-nerred, narrow, boat-shaped at the apex; siipules long, narrow, and blunt; flowers in dense spikes on slender stalks shorter than the leaves; occurs only in Aber Lake, Carnarvonshire-_Fl. June-July. Perennial.

15. P. preclóngis (Long-stalked Pond-weed).-A similar species with stout, greenish-white stem; leaves linear-oblong, blunt, entire, half-sheathing, concave at the tip, 3-nerved; stipules large, blunt; flowers in dense cylindric spikes on very long, stout stalks; catprels large, with sharp keels.-Lakes and deep river's; local._Fl. May-July. Perennial.

16. P. perfoliatus (Perfoliate Pond-weed).-Wtem rouni, stout, dichotomously branched; leaves all sub. mersed, egg-shaped, 2-3 in. long, embracing the stem, pellucid, 5-9-nerved, brown, and almost transparent, having when dry the appearance of gold-beaters' skin, and so sensitive to moisture that they will curl when laid on the palm of the hand; stipules small, falling off; flowers in dense spikes on short, stout stalks; carpels scarcely keeled, with short beaks.--Ponds and 
lakes ; common. - Fl. June - September. Perennial.

17. P. crispus (Curly Pond-weed).-Stem slender, compressed, dichotomously branched; leaves alter-

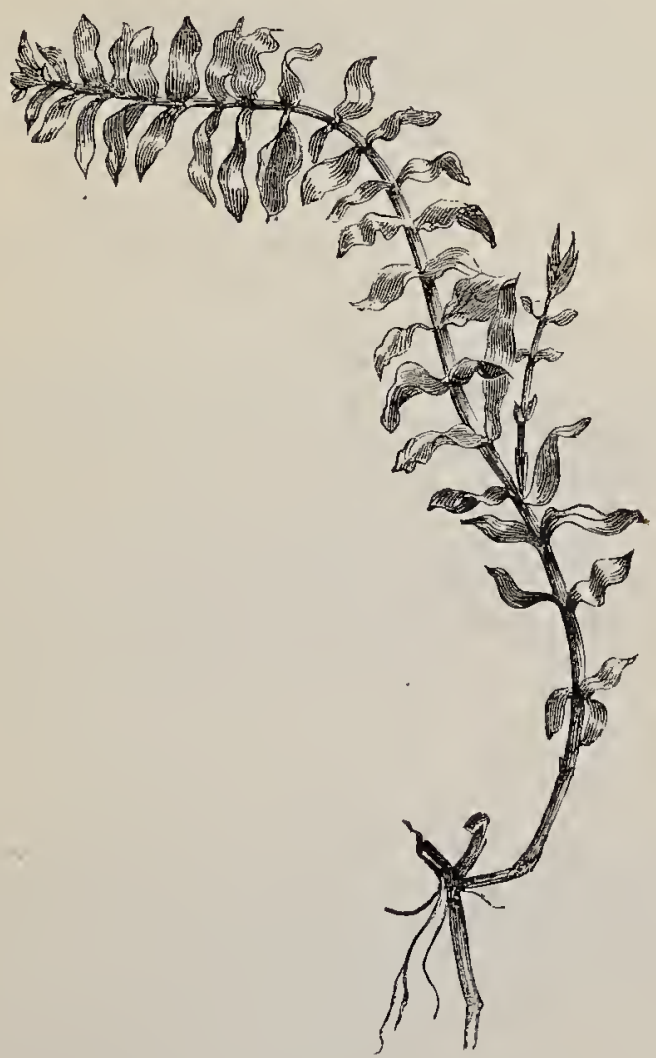

potamogéton dévsus (Opposite-leared Pond-weed)

nate, close-set, 1-3 in. long, oblong, wavy, toothed, 3-norved, spreading, and recurved; stipules small, blunt, falling off ; flowers $6-8$ in a loose spike on a tapering stalk; carpels with a long beak.-Ditches; common.-Fl. June-August. Perennial. 
** Leaves nearly opposite, involute, exstipulate.

18. P. dénsus (Opposite-leaved Pond-weed).-Stem slender, brittle, dichotomously brauched; leaves all submersed, embracing the stem, ovate, toothed, pellucid, 3-5-nerved, close-set, recurved; flowers few, in very short-stalked spikes; carpels with short, recurved beaks.-Ditches and ponds; common.-Fl. June-September. Perennial.

*** Leaves all similar, strap-shaped, with flat margins and free stipules.

19. P. zosterefótius.-Stem compressed, winged; leaves 4-10 in., acute, 3-5-nerved; stimules large, acute ; flowers many, in cylindric, long-stalked spikes; earpels compressed, 3-ribbed, - Ditches; local.-Fl. July, August. Perennial.

20. $P$. acutifólins. - Stem compressed, narrower than in the preceding; leaves much as in the preceding but shorter and with narrower stipules; flowers in a very short oval, short-stalked spike; carpels compressed, with a recurved beak.- Lakes and ditches; rare.-Fl. June-August. Perennial.

21. $P$. olutusifólius (Grassy Pond-rveed). - Stem slcnder, 4-angled, much branched ; Teares sessile, linear, obtusc, lark grcen, opaque, 3-nerred; stiputes broad, blunt; flowers few, in a dense, oval, short-stalked spike; carpels compressed, keeled, with a straight beak. - Ditches; frequent. - Fl. July, August. Perennial.

22. 7. Friésii.-Stem thread-like, compressed; Tear's often in tufts, linear, 1-3 in., 5-7-nerved; stiputes small, acute; flowers few, minute, in an interrupted spike on a slender, compressed stalk; carpels small, swollen, bluntly keeled, with short, stont bcak.Ponds and ditches; local. - Fl. July, August. Perennial. 
23. P. pusillus (Small Pond-weed). - A tangled mass of thread-like stems; and dull, olive-green, narrowly-linear, 1-3 nerved, acute leaves; with numerous, small, loose, long-stalked spikes of brownish flower's, which are either submersed, or rise partially above the surface of the water.-Ponds and lakes; common.-Fl. June-August. Perennial.

24. I. Sturróckii, a very slender, delicate, and elegant form, closely allied to the preceding, with bright green, pellucid, 3-5-nerved, obtuse leaves $2-3$ in. long; flowers in a very small spike on a very slender stalk; and carpets very small and shortly beaked, occurs only in Forfar and Perth.

25. P. trichóides (Hair-like Pond-weed)._Stem thread-like, with numerous sprearling dichotomous branches; lecw'es bristle-like, spreading, stiff, acute, 1-veined, dark green, $1-2$ in. long, witl slender', acute stipules; flower's 3-6, very minute, on a slender stalk; carpets 1 in each flower, compressed, with a short beak._Ponds; rare_-Fl. August-October. Perennial.

\section{*米米米 Leaves all similar, submerged, Tinear, with flat} margins and stipules united into a sheath.

26. P. pectinátus (Fennel-leaved Pond-weed).For'ming dense tangled masses of thread-like stems witl alternate branches; leaves $3-8$ in. long, apper 1nerved, of 2 hollow tubes, lower flat, 3-nerved; flowers few, in interrupted spikes on long, slender stalks; carpets large, swollen, slightly keeled, with short beaks. Streams ; common.-Fl. June-August. Perennial.

27. P. intermiptus, a closely allied form, with flat, 1-5-nerved leaves and obscurely keeled carpels, is less common.

28. P. filifórmis (Slender-leaved Pond-weed).Stem thread-like, with short branches below; leaves hair-like, 1-nerved, channelled; flower's in dense, sepa- 
rate whorls; carpels small, with very slight keels and beaks.-Lakes; local.-Fl. June-September. Perennial.

4. Rúppia (Tassel Pond-Treed).--Slender, aquatic herbs with thread-like, sheathing leaves and minute,

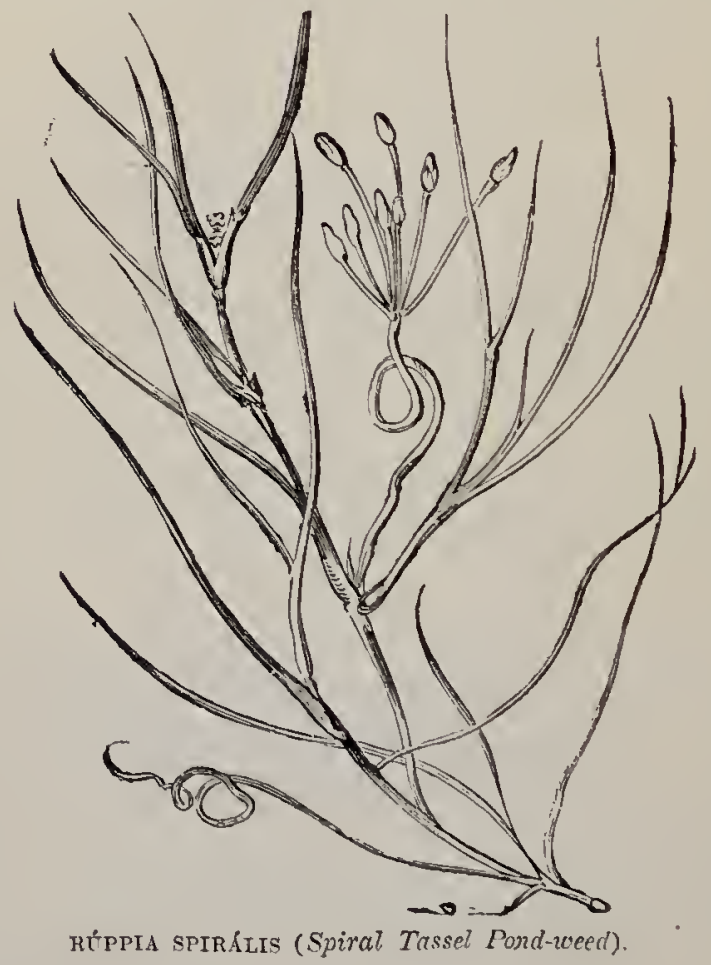

perfect flowers without a perianth ; stumens 2; carpels 4 , at first sessile, afterwards each raised on a long stalk. (Named in honour of H. B. Ruppius, a botanist of the 18th century.)

1. R.spivátis (Spiral Tassel Pond-weed).-A muchbranched, thread-like plant, with the habit of 
Potamogéton pectinátus, 2 feet or more long; leaves 1-3 in, long, with inflated shenths; flower-stalk becoming spirally coiled, and 5-6 in. long, when in fruit; carpels with short beaks on stalks, $1-2$ in, long.Brackish-water ditches ; rare.-Fl. July-September. Perennial.

2. 17. rostelláta (Beaked Tassel Pond-weed).-A more common form, differing in the small, close sheaths of its leaves, its short, not spiral flower-stalk, and the longer beaks of its carpels.-Fl. July, August. Perennial.

5. Zanvichéluta (Horned Pondweed).-Slender, submerged plants, with linear leaves with sheathing bases and adherent stipules; minute, axillary, generally monœcious flowers without a perianih; stamen 1 ; carpels 2-6; stigmas peltate. (Named in honour of J. J. Zannichelli, a Venetian botanist.)

1. Z. patustris (Common Horned Pond-weed). $-\mathbf{A}$ submersed aquatic with the habit of the preceding genus; stem slender, 3-6 in. long, with spreading branches; opposite, thread-like leaves 1-3 in. long; flower's axillary, sessile or nearly so; stamen $\frac{1}{2}-1$ in. long, with 4-chambered anther; corpels 2-4, sessile, with short styles and smail crenulate stigmas.-Ditches; common.-Fl. May-August. Annual.

2. Z. brachystémon, the commonest form, differs in having a stamen only a quarter as long, with a 2chambered anther, and a larger stigma.

3. Z. pedunculátx, a less common form, has a stcinzen of intermediate length, with a 2-chambered anther, long stytes, large stigmas, and stalked carpels.

4. Z. potycárpa, a rare form, occurring in the Orkney Islands, has a very short stamen with a 2chambered anther, $5=6$ sessile carpets, with very short styles and large stigmas. 
6. Zostúra (Grass-wrack).-Grass-like, submerged marine plants with creeping rhizomes; compressed

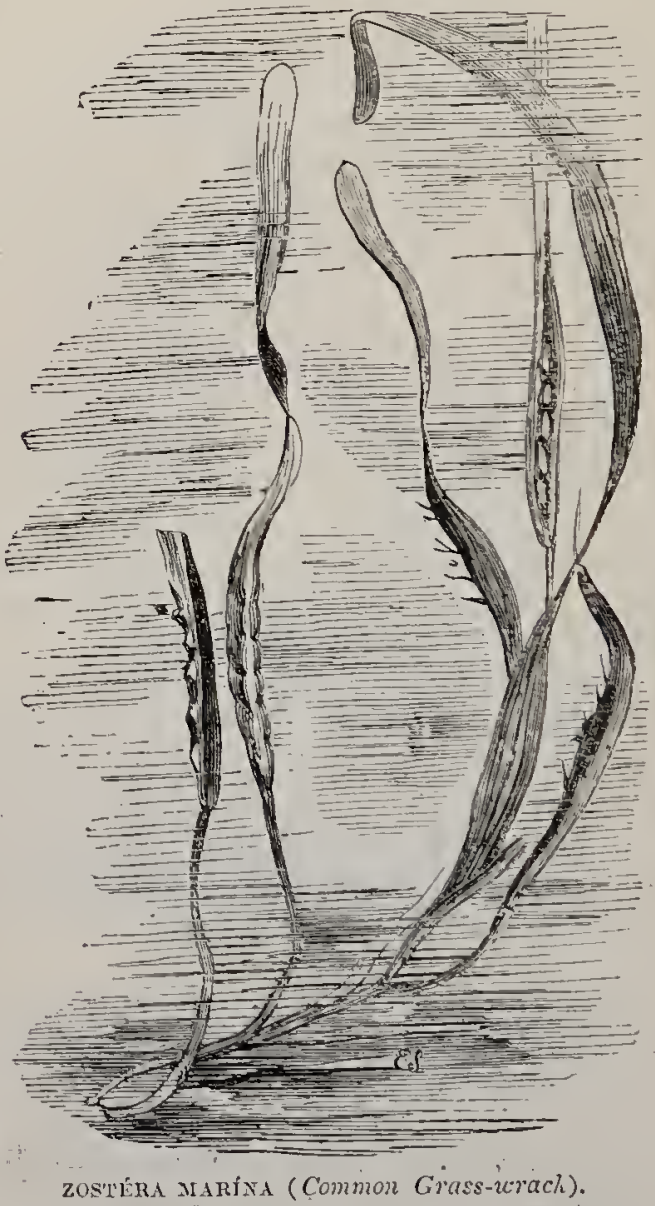

stems; alternate, long, linear, sheathing leaves with adherent stipules; flowers monncious, arranged alterantely in 2 lows on a long, linear, mémbranous spatis, enclosed in a spathe; perianth alsent; stamen 1, 
sessile, 1-chambered; carpels each witl 1 style, 2 stigmas, and 1 ovule. (Name from the Greek zostér, a girdle or riband, fron! the form of the lenves.)

1. Z. marina (Common Grass-wrack). - A common plant in the sea, near low-water mark, with long, cordiike stems, bright green grass-like leaves, 1-3 feet long, 3-7-veined, and long, leafy sheaths or spothes to the bead-like rows of numerous simple flowers. "The dried leaves and stems are collected, under the name of Alva, for stuffing mattresses and packing glass.-Fl. July-Septemuer. Perennial.

2. Z. nána (Dwarf Grass-wrack), an uncommon species, differs in having leaves not move than 6 in. long and 1-3-veined, and fewer flowers in a shorter spathe, with $2-5$ inflexed, membranous appendages or clasping bands.-Fl. A pril-August. Perennial.

7. Násas, - Slender, submerged, aquatic herbs with linear, whorled leaves, with adherent siipules; axillary, diøcious flower's; stamer 1, sessile, 1-4-chiambered, enclosed in 2 sheatlis or perianth-whorls ; carpel 1 , sessile; stigmas 2-4, awl-shaped. (Name from the Greek naias, a water-nymph.)

1. N. fléxilis (Flexible Najas).-A little, submerged plant, with thread-like, branched, brittle stems; linear, entire leaves in whorls of 3 , about an inch long, bright green, pellucid, with ciliate sheaths: flowers $1-3$ together.-Deep lakes, Perthshire, Skye, and Connemara.-Fl. August, September. Annual.

2. N. marnina (Larger Najas).- Stem less branclied; Terves in whorls of 2 or 3 , strongly spinosely serrate, with entire sheaths; flowers solitary.-Hickling Broad, Norfolk.--Tl. July.

3.* N. graménea.-Leaves olive-green, in tufts with serrate sheaths.-In a canal at Ashton-under-Lyne; not indigenous. 
Ord. LXXXIX. Eriocádlee.-The Pipe-wort Family.

A group of herbaceous plants chiefly inhabiting tropical swam ps, with their leaves mostly radical, linear and sheathing, and often hollow; minute, imperfect flowers in a bracteate head; perianth inferior, of 2 whorls of 2-3 leaves each; stamens double the number of the inner perianth-lobes, but half of them often rudimentary; carpels $2-3$, united ; style single, terminal, short, persistent ; stigmas 2-3, slender; orutes solitary in each carpel; fruit capsular.

1. Errocaúlor (Pipe-wort). - Staminate flowers chiefly in the centre of the head, generally 2-merous; outer perianth-leaves spathulate; inner united in a tube. (Name from the Greek crion, wool, liaulos: a stem, some species having a woolly peduncle.)

1. E. septanquzáré (Common Pipe-wort). -A little submerged plant with a creeping rothizome; short, leafy stem; leaves subulate, 2-4 in. long, green, pellucid, compressed; flowers on a 6-8-anglerl peduncte from 6 in. to 2 fect ligh, in a small hearl with lead-coloured bracts; outer perianth-leaves black, fringed; imner with a black spot; stamens usually 4, with dark anthers. - Lakes in Skye and Connemara; but maiuly North American.-Fl. August. Perennial.

\section{SUd-Class II. GLUMÍfER $\approx$.}

Flowers in spikelets (small spikes) each in the axil of one of the imbricate, rigid, chaff-like bracts or glumes; perianth absent or represented only by minute scales or bristles ; carpels $1-3$; ovary 1-chambered, 1-ovuled; seeds albuminous. 


\section{Ord. XC. Cyperácež.-The Sedge Family.}

A large Order of grass-like and rush-like plants, comprising more than 2,000 species in about 60 genera, occurring in all parts of the world, but especially in the colder parts of the Northern Hemisphere, where they often cover large areas of marshy ground. Their stems are generally solid, often 3 -angled, and without enlarged nodes; their lecves have a tubular sheath, and are generally linear, being commonly tristichous and sharply folded longitudinally; and their flowers are often imperfect. The pericunth is often absent, or consists of three or more scales or bilistles. The stcmens are 1-6, usually 3 in number, with fiattened filaments and basifixed anthers. The ovary is 1-chambered and sometimes 3-augled and enclosed in a flaskshaped membranous covering known as a utricle formed of 2 united bracteoles; there is a single terminal style and $2-3$ cleft stigma; and the fruit is a small indehiscent, 1-seeded caryopsis.

The Sedges differ mainly in structure from the Grasses in their solid, angular stems with unswollen nodes; their tristichous leaves with unsplit, tubular sheaths; their basifixed anthers; and their less feathery stigmas. They differ in a still more marked manner in their properties and uses to man. Their harsh leaves and stems contain but little sugar, and form but poor pasturage, nor do they seem readily susceptible of improvement under cultivation in the size of their grain. The stems of the Bulrush (Scrrpus lacustris) are used for the rush bottoms of chairs, for making hassocks and mats, and by coopers for placing between the stares of casks. Those of the African Papyrus antiquórum, cut in slices, furnished the paper of ancient Egypt. 
* Spitelets many-flowerech; fiowers perfect.

1. Crpúrus. - Simitelets compressed; glumes in 2 rows, deciduons.

2. Eleócharis. - Spikelet solitary, terminal; perianth of 3-6 included bristles.

3. Scírpus.-Spikelets clustered, lateral ; perianth of 3-6 included bristles, or absent.

4. Erióphorua.-Spikelets terminal; perianth of long exserted bristles becoming silly.

*** Spiticlets 1-or few-flowered; flowers perfect.

5. Rhrnchóspora.-Spitielets clustered in heads, terete; prerianth of 6 inclurled bristles; nut beaked.

6. Schóxus.-Spitelets in compact terminal heads, compressed; glumes in "2 l'ows; perianth of few bristles, ol absent; nut not benked.

7. Clánrus.-Spiliclets terete; perianth absent; net, blunt, with a fleshy coat.

\section{* Spitielets 1_-2-flowered; flowers moncecious; revianth absent.}

8. KoвRésia.-Upper flower in encli spikelet staminate, lower carpellate; oraiy enclosed by a glume.

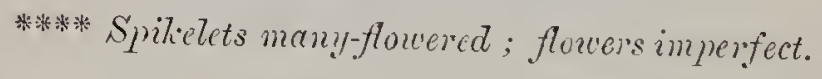

9. Círex.-Glumes imbricato; orary enclosed in a persistent bottle-shaped utricle.

1. Crpéres (Galingale).-Stems triangular ; spitielets many, compressed, in terminal or lateral bracteate heads or compound umbels; glumes numerous; distichous, deciduous, ench, except the outermost, containing a perfect flowcr; perianth absent. (Name from the Greek liupeiros, a reed.) 
1. C. fúscus (Brown Cyperus).-Stems short, tufted, grass-like, 2-10 in. high ; spikelets flattened, blunt, not more than $\frac{1}{3} \mathrm{in.} \mathrm{long,} \mathrm{in} \mathrm{a} \mathrm{compact} \mathrm{umbel,} \mathrm{with}$ 3 unequal, leaf-like bracts, $1-4$ in. long; glumes

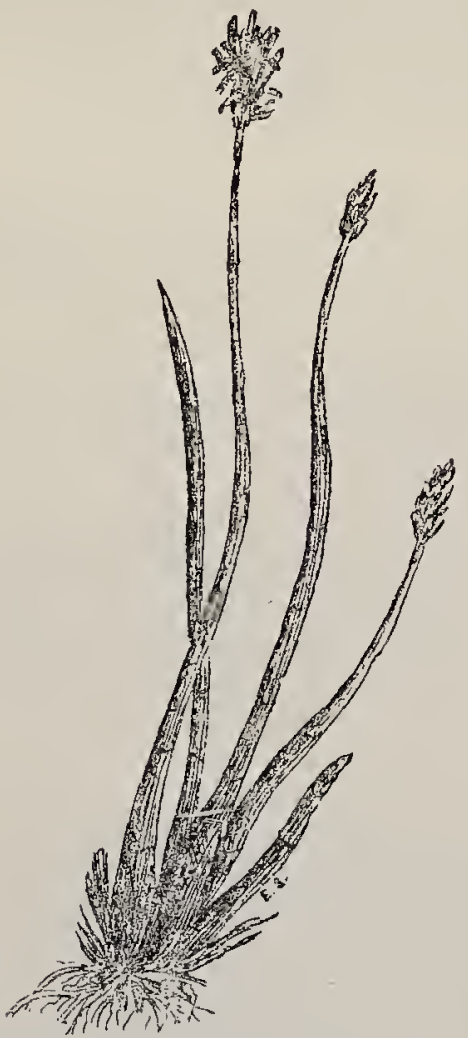

ELEÓCHARIS PALÚSTRIS (Marsh Spjite-rush).

brown, with green keels.-Wot mendows in Middlesex, Surrey, and the Channel Islands.--Fl. August, September. Annua?.

2. C. longus (Sweet Galingale). - A tall, stout 
plant, $2-4$ feet ligh, with a few leares at the base of the stem; spikelets numerous in a very large, loose, unequally-rayed, compound umbel, with $2-3$ long, leafy bracts; glumes numerous, blunt, reddish-brown, with green keels and pale margins.-Wet meadows in the Soutl of England; rare. The aromatic rhizome was formerly much esteemed as a tonic.-Fl. August, September. Perennial.

2. Eleócharis (Spike-rush). - Tufted, glabrous herbs with slender stems; solitary, terminal spilielets; glumes numerous, imbricate, nearly all containing perfect flowers ; perianth of 3-6 short bristles ; nut compressed, tipped with the persistent base of the style. (Name from the Greek hélos, a marsh, chairo, I rejoice.)

1. E. acicularis (Least Spike-1'ush).-A slender, tufted plant; rhizome slender, creeping; stems subulate, $2-4$, or even $12 \mathrm{in}$. high, with short sheaths at the base; spikelet minute, oblong, red-brown; flowers 6 -8; glumes blunt; stigmas 3 ; mut minute, oboroid, libbed, and transversely striate.-Wet sandy places; frequent.-Fl. July, August. Perennial.

2. E. patistris (Marsh Spike-rush). - A creeping plant with a stout, branched rhizome and many tufts of stems and leaves; stems not 6 in. high at edge of water, a foot or more high and more distant when in water, nearly round, with membranous, truncate sheaths; spikelets terminal, $\frac{1}{4}-\frac{1}{2}$ in. long, oblong; glumes numerous, dark brown, with pale, membranous edges and green keel; outer bract similar but rather larger; perianth-bristles 4-6; style 2.cleft; nut obovate.-Edges of pools; frequent.-Fl. June, July. Perennial.

3. E. uniglumis, differing mainly in having the outer bract broader, so as to enclose the base of the 
spikelet, occurs especially near the sea and is much less common.

4. E. multicaúlis (Many-stemmed Spike-rush).A similar but smaller plant with stems in 1 tuft with obliquely truncate, acute shecths; rather smaller spikelets; blunter ghumes: verianth-bristles usually 6 ; styles usually 3-cleft; nut obovate, 3-angled.-Bogs ; frequent.-Fl. July, August. Perennial.

3. Scírpus (Club-rush). - Mostly tall, aquatic plants with creeping rhizomes; solitary or clustered, terminal or lateral spitcelets, with 1 or 2 outer bracts broader and without flowers; perianth of $1-6$ included bristles, or absent; style slender at the base. (Name, the old Latin name; but said to be of Keltic origin.)

* Spikelets small, terminal, solitamy; perianth of 3-8 bristles.

1. S. pauciflórus (Chocolate-headed Club-rush).Stems tufted, with long runners, round, striate, seldom more than 6 in. higl, with a few thin, narrow scales and 1 tight truncate sheath; outer bracts 2, hlunt, shorter than the spikelet; flowers not more than 5 or 6 ; perianth-bristles usually 6 ; style usually $3-$ cleft; nut obovate, 3 -angled, with tapering point.-In wet mud; common.-Fl. July, August. Perennial.

2. S. ccespitósus (Deer's-hair).-A similar species, with the stem covered at the base for 1 or $2 \mathrm{in}$. with imbricate sheaths, the outer brown, the inner green, with narrow leafy tips 1 to 2 lines long; spikelet ovoid, brown, $\frac{1}{5}-\frac{2}{3} \mathrm{in}$. long; outer bract as long as the spikelet, green, stiff; flowers $6-8$; perianth-bristles 4-6; style 3-cleft; nut brown, obovate, pointed.-Bogs; common.-Fl. June-August. Perennial. 
3. S. niness (Dwarf Club-rusli). - A minute plant with long, creeping, hair-like rohizome with small tubers and distant, dense tufts, each of several round, grooved stems, 1-2 in. high, each with a close-pressed, trans-

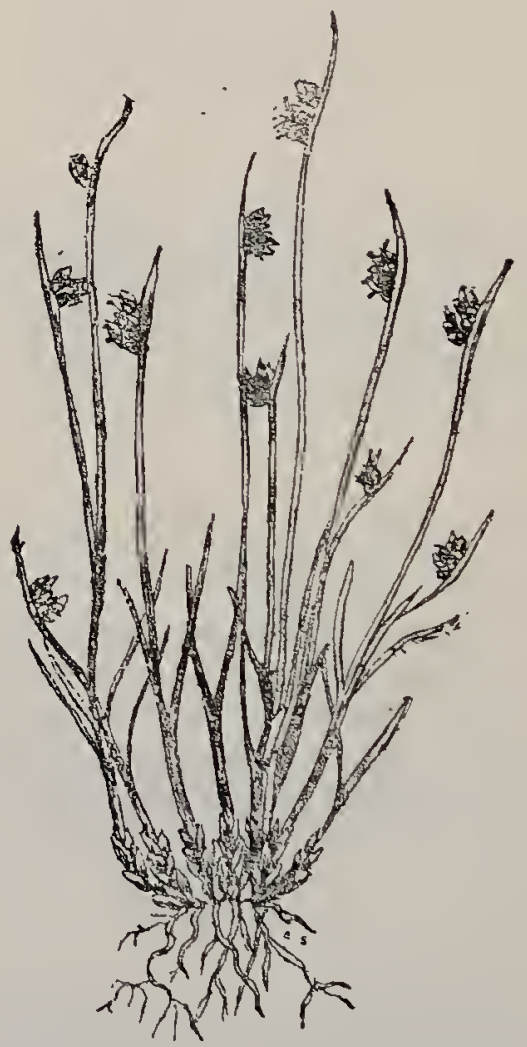

SCfRPUS SETÁCEUS (Bristle-like Mud-rush).

parent sheath: spikielet minute, pale ; outer bract short, blunt, flowerless; perianth of $4-8$ bristles ; nut obo. vate, 3-angled, pale.--Sandy sea-shores in the south; rare.-Fl. July. Annual. 
*** Spitielets smoll, Interal, sessile, clustered, or sometines solita.y; perianth absent.

4. S. flüituns (Floating Mud-rush).-A slender, floating plant, rooting from its lower nodes and much

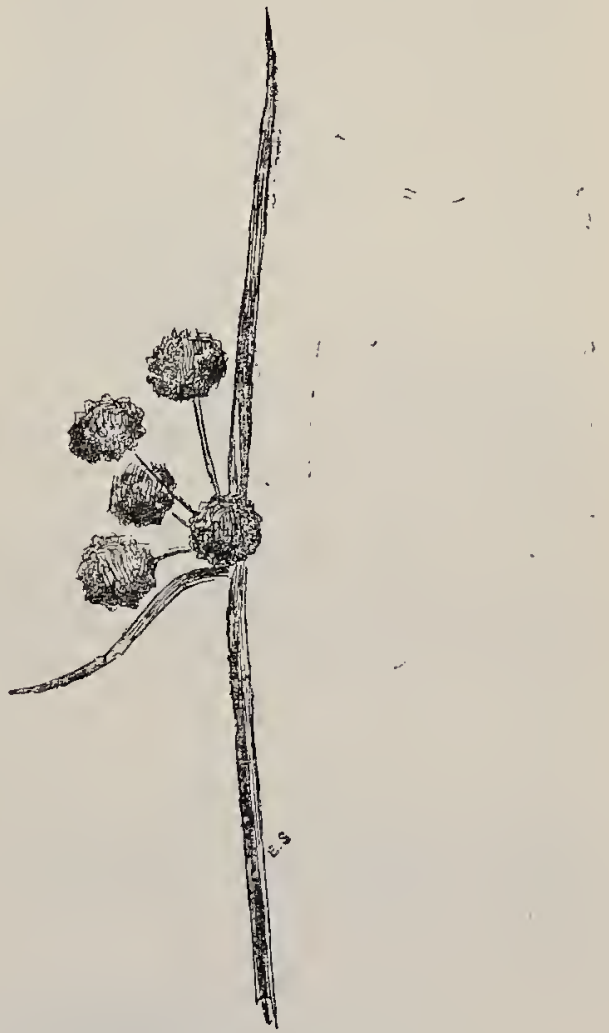

SCtRPUS HoLnschéNus (Round-headed Mud-rush).

branched in a zigzag manner; leaves linear, very slender, 1-2 in. long; spikelet solitary, terminal, ovate, pale; outr. 7 racls 2 , shorter than the spikelet enclosing it; flowers few; stigmas 2 ; nut obovate, 
smooth, pointed, pale.-Ditches; common.-Fl. June, July. Perennial.

5. S. cérnurs (Savi's Mud-rush)._A slender, tufted plant, 3-10 in. high, with 1 or 2 narrow, channelled leaves; spikelets $1-3$, sometimes an inch long; outer bracts not longer than the spikelet; stigmas 3 ; fruit sub-globose, 3 -angled, pale, shining, rough with lines of minute raised points.-Bogs; rare.-Fl. July. Perennial.

6. S. setáceus (Bristle-like Mud-rush).-A very similar, but smaller, less slender, darker plant, 2-6 in. high, with 1 or 2 short, subulate leaves on each stem; spikelets usually $2-3 \frac{1}{6}-\frac{1}{4}$ in. long, ovoid, lateral; outer bract long, subulate, resembling a continuation of the stem; glumes orate, blunt, dark brown, with green midribs; style 3-cleft; nut very small, marked with about 8 longitudinal ribs and furrows.-Moist sandy places ; common.-Fl. July, August. Perennial.

7. S. Holoschónus (Round-headed Mud-rush).Stems stiff, cylindrical, $1-4$ feet high, with 1 or 2 stiff leaves sheathing their bases; spilielets very numerous and small, upwards of 30 together in compact globular heads, each $\frac{1}{4}-\frac{1}{2}$ in. diameter, of a light brown colour, forming a lateral umbel; the largest outer bract stiff, forming a continuation of the stem.Sandy sea-shores in Somerset, North Devon, and the Channel Islands._Fl. September, October. Perennial.

\section{**** Spitielets Targe; glumes many; perianth of $1-6$ bristles.}

8. S. Tacustris (Common Bulrush). - Rhizome creeping; stems sometimes as thick as a man's thumb, spongy, erect, 3-8 feet high, cylindric at the base, gradually tapering upwards, green, usually leafless, or with 1 or 2 short keeled leaves in still water, or with 
long, nearly flat, floating leaves in running water; spifelets numerous, red-brown, ovoid, or oblong, $\frac{1}{4}-\frac{1}{2}$ in. long, in a compound, lateral, umbellate cyme, becoming terminal; outer bract continuing the stem;

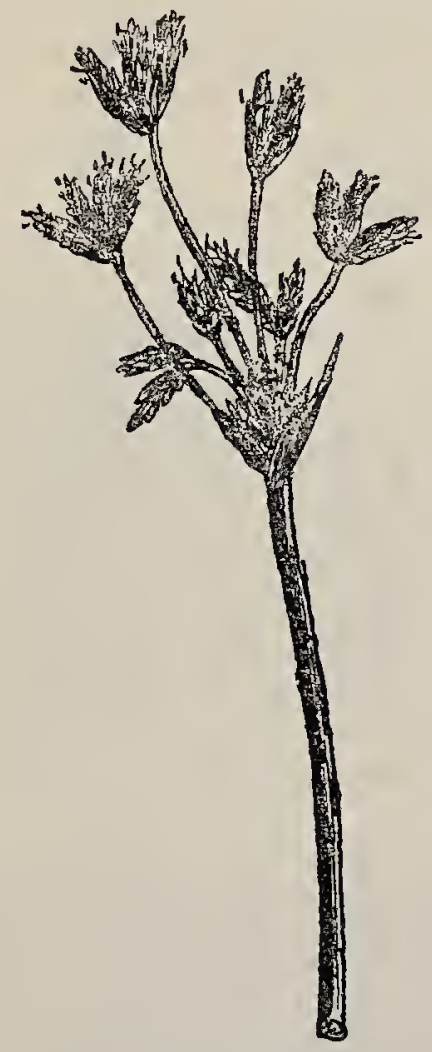

SCÍRPUS LACÚSTRIS (Common Bulrush).

glumes broad, brown, fringed at the edge, notched at the top, with a little point in the notch, glabrous; perianth of 5 or 6 bristles; anthers tipped with hairs; nut 3-angled, smooth.-Marshes and rivers; common. The rhizome is astringent, and the stems are largely 
used for making the bottoms of chairs, hassocks, \&c. -Fl. July, August. Perennial.

* The name Bulrush is now most commonly given to Týpha (see p. 757).

9. S. Taberncemontáni (Glaucous Bulrush). — A closely-allied form with glaucous stems, glumes rough with raised dots, and anthers not bearded, occuring mostly near the sea.

10. S. carinutus, another closely allied form, has green stems becoming obtusely triangular near the top, smooth glumes, and anthers not bearded.-Tidal livers in the south; rare.

11. S. triqueter (Three-edged Bulrush).-Dhlizome slender; stems 2-3 feet high, acutely triangula. throughout, leafless, except that 1 or 2 short shcaths at the base bear a short blade less than an inch long; spileetets usually 8,10 , or more, ovoid, less than $\frac{1}{2}$ in. long, central ones sessile, the others stalked, forming a compound lateral cyme; outer bract stiff, triangular, continuing the stem for an inch or more; ghumes lorown, broad, notched or fringed at top, with a minute point; perianth of $2-6$ bristles; stule 2-cleft; mut smooth and shining.-Mruddy banks of tidal rivers in the south; rare.-Fl. August, September. Perennial.

12. S. púngens (Sharp Club-rush). - An allied but smaller species, 6 - 18 in. ligh, with acutely triangular stems; 2 or 3 narrow, keeled leares 4-6 in. long; 3 -6 sessile, lateral spiticlets each $\frac{1}{2}$ in. long, in a close cluster: glumes brown, acutely 2-lobed.- Wet sand, Jersey.-Fl. Jume, July. Perennial.

13. S. maritimus (Sea Club-rush).-Stems sharply triangular, $1-3$ feet high, leafy; leaves long, channelled, dark green, $\frac{1}{2}$ ill. across ; spit.clets $1-10$, in a dense terminal cluster, the outer ones generally stalked, red-brown, about $\frac{3}{4}$ in. long; bracts several, leaf-like : glumes acutely 2-lobed with an awn between 
the lobes; perianth of $1-6$ bristles; style usually 3-cleft.-Salt markhes; common-Fl. July, August. Perennal.

14. S. sylváticus (Wood Club-rush). - Stem 2-3

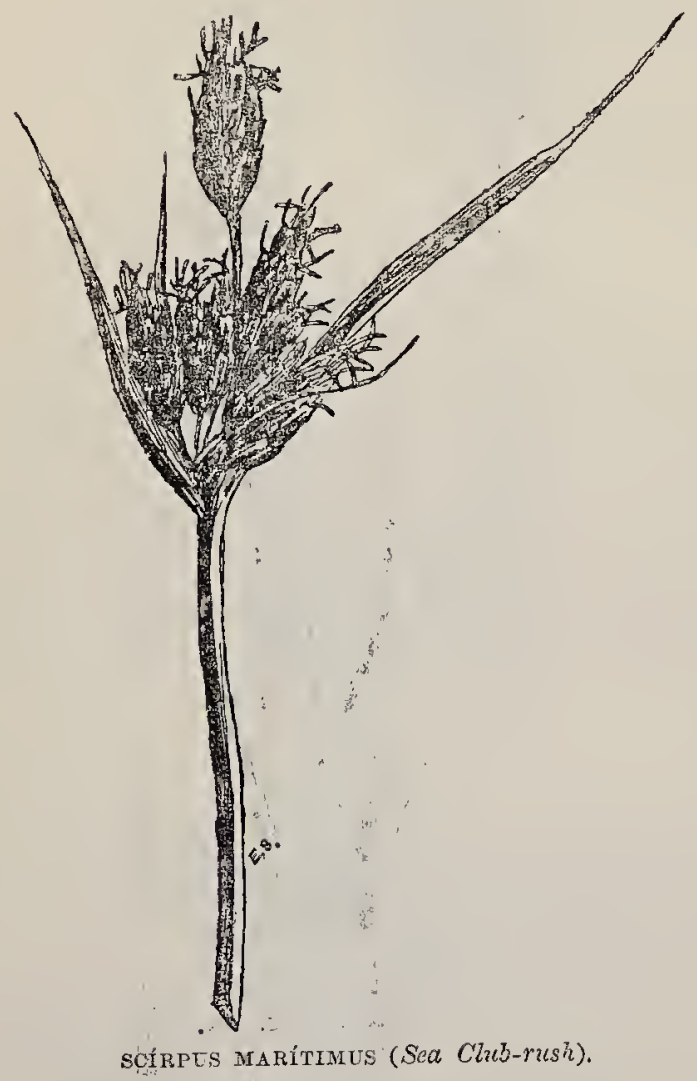

feet high, stout, leafy; leaves long, keeled, $\frac{1}{2}-\frac{3}{4}$ in。 across ; spiketets small, ovoid, dark shining green, very numerous, in a terminal, much-branched, compact 
panicle ; bracts several, leaf-like ; glumes ribbed, obtuse, apiculate; perianth of 6 bristles ; style 3 -cleft.-Moist woods; frequent.-Fl. July, August. Perennial.

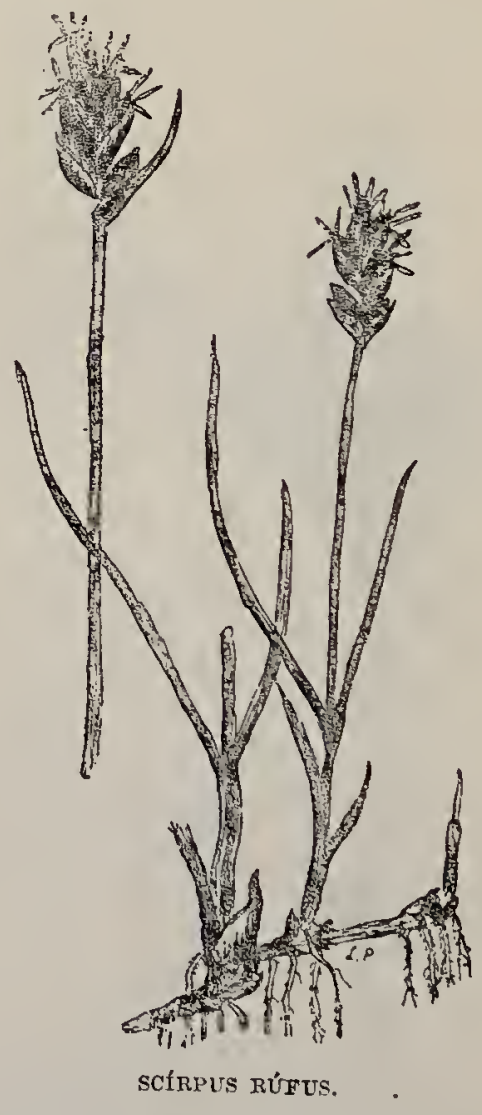

******* Spikeleis small, alternate, in a bracteate spite; glumes fer ; perianth of $3-6$ bristles.

15. S. Cáricis (Sedge-like Club-rush).-- R7izome creeping; stem $6-8$ in. high, triangular, sheathed at the base; leaves linear, flat, rougli ; spitic about an 
inch long, of 10-12 oblong, 6-8-flowered, pale brown spikelets, each about $\frac{1}{4}$ in. long; stamens

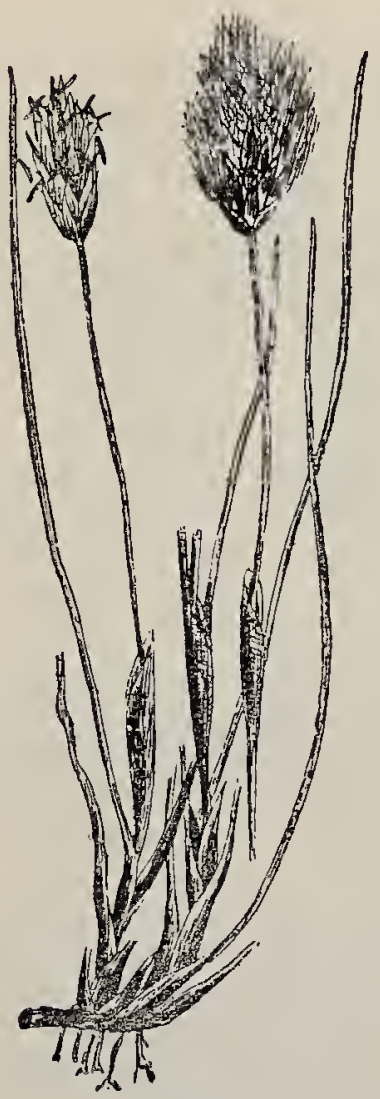

ERIóphorym Vagrvátum (Hare's-tail Cotton-grass).

usually 3 ; style 2-cleft ; nut tapering.-Boggy places ; not uncommon.-Fl. June, July. Perennial.

16. S. rufus, a plant of about the same size, with tufted, round stems; few, narrower, channelled, smooth leaves; spike $\frac{1}{2}-\frac{3}{4}$ in. long, of about 6 spike- 
lets, each 2-4-flowered, with shining, dark brown outer bracts, as long as the spikelets. - Wet pastures, rhiefly in the north; uncommon.-Fl. June, July. Perennial.

4. Erióphorum (Cotton-grass).-Tufted, herbaceous plants with terminal spilielets; numerous imbricate glumes ; perfect flowers ; perianth of hair-like bristles, forming long, cottony tufts.-(Name from the Greek erion, wool, phero, I bear.)

1. E. alpinum (Alpine Cotton-grass).-A plant resembling Scírpus crspitósus in every respect but the long perianth-bristles.-Forfar; now extinct.-Fl. June. Peremnial.

2. E. vayinátum (Hare's-tail Cotton-grass).Stems many, tufted, not a foot high, but lengthening in fruit, round below, triangular above, with 1 or 2 inflated sheaths; leaves linear ; spikelets solitary, terminal, ovoid, deep green, $\frac{1}{2}-\frac{3}{t}$ in., many-flowered; pericnth of very many bristles, forming together a thick, nearly globular, cottony tuft, about an inch across.Boggy moor's; common.-Fl. A pril, May. Perennial.

3. E. angustifólium (Common Cotton-grass).About a foot high, with solid, solitary stems : leaves channelled near the base ; spikelets $4-12$, in a terminal, umbellate cluster, the inner sessile, the outer on smooth peduncles; perianth of very numerous bristles, forming dense cottony tufts, $1-2$ in. long.-Bogs; the commonest species. Attempts liave been made to spin the cotton, but without much success. It is used for stufting pillows, under the name of "Arctic Vool." - El. May, Jume. Perennial.

4. E. latifólium (Broad-leaved Cotton-grass).Stems tufted, hollow; leaves flat; spiliclets generally less numerous, on rough peduncles.-Less common.

5. E. grácité (Slender Cotton-grass).-A rery slender species, somewhat intermediate between the two last, sometimes 2 feet high ; leaves channelled; 
spikelets about 4 , on downy peduncles. Bogs; very rare.-June, July. Perennial.

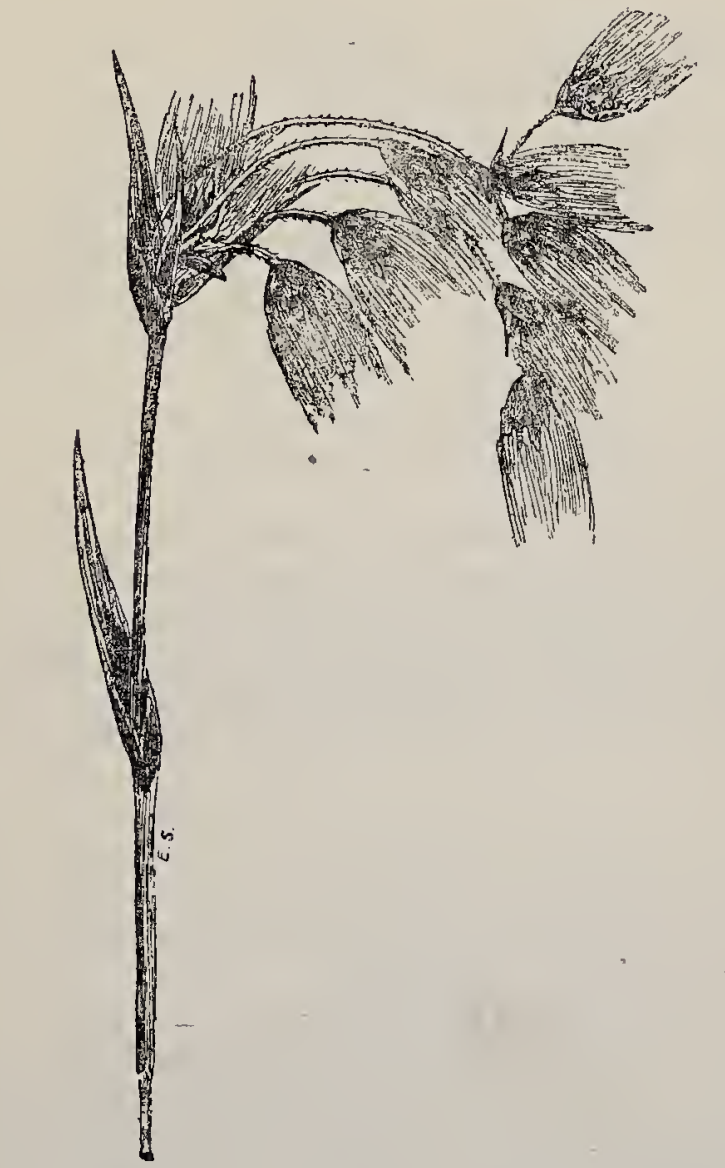

ERÍ́phorum Latifótum (Broad-leared Cotton-grass).

5. Rhiynchóspora (Beak-Sedge).-Tufted, leafy plants with terete spikelets clustered in terminal or 
axillary heads, each 1-2 flowered; glumes many; perianth of 6 included bristles; nut beaked. (Name from the Greek rhunchos, a beak, spora, seed-the permanent base of the style forming a beak to the fruit.)

1. R. fúsca (Brown Beak-Sedge).-Rhizome long; stems 6-10 in. high, very slender; leaves few, subulate; spikelets brown, usually in two clusters, one terminal, the other lateral; stamens 3.-Bogs in the south; very rare.-Fl. July, August. Perennial.

2. R. alba (White Beak-Sedge).--Rhizome short; stems 6-18 in. high, slender, in dense grass-like tufts spikelets nearly white, in a small, compact, terminal cluster, often with one or two smaller, axillary, lateral clusters ; stamens 2.-Spongy bogs; frequent.-. Fl. June, July. Perennial.

6. Sсп๕́nds (Bog-rush).—Stiff, rush-like plants; spikelets closely sessile, in compact terminal heads, 1-4-flowered, with 3 or 4 empty glumes ; fower's perfect; perianth of few bristles, or absent; stamens 3 ; nut not beaked. (Name from the Greek schoinos, a cord, some species having been used in making cordage.)

1. S. ferrugineus (Brown Bog-rush).-Wtems slender, tufted, about a foot high ; spitie narrow, ohlong, rusty-brown; 7ower bract as long as the spike; glumes in 2 rows, with a smooth keel.-Loch Tummel, Perthshire; very rare. Perennial.

2. S. nigricans (Black Bog-rush).-A very similir. but less slender plant; spitie obovoid, dark red, brown, or black, of 4-10 spikelets, with an inrolucre of 2-3 broad, brown, leafy bracts, with stiff points longer than the spike; glumes with a rough keel._Bogs; frequent._Fl. June, July. Perennial.

7. Crídidm (Fen Sedge).--Usually tall, coarse, rough, grassy plants witl rery numerous terete spike- 
lets in a compound panicle, 1-3-flowered; glumes 5 -6; perianth absent; unt with a thick fleshy coat. (Name from the Greek klcudos, a twig.)

1. C. jamaicénsé (Prickly Fen Sedge).-.Rhizome creeping; stem $3-6$ feet high, stout, very leafy ; leaves 2-4 feet long, $\frac{1}{2}$ in. across, sheathing, keeled, glaucous, stiff, with minute sharp teeth along the keel and margins ; spikelets pale brown, $\frac{1}{4} \mathrm{in}$. long, in numerous small clusters in corymbose, axillary panicles forming together a terminal leafy panicle a foot or more long; stamens usually 2 ; nut beaked.-Bogs; local. This plant used to be so common in the fens near Cambridge, before they were drained, that it was used in that town for lighting fires and for thatch. It forms floating islands in pools, and is still cut as a crop.-FI. July, August. Perennial.

8. Kobrésta, represented by one species, $K$. caricína (Sedge-like Kobresia), a low, densely tufted plant with stiff stems 4-8 in. high; leaves radical, sheathing, wiry, grooved, 2--5 in. long; spikelets 4 or 5, short, brown, closely sessile in a short terminal spike, the upper flower in each spikelet bearing stamens only, and the lower flower an ovary ; perianth absent ; style long, 3-cleft.-Mountainous moorlands in the north; rare. -Fl. August, September. Perennial. (Named after Dr. Kobres, of Augsburg.)

9. CÁREX (Sedge).-A large and well-defined genus of herbs with grass-like, chiefly radical leaves; monœcious, or rarely diœcious flowers, the stamens and ovaries being always in separate glumes, either in different parts of the same spikelet, which is then called "mixed," or in separate spikelets; glumes imbricate; stamens 3 , rarely 2 , without a perianth; ovary enclosed in a vase-shaped covering; style protruding; 
stigmas 2-3. (Name Classical, connected with the Greek leero, I cut, in allusion to the sharp-edged leaves.)

\section{+ Spikelet simple, solitury, and terminat.}

1. C. dióica (Drocious Sedge).-A slender plant, 6-12 in. high, with runners; leaves very narrow, smooth; spilelets bearing stamens only or pistits only, and with stamens and pistils on different plants, brown, the staminate ones cylindric and pale, the pistillate oroid, brown; style 2-cleft; fruit erect, with rough edges.-Spongy bogs; cominon.-Fl. May, June. Perennial.

2. C. Daralliuna (Darall's Sedge), a tufted plant, without runners, with rough edges to its leares and drooping fruit, oceurred formerly near Batls, but has been lost through drainage.

3. C. pulicuris (Flea Sedge).-A small tufted plant, without runners, $3-8$ in. high ; leaves narrow, erect, involute; spikelet about 9 lines long, the upper half bearing stamens; 3 to 7 of the lower glumes enclosing pistils; stule 2-cleft; fmit oblong, pointed, about 2 lines long, drooping when ripe--Bogs; common.Fl. May, June. Perennial.

4. C..mpestris (Rock Sedge).-A creeping, tufted plant, with rumners; stems $3-6$ in., 3-edged; leaves flat, stiff, rerolute, ending in a wavy, rough point; sprikelet $\frac{1}{2}-1$ in. long, linear, dark brown, shining, the upper half staninate; style 3-cleft; fruits obovate, adpressed.- Lofty Scottish mountains. - Fl. July, A ugust. Perennial.

5. C. panciflór (Few-flowered Sedge).-A slender species, with long runner's; stem soldom more than 6 in. high, slender, 3 -angled, smooth ; leaves narrow, involute; spikelets pale brown, 3 or 4 lines long; flnwers few, the 2 or 3 uppermost staminate, the 2 or 3 lower ones pistillate; styles 3 -cleft ; fruit narrow and pointed, 
reflexed.-Moorland bogs in the not.th.-Fl. June, July. Perennial.

t+ Spikelets several, all similar, short, sessile, in a compound spilee, mostly with both staminate and pistillate flowers; styles 2-cleft.

6. C. incúrva (Curved Sedge).- Root-stock long, creeping; stems stout, $2-3$ in. high, usually curved, so as to bring the large head of spikelets down to the ground; leaves channelled, involute, curved, about the same length; spikelets 3 or 4 , in a dense, nearly globular head, each with a few staminate flowers at the top; fruit broad, rather inflated, tapering into a short beak projecting beyond the glumes. - Sandy shores in the nortlı; rare. -Fl. June, July. Perennial.

7. C. divisa (Bracteate Marsh Sedge).-Root-stock stout; stems very slender, $1-3$ feet high, erect; leaves long, narrow ; spilielets few, short, crowded in a head with a leafy bract at its base, several upper flowers staminate; fruit plano-convex, not winged, with an acutely 2 -fid, finely toothed beak.-Marshes near the sea; frequent._Fl. May, June. Perennial.

8. C. disticha (Soft Brown Sedge). - Root-stock creeping; stems stouter than in the preceding, 1-3 feet high ; leaves long, narrow ; spikelets in an oblong, interrupted spike, pale brown, the middle ones staminate; fruit ovate-lanceolate, narrowly winged. Marshy places.-Fl. May-July. Perennial.

9. C. arenária (Sand Sedge).- Root-stock very lonę, stout, and branched, creeping over and binding the sands; stems tufted, 8-10 in. high, stout, rough, leafy at base; leaves radical, stiff, involute; spikelets many, rather large, ovoid, in an interrupted spike 1 or 2 in. long, the upper ones staminate, the lower pistillate, and the middle ones with flowers of both kinds ; fruit ovate, veined, winged, shining chestnutbrown.-Sandy sea-shores.-Fl. June. Perennial. 
10. C. teretiúscula (Lesser Panicled Sedge).—Rootstock creeping, with scattered tufts; stems $1-2$ feet high, slender, 3 -angled ; spikelets few, oblong, acute, forming a dense compound spike about an inch long;

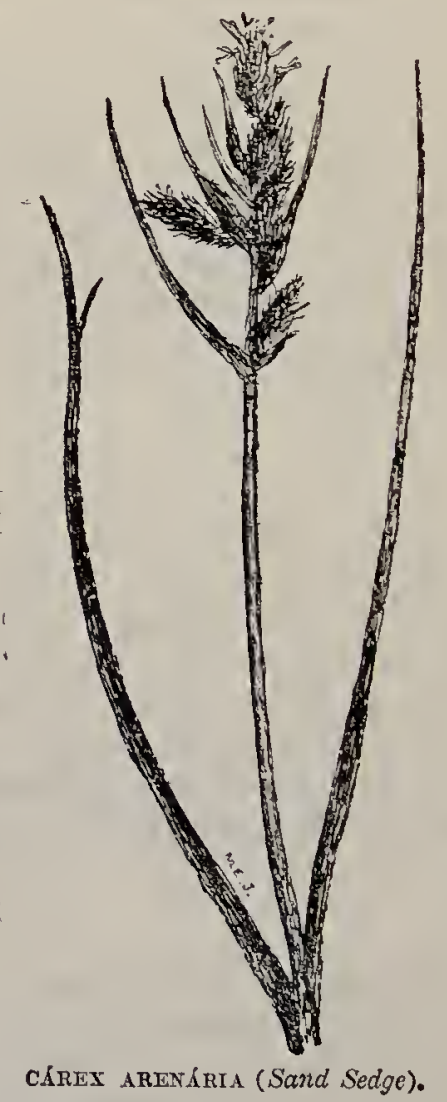

fruit ovate, swollen, brown, shining, with $2-5$ ribs on the back, beaked,-Boggy meadows.-Fl. June. Perennial.

、11. C.paradóxa, a rare form, intermediate between 
the preceding and following species, more densely tufted than the preceding; stem covered below by the black fibrous remains of dead leaves; spilielets elongate, in a panicle somewhat interrupted below ; fruit with numerous ribs near its base.-Bogs.-Fl. June, July. Perennial.

12. C. paniculáta (Great Panicled Sedge).-A stout species forming large tussocks, 2-4 feet across ; stems stout, 1-4 feet high, triangular, rough, leafy; leaves long, narrow, flat; spikelets numerous, brown, erowded into a compound spike or panicle, $4-5$ in. long, the lower branches. spreading; glumes with bristly points and pale membranous margins; fruit ovate, beaked, with many faint veins.-Bogs; common.-Fl. June, July. Perennial.

13. C. vulpina (Great or Fox Sedge).-A stout tufted plant, 2-4 feet high, with runners; stens numerous, 3-angled, with rough edges, leafy; leaves broad, flat, sharply pointed; spikelets numerous, green or pale brown, crowded into a compound interrupted spike 1-3 in. long; bracts bristly, spreading; fruit much flattened, ovate, beaked, pale.-Wet places; common.-Fl. June, July. Perennial.

14. C. vulpinóides, an allied North American species, has been recorded from the banks of the Thames near kew.

15. C. muricáta (Great Priekly Sedge).-A densely tufted species, with short runners; stems 1-2 feet high, slender, 3-angled, ruugh; leaves narrow, flat; spilielets $4-6$, rather short, brown or shining green, with a few staminate flowers at the top of each crowded into a terminal spike about an inch long, or the lower ones distant; fruit rather large, ovate, pointed, spreading, 2-fid, finely toothed above.Gravelly pastures; common.-Fl. May, June. Perennial.

16. C. divúlsa (Grey Sedge).-An allied species with more slender, flaccid stems and 5 or 6 paler, 
greyish, more distant spikelets, forming an interrupted spike, $2-3$ in. long, occurs in moist, shady places.Fl. May. June. Perennial.

17. C. echináta (Lesser Prickly or Star-headed

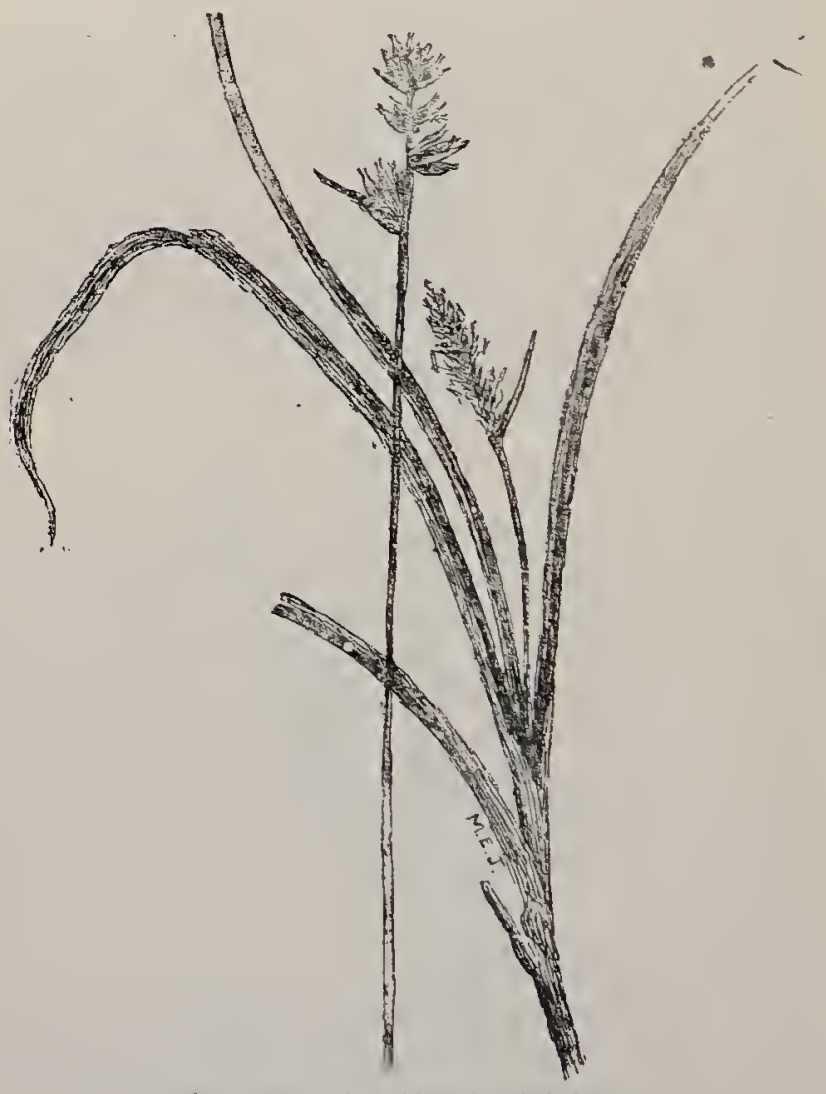

CAREX ECHINATA (Star-headed Selge):

Sedge).-Tufted, rarely above 6 or $S$ in. high ; teaves shorter than the stems; spitielets $3-5$, some distance npart, except sometimes the 2 uppermost, nearly globular when ripe, pale; fruit spreading, broadly 
ovate, much beaked, about 2 lines long. - Boggy places ; common.-Fl. May, June. Perennial.

18. C. remóta (Distant-spiked Sedge).-A tufted plant; stems slender, 1-2 feet high; leaves narrow;

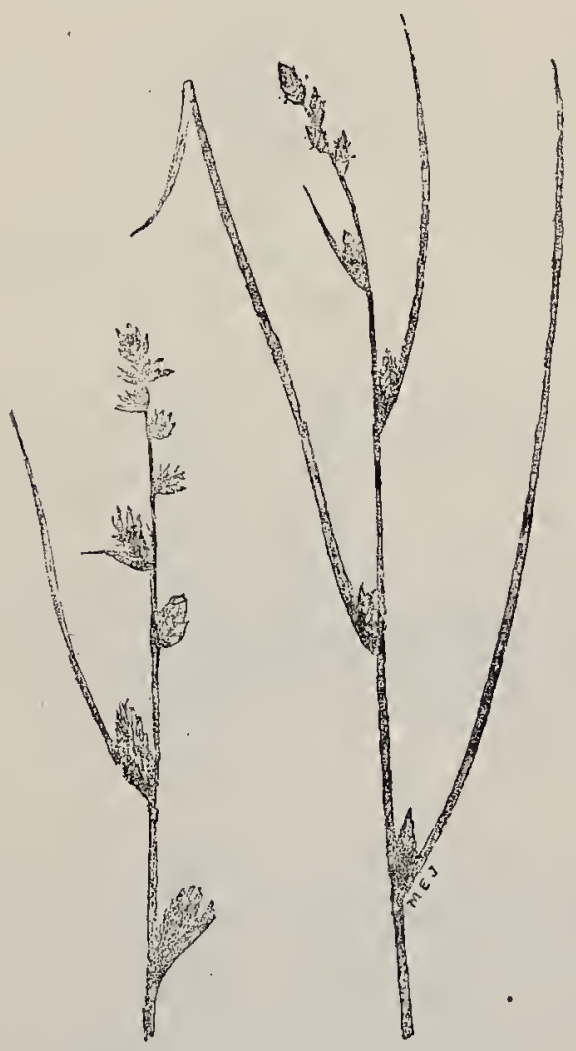

CAREX REMóta (Distant-spitied Sedge).

spitelets small, pale, a considerable distance apart, the lower ones each in the axil of a long, lcafy bract; the lower flowers mostly staminate; fruit ovate-lanceolate, longer than the glumes, with notched beak.-Damp copses ; common.-Fl. June. Perennial. 
19. C. axillàris (Axillary Sedge) possibly a hybrid between the preceding and C. muricáta; has taller, stouter, leafy stems, 1-2 feet high; flat leaves, and less distant spitielets, and the lowest spikelet is either branched, or there are 2 or 3 together; glumes broader, rigid.-Marshes; rare._Fl. June, July. Perennial.

20. C. Boenninghausiána, possibly a hybrid between C. remóta and $C$. paniculata, has slender, rough stems, 1-2 feet high ; spikelets small, in a spike sometimes a foot long, the upper ones simple, the lower branched, without bracts, and with pale silvery-brown, smooth, membranous glumes. - Marshes ; rare._El.June, July. Perennial.

21. C. elongáta (Elongated Sedge).--Tufted, without runners; stems numerous, slender, about 2 feet high, rough, leafy; leaves long, narrow, flat, flaccid; spikelets many, pale greenish-brown, oblong, touching one another, without bracts ; fruit spreading, linearoblong, beaked, not winged, 2 lines long.-Marshes; rare.-Fl. July, August. Perennial.

22. C. approximáta (Hare's-foot Sedge).-A tufted plant, with short runners ; stems wiry, $1-10$ in. high, 3-angled, smooth ; leaves flat; spikelets 2 -4, small, fuscous, ovoid, touching one another, with minute bracts; fruit erect, elliptic, not winged, with a short beak; glumes reddish, ovate, nearly as long as the fruit.Lofty mountains in Aberdeenshire; very rare.-Fl. July, August. Perennial.

23. C. currta (White Sedge).-Tufted, without runners; stems slender, 12-18 in. high; leaves not quite as long; spiketets 4-8, some distance apart, elliptical, 3 or 4 lines long, pale green ; ghumes membranous, whitish, with a green keel; fruit erect, broadly ovate, compressed, acute, with a short beak, faintly ribbed, not longer than the glumes.-Bogs; common.-Fl. June, July. Perennial.

24. C. hetrola differs in having fewer spikelets, few- 
flowered; glumes browner; fruit with a deeply 2-fid beak. - Mountain bogs in the north.

25. C. ovális (Oval-spiked Sedge).-Stems about a foot high, loosely tufted at the base, without runners;

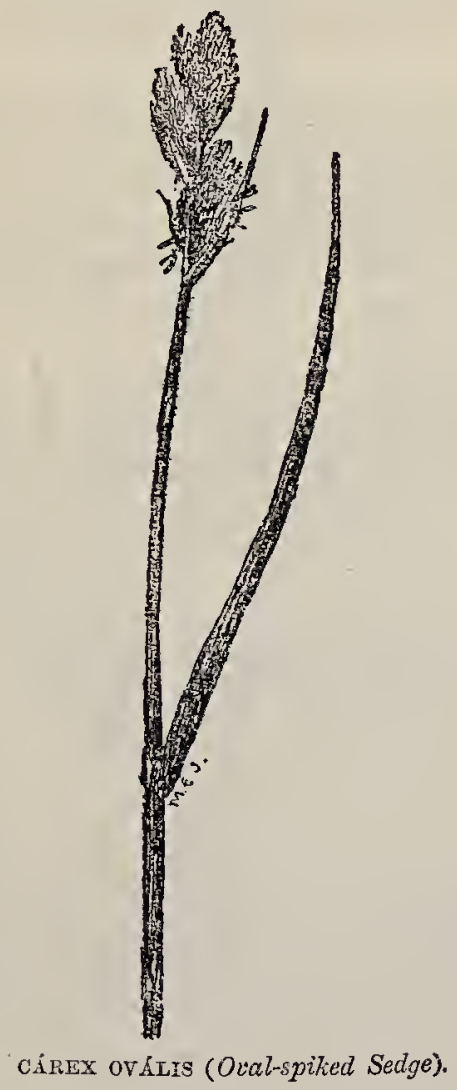

leaves shorter, narrow, flat, with fine points; spikelets about 6 , sessile, distinet, but close together, ovoid, pale brownish-green, shining, about 4 lines long, with a few staminate flowers at the base of each; fruit yellowish, erect, ovate-acuminate, with a membranous 
toothed margin.-Wet places; common.-Fl. June, July. Perennial.

It Spikelets several, dissinitar, the terminal one or more usually wholly stominate, the other (axillary) ones beariny pistits onty, or pistillate and staminate flowers.

26. C. alpina (Alpine Sedge).-A rather slender species, 6-18 in. high, tufted, with short runners; leaves short, narrow, flat, recurved ; spitielets $2-4$ close together, ovoid, black or dark brown; styles 3-cleft; fruit green, obovoid, shortly beaked, projecting beyond the glumes.-Clova Mountains; rare-_Fl. July, August. Perennial.

27. C. atráta (Black Sedge)-Another tufted alpine species, with runners; stems $6-18$ in. high, smooth; leaves broad and flaccid; spiluetets $3-6$, oblong, shortly stalked, near together, 8 or 9 lines long, very dark brown or black, ultimately drooping; outer bract leafy; styles 3-cleft; fruit elliptical, rery acutely triangular when ripe, witl a short beak.-Mountains of Scotland, Westmoreland, and North Wales.-FI. June, July. Perennial.

28. C. fúsca (Dark Sedge), found only on an island in Lough Neagh, is a creeping species, with stems 1_-2 feet ligh; leaves narrow, flat, with reddish-brown sheaths with filamentous edges ; spilielets 3 or 4 , oblong, in a loose spike; glumes dark brown, with a green keel prolonged into a point; styles 3-cleft; fruit flattened, glaucous green.-F'l. June-A.ugust. Perennial.

29. C. Mudsónii (Tufted Bog Sedge).--A densely tufted species; stems $1-3$ feet high, slender, stiff; leaves narrow, flaccid, with a webbing of filaments on the sheaths; spikelets 3 or 4 , erect, cylindric, $1-2$ in. long, sessile, styles 2-cleft ; fruits oblong, in $6-9$ rows, larger than the dark glumes.-Bogs ; local.-Fl. May, June. Perennial. 
30. C. acúta (Slender-spiked Sedge).-A tufted species, with or without runners ; stems $2-3$ feet high, 3 -angled; leaves as long, broad, flaccid, their sheaths not webbed ; spitielets 4--9, 1-4 in. long, nodding; styles

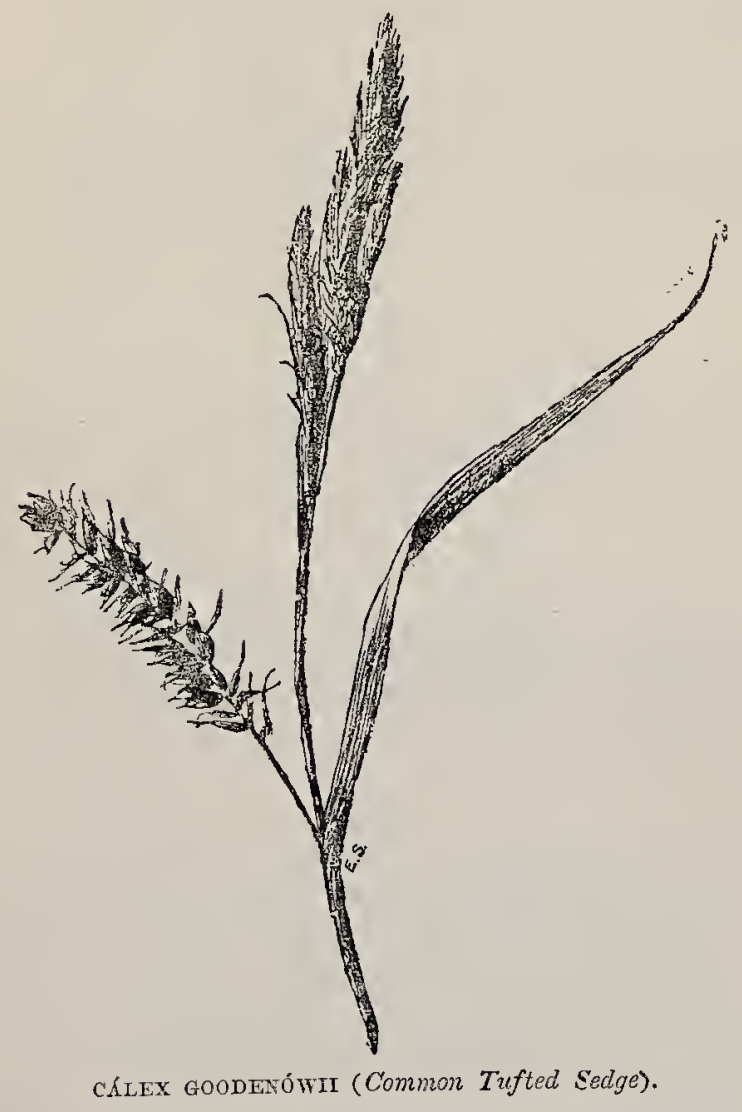

2-cleft; lower bract long, leaf-like, with long auricles. -Wet places; not uncommon.-Fl. June--August. Perennial.

31. C. trinérvis. a low-growing species, less than. 
a foot high, with long, scaly root-stocis and runners; stems smooth, 3-angled; leaves narrow, smooth, involute; spikielets few, close together, $\frac{1}{2}-1$ in. long; lower bract slender, stiff, longer than the spikelet; fruit compressed, brown, dotted. - Wet sandy places on the Norfolk coast.-Fl. July, August. Perennial.

32. C. rigida (Stiff Mountain Sedge).-A dwarf alpine form, scarcely 6 in. high, with short, flat, rigid leaves with revolute margins; spikelets $3-6$, erect, short, dark; fruit obovoid, compressed, not veined,-Wet stony places on mountains in the north. -Fl. June-August. Perennial.

33. C. aquátitis (Water Sedge).-A tall, tufted form, with runners; stems $1-2$ feet high, 3 -angled, rigid, polished, leafy below ; leaves long, erect, flat, ir.volute; spikelets $3-6$, cylindric, slender, $1-2 \frac{1}{2}$ in. long; fruit rounded, compressed, not veined.-Scottisi bogs; rare.-Fl. June-August. Perennial.

34. C. salína, var. Kattegaténsis, with erect, 3-angled stem, 12-1s in. high ; leaves of the same length, with rough keels and margins ; bracts leafy and longer than the spikelets; staminate spikelets $2-3$, sessile; pistitlate ones 3-4, on short stalks, dark brown, has been recorded from the sandy banks of the River Wick, Caithness.

35. C. Goodenórvii (Common Tufted Sedge).-A tufted or creeping species ; stems 1 -2 feet high, stiff, slender, 3-angled, rough ; leaves slender, narrow, erect, recurved; spikelets $3-5$, erect, sub-sessile, not more than an incl long, near together; bracts with short auricles; fruit rounded, compressed, many-veined.Marshes and wet meadows; common.-Fl. May_July.
Perennial.

36. C. flacca (Glaucous Sedge).-A creeping species; stems few, wiry, a foot or nore in height, 3-angled, smooth ; leaves narrow, flat, glaucous; staminate spitielets 2 or 3 ; pistillate spitielets $4-6$, sub-erect, cylindric, $\frac{1}{2}-1$ in. long, long-stalked; glumes dark brown; styles 
3-cleft; fruit ovoid, triangular, not beaked,-Damp places ; common.-Fl. June, July. Perennial.

37. C. magellánica.-A slender, creeping species; stems a foot or more high, nearly smooth ; leaves linear,

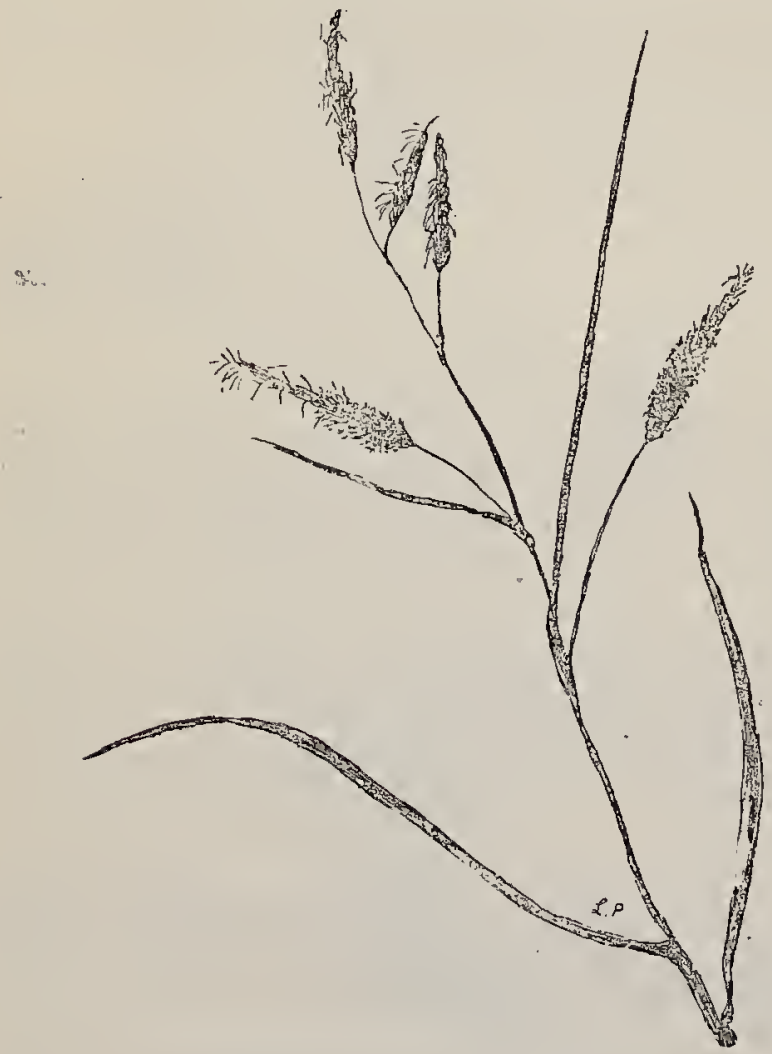

CÁEEX FLÁCCA (Glancous Sedge).

flat, smooth-edged, not glaucous; pistillate spitielets 2 or 3, long-stalked, drooping; bracts leafy, broad, flat; glumes purple, lanceolate, with long points; fruit roundish, faintly ribbed, beaked.-Spongy bogs in the north; rare.-Fl. June. Percmial. 
38, C. Timósa (Mud Sedge -A closely allied, slender, creeping species; stems $3-12 \mathrm{in}$. high, rough ; leaves narrow, glaucous, channelled; staminate spikelet $\frac{1}{2}-1$ in. long; pistillate spizielets 1 or 2 , on slender stalks, drooping, 6-8 lines long; bracts leafy; glumes rather dark brown with green mid-rib, orate, upper. ones pointed; styles 3-cleft; frut rathsi large, roundish, compressed, not beaked.-Wpongy bogs; rare.Fl. June. Perennial.

39. C. rariflóra (Loose-flowered Alpine Sedge).A creeping plant; stems 6 - 12 in. high, wiry, smooth; leaves narrow, erect, rough-edged; staminate spitelet short; sub-erect; pistillate spizielets 2 or 3, drooping, $\frac{1}{3}$ in. long, on slender stalks of the same length, 6-Sflowered; bracts with short sheaths; glumes brown, shining, obtuse, with a minute point; fruit obovoid, faintly veined, shortly benked.-Elevated bogs in Scottish Highlands.-Fl. June-August. Perennial.

40. C. digitúta (Fingered Sedge).-Densely tufted; stems slender, curved, 6-10 in. high, sheathed at the base, leafless; leaves radical, flat, shorter, revolute; staminate spikelet terminal, 6 lines long; pistillate spikelets close together, 2 or 3 , shortly stalked, spreading in a finger-like manner ; flowers lax; bracts brown and sheathing; styles 3-cleft; fruit obovoid, and minutely downy.-Woods on limestone; rare.-FI. April, May. Perennial.

41. C. oraitliópoda (Bird's-foot Sedge), a closely allied form, with broader bracts and longer firtit, occurs in Derbyshire and Yorkshire.-Fl. May-July. Perennial.

42. C. Thumilis (Dwarf Silvery Sedge).-A creeping, tufted species ; stem: $1-5$ in. high ; leaves longer, stiff, involute, curved; staminate spitie? st terminal, about 9 lines long; pistillate ones $3-5$, much sualler, stalked, placed at intervals on the stem, scarcely protruding from the sheath of silvery membranous bracts; glumes with membranous edges; styles long, 3-cleft; 
fruit ovoid, obtuse, ribbed, slightly downy.-Limestone hills in the south-west; rare.-Fl. May, June. Perennial.

43. C. montána (Mountain Sedge).-A creeping,

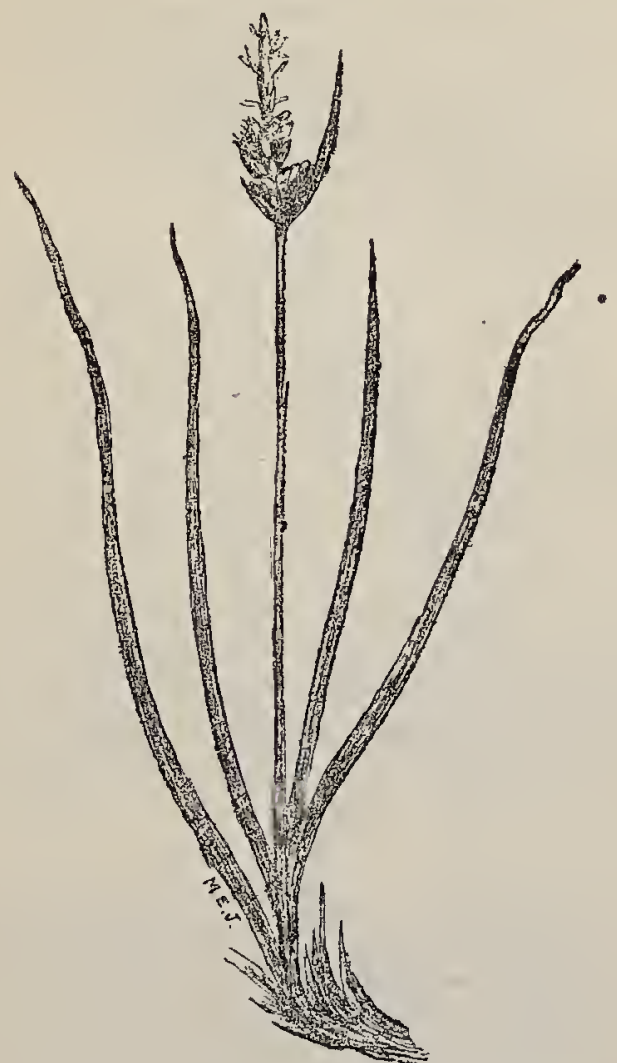

CáLEx PILULÍfERA (Round-headed Sedge).

tufted species, with slender stems, 6-18 in. high, narrow leaves; spikelets few, sessile, crowded, bright red-brown, polished ; fruit obovoid, hairy, longer than the glumes, with a short, notched beak.-Heaths and woods in the south.--Fl. A pril, May. Perennial. 
44. C. pilulifera (Round-headed Sedge).-Tufted, with few slender stems, 6-12 in. high, 3-angled, rough ; leaves shorter, broad, weak, and flexible; pistillate spitelets 2 or 3 globose, sessile, close under the terminal staminate one; bracts short, leafy; ghumes brown, broadly ovate, pointed; styles 3-cleft; fruit small, nearly globular, shortly beaked.-Wet heaths; common.-Fl. May-July. Perennial.

45. C. ericetorum (Heath Sedge)._ A creeping, tufted plant; stems 2-6 in. high, stiff, curred, 3angled, smooth; leaves recurred, keeled; staminate spikelet spindle-shaped, $\frac{1}{2}$ in. long; pistillate spirelets $1-3$, ovoid, sessile, small, close together, $6-10$ flowered ; glumes brown, with a broad pale edge, very blunt, ciliate, as long as the fruit.-Chalk banks in the eastern counties; rare-Fi. A pril--June. Perennial.

46. C. vérna (Spring Sedge).-A small, creeping species with runners; stem $6-12$ in. high, 3-angled; leaves short, keeled, curved, densely tufted; staminate spikelet slender, erect; pistillate spitielets $1-3$, oblong, close together; glumes small, broad, with a distinct fine point, brown edgres, and green midrib as long as the ovoid, 3-sided, shortly beaked and slightly downy fruit.-Dry pastures; common. - Fl. Aplil, May. Perennial.

47. C. tomentósa (Downy-fruited Sedge), known only from Minston Maisey, Wiltshire. Root-stock creeping; stem slender, erect, 12-18 in. high ; leaves narrow, erect, short; staminate spitielet terminal, about an inch long; pistillate spikelets 1 or 2 , at some distance, oblong, erect, nearly sessile, $\frac{1}{2}$ in. long, compact; lower bracts leafy; glumes small, brown; styles 3-cleft; finit small, globose, with copious white down.-Wet meadows.-Fl. Jume, July. Perennial.

48. C.palléscens (Pale Sedge).-Stems tufted, without rummers, leafy at the base, $1-2$ feet high; staminate spikelet terminal, light brown, about 6 lines long; 
pistillate spikelets 2 or 3 , pale yellowish-green, shortly stalked, erect or slightly drooping, oblong, shorter than the staminate one and at short distances below

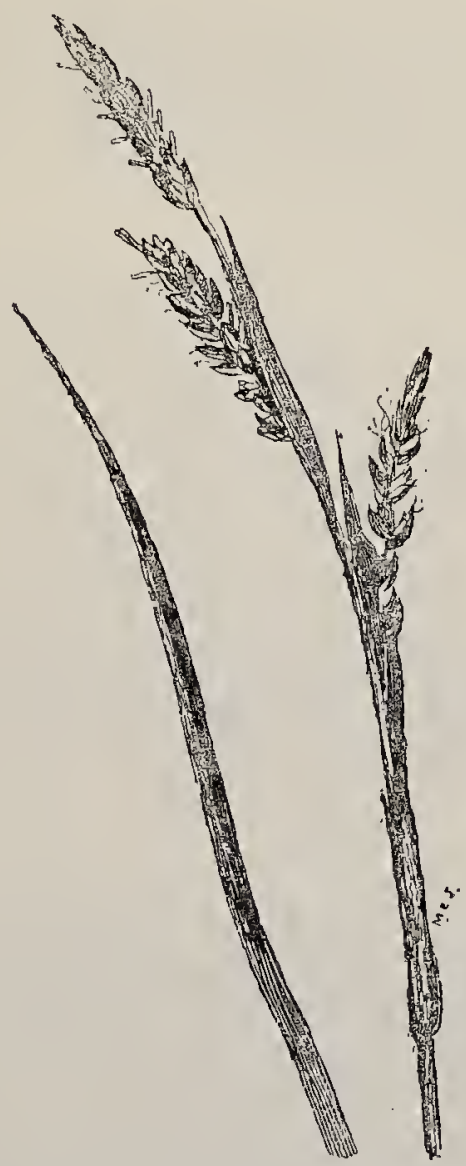

CAREX FANÍCEA (Carnation-grass).

it ; bracts leafy; styles 3-cleft ; fruit smooth, blunt.Wet places; common.--Fl. June, July. Perennial. 49. C. panźcea (Carnation-grass).-A tufted, creep- 
ing plant, with runners; stems $1-2$ feet high, smooth, leafy; leaves rather short, elect, flat, glaucous, resembling those of the Carnation, but with rough edges; spitielets usually 3 , the terminal one staminate, the others pistillate, distant, erect, stalked, $\frac{1}{2}-1$ in. long; flowers, especially the lowest, some distance apart; bracts short, leafy, with sheaths; qlumes brown; styles 3-cleft; fruit oroid, triangular, smootl, shortly beaked.-Wet meadows; common.-Fl. June, July. Perennial.

50. $C$, vagináta (Short Brown-spiked Sedge).-A closely allied alpine species, but not glaucous, with broader, recurved leaves; shorter bracts with looser, funnel-shaped sheaths; looser spitielets; paler and. more blunt glumes; and larger, more beaked frit.Scottish mountains.-Fl. July. Perennial.

51. C. atrofúsca (Dusky Sedge).-Stem 3--10 in. high; leaves very short, broad; staminate spitielet terminal; pistillate spitielets $2-4$, ovoid, shortly stalked; bracts sheathing; glumes ovate, acute, dark purple, with a pale midrib; fruit dark purple, rough-edged, with a 2-fid beak.-Ben Lawers.-Fl. July. Perennial.

52. C. frígida (Cold Sedge).-A small, tufted, and slightly creeping species, $3-12 \mathrm{in}$. high, with slender stems bearing 1 or 2 leaves, and numerous long, flat, brcad radical leaves : spitielets 4-6, spindleshaped, rich dark brown, the terminal one staminate, the upper ones sessile, the lower long-stalked and becoming pendulous; fruit with a long, slender, ciliate, 2-fid boak.-Wet turf, Glen Callater, Aberdeenshire.

-Fl. August. Perennial.

53. C. capilánis (Dwarf Capillary Sedge). - A tufted species; stems $3-9$ in. ligh, slender, smooth, longer than the soft, recurved leaves: staminate spikelet terminal, small; pistillate spilielets 2 or 3 , drooping, on long hair-like stalks, pale-coloured, loose, fewAlowered, seldom 6 lines long; lower bracts enclosing 
several peduncles; glumes ovate, obtuse, with membranous edges, as long as the beaked fruit; styles 3 -cleft.-Mountains in the north; local.-Fl. June, July. Perennial.

54. C.péndula (Great Drooping Sedge). - A tufted species, without runners; stems stout, triangular, leafy, 3-6 feet high ; leaves long, nearly $\frac{1}{2}$ in. broad; spitielets $4-6$ in. long, numerous, drooping; the stalks of the pistillate ones almost concealed in the sheaths of the long, leafy bracts; glumes ovate-lanceolate, brown, with green keel; styles 3-cleft; fruit small, ovoid, with short beak.-Wet woods; frequent.-Fl. May, June. Perennial.

55. C. strigósa (Loose-spiked Wood Sedgc).-A tufted, creeping plant; stems 1 -2 feet high, 3-angled, smootl, leafy; leaves short, broad, pale, flaccid ; spikelets slcnder, drooping, 1-3 in. long, the lower pistillate ones on long stalks; flowers many, lax; bracts leafy, short, with long sheaths; fruit tapering at both ends, longer than the pointed, transparent glumes.'Thickets ; rare.-F'. May, June. Perennial.

56. C.depauperáta (Starved Wood Sedge).-Tufted; stems slender, 1-2 fcet high, 3.angled, smooth, leafy; leaves long, narrow, flat; staminate spikelet slender, an inch or more long; pistillate spikelets $3-5$, about $\frac{1}{2}$ in. long, erect, green, 3-4-flowered, the lower on long stalks ; fruits few, very large, globose, many-ribbed, with a long beak.-Dry woods in the south; very rare.-Fl. May, June. Perennial.

57. C. syluática (Wood Sedge).--Tufted; stems weak, 1-3 feet high, leafy ; leaves flaccid; staminate spikelet pale, about an inch long; pistillate spilielets distant, slender, an inch or more in length, on long stalks, loose-flowered; bracts leafy, with long shcaths; glumes green, narrow, pointed; styles 3-cleft; fruit elliptical, smooth, obscurely veined, tapering into a long beak.-Damp woods; common.-Fl. May, June. Perennial. 
58. C. Tovigáta (Smooth-stalked Sedge).--Tufted, creeping; stems smoath, $2-3$ feet high; leaves short, broad, dotted beneath; staminate spitielet $1-2$ in. long, 3 angled; pistillate spitielets distant, cylindric, $1-2$ in.

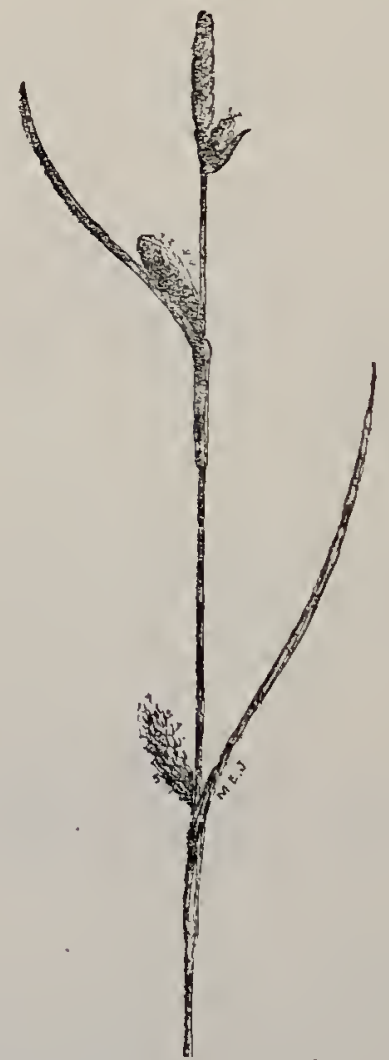

CAREX Dfstats (Loose Sedge).

long, slender, green, stalked ; fruit ovoid, tapering at both ends, ribbed, with a rough beak.-Wet places; not common.-Fl. June. Perennial.

59. C. binérvis (Green-ribbed Sedge).-A closely allied, but much smaller species, generally about a 
foot high; leaves rigid, keeled, recurved; pistillate spikelets not more than an inch long, brownish ; fruit with two prominent green ribs and a broad, smooth beak.-Heaths; common.-Fl. June, July. Perennial.

60. C. distans (Loose Sedge).-Another closely allied species, less coarse; leaves glaucous; spilkelets 4 or 5 , far apart, the terminal one staminate, sometimes with a small one close to it, the others pistillate, $\frac{1}{2}-1$ in. long, oblong, erect, stalked, but sometimes appearing sessile, the stalks being enclosed in the sheaths of the leafy bracts; glumes brownish ; styles 3-cleft ; fruit yellowish-brown, ovoid, smooth, faintly ribbed with a narrow, rough beak.--Brackish marshes near the sea. Fl. May, June. Perennial.

61. C. dilúta (Dotted-fruited Sedge).-Another nearly allied species, 12-18 in. high, slender; glumes pale red with a broad green band down the back; fruit ovoid, membranous, swollen, shining, only ribbed at the angles, dotted, longer than the glumes, with a slender, smooth beak.--Marshes near the sea.--Fl. June. Perennial.

62. C. fúlea (Tawny Sedge).--Another nearly allied species, with a rongh-edged stem, 2 or 3 pale pistillate spikelets, which are ovate-oblong; glumes ovate, not mucronate, with transparent tips; fruit broadly ovoid, ribbed, with a rough beak.--Marshes, chiefiy at high altitudes.-Fl. June. Perennial.

63. C. exténsa (Long-bracteate Sedge).--Tufted, rather slender, 8-18 in. high; leaves very narrow, stiff, erect, often convolute; spnkelets nearly sessile, near together at top of stem, or only the lower one distant, oblong, brown-green; bracts long, narrow, leafy, with short sheaths, the lowest much longer than the stem; glumes mucronate; styles 3-cleft; fruit ovoid; triangular, strongly-ribbed, tapering into a conical beak.-A sea-coast plant, general round the British Isles.-Fl. June, July. Perennial. 
64. C. fláva (Yellow Sedge).-Usually densely tufted and leafy, $3-18 \mathrm{in}$. high, acquiring frequently a yellowish hue, especially the pistillate spikelets; terminal staminate spitielet $6-9$ lines long; pistillate spiticlets 1, 2 or 3 , sessile or shortly stalked, and very near the terminal one, and often one much lower down on a longer stalk, all erect, ovoid, and when ripe nearly globular; lracts all leafy and sheathing; styles 3-cleft ; fruit ovoid, ribbed, beaked, spreading.Wet places ; frequent.-Fl. May, June.

65. C. filifôrmis (Slender Sedge). - Root-stock creepiug, with runners; stems $1-3$ feet high; leaves very slender, stiff; staminate spitielets 2 or 3 , slender, 1-2 in. long, brown; pistillate splkelets 1 -3, remote from them, nearly sessile, oblong, 6-9 lines long, loose-flowered; styles 3-cleft; fruit ovoid, with a short 2-fid beak, very downy.-Peat-bogs; lozal.-Fl. May. Perennial.

66. C. hivta (Hairy Sedge ur Hammersedge).Root-stock creeping, jointed, scaly ; stems weak, leafy, $1-2$ feet high, and, ns well as the leares, more or less hairy; terminal staminate spilielets 1 or 2 ; pistillate ones 2 or 3 , very distant, stalked, cylindric, an inch or more long; bracts with long sheaths; fruit tapering into a long, 2 -fid beals, covered with short, spreading hairs.-Damp woods.-Fl. May, June. Perennial.

67. C. I'sendo-cypérus (Cyperus-like Sedge).-A stout, tufted form ; stems 1-3 feet high, 3-angled, rough ; leaves broad, long, rough ; staminate spitivetet 2-3 in. long, slender, pale; pistitlate spitielets $4-5$, not more than 2 in. long, cylindric, green, longstalked, drooping when in fruit; bracts broad, long, and leafy, without sheaths; glumes narrow, pointed, rough, green ; styles 3-cleft; finit spreading, lanceolate, ribbed, with long, stiff; 2 -fid beak. - Riverbanks; not common.-Fl. June. Perennial.

68. C. acutifómis (Pond Sedge).-A tall, stout species, with a creeping root-stock and runners; stems 
2-3 feet high, stout, 3.angled, rough; leaves erect, long, broad, glaucous; staminate spikelets 2 or 3 , $1-2$ in. long, sessile, dark brown, with blunt glumes; pistillate spikelets 2 or 3 , rather distant, sessile, or the

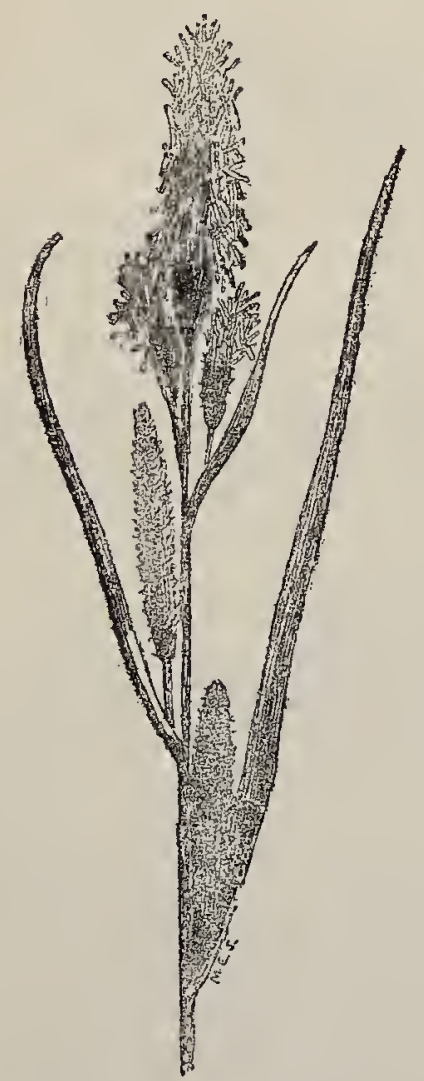

CAREX ACUTIFórmis (Pond Sedge).

lowest shortly stalked, often 2 in. long, erect, cylindric, blunt, with pointed glumes; bracts leafy, without sheaths; styles 3-cleft; fruit ovate, slightly triangular, but much flattened, tapering into a very short, 2 -fid 
beak. - Ditches ; common.-Fl. May, June. Perennial.

69. C. ripária (Greater Pond Sedge).-A nearly allied, but much larger species, being by far the largest British Sedge; stems 2-5 feet high; leaves broader; spitelets more numerous and very large, $3-6$ staminate, crowded, $1 \frac{1}{2}-2$ in. long, with acute glumes, 4-6 pistillate, pointed ; firut oblong-ovoid, convex on both sides.-Ditches; common.-Fl. May, Perennial.

70. C, rostráta (Bottle Sedge).-A stout, tufted and creeping species, with stems $1-2$ feet high, smooth, slightly 3-angled; Teaves long, channelled, glaucous ; spitielets 1-2 in. long or eren more, 2-3 staminate, 2-4 pistillate, remote, erect, stout, cylindric, pale, the lowest shortly stalked; bracts leafy, without sheaths; styles 3-cleft; firit flaskshaped, that is, ovoid, inflated, narrowing suddenly into a long slender beak.-Bogs ; common.-Fl. May, June. Perennial.

71. C. vhynchophýsa, a taller and more glancous, somewhat tufted plant, $2-3$ feet high ; bracts leaflike, longer than the staminate spikelets; spitielets curved outwards at the base, $3-4$ pistillate, $4-6$ staminate, the pistillate ones $2-3 \mathrm{in}$. long, the staminate ones $1-2$ in. ; styles deeply 3 -cleft; fruit globose, tapering into a rather long beak.-Found in $1892 \mathrm{by}$ Mr. Lloyd Praeger in Mullaghmore Lough, co. Armagh.--Fl. July, August. Perennial.

72. C. vesicáric (Bladder Sedge).-Nearly allied to $C$. rostráta, but with rough, triangular stems ; flat, green leaves; rather shorter spilielets; and fruits, although inflated, more conical, tapering gradually into a shorter subulate beak.-Bogs; less common than C. rostráta-Fl. May, June. Perennial.

73. C. pilla (Russet Sedge).-An alpine form of the preceding; root-stock creeping, the scaly rumners ending in tufts of leaves; stems $4-10$ in. high, leaf $y$; spilielets 3 or 4 , distant, 1 or 2 staminate, the pistillate 
ones ovoid, dark brown, 6-8 lines long, the lowest on a slender stalk, with a leafy bract at its base; styles 2-cleft ; fruit ovoid, inflated, with a very short, 2-fid point.-Only found on the higher Scottish mountains. -Fl. May, June. Perennial.

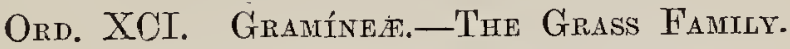

The grasses form one of the largest, most naturally clefined, and most widely distributed Orders in the Vegetable Kingdom, and at the same time one which is unrivalled in its utility to man. It comprises about 3,600 species in 310 genera. They are evergreen, annual, or peremnial herbs, though some of them reach a large size, Bamboos being sometimes 100 feet in height and nearly a foot in diameter. Many perennial grasses have $\%$ hizomes or grow in tufts. The stem is furnished with prominent nodes with long, generally hollow internodes, is circular in section, or 2-edged, and contains much siliceous matter, being often hard and polished externally. The Maize (Zéu Mays) and the Sugar-cane (Sáccharum officinarum) are exceptional in having solid stems. The leaves are alternate, simple, and usually linear, with no petiole, except in a few Bamboos, but with a long sheath embracing the stem, and split down the side opposite to that on which the blade is. At the junction of the sheath and blade there is generally a little membranous outgrowtl, termed the ligule. The flowers are in spekelets, and these are variously arranged in spikes, racemes, or panicles. Each spikelet consists of $1-5$ flowers, arranged alternately on a very short axis, or ractilla, but some of these flowers are often represented merely by glumes. At the base of the rachilla are usually two boat-shaped, green or purplisl glumes with nothing in their axils. Within these are the flowers, each with two other glumes, the lower or outer of which is termed the flowering glume, the inner, which is generally of very delicate texture and lias two green 
ribs, being termed the pale. Within these two glumes, and alternate with them, are found 2 , or rarely 3 , very minute scales, known as lodicules, but these are sometimes wanting. There is, in fact, a frequent suppression of certain parts of the floral envelope, glumes being often empty or sterile, and the 'whole spikelet, o1' locusta, sometimes consisting of only 1 glume and 1 pale. In many grasses onc or more of the glumes bears a brittle-like point or awn, which is sometimes
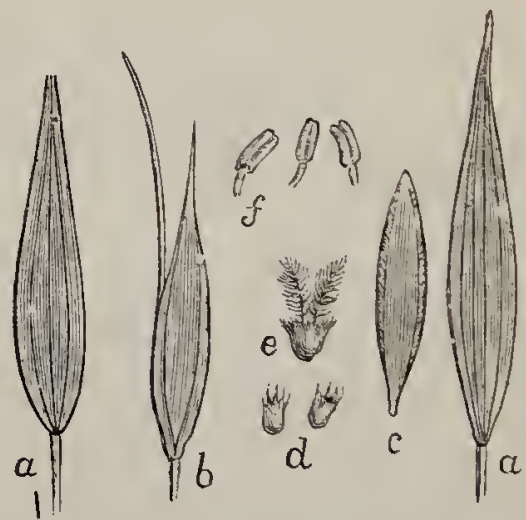

Epikelet of Wild Oat: $a$, outer glumes ; $b$, fowering glume, with amn; $c$, pale; $d$, lodicules ; $e$, ovary; $f$, stameus.

very long, and may either be terminal, proceeding from the point of the glume, as in Barley, or be inserted on its back or at its very base. Each flower has usually 3 stamens (rarely 1,2 or 6), with long antliers, the lobes of which diverge at each end, and weak, hair-like filaments. The orary is 1-chambered and 1-ovuled, and is crowned by 2 (rarely 1 or 3 ) styles with featlery stigmas, the pollen being generally carried by wind. The fruit or grain, technically known as a caryopsis, is entirely filled by the secd, so that their coats adhere; and the embryo lies to one side at the base of a mass of mealy or farinaceous albumen. 
Grasses are abundant everywhere on land, and therc are species inhabiting fresh water; but there are no marine forms. In the tropics they acquire a much greater height than in colder regions; but the compact grassy turf, which is such a charm of our English scenery, is almost entirely wanting in the Torrid Zone, those species which have the "social" habit being mainly characteristic, in fact, of the colder parts of the Temperate Zone.

The cereal grasses, Wheat (Tríticum astivum and

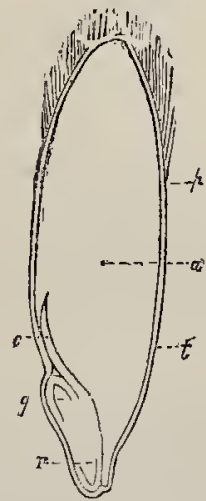

Section of the fruit of tho Oat: $p$, pericarp, or wall of the ovary; $t$, seed-conts ; $a$, albumen ; $c$, cotyledon ; $g$, plumule ; $r$, radicte.

1'. hybérnum), Oats (Avéna satíva), Barley (Hórdeum Gistichum and H. hexástichum), Rye (Secálé reveálé), Maize (Zéa Mays), Rice (Oríyza satíva), and vạrious Nlillets, cultivated for the sake of their grain, are the most valuable members of the Order to mankind; while the value of grasses as fodder for cattle is hardly second to that of their corn for human food.

Among the most esteemed fodder grasses are Ryegrass (Lólium perénné) and its variety, Italian Riyegrass (Lólium perénné var, itálicum), especially for hay; Cock's-foot grass (Dáctylis glomerćta) and Timothy-grass (Phléum praténsé), especially for heavy 
or peaty land; the sweet-scented Vernal-grass (Anthoxánthum odoratum) which gives much of its delicious fragrance to new-mown hay ; J'óc praténsis for dry, sandy soils; $P$. nemorális var. sempervirens and $P$. trivialis for permanent pasture: and the Fescues (Festúca duriúscula and $F$. elátior) also for permanent pasture, and $F$. vúbra for sandy soils. Cattle are very fond also of the Tussack-grass (Dáctylis ccespitósa) of the Falkland Islands, which has been introduced in the Hebrides.

Sugar is a general product of grasses, and can be easily tasted in spring if we chew the stem of almost any meadow grass. It is, howerer, chiefly manufactured from the stems of the Sugar-cane (Sáccharum officinarum, a native of South-Fastern Asia, now cultivated throughout the tropics; and, to a much smaller extent, from those of the Guinea Corn (ミórghum saccharátum). In eastern countries the Bamboos are used for numberless purposes-houses, furniture, cordage, and even sails of ships being made from it. Alfa or Esparto-grass (Macrochlóa tenacissima), a native of Northern Africa, is a valuable material for paper-making; and various Indian species of Andrópogon yield aromatic "Grass Oils," such as Vetirert, Lemon-grass, or Verbena, Citronella, and Geranium or Ginger-grass, which are largely used in perfumery.

The classification of grasses is a matter of great difficulty; but the British species fall under eight tribes, which may be grouped in two Sub-orders.

Sub-order I. Panicaced.-Spitielets jointed upon the pedicel; vachilla persistent ; glumes 1-4, only the "ppermost enclosing a perfect flower.

Tribe 1. Panicece.-Flouering glume 3-ormorenerved, not awned.

1. Ph́riour. - Glumes 4 ; pedicets of spikelets naked or hairy. 
2. Setánia.-Glumes 4; pedicels of spikelets bristly.

3. S'partína.-Glumes 3; spities upright, in a raceme.

Tribe 2. Orýzece.-.Spitelets laterally compressed; flowering glume and pule 1-nerved.

4. Homalocḱnchrus. - Spikelets in a loose panicle; empty glumes absent.

Sub-order II. Pó́cece.-Spikelets rarely jointed upon the pedicel; rachilla deciduous; glumes 3 or more, the two lowest emjity.

Tribe 3. Phalaridece.-Spikelets distinctly stalleed, laterally compressed; rachilla not produced beyond the uppernost glume; glumes 3-6, uppermost only with a perfect flower; pale absent or 1-nerved.

5. Phácaris. - Glumes 6, awnless ; stamens 3.

6. Anтнохи́nthum.-Glumes 6, 2-awned ; stamens 2.

7. Hierochuót.-.-Glumes 6,2-awned, with 3 stamens each; uppermost perfect flower with 2.

8. Alopecúrus.-Spitielets jointed on the pedicel in a spike-like panicle; glumes 3 or 4 ; flowering glume wit' dorsal awn; stamens 3.

Tribe 4. Agrostidece._Spikelet 1-flowered; glumes 3; flower perfect; pale 2-nerved.

* Rachilla not produced beyond flowering glame.

9. Mímun.-Panicle loose; flowering glume hardening round fruit; no awn.

10. Phú́um.-Panicle dense, cylindric, spike-lilie; flowering glume enclosing the fruit.

11. Munóra.-Spitelets in a 1-sided raceme, dorsally compressed, awnless.

12. Agróstıs.-Panicle loose; spikelets very small; flowering glume transparent.

13. Pourpógon.-Panicle spilze-like; glumes awned. 
14. Calamagróstis.-Rachilla with long, silky hairs; floweriny ghume awned.

** Rachilla produced beyond flowering glume.

15. G.Astridiun._Paniule spike-like; outer glumes awnless; flowering glume minute, 4-toothed.

16. APERA.-Panicle loose; flowering glume slightly 2-fid, with a long, slender awn.

17. Dexeúxia.-Rachilla hairy; flowering glame awned.

18. Amмóphila. - Panicle spike-like; spikelets large; rachilla long, silky; flowering glume minutely awned.

19. Lagúrus.-Panicle spike-like, ovate; oute. glumes ending in a long, fringed bristle; floweriny glume 3-awned.

Tribe 5. Avénece.-Spitielets in pranicles, 2-4flowered; rachilla generally moduced beyond the flowering glume; glumes 4 or more, 2 lowest empty, equalling or overtopping the flowers; flowering ylumes with twisted dorsal awns.

20. Aína.-Panicle loose; rachilla not produced; awn bent; fruit adnate to the flowering glume.

21. Weingertníria.-Flowers 2, perfect; awn jointed in the middle, with a club-shaped tip.

22. Deschámpsia.-Flowers 2; aun straight or twisted ; fruit not adnate to the flowering glume.

23. Hólous. - Flowers 2, lower perfect, awnless, upper staminate, awned.

24. Trıś́rum. -Flowers 2-6; flowering glume with 2 acite teeth and a bent, twisted dorsal awn; orary smooth.

25. Avb́na.-Flowers 2 or more; flowering glume. with 2 points and a bent, twisted, terminal awn; ovary hairy.

26. Arrienátherdi.--Flowers 2, lower staminate, with long, basal, bent, twisted awn, upper perfect awnless, or with short, straight awn. 
Tribe 6. Chtoridere.--Spiketets in 2 rovs on a flattened rachis, forming a 1-sided spitie or raceme, laterally compressed, 1-flowered.

27. Frbíchia._Spities spreading, digitate; glumes awnless.

Tribe 7. Festúcece.-Rachilla usually produced; glumes 6 or nore, the 2 lowest empty; awn terminat or absent.

28. Sirglíngia.-Spikelets seldom more than 5 or 6 , in a racemose panicle, awnless, 2-4-flowered ; flowering glume with 3 minute teeth at the top.

29. Phragmítes. - Spikelets in a spreading panicle, 1-6-flowered, awnless; ractitlce bearded with long, silky hairs.

30. Sestéria. S Spikelets in an ovoid, spike-like panicle, awnless, with a soft ciliate glume below each.

31. Cxnosúrus.-Spitielets in a 1-sided, spike-like panicle, 2-5-flowered, with bristly comb-like glumes below them.

32. Koentínia.-Spizelets in a sub-cylindric spike, 2-5-flowered ; flowering glume membranous, keeled, pointed.

33. Moxínia.-Spikelets in a narrow but loose panicle, laneeolate, 1-3-flowered; glumes hardening on the fruit.

34. Catabrósa._Spikelets in a spreading panicle, with whorled branches, 1 -3-flowered ; empty glumes very unequal, blunt; flowering glume truncate at the top.

35. MḱLICa._Spitelets in a slender panicle, ovate, nivnless, 1-2-flowered; ruper glumes forming a clublike rudiment.

36. DÁctruis. - Spizelets 3-5-flowered, densely crowded in a 1-sided panicle; flowering glume shortly awned.

37. Bríza.-Spikelets panicled, pendulour, short, 
flat, densely and distichously imbricate, 3- or moreflowered; glumes membranous, boat-shaped, blunt.

38. Pós.-Spikelets panicled, awnless, 2- or moreflowered; glumes acute, unequal; flowering glume keeled, $3-5$-veined.

39. Guxcéria._Spikelets panicled, awnless, manyflowered; glumes obtuse; flowering glume sub-cylindric, 3-9-ribbed, obtuse.

40. Festúca.-Leaf-sheath split to base : spitelets in a panicle or spike, 3- or more-flowered; flowering glume rounded at the back, 3-5-ribbed, pointed or awned; styles at the top of the smooth orary.

41. Bróncs.-Leaf-sheath split half-ray; spikelets panicled, many-flowered: flowering glume rounded at the back, with a long, dorsal awn; styles below the hairy top of the overy.

42. Brachypónium. - Spikelets in a spike or raceme, long, many-flowered; rachis not indented; glumes unequal; flowering glume with terminal awn; ovary hairy at the top.

Tribe 8. Hordere. - Sprite? ets in 2 or more rou's, sessite in the notches of a simp? rechis, forming a spilie; rachilla generailly moduced.

43. Lólium.-Spikelets solitary in the notches, with their edges to the rachis, 3. or more-flowered.

44. AgRoÝron.-. Spitelets solitary in the notches, with their broad sides to the rachis, 3- or moreflowered.

45. Leptúrus. - Spikelets solitiry in the notches, with their broad sides to the rachis, 1-flowered.

46. Nírdus.-Spikelets solitary in the notches of a 1-sided spike, 1-flowered.

47. Hóndeus, - Spikelets 3 in each notch, 1flowered, with long awns.

48. Euxarus.- Spiticlets 2 or 3 in each notch, 2-7flowered, awnless. 
1. Púnicum (Panic).-Spitielets 1-flowered, arranged 2 together along one side of linear, digitate spikes, or in a simple panicle; glumes 4, usually not awned, the lowest. small; flowering glume veined. (Name, the Classical name for a kind of millet, connected with panis, bread.)

1.* $P$. sanguinálé (Fingered Panic).-An introduced weed of cultivated ground ; stems $1-2$ feet long, spreading at base, then erect; leaves flat, hairy; panicle of $2-6$, rarely more, simple, slender, digitate, spike-like branches, 2-4 in. long.--South of Englana. -Fl. August. Annual.

2. P. glábrum (Red Millet, Finger-grass).--Very like the preceding, but much smaller and less hairy; stems $6-8$ in., prostrate; panicle of $2-5$ branches; spikelets minute, purplish, ovate, stalked, in pairs. Sandy fields in the south-eastern counties; rare.Fl. July, August. Annual.

3.* P. Crus-gálli (Loose, or Cockspur, Panic).-A coarse naturalised weed ; stems $1-4$ feet, ascending; lecuves broad, glabrous, rough-edged ; panicle 3-6 in. long, irregularly pyramidal, with alternate or opposite, rather 1 -sided branches and downy, 3-sided rachis; spilelets green, on hairy pedicels ; third glume pointed or awned; flowering glume polished.-Fields in the south-eastern counties.-Fl. July. Annual.

2. Setária (Bristle-grass).-Spikelets in a dense, cylindric, spike-like panicle, resembling those of Fánicum, but with stout bristles on their pedicels and no awus. (Name from the Latin seta, a bristle.)

1.* S. vúridis (Green Bristle-grass or Panic).-An erect plant, 1-2 feet high; leaves flat, rough on the edges; panicle green, $1-3$ in. long, with downy, 3-edged, whorled branclies; Wistles purplish, $\frac{1}{4}$ in. long, with ascending teeth; flowering glume smooth. -A casual in cultivated fields.-Fl. July, August. Annual. 
2.* S. glaúca (Graucous Bristle-grass). - A very similar plant; panicle $1-1 \frac{3}{4}$ in. long ; flowering glume transversely wrinkled.-A cornfield casual, Weybridge, Surrey.-Fl. September. Annual.

3.* S. verticilléta (Rough Bristle-grass or Panic). -Another very similar species ; but with a narrower, rather loose panicle; downward pointing barbs to the bristles; and a smooth fiowering glume.-Cultivated fields near London and Norwich.-Fl. July, August. Annual.

3. Spartína (Cord-grass).- Spikelets 1-flowered, $\frac{1}{2}$ in. long, laterally compressed, sessile in 2 rows along one side of the erect, spike-like branches of a racerne; glumes 3, lowest smaller, second 5-nerved; flowering glume shorter, 1-nerved, awnless ; styles long, united half-way up. (Name from the Greek spartiné, a cord, from a use to which the leaves have been put.)

1. S. strícta (Common Cord-grass). - A remarkably stiff, erect grass, with a long, branched, creeping rootstock; stems 1-2 feet, stout, polished, leafy; leaves erect, leathery, pointed, glaucous above, with blades jointed to their sheaths; spities 2 or 3 , adpressed, 1-3 in. long; outer glume 1-nerved, hairy; rachis scarcely extending beyond the last spikelet.-Muddy salt marshes in the south; local. It is cut at Southampton by the poorer classes for thatching.--Fl. July - September. Perennial.

2. S. alterniflora (Many-spiked Cord-grass).-A larger species, $2-3$ feet high; leaves with blades not jointed to the sheaths; spikes 3-8; outer glume 5nerved, glabrous except on its keel; rachis produced beyond the last spikelet._Mud flats, Southampton.Fl. August. Perennial.

3. S. Tounséndi, a still larger form, with shorter leaves; broader, larger spilielets; more lanceolate, downy glumes; and a flexuous tip to the rachis. Also occurs on Southampton Water and in the Isle of Wight. 
4. Homalocénchrus (Cut grass), of which $H$. oryzöides is the only British species, has a smooth, shining stem, 2--3 feet high, leafy and hairy at the nodes; broad, rough, glaucous leaves with a truncate, torn ligule; panicle few-flowered, very loose, with

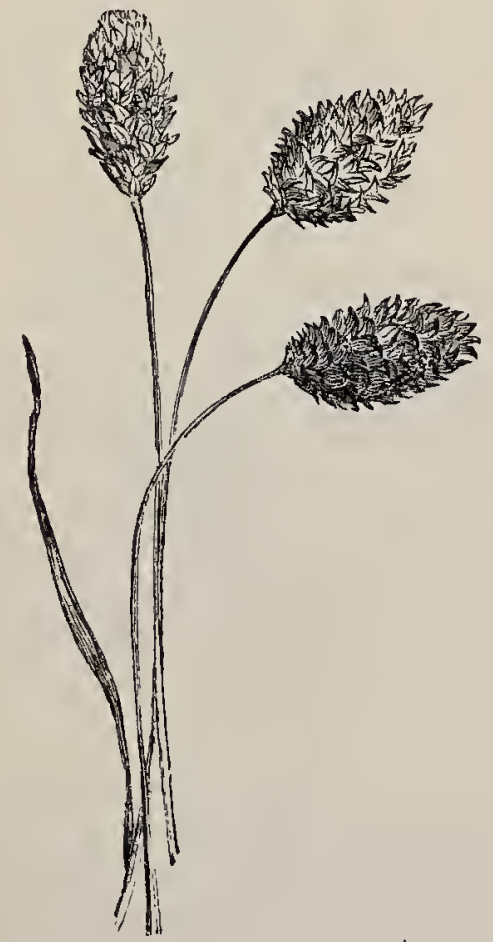

PHÁlaRIS CAYARTÉNSIS (Canary-grass).

slender, wavy tranche', mostly enclosed in the leafsheath ; spizelets shortly stalked, laterally compressed, consisting of only 2 parchment-like glumes.-Wet places, Surrey, Sussex, and Hants. (Name from the Greek homalos, even, leenchros, millet).-Fl. AugustOctober. Perennial. 
5. Phácaris (Reed-grass).- Spikelets 1-flowered, much compressed laterally, in panicles awnless; glumes boat-shaped, keeled, membranous, nearly equal ; flowering glume and pale leathery, closely investing

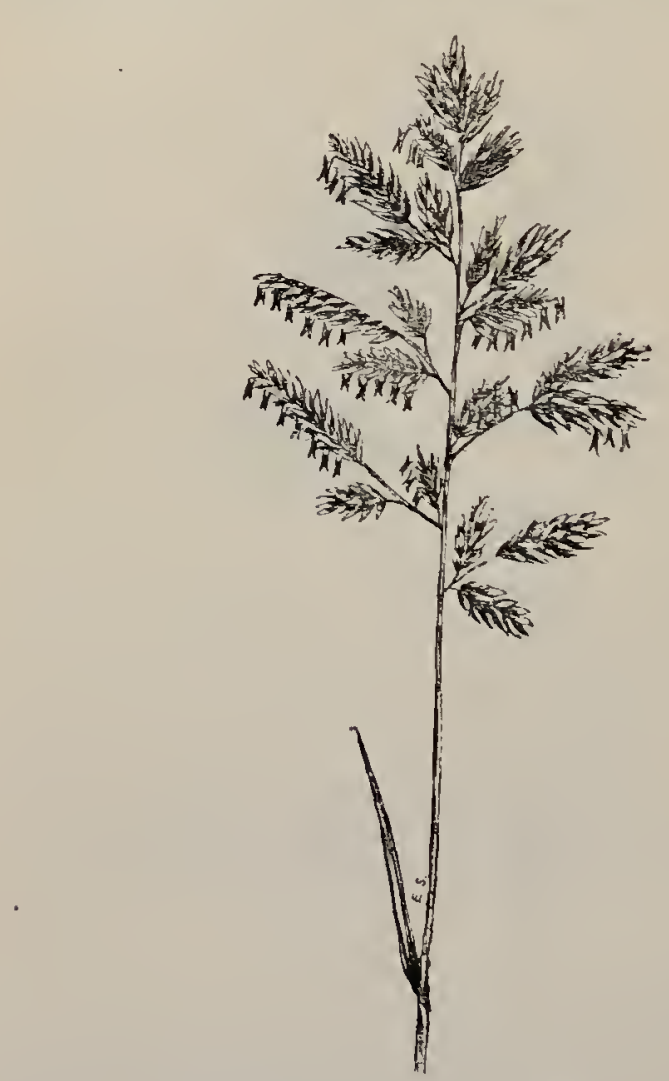

PHIIAARS ARTXIXACEA (Rect-grass).

the fruit. (Name from the Greek phalos, white, applied by Dioscorides to some plant with shining fruit.)

1." P. canariénsis (Canary-grass). - An erect, leafy plant, $2-3$ feet high, glaucous; spikelets densely 
crowded into an ovoid panicle, $1-1 \frac{1}{3}$ in. long; glumes very flat, acute, but not awned, winged on the keel, pale yellow, with a broad green line down each side.A casual escape. Much cultivated as canary-seed in central and southern Europe-Fl. June-August. Annuel.

2.* P. paradóxa, a branched plant, $1-3$ feet high, with a spike-like panicle, and glumes with a toothed wing on the keel and many-veined, has occurred, probably only casually, at Swanage, Dorset.-Fl. July. Annual.

3. P. arundinácea (Reed-grass). - A glabrous plant, with creeping root-stoch; stems $2-6$ feet high ; lecuves with large ligules; panicle erect, with spreading branches; outer glumes lanceolate, keoled, but not winged or awned, whitish with 3 green nerres.-On river banks and in marshes, especially on sand; common.-Fl. July, August. Perennial.

6. Axtiloxínthum (Vernal-grass).-Sweet-scented plants with stalked spikelets in a spike-like panicle; lowest glume 1-nerved, 2nd larger, 3-nerved, 3rd and 4th shorter, bifid, with dorsal awns ; flowering glume blunt, 5-7-nerved; stamens 2. (Name from the Greek anthos, flower, and xanthos, yellow.)

1. A. orlorátum (Sweet Vernal-grass). - Erect, shining, 6-18 in. high ; leaves hairy ; panicle oblong, spike-like, interrupted below, $1-5$ in. lons; anthers purple in meadow form, yellow in woods--Pastures, abundant, containing the aromatic principle coumarin, which exists also in Woodruff; Mclilot, and Tonkabean, and imparts its sweet scent to new-made hay.Fl. May_July. Perennial.

2.* A. Puétii, a smaller species, with many slender much-branched stems; lax panicles; long, slender awns; and a fainter perfume.-Occurs occasionally as a modern introduction in sandy fields.-Fl. July-September. Annual. 
7. Hierochloḱ (Holy-grass), of which H. boreális (Northern Holy-grass) is the only British species, is a fragrant grass, about a foot higl, glabrous, with creeping root-stock; tufted stems; long ligules; a spread.

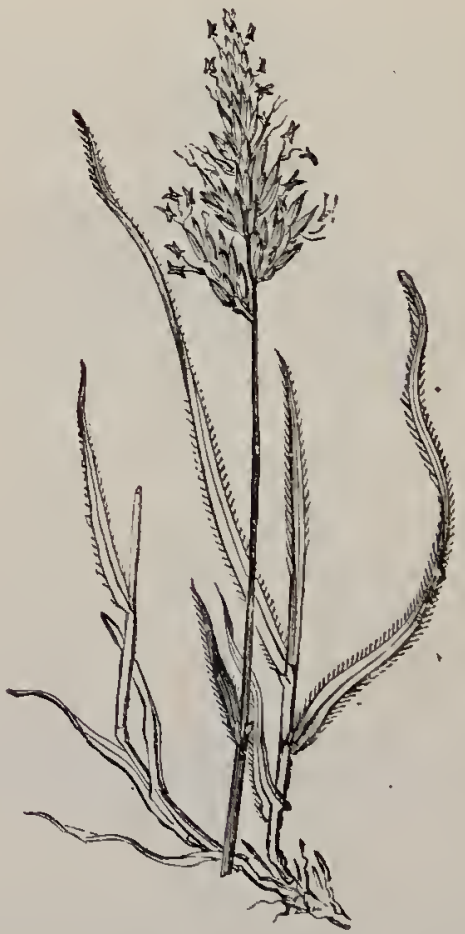

ANTEOXÁTHUM ODORÁTUM (Sweet Vernal-grass).

ing panicle of small, brown, shining, ovate, 3 -flowered spileelets; flowering glume with short awn; the two louer flowers with 3 stamens, the uppermost perfect, with 2 stamens. - Wet banks, Caithness, (Name from the Greek hieros, holy, chloé grass, it having been used to strew on church floors.) 
8. A lopecúrus (Foxtail-grass).--Spiletets much compressed laterally, 1-flowered, densely crowded into a cylindric, spike-like panicle; outer glumes nearly equal, often connate below, awnless; flowering glume

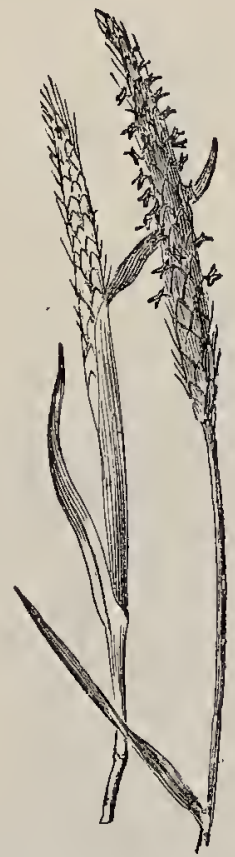

ALOPECÚRUS MYOSUROÏDES (Slender Foxtail-grass).

with a slender, bent, dorsal awn. (Name from the Greek alópex, fox, oura, tail.)

1. A. myosuróides (Black-grass, Slender Foxtail). -Stem erect, rough, 1-2 feet high; leaves with a large, blunt ligule; spike 2-3 in. long, slender, flexuous, more pointed than in the other species; glumes acute, united to about the middle, nearly smooth. - A troublesome weed in England.-Fl. April - November. Annual. 
2. A.fúturs (Orange-spiked Foxtail).--A glaucous plant; stem ascending, bent at the nodes, $1-2$ feet high; leaf-sheaths rather inflated; Tirule oblong; spike 2-3 in. long, pale; glums united below, ciliate; anthers short, broad, at first white, then

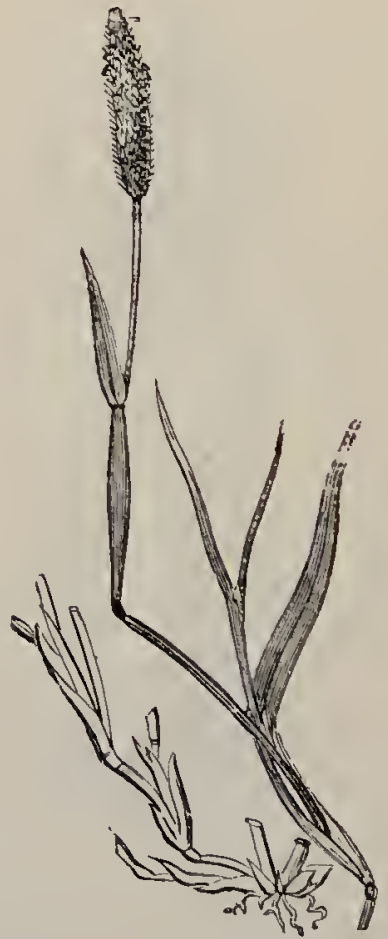

ALOPECÚRUS GEXICULATUS (Floating Foxtail).

orange.-Ditches in the midland and southern counties ; rare.-Fl. June-September. Perennial.

3. A. geniculátus (Marsh or Floating Foxtail).-A closely allied, not glaucous species; Teaf-sheaths cylindric ; spike $1-2$ in. long, blunt; glumes connate, blunt, ciliate; flovering glume with a sub-basal awn, 
half as long again as the glume; anthers linear, violet-yellow.-Wet places; common.-Fl. AprilAugust. Perennial.

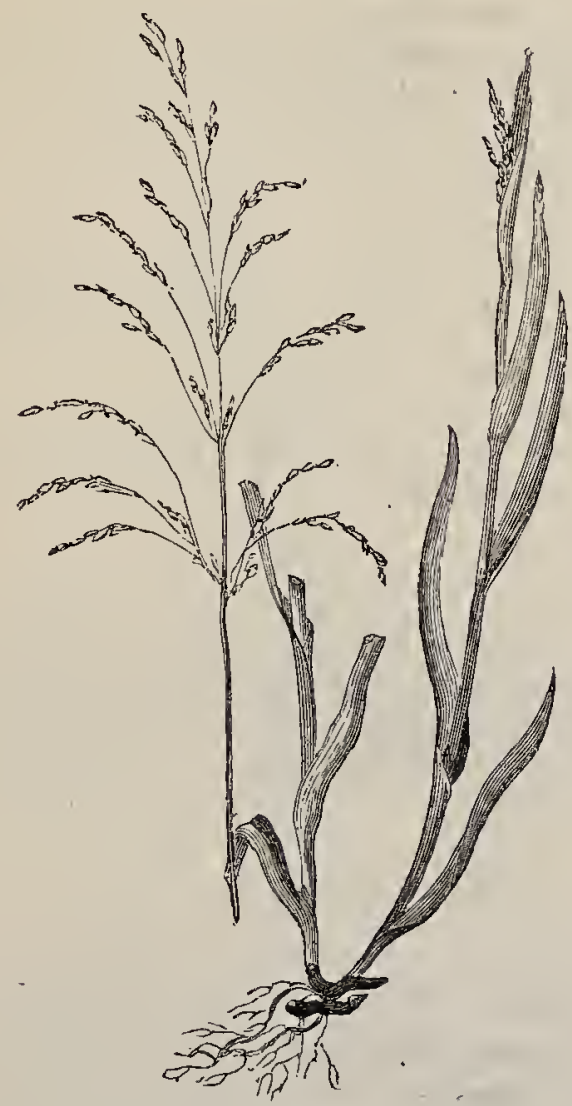

MfLIUM EFFÚsUM (Spreading Millet-grass).

4. A. bulbósus (Tuberous Foxtail).-A tufted, not glaucous, form with the lower part of the ascending stem forming ovate tubercles; upper leaf-sheaith inflated; spike $1 \mathrm{in.}$ long, pointed ; glumes not connate 
acute, downy; flowsring glume with sub-basal awn twics as long as the glume. - Salt marshes; rare.-Fl. May-July. Perennial.

5. A. praténsis (Meadow Foxtail).- Stem 1-2 feet high, erect, smooth, with runners; sheaths of upper leaves rather loose ; spitie $1-3$ in. long, blunt, soft, pale green; glumes acute, scarcely united at the base, hairy; aun twice as long as the flower iny glume; anthers yellow.-Rich pastures; common.-FI. April -June. Perennial.

6. A. alpinus (Alpine Fostail).-An allied, but usually shorter species, with looser sheaths to the upper leaves; spitie, seldom more than an iuch long, unless cultivated, and softly silky with the rather long hairs which cover the acute, connate glumes.-By streams on lofty 'Scottish mountains.-Fl. July, August. Perennial.

9. Míluur (Millet-grass), of which M. effúsum (Spreading Millet-grass) is the only British species, is a slender, erect, smooth grass, 1-4 feet high; with broad, flat, thin leares; panicle long, loose, spreading, and slender, its branclies whorled; spitielets small, pale green, or purple, awnless; flowering glume smooth, white, hardening round fruit.-Damp woods; common. (Name in Latin meaning millet.)

10. Phú́ur (Cat's-tail grass).-Panicle dense, cylindric, spike-like, of compressed, 1-flowered spikelets; flowering glume awnless, or shortly awned, enclosing the fruit. Resembling the Foxtails, but distinguished from them by the possession of a pale. (Name from the Greek phleos, some reed-like plant.)

1. P. alpinm (Mountain Cat's-tail). Stem solitary, ascending, 6-18 in. high; leaf-sheaths inflated; ligule short; spitie oblong, purplish, about au inch 
long; glumes truncate, with bristly awns as long as the glumes.-By streams on lofty Scottish mountains; rare.--Fl. July. Perennial.

2. P. praténsé (Timothy-grass, Meadow Cat's-tail). -Stem tufted, ascending, smooth, 1-3 feet high ; leaf-sheaths not inflated; ligule long; spike cylindric, obtuse, 1-6 in. long, green; glumes truncute, with

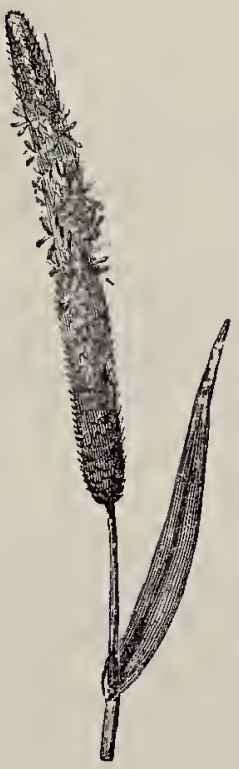

PHLÉUM PRATÉNSÉ (Meatoru Cat's-tail).

bristly awns, not half as long as the glumes; anthers yellow or purple.-Meadows ; common. (Named after Timothy Hanson who cultivated it in North America.) Fl. June-August. Perennial.

3. P. phalaroídes (Purple-stalked Cut's-tail).-Erect, like the Timothy-grass, but usually smaller; outer glumes linear-lanceolate, tapering into a minute, stiff point; margins white; anthers linear-oblong.- 
Dry fields in the eastern counties; rare,--Fl. July. Perennial.

4. P. arenárium (Sea Cat's-tail).-Erect, 2-12 in. high; leaves broad, with long ligules, the upper ones with inflated sheaths; spitie $\frac{3}{4}-1$ in. long, cylindric, tapering at the base, glaucous; glumes lanceolate, tapering into a short point; anther's minute, yellow.-Sandy coast:; frequent.-Fl. Mary-July. Annual.

11. Mrióra, of which M. rérna (Early Sand-grass) is the only species, is a little tufted plant, $2-4 \mathrm{in}$. high; leaves short, bristly, rough, with white, inflated sheaths ; spikelets 5-10, minute, sub-sessile, purplish, awnless, dorsally compressed, in a 1-sided spike, $\frac{1}{2}-1$ in. long; flowering glume thin, very hairy, truncate, jagged at top. - Wet sandy shores of Anglesea and the Channel Islands; rare.-Fl. Harch, April. Annual.

12. Agróstis (Bent).-A large genus having numerous small, 1-flowered spikelets in an elegant panicle, with whorled branches; outer glumes boat-shaped, unequal, pointed, awnless; flowering glume shorter, transparent, with a short, slender, dorsal awn, or awnless. (Name, the Greek name for some kind of grass.)

1. A. setácea (Bristle-leaved Bent).-Stems erect, rough, about a foot high; leaves numerous, mostly radical, densely tufted, finely subulate, involute, rough; panicle close, oblong, with short branches; glumes acute, the lowest longer than the second; flowering-ylume 4-ribbed, jagged at the top, with a fine, bent, and twisted basal awn.-Dry heaths in the sonth; rare.-June, July. Perennial.

2. A. canina (Brown Bent).-Stems ascending, 1-2 feet high, smooth, sometimes with rumers; leaves narrow, flat, smooth; panicle with long, slender 
branches, spreading when in flower, purplish or green ; ghumes acute, the lowest longer than the second; flowering glume 5-ribbed, jagged, with dorsal awn from

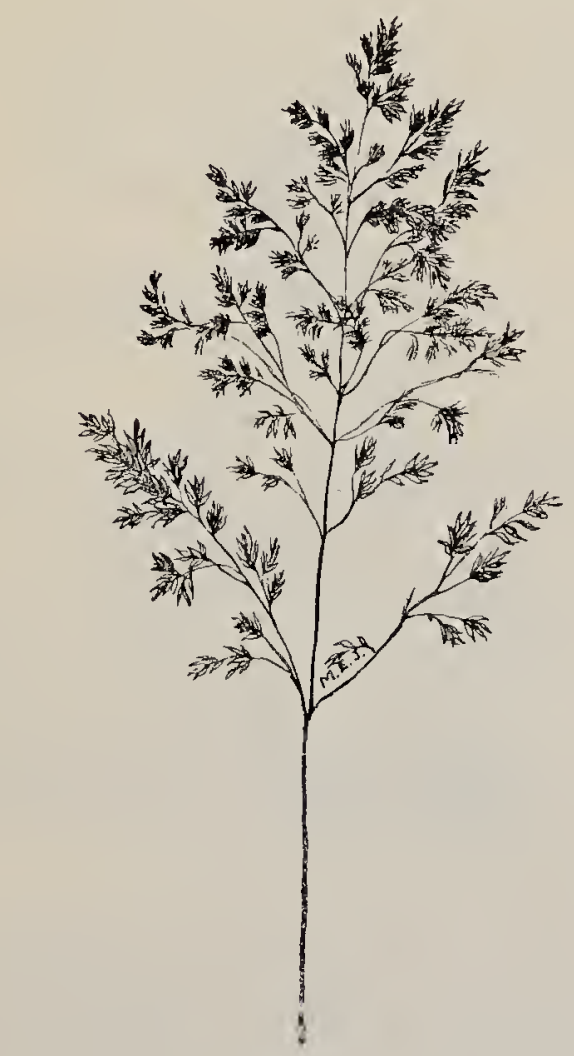

AGRóstIS PALƯSTRIS (Fiorin-grass, Marsh Bent).

below the middle.-Peaty heaths; common.-Fl. July, August. Perennial.

3. A. palústris (Fiorin-grass or Marsh 'Bent.)An elegant but most variable grass, nearly allied to the preceding; stems more or less prostrate below, of ten with long runners, $6-24 \mathrm{in}$. high, rough ; leaves 
with roughish sheaths and long, acute ligules; panicle spreading in flower, afterwards close; glumes near ${ }^{-1} y$ equal; flowering glume seldom awned.-Pastures; com. mon.-Fl. July-September. Perennial.

4. A. vulgáris (Fine Bent).-A closely allied, very variable, but generally smaller species, with smooth stems and leaf-sheaths, short, truncate ligules; panicle spreading both in flower and fruit.-Pastures; common.-Fl, June--September. Perennial.

13. Polypógon (Beard-grass)._Spitielets 1-flowered, densely crowded in a spike-like, cylindric, or branched panicle; glumes notched, with awns 2 or 4 times as long as the glumes, from below their tips; flowering glume shorter and more shortly awned. (Name from the Greek polus, many, pógón, beard, from the long awns.)

1. P. monspeliénsis (Anuual Beard-grass).-A very beautiful species, procumbent at base, or rarely erect, $1-1 \frac{1}{2}$ foot high ; stems stout, smooth; leaves large, broad, rough ; panicle 1-6 in. long, dense, lobed, of a yellowish, shining green, silky; glumes blunt, less than half as long as the awns; flowering glume awnless.-Damp pastures in the south-eastern counties; rare.-Fl. June-August. Annual.

2. P. Tittonális (Perennial Beard-grass). - Nearly allied, variable in size, sometimes several feet in height; panicle smaller, more branched, purplish; glumes longer, tapering into an awn scarcely longer than the glume itself. - Salt marshes on the southeast coast; rare.-Fl. July, August. Perennial.

14. Calairagróstis (Small-1eed). - Tall grasses with spreading, somewhat 1-sided panicles of 1flowered spikelets; flowering glume awned, with a tuft of long, silky hairs on the rachilla at its base. Distinguished from the true reed (Phraamites) by the 
1-flowered spikelets. (Name from the Greek kialamos, reed, agróstis, grass.)

1. C. epigéios (Wood Small-reed).-Stem 3-5 feet high, stout, erect; leaves long, acuminate, rough,

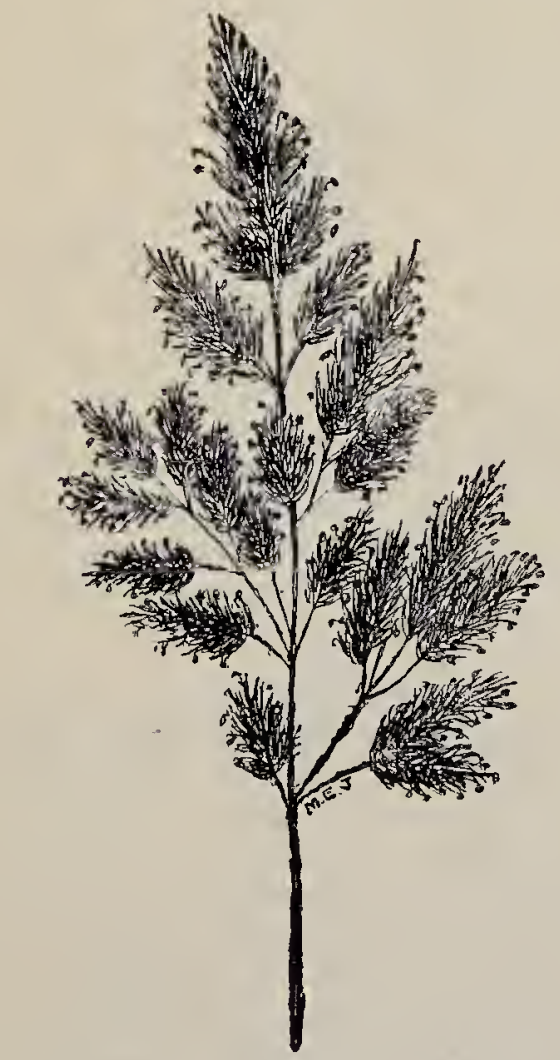

CALAMagróstis EPIGÉIOS (Wood Snall-reed).

glaucous beneath; panicle branched, but not spreading except when in full flower, 4-12 in. long, with numerous crowded, purplish spileelets; flowering glume with very short and slender awn from about the 
middle.-In moist open places in woods: not generally common. One of the handsomest grasses.-Fl. June-August. Perennial.

2. C. lanceoláta (Purple Small-reed).--A tall grass, $2-4$ feet high, resembling the preceding, but slender; leaves narrower and smoother; panicle looser, 5 or 6 in. long, drooping at the tip, shining purple; flowering glume notched with a very short terminal awn.-Wet places; rare.-Fl. June-August. Perennial.

15. Gastrídiom (Nit-grass), of which G. áustrálé (Awned Nit-grass) is the only species, is an elegant, erect grass, 6-12 in. high, with rough-edged, flat leaves and a tapering spike-like panicle 2-3 in. long, pale green with silvery lustre, and is ensily distinguished from other British grasses by the peculiar glossy, swollen base of the outer glumes. - Fields near the sea that are occasionally overflower, in the south; rare. (Name from the Greek gastriction, a swelling.) -El. June-October. Annual.

16. Arḱks (Wind-grass).-Annual grasses with panicles of small, shining, 1-flowered spitielets; outer glumes 2, membranous, acute, awnless, the lower the smaller; floweriny glume shorter, slightly 2-fid, with a long, slender, subterminal awn. (Name from the Greek, apéros, undivided.)

1. A. Spica-venti (Silky Wind-grass).-One of the handsomest of grasses, $2-3$ feet high, with rather narrow, llat leaves; panicle 3 in. long, sprending, with very slender branches, and little shining spikelets hardly a line long; awn 3 or 4 times as long as the spikelet; anthers linear.- Sandy fields; rare.-Fl. June, July. Annual.

2. A. interrupta, with a close panicle, the branches of which never spread, and short, oval anthers, occurs 
rarely in the eastern counties.-Fl. June, July.Annual.

17. Deyé́xia, a considerable genus of tall grasses, formerly classed with Calamagróstis, but differing in

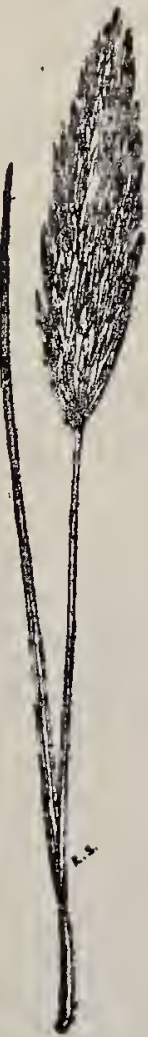

AMMÓPHILA ARUNDINACEA (Sea Marram).

the rachilla being produced into a point tipped with hairs. (Name in honour of M. Deyeux, an eminent French chemist.)

1. D. strigósa, found in 1885 by Robert Dick, the 
baker naturalist of Thurso, in Caithness, has larger spikelets and more acuminate glumes than the follow' ing. It is a Northern type.

2. D. neglécta (Narrow Small-reed).-Stem erect, $1-3$ feet high, slender, polished ; Teares short, stiff, with short ligules; panicle 2-6 in. long, narrow, erect, close, pale purplish, and green; glumes acute, longer than the hairs; flowering glume shorter, with awn inserted rather below the middle. - Bogs in Cheshire and Antrim; rare.-Fl. June, July. Perennial.

18. Amuóphila (Marram-grass).-Panicle spikelike; spilkelets large, 1-flowered, much compressed laterally; rachilla long, silky; glumes sub-equal, awnless ; flowering glume shorter, 5-nerved, with a minute sub-terminal awn. (Name from the Greek ammos, sand, plitio, I love.)

1. A. arundinácea (Sea Marram, Murram, or Matgrass, Sea-reed).-Root-stock creeping; stems erect, stiff, 2-4 feet high ; Teaves long, stiff, erect, glaucous above, polished below, with very long, torn ligules; panicle cylindric, straw coloured, $3-6$ in. long, acute; glumes acute; flowering glume 3 times as long as the hairs. Sand-dunes; frequent. Its value as a sand-binder cannot be overrated. At the end of the 18th century a large district near Moray Firth was destroyed by drifting sand owing to the wanton destruction of Marram.-El. July, August. Perennial.

2. A. báltica, distinguished by its looser, less cylindric panicle; lanceolate, acuminate glumes: and flowering glume twice as long as the lairs; occurs on Ross Links and Holy Isle, Northumberland.-Fl. July -September. Perennial.

19. LaGúrus (Hare's-tail grass), of which L. ovátus is the only species, is a very ornamental grass, with 
numerous, stout, pubescent stems 6-12 in. high ; short leaves hoary with soft down, with rather swollen sheaths; and spikelets closely crowded into an ovate, softly hairy, whitish head, $1-1 \frac{1}{2}$ in. long, the glumes being densely clothed with soft hairs. - Sandy places in Guernsey. (Name from the Greek lagós, hare, oura, tail)._Fl. June, July. Annual.

20. Aína (Hair-grass). - Spilelets 2-flowered, laterally compressed, in a loose panicle; glumes nearly equal, not awned; flowering glume 2-fid, with a twisted dorsal awn from below the middle; fruit furrowed on the back, adnate to the flowering glume and pale. (Name, the Greek name for some grass.)

1. A. caryophyjllea (Silver Hair-grass).-A tufted, slender, and graceful species; stems 2-12 in. high, bent below, rough, often purplish ; leaves short, bristlelike, blunt, with rough sheaths; panicle $1-2$ in. long, very spreading, with long, triply forked branches. -Dry places; common.-Fl. June, July. Annual.

2. A. précéc (Early Hair-grass).-A similar but smaller species, not more than 6 in. high, greener, with smooth leaf-sheaths and a close, oblong, spike-like panicle, $\frac{1}{2}-1$ in. long, with short branches.-Dry places; common.-Fl. April, May. Annual.

21. Weina zrtnéria, of which $W$. canéscens (Grey Hair-grass) is the only British species, is a tufted, slender species, less than a foot high, with numerous short, bristle-like, glaucous leaves with rough sheaths; panicle rather dense, $1-3$ in. long, spreading in flower, with short branches; spikelets variegated with purple and white; glumes with slender, transparent tips; flowering glume shorter, with a bent, sub-basal awn, bearded at the joint, and thickening into a clubshaped tip; anthers purple; fruit grooved, adnate to the flowering glume and pale.--Sandy coasts of 
Norfolk, Suffolk, and the Channel Islands.-Fl. June, July. Perennial.

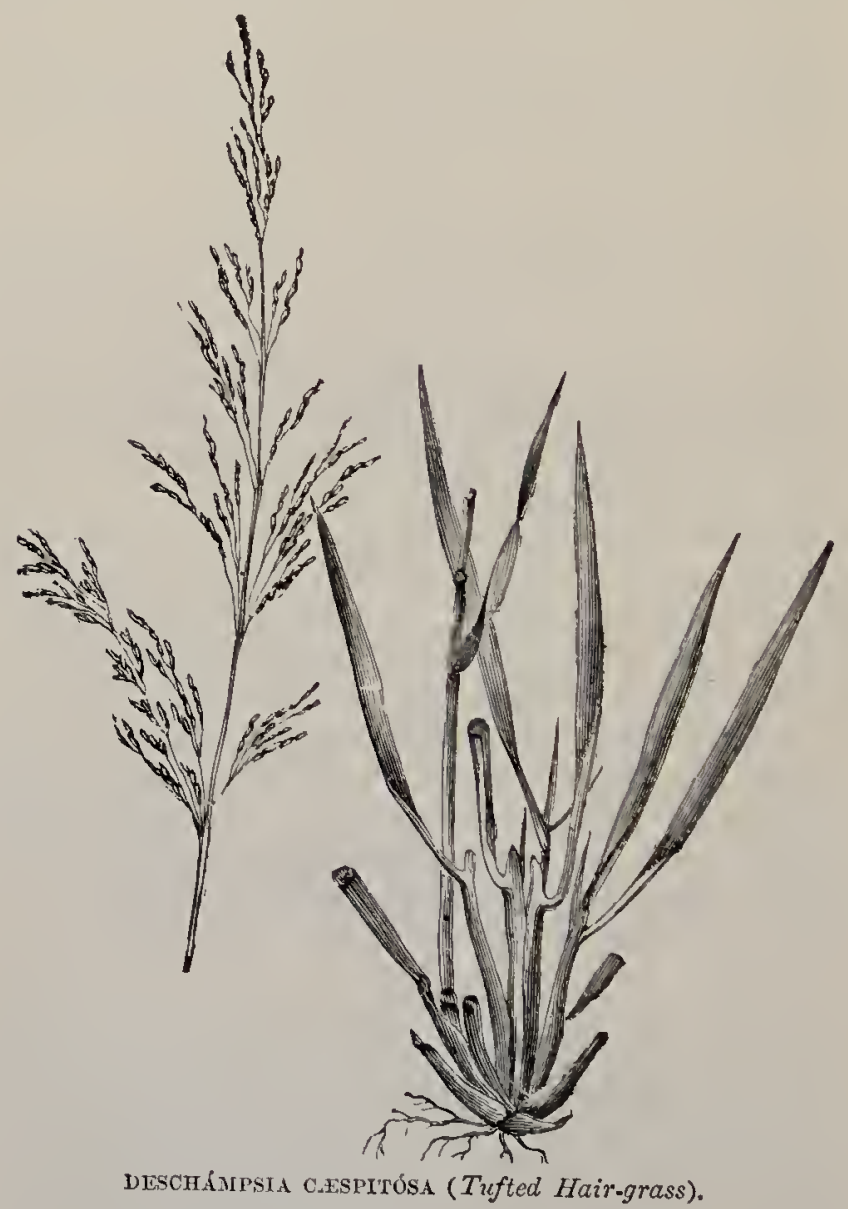

22. Deschámpsia, a genus including many species formerly classed under Aira, is distinguished by having the rachilla produced, the flowering glume truncate and jagged, and the fruit enclosed by, but not adnate 
to, it and the pale. (Named in honour of M. Deschamps, an eminent French chemist.)

1. D. cespitósc (Tufted Hair-grass).-Forming large dense tufts; stems $2-4$ feet high; leaves flat and rough; panicle $6-8$ in. long, very elegant, with slender, spreading, rough branches; spikelets $\frac{1}{4}$ in. long, much compressed, silver-grey or purplish, 2 -flowered ; floweriny glume with a short, fine, hair-like, straight, sub-basal awn.-Moist places; abundant, indicating that pasture requires under-draining.-Fl. JuneAugust. Perennial.

2. D. alpína (Alpine Hair-grass).--An allied but smaller species, 6-12 in. high, with channelled involute leaves; closer panicle with smooth branches; and a bent awn from above the middle of the flowering glume.-Wet rocks, Scotland and West of Ireland; rare.-Fl. June, July. Perennial.

3. D. díscolor (Bog Hair-grass).-Stems erect, slender, polished, about a foot high; leaves hair-like with linear-lanceolate ligules; panicle spreading, drooping at the end; flowering glume with bent, twisted, sub-basal awn; that of the upper flower on a stalk half its own length.-Wet peaty bogs._Fl. July, August. Perennial.

4. D. flewúsa (Wavy Hair-grass).-A closely allied species, with short, blunt, almost bristle-like leaves with short, truncate ligules and rough sheaths; panicle spreading, $2-3$ in. long, triply forked with wavy branches; spikelets shining, with fine, hair-like, bent, twisted, sub-basal awns protruding beyond the glumes; pedicel of upper flower not a quarter of its length.-Heathy places; common.-Fl. June, July. Perennial.

23. Hólcus (Soft-grass). - Spikelets numerous, much compressed laterally, in an open panicle, 2-flowered ; lower flower perfect, awnless ; upper stami- 


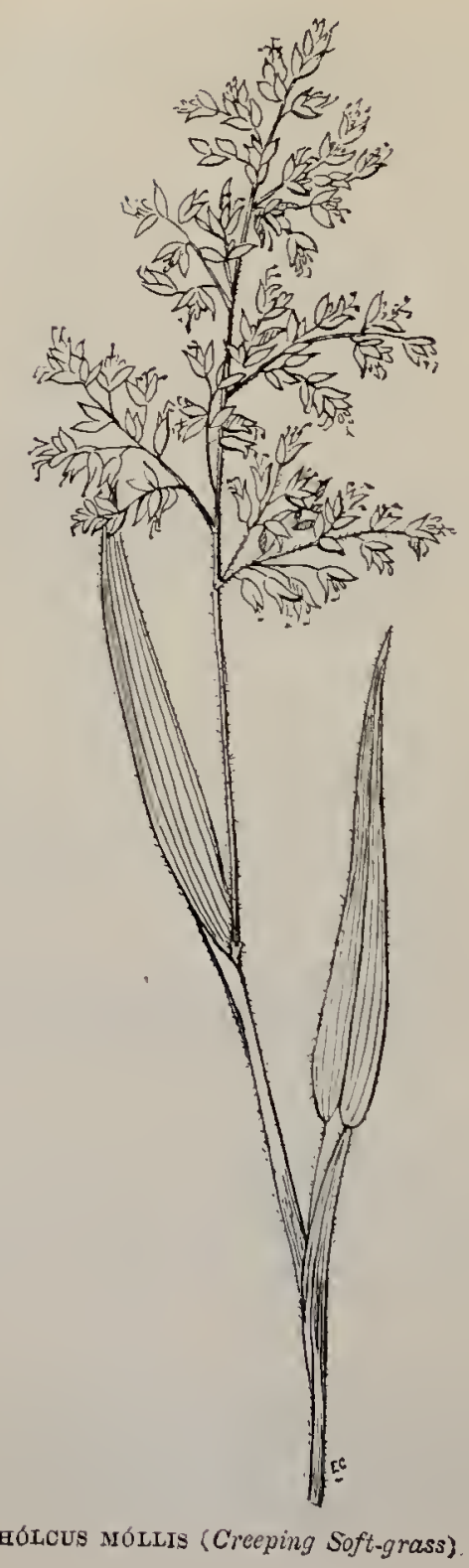


nate, with a twisted dorsal awn to its 5-nerved flowering glume: (Name said to be from the Greek hollos,

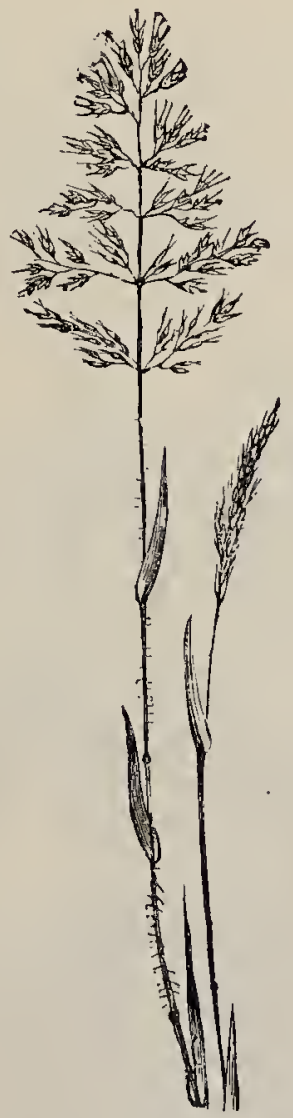

MRISÉTUM PRATÉNSÉ ( Yellow Oat).

connected with helkó, I draw, referring to a supposed power of drawing thorns out of the flesh.)

1. H. móllis (Creeping Soft-grass--Root-stock creeping; stems about a foot high, hairy at the nodes, 
slender; leaves rough, with smooth sheaths; panicle $2-3$ in. long, rather loose, whitish; upper glumes acute; the awn of the flowering glume of the upper flower rough, projecting beyond the glumes.-On light soil ; abundant.-Fl. July, August. Perennial.

2. H. lanátus (Yorkshire Fog, Meadow Soft-grass). -A similar plant, tufted, 1-2 feet high, the whole plant clothed with a very short down, giving it a pale soft appearance; panicle pale whitish or reddish; upper glumes blunt; awn smooth, except at the tip, not projecting.-Meadows; abundant.-Fl. July, August. Perennial.

24. Trisérum, of which $T$. praténsé (Yellow Oat) is the only British species, has erect, smooth stems, 1 - 2 feet high, with runners; radical leaves flat and hairy, with blunt ligules; panicle with slender, spreading branches; spikelets numerous, shining, yellowish, 3 - 4 flowered; glumes very unequal; flowering glume with two awned points and a short, twisted, bent, dorsal awn between them.-Diy pastures; common. (Name from the Latin $t_{r i}$, three, seta, bristle.) - Fl. JuneAugust. Perennial.

25. Avéna (Oat). - A genus closely allied to the preceding, with panicles of large, 2- or more-flowered spikelets; glumes sub-equal; flowering glume 2-fid, with a long, twisted, bent, terminal awn; orary hairy at the top ; fruit adherent to the glume. (Name, the Classical Latin name for the Oat.)

1. A. pubéscens (Downy Oat).-Stem creeping below, 1-2 feet high; radical leaves short, downy, with acute ligules; panicle nearly simple, lower branches in fives, bearing 2-4 sub-erect spikelets.Dry or chalky pastures; common._-Fl. June, July. Perennial. 
2. A. praténsis (Narrow-leaved Perennial Oat). - A nearly allied species, with runners; stems rough, erect, $1-3$ feet high; leaves smooth, glaucous, with

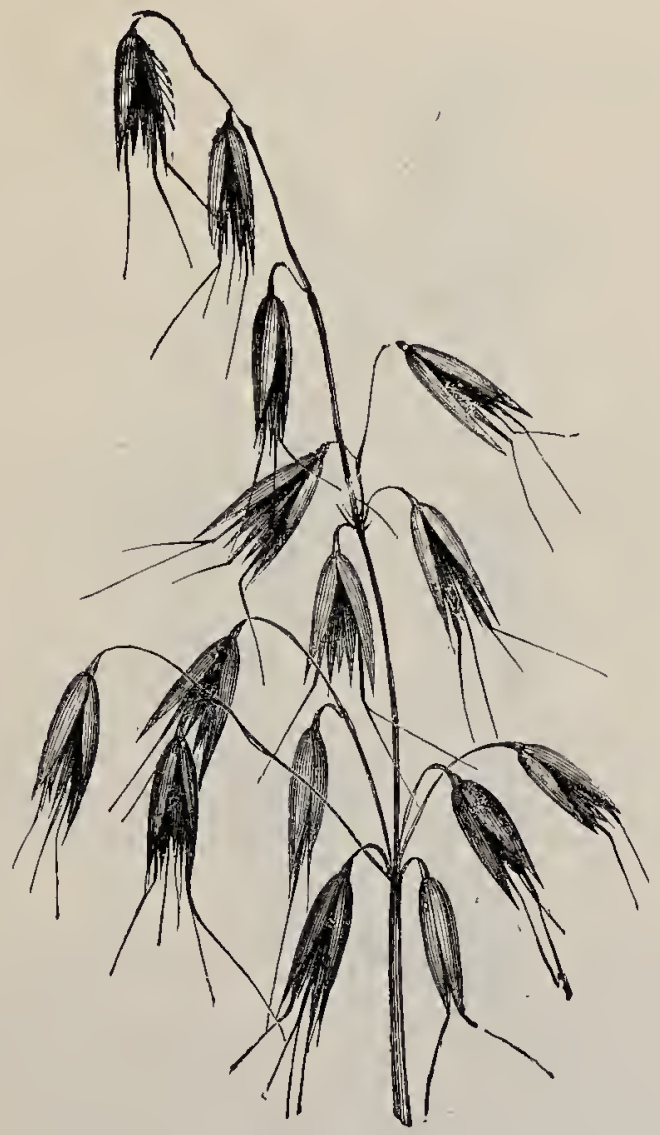

AVENA FATUA (Tavers, Wizd Oat).

ovate, acute ligules; panicle racemose ; spikelets erect, pale, shining, $\frac{1}{2}-\frac{2}{3} \mathrm{in}$. long, $3-4$-flowered; awn twice as long as the flowering glume.-Dry pastures; frequent.--Fl. June-August. Perennial. 
3.* A. strigósa (Bristle Oat). -Stems 2-3 feet high; leaves sometimes hairy; panicle 1-sided; spitielets 2-flowered, drooping; flowering glume smooth, end-

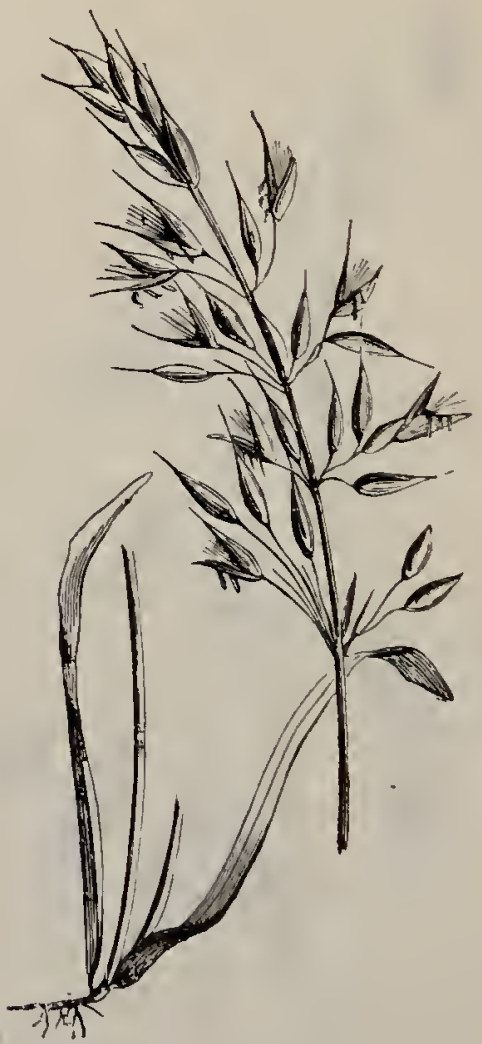

ARRHhat THERUM AYENÁCEUM (Common False Oat).

ing in 2 long, straight, bristles.-Cornfields : rare, not indigenous.-Fl. June-August. Annual.

4. A. fátua (Havers, Wild Oat). - Nearly allied to the preceding, but stouter; stems smooth, but with hairy nodes; lenves rough; panicle loose, 6-10 in. 
long, spreading; spikelets 3 -flowered, 1 in. long, on unequal pedicels, drooping, green; flowering glume with long, brown hairs outside.-Cornfields ; frequent.-Fl. June, July, Annual.

26. Arrhenátherum (Oat-grass), of which $A$. avenaceum (False Oat) is the only British species, has

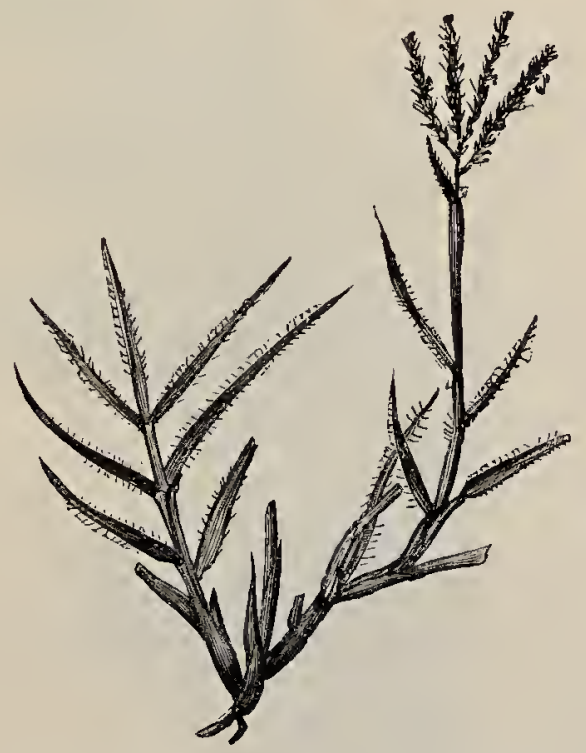

FIBICHA TMBELLATA (Creeping Dog's-tooth grass).

a creeping or tuberous root-stock; stem $2-3$ feet high, slender, smooth ; leaves rough, lat ; panicle 6-12 in. long, narrow, nearly simple, with sub-erect branches, only spreading when the flower's are open; spikelets $\frac{1}{2}$ in. long, pale greenish, 2 -flowered ; lower flower staminate, with long, basal, bent, twisted awn ; upper perfect, usually awnless.-Hedges and pastures ; common. (Name from the Greek arrhén, male, athér. awn.)-Fl. June, July. Perennial, 
27. Fibíchia (Dog's-tooth grass), of which $F$. umbet. lata (Creeping Dog's-tooth grass) is the only British species, is a low, prostrate grass, with long, tough runners and short, flat, glaucous leaves, distinguished from all

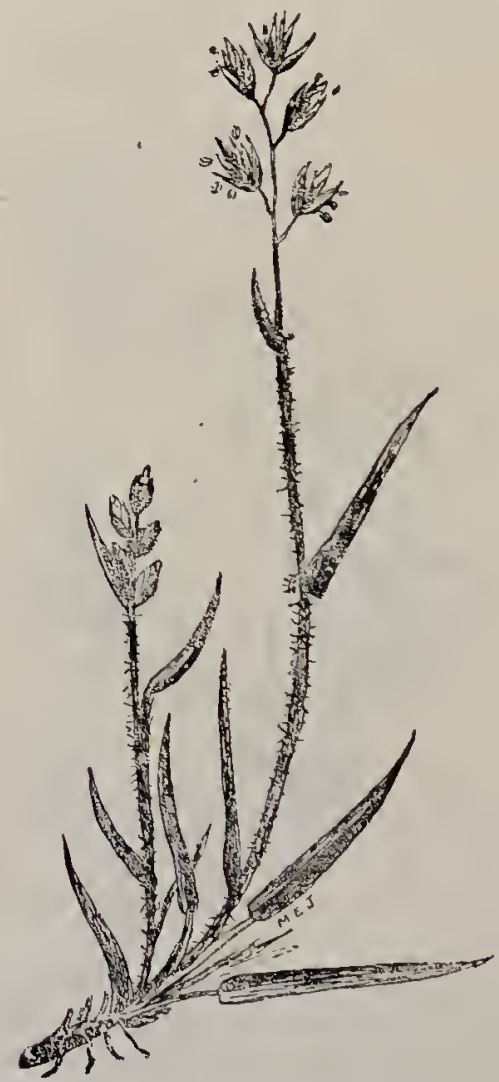

SIEGLfNGIA DECÚMBENs (Creeping Heath-grass).

other British grasses, except Pánicum sanguináté and $P$. glabrum, by the digitate arrangement of the $3-5$ slender, purplish spikes in its panicle, each of which is $1-1 \frac{1}{2}$ in. long, and from those two species by having 
its awnless spikelets arranged singly, not in pairs, along the spikes.- Sandy pastures by the sea in the south-western counties; very rare. It is a good sand-

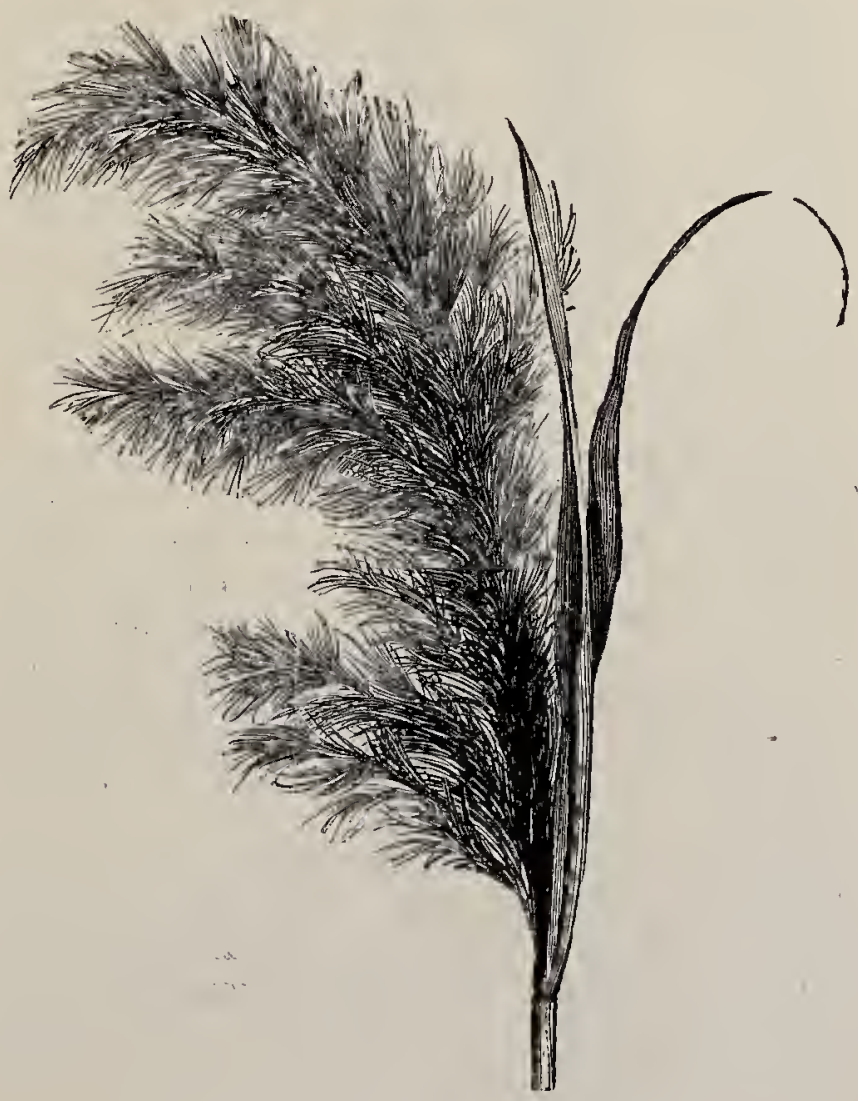

PHRAGMITES COMMÚNIS (Common Reed).

binder and one of the best pasture grasses of many dry climates, such as India, where it is called Doorba or Doab-grass, and Bermuda, where it is called Bermuda- 
grass. (Named in honour of J. Fibich, a German botanist.)-Fl. July, August. Perennial.

28. Sieglíngia (Heath-grass), of which S. decumbens (Creeping Heath-grass) is the only British species, is a bright green, densely tufted plant with stiff, smooth stems, 6-12 in. high; blunt, thick leaves with a tuft of hairs for a ligule; spikelets 5 or 6 , rarely $7-10$, in a flexuous raceme, 3-4-flowered, rather large, awnless, pale green and purplish; flowering glume 5ribbed, hairy at the base, with 3 minute teeth at the top.-Dry heaths and moors; common, indicating poor soil. (Named in honour of Professor Siegling, of Erfurt.) -Fl. July, August. Perennial.

29. Phragmítes (Reed), of which $P$. commúnis (Common Reed) is the only species, is a stout grass, 5-10 feet high, with a long, creeping root-stock; numerous long leaves, often an inch broad, glaucous beneath, all up the stem; a dense, drooping panicle $10-18$ in. long, of a purplish-brown colour, with numerous branches; spitielets very numerous, $\frac{1}{2}-\frac{3}{4}$ in. long, shining, 1 -6-flowered, awnless, with long, silky hairs on the rachilla which lengthen as the fruit ripens and give the panicle a beautiful silvery appearance. - In wet ditches, marshes, and shallow waters, almost all over the world; common. It is very serviceable on river banks for binding the soil, and is used for thatch. The runners are nutritious, containing much sugar, and might be used as fodder. (Name said to be from the Greek phragma, a hedge.) - Fl. July, August. Perennial.

30. Sretékid (Moor-grass), of which S. cerrútea (Blue Moor-grass) is the only British species, is a tufted plant with stems 6-12 in. high; short, linear, glaucous radical leaves with small rough points; 
panicle oblong, rather 1 -sided, $\frac{1}{2}-\frac{3}{4}$ in. long, dark bluegrey or lead colour.-Limestone and micaceous rocks;

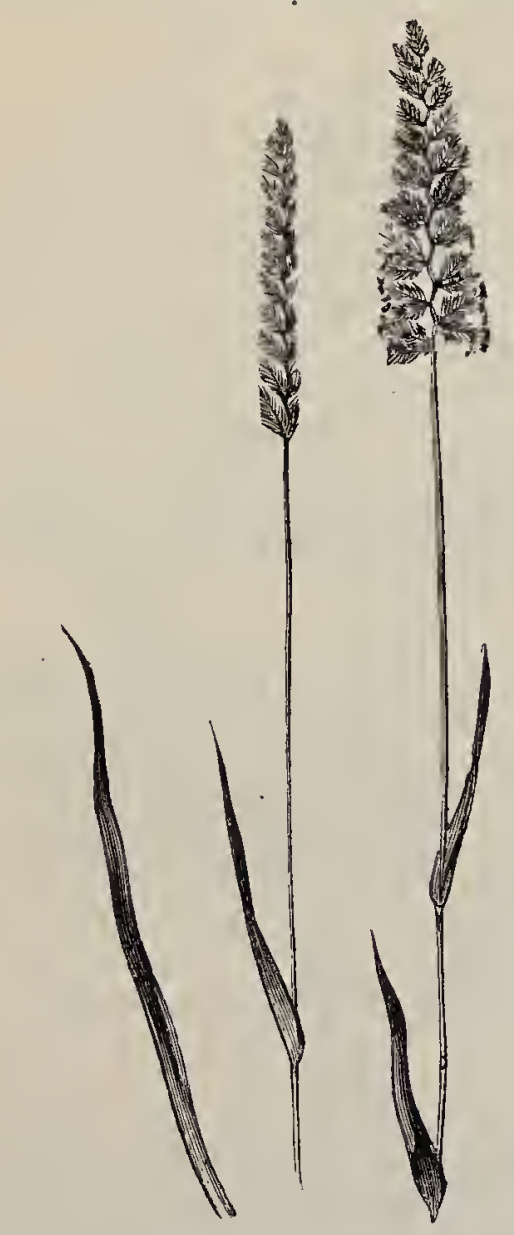

CYNOSỨRUS CRISTÁTUS (Crested Dog's-tail).

local in the north, and in the West of Ireland. (Named in honour of Leonard Sesler, an Italian botanist.) - Fl. April_June. Perennial. 
31. Cynosúrus (Dog's-tail).-Spitelets in a I-sided, spike-like panicle, 2 -5-flowered, with bristly com b: like glumes below them, awnless. (Name from the Greek oura, tail, kunos, of a dog.)

1. C. cristátus (Crested Dog's-tail). - Slightly tufted, with runners, stems slender, erect, about a foot high; leaves short, narrow, witl 2 -fid ligules: spitie $1-4 \mathrm{in}$. long, simple, unilateral ; flowering glumes shortly awned.-Pastures; abundant. A useful grass; but the wiry stalks when not eaten by sheep remain in a dry state and are known as "bents."-Fl. July, August. Perennial.

2. C. echinátus (Rough Dog's-tail).-A larger plant with broad, flat leaves and an ovate, irregularly lobed panicle; awn as long as the flowering glume.-Sandy places in the Channel Islands.-Fl. July, August. Annual.

32. Koenéria, of which $K$. cristáta (Crested Hairgrass) is the only British species, $6-12 \mathrm{in.} \mathrm{high,}$ downy; spiticlets 2 -5-flowered, compressed, in nearly sessile clusters, crowded into an interrupted oblong spike, 1-4 in. long; frowering glumes membranons, white, with a g'een keel, pointed, giving the spike a variegated, shining, silvery-grey aspect.-Dry pastures; commor. (Named in honour of G. L. Kïler, a German writer on grasses.) -Fl. June, July. Perennial.

33. Mouínsa, of which M. vária (Purple Molínia, or Purple Melic) is the only species, is a rather conrse, stiff plant, sometimes 3 feet high, with 1 node near the base of the stem; leares chiefly ladical, long, linear, attenuate, rather stiff, without ligules; panicle $6-12$ in. long, narrow, loose, generally purplish, with slender, erect branches ; spiticlets few, erect, lanceolato, 1-3-flowered, awnless; glumes acute, equal.-Wet 
heaths; common. Growing in tussocks in company with Scabiósa succisa. The stems are sold in bundles

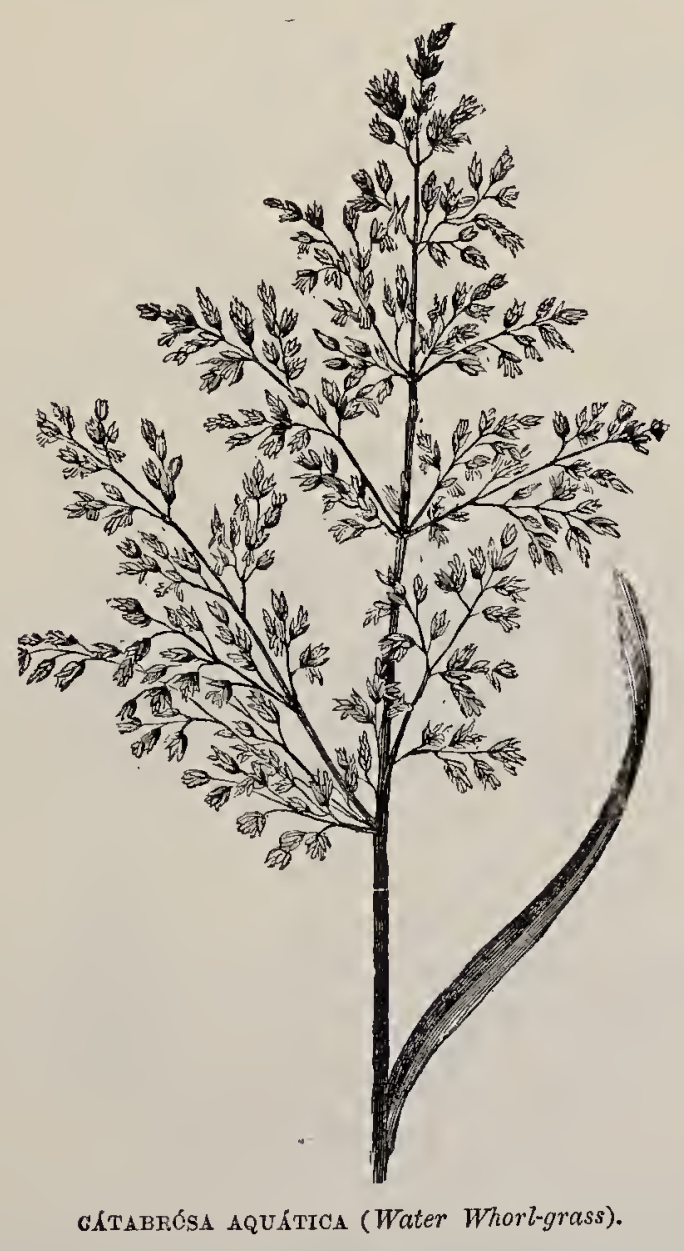

by tobacconists for cleaning pipes. (Named in honour of G. J. Molina, a Chilian botanist.) -Fl. July, August. Perennial. 
34. Catabrósa (Whorl-grass), of which C. aquática (Water Whorl-grass) is the only species, is a soft, smooth, pale green plant, creeping or floating below,

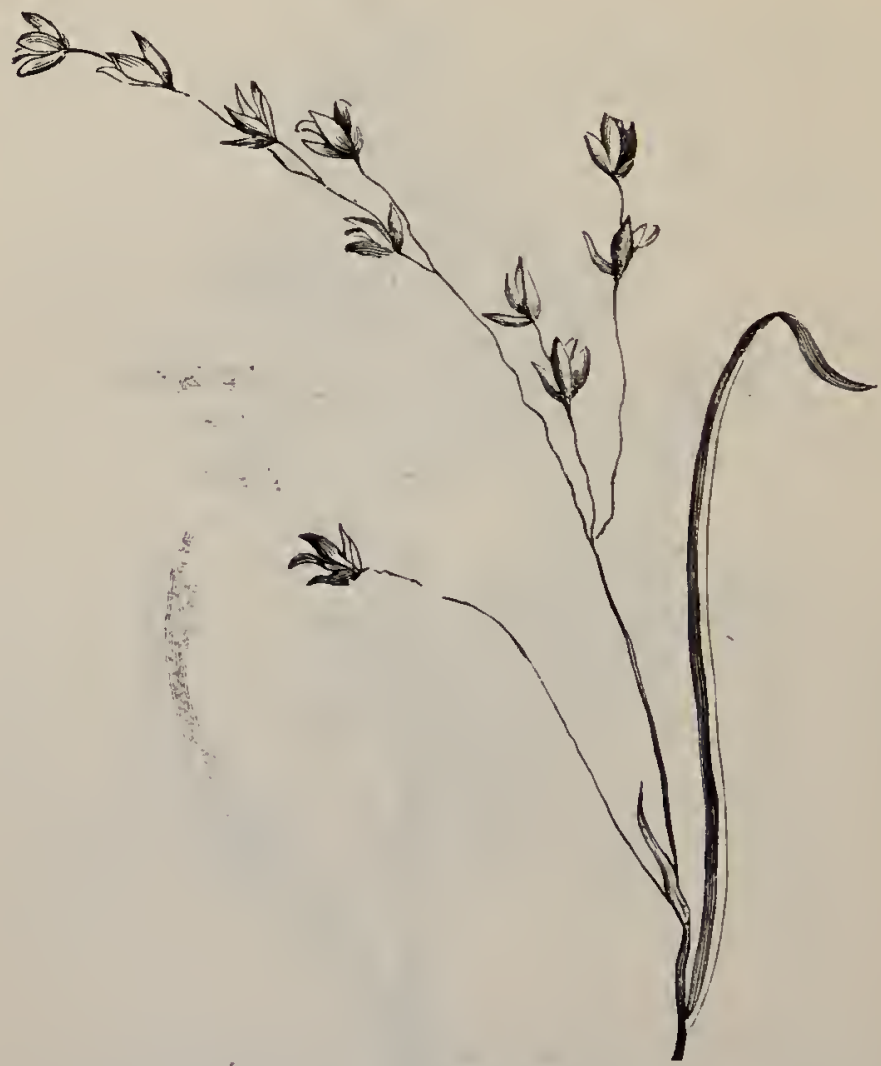

MÉLICA UNIFLÓRA (Wood Melic.grass).

sometimes much branched, 1-2 feet high; leaves short, flat, blunt, with inflated sheaths and blunt ligules; panicle 1-4 in. long, pyramidal, with slender, spreading, whorled branches; spitielets 1 -3-flowered; empty glumes very unequal, and both these and the 
flowering-glume truncate and torn at the top.-In ditches and by the margins of ponds; rather scarce, though distributed over the whole island. One of the sweetest of grasses, water-fowl and cattle being fond of it; but unsuitable for cultivation from the character of its habitat. (Name from the Greek katabrósis, an eating out, alluding to the torn ends of the glumes.)-Fl. May, June. Perennial.

35. MÉLica (Melic).-Panicle slender; spikelets rather large and few, ovate, awnless, 1-2-flowered; glumes nearly equal ; rachilla produced and terminated by a club-shaped rudimentary flower of empty glumes ; fruit loosely wrapped in the flowering glume. (Name said to be from the Latin mel, honey, on account of the sweetness of the stem.)

1. M. nútans (Mountain Melic).-A slender, erect plant, 1-2 feet high, with delicate, flat, sparsely hairy leaves; panicle 2-3 in. long, nearly a simple raceme, 1-sided, with slender, short, usually erect branches; spikelets about 5-15, drooping, brown or purple, 2-flowered.-Shady rocky places in the north and west.-Fl. May, June.-Perennial.

2. M. uniflóra (Wood Melic).-An elegant, very slender plant, 1--2 feet, with long, narrow leaves, with a sheath closed, as in the sedges, and a short, blunt ligule with a slender acuminate lobe on one side; panicle lax, slightly drooping, with few, long, slender branches, each bearing 1 or more of the erect, 1-flowered, purple spicelets.--Shady woods; common._Fl. May-July. Perennial.

36. Dáctylis, of which D. glomeráta (Cock's-foot Grass) is the only species, is a coarse grass, 1-2 feet high, creeping below, with long, broad, Hat leaves with rough sheaths and long ligules; spikielets numerous, 
small, rough, ovate, flattened, 3-5-flowered, densely crowded into thick 1-sided, ovate clusters, arranged in an irregular panicle with a few long branches below, horizontal in flower, erect in fruit; glumes

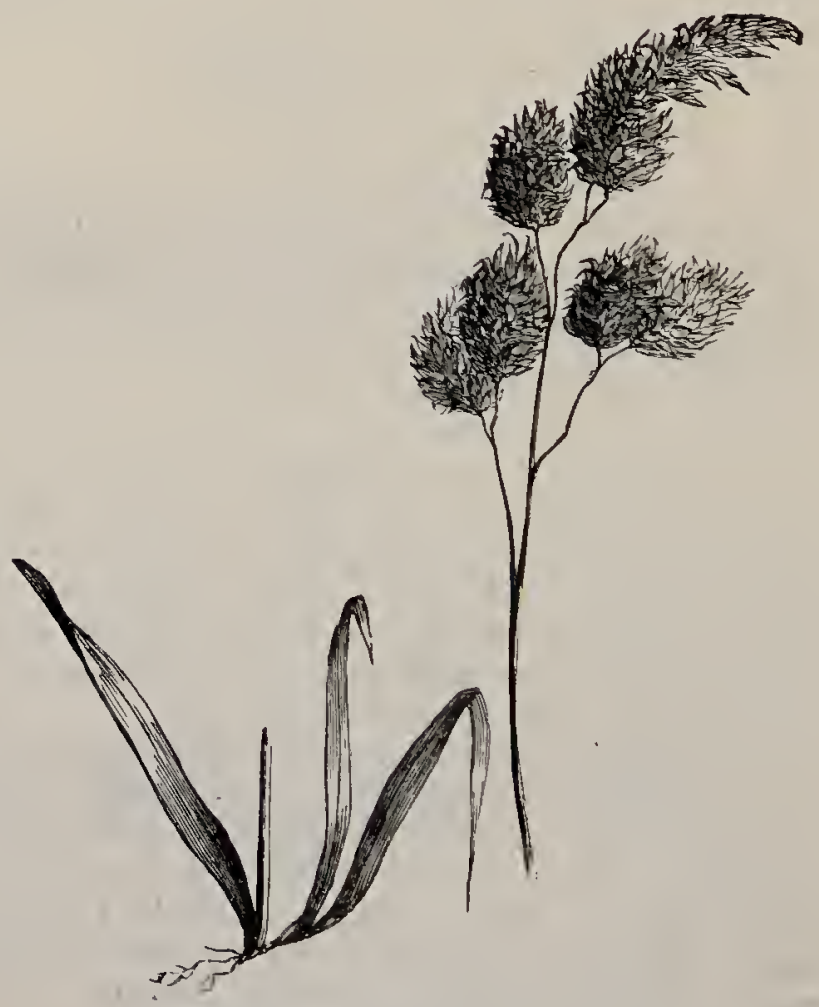

DÁCTYLIS GLOMERÁTA (Cock's-foot GTass)

lanceolate, strongly keeled, shortly awned just below the tip;-Meadows; abundant. A valuable agricultural grass. (Name from the Greek dálitulos, a finger, from the finger-like clusters of spikelets.)-Fl. June-August. Perennial. 
37. Bríza.-(Quaking- or Totter-grass).-Panicle loose, with slender branches; spilielets pendulous, short, flat, broad, 3- or more-flowered, unawned;

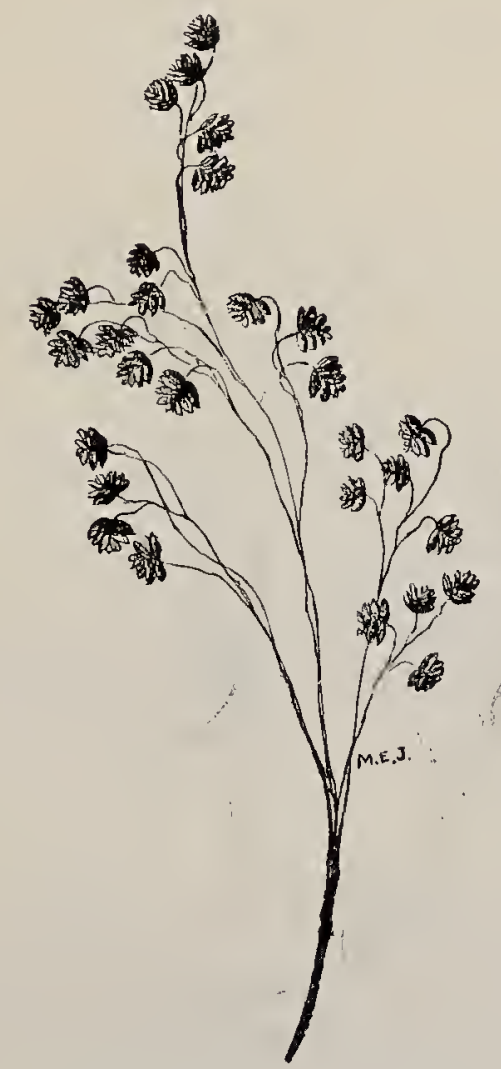

BRfzA MÉDIA (Common Quaking-grass).

glumes nembranous, boat-shaped, blunt, densely and distichously imbricate. (Name from the Greek brithó, I balance, from the delicately suspended spikelets.)

1.* B. máxima (Greatest Quaking-grass), with 
large, oblong, cordate, 9--1T-flowered spitielets, is becoming naturalised in Jersey.

2. B. média (Common Quaking-or Totter-grass).

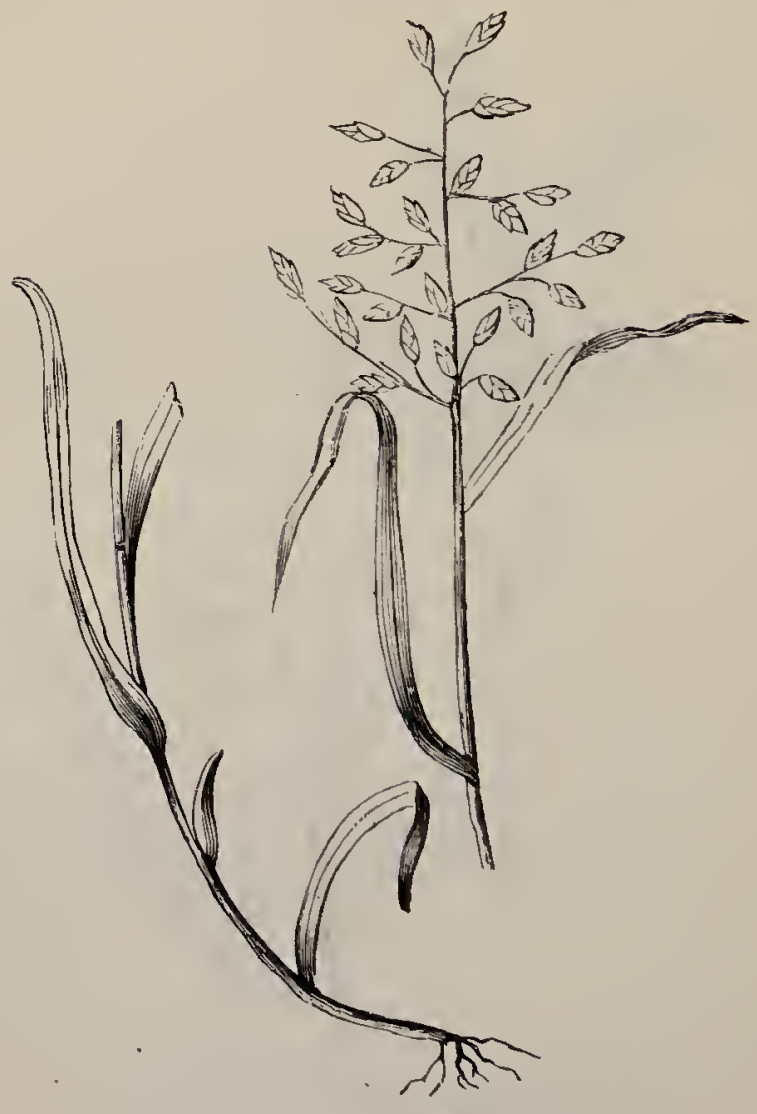

póa ÁNua (Amulal Meadou-grass).

-A favourite little plant, a foot or more in height, with a short, truncate ligule to its leaves, and a very loose, spreading panicle of ovate spikelets variegated with green and purple, and containing 5-9 flowers, 
usually 5 or 6.-Downs and dry pastures; common. -Fl. June, July. Perennial.

3. B. minor (Lesser Quaking-grass).-A smaller and more slender plant with a long, acute ligule to its leaves and more numerous, pale green, triangular, spikelets containing about 7 flovers.-Dry and sandy fields in the south-west; rare.-Fl. July, August. Aunual.

38. Póa (Meadow-grass).—Spikelets panicled, awnless, compressed, 2- or more-flowered ; glumes rather unequal, generally acute ; flowering glume compressed, keeled, 3-5-veined, not adherent to the fruit. (Name from the Greek poa, fodder.)

1. P. а́nпиа (Annual Meadow-grass). - Tufted, 2-10 in. high, with flat, flaccid, bright green glabrous leaves; panicle erect, loose, spreading, with a triangular outline, $1 \frac{1}{2}-3 \mathrm{in}$. long, somewhat 1-sided, with branches in pairs, becoming deflexed; spikelets 3-6-flowered ;' flowering glume 5-nerved. - Waste places, everywhere.-Fi. nearly all the year round. Annual.

2. P. bulbósa (Bulbous Meadow-grass).-A low, tufted, glabrous plant, 6-10 in. high, remarkable for the bulbs formed by the swollen base of the stems and leaf-sheaths; leaves narrow, finely serrate, with long, acute ligules; panicle ovoid, scarcely spreading, not much more than an inch long, with branches in pair's ; spikelets ovate, 3-4-flowered ; flowering glume pointed, keeled, with minute, silky hairs on keel and edges, and a fow short, woolly ones on the rachilla at its base. - Sandy shores, chiefly in the south-east; rare.-Fl. April, May. Perennial.

3. P. alpína (Alpine Meadow-grass).--A nearly allied species, tufted, often somewhat swollen at the base ; leaves short, rather broad, rounded and mucronate at the tip; panicle spreading, 2 in. long, with 
branches in pairs, frequently viviparous, the spikelets being converted into leafy bulbils.-Lofty mountains in the north; very rare.-Fl. June-August. Perennial.

4. P. strícta, a closely allied form, has slightly compressed stems; narrower leaves flat throughout; panicle open in flower and spreading in fruit, often viviparous; spikelets $3-4$-floweled, with few or no hairs on the rachilla.-Loch-na-Gar; very rare.-Fl. July, August. Perennial.

5. P. láxa (Wavy Meadow-grass), another ver'y closely allied form, has channelled leaves hollowed at the tip; panicle open in flower and closed in fruit, marely viviparous; spitielets 3-4-flowered, webbed with fine cottony fibres on the rachilla.-Loch-naGar ; very rare.-Fl. July-August. Perennial.

6. P. glaúca (Glaucous Meadow-grass). - A slightly creeping plant, $6-12$ in. high, with glaucous leaves with very short, blunt ligules; panicle slender, erect; spitielets 2-3-flowered ; flowering glume with 5 reins, only 3 hairy.-Lofty mountains, Ben Lawers, Ben Nevis, Clova, Snowdon; very rare.-Fl. July. Perennial.

7. P. Bafforivi, an almost indistinguishable form, rather larger, with leaves not glaucous, with longer, blunt ligules; spitielets 2-4-flowered, sometimes webbed.--Occur's in similar positions.

8. P. nemorális (Wood Meadow-grass).-Another closely allied, very variable form, or series of forms, is a slightly creeping, slender, glabrous plant, $1-3$ feet high; leaves narrow, with short ligules; panicle slender, lather drooping, $2-5$ inches long, spreading or close, sometimes 1 -sided, with branches $2-5$ together ; spritielets small, 1-5-flowered, generally 3flowered, yellowish-green and purplish, generally webbed; flowering glume with 5 veins, 3 hairy.Woods; general.-Wl. June, July. Perennial.

9. P. compréssa (Flat stalked Meadow-grass). -A 
glabrous and somewhat glaucous species, with creeping root-stock and runners; stem flattened, 6-18 in. high; leaves flat, with short, truncate ligules; panicle

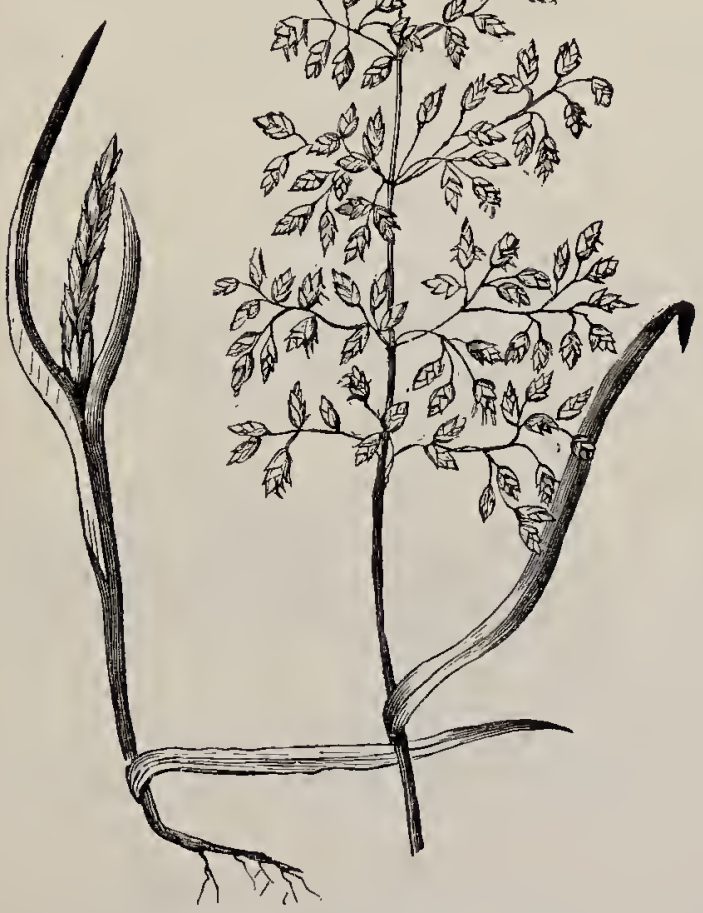

PÓA PRATENSIS (Smooth Meadow-grass).

2-3 in. long, slightly 1 -sided, spreading when in flower, branches 2-3 together; spikelets ovate, 4-7-flowered, slightly webbed; flowering glume with $3-5$ hairy veins.-Walls and other dry places; frequent.-Fl. June-July. Perennial. 
10* P. Chaivii, with a 2-edged stem 2-3 feet high; leaves with rough sheaths, midribs, and margins, and very short, blunt ligules ; panicle spreading ; spikelets oval, of 3 , rarely 5 flower's, not webbed; flowering glume with 5 smooth veins, occurs in deep shady places near Kelso. 'Perennial.

11. P. praténsis (Smooth Meadow-grass).-Rootstock creeping, with runners; stem round, smooth, $1-2$ feet high, but very variable in size; leaves sometimes glaucous, smooth, with long, blunt ligules; panicle 2-6 in. long, spreading, with slender branches 3 -5 together; spilielets ovate, 3--4-flowered, much webbed; flowering glumes with 5 prominent veins, 3 hairy.-Meadows; abundant._Fl. June, July. Perennial.

12. P. palústris (Marsh Meadow-grass).- Without runners; leaves with longer and more conspicuous ligules than the preceding; flowering glumes indistinctly veined.-Marshes by the Tay below Perth.Fl. July. Perennial.

13. P. triviális (Rough Meadow glass).-Chiefly distinguished from $P$. pratensis by the absence of runners; a general roughness of surface; long, acute ligules; more slender panicles, often 6 in. long, with slender, spreading brauches given off. 5 together ; spitielets usually 2 -flowered, rarely 1 or $3-5$; flowering glume 5-veined, margin $\mathbf{n}$ veins glabrous.-Moist places; abundant.-Fl. June, July. Perennial.

39. Glycéria (Manna-grass.)-Tall, semi-aquatic, perennial grasses, with unsplit leaf-sheaths; spilielets panicled, awnless, many-flowered; glumes unequal, membranous, obtuse; flowering glume sub-cylindric, 3-9-ribbed, obtuse. (Name from the Greek glukeros, sweet, in allusion to the sweeiness of the grain.)

1. G. flúitans (Flote-grass, Manna-croup).-liootstock creeping; stem $1-3$ feet, thick, but weak, smooth, 
floating, or creeping; leaves often floating, flat, acute, with long, compressed, striate sheaths ; panicle slender, about a foot long, slightly branched, branches erect in

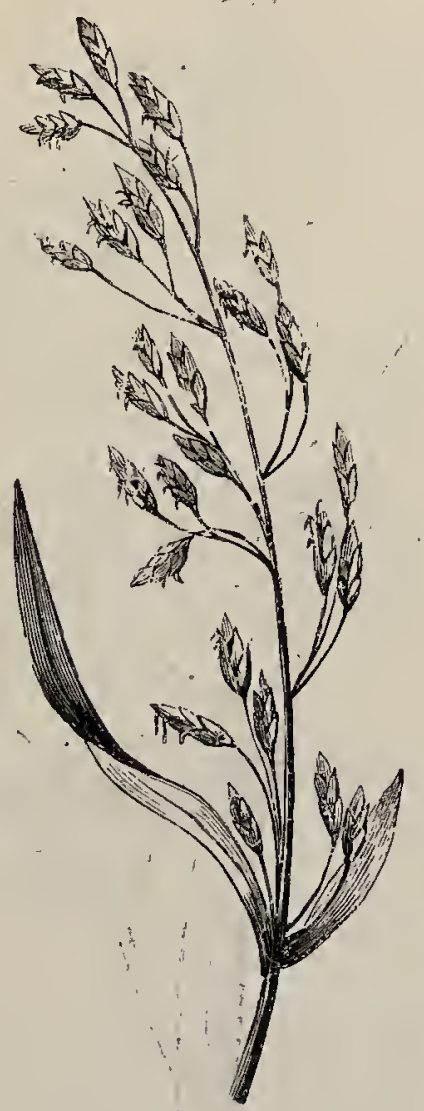

GLYCÉRI FLÚITANs (Flote-grass, Manna-croup).

fruit; spikelets few, linear, adpressed, $\frac{1}{4}-2$ in. long, 7-20-flowered; flowering glume nearly thrice as long as broad; anthers about five times as long as broad, purple, yellowish when empty.-Watery places ; common.-Fl. June-September. Perennial. 
2. G. plicáta (Plaited-leaved Manna-grass, a nearly allied form, has glaucous, rather blunt leaves, plaited

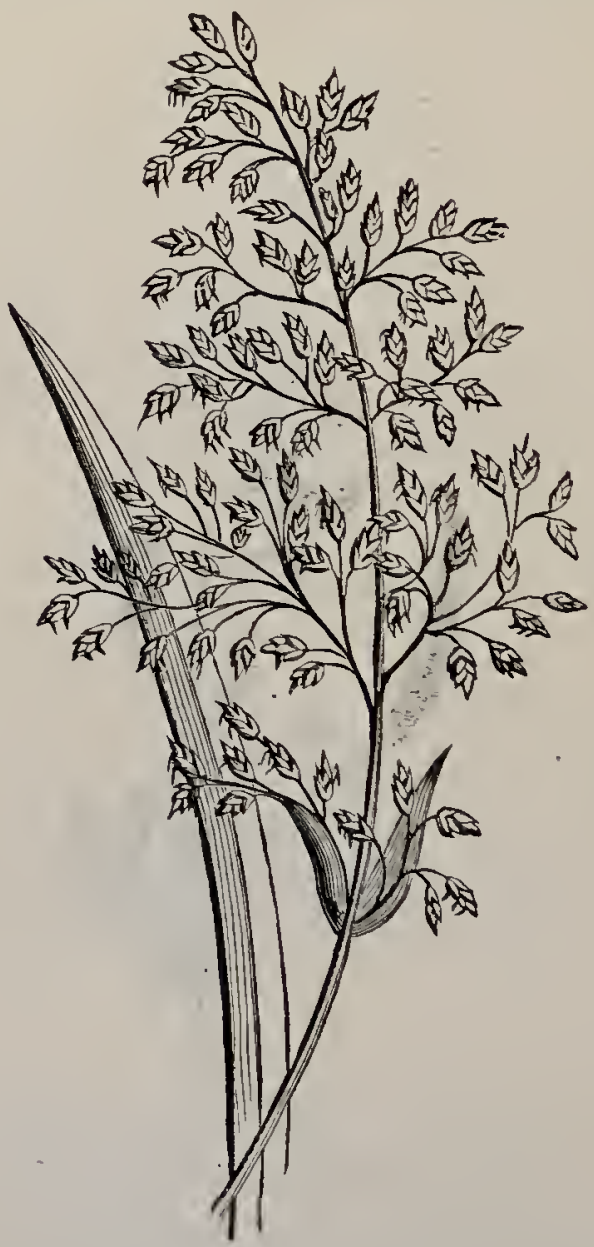

GLYCÉRIA AQUÁTICA (Reed Manna-grass).

when young, with furrowed sheaths: panicle with many branches, spreading when in fruit; flowering 
glume twice as long as broad; anthers about thrice as long as broad, cream-coloured, brownish when empty. -Stagnant water; frequent.-Fl. June-August. Perennial.

3. G. aquática (Reed Manna-grass).-A conspicuous and imposing grass, 4-6 feet high ; root-stock creeping; lear'es never floating, sub-erect, flat, rough on the edges, with long, smooth sheaths ; panicle erect, about a foot long, much branched, with spreading, slender branches; spikelets numerous, 5-10-flowered, oblong; flowering glumes $1 \frac{1}{2}$ line long, loosely imbricate, 5-7-ribbed.-Watery places ; frequent in England and Ireland, but rare in Scotland. A fine covert for waterfowl.-Fl. April-August. Perennial.

4. G. maritima (Sea Manna-grass). -Root-stock creeping, with runners; stems about a foot high; leaves involute, with smooth sheaths; panicle erect, 1-sided, 1-4 in. long, generally compact, branches short, solitary, or in pairs, rarely 3 or more together ; spikelets not numerous, 4-8-flowered; flowering glume apiculate.-Sandy or muddy-salt marshes; frequent. -Fl. June-September. Perennial.

5. G. distans (Reflexed Manna-grass).-An allied species, tufted and generally without runners; stems 1-2 feet high, slender; leaves flat; panicle spreading, with long, slender branches, $4-5$ together, ultimately deflexed; spikelets $\frac{1}{4}$ in. long, 3-7-flowered ; flowerini glume truncate. - Sandy salt marshes; not common.Fl. June--October, Perennial.

6. G. Borreri, somewhat intermediate between the two preceding species, is densely tufted, without runners, $6-20$ in. high ; leaves flat; panicle 3-6 in: long, with short branches $2-4$ together, ascending; spikeleis very small, crowded, 3-7-flowered; floweriny glume apiculate.-Salt marshes on the east and south coasts; rare.-Fl. June-August. Perennial.

40. Festúca (Fescue).-Leaf-sheath generally split 
to the base; spitcelets in a spike or panicle, 3 - or moreflowered; flowering glume rounded at the back, 3-5ribbed, pointed or awned; styles at the top of the smooth ovary. (Name, a Classical Latin name.)

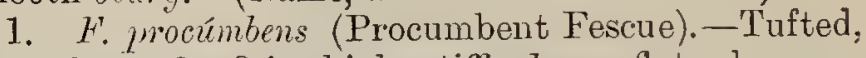
decumbent, $3-8$ in. high, stiff; leares flat, glaucous, with inflated sheaths; panicle 1-sided, 1-2 in. high, compact, with short, stout, ascending, rigid, distichous branches; spikelets small, crowded, nearly sessile, about 4-flowered; flowering ylumes 3-5, 5-ribbed, apiculate.-Salt marshes; uncommon.-Fl. JuneAugust. Annual.

2. F. rigia (Hard Fescue).-A tufted, stiff, glabrous, often purple plant, $4-6$ in. high ; panicle about 2 in. long, with distichous branches, a broadly channelled rachis, and 3-5 spitielets, which are about 3 lines long and 6 -S-flowered; flowering glume smooth, shining, apiculate.-Dry places; common.-Fl. June -July. Anuual.

3. F. rottbclliö̈les (Dwarf Darmel-like Fescue).A glabrous, green, stiff, dwarf plant, 2-6 in. high, resembling the preceding; spritielets nearly sessile in 2 rows on alternate sides of the rachis, but all turning one way so as to resemble a 1 -sided spike; spiticlets about 3 lines long, 6-12-flowered; flowering glumes mucronate, with well-marked marginal veins. -Sandy sea-shores; uncommon.-Fl. June-August. Anmual.

4. I. unighimis (Single-husked Fescue). - Stem 4-12 in. high, bent below, slender, glabrous, leafy; leaves bristle-like; panicle 1-sided, spike-like, but with some very short lower branches in pairs, $2 \mathrm{in}$. long, pale green, shining; spikelets 4-10-flowered; outermost glume wanting, 2nd awned; flou'ering ylumes onding in awns longer than themselves.--Sandy seashores in the south; rare.-Fl. June, July. Annual or biennial.

5. $\quad F$. ambiyza (Doubtful Fescue). - A slender 
plant, 8-12 in. high, with narrow, involute leaves; panicle long, narrow, erect, close; upper empty glume

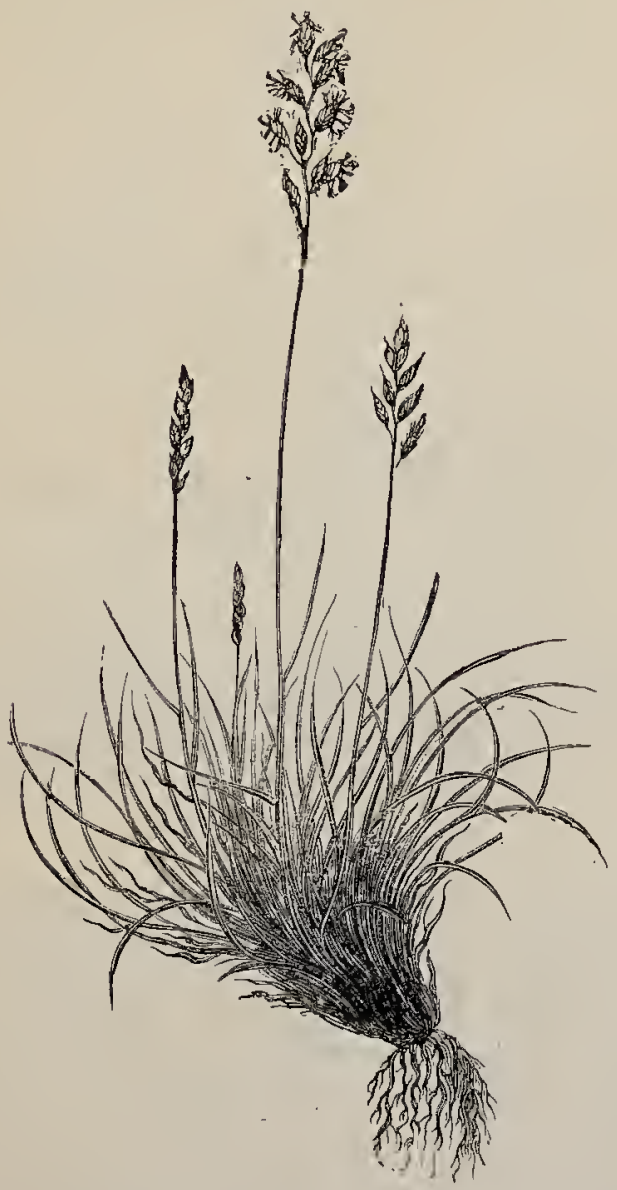

FeSTÚCA ovíns (Sheep's Fescue).

3-6 times as long as the lower; flowering glumes ending in awns as long as themselves; stamen 1.-Sandy 
places, Dorset, 1sle of Wight, Suffolk, and Norfolk; very rare.-Fl. May-June. Annual.

6. H. Myúros (Rat's-tail, or Wall Fescue).-A closely allied, but generally taller species, about a foot high, slender; panicle $2-6$ in. long, slender, 1-sided, sometimes spike-like, interrupted, nodding; upper empty glume thrice as long as the lower.Walls and sandy places; not uncommon.-Fl. June, July. Annual.

7. F. sciuróides (Squirrel-tailed Fescue).-Another closely allied species, differing in the upper part of the stem being leafless; the shorter panicle being more open, with slender ascending branches below; and the upper empty g7ume twice as long as the lower.-Occurs in similar situations more commonly. -Fl. June, July. Annual.

8. H. orina (Sheep's Fescue).--A densely tufted, glaucous grass, 3-24 in. high; stem slender, 4-angled, rough below the inflorescence; leaves chiefly radical, subulate, almost cylindric, with 2-lobed ligules; panicle rather compact, slightly 1 -sided, $1 \frac{1}{2}-4$ in. long, purplish ; spikelets small, 3-6-flowered; flowering glumes mucronate or with an awn shorter than themselves, often viviparous. - Dry hilly pastures; one of the commonest grasses. Very variable.-Fl. June, July. Perennial.

9. F. rúbra (Creeping Fescue).--A creeping plant with runners and scattered tufts; stemi many-angled, smooth below the inflorescence; leaves bristly, flat or involute; panicle broadish below, slightly 1 -sided, reddish; spikelets 4-10-flowered, shortly awned.Sandy places; common. Very variable.-Fl. June. Perennial.

10. $F$. dumetónum, a creeping plant with rushlike, cylindric, sharply-pointed teaves and downy flowering glumes, closely aliied to the preceding, and occurring on sandy sea-shores, has been recorded as British. 
11. F. heterophÿlla (Various-leaved Fescue).-A densely tufted plant, 2-4 feet high; radical leaves numerous, capillary, triangular, rough, sometimes a foot long; canline leaves flat, narrow, rather recurved;

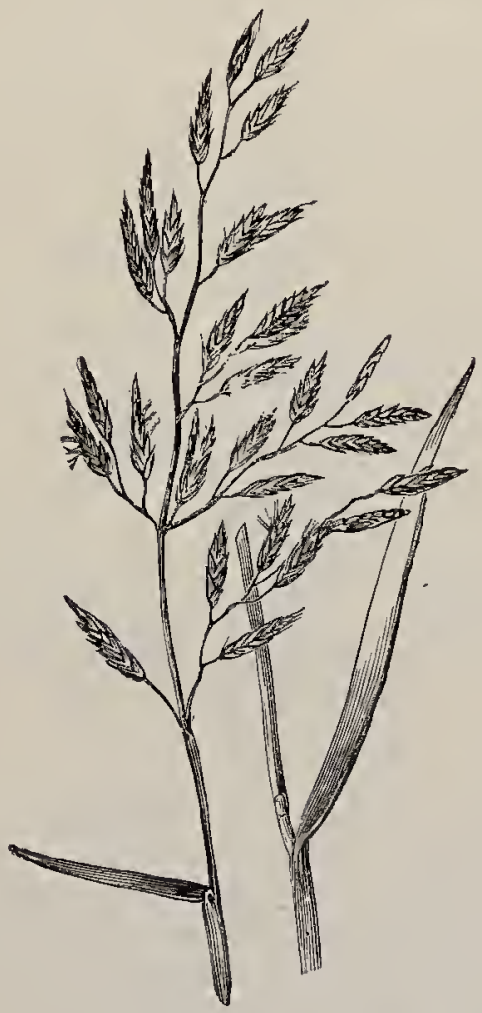

FESTÚCA ELÁTIOR (Tall Fescue).

ovary downy at the apex; otherwise resembling F. ritora.-Shady places in the south; a doubtful native.-Fl. June, July. Perennial.

12. F. sylvática (Reed Fescue).-A tall, reed-like grass, 2-4 feet high, stiff, glabrous, with short run- 
ners; Teares very long, ratlier broad, flat, glaucous above, rough-edged; panicle $3-6$ in. long,. much branched, spreading; spitielets numerous, small, awnlcss, 3-4-flowered, pale yellow-green; flowering glumes pointed, finely toothed along their dorsal ribs.Moist hilly woods; uncommon.-Fl. July, August. Perennial.

13. F. elátior (Tall Fescue). - Root-stoch creeping, with runners ; stems 1 -6 feet high, nodding, smooth; 7eares linear-lanceolate, flat, smooth; panicle $3-10$ in. long, nodding, with a 3 -angled, smooth rachis, either spreading with rough branches in pairs, or (var. jraténsis) reduced almost to a simple, 1-sided spike, with almost sessile, 3-i 0 -flowered spitictets, $\frac{1}{2}-\frac{3}{4}$ in. long; fowering glumes 5-ribbed, obtuse, mucronate or acute--River-banks and wet places; common.-Fl. June, July. Perennial.

14. F. amulinacoa (Sea Fescue) is a closely sillied species, forming large tufts, with stems $3-6$ feet high, and a panicle, the branches of which are in pairs, spread outwards both in flower and fruit, and each bears 2 or more 5-6-flowered spilielets.-Banks near the sea; common.-Fl. June, July. Perennial.

41. Brómus (Brome-grass).-Leaf-sheath generally split half-way down; spitielets panicled or racemed, many-flowered; flowering glume rounded at the back, witl a long dorsal awn; styles below the hairy top of the oicry. (Name from the Greek bromos, oats.)

1. B. giqúnteus (Giant Brome).-A glabrous plant, 3-4 feet high; leaves very long, broad, flaccid, bright green, rough above, with smooth sheaths; panicle loose, with long, drooping branches in pairs and rough, 3 -angled rachis; spitielets $\frac{1}{2}$ in. long, 3 -6-flowered, with slender, flexuous awn twice as long.-.Shady places; common.--Fl. July, August. Perennial.

2. B. ramósus (Rough or Hairy Brome) -2-6 
feet high; leaves long, flat, with scattered reflexed hairs on the sheaths; panicle loose, with long, slender branches, 2-6 together, drooping to one side ; spikelets glaucous, linear-lanceolate, above an inch long, 5-10-flowered; flowering glume hairy, 5-7-ribbed, with a straight, fine awn half as long as itself.-Damp

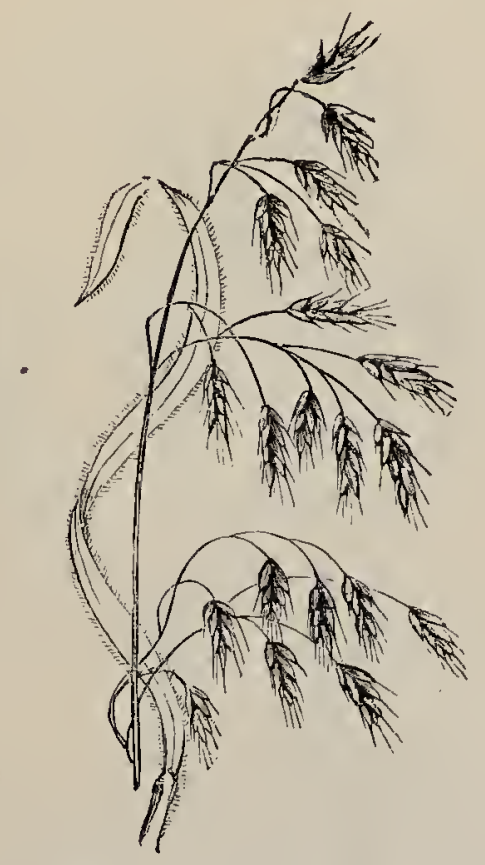

Brómus RaMósus (Hairy Brome).

woods ; common.--Fl. Juiy, August. Annual or Perennial.

3. B. eréctus (Upright Brome).-An erect plant, $2-3$ feet high; feaves narrow, almost subulate; sheaths hairy, with ascending hairs; panicle compact and erect, $3-5$ in. long; spikelets $\frac{1}{2}-1 \frac{1}{2}$ in. long, 6 - or more-flowered, linear-lanceolate; flowering glume hairy, 
indistinctly 7-ribbed, twice as long as the awn.-

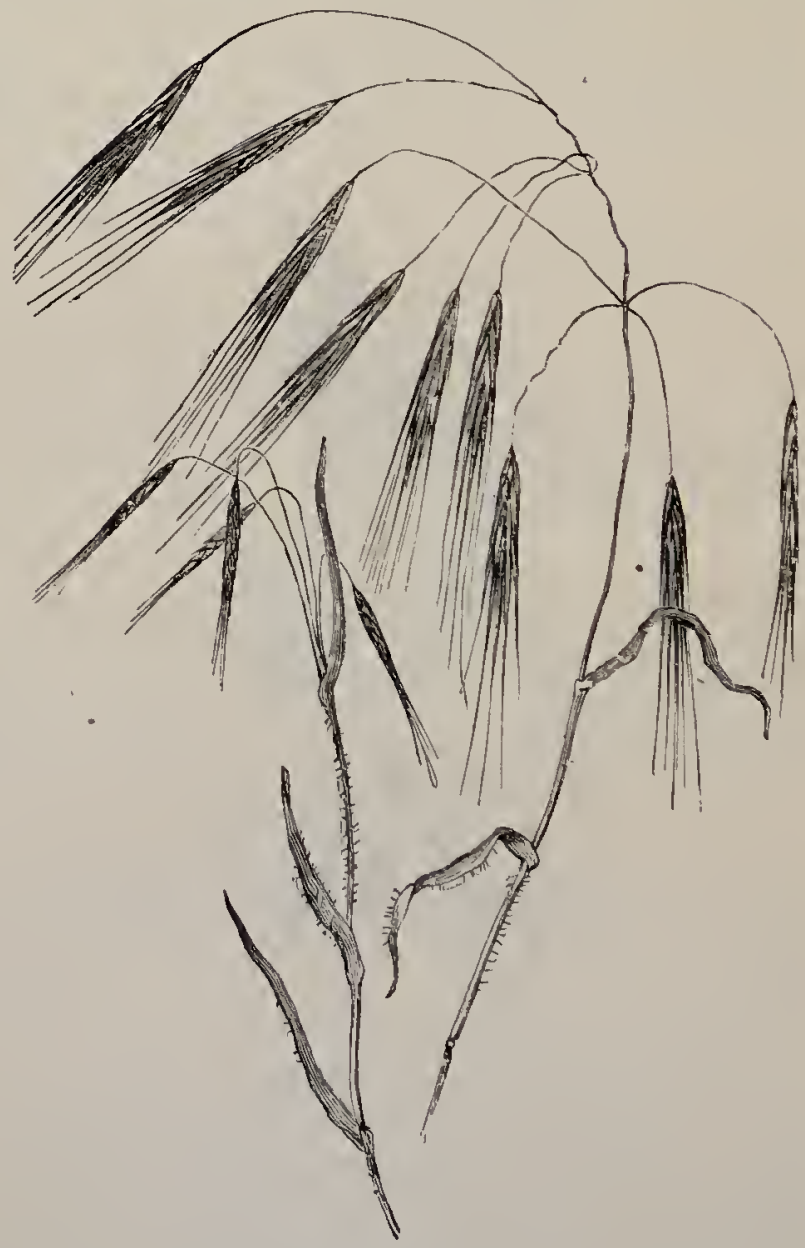

BRóALS STERILIS (Barren Brome).

Sandy fields; common.-Fl. July, August. Perennial. 
4. B. madriténsis (Compact Brome).-Stem erect, seldom above a foot high, smooth, leafy; Teaves narrow, flat, hairy; panicle erect, 2-4 in. long; with few, erect, adpressed branches and rough rachis and pedicels ; spitielets linear-lanceolate; flowering glume 7 -ribbed, with an awn as long as itself ; stamens usually two.-Dry places in the south; rare.-Fl. June, July. Annual.

5. B. tectórum, an introduced plant, occurring as a casual in cornfields, is closely allied to the preceding, but has a panicle drooping to one side and the pale much shorter than the flowering glume.

6. B. rígidus (Great Brome). - A beautiful grass, 1-2 feet high, pubescent; panicle erect, lax, ultimately drooping, slightly branched, 4-7 in. long; spikelets with their awns $2-3 \mathrm{in}$. Jong, pale green or purplish, long-stalked after flowering.--Sandy shores, Channel Islands.-Fl. June-August. Annual.

7. D. stéritis (Barren Brome). - Stem 1-2 feet high; leares hairy; panicle 6-16 in. long, very lax, drooping, with very long brinches; spitelets with their awns more than 2 in. long, 6-10-flowered; flowering glume rough on the back, distinctly 7 nerved, with a straight awn longer than itself.Fields and waste places.-Fl. June-August. Annual.

8. B. secatinus (Rye Brome).--Stems erect, stiff, 1--4 feet high, smooth, or rarely pubescent; panicle slightly branched, loose, spreading, 3-5 in. long, with rough, flexuous rachis and branches $3-5$ together; spikelets oblong, glabrous, 5-10-flowered; flowering glume longer than the pale, about as long as its awn.-Cornfields; common.-Fl. June-September. Annual.

9. B. racemósus (Smooth Brome).-A stiff, nearly smooth plant, 1-3 feet high; teaves stiff, ciliate; panicle long, erect, narrow, simple, with long, slender branches, 3-5-together; spikelets ovate, glossy, $6-10$ flowered, with awns as long: as the flowers; lower empty 
glume lanceolate; flowering glumes imbricate, rounded at the sides.-Fields and waste places.-Fl. JuneSeptember. Biennial.

10. B. commutátus (Meadow Brome). - A stouter form, more hairy; panicle more compound, loose,

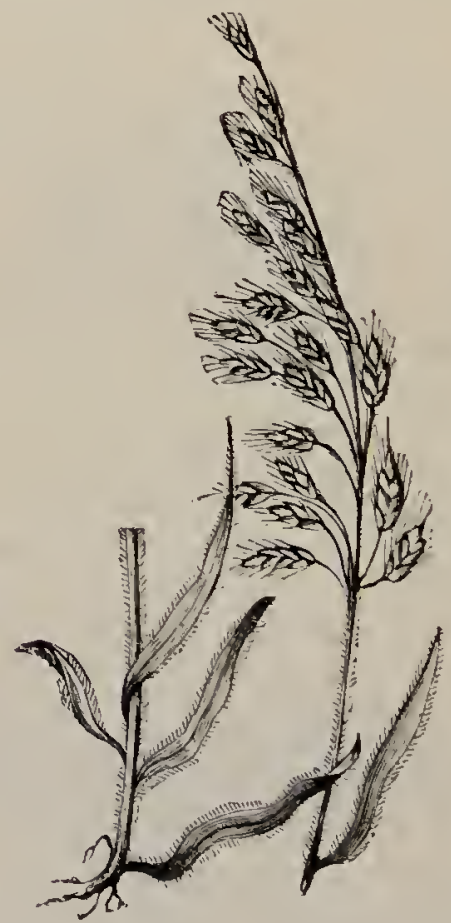

BRómus MótuIs (Soft Field Brome).

slightly drooping; spikelets shorter, oblong-lanceolate; flowering glumes imbricate, bluntly angular at the sides._Common,_Fl. June, July. Biennial.

11. B. móllis (Soft Brome, Lop-grass), -A glaucous green, pubescent plant, resembling 13. racemósus, 1-2 feet high ; leares soft, with rough edges; panicle 
1-3 in. long, ovoid, erect, close, slightly branched, with very short branches; spiliclets ovate, pubescent, 6-10-flowered; lower empty glume broadly ovate; flowering glumes imbricate, bluntly angular at the

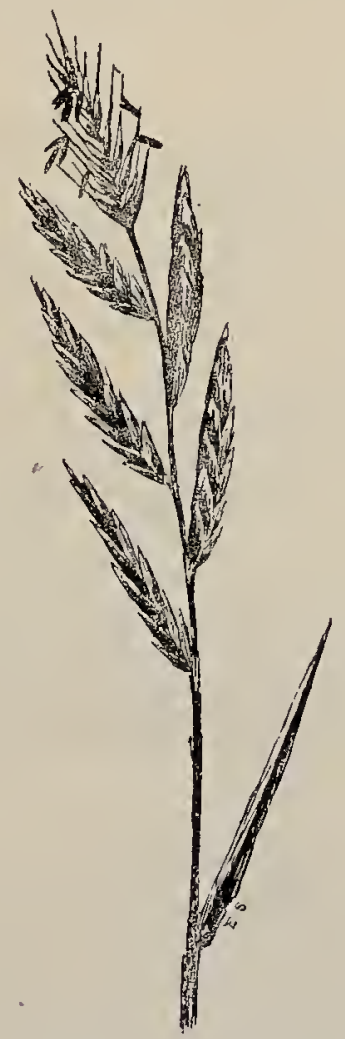

BRACHYPÓDIUM GRÁCILÉ (Slender False Brome).

sides, pubescent, with awns as long as themselves.Roadsides; common. Very variable.-Fl. MayJuly. Annual.

12.* B. arvénsis (Field Brome), 1-3 feet high, with smooth stem; hairy leaves; panicle spreading, 
pyramidal, $4-8$ in. long, with very long, hair-like, roughish branches giv 1 off $5-7$ together and becoming horizontal, with a few green or dull violet lanceolate spikelets, each about $\frac{1}{2}$ in. long, near their ends, and straight, dark awons as long as the flowers, is commonly naturalised.-Fl. July, August. Annual.

42. Brachyónium (False Brome). - Perennial grasses with long, many-flowered spitielets in a spike or raceme, with an unindented rachis; glumes unequal; flowering glume with a terminal awn; orary hairy at the top. (Name from the Greek brachús, short, poction, a foot-stalk, in allusion to the short stalks of the spikelets.)

1. B. grácité (Slender False Brome).-Root fibrous; stem usually solitary, erect, $1-3$ feet high; leaves broad, flat, rather long, flaccid, liairy; spikelets $6-1 \mathrm{~s}$, usually only 6 or 7 , distichous, sub-sessile, adpressed, $1-2$ in. long, nearly cylindric when young, flattened when in fruit, 8-10-flowered, in a loose spitie, more or less drooping; glumes pointed; flowering glume ending in an awn as long as, or longer than, itself.Woods and hedges; common.-Fl. June, July. Perennial.

?. B. pinnátum (Heath False Brome).-Root-stock: creeping; stems several, erect, $1-3$ feet high, smootì, glaucous; leaves narrow, involute, rigid, almost glabrous; spilie erect, with smaller, green or purplish spitielets curving away from the rachis; awn shorter. than the flowering glume-Dry places on limestone; not common, absent from Scotland and Ireland.-Fl. July, August. Perennial.

43. LóLıum (Rye-grass). - Perennial grasses with their spitelets solitary, sessile in the notches of a simple rachis, forming a spite, compressed, with their 
edges towards the rachis, 3- or more-Howered. (Name, a Classical Latin name.)

1. L. perénné (Rye-grass, Way Bent).-Stem ascending, 1-2 feet high, with leafy runners; spitie 6 -12 in. long; spilielets not close together, 8- or more-

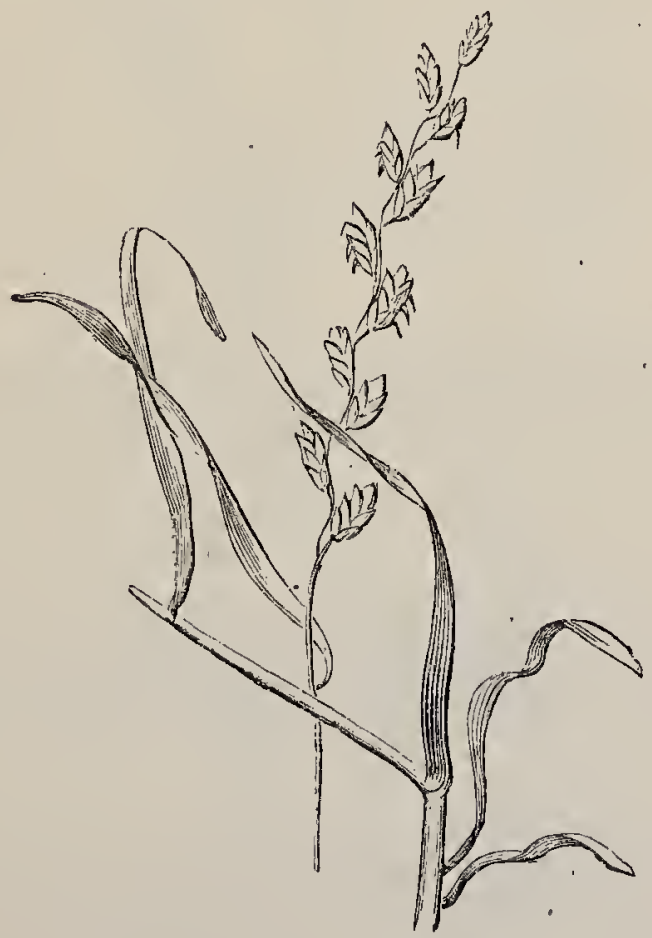

LÓLIUM PERÉNAÉ (Rye-grass Lolium).

flowered; outer glume strongly ribbed, not as long as the whole spikelet, varying in shape; flowering glume obtuse, pointed or awned.-Waste places; common.Fl. May-July. Perennial.

* itálicum (Italian Rye-grass) is an annual or 
biennial variety, with mucli longer spikelets and more flowers, known only in a cultivated state. It is one of the most valuable of fodder-grasses.

2.* L. Tinicola, occurring also in cultivated fields, is an annual, with no leafy runners, with a slender spike and spitielets 7-11-flowered.--Fl. June, July.

3. L. temuléntum (Darnel).-Closely allied to $L$. perénné, but without runners, and with spritielets usually about 6-flowered, not longer than the outer glume; flowering glume usually awned.-Cornfields; fortunately not common in Britain, as its fruit is so poisonous that when ground with flour it is said to cause serious headache and giddiness.-Fl. JuneAugust. Annual.

44. Agropýror (Couch-grass).--Perennial grasses with their spitielets solitary, sessile in the notches of a simple rachis, forming a spitie, compressed, with their broad sides towards the rachis, 3- or moreflowered. (Name from the Greek agros, field, puros, wheat.)

1. A. crninum (Bearded Couch).-Root fibrous; stem erect, 1-3 feet high, slender; sprite 2-10 in. long, very slender, often flexuous and nodding; spikelets 2-5-flowered, bright green; empty glumes 3-5ribbed, usually 3 , shortly awned; flowering glume longer, prominently 5-ribbed, with a rather long terminal awn. Woods and waste places; frequent.Fl. June, July. Perennial.

2. A. répens (Couch-grass).--Root-stock extensively creeping, long, jointed; stems solitary, ascending, glabrous, 1-2 feet high, hollow; Teaves at first involute, afterwards flat, flaccid, with numerous slender ribs each with 1 row of rough hairs above; spikelets $3-7$. flowered; rachis slender, not brittle; empty glumes acuminate, 5-ribbed; aruns usually short. A very variable, common, and troublesome weed.-Fl. JuneAugust, Perennial. 
GRASS FAMILY.

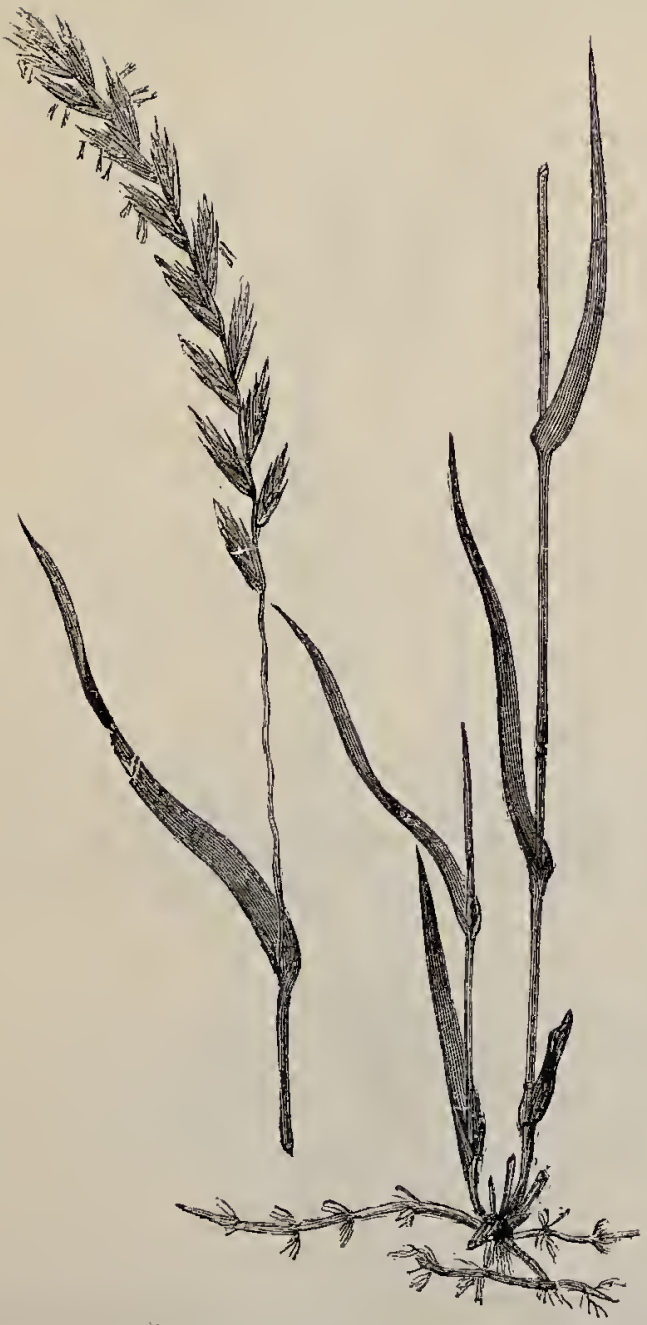

AGROPÝRON RÉPENS (COuch-grass). 
3. A. pungens (Stiff-leaved Cuuch). - Densely tufted ; stems solid above; leaves involute, firm, with numerous thick ribs, each with a row of sharp points

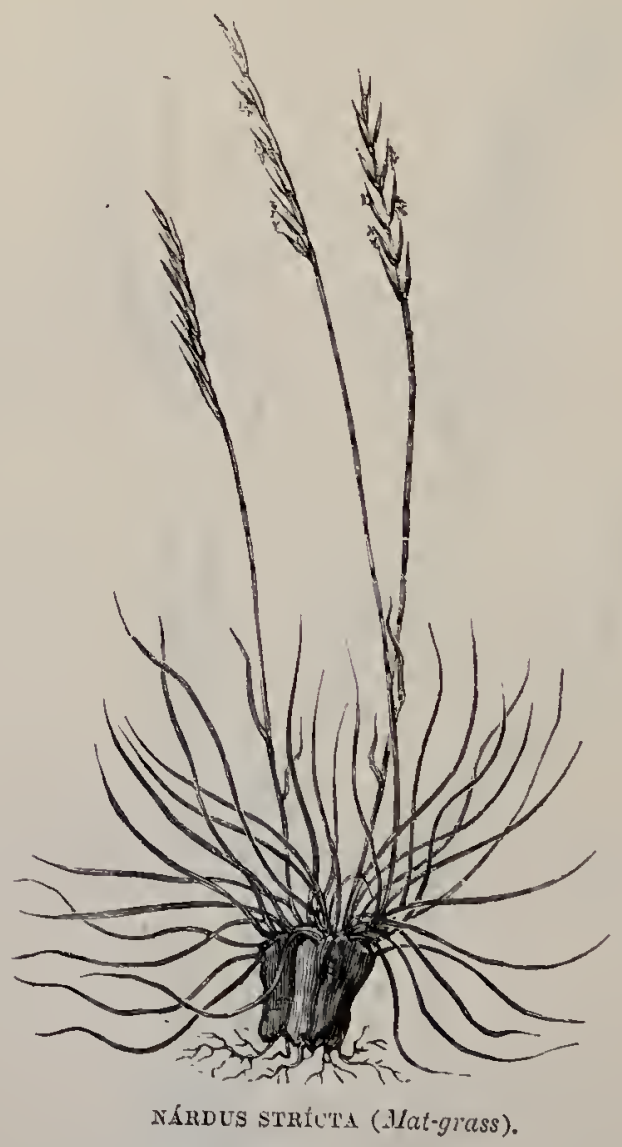

above; spilielets 5-12-flowered.-Sandy sea-shores; rare.-Fl. July. Perennial.

4. A. acritum (Acute Couch).-Loosely tufted; stems solid, bent betow; leaves much as in the pre- 
ceding; sprike long, lax, arching; spikelets 4-8. flowered; rachis very broad between the spikelets.Sandy sea-shores.-Fl. July, August. Perennial.

5. A. júnceum (Rnsh-like Couch).-- A prostrate, stiff plant, creeping extensively so as to form large patches, often glaucous ; stems ascending, smooth; lcaves leathery, involute, downy above; spile 2-4 in. long, curved, rather lax, with a brittle rachis; spitielets large, shining, pale, 4-8-flowered; glumes often obtuse._-Sandy sea-shores; local._-Fl. July, August: Perennial.

45. Leprónus, of which L. filifórmis (Sea Hardgrass) is the only British species, is a genus of slender grasses differing from Agropyyon in having 1-flowered spikelets. These are, as in that genus, solitary and sessile in the notches of the rachis, distichous, and placed with their broad sides towards the rachis, and are awnless. Our British species is a little glabrous, decumbent grass, 4-8 in. high ; leaves short, leathery, rough ; spitie 2-6 in. long, cylindric, slender, with a stiff, grooved rachis ; spikelets $\frac{1}{4}$ in. long, green. -Waste places near the sea; uncommon. (Name from the Greek leptos, slender, oura, tail, from its slender spikes.) - Fl. July_-September. Annual.

46. Núrdus (Mat-grass), of which N. stricta is the only species, is a densely tufted, erect, wiry, glabrous plant, 4-10 in. high, with fine, stiff, bristle-like lerves ; spike erect, slender, 1-3 in. high, 1 sided; spikelets reddish or purplish, rather far apart, solitary in the notches of the rachis, 1-flowered; outer glumes absent; flowering glume shortly awned; stamens 3; style 1.-Heaths; common. (Name from the Greek nardos, some strong-smelling plant; but why applied to this scentless grass it is difficult to say.) - Fl.June, July. Perennial. 
47. Hórdedr (Barley). - Spikelets 2 or 3 together in each notch of a simple rachis, sub-sessile, distichous, with their broad sides towards the rachis, each with one perfect flower; outer glumes and flowering glumes awned. (Name, the Classical Latin name.)

1. H. syluáticum (Wood Barley). - Stems 1-3 feet

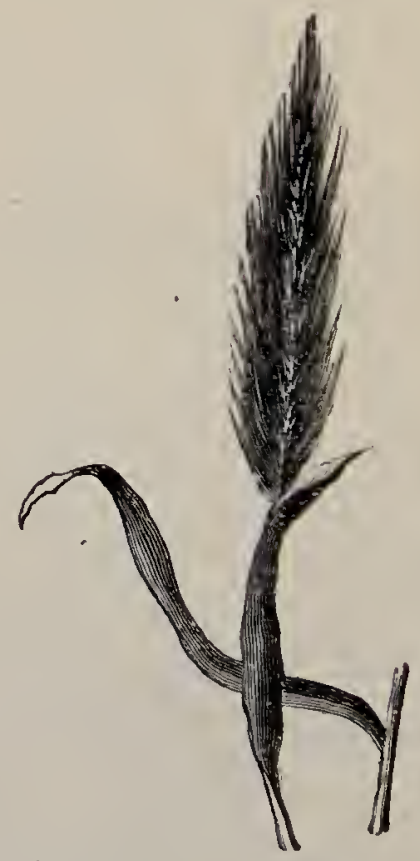

HóRdeUM MURíNuM (Tall Barley).

high, erect, smooth ; leaves broad, flat, thin, rough, with reflexed hairs on sheaths; spike cylindric, not very dense, about 3 in. long; spilielets 3 together; flovers of the two lateral spikelets in each notch perfect, the central spikelet reduced to two narrow, linear glumes, empty, or rarely containing a staminate flower; flovering glume terminating in a long awn.- 
Woods, on a calcareous soil ; rare.-Fl. July, August. Perennial.

2. H. secatinum (Meadow Barley).-Creeping; stems very slender, ascending, 1-2 feet high; leaves rather narrow; spitie $1-3$ in. long, close, cylindric, compressed, inclined, yellow-green ; spitielets 3 in each notch, the central one with a perfect flower, the two lateral ones imperfect; glumes all bristle-like, rough, with awns not longer than themselves.-Moist pastures; frequoxt.-Fl. June, July. Perennial.

3. H. murinum (Wall Barley).-A rather corrse grass; root fibrous; stem ascending, 6-18 in. high, smooth; leaves small, narrow, rough; spitie dense, cylindric, compressed, 1-3 in. long, slightly nodiling, green, thickly beset with long, rough awns; spilielets 3 in each notch, the central one with a perfect flower and linear-lanceolate, ciliate glumes, the two lateral ones with imperfect flowers and awn-like glumes.Waste places; common.-Fl. June, July. Annual.

4. II. marinum (Squirrel-tail Grass, Sea Barley). -Nearly allied to the prcceding but smaller and somewhat glaucous; spike 1-2 in. long, erect, with shorter, more spreading awns, becoming yellowbrown.- Pastures and banks near the sea in England, -El, June, July. Annual.

48. F́ Eurves (Lyme-grass), of which $E$. arenárius (Sand Lyme-grass) is the only British species, is a stiff, glaucous grass, with a long, creeping root-stock; stems 2-6 feet high, stout, smooth; leaves stiff, broad, pointed; spitie sometimes rather dense, $3-12$ in. long, with the spikelets in rather distant pairs, or 3 together in the notches of the flexuous rachis, each an inch long, imbricate, adpressed, inserted with their broad sides towards the raehis, 2-7-flowered, awnless; glumes lanceolate, stiff, generally downy, very pointed. 
896 GRAMÍNE.E.

-Sandy sea-shores, chiefly in the north.-Fl. July, August. Perennial.

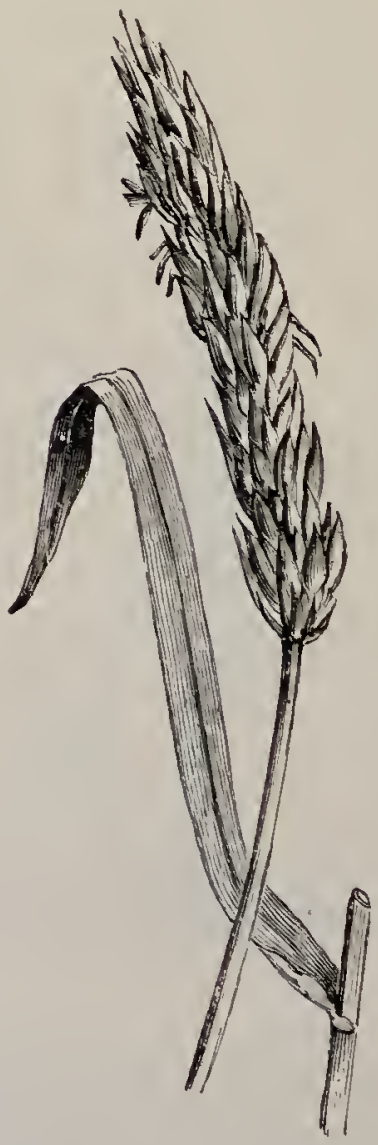

ELYMUS AREXIRILS (Sand Lyme-grass).

\section{DIVision II. GYMNOSPERMS.}

Having their seeds exposed, the carpels being either open so as not to form an ovary, or absent. 
They liave thus no style or stigma, the po!len-grains being carried directly into the micropyle of the ovule. This more lowly organised and, geologically speaking, more ancient Division of Flowering Plants is represented at the present day by far fewer forms than the Angiosperms; but falls into three very distinct classes, Coniferce, Cycadácece, and Gnetácece, of which the first only is represented in Britain, the other two classes being either tropical or sub-tropical. The three classes comprise 5 Natural Orders, 46 genera, and 470 species.

\section{CIASS T. CONÍFERAE.}

The largest of the three Classes of Gymnosperms, including 2 Natural Orders, 34 genera, and 350 species. They are trees or shrubs, mostly evergreen, often reaching a large or, as in the case of the Mammoth 'Tree and Redwood of California, a gigantic size. They have 2 cotyledons, sometimes deeply divided, so as to appear like many; and in the formation of annual rings of wood in the stem they resemble Dicotyledons. Resin-passages generally occur in all parts of these plants. The primary branches commonly appear to be whorled; but they generally themselves branch horizontally. There are sometimes short shoots or spurs of limited growth. In the genus Pinus foliage-leaves cecur only on such shoots. The leaves are either needle-shaped, linear, or scale-like, the only exception being the interesting Maiden-hair Tree of Japan (Ginkyo bitóba). The flowers are generally in the form of cones, that is, with an elongated florn axis, whence the name of the Class; and they are always imperfect; nor is there any perianth. Tho staminate flower consists of a cone of stamens, each of which is a flat or peltate scale bearing from 2-9 pollen-sacs on its lower surface. The seed-bearing or "fertile" flower differs widely in the two Orders. 
Ord. XCiI. Aradcariáce.e.-The Pine Family.

Lieaves spirally arranged or whorled, needle-shaped or scale-like; fertite flower, generally described as a "cone" or axis, bearing a number of scale-like carpels, which either bear the ovules directly, or have in their" axils other scales, the placentas, which bear them; ovules inverted or erect; cone becoming woody or fleshy as the seed ripens; seed with a woody or leathery testa, sometimes winged. The Arancariacece form extensive belts of forest in many regions, especially north of $40^{\circ} \mathrm{N}$. lat. and on mountains, large areas being sometimes occupied by a small number of species, such as the Larches (Lárir europrea and $I_{\text {. }}$. sibirica), the Northern Pine (Pimus syluestris), the Spruce (Picea excélsa), \&c. Japan and China, with the genera Cinntgo, Cryptomeria, \&c., the Himalayas, with the Deodar Cedar (Cédrus Deodára) and various species of Pine and Spruce, and the Pacific slope of North America, with the Mammoth Tree and Redwood (Sequóia gigántea and S. sempervirens), the Oregon or Douglas Spruce (Pseudotsiga Douglásii), Cupvéssus Lawsoniana, \&c., form other great centres of the Order in the Northern Hemisphere; whilst Araucária, the "Monkey-Puzzles," and other gener'a are confined to the Southern Hemisphere.

The Order is one of the highest utility to man. Among timber's, the Northern Pine (Pims syluestris), the Pitch Pine of the Southern United States $(P$. austrális) and others, the Lurch (Lairix europica) and the Douglas Spruce may be mentioned as pre-eminent. The turpentine of the Northern Pine, the Pitch Pine, and the Cluster Pine (P. Pináster); Canada balsam, obtained from Ábies balsámea; Isauri gum and other kinds of Dammar or varnish resin, obtained from species of Agathis in the Southern Hemisphere; the bark of the Hemlock Spruce (Tsuiga canadénsis), so 
largely used in tanning; and the wood of the so-called Pencil Cedars (Juniperus virginiana and $J$. bermudiana) are among the other valuable products of the Order.

1. Pínus.-Cone woody; scales persistent.

2. Juníperus,-Cone fleshy, berry-like.

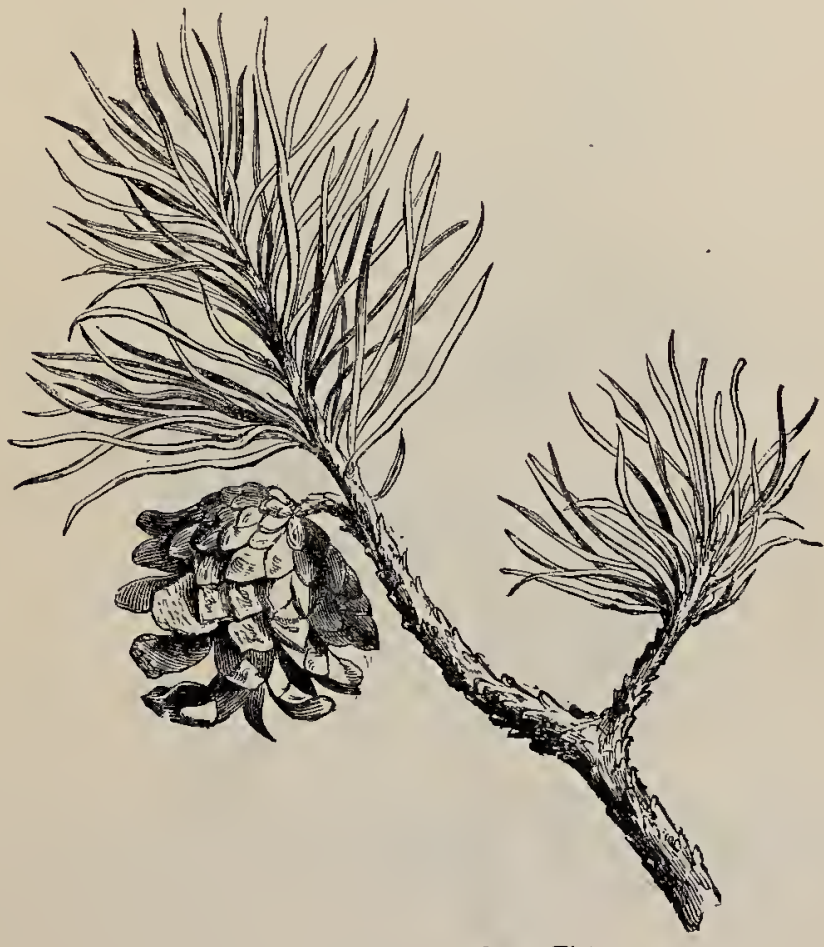

PfNUS SYLFÉSTRIS (Scots Fir).

1. Pírus (Pine).--Evergreen trees with leaves of two kinds, spirally arranged, scale-leaves on the long shoots, and needle-shaped leaves in elusters of 2,3 or 5 on short shoots; flowers monocious; staminate cones in spikes; stamens 2-chambered; pollen-grains with two air-bladders; cone-scales becoming woody and 
terminating above in a rhomboid mass (apophysis) with a deciduous point, persistent; outes 2 , inverted at the base of each scale. (Name, the Classical Latin name.).

1. P. sylvéstris (Scots Fir, Northern Pin 3 ).-A

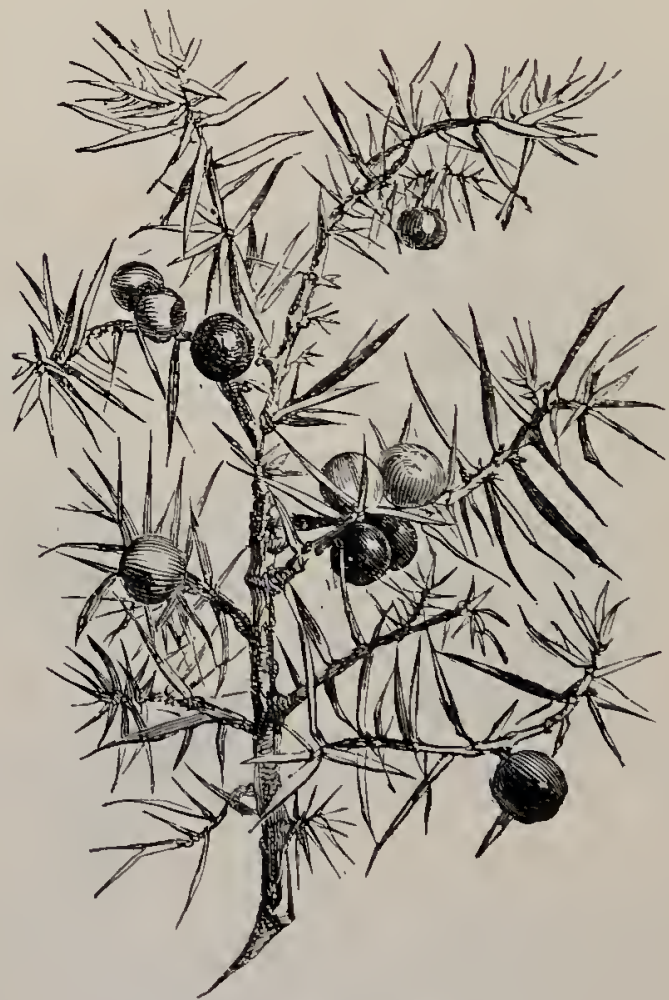

JUXíPERUS COMúxis (Common Juniper).

lofty tree, $50-100$ feet high; stem reaching 4 feet in diameter, with scaly, red-brown bark; leaves in pairs, $2-3$ in. long, glaucous, grooved along the upper surface; cones $1-3$ together, ovoid-conical when young, 1 -2 in. loug, scales recurved when ripe; seeds with a 
wing thrice their longth.--Only indigenous in the Northern Higllands of Scotland; but extensively planted and self-sown farther south._El. May, June. Perennial.

2.* P. Pináster (Cluster Pine), a native of Southern Europe, distinguished by its longer, more deeply channolled Teaves and cones 4-6 in. long, in clusters of $4-7$, has become almost naturalised at Poole, Dorsetshire.

2. Juníperus (Juniper).-Trees or shrubs, with fragrant red wood; leaves whorled, subulate, or scalelike; staminate flower of numerous 2-6-chambered anthers; cone small, globose, berry-like, of 4-6 whorled scales, becoming fleshy and confluent; ourtes 1 or 2 under each scale, erect. (Name, the Classical Latin name.)

1. J. commúnis (Common Juniper).-An evergreen, erect shrub, 1-5 feet high, rarely reaching the size of a small tree; bark red-brown, flaking; leaves subulate, less than an inch long, in decussating whorls of three, glaucous above; berry blue-black, glaucous, less than $\frac{1}{2}$ in. diam.-Dry hills, chiefly on calcareous soil; frequent.-Fl. May, June, Perennial.

2. J. nána (Dwarf Juniper).-A prostrate shrub, witl more crowded, shorter, broades", incurved leaves and longer bervies.-Mountains in the north.-Fl. May. Perennial.

\section{Ord, XCiII. Taxácee,-The Yew Family.}

A small Order of trees and shrubs, represented in both hemispheres and comprising 9 genera and about 75 species. Their flower's are diocious and they do not form perfect cones, the ovnles being frequently not on the carpels but in their axils, or the carpels being 
altogether absent. The seed has either a fleshy testa, or is surrounded by a fleshy aril. Several members of the Order yield valuable timber, such as the Huon

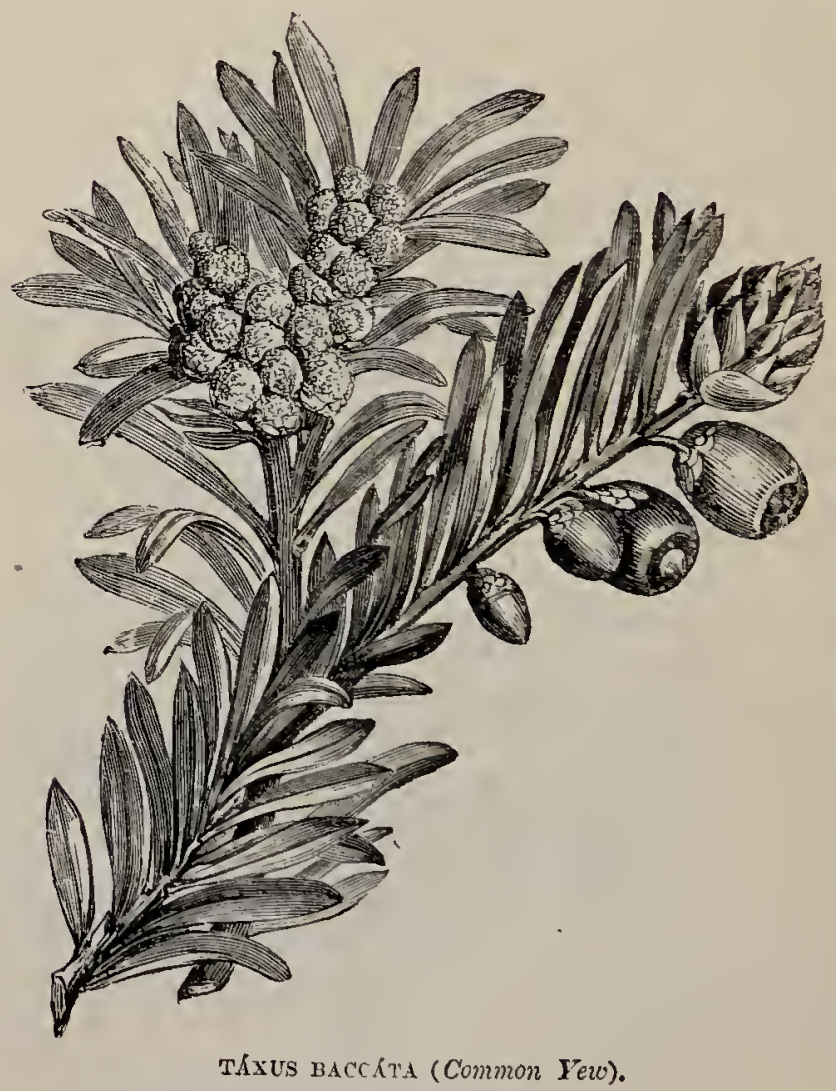

Pine (Dacrýlium Frantilinii) of Tasmania. The Yews (Táxus) are remarkable among Conifera for the absence of resin.

1. Táxus, of which T. baccúta (Common Yew) is the only British species, is an evergreen tree, seldom of 
any great height, but reaching a great age, probably sometirnes 2,000 years, and a diameter of nearly 10 feet; bark brown, fibrous; leaves linear, acute, leathery, about 1 in. long, polished above, lighter beneath, in 2 rows on the twigs from a twisting of their bases; staminate flower oval, witl 5-8 peltate anthers each 4-8-chambered, with imbricate scales below; ourte solitary, terminal, erect, green, with some scales below, surrounded later by a bright rose-red, fleshy, cup-shaped arit, about $\frac{1}{2}$ in. across.--Woods and hillsides, chiefly on calcareous soil; frequent. The wood was formerly much used for bows. The leaves have often proved fatal to cattle and children; but the aril, though insipid, is harmless. (Name, the Classical Latin name.)-Fl. Marcl, April. Perennial.

* TI. fastigiata (the Irish or Florence Court Yew), originally found at Florence Court, Enniskillen, is a variety with erect, fastigiate branches. 



\section{INDEX ACCORDING TO I'HE LINNTEAN SYSTEM.**}

Class 1. MonÁnDria : stamen 1. Order. 1. Monog ÝniA : carpel 1. Alchemílla, 221.

Hippúrís, 263.

Centránthus, 35 t.

Salicórnia, 621 .

Zostéra, 782 .

Nájas, 783.

Ord.2. DIGINIA : carpels 2. Callitriché, 265.

Class 2. DIÁNDria : stamens 3.

Oid. 1. Monogŕnia: carpel 1. Circéa, 273.

l'ríxinus, 481.

Tigústrum, 482.

Verónica, 548.

Utriculá1'ia, 560 .

P’inguíctua, 561 .

Lýcopus, 572.

Sillvia, 579.

Lémna, 764 .

Wolffa, 765 .

Ulass 3. TRIÁNDRIA : stamens 3.

Ord. 1. Monogínia : carpel 1.

Valeriána, 352.

Volerianélla, 35 .

Irídere, 709.

Jíncus, 747.

Many Cyperácex, 785.

Ord. 2. DIGÝrIA : c.rpels 2. Gramíneæ, 825.

Ord. 3. Trigrinia : carpels 3.

Holósteum, 107.

Polycárpon, 123.

Móntia, 124.

Tillǽa, 249.

Class 4. TeTrándRIA: stamens 4, of ecital length.

ord.1. Monogŕnia : carpel 1.

Epimédium, 29.

Cardamíné, 55.

Cor6nopus, 73.

Euónym $15,157$.
Alchemílla, 221.

Potérium, 224.

Ludwígia, 271.

Córnus, 332.

Rúbia, 343.

Gálium, 315.

Aspérula, 349.

Sherárdia, 35 ?.

Dipsacus, 358.

Scabi6sa, 359.

Centúncialus, 473 .

Microcála, 4 S8.

Gentiána, 491.

Cicéndia, 491.

Méntha, 568.

Thýmus, 574 .

Origanum, 574.

Plantágo, 608.

Parietária, 64.

Thésium, 649.

O1·d. 2. DIGÝNIA : carpels 2.

Gentiána, 491.

Cúscuta, 517.

Ord. 3. Tetragínia : calpels 4. Cerístium, 109.

Sagina, 119.

Radíola, 140 .

Ílex, 151 .

Tilléa, 249 .

Potamogéton, 773.

Rúppia, 780.

Class 5. PENTÁNDRIA : stamens 5.

Ord. 1. MONOGÝNIA : carpel 1.

Vío'a, 89.

Impátiens, 150.

Euónymus, 157.

Rhímnus, 159.

Ríbes, 246.

Hédera, 329.

Lonicéra, 310.

Campanuláceæe, 435 .

Loiseleviria, 4.58.

Primuláceæ, 466.

Vínca, 48 .

Erythréz, $48 ̊ 9$.

* The number's refer to the pages. 
Mrnyántbes, 491.

Limnúnthemum, 493.

Polemónium, 496.

Boragíneæ, 198.

Vólvulus, 515.

Conv6lvalus, 517 .

Solanáceæ, 519.

Verbáscủm, 528 .

Illécebrum, 607.

Thésium, 618.

Ord. 2. DIGÝNIA : carpels 2.

Umbellíferæ, 278 .

Gentiána, 491.

Cúseuta, 517.

Herniária, 608.

Scleránthus, 609.

Chenopódium, 613.

Béta, 616.

Sú́da, 622.

Sálsola, 622 .

Polýgonum, 6:4.

Ulmus, 639 .

Ord. 3. Trigrinia : carpels 3.

Holósteım, 107.

Stellária, 112.

Búda, 122.

Claytónia, 124.

Támarix, 125.

Sambiclis, 335.

Vibrirtum, 338.

Corrígiola, 608.

Chenopódium, 613.

Ord. 4. Tetragrini : carpels 4. Parnássia, 246.

Ord. 5. Prentagínia : carpels 5. Cerístium, 109.

Spérgula, 122.

Liume : 10.

Potentílla, 2ls.

Stíticé, 461.

Arméria, 465 .

Ord. 6. Hexagínia : carpels 6. Drósern, 256.

Ord. 7. POLYGÝNIA : carpls many.

Myosinns, 10.

Class 6. Hexánnta: stamens 6, of equal length.

Ord. 1, Monogínia: carpel ].

Bérberis, 28.

Frankénia, 96.

Péplis, 258.

Lýtlirum, 259.

Polýgonum, $6: t$

Amaryllidese, 715 .

Liliáces, 723 .

Jincácere, 746.

Ácoras, 763.

Ord. 2. DIG ívia: carpels 2. Oxýria, 630 .
Ord. 3. ThIG ÝNIA: carpels 3. Jlatíné, 127.

Rúmex, 630 .

C6lchicnm, 7 t?.

Tofiéldia, 744 .

Triglóehin, 7it.

Scheuchzéria, 73.

Ord. 4. Hexagrina : carpels 6. Damasónium, 763 .

Ord. 5. POLIGrista: carpels mauy.

Alísma, 767 .

Elísma, 707.

Class 7. HePtínnRA :stamens 7.

Ord. 1. MIONOGÍNIA: earpel 1. Trientális, 475.

Class 8. OCTÁnNRIA : stamens 8.

ord. 1. Monogris: carpel 1.

Ácer, 161.

Epilóbinm, :68.

Euothéra, 272.

Taccínium, 46.

Schóllera, 145.

Calluna $15 ?$

Eríca, 451.

Bryinthns, 159.

Borétla, 459.

Hspopitys, 463.

Blackstónia, 488.

Dáphné, 636 .

Ord. 2. DIGÝria : carpels 2.

Chrysospléninm, 24.

Sclerántlus, 609 .

Polýgonum, 624 .

Ord. 3. Triginia : cripels 3.

Polýgonum, 62*.

Fagonร́rาu, 629.

Ord. t. Tetragrinia : campls 4. Cerístium, 109 .

Elatíué, 127.

Adóxn, 33t.

Piris, $7+5$.

Class 9. FNNRíndRIA : stamens9.

Ord. 1. Hexagrisia : carpela 6. Hydrócharis, 684.

Butomns, $7 \% 0$.

Class 10. DECínDria : stamens 10.

Grd. 1. Monogŕnia : carpel 1.

Vacciuium, 446 .

Schóllera, 448.

Árbutus, 450 .

Andiómeda, 452 .

Bryínthus, 459 .

Borétta, 459 .

Pyrola, 459.

Monéses, 461.

II ypópitys, 453 . 
Ord. 2. DIGÝNIA: carpels 2.

Diánthus, 98.

Saponária, 101.

Saxifraga, 240.

Chrysosplénium, 244.

Scleránthus, 609 .

Yolýgonum, 624.

Ord.3. TrigÝnIA : carpels 3.

Siléné, 102.

Stellaria, 112.

Arenária, 115.

Polygonum, 624.

Ord.4. PENTAGÝNIA : carpels 5. Siléné, 102.

Lýchnis, 105.

Ceréstium, 109.

Stellária, 112.

Óxalis, 150.

Potentílla, 215.

Cotylédon, 249 .

Sédum, 251.

Adoxa, 334.

Class 11. DODFCÁNDRIA : stamens 12-18.

Ord. 1. Monorínia : carpel 1. Lýthrmın, 259.

Ksarum, 645.

Ord. 2. DrgÝNIA : carpels 2. Agrimónia, 222.

Ord. 3. TrigíniA : carpels 3. Reséda, 85 .

Orỏ. 4. Terrag'́nia : carpels 4 . Potentílla, 215.

Ord. 5. DODECAGÝnIa : carpels 12.

Sompervirum, 255.

Clnss 12. I 0 s $A$ NDRIA : stamels 20 or more, perigynous.

Rasáceæ, 199.

Class 13. Polyándria: stameus 20 or more, liypogynous.

Ord. 1. MonogŕxIs: calpel 1.

Delphinium, 24.

Actáea, 27.

Nymphǽa, 30.

Castália, 32.

Papaveráceæ, 33.

Heliánthemnm, 87.

Tília, 138.

Ord. 2. Pentragŕnia: carpels $2-6$.

Ranunculáceæe, 2.

Reséda, 85.

Ord. 3. POLYGÝNIA: carpels many.

Ranuveuláceæ, 2.
Class 14. Didrnámia: stamens 4, 2 louger than the other 2.

Linnǽa, 340.

Scrophularínæ, 526.

Orobánché, 554.

Lathræáa, 557.

Verbéna, 563.

Labiáte, 565.

Class 15. Tetradrámia : stamens 6,4 long and 2 short.

Crucíferæ, 43.

Class 16. MoNADÉLPHIA : stamens all united by tlieir filaments.

Or.d. 1. Pentándria : stamens 5.

Línum, 140.

Gerห́nium, 143.

Eródiım, 147.

Oid.2. DECÁniria: stameus 10. Geránium, 14:3.

Óxalis, $15^{\prime}$.

(Yenísta. 166.

Úlex, 168.

Cýtisus, 169.

Onónis, 171.

Anthýllis, 183.

Ord. 3. POLYÁNDIIA: stamens 20 or more.

Malvácero, 132.

Class 17. Diadélphia: stamens united by their filaments into 2 sets.

Ord. 1. Hexíndria : stamens 6. Tíckéria, 40.

Fumária, 41.

Ord. 2. OCTANDRIA: stamens 8. Polýgala, 93.

Ord. 3. DECÁNIDRa : stamens 10. Leguminósহe, 162 .

Class 18. Polyadílphia: stamed nuited by their filaments into 3 or more sets.

Hypéricum, 128.

Class 19. SxNGENÉsia: stamens nnited by their anthers: inflorescence a head.

Compósita3, 361.

Lobélia, 433.

Jasíoné, 438 .

Class 20. GynánDRIa: stamens united witl the carpels in a central columu.

Aristolochia, 645.

Orchídex, 687. 
Class 21. Mor ẾCIA : stamens and carpels in separate flowers on the same piant.

Ord. 1. Monándria : stamen 1. Euphórbia, 65 .

Callítriché, 265.

Árum, 761.

Zannichéllia, 781 .

Zostéra, 782.

Ord. 2. DIKNDRIA : strmens 2.

Callítriché, 265.

Lémna, 764 .

Wólffia. 765.

Cárex, 801.

Ord. 3. TRIKNDRIA : stamens 3 . Amarántlius, 611.

Týpha, 757.

Spargánium, 757.

Cyperáceæ, 785.

Ord. 4. TETR N NDRIA : stamens 4. Littorélla, 606.

Urtíoa, 612.

Parietária, 614.

Búxus, 660 .

Myríca, 664 .

Álnus, 669 .

Eriocaúlon, 73t.

Ord. 5. PENTÁNDRIA: stamens 5. Amaránthus, 611.

Átriplex, 618.

Ord. 6. PoLYÁNDRIA: stamens more than 5 , distinct.

Potérium, 22.

Mýrioplıyllum, 263.

Ceratoplýllım, 662 .

Cupulífere, 66t.

Arum, 761.

Sagittária, 768.

Ord. 7. MONADÉsPHA : stamens many, united.

Pinus, 899.

Class 22. Dr б́cra: stamens and carpels on different plants.

Ord. 1. DIÁNDRra : stamens 2. É́lix, 676 .

Ort. 2. TRIÁNDRIA : stamens 3. Valeriána, 352.

Ėmpetrum, 631 .

Sálix, 676 ,
Rúsens, 726 .

Flodéa, 633.

Old. 3. TETRÁNDRTA : stamens 4.

Rhámnus, 159.

Hippóphaê, 637.

Urtíca, 642.

Víscum, $6 \pm 6$.

Myríca, 664.

Ord.4. PeNTáNDRLA : stamens 5.

Ríbes, 246.

Bryónia, 276 .

Húmulns, 640.

Sálix, 676 .

Ord. 5. HEXáNDRIA : stamens 6.

Rúmex, 630 .

Támus, 723 .

Ord. 6. OCTÁNDRIA : stamens 8. Sédum, 251.

Pópulns, 680.

Ord:7. ENNEŔNDRIA : stamens9. Mercuriális, 661.

Ord. 8. Drcáx DRIA: stamens 10. Lýchnis, 105.

Ord. 9. PoLYíndRIA : stamens many.

Pópulns, 680.

Stratiótes, 656.

Ord.10. MoNanÉrpHIA; strmens muited in one set.

Juníperus, 901.

Táxus, 902.

Ord.11. PolfadélphI: stumens united into 3 sets.

Brý́nia, 276.

Class 23. Polygímia : Howers of 3 kinds, perfect, staminate and carpellate.

Atriples, 618.

Class 24. Cryptogáma : this Class, hy far the most es. tensive, comprises all plants in which stamens and carpels cannot be detected, viz., Fcrus, Mosses, Liverworts. Fungi, and Sea-weeds, none of which are described in this work. 


\section{GENERAL AND GLOSSARIAL INDEX.}

The names of Orders and larger groups are in small capitals; the scientific or Latin names of genera ln italies; the popular or English names in Roman characters; descriptive terms begin with small letter's and are indented.

Abele, 680 . accumbent cotyledons, 44 . Acer, 161 .

ACERÍNEE, 159. achene, xxvi. Achilléa, 380 .

ACHLAMÝDEÆ, xlix., 649. achlamydeous flowers, xvi.

Aconite, Winter, 22.

Aconitum, 25 .

Ácorus, 763 .

Actrea, 27. acuminate, with a long tapering point.

Adder's-meat, 114. adnate, united.

Aclónis, 10.

Adóxa, 334.

adpressed hairs, xii.

adventitious roots, ii.

Agopódium, 303.

aerrial stem, one that is above ground, iv., v.

astivation, $\mathrm{xxi}$.

Athúsa, 316.

Agrimónia, 222.

Agrimony, 222.

Agroptron, 890.

Agróstis, 84t.

Aira, 851.

Ajuga, 600 .

albumen, the food-store round the embryo in the seed.

Alchemílla, 221.

Alder, 665, 669 .

Alder, Berry-bearing, 159.

Ale-lioof, 582 .

Alexanders, 29:.

Alfa-grass, 828 .

Alísma, 7067.

ALISMACE, 760。

Alkanet, 503 .

Alleluia, 150.

Allium, 731.

All-seed, 123, 140.
Almond, 200.

Almus, 669.

Aloe, American, 716

Aloes, 724.

Alopecúrus, 839.

Althere, 133.

Alýssum, 67.

Amaranth, 611 .

AMARANTH FAMLLY, 611.

AMARANTHÁCE $E, 611$.

Amaránthus, 611 .

AMARXLLLDEE, 715.

AMARYLIIS FAMILY, 715.

Ánimi, 299.

Ammóphila, 850.

amplexicaul, embracing the stem, applied to the base of leaves.

Anaguillis, 477.

Anáphalis, 378.

Anchisa, 503.

Andróneda, 452.

Anemóne, 7, 10.

Angélica, 281, 320.

angiosperms, xxxii,, xxxviji., 1.

angustisept siliqua, $4 \pm$.

annular, ring-shaped.

Antemnárin, 377.

Anthemis, 387.

anther, xxii,, $x \times i i i$.

Anthoxánthum, 837.

Anthríscus, 311.

Anthýllis, 183.

Antirrhínum, 533.

autiscorbutic, 44.

Apéra, 848.

apiculate, with a small abrupt point.

Apium, 296.

apocarpous carpels, xxiii., xxiv.

apocarpous fruits, xxvi.

APOCYNACEF, 484 .

Apple, 236.

Aquilégia, 22.

Arabis, 53. 
ARALIÁCEE, 329.

ARAU CARIÁCEA, 898.

Arbutus, 450 .

Archangel, 597.

Archangélica, 321.

Árctium, 405.

Arctostiphylos, 451.

Areniria, 115.

aril, a fleshy outgrowth on the seed, as in the Spindle-tree, 157.

Aristolóchia, 645 .

ARISTOLOCHIÁCE

Armeric, 465 .

Anzoseris, 417.

AROIDEE, 759 .

Arrhenútherum, 859.

Arrow-grass, 771.

Arrow-head, 768 .

Artemisia, 393.

artificial system, xxx., xxxi.

Artum, 761.

Asarabacca, 64t, 645.

Asarum, 645 .

ascending stem, $v$.

Asli, 481.

Ash, Mountain, 234.

Aspáragus, 728.

Aspen, 682.

Asperugo, 501.

Asperula, 349.

Asphodel, Bog, 744.

Aster, 373.

Astrigalus, 186.

Astrintic, 289.

asymmetric Howers, xvii.

Atriplex, 618.

Atropa, 520, 524 .

Alicubr. 331.

auricle, an ear-like lobe at the base of a leat.

Avena, 85\%.

Avens, 212.

Awl wort, 71 .

awn, a long bristle-like appen. dage, 826 .

axil, iii.

axile-placentation, having the seeds attached to the central axis of the fruit.

axillary bud, iii.

Azalea, 458.

hacente, berry-like.

Bald-money, 318.

B̈illota, 598.

Balm, 578.

Ba'm, Bastard, 585.

Palsam, 150.

33aneberry, 27
Barbarea, 51.

Barberry, 28.

BARBERRI FAMILX, 28 .

Barley, 827, 89․

Barrenwort, 29.

Buirtsia, 541 .

basal, applied to ovules or seeds that spring trom the base of the oraly, xxir.

kasifixed anthers, $x x i i$.

Basil, 576 .

bast. 139 .

Beak sedge, 799.

Beam, White, 232.

Bearberry, 451.

Beard-grass. 846.

Bear"s-foot, 22.

Bedstraw, $313,3+5$.

BEDSTRAIT FAIILY, 342.

Beech. 666, 674.

Beet, 612, 616 .

Belladomma, 520,521 .

Bell-flower, 412.

BELL-FLOWER FAIILX, 435.

Bellis, s73.

Bent, 844 .

BERBERÍDE. 28.

Berberis, $2 \mathrm{~s}$.

Bermuda-grass, 8631 .

berry, xxvii.

Bita, 612,616 .

Betoliy, 588.

Betula, 666.

Bidens, 383.

vifid, notched, tro-lobed.

bi-labiate calyx, xviii.

bi-labiate corolla, $\mathbf{x x}$.

Bilberry, 416.

Bindweed, 515.

Biudweed, Black, 625 .

BINDWEED FAMIL: 514 .

bi pimate leaf, $r i$.

Birch, 665, 666 .

Bird's.eye, 550.

Bird's.foot, 187.

Bird's-foot Trefoil, 184.

Bird's-nest, 463.

BIRD'S-NEST FAIILY, 461 .

Birthwort, 645 .

BIRTIIWORT FANILY, 64.

Bishop's-weed. 304.

Bistort, 629.

Bittersweet, 522.

Blackberry, 208.

Blackstónia, 488.

Blackthorn, 202.

Bladder Campion, 102.

Bladder-seed, 291.

Bladderwort, 560 .

Blinks, Water, 125. 
Blite, Sea, 622 .

Blobs, Water, 19.

Blu ebell, 444, 737.

Blue-boitle, 413.

Bog-bean, 494.

Bog-rush, 800.

Borage, 502 .

BORAGE FAMILY, 498.

BORAGÍNE-E, 498.

Borágo, 502.

Borétta, 459 .

Box, 654, 660 .

Brachypódium, 888.

bract, xiii, xiv.

bracteoles, minute bracts below the flower.

Bramble, 208.

Brandy-bottle, 31 .

Bread-fruit, 638.

Briar, Sweet, 228.

Bristle-grass, 833.

Bríza, 869.

Brome, False, 888.

Brome-grass, 882.

Brómus, 882.

Brooklime, 553.

Broom, 369.

Broom-rape, 554 .

BROOM-RAPE FAMILY, 553.

Bryainthus, 459.

Bryonzia, 276.

Bryony, Black, 728.

Bryony, White, 276.

Buck-bean, 494.

Buckthorn, 159.

BUCRTHORN FAMILY, 157.

3uckthorn, Sea, 637.

Buckwheat, $624,625,629$.

Bída, 122.

Bugle, 600 .

Bugloss, 505 .

Bugloss, Viper's, 512.

bullb, iv.

Bullace, 203.

Bulrush, 746, 757, 785, 792.

Bupleúrum, 294.

Buplever, 294.

Burdock, 405.

Burnet, 224.

Burnet Saxifrage, 304.

Bur-Marigold, 383.

Bur-Parsley, 327.

Bur.reed, 757.

Bürsa, 72 .

Burweed, 353.

Butcher's Broom, 726.

Bútomus, 770.

Butter-bur, 396.

Buttercup, 16.

BUTTERCUP FAMLLY, 2.
Butterwort, 561.

BUTTRRWORT FAMILY, 558.

Cabbage, 63.

CABBige FAMilT, 43.

caducous calyx, xviii.

Cakílé, 83.

Calamagróstis, 846.

Calamint, 576 .

Calaméntha, 576.

Callétriché, 265.

Callína, 452.

callus, a swelling overgrown with cork.

Ceither, 19.

Calyciflore, xli., 154.

calycifloral insertion, $x$ viii.

calyx, xv., xviii., xix.

Campinula, 142.

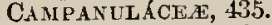

campanułate, bell-shaped.

Campion, 105.

Canary-grass, 836.

Candleberry My rtle, 66t.

Candy-tuft, 79.

Cauterbury Bells, 412.

capillary filaments, $x x i i$.

capitate, head-like, clustered. capitate stigma, 466 .

CAPRIFOLIACE.X, 333.

capsule, $\mathrm{xxvi}$.

Caraway, 800 .

Cardumüné, 55.

Cárduus, 406.

Cárex, 801.

Carlína, 402.

Carnation, 100.

Carnation-grass, 817. carpellate flowers, $x v i$. carpels, $x \times i i i,-x \times v$.

Carpinus, 670. carpophore, an elongated floral axis extending between the carpels, as in the Geríniex, p. 142 , and Umbellíferæ, p. 278 .

Carrot, 325 .

Cárum, 300.

CARYOPHYLLÁCE, 96. caryopsis, xxvi., 827.

Cistália, 32.

Castínea, 674.

Castor-oil, 654.

casual, a plant not truly wild, that occurs occasionally as a seedling for a year or two, but does not become established.

Catabrósa, 866.

Catchfly, 102. catkin, xiii.

Catmint, 581 . 
Cat's-ear, 425.

Cat's-foot, 378 .

Cat's-tail, 757.

Cat's-tail grass, 812.

Caúcalis, 327 . cauline leaves, ix.

Cayenne pepper, 521.

Cedar, 898, 899.

Celandine, $19,38$.

Celastrinese, 155.

Celery, 297.

Centaúrea, 413

Centaury, 489. central placentation, $\mathrm{xx}$.

Centúnculus, 478.

Century plant, 716 .

Cephalänthera, 696 .

Cerćstium, 109.

CeratophÝlLE. 661.

Ceratophyllum, 662 .

Charophyllum, 307.

Chaffweed, 478 .

chambers of the ovary, xxiv.

Chamomile, 387, 392.

Charlock, 65,66 .

Charlock, White, 84 .

Cheiränthus, 49.

Chelidónium, 38.

CHENOPODIÁCE. 612.

Chenopódium, 613.

Cherry, 199, 202, 205.

Cherry, Cornelian, 331.

Cherry, Winter, 521.

Chervil, 307, 311 .

Chestnut, 666,674 .

Chickweed, 113.

Ohickweed, Jagged, 107.

Chickweed, Mouse-ear, 109.

Chicory, 415 .

Chimney-sweeps, 755 .

Chives, 732 .

chlorophyll, the green colour. ing-matter of leaves.

Chrysainthemum, 389 .

Chrysosplénium, 244 .

Cicely, Sweet, 306.

Cicéndia, 491

Cichórium, 415.

Cicúta, 299.

cilia, delicate hairs.

ciliate, fringed with hairs.

Cinchóna, 342.

Oinquefoil, 215.

CISTINE, X, 87.

Circéa, 273.

circiriate, coiled up like a pas. toral staff, as in the leaves of ferms.

Clâdium, 800 .

cladode, 726 .
Clary, 579.

claw of petal, xix.

Claytónia, 124.

Oleavers, 347 .

cleistogene flowers, these which do not open, 89.

Clématis, 4.

Cloudberry, 211.

Clove Gillyflower, 100.

Clover, 177.

Club-rush, 789.

Crícus, 408.

cocci, or nutlets, portions of a partially dehiscent fruit, 133.

Cochleária, 68.

Cock's-comb, 515.

Cock's-foot grass, 827,867 .

Coffee, 312 .

Cólchicum, 724, 742 .

Cole-seed, 63.

Colocynth, 275.

Colt's-foot, 396.

Columbine, 22.

Comfrey, 501.

coinmissure, 278.

complete flower, $x \mathbf{x i}$.

Conpósite 361 .

Conposite Family, 361.

compound flowers, xiv.

compound inflorescence, xiv.

compound leaf, xi.

conduplicate leaf, viii.

cone, 898.

CoxífER.E, lii., 897.

Conium, 293.

connate leaves, $\mathbf{x}$.

connivent, with tips approach-

ing one anotlier.

Conopódium, 300 .

contorted petals, xxii.

Convallíria, 730.

convolute leaf, viii.

convolute petals, xxii.

CONYOLVuláce.玉, 514 .

Convolvulus, 517.

Coraltorhi za. 691 .

Ooral-root, 691. cordate, heart-shaped, generally applied to the base of a leaf.

Cord-grass, 834.

Coriander, 325.

Coriúndrum, 325.

cork, 665 .

corm, iv.

CORNACE. Е, 331.

Coru-Cockle, 106.

Oornel, 332.

Cornflower, 413 .

Corn Marigold, 389

Corn-salad, 354 . 
Cornus, 332.

corolla, $\mathrm{xv}$., xix.-xxi.

Corónopus, 73.

Corrigíala, $60 \mathrm{~s}$.

Corydalis, 40.

Córylus, 671 . corymb, xiv. corymbose, resembling a corymb. Cotoneáster, 238.

Cotton, 132.

Cotton-grass, 798.

Cotton-weed, 386.

Cótula, 393.

Cotylédon, 249. cotyledons, xxvii., 1.

Couch-grass, 890 .

Cowbane, 299.

Cowberry, 446.

Cow-Parsnip, 323.

Cowslip, 469.

Cow-tree, 638.

Dow-wheat, 546.

Crab-weed, 621 .

Crakeberry, 651.

Crámbé, 82.

Cranberry, 448.

CRANBERRY FAMTLY, 445.

Crane's-bill, 143.

Crane's-bili, FaMILX, 142.

CRASSULÁCE E, 248.

Cratégus, 236.

Creeping Jenny, 474. cremocarp, xxvii., 278. crenate leaf, $x$.

Crépis, 420.

Cress, 75 .

Cress, American, 53.

Cress, Bitter, 55, 57, 58 .

Cress, Rock, 53.

Cress, Thale, 57, 60 .

Cress, Wall, 60.

Oress, Winter, 51.

Cress, Yellow, 51.

Crithmum, 314.

Crócus, 713, 742 .

Crosswort, 345.

Croton-oil, 654.

Crowberry, 651 .

CROWBERRY FAMILY, 649.

Crowfoot, 13.

CruCfFer $\approx, 43$. cruciform corolla, xix. crumpled petals, xxii.

Cuckoo flower, $55,56$.

Cuckon-pint, 761 .

CUCKOO-PINT FAMILY, 759.

Cucumber, 276.

Cuczerbitácea, 275.

Cudweed, 375.

cupule, xv., 665 .
CUPULfFer. 664 .

Currant, 246.

Cúscuta, 517.

Cut-grass, 835.

Cýclamen, 472.

cyme, xiv.

Cynoglóssum, 499.

Cynosúrus, 864 .

CYPERACE $A, 785$.

Cypérus, 786.

Cyphel, Mossy, 119.

Cypripédium, 709

cypsela, xxvi,

Cytisus, 169 .

Dictylis, 867.

Daffodil, 717.

Daisy, Common, 373.

Daisy, Moon, 390.

Daisy, Ox-eye, 390.

Damasónium, 769 .

Dammar, 898.

Dandelion, 429.

Danewort, 338.

Dáphné, 636.

DAPHNE FAMILY, 634.

Darnel, 890.

Datúra, 524 .

Daúcus, 325.

Dead-nettle, 593.

deciduous calyx, xviii.

deciduous leaves, xii.

decompound leaves, $\mathbf{x i}$.

decumbent, prostrate.

decurrent, $x$.

decussate, applied to opposite or whorled leaves when the successive pairs are at right angles, or the successive whorls al ternate.

Deer's-hair, 789.

deflexed, bent downwards.

Delphínium, 24. deltoid leaf, ix., $x$.

dentate leaf, $x i$.

Deodar, 898.

Deschámpsia, 852.

descent, theory of $\mathrm{xxx}_{\text {. . }}$

diadelphous, in two brotherhoods or bundles, applied to the stamens, as in Fumariáceæ, 40.

Diainthus, 98.

dischasial cymes, cymes repeatedly forking into two. branches.

dichotomous, forking in two equal branches.

dicotyledonous seed, xxvii.

DICOTYLÉDONS, xxxii., xxxviii., 1. 
didynamous stamens, xxii.

Digitulis, 527, 540 .

dicecious flowers, $x v i$.

DIOSCÓRE.E, 72]

Diótis, 386.

Diplotaxis, 65.

DIPSÁCE.E, 356.

Dípsacus, 358.

disk. all outgrowth from the floral receptacle between the caly $x$ and the ovary.

disk-florets, 362.

distaut, far apart.

distichous, in two vert ical rows, as are the leaves of Grasses.

vittander, 75.

Doab-grass, 861.

Duck, 624, 630.

Dodder, 517.

Dog's-tail, 864. .

Dog's-tooth grass, 860 .

Dogwood, 159, 333 .

DUGWOOD FAMILY, 331.

Doronicum, 398.

dorsitixed anther's, xxiii.

Dríba, 67.

Dragon's Blood, 721.

Dropwort, 207.

Dropwort, Hemlock, 316.

Dropwort, Parsley, 316.

Dropw ort, Sulphur-wort, 315.

Dropwort, Water-, 31 .

Drósera, 256.

DROSERÍCE

drupaceous, resenbling a drupe. drupé, xxvi.

drupel, xxvi.

Ditgres, 212.

Duckweed, 764 .

DUCK WEED FAMILY, 764.

Dyer's Rocket, 85.

ebracteate inflorescence, xiv.

Echium, 512.

eglandular, without glands.

ELEAGNACEIE, 636.

Elatíné, 127.

ELATINEA, 127.

Elder, 335.

Elder, Water, 339.

Elecampane, 380

Eleóchar'is, 788.

Elisma, 767.

Elm, 638, 639.

Elodéa, 6 R3.

Elymus, 895 .

emarninate, notched at the apex.

embryo, the young plant when still euclosed in tlie seed.
EMPetríce E, 649.

Empetrum, 651 .

Enchanter's Nightshade, 273.

endocarp, the inner layer or " stone" in a fruit, 199.

entire leaf, $x$.

epicaly $x$, a circle of bracts below the calsx.

epicalp, the outer layer or " skin" in a fruit, 199 .

epigy nous insertion, xvili.

Epilóbium, 268.

Epimédizim, 29.

Epipactis. 697.

epipetalons stamens, sxii.

epiphytes, 687.

Epipogrim, 696.

Eriuthis, 22.

Erica, t54.

ERICÁCE.玉, 448.

Erigeron, 375.

ERIOCAĹLE.土, 781.

Eriocaúlon, 784.

Eriophorum, 795 .:

Eródium, 147.

Erophila, 68.

E'ryngium, 289.

Eryngo, 259.

Erýsımum, 62.

Erythrea, 189.

Esparto-grass, 828.

essential organs, $\mathbf{x}$.

etario, xxvi.

Evörym 157.

Eupatórium, 371.

Euphórbia, 652, 654 .

EUPHORBIÁLE, 651.

Euphrisia, 540.

evergreen leaves, xii.

Everlasting. $377,378$.

exogenous, 1.

expelling hairs, 363 .

exserted, projecting beyond the corolla, a term applied to the stamens.

extrorse antlers, xxi:i.

Eye-bright, 527, 510 .

Fagopȳrum, 629.

Figus. 674.

Falcária, 302.

falcate, sickle-shaped.

fascicled, crowded in a tuft, as the leaves of the Larch or the flowers of Sweet William.

fasciculate roots, iii.

Fat Hen, 614.

Fenutel, 312.

Fentuel, Hog's, 322.

Fen Sedye, Soo. 
Feuugreek, 172.

Férula, 281.

Fescue, 877.

Festúca, 877.

Feverfew, 390 .

Fibichia, 860 .

Fig, 638.

Figwort, 535.

FIGWORT FAMILY, 526.

Filágo, 375.

filament, $\mathrm{xxii}$.

filiform, thread-like, very slender.

Fiorin-grass, 815.

Fir-rape, 463.

Fir, Scots, 900.

fistular stems, iv.

Flag, Coru, 711.

Flax, 139.

FLAX FAMILY, 139.

Flax, New Zealand, 724 .

rlax-seed, 140.

Flea-bane, 3/5, 331.

Fleawort, 402.

flexuous, wavy, lass angular than is implied by the tern "zigzag."

Flixweed, $6 \mathrm{l}$. florets, xiv.

Flote-grass, 874 . flower, $x v$.

Flower-de-luce, 710. . flower-stalk, xiii.

Fluellen, 532 .

Faniculum, 312. follicle, xxvi. footstalk, xiii.

Forget-me-not, 498503.

Foxglove, 527,540 .

Foxtail-grass, 839 .

Fragúria, 213.

Frankenia, 96.

FRANKENIACEE, 96.

Fruixinus, 481.

free-central placentation, having tlue seeds attuclied to the central axis of the fruit without partitions connecting that axis with the side-walls of the ovary, xxiv.

Fritilléria, 739.

Fritillary, 739.

Frog-bit, 684 .

FRoG-BIT FAMILT, 683.

fruit, $x \times v$.

fugacious corolla, $\mathrm{xxi}$.

Fumairia, 41.

FUMARIACE 40.

Fumitory, 41.

FUMITORY FAMILY, 40.
Furze, 168.

fusiform, spindle-shaped, tapering towards botls ellds.

Gágea, 741 .

Galcinthus, 719.

Galeópsis, 590.

Galingale, 786.

Galinsóga, 385.

Gílium, 345 .

GAMOPETAL

gamosepalous calyx, xviii.

Gangweed, 93.

Garlic, 724, 731.

Garlic Mustard, 62.

Gastridium, 848.

Gean, 205.

Genista, 166.

Gentian, 491.

Gentiána, 491.

GENTIÁNE $48,486$.

Gentianella, 488, 491.

GLNTIAN FAMILY, 486.

generic name, xxviii. genus, $\mathrm{xxix}$.

GLHANÍ́CE,E, 142.

Gerínizem, 143.

Germander, 598.

Gexem, 212.

Gínkigo, 897.

Gipsywort, 572 .

glabrescent, becoming smootl. glabrous surface, $\mathrm{xii}$.

Gladden, 710.

Gládiolus, 715.

glauds, small interval hollows in the tissues of plants contaiuing special sectetions sucis as oils.

glandular surface, xii.

Glasswort, 621 .

Glaúcium, 38.

glaucons surface, xii.

Gilaux, 476.

Glube-fluwer, 19.

glomerules, axillary cymes with sessile or nearly sessile flowers. glumaceous, resembling a glume.

glume, a stiff bract drying into a chaff-like scilc, as in Glasses, 781.

Glune, Flcwering, $\$ 25$.

GLU MIFkHE, lii., 781.

Glycéria, 874.

Giaphélizm, 379.

Goat's-beald, 435 .

Golden-rod, 372.

Goldilocks, 15.

Goldilucks, llax-leaved, 374. 
Gold of Pleasure, 71.

Good Friday grass, 755 .

Good King Henry, 616.

Goodyéra, 696.

Gooseberry, 247.

Goosefoot, 613 .

GoosEFOOT FAMILX, 612.

Goose-grass, 219, 347.

Gorse, 168.

GoURD FAMILY, 275.

Gont-weed, 303.

GRAMÍNEA, 825.

Grass, Black, 839.

Grass, Blue-eyed, 713 .

Grass-cloth, 638 .

GraSS FAMILY, 825.

Grass of Parnassus, 246.

Grass-wrack, 783.

Green-weed, 166.

Gromwell, 511.

Gromwell, Smooth, 507.

Ground Ivy, 582.

Ground Pine, 602.

Groundsel, 399.

Guelder Rose, 338.

Guinea-corn, 828.

Gum Arabic, 164.

Grmnospérmia, xxvii., xxxii., lii., 896.

gynandrous stamens, xxi.

Habenairia, 707.

Hair-grass, 851, 864. .

hairs, xii.",

Mard-grass, 893.

Hard-hend, 413.

Harebell, 414.

Hare's-ear, 295.

Hare's-tail grass, 850.

Hart wort, 325.

lastate, halberd-shaped, $x$.

HALORÁGE E, 261.

Haver's, 858.

Hawk-bit, 427.

Hawk's-beard, 420.

IIawkweed, 422.

Iawthorn, 236.

ITazel, 671.

hoad, xiv.

Heartsease, 92.

Heath, 454.

Heatlier, 452.

HEATH FAMILY, 448.

Heath-grass, 862 .

Heath, St. Dabeoc's, 459.

Hédera, 329.

Hedge-mustard, 59.

Heliânthemum, 87.

Heliotrope, Winter, 398.

Heliebore, 20.
Helleborine, 696.

Helléborus, 20.

Hemlock, 280, 293, 299.

Hemlock Spruce, 898.

Hemlock, Water, 299.

Hemp, 638.

Hemp Agrimonv, 371.

Hemp-nettle, 590 .

Henbane, $521,525$.

Henbit-nettle, 594 .

Herácleum, 323 .

herbaceous, when applied to stems meaning not woody; when to leaves or other or. gans, green and leaf-like.

Herb Benet, 212.

Herb Ohristopher, 27.

Herb Gerard, 30 \&.

Herb Paris, 745.

Herb Robert. 147.

Hernínium, 705.

Hemiciria, 608.

Hésperis, 58.

lieterostyly, 469 .

Hierácium, 422.

Hierochloé, 838.

Hippocrépis, 190.

Hippóphat, 637.

Hippuris, 263.

hispid, with short stiff hairs.

Hog's-Fennel, 322.

Hog-weed, 324 .

Hólcus, 853.

Holly, 154.

Hodlx Family, 152.

Hollyhock, 133.

Holly, Sea, 289.

Holósterm, 107.

Holy-grass, 838.

Homalocénchrus, 835.

Honewort, 296.

Honeysuckle, 340.

HONEY'SUCKIE FAMILT, 333.

Hop, 638, 640 .

Hórdercm, 894 .

ITorehound, Black, 598.

Horehound, White, 586.

Hornbeam, 665,670 .

Hornwort, 662 .

HORNWORT FAMILY, 661.

Horse-radish, 71.

Horseshoe-vetcli, 190.

Hottónia, 468.

Hound's-tongue, 499.

IFouse-leek, 255.

Hutchinsia, 80.

Hyacintl1, Grape, 734.

Hyacinth, Starch, 734 .

IIyacintl:, Wild, 737.

HYDROCHARfDE.E, 683. 
Hydrócnaris, 684.

Hydrocótylé, 287.

Hyoscyanus, 525 .

HYPERICINE E, 128.

Hypéricum, 128.

Hypochéris, 425.

hypogynous insertion, xvii.

Hypópitys, 463.

Ibéris, 79.

Ilex, 154 .

IIICÍNEA, 152 .

ILLECEBRÁCE E, 606 .

Illécebrum, 607.

imbricate leaves, viii.

imbricate sepals, $\mathrm{xxi}$.

imparipinnate, pinnate with a terminal leaflet.

Tmpátiens, 150.

imperfect flowers, $x \nabla i$.

included, within the flower, generally applied to the stamens.

VCOMPLÉT

incoraplete flower, $x$ vi.

incumbent cotyledons, 44.

indehiscent fruit, $\mathrm{xxv}$.

..- diarubber, 484.

indigenous, native to the country, not known to be of human or recent introduction. inferior cal $y x$, xvii., xviii.

iuferior ovary, xviii., xxiv.

inflated calyx, xviii.

inflorescence, xii.

insertion of the flower, xvii.

internode, iii.

interruptedly pinnate, leaves in which alternate pairs of leaflets are large and small, as in Agrimony, 223.

introrse anthers, xxiii.

Inula, 380 .

involucel, a secondary involucre or circle of bracts on the branches of a compound inflorescence, 356 .

involucre, xiv.

involute leaf, viii.

Ipecacuanha, 342 .

IRÍDE $7,709$.

Iris, 710 .

IRIS FAMILY, 709.

Isatis, 81.

Isnardia, 271 .

Ivy, 329.

IVY FAMILY, 329.

Jacob's Ladder, 496.

JACOB's LADDER FAMILY, 496.
Jalap, 514.

Jasíoné, 438.

Jerusalem Artichoke, 364.

Joint-vetch, 189.

Jujube, 157.

JUNCÁCEA, 746 .

duncoúdes, 753 .

Jíncus, 747.

Juniper, 901 .

Juníperus, 901.

Jute, 138.

Kauri pine, 898.

keel, the two lower petals in the flowers of the Pea Family, xx.

Kidney-Vetch, 183.

Knapweed, 413.

Knawel, 609.

Knot-grass, 607, 626.

KNOT-GRASS FAMILY, 606.

Kobrésia, 801.

Koeléria, 864.

labellum, 688.

LABI ́́T

Lace-bark, 685.

Lactúca, 430.

Lady's Fingers, 184.

Lady's Mantle, 221.

Lady's Slipper, 709.

Lady's Smock, 55, 56 .

Lady's Tresses, 0994 .

Lagieruts, 850.

Lamb's Lettuce, 35 ‥

Lamb's-tongue, 603.

Láminem, 593.

lanceolate leaf, ix.

Lapsána, 418.

Larel, 898.

Larkspur, 24.

Lathréa, 557.

Läthyrue, 195.

latisept siliqua, 44 .

Laurel, Spurge, 636.

Lavatéra, 135.

Laveuder, 655 .

leaf, viii.-xii.

Leek, 724, 731.

legume, xxvi.

LEGUMINÓS

Lémna, 764.

LEMNÁCE

Lemon-plant, 563.

THETIBULARIÉ, 558.

Leóntodon, 427.

Leonúrus, 592.

Leopard's-bane, 398.

Lepídium, 75.

Leptúrus, 893.

Lettuce, 430. 
Leucójum, 721.

Lightwort, 507 . ligulate corolla, $\mathrm{xx}$., $\mathrm{xxi}$.

ligule, a small scale at the base of a leaf, as in Grasses, 825, or of a petal, as in the Mignonettes and Campions.

LIGULIFLÓR.E, 364.

Ligústicum, 320.

Ligústrum, 432.

Lilac, 481 .

LIIIACE.E, 723.

Líliium, 739 .

Lily, 739.

LILY FAMILY, 723.

Lily-of-the-Valley, 730.

limb of petal, xix.

Limuinthemum, 496.

Limosél!a, 537.

Linciria, 530.

Linden, 138.

LINDEN FAMILI, 137.

LINE.E, 139.

Ling, $45 \%$.

Linnáta, $3+0$.

Linuæan system, xxx., xxxi.

Linseed, 140 .

Linum, 140.

Lipuris, 691.

Liquorice, Wild, 171.

Listera, 694.

Lithospérmum, 511.

Littorélla, 606 .

Lloydia, $7 \pm 1$.

lohed leaf, xi.

Lobélia, 438.

Locust Beans, 164.

lodicule, 8:6.

Loiseleürin, 458 .

Lólizm, 838.

lomentum, a pol-like fruit with trausverse partitions, 14,47 .

London Fride,

Lonicera, $3 \pm 0$.

Loosestrife, 473.

LOOSLSTRIFE FAMILT, 258

Loosestrife, Purple, 259.

Lop-grass, S 86 .

LORANTII CCE. 616.

Lurds-and-Ladies, 762.

Lótus, 184.

Lovage, 320 .

Lucerne, 173.

Lucluefgice, 271.

Lungwort. 507.

Lychinis, 105.

Lixcium, 524.

I.ycópsis, 50 s.

Lycopus, 572.

Lyme-grtiss, 895. lyrate leaf, xi.

Lysimcichia, 473.

LYTHRARI É:.

Lythrum, 259.

Madder, 343.

Madder, Field, 350.

Maianthemum, 730 .

Mraidenhair tiee, 897 .

Maize, 825, 827 .

Malixis, 631.

Mallon, 135.

MaLIOW FaMILY, 132.

Mallow, Marsh, 133.

Mallow, Tree-, 135.

Múlva, 135.

MALVÁCEE, 132.

Manchineel, 653 .

Mandrake, 520 .

Mangold Wurzel, 61:.

Manioc, 653.

Manna, 481 .

Manna-croup, 874.

Manna-grass, 874 .

Maple, 161.

MAPLE FaniLr, 159.

marcescent, withering but re maining attached, xix.

Mare's-tail, 263.

Mare's TaIL Family, 62l.

Maricina, 411.

Marigold, Corn, 389.

Marigqld, Marsh, 19.

Marjoram, 574.

Marram, Sea, 850 .

Marrúbizm, 536.

Marsh-wort, 298.

MAST-BLARIVG FAMLIL, 65L.

Masterwort, $3: 3$.

Maté Tea, 153.

Matfellon, $\$ 13$.

Mat-grass, 850, 893 .

Mathiola, $4 \bar{\gamma}$.

Matricirice, 390.

May, 237.

May-Lily, 730 .

May-weed, $39 i$.

Meadow-grass, 871 .

Meadow-rue, 4.

Meadow-sweet, 206.

Meconopsis, 172.

Medicágo, 172 .

Medick, $17: 2$.

Medlar, 236.

Nelampyrum, $5 \pm 6$.

Melic, 86t. 867 .

Melica, 867.

Melilnt, 175

Melilótus. 175.

Melissa, 575 . 
Melittis, 585.

membranous leaf, viii.

Méntha, 568.

Menthol, 565 .

Menyinthes, 494 .

IIenziesia, 459.

Mercuriális, 661 .

Mercury, 616, 661 . mericarp, 279.

mesocarp, the middle layer or "flesh" of a fruit, 199.

Meu, 318.

Héum, 318.

Mezereon, 636.

Mitóra, 841.

Microcíla, 488.

Mignonette, 85 .

MIGNONETIE FAMLY, 85.

Milfoil, Common, 386.

Milfoil, Water, 263 . .

Hílium, $8 \pm 2$.

Milk-vetch, 186.

Milkwort, 93.

MILKWORT FAMILT, 93.

Millet, 827, 833 .

Millet, Grey, 511 .

Millet-grass, 842 .

vímulus, $53 \bar{i}$.

Mint, 568 ,

Mistletoe, 646 .

MISTLETOF FiNILY, 616.

Mcenchia, 109.

Molínia, 864.

Money-wort, 174.

Money-wort, Cornish, 538.

Monkey-Hower, 537.

Monkey-puzzles, 898.

Morik's-hood, 25. monadelphous stamens, $x$ xii.

Montéses, 461 . monocarpellary fruits, xxvi,

MONOCHLAMÝDE开, xlvii., 611. nonochlamydeous flowers, $x$ ri. monocotyledonous seed, $\mathrm{x} x$ vii.

MONOCOTYLEDONS, Xxxii., 1., 682 . moncecious flowers, $x$ vi. monosymmetric flowers, $x \times i i$.

MONOTRÓPEE, 461 .

Móntia, 124.

Moor-grass, 862.

Moschatel, 384 .

Moss Campion, 104 .

Mother-of-tlousands, 581 .

Motherwort, 592.

Mountain Ash, 234.

Mouse-ear, 507.

Mouse-tail, 10. inuero, 93.

Mud-rusil, 791.

Mudwort, 537.
Mugwort, 395.

Mulberry, 638 .

Mullein, 528.

Muscári, 734.

Mustard, 65, 66.

Mustard, Garlic, 62.

Wrustard, Mithridate, 78.

Mustard, Tower, 55.

Myosótis, 507.

Myosúrus, 10.

Myrica, 664 .

MYRICÁCE $1,664$.

Myriophyllum, 263.

Myrrhis, 306.

Myrtle, Bog, 664.

NAIADACE, 770 .

Níjas, 783.

Narcissus, 717.

Nürdus, 893.

Narthécium, 744

Nastúrtium, 50.

Natural Orders, xxxi, xxxviii.-lii.

natural system, $\mathrm{xxx},-\mathrm{xxxi}$.

naturalised, growing freely from self. sown seed, though not truly indigenous.

Navew, 63, 64 .

Néckiera, 40 .

nectary, any organ secreting honey, generally part of the flower.

Neóttia, 693.

Népeta, 581.

Nettle, 642.

Nettle, Dead, 593.

NeTtLE FAMIL1; 637. neuter flowers, xvi.

Nightshade, $520,52 I, 52 t$.

NIGHTSHADE FAMILT, 519.

Tipplewort, 418 .

Nit-grass, 848.

node, ii.

nodulose roots, iii.

Nonsuch, 173.

nut, xxvii.

nutlets, $\mathrm{xxv}$.

Nympha $a, 30$.

NYMPHÁ́CEA, 30 .

Oak, 672 .

Uat, $8: 77,856$.

Oat, False, 859 .

Oat-grass, 859.

Oat, Yellow, 856.

obconic, reversedly cone-shaped. oblanceolate leaf, ix.

oblique leaf, $x$.

obovate leaf, ix.

obovoid, nearly reversedly eggghaped. 
Encinthe, 314.

Enothéra, 272. offset, viii.

OLEÁCEA, 480.

Ole ander, 484 .

OLEASTER FA MILY, 636.

OLIVE FaMILT, 480.

ONAGRARIÉ $2,267$.

Onóbrychis, 190.

Onónis, 171.

Onópordon, 410.

Ophrys, 703 . opposite leaves, ix.

Orache, 618. orbicular, nearly round, applied to leaves.

ORCHÍDE E, 687.

ORCHID FAMILY, 687.

Orchis, 691,698 .

organ, any part of a plant which performs some definite function.

Oríganum, 574:

Ornithógalum, 737.

Ornéthopus, 187.

OROBANCHÁCE $E, 553$.

Orobánché, 554 :

Orpine, 252.

Orris-root, 709.

Osiers, 675,678 .

ovary, xxiv., xxv.

ovate leaf, ix.

ovoid, nearly egg-shaped. ovules, xxiv., xxv.

Oxalis, 150.

Ox-eye, 389.

Ox-lip, 172 .

Ox-tongue, 419 .

Oxýria, 630.

Oxgtropis; 186.

Paónia, 27.

Paigle, 472 .

pảle, 826.

palmate leaf, $x i$.

palmate veuation, ix.

palmatisect, cut in a palmate manner, xi.

Panic, 833.

panicle, a branclied cluster of flower's.

Pínicum, 833.

Pansy, 92.

Papaver, 34.

Papayer ́r. efe, 33.

papilionaceous corolla, xix.

pappose, in the form of a pappus or circle of hairs.

pappus, xviii.

parasite, a plant which is attached to, and derives its food from, another living being, as does the Mistletoe. They are often brown, as are the Broom-rapes. parietal placentation, $\mathrm{xxr}$.

Parietária, 641.

Páris, 745.

Pamássia, 246.

Parsley, 301.

Parsley,.Beaked, 311.

Parsley, Bur-, 327.

Parsley, False Milk. 320.

PARSLEY FAUILT, 278.

Parsley, Fool's, 316.

Parsley, Hedge-, ¿27.

Parsley, Milk, 323.

Parsley, Piert, 221.

Parsley, Stone, 301.

Parsnip, 323.

Parsnip, Cow, 323.

Parsnip, Water, 302.

Pasque-flower, 8.

Patchouli, 565.

Pea, Everlasting, 197.

PEA FAMILY, 162.

Pear, 235.

Pearl-wort, 119.

Peas Earth-nut, 197.

pedate, with lateral lobes given off from one another in at cymose manner.

pedicel, xiii.

Pediculáris, 543 .

peduncle, xii.

Pellitory, $6 \pm 4$.

peltate leaf, $x$.

Penny Cless, 78 .

Pennyroyal, 572 .

Pennywort, Marsh, 287.

Pennywort, Wall, 250.

pentamerous (often written 5 -merous) having 5 leaves in each whorl.

Peony, 27.

Péplis, 25s.

Pepper, Cayen11e, 521.

Peppermint, 570 .

Pepperwort, 75.

perennials, herbaceous, $v$.

perfect flower, $x$ vi.

perfoliate leaf, $x$.

perianth, $\mathrm{xv}$.

perigynous iusertion, xvii.

Periwinkle, 484.

PERI Winkle FAMILY, 484.

Persicaria, 624.

Persicaria Family, 623.

persistent calyx, xviii., xix.

persistent corolla, xxi. 
personate corolla, $\mathrm{xxi}$.

petaloid bracts, xiv.

petaloid calyx, xviii.

petaloid flaments, xxiii.

PETALOIDEE, 1., 683 .

petals, $\mathrm{xv}$. , xix. $-\mathrm{xxi}$.

Petasites, 396.

petiole, the stalk of the leaf.

Pencédanum, 322.

Phálaris, 836.

PhaNeRog $\mathrm{MIA}$, xxxii., xxxviii.

Pheasant's-eye, 10.

Phléunz, 842.

Phlóx, 496.

Phragmites, 862.

phyllodes, leaf-stalks sc flattened as to resemble leaf blades, 195 .

Physospérnum, 291.

Phyteuma, 441.

Picris, 419.

Pig-nut, 306. pilose, hairy, 363.

Pimpernel, 477.

Pimpernel, Bastard, 478.

Pimpernel, Yellow, 475.

Pimpinélla, 304.

Pine, 899.

PiNE FAMILY, 898.

Pine, Ground, 602.

Pinguícula, 561.

Pink, 96.

Pink Familx, 96 . pinuate leaf, $x i$. pinnate venation, ix. pinnatifid, slightly pinnately cut.

Pínus, 899.

Pipewort, 781.

Pipewort Family, 784.

placenta, xxiv.

placentation, $\mathrm{xxiv}$, $\mathrm{x} \times \mathrm{v}$.

plaited eal $y \mathrm{x}, \mathrm{x}$ viii.

plaited leaf, viii.

PLANTAGINEA, 602 .

Plantágo, 603.

Plantain, 603.

Plantain Famiti, 602.

Plum, 202, 204.

Plumbagfnes, 463. plumose, feathery, 363.

plumile, 1.

Pnenuária, 507 .

Póa, 871 .

pod, xxvi.

POLEMONI KCE $2,406$.

Polemónium, 496

pollen, $\mathrm{x} \times \mathrm{ii}$.

pollinia, 688 .

polyadelphous stamens, xxii. polycarpellary fruits, xxvi.
Polycárpon, 123.

Polyggala, 93.

Polygalácere, 93.

POLYGONACEA, 623.

Polygonátum, 730.,

Polygonum, 624.

PoLY PÉTAL X, xxxviii., 2. polypetalous corolla, xix.

Polypogon, 846. polysepalous caly $x$, $x$ viii.

polysymmetric flowers, xvii.

pome, xxvii.

Pond-weed, 773 .

POND-WEED FAMILT, 770.

Poplar, 680.

Poppy, 34.

POPPY FAMILY, 33.

Poppy, Horned, 38.

Poppy, Violet Horned, 38.

Poppy, Welsh, 37.

Pópulus, 680.

Port Ulace, 123.

Potato, 519.

Potato, Sweet, 515.

Potentílla, 215.

Potérim, 221.

premorse rhizome, $\nabla$.

Primrose, 469.

Primrose, Evening, 272.

Primrose Family, 466.

Primula, 469.

Primulaceat, 466.

Privet, 183.

Prunélla, 584.

Prúnus, 202.

pseudobulbs, 687.

Pillicária, 381.

Pulmonária, 507.

Pulqué, 716.

Purslane, 123.

Purslane Familt, 123.

Purslane, Sea, 118, 621.

Purslane, Water, 258.

Púrola. 459.

Py̆rus, 231.

Quaking-grass, 869 .

Quércus, 672.

quinate leaf, $x i$.

Quinsy-wort, 350 .

raceme, xioi.

rachilla, 825 .

radical leaves, $i x$.

radicle, 1.

Rádiola, 140.

Radish, 84.

Ragged Robin, 105.

Ragwort, 400.

Rampions, 436, 4t1, $44 t$.

Ramsolis, 734. 
RANUNCTLÁCE, 2.

Tianínculus, 13.

Rape, 63.

Ráphanus, 84 .

raphides, 760 .

Raspberry, 208.

ray-florets, 362 .

receptacle, $\mathrm{xr}$., $\mathrm{xvii}, \mathrm{xviii}$

receptacle, common, xiv., 362.

receptacular tube, xrii., xviii.

Red-rattle, 543.

Reed-grass, 896.

Reed-mace, 757 .

REED FAMILY, 755.

Reed, Small, 846.

regma, xxvi.

reniform, kidney-shaped, apl,lied to leaves, ix.

replum, xxv.

Reséda, 85.

RESED KCE: $7,85$.

Rest-harrow, 171. resupinate, reversed, hanging dowluwards, 182.

retinaculum, 688 .

revolute leaf, vii".

RHÁMNEX, 157 .

Rhiminus, 159.

Rhinánthus, $5+5$.

rhizone, $v$.

rhomboid leuf, $x$.

Rhubarb, 623 .

Rhubarb, Monk's, 634 .

Rhynchóspora, 799.

Ribes, 246.

Rice, 827.

ringeut, corolla, $\mathrm{xx}$., $\mathrm{xxi}$.

Rocket, 65.

Rocket, London, 62 .

Rocket, Sea, 83.

Rock-rose, 87.

ROCK-ROSE FAMILY, 87.

Rocmérica, 39.

Romeulin, 713. root, ii., iii.

root-lairs, iii.

root-stock, $r$.

Rósar, 226.

Ros \{ $\mathrm{CEF}, 199$.

Rose, 226.

Rose-bag, 269.

Rose FAMILY, 199.

Roseniary, 566 .

Rose-root, 251.

Rosewood, 163.

rosulate, in a rosette, applied to leaves.

rotate corolla, $\mathrm{xx}$.

Rowan, 234.

Ruibia, $3 \pm 3$.
RTBLĆCE, 342.

Rúbus, 208.

Rúmer, 630 .

ruminate, $3: 2$.

runcinate, 60 .

runner, rii.

Rúppiı, 780 .

Rupture-wort, 608.

Rúscus, 7:6.

Rush, 747

RUSH FaMILY. 746.

Rush, fiowering, 7to.

Rye, 827.

Rye-grass, 827,888 .

Saftlorer, 365 .

Saffron, 710,712 .

Sage, 579 .

Sage, Wood, 600 .

Sagína. 119.

Sagittôria, 768 .

sagittate, barbed like an arrow at the base, applied to leares.

Sainfoin, 190.

SALICINEA, 675 .

Salicórnia, 621 .

Silix, 676.

Sallow, 679 .

Salsafy, 365, 135 .

Sílsola, $6 \geq 2$.

Saltwort, 622. salver-shaped coralla. $x x$.

Sálvia, 566, 579 . samala, xxri.

Sambúcus, 335.

Simolus, 180.

Samphire, 281.

Samphire, Goldeu, 350.

Samplitre, Marslı, 621.

Samphire, Rock. 314.

SaNdalwood Famity, 649.

Sand-grass, 8t4.

Sandwort, 115.

Sandwort-Spurrey, 122.

Sanicle, 289.

Sinicula, 289.

SANTALACE.t. 648.

Saponária, 101.

saproplyte, a plaut living on decayiug organic matter, sucls as dead leaves or manure. They are often irown, as is the Bird's-nest ( $p \quad 463$ ).

Satin-Hower, 114.

Sanssúrea, 411 .

Saw-rort, 411 .

Saxifraga, 240.

Saxifrage, $2 t 0$.

Saxifrage, Burnet, 304.

Saxifrage Familt, 239. 
Eaxifrage, Golden, 244.

Saxifrage, Meadow, 311 .

Saxifrage, Pepper, 318.

SAXIFRAGE., 239 .

Scabiósa, 359.

Scabious, 359.

Scabious, Sheep's, 433.

Scammony, 514 .

Scúndix, 309 .

scape, xiii.

scattered leaves, ix.

Scheuchzéria, 773.

Schónus, 800 .

Schóllera, 418.

Scirpus, 789.

Sclerinthas, 609.

Scorpion-grass, 507.

Scorzonéra, 365.

Scrophulciria, 535.

GCROPHULARINA, 526.

Scurvy.grass, 68 .

Scutellaria, 582.

Sea-Campion, 102.

Sea-Heath, 96.

Sea-Hedth Famir, 96.

Sea-kale, 82.

Sea-Lavender, 464.

Sea-Milkwort, \pm 76 .

Sea-Pink, 466.

Sedge, 801 .

SEDGE FAMILT, 785.

Sedge, Sweet, 760,763 .

Sédiom, 251. seeds, xxvii.

Self-heal, 584 .

Selinum, 320.

Sempervívum, 255.

Senécio, 398.

sepals, xv., xviii., xix. septum, a partition. serrate leaf, xi.

Serritula, 411 .

Service-tree, 231, 234.

Séseli, 311.

Sesléria, 862. sessile anthers, $x x i i i$. sessile leaf, viii.

Setuiria, 833.

Setterwort, 22.

Sheep's-bit, 438.

Shepherd's Needle, 309

Shepherd's Purse, 72.

Sheplierd's Rod, 358.

Sherírdia, 350.

Shore-weed, 606. slurub, $v$.

Slurubby Rocket, 86.

Sibbaldia, 220.

Sibthórpia, 538.

Sieglíngia, 86z.
Siluius, 318.

Siléné, 102.

Súler, 317.

silicle, 44.

siliqua, xxvi., 44.

Silver-weed, 219.

Simethis, 731.

simple leaf, $x i$.

Síson, 301.

Sisymbrium, 59.

Sisyrinchizen, 712.

Sínem, 302.

skull-cap, 582.

sleep of plants, .63.

Sloe, 202.

Smallage, 297.

Smyrnium, 294.

Snake's-head, 739.

Snake-root, 629.

Snakeweed, 629.

Snapdragon, 533 .

Sneezewort, 386 .

Snowdrop, 719 .

Snowflake, 721 .

Soapwort, 101.

Soft-grass, 853.

SOLAYÁCEA, 519.

Solânum, 521.

Solidágo, 372.

Solomon's Seal, 730 .

Sorre], $624,630,634$.

Sormel, Mountain, 630.

Sowbane, 614 .

Sow-bread, 472 .

Sow-thistle, 432.

Sow-thistle, Blue, 432.

spadix, xiii., 759 .

Spargámzeni, 757.

Spartina, 834 .

spathe, a large sheathing bract, such as tlie brown membran. ous one enclosing the flower of the Daffodil, or the pale green one enclosing the spadix of the Lords-and-Ladies, 759 . spathulate, spoon-shaped.

Spearwort, 15. species, Xxviii.

specific name, xxviii.

Speculária, 445.

Speedwell, $5+8$.

Spérgnla, 122.

SPERMAPH $\operatorname{x}^{\prime} A$, xxxii., xxxviii.

Spider wort, $7 \pm 1$.

Spignel, 318.

spike, xiii.

spike, compound, xiv.

Spikenard, 351.

Spikenard, Ploughnıan's, 380.

Spike-rush, 788. 
Spinach, 612.

Spindle-tree, 157.

SPINDLE-TREE FAMILY, 155. spinescent stem, vii.

Spiráa, 206.

Spiranthes, 694.

Spruce, 898

Spurge, 652, 65t.

SPURGE FAMIIY, 651.

Spurge Laurel, 636.

Spurrey, 121, 122.

Spurrey, Sandwort, 12:

Squills, 724,734 .

Squirrel-tail Grass, 895 .

sub-, partly.

subulate, awl-shaped, slender, and tapering, as in the prickles of the Grorse.

subulate filaments, xxii.

sucker, $v$.

Stáchys, 588.

stamens,jxxii, xxiii.

staminate flowers, xvi.

staminode, an aborted stamen, not containing pollen.

standard petal, $\mathrm{xx}$.

Star-fruit, 769 .

Star-of-Bethlehem, 737, 741.

Star-thistle, 415.

Starwort, S ea, 373.

Starwort, Water, 265.

Státicé, 464.

Stellária, 112.

stellate, star-shaped, applied to hairs.

stem, iii.-viii.

stigma, xxiv.

stipules, viii.

stipules, interpetiolar, 342 .

Stitchwort, 112.

St. John's-wort, 128.

ST. JoHN'S.WORT FAMLT, 128.

Stock, 47.

stolouiferous, with stolons or runuers.

Stonecrop, 251.

STONECROP FaMiLY, 248.

Btonewort, 302.

Stork's-bill, 147.

Strapwort, 608 .

Stratiótes, 686.

Strawberry, 213, 215.

Strawberry-tree, 450 . styles, xxiv.

Sućda, 622.

Subulária, 71 .

Succory, 415.

Succory, Lamb's, 417.

Succory, Swine's, 417.

Sugar-cane, 825, 828 .
Sulphur-wort, 318, 323.

Sundew, 256.

SUNDEW FAMILY, 255.

superficial ovules, xsiv.

superior calyx, xviii.

superior carpels, xvii.

superior ovary, xxiv.

Swede, 63.

Sweet Gale, $66 \pm$.

STEET GALE FAMILT, 664.

Swine's-cress, 74 .

Sfcamore, 161.

Sýmphytum, 501.

sympodial, a term applied tu inflorescences in which a series of successive branches simulate a continuous axis.

syncarpous carpels, xxic.

syncarpous ovary, xxiv.

syngenesious stamens, xxii.

TAMARISCLNEE, 125.

Tamarisk, 126.

TAMARISK FAMILT, 125.

Tämarix, 126.

Támus, 723.

Tinacetum, 393.

Tansy, 393.

tap-root, ii.

Taráxacum, 429.

Tare, 191.

TAX $A C E . E, G 01$.

Táxus, 902 .

Teak, 563.

Tea-tree, Duke of Argyll's, 524.

Teazle, 358 .

TEAzLE FAMILI, 356.

Teazle, Fuller's, 356, 359.

Teesdatia, 79.

I'elegraph-plant, 163.

tendril, a slender, spirally f wist. ing climbing or gan.

tentacles, pointed leaf-lobes, as in Droseracea, 256.

terete, round aud tapering.

terminalov ule, xxiv.

teruate leaf, $x i$.

testa, the onter skiu or coat of a seed, often brown aud bitter, xxvii.

tetradynamous stamens, xxii.

tetramerous (often written 4 . merous), having 4 leaves in each whorl.

Teúcrizem, 598.

THALAMIFLÓRE, XXXViii,, 2.

thalamifloral insertion, xvii.

thalamus, $x v$.

Thalictmom, 4 .

Théstum, 61S. 
Thistle, 406.

Thistle, Carline, 402.

Thistle, Cotton-, 410.

Thistle, Ground, 410.

'Thistle, Milk-, 411, 432.

Thistle, Plume-, 408.

Thistle, Scottish, 410 .

Thlispi, 77.

Thorn Apple, 521, 524.

Thorow-wax, 295 .

Thrift, 465 .

ThRIFT FAMILY, 463.

throat of corolla, xix.

Thrumwort, 769 .

Thyme, 574 .

Thyme, Basil, 577.

THYMELAKCE 634.

Thymus, 574 .

Tília, 138.

TILIÁCEe, 137.

Tilláa $a, 249$.

Timothy-grass, 827, 843.

Toad-flax, 530 .

Toad-flax, Bastard, 618.

Tobacco, 520 .

Tofiéldia, 714.

Tomatoes, 521.

Toothwort, 557.

Tordýluum, 325 .

Tormentil, 217.

Totter-grass, 869.

Touch-me-not, 152.

Tragopógon, 435.

Traveller's Joy, 4.

Treacle-mustard, 62.

Trefoil, IT7.

Trefoil, Bird's-foot, 184.

Trefoil, Marsh, 494 .

Trientúles, 475 .

Trifólium, 177.

Triglóchın, 771.

Trigonélla, 172.

trimurphism, 261.

Trínia, 296.

tripinnate, thrice divided pinnately, as in the leaves of many ferns and U mbelliferæ.

Trisétum, 856.

tristichous, in three vertical rows, as are the leaves of Sedges.

Tróllius, 19.

Trumpet-lily, 760.

tuber, iv.

tubercle, iii.

tuberculate root, iii. tubular calyx, xviii. tubular corolla, $\mathrm{xx}$.

TUBULIFĹR巴, 364.

Tulip, 741 .
Túlipa, 741.

tunicate bulb, $\nabla$.

Turnip, 63 .

Tussack-grass, 828.

Tussiligo, 396.

Tutsan, $12 y$.

Tway-blade, 694 .

Týpha, 757.

TYPHACEA, 755 .

Ǵlex, 168.

Ulmuss, 638, 639 . umbel, xiv.

UMBELIITER $2,278$. umbellules, secondary or partial umbels, 278.

undershrub, $v$.

urceolate calyx, xviii. urceolate corolla, $\mathrm{xx}$.

Urtica, 642 .

DRTICACE $\$, 697$. utricle, 785 .

Vtriculária, 560 .

VACCINI ́́CE, .445.

Vaccínium, 446.

Valerian, 351, 352.

Valerian Family, 356.

Valerian, Greek, 497.

Valerian, Spur, 354.

Valeriána, 352.

VALERÍNE $2,350$.

Valerianélla, $35 \mathrm{t}$.

Valonia, 665. valvate leaves, viii. valvate sepals, $\mathrm{xxi}$.

Vanilla, 689 . variety, $\mathrm{xxix}$.

Venus' Comb, 310.

Venus' Fly-trap, 256.

Venus' Looking-glass, 445.

Verbísc um, 528.

Verbéna, 565.

VERBENACHE, 563.

Vernal-grass, 837. vernation, viii.

Verónica, 548 . versatile anthers, $x x i i i$. verticillaster, xiv.

Vervain, 565 .

VERVAIN FAMILY, 563.

Vetch, 191.

Veteh, Bitter, 197.

Veteh, Horseshoe-, 180.

Vetch, Joint", 189.

Vetch, Milk-, 186.

Vetchling, 195.

Vibúrnum, 338.

Vícia, 191.

Villairsia, 496. 
Vinca, 484 .

Viola, 89.

VIOLÁ́CE, 89.

Violet, 89.

Violet, Dame's, 58

VIolet Family, 89.

Viper's Bugloss, 512 .

Víscum, 646 .

vittx, 279

Tólvulus, 515 .

Wahlenbérgia, 439.

Wallflower, 49 .

Wall-pepper, 253.

Wart-cress, 73.

Watercress, 50 .

Water-lily, 30.

WATER-LILY FAMILY, 30.

Water Pepper, 627.

Water Plantain, 767.

WATER PLANTAIN FAMIIY, 765.

Water Soldier, 686 .

Water-thyne, 683.

Water Violet, 469 .

Water-weed, American, 683,

Waterwort, 127.

WATERWORT FAMIILY, 127.

Way Bent, 889 .

Way-bread, 603.

Wayfaring-tree, $3 \pm 0$.

Weasel-snout, 597 .

Weingartnéria, $85 \mathrm{i}$.

Weld, 85.

Wheat, 827 .

Whin, 166, 168.

Whinberry, 446 .

White Bottle, 102.

White-rot, 288 .

Whitetlorn, 237 .

Whitlow-grass, 67.

whorled leaves, ix.
Whorl-grass, 866 .

Whortleberry, $4 \pm 6$.

Willow, 676 .

WILLOW FAMILY, 675.

Willow-herb, 268.

WILLOW-HERB FAMILY, 267.

Willow, French, 269.

Windflower, 7.

Wind-grass, 818 .

wing petals, $\mathrm{xx}$.

Winter-green, 459.

Winter-green, Chick weed, 475 .

Witches? Gowan, 19.

Withy, 677 .

Woad, 81.

Woad-waxen, 166.

Wólfra, 765 .

Wolf's-bane, 26 .

Wood Anemone, 10.

Woodbine, 311

Woodruff, $3 \pm 3,3 \pm 9$.

Wood-rush, 753 .

Wood Sage, 600 .

Wood-sorrel, 150.

Wormwood, 393.

Woundwort, $58 s$.

Xinthium, $3 \subseteq 3$.

Fan Famit, 721.

Yarrow, $360^{\circ}$.

Xellow-rattle, 5 t5.

Yellow-weed, 85.

Yellow-wort, 488.

Yew, 902.

IEW FAMILY, 901.

Yorkshire Fog, 856 .

Zannichéllia, 781.

Zostéra, 782. 


\section{PUBLICATIONS}

OF THE

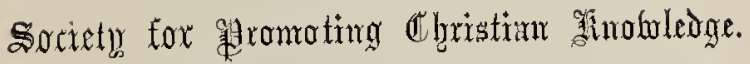

\section{THE ROMANCE OF SCIENCE.}

A series of books which shows that science has for the masses as great nterest as, and more edification than, the romances of the day.

Small Post 8vo, Cloth boards.

Coal, and what we get from it. By Professor RAPHAEL MeLdota, F.R.S., F.I.C. With several Mhustrations. $2 s .6 d$.

Colour Measurement and Mixture. By Captan W. DF W. ABNEY, C.B., R.E. With numerous Illus!rations. 2s. 6d. The Making of Flowers. By the Rev. Professor GEoRge Henslow, MI.A., F.L S. With Several Illustrations. 2s. $6 d$. The Birth and Growth of Worlds. By the late Professor A. H. Green, M.A., F.R.S. $1 s$.

Soap-Bubbles, and the Forces which Mould Them. A course of Lectures by C. V. Boys, A.R.S.M., F.R.S. With numerons Diagrams. $2 s .6 d$.

Spinning Tops. By Professor J. PeRRY, M.E., D.Sc. F.R.S. With numerous Diagrams. 2s. 6d.

our Secret Friends and Foes. By P. F. Frankeari, F.R.S. With numerons Illustrations. New Edition, $3 s$.

Diseases of Plants. By Professor Marsaali TVaro, M.A., F.R.S., F.L.S. With numerous lllastrations. $2 s, 6 d$.

The Story of a Tinder-Box. By the la'e Crarles MeYmotr Tidy, M.B., M.S. With numerous Illustrations. $2 s$.

Time and Tide. A Romance of the Moon. By Sir RoBERT S. BaLL, LL.D., Royal Astronomer of Ireland. With Illustrations. Third Edition, revised. 2s. $6 d$.

The Machinery of the Universe. Mechanical Concep. tions of Physical Phenomena. By Professor A. E. Dolbear, A.B., A.M., M.E., Ph.D. $2 s$.

The Splash of a Drop. By Professor A. M. WorthingTON, F.R.S. With numerous Illustrations. 1s. $6 d$. 


\section{NATURAL HISTORY RAMBLES.}

Fcap. 8vo, with numerous Hoodcuts, Cloth boards, 2s. 6d. each.

IN SEARCH OF MINERALS.

By the late D. T. Ansted, M.A., F.R.S.

LAKES AND RIVERS.

By C. O. Groom NAPIER, F.G.S

LANE AND FIELD.

By the late Rev. J. G. Woon, M.A., Author of "Man and his Handiwork," \&c.

MOUNTAIN AND MOOR.

By J. E. TAYLOR, F.L.S., F.G.S.

PONDS AND DITCHES.

By M. C. Cooke, M.A., LL.D.

THE SEA-SHORE.

By Professor P. Martin Duncan, M.B. (London), F.R.S.

UN DERGROUND.

By J. E. TAYLOR, F.L.S., F.G.S.

THE WOODLANDS.

By M. С. Сооке, M.A., LL.D., Author of "Freaks and Marvels of Plant Life," \&c.

\section{HEROES OF SCIENCE.}

Croun 8vo. Cloth boards, 48 . each.

ASTRONOMERS. By W. J. C. Morton, B.A. With numerous diagrams.

BOTANISTS, ZOOLOGISTS, AND GEOLOGISTS By Professor P. MarTin DUNCAN, F.R.S., do. CHEMISTS. By M. M. PATtison MuIR, Esq., F.R.S.E. With several Diagrams.

MECHANICIANS. By T. C. LEwIs, M.A.

PHYSICISTS. By W. Garnett, Esq., M.A. 


\section{MANUALS OF HEALTH.}

Fcap. 8vo, 128 pp. Limp Cloth, price 1s. each.

HEALTH AND OCCUPATION. By the late Sir B. W. RiCHARDSON, F.R.S., M.D.

HABITATION IN RELATION TO HEALTH (The), By F. S. B. Chadmont, M.D., F.R.S.

NOTES ON THE VENTILATION AND WARMING OF HOUSES, CHURCHES, SCHOOLS, AND OTHER BUILDINGS. BJ the late Ernest H. JACOB, M.A., M.D. (OxON.).

ON PERSONAL CaRe OF health. By the late E. A. Parkes, M.D., F.R.S.

AIR, WATER, AND DISINFECTANTS. By C. H. AikMan, M.A., D.Sc., H.R.S.E.

\section{MANUALS OF ELEMENTARY SCIENCE,}

Foolscap 8vo, 128 pp. with Illustrations, Limp Cloth, 1s. each.

Electricity. By the late Prof. Fleening Jenkin.

GeOLOGY. By the Rev. T. G. Bonney, M.A., F.G.S.

Physiology. By Professor A. Macalister, LL.D., M.D., F.R.S., F.S.A.

astronomy. By W. H. Christie, M.A., F.R.S.

Botany. By the late Professor. Robert Bentley.

Z00loGY. By Alfred Newton, M.A., F.R.S., Profegeor of Zoology in the University of Cambridge.

MATTER AND MOTION. By the late J. CleRK MAXWELL, M.A., Trinity College, Cambridge.

Crystallography. By Henry Palin Gurney, M.A., Clare College, Cambridge. 


\section{MISCELLANEOUS PUBLICATIONS.}

s. d.

Animal Creation (The). A popular Introduction to Zoology. By the late Thomas Rymer JoNes, F.R.S. With 488 Woodcuts. Post 8 ro........... Cloth boards $7 \quad 6$

Birds (A Chapter on). Rare British Visitors. By R. Bowdler Sharpe, LL.D., F.L.S. With 18 coloured plates. Crown 8ro ............ Cloth boards 36

British Birds (Sketch Book of), By R.

Bowdler Sharpe, LL.D., F.L.S. With numerous coloured illustrations by A. F, and C. Lydon. Crown 4to. .............................. Cloth boards 140

British B rds in their Haunts. By the late Rev. C. A. Jonss, B.A., F.L.S. With 190 engrarings by Wolf and Whymper. Post Svo. ... Cloth boards 60

Evenings at the Microscope; or, Researches among the Minuter Organs and Forms of Animal Life. By the late Philip H. Gosse, F.R.S. A New Edition, revised by Professor F. JEFFRey Betr. With nameruas Woodeats. Post Sro. Cloth boards 50

Fern Portfolio (The). By Erancis G. Heatm, Author of "Where to Find Ferns," \&o. With 15 plates, elaborately drawn life-size, exquisitely coloured from Nature, and accompanied with descriptive text............................ Cloth boards $8 \quad 0$

Fishes, Natural History of British ; their Structure, Economic Uses, and Capture by Net and Rod. By the late Frank BuCkLAND. With numerous illastrations. Crown 8 vo. 
SOCIETY FOR PROMOTING CHRISTIAN KYOWLEDGE. 5

8. d.

Forest Trees (The) of Great Britain. By the late Rev. C. A. Johns, B.A., F.L.S. With 150 woodcuts. Post $8 \nabla 0 . . . . . . . . . . . . . . . . . . . . . . . . . C l o t h$ boards 50

Freaks and Marvels of Plant Life; or, Curiosities of Vegetation. By M. C. CookE, M.A., LL.D. With numerous illustrations. Post 8vo. Cloth boards 60

Man and his Handiwork. By the late Rev: J. G. Woon, Authol of "Lane and Field," \&c. With about 500 illustrations. Large Post 8 vo. Cloth boards $7 \quad 6$

Natural History of the Bible (The). By the Rev. Canon Tristram, Author of "The Land of Israel," \&c. With numerous illustrations. Crown 8 ro. Cloth boards 50

Nature and her Servants; or, Sketches of the Animal Kingdom. By the Rev. THEODORE WOUD. With numerous woodents. Post 8 vo. Cloth boards 40

Ocean (The). By the late Phimip H. Gosse, F.R.S., Author of "Evenings at the Microscope."

With 51 illustrations and woodents. Post 8vo. Cloth boards $3 \quad 0$

Our Bird Allies. By the Rev. Theodore. Woon.

With numerousillustrations. Fcap 8vo, Cloth boards 2 . 6

Our Insect Allies. By the Rev. TheOdore WOOD. With numerous illustrations. Feap. 8vo. Cloth boards 26

Our Insect Enemies. By the Rev. T'HeOdore Wood. With numerous illustrations. Feap. 8vo. Cloth boards 26

Our Island Continent. A Naturalist's Holiday in Australia. By J. E. TAYLOR, F.L.S., F.G.S. With Map. Fcap. 8ro...................... Cloth boards 2 
Our Native Songsters. By AnNe PRatr, Author of "Wild Flowers" With 72 coloured plates. $16 \mathrm{mo}$.

Romance of Low Life amongst Plants. Facts and Phenomena of Cryptogamic Vegetation. By M. C. CoоKe, M.A., LL.D., A.L.S. With numerous woodcnts. Large post 8 vo............... Cloth boards 40

Selborne (The Natural History of). By the late Rev. GIIBERT White. With Frontispiece, Map, and 50 woodonts. Pcst 8ro.......Cloth boards 26

Toilers in the Sea. By M. C. COOKE, M.A. Post 8ro. With numerous illustrations. Cloth boards 50

Vegetable Wasps and Plant Worms. By M. C.

Cooke, M.A. Illnstrated. Post 8ro. Cloth boards 50 Wayside Sketches. By F. Edward Hulme, F.L.S. With numerous illustrations. Crown $8 \mathrm{ro}$.

Where to find Ferns. By Frascis G. Heath, Author of "The Fern Portfolio," \&c. With numerons illustrations. Feap. Svo. Cloth boards 16 Wild Flowers, By Anne Pratt, Author of "Our Native Songsters," \&c. With 192 coloured plates. In two volnmes. 16mo......... Cloth boards 8 .

LONDON : NoRthumberland ATEnue, W.C.; 43, QUEEN VICTORTA STREET, E.C. BRIGHTON : 129, NORTH STREET. 



\section{DATE DUE / DATE DE RETOUR}

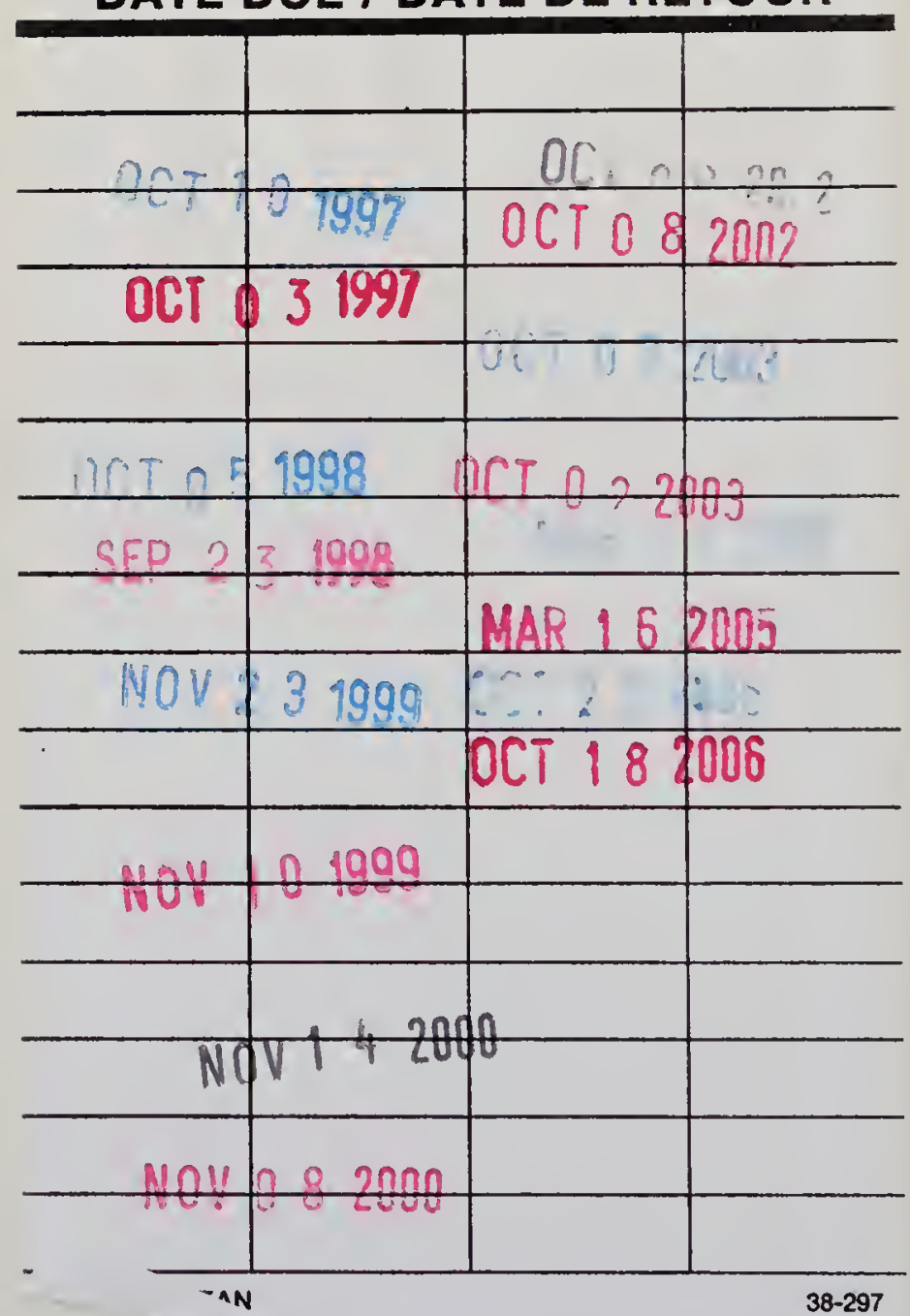




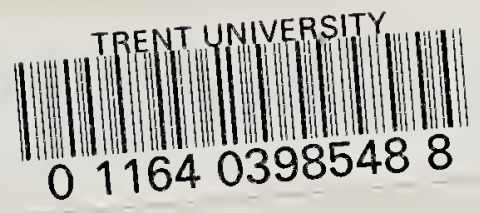


